UNIVERSIDADE DE SÃO PAULO

FACULDADE DE FILOSOFIA, LETRAS E CIÊNCIAS HUMANAS

DEPARTAMENTO DE HISTÓRIA

PROGRAMA DE PÓS-GRADUAÇÃO EM HISTÓRIA SOCIAL

LAURENT AZEVEDO MARQUES DE SAES

A Société des Amis des Noirs e o movimento antiescravista sob a Revolução francesa (1788-1802)

VERSÃO CORRIGIDA

São Paulo

2013 
UNIVERSIDADE DE SÃO PAULO

FACULDADE DE FILOSOFIA, LETRAS E CIÊNCIAS HUMANAS

DEPARTAMENTO DE HISTÓRIA

PROGRAMA DE PÓS-GRADUAÇÃO EM HISTÓRIA SOCIAL

\title{
A Société des Amis des Noirs e o movimento antiescravista sob a Revolução francesa (1788-1802)
}

\author{
Laurent Azevedo Marques de Saes \\ Tese apresentada ao Programa de Pós-Graduação \\ em História Social do Departamento de História da \\ Faculdade de Filosofia, Letras e Ciências Humanas \\ da Universidade de São Paulo, para a obtenção do \\ título de Doutor em História
}

Orientador: Prof. Dr. Carlos Alberto de Moura Ribeiro Zeron

VERSÃO CORRIGIDA

São Paulo

2013 
Autorizo a reprodução e divulgação total ou parcial deste trabalho, por qualquer meio convencional ou eletrônico, para fins de estudo e pesquisa, desde que citada a fonte. 
Nome: SAES, Laurent Azevedo Marques de

Título: A Société des Amis des Noirs e o movimento antiescravista sob a Revolução francesa (1788-1802)

Tese apresentada ao Programa de História Social do Departamento de História da Faculdade de Filosofia, Letras e Ciências Humanas da Universidade de São Paulo para obtenção do título de Doutor em História.

Aprovado em:

Banca Examinadora

Prof. Dr.: Instituição:

Julgamento: Assinatura:

Prof. Dr.: Instituição:

Julgamento: Assinatura:

Prof. Dr.: Instituição:

Julgamento: Assinatura:

Prof. Dr.: Instituição:

Julgamento: Assinatura:

Prof. Dr.: Instituição:

Julgamento: Assinatura: 


\section{Agradecimentos}

Aos meus pais, Michèle e Décio, e ao meu irmão, Guillaume, a quem dedico esta tese.

Aos professores Dr. Rafael de Bivar Marquese, Dr. Maximiliano Mac Menz, Dra. Maria Cristina Cortez Wissenbach, Dr. Modesto Florenzano, Dr. Carlos Ziller Camenietzki e Dr. Rodrigo Faustinoni Bonciani por seus comentários, críticas e sugestões. Sua contribuição foi preciosa para que este trabalho tenha chegado a bom termo.

Aos colegas de graduação e pós-graduação, em especial todos os participantes do grupo de discussão organizado por nosso orientador, que contribuíram com suas perguntas e observações para o desenvolvimento de nossa reflexão.

A Flávio, Sylvia e Alexandre Saes, pelo apoio constante manifestado ao longo da pesquisa.

Aos Archives Départementales de Loire Atlantique (ADLA), aos Archives Nationales de France (sítio de Paris) e à Bibliothèque Nationale Française (sítio François Miterrand), que nos receberam durante nossas estadias em Nantes e Paris.

A Maria de Fátima S. G. Morashashi e todos os responsáveis pela coordenação do Programa de Aperfeiçoamento de Ensino (PAE - FFLCH).

E, acima de tudo, ao Prof. Dr. Carlos Alberto de Moura Ribeiro Zeron, nosso orientador, mentor e amigo. Devemos às suas virtudes como professor, pesquisador e leitor as eventuais qualidades deste trabalho.

O presente trabalho foi realizado com apoio do CNPq, Conselho Nacional de Desenvolvimento Científico e Tecnológico - Brasil. 


\section{$\underline{\text { Resumo }}$}

No final do século XVIII, o poderio econômico da França repousava essencialmente sobre o comércio que o país realizava com as suas colônias. Graças, principalmente, ao açúcar e ao café de São Domingos, a "pérola das Antilhas", o comércio colonial francês atingia o seu auge no mesmo momento em que o país rumava para um processo violento de transformação de suas instituições. Ao mesmo tempo, havia, na metrópole, questionamentos a respeito da gestão de colônias cada vez mais povoadas de escravos, arrancados de seus lares para exercer o cultivo nas plantations. Nesse contexto, em 1788, formou-se a primeira organização antiescravista francesa, a Sociedade dos Amigos dos Negros. Sob a liderança de alguns dos principais personagens do período revolucionário, como Brissot, Clavière, Mirabeau, La Fayette e Condorcet, essa sociedade de nobres, homens de letras e financistas procurou introduzir a questão do tráfico negreiro na ordem do dia dos debates políticos que marcaram a Revolução francesa. Procuramos, no presente trabalho, retraçar a atividade desses homens, cuja moderação contrasta com o rumo que a questão colonial tomou, a partir da grande insurreição dos escravos em São Domingos, de agosto de 1791. Acreditamos que o estudo dos limites do discurso antiescravista do final do século XVIII e da política colonial das assembleias revolucionárias traz consigo ensinamentos sobre os limites da própria Revolução francesa.

Palavras-chave: Revolução francesa, escravidão, antiescravismo, comércio colonial, revolta escrava

\section{$\underline{\text { Abstract }}$}

At the end of the 18th century, France's economic power relied foremost on trade with its colonies. Thanks to the sugar and coffee produced in Saint-Domingue, the "pearl of the Antilles", French colonial commerce reached its peak at the very moment the country was moving toward a violent process of radical institutional transformation. At the same time, it was a moment of interrogations about the administration of colonies whose slave population was in continuous increase. In this context, in 1788, the first French antislavery organization was created, the Society of the Friends of the Blacks. Under the leadership of some of the key-characters of the revolutionary period, like 
Brissot, Clavière, Mirabeau, La Fayette and Condorcet, this society of nobles, intellectuals and financiers endeavored to bring the issue of slave trade to the political debate that marked the French Revolution. We intend, with this study, to retrace the activities of those men, whose moderation of principles was in contrast with the turn of events that marked the colonial space, with the slave insurrection of August 1791, in Saint-Domingue. We hope that, by approaching the limits of the antislavery program of the late-18th century and of the colonial policies of the revolutionary assemblies, this study might offer teachings on the limits of the Revolution itself.

Keywords: French Revolution, slavery, antislavery, colonial commerce, slave revolt

\section{Résumé}

À la fin du XVIIIe siècle, la puissance économique de la France reposait avant tout sur le commerce qu'elle entreprenait avec ses colonies. Grâce, notamment, au sucre et au café produits à Saint-Domingue, la "perle des Antilles", le commerce colonial français avait atteint son apogée, alors que le pays avançait vers un processus violent de transformation de ses institutions. En même temps, on se posait, en métropole, des questions à propos de l'administration de colonies de plus en plus peuplées d'esclaves, arrachés de leur sol pour cultiver le sol des habitations coloniales. Dans ce contexte, en 1788, s'est formée la première organisation anti-esclavagiste française, la Société des Amis des Noirs. Sous la direction de certains des personnages-clés de la période révolutionnaire, comme Brissot, Clavière, Mirabeau, La Fayette et Condorcet, cette société, composée de nobles, hommes de lettres et financiers, a tenté d'introduire la question de la traite négrière à l'ordre du jour des débats politiques qui ont marqué la Révolution française. Dans ce travail, nous chercherons à retracer l'activité de ces hommes, dont la modération des idées contraste avec la tournure qu'a prise la question coloniale, à partir de la grande insurrection des esclaves à Saint-Domingue, en août 1791. Nous espérons que l'étude des limites du discours anti-esclavagiste de la fin du XVIIIle siècle et de la politique coloniale des assemblées révolutionnaires soit révélateur des limites de la Révolution elle-même.

Mots-clés: Révolution française, esclavage, anti-esclavagisme, commerce colonial, révolte d'esclaves 
ABREVIATURAS

ADLA: Archives Départementales de Loire Atlantique (Nantes, França)

AP: Archives Parlementaires

BFEA: Biblioteca da Faculdade de Economia, Administração e Contabilidade da USP

BFF: Biblioteca Florestan Fernandes (FFLCH-USP)

BN: Bibliothèque Nationale Française

Observação: as citações incluídas no texto foram livremente traduzidas por nós.

Incluímos, para as citações mais extensas, o texto original nas notas de rodapé. 


\section{Sumário}

Introdução. .$p .14$

Parte I - A Revolucão francesa diante da escravidão negra (fevereiro de 1788 -

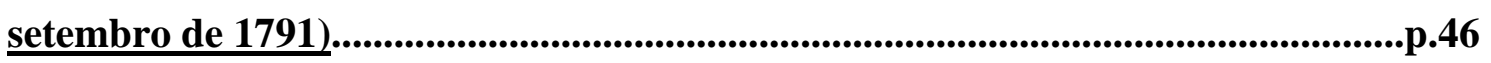

I.1) A Sociedade dos Amigos dos Negros.........................................................................p.47

I.1.1) Uma sociedade antiescravista às vésperas da Revolução.......................p.47

I.1.1.1) O comércio colonial no quadro da economia francesa.............p.47

I.1.1.2) Um contexto político favorável...........................................p.58

I.1.1.3) Brissot e o problema da escravidão.......................................p.67

I.1.1.4) A fundação....................................................................... 71

I.1.1.5) Um novo tipo de sociedade................................................p.77

I.1.1.6) Uma sociedade de elite......................................................p.81

I.1.1.7) Composição....................................................................p. 84

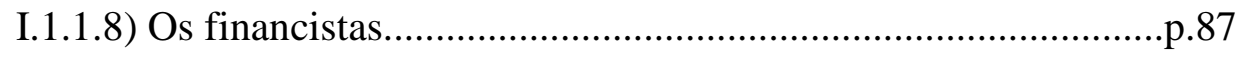

I.1.2) Um programa antiescravista moderado...............................................p.96

I.1.2.1) Condenação moral, cautela política: uma herança das Luzes..p.98

I.1.2.2) A crítica econômica à escravidão na França..........................p.123

I.1.2.3) As reflexões de Condorcet sobre a escravidão.......................p.130

I.1.2.4) O programa da Sociedade dos Amigos dos Negros...............p.134

I.1.2.4.1) Abolição do tráfico: uma luta internacional............p.134

I.1.2.4.2) Abolição gradual da escravidão.............................p.138

I.1.2.4.3) Suavização da condição dos escravos....................p.141

I.1.2.4.4) Um novo projeto colonial.....................................p.146

I.1.2.5) Variações de um mesmo programa......................................p.153

I.1.2.6) Um início pouco promissor...................................................... 161

I.2) Os Amigos dos Negros e a Revolução.......................................................................p.164

I.2.1) Os Estados Gerais: uma nova perspectiva........................................p.164

I.2.1.1) As considerações de Brissot sobre os Estados Unidos..........p.164

I.2.1.2) A causa dos negros nos cadernos de queixas.......................p.166

I.2.1.3) A campanha junto aos deputados.......................................p.170

I.2.2) O primeiro debate: a questão da representação colonial.......................p.175

I.2.3) Formação do bloco antagonista........................................................p.185 
I.2.4) A Declaração dos Direitos do Homem e do Cidadão............................p.192

I.2.5) A campanha contra o tráfico..............................................................p.195

I.2.5.1) O tráfico negreiro: um comércio ruinoso para a Nação..........p.195

I.2.5.2) O discurso de Mirabeau......................................................p.200

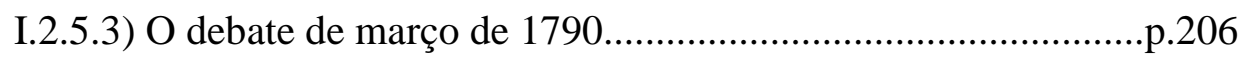

I.3) O combate pelos homens de cor livres..............................................................p.215

I.3.1) O movimento antiescravista na luta contra o preconceito...................p.215

I.3.1.1) Julien Raimond e a Sociedade dos Cidadãos de Cor..............p.216

I.3.1.2) Os Amigos dos Negros na luta pela igualdade da epiderme..p.230

I.3.1.3) O memorial de Grégoire e a resposta do campo colonial.......p.235

I.3.2) Março e outubro de 1790: reviravoltas no debate colonial...................p.242

I.3.2.1) As Instruções de 28 de março: uma vitória aparente...............p.242

I.3.2.2) 12 de out. de 1790: consagração da competência colonial.....p.245

I.3.2.3) Reações do campo antiescravista..........................................p.248

I.3.3) O martírio de Ogé e as novas investidas dos cidadãos de cor...............p.252

I.3.4) O debate de maio de 1791: uma vitória momentânea..........................p.261

I.3.4.1) Constitucionalização da escravidão, igualdade da epiderme.p.261

I.3.4.2) Repercussões do decreto de 15 de maio...............................p.272

I.3.5) Maio-setembro de 1791: o retrocesso..............................................p.279

I.3.5.1) A ofensiva colonial contra o decreto de 15 de maio..............p.279

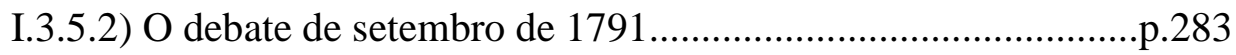

I.3.5.3) Reações à lei de 24 de setembro.........................................p.286

I.3.5.4) Duas ordens constitucionais distintas................................p.289

Parte II - A Revolucão na via abolicionista (outubro de 1791 - julho de 1794).p.293 II.1) A insurreição escrava no debate colonial (outubro de 1791 - abril de 1792)

II.1.1) A Legislativa e a ascensão política dos Brissotinos...........................p.294

II.1.2) Insurreição geral em São Domingos.................................................p.297

II.1.2.1) A Revolução nas colônias....................................................p.297

II.1.2.2) São Domingos em chamas..................................................p.311

II.1.2.3) A rebelião escrava na via revolucionária.............................p.315

II.1.3) A Assembleia Nacional diante da insurreição negra..........................p.322

II.1.3.1) O ceticismo perante o "impensável".....................................p.322 
II.1.3.2) Os Amigos dos Negros contra a parede..............................p.331

II.1.4) A igualdade da epiderme...............................................................p.334

II.1.4.1) Os cidadãos de cor e a preservação da ordem colonial.........p.334

II.1.4.2) A lei de 24 de março - 4 de abril de 1792: maior e derradeira vitória dos Amigos dos Negros.......................................p.345

II.1.4.3) Uma nova comissão civil.................................................... 351

II.1.5) Fim do antiescravismo sob a Revolução?..............................................356

II.1.5.1) O apagamento dos Amigos dos Negros...............................p.356

II.1.5.2) A guerra entre Girondinos e Montanheses: a tese de um deslize da esquerda

II.2) Insurreição escrava e impulso republicano: a superação do gradualismo.p.366

II.2.1) A ascensão do abolicionismo radical...............................................p.366

II.2.1.1) Alguns planos de abolição gradual.....................................p.367

II.2.1.2) A insurreição negra na imprensa patriótica: os primeiros

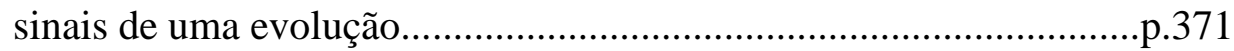

II.2.1.3) A popularização da causa antiescravista..............................p.378

II.2.1.4) Milscent: o modelo de uma evolução.................................p.383

II.2.1.5) Os homens de cor na luta abolicionista..............................p.389

II.2.2) A República radical......................................................................p. 393

II.2.2.1) A petição de 4 de junho de 1793 ..........................................p.393

II.2.2.2) A abolição das subvenções ao tráfico..................................p.398

II.2.3) A conquista da liberdade em São Domingos.....................................p.401

II.3) A abolição (lei de 16 pluvioso do ano II - 4 de fevereiro de 1794)................p.410

II.3.1) A deputação da igualdade e a supressão da escravidão colonial.........p.410

II.3.2) As reações à lei: sinais de uma adesão popular.................................p.423

II.3.3) A guerra pela liberdade .............................................................p.434

II.3.3.1) A atitude dos robespierristas............................................p.434

II.3.3.2) A perseguição aos colonos................................................p.439

II.3.3.3) As medidas de execução.................................................p.445

Parte III - Do colonialismo assimilacionista ao restabelecimento da escravidão

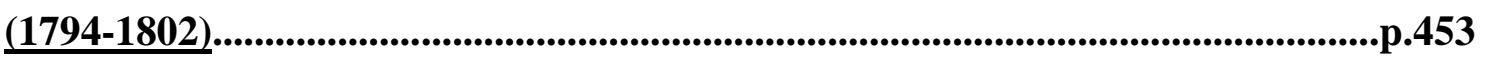

III.1) Emancipação dos negros e assimilação das colônias...................................p.454

III.1.1) A aplicação da abolição: o problema dos regimes de trabalho..........p.454 
III.1.2) A transição thermidoriana................................................................p.463

III.1.2.1) O fim da repressão aos colonos.........................................p.464

III.1.2.2) Uma nova ofensiva colonial.............................................p.467

III.1.2.3) Os representantes das ilhas Mascarenhas...........................p.469

III.1.3) A Constituição do ano III............................................................p.474

III.1.3.1) Ruma a uma nova política colonial...................................p.474

III.1.3.2) A nova Constituição.........................................................p.478

III.1.3.3) As tentativas de aplicação......................................................482

III.1.4) Os escravistas no seio da reação monarquista....................................p.486

III.1.4.1) Uma tendência reacionária em matéria colonial..................p.486

III.1.4.2) As eleições da primavera de 1797 e a ofensiva

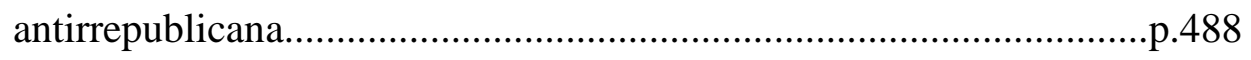

III.1.5) O golpe de 18 fructidor do ano V (4 de setembro de 1797)..............p.497

III.2) A Sociedade dos Amigos dos Negros e das Colônias......................................p.500

III.2.1) Continuidade e renovação do movimento antiescravista....................p.500

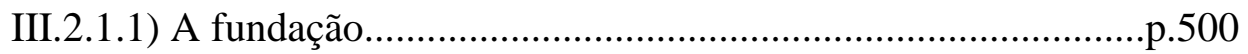

III.2.1.2) Composição...................................................................p.502

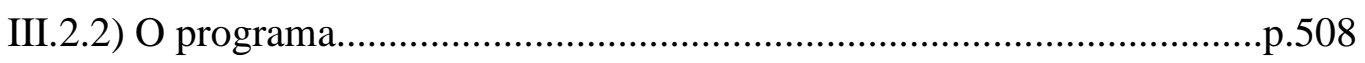

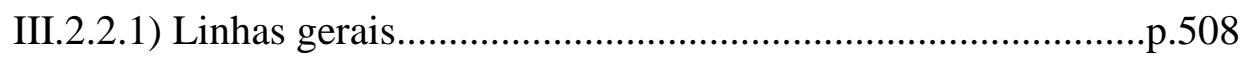

III.2.2.2) Emancipação dos negros..................................................p.511

III.2.2.3) Educação dos novos livres................................................p.514

III.2.2.4) Trabalho livre nas colônias e inovações na cultura

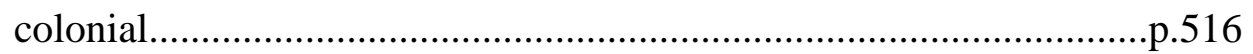

III.2.2.5) Expansão colonial sobre novas bases................................p.519

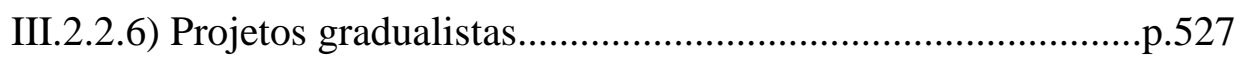

III.2.3) A organização constitucional das colônias........................................p.530

III.2.3.1) A lei de 12 nivoso do ano VI ( $1^{\circ}$ de janeiro de 1798).........p.530

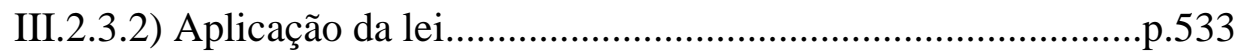

III.2.3.3) Os Amigos dos Negros e Toussaint Louverture...................p.537

III.2.4) O fim da Sociedade..................................................................p.539

III.3) O restabelecimento da escravidão (novembro de 1799 - maio de 1802)...p.544

III.3.1) Um novo contexto.....................................................................p. 546

III.3.1.1) Bonaparte e seu círculo..................................................p.546

III.3.1.2) A propaganda escravista...............................................p. 552 
III.3.1.3) O antiescravismo sob o Consulado....................................p.560

III.3.2) Uma nova política colonial............................................................p.566

III.3.2.1) Relações tensas com as colônias........................................p.566

III.3.2.2) A Constituição do ano VIII................................................p.569

III.3.2.3) A Constituição de São Domingos.......................................p.573

III.3.3) A revogação da abolição.............................................................p.578

III.3.3.1) A paz com a Inglaterra........................................................5.578

III.3.3.2) A lei de 30 floreal do ano X (20 de maio de 1802).............p.584

III.3.3.3) Resultado final.................................................................... .591

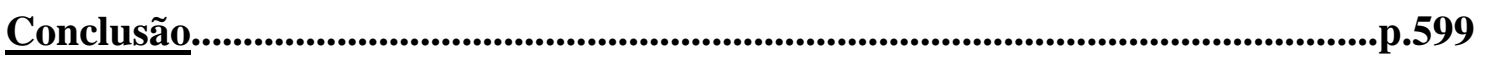

Bibliografia............................................................................................................p.614

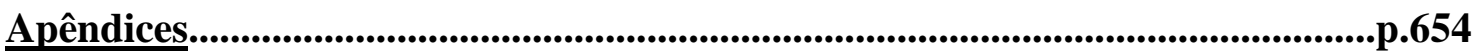




\section{Introdução}


[...] a partir do momento em que as artes e o comércio conseguem penetrar no povo e criam um novo meio de riqueza em proveito da classe laboriosa, prepara-se uma revolução nas leis políticas; uma nova distribuição da riqueza produz uma nova distribuição do poder. Assim como a posse das terras elevou a aristocracia, a propriedade industrial eleva o poder do povo; ele adquire a sua liberdade, ele se multiplica, ele começa a influir nos seus assuntos. ${ }^{1}$ (grifo nosso)

As palavras acima foram escritas no ano de 1792, por Antoine Pierre Joseph Marie Barnave, então antigo deputado da Assembleia Constituinte. Antes de cair em desgraça na esteira da derrubada da realeza ${ }^{2}$, Barnave havia se afirmado como um dos mais populares e influentes oradores da Assembleia Constituinte e um dos principais protagonistas da primeira fase da Revolução francesa. No texto em questão, ele, que tinha sido um dos fundadores do Clube dos Jacobinos e, posteriormente, dos Feuillants, refletia a respeito das origens da Revolução. Manifestava a percepção segundo a qual esta marcava o fim de uma sociedade baseada na propriedade fundiária e dominada pela aristocracia feudal e o começo de uma nova, baseada em outra forma de propriedade e tendente à igualdade. Barnave afirmava que uma sociedade fundada na propriedade da terra, onde a produção agrícola era a única fonte de riqueza, tendia à desigualdade em favor da aristocracia, ao passo que "[...] aí onde existe uma renda de comércio e de indústria, o trabalho dos pobres consegue, pouco a pouco, atrair para si uma porção das terras dos ricos". ${ }^{3}$ Barnave identificava nessa "riqueza mobiliária" o marco do declínio da aristocracia feudal e, consequentemente, o fundamento de numa nova sociedade baseada na liberdade e na igualdade jurídica, uma sociedade que ele entendia por democrática. ${ }^{4}$ A Revolução se explicava, assim, pela necessidade de mudar as instituições políticas sobre as quais a aristocracia feudal se apoiava e, com isso, libertar o comércio e a indústria de suas amarras.

\footnotetext{
1 "[...] dès que les arts et le commerce parviennent à pénétrer dans le peuple et créent un nouveau moyen de richesse au secours de la classe laborieuse, il se prépare une révolution dans les lois politiques; une nouvelle distribution de la richesse produit une nouvelle distribution du pouvoir. De même que la possession des terres a élevé l'aristocratie, la propriété industrielle élève le pouvoir du peuple; il acquiert sa liberté, il se multiplie, il commence à influer sur les affaires" (BARNAVE, Antoine. Introduction à la Révolution française. In: Oeuvres. Paris: J. Chapelle et Guiller, 1843, v.1, pp.13-14).

${ }^{2}$ Barnave foi comprometido pela descoberta, após a jornada de 10 de agosto de 1792, de documentos que o associavam à Coroa. O trecho aqui reproduzido integra, aliás, uma obra escrita na prisão em 1792 e publicada somente em 1843, sob o título Introduction à la Révolution française. O título original dado por Barnave era De la Révolution et de la Constitution.

3 "[...] là où il existe un revenu de commerce et d'industrie, le travail des pauvres parvient peu à peu à attirer à lui une portion des terres des riches" (BARNAVE, Antoine. Introduction à la Révolution française, p.9).

${ }^{4}$ Ibidem, p.31.
} 
A Revolução não resultou somente da liderança de uma burguesia homogênea, mas da ação de diferentes classes e frações, cada uma na luta por seus próprios objetivos: nobres, grandes negociantes, pequenos artesãos, camponeses abastados e diaristas, todos viram naquele momento de convulsão social e política uma oportunidade de concretizar as suas aspirações na nova ordem que estava sendo construída. Objetivamente, o processo revolucionário como um todo resultaria no estabelecimento das condições institucionais necessárias para o desenvolvimento capitalista da França, o qual ocorreria essencialmente a partir da segunda metade do século XIX. ${ }^{5}$

Barnave, entretanto, procurava apresentar a ascensão da classe detentora da propriedade mobiliária como o sinal do advento da democracia. Esse advogado de Grenoble poderia ser um dos "intelectuais" de que falava Karl Kautsky em suas reflexões sobre a luta de classes em 1789, isto é, homens de letras que representavam os interesses de burgueses, apresentando-os sempre como o interesse social geral. ${ }^{6}$ Essa burguesia não apresentava a si mesma como classe, mas como representante da sociedade como um todo. Defensor do ideal de liberdade na metrópole, Barnave foi também, sob a Constituinte, o principal porta-voz dos grupos ligados ao comércio com as colônias francesas, o que o levou a defender, por um lado, os termos do sistema exclusivo e, por outro, o tráfico e a escravidão negra. Para homens como ele, a riqueza gerada pelo comércio de insumos coloniais, produzidos com base na exploração da mão de obra escrava, era uma das bases da nova sociedade democrática em construção. Paradoxalmente, a liberdade que se proclamava na metrópole emanava da privação da liberdade de centenas de milhares de indivíduos nas colônias.

Ao longo dos anos que marcaram a Revolução, a França viu a criação de um regime parlamentar, a proclamação da liberdade de imprensa e da liberdade religiosa, a abolição dos privilégios de ordem e dos direitos senhoriais, o estabelecimento de uma nova organização judiciária e a instituição da liberdade no uso da propriedade. Na sua faceta mais radical, a Revolução promoveu uma certa redistribuição da terra, por meio de medidas como a venda dos bens nacionais. Entretanto, nesse processo de construção

\footnotetext{
${ }^{5}$ Nesse sentido, o que entendemos por revolução burguesa não é a revolução planejada pela burguesia com vistas à criação imediata de uma sociedade capitalista, mas aquela que estabelece as condições necessárias para o desenvolvimento ulterior do capitalismo. Por criação de condições, entendemos a transformação do Estado e de sua expressão normativa, o Direito, cujo papel na reprodução das relações de exploração econômica é fundamental. Christopher Hill desenvolveu semelhante linha de pensamento em Reformation to Industrial Revolution, 1530-1780 (Middlesex/New York: Penguin Books, 1969).

${ }^{6}$ Cf. KAUTSKY, Karl. La lutte des classes en France en 1789. Tradução de Édouard Berth. Paris: Librairie G. Jacques \& Cie, 1901, p.74.
} 
de uma ordem jurídica burguesa, o fim da escravidão nas colônias não seria, no final das contas, incluído. A Declaração dos direitos do homem e do cidadão de 1789 trazia, no seu artigo $1^{\circ}$, o princípio segundo o qual "os homens nascem e permanecem livres e iguais em direitos". Mas a história revolucionária mostrou que essa fórmula clássica do liberalismo político foi capaz de gerar, de imediato, posturas contraditórias entre os diferentes atores históricos do período, que interpretavam os termos liberdade e igualdade à luz de suas próprias aspirações e interesses. Para a maioria dos homens nas assembleias revolucionárias, esses "princípios" encontravam uma fronteira, um limite ditado pela condição da França de potência colonial.

Tradicionalmente, prevalecia no território francês o princípio da liberdade, isto é, a noção de que qualquer escravo que pusesse os pés no solo francês seria considerado livre. Esse princípio, cujas primeiras manifestações remontavam aos séculos XV e XVI, fortaleceu-se, ao longo do tempo, por conta da ação das cortes francesas. Sue Peabody aponta que, ao longo do século XVIII, quando intensificou-se a chegada de escravos nos portos franceses, ocorreram esforços por parte da Administração, pressionada pelos meios ligados ao comércio colonial e preocupada com a proliferação de uma população negra livre na metrópole, em flexibilizar ou mesmo erradicar o princípio da liberdade. Essa tentativa foi, entretanto, neutralizada pelo Parlamento de Paris e o Amirauté de France, que continuaram libertando escravos durante a segunda metade do século XVIII, até a Revolução. ${ }^{7}$ Assim, no final do Antigo Regime, centenas de escravos trazidos por seus senhores como serviçais recorreram, com sucesso, às cortes soberanas francesas para obter, com base no princípio da liberdade, o reconhecimento da sua emancipação. Consagrava-se a noção de que não havia escravos na França.

\footnotetext{
${ }^{7}$ Um edito de outubro de 1716 autorizava senhores a trazer, sob autorização e registro prévios, seus escravos à metrópole para aprender um determinado ofício ou receber educação religiosa, sem que sua propriedade fosse ameaçada. Apenas se as condições não fossem respeitadas, os escravos seriam declarados livres. Uma declaração de 1738 reiterou essa medida, acrescentando somente que, caso as formalidades não fossem cumpridas, os escravos não seriam mais libertados, mas confiscados em nome do rei e devolvidos às colônias. Contudo, nem o edito de 1716, nem a declaração de 1738 foram registrados pelo Parlamento de Paris, corte mais poderosa do país e cuja jurisdição cobria um terço do território. No geral, tais leis não tiveram aplicação. Uma lei de 9 de agosto de 1777, Déclaration pour la police des Noirs, proibia a entrada de todos os negros, mulatos e outras pessoas de cor no reino. A lei não falava em escravos, para evitar a rejeição do registro pelo Parlamento de Paris. Ela estabelecia a criação de depósitos nos portos franceses, onde ficariam detidos os escravos que acompanhassem seus senhores em viagens. As cortes soberanas de Paris mantiveram-se, entretanto, fiéis ao princípio da liberdade e continuaram a julgar pedidos de liberdade, que chegaram ao auge nos anos 1780 (cf. PEABODY, Sue. "There Are No Slaves in France": The Political Culture of Race and Slavery in the Ancien Régime (versão digital). New York: Oxford University Press, 1996, páginas não numeradas).
} 
Mesmo a servidão, que muitos viam como um estágio intermediário entre a escravidão e a liberdade $^{8}$, era uma instituição em vias de extinção, embora ainda subsistisse em algumas províncias, sobretudo no Nordeste do reino. Na noite de 4 de agosto de 1789, a Revolução apagaria os seus últimos traços. Contudo, o longo processo de erradicação das formas de submissão pessoal no continente europeu foi acompanhado pela introdução e a intensificação da exploração da mão de obra escrava nas colônias. Enquanto celebrava-se a liberdade na França, o país tornava-se cada vez mais economicamente vinculado à escravidão colonial e ao tráfico negreiro. No momento em que explodia a Revolução, o dualismo entre "uma dedicação crescente à liberdade, na Europa, e uma expansão do sistema mercantil baseado no trabalho do negro na América"" atingia o seu paroxismo, em razão do sucesso da produção colonial francesa.

Apesar das perdas ocasionadas pela Guerra dos Sete $\operatorname{Anos}^{10}$, as colônias ocupavam um lugar primordial na organização econômica da França do final do século XVIII. As suas posses ultramarinas podiam ser divididas em dois grandes grupos. Havia, em primeiro lugar, um domínio situado além do cabo da Boa Esperança, que incluía cinco comptoirs (feitorias) nas Índias orientais (Pondichéry, Chandernagor, Mahé, Yanaon, Kârikâl), cuja importância comercial era reduzida. No Oceano Índico, as posses mais importantes eram as ilhas Mascarenhas: a Île-de-France (atual Maurício) e a ilha Bourbon (atual Reunião), que possuíam importantes plantações escravistas. Podemos ainda incluir nesse grupo as posses francesas na África, mais precisamente na ilha de Madagascar, estabelecimento destinado à compra de escravos, e alguns territórios na costa ocidental do continente (Saint-Louis do Senegal, a ilha de Gorée e Judá, no atual Benin).

Contudo, consideravelmente mais importantes do que esses territórios orientais e africanos, eram as colônias da América, ou Índias Ocidentais. Elas incluíam, primeiramente, duas ilhas importantes, temporariamente perdidas para os britânicos,

\footnotetext{
${ }^{8}$ Ao contrário do escravo, o servo era sujeito de direito, mas, por conta da mão-morta, ele sofria uma série de limitações que restringiam a sua capacidade de contratar. Assim como o título de propriedade sobre o escravo, os direitos do senhor sobre o servo eram vistos como uma propriedade inviolável (cf. BART, Jean. Esclavage et servage tardif. In: M. DORIGNY (org.). Les abolitions de l'esclavage, de L.F. Sonthonax à V. Schoelcher 1793-1794-1848. Paris: Presses Universitaires de Vincennes / Éditions UNESCO, 1995, p.28).

${ }^{9}$ Cf. DAVIS, David Brion. O Problema da Escravidão na Cultura Ocidental. Rio de Janeiro: Civilização Brasileira, 2001, p.130.

${ }^{10}$ Com o tratado de Paris, de 10 de fevereiro de 1763, a França havia cedido Dominica, Granada, SaintVincent e as Grenadines, a Louisiana, Tobago, Minorca, Acadie, as ilhas de Cap Breton e Saint-Jean e o Canadá.
} 
mas devolvidas pelo Tratado de Paris: a Martinica - até 1740, a mais próspera das colônias francesas - e a Guadalupe, com suas dependências (Marie-Galante, Les Saintes e La Désirade). Havia ainda a ilha de Sainte-Lucie e o arquipélago de Saint-Pierre-etMiquelon, recuperados com o mesmo tratado. No continente, encontrava-se a Guiana, uma pequena e pouco lucrativa colônia, marginalizada num momento em que as ilhas atingiam o seu ápice comercial. Mas, acima de tudo, o império colonial francês girava em torno da "pérola das Antilhas", São Domingos, não propriamente uma ilha, mas parte de uma ilha, a Hispaniola, cujo restante pertencia à Espanha. Era essa colônia que havia projetado a França para o topo do mercado internacional de produtos coloniais. As perdas ocasionadas pela Guerra fizeram com que o comércio marítimo francês se voltasse quase que exclusivamente para as suas ilhas, iniciando uma fase de desenvolvimento vertiginoso. Contando com uma mão de obra de cerca de meio milhão de escravos, São Domingos tornava-se a colônia mais produtiva do mundo. ${ }^{11} \mathrm{O}$ sucesso da produção caribenha era a base da riqueza da burguesia dos portos franceses, detentora da "riqueza mobiliária" que, nos termos de Barnave, constituía o fundamento da sociedade que estava emergindo.

O sucesso da produção colonial não deixava, entretanto, de levantar questões na metrópole a respeito da manutenção da ordem em sociedades construídas em torno da escravidão. Embora nunca tenha sido de fato aplicado, o Code Noir de 1685, a lei da escravidão francesa, já era a tradução de preocupações relativas ao aumento da população escrava nas colônias, aos efeitos do tratamento cruel dessa população e ao consequente crescimento de atos de resistência escrava. Conforme desenvolvia-se o comércio colonial e, consequentemente, aumentava a demanda por mão de obra nas colônias, essas preocupações se intensificaram.

Nas primeiras décadas do século XVIII, as eventuais observações críticas à escravidão e ao tráfico tendiam ainda a ser contrabalançadas pela reiteração de determinadas justificativas que autorizavam essas práticas, tais como a guerra justa, a comutação de uma condenação à pena de morte, a alienação da própria pessoa em caso

${ }^{11}$ Cf. GAUTHIER, Florence. Triomphe et mort du droit naturel 1789-1795-1802. Paris: PUF, 1992, p.155; BÉNOT, Yves. La Guyane sous la Révolution française. Kourou: Ibis Rouge éditions, 1997, p.15; TARRADE, Jean. L'esclavage est-il réformable? Les projets des administrateurs coloniaux à la fin de l'Ancien Régime. In: M. DORIGNY (org.). Les abolitions de l'esclavage, p.11. 
de necessidade extrema e o nascimento na escravidão. ${ }^{12}$ Assim, a escravidão aparecia legitimada por razões religiosas e humanitárias, além de cumprir uma função econômica indispensável. É o que verificamos no seguinte trecho, de Jacques Savary des Brûlons, extraído do seu Dictionnaire universel du commerce (1723-1730):

É difícil justificar totalmente o comércio dos Negros; entretanto, é verdade que esses miseráveis escravos encontram ordinariamente a sua salvação na perda da sua liberdade e que a razão da instrução cristã que lhes é dada, associada à necessidade indispensável que se tem deles para a cultura dos açúcares, dos tabacos, dos anis, etc., suaviza o que parece desumano num negócio onde homens são os mercadores de outros homens e os compram como se fossem animais para cultivar as suas terras [...]. (grifo nosso) ${ }^{13}$

O que era o princípio de uma condenação moral da escravidão encontrava uma compensação imediata na ideia de que a escravização do Negro vinha comumente como a comutação de uma pena de morte decretada em seu país de origem. $\mathrm{O}$ autor citava ainda os benefícios da evangelização dos Negros e o caráter necessário da mão de obra escrava para o cultivo das terras. $\mathrm{O}$ autor fazia apenas uma ressalva quanto aos excessos no tratamento dispensado aos escravos.

Conforme avançamos no século XVIII, verificamos o desenvolvimento de uma crítica mais pronunciada ao sistema escravista. Marcel Dorigny afirma que a década de 1740, em particular, foi marcada por uma "tomada de consciência moral do caráter criminoso do tráfico e da escravidão". ${ }^{14}$ Mas o que essa conscientização mais ou menos generalizada expressava era menos a necessidade de abolir tais instituições do que atentar para os efeitos prováveis das práticas desumanas existentes nas colônias. Ao denunciar o caráter bárbaro da escravidão, pensadores como Montesquieu e Jaucourt indicavam a necessidade de reformar o sistema colonial. Houve, com isso, um deslocamento no debate sobre a questão colonial, com o recuo progressivo, no campo

\footnotetext{
${ }^{12}$ Como explica Carlos Alberto de Moura Ribeiro Zeron, esses títulos foram extraídos da tradição jurídica romana e acabaram sendo retomados pela jurisprudência medieval (cf. ZERON, Carlos Alberto de Moura Ribeiro. Linha de fé. A Companhia de Jesus e a Escravidão no Processo de Formação da Sociedade Colonial (Brasil, Séculos XVI e XVII). Tradução de Antonio de Padua Danesi. São Paulo: Edusp, 2011, p.109).

13 "Il est difficile de justifier tout-à-fait le commerce des Nègres; cependant il est vrai que ces misérables esclaves trouvent ordinairement leur salut dans la perte de leur liberté et que la raison de linstruction chrétienne qu'on leur donne, jointe au besoin indispensable qu'on a d'eux pour la culture des sucres, des tabacs, des indigos, etc., adoucit ce qui paraît inhumain dans un négoce où des hommes sont les marchands d'autre hommes et les achètent de même que des bestiaux pour cultiver leurs terres [...]" (SAVARY DES BRÛLONS, Jacques. Un Négoce où des hommes sont les marchands d'autres hommes. In: L'abolition de l'esclavage. Un combat pour les droits de l'homme. GEORGEL, Chantal (org.). Paris: Éditions Complexe, 1998, p.48).

${ }^{14}$ DORIGNY, Marcel, GAINOT, Bernard. La Société des Amis de Noirs 1788-1799: Contribution à l'histoire de l'abolition de l'esclavage. Paris: UNESCO, 1988, p.16.
} 
escravocrata, das tradicionais justificativas morais, jurídicas e religiosas da escravidão. Entre os adeptos da escravidão, a invocação dos títulos que constituíam o fundamento de uma escravização "legítima" foi, a partir de então, dando lugar à defesa de considerações materiais ou econômicas. Doravante, embora as antigas justificativas continuassem a aparecer, a escravidão começaria a ser defendida essencialmente como um "mal necessário" à conservação das colônias. Em resposta às acusações de barbárie, o interesse dos colonos na conservação de seus escravos seria apresentado como a garantia material de um tratamento justo e humano. Nesse sentido, tornar-se-ia comum o argumento de que os camponeses na França eram mais miseráveis do que os escravos nas colônias. ${ }^{15} \mathrm{O}$ que estava em discussão era menos a legitimidade da escravidão do que a boa ordem colonial.

Após a Guerra dos Sete anos, as questões coloniais ganharam nova urgência. Durante o conflito, a França tinha dado prioridade total às colônias da América do Norte, deixando o Caribe desprotegido. O bloqueio britânico havia cortado o comércio francês com São Domingos em 70\%. A Guadalupe tinha se rendido aos ingleses sem resistência e a Martinica, embora tivesse repelido uma primeira tentativa britânica em 1759, havia seguido o mesmo caminho em 1762. A Guerra suscitou suspeitas recíprocas entre colonos e administração metropolitana. Esta desconfiava da fidelidade dos colonos, enquanto estes projetavam, cada vez mais, libertar-se das amarras do sistema exclusivo. ${ }^{16}$ Ao mesmo tempo, os anos que seguiram a Guerra marcaram o início do auge da produção antilhana, multiplicando a entrada de escravos africanos nas ilhas do Caribe. Nesse contexto, sentia-se a necessidade de repensar o sistema colonial.

Dorigny entende que, a partir da década de 1770, teve início, um novo período na evolução do antiescravismo francês, com "a passagem de uma denúncia moral da escravidão a uma radicalização espetacular do discurso". ${ }^{17}$ No fundo, a radicalização talvez não tenha sido tão espetacular assim, mas, de fato, houve, a partir dos anos 1770, o aparecimento de textos que não se limitavam a denunciar o caráter abominável da

\footnotetext{
${ }^{15}$ Em 1785, um autor anônimo escreveu: "Os Negros das Colônias são muito menos infelizes que os Jornaleiros da Europa, que, não possuindo nada e não podendo contar com nada, existem apenas para temer e sofrer" ("Les Nègres des Colonies sont moins malheureux que les Journaliers de l'Europe, qui, n'ayant rien et ne pouvant compter sur rien, n'existent que pour craindre et souffrir"; Du commerce des Colonies, ses principes et ses lois. La Paix est de temps de régler \& d'agrandir le commerce. S.l: 1785, p.51).

${ }^{16}$ Cf. GARRIGUS, John D. Before Haiti: Race and Citizenship in French Saint-Domingue. New York: Palgrave MacMillan, 2006, pp.111-112; BÉNOT, Yves. La Révolution et la fin des colonies. Paris: La Découverte, 1987, pp.13-14.

${ }^{17}$ DORIGNY, Marcel, GAINOT, Bernard. La Société des Amis de Noirs, p.18.
} 
escravidão e do tráfico, mas que se propunham a explicitar as consequências da manutenção dessas práticas para as colônias e para aqueles que se beneficiavam dessas instituições. Novamente, o objetivo era menos pregar a abolição total da escravidão do que alertar para a necessidade de medidas que atenuassem os seus aspectos mais cruéis e destrutivos. Mas, nesse intuito, surgiram textos que, pela sua virulência, permitiam conceber o "inconcebível": uma insurreição geral dos escravos negros e a obtenção da liberdade pela força. Uma "profetização" dessa insurreição apareceu em L'An deux mille quatre cent quarante, rêve s'il n'en fut jamais (1771), de Louis-Sébastien Mercier, para ser retomada nas segunda e terceira edições da Histoire des deux Indes (1774 e 1780) do abade Raynal. Como veremos adiante, longe de conclamar os negros para uma rebelião geral, tratava-se antes de alertar para os perigos que poderiam ser eventualmente evitados caso reformas fossem promovidas no sistema escravista. Mas essas "profecias apocalípticas" $^{18}$ permitiram também ampliar o campo argumentativo dos críticos da escravidão, autorizando-os a pregar medidas de reforma ou abolição gradual como algo do interesse dos próprios colonos.

As discussões sobre a necessidade de reformar a escravidão não permaneceram confinadas ao plano teórico. Alimentadas por homens afeitos às novas ideias, elas inspiraram as ordenações reais de 1784-85, destinadas a recuperar e complementar as medidas protetivas do Code Noir. É nesse contexto de auge da economia escravista nas colônias, mas também de questionamentos a respeito do funcionamento das sociedades coloniais, que a França ganhou a sua primeira sociedade antiescravista organizada.

No ano de 1788, um grupo reduzido, porém seleto, de nobres, homens de letras e de finanças fundou, na capital francesa, a Sociedade dos Amigos dos Negros. Animada por alguns dos futuros protagonistas da cena política da Revolução, como Brissot, La Fayette, Mirabeau, Condorcet e Clavière, a Sociedade se tornaria o símbolo da opinião antiescravista francesa, desenvolvendo suas atividades em duas fases distintas (1788-92 e 1797-99). No vocabulário da oposição colonial, ser antiescravista significaria ser um Amigo dos Negros.

Os relatos e rumores sobre os trabalhos da Sociedade provocariam, aliás, alarme nas colônias, onde tendia-se a exagerar as intenções e o impacto da propaganda antiescravista. Os Amigos dos Negros seriam vistos como os responsáveis por todas as

\footnotetext{
${ }^{18}$ Ibidem, p. 20.
} 
perturbações existentes no espaço colonial. Conscientes da instabilidade das sociedades escravistas, os colonos viam o surgimento de uma sociedade antiescravista como uma fagulha capaz de detonar uma onda incontrolável de insurreições escravas. No entanto, fomentar movimentos revolucionários nas colônias estava muito longe das intenções dos Amigos dos Negros.

A exemplo do movimento inglês fundado um ano antes e que lhe serviu de inspiração, a Sociedade dos Amigos dos Negros se situava numa linha antiescravista moderada, voltada essencialmente para a abolição do tráfico negreiro. A supressão efetiva da escravidão era concebida apenas num futuro mais ou menos distante, promovida por medidas de emancipação gradual da população escrava. Na base desse programa, havia, ao lado da indignação quanto à barbárie do tráfico e da escravidão, a preocupação fundamental com a capacidade das colônias de se adaptarem a um novo sistema de exploração e reposição da mão de obra, assim como uma preocupação com a inserção produtiva dos negros num regime de trabalho livre. Havia também a projeção de uma ampliação do império colonial francês, a partir de um novo modelo colonial, sem escravidão e voltado para novas relações comerciais com os povos africanos.

Os Amigos dos Negros estavam, portanto, longe de querer a subversão da ordem colonial. De certa forma, eles não estavam distantes da lógica que havia orientado a crítica à escravidão desde meados do século XVIII. Eles se pretendiam uma superação do mero reformismo, na medida em que concebiam, ainda que de forma um tanto vaga, o fim da escravidão nas colônias, mas veremos que, no esforço de acomodar-se às complexidades do contexto revolucionário, sua atitude diante do problema da escravidão tendeu, em certos momentos, a cruzar a fronteira da crítica preservacionista do sistema. Para eles, não se tratava de eliminar o comércio com as colônias, mas de repensar o sistema colonial de uma forma que fosse compatível com a moral, com a estabilidade das sociedades coloniais e com os interesses gerais da Nação.

Fundada às vésperas da Revolução, a Sociedade procuraria levar a sua causa para a Assembleia Nacional, agora fundada em princípios constitucionais de liberdade e igualdade jurídica. Mas mesmo as intenções conciliatórias dos Amigos dos Negros não seriam capazes de superar os obstáculos interpostos pelos representantes dos interesses das colônias e do comércio francês. A história da primeira sociedade antiescravista francesa seria a história de um fracasso. 
À primeira vista, poderíamos pensar que o processo revolucionário de derrubada das instituições do Antigo Regime - e que poderíamos, a posteriori, chamar de précapitalistas - implicava ideologicamente a eliminação da escravidão nas colônias. Politicamente, entretanto, a conversão da oposição à ideia da escravização de seres humanos em tomadas de posição mais concretas sobre as colônias enfrentaria, ao longo do período, obstáculos importantes, quando não intransponíveis. Num momento de sucesso das ilhas do açúcar, poucos eram os que contestavam a importância das colônias para a economia francesa e, para a maioria, não era possível pensar a colonização em outros termos que não os do escravismo. Assim, fazer a defesa da emancipação da mão de obra empregada nas plantations coloniais era algo muito problemático. Num quadro de concorrência com outras potências europeias, especialmente a Grã-Bretanha, alterar a política colonial naquilo que ela tinha de mais essencial era, na prática, pouco viável.

No entanto, com a Revolução, os legisladores se viram imediatamente obrigados a definir as colônias em termos legais, o que levantava o problema de sua incorporação ou não à nova ordem jurídica em construção. A Declaração dos direitos do homem e do cidadão, base da Constituição francesa, implicava, em razão de sua vocação universalista, problemas ligados à manutenção do escravismo nas colônias francesas. Em que medida os princípios nela contidos se aplicavam aos territórios ultramarinos? Essa foi a questão fundamental que orientou os debates sobre as colônias durante a Revolução. No plano do discurso, a Revolução era comumente apresentada como um movimento contínuo, destinado a disseminar o germe da mudança pelos quatro cantos do planeta. Essa percepção encontrava, entretanto, o seu primeiro limite na questão colonial, no argumento de que, aplicada às colônias, a Declaração dos direitos do homem produziria inevitavelmente a sua destruição.

Os debates do período revolucionário sobre a escravidão remetem fundamentalmente ao problema da contradição ou não da ideologia liberal com a prática escravista. As cidades marítimas da França, como Nantes, Bordeaux, La Rochelle, Le Havre e Marselha, representavam perfeitamente a contradição entre a exaltação da liberdade e a defesa de um comércio baseado na escravização e na venda de seres humanos. No caderno de queixas de Bordeaux, produzido por ocasião da convocação dos Estados Gerais, o Terceiro Estado louvava "a liberdade do homem na disposição de sua pessoa, de seus bens e de todas as suas faculdades", pregava o fim dos privilégios e dos direitos senhoriais, ao mesmo tempo em que pedia encorajamentos e a eliminação 
de quaisquer obstáculos ao comércio das colônias, o que significava proteger o tráfico. ${ }^{19}$ Já para os colonos, a Revolução francesa trazia a esperança de uma forma de liberdade de comércio, com o fim ou a atenuação do sistema exclusivo. Ora, para eles, comércio livre estava muito longe de implicar trabalho livre. Para negociantes e colonos, e mesmo para a maioria dos que compunham a Assembleia Constituinte, a concretização da ideologia liberal na metrópole não implicava, ou até mesmo afastava, a sua extensão às posses ultramarinas. Cyril James afirmou que "o comércio de escravos e a escravidão foram a base econômica da Revolução francesa". ${ }^{20}$ A questão da escravidão era embaraçosa para a maioria dos revolucionários, que preferiam cobrir as realidades coloniais com um véu.

Apesar disso, a lei consular de 30 floreal do ano X (20 de maio de 1802), ao restabelecer o tráfico e a escravidão nas colônias francesas, falaria expressamente em restaurá-los tal como eram praticados em 1789 , o que era estranho visto que medidas abolicionistas só foram adotadas em 1793-94. A referência a 1789 não faz sentido a não ser pelo fato de que, a despeito das intenções da maioria da burguesia revolucionária, a Revolução francesa, ao entrar em contato com as realidades coloniais, desencadeou, de imediato, um curso de eventos cujos resultados superaram até mesmo as pretensões dos antiescravistas da metrópole.

Ao chegarem aos territórios ultramarinos, as noções de liberdade e igualdade proclamadas na metrópole foram reinterpretadas e reformuladas pelos diferentes grupos sociais das sociedades crioulas. Para os ricos plantadores de açúcar e café de São Domingos, impactados pela independência dos Estados Unidos, a liberdade significava a possibilidade da restrição ou mesmo do fim do controle metropolitano sobre os assuntos internos e externos da colônia, isto é, autonomia política e liberdade de comércio. Por outro lado, os brancos mais pobres da sociedade colonial, os chamados petits blancs, viram na Revolução uma oportunidade de subverter um quadro social que os mantinha numa posição humilhante nas colônias. Abraçaram a causa patriótica, mas redefinindo-a nos seus próprios termos, o que implicava reforçar a segregação racial. Para um branco sem propriedade e sem talento, a cor branca da pele era o único fator que lhe dava algum status. Inversamente, para os chamados "homens de cor livres", a

\footnotetext{
${ }^{19}$ Cf. AP, v.2, pp.397-405.

${ }^{20}$ Cf. JAMES, C.L.R.. Os jacobinos negros: Toussaint L'Ouverture e a revolução de São Domingos. São Paulo: Boitempo editorial, 2000, p.58.
} 
Revolução representava a possibilidade de pôr fim à segregação e reivindicar a igualdade com os brancos. A história da Revolução de São Domingos-Haiti não começou com um levante de escravos, mas com lutas entre brancos em torno da questão da autonomia legislativa da colônia e lutas entre brancos e "pessoas de cor" a respeito da igualdade dos homens livres de todas as cores. As centenas de milhares de escravos que povoavam a mais rica colônia francesa observavam os acontecimentos e modificavam suas expectativas de acordo com as condições objetivas nas quais se encontravam. A Revolução na metrópole e os seus efeitos na colônia ampliavam os seus horizontes e permitiam conceber uma alteração do estado de opressão no qual se encontravam. A historiografia tem questionado recentemente a existência ou não de uma ideologia abolicionista entre os milhares de escravos que se revoltaram em agosto de 1791. Sabe-se que a atitude dos revoltosos não foi homogênea ao longo da revolução e que a supressão da escravidão como sistema não estava necessariamente nos planos dos primeiros líderes da insurreição. Para alguns escravos, tratava-se de ampliar a margem de autonomia existente dentro da escravidão; para outros, a revolta era a possibilidade de garantir a liberdade pessoal, sem, entretanto, que a emancipação geral fosse concebida. Como mostrou David Geggus em seus estudos sobre Toussaint Louverture $^{21}$, a própria atitude do grande líder negro não é fácil de decifrar e sofreu variações de acordo com o momento. O que se pode afirmar é que cada reviravolta na história da revolução levava os revoltosos a alterar a sua percepção das coisas e seus objetivos à luz dos acontecimentos. Objetivamente, a insurreição de agosto de 1791 evoluiu, no espaço de dois anos, para uma luta pela abolição e, mais tarde, pela independência.

Assim, se os conflitos entre as diferentes camadas da sociedade escravista já germinavam muito antes do período revolucionário, um fator exógeno - a Revolução na França - exacerbou as contradições existentes no seio dessa sociedade e abriu a via para a derrubada da ordem estabelecida. ${ }^{22}$ Da mesma forma, os eventos ocorridos no espaço colonial alteraram a percepção que se tinha na metrópole da questão da escravidão. A insurreição massiva dos escravos em São Domingos, um acontecimento visto como improvável pelos antiescravistas moderados da Sociedade dos Amigos dos Negros, também abriu a via para que a Revolução evoluísse rumo à abolição da escravidão.

\footnotetext{
${ }^{21}$ Cf. GEGGUS, David Patrick. Haitian Revolutionary Studies: Blacks in the Diaspora. Bloomington, IN: Indiana University Press, 2002, pp.119-136.

${ }^{22}$ Cf. CARDOSO, Ciro Flamarion Santana. Agricultura, escravidão e capitalismo. $2^{\mathrm{a}}$ edição. Petropolis: Vozes, 1982, p.103.
} 
Como veremos ao longo deste trabalho, não se deve, entretanto, ver as atitudes na metrópole diante da escravidão unicamente como uma resposta à evolução dos acontecimentos na colônia. Fenômenos históricos são pluricausais e, no caso da história colonial da Revolução francesa, fatores internos e externos se combinaram constantemente para produzir reviravoltas na esfera política. Primeiramente, não se deve jamais esquecer que a história da França revolucionária é a história de um país em guerra e que as decisões mais importantes tomadas durante o período traduziam, em parte, as flutuações da situação militar. Da mesma forma, a situação política na metrópole é um fator frequentemente desprezado pela historiografia dedicada aos temas coloniais e, no entanto, trata-se de um elemento fundamental para a compreensão da política colonial da Revolução. Nesse sentido, a atuação do movimento popular, cuja influência sobre as esferas de poder foi, em muitos momentos, capital, não pode ser esquecida. A abolição da escravidão, proclamada em 16 pluvioso do ano II (4 de fevereiro de 1794), muitas vezes interpretada como "lei de circunstância" ou como um "paradoxo histórico", deve ser compreendida à luz das condições objetivas existentes nas colônias e na metrópole.

Apesar da enorme quantidade de panfletos e projetos produzidos durante o período sobre a questão colonial, esta foi praticamente omitida das grandes narrações da Revolução francesa. Autores simpáticos ao Antigo Regime, como Pierre Gaxotte ou Charles Maurras, decidiram ignorar o tema, talvez incomodados em explicitar a escravidão colonial como uma das bases econômicas do Estado absolutista. Mas também autores republicanos, como o "dantonista" Jules Michelet e os da tradição marxista (Albert Mathiez, Georges Lefebrevre, Albert Soboul), dedicaram um espaço ínfimo aos eventos que marcaram a página colonial da Revolução. Isso talvez traduza a dificuldade em acomodar as atitudes das assembleias revolucionárias diante do problema da escravidão a uma determinada visão da revolução liberal e burguesa. Apenas Jean Jaurès abordou o tema, destacando que, longe de ser um aspecto secundário da Revolução, o problema colonial era revelador de suas contradições: "A burguesia revolucionária ficou presa, na questão colonial, entre o idealismo da Declaração dos Direitos e os interesses de classe mais brutais, os mais tacanhos". ${ }^{23}$

\footnotetext{
${ }^{23}$ "La bourgeoisie révolutionnaire fut prise, dans la question coloniale, entre l'idéalisme de la Déclaration des Droits et les intérêts de classe les plus brutaux, les plus bornés" (JAURÈS, Jean. Histoire socialiste de la Révolution Fra\çaise. 2a edição. Paris: Éditions de la Librairie de l'Humanité, 1927, v.2, p.209).
} 
Contudo, o autor da Histoire socialiste de la Révolution française inexplicavelmente silenciou a respeito da lei de abolição de 16 pluvioso do ano II. Para Carolyn Fick, o pequeno lugar que a questão da escravidão e da abolição tradicionalmente ocupou na historiografia da Revolução pode expressar:

[...] a inabilidade dos próprios revolucionários franceses em confrontar diretamente a questão da escravidão nas assembleias legislativas, e fazê-lo francamente em nome dos princípios que guiavam a revolução - isto é, os princípios universalistas de liberdade e igualdade. ${ }^{24}$

Como veremos, a atitude das assembleias não resultou apenas de uma mera "inabilidade", mas o fato é que a questão da escravidão mostrou-se, durante muito tempo, incômoda aos estudiosos da Revolução francesa. Foi necessário que se desenvolvesse, à margem das grandes interpretações da Revolução, uma linha historiográfica voltada especificamente para a questão colonial. Por muito tempo, as narrativas da Revolução de São Domingos-Haiti constituíram a principal fonte de reflexão sobre o problema colonial. A Histoire de la révolution de Saint-Domingue (publicada em 1814), escrita por Antoine Dalmas, antigo colono do Norte de São Domingos, talvez seja o mais antigo relato da grande insurreição escrava. Apesar dos partis pris do autor, a obra mantém o seu interesse por ter sido supostamente composta no calor dos eventos.

Em meados do século XIX, essa mesma história foi objeto de importantes narrações por parte de pioneiros historiadores haitianos, como Thomas Madiou (cf. Histoire d'Haïti, 1847-48) e Beaubrun Ardouin (cf. Études sur l'histoire d'Haïti, 185360). Suas contribuições se inscreviam numa ótica nacionalista que procurava enfatizar o papel das grandes lideranças da Revolução, apresentado-as como personagens portadores das aspirações de liberdade de toda a raça negra. ${ }^{25}$

No final do século XIX e no início do século XX, outros autores dedicaram-se a analisar os efeitos da Revolução francesa na questão colonial, caso de Herbert E. Mills

\footnotetext{
24 "[...] the inability of the French revolutionaries themselves to confront the issue of slavery head on in the legislative assemblies, and to do so forthrightly in the name of those principles guiding the revolution - that is, the universalists principles of liberty and equality" (FICK, Carolyn. The French Revolution in Saint-Domingue. A Triumph or a Failure. In: D.B. GASPAR (orgs). A Turbulent Time: the French Revolution and the Greater Caribbean. Bloomington: Indiana University Press, 1997, p.52).

${ }^{25}$ A partir de meados da década de 1940, desenvolveu-se no Haiti uma outra vertente historiográfico com maior conotação social. Um dos expoentes dessa nova corrente, Jean Fouchard, dedicou-se, por exemplo, ao estudo da resistência marron desde antes da grande insurreição de 1791 (cf. HECTOR, Michel. L'historiographie haïtienne après 1946 sur la Révolution de Saint-Domingue. Annales historiques de la Révolution française, Paris, n.293-294, 1993, pp.545-549. Disponível em: http://www.persee.fr/web/revues/home/prescript/article/ahrf_0003-4436_1993_num_293_1_3395.
} Acesso em: 4 de jun de 2013). 
(cf. The Early Years of the French Revolution in San Domingo, 1892) e Pierre Boissonnade (Saint-Domingue à la veille de la Révolution française et la question de la représentation coloniale aux États Généraux, 1906). Victor Schoelcher, o homem da abolição de 1848, abordou o tema em sua biografia de Toussaint Louverture (cf. Vie de Toussaint Louverture, 1899), enquanto Adolphe Cabon dedicou à Revolução a maior parte dos quatro volumes de sua Histoire d'Haïti (1895-1919). Já Lothrop Stoddard dedicou The French Revolution in San Domingo (1914) a uma abordagem da Revolução haitiana enquanto guerra racial. No mesmo ano, T.G. Steward, um militar, empreendeu nova narrativa da revolução, com o mérito de destacar o protagonismo dos escravos no processo de emancipação e independência (cf. The Haitian Revolution, 1791-1804).

No que se refere especificamente à atuação das assembleias revolucionárias da metrópole, pode-se mencionar trabalhos como Les colonies pendant la Révolution française (1898), de Léon Deschamps, e The French Colonial Question, 1789-1791 (1918), de Mitchell Bennett Garrett, ambos restritos aos debates coloniais da Assembleia Constituinte. Os volumes que compõem La colonisation française pendant la Révolution (1930), de J. Saintoyant, talvez tenham sido os primeiros a oferecer uma análise mais ampla - embora pouca profunda - sobre o conjunto da política colonial da Revolução.

A reflexão sobre o tema ganhou um forte impulso, fora da França, com a publicação de Os Jacobinos Negros (1938), do marxista nascido em Trininad, e radicado na Inglaterra, Cyril Lionel Robert James. Trata-se, ainda hoje, da mais influente narração dos eventos que marcaram a Revolução haitiana e suas repercussões na França revolucionária. A despeito de alguns erros factuais e generalizações que exigem certo cuidado por parte do leitor, a obra permanece incontornável por sua qualidade literária e pela análise consistente das forças históricas - em especial, o embate entre as classes - que pesaram sobre os agentes das revoluções haitiana e francesa.

Nessa mesma época, o francês Gabriel Debien esforçou-se em renovar os estudos sobre o Caribe com abordagens quantitativas sobre as plantations escravistas de São Domingos antes da Revolução. Suas conclusões seriam posteriormente reunidas na sua principal publicação, L'esclavage aux Antilles françaises (XVIIe-XVIIIe siècles) (1974). Antes disso, entretanto, ele ofereceu uma importante contribuição ao estudo da política colonial do período revolucionário com Les colons de Saint-Domingue et la Révolution: Essai sur le Club Massiac (1953), obra bastante detalhada sobre o 
movimento de pressão dos colonos pela defesa do escravismo num contexto de agitação política.

Mais tarde, o encontro das revoluções na França e em São Domingos foi o objeto de reflexão do poeta e militante político martinicano Aimé Césaire, em Toussaint Louverture: la Révolution française et le problème colonial (1962), obra em que a questão colonial aparece como o problema crucial da Revolução francesa. Ao mesmo tempo, Césaire procurou apresentar a Revolução em São Domingos como uma força autônoma e não como uma mera decorrência dos eventos da metrópole: uma ideia importante para estabelecer a especificidade da insurreição dos escravos, mas que não deve levar ao desprezo da relação dialética existente entre as duas revoluções, a da metrópole e a da colônia. Charles Frostin, por outro lado, pouco escreveu sobre o período que nos interessa, mas ofereceu um importante estudo sobre as tendências secessionistas da população branca de São Domingos nos dois séculos que precederam a Revolução (cf. Les révoltes blanches à Saint-Domingue aux XVIIe et XVIIIe siècles, 1975), aspecto relevante para a compreensão do quadro político e social no qual se deu a insurreição escrava. Já o historiador norte-americano Eugene Genovese dedicou a sua obra From Rebellion to Revolution: Afro-American Slave Revolts in the Making of the Modern World (1979) a uma reflexão sobre o caráter inovador do caso haitiano na história das rebeliões escravas. Genovese desenvolveu a ideia de um salto qualitativo na ideologia da resistência escrava, sob o impacto da Revolução na metrópole, passando do "restauracionismo" a uma ideologia revolucionária burguesa e democrática. ${ }^{26}$ Embora a formulação tenha os seus limites, ela estabeleceu as bases para o debate, ainda atual, sobre a ideologia dos escravos em revolta.

As contribuições citadas acima tornaram-se referências para as discussões sobre a Revolução e as colônias. Um verdadeiro fluxo de publicações sobre o tema, entretanto, viria a partir da agitação em torno do bicentenário da Revolução francesa. A exaltação da primeira abolição da escravidão, de 1794, foi inscrita na ordem do dia das celebrações, muito embora a lei tenha conhecido uma vida curta e uma aplicação pouco efetiva. Com isso, muitos autores dedicaram-se a refletir sobre a postura das assembleias revolucionárias diante do problema colonial. Yves Bénot, por exemplo, procurou, em La Révolution française et la fin des colonies (1987), resgatar o papel das Luzes e dos antiescravistas no longo processo que levou à abolição. Embora

\footnotetext{
${ }^{26}$ Cf. GENOVESE, Eugene. Da rebelião à revolução. São Paulo: Global, 1983, pp.14-18.
} 
reconhecesse o papel fundamental da insurreição escrava no processo, Bénot sustentou que, para que a Convenção tomasse a decisão de abolir a escravidão, sob o impacto dos eventos em São Domingos, era necessário "um quadro de pensamento previamente constituído, e que o papel daqueles que por muito tempo gritaram no deserto é, nesse sentido, capital". ${ }^{27}$ Procuraremos mostrar, entretanto, que, se o papel das ideias no processo político não deve ser rejeitado, é acima de tudo o exame das condições e das práticas (o peso econômico e político da burguesia mercantil, a situação nas colônias, os movimentos de revolta escrava, a guerra entre as nações europeias, a composição das assembleias, a pressão do movimento popular parisiense) que deve nortear o olhar do historiador, na medida em que ora propulsionam, ora neutralizam a conversão das ideias em ação política concreta.

Numa outra linha, herdeiros da tradição jacobina, historiadores como Florence Gauthier, Jean-Daniel Piquet e Claire Blondet dedicaram-se a recuperar o papel da Convenção montanhesa e dos robespierristas no processo abolicionista. Muito bem documentado, L'émancipation des Noirs dans la Révolution française (2002), de JeanDaniel Piquet, teve o grande mérito de destacar a transição, durante a Revolução, do antiescravismo moderado para o abolicionismo propriamente dito, com uma penetração maior dos ideais abolicionistas nos meios populares. $\mathrm{O}$ autor exagera apenas ao querer identificar um abolicionismo militante entre a cúpula do governo do ano II, sem perceber que talvez mais importante do que as convicções desses homens era o conjunto de fatores - em especial, a atuação das massas populares, coloniais e metropolitanas que informavam as suas ações. Nesse sentido, vale destacar o trabalho de Jean-Claude Halpern, que dedicou-se a estudar o envolvimento popular na questão colonial a partir das manifestações de apoio à lei de abolição. ${ }^{28}$

Claude Wanquet e Bernard Gainot, por outro lado, dedicaram-se à política colonial da Convenção thermidoriana e do Diretório. Gainot destacou a ação das correntes republicanas (ou "neojacobinas") sob o Diretório e seu combate contra os adeptos da restauração da ordem escravocrata nas colônias. No caso de Wanquet, a ênfase foi dada ao caso das ilhas Mascarenhas. Em La France et la première abolition de l'esclavage 1794-1802: le cas des colonies orientales, o autor abordou a atuação dos

\footnotetext{
${ }^{27}$ Cf. BÉNOT, Yves. La Révolution et la fin des colonies, p. 18.

${ }^{28}$ Cf. HALPERN, Jean-Claude. L'universel et le lointain. Les mondes exotiques dans la culture populaire, à la fin du XVIIIème siècle. History of European Ideas, v.15, n.4-6, 1992, pp.767-772; Idem. Les fêtes révolutionnaires et l'abolition de l'esclavage en l'an II. In: M. DORIGNY (org.). Les abolitions de l'esclavage, de L.F. Sonthonax à V. Schoelcher 1793-1794-1848. Paris: Presses Universitaires de Vincennes / Éditions UNESCO, 1995, pp.187-198.
} 
representantes da Île-de-France e da Reunião (Bourbon) sob a Convenção, o Diretório e os primeiros anos do Consulado, destacando a sua habilidade em usar as ambiguidades da política colonial revolucionária e as clivagens nas esferas de poder para impedir a aplicação da lei de abolição nesses territórios.

Sobre a evolução do problema colonial sob o Consulado e o Império, deve-se mencionar La démence coloniale sous Napoléon (1992), de Yves Bénot. O autor procurou caracterizar a política colonial de Bonaparte sob a ótica da formação de uma ideologia racista, contrapondo-a a uma corrente antiescravista pouco incisiva e cujas ambiguidades prenunciavam uma segunda onda de colonização. O que não fica claro na obra é como a política colonial de Bonaparte se insere no quadro mais geral das bases políticas e econômicas do regime consular e de que forma ela se relaciona com a reconstituição de um grupo de interesse ligado ao comércio colonial. Uma tentativa de elucidar essas questões foi empreendida em Napoléon, l'esclavage et les colonies (2006), de Pierre Branda e Thierry Lentz, ainda que não de forma totalmente conclusiva.

Recentemente, em The Old Regime and the Haitian Revolution (2012), Malick Ghachem trouxe novas perspectivas, ao aplicar à questão colonial a ideia de Tocqueville de uma continuidade entre o Antigo regime e a Revolução. $\mathrm{O}$ autor dedicou-se a mostrar a sobrevivência da lógica precaucionária por trás do Code Noir no discurso sobre a escravidão das Luzes, na legislação revolucionária e até mesmo na ideologia das lideranças negras. Ghachem é bastante preciso na sua caracterização da crítica preservacionista à escravidão, muitas vezes confundida pela historiografia com um abolicionismo autêntico. Por outro lado, o autor talvez vá um pouco longe nos paralelos traçados entre o Code Noir, a Declaração dos direitos do homem e do cidadão, a lei de abolição e a Constituição de Toussaint Louverture. Ainda que seja, de fato, possível reconhecer traços da legislação do Antigo Regime nessas leis, os seus significados e finalidades essenciais guardam elementos de ruptura que não se pode negligenciar.

No que se refere à história da Revolução haitiana, o movimento de produção intelectual foi ainda mais intenso. Na França, Jacques Thibau trouxe, em Le temps de Saint-Domingue: l'esclavage et la Révolution française (1989), uma interessante abordagem do processo que levou à insurreição de agosto de 1791. Seu relato se inicia com a narração do famoso caso Lejeune, senhor acusado pela tortura e morte de duas escravas na São Domingos dos anos 1780, espécie de prenúncio dos eventos que marcariam a colônia durante a Revolução. Thibau alterna o relato da insurreição com a 
descrição do impacto desses eventos nas discussões parlamentares na metrópole. Com isso, pretende mostrar "o encontro entre a Revolução francesa e a escravidão francesa". ${ }^{29}$ Infelizmente, o autor não incluiu a abolição de 1794 na sua obra.

Foi, entretanto, entre os historiadores da América do Norte que os estudos sobre São Domingos e o Caribe em geral tiveram uma maior evolução. A canadense Carolyn Fick dedicou-se, com The Making of Haiti (1990), a revisitar a grande insurreição escrava sob a ótica da tradição do marronnage (fuga de escravos) nas colônias, numa linha semelhante à adotada pelo haitiano Jean Fouchard na década de 1970 (cf. Les marrons de la liberté, 1972). A abordagem possui alguns limites, cuidadosamente apontados por David Geggus ${ }^{30}$, mas a obra é incontornável pela sua análise sempre lúcida das posturas dos negros diante da revolução e da abolição. A autora teve ainda o mérito de enfatizar a evolução dos acontecimentos no Sul de São Domingos, província até então pouco estudada pelos historiadores do período.

Por falar em David Geggus, devemos a ele uma série de reflexões críticas sobre diversos temas relativos a São Domingos-Haiti, muitas delas reunidas na coletânea Haitian Revolutionary Studies: Blacks in the Diaspora (2002), que permitem a superação de estereótipos e generalizações reiteradas na historiografia, sobretudo no que se refere à investigação das mentalidades e aspirações dos negros insurretos. Por fim, é preciso citar a obra de Laurent Dubois, autor de narrações importantes sobre a Guadalupe (A Colony of Citizens, 2004) e São Domingos (Avengers of the New World, 2005) durante a Revolução. Suas contribuições nos ajudam a compreender de que forma as diferenças fundamentais entre as duas colônias (grau de integração ao mercado, dimensão e estrutura da população escrava, importância da população de cor livre) estão relacionadas aos resultados nelas produzidos pela Revolução.

Parte importante da historiografia tem se dedicado ao tema dos homens de cor livres das colônias francesas, aspecto fundamental para a compreensão da dinâmica da Revolução haitiana. Inspirados pelo trabalho pioneiro de Yvan Debbasch, alguns autores têm direcionado seus esforços para a tese da racialização das relações sociais e jurídicas em São Domingos, na segunda metade do século XVIII. John D. Garrigus trouxe, em Before Haiti: Race and Citizenship in French Saint-Domingue (2006), uma nova visão sobre o tema, ao abordar a construção de uma linha de cor entre brancos e os

\footnotetext{
${ }^{29}$ Cf. THIBAU, Jacques. Le temps de Saint-Domingue: l'esclavage et la Révolution française. Paris: J.-C. Lattès, 1989 , p.7.

${ }^{30}$ Cf. GEGGUS, David Patrick. Haitian Revolutionary Studies, capítulos 2 e 5.
} 
chamados mulatos da principal colônia francesa como forma de fortalecer os vínculos da população branca com a metrópole, na esteira das tensões que marcaram a Guerra dos Sete Anos. A abordagem é original e válida, ainda que acreditemos ser necessário aliar essa explicação a outras mais tradicionais, que encaram o preconceito como instrumento de controle ideológico da população escrava e de contenção da ascensão social dos proprietários de cor num momento em que as colônias conheciam novas levas de imigração branca. Essas teses, que encontram amparo na documentação da época revolucionária, já eram defendidas por Gwendolyn Midlo Hall, em Social Control in Slave Plantation Societies (1971). ${ }^{31}$ A obra de Garrigus tem, entretanto, o mérito de destacar a particularidade da população de cor do Sul de São Domingos, que se caracterizava por uma maior integração à elite crioula. Essa distinção é importante para caracterizar as atitudes de Julien Raimond, um importante quadrarão do Sul da ilha, e seu movimento pelos direitos de cidadania dos livres de cor durante a Revolução.

Em L'aristocratie de l'épiderme. Le combat de la société des citoyens de couleur 1789-1791 (2007), Florence Gauthier contornou essa distinção e procurou descrever a atuação dos homens de cor livres na França revolucionária como uma luta pelo fim do preconceito e até mesmo da escravidão. Embora bem documentada, a sua reflexão procura atribuir ao movimento liderado por Julien Raimond um combate pela totalidade dos homens de cor e negros livres da colônia. A história do período mostra, ao contrário, que havia entre a população de cor livre diferentes atitudes diante de questões como preconceito e escravidão.

No que se refere ao antiescravismo propriamente dito, encontramos uma série de estudos centrados na evolução da crítica à escravidão na Era Moderna. A obra de David Brion Davis, O problema da escravidão na cultura ocidental (1966), continua sendo uma referência essencial sobre a evolução intelectual do pensamento antiescravista. Demonstrando uma invejável erudição, o autor procurou demonstrar o peso da religião - forte no caso inglês - e do Iluminismo na formação do pensamento antiescravista. Contudo, a abordagem proposta por Davis pode induzir a uma concepção puramente idealista da história do antiescravismo, caso não seja completada pelo estudo das condições que fizeram com que determinadas ideias se difundissem em determinado tempo e espaço. Verificamos esse problema em trabalhos dedicados a evidenciar a relação entre as Luzes e o antiescravismo, sem vincular a evolução das ideias a uma

\footnotetext{
${ }^{31}$ Cf. HALL, Gwendolyn Midlo. Social Control in Slave Plantation Societies: a comparison of St. Domingue and Cuba. Baltimore, Londres: The John Hopkins Press, 1971, pp.136-148.
} 
evolução das práticas sociais. Tende-se, com isso, a apresentar, o movimento de ideias como um prelúdio à formação de sociedades antiescravistas organizadas, o que não é falso, desde que se entenda a formação desses movimentos como parte de uma evolução condicionada por fatores conjunturais e estruturais.

De resto, verifica-se, sobretudo na literatura de língua francesa, uma tendência à exaltação da postura iluminista diante da escravidão, apesar de todas as suas ambiguidades. Jean Ehrard, por exemplo, procurou resgatar o antiescravismo das Luzes, atribuindo as eventuais contradições diante do problema da escravidão a uma dualidade do discurso, em que uma prudência prática viria contrabalançar a audácia da crítica à escravidão. Da mesma forma, autores como os já mencionados Jean-Daniel Piquet e Yves Bénot não questionam o antiescravismo das Luzes e chegam a reconhecer nele uma incontornável postura anticolonialista. ${ }^{32}$ Tal interpretação é bastante problemática, visto ser difícil encontrar, até mesmo entre os abolicionistas mais radicais do período revolucionário, um abandono da postura colonial. Além disso, a distinção entre a crítica preservacionista da escravidão, o antiescravismo gradualista e o abolicionismo propriamente dito tende a se perder nessa linha de análise.

Louis Sala-Molins ofereceu uma visão mais crítica, questionando de forma virulenta o antiescravismo das Luzes (cf. Les misères des Lumières. Sous la raison l'outrage, 1992), ainda que fazer o julgamento moral dos Filósofos talvez não seja a melhor forma de situá-los no debate colonial. Nesse sentido, a citada obra de Malick Ghachem, ao ressaltar a reiteração de uma lógica precaucionária na crítica à escravidão, reveste-se de grande importância para a compreensão da literatura antiescravista do final do século XVIII.

Todos os temas mencionados acima ainda encontram-se, no momento em que escrevemos este trabalho, em pleno desenvolvimento. Um turbilhão de novas publicações têm, a cada ano, enriquecido o debate sobre a questão colonial, o que mostra que algumas questões ainda permanecem abertas. A Sociedade dos Amigos dos Negros, por exemplo, atraiu pouco interesse por parte dos historadores do período, que tenderam a desprezá-la como uma fraca contrapartida da sociedade antiescravista inglesa surgida um ano antes. Tratados de forma marginal nas obras sobre as revoluções francesa e haitiana, os Amigos dos Negros foram objeto de poucos trabalho específicos.

${ }^{32}$ Cf. BÉNOT, Yves. La Révolution et la fin des colonies, pp.7-9, 12, 18. PIQUET, Jean-Daniel. L'émancipation des Noirs dans la Révolution française (1789-1795). Paris: Éditions Karthala, 2002, pp.24-26. 
No início do século XX, a Sociedade foi abordada em, pelo menos, dois artigos: "Condorcet et la Société des amis des Noirs" (1906), de Léon Cahen, e "La Société française des Amis des Noirs" (1916), de Claude Perroud. Décadas mais tarde, o tema foi abordado em textos de Daniel Resnik (cf. "The Société des Amis des Noirs and the abolition of Slavery", 1972), Serge Daget (cf. "A Model of the French Abolitionist Movement", 1980) e Françoise Thésée (cf. "Autour de la Société des Amis des Noirs: Clarkson, Mirabeau et l'abolition de la traite, août 1789 - mars 1790", 1983). Já Seymour Drescher (cf. dois artigos, "Two Variants of Anti-Slavery: Religious Organization and Social Mobilization in Britain and France, 1780-1870"; "British Way, French Way: Opinion Building and Revolution in the Second French Emancipation") abordou o tema em estudos que procuraram contrapor os Amigos dos Negros a um modelo abolicionista "anglo-americano", abordagem problemática, tendo em vista que os antiescravistas franceses e britânicos se inscreviam ambos numa mesma lógica gradualista e moderada. Quaisquer diferenças entre as duas correntes devem ser situadas na especificidade do momento histórico de cada país.

Devemos a Marcel Dorigny e Bernard Gainot a principal contribuição ao estudo da entidade, com a publicação de La Société des Amis de Noirs 1788-1799: Contribution à l'histoire de l'abolition de l'esclavage (1988), uma compilação do registro das sessões das duas fases dos Amigos dos Negros e outros documentos, com textos introdutórios produzidos pelos autores. Embora tenham empreendido uma breve - e nem sempre convincente - análise do programa e do funcionamento da Sociedade, a partir de dados extraídos do registro (atas das sessões, composição, frequência), os textos não pretendem oferecer uma reflexão profunda sobre o antiescravismo da época revolucionária. Dorigny, entretanto, voltou ao tema com um valioso artigo, "Mirabeau et la Société des Amis de Noirs: quelles voies pour l'abolition de l'esclavage?" (1995), em que destacou a especificidade da argumentação de Mirabeau no seio dos Amigos dos Negros, aspecto que exploraremos na primeira parte da tese. Mais recentemente, a Sociedade foi finalmente objeto de um livro específico, graças a Jean-Pierre Barlier, a quem devemos La Société des Amis des Noirs, 1788-1791: Aux origines de la première abolition de l'esclavage (2010). Infelizmente, pouco documentado, o estudo se limita à primeira formação da Sociedade, destacando os principais aspectos de sua atuação. Se ele reconhece as contradições do discurso dos Amigos dos Negros sobre a escravidão, Barlier não oferece propriamente explicações que permitam relacionar tais contradições a aspectos estruturais da França do final do século XVIII. De resto, o autor procura 
sustentar um suposto "papel motor" que a Sociedade teria desempenhado na evolução que levou à Revolução haitiana e, portanto, à abolição. ${ }^{33}$ Assim, ainda sentimos falta, no que se refere aos Amigos dos Negros, de uma interpretação que possa integrar diferentes níveis de observação e oferecer elementos para a reconstituição de uma lógica histórica ${ }^{34}$ capaz de explicar a Revolução francesa e suas atitudes diante da escravidão. Assim, acreditamos que, apesar do enorme volume editorial relativo aos temas apontados, algumas questões merecem ser revistas e aprofundadas.

Embora conduzida em nome de princípios universais de liberdade e igualdade jurídica, a Revolução acabaria, apesar do episódio da abolição de 1794, incorporando a escravidão colonial à nova ordem jurídica. Por que a Revolução não foi capaz de resolver essa contradição? Em outros termos, por que os princípios sobre os quais se construía a nova sociedade não foram estendidos aos territórios coloniais? O que isso nos diz sobre a Revolução como um todo? A questão colonial evidencia, sob certos aspectos, os limites - geográficos, mas também políticos e econômicos - da revolução liberal e burguesa feita na metrópole. Dentro da ótica mercantilista que havia orientado a economia francesa desde o século XVII, a prosperidade da Nação era associada a uma balança comercial favorável e, nesse sentido, o papel do comércio com as colônias e da reexportação dos produtos proporcionados por esse comércio era visto como capital. Apesar dos ataques dos economistas e fisiocratas aos sistemas de monopólios característicos do mercantilismo, a noção de que o futuro da França dependia da sua capacidade de exportação mantinha-se absolutamente viva no momento em que explodia a Revolução. Não foi a política colonial das Assembleias revolucionárias o retrato de uma nação que, no mesmo momento em que promovia mudanças profundas em suas instituições, mostrava-se incapaz de pensar a si mesma em termos outros que os da política mercantilista do Antigo Regime? Essa é a ideia que procuramos desenvolver ao longo deste trabalho.

Tomamos como ponto de apoio o tema do antiescravismo sob a Revolução francesa, na medida em que encontramos nele, de certa forma, a reiteração de determinadas concepções a respeito da França enquanto potência colonial e mercantil. O programa gradualista da Sociedade apontava para uma superação progressiva do modelo

\footnotetext{
${ }^{33}$ Cf. BARLIER, Jean-Pierre. La Société des Amis des Noirs, 1788-1791: Aux origines de la première abolition de l'esclavage (4 février 1794). Paris: Éditions de l'Amandier, 2010, p.149.

${ }^{34}$ Cf. THOMPSON, E.P. A miséria da teoria. Tradução de Waltensir Dutra. Rio de Janeiro: Zahar, 1981, p.47.
} 
de exploração colonial baseado na escravidão e no tráfico, concepção que tinha no seu âmago a promoção de uma certa ideia da ordem colonial. Num momento em esta só era concebida na França, sob a influência do poderoso partido formado por colonos e negociantes dos portos, pela ótica do escravismo, os Amigos dos Negros viram-se confrontados a obstáculos intransponíveis. A atitude conservadora que assumiram diante das notícias da insurreição escrava em São Domingos traduzia também a sua incapacidade de superar essas contradições. Nesse sentido, os limites do programa antiescravista dos Amigos dos Negros estão intimamente relacionados às razões de seu fracasso. Veremos que a abolição de 16 pluvioso do ano II (4 de fevereiro de 1794) se explica pela superação momentânea desses limites, motivada por circunstâncias excepcionais que será preciso analisar cuidadosamente. Inversamente, a restauração da escravidão e do tráfico sob o Consulado expressaria o retorno e a prevalência da lógica mercantilista que havia orientado a vida econômica francesa desde os tempos de Colbert.

A página colonial da Revolução é, assim, uma história em três movimentos, os quais irão nortear a organização do presente trabalho. No intuito de compreender como a Revolução na metrópole confrontou a escravidão nas colônias, para finalmente acomodar-se a ela, propomos um estudo centrado na evolução do antiescravismo durante o período, na esperança de que a compreensão dos seus limites nos conduza à compreensão das razões que determinaram a aceitação pela França revolucionária do status quo colonial.

Teremos na formação da Sociedade dos Amigos dos Negros o nosso ponto de partida e no restabelecimento da escravidão por Bonaparte - símbolo do fracasso final da corrente antiescravista do final do século XVIII - o ponto de chegada. Entre esses dois extremos, a insurreição dos escravos em São Domingos e a abolição de 1794 funcionarão como uma espécie de contraprova da lógica maior que orientou a história colonial da Revolução. Em razão do recorte temporal extenso que adotamos, cobrindo o período revolucionário inteiro e os primeiros anos do Consulado, limitamo-nos, por restrições de tempo, ao antiescravismo francês, sem integrar ao nosso estudo o movimento britânico, cujos laços com a Sociedade dos Amigos dos Negros teriam permitido alargar o nosso campo de análise. Uma análise de conjunto dos diferentes movimentos de contestação e derrubada da escravidão nas colônias das potências europeias foi empreendida com brilhantismo por Robin Blackburn (cf. Queda do 
Escravismo Colonial, 1988, e, mais recentemente, The American Crucible: Slavery, Emancipation and Human Rights, 2011).

Na primeira parte deste trabalho, procuraremos, antes de tudo, traçar, ainda que de forma sumária, um quadro geral da economia francesa no final do século XVIII, destacando o lugar ocupado pelo comércio colonial no desenvolvimento do reino, etapa fundamental para compreender as atitudes dos diferentes agentes diante da questão da escravidão. Será necessário também caracterizar a evolução das mentalidades no seio da Administração quanto ao problema das colônias, visto que as mudanças ocorridas nas duas últimas décadas do Antigo Regime haviam motivado questionamentos a respeito da necessidade de reformas no sistema colonial. É nesse contexto preciso que deve-se situar o surgimento da Sociedade dos Amigos dos Negros.

A Sociedade ocupará boa parte deste primeiro segmento. Analisaremos o seu processo de formação, a sua composição, organização e funcionamento. Dedicaremos uma maior atenção à análise do programa da entidade, de caráter moderado e gradualista. Para caracterizá-lo, procuraremos situá-lo no quadro da evolução da crítica à escravidão do século XVIII. Estamos cientes do risco de apresentar o desenvolvimento do pensamento antiescravista como um mero prólogo ao antiescravismo propriamente dito. ${ }^{35}$ É certo que as duas coisas estão vinculadas, mas a reconstrução desse elo perde o seu sentido se não forem analisadas as condições históricas nas quais ela se deu. A Sociedade dos Amigos dos Negros pode efetivamente ser vista como parte da evolução da crítica à escravidão que se iniciou em meados do século XVIII, mas não se deve jamais abandonar a percepção de que essa evolução, assim como a própria formação da Sociedade, se deu sob a influência de transformações operadas no espaço colonial e na metrópole e que informaram a reflexão sobre a escravidão.

Concluiremos a primeira parte da tese com o exame da atuação dos Amigos dos Negros na primeira fase da Revolução, sob a Constituinte. Isso implicará examinar duas questões em particular. Em primeiro lugar, veremos como a Sociedade, em concordância com seu programa, procurou apresentar, sem sucesso, uma moção contra

\footnotetext{
${ }^{35}$ Christopher Brown apontou a diferença existente entre: 1) a história da ideologia antiescravista (desenvolvimento de ideais e valores hostis à escravidão); 2) a história do abolicionismo (cristalização de programas para reformar ou transformar a política colonial); 3) história da abolição (análise do processo político e das forças que levaram à mudança política). Brown entende que, embora esses temas estejam vinculados, seus objetos exigem abordagens distintas (BROWN, Christopher Leslie. Moral Capital: Foundations of British abolitionism. Chape Hill: The University of North Carolina Press, 2006, pp.1718). No caso francês, isso é particularmente verdadeiro, pois há uma descontinuidade entre a história dos Amigos dos Negros e a história da abolição de 16 pluvioso do ano II.
} 
o tráfico de escravos perante a Assembleia Nacional. Isso nos levará a examinar de que forma se articulou a oposição constituída por colonos e mercadores, dentro e fora da Assembleia, para neutralizar as ações dos Amigos dos Negros, valendo-se da percepção mais ou menos generalizada de que o comércio colonial tal como era praticado constituía um dos fundamentos econômicos da Nação.

Em seguida, veremos como, incapazes de levar adiante a luta contra o tráfico, os Amigos dos Negros se voltaram para a questão dos homens de cor livres das colônias, fazendo da luta contra o preconceito a sua principal frente de combate. Será interessante observar como, no intuito de convencer a Assembleia da necessidade do reconhecimento dos direitos de cidadania dos negros e mestiços livres, os Amigos dos Negros paradoxalmente recorreram a argumentos preservacionistas da ordem colonial escravista.

O segundo movimento da história colonial da Revolução, que ocupará a segunda parte desta tese, tem como evento fundador a extraordinária insurreição dos escravos em São Domingos. Não cabe, nos limites deste trabalho, fazer uma reconstituição detalhada da Revolução haitiana, já empreendida por especialistas na história colonial (C.L.R. James, Laurent Dubois, Carolyn Fick). O tema deve, entretanto, ser abordado em razão do impacto que a insurreição produziu sobre a percepção que se tinha na metrópole do problema colonial. É a partir desse evento que a política colonial da Revolução sairia ainda que temporariamente - da sua lógica inicial para incorporar o princípio da emancipação geral. Traçaremos, numa breve introdução, um quadro geral da sociedade e da economia de São Domingos no final do século XVIII, no intuito de situar a insurreição no seu contexto preciso.

Essa abordagem permitir-nos-á inserir em nossa análise um outro nível de observação, o dos escravos. Recentemente, o historiador português João Pedro Marques esteve no centro de um debate a respeito da ideologia abolicionista dos escravos. Suas posições, assim como as respostas de diferentes historiadores, foram reunidas na coletânea Who Abolished Slavery? Slave Revolts and Abolitionism: a debate with João Pedro Marques (2010). Contestando as visões teleológicas que procuram ver em quaisquer atos de resistência escrava uma oposição à escravidão como sistema, Marques vê o caso de São Domingos como um marco na história das revoltas escravas, onde um levante por melhores condições de servidão evoluiu, pela primeira vez, para uma forma 
de luta abolicionista. ${ }^{36}$ Não temos a pretensão de elaborar uma reflexão geral sobre o conjunto das revoltas escravas da Era Moderna, mas procuraremos nos posicionar sobre o caso específico de São Domingos, sobretudo no que se refere às relações entre as duas revoluções, a da metrópole e a da colônia, verificando de que forma uma repercutiu na outra.

Mostraremos como os Amigos dos Negros reagiram diante da insurreição, apresentando-a tão somente como uma prova da necessidade de aliar os homens de cor livres à ordem, por meio do reconhecimento de seus direitos. A grande e última conquista da primeira formação da Sociedade, a lei de 24 de março de 1792, nada teve a ver com a abolição do tráfico ou a emancipação dos negros. No entanto, no momento em que as atividades da primeira formação dos Amigos dos Negros chegavam ao fim, formava-se paralelamente uma corrente antiescravista alternativa e radical, capaz de estabelecer um elo entre a revolução das massas da metrópole e a luta dos negros nas colônias. Veremos como, no contexto da radicalização do processo político metropolitano e da guerra na Europa, essa opinião antiescravista se difundiu em esferas antes alheias ao debate colonial. No quadro do governo radical do ano II, em que a primazia dos interesses do capital mercantil se viu neutralizada pelas exigências de um movimento popular bastante atuante na luta contra os privilégios das classes possuidoras, a Revolução rumou para a abolição. O objetivo maior deste segmento será mostrar como se constituíram os diversos fatores que levaram à abolição da escravidão, proclamada pela Convenção em 16 pluvioso do ano II (4 de fevereiro de 1794). Isso permitirá um afastamento das interpretações que tenderam a privilegiar uma explicação única para essa decisão que contrariava totalmente a política colonial da primeira fase da Revolução. Apenas num contexto excepcional tal medida poderia ser tomada.

Na terceira e última parte desta tese, veremos justamente como a desconstrução dos fatores que haviam tornado a abolição possível e necessária permitiu a sua revogação. Esse processo se deu gradualmente, ao longo da Convenção thermidoriana e do Diretório, para se completar apenas sob o Consulado. Veremos como os adeptos da restauração escravista reconstituíram o lobby colonial na esteira do 9 thermidor ( 27 de julho de 1794), detonando uma ofensiva contra a aplicação da lei de abolição. Eles se valeram das dificuldades encontradas pelos agentes franceses na execução do decreto

\footnotetext{
${ }^{36}$ Cf. MARQUES, João Pedro. Slave Revolts and the Abolition of Slavery: An Overinterpretation. In: DRESCHER, Seymour, EMMER, Pieter C. (eds.). Who Abolished Slavery? Slave Revolts and Abolitionism: a debate with João Pedro Marques. Oxford, New York: Berghahn Books, 2010, pp.24-25.
} 
para alegar a impossibilidade de uma colonização sem escravos. Veremos também como se articulou a resistência a essa ofensiva, com o ressurgimento da Sociedade dos Amigos dos Negros. Sem renegar o princípio gradualista, os Amigos dos Negros dedicaram-se então a defender uma abolição que acreditavam ser irreversível, ao mesmo tempo em que pensaram a transição das economias escravistas para um regime de trabalho supostamente livre. Acima de tudo, eles priorizaram a formulação de projetos de ampliação do império colonial francês, agora sobre novas bases.

A rápida neutralização dos novos Amigos dos Negros e das demais vozes favoráveis à abolição, no momento em que se anunciava o 18 brumário, pode ser vista como um prenúncio da política colonial consular, que ocupará o restante da terceira parte. Será necessário caracterizar o novo regime e suas bases de apoio para compreender as atitudes de Bonaparte diante do problema colonial. O quase silêncio da opinião abolicionista num momento em que a propaganda escravista ganhava um novo fôlego é uma evidência dos rumos que a França tomava naquele momento de consolidação da obra revolucionária. É com a restauração da escravidão, promovida pela lei de 30 floreal do ano X (20 de maio de 1802) e outras medidas análogas, que concluiremos o nosso relato.

Para reconstituir os eventos que marcaram o período, nós recorremos a uma certa variedade de documentos. No que se refere especificamente à Sociedade dos Amigos dos Negros, é preciso, mais uma vez, destacar o mérito de Marcel Dorigny e Bernard Gainot, a quem devemos a publicação do registro com as atas das sessões das duas formações da entidade. Essa documentação, aliada às petições, cartas e libelos publicados pela Sociedade nos permitiu reconstituir a sua organização, o seu funcionamento e as bases de seu programa. Outros elementos vieram da análise das memórias, dos papéis e da correspondência de Brissot, principal líder da Sociedade. Para identificar a composição da Sociedade, recorremos ao registro e às listas de membros por ela produzidos, cujas lacunas procuramos suprir, na medida do possível, por meio do recurso à bibliografia, à coleção Biographie universelle ancienne et moderne e a recursos eletrônicos especializados em genealogia.

Para traçar a evolução da política colonial da Revolução, as coleções dos Archives Parlementaires e do Moniteur Universel permitiram reconstituir os debates nas assembleias. Da mesma forma, a compilação das atas do Comitê de Salvação Pública (Recueil des actes du Comité de salut public) ofereceu-nos uma perspectiva dos 
trabalhos do órgão executivo máximo do governo do ano II. Encontramos nos documentos do clube dos Jacobinos, reunidos por Aulard (La Société des Jacobins Recueil de documents pour l'histoire du club des Jacobins de Paris), elementos para entender de que forma os debates sobre a questão colonial se estendiam para outras esferas de debate. Já os manuscritos do fundo da Câmara de comércio de Nantes, reunido nos Archives Départementales de Loire Atlantique (ADLA), nos ajudaram a compreender como se articulavam politicamente as cidades marítimas na defesa de seus interesses sob a Revolução. Para o período consular, o recurso à correspondência de Bonaparte permitiu reconstruir o processo de restauração da escravidão nas colônias francesas.

Acima de tudo, o núcleo de nossa investigação consistiu no exame dos numerosos panfletos, libelos e jornais publicados durante o período, por antiescravistas assim como por seus opositores, conservados, na sua maioria, no acervo da Biblioteca Nacional Francesa. Foi o recurso a essa documentação que nos permitiu traçar o quadro evolutivo da difusão - mas também da neutralização - dos ideais antiescravistas na França revolucionária, onde a questão colonial assumiu as feições de um debate público. Isso nos levou a reconhecer o papel da opinião pública no processo histórico.

Temos consciência de que o conceito de opinião pública é bastante controverso. Se o uso dessa expressão era recorrente na França do final do século XVIII, ele não deixa de suscitar interrogações sobre a existência real de um espaço público de discussão, assim como sobre o uso ideológico do conceito. De acordo com o modelo habermasiano, muito difundido desde os anos 1960, a existência de uma verdadeira opinião pública ficaria circunscrita dentro de uma cronologia precisa: ela teria nascido na sociedade inglesa do final do século XVII e começaria a degenerar já na primeira metade do século XIX. ${ }^{37}$ Fora desse recorte, o uso da expressão seria, portanto, anacrônico. São contrárias ao modelo de Habermas tanto a visão naturalista, segundo a qual a opinião pública sempre existiu, quanto a visão dos que, como Pierre Bourdieu, entendem que ela é uma construção usada para fins de manipulação política. Não temos a pretensão de resolver esse debate. Contudo, dada a vasta circulação de jornais, libelos e brochuras direcionados a um público amplo, o surgimento de clubes de pensamento e associações com finalidades políticas, o final do século XVIII caracterizava-se, de fato, pela existência de espaços contíguos de opinião que praticamente permitiram que

\footnotetext{
${ }^{37}$ Cf. HABERMAS, Jürgen. L'espace public: Archéologie de la Publicité comme dimension constitutive de la société bourgeoise. Tradução de Marc B. de Launay. Paris: Payot, 1978, pp.25-37 e 183-198.
} 
determinadas ideias assumissem a condição de crenças de caráter coletivo. No período revolucionário, atingir diferentes esferas de opinião tornava-se uma ferramenta essencial para influir no processo político.

Para o conjunto da Revolução, fala-se em mais de 1.400 títulos de jornais e periódicos diferentes e esse número provavelmente não é definitivo. A tiragem da maioria dos jornais não chegava aos mil exemplares, mas alguns títulos atingiram o patamar de 10 mil, caso do Patriote Français, jornal de Brissot e principal veículo dos Amigos dos Negros. Ouzi Elyada estima em 300 mil o número de exemplares de jornais distribuídos diariamente sob a Revolução. Cada exemplar era lido, em média, por quatro pessoas, o que significa que cerca de 1,2 milhões de pessoas estavam expostas cotidianamente ao conteúdo veiculado pela imprensa. E esses números levam em conta apenas a tiragem para assinantes e não a venda nas ruas, que era mais importante. Além disso, graças à leitura coletiva nos cafés, cabarés, bistrôs, cabinets de lecture, clubes políticos e sociedades populares, a audiência dos periódicos ultrapassava em muito o círculo dos assinantes e a população alfabetizada. Jornais como Les Révolutions de Paris e Le Père Duchesne, por exemplo, eram particularmente populares entre a sansculotterie parisiense. Ainda mais eficazes do que os jornais como instrumento de propaganda eram os panfletos, cuja produção não dependia de uma estrutura complexa de publicação e permitiam uma reação mais rápida aos eventos, sendo produzidos no mesmo dia em que estes ocorriam. ${ }^{38}$ Não se tratava mais, portanto, de tratados destinados a uma elite erudita, mas de uma massa de escritos voltados para um público amplo e implicado nos acontecimentos que se desenvolviam no país.

O povo da metrópole, em especial o da capital, não era um mero espectador, mas um agente ativo do processo revolucionário, provocando, por meio da sua intervenção, mudanças bruscas no status quo. Os diferentes partidos e facções manifestaram, por meio de suas publicações, a consciência de que a intervenção das massas a favor ou contra um determinado projeto era um fator não negligenciável. A análise do movimento editorial em torno da questão da escravidão permite medir as tendências, em cada momento da Revolução, a favor ou contra uma determinada causa. O estudo desse material requer certo cuidado, pois, na medida em que o debate colonial assumiu comumente a forma de troca de acusações e campanhas de difamação, os documentos

\footnotetext{
${ }^{38}$ Cf. ELYADA, Ouzi. La modification de l'hégémonie médiatique pendant la Révolution française: le livre face à la presse. In: M. BIARD et alii (orgs). La plume et le sabre. Paris: Publications de la Sorbonne, 2002, pp.78-85; Atlas de la Révolution française. E. Ducoudray, R. Monnier, D. Roche (orgs). Pairs: Éditions de l'École des Hautes Études, 2000, v.11, pp.80-81.
} 
contêm frequentemente um grande número de falsidades e distorções. Cada documento deve, é claro, ser lido à luz de seu contexto preciso.

Esperamos que o estudo dessas fontes nos tenha permitido trazer à luz alguns elementos de resposta para a difícil questão da relação entre a Revolução, a sua ideologia liberal e a escravidão colonial. 


\section{Parte I}

A Revolução francesa diante da escravidão negra (fevereiro de 1788 - setembro de 1791) 


\section{I.1) A Sociedade dos Amigos dos Negros}

\section{I.1.1) Uma sociedade antiescravista às vésperas da Revolução}

\section{I.1.1.1) O comércio colonial no quadro da economia francesa}

A evolução do antiescravismo na França deve ser compreendida à luz das transformações que ocorreram no país e em suas colônias ao longo de todo o século XVIII. Interpretações mais tradicionais procuraram atribuir a formação de uma opinião antiescravista e, consequentemente, de uma sociedade antiescravista na França ao desenvolvimento da crítica iluminista à escravidão colonial. Se o impacto dessa corrente intelectual sobre a história do antiescravismo do período revolucionário é inegável, não se deve jamais esquecer que a formação de movimentos de ideias não se dá no vazio, que ela se encontra sempre amparada em determinadas práticas sociais e que as condições materiais objetivas exercem um papel fundamental na evolução que tais ideias encontram entre os agentes históricos. Formada às vésperas da grande Revolução, a Sociedade dos Amigos dos Negros foi o produto de um contexto específico, marcado por transformações e questionamentos no seio da sociedade francesa.

A França, a exemplo de muitos países europeus, tinha se enriquecido ao longo do século XVIII. O seu produto físico bruto, entre os decênios 1701-1710 e 1786-1795 tinha sido multiplicado por 2,8. Essa tendência tinha sido particularmente pronunciada a partir dos anos 1750, em grande parte, por conta do crescimento populacional, mas também em razão do aumento da produção. No que se refere à estrutura do produto interno bruto, de acordo com os números levantados por Jean-Claude Toutain para o período 1781-1790, teríamos, para um produto de 5.941 milhões de libras tornesas, a seguinte distribuição: 2.424 milhões para a agricultura (40,8\%), 2.200 milhões para a indústria (37\%) e 1.317 milhões para os serviços $(22,2 \%)$, o que incluía o comércio. A economia francesa ainda conhecia, portanto, a primazia da produção agrícola, mas o fato é que a parte desta na produção total do país tinha diminuído durante o período, em razão das maiores taxas de crescimento observadas na indústria e no comércio. ${ }^{39}$ Assim, se a França ainda era essencialmente um país agrário, com quase $80 \%$ de sua população

\footnotetext{
${ }^{39}$ Cf. TOUTAIN, Jean Claude apud DAUDIN, Guillaume. Commerce et prospérité. La France au XVIIIe siècle. Paris: Presses de l'Université Paris-Sorbonne, 2005, pp.23-51.
} 
vivendo nos campos, a economia do país passava por algumas mudanças estruturais que repercutiam na organização da sociedade.

A produção agrícola aumentava, mas ainda esbarrava nos direitos comunitários camponeses e no regime feudal da propriedade, que impediam a modernização da produção, ao impor o pastoreio coletivo sobre os campos abertos em pousio e ao neutralizar grande parte das receitas sob a forma de tributos senhoriais. Em seus relatos de viagem pela França do final do século XVIII, Arthur Young descreveu o estado de profundo atraso da agricultura francesa, onde a ausência de investimentos em gado e tecnologias de irrigação e drenagem tornava a terra pouco produtiva. Young calculava que havia entre a Inglaterra e a França uma diferença de 450 milhões de libras, em termos de capital investido na agricultura. Com exceção da cultura de vinhos, que vivia o seu auge, a agricultura francesa via-se incapaz de atender a demanda de uma população em expansão, razão pela qual o país viu-se obrigado a importar cerca de 145 milhões em produtos agrícolas por ano, ao longo da década de $1780 .{ }^{40} \mathrm{Se}$, na Inglaterra, as enclosures tinham permitido uma modernização do cultivo do solo, na França, apenas a Revolução libertaria a propriedade fundiária dos entraves ao uso mais intensivo da terra.

$\mathrm{Na}$ indústria, o crescimento ao longo do século XVIII foi mais pronunciado. Alguns setores mostravam uma força particular, como o agroalimentar, o madeireiro, a metalurgia e, sobretudo, o têxtil, que, a partir de 1759, com a proclamação da liberdade de fabricação de tecidos, conheceu um crescimento acentuado, chegando a atingir quase a metade da produção industrial francesa. O setor metalúrgico tinha visto o surgimento de grandes sociedades por ações, como Le Creusot, dotada de um maquinário importante. O fato, entretanto, é que os produtos franceses ainda não conseguiam competir com os da Inglaterra, país que estava muito mais avançado em seu processo industrializante. A produção inglesa tinha sido impulsionada pela concentração e a introdução de novas tecnologias, como a máquina a vapor. Na França, a inovação tecnológica também ocorria, mas num ritmo muito mais lento. Barreiras corporativas e regulamentos burocráticos entravavam a inovação técnica, de modo que o país encontrava-se meio século atrasado em relação à Inglaterra. No têxtil, por exemplo, a mecanização se dava de forma tardia, o que dava aos produtos franceses a reputação de

\footnotetext{
${ }^{40}$ Cf. YOUNG, Arthur. Travels, during the years 1787, 1788, and 1789. Undertaken more particularly with a view of ascertaining the cultivation, wealth, resources, and national prosperity of the Kingdom of France. London: J. Rackham for W. Richardson, 1792, pp.429-431 e 489-494.
} 
serem de qualidade inferior. Na maioria dos casos, o tratamento da matéria-prima era bastante antiquado, praticamente sem divisão do trabalho: um mercador fazia trabalhar operários que tinham de produzir os fios manualmente, por conta própria e sem assistência, ao passo que, na Inglaterra, os trabalhadores já eram reunidos em unidades produtivas maiores e máquinas (jennys) e animais eram utilizados até mesmo nos vilarejos. ${ }^{41} \mathrm{Na}$ França do final do século XVIII, havia a certeza de que os produtos franceses não podiam competir com os britânicos, de melhor qualidade e menos custosos. No plano econômico, a Europa continental encontrava-se em atraso em relação à economia britânica, que tirava grande parte de sua força da existência de um mercado interno de consumo. O inglês consumia, por exemplo, dez vezes mais açúcar que o francês. ${ }^{42}$

Invejosos da superioridade industrial britânica, homens da elite esclarecida, como Philippe d'Orléans, projetavam uma modernização do país: foi ele o primeiro a introduzir a máquina a vapor como força motriz. Da mesma forma, industriais britânicos, como Wilkinson, vinham instalar-se na França e traziam consigo tecnologias ainda desconhecidas no país. ${ }^{43}$ Mas, antes que esses esforços permitissem ao país tornar-se realmente competitivo, veio o catastrófico Tratado franco-inglês de 1786, que abriu o comércio entre os dois países, por meio da redução drástica dos direitos de alfândega sobre os produtos manufaturados em metal e sobre os têxteis.

O tratado era a aplicação das teses liberais dos Economistas, como o fisiocrata Dupont de Nemours, grande inspirador da medida, e voltava-se, portanto, contra a tradição protecionista da França. O tratado sofreu enorme oposição dos manufatureiros franceses, incapazes de suportar a concorrência dos produtos britânicos, muito superiores em qualidade e mais baratos. Para homens como Holker, fabricante de tecidos de algodão instalado na França, mesmo a taxação era insuficiente; apenas a proibição da entrada de produtos britânicos podia salvar a indústria têxtil francesa. Ainda assim, o Tratado, obra de teóricos, foi assinado sem consulta dos interessados.

\footnotetext{
${ }^{41}$ Em 1789, estimava-se o número de jennys na França em 900, contra 20.000 na Grã-Bretanha (cf. LEFEBVRE, Georges. La Révolution Française. 5a edição. Paris: Presses Universitaires de France, 1963, p.40).

${ }_{42}$ Cf. SOBOUL, Albert. Histoire de la Révolution française. Paris: Gallimard, 1962, v.1, pp.45-47; LEFEBVRE, Georges. La Révolution Française, pp.36-43; SÉE, Henri. L'évolution commerciale et industrielle de la France sous l'Ancien Régime. Reimpressão da edição de 1925. Genebra: Slatkine Reprints, 1980, pp.299-305; JOUVENEL, Bertrand de. Napoléon et l'économie dirigée. Le blocus continental. Bruxelas, Paris: Les Éditions de la Toison d'Or, 1942, pp. 41-42, 49-50; YOUNG, Arthur. Travels, during the years 1787, 1788, and 1789, pp.49-50.

${ }^{43}$ Cf. JOUVENEL, Bertrand de. Napoléon et l'économie dirigée, pp.43-44; YOUNG, Arthur. Travels, during the years 1787, 1788, and 1789, p.90.
} 
Imediatamente, produtos ingleses abundaram nos mercados franceses, desequilibrando a balança comercial: segundo Young, para o ano de 1788, o comércio com a Inglaterra gerou uma balança negativa de 29.480 .130 de libras para a França. Os efeitos foram graves: já em 1787, os fabricantes de lençóis de Sedan afirmaram, em petição ao Conselho de Comércio, que, em razão da concorrência britânica, 9 mil dos 15 mil operários da região já estavam desempregados. Revoltados, muitos fabricantes aguardavam uma guerra contra a Inglaterra que permitisse uma volta ao protecionismo. Esses homens apoiariam a declaração de guerra de fevereiro de $1793 .^{44}$

Se a França era, assim mesmo, vista como a única real concorrente da Inglaterra no plano econômico, isso se devia fundamentalmente ao seu comércio. O setor comercial foi o de crescimento mais rápido na economia francesa do século XVIII. Note-se que o comércio interno progredia, mas ainda era insuficiente. Isso podia ser atestado pela deficiência da circulação interna no país. Se, na Inglaterra, o tráfego interno era largamente favorecido pela existência de uma rede de canais aptos à prática da cabotagem, na França, o tráfico fluvial era reduzido ou quase nulo. Apenas dois canais eram operacionais (Midi e Flandres), com três outros ainda não terminados. Os rios eram subutilizados. A rede de estradas também era muito incompleta e, embora tivessem sofrido uma melhora nas últimas décadas do século, as vias internas ainda eram pouco utilizadas. Arthur Young relatou, com espanto, em suas viagens pela França, a quase inexistência de tráfego, mesmo nas novas e modernas estradas do país. Não havia praticamente circulação interna, razão pela qual também as estalagens e hotéis franceses eram de baixa qualidade se comparados aos ingleses. Para piorar, havia alfândegas e tributos de passagem que dificultavam a circulação de mercadorias entre as províncias. O comércio de vinho era particularmente gravado por tributos: os vinhos que eram transportados do Orléanais à Normandia, por exemplo, chegavam majorados de vinte vezes, pelo menos, o seu preço, por conta dos numerosos direitos que tinham de ser pagos durante o trajeto. Também existia a proibição de exportar trigo de uma província para outra sem uma permissão especial, que era difícil de conseguir. Young afirmou que "os Franceses devem ser o povo mais estacionário da Terra [...]". ${ }^{45}$

\footnotetext{
${ }^{44}$ Cf. JOUVENEL, Bertrand de. Napoléon et l'économie dirigée, pp.45-51; YOUNG, Arthur. Travels, during the years 1787, 1788, and 1789, pp.58, 73 e 500-501.

${ }^{45}$ Cf. YOUNG, Arthur. Travels, during the years 1787, 1788, and 1789, pp.15, 30-33, 39-40, 61; LEFEBVRE, Georges. La Révolution Française, p.39; KAUTSKY, Karl. La lutte des classes en France en 1789, pp.57-59.
} 
Mais importante do que isso era o fato de que, em razão da distribuição da grande maioria da população em pequenas aldeias de menos de mil habitantes e do estado de carência em que se encontrava a população camponesa no final do século, o comércio francês tinha dificuldades em encontrar mercados no interior das fronteiras do país. Massacrados pelas cobranças senhoriais e fechados em si mesmos, os camponeses franceses não consumiam. Fabricavam domesticamente tudo o que precisavam para viver. Mesmo os mais abastados preferiam investir em terras e construções. Pouco mais de um quinto da população morava nas cidades, que eram incapazes de estimular a circulação interna de pessoas e produtos. Embora a população francesa fosse duas vezes maior do que inglesa, o mercado francês era estreito, pois apenas 5 a 6 milhões de citadinos estavam em condições de comprar. Os operários das manufaturas, mal remunerados, tampouco constituíam um fator de dinamismo para mercado interno. ${ }^{46}$ Como diz Lefebvre, os estados europeus, com a exceção da Inglaterra ${ }^{47}$, não formavam propriamente mercados nacionais. ${ }^{48} \mathrm{~A}$ indústria francesa tendia, assim, a produzir artigos de luxo (tecidos de seda, veludo, tapetes, porcelana), voltados para a exportação. ${ }^{49}$ Se o comércio francês tinha conhecido um forte crescimento, isso se devia essencialmente ao comércio exterior.

Dentro da ótica mercantilista, o poder do estado dependia de suas reservas em ouro e prata, de tal forma que, para aumentar as espécies monetárias em circulação, era preciso exportar a maior quantidade possível de bens e importar uma quantidade menor. Esse sistema impunha, assim, a adoção de medidas protecionistas, que taxassem fortemente as importações e, ao mesmo tempo, estimulassem as exportações. Dentro dessa lógica, o consumo interno era substancialmente menos importante para a Nação do que a sua capacidade de manter uma balança comercial favorável.

Na segunda metade do século XVIII, essa política havia mostrado resultados expressivos. O comércio exterior francês tinha passado de 600 milhões de libras

\footnotetext{
${ }^{46}$ Cf. YOUNG, Arthur. Travels, during the years 1787, 1788, and 1789, p.18, 503-504; JOUVENEL, Bertrand de. Napoléon et l'économie dirigée, pp.29-30

${ }^{47}$ Ao longo do século XVIII, o comércio interno se desenvolveu fortemente na Inglaterra. A reforma das estradas e o desenvolvimento da navegação interna tiveram efeitos notáveis na circulação de mercadorias. Progressivamente, os mercados internos começaram a se aproximar e grandes centros comerciais surgiram na vizinhança de aglomerações manufatureiras, como Manchester. Esse processo foi fundamental para a constituição da grande indústria nas últimas décadas do século (cf. MANTOUX, Paul. La révolution industrielle au XVIIIe siècle. Paris: Éditions Génin, 1959, pp.91-119).

${ }^{48}$ Cf. LEFEBVRE, Georges. La Révolution Française, p.26.

${ }^{49}$ Cf. KAUTSKY, Karl. La lutte des classes en France en 1789, pp.61-62.
} 
tornesas em 1750 para 1.153 milhões em $1787 .{ }^{50}$ Esse aumento tinha sido, em parte, favorecido pelo aumento da produção manufatureira: entre 1716 e 1787, o crescimento da exportação de produtos fabricados tinha sido de $221 \%$, contribuindo para um aumento global de $298 \%$ das exportações francesas. ${ }^{51}$ Mas o verdadeiro elemento-motor do comércio francês no final do Antigo Regime, era o comércio colonial.

Um dos principais eixos da política mercantilista residia no comércio com as colônias, submetido ao sistema do exclusivo, segundo o qual apenas os negociantes e armadores franceses podiam importar escravos e mercadorias nas ilhas e, reciprocamente, apenas esses mesmos negociantes tinham o direito de comprar os produtos coloniais e importá-los na França. Às vésperas da Revolução, o comércio com as colônias representava cerca de $40 \%$ de todo o comércio francês e grande parte do que a metrópole recebia alimentava as suas exportações para o continente europeu. Após a perda do Canadá com a Guerra dos Sete Anos, o comércio marítimo francês tinha se voltado fundamentalmente para as ilhas da América: Martinica, Guadalupe e, sobretudo, São Domingos, cujas exportações anuais em 1788 giravam em torno de 200 milhões de libras $^{52}$ e cuja população escrava ultrapassava a barreira de 500 mil. $^{53}$ A produção de açúcar e café haviam feito da ilha a colônia mais cobiçada do mundo. Na Inglaterra, o comércio colonial também ocupava um lugar de destaque na economia, mas, ao contrário da França, o país consumia praticamente a totalidade das produções provenientes do Caribe britânico. A França reexportava a maior parte dos produtos coloniais para o mercado europeu, sobretudo para a Alemanha e a Holanda. ${ }^{54}$ Entre 1785 e 1789, cerca de $90 \%$ do café, $70 \%$ do açúcar e $75 \%$ das commodities coloniais foram reexportadas pela França, que assumia as feições de um grande entreposto

\footnotetext{
${ }^{50}$ Esse número inclui cerca de 612 milhões em importações e 542 milhões em exportações. Essa balança era, contudo, reequilibrada pelo fato de que grande parte dos produtos importados era reexportada. Assim, cerca de dois terços dos produtos vindos das colônias eram vendidos no continente europeu (cf. THIBAU, Jacques. Le temps de Saint-Domingue, p.72).

${ }^{51}$ Cf. SOBOUL, Albert. Histoire de la Révolution française, v.1, pp.46-47.

${ }^{52}$ De acordo com diferentes estatísticas, a exportações de São Domingos para a França representavam 174.615.766 ou 213.438.394 libras. Quanto às exportações da França para a colônia, os números variam entre 86.414.040 e 104.193.625 libras (cf. WIMPFFEN, Alexandre-Stanislas de. Haïti au XVIIIe siècle. Richesse et esclavage dans une colonie française. Pierre Bluchon (org.). Paris: Karthale, 1993, Anexo II, p.296). Robert Stein fala numa média de 178 milhões em exportações de açúcar para a França, para o período 1784-90 (cf. STEIN, Robert Louis. The French Sugar Business in the Eighteenth Century. Baton Rouge, Londres: Louisiana University Presss, 1988, p.97).

${ }^{53}$ Cf. DAVIS, David Brion. O Problema da Escravidão na Cultura Ocidental, p.179.

${ }^{54}$ Cf. BERBEL, Márcia, MARQUESE, Rafael, PARRON, Tâmis. Escravidão e Política: Brasil e Cuba, 1790-1850. São Paulo: Hucitec, Fapesp, 2010, p.41; STEIN, Robert Louis. The French Sugar Business in the Eighteenth Century, p.100.
} 
comercial. Os produtos do Caribe correspondiam a metade das exportações francesas. ${ }^{55}$ A França havia se tornado a maior produtora e revendedora de insumos coloniais no mundo.

Assim, naquele fim de século, o comércio marítimo, embora por vezes descrito como uma empresa "aventureira", gerava importantes lucros e estava na origem de grandes fortunas. Em 1664, um sistema de monopólio havia sido estabelecido em favor de companhias de comércio para as Índias Ocidentais e Orientais, mas esse privilégio teve vida curta, dada a incapacidade de tais empresas de atender a demanda das colônias, que viam-se obrigadas a recorrer a contrabandistas franceses e estrangeiros. ${ }^{56}$ As cartas patentes de janeiro de 1716 abriram oficialmente o tráfico de escravos a todos os armadores franceses dos cinco maiores portos do país: Rouen, Saint-Malo, Nantes, La Rochelle e Bordeaux. Gradualmente, as demais cidades portuárias também adquiriram o direito de exercer esse comércio. Com o fim do sistema de monopólio, negociantes dos grandes portos franceses lançaram-se na aventura colonial, dando início à grande era do tráfico de escravos. Ao longo do século XVIII, o tráfico francês conheceu um crescimento vertiginoso, mantendo-se atrás apenas dos tráficos britânico e português. ${ }^{57}$ Nas cidades portuárias, o tráfico representava apenas uma parte das atividades econômicas, mas, ao mesmo tempo, ele era o fator condicionante e principal motor dos demais ramos do comércio. No quadro de uma sociedade em que a manufatura, o artesanato e o pequeno comércio ainda estavam presos a regulamentos corporativos, o comércio colonial oferecia possibilidades de ascensão econômica mais rápida. A evolução do comércio com as colônias, e, sobretudo, com São Domingos, determinou a elevação econômica e social das cidades portuárias francesas, como Nantes, Bordeaux, Marselha, Le Havre, La Rochelle, Lorient e Saint-Malo. Bordeaux

${ }^{55}$ Cf. DUBOIS, Laurent. A Colony of Citizens. Chapel Hill: Univ. North Carolina Press, 2004, p.47.

${ }^{56} \mathrm{O}$ privilégio da Companhia das Índias Ocidentais foi dissolvido pelo rei já em 1674. Já o monopólio da Companhia das Índias Orientais, que valia para as colônias situadas além do Cabo da Boa-Esperança, foi suprimido em 13 de agosto de 1682. Em 1719, essa Companhia foi absorvida, ao lado da Companhia do Senegal e da Companhia da China, pela Companhia do Ocidente, de John Law, que ganhou o nome de Companhia das Índias. Essa nova Companhia não exerceu o seu monopólio, delegando, ao contrário, o direito de fazer o comércio com a África a particulares, contra o pagamento de 10 libras por escravo introduzido nas ilhas da América. Com uma decisão de 31 de julho de 1767, o monopólio da Companhia foi finalmente rompido (cf. MARTIN, Gaston. Histoire de l'esclavage dans les colonies françaises. Paris: Presses Universitaires de France, 1948,pp.130-131; HAUDRÈRE, Philippe. La Compagnie française des Indes, au XVIIIe siècle. Paris: Les Indes Savantes, 2005, v.1, pp.264-265, v.2, pp.768-770).

57 A Grã-Bretanha manteve, ao longo do século XVIII, o seu domínio sobre o tráfico de escravos, controlando sempre cerca de $40 \%$ do tráfico total. A França manteve-se sempre abaixo desses números, mas conheceu um crescimento mais pronunciado no período: se entre 1701-25, navios franceses importaram 106.300 escravos nas colônias (cerca de 11\% do tráfico total), para o período 1776-1800, eles levaram 419.500 escravos, isto é, $22 \%$ do tráfico total (cf. POSTMA, Johannes. The Atlantic Slave Trade. Gainesville: University Press of Florida, 2003., p.36). 
era o principal porto de saída das exportações para São Domingos (cerca de $40 \%$ dos navios) e de chegada do açúcar e do café caribenho, assim como o principal porto de distribuição desses produtos para o Norte da Europa. Nantes, por outro lado, era o principal porto do comércio de escravos, chegando a controlar metade de todo o tráfico negreiro francês. Entre 1789-93, essa proporção caiu para 36,1\%, mas apenas por conta da ascensão de outros portos franceses. ${ }^{58}$

A riqueza gerada pelos fluxos comerciais dinamizava profundamente essas cidades. Young apontou o contraste gritante entre a miséria existente nos campos franceses e a riqueza, o luxo e a efervescência cultural de cidades portuárias como Bordeaux. O crescimento do comércio marítimo e dos grupos a ele ligados não deixava de afetar o equilíbrio de uma sociedade tradicionalmente baseada na posse da terra. As cidades marítimas representavam a nova França, onde indivíduos ascendiam econômica e politicamente sem estarem amparados em privilégios de ordem. Ironicamente, entre esses homens, que lucravam em cima da venda de escravos e de produtos produzidos com mão de obra escrava, difundiam-se os ideais do liberalismo, inspirados na independência norte-americana. ${ }^{59}$ Os portos franceses tiveram um papel crucial na agitação intelectual que marcou a Revolução francesa.

Por outro lado, a ascensão do comércio marítimo gerava problemas que, às vésperas da Revolução, faziam emergir questionamentos relativos ao sistema colonial. O aumento do consumo de produtos coloniais na Europa e, portanto, o aumento das exigências de produtividade nas economias coloniais haviam incrementado a demanda por escravos nas ilhas francesas. Entre 1700-1792, as Índias Ocidentais receberam anualmente cerca de 14.500 escravos, mas essa média aumentou muito após a Guerra dos Sete Anos: para o período 1764-92, foram 26.400; e para o período 1783-92, foram 37.000 por ano. ${ }^{60} \mathrm{O}$ governo francês esforçava-se em manter o sistema do exclusivo, mas os plantadores coloniais pressionavam pela abertura dos portos aos negreiros estrangeiros: queixavam-se, às vezes com certo exagero, da insufiência e do alto preço do tráfico francês. Para os colonos, o tráfico era menos um negócio do que um serviço,

\footnotetext{
${ }^{58}$ Cf. JOUVENEL, Bertrand de. Napoléon et l'économie dirigée, p.34-38; FICK, Carolyn. The French Revolution in Saint-Domingue, p.53. idem. The making of Haiti: the Saint Domingue revolution from below. Knoxville: The University of Tennessee Press, 1990, p.23; STEIN, Robert Louis. The French Sugar Business in the Eighteenth Century, pp.20-21 e 110-111; MARTIN, Gaston. Histoire de l'esclavage dans les colonies françaises, p.35; WEBER, Jacques. La traite négrière nantaise de 1763 à 1793 . Ètude statistique, Revue des Mascareignes, n.2, 2000, p.26. Disponível em: http://www.cresoi.fr/IMG/pdf/revue mascareigne_02-part3.pdf. Acesso em: 29 de jan de 2013.

${ }^{59}$ Cf. YOUNG, Arthur. Travels, during the years 1787, 1788, and 1789, pp.45-47 e 91.

${ }^{60}$ Cf. FICK, Carolyn. The making of Haiti, p.22.
} 
cuja função era viabilizar a economia colonial. ${ }^{61} \mathrm{Na}$ prática, uma parte do abastecimento para as ilhas era fornecida por contrabandistas estrangeiros. ${ }^{62}$ Apesar do sucesso da produção colonial caribenha, a França matinha-se muito atrás dos ingleses no que se referia ao comércio de escravos e, mesmo tendo progredido ao longo da década de 1780, com um aumento de $172 \%$, o tráfico francês ainda não acompanhava inteiramente o aumento da demanda proveniente das ilhas francesas. $\mathrm{O}$ edito de 30 de agosto 1784 havia reconhecido legalmente essa situação, ao abrir alguns portos coloniais ao tráfico estrangeiro, mas muitos navios estrangeiros sequer respeitavam os limites desse Exclusivo "mitigado".

Segundo François Crouzet, a razão principal do sucesso do tráfico britânico estava na qualidade de seus trade goods, mercadorias exportadas para a África em troca de escravos. A clientela africana preferia os produtos ofertados pela Inglaterra e pela Holanda: armas, metais, ferramentas, jóias e, sobretudo, os têxteis provenientes da Índia, com suas cores vibrantes. A reputação dos produtos franceses era ruim, o que obrigava os armadores do país a importarem mercadorias para trocar por escravos. Se os produtos alimentares - em especial, os aguardentes - eram fornecidos pelos campos franceses, grande parte dos manufaturados envolvidos no tráfico vinham de fora do país. A manufatura francesa não era capaz de produzir esses produtos com a mesma qualidade e, consequentemente, o comércio colonial francês movimentava poucos produtos nacionais. ${ }^{63}$ As armas francesas, por exemplo, eram pouco atraentes para os africanos, sobretudo os angolanos, que preferiam as armas mais longas e pesadas feitas por ingleses e holandeses. Da mesma forma, o rei do Daomé não hesitava em manifestar a sua preferência por produtos britânicos, sobretudo as armas. ${ }^{64}$ Os fuzis franceses eram mal montados e mais caros. Isso gerava disputas entre fabricantes franceses, que reclamavam uma política protecionista, e armadores, que pediam, ao contrário, isenção total sobre produtos importados destinados à Guiné. Os compradores africanos também

\footnotetext{
${ }^{61}$ Cf. WEBER, Jacques. La traite négrière nantaise de 1763 à 1793, p.28; STEIN, Robert Louis. The French Sugar Business in the Eighteenth Century, p.38.

${ }^{62} \mathrm{O}$ contrabando era bastante intenso na Martinica e na Guadalupe, ilhas que tendiam a ser preteridas pelos armadores franceses em relação a São Domingos. Em 1786, por exemplo, o número de escravos trazidos à Martinica por estrangeiros foi de 1.683 , ao passo que os mercadores franceses trouxeram apenas 191 (cf. VILLIERS, Patrick. The slave and colonial trade in France just before the Revolution. In: B.L. SOLLOW (org.). Slavery and the Rise of the Atlantic System. Cambridge: Cambridge University Press, 1991, p.229).

${ }^{63}$ Cf. CROUZET, François. La guerre économique franco-anglaise au XVIIIe siècle. Paris: Fayard, 2008, pp.306-307; MARTIN, Gaston. Histoire de l'esclavage dans les colonies françaises, pp.44-45.

${ }^{64}$ Cf. Carta a M. S. Worel, comandante do porto de Saint-Louis, de 3 de junho de 1755, ADLA, C 604, fl.156.
} 
eram bastante exigentes quanto aos tecidos. Houve casos em que tecidos das manufaturas de Lyon foram rejeitados por sua baixa qualidade e retornaram à metrópole. Os têxteis mais procurados pelos africanos e, portanto, mais valiosos no tráfico de escravos eram os tecidos indianos, razão pela qual a França se viu obrigada, desde 1759, a liberar a entrada de tecidos indianos estrangeiros pelo porto de Marselha. ${ }^{65}$

Os problemas não paravam por aí. Muitos entendiam que o tráfico era, em si mesmo, um comércio de rentabilidade duvidosa. Em razão dos muitos riscos envolvidos na travessia do Atlântico, em que epidemias, acidentes, suicídios e revoltas de escravos eram comuns, a empresa podia ser vista como uma verdadeira "loteria", podendo gerar grandes lucros ou enormes perdas. É verdade que os custos de uma expedição eram bastante elevados: eles compreendiam a compra ou aluguel do navio, o abastecimento da embarcação, a compra de produtos para troca, o seguro, os impostos e os diferentes subornos pagos a funcionários nas colônias e na metrópole. Entre 1783 e 1792, uma expedição originária de Nantes custava, em média, 275 mil libras, muito embora os custos fossem bastante variáveis. O financiamento de tais empresas era difícil e exigia a formação de parcerias e o envolvimento de múltiplos investidores menores, que podiam assumir até metade dos custos e, portanto, dos lucros. Além disso, havia o problema da satisfação dos créditos. O preço era raramente pago na hora e, segundo Robert L. Stein, o lucro real da empresa chegava, com sorte, a 10\%. Assim, se o tráfico apresentava possibilidades bastante únicas de enriquecimento rápido e, nesse sentido, ele permitiu a ascensão de uma nova forma de aristocracia nas cidades marítimas, os riscos implicados eram altos e os lucros, muitas vezes, modestos. ${ }^{66} \mathrm{O}$ Estado procurava compensar os riscos com isenções fiscais e o pagamento de prêmios por escravo transportado para as colônias francesas, como veremos adiante. No entanto, para muitos, essas subvenções apenas evidenciavam o caráter supostamente ruinoso do comércio de escravos. Esse aspecto tinha sido profundamente agravado pelo aumento contínuo dos preços dos escravos ao longo do século, sobretudo na década de 1780. De acordo com os dados fornecidos por Bonnemain para escravos introduzidos em São Domingos, em 1783, para um total de 9.370 escravos adquiridos, foi pago um valor de 15.650.000 libras, gerando

${ }^{65}$ Cf. Le Commerce de l'Amérique par Marseille. Avignon: s.n., 1764, v.2, pp.383-191; MARTIN, Gaston. Nantes au XVIIIe siècle. L'ère des négriers (1714-1774). Paris: Éditions Karthala, 1993, pp.347348.

${ }^{66}$ Cf. STEIN, Robert Louis. The French Sugar Business in the Eighteenth Century, pp.24-25 e 36-37; VISSIÈRE, Isabelle, VISSIÈRE, Jean Louis. La traite des Noirs au siècle des Lumières. In: traite des Noirs au siècle des Lumières (Témoignages de négriers). Paris: Éditions Mátailié, 1982, p.12. 
um preço médio de 1670,22 libras por escravo. Em 1788, apenas cinco anos depois, para 29.506 escravos, foram pagas 61.936 .000 libras, gerando um preço médio de 2099,10 libras por escravo, o que representa um aumento de cerca de $25 \%$. A consequência direta desse processo era o aumento do preço dos produtos coloniais. A libra de café, por exemplo, teria passado de 15 soldos em 1783 para 27 soldos em 1788, isto é, um aumento de $80 \%{ }^{67}$

Além disso, com o aumento do preço dos escravos, aumentavam também as dívidas dos colonos junto aos mercadores. Os plantadores das colônias francesas raramente dispunham de capital suficiente para pagar a compra de escravos, de modo que os mercadores tornavam-se os seus principais credores. Habitualmente, a taxa de inadimplência dos colonos era de $10 \%$ e, entre 1783 e 1792, as dívidas dos plantadores junto aos mercadores de Nantes atingiram a marca de 45 milhões de libras tornesas. Essa situação alimentava as tensões existentes entre negociantes e colonos. Para a burguesia marítima francesa, estes eram aproveitadores inadimplentes que violavam os termos do pacto colonial com o recurso ao contrabando, ao passo que, para os plantadores das ilhas, os negociantes franceses eram uma classe parasitária que se beneficiava dos privilégios do sistema Exclusivo. ${ }^{68}$ Sob a Revolução, colonos e mercadores ver-se-iam obrigados a encontrar um campo de entendimento, em nome da defesa do escravismo, mas, no final do Antigo Regime, as duas classes confrontavam-se em torno dos limites ditados pelo pacto colonial. Nas Antilhas, revoltas contra a política mercantilista do estado francês não eram novidade e remontavam às últimas décadas do século XVII ${ }^{69}$, mas, num contexto revolucionário, as aspirações de autonomia dos colonos não tardariam a assumir a forma de projetos de independência.

Assim, no momento em vivia o seu auge, o comércio colonial, amparado no sistema do tráfico e da escravidão, tornava-se o palco de contradições, que, por sua vez, suscitavam questionamentos quanto ao funcionamento desse sistema. Se ele ocupava, de fato, um lugar primordial num país ainda conformado às concepções mercantilistas, a verdade é que alguns espíritos mais avançados começavam a questionar os benefícios desse comércio, tal como ele era praticado, no quadro geral da economia francesa. Empresa arriscada, dispendiosa para os colonos e onerosa para o Estado, o tráfico

\footnotetext{
${ }^{67} \mathrm{Cf}$. BONNEMAIN. Régénération des colonies, ou moyens de restituer graduellement aux hommes leur état politique, et d'assurer la prospérité des Nations; et moyens pour établir promptement l'ordre dans les colonies Françaises. Paris: Imprimerie du Cercle Social, 1792, p.33-34.

${ }^{68} \mathrm{Cf}$. FICK, Carolyn. The making of Haiti, pp.24-25.

${ }^{69}$ Cf. FROSTIN, Charles. Les révoltes blanches à Saint-Domingue aux XVIIe et XVIIIe siècles (Haïti avant 1789). Rennes: Presses Universitaires de Rennes, 2008, pp.39-96.
} 
movimentava poucos produtos manufaturados nacionais e, para algumas pessoas, ele não constituía um real fator de dinamismo para a economia metropolitana. ${ }^{70}$ Os produtos coloniais eram, na sua enorme maioria, reexportados e tampouco estimulavam o desenvolvimento de mercados internos de consumo. O economista Jean-Baptiste Say, membro da segunda fase dos Amigos dos Negros, expressaria essa visão no seu famoso Traité d'économie politique de 1803: para ele, o tráfico e a escravidão eram os elementos-chave de um sistema que beneficiava apenas uma classe de indivíduos, sem trazer grandes vantagens para a metrópole. Homens como Say acreditavam que, na medida em que o interesse dos comerciantes e o do restante do país estavam dissociados, esse sistema estava condenado. ${ }^{71}$

A esses questionamentos relativos aos benefícios do tráfico para a economia metropolitana, somavam-se outros relativos à estabilidade das sociedades coloniais. $\mathrm{O}$ sucesso dos produtos do Caribe nos mercados europeus tinha por efeito necessário a entrada massiva de escravos nas colônias europeias. Essa exigência gerava um efeito perigoso: a desproporção esmagadora da população escrava em relação à população livre daqueles territórios e o aumento da população de escravos boçais em relação aos crioulos. Submetida a um grau de exploração mais elevado, dadas as exigências de produtividade e a facilidade de sua reposição por meio do tráfico, essa mão de obra reagia à sua opressão por meio de atos de resistência ou mesmo de rebelião. Estes eram fatores que comprometiam seriamente a estabilidade das sociedades coloniais. A constante ameaça de atos de revolta escrava durante o século XVIII permite ilustrar o caráter contraditório de um sistema que, no momento em que atingia o seu auge, semeava os germes de sua própria destruição. Para muitos, reformar o sistema era a única forma de preservá-lo.

\section{I.1.1.2) Um contexto político favorável}

\footnotetext{
${ }^{70}$ É verdade que, como explica Lefebvre, durante muito tempo, a indústria funcionou na França como um anexo do comércio. O capital comercial se apoderou do artesanato e começou a desenvolver, nos campos, uma indústria rural, de baixos salários e pouco regulamentada. Na maioria dos casos, os negociantes forneciam a matéria-prima e, por vezes, as ferramentas. A "fábrica" era, muitas vezes, o conjunto dos habitantes operários de uma aldeia engajados pelos negociantes. Em Lyon, por exemplo, o "fabricante" era um negociante que importava a seda e exportava tecidos fabricados com ela, deixando o trabalho para operários remunerados (cf. LEFEBVRE, Georges. La Révolution Française, pp.29-30 e 39-40).

${ }^{71}$ Cf. SAY, Jean-Baptiste. Traité d'économie politique, ou simples exposition de la manière dont se forment, se distribuent, et se consomment les richesses. Paris: Deterville, 1803, v.1, pp.227-228.
} 
A fundação da Sociedade dos Amigos dos Negros ocorreu num contexto político específico, marcado por uma pronunciada tendência reformista na monarquia do final do Antigo Regime. A partir de meados do século XVIII e, sobretudo, após a Guerra dos Sete Anos (1756-1763), verificou-se na Administração uma tendência favorável à adoção de certas reformas, nos mais variados campos. Na agricultura, por exemplo, desde o final da década de 1760, ocorreram tentativas sérias - embora pouco frutíferas de modernização da agricultura, com a proteção das propriedades individuais contra os costumes agrários tradicionais, que entravavam as formas de produção mais intensivas. ${ }^{72}$ Ministros reformadores buscavam reduzir a regulamentação da economia e atenuar a política protecionista da monarquia, o que nem sempre agradava aos homens de negócios franceses. O tratado de comércio de 1786 se inscrevia nesse contexto.

Havia um sentimento geral de que o Estado francês tinha de ser modernizado e fortalecido, e isso implicava reformar as instituições sobre as quais a economia e a sociedade francesas se sustentavam. Essa tendência repercutiu nos assuntos coloniais, traduzindo-se na escolha de administradores sensíveis às novas ideias filosóficas. Após a Guerra - fruto, em grande parte, das tensões resultantes das disputas imperiais anglofrancesas -, sentia-se a necessidade de repensar as políticas coloniais. Acreditava-se que, apesar das perdas territoriais que a França tinha sofrido, o Tratado de Paris de 1763 tinha permitido ao país preservar o essencial de suas posses ultramarinas, o que foi confirmado pelos números do comércio exterior das décadas seguintes (após o conflito, os envios anuais das colônias da América passaram de 69 para 166 milhões de libras). Contudo, havia uma forte preocupação em manter o que restava do império colonial francês. $^{73}$

Durante o conflito, dada a incapacidade da França de abastecer as suas colônias, estas haviam recorrido aos produtos da América do Norte e não ficaram felizes em ver o exclusivo restabelecido após a paz. O recurso ao contrabando era bastante intenso. As perdas sofridas pela França, aliadas a um sentimento de desconfiança reinante entre as colônias e a metrópole, haviam colocado a questão colonial em pauta. A ordenação de 1784, que flexibilizou o exclusivo, era uma resposta a essas tensões, permitindo que os portos do Cap Français, Porto Príncipe e Les Cayes, em São Domingos, vendessem a mercadores estrangeiros produtos do açúcar e comprassem deles madeira e certos

\footnotetext{
${ }^{72}$ Desenvolvemos esse tema em nossa dissertação de mestrado (cf. SAES, Laurent Azevedo Marques de. A propriedade sob a República jacobina: o impacto da legislação revolucionária sobre a questão fundiária. Dissertação de mestrado. São Paulo: Universidade de São Paulo, 2008, pp.52-54).

${ }^{73}$ Cf. JOUVENEL, Bertrand de. Napoléon et l'économie dirigée, p.21.
} 
alimentos. Ficava, entretanto, proibida a venda de anil, café e algodão, razão pela qual a medida não foi capaz de acabar com o contrabando. ${ }^{74}$

Mas o problema colonial não se resumia às tensões decorrentes do regime proibitivo de comércio. Em Versalhes, havia uma preocupação crescente com a boa administração das plantações nas colônias, o que incluía o tratamento dispensado aos escravos. Esse era o objeto do Edito de 1685, também conhecido como Code Noir, que procurava neutralizar os riscos de uma escravidão não regulada. A lei tinha sido produzida numa época de transição, em que a mão de obra predominante no Caribe deixava-se de ser o engagé para tornar-se o escravo negro. O objetivo do código era estabilizar a escravidão colonial, garantindo os direitos de propriedade do senhor e definindo o status jurídico do escravo. Mas esse objetivo de estabilização também implicava a definição de regras para o tratamento da escravaria, o que incluía alimentação, vestimenta e cuidados médicos, assim como a imposição de restrições à punição dos escravos. ${ }^{75}$ Temia-se que a barbárie de senhores cruéis pusesse em risco a estabilidade da ordem colonial, levando os escravos a atos de violência desesperada. Contudo, na época, a ameaça de uma grande rebelião escrava ainda não era suficientemente concreta para motivar uma aplicação rígida do código. Além disso, não havia, nas colônias, mecanismos legais eficazes para impor a aplicação de uma lei que era vista pelos plantadores como uma ingerência ilegítima na esfera doméstica e uma violação perigosa da autonomia das plantations. Alguns senhores chegaram a receber penas leves (em geral, multas), mas no geral, o Code Noir não teve aplicação real. Como diz Ghachem, a lógica escravista tradicionalmente se baseava na crença de que a relação senhor-escravo se autorregulava. O Code Noir contrapunha-se a esse princípio. Assim, embora a lei viesse a ser definitivamente revogada apenas em 1848, o fato é que, nas colônias, a verdadeira lei da escravidão era a do plantador. ${ }^{76}$

\footnotetext{
${ }^{74}$ Cf. GARRIGUS, John D. Before Haiti, pp.174-175.

${ }^{75}$ Dentre as obrigações do proprietário estavam as de fornecer ao escravo uma alimentação suficiente, não vender separadamente a mãe e seus filhos impúberes, não condenar escravos à morte, prisão ou mutilação sem um julgamento regular dos tribunais ordinários instituídos para as pessoas livres e não prolongar a jornada de trabalho para além do intervalo entre a alvorada e o pôr do sol. O escravo tinha até mesmo o direito - apenas teórico - de apelar perante o tribunal contra o senhor que não cumprisse com seus deveres. Por outro lado, a lei dava ao cativo os atributos de bem "móvel", podendo ser alienado de acordo com a vontade do proprietário. Este tinha o direito de punir o escravo indisciplinado ou rebelde, açoitando-o, acorrentando-o ou até mesmo mutilando-o (cf. Code Noir (1685). Disponível em: http://www.axl.cefan.ulaval.ca/amsudant/guyanefr1685.htm; MARTIN, Gaston. Histoire de l'esclavage dans les colonies françaises, pp.27-28).

${ }^{76}$ Depois do Code Noir, a Monarquia francesa chegou a fazer outras tentativas infrutíferas de intervir na administração dos escravos. Foi o caso da ordenação real de 30 de dezembro de 1712, que proibia que escravos fossem torturados sob sua autoridade, sob o argumento de que abusos acabariam gerando fugas e
} 
Contudo, após a Guerra dos Sete Anos, as preocupações que haviam motivado o Code Noir se manifestaram de forma mais concreta. A ascensão econômica das colônias francesas da América e o consequente aumento vertiginoso de sua população escrava davam à questão novos contornos. A forte desproporção entre escravos e brancos nas ilhas, especialmente em São Domingos, tornava-se o elemento central em torno do qual se articulava o debate colonial. Ao longo das décadas de 1760 e 70, ganhou força a ideia de que um melhor tratamento dos escravos permitiria incrementar as atividades produtivas, assim como reforçar a segurança nas colônias. A consolidação do marronnage $^{77}$ no espaço colonial e a irrupção de revoltas evidenciavam os perigos da brutalidade da escravidão e, consequentemente, da resistência escrava para a sociedade colonial. Além disso, alguns acreditavam que as eventuais dificuldades de abastecimento de mão de obra por meio do tráfico impunham limites à superexploração de uma escravaria que praticamente não se reproduzia. Isso colocou a esfera doméstica das colônias em debate, pois, embora a Monarquia estivesse tão interessada quanto os plantadores na preservação do escravismo colonial, havia a percepção de que a soberania absoluta do plantador em seus domínios colocava em risco o interesse mais amplo de estabilidade representado pela Administração real. ${ }^{78}$

Na década de 1780, verificou-se, na Administração, um progresso da crítica preservacionista à ordem colonial. A escolha do marquês de Castries como Ministro da Marinha e das Colônias em 1780 foi uma manifestação dessa nova tendência. Ele representava uma parte da nobreza que acreditava que, para conservar o sistema colonial, era preciso reformá-lo. Outros administradores nomeados na época inseriam-se na mesma perspectiva. O barão de Bessner, nomeado governador da Guiana por Castries, propunha planos de extinção progressiva da escravidão. Em 1768, como oficial das forças armadas, ele tinha proposto fazer dos filhos de escravos da plantação Mont Joly em Caiena, cultivadores "livres", que trabalhariam para o senhor até os 25 anos, recebendo então a sua liberdade em troca de cinco dias de trabalho por semana. Os filhos dessa geração trabalhariam até os vinte anos, para então receber a liberdade civil. Como governador, Bessner projetou estender esse plano à colônia como um todo. Tinha também o projeto de atrair os marrons do Suriname para a Guiana e fazer deles

desordens (cf. GHACHEM, Malick W. The Old Regime and the Haitian Revolution. New York: Cambridge University Press, 2012, pp.46, 55-57, 62-63, 68-69, 126-129).

${ }^{77}$ Nas colônias, um escravo se tornava marron, isto é, "em fuga", um mês após a declaração feita pelo proprietário de sua partida. Nesse prazo, podia o escravo retornar à sua plantation sem sofrer penas mais graves (cf. THIBAU, Jacques. Le temps de Saint-Domingue, p.24).

${ }^{78}$ Cf. GHACHEM, Malick W. The Old Regime and the Haitian Revolution, pp.129-130. 
trabalhadores livres. ${ }^{79}$ Da mesma forma, Daniel Lescallier, que publicaria uma obra antiescravista em 1789 (Réflexions sur le sort des Noirs dans nos colonies) e integraria a Sociedade dos Amigos dos Negros, foi nomeado ordenador ${ }^{80}$ na Guiana, exercendo as suas funções entre 1785 e 1788. Segundo Ghachem, ele teria recebido, em 1785, instruções secretas de Castries para emancipar todos os escravos da Coroa na Guiana, assim como diretivas para encorajar plantadores a libertarem os seus. ${ }^{81}$ Nada disso aconteceu, mas a presença desses homens constitui um indício de que uma nova mentalidade orientava a política colonial do Estado francês no final do Antigo Regime.

Essa tendência reformista produziu, no plano jurídico, alguns resultados concretos. Os temores relativos aos efeitos da autonomia na gestão dos escravos tornaram-se cada vez mais pronunciados nos anos 1770-80, por conta do absenteísmo crescente dos proprietários coloniais, que alimentava abusos no tratamento da escravaria por parte dos gerentes. Com isso, crescia a opinião de que era necessário reformar o Code Noir, ou melhor, reforçá-lo por meio de uma lei dotada de eficácia. Esses temores foram codificados sob a forma das ordenações de 3 de dezembro de 1784 e 23 de dezembro de 1785, conhecidas como "ordenações contra os feitores". Elas permitiam à administração intervir na gestão de bens cujos proprietários estavam ausentes e velar pelo tratamento "justo" dos escravos. ${ }^{82}$ A nova legislação garantia ao negro a concessão de uma horta (manse) para o cultivo de víveres, assim como as tardes de sábado livres para a realização desse cultivo, e dispensava o escravo de possuir justificativa ou billet de sortie para ter acesso ao mercado dos domingos. Mas as disposições mais controversas tinham a ver com a fiscalização da administração dos escravos pelo Estado. Nos termos da ordenação de 1784, os gerentes ficavam obrigados a manter um registro de nascimentos e mortes de escravos, assim como de acidentes e eventos relativos à administração do plantel. Esse registro tinha de ser enviado mensalmente ao proprietário legal residente na metrópole, o que permitia estabelecer responsabilidades em caso de abusos e afastar gerentes e agentes infratores. A lei restringia e regulamentava as punições aos escravos, estabelecendo um máximo de cinquenta chibatadas, além de proibir mutilações, pauladas e mortes de diferentes modos. O gerente ou agente ficava submetido a uma tutela administrativa: comissários

\footnotetext{
${ }^{79}$ Cf. THIBAU, Jacques. Le temps de Saint-Domingue, pp.57-58; GHACHEM, Malick W. The Old Regime and the Haitian Revolution, pp.145-146.

${ }^{80} \mathrm{O}$ Ordenador era um dos chefes de administração colonial, submetido à autoridade do Governador. Era responsável pelos serviços civis, além de cuidar de questões orçamentárias.

${ }^{81}$ Cf. GHACHEM, Malick W. The Old Regime and the Haitian Revolution, pp.229-230.

${ }^{82}$ Cf. TARRADE, Jean. L'esclavage est-il réformable?, p.135.
} 
independentes eram responsáveis pela fiscalização da alimentação e cuidados médicos dos plantéis, podendo até mesmo tomar depoimentos de escravos em busca de evidências de excessos. O governador e o intendente colonial cuidavam da polícia das plantações, e eram instruídos a incluir na sua jurisdição as reclamações de escravos injustamente tratados. Podiam processar quem violasse as disposições da lei, que previa, como pena aos senhores, desde a declaração de incapacidade de possuir escravos até a pena capital, para o caso de assassinato de escravos. Tratava-se de uma inegável diminuição da autoridade doméstica diante da Administração, o que irritou profundamente os proprietários caribenhos. ${ }^{83}$

A ordenação gerou intensos protestos em São Domingos. O Conselho Superior do Cap Français decidiu suspender a publicação da lei, o que, aliás, provocou a extinção do órgão e sua fusão com o Conselho de Porto Príncipe. A pressão, contudo, levou a Monarquia a modificar aspectos da lei, por meio de uma nova ordenação, de 1785. As emendas davam agora direito de apelação contra as observações dos comissários independentes encarregados de investigar violações cometidas por plantadores e enfatizavam os deveres de respeito e obediência de escravos para com senhores e agentes. Além disso, especificavam que as novas regras só produziriam efeitos ex nunc, não se aplicando a casos cometidos anteriormente à sua publicação. ${ }^{84}$ Mesmo com essas concessões, os colonos continuaram protestando contra a medida, que, no geral, teve aplicação inexistente.

Assim, as inclinações dos novos administradores não foram capazes de promover qualquer recuo do sistema escravista nas colônias francesas, e, de fato, não era essa a sua intenção. Mesmo os mais críticos em relação à escravidão, como Pierre Poivre, ordenador nas ilhas de France e Bourbon, aceitavam a instituição como um mal necessário, limitando-se a pregar atenuações no tratamento aos escravos, com base nas normas de proteção do Code Noir. ${ }^{85} \mathrm{O}$ que queriam era reformar a escravidão para poder preservá-la. Além disso, as eventuais boas intenções dos administradores esbarravam inevitavelmente na resistência promovida pelos plantadores a qualquer tipo de ingerência na esfera privada. Qualquer legislação vinda da metrópole encontrava dificuldades de aplicação nas colônias, onde os aparelhos administrativo e judiciário encontravam-se vinculados ao mundo dos plantadores.

${ }^{83}$ Cf. GHACHEM, Malick W. The Old Regime and the Haitian Revolution, pp.158-159; THIBAU, Jacques. Le temps de Saint-Domingue, p.57.

${ }^{84}$ Cf. GHACHEM, Malick W. The Old Regime and the Haitian Revolution, pp.160-161.

${ }^{85}$ Cf. TARRADE, Jean. L'esclavage est-il réformable?, pp.138-139. 
Assim mesmo, o contexto político era, até certo ponto, propício ao surgimento de um movimento antiescravista organizado. A existência de uma corrente reformadora no seio do Ministério da Marinha e das Colônias permitia entrever resistências menores à constituição de uma sociedade dessa natureza, e, de fato, o nascimento da Sociedade dos Amigos dos Negros foi viabilizado por negociações com o ministério. Não se deve confundir a crítica preservacionista do escravismo com uma postura propriamente antiescravista, cujo sentido é erradicar o sistema, ainda que de forma gradual. Entretanto, a moderação que os Amigos dos Negros manifestariam desde a sua fundação e sua constante afirmação da necessidade de preservação das colônias permitiam estabelecer um campo comum de argumentação (e, de fato, haveria momentos em que a distinção entre antiescravismo e reformismo no seio da Sociedade não se faria clara). Além disso, havia, naquele final de século, um clima de abertura e diálogo entre as nações que alimentava as esperanças quanto a reformas no sistema colonial. A política externa da Monarquia, a partir de 1786, tendeu, para uma reaproximação com a Inglaterra, o que permitia entrever a possibilidade de uma ação antiescravista comum com um país concorrente da França no comércio colonial. ${ }^{86}$

A formação do movimento abolicionista francês não foi, aliás, um fenômeno isolado, mas, ao contrário, parte de uma tendência internacional que viu o surgimento de sociedades antiescravistas nas principais potências ligadas à exploração do trabalho escravo. A Guerra dos Sete Anos e, posteriormente, a Independência dos Estados Unidos haviam alterado a percepção que se tinha das colônias da América, estimulando a difusão de uma visão crítica sobre o funcionamento das sociedades escravistas. Nos Estados Unidos e na Grã-Bretanha, esse processo tinha sido amplamente favorecido pelo desenvolvimento das igrejas não-conformistas e o estabelecimento de redes internacionais de comunicação religiosas, que, em razão de sua independência perante o Estado, podiam funcionar como canais de mobilização da opinião pública contra uma instituição econômica tradicional, como a escravidão. ${ }^{87}$

Os quacres, em particular, desempenharam um papel fundamental na difusão do pensamento abolicionista. Por muito tempo, é verdade, eles haviam se mantido alinhados com o sistema da escravidão. A formação de comunidades quacres na América (Pensilvânia, Rhode Island) esteve fortemente atrelada ao tráfico e à

\footnotetext{
${ }^{86}$ Cf. BÉNOT, Yves. La Révolution et la fin des colonies, p.40.

${ }^{87}$ Cf. DRESCHER, Seymour. Two Variants of Anti-Slavery: Religious Organization and Social Mobilization in Britain and France, 1780-1870. In: From Slavery to Freedom: comparative studies on the rise and fall of Atlantic Slavers. New York: New York University Press, 1999, p.51.
} 
exploração do trabalho escravo. Muitos quacres eram senhores de escravos; outros eram mercadores que vendiam mão de obra para as Índias Ocidentais. ${ }^{88}$ Mas a sua postura diante do mundo permitiu aos quacres estabelecer uma associação entre o mal moral e as instituições do mundo externo. Por volta do final do século XVII, as primeiras manifestações contra a escravidão começaram a aparecer. Bastante significativo é o panfleto An Exhortation \& caution to Friends concerning buying or keeping of Negroes (1693), de George Keith, no qual o autor recomendava que não se comprasse nenhum negro, a não ser que fosse para libertá-lo. Keith reconhecia a impossibilidade de libertar de uma só vez todos os escravos, entendendo que os cativos deveriam ser preparados para a liberdade, por meio da educação cristã e da passagem por etapas intermediárias entre a servidão e a liberdade. ${ }^{89}$ Essa combinação de uma condenação moral da escravidão com considerações de ordem prática prefigurava as ideias centrais do antiescravismo do final do século XVIII. ${ }^{90}$

O início do século XVIII foi marcado por uma forte tendência antiescravista nas reuniões dos quacres da América. Alguns quacres radicais, como Benjamin Lay, fizeram do antiescravismo o veículo para atacar um grande número de males, como um instrumento de purificação. Muitos quacres passaram a libertar seus escravos. Gradativamente, os esforços missionários do início do século XVIII foram dando lugar a movimentos organizados em torno do ideal abolicionista. Em meados do século, a atuação dos quacres ganhou uma dimensão internacional, com o estabelecimento de uma ampla rede de comunicação que permitiu criar mecanismos eficazes de ação política. ${ }^{91}$ A Sociedade Religiosa dos Amigos afirmou-se como um grupo de pressão internacional e, mesmo que os abolicionistas permanecessem minoritários, a ampliação

\footnotetext{
${ }^{88}$ Cf. DAVIS, David Brion. O Problema da Escravidão na Cultura Ocidental, pp.337-342. Havia membros importantes da Sociedade dos Amigos (Quacres) na Companhia Real Africana.

${ }^{89}$ Cf. KEITH, George. An Exhortation \& Cation to Friends Concerning Buying or Keeping of Negroes. Disponível em: http://www.qhpress.org/quakerpages/qwhp/gk-as1693.htm). Acesso em: 17 de set de 2009.

${ }^{90}$ Posteriormente, Keith converter-se-ia ao anglicanismo e faria parte da Sociedade de Propagação do Evangelho, bastante atuante na catequese dos negros nas colônias. Fundada em 1701, a entidade moveu esforços pela cristianização dos negros, levantando até mesmo fundos para a construção de escolas para crianças negras. Esse esforço, que teve alguns resultados importantes na Carolina do Sul, na Filadélfia e em Nova York, dificilmente poderia ter alcançado os mesmos resultados nas Índias Ocidentais, onde os missionários não superavam a aceitação da escravidão e do tráfico, vendo neles instrumentos úteis à conversão de pagãos. Como diz Brion Davis, "é compreensível por que alguns negros viam poucos benefícios em uma religião que sancionava a autoridade de seus senhores, que os mandava evitar a preguiça e trabalhar mais diligentemente, e que prometia privá-los de seus poucos prazeres e liberdades" (DAVIS, David Brion. O Problema da Escravidão na Cultura Ocidental, p.248).

${ }^{91}$ Ibidem, pp.361-367.
} 
do movimento dos quacres em meados do século XVIII propiciou um cenário cultural favorável à difusão de ideias antiescravistas.

Em 1775, foi fundada na Filadélfia a Society for the Relief of Free Negroes Unlawfully Held in Bondage, sob os auspícios de Benjamin Franklin. Essa sociedade se reorganizou e entrou efetivamente em atividade em 1784, sob o nome de Pennsylvania Abolition Society. Outras cidades norte-americanas, como Nova York, Boston e Baltimore, seguiram o exemplo da Filadélfia. Igrejas metodistas e quacres, inspiradas pelos ensinamentos de Anthony Benezet, fundavam comitês abolicionistas na maioria das cidades, até mesmo nos Estados do Sul, onde a força econômica da escravidão era particularmente importante.

Em Londres, após apresentarem uma petição contra o tráfico ao Parlamento, os quacres tinham formado, em 1783, um comitê antiescravista informal para publicar e distribuir textos abolicionistas. Estimulados por esses exemplos, o anglicano Thomas Clarkson pôs-se a produzir textos sobre o tema, enquanto William Wilberforce procurou encorajar todas essas pessoas a se unirem numa campanha nacional contra o comércio de escravos. ${ }^{92}$ Assim, em 1787, surgiu a Society for Effecting the Abolition of Slave Trade, organização que atuaria ativamente na difusão dos ideais abolicionistas, contando com Wilberforce como porta-voz no Parlamento. Por meio da publicação contínua de panfletos e da organização de abaixo-assinados em grandes centros urbanos $^{93}$, os antiescravistas britânicos procurariam construir um movimento de opinião extenso, com grande penetração na classe trabalhadora dos centros industriais. De fato, entre 1787 e 1789, verificou-se uma explosão de interesse pela causa abolicionista na Grã-Bretanha e notícias da evolução desse movimento de opinião não demoraram a cruzar o canal da Mancha. ${ }^{94}$

Os antiescravistas ingleses chegaram a pôr em prática as suas ideias, ao promover uma experiência de colonização livre na África, com a instituição, em 1787,

\footnotetext{
${ }^{92}$ Cf. BROWN, Christopher Leslie. Moral Capital, p.1.

${ }^{93} \mathrm{Em} \mathrm{1787}$, foram colhidas mais de dez mil assinaturas em Manchester para uma petição antiescravista ao Parlamento. Esse número correspondia a mais da metade dos homens adultos da cidade. Durante a sessão de 1788, 102 petições favoráveis foram apresentadas ao Parlamento. Em 1792, o número de petições chegaria a 519 (cf. BLACKBURN, Robin. A Queda do Escravismo Colonial 1776-1848. Rio de Janeiro: Record, 2002, pp.155-160).

${ }_{94} \mathrm{O}$ Mercure de France, de $1^{\circ}$ de março de 1788 , afirmava, ao comentar a apresentação de uma petição contra o tráfico no Parlamento, que "[...] seria mais fácil nomear hoje os Condados e Cidades que guardam o silêncio sobre esse objeto do que enumerar as Petições que se elevam de todas as partes em favor da próxima moção" ("[...] il serait plus aisé aujourd'hui de nommer les Comtés et les Villes qui gardent le silence sur cet objet, que d'énumérer les Pétitions qui s'élèvent de toutes parts en faveur de la motion prochaine"; Mercure de France, v.134, p.218).
} 
de Free Town, em Serra Leoa, um estabelecimento destinado a receber escravos libertados da América. Os resultados, segundo Dorigny, foram desastrosos: na impossibilidade de promover o cultivo das terras, dos 411 indivíduos que embarcaram na Inglaterra, apenas 100 sobreviveriam. ${ }^{95}$ Ainda assim, a experiência mostra o grau de envolvimento e organização do movimento abolicionista britânico.

Seus principais fundadores - Granville Sharp, Thomas Clarkson, William Wilberforce, James Ramsay, James Philips - seriam os inspiradores e correspondentes da Sociedade dos Amigos dos Negros, criada justamente como parte dessa rede internacional de sociedades antiescravistas.

\section{I.1.1.3) Brissot e o problema da escravidão}

$\mathrm{Na}$ França, o surgimento de uma organização antiescravista também estava relacionado aos conflitos que haviam marcado o espaço colonial na segunda metade do século XVIII. A independência dos Estados Unidos havia se tornado uma referência para aqueles que pensavam em transformar os modos de viver e pensar no Velho Continente. A Sociedade dos Amigos dos Negros pode ser vista como um desdobramento de uma sociedade anterior, formada um ano antes, no seio da qual aquele que viria a ser o seu núcleo principal já tinha sido esboçado. Em 2 de janeiro de 1787, quatro futuros Amigos dos Negros, Jacques-Pierre Brissot de Warville (um advogado e homem de letras), Étienne Clavière (um banqueiro), Nicolas Bergasse (outro advogado) e Michel Guillaume Jean de Crèvecoeur (um escritor) fundaram, em Paris, a Société gallo-américaine, uma associação política voltada para o fortalecimento das relações entre a França e os Estados Unidos.

Clavière tinha participado da revolução genebrina de 1781-82 e via na experiência americana um exemplo do que os genebrinos deveriam fazer. Ao mesmo tempo, o banqueiro tinha se arruinado com investimentos na dívida do Estado francês ${ }^{96}$, o que estimulou de sua parte uma postura crítica em relação à administração francesa, marcada por dívidas impagáveis, corrupção financeira, intrigas políticas e monopólios.

\footnotetext{
${ }^{95}$ Cf. DORIGNY, Marcel, GAINOT, Bernard. La Société des Amis de Noirs, p.101.

${ }^{96}$ Acreditando que todas as dívidas do Estado francês estavam garantidas, Clavière encorajou, até o verão de 1783, seus agentes em Paris a investir fundos na dívida, inclusive na Caisse d'Escompte. Ora, uma decisão de 27 de setembro de 1783 retardou o pagamento das notas da Caisse, levando Clavière à beira da falência (cf. WHATMORE, Richard, LIVESEY, James. Étienne Clavière, Jacques-Pierre Brissot et les fondations intellectuelles de la politique des girondins. Annales historiques de la Révolution française, Paris, n. 321, jul-set de 2000. Disponível em: http://ahrf.revues.org/175. Acesso em: 7 de fev. de 2013).
} 
Ao lado de Brissot, panfletário conhecido por abraçar as causas mais diversas, ele defendia uma moralização do comércio e uma organização racional da ordem econômica. ${ }^{97}$ Inimigos do despotismo, o objetivo desses homens era estabelecer um canal de comunicação com os norte-americanos, com vistas a facilitar as trocas comerciais entre a França e os Estados Unidos. Mas, acima de tudo, pretendiam introduzir na França os princípios da liberdade americana. ${ }^{98}$ Defendiam, assim, a erradicação da intervenção estatal nas relações comerciais e a promoção de um comércio livre e direto, benéfico a ambos os países: a França, que precisava de novos mercados para os seus manufaturados; os Estados Unidos, país recente, que precisava trocar as suas matérias-primas por produtos europeus.

"A utilidade dos dois Mundos: eis o objetivo desta Sociedade", dizia o prospecto da entidade. ${ }^{99}$ Mas, além de reforçar as relações comerciais entre os países, o foco principal da Sociedade era atacar as instituições políticas ilegítimas. Para Brissot, os Estados Unidos independentes apareciam como a grande terra da liberdade, um exemplo do espírito democrático e republicano que ele desejava para a França. Brissot e Clavière defenderam esses princípios numa obra conjunta, De la France et des États-Unis, ou de l'importance de la Révolution de l'Amérique pour le bonheur de la France (1987). A Société gallo-américaine inscrevia-se, portanto, no contexto mais amplo da proliferação de associações voltadas para a promoção dos ideais burgueses de cidadania, ideais esses que procuravam na Revolução americana um modelo programático. Na visão desses homens, a Revolução Americana tinha apontado caminhos para a formulação mais concreta de novos rumos políticos que levariam a França a superar o despotismo em todas as suas manifestações. Ora, a revolução tinha sido marcada pelo amplo uso da retórica antiescravista, pelos dois lados do conflito, levando a uma "politização inédita da instituição da escravidão". ${ }^{100}$ Os debates da Convenção Constitucional de maiosetembro de 1787 resultariam na preservação da escravidão negra nos Estados Unidos,

\footnotetext{
${ }^{97}$ Ibidem, s.p.

${ }^{98}$ O prospecto da Sociedade dizia o seguinte: "É preciso, por exemplo, que na França se saiba tudo o que se passa nos Estados Unidos, que se registre tudo o que lá se faz de útil, que isso seja difundido e então que a Sociedade empregue a sua influência para fazer adotar as instituições úteis" ("Il faut, par exemple, qu'en France on sache tout ce qui se passe dans les États-Unis, qu'on y enregistre tout ce qui s'y fait d'utile, qu'on le répande et qu'ensuite la Société emploie son influence pour faire adopter les institutions utiles"; Prospectus de la Société Gallo-Américaine établie à Paris en 1787. In: BRISSOT DE WARVILLE, Jacques-Pierre, CLAVIÈRE, Étienne. De la France et des États-Unis, ou de l'importance de la Révolution de l'Amérique pour le bonheur de la France. Londres: s.n, 1787, p.340)

99 "L'utilité des deux Mondes: voilà le but de cette Société" (Prospectus de la Société Gallo-Américaine, p.342).

${ }^{100}$ Cf. BERBEL, Márcia, MARQUESE, Rafael, PARRON, Tâmis. Escravidão e Política, p.70.
} 
mas, naquele momento, Brissot e seus colegas acreditavam que a nova nação independente tinha, de fato, se inscrito na via abolicionista.

A questão da escravidão foi abordada logo nas primeiras sessões da Sociedade. Em 3 de abril de 1787, Brissot interveio para apresentar algumas ideias aos membros presentes. Uma delas tinha "[...] por objetivo a destruição da escravidão dos negros, ou os auxílios para essa destruição operada pelos Quacres". ${ }^{101}$ Brissot prometeu apresentar um vasto plano sobre esse objeto.

Era natural que a questão da escravidão surgisse nos debates da Société GalloAmericaine. Crèvecoeur, um de seus membros fundadores, era o autor de Lettres d'un Cultivateur américain (1784), que trazia uma denúncia dos horrores da escravidão e da crueldade dos plantadores brancos para com os negros. ${ }^{102}$ Impactado pela obra de Crèvecoeur, Brissot também tinha dissertado a respeito da escravidão num capítulo do Examen critique des voyages dans l'Amérique septentrionale, de M. le marquis de Chatellux (sic) (1786), no qual atacava a proposta de Chastellux ${ }^{103}$, em resposta aos abusos cometidos contra os escravos na América do Norte, de simplesmente suavizar a condição dos negros. Para Brissot, os negros não precisavam de caridade, mas de justiça e liberdade:

O que concedeis aos Negros é piedade, e o que lhes deveis, se sois Filósofo, é justiça e defesa; o que desejais dos Senhores é humanidade, e o que eles lhes devem é justiça. Vós os louvais por essa humanidade, mas deverieis criticá-los por limitarem-se a ela. ${ }^{104}$

Dito isso, a situação nos Estados Unidos pós-independência tinha alimentado as expectativas antiescravistas. Em todos os estados, exceto nas duas Carolinas e na Georgia, a importação de novos escravos tinha sido proibida (a Carolina do Sul a tinha proibido por apenas três anos). A Pensilvânia tinha ido mais longe, declarando legalmente livres todos os escravos nascidos após a promulgação da lei. Nos estados do

101 "[...] pour but la destruction de l'esclavage des nègres, ou les concours à cette destruction opérée par les Quakers" (BRISSOT DE WARVILLE, Jean-Pierre. Correspondance et papiers. Paris: Picard et fils, 1912, pp.134-135).

${ }^{102}$ Cf. CRÈVECOEUR, Michel-Guillaume Jean. Lettres d'un cultivateur américain. Paris: chez Cuchet, 1784, v.2, pp.365-380.

103 O marquês de Chastellux era um homem de letras e um militar que havia atuado na guerra de independência norte-americana.

104 "C'est de la pitié que vous accordez aux Nègres, et vous leur devez, si vous êtes Philosophe, justice et défense; c'est de l'humanité que vous souhaitez aux Maîtres, et ils leur doivent justice. Vous les louez de cette humanité, vous deviez les blâmer d'en rester-là" (BRISSOT DE WARVILLE, Jacques-Pierre. Examen critique des voyages dans l'Amérique septentrionale, de M. le marquis de Chatellux, ou Lettre à M. le marquis de Chatellux, dans laquelle on réfute principalement ses opinions sur les Quakers, sur les nègres, sur le peuple, et sur l'homme. Londres : [s.n.], 1786, p.85). 
Norte, leis semelhantes tinham sido promulgadas. ${ }^{105}$ Esses fatos seriam constantemente relembrados na campanha dos Amigos dos Negros. Na cabeça dos antiescravistas franceses, eles apontavam para o fim próximo da escravidão na América setentrional. Essa aparente tendência abolicionista norte-americana era, como se sabe, enganosa. A prosperidade gerada pela escravidão na América tinha impulsionado fortemente as suas aspirações de independência. Os antiescravistas franceses não percebiam o paradoxo que a Revolução americana tinha no seu âmago: a de ser uma luta de proprietários de escravos pelos direitos do Homem ${ }^{106}$, paradoxo que eles próprios teriam de enfrentar no seio das assembleias revolucionárias, quando confrontados aos representantes das colônias e do comércio colonial. Mas, naquele momento, os antiescravistas franceses referiam-se comumente aos Estados Unidos como o modelo a ser seguido ${ }^{107}$, sem suspeitar que, entre a Declaração de Independência e a abolição final da escravidão, após a Guerra Civil, seriam necessários quase noventa anos.

Então, para fugir da ameaça de uma lettre de cachet ${ }^{108}$, Brissot viu-se obrigado a procurar refúgio na Inglaterra, onde permaneceu da segunda metade de 1787 até janeiro de $1788 .^{109}$ Em Londres, conheceu pessoalmente os abolicionistas britânicos, em especial Granville Sharp, presidente da Sociedade pela abolição do tráfico, e Thomas Clarkson. Por meio de uma resolução de 27 de agosto de 1787, Brissot e Clavière foram escolhidos pela sociedade londrina para serem seus representantes na França e foi-lhes

\footnotetext{
${ }^{105}$ Cf. CONDORCET, Jean-Antoine-Nicolas de Caritat. Réflexions sur l'esclavage des nègres. Par M. Schwartz, Pasteur du Saint Evangile à Bienne, Membre de la Société économique de B.***. Nouvelle édition revue \& corrigée. Neufchâtel et Paris: Froullé, 1788, pp.83-84.

${ }^{106}$ Cf. DAVIS, David Brion. O Problema da Escravidão na Cultura Ocidental, p.20.

${ }^{107}$ Brissot estava fascinado pela Convenção constitucional em progresso na Filadélfia, mas o fato é que a Constituição americana, adotada em setembro de 1787, não incluiria a abolição - a proposta de Thomas Jefferson de incluir a condenação da escravidão seria afastada. $O$ art. $1^{\circ}$ da seção 9 proibiria o Congresso de estabelecer limites à importação de pessoas até 1808, o que significava que o tráfico estaria protegido por, pelo menos, 20 anos.

Figura um tanto contraditória, no que se refere à escravidão, Thomas Jefferson seria convidado por Brissot a integrar a Sociedade dos Amigos dos Negros. Em carta, Jefferson agradeceria a honra do convite, mas a sua posição de embaixador dos Estados Unidos em Paris inviabilizava o aceite: "Estou aqui como servidor público, e na medida em que aqueles a quem sirvo não tiveram jamais o poder de dar a sua voz contra a escravidão, é um dever para mim evitar manifestar tão publicamente o meu desejo de a ver abolida" ("Je suis ici comme serviteur public, et ceux que je sers n'ayant jamais eu le pouvoir de donner leur voix contre l'esclavage, c'est um devoir pour moi d'éviter de montrer trop publiquement mon désir de le voir aboli"; REGISTRE de la Société des Amis des Noirs. In: DORIGNY, Marcel, GAINOT, Bernard. La Société des Amis de Noirs 1788-1799: Contribution à l'histoire de l'abolition de l'esclavage. Paris: UNESCO, 1988, p.94).

${ }^{108}$ A lettre de cachet teria sido motivada por um panfleto escandaloso escrito por Brissot: Point de Banqueroute (cf. ELLERY, Eloise. Brissot de Warville: A Study o the History of the French Revolution. New York: Burt Franklin, 1970, p.183).

${ }^{109}$ Cf. BRISSOT DE WARVILLE, Jacques-Pierre. Mémoires. Paris: Picard et fils, s.d., v.2, p.71.
} 
recomendada a criação de uma sociedade nos mesmos moldes. ${ }^{110}$ Na sua volta à França, eles conduziram o projeto de criar a primeira sociedade antiescravista francesa. Em carta publicada no jornal Analyse des papiers anglais (número de 31 de janeiro $-1^{\circ}$ de fevereiro de 1788), dirigido por Mirabeau, Brissot e Clavière anunciaram o seu plano de concorrer para que a Nação francesa se unisse aos abolicionistas de Londres na sua campanha contra o tráfico de Negros:

Nesse intuito, essa Sociedade nos nomeou seus Agentes e Correspondentes: ela desejou que, em concerto com ela, formássemos na França uma Sociedade cujo objeto fosse, primeiramente, lançar por meio de escritos a maior luz possível sobre esse objeto, e, em seguida, agir junto ao Governo da maneira mais eficaz, para fazer abolir o comércio dos Negros. ${ }^{111}$ (itálico no original)

Na mesma edição do jornal, foi publicada carta de Granville Sharp, presidente da sociedade londrina, na qual afirmava estar a par dos esforços empreendidos. Assim, desde o início, a Sociedade dos Amigos dos Negros foi concebida pelos seus fundadores como a parte francesa de um amplo movimento com ramificações em diferentes países. Essa dimensão internacional, abertamente afirmada pelos fundadores da Sociedade, lhes valeria sérios problemas. A "paternidade inglesa" dos Amigos dos Negros seria recorrentemente explorada pelos colonos e negreiros que os acusariam de serem agentes da Grã-Bretanha encarregados de arruinar as colônias francesas.

\section{I.1.1.4) A fundação}

Em 19 de fevereiro de 1788, um grupo liderado por Brissot, Clavière e Mirabeau, e que contava ainda com Brack (censor real e diretor geral das alfândegas internas), Carra (um homem de letras), Cerisier (um jornalista), Duchesnay (censor real), o Marquês de Valady e Dufossey de Bréban (diretor da Régie Générale) ${ }^{112}$ se reuniu na Rue Française, $n^{\circ} 3$, em Paris. Juntos, decidiram "[...] que os subscritos se formam em Sociedade, no intuito de concorrer, com aquela formada em Londres, para a

\footnotetext{
${ }^{110}$ Cf. REGISTRE de la Société des Amis des Noirs, pp.62-63

111 "Dans cette persuasion, cette Société, nous a nommés pour ses Agents et Correspondants: elle a désiré que de concert avec elle nous formassions en France une Société dont l'objet fût d'abord de répandre par les écrits, la plus grande lumière sur cet objet, et ensuite d'agir auprès du Gouvernement de la manière la plus efficace pour faire abolir le commerce des Nègres" (Analyse des papiers anglois, v.1, p.474).

112 Esses são os nomes constantes da ata da sessão. É possível, entretanto, que mais alguém tenha assistido à sessão e não tenha assinado o registro (cf. REGISTRE de la Société des Amis des Noirs, pp.68-69).
} 
abolição do tráfico e da escravidão dos Negros [...]". ${ }^{113}$ A resolução falava explicitamente na abolição do tráfico e da escravidão, posicionando-se, em princípio, numa linha mais claramente abolicionista do que a sociedade londrina. Clavière foi eleito por unanimidade presidente da nova sociedade e Brissot foi escolhido como Secretário.

Ainda nessa primeira assembleia oficial, Brissot fez a leitura de uma carta de 11 de fevereiro do Marquês de La Fayette, que não pôde comparecer, mas manifestou a sua profunda satisfação com a formação da Sociedade, da qual já se considerava membro. Quanto ao programa a ser adotado pela entidade, o marquês já manifestava a percepção de "que o melhor meio de obter sucesso não é abandonar-se unicamente às reflexões filosóficas, mas procurar conciliar os interesses da humanidade com os do comércio, e mesmo os dos colonos, o que não é impossível" (grifo nosso). La Fayette aproveitou para mencionar os experimentos por ele promovidos nas suas plantações da Guiana (La Gabrielle et Saint-Régis), para conduzir gradualmente os negros ao estado de liberdade e de propriedade. Acreditava que "[...] esse estabelecimento tende a provar que tal sistema seria mais útil, não somente à prosperidade das colônias, mas também à fortuna dos possuidores atuais". ${ }^{114}$ Não havia demagogia por parte do marquês, que, aliás, emanciparia formalmente todos os seus escravos da Guiana em $1789^{115}$, mas suas palavras já enfatizavam a necessidade de preservar os interesses estabelecidos. La Fayette exerceria, em razão de sua influência junto ao ministério e de seus contatos na nobreza esclarecida, um papel fundamental nesses primeiros anos da Sociedade, negociando, aliás, no final do mês de março de 1788, com o ministro Loménie de Brienne, uma autorização para os trabalhos da entidade. Brienne concordou, sob a condição de que estes fossem orientados pela "prudência" e estivessem voltados para a demonstração do interesse dos plantadores e do físco na substituição do trabalho escravo pelo trabalho livre. ${ }^{116}$ A conciliação dos interesses aparecia como o eixo sobre o

\footnotetext{
113 "[...] que les soussignés se forment en Société, à l'effet de concourir, avec celle formée à Londres, à l'abolition de la traite et de l'esclavage des Nègres [...]" (Ibidem, pp.61-62).

114 "[...] que le meilleur moyen de réussir n'est pas de s'abandonner uniquement aux réflexions philosophiques, mais de chercher à concilier les intérêts de l'humanité avec ceux du commerce, et même des colons, ce qui n'est pas impossible"; "[...] cet établissement tend à prouver qu'un pareil système serait plus utile, non seulement à la prospérité des colonies, mais à la fortune des possesseurs actuels" (Ibidem, p.66). Daniel Lescallier, ordenador da Guiana, tinha adquirido essas propriedades para La Fayette. A experiência envolvia medidas de suavização da condição dos negros, como a supressão dos castigos corporais e a outorga de salários. Segundo Dorigny, esses princípios aparentemente não foram aplicados com rigor (Ibidem, p.66, nota 15).

${ }^{115}$ Cf. GHACHEM, Malick W. The Old Regime and the Haitian Revolution, p.229.

${ }^{116}$ Cf. REGISTRE de la Société des Amis des Noirs, p.109.
} 
qual deveria se estruturar o programa da entidade. Como diria Brissot, nas suas memórias, La Fayette "[...] tinha apresentado a Sociedade sob um aspecto inofensivo, e esse era um grande ponto para a sua tranquilidade e a sua existência sob um governo ainda despótico". ${ }^{117}$

Ainda na sessão inaugural, Brissot tomou a palavra para fazer aquele que seria conhecido como o discurso de fundação da Sociedade dos Amigos dos Negros. A empresa foi apresentada como uma filial da sociedade abolicionista londrina:

Uma Sociedade respeitável se formou em Londres para fazer abolir legalmente o horrível tráfico dos Negros: ela convida todos os homens, amigos de seus semelhantes, a concorrerem com ela, para realizar em todos os lugares essa obra de justiça: ela nos convida a procurar, a reunir na França pessoas zelosas e capazes de difundir as luzes que devem preparar e determinar essa revolução. ${ }^{118}$

Brissot falava, portanto, em reunir e divulgar informações que pudessem preparar a abolição legal do tráfico negreiro, ponto de partida para uma erradicação gradual da escravidão. Isso implicava afastar os temores que cercavam a questão dos negros e que constituíam entraves a quaisquer mudanças propostas no sistema da escravidão: o temor da revolta escrava, da abolição pela força e da vingança dos negros libertados contra os seus antigos senhores. Brissot mostrava-se um adepto da prudência e da circunspeção, o que significava rejeitar mudanças abruptas e generalizadas, nocivas até mesmo aos escravos:

na ausência de sábias precauções que acompanhem essa mudança, poder-seia reduzir à miséria aqueles que se quer tirar da servidão, e com isso tornar nulo o benemérito da liberdade, e fornecer um novo pretexto à tirania do interesse pessoal e às calunias contra os políticos Filósofos. ${ }^{119}$

\footnotetext{
117 "[...] avait présenté la Société sous un aspect inoffensif, et c'était un grand point pour sa tranquillité et son existence sous un gouvernement encore despotique" (BRISSOT DE WARVILLE, Jacques-Pierre. Mémoires, v.2, p.78).

118 "Une Société respectable s'est formée à Londres pour faire abolir légalement, l'horrible trafic des Nègres: elle invite tous les hommes, amis de leurs semblables, à concourir avec elle, pour accomplir partout cet oeuvre de justice: elle nous invite à chercher, à rassembler en France des personnes zélées, et capables de répandre les lumières qui doivent y préparer et déterminer cette révolution" (Discours sur la nécéssité d'établir à Paris une Société pour concourir, avec celle de Londres, à l'abolition de la traite \& de l'esclavage des Nègres. Prononcé le 19 février 1788, dans une Société de quelques amis, rassemblés à Paris, à la prière du Comité de Londres. S.l. [Paris]: s.n., s.d. [1788], p.2).

119 "faute d'accompagner ce changement de sages précautions, on pourrait réduire à la misère ceux qu'on veut tirer de la servitude, par là rendre nul le bienfait de la liberté, et fournir un nouveau prétexte à la tyrannie de l'intérêt personnel, et aux calomnies contre les politiques Philosophes" (Ibidem, pp.5-6).
} 
Brissot não apresentava o problema da escravidão de forma isolada, mas como um obstáculo à reconstrução da liberdade geral, vista como fundamental para o desenvolvimento da razão humana e para o estabelecimento da paz universal:

Numa Sociedade livre, o homem é levado pelo seu interesse pessoal a desenvolver as suas faculdades no mais alto grau: numa Sociedade livre, só se pode governar por meio da razão universal, e a razão universal impõe que se queira essencialmente a paz e o bem de todos os homens. ${ }^{120}$

A liberdade era o caminho para a razão; o estado de catividade restringia e neutralizava as aptidões e faculdades humanas, de modo que "a luz geral, aquela que tende à felicidade pública, é, portanto duplamente incompatível com o espírito de servidão". ${ }^{121}$ Dessa convicção, Brissot concluía pela necessidade de devolver a liberdade aos escravos:

A liberdade - Ao devolvê-la aos Negros, deixais então de temê-los: ao se tornarem nossos irmãos, eles não tardarão a se esclarecerem, a se tornarem bons, e, o que talvez seja mais difícil, até mesmo os Senhores serão forçados a se esclarecerem, a se tornarem bons; pois a escravidão é um meio infalível de corromper, ao mesmo tempo, o Senhor e o Escravo. ${ }^{122}$

Para um homem como Brissot, o fim da escravidão se inseria no quadro da luta mais ampla pelos direitos de cidadania que se iniciava na metrópole. Acreditava que a Revolução americana havia plantado a semente da liberdade, inspirando em todos os homens uma aversão total por todas as formas de tirania, e previa que, num futuro próximo, todos os estados teriam proscrito o tráfico. ${ }^{123} \mathrm{Na}$ sua opinião, a Grã-Bretanha começava a seguir os mesmos passos. A formação da sociedade antiescravista de Londres e a formulação de um projeto de lei para a abolição do tráfico eram os mais claros indícios desse processo. Petições vindas das maiores cidades inglesas tinham sido apresentadas ao Parlamento em apoio ao projeto. Brissot acreditava realmente que a Grã-Bretanha estava prestes a se tornar "[...] o primeiro, o grande exemplo de uma Nação que renuncia a uma opressão vista como útil". ${ }^{124}$

\footnotetext{
120 "Dans une Société libre, l'homme est entraîné par son intérêt personnel à développer ses facultés au plus haut degré: dans une Société libre, on ne peut se gouverner que par la raison universelle, et la raison universelle force à vouloir essentiellement la paix et le bien de tous les hommes" (Ibidem, pp.6-7)

121 "La lumière générale, celle qui tend à la félicité publique, est donc doublement incompatible avec l'esprit de servitude" (Ibidem, pp.7-8).

122 "La liberté - En la rendant aux Nègres, cessez donc de les craindre: devenus nos frères, ils ne tarderont pas à s'éclairer, à devenir bons, et, ce qui peut-être est plus difficile, les Maîtres eux-mêmes seront forcés de s'éclairer, de devenir bons; car l'esclavage est un moyen infaillible de corrompre deux hommes à la fois, le Maître et l'Esclave" (Ibidem, p.9).

${ }^{123}$ Ibidem, p. 12 .

${ }^{124}$ Ibidem, p.14.
} 
Assim, a França devia seguir o exemplo britânico e concorrer para que os objetivos primordiais da humanidade fossem atingidos, sob pena de ver as suas colônias arruinadas. O líder antiescravista apresentava a transição da escravidão para uma colonização livre como algo do interesse da Nação e uma necessidade para a conservação das colônias. ${ }^{125}$ Incorporava, nesse sentido, a crítica econômica à escravidão, ao apontar as vantagens do trabalho livre sobre a mão de obra escrava:

uma mão livre fecunda melhor o solo do que uma mão escrava. $\mathrm{O}$ regime da liberdade faz nascer a abundância: ora, quanto maior a abundância, mais o Plantador vende, mais o fisco recebe, mais a concorrência é afastada pelo bom preço, resultante da abundância; e consequentemente, mais cedo o comércio das Nações rivais da Inglaterra é esmagado. ${ }^{126}$

Assim, a erradicação da escravidão era apresentada como condição para a conservação das colônias, para a saúde fiscal do reino e para o florescimento do comércio. Ou seja, não estamos no campo de uma condenação unicamente moral da escravidão e do tráfico, mas numa crítica que une as considerações morais a outras, de ordem econômica. Estava aí enunciada uma das linhas de força da campanha dos Amigos dos Negros: a que consistia em demonstrar que os interesses das colônias e da metrópole coincidiam com o interesse da humanidade.

Tendo isso em vista, Brissot sustentava a necessidade de iniciar o quanto antes o processo de erradicação do tráfico, de modo a controlá-lo melhor. Essa proscrição teria por efeito imediato pôr fim ao estado de guerra permanente que devastava os povos da África e traria o benefício de abrir novos caminhos no continente africano, ampliando as possibilidades para o comércio europeu. ${ }^{127}$ A sociedade londrina já teria apresentado amostras de diferentes produtos provenientes da África, essenciais para as manufaturas inglesas e que constituiriam o objeto de um amplo e lucrativo comércio. Por todos esses motivos, Brissot via como necessária a adesão à causa da sociedade de Londres.

Brissot ressaltava o caráter moderado da nova sociedade, atenta a todos os interesses envolvidos no problema colonial:

Ela será, ao mesmo tempo, a defensora dos Negros, do interesse nacional, do interesse do Fisco, e até mesmo do interesse dos Plantadores; pois ela deve

\footnotetext{
125 Ibidem, p.16.

126 "une main libre féconde mieux le sol qu'une main esclave. Le régime de la liberté fait naître l'abondance: or, plus il a d'abondance, plus le Planteur vend, plus le fisc reçoit, plus la concurrence est écartée par le bon marché, suite de l'abondance; et plutôt, par conséquent, le commerce des Nations rivales de l'Angleterre est écrasé" (Ibidem, pp.16-17).

${ }^{127}$ Ibidem, p.19.
} 
buscar o meio de conciliar o respeito pela sua propriedade, com aquele que se deve à humanidade. ${ }^{128}$

Como prova dessa circunspeção, a sociedade se mostrava aberta à participação de plantadores e proprietários coloniais, que poderiam contribuir com o seu

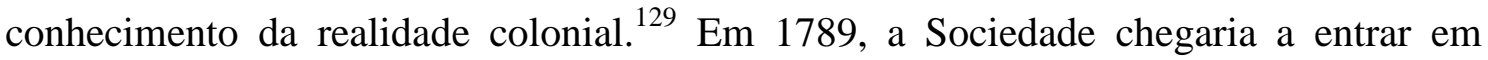
contato com o Círculo dos Filadelfos, espécie de academia colonial de ciências formada em 15 de agosto de 1784, em São Domingos, com o objetivo de trazer o progresso científico para a colônia. ${ }^{130} \mathrm{O}$ Círculo jamais questionou, durante a sua existência, o sistema escravista, admitindo, no máximo, reformas destinadas a garantir a sua perpetuação. Mesmo assim, um encontro dos Amigos dos Negros com membros do Círculo teria ocorrido em 26 de fevereiro de 1789. Não se tratava, portanto, para a Sociedade de promover agitação revolucionária em torno da questão da escravidão, mas de buscar uma solução conciliadora que garantisse a preservação das colônias francesas e dos diferentes interesses nelas envolvidos.

Mirabeau propôs-se a publicar o discurso de Brissot em seu jornal, Analyse des papiers anglais, o que ele de fato fez, em quatro partes, entre os números XXV (19-22 de feveiro) e XXVIII (29 de fevereiro - 4 de março). ${ }^{131}$ Além disso, foi decidido que exemplares impressos desse discurso seriam distribuídos ao público. Nascia então a Société instituée pour l'abolition de la traite des Nègres (tradução francesa do nome da Sociedade inglesa), que, mais tarde, em 27 de maio de 1788, ganharia oficialmente o nome mais emblemático de Société des Amis des Noirs. ${ }^{132}$

\footnotetext{
128 "Elle sera tout à la fois le défenseur des Nègres, de l'intérêt national, de l'intérêt du Fisc, de celui des Planteurs même; car elle doit chercher le moyen de concilier le respect pour leur propriété, avec celui qu'on doit à l'humanité" (Ibidem, p.26).

${ }^{129}$ Ibidem, p.28, nota 1. De fato, a Sociedade contaria inicialmente entre os seus membros com os irmãos Lameth, proprietários coloniais.

${ }^{130}$ Cf. McCLELLAN III, James E.. L'historiographie d'une académie coloniale: le Cercle des Philadelphes (1784-1793). Annales historiques de la Révolution française, Paris, n. 320, abr-jun de 2000, pp.2 e 7. Disponível em: http://ahrf.revues.org/148. Acesso em: 22 de mar de 2013.

${ }^{131}$ Cf. Analyse des papiers anglois. Paris: s.n., 1787-1788, v.2, números XXV-XXVIII.

${ }^{132}$ É interessante notar a escolha da palavra noirs, e não esclaves ou nègres, tradicionalmente mais usadas para designar a mão de obra de origem africana escravizada nas colônias. Isso pode ser interpretado, como aponta Serge Daget, como uma forma de evitar termos imbuídos de uma carga pejorativa e que remetiam ao estereótipo do negro como instrumento de produção (cf. DAGET, Serge. Les mots esclave, nègre, Noir, et les jugements de valeur sur la traite négrière dans la littérature abolitionniste française de 1770 à 1845. Nuevo Mundo Mundos Nuevos, colocado em linha em 19 de dezembro de 2009. Disponível em: http://nuevomundo.revues.org/58128. Acesso em: 31 de março de 2013. Sobre esse tema, ver também BOULLE, Pierre H.. Les déclarations parisiennes de non-blancs entre 1738 et 1790: permanence des catégories et interchangeabilité des statuts. Nuevo Mundo Mundos Nuevos, colocado em linha em 19 de dezembro de 2009. Disponível em: http://nuevomundo.revues.org/58021. Consultado em: $1^{\circ}$ de abr. de 2013).
} 


\section{I.1.1.5) Um novo tipo de sociedade}

As últimas décadas do Antigo Regime na França viram uma verdadeira profusão de sociedades filantrópicas, que se beneficiavam da proteção e do apoio financeiro de grandes personagens da época. Associações com fins humanitários, como a Société de la charité maternelle, a Association de bienfaisance e a Société philanthropique eram patrocinadas por membros da nobreza esclarecida. No geral, eram entidades sem finalidades políticas mais amplas: não visavam à transformação da sociedade ou do regime político, mas a atenuar o sofrimento das vítimas das desigualdades estruturais da época. ${ }^{133}$ Muito embora alguns inicialmente a tenham visto como parte dessa tendência, a Sociedade dos Amigos dos Negros enfrentava um problema diverso: os desafortunados que ocupavam os seus pensamentos viviam num país distante, numa realidade alheia à grande maioria do povo da metrópole. Não se tratava, no caso dos negros, de distribuir alimentos, roupas e remédios a alguns miseráveis, mas de atacar um sistema complexo, sobre o qual se sustentava um comércio bastante lucrativo.

Embora frequentemente utilizada para descrever a ação dos Amigos dos Negros, a palavra "filantropia" é inadequada para definir os objetivos e os meios de ação da Sociedade. Se ela era recorrente no discurso dos Amigos dos Negros, tratava-se essencialmente de uma forma de contrapor a ação da Sociedade ao egoísmo dos colonos escravistas. ${ }^{134} \mathrm{O}$ seu programa, por outro lado, não permite qualificar a ação da Sociedade como filantrópica. Seu objetivo não era coletar meios materiais para serem distribuídos aos escravos, nem reunir meios financeiros para comprar a sua liberdade. Embora vários de seus membros participassem de entidades de caridade $^{135}$, as tradicionais formas de ação das sociedades filantrópicas foram ignoradas pela entidade. A filantropia não buscava questionar interesses concretos ou abalar uma ordem econômica e social. A Sociedade, por outro lado, confrontava interesses coloniais e comerciais, o que permitia situar a sua ação no plano intelectual e político.

O preâmbulo do Regulamento da Sociedade demonstrava a preocupação em diferenciar a entidade das sociedades meramente filantrópicas que abundavam naquele final de século:

\footnotetext{
${ }^{133}$ Cf. DORIGNY, Marcel, GAINOT, Bernard. La Société des Amis de Noirs, pp.26-27.

134 Ibidem, p.28.

${ }^{135}$ Os Amigos dos Negros mais ligados à filantropia eram, na sua maioria, provenientes da alta nobreza e tiveram um papel secundário dentro da Sociedade. A maior parte deles se afastou da entidade após 1789, caso dos irmãos Lameth, de Béthune-Charost, do duque de Aiguillon, de Beauvau, de Lavoisier e dos irmãos Trudaine (Ibidem, p.30).
} 
A Sociedade dos Amigos dos Negros não goza das mesmas vantagens; é longe de nós que são sacrificadas as infelizes vítimas das quais ela se declarou amiga; aqueles que poderiam se tornar os seus verdadeiros defensores foram, eles próprios, cegados por um preconceito cruel; enfim, não é com dinheiro que se pode aliviar a sua miséria; mas se o seu infortúnio se encontra ligado a grandes interesses políticos, se as suas correntes encontram-se ainda mais comprimidas pela força cega do preconceito, se existem, enfim, grandes obstáculos a transpor, devem esses obstáculos nos fazer esquecer que não é uma classe limitada de infelizes que se trata de socorrer, são nações inteiras, é uma parte do mundo que, esmagada sob o peso de suas correntes, reclama junto a nós os direitos sagrados da humanidade. ${ }^{136}$

Ou seja, não se tratava simplesmente de encaminhar recursos para uma classe de desafortunados, mas de perseguir um objetivo político mais amplo e, ao mesmo tempo, mais preciso: provocar mudanças institucionais para que nações inteiras pudessem gozar dos direitos do homem. Era, ao mesmo tempo, uma sociedade de pensamento, que procurava difundir informações e ideias, por meio da publicação de panfletos, petições e traduções de obras estrangeiras, e uma sociedade política, que buscava, por meio de uma intervenção direta junto aos órgãos de poder e aos meios econômicos, medidas que permitissem o abandono gradual do sistema de exploração escravista. No intuito de auxiliar o governo no exame da questão, ela se atribuía as funções de

[...] reunir todos os fatos, dar-lhes autenticidade, recolher todos os planos que se pode formular para mudar o sistema atual, examiná-los, submetê-los ao cálculo, procurar quais conhecimentos podem ainda faltar, encontrá-los, propor as questões, recolher as respostas e compará-las, e talvez até mesmo tentar experiências. ${ }^{137}$

A combinação de modos de ação diferentes permite diferenciar a entidade das sociedades literárias típicas daquele fim de século. Ao mesmo tempo, os Amigos dos Negros não se viam como uma sociedade doutrinária, nos moldes de um partido

\footnotetext{
136 "La Société des amis des Noirs ne jouit pas des mêmes avantages; c'est loin de nous que sont sacrifiées les malheureuses victimes dont elle s'est déclarée l'amie; ceux qui pourraient devenir leurs véritables défenseurs, sont eux-mêmes aveuglés par un préjugé cruel; enfin ce n'est point avec de l'argent que l'on peut soulager leur misère; mais si leur infortune se trouve liée à de grands intérêts politiques, si leurs chaînes sont encore resserrées par la force aveugle du préjugé, s'il est enfin de grands obstacles à vaincre, ces obstacles doivent-ils nous faire oublier que ce n'est pas non plus une classe limitée de malheureux qu'il s'agit de secourir, ce sont des nations entières, c'est une partie du monde qui, écrasée sous les poids de ses fers, réclame auprès de nous les droits sacrés de l'humanité" (RÈGLEMENS de la Société des Amis de Noirs. S.l. [Paris]: s.n., s.d. [1789], p.2).

137 "[...] rassembler tous les faits, leur donner de l'authenticité, recueillir tous les plans qu'on peut former pour changer le systême actuel, les examiner, les soumettre au calcul, chercher quelles connaissances peuvent manquer encore, se les procurer, proposer les questions, recueillir les réponses et les comparer, et peut-être même tenter des expériences" (Ibidem, p.13).
} 
político. Buscavam, em princípio, a discussão de ideias, razão pela qual alguns proprietários coloniais, como os irmãos Lameth, seriam admitidos no seu quadro.

Nesse momento inicial, os meios de ação dos Amigos dos Negros estavam absolutamente circunscritos ao contexto e ao sistema político em que a Sociedade se inseria. A Sociedade de Londres beneficiava-se da existência de um regime parlamentar, o que lhe permitia apresentar projetos de lei e provocar debates perante os Comuns. Na sessão de 28 de fevereiro de 1788, Brissot manifestou, em resposta a uma carta de La Fayette, o seu desejo de ver a criação de uma assembleia nacional francesa, capaz de concorrer com o Parlamento britânico na luta contra o tráfico. ${ }^{138} \mathrm{Na}$ França, a ausência de um sistema parlamentar e a vigência do "despotismo político" apareciam como fortes obstáculos para o movimento. A única forma de fazer avançar a causa dos negros era, naquele momento, exercer a sua influência junto ao Ministério e, eventualmente, junto ao rei. Dentre os membros da Sociedade, Mirabeau, La Fayette, La Rochefoucauld e talvez Clavière, pelo seu status e influência, eram os mais indicados para exercer esse tipo de pressão.

No discurso de fundação, Brissot declarou ver no então Ministério uma vontade concreta de combater os mais diferentes tipos de abuso. Acreditava que, quando a Nação como um todo estivesse convencida de que a escravidão dos negros era um crime, o Ministério não hesitaria em levar ao rei esse voto universal. As reformas promovidas por Luís XVI apontavam, segundo Brissot, para uma derrubada de todas as diferentes formas de servidão, de modo que a liberdade dos negros seria, na sua opinião, inevitavelmente inserida no quadro das transformações do Estado francês:

Como poderia a sua mão benfeitora não se estender um dia sobre os Negros que vivem sob as suas Leis? As Colônias Francesas não fazem parte de seus Estados? Os Negros não são seus súditos, tal como os Brancos que as habitam? ${ }^{139}$

A Sociedade tinha, portanto, de investir os seus esforços na difusão de informações, funcionando como um centro de pesquisas e discussão, de modo a construir uma corrente de opinião suficientemente forte para repercutir na esfera ministerial. Na sua condição de centro de propagação de informações sobre a questão negra, o principal meio de ação da Sociedade residia na sua atividade editorial. A

\footnotetext{
${ }^{138}$ Cf. REGISTRE de la Société des Amis des Noirs, p.70.

139 "Comment sa main bienfaisante ne s'étendrait-elle pas un jour sur les Nègres qui vivent sous ses Lois? Les Colonies Françoises ne sont-elle (sic) pas partie de ses États? Les Nègres ne sont-ils pas ses sujets, comme les Blancs qui les habitent?" (Discours sur la nécéssité d'établir à Paris une Société, pp.31-32).
} 
publicação de textos antiescravistas foi definida, desde o início, como uma prioridade. Uma das principais preocupações era a tradução de obras estrangeiras, sobretudo as britânicas, que serviam de inspiração para o discurso dos Amigos dos Negros. Na sessão de 4 de março de 1788, Brissot falou sobre a necessidade de publicar tais obras, mesmo sem permissão oficial. Tratados como Essai sur les désavantages politiques de la traite des Nègres (An Essay on the Impolicy of the African Slave Trade), de Thomas Clarkson, seriam publicados logo nos primeiros anos de atividade. Mas, como advertia Brissot em 18 de março de 1788, as traduções seriam versões modificadas das obras originais, com todas as adições e supressões determinadas "[...] pelo gosto dos leitores franceses, pelo estado atual da opinião pública, e por todas as circunstâncias que nos cercam". ${ }^{140} \mathrm{Na}$ prática, isso significava, por exemplo, eliminar ou atenuar, como indicou Brissot nas suas memórias, as considerações de ordem religiosa dos textos de Clarkson, um anglicano fervoroso. ${ }^{141}$

Com a Revolução e a proclamação da liberdade de imprensa, a Sociedade teria a liberdade de publicar textos e artigos em diversos jornais e panfletos, mas, naquele final de Antigo Regime, a censura existente tornava difícil a publicação de textos antiescravistas. A natureza da Sociedade a impedia de ter um jornal próprio, em razão do regime de imprensa bastante rigoroso em vigor sob a Monarquia absoluta. Conseguir autorização para publicações que confrontavam os interesses de todo um setor da economia francesa era improvável. A edição de traduções de obras inglesas apresentava menores problemas, pois a censura tendia a ser menos vigilante em relação aos livros. ${ }^{142}$ Ainda assim, a forte censura na França levava muitos a imprimirem seus escritos em países limítrofes, como a Suíça. ${ }^{143}$

Naquele momento, Mirabeau oferecia uma solução providencial para contornar o problema. Ele tinha obtido, por meio de relações pessoais, uma autorização ministerial para publicar, em Paris, um jornal não submetido à censura do Bureau de la Librairie, órgão responsável pela controle da produção impressa. A semi-imunidade de que gozava o periódico explicava-se, em parte, pelo seu objetivo primordial de divulgar

\footnotetext{
${ }^{140}$ REGISTRE de la Société des Amis des Noirs, p.106.

${ }^{141}$ Cf. BRISSOT DE WARVILLE, Jacques-Pierre. Mémoires, v.2, p.73.

${ }^{142}$ Cf. DORIGNY, Marcel. Mirabeau et la Société des Amis de Noirs: quelles voies pour l'abolition de l'esclavage? In: _. Les abolitions de l'esclavage, pp.153-154.

${ }^{143}$ As obras impressas entravam no território francês pelo monte Jura. Brissot e outros publicaram, assim, obras pela Société typographique de Neufchâtel (STN) (cf. DAVID, Thomas. L'internationale abolitionniste: les Suisses et l'abolitionisme français, 1760-1840. In: O. PÉTRÉ-GRENOUILLEAU (org.). Abolir l'esclavage: un réformisme à l'épreuve (France, Portugal, Suisse, XVIII-XIXe siècles). Rennes: Presses Universitaires de Rennes, 2008, pp.117-118).
} 
exclusivamente notícias vindas da Inglaterra. O jornal, intitulado Analyse des papiers anglais, em circulação desde 14 de novembro de 1787, já tinha publicado o discurso de fundação da Sociedade. Na sessão dos Amis des Noirs de 28 de fevereiro, Mirabeau foi além e propôs a inclusão em seu jornal de todos os resultados dos trabalhos da Sociedade. ${ }^{144}$ Alguns dias depois, em 4 de março, ofereceu-se também para publicar, como suplemento ou apêndice, textos sobre o tráfico e assuntos relativos à Sociedade, prevendo até mesmo reduzir o preço pela metade, de modo a atingir um maior número de leitores. ${ }^{145}$ As vantagens de um periódico sobre um livro eram inegáveis, permitindo, como dizia Brissot, "[...] esclarecer rapidamente uma massa de homens que reagem no mesmo instante, em todos os sentidos, numa esfera muito grande". ${ }^{146}$

A partir de então, o jornal daria à questão do tráfico um lugar de destaque em suas edições e, até o surgimento dos primeiros números do Patriote Français de Brissot, a Analyse des papiers anglais funcionaria como tribuna para os Amigos dos Negros. A necessidade de se conformar ao projeto inicial do jornal, isto é, o de divulgar notícias da Inglaterra, implicava apresentar os artigos referentes ao tráfico e a escravidão como referentes à atualidade britânica. As menções às grandes cidades da Grã-Bretanha tornavam-se quase obrigatórias para justificar a publicação desses artigos. Como aponta Dorigny, o efeito colateral dessa tática era reforçar a imagem de um movimento antiescravista francês estreitamente sujeito aos interesses da Inglaterra. ${ }^{147}$

\section{I.1.1.6) Uma sociedade de elite}

Assim como havia acontecido com a Société gallo-américaine, a busca e a admissão de novos membros se pautava por critérios qualitativos e não quantitativos. A leitura dos Regulamentos da Sociedade dos Amigos dos Negros, apresentados em março-abril de 1788, permite identificar uma forte inclinação elitista na sua organização, mesmo que a Sociedade procurasse se afirmar como uma entidade aberta.

Assim, no que se refere à subscrição mínima para integrar a Sociedade, os Regulamentos dispunham, no seu preâmbulo, que "[...] a cotização foi fixada em

\footnotetext{
${ }^{144}$ Cf. REGISTRE de la Société des Amis des Noirs, pp.71-72.

${ }^{145}$ Ibidem, p.75. No número XXXII, de 14-18 de março de 1788, da Analyse des papiers anglais, Mirabeau explicou que, devido à grande quantidade de material, essa compilação de textos sobre o tráfico seria publicada em vários volumes de cerca de 25 páginas cada, num suplemento à parte. $\mathrm{O}$ jornal propriamente dito se limitaria a publicar cartas, notícias e documentos referentes ao tema (cf. Analyse des papiers anglois, v.2, pp.199-200).

${ }^{146}$ REGISTRE de la Société des Amis des Noirs, p.76.

${ }^{147}$ Cf. DORIGNY, Marcel. Mirabeau et la Société des Amis de Noirs, p.156.
} 
apenas dois louis para Paris, e um louis para o Interior, de modo a não afastar nenhum dos que poderiam lhe trazer luzes" (grifo nosso). ${ }^{148} \mathrm{O}$ art.I do capítulo II estabelecia ainda que o número de membros da entidade era indeterminado e que tanto estrangeiros quanto mulheres seriam bem-vindos. ${ }^{149}$ Esse suposto espírito de abertura não era condizente com os valores exigidos para a cotização anual. Dois louis correspondiam, à época, a 48 libras tornesas, o que representava mais ou menos dois meses de salário de um operário agrícola. Como diz Dorigny, essa soma era suficiente para constituir uma verdadeira "barreira social". 150

O procedimento de admissão reforçava o caráter restrito da Sociedade. Uma pessoa só podia ser admitida na Sociedade por meio da apresentação por escrito de um membro efetivo, que cumpria o papel de padrinho, e da assinatura de quatro outros membros. Era ainda necessário apresentar ao tesoureiro esse certificado e pagar-lhe o montante da cotização anual. Apenas com o certificado e a quitação desse valor, o pretendente teria o seu nome inscrito pelo Secretário no registro correspondente, recebendo então o convite para a sua primeira assembleia geral. ${ }^{151}$

Além disso, a organização e os procedimentos da Sociedade eram bastante formalizados. Ela possuía: 1) um Presidente, encarregado de propor matérias para deliberação, recolher as opiniões, resumi-las e reunir os votos, velando ainda pela ordem nas assembleias e pelo respeito aos estatutos e regulamentos; 2) um Secretário, encarregado de registrar os novos membros, cuidar da correspondência e dos livros, papéis e documentos da Sociedade, assim como registrar as propostas feitas na assembleia e as resoluções tomadas pelo Comitê e pela assembleia geral; e 3) um Tesoureiro, que tinha por função receber as cotizações dos membros e eventuais contribuições de outras pessoas interessadas, assim como prestar periodicamente contas das receitas e despesas da entidade. ${ }^{152}$

A Sociedade contava com um Comitê de 21 membros - entre os quais figuravam o presidente, o secretário e o tesoureiro - que se reunia, em princípio, todas as terças-

\footnotetext{
148 "[...] la cotisation n'a été fixée qu'à deux louis pour Paris, et à un louis pour la Province, afin de n'écarter aucun de ceux qui pourroient y apporter des lumières" (RĖGLEMENS de la Société des Amis de Noirs, p.15).

${ }^{149}$ Ibidem, p.19. Entre os primeiros aderentes, estavam algumas mulheres, na sua maioria esposas de membros importantes da Sociedade, como a Marquesa de La Fayette, a duquesa de La Rochefoucauld, a marquesa de Condorcet e Mme Clavière. Havia também uma quantidade não desprezível de associados estrangeiros.

${ }^{150}$ Cf. DORIGNY, Marcel, GAINOT, Bernard. La Société des Amis de Noirs, p.62.

${ }^{151}$ Cf. RĖGLEMENS de la Société des Amis de Noirs, pp.19-20.

${ }^{152}$ Ibidem, pp.35-36.
} 
feiras. Esse órgão permanente era responsável pela direção geral da Sociedade, tomando decisões a respeito dos objetos a serem pesquisados e das publicações a serem feitas e submetendo essas decisões à aprovação da assembleia geral. Cabia ao Comitê estabelecer uma comunicação com as demais sociedades estabelecidas para o mesmo objeto, em outros países. ${ }^{153}$ Acima de tudo, cabia ao Comitê recolher informações sobre todos os aspectos ligados ao tráfico e à escravidão: os números do comércio de negros, a perda de marinheiros na travessia, o número de escravos nas ilhas, o tratamento a eles dispensado, o produto do trabalho escravo, a quantidade de marrons nas colônias, etc. Para isso, era necessário ler todas as publicações existentes sobre a África e as ilhas, as correspondências particulares de colonos e armadores, os registros das companhias coloniais especializadas no tráfico e quaisquer outros documentos disponíveis.

Os artigos I e II do capítulo III dos Regulamentos estabeleciam a frequência das assembleias. A previsão era de uma assembleia geral mensal, na primeira terça-feira do mês, com a possibilidade de eventuais assembleias extraordinárias, convocadas por ordem do comitê. Uma outra assembleia seria reunida ao final de cada semestre, para uma recapitulação dos trabalhos do semestre. ${ }^{154}$

As sessões iniciavam-se com a leitura pelo Secretário da ata da sessão anterior. Em seguida, era feita a leitura das atas de várias sessões do Comitê. Por fim, era feito o anúncio dos diferentes objetos de deliberação atual, preparados pelo Comitê. As opiniões tinham de ser dadas segundo uma ordem pré-estabelecida: em primeiro lugar, os Oficiais, pertencentes à alta nobreza; em seguida, os membros do Comitê; e, por fim, os demais membros da assembleia. Normalmente, o Presidente opinava por último, salvo quando era o autor da moção. ${ }^{155}$ Pelo art.IV do capítulo VIII do Regulamento, ninguém podia falar em pé ${ }^{156}$

O caráter restrito da Sociedade e o excessivo formalismo de seu funcionamento não deixavam de expressar a própria natureza de uma sociedade que não buscava promover agitação política e cujo programa residia na esperança de conciliar interesses contraditórios. Alguns relatos da época revelam que esse modo de organização tornava as sessões da Sociedade tediosas e acabava afastando alguns membros. Étienne Dumont, em carta de 22 de maio de 1789, fez uma descrição pouco animadora das atividades da Sociedade: "Tudo é formalidade na assembleia, a sua maneira de recolher

\footnotetext{
${ }^{153}$ Ibidem, pp.39-42.

${ }^{154}$ Ibidem, p. 21.

155 Ibidem, pp. 24-25.

${ }^{156}$ Ibidem, p.44.
} 
as opiniões é tão ruim que a menor questão se arrasta durante horas e o tédio sempre me fez deixá-la antes do final da discussão". ${ }^{157}$

A contagem de presença nas sessões é difícil, pois as listas constantes do registro são pouco confiáveis. Elas revelam uma média de 12,5 presentes por sessão para o ano de 1788; 14 para o ano de 1789; e 11 para o ano de $1790 .{ }^{158}$ A dificuldade em realizar as sessões era grande: os membros que seriam eleitos deputados ficariam muitas vezes retidos em Versalhes e mesmo membros da cúpula da Sociedade, como La Fayette e Brissot ficariam, por vezes, impossibilitados de comparecer em razão de suas outras atividades. Mais grave do que isso era o fato de que, mesmo entre os membros presentes, havia frequentemente espiões enviados pelo partido colonial. ${ }^{159} \mathrm{O}$ que é certo é que as sessões da Sociedade não reuniam multidões. Muitos de seus membros agiam, na verdade, como meros simpatizantes.

O número de aderentes provavelmente nunca chegou a duzentos. A Sociedade não era e nem pretendia ser um clube popular. Assim, na sessão de 8 de abril de 1788 , Clavière comemorou a chegada de novos aderentes, mas apontou a necessidade de estabelecer certos limites à ampliação do quadro de membros, sob o pretexto de que, numa assembleia mais numerosa, as deliberações tornar-se-iam longas demais e os trabalhos da entidade demasiadamente lentos. ${ }^{160} \mathrm{Na}$ verdade, o que se queria limitar, mais do que o número de membros, era o próprio conteúdo do programa do movimento. É bom lembrar, aliás, que, ao longo da Revolução, os brissotinos se manifestariam recorrentemente contra o apelo ao movimento popular. Da mesma forma, a campanha dos Amigos dos Negros não era uma luta respaldada num movimento de massa.

\section{I.1.1.7) Composição}

O caráter restrito da Sociedade estava mais do que evidenciado na sua composição. Utilizando o quadro de membros publicado pela própria Sociedade em 1789, uma segunda lista divulgada por Eloise Ellery e o registro das sessões, além de informações adicionais trazidas por Claude Perroud, pudemos levantar um total de 189

\footnotetext{
157 "Tout est formalité dans l'assemblée, leur manière de recueillir les opinions est si mauvaise que la moindre question trâne durant des heures et l'ennui m'en a toujours chassé avant la fin de la discussion" (Citado em DAVID, Thomas. L'internationale abolitionniste, p.120).

${ }^{158}$ Cf. DORIGNY, Marcel, GAINOT, Bernard. La Société des Amis de Noirs, p.43.

${ }^{159}$ Cf. CLARKSON, Thomas. History of the Rise, Progress and Accomplishment of the Abolition of the Slave Trade by the British Parliament. Londres: John W. Parker, 1839, p.389.

${ }^{160}$ Cf. REGISTRE de la Société des Amis des Noirs, p.128.
} 
nomes (ver Apêndice A). Esse quadro está certamente incompleto, em razão das muitas lacunas que contêm os documentos, mas ele permite identificar algumas tendências bastante reveladoras. Para quinze dos nomes listados, não foi possível levantar quaisquer informações a respeito de sua procedência, origem social ou atividade profissional, de modo que os dados a seguir levam em conta apenas os 174 nomes restantes.

O primeiro aspecto que salta aos olhos é a sobrerepresentação da nobreza dentro da Sociedade. Pelo menos $50 \%$ dos membros eram nobres. É verdade que muitos deles tinham sido annoblis pela aquisição de cargos, mas, na maioria dos casos, tratava-se de indivíduos pertencentes à alta-nobreza. Muitos desses nobres eram oficiais das forças armadas, sendo que vários deles haviam participado da guerra de independência norteamericana. Alguns deles tiveram uma participação ativa na campanha: homens como Mirabeau, La Fayette, Condorcet e La Rochefoucauld, líderes da nobreza liberal que estaria na vanguarda da agitação política do inverno de 1788-89. Alguns deles se reuniriam, aliás, no seio da Sociedade dos Trinta, fundada em novembro de 1788, para discutir as questões a serem agitadas nos Estados Gerais, caso de Duport, La Fayette, Condorcet, Mirabeau, La Rochefoucault e os irmãos Lameth. ${ }^{161}$ Essa ala da nobreza reforçaria a reivindicação do Terceiro Estado pela representação dupla e pelo voto por cabeça.

É possível que, para outros membros da nobreza, os Amigos dos Negros não fossem muito diferentes das inúmeras sociedades filantrópicas que haviam se tornado bastante prestigiosas entre a elite francesa. Atraídos pelo exotismo da Sociedade, talvez não percebessem as motivações fundamentalmente políticas da causa antiescravista. Grande parte desses nobres deixaria a Sociedade quando das primeiras grandes polêmicas sobre a questão colonial.

Por outro lado, as categorias que poderiam, em tese, ocupar um lugar de destaque na Sociedade encontravam-se subrepresentadas. Os jornalistas, homens de letras e de ciência, advogados, médicos e profissionais liberais em geral representavam "apenas" cerca de $18 \%$ dos membros da Sociedade. São essas categorias, desvinculadas

${ }^{161}$ Cf. BLANNING, T.C.W. Aristocratas versus Burgueses? A Revolução Francesa. (trad: Cid Knipell Moreira). São Paulo: Editoa Ática, 1991, pp.46-47. A Sociedade dos Trinta, que ainda contava com a presença de outros amigos dos Negros como Clavière, Bergasse, Volney e Sieyès, só assumiria esse nome em 1791. Ele se explica pelo fato de muitos de seus membros serem maçons. Houve quem especulasse sobre os laços existentes entre o antiescravismo e a maçonaria. É uma tese que exigiria uma maior fundamentação, visto que a maçonaria reunia tanto homens como Brissot e Mirabeau quanto escravistas declarados como Moreau de Saint-Méry. Nas cidades portuárias, negociantes e armadores eram a maioria entre os maçons. Além disso, deve-se lembrar a existência de lojas maçônicas no seio das elites coloniais. 
das instituições do Antigo Regime, que poderiam ter levado o movimento para uma linha abolicionista mais avançada. Sua dependência, entretanto, da influência política e financeira da nobreza liberal certamente limitava o seu poder de direção.

Verifica-se, assim, uma ausência notável do pessoal dirigente da futura esquerda revolucionária. Robespierre nunca foi membro, apesar de alguns textos sugerirem o contrário. ${ }^{162}$ Aliás, nenhum dos futuros chefes montanheses do governo do ano II pertenceu à Sociedade. ${ }^{163}$ Por outro lado, verifica-se uma forte presença dos futuros líderes da Gironda (Brissot, Condorcet, Clavière) e também uma parte considerável dos futuros Feuillants (Lameth, La Fayette, Sieyès, Lacépède, Duport). Os Amigos dos Negros reuniam, portanto, nomes importantes daquele que seria o pessoal político da Revolução, mas não eram nomes dos campos mais radicais.

O clero contribuía com cerca de $8 \%$ dos membros, um número aparentemente alto, se considerarmos a participação da ordem na população francesa, mas pouco expressivo em termos absolutos (apenas 14 membros). Isso revela o papel secundário da religião no antiescravismo francês, contrastando com o movimento inglês, no qual as correntes religiosas foram determinantes. Esse fato pode ser explicado pela ausência de uma postura antiescravista oficial por parte da Igreja, tradicionalmente tolerante em relação à escravidão negra. ${ }^{164}$ Apenas um clérigo se mostraria realmente ativo na causa dos negros: o abade Grégoire.

Marcel Dorigny sustenta a tese de que a composição da Sociedade seria indicativa da "orientação colonial" do programa antiescravista dos Amigos dos

\footnotetext{
${ }^{162}$ Quando, em maio e setembro de 1791, Robespierre defendeu as mesmas posições que os Amigos dos Negros, a respeito dos homens de cor livres, ele o fez a título individual e não como membro da Sociedade.

${ }^{163}$ Em fevereiro de 1788, Hérault de Séchelles foi convidado a entrar na entidade, mas, embora tivesse manifestado a sua simpatia pela causa, acabou renunciando à ideia de integrar uma Sociedade não aprovada pelo Parlamento, onde atuava como advogado (REGISTRE de la Société des Amis des Noirs, p.67). Mais tarde, Brissot diria, nas suas Memórias, que: "Hérault, então advogado geral no Parlamento, temia mostrar-se o advogado da liberdade dos negros e passar por cúmplice daqueles que preparavam a Revolução, e hoje ele não teme ser o defensor dos revolucionários mais sujos, e colocou-se ao lado dos mais intrépidos amigos da licença e da anarquia!" ("Hérault, alors avocat général au Parlement, craignait de se montrer l'avocat de la liberté des noirs et de passer pour complice de ceux qui préparaient la Révolution, et il ne craint pas d'être aujourd'hui le défenseur des plus sales révolutionnaires, et il s'est placé au rang des plus intrépides amis de la licence et de l'anarchie!", BRISSOT DE WARVILLE, Jacques-Pierre. Mémoires, v.2, p.76)

${ }^{164}$ As primeiras tomadas de posição oficiais da Igreja contra o tráfico negreiro viriam nas primeiras décadas do século XIX. Em 1814, no Congresso de Viena, o papa Pio VII proibiria a qualquer homem do clero dar o seu apoio ao tráfico de escravos negros. Mais tarde, em 1839, na Constituição In Supremo Apostolatus Fastigio, Gregório XVI condenaria abertamente o tráfico negreiro (cf. QUENUM, Alphonse. Some Remarks on the Christian Churches and the Atlantic Slave Trade from the Fifteenth to the Nineteenth Century. In: D. DIÈNE. From Chains to Bonds: the Slave Trade Revisited. New York: Bergahn/Paris: Unesco Publishing, 2001, p.270).
} 
Negros. ${ }^{165}$ Essa é uma afirmação que se deve precisar melhor. A presença de colonos propriamente ditos na Sociedade é quase desprezível. Com exceção dos cinco cidadãos de cor, que tiveram uma passagem efêmera pela Sociedade, poucos proprietários coloniais foram citados nas fontes disponíveis. Os irmãos Lameth, com posses em São Domingos, eram certamente os nomes mais expressivos, mas não se pode dizer que tenham sido membros ativos do movimento. Sabe-se também que La Fayette tinha posses nas colônias - na Guiana, sobretudo -, mas considerá-lo um colono, ao mesmo título que os demais, seria um exagero. Além desses nomes, um personagem obscuro, Bouteiller, é citado no registro como colono, mas trata-se provavelmente de um dos Bouteillers, grandes negociantes de Nantes que tinham plantações nas ilhas. O registro também indica a presença de um Segretier, que pode ou não ter sido um colono de São Domingos. Além dos proprietários coloniais, encontramos a presença de três antigos administradores coloniais - Bellier, Boufflers e Daniel Lescallier - e dois armadores de Missy e Bérard -, além de alguns militares que haviam atuado nos territórios coloniais, caso de Servan de Gerbey, na Guiana. No geral, entretanto, as pessoas com interesses diretos nas colônias, ou mesmo uma experiência concreta nos territórios coloniais, permaneceram largamente minoritárias. Os Amigos dos Negros encaravam a questão colonial sob uma perspectiva essencialmente metropolitana.

\section{I.1.1.8) Os financistas}

Havia, por outro lado, uma fortíssima presença de pessoas ligadas aos meios da Finança, em especial os coletores e funcionários ${ }^{166}$ da Ferme Générale e da Régie Générale, isto é, financistas que compravam do Estado o direito de cobrar determinados tributos. ${ }^{167}$ Esse sistema permitia ao Estado tratar com um grupo reduzido de financistas solventes, que assumiam os riscos e inconvenientes da cobrança. Nessa condição, eles eram os principais credores do Estado francês, concedendo-lhe, por meio de

\footnotetext{
${ }^{165}$ Cf. DORIGNY, Marcel, GAINOT, Bernard. La Société des Amis de Noirs, p.39.

${ }^{166}$ Era comum que funcionários subalternos da Ferme Générale acumulassem dinheiro suficiente para tornarem-se coletores (cf. JOUVENEL, Bertrand de. Napoléon et l'économie dirigée, pp.36-37).

${ }^{167}$ Nesse sistema de privatização da coleta de impostos, havia dois contratos possíveis. Pelo contrato de ferme, a companhia se comprometia a pagar um valor fixo, sob forma de caução, ao Estado, em troca da concessão, assumindo, assim, o risco das flutuações de receita, mas acumulando tudo o que ultrapassasse o valor da concessão. Já o contrato de régie, dava os membros da companhia - régisseurs - uma remuneração ou retribuição fixa, de modo que era o governo que suportava os riscos (cf. WHITE, Eugene N. L'efficacité de l'affermage de l'impôt: la Ferme Générale au XVIIIe siècle. In: L'administration des finances sous l'Ancien Régime. Paris: Comité pour l'histoire économique et financière, 1997, pp.104-105).
} 
adiantamentos sobre os impostos a serem coletados, crédito financeiro para cumprir sua folha de gastos. Os financistas atuavam, sobretudo, como intermediários entre o Estado e outros credores privados e lucravam muito com as possibilidades de crédito e investimento. ${ }^{168}$ Símbolo do sistema tributário do Antigo Regime ${ }^{169}$, a Ferme Générale, desde a reforma de 1780, cuidava da gabela (imposto sobre o sal) e dos direitos aduaneiros de entrada, saída e passagem, ao passo que a Régie Générale ficava encarregada dos direitos sobre bebidas e alimentos. Pela natureza de sua função, essas companhias, que tinham atingido o seu auge naquele final de século ${ }^{170}$, tinham interesse no fortalecimento do comércio, na medida em que eram responsáveis pela cobrança dos impostos indiretos sobre a venda de certos objetos de consumo (aides), especialmente os vinhos, e de direitos sobre o trânsito de mercadorias (traites, alfândegas na entrada, saída e passagem). ${ }^{171}$ A Ferme Générale detinha ainda o monopólio do comércio do tabaco. $^{172}$

Os membros pertencentes ao sistema financeiro representavam cerca de $17 \%$ dos Amigos dos Negros, um número bastante elevado para ocupações tão específicas. Sua presença na Sociedade não era um acaso. Essas eram instituições que, pela sua própria natureza, preocupavam-se com a eficiência da organização financeira do país e com a ampliação da base de contribuição. Nesse sentido, a política do Estado absolutista de favorecimento do comércio colonial as colocava frequentemente em conflito com os grupos ligados ao comércio com as colônias.

168 Cf. DONOVAN, Arthur. Antoine Lavoisier, pp.114-128; COLL, Elisa Badosa. Hacienda real y sociedad en la Francia del siglo XVII. Pedralbes: revista d'història moderna, Barcelona, n.14, 1794. Disponível em: http://www.raco.cat/index.php/Pedralbes/article/view/101379. Acesso em: 7 de mar de 2013, p.126, 148-149. Em 1780, a dívida do governo para com a Ferme Générale já tinha atingido 72 milhões de libras (cf. WHITE, Eugene N. L'efficacité de l'affermage de l'impôt, p.107).

${ }^{169}$ A Ferme Générale era particularmente odiada por conta da truculência que empregava na cobrança dos tributos. Ela simbolizava, aos olhos da população, um sistema tributário marcado pela desigualdade e pela injustiça. Em razão disso, 28 fermiers généraux seriam executados em 8 de maio de 1794. Alguns deles eram antigos membros da Sociedade dos Amigos dos Negros.

${ }^{170}$ As receitas da Ferme Générale tinham passado de 99 milhões de libras, em 1725, para 253 milhões em 1788 (cf. DONOVAN, Arthur. Antoine Lavoisier. Science, Administration and Revolution. Cambridge: Cambridge University Press, 1993, p.118).

${ }^{171}$ Cf. WHITE, Eugene N. L'efficacité de l'affermage de l'impôt, pp.109-110.

${ }^{172}$ A relação entre o tabaco e o tráfico francês não era tão imediata quanto a que existia no caso do açúcar e do café. Afinal, havia produção de tabaco no território francês, com mão de obra livre, em províncias do Leste e do Sudoeste, embora fosse proibida no restante do país. Além disso, em São Domingos, a produção de tabaco, que chegou a ser, no final do século XVII, a mais importante da colônia, declinou bastante durante as últimas duas décadas do século XVIII, em favor do café, do anil e do açúcar. A França se via obrigada a importar tabaco de outros lugares (Virgínia, Brasil, Espanha, Cuba) (cf. GHACHEM, Malick W. The Old Regime and the Haitian Revolution, p.37; Le Commerce de l'Amérique par Marseille, v.1, p.566). 
As disputas entre financistas e negociantes foram uma constante durante $\mathrm{o}$ Antigo Regime, em razão da política econômica do Estado francês. ${ }^{173}$ Desde o tempo de Colbert, a Monarquia havia estabelecido como prioridade favorecer o comércio com as colônias e a reexportação dos insumos coloniais para a Europa. O Edito de maio de 1664 havia fixado o privilégio exclusivo da Companhia das Índias Ocidentais para o comércio com as colônias da América. Esse monopólio foi posteriormente revogado, mas a base da política de incentivos ao comércio colonial foi mantida: pagamento de gratificações em dinheiro por mercadorias levadas às colônias e trazidas das mesmas, além de isenções sobre os direitos de entrada e saída desses produtos. As Cartas patentes do rei de 1716 e os regulamentos posteriores estabeleceram a liberdade do comércio colonial e definiram um sistema de isenções destinado a dar todo o incentivo a esse ramo da economia francesa: isenção completa dos direitos de saída para produtos nacionais destinados às colônias; isenção de metade dos direitos de entrada para produtos provenientes das colônias para serem consumidos internamente; isenção total dos direitos locais (alfândegas internas) para produtos que atravessassem o território francês para serem reexportados; isenção total até mesmo para produtos estrangeiros que fossem destinados ao comércio da Guiné. ${ }^{174}$

Essa política de incentivos fiscais originou, desde o final do século XVII, conflitos sucessivos entre fermiers généraux e negociantes envolvidos no comércio colonial. Os fermiers eram responsáveis não apenas pela cobrança dos tributos sobre a circulação de mercadorias como também pela restituição dos direitos pagos sobre mercadorias isentas. Os negociantes, muitas vezes, aproveitavam-se das brechas ou obscuridades da lei para obter vantagens indevidas, enquanto os fermiers buscavam sempre introduzir novos regulamentos ou interpretações que lhes permitissem derrubar as isenções. Tudo girava em torno da taxação ou não das mercadorias ou então da mensuração dos impostos a serem pagos. Negociantes dos portos protestavam contra as formalidades cada vez mais rigorosas que eram introduzidas pelos coletores. ${ }^{175}$ Havia muitas disputas relativas aos certificados de origem nacional dos produtos, assim como

\footnotetext{
${ }^{173}$ Financistas e negociantes não tendiam a se misturar. Segundo Yves Durand, o estudo das fortunas dos fermiers généraux mostra que estes fizeram poucos investimentos no comércio ou nas colônias. Sua fortuna era, geralmente, investida na própria Ferme, em senhorias, em imóveis ou - o que era raro - em ações de companhias industriais. Os que investiam nas colônias e no tráfico eram uma exceção e, mesmo no seu caso, esses investimentos representavam uma parte pequena de seu patrimônio (cf. DURAND, Yves. Négociants et financiers en France au XVIIIe siècle. In: La fiscalité et ses implications sociales en Italie et en France aux XVIIe et XVIIIe siècles. Roma: École Française de Rome, 1980, pp.98-99).

${ }^{174} \mathrm{Cf}$. Le Commerce de l'Amérique par Marseille, v.1, pp.19-27.

${ }^{175}$ Ver, por exemplo, carta a Bayonne, 14 de agosto de 1751, ADLA, C 600, fl.47.
} 
disputas relativas às práticas de contrabando. Em muitos casos, os coletores de impostos tentavam taxar produtos destinados ao tráfico, gerando reclamações dos negociantes. ${ }^{176}$ Eram comuns os conflitos decorrentes do trânsito de produtos coloniais dentro do país, supostamente para serem exportados: alguns negociantes se valiam dessa alegação para obter a restituição dos direitos pagos na entrada, muito embora as mercadorias se destinassem ao consumo interno. Os fermiers généraux recusavam-se a pagar e protestavam junto à Administração real. ${ }^{177}$ Outros conflitos giravam em torno do entreposto, isto é, da possibilidade dada aos negociantes de colocar em entreposto durante um ano ou mais todas as mercadorias, na entrada e na saída, para o comércio da Guiné ou das colônias. Os fermiers trancavam, num armazém próprio, até o embarque, as mercadorias sujeitas ao direito de entrada ou mesmo proibidas na França, mas que eram permitidas no tráfico. Expirados os prazos, os fermiers vinham cobrar os direitos correspondentes, o que gerava protestos dos negociantes. ${ }^{178}$ Também eram comuns os desacordos quanto ao peso e volume das mercadorias e as disputas relativas à base de cálculo para a tributação, que podia ser a mercadoria embarcada nas colônias ou o carregamento vendido na França. ${ }^{179}$

Essas disputas motivavam a emissão contínua de novas regulamentações por parte do Estado francês. A complexidade da legislação era tal que cada nova decisão gerava novas altercações, baseadas em interpretações conflitantes dos instrumentos legais. No final de 1745, por exemplo, os negociantes de Nantes e os fermiers généraux entraram em confronto a respeito da extensão ou não dos privilégios da Companhia das Índias aos particulares que passavam a exercer o comércio da África. Em casos como esse, era interessante observar o nível de articulação entre as diferentes praças de comércio que trocavam uma abundante correspondência para orquestrar a oposição à Ferme. ${ }^{180}$ Ambas as partes se acusavam reciprocamente de fraude. Para os armadores de Nantes, os fermiers queriam arruinar o comércio.

\footnotetext{
${ }^{176}$ Em 1748, por exemplo, os fermiers généraux tentaram taxar os aguardentes da Guiana destinados à Costa da África. Ora, mercadorias destinadas ao tráfico estavam isentas de direitos de saída, o que gerou protestos violentos dos negociantes de Bordeaux (cf. SAUGERA, Éric. Bordeaux port négrier XVIIe XIXe siècles. Paris: Karthala, 2002, p.70).

${ }^{177}$ Ver, nesse sentido, a Carta da Companhia dos Fermiers Généraux de 20 de dezembro de 1741 a M. de Callas, Diretor das Fermes do departamento de Marselha (reproduzida em Le Commerce de l'Amérique par Marseille, v.1, pp.110-111).

${ }_{178}$ Cf. DURAND, Yves. Négociants et financiers en France au XVIIIe siècle, pp.105-106; MARTIN, Gaston. Nantes au XVIIIe siècle, p.345 e 351.

${ }^{179}$ Cf. DURAND, Yves. Négociants et financiers en France au XVIIIe siècle, p.104.

${ }^{180}$ Cf. ADLA C 599, fls.46/47/49.
} 
Além das isenções, havia também problemas relativos ao pagamento dos prêmios ao tráfico negreiro. Essa política tinha sido instituída pela ordenação de SaintGermain-en-Laye de 1662, que tinha dado aos negociantes dez libras por negro da costa da Guiné enviado às ilhas da América. Mas, na última década do Antigo regime, esse sistema foi ampliado, para atender as demandas da produção colonial, que vivia o seu auge. Para pôr fim aos inúmeros casos de fraude, e certamente por pressão dos fermiers $^{181}$, o Estado francês decidiu substituir a isenção de metade do imposto de entrada pelo pagamento de prêmios. De acordo com o regime estabelecido pela decisão do Conselho do rei de 26 de outubro de 1784, completada pelas decisões de 5 de junho de 1785 e 10 de setembro de 1786, os incentivos compreendiam o pagamento, na saída do navio, de 40 libras por tonel de mar (pouco mais de um metro cúbico) de mercadoria, para navios destinados ao tráfico, e um prêmio adicional de 160 libras por escravo introduzido nas colônias francesas. Os maiores incentivos estavam voltados para a venda de escravos para o Sul de São Domingos, tradicionalmente pouco abastecido pelo tráfico e cujas exigências cresciam com o boom do café na província: 200 libras por escravo vendido no porto de Cayes-Saint Louis. Essas subvenções representavam, para o traficante, uma garantia contra eventuais perdas, atrasos e falta de pagamento por parte dos colonos. ${ }^{182} \mathrm{Se}$, em Portugal, o traficante pagava ao Estado para exercer sua atividade, na França, era o Estado quem pagava, por meio de financistas, ao traficante. A substituição do meio-imposto pelas gratificações foi inicialmente mal recebida pelos negociantes de Nantes, que tentaram adiar a sua aplicação até 1795 , sob o argumento de que, sem isenções, os riscos inerentes ao tráfico tornariam esse comércio insustentável. ${ }^{183}$ Em pouco tempo, entretanto, esses prêmios começaram a ser vistos como imprescindíveis para a continuação do tráfico. Começaram também os problemas de pagamento desses prêmios pelos fermiers généraux, que acusavam os negociantes de fraude. ${ }^{184}$ No final dos anos 80 , os problemas relativos ao pagamento dos prêmios eram bastante frequentes. ${ }^{185}$

\footnotetext{
${ }^{181}$ Encontramos referências a pressões dos fermiers généraux pela substituição das isenções por prêmios em 1755 (cf. ADLA C 604, fl.187).

${ }^{182}$ Cf. BÉNOT, Yves. La Révolution et la fin des colonies, p.91; THIBAU, Jacques. Le temps de SaintDomingue, pp.70-71; WEBER, Jacques. La traite négrière nantaise de 1763 à 1793, p.28.

${ }^{183}$ Cf. ADLA, C 607, fl.68 e, sobretudo, carta ao Controlador Geral e ao Marechal de Castries, 4 de dezembro de 1784 , fls.72/73.

${ }^{184}$ Cf. carta a Monseigneur le Comte de Montmorin, 3 de janeiro de 1788, ADLA C 607, fls.238/239.

185 A Ferme recusou-se, em 1788, a pagar os prêmios para a introdução de bacalhau nas ilhas aos negociantes Preau e Le Boterf, gerando revolta em Nantes (cf. ADLA C 607, fls.248/249/256/257/258/268/269; C 626, fls.224/225). Em 16 de novembro de 1789, a Câmara de
} 
Assim, a política do estado absolutista francês de conceder favorecimentos ao tráfico negreiro era o palco de disputas constantes entre financistas e negociantes dos portos. Às vésperas da Revolução, as tensões tinham atingido o seu auge. Entre o final de 1788 e os primeiros meses de 1789, a Câmara de comércio de Nantes multiplicou a sua correspondência com Necker para protestar contra os obstáculos interpostos pelos fermiers généraux ao comércio com a África. ${ }^{186}$ Aliás, no momento da reunião dos Estados Gerais, a General do Comércio de Nantes viria a pedir a supressão dos fermiers généraux. ${ }^{187}$ Esse quadro permite compreender a presença de coletores de impostos na Sociedade dos Amigos dos Negros. Para esses homens, a luta antiescravista era, acima de tudo, uma luta antitráfico ou, pelo menos, uma luta contra a política do Estado francês de favorecimento dos negociantes ligados ao tráfico, em detrimento dos seus interesses.

Vale também notar a expressiva participação na Sociedade de membros ligados às cortes soberanas: cerca de $12 \%$ dos membros. Havia vários advogados e conselheiros dos Parlamentos (tribunais regionais de segunda instância), mas também vários advogados e conselheiros da Cour des Aides, corte soberana de segunda instância competente para julgar causas envolvendo finanças do Estado, o que compreendia as questões fiscais ligadas a impostos indiretos (traites, aides, gabela). Desta forma, eles reforçavam o campo ligado às questões financeiras. ${ }^{188}$ Estava, portanto, fortemente representada no seio do movimento antiescravista, toda uma classe cuja prosperidade tinha sido determinada pela política da Monarquia de estabelecer impostos indiretos, confiando a sua coleta a fornecedores privados de serviços públicos, e de tomar empréstimos para financiar os altos custos da vida na Corte e da guerra. Se havia uma prevalência do sentimento humanitário no discurso da Sociedade, os interesses materiais também ocupavam um lugar importante na entidade.

Para além da simples contestação das isenções e subvenções do estado francês ao tráfico negreiro, poderíamos ver nessa burguesia das finanças uma fração de classe em oposição a um setor da economia francesa visto como parasitário. Devemos observar que, quando falamos em fração de classe, não empregamos a expressão na sua

comércio de Bordeaux queixou-se junto à de Nantes a respeito da tentativa dos fermiers généraux de alterar a forma do pagamento dos prêmios ao comércio (cf. ADLA C 626, pasta 2, fl.15).

${ }^{186}$ Cf. ADLA C 608, fls.23/24, 48.

${ }^{187}$ Cf. DURAND, Yves. Négociants et financiers en France au XVIIIe siècle, p.110.

${ }^{188}$ Dorigny aponta que os endereços sucessivos dos Amigos dos Negros concentraram-se nas imediações da Caisse d'escompte, da Sociedade de seguro sobre a vida e da Bolsa, o que pode evidenciar o papel importante dos financistas no seio da Sociedade (cf. DORIGNY, Marcel, GAINOT, Bernard. La Société des Amis de Noirs, pp.45-46). 
formulação tradicional. Poulantzas desenvolveu a ideia de que, no quadro do modo de produção capitalista, a classe detentora do capital se divide em frações com interesses próprios. No funcionamento de tal sistema, o capital como um todo percorre um ciclo reprodutivo, ao longo do qual ele cumpre, em cada um de seus momentos específicos, uma função diferente, fenômeno que acarreta diferenças de posição entre os vários capitalistas portadores dessas funções: o capital bancário cumpre a função de financiamento; o capital industrial, a de produção; e o capital comercial, a de distribuição. $^{189}$ No nível do circuito do capital, existem, portanto, três frações essenciais, que podem se articular com outros sistemas de fracionamento. Os indivíduos portadores desses capitais manifestam diferenças de posicionamento dentro do processo de reprodução do capital, mas também quanto ao papel do Estado nesse processo. É na medida dessas diferenças que as frações se manifestam.

Na base da teoria das frações, está a compreensão de que o processo de geração da mais-valia se dá na esfera da produção, mas a mais-valia tem de ser repartida entre todas as funções do capital. Os portadores de cada função lutam politicamente para obter para si uma fatia maior, seja sob a forma de taxa de juros (no caso do capital bancário), de lucro industrial (para o capital industrial) ou de lucro mercantil (para o capital comercial). O Estado não é neutro na repartição da mais-valia, pois suas medidas sempre desequilibram a distribuição em favor de um setor e interferem na relação entre as formas do capital. A fração de classe aparece efetivamente na reação às medidas tomadas pelo Estado na política econômica e social, gerando o que Poulantzas chama de "efeitos pertinentes" no plano político. ${ }^{190}$ Isso não significa necessariamente que cada fração irá constituir um partido político ou grupo de interesse. Não é indispensável para a existência das frações a formação de grupos politicamente organizados. ${ }^{191}$ Elas podem manter-se caladas, até reagirem diante de uma política estatal. As frações se manifestam preferencialmente por meio da formação de grupos de pressão, mas elas podem também

${ }^{189}$ Cf. POULANTZAS, Nicos. Pouvoir politique et classes sociales. Paris: François Maspero, 1971, v.1, p.77, nota 26.

${ }^{190}$ Cf. POULANTZAS, Nicos. Pouvoir politique et classes sociales, v.1, pp.77-85; RESCH, Robert Paul. Althusser and the Renewal of Marxist Social Theory. Berkeley, Los Angeles, Oxford: University of California Press, 1992, pp.326-327.

${ }^{191}$ A forma do partido político é, aliás, bastante imprópria para que a fração se manifeste, pois um partido dos banqueiros, dos industriais ou dos comerciantes não seria capaz de convencer a sociedade como um todo de que seu projeto atende ao interesse geral. Isso não impede, entretanto, que as frações apoiem ou mesmo financiem partidos políticos cujo programa encontra-se alinhado com seus interesses concretos (cf. CLARKE, Simon. Capital, Fractions of Capital and the State: 'Neo-Marxist' Analysis of the SouthAfrican State, pp.63-64. Disponível em: https://files.warwick.ac.uk/simonclarke/files/pubs/Fractions.pdf Acesso em: 8 de maio de 2012). 
gerar "efeitos pertinentes" sem mesmo aparecer publicamente. O Estado pode definir uma política econômica sem esperar que os grupos se manifestem. Nesse caso, as frações só se manifestarão efetivamente quando sentirem que as medidas tomadas pelo governo lhes são prejudiciais, emergindo então como grupo político, lobby ou thinkthank.

Falar em frações de classe no contexto da França do fím do século XVIII, entretanto, é uma tarefa complexa, na medida em que implicaria situar cada uma das frações no processo reprodutivo do capital. Isso é problemático, tendo em vista que o capital industrial encontrava-se ainda num estágio bastante incipiente e pouco vinculado às outras formas do capital. Numa sociedade de feições ainda pré-capitalistas, as diferentes classes ainda não estavam tão articuladas. Nesse sentido, não se pode falar em frações de classe num sentido mais tradicional.

Contudo, o estudo da sociedade francesa do final do século XVIII revela que, no mesmo momento em que a burguesia se organizava como classe e se preparava para tomar o poder político, era possível encontrar, dentro da própria burguesia, conflitos entre grupos - "frações" - que reagiam à sua forma às políticas estatais. O Estado monárquico era a base do poder dos financistas, seus maiores credores, mas a sua política de subvencionar o tráfico negreiro, por meio de isenções fiscais dos produtos envolvidos no comércio triangular e do pagamento de prêmios em dinheiro por escravo e mercadorias nelas introduzidas, atingia diretamente os interesses da Finança. A participação dos meios financeiros num grupo de pressão como a Sociedade dos Amigos dos Negros, em oposição à burguesia ligada ao tráfico e em resposta à proteção a ela concedida pelo Estado monárquico, caracteriza um "efeito pertinente" produzido no nível político. Embora estivessem vinculados à estrutura econômica do Estado absolutista, os financistas não deixavam de ter uma postura crítica quanto às políticas concretas adotadas pela Monarquia, que tinham muitas vezes por arbitrárias. ${ }^{192}$

Teríamos, assim, duas "frações" distintas do capital-moeda: de um lado, uma fração mercantil, ligada ao comércio com as colônias e a reexportação dos insumos coloniais para o continente europeu; de outro, uma fração financeira (ou usurária), que

\footnotetext{
${ }^{192}$ Elisa Coll explica que, embora dependesse dos financistas, o Estado exercia um controle muitas vezes arbitrário sobre o sistema de finanças, com a modificação unilateral dos termos e valores das adjudicações. Por meio das Chambres de Justice - tribunais excepcionais que se reuniam, em média, a cada dez anos - , o Estado exercia pressão sobre os financistas, não apenas para reprimir fraudes - que eram constantes -, mas também como meio de obter dinheiro, por meio de multas, confiscos, empréstimos forçados, etc. (cf. COLL, Elisa Badosa. Hacienda real y sociedad en la Francia del siglo XVII, pp.140-145).
} 
especulava sobre a própria moeda e via essa burguesia mercantil como um setor parasitário no quadro da economia nacional. Eram frações vinculadas a duas funções cumpridas pelo capital monetário naquela sociedade: no caso do capital usurário, a de comerciar a própria moeda; no caso do capital mercantil, a de comerciar certos produtos (escravos, trade goods, víveres, ferramentas para a produção colonial). Cada uma dessas frações via a si própria como agente do desenvolvimento, atribuindo à fração oposta uma condição parasitária. Ao se voltarem para produtos diferentes, os portadores desses capitais, que compunham o topo da burguesia francesa do século XVIII, necessariamente assumiam posturas diferentes em relação à política do Estado absolutista. Os Amigos dos Negros tornaram-se um veículo possível para a organização política de uma parte da fração financeira, na medida em que atacavam um dos pilares do poder econômico da burguesia comercial, o tráfico negreiro. Esses financistas não se opunham ao comércio com as colônias, mas à forma como este era realizado.

Uma sociedade de elite, com forte presença das classes privilegiadas, de pessoas ligadas à administração, aos meios financeiros e jurídicos do Antigo Regime; uma sociedade desprovida de base popular e, mais do que isso, avessa ao envolvimento das massas na sua campanha: que tipo de programa político podia inspirar uma entidade com essas feições? Certamente não um abolicinismo radical ou revolucionário. A causa antiescravista, na França daquele final de século, não era uma causa própria a estimular a agitação popular. O conteúdo do programa dos Amigos dos Negros adequava-se à sua composição. Ele se inscrevia dentro de uma evolução intelectual particular que, a partir de meados do século XVIII, tinha estabelecido os limites ideológicos para uma ação antiescravista na França. 


\section{I.1.2) Um programa antiescravista moderado}

O discurso lido por Brissot em 19 de fevereiro de 1788, dia da fundação da Sociedade, é revelador dos limites dentro dos quais operavam os antiescravistas franceses daquele final de século. Esse discurso retomava, em grande medida, ideias que vinham sendo desenvolvidas desde meados do século XVIII, quando ganhou força a crítica à gestão incontrolada da escravaria pelos plantadores. Eventualmente, essa lógica administrativa, de caráter preservacionista, repercutiu no desenvolvimento de uma opinião antiescravista.

A formação de uma crítica sistemática à escravidão na França foi um processo lento. Durante a Idade Média, a aceitação do princípio da escravidão era quase universal, mesmo nas áreas em que ela estava praticamente extinta. O Renascimento, entretanto, viu uma crescente hostilidade, entre humanistas e juristas, à ideia da servidão perpétua. Esse movimento acompanhava a erosão progressiva da escravidão e da servidão na Europa ocidental. Ao mesmo tempo, como aponta David Brion Davis, o resgate do aprendizado clássico reforçava as justificativas tradicionais da escravidão. ${ }^{193}$

No último quartel do século XVI, Jean Bodin estabeleceu um marco para a crítica à escravidão na França. Nos Seis Livros da República (1576), ele refutou o argumento segundo o qual a escravização do prisioneiro condenado à morte seria um ato de misericórdia: "Dizer que é uma caridade louvável guardar o prisioneiro que se pode matar é a caridade dos ladrões e corsários, que se glorificam por ter dado a vida àqueles que não mataram". ${ }^{194}$ Bodin queria com isso menos contestar a escravidão em geral do que ressaltar que, na guerra, o vencedor não era sempre o mais justo, e que homens doces e pacíficos eram comumente a presa de homens maus. Ao mesmo tempo, ao retomar a concepção aristotélica de servidão natural ${ }^{195}$, acabava sugerindo, desta forma, que a sujeição do homem mau e ignorante ao homem justo e sábio era legítima.

\footnotetext{
${ }^{193}$ Cf. DAVIS, David Brion. O Problema da Escravidão na Cultura Ocidental, pp.113 e 128-129.

194 "De dire que c'est une charité louable [de] garder le prisonnier qu'on peut tuer, c'est la charité des voleurs et corsaires, qui se glorifient d'avoir donné la vie à ceux qu'ils n'ont pas tués" (BODIN, Jean. Les Six livres de la République. Paris: Librairie Générale Française, 1993, p.86).

${ }^{195} \mathrm{Na}$ Política, Aristóteles sustentou que a relação de obediência que se dá entre a alma e o corpo se reproduz entre homens de constituição diferente. Existiriam, na espécie humana, seres tão inferiores aos outros quanto o corpo em relação à alma. Esses indivíduos, próprios apenas aos trabalhos do corpo, estariam destinados à escravidão. Em razão de suas faculdades limitadas e da sua incapacidade de atingir a plenitude da razão, eles poderiam e deveriam pertencer a outros indivíduos, estes criados para a liberdade (cf. ARISTÓTELES. A Política; tradução Roberto Leal Ferreira. $2^{a}$ edição. São Paulo, Martins Fontes, 1998, pp.12-14).
} 
Em certos aspectos, entretanto, Bodin já prenunciava algumas ideias que se tornariam comuns no final do século XVIII. Em primeiro lugar, fazia o elogio a uma escravidão mais humana e suave, que afastava o perigo de revoltas e guerras civis. Citava, nesse sentido, as leis de Constantino que tinham proibido que o escravo fosse açoitado e haviam determinado que aquele que tivesse um membro amputado por ordem de seu senhor deveria ser libertado. Referia-se também aos senhores de escravos espanhóis, que supostamente tratavam os seus escravos com mais suavidade, de modo que estes os serviam "com uma alegria e amor incríveis". ${ }^{196}$ Assim, para Bodin, era necessário impor limites à autoridade dos senhores nas repúblicas escravistas para, deste modo, garantir uma ordem estável. Isso implicava interferir no gozo dos direitos de propriedade de senhores, o que permitia ao autor associar a sua crítica à escravidão a uma teoria da soberania absoluta. ${ }^{197}$ Em segundo lugar, Bodin rejeitava categoricamente o princípio de uma libertação geral dos escravos, pregando a necessidade de fases intermediárias, destinadas a preparar e educar o escravo para a liberdade, tendo em vista que o estado de servidão corrompia o coração do homem:

Da mesma forma, não acredito que se deva, repentinamente, emancipar os escravos, como fez o Imperador no Peru, pois não possuindo bens para viver, nem trabalho para ganhar a vida, e estando até mesmo seduzidos pela doçura do ócio, e da liberdade, não queriam trabalhar, de modo que a maioria morreu de fome. Mas, devendo libertá-los, o meio é ensinar-lhes algum ofício. $^{198}$

Apesar da influência de Jean Bodin, o pensamento político do século XVII não se moveu em direção a uma crítica profunda do escravismo. Para David Brion Davis, o pensamento antiescravista precisava, para desenvolver-se, da doutrina de uma lei maior, universal e imutável, cuja autoridade se sobreporia às instituições concretas. O Iluminismo voltou-se contra as correntes da autoridade, da tradição e do obscurantismo, apontando para um ideal de perfeição e de felicidade como base para a defesa dos direitos naturais do homem: a ideia de um progresso inevitável, que levaria à superação dos males do passado. ${ }^{199}$ Nesse sentido, ele forneceu alguns dos elementos centrais do

\footnotetext{
${ }^{196}$ Cf. BODIN, Jean. Les Six livres de la République, pp.87-88.

${ }^{197}$ Esse aspecto foi profundamente analisado por Malick Ghachem (cf. GHACHEM, Malick W. The Old Regime and the Haitian Revolution, pp.47-53).

198 "Aussi je ne suis pas d'avis que tout à coup on affranchisse les esclaves, comme l'Empereur fit au Pérou, car n'ayant point de biens pour vivre, ni de métier pour gagner, et même étant affriandés de la douceur d'oisiveté, et de liberté, ne voulaient travailler, de sorte que la plupart mourut de faim. Mais le moyen c'est, devant les affranchir, leur enseigner quelque métier" (BODIN, Jean. Les Six livres de la République, pp.89-90).

${ }^{199}$ Cf. DAVIS, David Brion. O Problema da Escravidão na Cultura Ocidental, p.435.
} 
discurso antiescravista do final do século XVIII, mesmo que um exame mais atento permita constatar a sobrevivência de justificativas da escravidão dentro do próprio discurso dos Filósofos.

O principal problema estava na diferença entre a afirmação dos princípios e a recomendação das soluções. De Montesquieu ao abade Raynal, os filósofos das Luzes se dedicaram a denunciar os abusos cometidos contra os negros nas colônias, mas essa crítica veemente à escravidão e ao tráfico não os conduziu a uma postura efetivamente abolicionista. Essa contradição levou historiadores como Louis Sala-Molins a contestar o antiescravismo dos pensadores iluministas. Outros procuraram atribuí-la a um certo pragmatismo. Para Yves Bénot, por exemplo, "não é que eles sejam tímidos ou hesitantes, é que eles conhecem bem demais a realidade econômica de seu século, as exigências e as necessidades da classe que representam". ${ }^{200}$ No mesmo sentido, Marcel Dorigny aponta que, na crítica que o Iluminismo fez à escravidão, verifica-se a existência de "um verdadeiro conflito interno entre a exigência moral e o dogma, igualmente central, da busca da eficácia econômica e do elogio do enriquecimento das sociedades [...]". ${ }^{201}$ Assim, os Iluministas teriam hesitado em lançar-se num combate que poderia arruinar economicamente as potências escravistas.

O que é certo é que essa combinação entre, de um lado, uma crítica feroz à escravidão e ao tráfico e, de outro, a moderação das soluções pregadas antecipou os limites dentro dos quais se desenvolveu o antiescravismo do final do século XVIII, limites estes ditados pelo imperativo da preservação da ordem colonial.

\section{I.1.2.1) Condenação moral, cautela política: uma herança das Luzes}

A argumentação dos Amigos dos Negros repousava, em larga medida, numa condenação implacável da escravidão e do tráfico enquanto práticas contrárias à moral universal. No antiescravismo britânico, a formação dessa consciência antiescravista esteve amplamente relacionada ao desenvolvimento de movimentos religiosos não conformistas. Na França, entretanto, o papel da religião foi muito mais obscuro. Ao

\footnotetext{
200 "ce n'est pas qu'ils soient timides ou hésitants, c'est qu'ils connaissent trop bien la réalité économique de leur siècle, les exigences et les besoins de la classe qu'ils représentent" (BÉNOT, Yves. Diderot, Pechmeja, Raynal et l'anticolonialisme. In: ___ Les Lumières, l'esclavage, la colonisation. Paris: La Découverte, 2005, p.107).

201 "un véritable conflit interne entre l'exigence morale et le dogme, tout aussi central, de la recherche de l'efficacité économique et de l'éloge de l'enrichissement des sociétés [...]" (DORIGNY, Marcel. Les abolitions de l'esclavage (1793-1794-1848). Une célébration nécessaire. In: Les abolitions de l'esclavage, p.11).
} 
longo do século XVIII, teólogos franceses tenderam a justificar a posse e o comércio de escravos como autorizados pelas leis natural e divina. Eventuais questionamentos religiosos da escravidão não vinham da Igreja oficial, mas, como diz Jean Ehrard, de "crentes marginais, franco-atiradores heterodoxos ou heréticos". ${ }^{202}$ Claude Prudhomme sustenta que a motivação religiosa não foi secundária e que a luta contra a escravidão aparecia como um aspecto da consciência missionária do final do século XVIII. ${ }^{203}$ Acreditamos, ao contrário, que o elemento religioso manteve-se discreto, para não dizer oculto, no discurso antiescravista francês, como indica a presença relativamente fraca de clérigos entre os Amigos dos Negros. ${ }^{204}$

Para Brissot, líder maior do movimento, a defesa da liberdade como um direito inerente ao homem decorria de uma concepção que se afastava da ideia de um direito natural de origem divina. Como ele diria nas suas memórias:

[...] não era preciso buscar outra origem para os direitos do homem do que o próprio fato da existência do homem, nem supor que ele pudesse gozar de sua liberdade, de seus direitos naturais por razões sobrenaturais ou divinas: $o$ homem é livre porque ele existe. ${ }^{205}$ (itálico no original)

A crítica dos Amigos dos Negros contra a escravidão e o tráfico tinha como principal referência literária a ofensiva iluminista contra essas instituições. A partir de meados do século XVIII, os Filósofos haviam direcionado o seu olhar crítico para as realidades coloniais. Contudo, para além de uma reflexão sobre valores, a sua abordagem também inscrevia-se num contexto de intensificação das instabilidades nas colônias europeias das Américas. As décadas de 1720, 30 e 40, em especial, tinham sido marcadas por uma verdadeira guerra travada pelos maroons da Jamaica, além de numerosas rebeliões e levantes em outras colônias, como a Guadalupe, a Guiana, a Martinica e o Suriname. Essa tendência suscitava interrogações sobre a boa

\footnotetext{
${ }^{202}$ Cf. EHRARD, Jean. Lumières et esclavage. L'esclavage colonial et l'opinion publique en France au XVIIIe siècle. Bruxelas: André Versaille Éditeur, 2008, pp.95-104.

${ }^{203}$ Cf. PRUDHOMME, Claude. L'expérience et la conviction contre la tradition: les Églises chrétiennes et la critique de l'esclavage 1780-1888. In: O. PÉTRÉ-GRENOUILLEAU (org.). Abolir l'esclavage: un réformisme à l'épreuve (France, Portugal, Suisse, XVIII-XIXe siècles). Rennes: Presses Universitaires de Rennes, 2008, p.58.

${ }^{204} \mathrm{O}$ elemento religioso só assumiria um papel de destaque na campanha abolicionista sob a Restauração, com a criação, em 1822, pela Société de la Morale Chrétienne, de um comitê para a abolição do tráfico. Também na posterior Société Française pour l'abolition de l'esclavage, bastante atuante na campanha que precedeu a abolição de 1848, a presença de protestantes seria expressiva (DAVID, Thomas. L'internationale abolitionniste, pp.125-128).

205 "[...] il ne fallait pas chercher d'autre origine des droits de l'homme que le fait même de l'existence de l'homme, ni supposer qu'il pût jouir de sa liberté, de ses droits naturels par des raisons surnaturelles ou divines: l'homme est libre parce qu'il est" (BRISSOT DE WARVILLE, Jacques-Pierre. Mémoires, v.2, p.92).
} 
administração das colônias e os efeitos das crueldades cometidas contra os negros. Assim, a crítica à escravidão colonial empreendida pelos Filósofos não era simplesmente uma questão de princípios: o imperativo humanitário era indissociável de considerações estratégicas sobre ordem e segurança, assim como o próprio interesse dos plantadores. Essa lógica também estaria presente no discurso dos Amigos dos Negros.

Mesmo com suas ambiguidades e contradições, Montesquieu ${ }^{206}$ é tido como um divisor de águas na evolução da crítica antiescravista. O filósofo abordou a escravidão no livro XV do Espírito das Leis (1748), denunciando o seu caráter corruptor:

Ela não é boa por natureza; não é útil nem ao senhor nem ao escravo; a este, porque nada pode fazer por virtude; àquele porque contrai de seus escravos todo tipo de mau hábito, acostuma-se insensivelmente a faltar com todas as virtudes morais, torna-se orgulhoso, brusco, duro, colérico, voluptuoso, cruel. $^{207}$

Mais importante, entretanto, do que a condenação moral da escravidão foi a forma como Montesquieu derrubou sistematicamente as justificativas tradicionais para a escravidão. Demonstrando um perfeito conhecimento dos argumentos escravistas, ele os rebateu um a um, por meio da contra-argumentação ou do simples desprezo.

Montesquieu contestou, assim, o direito do vencedor de uma guerra de escravizar o seu prisioneiro, para poupar-lhe a vida. Essa justificativa era, em certa medida, aceita por Locke, que entendia que, numa guerra justa, se alguém perdia o direito à própria vida, aquele para quem havia perdido esse direito podia demorar-se em tirar a sua vida e fazer uso dessa pessoa em seu serviço. ${ }^{208}$ Montesquieu sustentava, ao contrário que, na guerra, o direito de matar só existia diante da mais absoluta necessidade - a legítima defesa. Ora, se um homem era feito escravo de outro, estava claro que a necessidade de matá-lo não existia. ${ }^{209}$ Ele tinha, no máximo, um direito temporário de sujeitar o vencido.

O direito romano permitia que os devedores incapazes de quitar as suas dívidas vendessem a si mesmos aos credores. Montesquieu, entretanto, negou que um homem

\footnotetext{
${ }^{206}$ Montesquieu tinha sido presidente do Parlamento de Bordeaux, um dos grandes portos do comércio colonial, de modo que tinha tido contato com a realidade do tráfico e da escravidão.

207 "Il n'est pas bon par sa nature: il n'est utile ni au maître ni à l'esclave: à celui-ci, parce qu'il ne peut rien faire par vertu; à celui-là, parce qu'il contracte avec ses esclaves toutes sortes de mauvaises habitudes, qu'il s'accoutume insensiblement à manquer à toutes les vertus morales, qu'il devient fier, prompt, dur, colère, voluptueux, cruel" (MONTESQUIEU, Charles de Secondat. De l'esprit des lois. Paris: Editions Garniers Frères, 1956, v.1, p.254).

${ }^{208}$ Cf. LOCKE, John. Dois tratados sobre o Governo. 2a ed. São Paulo: Martins Fontes, 2005, pp.403404. Vale observar que, embora tivesse feito observações críticas à escravidão, Locke possuía ações na Real Companhia Africana (Cf. BLACKBURN, Robin. A Queda do Escravismo Colonial, p.54).

${ }^{209}$ Cf. MONTESQUIEU, Charles de Secondat. De l'esprit des lois, v.1, p.255.
} 
livre pudesse vender a própria liberdade, sendo esta um bem inalienável. Da mesma forma, dizia o filósofo, "[...] se um homem não pode vender-se, muito menos pode vender a seu filho, que ainda não era nascido; se um prisioneiro de guerra não pode ser reduzido à servidão, podem-no ainda menos os seus filhos". ${ }^{210} \mathrm{O}$ nascimento era, para ele, o mais escuso dos títulos tradicionais da escravidão.

Montesquieu estendeu a sua crítica a outras origens históricas da escravidão, como o desprezo de uma nação por outra, caso dos conquistadores espanhóis em relação às populações indígenas da América. Condenou ainda a catequese como causa legitimadora da escravidão colonial, isto é, a ideia de que a religião dava aos que a professavam o direito de reduzir em servidão os demais, de modo a facilitar a propagação da palavra de Deus: "foi essa maneira de pensar, dizia, que encorajou os destruidores da América nos seus crimes". ${ }^{211}$

Para o filósofo, a escravidão negra se explicava unicamente por razões práticas: afirmava, não sem ironia, que os povos da Europa haviam exterminado os da América e tiveram então de escravizar os da África, pois, sem mão de obra escrava, o preço do açúcar tornar-se-ia demasiadamente caro. ${ }^{212}$

Entretanto, a posição de Montesquieu a respeito da realidade concreta da escravidão dos negros nas colônias não era clara. Se afirmava firmemente que a escravidão não tinha sentido na Europa, onde tudo podia ser feito por trabalhadores livres, ele reconhecia que ela era menos ofensiva à razão nos climas tropicais, onde o calor tornava os homens indolentes e indispostos a cumprirem o seu dever, a não ser sob a ameaça do castigo. Em certos climas, e apenas neles, a escravidão encontrava a sua razão de ser:

[...] como todos os homens nascem iguais, é preciso dizer que a escravidão é contra a natureza, embora em certos países ela esteja fundada numa razão natural; e é preciso distinguir bem esses países daqueles onde as próprias razões naturais a rejeitam, como os países da Europa, onde ela foi tão felizmente abolida. ${ }^{213}$ (grifo nosso)

\footnotetext{
210 "[...] si un homme n'a pu se vendre, encore moins a-t-il pu vendre son fils qui n'étais pas né. Si un prisonnier de guerre ne peut être réduit en servitude, encore moins ses enfants" (Ibidem, p.256).

211 "Ce fut cette manière de penser qui encouragea les destructeurs de l'Amérique dans leurs crimes" (Ibidem, p.257).

${ }^{212}$ Ibidem, p.258.

213 "[...] comme tous les hommes naissent égaux, il faut dire que l'esclavage est contre la nature, quoique dans certains pays il soit fondé sur une raison naturelle; et il faut bien distinguer ces pays d'avec ceux où les raisons naturelles mêmes les (sic) rejettent, comme les paus d'Europe, où il a été si heureusement aboli" (Ibidem, p.260).
} 
Assim, ao mesmo tempo em que a escravidão era contra a natureza, ela podia encontrar uma razão natural e, portanto, uma justificativa. No entanto, um pouco adiante na obra, Montesquieu afirmava que "talvez não haja nenhum clima sobre a terra onde não se possa empregar o trabalho de homens livres. Porque as leis foram mal feitas, foram encontrados homens preguiçosos; porque esses homens eram preguiçosos, foram colocados na escravidão". ${ }^{214}$

Diante das contradições do texto de Montesquieu, a historiografia procurou uma série de explicações. Catherine Larrère, por exemplo, defende a tese de um discurso dual: de um lado, haveria uma consideração universal da escravidão como contrária ao direito natural; de outro, uma consideração da escravidão com base na realidade das colônias americanas, em que a instituição se impunha por razões econômicas. ${ }^{215}$ Para David Brion Davis, se Montesquieu partia de um sistema de lei eterna e universal, ele não extraía dessa lei maior uma série de regras abstratas; essa lei só podia ser compreendida a partir de situações concretas. Ela devia ser derivada de um exame empírico de relações sociais, funcionando então como norma para a ação futura. As forças limitadoras do clima, do solo e da geografia impunham ajustes nas instituições de acordo com a lei natural. ${ }^{216}$ A ciência do governo era, para o filósofo, uma ciência de combinações, aplicações e exceções, que se impunham, no tempo e no espaço, de acordo com as circunstâncias.

Concretamente, Montesquieu estava muito longe de pedir a abolição da escravidão nas colônias e, nesse sentido, suas considerações também serviam aos escravocratas. Suas propostas se limitavam à promoção de reformas destinadas a suavizar a escravidão, de modo a "[...] dela suprimir, de um lado, os abusos e, de outro, os perigos". ${ }^{217} \mathrm{O}$ discurso de Montesquieu traduzia o temor do marronnage, bastante intenso nas décadas de 1730-40 em razão da experiência jamaicana, que tinha repercutido fortemente na França. ${ }^{218}$ Nesse sentido, ele apontava para a busca de um equilíbrio. Uma das preocupações essenciais de Montesquieu era, de fato, com a segurança e a ordem nas colônias, onde, em razão do grande número de escravos, a

\footnotetext{
214 "Il n'y a peut-être pas de climat sur la terre où l'on ne pût engager au travail des hommes libres. Parce que les lois étaient mal faites, on a trouvé des hommes paresseux: parce que ces hommes étaient paresseux, on les a mis dans l'esclavage" (Ibidem, p.261).

${ }^{215}$ Cf. LARRĖRE, Catherine. Économie politique et esclavage au XVIIIIe siècle, une rencontre tardive et ambigüe. In: O. PÉTRÉ-GRENOUILLEAU (org.). Abolir l'esclavage: un réformisme à l'épreuve (France, Portugal, Suisse, XVIII-XIXe siècles). Rennes: Presses Universitaires de Rennes, 2008, p.209.

${ }^{216}$ Cf. DAVIS, David Brion. O Problema da Escravidão na Cultura Ocidental, p.449.

${ }^{217}$ Cf. MONTESQUIEU, Charles de Secondat. De l'esprit des lois, v.1, p.263).

${ }^{218}$ Cf. GHACHEM, Malick W. The Old Regime and the Haitian Revolution, p.122.
} 
ameaça de revoltas era constante. Assim, tratar os escravos com humanidade não era apenas um imperativo moral, mas uma forma de prevenir atos de rebelião escrava: "a humanidade que se terá para com os escravos poderá prevenir, num Estado moderado, os perigos que poder-se-ia temer em razão de seu número excessivo". ${ }^{219}$

Montesquieu apresentou, no capítulo XVII do livro XV, alguns regulamentos a serem adotados na relação entre o senhor e seu escravo, que garantissem ao escravo: alimentação e vestimentas suficientes; cuidados médicos na doença e na velhice; o respeito a certas formalidades quanto à aplicação da punição, sobretudo a morte; a possibilidade de ser separado de um senhor irritado com ele; e o acesso à defesa civil, contra maus tratos, insultos e injúrias. ${ }^{220}$ No fundo, Montesquieu retomava a lógica preservacionista do Code Noir.

O filósofo manifestava a sua oposição à concessão repentina, por meio de uma lei geral, de um número considerável de alforrias. ${ }^{221}$ Ao longo da história da escravidão colonial, a manumissão tendeu a ser vista ora como causa, ora como remédio para a resistência escrava. Essa ambivalência se reproduzia no discurso de Montesquieu. Na sua busca pelo equilíbrio necessário à manutenção da ordem, a autor argumentava, por um lado, que um grande número de alforriados geraria um gasto enorme para a administração, encarregada de sustentá-los, e poderia incrementar a ameaça de revoltas. Por outro, entendia que a existência de um grande número de escravos também implicava o perigo constante de rebeliões. Assim, Montesquieu pregava a adoção de modos de fazer novos cidadãos, sem grandes abalos. Sugeria um sistema que favorecesse o pecúlio e colocasse o escravo em condição de comprar a própria liberdade, isto é, um sistema em que o escravo tivesse uma economia própria ${ }^{222}$, podendo vender o produto de sua atividade e reunir os fundos para a própria alforria. Sugeria ainda estabelecer um termo para a escravidão, além de alforriar anualmente um determinado número de escravos que se mostrassem aptos a ganhar a sua subsistência. $^{223}$ Com isso, Montesquieu prenunciava algumas das propostas de emancipação graduada do final do século.

\footnotetext{
219 "L'humanité que l'on aura pour les esclaves pourra prévenir dans l'Etat modéré les dangers que l'on pourrait craindre de leur trop grand nombre" (MONTESQUIEU, Charles de Secondat. De l'esprit des lois, v.1, p.266).

220 Ibidem, p.268-269.

221 Ibidem, pp.269-270.

222 O Code Noir de 1685 proibia, no seu art.24, que o proprietário se eximisse da obrigação de alimentar seus escravos, por meio da concessão de um dia da semana para que estes cultivassem a sua subsistência. Na prática, entretanto, essa regra não era observada.

223 Cf. MONTESQUIEU, Charles de Secondat. De l'esprit des lois, v.1, p.270.
} 
Chegava a afirmar que os alforriados, mesmo num governo popular, não deveriam gozar dos direitos políticos, justificando, assim, uma discriminação entre os homens: "sente-se que a sua condição deve ser mais favorecida no estado civil do que no estado político, pois mesmo no governo popular, o poder não deve jamais cair nas mãos do baixo povo". ${ }^{224}$

Jean Ehrard destaca a "distância entre a firmeza da condenação filosófica dirigida contra a escravidão do Livro XV do Espírito das Leis e a timidez das conclusões práticas que são dela extraídas". ${ }^{225}$ Para o autor, há uma notável diferença entre a "audácia teórica" e a "prudência prática" de Montesquieu. ${ }^{226}$ Talvez a própria "firmeza" da sua condenação filosófica da escravidão seja questionável, tendo em vista a sua adoção da teoria dos climas. Concretamente, o que Montesquieu propunha era, acima de tudo, uma intervenção suficiente da Administração no domínio privado para manter a ordem colonial, por meio do bom tratamento da escravaria e de uma política moderada de manumissões.

A suposta "dualidade" do discurso de Montesquieu inspirou leituras diferentes de sua obra. Como diz Jean-Yves Grenier, suas considerações podiam servir à causa dos que toleravam a servidão, na medida em que esta aparecia como uma necessidade incontornável nas colônias. ${ }^{227}$ Numa publicação de 1786, Duval de Sanadon, defensor da escravidão, louvaria os "sublimes escritos de Montesquieu", que haviam tido o mérito de indicar "os limites que não puderam ultrapassar". ${ }^{228}$ Além disso, a passagem do Espírito das Leis referente aos efeitos dos climas sobre certos povos foi invocada por Lejeune, plantador acusado de torturar e matar escravos em São Domingos nos anos 1780, assim como por Félix Carteau, plantador escravista exilado, na epígrafe às Soirées bermudiennes (1802). Por outro lado, é preciso atentar para o fato de que alguns revolucionários abertamente abolicionistas referir-se-iam a Montesquieu como um de

\footnotetext{
224 "On sent que leur condition doit être plus favorisée dans l'État civil que dans l'État politique, parce que dans le gouvernement même populaire, la puissance ne doit point tomber entre les mais du bas peuple" (Ibidem, p.270).

225 "écart entre la fermeté de la condamnation philosophique portée contre l'esclavage du Livre XV de L'Esprit des Lois et la timidité des conclusions pratiques qui en sont tirées" (EHRARD, Jean. L'esclavage devant la conscience morale des Lumières françaises: indifférence, gêne, révolte. In: M. DORIGNY (org.). Les abolitions de l'esclavage, p.145).

${ }^{226}$ Cf. EHRARD, Jean. Audace théorique, prudence pratique: Montesquieu et l'esclavage colonial. In: O. PÉTRÉ-GRENOUILLEAU (org.). Abolir l'esclavage: un réformisme à l'épreuve (France, Portugal, Suisse, XVIII-XIXe siècles). Rennes: Presses Universitaires de Rennes, 2008.

${ }^{227}$ Cf. GRENIER, Jean-Yves. "Faut-il rétablir l'esclavage en France?" Droit naturel, économie politique et esclavage au XVIIIe siècle. Revue d'Histoire moderne et contemporaine, Paris, n.57-2, 2010, p.7.

${ }^{228}$ Cf. DUVAL DE SANADON, David. Discours sur l'esclavage des nègres et sur l'idée de leur affranchissement dans les colonies. Amsterdam: Hardouin et Gattery, 1786, p.8.
} 
seus grandes inspiradores. Chaumette, no seu discurso de 30 pluvioso do ano II, em homenagem ao decreto de abolição do dia 16 (4 de fevereiro de 1794), citaria textualmente diversos trechos do livro XV do Espírito das Leis. ${ }^{229}$ Da mesma forma, o abade Grégoire, nome proeminente da luta antiescravista, também referir-se-ia a Montesquieu como um dos principais inspiradores da luta contra a servidão, citando-o na dedicatória "a todos os homens corajosos que pleitearam a causa dos pobres Negros e Mestiços" ${ }^{230}$, que abriria De la littérature des nègres (1808). Um colono antiescravista, Milscent, chegou, na sua época mais moderada, até mesmo a condenar o que acreditava ser um abolicionismo estrito por parte de Montesquieu, criticando o fato de que o filósofo não levava em conta a prosperidade das colônias, comprometida por uma eventual abolição abrupta da escravidão, nem os direitos legítimos de propriedade dos senhores de escravos. ${ }^{231}$ Já Barère faria uma leitura mais atenta do Espírito das Leis: em Montesquieu peint d'après ses ouvrages (1796), ele apontaria a incoerência de Montesquieu, louvando o seu antiescravismo, mas condenando a sua ideia de que a liberdade se submetia ao império dos climas. Mas, feita essa ressalva, Barère preferia ressaltar a denúncia feita por Montesquieu da escravidão colonial e a sua defesa da liberdade natural do homem. ${ }^{232}$ Prevaleceu historicamente a imagem de um Montesquieu crítico da escravidão colonial.

A abordagem da escravidão no Espírito das Leis inspiraria novas contribuições sobre o tema na segunda metade do século. Ao mesmo tempo, esses novos escritos manifestariam uma radicalização progressiva do discurso a respeito da escravidão, traduzindo a preocupação crescente com as instabilidades no mundo colonial. Conforme a importância econômica das colônias crescia, os atos de rebelião escrava tornavam-se mais numerosos. Em São Domingos, um movimento importante abalou a colônia em

${ }^{229}$ Cf. CHAUMETTE, Anaxagoras. Discours prononcé au nom de la Commune de Paris, le Décadi 30 pluviôse, l'an II de la République Française, une et indivisible, à la fête célébrée à Paris, en réjouissance de l'abolition de l'esclavage. Paris: Imprimerie Nationale, s.d. [ano II], p.8.

230 "à tous les hommes courageux qui ont plaidé la cause des malheureux Noirs et Sang-mêlés" (GRÉGOIRE. De la littérature des nègres, ou Recherches sur leurs facultés intellectuelles, sur leurs qualités morales et leur littérature. Paris: chez Maradan, libraire, 1808, pp.v-vii).

${ }^{231}$ Assim escreveu Milscent: "Montesquieu só indica a abolição da escravidão por uma retiscência absoluta sobre a sorte dos negros; o meio é não apenas perigoso para a ordem e a prosperidade das colônias, mas também contra a toda equidade, contra o direito de propriedade do qual não se poderia privar impunemente o senhor do escravo" ("Montesquieu n'indique que l'abolition de l'esclavage par une réticence absolue sur le sort des nègres; le moyen est non-seulement dangereux à l'ordre et à la prospérité des colonies, mais encore contre toute équité, contre le droit de propriété dont on ne pourrait impunément dépouiller le maître de l'esclave", MILSCENT, Claude-Louis-Michel. Du régime colonial. Paris: Imprimerie du Cercle Social, 1792, p.25).

${ }^{232}$ Cf. BARÈRE, Bertrand. Montesquieu peint d'après ses ouvrages. S.1.: s.n., 1796, pp.99-106. 
1753-57, detonando um clima de paranoia entre colonos e administradores. Além disso, o mundo colonial também vivia sob a ameaça de uma crise em razão das dificuldades de abastecimento dos mercados de escravos, o que impunha a necessidade de repensar toda a administração colonial.

Muito influente entre os antiescravistas do final do século, a Enciclopédia trazia, no conjunto dos textos que a compunham, a marca dessa evolução. De fato, entre os diferentes artigos referentes ao tema da escravidão, existem algumas variações importantes. Se alguns deles defendiam abertamente a escravidão negra - caso, por exemplo, do verbete "Nègres, (Commerce)" -, outros incorporavam um olhar crítico. Vamos nos concentrar em dois deles: "Esclavage" e "Traite des Noirs".

O verbete "Esclavage" (1755), presente no volume V da Enciclopédia, retomava essencialmente o conteúdo do livro XV do Espírito das Leis. Escrito pelo Chevalier de Jaucourt $^{233}$, o texto tomava emprestado passagens inteiras da obra de Montesquieu, situando-se essencialmente na mesma linha argumentativa. Jaucourt apresentava a escravidão como uma instituição "inútil", "contrária ao direito natural e civil" e incompatível com "as formas dos melhores governos". ${ }^{234}$ Negava que pudesse haver propriedade propriamente dita sobre pessoas e nenhum dos títulos tradicionalmente invocados para justificá-la - o direito da guerra, a aquisição, o nascimento, a catequese - era aceitável. ${ }^{235}$ Acreditava que, em qualquer governo e país, todo tipo de trabalho podia ser feito por homens livres, encorajados por recompensas e assessorados por máquinas criadas pelo gênio humano. Entretanto, retomava a mesma ressalva do Espírito das Leis, relativa aos climas quentes:

Entretanto, não haveria casos ou locais onde a escravidão deriva da natureza das coisas? Respondo, primeiramente, a essa questão que não; respondo, em seguida, com o Sr. Montesquieu, que, se há países onde a escravidão parece fundada numa razão natural, são aqueles em que o calor enerva o corpo, e enfraquece de tal forma a coragem que os homens são levados a cumprir um dever penoso apenas por medo do castigo. ${ }^{236}$

\footnotetext{
${ }^{233}$ Médico e filósofo discípulo de Montesquieu, Louis de Jaucourt (1704-1779) foi, ao lado de Buffon, um dos principais redatores da Encyclopédie, dirigida por d'Alembert e Diderot.

${ }^{234}$ Cf. Encyclopédie ou Dictionnaire raisonné des sciences, des arts et des métiers, par une société de gens de lettres. Paris: Briasson, David, Le Breton, Durand, 1751-1765, v.5, pp.936-937.

${ }_{235}$ Ibidem, pp.937-938.

236 "Cependant n'y a-t-il point de cas ni de lieux où l'esclavage dérive de la nature des choses? Je réponds $1^{\circ}$ à cette question qu'il n'y en a point; je réponds ensuite, avec M. de Montesquieu, que s'il y a des pays où l'esclavage paraisse fondé sur une raison naturelle, ce sont ceux où la chaleur énerve le corps, et affaiblit si fort le courage, que les hommes ne sont portés à un devoir pénible que par la crainte du châtiment" (Ibidem, p.938).
} 
Assim, embora afirmasse que a escravidão era contra a natureza, Jaucourt retomava o argumento de Montesquieu que procurava justificar o status quo colonial. Uma pequena, mas importante, diferença deve ser destacada: enquanto Montesquieu dizia "embora em alguns países ela esteja fundada numa razão natural", Jaucourt usa uma fórmula mais ambígua, "se há países onde a escravidão parece fundada numa razão natural" (grifo nosso), denotando uma adesão muito menos convicta à tese de que o meio autoriza determinadas práticas contrárias à razão universal.

O texto não fazia qualquer menção à abolição, nem propunha medidas concretas de reforma, mas afirmava que a humanidade exercida para com os escravos era a única forma de prevenir, num governo moderado, os perigos decorrentes de seu grande número. A construção da imagem idílica da escravidão entre os primeiros romanos, na qual as diferenças entre a condição do escravo e do homem livre eram praticamente imperceptíveis, sugeria, por parte de Jaucourt, uma postura reformista. ${ }^{237}$ No geral, a mesma lógica prudencial de Montesquieu era reproduzida no artigo.

Em outro artigo posterior, "Traite des Nègres" (1765), observava-se uma mudança de atitude. Assinado novamente por Jaucourt, o texto elevava o tom contra a instituição escravista, ao afirmar que, na medida em que um homem não tinha o direito de comprar outro, aqueles que eram tidos como escravos tinham o direito de serem declarados livres, pois jamais haviam perdido a liberdade. A venda de um homem como escravo era, ou deveria ser, nula perante a lei: "é, portanto, uma desumanidade manifesta, por parte dos juízes dos países em que é transportado, não alforriá-lo imediatamente, declarando-o livre, pois ele é seu semelhante, possuindo, assim como eles, uma alma". ${ }^{238}$ Jaucourt contestava o argumento de que as questões relativas ao estado das pessoas tinham de ser decididas pelas leis dos países aos quais elas pertenciam, na medida em que os direitos da humanidade não poderiam jamais ser abrogados pelas leis civis locais. O autor negava, portanto, que considerações materiais permitissem afastar o respeito aos direitos da natureza. Ao argumento de que uma abolição do tráfico e da escravidão arruinaria as colônias, Jaucourt respondia: "Que as colônias europeias sejam destruídas, antes que se façam tantos infelizes!". ${ }^{239}$ Essa frase prenunciava a famosa fórmula "Pereçam as colônias antes que um princípio!", repetida

\footnotetext{
${ }^{237}$ Ibidem, p.935.

238 "c'est donc une inhumanité manifeste de la part des juges des pays libres où il est transporté, de ne pas l'affranchir à l'instant en le déclarant libre, puisque c'est leur semblable, ayant une ame comme eux" (Encyclopédie, v.16, p.532).

239 "Que les colonies européennes soient plutôt détruites, que de faire tant de malheureux!" (Ibidem, p.533).
} 
tantas vezes, sob formas variadas, ao longo da Revolução, o que permite medir a influência desse artigo.

Mas essa exclamação aparentemente anticolonialista era temperada pela afirmação, no parágrafo seguinte, de que a supressão da escravidão não provocaria a ruína das colônias, abrindo, ao contrário, a via para uma regeneração desses territórios e a implantação de um sistema muito mais vantajoso, em que as artes e os talentos floresceriam pelas mãos de trabalhadores livres e, portanto, industriosos: "É a liberdade, é a indústria que são as fontes reais da abundância". ${ }^{240}$

Segundo Jean-Daniel Piquet, no caso desse segundo artigo, Jaucourt teria sido apenas o tradutor e signatário de um artigo escrito, em 1760, pelo pastor britânico George Wallace, o que explicaria a radicalização do discurso. ${ }^{241} \mathrm{O}$ texto superava as contradições de Montesquieu, pregando a liberdade como condição essencial para o progresso, mesmo nos espaços coloniais.

Outros expoentes das Luzes também abordaram o tema da escravidão, muito embora suas contribuições não tenham tido o mesmo impacto. No Discours sur l'origine et les fondements de l'inégalité (1755), Rousseau abordou uma ideia que seria central no pensamento antiescravista: a da perfectibilidade do homem. Para ele, era a "faculdade de se aperfeiçoar" que distinguia o homem do animal, que lhe permitia evoluir para um estágio superior, assim como regredir para um estágio mais primitivo. ${ }^{242} \mathrm{~A}$ ideia da perfectibilidade humana seria uma das bases do gradualismo dos Amigos dos Negros.

Sobre a escravidão, Rousseau afirmava que, se o homem podia dispor de tudo o que possuía, na medida em que a propriedade era de convenção humana, o mesmo não podia ser dito dos "dons essenciais da natureza, tais como a vida e a liberdade". Mesmo que fosse possível alienar a própria liberdade, como uma propriedade qualquer, ainda assim não se poderia admitir a escravidão por nascimento: "[...] os jurisconsultos que pronunciaram gravemente que o filho de um escravo nasceria escravo decidiram, em outros termos, que um homem não nasceria homem". ${ }^{243}$

\footnotetext{
240 "C'est la liberté, c'est l'industrie qui sont les sources réelles de l'abondance" (Ibidem, p.533).

${ }^{241}$ Cf. PIQUET, Jean-Daniel. L'émancipation des Noirs dans la Révolution française, p.22-24. O texto em questão seria A System of the Principles of the Law of Scotland (1760), talvez o primeiro tratado europeu a atacar a escravidão de forma radical, pedindo a sua abolição total (cf. BLACKBURN, Robin. $A$ Queda do Escravismo Colonial, p.63).

${ }^{242}$ Cf. ROUSSEAU, Jean-Jacques. Discours sur l'origine et les fondements de l'inégalité. Paris: Bookking International, 1996, p.193.

243 "[...] les jurisconsultes qui ont gravement prononcé que l'enfant d'une esclave naîtrait esclave ont décidé en d'autre termes qu'un homme ne naîtrait pas homme" (Ibidem, pp.254-255).
} 
Se havia, nessa passagem, uma condenação da escravidão, é preciso notar que o comentário em questão estava inserido numa reflexão sobre o governo tirânico e o poder arbitrário que o institui, não se tratando, portanto, de uma observação a respeito da escravidão colonial. Da mesma forma, no Contrat social (1762), quando Rousseau voltava a falar da escravidão, tratava-se, novamente, de um viés para abordar o despotismo. Ao estabelecer que, ainda que fosse possível alienar a si mesmo, o mesmo não poderia ser feito com os próprios filhos, o filósofo sustentava que seria ilegítimo uma geração posterior herdar o governo arbitrário admitido por seus pais. ${ }^{244}$ Rousseau estava interessado em questões mais amplas do que a escravidão. Para os Filósofos, abordar a figura do escravo era, muitas vezes, um veículo para expor o caráter execrável da tirania. $\mathrm{O}$ ataque ao princípio da servidão era uma via para a condenação de todos os tipos de arbitrariedade. É da escravização da humanidade como um todo, e do francês em particular, que tratava a sua obra. ${ }^{245}$

Por outro lado, extraída de seu contexto, a crítica de Rousseau à escravidão podia servir aos abolicionistas. O filósofo era contundente ao afirmar que "renunciar à própria liberdade é renunciar à sua qualidade de homem" e que "uma tal renúncia é incompatível com a natureza do homem, e privar a sua vontade de qualquer liberdade é privar suas ações de qualquer moralidade". ${ }^{246}$ A escravidão era, assim, uma relação baseada na força, não estando amparada em nenhum direito ou princípio. Rousseau contestava o direito de escravidão resultante da guerra, defendido por Grotius, isto é, o princípio segundo o qual o vencedor tinha o direito de matar o vencido e podia, portanto, poupar-lhe a vida em detrimento de sua liberdade. O fim da guerra era a destruição do Estado inimigo e não de seus defensores, que só podiam ser mortos em combate. Assim, se a guerra não dava ao vencedor o direito de matar o vencido, ela certamente não lhe dava o direito de escravizá-lo: "é, portanto, uma troca iníqua fazê-lo comprar, ao preço de sua liberdade, a sua vida, sobre a qual não se possui qualquer direito". 247

\footnotetext{
${ }^{244}$ Cf. ROUSSEAU, Jean-Jacques. Du contrat social. Paris: Bookking International, 1996, pp.23-24.

${ }^{245}$ Nesse sentido, pode-se dar certa razão a Louis Sala-Molins quando ele diz que, leitora de Rousseau, a esquerda revolucionária não incluiu os negros das colônias na sua agenda política. Se manifestaram posições antiescravistas, os líderes da esquerda jacobina, na sua maioria, não fizeram dessa questão uma prioridade (cf. SALA-MOLINS, Louis. Le Code Noir ou le calvaire de Canaan, Paris: Presses Universitaires de France, 2002, p.254).

246 "renoncer à sa liberté c'est renoncer à sa qualité d'homme"; "une telle renonciation est incompatible avec la nature de l'homme, et c'est ôter toute moralité à ses actions que d'ôter toute liberté à sa volonté" (ROUSSEAU, Jean-Jacques. Du contrat social, p.24).

247 "c'est donc un échange inique de lui faire acheter au prix de sa liberté sa vie sur laquelle on n'a aucun droit" (Ibidem, p.26).
} 
David Brion Davis acredita que a crítica de Rousseau à escravidão ensejava um paradoxo, pois, na medida em que um retorno ao estado de natureza era impossível, a liberdade só podia ser concebida por meio de uma sujeição à Vontade Geral. Assim, Rousseau retomava a ideia de que a única libertação genuína residia numa forma de servidão maior e, ao associar a escravidão às formas de autoridade e subordinação, o filósofo também abria espaço para a sua legitimação. ${ }^{248}$ No geral, entretanto, prevaleceria, na concepção dos revolucionários, a imagem de um Rousseau inequivocamente crítico da escravidão, muito embora ele não tivesse efetivamente abordado a escravidão negra nas colônias. O uso do tema da escravidão como metáfora política da tirania reapareceria com muita força sob a Revolução, sobretudo na sua fase mais radical. Rousseau seria, aliás, frequentemente citado nas cartas à Convenção em homenagem ao decreto de abolição de 16 pluvioso do ano II. No seu discurso de celebração da abolição, de 30 pluvioso do ano II, Chaumette leria trechos do Contrato social $^{249}$, o que permite avaliar a apropriação que foi feita, sob a Revolução, dos escritos dos filósofos para defender ideias que eles jamais pregaram.

Voltaire, por sua vez, abordou diretamente a questão da escravidão negra. No Essai sur les moeurs et l'esprit des nations (1756), teceu críticas à escravidão, embora apontando a inferioridade dos povos africanos diante dos Europeus, a qual determinava que os negros fossem os escravos dos outros homens. ${ }^{250}$ Sua contribuição mais famosa sobre o tema viria com o capítulo 19 de Candide, ou l'Optimisme (1759), que contava a viagem do herói ao Suriname e seu encontro com um negro estendido ao chão, com a perna esquerda e a mão direita amputadas. Ao ser perguntado por Cândido se era o seu senhor que o havia tratado dessa forma, o negro respondia:

Sim, Senhor, disse o negro, é o costume. Por vestuário, dão-nos, duas vezes por ano, umas calças de tela. Quando trabalhamos nos engenhos de açúcar e o rebolo nos apanha o dedo, cortam-nos a mão; quando tentamos fugir,

\footnotetext{
${ }^{248}$ Cf. DAVIS, David Brion. O Problema da Escravidão na Cultura Ocidental, p.459.

${ }^{249}$ Cf. CHAUMETTE, Anaxagoras. Discours prononcé au nom de la Commune de Paris, p.6. Trechos do Contrato Social também seriam citados no plano de abolição da escravidão, apresentado por Viefville des Essarts em 26 de março de 1790 (cf. VIEFVILLE DES ESSARTS, Jean Louis de. Discours et projet de loi pour l'affranchissement des Nègres, ou l'adoucissement de leur régime, et Réponse aux objections des Colons. Paris: Imprimerie Nationale, s.d. [1790], p.12).

${ }^{250}$ Nas suas palavras: "a natureza subordinou a esse princípio esses diferentes graus de gênio e esses caracteres das nações que se vê tão raramente mudar. É por isso que os negros são os escravos dos outros homens [...]" ("La nature a subordonné à ce principe ces différents degrés de génie et ces caractères des nations qu'on voit si rarement changer. C'est par-là que les nègres sont les esclaves des autres hommes [...]"; VOLTAIRE. Essai sur les moeurs e l'esprit des nations. Paris: chez Treuttel et Würtz, 1835, v.3, p.263).
} 
cortam-nos a perna: encontrei-me nos dois casos. É a esse preço que comeis açúcar na Europa. ${ }^{251}$

O negro invocava então o princípio da unidade do gênero humano, para denunciar o caráter criminoso das brutalidades cometidas contra os escravos na colônia, provocando lágrimas em Cândido:

Os cães, os macacos, os papagaios são mil vezes menos infelizes que nós. Todos os domingos, os pastores holandeses que me converteram me dizem que somos todos, brancos e negros, filhos de Adão. Não sou genealogista, mas se esses pregadores dizem a verdade, somos todos primos-irmãos. Ora, hão de admitir que não se pode tratar os parentes de maneira mais horrível. ${ }^{252}$

O texto era bastante exemplar do sentimento de indignação que os "abusos" da escravidão colonial geravam nos filósofos. A sujeição do negro à barbárie e à avareza do homem branco aparecia como uma violação dos direitos mais básicos da natureza. Contudo, a indignação de Voltaire diante das crueldades cometidas contra os escravos não implicava, por parte do autor, uma contestação absoluta da escravidão e muito menos a defesa de sua abolição completa. Não havia nessa fábula literária um programa de medidas concretas. Pode-se dizer que ela sugeria, no máximo, uma defesa de reformas inspiradas no Code Noir, que atenuassem e suavizassem a escravidão, humanizando a condição dos negros nas colônias. Por outro lado, na medida em que Voltaire não tirava conclusões precisas de sua narrativa, o leitor estava autorizado a fazer uma leitura que ultrapassasse as intenções originais do autor. As posições políticas dos Iluministas e as lições que foram extraídas de seus escritos são duas coisas diferentes. Quando se observa a apropriação que os revolucionários fariam desses autores, percebe-se que a leitura que fizeram de suas obras foi muito mais seletiva do que sistemática.

Após o término da Guerra dos Sete Anos (1756-1763), os temas da colonização, da escravidão e do tráfico foram colocados no centro de um vasto debate. Com as

\footnotetext{
251 "Oui, Monsieur, dit le nègre, c'est l'usage. On nous donne un caleçon de toile pour vêtement deux fois l'année. Quand nous travaillons aux sucreries, et que la meule nous attrape le doigt, on nous coupe la main; quand nous voulons nous enfuir, on nous coupe la jambe: je me suis trouvé dans les deux cas. C'est à ce prix que vous mangez du sucre en Europe" (VOLTAIRE. Candide ou l'optimisme. Paris: Larousse, 2004, p.123).

252 "Les chiens, les singes, les perroquets sont mille fois moins malheureux que nous. Les fétiches hollandais qui m'ont converti me disent tous les dimanches que nous sommes tous enfants d'Adam, blancs et noirs. Je ne suis pas généalogiste; mais, si ces prêcheurs disent vrai, nous sommes tous cousins issus de germains. Or vous m'avouerez qu'on ne peut pas en user avec ses parents d'une manière plus horrible" (Ibidem, p.123).
} 
perdas territoriais sofridas pela França, a questão da conservação das colônias tornou-se uma preocupação central nos gabinetes ministeriais. O crescimento da produção açucareira e cafeeira no Caribe e o aumento vertiginoso da importação de escravos davam um novo impulso ao debate sobre a escravidão. A Histoire philosophique et politique des établissements et du commerce des Européens dans les deux Indes, ou simplesmente Histoire des deux Indes, do Abade Raynal foi, sob vários aspectos, o marco principal dessa evolução intelectual. Um estrondoso sucesso comercial ${ }^{253}$, a obra representou uma radicalização da crítica desenvolvida desde meados do século, não tanto quanto ao seu conteúdo, mas, sobretudo, quanto ao tom adotado. ${ }^{254}$

A obra recorria ao que Reinhart Koselleck chamou de "ciência do prognóstico histórico" 255 , ferramenta bastante representativa da forma como, naquele momento, a história começava a ser concebida. O futuro aparecia como portador de uma ruptura com formas passadas que não mais atendiam aos imperativos morais da humanidade. A obra inscrevia-se nesse novo registro, ao opor o passado e o futuro do espaço colonial por meio de uma predição de movimentos de independência. Devemos, contudo, nos interrogar a respeito das reais intenções por trás desse "prognóstico". Para isso, é necessário analisar as três versões em que a obra foi editada no espaço de dez anos.

A Histoire des deux Indes, editada pela primeira vez em 1770 (embora efetivamente publicada apenas em 1772) ${ }^{256}$, tinha por meta refletir sobre o problema colonial tal como ele havia sido posto pelo Tratado de Paris de 1763, que levou à perda de grande parte das posses coloniais francesas. Isso implicava necessariamente refletir sobre o tráfico e a escravidão dos negros. ${ }^{257}$ A obra foi um dos manifestos filosóficos mais populares e influentes de sua época, ganhando, num espaço de uma década, outras duas versões - 1774 e 1780 - com diferenças importantes entre elas. Essas diferenças se devem ao aporte de colaboradores chamados por Raynal para rever o texto e reescrever

\footnotetext{
${ }^{253}$ A sua primeira versão, de 1770, teve oito edições; a segunda, de 1774, nove; e a terceira, de 1780, chegou a dezoito edições (cf. BÉNOT, Diderot, de l'athéisme à l'antocolonialisme, p.258).

${ }^{254}$ A obra de Raynal apareceu em meio a outros escritos sobre o tema, alguns deles mais radicais, mas menos célebres. No mesmo ano de sua primeira edição (1770), por exemplo, foi publicado o Mémoire pour un nègre qui reclame sa liberté, de Henrion de Pansey, advogado famoso por defender escravos perante o Parlamento de Paris. Ironizando a Filosofia, eficaz em identicar a existência do mal, mas não o seu remédio, o autor rebatia a tese de que certos climas poderiam justificar práticas imorais, como a escravidão. Negava ainda que o interesse colonial pudesse autorizar violações ao direito natural (cf. HENRION DE PANSEY, Pierre-Paul-Nicolas. Mémoire pour un nègre qui reclame sa liberté. Paris: Hérissant, 1770, pp.12 e 26).

255 Cf. KOSELLECK, Reinhart. Le futur passé. Contribution à la sémantique des temps historiques. Paris: Éditions de l'École des Hautes Études en Sciences Sociales. 1990 (reimpressão: 2000).

${ }^{256}$ Segundo Yves Bénot, uma primeira versão já existia em 1765 (cf. BÉNOT, Yves. Diderot, de l'athéisme à l'anticolonialisme. Paris: François Maspero, 1981, p.157).

${ }^{257}$ Cf. BÉNOT, Yves. Diderot, Pechmeja, Raynal et l'anticolonialisme, p.108.
} 
determinadas passagens. As descrições do tráfico negreiro, por exemplo, aumentaram consideravelmente de uma edição para outra. Diderot, sabe-se, foi encarregado de fazer a revisão completa da segunda edição e reescrever a terceira. ${ }^{258}$

Na edição de 1770, o tema da escravidão, desenvolvido no Livro XI, ficou a cargo do filósofo idealista Jean de Pechméja ${ }^{259}$, inspirado no artigo "Nègres" da Enciclopédia. ${ }^{260}$ Raynal-Pechméja refutavam as explicações teológicas que procuravam atribuir a cor negra a uma descendência de Cam. Opondo a teologia à filosofia, afirmavam que "a filosofia se eleva às causas pelos efeitos; a teologia forjou a causa para interpretar os efeitos". ${ }^{261}$ A cor negra da pele dos africanos explicava-se por razões científicas - uma substância gelatinosa encontrada entre a epiderme e a pele -, que faziam do negro uma espécie particular de homens. A obra recorria à ideia aristotélica da servidão natural, isto é, à ideia de que a natureza cria alguns homens para serem escravos, ao afirmar que, em razão de sua constituição inata, o negro era mais apto à escravidão: "[...] o medo e o amor são excessivos nesse povo; e é o que o torna mais efeminado, preguiçoso, fraco e infelizmente mais adequado à escravidão". ${ }^{262}$

O tema do tráfico era abordado a partir de seus efeitos no continente africano, onde os reis multiplicavam as guerras para atender à demanda dos mercadores europeus por escravos. Em troca, os europeus estimulavam hábitos de luxo entre as nações africanas, para obter escravos em troca de bens de consumo. O ritmo desse comércio estava na origem da dizimação da população africana. Mas era o resultado desse processo na exploração colonial que orientava as conclusões da obra. As "riquezas comerciáveis" da África estavam se esgotando, levando a uma alta pronunciada dos

${ }^{258}$ Cf. DUCHET, Michèle. Diderot et l'Histoire des Deux Indes ou l'écriture fragmentaire. Paris: Éditions A.-G. Nizet, 1978, p.10. Sabe-se, desde os estudos realizados por Feugère, que a contribuição de Diderot para a obra de Raynal foi decisiva. A confrontação de certos trechos da Histoire des Deux Indes com certos fragmentos constantes das Obras de Diderot permite verificar a procedência de algumas das passagens mais importantes da obra. Na mesma época, Diderot havia se manifestado violentamente contra a escravidão em outros textos. Nos Fragments échappés du portefeuille d'un philosophe, ele atacou a legalidade da escravidão e até defendeu o direito dos cativos de usarem todos os meios disponíveis para recuperarem a sua liberdade. As contribuições de Diderot para a Histoire foram estudadas com profundidade por Yves Bénot e Michèle Duchet.

${ }^{259}$ Pechméja ficaria conhecido por suas considerações sobre a propriedade e a desigualdade extrema de fortunas como fontes de infelicidade sobre a terra. Essa crítica estava presente no Éloge de Colbert (1773). Ele voltaria a abordar o tema da escravidão no Téléphe (1784), em que narraria a revolta de escravos na Grécia, concluindo, entretanto, com uma reconciliação entre opressores e oprimidos (cf. BÉNOT, Yves. Diderot, de l'athéisme à l'anticolonialisme, pp.215-216).

${ }^{260}$ Cf. BÉNOT, Yves. Diderot, Pechmeja, Raynal et l'anticolonialisme, p.109.

261 "La philosphie s'élève aux causes par les effets; la théologie a forgé la cause pour interpréter les effets" (RAYNAL, Guillaume-Thomas. Histoire philosophique et politique des établissements et du commerce européen dans les deux Indes. Amsterdam: [s.n.], 1770, v.4, p.118).

262 "[... [a crainte et l'amour sont ils excessifs chez ce peuple; et c'est ce qui le rend plus efféminé, plus paresseux, plus faible, et malheureusement plus propre à l'esclavage" (Ibidem, p.120). 
preços dos escravos, que haviam quadruplicado em vinte anos. Assim, para RaynalPechméja, o tráfico era um comércio imoral, dispendioso e fadado a desaparecer. Mantê-lo significava forçar as colônias a produzir e vender a um preço demasiadamente caro. $^{263}$

No centro da crítica de Raynal-Pechméja, havia uma denúncia das terríveis condições em que o escravo era mantido nas ilhas da América: "privado de tudo, ele é condenado a um trabalho contínuo, num clima ardente, sob o açoite sempre agitado de um condutor feroz". ${ }^{264}$ Se existiam alguns senhores humanos, outros pareciam ver a piedade como fraqueza. Raynal-Pechméja proclamavam: "Graças aos céus, eles são punidos por meio da negligência, da infidelidade, da deserção, do suicídio das deploráveis vítimas de sua cupidez". ${ }^{265}$ Embora bastante contundente, a passagem não deve ser lida como uma autorização pura e simples a atos de resistência por parte dos escravos, a quem a obra não era destinada, mas como um alerta sobre as consequências da brutalidade dos plantadores, cuja conduta estava em exame.

Ao falar sobre a alta mortalidade dos negros na América, Raynal sustentava que a razão estava no "governo dos escravos". ${ }^{266}$ A obra assumia a sua vocação reformista, ao afirmar que a melhor forma de prevenir a revolta dos homens privados de sua liberdade era tratá-los com suavidade e humanidade. Pregava, nesse sentido, uma "[...] moderação política que consiste em poupar os trabalhos, em mitigar as penas, em devolver ao homem uma parte de seus direitos, para extrair dele, de forma mais segura, o tributo de seus deveres". ${ }^{267} \mathrm{Na}$ prática, isso significava melhorar a alimentação, a moradia e a vestimenta do escravo, além de conceder-lhe maior tempo de lazer e protegê-lo dos castigos corporais. Ou seja, era de uma renovação e ampliação do Code Noir que se estava falando.

Essa reforma era apresentada como a única forma de favorecer a população escrava, algo necessário em razão do declínio da oferta de escravos africanos. A crueldade e os excessos no tratamento dado aos escravos eram os maiores obstáculos à sua reprodução. Para Raynal-Pechméja, as colônias ganhariam muito com uma

\footnotetext{
${ }^{263}$ Ibidem, pp.142-143.

264 "Privé de tout, il est condamné à un travail continuel, dans un climat brûlant, sous le fouet toujours agité d'un conducteur féroce" (Ibidem, p.157).

265 "Graces au ciel, ils en sont punis par la négligence, par l'infidélité, par la désertion, par le suicide des déplorables victimes de leur cupidité" (Ibidem, p.155).

${ }^{266}$ Ibidem, p. 160.

267 "[...] modération politique qui consiste à épargner les travaux, à mitiger les peines, à rendre à l'homme une partie de ses droits, pour en retirer plus sûrement le tribut de ses devoirs" (Ibidem, p.161).
} 
substituição progressiva do escravo estrangeiro pelo crioulo, mais aclimatado, mais produtivo e mais dócil:

Se não estamos enganados, cultivadores nascidos nas próprias ilhas da América, respirando sempre o seu primeiro ar, criados sem outro gasto além de uma alimentação barata, formados desde cedo para o trabalho pelos seus pais, dotados de uma inteligência ou de uma aptidão singular para todas as artes; esses cultivadores deveriam ser preferíveis a escravos vendidos, expatriados e sempre forçados. ${ }^{268}$

Os meios de promover a substituição do africano pelo crioulo eram simples: cuidar das crianças negras nascidas nas ilhas; concentrar a massa dos escravos nas plantations; exigir dos navegantes que frequentavam as costas africanas que trouxessem um número igual de homens e de mulheres ou até mesmo, durante alguns anos, um número superior de mulheres, de modo a superar a desproporção existente entre os dois sexos. ${ }^{269}$ Com isso, os negros, tratados com mais humanidade, tenderiam a se multiplicar, fornecendo toda a mão de obra necessária à produção colonial, sem que fosse necessário recorrer ao comércio de escravos.

Essa defesa de um bom governo dos escravos se inscrevia dentro da lógica preservacionista que havia orientado a legislação monárquica desde o final do século XVII. A diferença agora era que essas considerações estratégicas sobre a ordem colonial eram associadas à perspectiva de um fim, mais ou menos longínquo, da escravidão negra. Raynal-Pechméja afirmavam não fazer parte daqueles que procuravam "justificar pela política o que reprova a moral". Isto é, queriam distinguir-se daqueles, como Montesquieu, que encontravam razões locais que autorizavam a prática da escravidão. Para Raynal-Pechméja, esta não se justificava nunca. Assim, as reformas pregadas visavam, em última instância, ao desaparecimento da escravidão:

Se tudo o que dissemos pareceu tender apenas a diminuir o peso da servidão, é que era preciso antes aliviar os infelizes que não se podia libertar; é que tratava-se de convencer seus próprios opressores que eles eram cruéis em prejuízo de seus próprios interesses. ${ }^{270}$

\footnotetext{
268 "Si nous ne nous trompons, des cultivateurs nés dans les iles mêmes de l'Amérique, respirant toujours leur premier air, élevés sans autre dépense qu'un nourriture peu chère, formés de bonne-heure au travail par leurs propres pères, doués d'une intelligence ou d'une aptitude singulière pour tous les arts: ces cultivateurs devraient être préférables à des esclaves vendus, expatriés et toujours forcés" (Ibidem, p.165). ${ }^{269}$ Ibidem, p. 165.

270 "Si tout ce que nous avons déjà dit, n'a paru tendre qu'à diminuer le poids de la servitude, c'est qu'il fallait soulager d'abord des malheureux qu'on ne pouvoit délivrer; c'est qu'il s'agissait de convaincre leurs oppresseurs même qu'ils étaient cruels au préjudice de leurs intérêts" (Ibidem, p.167).
} 
Nesse sentido, Raynal pretendia superar alguns dos limites do discurso de Montesquieu, imprimindo à obra um tom mais violento, legitimando aparentemente o uso da violência pelo escravo contra o seu opressor: "Aquele que justifica um sistema tão odioso merece do filósofo um silêncio cheio de desprezo, e do negro uma punhalada". ${ }^{271}$ Evocando Jaucourt, Raynal-Pechméja proclamavam: "Quebremos as correntes de tantas vítimas de nossa cupidez, mesmo que sejamos obrigados a renunciar a um comércio que tem por base apenas a injustiça e, por objeto, apenas o luxo". ${ }^{272}$ Mas, para os autores, as produções coloniais podiam perfeitamente ser cultivadas por mãos livres e consumidas, portanto, sem remorso. Propunham devolver a liberdade aos negros, "[...] mas sucessivamente, como uma recompensa por sua economia, sua conduta, seu trabalho [...]". ${ }^{273} \mathrm{Na}$ aparência, a obra propunha a superação do mero reformismo.

A segunda versão da Histoire des Deux Indes foi precedida pela publicação, em 1771, de L'an deux mille quatre cent-quarante: rêve s'il n'en fut jamais, de LouisSébastien Mercier. Em sua passagem mais famosa, a obra construía a profecia de uma insurreição massiva escrava nas colônias, a partir da imagem de um grande líder negro responsável por conduzir as massas na destruição das correntes da servidão. Mercier narrava as aventuras de um personagem que despertava inexplicavelmente no ano 2440 , numa sociedade renovada e purificada. Tratava-se de um artifício do autor para descrever um futuro utópico e criar um contraponto com a realidade da sociedade contemporânea, marcada pelo absolutismo. No capítulo XXII, intitulado "Singular Monumento", o herói se deparava com a estátua de um negro, aos pés da qual lia-se a inscrição "Ao vingador do novo mundo!". Ao herói era dada a seguinte explicação:

a natureza enfim criou esse homem surpreendente, esse homem imortal que devia livrar um mundo da tirania mais atroz, a mais duradoura, a mais insultante. Seu gênio, sua audácia, sua paciência, sua firmeza, sua virtuosa vingança foram recompensadas: ele rompeu as correntes de seus compatriotas. Tantos escravos oprimidos sob a mais odiosa escravidão pareciam aguardar apenas o seu sinal para formar tantos heróis. [...] No mesmo instante, eles derramaram o sangue de seus tiranos. Franceses, Espanhóis, Ingleses, Holandeses, Portugueses, todos foram presas do ferro, do veneno e das chamas. A terra da América bebeu com avidez esse sangue que ela aguardava há muito tempo e as ossadas de seus ancestrais

\footnotetext{
271 "Quiconque justifie un si odieux système, mérite du philosophe un silece plein de mépris, et du nègre un coup de poignard" (Ibidem, pp.167-168).

272 "Brisons les chaînes de tant de victimes de notre cupidité, dussions-nous renoncer à un commerce qui n'a que l'injustice pour base et que le luxe pour objet" (Ibidem, p.172).

${ }^{273}$ Ibidem, p. 173.
} 
covardemente assassinados pareceram então elevar-se e estremecer de alegria. ${ }^{274}$

Mercier, que, em abril de 1788, seria admitido como membro da Sociedade dos Amigos dos Negros, usava a técnica da antecipação, para confrontar o modelo ideal de uma sociedade livre com a realidade da segunda metade do século XVIII. A sua intenção, entretanto, era muito mais denunciar os abusos do presente, na esperança de que os dirigentes fizessem as reformas necessárias, do que profetizar de fato um futuro desejável. Na passagem em questão, a revolução dos escravos aparecia essencialmente como uma ameaça, uma consequência possível das taras que definiam a escravidão colonial. O grande líder negro tinha dado "o exemplo de que, cedo ou tarde, a crueldade será punida [...]". ${ }^{275}$ Contudo, se as aspirações de Mercier eram essencialmente reformistas $^{276}$, a introdução da noção de uma revolução conduzida pelos próprios escravos negros representava uma inegável radicalização do discurso. Numa época em que o medo de uma rebelião escrava nas colônias era constante, o negro começava a ser apresentado não como uma coisa ou como um ser desprovido de sensibilidade, mas como um homem capaz de lutar pela própria liberdade e conquistar a sua independência.

Em 1774, foi publicada uma nova edição, revista, da Histoire des deux Indes. Ela reproduzia, em linhas gerais, o conteúdo do livro XI, dedicado à escravidão colonial. A notável diferença estava no capítulo XXXI, onde a abordagem do tema assumia um tom mais inflamado e ameaçador. Raynal indicava que os sinais de uma revolução escrava já podiam ser percebidos, nas diferentes formas assumidas pela resistência escrava: fugas, assassinatos, envenenamentos, suicídios... No auge da

\footnotetext{
274 "la nature a enfin créé cet homme étonnant, cet homme immortel, qui devait délivrer un monde de la tyrannie la plus atroce, la plus longue, la plus insultante. Son génie, son audace, sa patience, sa fermeté, sa vertueuse vengeance ont été récompensés: il a brisé les fers de ses compatriotes. Tant d'esclaves opprimés sous le plus odieux esclavage, semblaient n'attendre que son signal pour former autant de héros. [...] Dans le même instant ils ont versé le sang de leurs tyrans. Français, Espagnols, Anglais, Hollandais, Portugais, tout a été la proie du fer, du poison et de la flamme. La terre de l'Amérique a bu avec avidité ce sang qu'elle attendait depuis longtemps, et les ossements de leurs ancêtres lâchement égorgés ont paru s'élever alors et tressaillir de joie" (MERCIER, Louis-Sébastien. L'an deux mille quatre cent-quarante: rève s'il n'en fut jamais. Paris: 1786, v.1, pp.194-195).

${ }^{275}$ Ibidem, pp.195-196.

${ }^{276}$ Embora tenha aderido, em abril de 1788, aos Amigos dos Negros, Mercier renegaria a Sociedade posteriormente, após a insurreição dos escravos em São Domingos, acusando-a de incitar o caos nas colônias. Essa postura indica claramente que nunca foi a intenção do autor conclamar os negros para uma revolta geral nas colônias francesas.
} 
produção açucareira das Antilhas, os negros indicavam que o limite do suportável tinha sido ultrapassado. ${ }^{277}$

A influência de Mercier ${ }^{278}$ aparecia quando Raynal, de forma profética, evocava um futuro líder que guiaria as massas escravas na sua luta pela liberdade e na vingança pelos séculos de sofrimento; um Espártaco negro, imagem que seria, no futuro, tão comumente associada a Toussaint Louverture:

[...] falta aos negros apenas um chefe suficientemente corajoso, para conduzi-los à vingança e à carnificina.

Onde está esse grande homem, que a natureza talvez deva à honra da espécie humana? Onde está, esse novo Espártaco, que não encontrará nenhum Crasso? Desaparecerá então o código negro; e como será terrível o código branco, se o vencedor consultar apenas o direito das represálias! ${ }^{279}$

O trecho em questão ${ }^{280}$ foi objeto de diferentes interpretações. Como aponta Bénot, isolado, ele podia ser visto como um apelo à insurreição escrava, como conclusão necessária de um processo de regeneração das colônias, levando a uma independência dos escravos. Contudo, inserido no contexto do capítulo XXXI, que propunha reformas à escravidão e planos de abolição gradual, ele adquiria o caráter de alerta aos soberanos europeus para a necessidade de melhorar imediatamente as condições da escravaria nas ilhas e preparar a sua emancipação gradual. ${ }^{281}$

O tema da insurreição escrava estava longe de ser fantasioso. O crescimento vertiginoso da população escrava nas colônias e, sobretudo, nas Antilhas, tinha multiplicado o número de revoltas. As colônias inglesas viveram, nas décadas de $1730 \mathrm{e}$ 40, sucessivas ondas de pânico. No século XVIII, mais de uma dúzia de revoltas

\footnotetext{
${ }^{277}$ Cf. RAYNAL, Guillaume-Thomas. Histoire philosophique et politique des établissements et du commerce européen dans les deux Indes. Haia: Gosse fils, 1774, v.4, pp.167-168.

${ }^{278} \mathrm{O}$ tema da insurreição também apareceu em outras obras. Em seu poema L'Esclavage des Américains et des Nègres, que, em 1775, concorreu ao prêmio da Academia francesa, Claude-Louis-Michel de Sacy evocava os horrores da escravidão num tom ameaçador reminiscente de Mercier e Raynal: "Reis, temeis um mortal sob o jugo aviltado, o Estado é, aos seus olhos, o primeiro inimigo" ("Rois, craignez un mortel sous le joug avili, L'Etat est à ses yeux son premier ennemi" (SACY, Claude-Louis-Michel de. L'Esclavage des Américains et des Nègres. Paris: Demonville, 1775, p.11).

279 "[...] il ne manque aux nègres qu'un chef assez courageux, pour les conduire à la vengeance et au carnage. Où est-il ce grand homme, que la nature doit peut-être à l'honneur de l'espèce humaine? Où estil, ce Spartacus nouveau, qui ne trouvera point de Crassus? Alors disparaîtra le code noir; et que le code blanc sera terrible, si la vanqueur ne consulte que le droit de représailles!" (RAYNAL, GuillaumeThomas. Histoire des deux Indes (1774), v.4, pp.167-168).

${ }^{280}$ Não se sabe ao certo se essa passagem é de autoria de Pechméja ou se já é uma contribuição de Diderot, que trabalhou como revisor dessa versão. Yves Bénot sustenta que as contribuições de Diderot na edição de 1774 já são inegáveis (cf. BÉNOT, Yves. Diderot, Pechmeja, Raynal et l'anticolonialisme, pp.111 e ss).

${ }^{281}$ Cf. BÉNOT, Yves. La Révolution et la fin des colonies, p.29.
} 
ocorreu somente na Jamaica. ${ }^{282}$ Muitos alertavam para o perigo de um número demasiadamente grande de escravos nas colônias, o que não impedia os colonos de continuarem a importar mão de obra.

Em 1780, veio uma terceira versão da Histoire des deux Indes, reescrita e completada por Diderot e publicada efetivamente em 1781. Além de ampliá-la com maiores informações sobre o tráfico e o continente africano, o filósofo imprimiu à obra tonalidades mais revolucionárias. A passagem da edição de 1770, mantida na de 1774, em que Raynal-Pechméja sustentavam que, pelas suas características naturais e sua baixa inteligência, o negro era mais apto à escravidão, foi eliminada. Em seu lugar, Diderot inseriu uma ampla digressão sobre a ciência e a necessidade de novas investigações em todas as diferentes áreas do conhecimento, anunciando que:

o momento se aproxima em que a razão, a justiça e a verdade irão arrancar das mãos da ignorância e da bajulação uma pena que elas seguraram por tempo demais. Tremei, vós que cobris os homens de mentiras, ou que os fazeis gemer sob a opressão. Sereis julgados. ${ }^{283}$

Ao falarem das terríveis condições dos negros nas colônias, Raynal-Diderot apontavam que, na Europa, todos os tipos de crueldade civil e religiosa eram motivo de indignação, mas que a escravidão dos negros permanecia esquecida e à margem dos escritos que louvavam a fraternidade de todos os homens. ${ }^{284}$ No capítulo XXIV, a passagem profética sobre a insurreição escrava reaparecia e, embora a expressão "novo Espártaco" tivesse sido suprimida, a evocação de um "herói que terá restabelecido os direitos da espécie humana"285 estava presente. Diderot a completou com uma reflexão sobre a liberdade, afirmando que a liberdade natural era o caráter distintivo do homem, o princípio de seus vícios e virtudes. Sem ela, o homem ficava reduzido a uma condição inferior até mesmo à dos cães. O tráfico e a escravidão eram a negação dessa verdade imutável. $^{286}$

Dito isso, se Raynal-Diderot pregavam o fim da escravidão, eles não propunham uma libertação geral dos escravos atuais:

\footnotetext{
${ }^{282}$ Cf. DAVIS, David Brion. O Problema da Escravidão na Cultura Ocidental, pp.161-162.

283 "Le moment approche où la raison, la justice et la vérité vont arracher des mains de l'ignorance et de la flatterie une plume qu'elles n'ont tenue que trop longtemps. Tremblez, vous qui repaissez les hommes de mensonge, ou qui les faites gémir sous l'oppression. Vous allez être jugés" (RAYNAL, GuillaumeThomas. Histoire philosophique et politique des établissements et du commerce européen dans les deux Indes. Genebra: J.-L. Pellet, 1780, v.3, p.129).

${ }^{284}$ Ibidem, p. 177.

285 Ibidem, p. 204.

286 Ibidem, p. 194.
} 
Esses homens estúpidos, que não teriam sido preparados para uma mudança de estado, seriam incapazes de conduzirem a si próprios. A sua vida seria apenas uma indolência habitual, ou uma teia de crimes. $O$ grande benefício da liberdade deveria ser reservado à sua posteridade, e mesmo com algumas modificações. ${ }^{287}$ (grifo nosso)

Assim, a nova edição acabava seguindo a mesma orientação das anteriores. Pregava uma melhoria das condições dos escravos atuais, favorecendo a sua reprodução, de modo a dispensar o tráfico e preparar uma abolição por etapas da escravidão. Raynal-Diderot especificavam melhor como se daria essa emancipação gradual. Propunham um sistema em que os filhos de escravos pertenceriam ao senhor até os 20 anos de idade, para que este fosse indenizado pelos gastos feitos com a sua criação. Nos cinco anos seguintes, os jovens negros teriam de continuar a servir o mesmo senhor, mas contra o pagamento de um salário fixado por lei. Depois desse período de transição, se não tivessem cometido faltas graves, ganhariam finalmente a sua independência. Esses novos cidadãos receberiam uma cabana e um terreno suficiente para constituir uma pequena cultura. A esperança era de que tal sistema estimularia uma multiplicação da população negra, fornecendo mão de obra (futuramente remunerada) suficiente para ampliar a produção colonial e o comércio com a metrópole. ${ }^{288}$

É provável que Diderot tivesse intenções diferentes das de Raynal ${ }^{289}$, tendo em vista a sua defesa do direito à insurreição como um direito inalienável e natural do homem, mas a obra deve ser interpretada na sua totalidade. E, nesse sentido, é o caráter reformista que prevalece. Como explica Jean-Daniel Piquet, não havia contradição entre o apelo ao levante dos escravos e a pregação de uma simples reforma do estatuto desses escravos, na medida em que o público a que essas duas linhas de argumentação se

\footnotetext{
287 "Ces hommes stupides qui n'auraient pas été préparés à un changement d'état, seraient incapables de se conduire eux-mêmes. Leur vie ne serait qu'une indolence habituelle, ou un tissu de crimes. Le grand bienfai de la liberté doit être réservé pour leur postérité, et même avec quelques modifications" (Ibidem, p.202).

${ }^{288}$ Ibidem, pp.202-203.

${ }^{289}$ No seu Essai sur l'administration de Saint-Domingue (1785), Raynal, sob a influência direta de Malouet, reabilitaria parcialmente a escravidão, justificando-a com base numa abordagem realista do mundo colonial, cujo clima tórrido não permitia que o branco fosse empregado como mão de obra. Abordando a contraposição entre autoridade pública e autoridade doméstica, Raynal limitava-se a apontar os abusos de alguns senhores e a insuficiência do Code Noir, nunca efetivamente aplicado nas colônias. O abade pedia apenas reformas no sentido de melhorar a condição geral dos escravos nas colônias (cf. RAYNAL, Guillaume-Thomas. Essai sur l'administration de Saint-Domingue. S.l: 1785, pp.13-15).
} 
dirigiam era a mesmo: o metropolitano, que se procurava alertar para as consequências graves da recusa de uma eliminação gradual da escravidão. ${ }^{290}$

Os homens das Luzes não tinham a intenção de incitar os escravos à revolta. Como aponta Marcel Dorigny, as profecias de Mercier e Raynal tinham, acima de tudo, uma função pedagógica. ${ }^{291}$ Os Amigos dos Negros aprenderam bem essa lição. Em 1789, Brissot escreveria:

que os Colonos agradeçam a esses Filósofos; mais alguns anos, talvez, e cansados de um jugo insuportável, os Negros, revoltando-se, teriam vingado em seu sangue os tormentos de dois séculos. A reforma prevenirá esse massacre, vinculando então os Negros aos Brancos, devolvendo àqueles todos os seus direitos. ${ }^{292}$

Obras como as de Montesquieu, Voltaire, Rousseau, Mercier e Raynal expressaram a evolução de uma consciência antiescravista na França ao longo do século XVIII, uma evolução que expressava preocupações decorrentes de transformações em curso nos espaços coloniais. A Histoire des deux Indes marcou o momento em que a crítica prudencial da escravidão colonial evoluiu para planos de sua supressão gradual. Nesse sentido, as bases do discurso dos antiescravistas do final do século estavam dadas. É certo que apenas a leitura dos philosophes não é suficiente para compreender a totalidade das posições que esse movimento assumiria, mas ela permite compreender os limites de um programa filosoficamente antiescravista e politicamente reformista.

Os ataques da filosofia à escravidão e ao tráfico contribuíram para despertar, na França do século XVIII, um sentimento humanitário contra as crueldades cometidas nas colônias. Esse sentimento geral repercutiu também num movimento literário que, nas últimas décadas do século, procurou humanizar a figura do negro na consciência europeia, por meio de uma exaltação de seus valores morais e sentimentos. Os argumentos pró-escravistas tiravam grande parte de sua eficácia do fato de que os europeus viam os negros como seres destituídos de verdadeira humanidade. A literatura voltou-se contra essa percepção, por meio de uma transposição para o universo das colônias escravistas de temas universais da cultura clássica, como a punição injusta de

\footnotetext{
${ }^{290}$ Cf. PIQUET, Jean-Daniel. L'émancipation des Noirs dans la Révolution française, p.27.

${ }^{291}$ Cf. DORIGNY, Marcel, GAINOT, Bernard. La Société des Amis de Noirs, p.20.

292 "que les Colons remercient ces Philosophes; encore quelques années, peut-être, et las d'un joug insupportable, les Noirs se révoltant, auraient vengé dans leur sang les tourments de deux siècles. La réforme préviendra ce massacre, en attachant désormais les Noirs aux Blancs, en rendant aux premiers tous leurs droits" (BRISSOT DE WARVILLE, Jacques-Pierre. Réflexions sur l'admission, aux états généraux, des députés de Saint-Domingue. S.l: s.n., s.d., p.30).
} 
um inocente ou a separação de jovens amantes. Esses textos também serviam de veículo para a crítica da escravidão colonial, mesmo que numa ótica apenas reformista.

O conto Ziméo (1769), por exemplo, de Jean-François de Saint-Lambert, que faria parte dos Amigos dos Negros, relatava uma revolta de escravos na Jamaica contra os maus tratos de que eram vítimas. O seu líder, Ziméo, um negro do Benin, era um produto das crueldades inspiradas pela avareza e pelo espírito mercantil. Mas, longe de fazer de Ziméo uma figura fria e desumanizada, Saint-Lambert deu-lhe uma voz, permitindo-lhe relatar a sua história, sua captura e venda aos traficantes, assim como os horrores da travessia. O escravo não aparecia como um ser insensível, nem a sua revolta era apresentada como um ato sem sentido.

Ao mesmo tempo em que denunciava esses abusos, Saint-Lambert apresentava a imagem de uma escravidão mais humana e suave na pessoa de Wilmouth, senhor que tratava seus escravos com moderação, a tal ponto que estes preferiam continuar vivendo sob os seus cuidados a se juntarem aos marrons. ${ }^{293}$ Assim, Saint-Lambert procurava contrapor dois modelos de escravidão: uma, bárbara e cruel, que só podia levar à revolta dos escravos; outra, mais justa e humana, que mantinha os negros fiéis aos seus senhores. Ao final, o autor propunha um novo tipo de colonização, esclarecida pelos princípios do direito natural, em que os europeus levariam os seus conhecimentos e descobertas aos demais povos, ideia importante para os Amigos dos Negros. ${ }^{294}$

Outra obra bastante emblemática do período é a peça L'esclavage des Nègres ou l'heureux naufrage de Olympe de Gouges. ${ }^{295}$ A obra só seria efetivamente encenada em 1789 e publicada em 1792, mas já tinha sido admitida no repertório da Comédie Française desde 1783, sob o nome Zamore et Mirza, ou l'heureux naufrage. A peça trazia um drama sentimental bastante convencional, não estivesse centrado nas aventuras de dois escravos fugitivos, Zamore e Mirza. Em meio às suas peripécias, o casal discutia as diferenças entre brancos e negros, que Zamore reduzia apenas à cor da pele e ao grau de instrução. O personagem denunciava os senhores brancos que

\footnotetext{
${ }^{293}$ Cf. SAINT-LAMBERT, Jean-François de. Ziméo. In: Contes. Paris: Librairie des Bibliophiles, 1883, pp.42-43.

${ }^{294}$ Ibidem, pp.73-74.

${ }^{295}$ Olympe de Gouges nunca fez parte da Sociedade dos Amigos dos Negros. Aliás, em 1790, ela publicaria um panfleto para dissociar o seu combate da campanha dos Amigos dos Negros, afirmando que nunca pretendeu fazer de sua obra um "brandão de discórdia, um sinal de insurreição" (cf. GOUGES, Olympe de. Réponse au champion américain, ou colon très-aisé à connoître. S.l. [Paris]: s.n., s.d. [1790], p.8).
} 
mantinham seus negros na ignorância para poder dominá-los. ${ }^{296}$ Ao mesmo tempo, Zamore falava do desenvolvimento de novas ideias na Europa, onde os homens esclarecidos lançavam sobre os negros "olhares enternecidos" e preparavam a sua liberdade. ${ }^{297}$ Esse novo espírito se manifestava na figura de M. de Saint-Frémont, plantador que, ao final, decidia dar a liberdade aos seus escravos.

Essa corrente literária traduzia a existência de um movimento de opinião simpático à causa dos negros, sobretudo nos meios da elite esclarecida. No final da década de 1780, começaram a ser publicados memoriais de autoria de antigos escravos, como as Réflexions sur la traite et l'esclavage des nègres (1788), de Ottobah Cugoano. ${ }^{298}$ Os antiescravistas valer-se-iam dessa imagem humanizada do Negro, como ser capaz de virtude e sensibilidade, mesmo oprimido e submetido a condições subumanas.

\section{I.1.2.2) A crítica econômica à escravidão na França}

A condenação moral da escravidão colonial tinha atingido, ao final do século XVIII, um nível sem precedentes na história da França. Era bastante difícil legitimar moralmente a escravização dos negros com base em algum título fundado no direito ou na religião. Era possível defendê-la essencialmente como um "mal necessário", isto é, como uma prática que encontrava a sua razão na realidade da empresa colonial e no interesse que tanto os colonos quanto a metrópole tinham na sua conservação. ${ }^{299}$ Assim, o grande desafio, para os antiescravistas, era travar a luta no plano dos interesses materiais, o que implicava fazer a crítica econômica da escravidão.

Na Grã-Bretanha, o aporte da crítica econômica ao movimento antiescravista era certamente mais forte. É recorrente a ideia de que a economia política contribuiu muito para o avanço da consciência antiescravista, associando ao discurso filosófico da defesa da liberdade natural a apologia do liberalismo econômico. Adam Smith tornou-se referência obrigatória no que se refere à crítica econômica à escravidão. As suas

\footnotetext{
${ }^{296}$ Cf. GOUGES, Olympe de. L'esclavage des Noirs, ou l'heureux naufrage. Paris: Côté-femmes éditions, 1989, p.45.

${ }^{297}$ Ibidem, p.47.

${ }^{298}$ Cf. CUGOANO, Ottobah. Réflexions sur la traite et l'esclavage des nègres, traduites de l'Anglais d'Ottobah Cugoano, afriquain, esclave à la Grenade et libre en Anglaterre [par Antoine Diannyère]. Londres, Paris: Royer, 1788.

${ }^{299}$ Ver, por ex., DUVAL DE SANADON, David. Discours sur l'esclavage des nègres, pp.14-15.
} 
contribuições sobre o tema na Riqueza das Nações (1776) seriam frequentemente recuperadas pelos antiescravistas, não apenas na Inglaterra, mas também na França. ${ }^{300}$

Smith atacou todo o sistema de leis e costumes que sufocavam a livre iniciativa, favorecendo interesses pessoais em detrimento do bem público. A escravidão era vista como parte desse sistema de monopólios e privilégios, que impunha restrições à iniciativa e impediam que o interesse pessoal contribuísse para o bem geral. $\mathrm{O}$ trabalho escravo era, para Smith, notoriamente mais caro do que o trabalho livre; mais caro e menos produtivo, na medida em que o escravo não possuía motivação para trabalhar bem: "Uma pessoa que não possa adquirir propriedade não tem outro interesse senão comer o máximo e trabalhar o menos possível". Para Smith, o recurso à escravidão explicava-se não por razões econômicas, mas passionais: o orgulho e a vontade de dominar. ${ }^{301}$ Além disso, a escravidão gerava distorções, na medida em que os escravos eram melhor tratados e, portanto, mais produtivos, sob governos arbitrários do que sob governos livres, onde a autoridade doméstica não encontrava barreiras e tendia ao esgotamento da escravaria. ${ }^{302}$ Não havia, assim, uma racionalidade econômica que explicasse a escravidão.

Um dos vetores da crítica econômica à escravidão era o desinteresse das sociedades escravocratas em relação às melhorias que podiam ser introduzidas nas colônias para aumentar o valor da terra e melhorar a vida da comunidade. A escravidão era vista como o grande entrave para a introdução de máquinas e novas técnicas de cultivo, assim como para o investimento em infraestruturas (estradas, escolas, etc.). A tendência dos proprietários coloniais ao absenteísmo era um forte agravante: distantes de suas plantações, não se preocupavam em promover melhorias. ${ }^{303}$

Na França, a crítica econômica teve uma evolução mais difícil. Na maioria dos tratados econômicos do século XVIII, o assunto era abordado de forma passageira. Muitos, ao contrário, esforçavam-se em justificar, em termos econômicos, a instituição escravista. Era o caso de Richard Cantillon, nascido na Irlanda, mas radicado em Paris, que abordou, no Essai sur la nature du commerce en général (escrito em 1730 e publicado na França apenas em 1755), o tema da escravidão pelo ângulo do custo de

\footnotetext{
${ }^{300}$ Smith seria citado em textos de alguns Amigos dos Negros, como Brissot (cf., por exemplo, BRISSOT DE WARVILLE, Jacques-Pierre. Réflexions sur l'admission, aux états généraux cit, p.11). Em carta de fevereiro de 1789, o barão de Wimpffen, oficial alemão de passagem em São Domingos, citaria trechos de Adam Smith, para sustentar a maior produtividade do trabalho livre em relação ao servil (cf. WIMPFFEN, Alexandre-Stanislas de. Haïti au XVIIIe siècle, pp.80-81).

${ }^{301}$ Cf. SMITH, Adam. A Riqueza das Nações. São Paulo: Martins Fontes, 2003, v.1, p.486.

302 Ibidem, pp.742-743.

${ }^{303}$ Cf. DAVIS, David Brion. O Problema da Escravidão na Cultura Ocidental, p.182.
} 
manutenção do escravo. Chegou à conclusão de que o trabalho diário do mais vil escravo correspondia em valor ao dobro do produto da terra do qual ele subsistia, ao passo que vassais ou camponeses livres exigiam custos de manutenção maiores. Sem abordar a questão da produtividade do escravo, Cantillon sustentava a tese de que

[...] seria sempre mais vantajoso para o Proprietário manter Escravos do que camponeses livres, visto que, quando ele tiver criado um número grande demais de escravos para o trabalho, ele poderá vender os Excedentes como animais, e poderá tirar da venda um preço proporcional ao gasto que tiver feito para criá-los até a idade da virilidade ou do trabalho. ${ }^{304}$

Já o pioneiro economista Jean-François Melon sustentou, no Essai politique sur le commerce (1734), que o bem da nação podia justificar aparentes injustiças. Seguindo uma visão utilitarista, seu argumento principal era de que "as Colônias são necessárias à Nação; e os Escravos são necessários às Colônias [...]". ${ }^{305}$ Melon limitava-se a pregar uma atenuação do tratamento dado aos escravos por meio de uma aplicação mais ampla das disposições do Code Noir. ${ }^{306}$ Defendia uma escravidão suavizada, com a atribuição de determinados direitos ao escravo - o pecúlio, por exemplo - e o favorecimento de sua reprodução. Nesse sentido, acreditava que a emancipação de alguns dos filhos de escravos podia ser útil. ${ }^{307}$

Um dos colaboradores da Enciclopédia, F. Verón de Forbonnais não tinha incluído o tema da escravidão no artigo "Colônia" (1753), de sua autoria. Um ano depois, entretanto, ele o abordou de forma passageira em Éléments de commerce (1754), adotando a perspectiva do interesse da metrópole no comércio colonial. Nesse tocante, o autor se dedicava essencialmente a uma defesa do exclusivo, isto é, da subordinação imediata do interesse da colônia ao da metrópole. ${ }^{308}$ Quanto à escravidão, procurava justificá-la, de um lado, pelos costumes ferozes e leis bárbaras da África e, de outro, pelo interesse da metrópole na introdução de escravos na colônia:

\footnotetext{
304 "[...] il serait toujours plus avantageux au Propriétaire d'entretenir des Esclaves, que des Paysans libres, attendu que lorsqu'il en aura élevé un trop grand nombre pour son travail, il pourra vendre les Surnuméraires comme des bestiaux, et qu'il en pourra tirer un prix proportionné à la dépense qu'il aura fait pour les élever jusqu'à l'âge de virilité ou de travail" (CANTILLON, Richard. Essai sur la nature du commerce en général. Londres: Fletcher Gyles, 1755, p.45).

${ }^{305}$ MELON, Jean-François. Essai politique sur le commerce. S.d.: s.n., 1761, pp.51-52.

${ }^{306}$ Ibidem, p.51.

${ }^{307}$ Melon pregava a libertação de um de cada três filhos, à escolha do pai. De cada cinco filhos, um outro seria emancipado, à escolha do patrão (Ibidem, p.56).

${ }^{308}$ Cf. FORBONNAIS, François Véron Duverger de. Éléments du commerce. Leyde: Briasson, 1754, v.2, pp.21-22.
} 
A metrópole extrai um duplo benefício de sua importação nas colônias: a vantagem de um maior consumo de seus produtos, seja para a sua compra, seja para a sua manutenção, e a vantagem de aumentar o seu supérfluo em produtos das colônias. ${ }^{309}$

Sobre o tráfico, Forbonnais, que tinha administrado uma empresa familiar em Nantes, importante porto negreiro, sustentava que "o comércio dos Negros deve, portanto, ser visto, favorecido e sustentado, como a base da cultura das colônias". ${ }^{310}$ Sua preocupação era evitar o encarecimento dos produtos coloniais, o que tornaria o exclusivo ruinoso para a metrópole.

A crítica econômica à escravidão só ganhou um impulso verdadeiro na França com o desenvolvimento da corrente fisiocrática. Os Fisiocratas abordaram o tema sob o enfoque da eficácia econômica, comparando o trabalho servil ao trabalho livre. Nem todos os fisiocratas deram atenção à questão, mas houve algumas contribuições importantes, como as de Victor Riqueti de Mirabeau, pai de Honoré Gabriel Riqueti de Mirabeau, o famoso revolucionário e Amigo dos Negros. Em 1756, um ano após a publicação dos cálculos de Benjamin Franklin sobre o custo da escravidão ${ }^{311}$, Mirabeaupai abordou o tema num tratado sobre o crescimento da população, as leis econômicas e a felicidade humana: L'Ami des hommes, ou traité de la population. Mostrando-se extremamente crítico em relação às barreiras ditadas pelo exclusivo, o autor descrevia o modelo de colonização adotado nas ilhas como incapaz de promover o crescimento das colônias. Defendia a ideia de que o comércio e a indústria prosperariam se a população continuasse a crescer, o que exigia um estado saudável da agricultura. Ora, nas colônias, a solução adotada para promover o seu povoamento, isto é, a importação de escravos africanos, mostrava-se incapaz de atender aos imperativos de crescimento populacional, visto que as condições de vida desses escravos, submetidos a um trabalho excessivo e contínuo, entravavam a sua reprodução. Além disso, a sujeição de escravos ao cultivo

\footnotetext{
309 "La métropole retire un double profit de leur importation dans les colonies: l'avantage d'une plus grande consommation de ses denrées, soit pour leur achat, soit pour leur entretien, et l'avantage d'accroître son superflu en denrée des colonies" (Ibidem, pp.32-33).

310 "le commerce des Nègres doit donc être regardé, favorisé et soutenu, comme la base de la culture des colonies" (Ibidem, p.33).

${ }^{311}$ Franklin empreendeu um exame da escravidão a partir de uma análise contábil. Ele avaliou o custo do trabalho escravo a partir do investimento original, dos riscos, da falta de lucro do capital e da manutenção. Concluiu que o trabalho escravo era muito mais caro que o trabalho livre, o que colocava as colônias em desvantagem comercial (cf. FRANKLIN, Benjamin. Observations concerning the increase of Mankind, Peopling of Countries, etc. Boston: S. Kneeland, 1755, pp.5-6).
} 
da terra tinha gerado o efeito nefasto de "colocar no último escalão a arte e o trabalho que deveriam estar no mais alto escalão na estima dos homens". ${ }^{312}$

Afirmava não ignorar que "o pior dos abusos é querer atacar de frente e destruir com um só golpe os abusos enraizados na natureza das coisas". Não pregava, portanto, o fim da escravidão negra nas colônias, mas apontava meios de torná-la inútil, a partir da transformação do sistema colonial. Era, a seu ver, preciso encorajar a cultura das terras nas colônias por meio da instituição de uma liberdade total de importação e exportação e abrir, com isso, novas saídas para produtos coloniais. A valorização das terras por meio da cultura atrairia cultivadores e artesãos da Europa que, contra o recebimento de um salário, ofereceriam um trabalho superior e menos custoso que o dos escravos. ${ }^{313}$ No fundo, Mirabeau mostrava-se pouco interessado na situação dos negros escravizados, mas a sua crítica ao sistema colonial baseado na escravidão negra abria as portas para uma contestação do escravismo pela ótica econômica, algo que seu filho empreenderia nos primeiros anos da Revolução.

Discípulo de Mirabeau-pai, o abade Baudeau era um defensor da colonização baseada no trabalho livre. Em 1763, em Idées d'un citoyen sur la puissance du roi et le commerce de la nation dans l'Orient, Baudeau apresentou uma proposta concreta para a superação do sistema escravista, com a instauração de uma colonização livre em Madagascar, Île-de-France e Bourbon. Propunha a compra de homens, mulheres e crianças africanas e asiáticas, não para fazer deles escravos, mas cidadãos das colônias, cultivadores e artesãos, após terem sido civilizados e disciplinados. ${ }^{314}$ Defendia também a incorporação de escravos em regimentos militares: reunidos num corpo de tropas nacionais, eles seriam submetidos à disciplina militar, com vistas à sua educação e conversão em cidadãos livres. ${ }^{315}$ Baudeau também desenvolveria essas ideias no periódico Ephémérides du Citoyen, um dos principais veículos para as ideias fisiocráticas. ${ }^{316}$

\footnotetext{
312 MIRABEAU, Victor Riqueti de. L'Ami des Hommes, ou Traité de la population. Troisième partie. Avignon: s.n., 1758, pp.203-205.

313 Ibidem, p. 206.

${ }^{314}$ Cf. BAUDEAU, Nicolas. Idées d'un citoyen sur la puissance du roi et le commerce de la Nation dans l'Orient. Amsterdam: s.n., 1763, p.24.

${ }^{315}$ Ibidem, pp.25-26. Alguns anos depois, o conde de Maudave tentaria, de fato, criar uma colônia não escravista no Sul de Madagascar. A experiência seria um fracasso total. Somente após a abolição de 1848, o plano de Baudeau seria aplicado, embora de forma clandestina, em plantações da Guadalupe e da Martinica (cf. BÉNOT, Yves. La Révolution et la fin des colonies, pp.32-33).

${ }^{316}$ Em 1768, o célebre fisiocrata Dupont de Nemours sucederia a Baudeau como editor do jornal.
} 
Outro fisiocrata, Lemercier de la Rivière, que tinha sido intendente na Martinica entre 1759 e 1764, sustentava que o trabalho escravo, embora inevitável nas colônias, era custoso e, atingidos determinados níveis de preço, podia bloquear a produção. $\mathrm{O}$ trabalho do escravo tinha de gerar um produto capaz de recuperar o preço da sua compra, o que era difícil tendo em vista que o escravo representava um capital sujeito a avarias, ao perecimento diário e à destruição total, de modo que o trabalho do branco livre era necessariamente menos caro. ${ }^{317}$

Bastante próximo dos Fisiocratas, Turgot abordou, nas Réflexions sur la formation et la distribution des richesses (1766), a questão do cultivo da terra por escravos, no quadro de uma reflexão sobre os meios pelos quais o proprietário podia extrair a receita da terra. Turgot limitou-se a apontar que a escravidão era o motivo das inúmeras guerras fomentadas pelos mercadores europeus nas costas da Guiné. Os trabalhos excessivos a que eram submetidos os cativos geravam uma necessidade de constante reposição da escravaria. Como era a guerra que alimentava esse comércio, ele só podia subsistir enquanto os homens estivessem divididos em pequenas nações, em constante confronto. ${ }^{318}$ Em 1769, o fisiocrata Dupont de Nemours decidiu publicar uma nova versão do texto, nas Éphémérides du citoyen. Sem prevenir Turgot, Dupont fez uma revisão do conteúdo, procurando adequá-lo às doutrinas da fisiocracia. Acrescentou, assim, que o cultivo feito por escravos era pouco lucrativo e excessivamente dispendioso para o senhor, por dois motivos essenciais. O primeiro residia no fato de que "os escravos não têm nenhum motivo para realizar os trabalhos aos quais são obrigados, com a inteligência e os cuidados que poderiam garantir o seu sucesso; segue-se que esses trabalhos produzem muito pouco". ${ }^{319} \mathrm{O}$ segundo motivo estava na avidez de riquezas dos próprios senhores, que, ao submeterem os seus escravos a esforços cada vez mais penosos, levavam-nos a uma morte precoce, o que obrigava o proprietário a fazer novas inversões para repor esses "maus operários". 320

Zangado, Turgot escreveu a Dupont para queixar-se das alterações e enfatizar que, encarado na perspectiva do proprietário individual, o trabalho escravo podia ser

\footnotetext{
317 Cf. STEINER, Philippe. L'esclavage chez les économistes français (1750-1830). In: M. DORIGNY (org.). Les abolitions de l'esclavage, p.168.

${ }^{318}$ Cf. TURGOT, Anne-Robert-Jacques. Oeuvres et documents le concernant. Paris: Felix Alcan, 19131923 , v.1, p.547.

319 "les esclaves n'ont aucun motif pour s'acquitter des travaux auxquels on les contraint, avec l'intelligence et les soins qui pourraient en assurer le succès; d'où suit que ces travaux produisent très-peu" (TURGOT, Anne-Robert-Jacques. Réflexions sur la formation et la distribution des richesses. In: Oeuvres. Paris: Guillaumin, 1844, v.1, p.18).

${ }^{320}$ Ibidem, pp.18-19.
} 
lucrativo, mesmo que a prática da escravidão fosse moralmente condenável. ${ }^{321}$ Como diz David Brion Davis, "embora os fisiocratas ajudassem a estimular a opinião antiescravocrata, a divisão entre Dupont e Turgot era sintomática de problemas fundamentais que perturbariam durante muito tempo o liberalismo econômico". ${ }^{322}$

Dupont de Nemours publicaria, em 1771, De l'esclavage des Nègres, apresentando cálculos destinados a demonstrar o caráter não lucrativo do trabalho escravo, devido à sua baixa produtividade. Inspirado nos cálculos anteriores de Benjamin Franklin, Dupont procurou mostrar que o que era injusto também era ruinoso. O economista rebateu as propostas voltadas para uma humanização do tráfico de escravos: a única solução era a sua supressão e a transformação do sistema de trabalho colonial, com a introdução de operários livres. ${ }^{323}$ Afirmou que:

A humanidade e a filosofia gritam há muito tempo que é abominável possuir [escravos]. A aritmética começa a provar que isso também é absurdo; que operários não custariam mais, seriam mais felizes, não se exporiam aos mesmos perigos e trabalhariam dobrado. ${ }^{324}$

Nemours tentava conciliar os interesses dos colonos, da metrópole e dos escravos. Essa conjunção de interesses econômicos e princípios morais apareceria em muitos textos antiescravistas do final do século. Contudo, o impacto dos argumentos dos Fisiocratas foi, em grande medida, neutralizado pelo rápido crescimento do comércio com as Antilhas ao longo do século XVIII. A defesa do interesse nacional na abolição esbarrava na forte influência das classes ligadas ao comércio colonial, que, justamente, tendiam a definir o combate abolicionista como antinacional. O raciocínio era simples: sendo o tráfico essencial para as colônias e estas para o comércio da metrópole, a abolição do tráfico de escravos só podia ser ruinosa para a economia francesa. ${ }^{325}$ Necker, por exemplo, em De l'administration des finances de la France (1784), limitou-se a atacar a escravidão pelo ângulo da moral, reconhecendo que, do

\footnotetext{
${ }^{321}$ Cf. TURGOT, Anne-Robert-Jacques. Oeuvres et documents le concernant, v.2, pp.27-29.

${ }^{322}$ Cf. DAVIS, David Brion. O Problema da Escravidão na Cultura Ocidental, p.479.

${ }^{323}$ Ibidem, pp.477-478.

324 "L'humanité et la philosophie crient depuis longtemps qu'il est abominable d'avoir [des esclaves]. L'arithmétique politique commence à prouver que cela est absurde, que des ouvriers libres ne coûteraient pas plus, seraient plus heureux, n'exposeraient point aux mêmes dangers, et feraient double ouvrage" (Citado em STEINER, Philippe. L'esclavage chez les économistes français, p.170).

${ }^{325}$ Cf. PÉTRÉ-GRENOUILLEAU, Olivier. Abolitionnisme et idée nationale: divorces et compromis, France, 1789-1831. In: Abolir l'esclavage: un réformisme à l'épreuve (France, Portugal, Suisse, XVIII-XIXe siècles). Rennes: Presses Universitaires de Rennes, 2008, pp.191-192.
} 
ponto de vista econômico e político, o tráfico e a escravidão ainda se faziam necessários. ${ }^{326}$ As lições de Adam Smith não tinham sido incorporadas.

A famosa frase Périssent les colonies plutôt qu'un principe!, proferida no calor dos debates de maio de 1791 por Dupont de Nemours e Robespierre, poderia ser vista como um indício da fragilidade das considerações econômicas no movimento antiescravista francês. Diante da dificuldade de contestar setores-chave da economia nacional, o discurso moral e humanitário seria frequentemente colocado no primeiro plano. Contudo, não se deve desconsiderar a importância da crítica econômica no antiescravismo francês, no seio do qual tal enfoque esteve sempre presente. Mas, em razão da situação favorável das colônias francesas no comércio internacional de produtos coloniais, a crítica econômica impunha-se com maior dificuldade.

\section{I.1.2.3) As reflexões de Condorcet sobre a escravidão}

As bases do programa dos Amigos dos Negros foram, em larga medida, antecipadas pela publicação, em 1781, das Réflexions sur l'esclavage des nègres, de Condorcet, aristocrata de origem protestante e um dos futuros líderes da Sociedade. Escrevendo sob o pseudônimo de Joachim Schwartz, Condorcet preocupou-se essencialmente em rebater as razões costumeiramente invocadas para justificar o crime da escravidão, sobretudo as que procuravam apresentar o tráfico como um "ato de humanidade". A respeito da "pretensa necessidade da escravidão dos Negros", Condorcet entendia que, mesmo admitindo essa possibilidade, que não era certa, não se podia legitimar um crime com base no interesse dos colonos. ${ }^{327}$ Além disso, o autor procurou mostrar que, se na cultura por escravos o produto líquido era mais elevado, em razão dos menores custos de produção, o produto bruto era maior na cultura livre, de modo que o trabalho escravo só podia se justificar pelo interesse egoísta dos plantadores individuais. ${ }^{328}$ Se a diferença entre o preço do salário do operário, determinada pela concorrência, e os custos de manutenção do escravo, reduzidos ao mínimo, determinavam o caráter vantajoso do trabalho escravo para o proprietário, esse cálculo não levava em conta as perdas decorrentes das mortes, acidentes e fugas de escravos.

\footnotetext{
${ }^{326}$ Cf. NECKER, Jacques. De l'administration des finances de la France. In: Oeuvres Complètes. Paris: s.n., 1820-1821, v.4, pp.373-374.

${ }^{327}$ Cf. CONDORCET, Jean-Antoine-Nicolas de Caritat. Réflexions sur l'esclavage des nègres, pp.3-8.

${ }^{328}$ Ibidem, pp.21-22.
} 
No final das contas, as vantagens do trabalho escravo eram pequenas demais para contrabalançar os benefícios que o cultivo livre traria.

Defendendo o fim do tráfico e da escravidão, Condorcet afirmava rejeitar uma política que apenas suavizasse a condição do escravo. Medidas de atenuação e suavização da escravidão podiam ser úteis, mas apenas quando estabelecidas por um tempo limitado e quando feitas para acompanhar um "sistema de alforria". ${ }^{329}$ Isto é, não podiam ser utilizadas para perpetuar um mal. Mas essa postura aparentemente abolicionista era contrabalançada por considerações de ordem prática:

Assim, no reparo de uma injustiça, pode o legislador atentar para os interesses daquele que sofreu a injustiça e esse interesse pode exigir, no modo de repará-la, precauções que acarretem adiamentos. É preciso atentar também para a tranquilidade pública; e as medidas necessárias para conservá-la podem exigir que se suspenda as operações mais úteis. ${ }^{330}$

Condorcet entendia que, diante da certeza de que um homem estava fora de condições de exercer os seus direitos, correndo o risco de fazer deles um exercício abusivo e prejudicial, a outrem como a si mesmo, a sociedade podia entender que esse homem tinha perdido os seus direitos, ou então não os tinha adquirido ainda. Era o caso das crianças muito novas, dos imbecis, dos loucos e, segundo o autor, dos escravos. Em razão do estado de embrutecimento a que tinham sido submetidos e da corrupção de seus costumes, os escravos das colônias europeias encontravam-se incapazes de cumprir as funções de homens livres. Condorcet propunha que fossem tratados

[...] como esses homens que o infortúnio ou a doença privou de parte de suas faculdades, a quem não se pode deixar o exercício integral de seus direitos, sem expô-los a fazer mal a outrem, ou a prejudicar a si mesmos, e que precisam não apenas da proteção das leis, mas também dos cuidados da humanidade. ${ }^{331}$

Condorcet pregava a eliminação da escravidão dos negros, mas argumentava que devolver-lhes abruptamente a liberdade seria condená-los à miséria. Corrompidos pelo mau exemplo dos senhores e embrutecidos pelas condições subumanas em que viviam,

\footnotetext{
${ }^{329}$ Ibidem, p.46.

330 "Ainsi, dans la réparation d'une injustice, le législateur peut avoir égard aux intérêts de celui qui a souffert l'injustice, et cet intérêt peut exiger dans la manière de la réparer, des précautions qui entraînent des délais. Il faut avoir égard aussi à la tranquillité publique; et les mesures nécessaires pour la conserver, peuvent demander qu'on suspende les opérations les plus utiles" (Ibidem, p.12).

331 "...] comme ces hommes que le malheur ou la maladie a privés d'une partie de leurs facultés, à qui on ne peut laisser l'exercice entier de leurs droits, sans les exposer à faire du mal à autrui, ou à se nuire à euxmêmes, et qui ont besoin, non seulement de la protection des lois, mais des soins de l'humanité" (Ibidem, p.13).
} 
os negros não eram, na sua opinião, capazes de gozar da liberdade. Para que uma libertação geral fosse adotada, diversas condições tinham de ser observadas, com vistas à preservação da ordem: a garantia da subsistência de velhos, enfermos e órfãos e até mesmo de negros válidos que não pudessem encontrar trabalho junto aos plantadores; uma sujeição dos novos livres a uma estreita disciplina, para evitar que se lançassem em roubos ou vinganças ou que se entregassem a uma vida vagabunda; e a aceitação da perda parcial da colheita de um ano, levando a uma alta dos preços e a perdas para os credores dos plantadores. ${ }^{332}$

Tendo em vista todos os preparativos e gastos que uma libertação geral exigiria, Condorcet entendia que a melhor forma de promover a abolição era por etapas, mesmo que ele próprio encarasse esse sistema como uma "espécie de consentimento forçado" e temporário à injustiça. ${ }^{333}$ Se uma abolição total e imediata da escravidão era inviável, era possível, dizia o autor, tomar medidas que, desde os primeiros instantes, atenuassem a condição dos negros, preparando a via para o desaparecimento completo da escravidão, numa época determinada e pouco distante.

Os meios propostos por Condorcet para essa abolição gradual eram os seguintes:

1) Abolição imediata do tráfico negreiro, medida que produziria um efeito imediato no estado dos escravos, forçando os proprietários a suavizarem a sua condição para melhor conservá-los.

2) Alforria dos negros nascidos nas plantações, não ao nascerem, mas aos 35 anos, ficando o senhor obrigado a prover a sua educação. Caso este se recusasse a cuidar da criança, ela seria declarada livre. Ou seja, Condorcet propunha um sistema de tutela dos jovens negros, que trabalhariam para o senhor até o momento de sua emancipação.

3) Declarar livres aos 40 anos todos os negros que tivessem menos de 15 anos no momento da publicação da lei. Os que tivessem mais de 15 anos poderiam decidir, quando chegassem aos 50, se preferiam permanecer com seu senhor ou servir num estabelecimento público.

4) Os que permanecessem escravos, e que Condorcet chamava de domestiques engagés à temps, teriam a possibilidade de comprar a sua liberdade, pagando uma tarifa, estabelecida com base no preço médio de um negro, de acordo com a idade. Se o senhor se recusasse a conceder a alforria, mesmo após o depósito do

\footnotetext{
${ }^{332}$ Ibidem, pp.28-32.

333 Ibidem, p.33.
} 
valor, ele seria culpado do "crime de reter um homem livre na escravidão", devendo ser punido "como se houvesse cometido um roubo".

Para Condorcet, esse sistema evitaria mudanças bruscas, danosas à economia colonial, permitindo aos colonos adaptar-se a um novo método de cultivar as suas terras e ao governo estabelecer novas leis e um novo sistema de polícia para as colônias. A previsão de Condorcet é que em 70 anos não haveria mais escravos nas colônias. ${ }^{334}$

No fundo, o marquês retomava, em novos termos, ideias já desenvolvidas anteriormente por Raynal. Em apenas um aspecto, ele inovava: ao afirmar que o problema colonial não se limitava à escravidão e que era todo o sistema de grandes plantações que devia ser alterado. Acreditava que, com a supressão da escravidão, o proprietário de terras não ficaria mais na obrigação de explorar suas posses por si mesmo, suportando todos os gastos de produção. Ele poderia simplesmente arrendar suas terras a fazendeiros (arrendatários), podendo até mesmo fazê-lo em pequenas parcelas, o que permitiria uma melhor exploração do solo. Condorcet sugeria, portanto, uma transformação do modo de produção existente nas colônias, com a implantação de um sistema de pequenas explorações. Incentivos governamentais poderiam ser dados a famílias brancas que viessem se estabelecer nas colônias, para cultivar pequenas propriedades. Algumas liberdades poderiam ser concedidas a minorias religiosas (judeus, protestantes), de modo a estimular a sua transferência para as colônias. ${ }^{335}$ Os negros livres forneceriam a mão de obra barata para a agricultura, trabalhando como simples jornaleiros nas diferentes plantações.

Esse último aspecto do memorial de Condorcet não foi recuperado pela Sociedade dos Amigos dos Negros, no seio da qual a questão fundiária permaneceu marginal. Mas esse texto aparecia, no início da década de 1780, como uma espécie de síntese da evolução da crítica antiescravista das três décadas anteriores. A exemplo dos filósofos e fisiocratas, o que concretamente Condorcet propunha de imediato? Uma mudança da forma de reposição da mão de obra escrava, substituindo o tráfico pela reprodução endógena da escravaria. O fim da escravidão era concebido apenas num futuro mais distante e, nesse sentido, a linha que separava o antiescravismo gradualista do mero reformismo preservacionista nem sempre era muito clara. A prioridade dada à preservação da ordem e da economia coloniais, como justificativa ao não

\footnotetext{
${ }^{334}$ Ibidem, pp.33-45.

${ }^{335}$ Ibidem, pp.55-58.
} 
reconhecimento imediato dos direitos naturais do homem, sinalizava os limites dentro dos quais a Sociedade dos Amigos dos Negros formularia o seu programa.

\section{I.1.2.4) O programa da Sociedade dos Amigos dos Negros}

O movimento intelectual que precedeu a formação da Sociedade dos Amigos dos Negros traduziu a evolução das mentalidades em relação ao que acontecia nas colônias francesas. Ele também forneceu as ideias-chave que a sociedade antiescravista defenderia na sua campanha, reproduzindo a disparidade entre o rigor da condenação moral da escravidão e a moderação política das medidas propostas. Vejamos, portanto, quais eram os principais pontos do programa dos Amigos dos Negros.

\section{I.1.2.4.1) Abolição do tráfico: uma luta internacional}

A exemplo do que acontecia com a sociedade londrina que lhe serviu de inspiração, os Amigos dos Negros tinham como ponto de partida e meta principal a abolição do tráfico. Com isso, a emancipação efetiva da massa dos escravos das colônias era deixada para um futuro mais ou menos distante. Havia três motivos fundamentais para essa disposição. Em primeiro lugar, os Amigos dos Negros acreditavam - erroneamente - que a evolução da campanha contra o tráfico na GrãBretanha estava perto de gerar frutos no Parlamento, o que tornava a conjuntura para uma medida análoga na França mais favorável. Em segundo lugar, acreditavam que, dados os riscos humanos e financeiros inerentes ao tráfico, a sua abolição seria mais fácil de obter. Uma supressão dos incentivos estatais aos traficantes de escravos já seria suficiente para derrubar esse comércio, que viam como pouco lucrativo em si. Mais importante do que isso, entretanto, era a confiança que tinham os Amigos dos Negros de que a abolição do tráfico promoveria uma melhoria imediata e significativa na condição dos escravos existentes nas colônias. $\mathrm{Na}$ impossibilidade de repor a mão de obra por meio do recurso aos mercadores, os plantadores ficariam na obrigação de velar pela saúde dos escravos, reduzir a sua mortalidade e criar condições para a sua reprodução. Assim, ao lado da denúncia do caráter bárbaro do tráfico, havia uma preocupação fundamental com o abastecimento de mão de obra nas plantações coloniais.

O discurso dos Amigos dos Negros sobre o tráfico sofreria variações de acordo com o momento: em certas ocasiões, eles se esforçariam em separá-lo da questão da 
escravidão propriamente dita, apresentado-o como um problema distinto. Em outros, a abolição do tráfico seria apresentada como a primeira etapa preparatória à erradicação da escravidão, reintroduzindo o vínculo entre as duas questões. Em todos os casos, entretanto, a crítica ao tráfico procurava unir a condenação moral dessa prática a uma denúncia de seu caráter oneroso. Assim, por um lado, os Amigos dos Negros apresentariam relatos detalhados dos horrores da travessia, com detalhes muitas vezes chocantes das brutalidades cometidas a bordo dos navios negreiros. ${ }^{336}$ Por outro, os Amigos dos Negros se esforçariam em demonstrar que, além de imoral, o tráfico era uma empresa lesiva a todas as partes envolvidas. Essa linha de argumentação apareceria, por exemplo, no Discours sur la traite des Noirs (1790), de Pétion de Villeneuve. No texto, o tráfico apareceria como oneroso:

1) Ao Estado, que via-se obrigado, para manter vivo esse comércio e garantir o abastecimento de escravos às ilhas, a pagar subvenções aos mercadores de escravos. Além disso, os altos riscos da travessia levavam à morte de muitos dos homens empregados, privando a Nação de grande parte de seus marinheiros. ${ }^{337}$

2) Ao comércio. A necessidade de pagamento de prêmios por parte do Estado evidenciava, segundo o autor, o caráter desvantajoso do tráfico do ponto de vista comercial. Os Amigos dos Negros difundiriam a ideia de que esse comércio era uma "verdadeira loteria", em razão dos altos riscos envolvidos. ${ }^{338}$

3) Às colônias. O tráfico era apresentado como um obstáculo à reprodução da população negra nas colônias. Em razão da possibilidade de abastecimento pelo tráfico, os plantadores preferiam esgotar rapidamente os seus escravos, de modo a recuperar o quanto antes o investimento feito na sua compra e substituí-los por outros mais jovens e vigorosos. Com isso, nenhum esforço era feito para favorecer a reprodução da escravaria, cuja população não se multiplicava. Os plantadores viam-se então forçados a contrair novas dívidas para sanar a carência de mão de obra. Além disso, a entrada constante de escravos africanos era apresentada pelos Amigos dos Negros como o principal fator de instabilidade nas colônias: retomavam a ideia de que os boçais, arrancados de

\footnotetext{
${ }^{336}$ Em 1789, a Sociedade publicaria um desenho com uma descrição detalhada de um navio negreiro, para denunciar as condições em que os negros faziam a travessia (cf. Description d'un navire négrier. S.1.: s.n., s.d.). É possível que o desenho tenha sido feito pelo sueco Carl Bernhard Wadström, um líder da segunda fase da Sociedade, e transmitido aos Amigos dos Negros pelos antiescravistas britânicos.

${ }^{337}$ Cf. PÉTION. Discours sur la traite des Noirs. Paris: Desenne, 1790, pp.44-45.

${ }^{338}$ Ibidem, p.48.
} 
seu país, eram muito mais propensos à revolta do que os ladinos, mais aclimatados, habituados ao trabalho e à obediência desde a infância. ${ }^{339}$

4) Às manufaturas francesas. Os objetos envolvidos no tráfico de escravos eram, na sua maioria, provenientes de outras nações europeias, de modo que uma abolição desse comércio pouco afetaria as manufaturas francesas. Estas se beneficiariam ao contrário da substituição do tráfico por um comércio de outra espécie com o continente africano, que lhes abrisse novos mercados de consumo. $^{340}$

Assim, é a lógica do interesse nacional, corporificado nos interesses específicos dos diferentes atores envolvidos na exploração das colônias, que orientava a defesa da abolição do tráfico. Esta aparecia como o passo inicial de um processo de reformulação do sistema colonial.

Embora destacassem o interesse da Nação na supressão do tráfico, esta era concebida pelos Amigos dos Negros como uma medida a ser obtida por meio de um acordo internacional entre as diferentes potências ligadas ao comércio de escravos. A Sociedade foi inicialmente idealizada não como uma entidade absolutamente autônoma, mas como parte de uma rede internacional antiescravista, com vínculos formais com outras sociedades do mesmo gênero. Assim, a correspondência com o Comitê de Londres foi definida como uma das tarefas principais da Sociedade. O Regulamento da entidade estabelecia, nesse sentido, que os membros das sociedades de Londres e da América fossem admitidos de direito nas Assembleias gerais dos Amigos dos Negros (capítulo III, art. VI). ${ }^{341}$ Brissot falava em estabelecer uma "filiação" entre as sociedades. $^{342}$

Por trás dessa concepção, havia a percepção de que, em função da lógica internacional na qual se inscrevia o tráfico de escravos e da concorrência a que as diferentes potênciais coloniais estavam sujeitas, a ação contra o sistema escravista tinha necessariamente de envolver as diferentes nações implicadas na exploração colonial, de

\footnotetext{
${ }^{339}$ Ibidem, p.55.

${ }^{340}$ Ibidem, pp.57-58.

${ }^{341}$ Cf. RÈGLEMENS de la Société des Amis de Noirs, p.22.

342 A Sociedade londrina, por meio de Granville Sharp afirmaria que, em razão das circunstâncias locais, seria mais prudente que as sociedades continuassem a sua luta como aliadas, e não como uma única e mesma sociedade. Sharp revelava, entretanto, talvez não ter entendido bem o sentido da palavra "filiação". Brissot esclareceria que, na verdade, a filiação nada mais era do que uma relação de fraternidade entre as duas sociedades, de modo que a aliança proposta por Sharp correspondia bem ao que havia sugerido (cf. REGISTRE de la Société des Amis des Noirs, p.146).
} 
modo a atingir igual e simultaneamente todas as economias escravistas, sem que nenhuma delas fosse necessariamente favorecida.

Essa ideia não era nova. Na Histoire des deux Indes, Raynal já tinha defendido que a derrubada do edifício da escravidão, construído com base na rivalidade das nações mais poderosas da Europa, tinha de ser a obra de seus reis reunidos. Da mesma forma, em De l'administration des finances de la France (1784), Necker tinha feito uma condenação moral da escravidão e do tráfico, mas, reconhecendo que a riqueza das nações era um dos fundamentos de seu poder, entendia que nenhum soberano, por mais sensível que fosse aos deveres da humanidade, renunciaria sozinho ao serviço dos escravos nas colônias. Dito isso, Necker tinha aventado a possibilidade de um pacto entre nações contra o comércio de escravos:

Entretanto, seria um projeto ilusório o de um pacto geral, pelo qual todas as nações renunciariam, de comum acordo, ao tráfico dos negros? Elas se encontrariam então, umas em relação às outras, nas mesmas proporções que existem atualmente; pois é unicamente a riqueza comparativa que importa nos cálculos de potência. ${ }^{343}$

É possível que Necker não acreditasse muito nessa possibilidade, ou então que ele a concebesse apenas num futuro muito distante, mas o fato é que a ideia de que a luta antiescravista era, por sua própria natureza, uma luta internacional tinha sido inicialmente incorporada pelos Amigos dos Negros. ${ }^{344}$ Já no seu discurso inaugural, de 19 de fevereiro de 1788, a união entre a França e a Grã-Bretanha tinha sido apresentada como condição sine qua non para o sucesso da campanha contra o tráfico. Retomando as palavras de Necker, o Regulamento da Sociedade indicava que "é, portanto, provável que a abolição do tráfico dos Negros ocorrerá por meio de um acordo geral, por uma espécie de pacto entre as potências". 345

\footnotetext{
343 "Cependant, serait-ce un projet chimérique que celui d'un pacte général, par lequel toutes les nations renonceraient d'un commun accord à la traite des nègres? Elles se trouveraient alors, les unes envers les autres, dans les mêmes proportions qui existent actuellement; car c'est uniquement la richesse comparative qui importe aux calculs de puissance" (NECKER, Jacques. De l'administration des finances de la France, p.374).

${ }^{344}$ Conforme as perspectivas de um sucesso no Parlamento britânico foram se esvaindo, os Amigos dos Negros abandonaram essa ideia. Na Adresse à l'Assemblée Nationale, de 1791, Clavière afirmaria que "é por ter examinado fragilmente a questão que se pretendeu que as potências marítimas só podem abolir o tráfico de escravos de concerto" (cf. CLAVIÈRE, Etienne. Adresse de la Société des Amis des Noirs, à l'Assemblée Nationale, à toutes les villes de Commerce, à toutes les Manufectures, aux Colonies, à toutes les Sociétés des Amis de la Constitution. Paris: Desenne; au Bureau du Patriote François, 1791, p.120).

345 "il est donc probable que l'abolition de la traite des Nègres aura lieu par um accord général, par une espèce de pacte entre les puissances" (RĖGLEMENS de la Société des Amis de Noirs, p.10).
} 
No fundo, essa ideia expressava a preocupação com o interesse nacional, que tinha de ser preservado mesmo quando se tratava de atender aos imperativos da humanidade. A abolição do tráfico não podia acarretar a ruína das colônias francesas. Mas esse internacionalismo tornava, aos olhos de muitos, suspeita a campanha dos Amigos dos Negros contra a escravidão. A sua filiação a uma sociedade antiescravista inglesa seria constantemente explorada pelos seus adversários, que os acusariam de integrarem um complexo plano de perda das colônias francesas, num momento em que as colônias britânicas se mostravam incapazes de competir com os preços do açúcar de São Domingos. A expressão "amigos dos negros" tornar-se-ia sinônimo de "amigos da Inglaterra".

\section{I.1.2.4.2) Abolição gradual da escravidão}

Na sessão de 8 de abril de 1788, Clavière tomou a palavra para comentar os fins da Sociedade. Se ele reiterou que a abolição da escravidão era de fato o objetivo principal dos Amigos dos Negros, ressaltou também que a escravidão

[...] encontra-se infelizmente vinculada a uma ordem de coisas, na qual se reúnem as máximas imperiosas da política, os interesses respeitáveis da propriedade, e a perseverança de uma catividade tão ativa que ela se sustenta num longo hábito de preconceitos numerosos e cômodos. ${ }^{346}$

Assim, longe de querer provocar algum tipo de revolução, a Sociedade buscava seguir "o curso da razão".

De Montesquieu a Condorcet, passando por Raynal, muitos já tinham alertado para os perigos das emancipações abruptas. A necessidade de consideração do interesse público - isto é, a conservação das colônias - era uma ideia presente também no discurso dos Amis des Noirs, que acreditavam ser possível - e necessário - avançar na via emancipadora, sem infringir os interesses legalmente estabelecidos. Desde a sua primeira reunião, os Amigos dos Negros expressaram a sua preocupação em conciliar os interesses da humanidade com os do comércio e até mesmo dos colonos. $\mathrm{Na}$ sua concepção, era preciso promover mudanças sem provocar grandes abalos no sistema colonial. Assim, a propriedade privada, mesmo a propriedade sobre o escravo, não

\footnotetext{
346 "[...] se trouve malheureusement lié à um ordre de choses, où l'on rencontre les impérieuses maximes de la politique, les intérêts respectables de la propriété, et la persévérance d'uma captivité d'autant plus active, qu'elle s'appuie sur une longue habitude de préjugés nombreux et commodes" (REGISTRE de la Société des Amis des Noirs, pp.128-129).
} 
podia ser abruptamente suprimida pelo direito. O plantador, fomentador da produção colonial, não podia ser, de uma hora para outra, privado da totalidade de seus cativos. Era preciso preparar a economia colonial para a transição para o trabalho livre, permitindo que os plantadores se ajustassem ao novo sistema, absorvendo o impacto das perdas iniciais. Era preciso, por fim, pensar a questão da integração da massa de escravos das colônias a uma sociedade livre, despreparados que estavam para a liberdade.

O segundo grande ponto do programa da Sociedade consistia, assim, na elaboração de uma legislação que permitisse o abandono gradual e progressivo do trabalho escravo nas colônias. Essa legislação emancipacionista viria apenas após a abolição do tráfico, de modo a permitir que o fim do comércio de escravos levasse os plantadores a promover transformações no tratamento dispensado aos cativos, a favorecer a sua reprodução e suprir, desta forma, a carência de mão de obra gerada pela supressão do tráfico. Então, uma vez percorrida essa primeira etapa, seria colocado em prática um programa de medidas que promovesse a emancipação gradual da escravaria, sem abalar a economia, e permitisse a regeneração dos escravos, preparando-os para a liberdade.

É interessante notar que a Sociedade não chegou a formular um plano unificado de abolição gradual da escravidão. Os vários projetos formulados individualmente por alguns de seus membros apresentavam variações consideráveis quanto às modalidades de emancipação e quanto ao prazo para o desaparecimento total da escravidão. Um ponto comum, entretanto, aos planos era o favorecimento das alforrias pelos senhores. Nesse sentido, um dos principais alvos dos Amigos dos Negros era a taxa que os plantadores tinham de pagar para libertar cada um de seus cativos. ${ }^{347}$ Esse verdadeiro "imposto sobre a liberdade" era o maior obstáculo à alforria.

O gradualismo partia, portanto, de duas preocupações essenciais, uma ligada à economia, outra ligada à ordem social. Por um lado, havia o problema da transição de um modo de produção baseado na mão de obra escrava para outro, baseado na mão de obra remunerada. Os Amigos dos Negros, a exemplo da quase totalidade dos antiescravistas da época, acreditavam na necessidade de etapas intermediárias que permitissem evitar a ruína dos estabelecimentos existentes. O pressuposto desse

\footnotetext{
${ }^{347}$ Para contornar essa exigência, alguns escravos serviam por alguns anos na maréchaussée, a milícia de cor que fazia a polícia sobre a escravaria, o que dispensava os seus senhores respectivos de pagar o imposto sobre as eventuais alforrias.
} 
programa era que, introduzido progressivamente, o trabalho livre geraria, num prazo não muito longo, um aumento de produtividade que compensaria as eventuais perdas iniciais sofridas pelos plantadores.

Além disso, havia a questão da inserção social da massa de escravos, despreparados, na ótica dos Amigos dos Negros, para a vida civil em razão do estado de embrutecimento a que estavam submetidos e que os havia praticamente privado de faculdades intelectuais e morais. Como diriam os Amigos dos Negros em 1789, em resposta a um escrito de Malouet:

Tão justo e humano seria devolver SUBITAMENTE a liberdade aos Negros quanto é justo e humano tê-los mantido na escravidão. A primeira operação do Governo deve, portanto, ser a de lhes devolver A FACULDADE de serem livres. ${ }^{348}$ (itálico no original)

Pensavam, portanto, que era necessária uma fase de transição, durante a qual os negros, colocados sob uma espécie de tutela, seriam "educados para a liberdade", o que não deixava de retomar a ideia iluminista de que o homem era perfectível, de que existiam graus de civilização e até mesmo de humanidade. ${ }^{349}$ Os Amigos dos Negros não explicitavam em que termos se daria essa "educação" dos antigos escravos, mas o seu discurso aponta fundamentalmente para o temor de que, uma vez livres, os negros das colônias tenderiam a abandonar o trabalho nas plantações. Era a desagregação da produção colonial que se queria evitar.

Assim, se o objetivo final da Sociedade era o desaparecimento da escravidão como modo de exploração das colônias, ela só o concebia como o resultado de uma conversão suave. A busca pela boa ordem colonial, elemento comum ao discurso reformista do final do Antigo Regime e ao antiescravismo dos Amigos dos Negros, afastava a ideia de uma abolição geral que beneficiaria simultaneamente todos os escravos.

Essa opção política e filosófica por uma abolição apenas gradual da escravidão excluía, é claro, a hipótese de uma emancipação que não se desse pela via legal, isto é, uma abolição promovida pela força. Os Amigos dos Negros rejeitavam ou sequer

\footnotetext{
348 "Il ne seroit pas plus juste \& plus humain de rendre SUBITEMENT la liberté aux Noirs, qu'il n'est juste et humain de les avoir retenus dans l'esclavage. La première opération du Gouvernement doit donc être de leur rendre LA FACULTÉ d'être libres" (RÉPONSE à l'écrit de M. Malouet sur l'esclavage des nègres. Dans lequel est exprimé le voeu formé par les colons d'avoir des Représentans aux EtatsGénéraux. Par un Membre de la Société des Amis des Noirs. S. 1. [Paris]: s.n., 1789, p.58).

${ }^{349}$ Cf. TROUILLOT, Michel-Rolph. Silencing the Past: Power and the Production of History. Boston, Mass: Beacon Press, 1995, pp.80-81.
} 
concebiam a ideia de associar a sua campanha a um movimento escravo nas colônias. Alguns membros temiam até mesmo que a própria existência da Sociedade pudesse provocar reações violentas entre os escravos nas colônias. ${ }^{350}$ Essa aversão pela via revolucionária manifestar-se-ia na atitude ambígua de alguns líderes da Sociedade diante das notícias da insurreição escrava em São Domingos, no outono de 1791.

O tema da revolta escrava apareceria constantemente nos textos dos Amigos dos Negros, mas, à moda de Raynal, como um alerta. Em 1786, Brissot tinha assumido posições audaciosas, no seu Examen critique des voyages dans l'Amérique septentrionale, de M. le marquis de Chatellux, no qual parecia justificar os atos de violência dos escravos:

Devemos caracterizar os esforços que faz um escravo para recuperar a liberdade como vícios ou crimes? Na medida em que abandonais a ordem da natureza em relação a eles, por que eles não a abandonariam nas suas relações com vós? Roubais a sua liberdade, e não quereis que roubem o vosso ouro! Vós os fazeis gemer sob os açoites e nos mais cruéis tormentos, e não quereis que eles se debatam para livrar-se deles! Vós os assassinais lentamente e a cada dia, e não quereis que eles vos assassinem uma só vez! Vós chamais vossas atrocidades de direito e, de crime, a coragem com que eles as rebatem. ${ }^{351}$

Contudo, mesmo nesse caso, a violência escrava aparecia como a consequência natural de um sistema brutal que era necessário modificar ou suprimir. Brissot evitava falar numa emancipação geral imposta por meio da insurreição escrava, uma emancipação imposta "de baixo", capaz de subverter a ordem colonial. A partir da fundação da Sociedade, a política oficial adotada pelos seus membros seria a de evitar um discurso inflamado, adotando, ao contrário, um tom conciliador. A opção pela abolição gradual era a expressão da preocupação com a preservação das colônias.

\section{I.1.2.4.3) Suavização da condição dos escravos}

\footnotetext{
350 Em 19 de agosto de 1788, De Bourges manifestou essa preocupação. Temia que os escravos entendessem uma eventual autorização governamental ao funcionamento da Sociedade como um anúncio de sua liberdade e se revoltassem para apressar a sua libertação (cf. REGISTRE de la Société des Amis des Noirs, p.175).

351 "Doit-on caractériser les efforts que fait un esclave pour recouvrer la liberté, comme des vices ou des crimes? Dès lors que vous sortez à leur égard de l'ordre de la nature pourquoi n'en sortiraient-ils pas dans leurs rapports avec vous? Vous leur volez leur liberté, et vous ne voulez pas qu'ils volent votre or! Vous les faites gémir sous les fouets et dans les plus cruels tourments, et vous ne voulez pas qu'ils se débattent pour s'en délivrer! Vous les assassinez lentement et chaque jour, et vous ne voulez pas qu'ils vous assassinent une fois! Vous appellez vos atrocités, des droits, et crime, le courage avec lequel ils les repoussent" (BRISSOT DE WARVILLE, Jacques-Pierre. Examen critique des voyages dans l'Amérique septentrionale, p.90).
} 
Na medida em que o fim da escravidão só era concebido no longo prazo, colocava-se automaticamente a questão do estado daqueles que permaneceriam escravos e do tratamento a eles dispensado. Nesse ponto especificamente, era possível obter respaldo até mesmo dentro do campo colonial. Naquele final de século, a ideia de que era necessário reformar a escravidão era menos questionada.

No início do século XVIII, algumas vozes tinham se erguido para apontar os efeitos da avareza no tratamento dispensado aos escravos nas colônias. Defensor da escravidão e proprietário de escravos nas Antilhas, o padre Labat denunciou, no seu Nouveau voyage aux Iles françaises de l'Amérique (1722), os maus tratos cometidos contra os cativos nas colônias. ${ }^{352}$ Contudo, entre a publicação da obra de Labat e a década de 1750, não houve nenhuma contribuição nova sobre as práticas administrativas nas plantations escravistas das Antilhas. Durante esse período, verificou-se uma consagração do princípio da soberania doméstica nas colônias. ${ }^{353}$

A segunda metade do século XVIII, entretanto, viu o surgimento de numerosos tratados referentes ao governo e à administração dos escravos. Foram esses textos, muito mais do que os tratados econômicos, que difundiram a preocupação com o tratamento conferido aos escravos, pregando a necessidade de reformas. Proliferou na Administração, e mesmo entre os colonos, a ideia de que os senhores deveriam tratar melhor os seus escravos não apenas para se conformarem ao padrão de comportamento próprio aos seres humanos, mas também em razão de seus interesses materiais. Como diz Rafael de Bivar Marquese, esse binômio humanidade/interesse impulsionou as reflexões sobre a administração de escravos da segunda metade do século XVIII. ${ }^{354}$ Deve-se ainda ter em mente o fato de que, em momentos de expansão da produção colonial e de superexploração da mão de obra, a multiplicação de atos de resistência escrava, com, por exemplo, a proliferação de comunidades marrons nas colônias, impunha a necessidade de repensar o tratamento dispensado aos cativos.

Assim, obras como Observations sur les maladies des nègres (1776), de JeanBarthélemy Dazille, consagraram a ideia de que cuidar da saúde e reduzir a mortalidade dos escravos seria preservar os interesses dos colonos, do comércio e do próprio

\footnotetext{
${ }^{352}$ Labat denunciava, por exemplo, a insuficiência da alimentação concedida pelos senhores aos seus escravos, obrigando-os a utilizar os sábados para a produção de sua subsistência. Em caso de doença, o escravo ficava impossibilitado de obter a alimentação mínima necessária à sua conservação, o que acabava prejudicando o próprio senhor (cf. LABAT, Jean-Baptiste. Nouveau voyage aux Iles d'Amérique. Paris: G. Cavelier (et P.-F. Giffard), 1722, v.3, p.442).

${ }^{353}$ Cf. MARQUESE, Rafael de Bivar. Feitores do corpo, missionários da mente: senhores, letrados e o controle dos escravos nas Américas, 1660-1860. São Paulo: Companhia das Letras, 2004, pp.87-89.

${ }^{354}$ Ibidem, p. 90 .
} 
Estado. ${ }^{355}$ Outro texto representativo dessa tendência, o Traité sur le gouvernement des esclaves (1777) de Émilien Petit, era uma compilação jurídica de diferentes documentos e leis francesas, britânicas e espanholas que regulamentavam o tratamento dado aos escravos. Petit defendia a legitimidade da propriedade sobre o escravo, assim como o caráter lucrativo do trabalho escravo nas colônias, mas, ao mesmo tempo, defendia reformas no governo dos escravos, com base na ameaça constante de revoltas. O abuso de poder por parte do senhor aparecia como algo lesivo aos seus próprios interesses. Esses textos traduziam a formação de uma forte convicção quanto à necessidade de melhorar a condição dos escravos como forma de preservar a própria escravidão. $\mathrm{Na}$ mesma época, diferentes potências coloniais, como a Holanda (em 1772) e a Espanha (em 1784) emitiram leis que expressavam essa mesma preocupação, trazendo um número grande de medidas protetivas aos escravos, assim como determinações voltadas para o favorecimento de sua reprodução. ${ }^{356}$

O verdadeiro debate se dava em torno de intervenção ou não do Estado na administração dos escravos, isto é, da oposição entre a autoridade pública e a autoridade doméstica. Tradicionalmente, os colonos reclamavam uma maior autonomia na condução dos assuntos coloniais. Qualquer interferência ou mediação entre o senhor e o escravo era considerada uma violação do direito de propriedade. Os defensores da autoridade pública, por outro lado, sustentavam que senhores e escravos eram todos súditos do rei, que podia intervir para regulamentar o governo dos cativos. Era o princípio por trás do Code Noir. ${ }^{357}$ Havia nisso um paradoxo, que Adam Smith já tinha destacado: os escravos tendiam a ser melhor tratados sob um governo arbitrário do que sob um governo "livre".

Mesmo no campo escravista, entretanto, havia quem pregasse a necessidade de uma intervenção do poder público no tratamento dado aos escravos. Assim, Hilliard d'Auberteuil, advogado francês radicado em São Domingos, publicou Considérations sur l'état présent de la colonie française de Saint-Domingue (1776-77), obra polêmica

\footnotetext{
355 Cf. DAZILLE, Jean-Barthélémy. Observations sur les maladies des nègres, leurs causes, leurs traitements et les moyens de les prévenir. Paris: Didot le jeune, 1776, pp.2-3.

${ }^{356}$ No caso holandês, trata-se da Regra sobre o tratamento de servos e escravos, um conjunto de normas destinadas a restringir a violência e a negligência dos proprietários e a impor mais eficazmente a disciplina aos escravos (cf. COSTA, Emília Viotti da. Coroas de glória, lágrima de sangue: a rebelião dos escravos de Demerara em 1823. São Paulo: Companhia das Letras, 1998, pp.68-69). A lei espanhola em questão é o Decreto sobre a educação, o tratamento e os trabalhos dos escravos em todos os domínios das Índias e das Filipinas. Ela foi o objeto de análise de Louis-Sala Molins, que destacou a intenções da lei de supostamente proteger o negro, para garantir a perpetuação de sua escravidão (cf. SALA-MOLINS, Louis. L'Afrique aux Amériques: Le Code Noir espagnol. Paris: PUF, 1992).

${ }^{357}$ Cf. LARRÈRE, Catherine. Économie politique et esclavage au XVIIIe siècle, pp.217-218.
} 
na qual defendia a imposição legal de um tratamento mais humano aos escravos, no intuito de melhorar a eficácia do sistema escravista. Auberteuil foi duramente atacado na época por colonos que defendiam não o recurso à lei, mas o autopoliciamento ou, no máximo, o policiamento comunitário para conter os excessos de uma minoria de plantadores tiranos. ${ }^{358}$ Talvez a figura mais importante nesse debate tenha sido Malouet, plantador de açúcar em São Domingos que, durante a Revolução, seria um dos mais ardentes porta-vozes do partido colonial. Ele defendeu, em Mémoire sur l'esclavage des nègres (que teve a sua primeira parte escrita em 1775, mas só foi publicado na sua versão completa em 1788), a necessidade de reformas que neutralizassem os abusos do despotismo doméstico para prevenir insurreições escravas. Malouet via a abolição da escravidão e do tráfico como impraticável e contrária aos interesses atuais da justiça e da humanidade ${ }^{359}$, mas defendia restrições necessárias à autoridade doméstica, de modo a conciliar a justiça e o interesse. Para garantir um tratamento mais suave aos escravos, entendia necessário sujeitar os senhores a um estado de ordem e de polícia e isso em seu próprio benefício, pois uma melhor administração geraria necessariamente melhores resultados na produção. Em 7 de abril de 1788, Malouet, então intendente da Marinha em Toulon, chegou a reunir-se em Versalhes com o ministro La Luzerne e seu antecessor Castries para discutir essas questões. ${ }^{360}$ Da mesma forma, numa brochura de 1786, Duval de Sanadon, outro importante defensor da escravidão colonial, sustentou como justo e necessário o emprego de meios para suavizar a escravidão, eliminando os seus traços mais brutais. ${ }^{361}$

Outros tratavam da necessidade de suavizar o tratamento dos escravos como imperativo de segurança pública. Na década de 1780, o intendente Barbé de Marbois, por exemplo, ressaltou, na Câmara de agricultura de São Domingos, a necessidade da proteção dos tribunais aos escravos contra os excessos de seus senhores e a publicidade dos castigos administrados:

Pensamos que nenhum habitante estaria em segurança no seu lar se os negros não tivessem a garantia da proteção dos tribunais; eles logo se entregariam a atos de desespero, ignorando que a lei e os magistrados velam pela sua segurança, eles fariam por si mesmos uma justiça que acreditariam

\footnotetext{
${ }^{358}$ Cf. GHACHEM, Malick W. The Old Regime and the Haitian Revolution, pp.146-150.

${ }^{359}$ Cf. MALOUET, Pierre-Victor. Mémoire sur l'esclavage des nègres. Neufchâtel: 1788, p.20.

${ }^{360} \mathrm{Cf}$. THIBAU, Jacques. Le temps de Saint-Domingue, pp.55-56.

${ }^{361}$ Cf. DUVAL DE SANADON, David. Discours sur l'esclavage des nègres, pp.53 e $115-116$.
} 
ser-lhes recusada pela sociedade. A publicidade dos castigos dos Brancos e dos Negros será, ao contrário, a garantia do repouso desta colônia. ${ }^{362}$

Esses homens estavam longe de ser abolicionistas. Sua abordagem dos excessos da escravidão tinha um caráter preservacionista e apontava para um escravismo moderado. Queriam suprimir os aspectos mais nefastos de uma instituição que tinham por incontornável e, nesse sentido, queriam um novo sistema legal que substituísse o obsoleto Code Noir. ${ }^{363}$

Os Amigos dos Negros obviamente tinham na condição dos escravos uma de suas principais preocupações, mas entendiam que, para que essa suavização ocorresse, era preciso mais do que uma legislação nova que ampliasse as disposições do Code Noir: era preciso que os senhores fossem levados a promover mudanças por absoluta necessidade. A superexploração do escravo e a minimização dos gastos com a sua manutenção tinham por condição essencial a existência de um mercado de escravos regularmente abastecido. ${ }^{364}$ Os Amigos dos Negros procurariam demonstrar que, havendo a possibilidade de rápida reposição do plantel por meio do tráfico, o interesse do senhor não era o de conservar o seu escravo, mas de extrair dele o maior proveito enquanto ele durasse. A inobservância do Code Noir e de outras leis do gênero era um indício de que a aplicação de uma nova legislação na esfera colonial seria ineficiente para garantir um tratamento mais humano aos cativos, visto que, numa plantation, a única autoridade era o proprietário. O Regulamento da Sociedade afirmava que, diante da ineficácia das leis e regulamentos,

[...] o Escravo não tem outra salvaguarda a não ser o interesse daquele de quem tornou-se a propriedade; em vão, serão opostas leis que fixem os limites do poder do Senhor, pois a manutenção das leis só pode ser confiada a ele próprio. ${ }^{365}$

Para os Amigos dos Negros, apenas a abolição do tráfico permitiria resolver esse impasse, na medida em que ela determinaria o interesse dos senhores na

\footnotetext{
362 "Nous pensons qu'aucun habitant ne serait en sûreté chez lui si les nègres n'étaient pas assurés de la protection des tribunaux; ils se porteraient bientôt à des actes de désespoir ignorant que la loi et les magistrats veillent pour leur sûreté, ils se feraient eux-mêmes une justice qu'ils croiraient que la société leur refuse. La publicité des châtiments des Blancs et des Noirs sera au contraire la garantie du repos de cette colonie" (Citado em THIBAU, Jacques. Le temps de Saint-Domingue, p.74).

${ }^{363}$ Cf. GHACHEM, Malick W. The Old Regime and the Haitian Revolution, pp.222-227.

${ }^{364}$ Cf. CARDOSO, Ciro Flamarion Santana. El modo de producción esclavista colonial en América. In: C.S. ASSADOURIAN et alii (orgs). Modos de producción en América Latina. $2^{\mathrm{a}}$ edição. Córdoba: Ediciones Pasado y Presente, 1974, p.195.

365 "[...] l'Esclave n'a plus d'autre sauvegarde que l'intérêt de celui dont il est devenu la propriété; en vain opposera-t-on les lois qui fixent les bornes de la puissance du Maître, puisque le maintien de ces lois ne peut être confié qu'à lui seul" (RÈGLEMENS de la Société des Amis de Noirs, p.6).
} 
conservação e na reprodução de seus plantéis respectivos. No fundo, é fundamentalmente nesse aspecto - a erradicação do tráfico como modo de reposição da mão de obra - que os Amigos dos Negros procuravam distinguir-se da crítica preservacionista do final do Antigo Regime.

\section{I.1.2.4.4) Um novo projeto colonial}

Do ponto de vista econômico, para um antiescravista, havia duas formas possíveis de encarar a questão da escravidão naquele momento: questionar o valor econômico das colônias e, portanto, a utilidade da escravidão; ou reconhecer o valor das colônias, mas contestar a escravidão como forma de valorização ideal das posses ultramarinas. A primeira linha de argumentação estaria presente no discurso que Mirabeau apresentaria ao clube dos Jacobinos em 1790, mas, de forma geral, escapou ao discurso oficial dos Amigos dos Negros. Para a Sociedade, não era viável - e mesmo desejável - questionar a conservação das colônias pela França, sobretudo diante da posição atual de São Domingos, no quadro do comércio internacional.

Como aponta Yves Bénot,

o antiescravismo é um protesto contra um certo modo de exploração das colônias, e que não implica, portanto, automaticamente um anticolonialismo de princípio. Ele pode até mesmo estar na base de uma concepção mais moderna, mais eficaz da colonização. ${ }^{366}$

Essa concepção mais moderna de colonização partia da ideia de que o escravismo não apenas impunha um trabalho de má qualidade e incompatível com a introdução de novas técnicas de plantio e conservação da terra, mas também impossibilitava a constituição de um verdadeiro mercado de consumo nas colônias.

A possibilidade de um novo tipo de colonização era uma preocupação constante no discurso dos Amigos dos Negros, inspirados por Thomas Clarkson. Bénot entende, entretanto, que, na medida em que todas as colônias francesas eram escravistas, o antiescravismo implicava, já naquela época, um certo anticolonialismo. Acreditamos, na verdade, que é justamente a dificuldade dos Amigos dos Negros em conciliar o discurso antiescravista com o escopo de manutenção e ampliação do império colonial que explica

\footnotetext{
366 "l'antiesclavagisme est une protestation contre un certain mode d'exploitation des colonies, et qui donc n'implique pas automatiquement un anticolonialisme de principe. Il peut même être à la base d'une conception plus moderne, plus efficace de la colonisation" (BÉNOT, Yves. La Révolution et la fin des colonies, p.12).
} 
os limites de sua ação política. Concordamos, por outro lado, com o autor quando afirma que, "separado do anticolonialismo, o antiescravismo na França se choca com contradições insolúveis na medida em que ele não questiona o sistema que tem necessidade de escravos". ${ }^{367}$ A ausência de uma postura anticolonial por parte dos Amigos gerava um impasse. Inicialmente, Brissot, um adepto do livre comércio, chegou a manifestar-se contra o pacto colonial e a favor da autonomia das colônias, mas essa postura, que ele mesmo acabaria abandonando, estava mal articulada com o seu programa antiescravista. Apenas Mirabeau cruzaria a fronteira entre o antiescravismo e o anticolonialismo, no seu discurso sobre o tráfico.

Com a Revolução, as possibilidades de uma vertente anticolonial no discurso antiescravista diminuiriam ainda mais. Jennifer Pitts esclarece que a Revolução, longe de questionar a legitimidade das posses ultramarinas francesas, resgatou a concepção segundo a qual a França deveria afirmar-se como uma importante potência colonial: "[...] a França era a nação 'universal', aquela que encarnava o futuro da civilização e tinha por missão salvar os outros povos da tirania e da ignorância". ${ }^{368}$ É preciso lembrar ainda que o grupo brissotino, que constituía o núcleo da Sociedade dos Amigos dos Negros, foi responsável pela campanha de opinião em favor da guerra e da exportação da Revolução. De fato, a partir de 1791, Brissot e os Girondinos sustentariam, no calor do debate sobre a guerra, a necessidade de levar a Revolução para além dos limites territoriais da França, projeto que visava à reconstituição das fronteiras naturais da Nação. ${ }^{369}$ Esse projeto belicista de consolidação da Revolução por meio de sua exportação sugeria uma postura de conservação de suas posses ultramarinas.

O programa político da Sociedade jamais questionou a legitimidade da conservação das colônias ou a importância do comércio colonial para a prosperidade da França. ${ }^{370}$ Pregava-se uma reconversão do sistema colonial, na qual a superação progressiva da escravidão aparecia como um meio de conservação e até mesmo de extensão do império colonial. Em março de 1790, Lanthenas, um dos membros da Sociedade, expressaria a opinião geral dos Amigos dos Negros sobre a questão colonial:

\footnotetext{
367 "séparé de l'anticolonialisme, l'antiesclavagisme en France se heurte à des contradictions insolubles dans la mesure où il ne remet pas en cause le système qui a besoin des esclaves" (Ibidem, p.34).

368 "[...] France était la nation 'universelle', celle qui incarnait l'avenir de la civilisation et avait pour mission de sauver les autres peuples de la tyrannie et de l'ignorance" (PITTS, Jennifer. Naissance de la bonne conscience coloniale. Paris: Atelier, 2008, p.194).

${ }^{369}$ A teoria das fronteiras naturais tinha sido formulada no século XVII, na época da expansão territorial da monarquia absoluta. De acordo com tal teoria, a França teria suas fronteiras territoriais marcadas pela natureza: o oceano no Oeste, os Pirineus no Sul, os Alpes no Leste e o Reno no Norte.

${ }^{370}$ Cf. RÈGLEMENS de la Société des Amis de Noirs, p. 10.
} 
[...] o que o mundo não percebe, e os Amigos dos Negros podem hoje demonstrar, é a necessidade para um país realmente livre de ter colônias onde se possa gozar, sem mudar de pátria, de todos os seus direitos. ${ }^{371}$

O quarto grande ponto do programa da Sociedade dos Amigos dos Negros consistia, justamente, em propor orientações novas à colonização francesa, com a reconversão das colônias existentes e a promoção de um novo tipo de relação comercial com a África. No que se refere às colônias existentes, queriam promover a passagem da exploração extensiva das ilhas, baseada numa mão de obra desqualificada, para um tipo de exploração mais elaborada, com um trabalho mais especializado e produtivo e técnicas mais modernas de produção. $\mathrm{O}$ trabalho livre tornaria possível uma inovação tecnológica que permitiria superar a estagnação de rendimentos a que a cultura açucareira estava condenada nas colônias. ${ }^{372}$ Os Amigos dos Negros entendiam que, de modo geral, a escravidão era incompatível com qualquer inovação técnica. ${ }^{373}$ Nesse ponto, o impacto das ideias dos pensadores liberais e fisiocratas era inegável.

A Sociedade chegou a discutir formas de produzir, sem trabalho escravo, os produtos cultivados nas colônias. Assim, Lanthenas apresentou um projeto de substituição do açúcar de cana pelo érable-à-sucre (bordo de açúcar), planta que podia ser facilmente cultivada por uma pequena unidade familiar. Acreditava que esse cultivo deveria ser difundido não apenas nas colônias, como também na Europa. ${ }^{374}$

Havia também, como aponta Dorigny, uma condenação teórica da concentração, no seio da mesma plantation, do cultivo e do trabalho de transformação da cana-deaçúcar. ${ }^{375}$ As ilhas francesas, a exemplo das inglesas, caracterizavam-se por uma integração do processo produtivo. ${ }^{376}$ Alguns membros, como Condorcet, entendiam que o fim da escravidão favoreceria a transferência do trabalho industrial para uma certa

\footnotetext{
371 "ce que tout le monde n'apperçoit pas, et que les amis des Noirs peuvent aujourd'hui démontrer, c'est la nécessité pour un pays réellement libre d'avoir des colonies où l'on puisse aller jouir, sans changer de Patrie, de tous ses droits" (LANTHENAS, François-Xavier. M. Lamiral réfuté par lui-même, ou Réponse aux Opinions de cet auteur, sur l'abolition de la Traite des Noirs, suivie de quelques idées sur les établissemens libres que la France ne doit point différer de faire au Sénégal. Par un Ami des Blancs \& des Noirs. S.1. [Paris]: Imp. Potier de Lille, 1790, pp.53-55).

${ }^{372}$ Cf. DORIGNY, Marcel, GAINOT, Bernard. La Société des Amis de Noirs, p.36.

${ }^{373}$ Vale notar que mesmo um instrumento tão antigo quanto a charrua era praticamente desconhecido nas Antilhas francesas, onde seria introduzido apenas em 1835 (Ibidem, p.37).

${ }^{374}$ Cf. Patriote Français. Journal libre, impartial et national. Par une Société de Citoyens, \& dirigée par J.P. Brissot de Warville. Reimpressão. Frankfurt am Main: Keip Verlag, 1989, v.1, número CXLV, 31 de dezembro de 1789, pp.5-6.

${ }^{375}$ Cf. DORIGNY, Marcel, GAINOT, Bernard. La Société des Amis de Noirs, p.36.

${ }^{376}$ Cf. BERBEL, Márcia, MARQUESE, Rafael, PARRON, Tâmis. Escravidão e Política, p.46.
} 
quantidade de unidades de produção de dimensões suficientes para permitir a introdução de novas tecnologias. 377

É preciso ressaltar, por outro lado, que a questão fundiária foi pouco discutida no seio da Sociedade. Deveria o abandono progressivo do trabalho escravo levar a um desmantelamento das grandes propriedades, de modo a transformar os novos livres em pequenos agricultores independentes, ou deveriam as grandes plantações ser preservadas? Não houve uma posição oficial a esse respeito, mas pode-se dizer que, com algumas exceções ${ }^{378}$, não havia propriamente, no movimento antiescravista, uma tendência à superação do modelo da grande plantação.

No que se refere às novas etapas da colonização francesa, os Amigos dos Negros viam com bastante otimismo a possibilidade de inaugurar novas empresas na África. $\mathrm{O}$ objetivo não seria mais a captura e deportação de Negros para as Américas, mas a criação de estabelecimentos que permitiriam a introdução de técnicas modernas de exploração e a instituição de um novo comércio que levaria para a Europa os mais ricos recursos naturais do continente africano: madeiras, algodão, arroz, tabaco, ervas e drogas, etc. ${ }^{379}$ As ilhas de France e Bourbon desempenhariam, pela sua posição geográfica, o papel de local de depósito e centro de distribuição dos produtos oriundos da África. ${ }^{380}$

Ao mesmo tempo, esse novo sistema permitiria "civilizar" os africanos, transformando-os em consumidores das produções manufaturadas da metrópole. A criação de mercados de consumo para produtos europeus nos territórios ultramarinos era uma das ideias centrais dos Amigos dos Negros. Tratava-se de um tipo de colonização sem dominação territorial, direcionando o papel dos europeus para o comércio com as populações locais. Longe, portanto, de contestar o princípio da colonização, o programa da Sociedade tinha, no seu âmago, a ideia de uma transformação das relações entre a França e seu império, com vistas a abrir novas possibilidades de desenvolvimento para a Nação. Esse tema seria aprofundado na segunda fase da Sociedade, a partir de 1797.

\footnotetext{
${ }^{377}$ Esse projeto só seria posto em prática nos anos 1830, quando foram constituídas as primeiras Usinas centrais. Na ocasião, ficou claro que a manutenção da escravidão freava a introdução dessas usinas, o que reforçou o argumento pela abolição.

378 Além de Condorcet, outro membro da Sociedade manifestou-se sobre esse tema: Antoine-JeanThomas Bonnemain. Em Régénération des colonies (escrito em 1790, mas publicado em 1792), o autor afirmou que "na América como na Europa, as grandes propriedades são nocivas à sociedade", manifestando sua preferência por pequenas e médias explorações agrícolas (cf. BONNEMAIN. Régénération des colonies, pp.46 e 67).

${ }^{379} \mathrm{Cf}$. RÉPONSE à l'écrit de M. Malouet sur l'esclavage des nègres, pp.82-83

${ }^{380}$ Ibidem, p.85.
} 
Esse programa foi objeto de diferentes interpretações por parte da historiografia. Alguns procuraram explicar a prudência dos Amigos dos Negros por razões táticas: a necessidade de estabelecer compromissos com as classes ligadas ao status quo colonial, para fazer avançar a causa antiescravista. Assim, para Saintoyant, a moderação do programa da Sociedade traduzia a sua estruturação e organização enquanto partido político, o que impunha à sua linha de conduta considerações sobre as etapas a serem transpostas e as possibilidades concretas de ação no quadro dos interesses conflitantes que se manifestavam em torno da questão escravista. ${ }^{381}$

Outros procuraram contrapor o programa e os meios de ação da Sociedade ao um modelo abolicionista britânico, supostamente mais avançado. Segundo Daniel Resnik, a preocupação dos Amigos dos Negros com a escravidão era apenas uma decorrência de seu desejo de restaurar a liberdade natural, de modo que eles não tinham uma real compreensão das diferenças fundamentais entre a escravidão e as outras formas de tirania. Seu alvo era o privilégio social e político, onde quer que ele se manifestasse. A escravidão era, para eles, apenas uma "preocupação muito derivativa", ao passo que, na Inglaterra, era uma questão central, que atraía um interesse específico. $^{382}$

Para o autor, "uma razão maior para o fracasso da propaganda abolicionista francesa deve ser identificada na pobreza do seu argumento econômico". Na medida em que a escravidão e o tráfico eram a base da exploração colonial francesa, qualquer crítica à posse ou ao comércio de escravos, para ser politicamente eficaz, tinha de ser formulada tanto em termos econômicos quanto em termos morais. Os pró-escravistas não hesitaram em apontar o custo econômico da abolição, o que obrigava os antiescravistas a negar o impacto negativo da abolição na economia. Mas, segundo Resnik, os antiescravistas franceses, ao contrário dos ingleses, pouco exploraram esse aspecto. $^{383}$ Isso é apenas parcialmente verdadeiro: em primeiro lugar, é preciso dizer que o argumento econômico foi sim explorado pelos antiescravistas franceses. Se ele não ocupou uma posição central na sua campanha, isso se deve, em parte, a um contexto bastante diferente: por um lado, a agitação revolucionária que tomava conta do país, a

${ }^{381}$ Cf SAINTOYANT, J.. La colonisation française pendant la Révolution. Paris: La Renaissance du Livre, 1930, v.1, pp.308-309.

${ }^{382}$ Cf. RESNIK, D.P.. The Sociéte des Amis des Noirs and the abolition of Slavery. French Historical Studies, v.7, n.4, 1972, pp.560-561.

${ }^{383}$ Ibidem, pp.563-564. 
afirmação dos direitos do Homem, a proclamação de princípios fundamentais da Nação francesa, a contestação de antigos privilégios ofereciam um arsenal ideológico diferenciado aos Amigos dos Negros, permitindo-lhes inserir a luta antiescravista na onda de mudanças que atravessava o país. Nesse contexto, o argumento moral ganhava mais força. Por outro, num momento em que São Domingos afirmava-se como a primeira colônia produtora de açúcar, argumentar pelo caráter não lucrativo da escravidão colonial era, de fato, uma tarefa ingrata.

Resnik faz, nesse sentido, uma pergunta relevante:

Estavam os abolicionistas franceses condenados ao fracasso em razão do tamanho do investimento de capital francês nas suas colônias e da dependência econômica da metrópole em relação à escravidão, à economia de plantation e ao comércio colonial? ${ }^{384}$

Essa foi a linha de pensamento adotada por Eric Williams, para quem os abolicionistas ingleses podiam ir mais longe justamente porque a economia inglesa era menos dependente das Índias Ocidentais. Resnik acredita que isso não é inteiramente verdadeiro, e que tal argumentação tenderia a subestimar o papel decisivo dos abolicionistas ingleses - tão decisivo que, entre a fundação da socidade londrina e a abolição da escravidão pela Inglaterra, seriam necessários quase cinquenta anos.

Seymour Drescher também procurou contrapor a Sociedade dos Amigos dos Negros a um modelo abolicionista anglo-americano, que teria como principal característica um relativo apelo de massa, aproximando-se de um movimento social. As diferenças estariam, portanto, menos no conteúdo programático do que nos meios de ação adotados pela entidade. $\mathrm{O}$ antiescravismo anglo-americano teria como estratégia principal estimular uma pressão pública capaz de agir, por meio de petições, manifestações públicas e boicotes, sobre os interesses econômicos e órgãos estatais hostis à causa abolicionista. ${ }^{385}$

A Sociedade dos Amigos dos Negros, ao contrário, pertenceria a um modelo "continental", que teria características opostas:

Eles estavam usualmente confinados a uma elite política ou cultural bastante pequena. Eram geralmente relutantes ou incapazes de buscar um

\footnotetext{
384 "Were the French abolitionists foredoomed to failure because of the size of the French capital investment in her colonies and the mainland's economic dependence on slavery, plantation agriculture, and colonial commerce?" (Ibidem, p.568).

${ }^{385}$ Cf. DRESCHER, Seymour. Two Variants of Anti-Slavery, pp.35-36.
} 
recrutamento de massa. [...] O abolicionismo continental, em outras palavras, preferia trabalhar silenciosamente nos bastidores. ${ }^{386}$

Acreditamos que essa contraposição entre o abolicionismo francês e o abolicionismo britânico é um tanto problemática. Havia entre os dois movimentos diferenças conjunturais importantes - a situação das colônias dos dois países, a existência de um regime parlamentar na Grã-Bretanha, a existência das redes de comunicação religiosas, o estágio de desenvolvimento interno das duas nações, o envolvimento do operariado - que influíram na sua organização e na sua composição. De fato, o movimento francês apareceu, desde a sua fundação, como um movimento mais elitista, de acesso restrito e voltado muito mais para uma campanha de pressão nos círculos do poder do que para a constituição de um movimento de massa. Mesmo com o advento da Revolução, essa postura seria pouco alterada, como veremos adiante. Sob esse aspecto, portanto, existem diferenças entre os dois movimentos.

Contudo, no que se refere à sua natureza, isto é, ao conteúdo de seu programa, a Sociedade dos Amigos dos Negros nos parece ser absolutamente derivada da sociedade britânica, de modo que estaríamos diante de duas variações de um mesmo modelo político. Como aponta Serge Daget, a doutrina dos Amigos dos Negros foi, em grande parte, extraída dos escritos de Thomas Clarkson. Não havia no discurso dos antiescravistas franceses nenhuma solução original. ${ }^{387}$

Se tomarmos uma das principais obras de Clarkson, An Essay on the Impolicy of the African Slave Trade, cuja tradução a Sociedade fez publicar na França, percebe-se que as linhas gerais do abolicionismo inglês se confundiam com as dos Amigos dos Negros. No sistema de Clarkson, a abolição do tráfico também aparecia como o ponto de partida de um processo de regeneração das colônias, que levaria os plantadores a favorecerem a reprodução da escravaria por meio de uma melhoria de suas condições de existência. ${ }^{388}$ Se Clarkson desenvolvia muito mais a argumentação econômica, o teor de suas propostas era essencialmente o mesmo que os Amigos dos Negros adotavam na sua campanha. Ambos os movimentos se inscreviam na lógica gradualista.

\footnotetext{
386 "They were usually confined to a very small political or cultural elite. They generally were reluctant or unable to seek mass recruitment. [...] Continental abolitionism, in other words, preferred to work quietly from within" (Ibidem, p.36).

${ }^{387}$ Cf. DAGET, Serge. A Model of the French Abolitionist Movement. In: BOLT, DRESCHER (orgs.). Antislavery, Religion and Reforms. Folkestone: Dawson; Hamden: Archon, 1980, p.66.

388 Cf. CLARKSON, Thomas. Essai sur les désavantages politiques de la traite des nègres. Paris: A. Égron, 1814, pp.89-105.
} 
No geral, o programa da Sociedade dos Amigos dos Negros mesclava duas preocupações principais: de um lado, uma preocupação moral com a ofensa aos direitos naturais e os princípios de humanidade, isto é, uma indignação quanto ao caráter bárbaro da escravidão, que contrastava com os ideais de cidadania que começavam a ser concretizados na metrópole; de outro, uma preocupação concreta com o funcionamento do sistema colonial, apontando para a necessidade de mudanças que eliminassem os aspectos considerados nocivos e perigosos para a sua estabilidade e produtividade. Havia ainda uma terceira preocupação, que dizia respeito à possibilidade de fazer das colônias um fator de dinamismo para a economia nacional, por meio da transformação dos cultivadores dos territórios ultramarinos em consumidores de produtos franceses. Em suma, o que estava em discussão era uma certa concepção da empresa colonial, capaz de conciliar os princípios, a preservação da ordem e o desenvolvimento econômico. Uma linha de argumentação desvinculada desse entendimento permaneceu excepcional, como veremos adiante.

\section{I.1.2.5) Variações de um mesmo programa}

A partir da insurreição escrava em São Domingos, no verão de 1791, um antiescravismo mais pronunciado se desenvolveria na França, mas no final da década de 1780, não havia propriamente uma alternativa ao modelo dos Amigos dos Negros. O programa da Sociedade aparecia como um parâmetro para qualquer manifestação contrária ao escravismo. O gradualismo parecia ser um elemento constante dos diferentes tratados antiescravistas da época. É possível verificar essa tendência na leitura de vários escritos publicados na esteira da fundação da Sociedade. Vejamos cinco exemplos diferentes dessa tendência.

Em La cause des esclaves nègres et des habitants de la Guinée (1789), Benjamin-Sigismond Frossard ${ }^{389}$ pregava "a abolição total do tráfico dos Negros e a sua

\footnotetext{
${ }^{389}$ Pastor e ativista político, Benjamin Frossard pertencia ao círculo de amizades de Brissot e Clavière. Uma viagem à Inglaterra em 1784-85 permitiu que estabelecesse contato com os antiescravistas locais. Isso marcou o início de seu engajamento na causa dos negros. O seu memorial La cause des esclaves nègres seria apresentado ao comitê de agricultura e comércio em 9 de novembro de 1789. Embora ele provavelmente não tenha integrado os Amigos dos Negros na sua primeira fase, ele seria um dos membros mais importantes da refundação da Sociedade (cf. GAINOT, Bernard. Robert BLANC, Un pasteur du temps des Lumières, Benhamin Sigismond Frossard, 1754-1830, Paris, Honoré Cahmpion. Annales historiques de la Révolution française, Paris, n. 327, jan-mar de 2002, colocado em linha em 19 de março de 2008. Disponível em: http://ahrf.revues.org/1219. Acesso em: 19 de amio de 2011).
} 
emancipação gradual". ${ }^{390}$ Para ele, o tráfico devia ser suprimido imediatamente, mas a escravidão só podia ser destruída com precauções capazes de prevenir o impacto que tal mudança pudesse causar no interesse dos proprietários e na segurança pública: "A libertação geral dos Negros é um projeto sublime na teoria. Mas a sua execução só é possível gradualmente, de modo a não prejudicar nem as Colônias, nem os Colonos". ${ }^{391}$ Além disso, para o autor, os efeitos da servidão sobre o homem não podiam ser rapidamente apagados. $\mathrm{Na}$ medida em que os negros ainda estavam na "infância da civilização", uma liberdade súbita os levaria a abusar de seu novo estado. Tornar-se-iam um encargo para a sociedade, tendo em vista "[...] a preguiça pela qual têm um gosto natural". Assim, antes de libertá-los, era necessário torná-los dignos de serem cidadãos, ensinando-lhes as obrigações morais e religiosas correspondentes, e fazer com que a sua liberdade fosse o fruto de sua indústria, sendo concedida apenas aos que se mostrassem dispostos a trabalhar em benefício de sua nova pátria. ${ }^{392} \mathrm{O}$ tempo necessário a essa educação seria também o tempo indispensável para que os senhores recuperassem o preço de compra de seus escravos. Frossard estimava em oito a dez anos o prazo suficiente para o reembolso do capital invertido e dos juros. Assim, somente a partir do fim desse prazo poder-se-ia iniciar o processo de emancipação dos negros. ${ }^{393}$

Esta deveria dar-se de forma sucessiva, premiando os negros pela sua indústria. $\mathrm{O}$ negro que trabalhasse dobrado poderia obter a sua alforria antecipadamente. $\mathrm{O}$ estabelecimento de tarefas mínimas permitiria que aqueles que as cumprissem pudessem usar o tempo restante para executar outra tarefa ou indústria que lhes valesse uma remuneração, a ser usada na compra da própria liberdade. ${ }^{394}$ Quanto aos filhos de escravos, Frossard entendia que eles deviam ser alimentados e criados pelo senhor, a

\footnotetext{
${ }^{390}$ FROSSARD, Benjamin Sigismond. La cause des esclaves nègres et des habitans de la Guinée, portée au tribunal de la justice, de la religion, de la politique. Genebra: Slatkine Reprints, 1978, p.17.

391 "L'affranchissement général des Nègres est un projet sublime dans la théorie. Mais son exécution n'est possible que graduellement, afin de ne nuire ni aux Colonies ni aux Colons" (Ibidem, p.21). Frossard acreditava que uma libertação geral e imediata dos escravos exigiria a indenização de seus donos, que os tinham adquirido sob a proteção da lei. Estimava que o valor total das indenizações atingiria 612 milhões, valor absolutamente inviável para o governo.

${ }^{392}$ Ibidem, pp.22-23.

${ }^{393}$ Ibidem, pp.157-158.

${ }^{394}$ Frossard concebia um sistema em que os escravos teriam um dia da semana para si próprios, com a faculdade de comprar os demais. Assim, poderiam comprar sucessivamente os dias da semana, até obter a liberdade total (Ibidem, pp.271-272).
} 
quem serviriam até os 30 anos, para indenizá-lo desses gastos. ${ }^{395}$ A libertação imediata só era admitida como penalidade, em casos de abusos de autoridade por parte do senhor.

No geral, o sistema de Frossard era um emaranhado de propostas que, embora apresentadas como uma forma de suprimir progressivamente a escravidão, não permitiam estabelecer um prazo para a seu desaparecimento total. Aliás, Frossard apresentava diversas propostas no sentido de favorecer a reprodução da população escrava, reduzindo o seu sistema a uma alteração da forma de reposição do plantel. A abolição do tráfico teria justamente por efeito imediato forçar os senhores a conceder um melhor tratamento aos seus escravos e a favorecer a sua população. ${ }^{396}$ No final das contas, o antiescravismo de seu projeto ficava praticamente soterrado.

O abade Sibire, que tinha atuado como missionário no reino de Loango (Guiné meridional) em 1764, apresentou, em L'Aristocratie négrière, ou Réflexions philosophiques et historiques sur l'esclavage et l'affranchissement des Noirs (1789), ideias semelhantes. ${ }^{397} \mathrm{O}$ texto retomava a linha geral adotada pela Sociedade dos Amigos dos Negros, à qual Sibire aderiu em junho de 1789. O abade imprimia um tom revolucionário à obra ao comparar os colonos às classes privilegiadas da metrópole. Se estas haviam sido obrigadas a abrir mão dos dízimos, censos e privilégios, cabia agora aos colonos abrirem mão da escravidão e do tráfico. A ideia de que os senhores de escravos constituíam a "aristocracia das colônias" passaria, sob a Revolução, a ser central no discurso antiescravista francês. ${ }^{398}$

Afirmando o direito de resistência à opressão, Sibire fazia da insurreição escrava uma consequência natural dos crimes e sofrimentos dos negros: "olho por olho, dente por dente, essa será a sua primeira moral [...]". ${ }^{399}$ Sibire estabelecia um paralelo entre a revolta iminente dos escravos nas colônias e a Revolução do povo da metrópole. Mas, a

\footnotetext{
${ }^{395} \mathrm{O}$ autor especificava que, se a educação dos filhos não tivesse gerado gasto algum para o proprietário, por conta da atividade dos pais durante o seu tempo livre, eles seriam alforriados junto com os pais (Ibidem, p.277).

${ }^{396}$ Frossard pregava a necessidade de medidas que estimulassem o casamento legítimo dos escravos e, portanto, a sua reprodução. Sugeria, por exemplo, a alforria de todos os escravos que gerassem cinco filhos de um casamento legítimo (Ibidem, p.275).

${ }^{397} \mathrm{O}$ texto seria apresentado à Assembleia Nacional, em 1789.

${ }^{398}$ Esse tema apareceria, por exemplo, num panfleto de dezembro de 1789: "[...] existe uma aristocracia mil vezes mais odiosa que a dos Nobres, a dos ricos Colonos brancos [...]" (IL est encore des Aristocrates, ou Réponse à l'infâme auteur d'un écrit intitulé: Découverte d'une conspiration contre les intérêts de la France. S.1. [Paris]: s.n., s.d. [1789], p.6).

${ }^{399}$ SIBIRE, Abbé Sébastien-André. L'Aristocratie négrière, ou Réfléxions philosophiques et historiques sur l'esclavage et l'affranchissement des Noirs, dédiées à l'Assemblée Nationale; par M. l'abbé Sibire, ancien ami des Africains, et leur premier missionnaire dans le Royaume de Loango. Paris: Lesclapart et Desray, 1789, p.87.
} 
exemplo de Raynal, a sua predição não servia para a defesa de uma abolição imediata da escravidão:

deve-se abalar o estado atual das coisas para nada colocar em seu lugar, dar o sinal de uma revolta que trata-se de prevenir, arruinar possuidores legítimos, colocar sob ameaça e em perigo todos os proprietários, sublevar os Negros contra os Brancos, devolvendo-lhes uma liberdade mais mortífera para si mesmos e que seria uma arma terrível em mãos furiosas? $?^{400}$

Sibire afirmava a necessidade de estabelecer uma espécie de compromisso entre os direitos da natureza e os interesses da Nação e da ordem. Para o abade, os escravos não saberiam o que fazer com a liberdade e tinham de ser preparados para recebê-la, ou "sua luz vívida cegá-los-ia". ${ }^{401}$ Tampouco queria que a libertação dos negros viesse a provocar a ruína das colônias. Ela tinha de servir o interesse geral.

A exemplo de Frossard, Sibire também pregava a abolição imediata do tráfico como forma de impor um melhor tratamento dos escravos. Essa probição teria de vir por meio de um acordo comum entre as diferentes nações participantes, uma espécie de "confederação geral das diversas cortes da Europa". ${ }^{402}$ Quanto à escravidão, entretanto, havia um único meio de proceder: criar as condições para que os negros pudessem comprar a própria liberdade, por meio de uma legislação que protegesse o pecúlio e fixasse um procedimento de alforria que levasse em conta a idade, os serviços prestados e o valor do escravo. ${ }^{403}$ Sibire propunha que fosse reservado um dia por semana para que o escravo trabalhasse para si, assim como a fixação de tarefas cotidianas ou semanais, permitindo que o tempo restante fosse utilizado em proveito do próprio escravo. Durante esse período de transição, o escravo reuniria os fundos necessários à sua alforria e receberia do senhor a educação moral e religiosa necessária à vida civil.

Por fim, Sibire abordava um tema caro aos Amigos dos Negros: o projeto de uma nova colonização do continente africano, com vistas a estabelecer um comércio não de homens, mas de produções naturais. Esse comércio traria a grande vantagem de permitir a propagação da religião cristã no interior da África. ${ }^{404}$

\footnotetext{
400 "faut-il bouleverser l'état actuel des choses pour ne rien substituer à leur place, donner le signal d'une révolte qu'il s'agit de prévenir, ruiner des possesseurs légitimes, mettre en crainte et en péril tous les propriétaires, soulever les Noirs contre les Blancs, en leur rendant une liberté plus meurtrière pour euxmêmes que l'esclavage et qui seroit une arme redoutable dans des mains furieuses" (Ibidem, pp.96-97).

${ }^{401}$ Ibidem, p. 102.

${ }^{402}$ Ibidem, p. 118.

403 Ibidem, p. 105.

${ }^{404}$ Ibidem, pp.116-118.
} 
Daniel Lescallier, que tinha servido como ordenador na Guiana até 1788, onde havia participado dos experimentos de La Fayette com trabalhadores negros livres, e que se juntaria aos Amigos dos Negros em junho de 1789, também procurou, com Réflexions sur le sort des Noirs dans nos colonies $(1789)^{405}$, conciliar a moral e a política. Referindo-se a revoltas ocorridas na Jamaica e na Guiana holandesa, pregou a necessidade de melhorar a situação dos negros nas colônias. Se acreditava na possibilidade de uma colonização sem escravidão, entendia que "[...] os projetos de humanidade manifestados em favor dos Negros só podem ser executados em boa política com tempo e gradações" (grifo nosso). ${ }^{406}$ Lescallier apresentava um conjunto de medidas a serem adotadas:

1) A abolição imediata do tráfico de escravos, para obrigar os colonos a cuidarem melhor de seu plantel e favorecer o aumento da população escrava.

2) Emancipação dos escravos domésticos e das cidades, tendo em vista que a necessidade da escravidão só se justificava para o cultivo e a fabricação do açúcar.

3) Emancipação de todos os escravos mulatos e mestiços, isto é, a ab-rogação da lei partus sequitur ventrem, para prevenir a libertinagem nas colônias.

4) Uma legislação "razoável e não arbitrária" que garantiria a ordem e a disciplina nas plantations, com especificações quanto a alimentação, moradia, vestimenta, instrução, horas de trabalho, propriedade de hortas e animais, além de assistência na velhice, enfermidade, gravidez e infância.

5) Atribuição ao escravo de uma gratificação de um décimo dos produtos, um "sacrifício aparente" para o plantador, que seria compensado pela maior produtividade dos escravos, agora motivados para trabalhar. Haveria ainda um aumento sucessivo da parte dos negros na receita, podendo chegar a um terço, sem que o proprietário sofresse uma diminuição nos seus ganhos.

6) Adoção, no décimo ano desse programa de medidas, de um "Novo Código Colonial", que substituiria o Code Noir, para regular os direitos dos proprietários e dos "vassalos" (o autor era contra o emprego da palavra "escravos").

\footnotetext{
${ }^{405} \mathrm{O}$ texto seria enviado aos deputados da Assembleia Nacional.

406 "[...] les projets d'humanité que l'on manifeste en faveur des Noirs ne peuvent s'exécuter en bonne politique qu'avec du temps et des gradations" (LESCALLIER, Daniel. Réflexions sur le sort des Noirs dans nos colonies. Paris: s.n., 1789, p.14).
} 
7) Emancipação sucessiva e integral de famílias de Negros, que comprariam a liberdade com os fundos reunidos durante os anos dessa servidão reformada e se estabeleceriam em pequenas terras cedidas pelo proprietário ou pelo Governo ou então exerceriam algum ofício nas cidades. ${ }^{407}$

Ainda mais conservador, o quacre Lecointe-Marsillac também procurou esboçar uma forma prudente de pôr fim à escravidão colonial, com Le More-Lack, ou Essai sur les moyens les plus doux et les plus équitables d'abolir la traite et l'esclavage des Nègres d'Afrique, en conservant aux Colonies tous les avantages d'une population agricole (1789). A obra reproduzia bem o descompasso entre a contundência das denúncias e a moderação das propostas. A primeira parte da obra trazia o relato de um ex-escravo, o More-Lack do título, a respeito dos horrores e a barbárie do tráfico e da escravidão. A sanguinolência do relato era chocante e tinha por objetivo inculcar um sentimento de culpa no cidadão europeu, cúmplice das guerras que dizimavam o continente africano e da barbárie que provocava a morte de centenas de milhares de negros nas ilhas. ${ }^{408} \mathrm{O}$ texto apresentava o tratamento desumano dado aos negros como uma decorrência da própria racionalidade do sistema escravista: o interesse do colono não era o de cuidar bem de seus escravos, mas reduzir os gastos de manutenção ao mínimo e extrair deles a maior quantidade possível de trabalho, de modo a reunir os meios suficientes para substituir os escravos esgotados por outros, jovens e vigorosos. Essa observação poderia sugerir uma superação da perspectiva reformista. ${ }^{409}$

Mas, quando se tratava de refletir a respeito da modalidade de abolição a ser adotada, o autor falava em buscar os "meios felizes" de promover essa abolição, "[...] sem provocar trovoadas, sem atentar contra a propriedade dos colonos, sem privá-los dos braços acostumados a cultivar as suas terras". Isso significava rejeitar a

\footnotetext{
${ }^{407}$ Ibidem, pp.21-60.

${ }^{408} \mathrm{O}$ texto narrava a execução de um escravo durante a travessia, para servir de exemplo aos demais e incitar o terror entre os cativos: "ele foi degolado diante de todos os seus irmãos; [o capitão Harding] mandou então arrancar o coração, o fígado e as entranhas, que foram espalhadas pelo chão. Cortou-se-lhe o coração e o fígado ainda palpitante em trezentos pedaços e [o capitão] mandou, por meio das ameaças mais aterrorizantes, que cada um dos outros escravos comesse um pedaço desse coração retalhado e ensanguentado de seu camarada, jurando-lhes, por meio dos sermões mais horríveis, submeter ao mesmo suplício todos aqueles que se recusassem a comer" ("il fut égorgé devant tous ses frères; il lui fit ensuite arracher le coeur, le foie et les entrailles qui furent répandus par terre. On coupa son coeur et son foie encore palpitant, en trois cents morceaux et il obligea, par les menaces les plus effroyables, chacun des autres esclaves de manger un morceau de ce coeur déchiré et ensanglanté de leur camarade, leur jurant, par les serments les plus affreux, qu'il ferait subir le même supplice à tous ceux qui refuseraient d'en manger"; LECOINTE-MARSILLAC. Le More-Lack, ou Essai sur les moyens les plus doux \& les plus équitables d'abolir la traite \& l'esclavage des Nègres d'Afrique, en conservant aux Colonies tous les avantages d'une population agricole. Londres et Paris: Prault, 1789, p.48).

${ }^{409}$ Ibidem, p.78.
} 
emancipação geral dos escravos, "[...] um ato de autoridade arbitrário que arruinaria as colônias, e provocaria uma revolução perigosa em corações ulcerados de dores e desespero". ${ }^{410}$ Embora apresentasse a liberdade como um direito inalienável, o autor reconhecia o direito de propriedade do senhor sobre o seu escravo e afirmava que esse direito não poderia ser suprimido, a não ser contra uma justa indenização. ${ }^{411}$

Até mesmo a abolição do tráfico, sem um acordo entre todos os governos da Europa, seria ruinosa, pois favoreceria as nações que continuassem, pública ou clandestinamente, esse comércio, podendo vender a um preço mais baixo as produções coloniais. O único meio verdadeiramente eficaz de promover o fim desse comércio era eliminar os fatores que tornavam o tráfico necessário aos olhos dos colonos. A exemplo dos demais autores citados, Lecointe-Marsillac propunha suavizar a condição dos escravos de modo a favorecer a sua reprodução: "[...] tão logo apegados à vida, eles entregar-se-ão ao mais doce sentimento da natureza humana e não mais temerão reproduzir-se". ${ }^{412} \mathrm{O}$ favorecimento dos casamentos entre Negros e a alforria de filhos de escravas casadas aos 25 anos seriam meios de incentivar a multiplicação da população. Lecointe-Marsillac chegava a propor incentivos ao tráfico de negras, para aumentar a população feminina nos plantéis. ${ }^{413}$

Em seu sistema de abolição por etapas, o autor propunha fazer do escravo casado uma espécie de meeiro: ele receberia do senhor uma pequena parcela de terra, em plena propriedade, para cultivo próprio, em troca de metade da colheita. ${ }^{414}$ Além disso, um em cada vinte negros poderia ser alforriado anualmente, em todas as plantations. Esses meios permitiriam, segundo o autor, uma passagem progressiva e suave para uma agricultura com mão de obra livre, com o possível desenvolvimento de uma classe de pequenos proprietários negros.

\footnotetext{
410 "[...] sans exciter des orages, sans porter atteinte à la propriété des colons, sans les priver des bras accoutumés à cultiver leurs terres"; "[...] un acte d'autorité arbitraire qui ruinerait les colonies, et exciterait une révolution dangereuse dans des coeurs ulcérés de peines et de désespoir" (Ibidem, p.xii).

${ }^{411}$ Ibidem, p.212.

412 "[...] bientôt attachés à la vie, ils se livreront au plus doux sentiment de la nature humaine, et ne craindront plus de se reproduire" (Ibidem, p.197).

${ }^{413}$ A mesma proposta apareceu num texto anônimo de 1789, em que o autor pregava a fixação pelo Estado da quantidade de mulheres negras a serem transportadas em cada navio: dois terços ou até mais. Propunha também a concessão de subvenções à importação de mulheres (Cf. Réflexions sur l'abolition de la Traite \& la liberte des Noirs. Orléans: L.P. Couret, s.d., pp.6-7).

${ }^{414}$ Cf. LECOINTE-MARSILLAC. Le More-Lack, p.224.
} 
Finalmente, em Voeux d'un solitaire (outubro de 1789), o escritor Bernardin de Saint-Pierre ${ }^{415}$, que era nascido no Havre e tinha atuado como capitão-engenheiro na Île-de-France em 1768-71, procurou situar o problema da escravidão negra no quadro das várias formas assumidas pela servidão humana, uma praga que, disseminada nas colônias, podia atingir a metrópole. O regime tirânico que fazia dos negros "escravos por natureza" dos senhores brancos nas colônias inspirava, na opinião do autor, os senhores da metrópole a verem o povo branco que os alimentava como "destinado à servidão". ${ }^{416}$ Bernardin de Saint-Pierre acreditava que, caso a escravidão colonial não fosse suprimida, ela poderia um dia estender-se sobre o território da metrópole.

Ao mesmo tempo, o escritor alertava para a possibilidade de arruinar os homens que se queria reformar, entendendo necessário proceder à abolição "pouco a pouco". Assim, a primeira medida a ser tomada era suprimir a fonte da escravidão nas ilhas, $o$ tráfico. Em seguida, era preciso reduzir a servidão pessoal dos negros a uma servidão da gleba, transformando-os em servos. Somente após esse estágio intermediário o negro poderia, em caso de boa conduta, obter a emancipação completa. $\mathrm{O}$ autor acreditava que a erradicação da escravidão poderia transformar as colônias numa solução para a pobreza na metrópole. As grandes plantações poderiam ser divididas em pequenas propriedades livres e distribuídas a camponeses e operários franceses que se transformariam, assim, em fazendeiros industriosos. ${ }^{417}$

Outros textos menos célebres apareceriam na mesma época, com ideias semelhantes. ${ }^{418} \mathrm{O}$ fato é que esses escritos apresentavam traços comuns. Todos eles falavam em abolir a escravidão apenas gradualmente e, com exceção de LecointeMarsillac, todos os autores estabeleciam a supressão imediata do tráfico como etapa inicial do processo, de modo a favorecer a reprodução endógena da escravaria. $\mathrm{O}$ processo emancipatório se resumia, na quase totalidade dos textos da época, em dar ao

\footnotetext{
${ }^{415}$ Bernardin de Saint-Pierre tinha sido o autor do Voyage à l'Ile-de-France, publicado anonimamente em 1773, onde já fazia uma abordagem crítica da escravidão. Na esteira da fundação dos Amigos dos Negros, Bernardin foi convidado por Brissot a integrar a Sociedade, mas recusou respeitosamente, alegando motivos de saúde, além de seu inabalável "gosto pela solidão". Apesar disso, o autor desejou todo o sucesso à Sociedade, cujos trabalhos acompanharia de longe, e fez menção a ela em Voeux d'un solitaire (cf. BRISSOT DE WARVILLE, Jean-Pierre. Correspondance et papiers, pp.171-173).

${ }^{416}$ Cf. BERNARDIN DE SAINT-PIERRE, Jacques Henri. Voeux d'un solitaire. In: Oeuvres complètes. Paris: Méquignon-Marvis, 1818, v.11, p.138.

${ }^{417}$ Ibidem, p.141-144.

${ }^{418}$ Um texto anônimo, publicado sob o nome L'Esclavage des Nègres aboli, ou Moyens d'améliorer leur sort (1789), propunha assimilar a escravidão dos negros ao serviço dos soldados, transformando-a num engajamento temporário de dez anos, ao término do qual a liberdade seria devolvida ao escravo (cf. L'Esclavage des Nègres aboli, ou Moyens d'améliorer leur sort. Paris: Froullé, 1789, pp.5-6).
} 
escravo as condições de comprar a própria alforria. Isto é, eles propunham uma ampliação da economia própria do escravo, algo que já existia nas colônias francesas.

Todos esses textos prestavam reverência expressa à Sociedade dos Amigos dos Negros. ${ }^{419}$ Nada mais natural, pois todos se inseriam no mesmo modelo argumentativo. O seu principal foco estava na constituição de um regime transitório, mesclando características do trabalho remunerado à disciplina da condição servil. ${ }^{420}$ Olhando mais no futuro, esses planos sugeriam a possibilidade da formação de um proletariado agrícola nas grandes plantações, e talvez até uma classe de pequenos proprietários negros. Mas, para esses autores, a preservação dos interesses dos proprietários, isto é, a preservação da economia colonial aparecia como elemento primordial. Com algumas exceções $^{421}$, no antiescravismo daquele final de século, o respeito pela propriedade, mesmo sendo ilegítimo o seu objeto, era total. Na medida em que a emancipação efetiva dos escravos não era definida em termos muito concretos, o antiescravismo gradualista flertava perigosamente com a crítica preservacionista da escravidão colonial.

\section{I.1.2.6) Um início pouco promissor}

Apesar da moderação de seu programa e do caráter elitista de sua composição, o surgimento da Sociedade dos Amigos dos Negros gerou inquietação entre os colonos. Havia a percepção, na época, de que o mundo colonial era uma bomba-relógio prestes a explodir. Qualquer fagulha era vista como uma séria ameaça capaz de detonar uma onda de revoltas escravas. O surgimento de uma sociedade antiescravista na metrópole era em si mesmo algo subversivo, de modo que o conteúdo exato de seu programa passava automaticamente para o segundo plano. $\mathrm{O}$ caráter fechado da entidade, cujos registros e arquivos eram de acesso restrito, fazia com que seus inimigos a vissem como uma

\footnotetext{
${ }^{419}$ Bernardin de Saint-Pierre, por exemplo, falava de uma "sociedade respeitável", "uma sociedade amiga e patrona dos pobres negros escravos" (cf. BERNARDIN DE SAINT-PIERRE, Jacques Henri. Voeux d'un solitaire, p.141). Já Frossard louvou o surgimento da uma sociedade antiescravista em Paris, filiada à de Londres, ressaltando o papel desempenhado por Brissot (cf. FROSSARD, Benjamin Sigismond. La cause des esclaves nègres, p.70).

${ }^{420}$ Ideias semelhantes seriam postas em práticas nas colônias, após a abolição, como veremos adiante.

${ }^{421}$ Podemos encontrar uma linha de argumentação mais radical em Observations sur l'esclavage et le commerce des Nègres de Théophile Mandar, publicista conhecido como um dos primeiros a ter entrado na Bastilha em 14 de julho de 1789. No seu ataque à escravidão, o autor não previa qualquer tipo de plano gradual de emancipação, mas tampouco previa as modalidades de uma abolição geral da escravidão. No geral, textos desse tipo permaneceram minoritários (cf. MANDAR, Théophile. Observations sur l'esclavage et le commerce des Nègres. S.1. [Paris]: Imp. Grand., s.d., p.18).
} 
sociedade secreta. Era preciso, a qualquer custo, neutralizar a sua ação e isso implicava distorcer os seus argumentos.

Assim que soube da fundação da Sociedade, o campo colonial se mobilizou. Malouet escreveu ao ministro da Marinha Castries, para atacar os projetos dos Amigos dos Negros e propor, no lugar, um regulamento destinado a melhorar a condição dos escravos nas colônias. ${ }^{422}$ Gouy d'Arcy, que tinha sido tenente-general do governo da Îlede-France e estava ligado por casamento à classe dos proprietários de São Domingos, pediu ao rei que proibisse as sessões da Sociedade, ao que Luís XVI teria respondido: "Esses pobres negros possuem então amigos na França? Ainda bem; não desejo interromper os seus trabalhos". ${ }^{423}$

Essa suposta aprovação real pode ter dado algum ânimo aos Amigos dos Negros. O seu número de membros aumentou consideravelmente entre março e maio de 1788. Mas, naqueles primeiros meses de atividade, as perspectivas de sucesso real para a Sociedade eram magras. Inserida num contexto de despotismo, a Sociedade limitava-se a discutir internamente as questões relativas à escravidão colonial e organizar a publicação de textos estrangeiros sobre o tema. Nem mesmo havia sido possível obter autorização ministerial para a publicação dos Regulamentos.

Em 4 de março de 1788, Brissot revelou que teria, dentro de dois meses, de renunciar às suas funções na Sociedade, em razão de uma importante viagem aos Estados Unidos. Explicou que essa viagem tinha dois objetivos primordiais. Em primeiro lugar, falava em buscar informações sobre a emancipação dos negros no país, sobre o estado das ilhas do açúcar, sobre as relações da França com os Estados Unidos e as mudanças que essas relações deveriam sofrer. ${ }^{424} \mathrm{Na}$ verdade, Brissot partia a mando do banqueiro Clavière e dois outros associados, Stadinski e Cazenove, com o objetivo de levantar informações sobre a dívida americana e as possibilidades de especulação financeira sobre a mesma. ${ }^{425}$ Mas, para o líder dos Amigos dos Negros, aquela era também a oportunidade de investigar a condição dos negros na América e de estabelecer

\footnotetext{
${ }^{422}$ Cf. Lettre au Maréchal de Castries, Ministre de la Marine. Toulon, 21 juillet 1788. In: MALOUET. Mémoires. 2a edição. Paris: E. Plon et cie., 1874, v.1, pp.370-371.

423 "Ces pauvres noirs ont-ils donc des amis en France? Tant mieux; je en veux pas interrompre leurs travaux" (Citado em GAUTHIER, Florence. L'aristocratie de l'épiderme. Le combat de la société des citoyens de couleur 1789-1791. Paris: CNRS éditions, 2007, p.22).

${ }^{424}$ Cf. REGISTRE de la Société des Amis des Noirs, pp.83-84.

${ }^{425}$ Cf. ELLERY, Eloise. Brissot de Warville, p.66. De acordo com o contrato firmado com Clavière, Cazenove e Stadinsky, o valor oferecido a Brissot foi de 10 mil libras. O contrato estipulava que Brissot ficaria encarregado de reunir informações sobre a dívida do Congresso estadunidense (cf. BRISSOT DE WARVILLE, Jean-Pierre. Correspondance et papiers, pp.179-180).
} 
contato com os antiescravistas e quacres norte-americanos. Além disso, a viagem de Brissot tinha outra finalidade não declarada: uma possível emigração para uma terra "livre". Com a partida de Brissot, em maio de 1788, Condorcet assumiria um papel de liderança no seio da Sociedade, chegando à presidência em janeiro do ano seguinte.

Antes disso, entretanto, um evento alteraria completamente o quadro político no qual a Sociedade estava inserida. Em 8 de agosto de 1788, para remediar o estado calamitoso das finanças francesas, os Estados Gerais tinham sido convocados para $1^{\circ}$ de maio do ano seguinte. Após 175 anos, as três ordens do reino voltavam a ser convocadas para apresentarem as suas queixas, por meio de seus representantes reunidos em assembleia. Todas as camadas da sociedade francesa vislumbraram naquele evento a possibilidade de manifestar os seus anseios e insatisfações. Para qualquer movimento político, era a oportunidade de levar a sua causa para o espaço público.

A Sociedade dos Amigos dos Negros viu-se estimulada a redefinir a sua estratégia. Na assembleia geral de 7 de outubro, Clavière sustentou que a convocação dos Estados Gerais oferecia à Sociedade a chance de tornar pública a sua existência. Um memorial tinha de ser preparado para ser levado aos Estados Gerais. ${ }^{426}$ Uma possível regeneração do sistema político francês abria novas possibilidades para os Amigos dos Negros. Ao receber a notícia da convocação dos Estados Gerais, Brissot, que, àquela altura já pensava em se instalar definitivamente nos Estados Unidos ${ }^{427}$, decidiu antecipar o seu retorno para janeiro de $1789 .{ }^{428}$

\footnotetext{
${ }^{426}$ Cf. REGISTRE de la Société des Amis des Noirs, p.183.

427 Segundo Ellery, ele já tinha decido instalar-se na Pensilvânia (cf. ELLERY, Eloise. Brissot de Warville, p.84).

${ }^{428}$ Cf. REGISTRE de la Société des Amis des Noirs, p.188. Antes de retornar a Paris, Brissot teria passado pela Holanda, onde teria buscado apoio para a eventual organização de uma sociedade antiescravista no país (cf. BARLIER, Jean-Pierre. La Société des Amis des Noirs, pp.98-99).
} 


\section{I.2) Os Amigos dos Negros e a Revolucão}

\section{I.2.1) Os Estados Gerais: uma nova perspectiva}

\section{I.2.1.1) As considerações de Brissot sobre os Estados Unidos}

Em 9 de fevereiro de 1789, Brissot, de volta a Paris, apresentou, aos Amigos dos Negros, um balanço de sua viagem aos Estados Unidos, com as informações recolhidas a respeito da situação dos negros naquele país. Brissot traçou um quadro essencialmente otimista, apontando a existência de uma forte tendência contra o comércio de escravos, abolido em nove dos treze estados. A luta pela independência na América tinha, na sua opinião, evidenciado o caráter inconsequente da escravidão, incompatível com a liberdade e com as bases do Republicanismo.

Brissot esclareceu, entretanto, que nem todos os estados tinham feito os mesmos avanços. Se os estados do Norte e do Centro tinham proscrito definitivamente a importação de escravos, outros tinham tomado, quando muito, medidas parciais. Alguns, como a Geórgia, continuavam a receber cativos. ${ }^{429}$ Brissot admitiu também que essa legislação não tinha sido motivada apenas pelo respeito aos direitos da humanidade e que "[...] o interesse teve uma grande influência sobre essa revolução". ${ }^{430}$ Os Estados do Norte, por exemplo, não baseavam a sua economia na escravidão e não encontravam, portanto, fortes resistências à supressão do tráfico:

sem dúvida, pode-se suspeitar que os Estados do norte e do centro tenham adotado [a proibição do tráfico] com tanto ardor e prontidão pelo fato de que têm menos necessidade de braços escravos para o tipo de produções que cultivam, que suas necessidades são mais circunscritas, e que a sua população, sempre crescente, os dispensa de recorrer a recrutas estrangeiros para tirar de seu solo um produto proporcional às suas necessidades. ${ }^{431}$

\footnotetext{
${ }^{429}$ Cf. BRISSOT DE WARWILLE, Jacques-Pierre. Mémoire sur les Noirs de l'Amérique Septentrionale, lu à l'Assemblée de la Société des Amis des Noirs, le 9 février 1789. Paris: au Bureau du Patriote François, 20 décembre 1789, pp.6-7.

${ }^{430}$ Ibidem, p.7.

431 "sans doute les États du nord et du midi peuvent être soupçonnés de l'avoir adoptée avec d'autant plus d'ardeur et de promptitude qu'ils ont moins besoin de bras esclaves pour le genre de productions qu'ils cultivent, que leurs besoins sont plus circonscrits, et que leur population toujours croissante les dispense d'avoir recours à des recrues étrangères pour tirer de leur sol un produit proportionnel à leurs besoins" (Ibidem, pp.7-8).
} 
Da mesma forma, as razões da suspensão do comércio de escravos pela Carolina teriam sido mais financeiras do que humanitárias, tendo em vista as enormes dívidas que os seus cidadãos tinham contraído junto aos traficantes ingleses.

Apesar disso, Brissot ressaltava o caráter pioneiro dos americanos na defesa dos direitos do homem. Se a força do interesse por trás das leis humanitárias era inegável, ela não apagava as motivações morais e religiosas daqueles que as defendiam. A luta iniciada pelos quacres no continente americano finalmente alcançava resultados concretos. Se a sua opinião ainda não tinha se tornado universal, era porque a força do interesse ainda criava obstáculos, sobretudo no Sul, onde muitos sustentavam a impossibilidade de cultivar o solo sem escravos. Na Virgínia, por exemplo, a escravidão estava de tal forma sedimentada nos usos e costumes dos habitantes, que estes não aceitavam a ideia de uma organização social que não girasse em torno da posse do escravo. A esse partido devia-se o artigo constitucional que proibia, por vinte anos, o Congresso de proscrever a importação de escravos.

Ainda assim, Brissot acreditava que a abolição do tráfico em todos os Estados Unidos estava "muito próxima". Acreditava ainda que a existência de estados livres aumentava as chances de fuga para os escravos, pois aqueles que adentrassem o seu território ganhariam automaticamente a liberdade. Assim, o sistema federativo gerava contradições que, em última instância, tornariam a escravidão inviável no país. ${ }^{432}$

Brissot também abordou a questão dos negros livres na América. Nos estados do Norte e do Centro, eles atuavam como domésticos, lojistas ou cultivadores. A recusa dos brancos em conceder empréstimos impedia que esses negros ampliassem o seu comércio ou as suas plantações, de modo que o preconceito ainda era uma forte barreira social. ${ }^{433}$ Brissot contou ter visitado, na Filadélfia, uma escola para Negros, fundada por Benezet, com o objetivo de preparar os negros para a vida civil e "[...] elevá-los pela instrução ao patamar dos homens". ${ }^{434}$ A diferença do trabalho produzido por negros livres e instruídos para com o dos demais negros era abissal. Esses negros mostravam-se aptos a quaisquer profissões e atividades.

Os progressos feitos na América deviam-se, para Brissot, ao zelo constante das sociedades antiescravistas da Filadélfia e de Nova York, que haviam recebido com entusiasmo a notícia da formação dos Amigos dos Negros. Ao contrário das sociedades

\footnotetext{
432 Ibidem, pp.8-12.

${ }^{433}$ Ibidem, pp. 27-29.

${ }^{434}$ Ibidem, p.26.
} 
de Paris e de Londres, as duas entidades americanas contavam com a vantagem de ter contato direto com aqueles que buscavam proteger, o que lhes permitia, por exemplo, dar assistência material e jurídica aos negros que sofressem maus tratos ou reclamassem a liberdade. ${ }^{435}$

Brissot retornava, assim, de sua viagem à América setentrional com esperanças renovadas. O avanço da causa dos negros nos Estados Unidos pós-independência, aliado à perspectiva de um bill contra o tráfico no Parlamento britânico, davam ao líder dos Amis des Noirs a certeza de que a luta antiescravista internacional vivia um momento decisivo. A convocação dos Estados Gerais era vista como o sinal de que tinha chegado a vez da França dar a sua contribuição.

\section{I.2.1.2) A causa dos negros nos cadernos de queixas}

A convocação dos Estados Gerais tinha alterado completamente o quadro político dentro do qual operava a Sociedade. Havia agora uma maior liberdade para a publicação de libelos, o que tornava o contexto mais favorável à divulgação de ideias e projetos de natureza política. Brissot publicaria, a partir de 10 de abril de 1789 , o Patriote Français, jornal que se transformaria no principal veículo para os Amigos dos Negros. ${ }^{436}$ Antes disso, em 13 de janeiro de 1789, para difundir a causa, a Sociedade decidiu finalmente publicar os Regulamentos da Sociedade, assim como distribuí-los nas províncias. ${ }^{437}$ Nesse sentido, os Regulamentos foram alterados, para que o valor das subscrições dos membros das províncias passasse a ser indeterminado, isto é, sem um mínimo prescrito. Era uma clara tentativa de popularizar a Sociedade e difundi-la fora da área próxima a Paris, onde estava concentrada a maioria de seus membros. ${ }^{438}$

As atividades da Sociedade se intensificavam. Em 27 de janeiro, Condorcet apresentou uma moção para ressaltar o quanto era importante que a causa dos negros fosse abordada nos Estados Gerais. Recomendou que uma carta fosse enviada aos bailiados e assembleias municipais para dar-lhes conhecimento da Sociedade e seus

\footnotetext{
${ }^{435}$ Ibidem, p. 47.

${ }^{436} \mathrm{O}$ jornal chegaria a ter tiragens de 10 mil exemplares, o que significa que atingia um público bastante vasto, se levarmos em conta que publicações desse tipo eram lidas em voz alta em praças públicas e clubes populares. Essa liberdade de publicação não impediria que Brissot tivesse problemas com a censura. De fato, a publicação do Patriote Français chegou a ser suspensa em algumas ocasiões (cf. BRISSOT DE WARVILLE, Jacques-Pierre. Mémoires, v.2, pp.180-184).

${ }^{437}$ Cf. Registre de la Société des Amis des Noirs, pp.189-190. Foi decidido que seriam impressos dois mil exemplares dos Regulamentos.

${ }^{438}$ Ibidem, p. 190 .
} 
objetivos, assim como pregar-lhes a inclusão da questão do tráfico e da escravidão nos cadernos de queixas. ${ }^{439}$ Em 17 de fevereiro, a Sociedade decidiu distribuir exemplares da Réponse à l'écrit de M. Malouet sur l'esclavage des Nègres (1789). ${ }^{440}$

Assim que foram formadas as assembleias eleitorais para a escolha dos representantes das ordens nos Estados Gerais, os Amigos dos Negros traçaram planos mais concretos para influir na redação dos cadernos de queixas. ${ }^{441}$ Brissot, pelo terceiro estado, e Condorcet, pela nobreza, eram membros das assembleias eleitorais e atuariam na propagação da mensagem antiescravista. Concorcet distribuiria, por todo o país, um manifesto, Au corps électoral contre l'esclavage des Noirs (1789), em que buscava ressaltar a contradição existente entre os direitos reclamados pelo povo francês e a manutenção da escravidão nas colônias. ${ }^{442}$

Condorcet esclarecia não pedir a abolição imediata, afirmando que certas injustiças, vinculadas ou aparentemente vinculadas ao interesse político, só podiam ser destruídas com certas precauções, necessárias para garantir o bem geral. Afirmava que os Amigos dos Negros não eram inimigos dos colonos, nem da propriedade: "não queremos destruir as suas riquezas, desejaríamos apenas depurar a sua fonte, e torná-las inocentes e legítimas". ${ }^{443}$ Mais do que isso, os Amigos dos Negros atuavam no sentido dos próprios interesses das colônias, tendo em vista que a escravidão e o tráfico não eram apenas injustos, mas também nocivos aos interesses pecuniários. A campanha procurava, acima de tudo, evitar que a sociedade fosse encarada como uma entidade subversiva. Condorcet pedia concretamente ao corpo eleitoral que inserisse, nos cadernos de queixas, o projeto de uma comissão especial, que encarregasse os deputados eleitos de pedir aos Estados Gerais "[...] o exame dos meios de destruir o tráfico, e de preparar a destruição da escravidão". ${ }^{444}$

Cerca de 40 ou 50 mil cadernos foram produzidos nas cidades, aldeias e corporações do país. Esses cadernos foram resumidos pelas assembleias dos bailiados

\footnotetext{
${ }^{439}$ Ibidem, p.194.

${ }^{440}$ Segundo Dorigny, o texto, assinado simplesmente por um "Amigo dos Negros", pode ter sido escrito por Gramagnac, secretário da Sociedade.

${ }^{441}$ Em 10 de março, Brissot chegou a propor uma última investida junto ao Ministério, sugerindo o envio dos Regulamentos. A moção foi, por razões de prudência, rejeitada pelo Comitê da Sociedade (cf. Registre de la Société des Amis des Noirs, p.209).

${ }^{442}$ Cf. CONDORCET, Jean-Antoine-Nicolas de Caritat. Au Corps Electoral, contre l'esclavage des Noirs. In: Oeuvres Complètes. Brunswick, Paris: Heinrichs, 1804, p.151.

443 "nous ne voulons pas détruire leurs richesses, nous voudrions seulement en épurer la source, et les rendre innocentes et légitimes" (Ibidem, p.154).

${ }^{444}$ Ibidem, p. 152.
} 
principais, que elegeram os deputados. No conjunto do território, esses bailiados produziram 482 cadernos. Jacques Thibau apresentou uma valiosa relação dos cadernos de queixas que se manifestaram a respeito da escravidão. ${ }^{445}$ Dentre os cadernos que abordaram o tema, houve diferenças de postura: alguns pediram a abolição direta da escravidão, outros, apenas a do tráfico; uns desejaram uma reforma do Code Noir e uma melhoria da condição dos negros, enquanto outros se limitaram a apontar as contradições da escravidão com o direito natural.

Dentre os cadernos do terceiro estado, uma dúzia pediu a abolição do tráfico e, dentre esses, apenas quatro pediram o fim da escravidão. ${ }^{446}$ Oito cadernos manifestaram alguma reprovação, mas sem propor nada de concreto. ${ }^{447}$ No geral, dos 164 cadernos do terceiro estado, 144 mantiveram-se silenciosos. Quanto aos cadernos da nobreza, que totalizaram 140, três reclamaram a abolição do tráfico, e dois deles pediram o fim da escravidão. Sete cadernos emitiram vontades imprecisas e o resto manteve-se silente. Por fim, dentre os cadernos do clero, oito pediram o fim do tráfico, dentre os quais quatro também pediram o da escravidão. ${ }^{448}$ Quatro cadernos abordaram a questão com prudência e 132 nada disseram a respeito.

Geograficamente, as regiões com maior número de protestos e reivindicações antiescravistas foram a Île-de-France ${ }^{449}$ e a Picardia ${ }^{450}$, próximas a Paris e, portanto, inseridas na área de maior influência da Sociedade dos Amigos dos Negros. ${ }^{451} \mathrm{Um}$ pequeno e distante vilarejo como Champagney, na Haute-Saône, constitui uma exceção. $\mathrm{Na}$ capital, a assembleia dos eleitores do Terceiro Estado discutiu o tema da escravidão

\footnotetext{
${ }^{445}$ Para os dados sobre os cadernos de queixas, reportar-nos-emos ao trabalho de Thibau (cf. THIBAU, Jacques. Le temps de Saint-Domingue, pp.119-123).

${ }^{446} \mathrm{O}$ terceiro estado de Versalhes, por exemplo, reclamou uma legislação sobre os negros das colônias e pediu que os Estados Gerais se ocupassem dos meios de destruir a escravidão. Pediu uma lei que suprimisse os obstáculos financeiros (os impostos) às alforrias de escravos. O terceiro estado de Senlis propôs uma lei geral para a abolição da escravidão dos negros, além de pedir que os Estados Gerais conciliassem o interesse político com os direitos da natureza. Em Amiens, o terceiro estado reclamou o fim do tráfico e da escravidão. Em Charolles, o caderno do Terceiro estado incluiu a abolição da escravidão, talvez por influência de Étienne Maynaud Bizefranc de Lavaux, eleito deputado suplente da nobreza de Charolles e futuro personagem da Revolução de São Domingos.

${ }^{447} \mathrm{O}$ caderno de Rennes apresentava pedidos contraditórios. No art.44, pedia o fim do tráfico e da escravidão, mas, em outro dispositivo, diante da eventualidade de interesses políticos que impedissem a abolição dessas práticas, limitava-se a pedir uma suavização do estado dos negros (Ibidem, p.112).

${ }^{448}$ Em Reims, o clero pediu a abolição da escravidão ou, ao menos, a sua suavização, caso razões políticas se opusessem à sua supressão imediata.

${ }^{449}$ Em Mantes (Île-de-France), por influência de Condorcet, a nobreza e o clero manifestaram-se, pedindo a criação de uma comissão para propor os meios de destruir o tráfico e preparar a destruição da escravidão (cf. GAUTHIER, Florence. L'aristocratie de l'épiderme, p.23).

${ }^{450} \mathrm{Na}$ Picardia, onde a campanha dos Amigos dos Negros foi mais forte, uma dezena de cadernos se referiu à escravidão: o terceiro estado em Château-Thieny, no Laon e em Peronne; a nobreza do Vermandois; e o clero de Peronne, Montdidier, Rouze, Boulogne e Calais.

${ }^{451}$ Cf. PIQUET, Jean-Daniel. L'émancipation des Noirs dans la Révolution française, p.53.
} 
nos primeiros dias de maio de 1789. De Bourges tinha sido encarregado de entregar ao presidente da assembleia eleitoral parisiense uma carta da Sociedade dos Amigos dos Negros aos eleitores, assim como os Regulamentos da entidade. Condorcet, que não havia sido eleito em Mantes, fez nova tentativa junto à nobreza de Paris. ${ }^{452}$ Em 9 de maio, na assembleia eleitoral, Carra, um dos fundadores da Sociedade, pediu para que a questão fosse inserida no caderno de queixas. Moreau de Saint-Méry, membro do Conselho Superior de São Domingos - e, a partir de outubro, deputado da Martinica pediu prudência, alertando para os perigos de medidas impensadas. Obteve sucesso, pois o princípio da abolição do tráfico e da escravidão não foi inserido no caderno. No lugar, foi inscrita uma fórmula genérica: "Os Estados Gerais levarão em conta a situação dos escravos e dos homens de cor tanto nas colônias quanto na França". 453

No dia 10 de maio, na reunião dos grandes eleitores da nobreza parisiense, houve um confronto feroz entre Gouy d'Arcy, que reclamava a admissão imediata dos eleitos de São Domingos nos Estados Gerais, e Condorcet, que afirmava a necessidade de abordar previamente a questão da escravidão. No final, foi estipulado justamente o inverso: uma vez admitidos os deputados das colônias, a questão dos negros seria abordada, e não antes. ${ }^{454}$

Como consolo, o clero de Paris referiu-se aos escravos negros, ainda que de forma pouco contundente:

Que o tráfico dos negros seja, ele próprio, totalmente suprimido, se possível, ou, ao menos, que se garanta, por meio de boas leis, a todos os Negros de nossas colônias, um tratamento suave e moderado e todos os socorros da religião e da humanidade. ${ }^{455}$

Como esperado, as cidades marítimas, como Bordeaux, Marselha, Nantes e Le Havre, nada disseram sobre os escravos, insistindo, ao contrário, na necessidade de desenvolver as fontes do comércio que faziam a riqueza da França.

No total dos cadernos produzidos pelas três ordens, apenas 42 , isto é menos de $10 \%$, tomaram posição a respeito do tema. ${ }^{456} \mathrm{~A}$ enorme maioria dos cadernos sequer mencionou a questão. Os esforços dos Amigos dos Negros produziram resultados

\footnotetext{
${ }^{452}$ Cf. Registre de la Société des Amis des Noirs, pp.221-222.

453 "Les États généraux prendront en considération le sort des esclaves et des hommes de couleur tant dans les colonies qu'en France" (citado em THIBAU, Jacques. Le temps de Saint-Domingue, p.128).

${ }^{454}$ Ibidem, p. 129.

455 "Que la traite des nègres soit elle-même totalement supprimée, s'il est possible, ou que du moins l'on assure, par de bonnes lois, à tous les Noirs de nos colonies, un traitement doux et modéré et tous les secours de la religion et de l'humanité" (Ibidem, p.131).

${ }^{456}$ Ibidem, p.119.
} 
bastante magros. Se, na Inglaterra, a campanha de petições havia gerado o envolvimento das massas na campanha contra o tráfico ${ }^{457}$, na França em plena agitação revolucionária, o modelo elitista dos Amigos dos Negros começava a revelar os seus limites.

\section{I.2.1.3) A campanha junto aos deputados}

Se o impacto da campanha antiescravista na redação dos cadernos de queixas foi fraco, esse fato foi relativamente compensado pela eleição, como deputados nos Estados Gerais, de um número razoável de membros dos Amigos dos Negros. ${ }^{458}$ Entre os representantes do clero, apenas um amigo dos Negros, o bispo de Chartres, foi eleito, mas, em contrapartida, entre os da nobreza, encontramos dez membros da Sociedade: o Conde de Crillon (Beauvais), La Rochefoucauld (Paris), Rochechouart (Paris), Duport (Paris), o Duque de Havré (Amiens), Alexandre de Lameth (Péronne), Charles de Lameth (Artois), La Fayette (Riom), Aiguillon (Agen) e Boufflers (Nancy). Além disso, outros seis amigos dos Negros foram escolhidos como suplentes da nobreza: Malartic de Fondat (Paris), o Visconde de Valence (Paris), Rohan-Chabot (Paris), De Blaire (Paris hors-les-murs), Lavoisier (Blois) e o príncipe de Salm (Nancy). Como representantes do terceiro estado, foram eleitos Mirabeau (Aix), Henry (Béarn) e Sieyès (Paris), além dos suplentes Desfaucherets (Paris) e Bergasse (Lyon).

Também era possível encontrar no quadro de eleitos alguns dos futuros membros dos Amigos dos Negros, sendo três deles particularmente importantes: Pétion de Villeneuve (terceiro estado de Chartres), o abade Grégoire (clero de Nancy) e Garran de Coulon (suplente do terceiro estado de Paris). Também estavam presentes outros personagens que, mesmo sem fazer parte da Sociedade, desempenhariam um papel importante na história colonial da Revolução, manifestando-se, em algum momento, em favor dos negros. Era o caso de Dupont de Nemours, Viefville des Essarts, Blanc-Gilli, Rewbell, Barère de Vieuzac, Boissy d'Anglas, Lanjuinais e, por que não, Robespierre.

Para a Sociedade, o quadro de eleitos lhe dava algumas possibilidades de ação, o que a motivaria a continuar os seus esforços para obter a introdução da questão nos Estados Gerais. Em 23 de junho, Brissot manifestou, no Comitê da Sociedade, a sua alegria em ver tantos Amigos dos Negros entre os deputados eleitos, o que lhe dava a

\footnotetext{
${ }^{457} \mathrm{Na}$ Inglaterra, os pedidos de medidas contra o tráfico corresponderam a mais da metade das cerca de 200 petições públicas submetidas à Câmara dos Comuns durante o ano de 1788.

${ }^{458}$ Para a lista completa dos deputados e suplentes eleitos para os Estados Gerais de 1789, cf. AP, v.1, pp.593-608.
} 
esperança de ver as reclamações da Sociedade acolhidas pela assembleia nacional. ${ }^{459}$ Esse otimismo carecia, como veremos, de fundamento. Mais de 150 dos deputados eleitos tinham propriedades nas Antilhas. ${ }^{460}$ Além disso, muito mais do que a causa antiescravista, o que estava fortemente representado nos Estados Gerais era o comércio francês. Desde meados de 1788, as diferentes praças comerciais - as grandes, assim como também as menores - concertaram-se, por meio de suas Câmaras de comércio, para pedir representação nos Estados Gerais e construir, assim, uma maioria parlamentar capaz de defender os seus interesses. ${ }^{461} \mathrm{O}$ sucesso dessa empresa selaria o destino da campanha dos Amigos dos Negros.

De qualquer forma, a reunião dos Estados Gerais e os eventos subsequentes modificariam profundamente a natureza do regime político francês. A França, mais do que a Grã-Bretanha, passava, em tese, a apresentar as perspectivas mais favoráveis para uma iniciativa quanto à abolição do tráfico. Na assembleia geral dos Amigos dos Negros de 7 de abril, Brissot falou da necessidade de preparar um memorial a ser submetido aos Estados Gerais e nomear uma comissão de três membros para acompanhar a evolução dos debates. Os nomes escolhidos foram: Condorcet, Brissot e De Bourges. ${ }^{462}$

Em 5 de maio de 1789, ao discursar na abertura dos Estados Gerais, o ministro Necker apresentou um panorama geral da economia e das riquezas da Nação. Nesse intuito, abordou o tema das colônias e, consequentemente, da escravidão. Sua intervenção indicava um sentimento favorável à causa dos negros, contrabalançado por um pretenso realismo que afastava a possibilidade de uma decisão atual a respeito do tráfico e da escravidão: "virá talvez o dia em que, associando a vossas deliberações os deputados das colônias, lançareis um olhar de compaixão sobre esse povo infeliz, tranquilamente transformado num bárbaro objeto de tráfico". ${ }^{463}$ Necker apenas propunha uma melhoria das condições dos escravos para favorecer a sua reprodução, mas, ainda assim, o seu discurso foi visto com maus olhos pelos representantes das

\footnotetext{
${ }^{459}$ Cf. Registre de la Société des Amis des Noirs, p. 233.

${ }^{460}$ Cf. BARLIER, Jean-Pierre. La Société des Amis des Noirs, p.16.

${ }^{461}$ Ver, por exemplo, ADLA C 626, pasta 1, fls.12/47/50/58/60.

462 A realização dos Estados Gerais em Versalhes era um obstáculo às investidas parlamentares da Sociedade, localizada em Paris. Daí, a necessidade de uma comissão para acompanhar os eventos (cf. Registre de la Société des Amis des Noirs, pp.217, 227 e 232).

463 "un [...] jour viendra peut-être où, associant à vos délibérations les députés des colonies, vous jetterez un regard de compassion sur ce malheureux peuple dont on a fait tranquillement un barbare objet de trafic" (Citado em THIBAU, Jacques. Le temps de Saint-Domingue, p.113).
} 
colônias e das cidades marítimas, que perceberam a existência de uma atmosfera propícia à discussão da escravidão colonial. Os Amigos dos Negros tiveram a mesma impressão.

No final de maio de 1789, a Sociedade publicou e distribuiu uma carta aos deputados das três ordens, no intuito de chamar a atenção dos representantes eleitos para a situação dos negros das colônias, que o texto procurava equiparar aos cidadãos da metrópole. A carta, que repetia essencialmente as bases do programa gradualista da Sociedade, tinha por objetivo principal denunciar o caráter ruinoso do tráfico. Dava destaque às subvenções pagas pelo Estado aos traficantes, a título de prêmio por escravo importado, e que, em quatro anos, já tinham chegado a 9,6 milhões de libras. Pior, essas subvenções acabavam muitas vezes beneficiando os ingleses, que vendiam grande parte dos escravos às colônias francesas. ${ }^{464}$ Os altos preços do tráfico, resultantes do despovoamento crescente da Guiné, já faziam dele um comércio em vias de extinção, de modo que era preciso aboli-lo antes que as dívidas dos colonos os levassem à ruína completa. $^{465}$

Os Amigos dos Negros também queriam mostrar que o fim do tráfico não seria pernicioso às manufaturas francesas. Ao contrário, ele abriria a possibilidade para a criação de um mercado de consumo dentro das colônias: se os negros ganhassem um dia da semana para trabalhar para si próprios e mesmo que apenas um quarto deles aproveitasse esse dia para trabalhar efetivamente, eles já seriam capazes de gerar uma renda de 3,9 milhões por ano, soma que, aplicada ao consumo, permitiria alimentar mais de quinze mil operários na França. ${ }^{466} \mathrm{O}$ fim do tráfico abriria também a via para um novo tipo de comércio com a Guiné, voltado para as produções naturais africanas.

Sobre a abolição da escravidão, o texto apenas sugeria, numa nota de rodapé, que cada escravo deveria ser libertado após 15 anos de trabalho, tempo suficiente para indenizar o colono do preço pago na compra. Quanto aos filhos de escravos, eles trabalhariam dos 15 aos 25 anos para indenizar o colono dos gastos com a educação. ${ }^{467}$

A Carta concluía pela necessidade da formação de uma Comissão de vinte a trinta homens para examinar a causa dos negros e contemplar as queixas de "500 mil

\footnotetext{
${ }^{464}$ Cf. LETTRE à MM. les Députés des Trois Ordres, pour les engager à faire nommer par les EtatsGénéraux, à l'exemple des Anglois, une Commission chargée d'examiner la cause des Noirs. S.1. [Paris]: s.n., s.d. [1789], pp.11-12.

465 Ibidem, p. 15.

466 Ibidem, pp.14-15.

467 Ibidem, p.18, nota 1.
} 
inocentes que gemem na escravidão". ${ }^{468} \mathrm{Na}$ medida em que a Inglaterra já dava os primeiros passos, "seria, sem dúvida, vergonhoso para Franceses deixarem-se antecipar pelos seus rivais e receber deles lições de beneficiência". ${ }^{469}$ Uma das primeiras questões que essa Comissão teria de enfrentar era a do imposto sobre a liberdade, isto é, a taxa de duas mil libras que o proprietário tinha de desembolsar para alforriar seu escravo e que constituía um dos maiores obstáculos à emancipação de escravos. ${ }^{470}$

Os Amigos dos Negros procuraram também articular o apoio à sua causa junto ao ministério. Em 6 de junho de 1789, a Sociedade dos Amigos dos Negros escreveu a Necker, manifestando um forte reconhecimento pela menção feita, no seu discurso de abertura dos Estados Gerais, aos direitos dos africanos e à possibilidade de conciliar a abolição do tráfico com a prosperidade das colônias. Indicou a necessidade de seguir a via assinalada pelo Parlamento britânico, que tinha nomeado um Comitê para estudar a questão do tráfico. ${ }^{471}$

Por outro lado, a Sociedade criticou o fato de Necker ter sugerido, em seu discurso, apenas uma diminuição e não a supressão completa dos prêmios pagos pelo Estado ao tráfico negreiro. Necker tinha dito que a soma concedida ao tráfico, que já atingia 2,4 milhões de libras, poderia ser reduzida de perto da metade e que o rei já tinha manifestado as suas intenções nesse sentido. A Sociedade dos Amigos dos Negros julgava a medida insuficiente:

Ela, assim como as Sociedades de Londres e da América, acredita que o Tráfico de Negros está fundado no roubo, no assassinato, na bandidagem; que não é da equidade, nem da dignidade de uma Nação esclarecida modificar ou regulamentar um tráfico que só pode ser atroz e criminoso, tráfico tão funesto quanto desonroso para a Nação Francesa; que é, portanto, impolítico alimentar e encorajar o Tráfico por meio de prêmios, por mais medíocres que sejam; que é duplamente impolítico, tendo em vista que a maior parte desse prêmio passa para as mãos dos Ingleses, aos quais Negociantes Franceses não hesitam em emprestar seu nome, para eludir a intenção do Conselho; e, que para pagar esse prêmio, priva-se o Habitante indigente dos nossos campos de seu pão, fruto de seu labor. ${ }^{472}$

\footnotetext{
${ }^{468}$ Ibidem, pp.26-27.

469 "sans doute, il serait honteux pour des Français de se laisser prévenir par leurs rivaux et de recevoir d'eux des leçons de bienfaisance" (Ibidem, pp.31).

470 Ibidem, p.41.

${ }^{471}$ Cf. LETTRES de la Société des Amis des Noirs, à M. Necker, avec la Réponse de ce Ministre. S.1. [Paris]: s.n., s.d. [1789], pp.3-5.

472 "Elle croit, avec les Sociétés de Londres et d'Amérique, que la Traite des Noirs est fondée sur le vol, l'assassinat, le brigandage; qu'il n'est ni de l'équité, ni de la dignité d'une Nation éclairée, de modifier, ou de réglementer un trafic, qui ne peut jamais être qu'atroce et criminel; trafic aussi funeste que déshonorant pour la Nation Française; qu'il est donc impolitique d'alimenter et d'encourager la Traite par des primes,
} 
A Sociedade anunciava, assim, a Necker a sua intenção de pedir aos Estados Gerais uma abolição completa da subvenção estatal ao tráfico. Necker respondeu aos Amigos dos Negros, em 14 de junho, que a sua proposta visava apenas ao momento presente, isto é, enquanto subsistisse o tráfico. ${ }^{473}$ A Sociedade replicaria, em 24 de junho, para manifestar novamente a sua insatisfação com o que lhe parecia ser uma espécie de compromisso por parte de Necker. ${ }^{474}$ Uma subvenção pela metade ainda era uma subvenção.

Assim, no momento em que se reuniam os Estados Gerais, a Sociedade dos Amigos dos Negros procurou inserir nos debates a questão do tráfico negreiro, sempre sob a ótica do interesse das colônias e da metrópole. Mas não foi a propaganda dos Amigos dos Negros e sim o pedido das colônias por uma representação nos Estados Gerais que fizeram com que estes incorporassem às suas discussões a questão colonial.

quelques médiocres qu'elles soient; qu'il l'est doublement, en ce que la plus grande partie de cette prime passe entre les mains des Anglais, auxquels des Négocians Français ne rougissent pas de prêter leur nom, pour éluder l'intention du Conseil; et en ce que pour payer cette prime, on enlève à l'indigent Habitant de nos campagnes son pain, le fruit de son labeur" (Ibidem, pp.6-7).

${ }^{473}$ Ibidem, p.9.

${ }^{474}$ Ibidem, pp.10-11. 


\section{I.2.2) $O$ primeiro debate: a questão da representação colonial}

Se aquele parecia ser o momento ideal para propor a abolição do tráfico, dada a agitação revolucionária na capital francesa, o fato é que a Sociedade logo se viu envolvida num outro debate. Desde a convocação dos Estados Gerais, os colonos de São Domingos haviam se organizado para formar uma deputação capaz de defender os seus interesses de classe. No fim de 1788, deputados já tinham sido escolhidos, na esperança de que fossem aceitos nos Estados Gerais. Não tinham direito de representação, mas reivindicavam sua admissão com base no princípio no taxation without representation, que havia orientado a luta pela indepedência das colônias americanas. ${ }^{475}$

Em 16 de junho de 1789, na assembleia do Comitê dos Amigos dos Negros, Clavière alertou para a necessidade de tomar imediatamente a defesa dos negros junto aos Estados Gerais, em razão da apresentação dos deputados das colônias, alguns dias antes. ${ }^{476}$ As colônias não eram pays d'état ${ }^{477}$ e estavam, portanto, sob o domínio direto da Coroa, de modo que não foram convocadas para os Estados Gerais. Contudo, por iniciativa de Gouy d'Arcy, Moreau de Saint-Méry ${ }^{478}$ e Reynaud de Villeverd, um grupo de colonos presentes em Paris tinha se reunido para reclamar uma representação nos Estados Gerais e preparar uma constituição para as colônias. O grupo assumiu o nome de Comitê dos colonos de São Domingos. ${ }^{479}$ Em setembro de 1788, esse Comitê tinha sido recebido pelo ministro da Marinha e pelo rei, mas seu pedido de representação tinha sido rejeitado. ${ }^{480}$ A questão tinha de ser decidida pelos próprios Estados Gerais.

Um comitê eleitoral secreto tinha desconsiderado a ausência de convocação e eleito representantes para a colônia de São Domingos. Eles estavam em Versalhes, prontos para participar dos Estados Gerais. Essa representação, que não tinha base legal

${ }^{475}$ Cf. FICK, Carolyn. The making of Haiti, pp.76-77.

${ }^{476}$ Cf. Registre de la Société des Amis des Noirs, p.229.

${ }^{477}$ Os pays d'état eram as províncias em que os Estados haviam conseguido manter, contra a pressão do poder central, o princípio da representação das três ordens, o que lhes permitiu conservar, até o final do Antigo Regime, o direito de discutir o montante dos impostos. Já nos pays d'élection, o rei designava diretamente os seus administradores e o poder de seus intendentes era amplo.

${ }^{478}$ Figura proeminente do campo colonial, Moreau de Saint-Méry era um magistrado de São Domingos e especialista em questões coloniais. Foi um dos redatores do caderno de queixas da Igreja de SaintEustache em Paris, no qual propôs a admissão das colônias nos Estados Gerais. Ele também foi um dos personagens mais ativos do 14 de julho, tendo participado da tomada do poder municipal. Recepcionou Luís XVI em 17 de julho, liderando o aplauso dos deputados ao reconhecimento pelo rei da Assembleia Nacional. Em 24 de julho, foi um dos 122 eleitos para a Comuna de Paris. Três dias depois, tornou-se o seu vice-presidente (cf. THIBAU, Jacques. Le temps de Saint-Domingue, pp.98-100 e 144-146).

${ }^{479}$ Cf. GAUTHIER, Florence. L'aristocratie de l'épiderme, p.22.

${ }^{480}$ Apesar disso, em 26 de dezembro de 1788, o governador geral Chillau e o intendente Barbé de Marbois autorizaram os habitantes de São Domingos a exporem as suas reivindicações em cadernos de queixas (cf. MARTIN, Gaston. Histoire de l'esclavage dans les colonies françaises, p.184). 
alguma, entregou a cada uma das ordens um pedido de admissão. ${ }^{481} \mathrm{O}$ clero não acolheu o pedido dos deputados coloniais, mas o Terceiro Estado viu nesse grupo um possível reforço às suas posições. A oposição dos colonos ao chamado "despotismo ministerial" fazia com que tivessem um campo de luta comum com os revolucionários da metrópole. Isso faria com que, nos primeiros anos da Revolução, os colonos fossem dificilmente associados à contrarrevolução. Desinformados sobre a real situação nas colônias, muitos representantes do povo entendiam que a hostilidade dos colonos ao poder estabelecido era útil aos seus fins. Além disso, as reivindicações dos colonos de self-government podiam aparecer, aos olhos do povo da metrópole, como democráticas.

Como nenhuma convocação legal tinha sido feita para validar a eleição desses deputados, a sua admissão acabou sendo, num primeiro momento, rejeitada. Foi concedido, entretanto, como gesto de boa-vontade, um direito de sessão, sem sufrágio. Oito desses deputados foram admitidos como observadores nas sessões do Terceiro Estado, enquanto os seus poderes eram verificados.

A questão da representação das colônias nos Estados Gerais acabou abrindo a via para o primeiro debate sobre a questão colonial e, para desgosto do campo escravocrata, sobre os escravos negros. $\mathrm{O}$ que permitiu esse debate foi o fato de que os deputados coloniais pediram uma representação proporcional à população das colônias, sem levar em consideração que os negros e homens de cor livres, embora proprietários e contribuintes, não tinham permissão para votar, e que os escravos sequer eram considerados homens pela lei.

Os Amigos dos Negros logo se pronunciaram a respeito dessa questão, mas com algumas oscilações. Na sua resposta ao escrito de Malouet sobre os negros, no qual este manifestava a sua vontade de ver os delegados das colônias admitidos nos Estados Gerais, os Amigos dos Negros já haviam retrucado que esses representantes, eleitos apenas por colonos brancos, longe de defender o interesse da humanidade, procurariam apenas usar a assembleia como instrumento para "[...] tentar estabelecer como máximas a servidão e o despotismo". ${ }^{482}$ Mas, dito isso, o texto não se opunha a uma representação colonial que aderisse solenemente aos princípios de justiça e humanidade.

Nessa mesma linha, em abril de 1789, Brissot havia publicado um Plan de Conduite pour les députés du peuple aux États Généraux. O líder antiescravista protestava contra o pedido de admissão de 21 deputados coloniais, número que levava

\footnotetext{
${ }^{481}$ Cf. THIBAU, Jacques. Le temps de Saint-Domingue, pp.107-108.

${ }^{482}$ RÉPONSE à l'écrit de M. Malouet sur l'esclavage des nègres, pp.2-3.
} 
em conta a população negra das colônias: "Como esses mesmos homens, que não hesitam em comprar Africanos e tratá-los como bestas de carga, querem hoje elevá-los não apenas ao nível de homens, mas ao nível de homens livres!". ${ }^{483}$ Se eles reclamavam uma deputação numerosa, não era para devolver a liberdade aos negros, nem para proscrever o tráfico, mas "para fazer sancionar pela Nação o regime atual". ${ }^{484}$ Elevavam momentaneamente os negros ao patamar dos homens, para ter o direito de representálos e, então, rebaixá-los ao nível dos animais.

Brissot entendia que, para serem admitidos nos Estados Gerais, os plantadores tinham de dar provas de sua mudança de mentalidade, por meio de uma "profissão de fé" ${ }^{485}$, o que implicava reconhecer publicamente:

que todos os homens nasceram livres e iguais em direitos; que os Negros são os irmãos dos Brancos; que eles têm os mesmos direitos; que nenhum poder na terra pode privá-los destes; que nenhum contrato pode alienar, transferir a liberdade de um homem para outro; que eles reconhecem a iniquidade do tráfico, a iniquidade da escravidão, a necessidade de aboli-los, um como o outro; que eles se comprometem por juramento, a não colocar nenhum obstáculo a essa abolição, que eles se obrigam a facilitar todos os arranjos que a Nação adotar, seja para não fazer com que percam a sua propriedade, seja para restituir gradualmente aos Negros os seus direitos [...]. ${ }^{486}$

Brissot duvidava que os plantadores se dispusessem a adotar tais princípios. Eles vinham aos Estados Gerais com o intuito de preservar uma ordem baseada na desigualdade e na servidão. Assim, uma representação muito numerosa dos plantadores seria necessariamente nefasta aos negros. Se estes não eram considerados homens, então não podiam ser representados por ninguém. Se Brissot reconhecia o direito dos colonos

483 "Comment ces mêmes hommes qui ne rougissent pas d'acheter les Africains, \& de les traiter comme des bêtes de somme, veulent aujourd'hui les élever au niveau, non-seulement d'hommes, mais d'hommes libres!" (BRISSOT DE WARVILLE, Jacques-Pierre. Plan de conduite pour les députés du peuple aux Etats-généraux de 1789. S.1.: s.n., 1789, p.21).

484 Ibidem, p.22.

${ }^{485} \mathrm{O}$ tema da "profissão de fé" seria abordado num outro panfleto voltado para a questão da representação colonial. Em Sur l'admission des députés des planteurs de Saint-Domingue dans l'Assemblée Nationale, Condorcet comparava o que seria a profissão de fé de um deputado de uma nação livre com a de um plantador das colônias. A ideia era mostrar que o plantador sustentava princípios contrários aos direitos naturais do homem e não podia, portanto, participar da nova ordem que se estava construindo. Condorcet propunha que se admitisse um ou dois deputados coloniais, no máximo (cf. CONDORCET, JeanAntoine-Nicolas de Caritat. Sur l'admission des députés des planteurs de Saint-Domingue dans l'Assemblée Nationale. In: Oeuvres Complètes. Brunswick, Paris: Heinrichs, 1804, pp. 155-166).

486 "que tous les hommes sont nés libres et égaux en droits; que les Noirs sont les frères des Blancs; qu'ils ont les mêmes droits; que nul pouvoir sur la terre ne peut les en dépouiller; que nul contrat ne peut aliéner, transférer la liberté d'un homme à un autre homme; qu'ils reconnaissent l'iniquité de la traite, l'iniquité de l'esclavage, la nécessité de les abolir l'un et l'autre; qu'ils s'engagent par serment, à ne mettre aucun obstacle à cette abolition, qu'ils s'obligent à faciliter tous les arrangements que la Nation prendra, soit pour ne pas leur faire perdre leur propriété, soit pour restituer graduellement leurs droits aux Noirs (BRISSOT DE WARVILLE, Jacques-Pierre. Plan de conduite pour les députés du peuple aux Etatsgénéraux de 1789, pp.23-24). 
de contribuir para a formação das leis, ele submetia a sua admissão nos Estados Gerais às regras que haviam fixado a proporção da representação dentro da própria metrópole. Se Paris, com seus 800 mil habitantes, tinha direito a 40 representantes, São Domingos, com uma população branca livre de cerca de 38 mil pessoas, teria direito a, no máximo, três deputados. ${ }^{487}$

Também no post-scriptum da Lettre à MM. les Députés des Trois Ordres, o tema da representação colonial tinha sido abordado. O texto sustentava que a ilha de São Domingos não podia ser equiparada a uma Província da França, como queriam os colonos, e que conceder-lhes representação seria uma injustiça para com as pessoas de cor livres, a quem não havia sido reconhecido o direito de participar da eleição, muito embora reunissem condições para tal. No fim, a carta admitia que esses colonos brancos tivessem um único representante, seguindo a razão de um deputado para cada 20 mil habitantes, observada na França. ${ }^{488}$

Mirabeau também comentou a questão na décima Lettre du comte de Mirabeau à ses commettants (7-12 de junho de 1789). Reconheceu que, enquanto estivessem ligadas à metróple e esmagadas pelo exclusivo, as colônias teriam o direito à representação. O problema estava no número de representantes pleiteado, que se baseava numa população que sequer era juridicamente reconhecida como humana:

se os colonos querem que os negros sejam homens, que eles os libertem, que sejam eleitores, e que possam ser eleitos. Caso contrário, nós os faremos observar que, ao proporcionar o número de deputados à população da França, não levamos em consideração a quantidade de nossos cavalos, nem de nossas mulas. ${ }^{489}$

Apesar dessa oposição, os eventos políticos do mês de junho de 1789 dariam força ao campo colonial. Em 19 de junho, dois dias após a assembleia do Terceiro Estado ter assumido o nome da Assembleia Nacional, a questão da representação ainda permanecia em aberto, muito embora comitês de verificação tivessem sido designados para analisar os poderes dos deputados das colônias. Gouy d'Arcy aproveitou a ocasião para afirmar a vontade da colônia de unir-se fortemente à França na grande obra da Constituição. Nos Amigos dos Negros, a questão também era debatida, mas sem que

\footnotetext{
${ }^{487}$ Ibidem, p.26.

${ }^{488}$ Cf. LETTRE à MM. les Députés des Trois Ordres, pp.46-51.

489 "les colons veulent que les nègres soient hommes, qu'ils les affranchissent, qu'ils soient électeurs, et qu'ils puissent être élus. Dans le cas contraire, nous les prierons d'observer, qu'en proportionnant le nombre des députés à la population de la France, nous n'avons pas pris en considération la quantité de nos chevaux, ni de nos mulets" (Lettres du comte de Mirabeau à ses commettans, pendant la tenue de la première Législature. Reimpressão. Paris: Chez Lavillette, 1791, Lettre X, 7-12 juin 1789, pp.189-190).
} 
uma decisão fosse tomada: uma moção de Clavière para que a Sociedade se opusesse formalmente à admissão dos deputados coloniais, no número por eles pretendido, foi rejeitada. ${ }^{490}$ Em 20 de junho, quando os deputados do Terceiro Estado se reuniram na sala do jogo da péla e prestaram o juramento de não se separarem até que a Nação ganhasse uma constituição, os deputados coloniais, liderados por Gouy d'Arcy, estavam presentes: Thibault, o conde de Magallon, o marquês de Rouvray, o marquês de Perrigny, Bodkin de Fitz-Gérald, Thébaudière, Cocherel e o conde de Reynaud.

A Assembleia decidiu que esses deputados seriam admitidos provisoriamente, após prestarem o juramento. Era, na prática, o reconhecimento do direito das colônias de serem representadas na assembleia da metrópole. Gouy d'Arcy afirmou que a colônia de São Domingos se colocava sob a proteção da Assembleia Nacional, assumindo doravante o nome de "Colônia nacional". ${ }^{491} \mathrm{O}$ colono ainda distribuiu aos deputados um panfleto, no qual exaltava os benefícios trazidos por São Domingos à metrópole e procurava legitimar as eleições realizadas na colônia, que tinha, assim como todas as províncias francesas, o direito de tomar parte das deliberações da Assembleia. Afirmava que, dividida em dez sénéchaussées (senescalados), São Domingos tinha direito a quarenta representantes, mas que tinha se contentado em nomear "apenas" trinta. ${ }^{492}$

Como diz Thibau, se esses deputados não tivessem prestado o juramento e tivessem se aliado aos privilegiados, a história colonial da Revolução francesa poderia ter sido diferente. ${ }^{493}$ No dia seguinte ao juramento, 21 de junho, Gouy d'Arcy conclamou para uma mobilização contra o despotismo ministerial. Essa oposição ao despotismo permitia situar o campo escravocrata no lado da Revolução que se iniciava. Não há como negar que o diagnóstico feito pelos coloniais da situação política da metrópole tinha sido preciso e essa seria uma grande barreira que os antiescravistas teriam de enfrentar. Como diria Brissot, nas suas Memórias,

esses deputados anunciavam apenas intenções favoráveis à liberdade. Acreditou-se em sua palavra; quando da verificação dos poderes, foram admitidos sem dificuldade. A confusão que reinava na época, a impossibilidade que se tinha de examinar a legitimidade das deputações, dava ao zelo hipócrita a facilidade de enganar deputados para quem tudo era

\footnotetext{
${ }^{490}$ Cf. Registre de la Société des Amis des Noirs, p. 232.

${ }^{491}$ Cf. THIBAU, Jacques. Le temps de Saint-Domingue, p.135.

492 Cf. GOUY D'ARCY, Louis-Marthe de. Précis sur la position actuelle de la députation de SaintDomingue aux États Généraux, le 20 juin 1789. S.1: s.n., s.d., p.11-13.

${ }^{493}$ Cf. THIBAU, Jacques. Le temps de Saint-Domingue, p.136.
} 
novo; mas esses plantadores que, no Jogo da Péla, exaltavam a Revolução, já declamavam contra ela na sua correspondência com as ilhas. ${ }^{494}$

Em 27 de junho, na Assembleia Nacional, o tema de São Domingos voltou a ser discutido, com a comunicação, por Prieur de la Marne, do resultado da deliberação do Comitê de verificação das eleições. O Comitê tinha sido unânime quanto à admissão dos deputados das colônias e quanto à legitimidade das eleições realizadas em São Domingos, mas estava dividido no que se referia ao número de representantes a serem admitidos: dezoito deputados, dentre os quais o próprio relator, haviam se pronunciado pela admissão de vinte representantes de São Domingos, tendo em vista a importância de seu comércio e a riqueza dos colonos, ao passo que outros dezoito haviam optado por admitir apenas doze, apontando que os negros não poderiam ser contabilizados na fixação da proporção. ${ }^{495}$

Na mesma sessão, Lanjuinais, Clermont-Tonnerre, Target e Biauzat, que não eram da Sociedade dos Amigos dos Negros, aproveitaram a discussão sobre as colônias para pedir que a Assembleia se ocupasse dos escravos negros. Lanjuinais afirmou que, enquanto nenhuma decisão fosse tomada a esse respeito, apenas os brancos da ilha poderiam ser representados. Membro dos Amigos dos Negros, La Rochefoucauld interveio para lembrar que uma sociedade havia sido formada em Paris para reunir todas as informações referentes a esse objeto e pediu que a Assembleia Constituinte tomasse em consideração a liberdade dos negros antes de se separar. ${ }^{496}$ A decisão sobre a deputação de São Domingos foi remetida à semana seguinte. Já a decisão sobre os negros foi adiada para "tempos mais calmos", mas muitos coloniais perceberam que a mera presença dos deputados das colônias na Assembleia já era suficiente para colocar em pauta a questão da escravidão.

Em 30 de junho, nos Amigos dos Negros, Condorcet fez um relato dos debates em Versalhes sobre a deputação das colônias. Afirmou que, ao que tudo indicava, a Assembleia parecia inclinada a admitir doze deputados das colônias e que, dado o curso dos eventos, "[...] os esforços que a Sociedade dos Amigos dos Negros faria para

\footnotetext{
494 "ces députés n'annonçaient que des intentions favorables à la liberté. On les crut sur parole; lors de la vérification des pouvoirs, ils furent admis sans difficulté. La confusion qui régnait à cette époque, l'impossibilité où l'on était de s'occuper de la légitimité des députations, donnait au zèle hypocrite la facilité de tromper des députés pour qui tout était nouveau; mais ces planteurs qui, au Jeu de Paume, exaltaient la Révolution, déclamaient dès lors contre elle dans leur correspondance avec les îles" (BRISSOT DE WARVILLE, Jacques-Pierre. Mémoires, v.2, p.106).

${ }^{495}$ Cf. AP, v.8, p. 164.

${ }^{496}$ Ibidem, p.165.
} 
impedir essa admissão, longe de serem úteis à Sociedade, poderiam, ao contrário, prejudicar os seus interesses". ${ }^{497}$ A batalha lhe parecia perdida.

Mesmo assim, com o adiamento da discussão na Assembleia, alguns continuaram a sua campanha contra a representação colonial. Mirabeau protestou, na décima quarta Lettre du comte de Mirabeau à ses commettants (26-27 de junho de 1789), contra os debates de 27 de junho, que julgou "superficiais" e "indignos" de um tema tão importante. ${ }^{498}$ Quanto ao argumento de que a proporção da representação deveria levar em conta as riquezas produzidas e comercializadas pelas colônias, Mirabeau respondia que:

[...] está demonstrado hoje que os resultados das pretensas balanças comerciais eram inteiramente falsos e insignificantes, que as colônias, fossem elas de uma utilidade tão incontestável, o que negaram e negam os melhores espíritos, seria impossível conceber que elas reclamassem para a proporção de seus representantes princípios outros que aqueles que serviram para a fixação dessa proporção em todas as províncias do reino. ${ }^{499}$

Brissot também voltou a manifestar-se sobre o tema no panfleto Réflexions sur l'admission aux États Généraux des députés de Saint-Domingue. Desta vez, o líder dos Amis des Noirs atacava o próprio princípio de uma deputação das colônias na Assembleia, sob o argumento de que a representação de um país pertencente a outro hemisfério, a mais de 1.500 léguas de distância, era inviável. Os eleitos, embora bem instruídos sobre a realidade colonial, só podiam conhecer imperfeitamente os problemas da metrópole; pertenciam a uma colônia, cujos hábitos, valores e interesses eram não apenas diferentes, mas, muitas vezes, opostos aos da França. Adepto do livre comércio e contrário ao despotismo ministerial ${ }^{500}$, Brissot acreditava que o contrato entre a metrópole e suas colônias era um "contrato de escravidão", que obrigava os colonos a recorrerem ao contrabando para sobreviverem. Tendo em vista os interesses

\footnotetext{
497 "[...] les efforts que la Société des Amis des Noirs ferait pour empêcher cette admission, loin d'être utiles à la Société, pourraient au contraire nuire à ses intérêts" (Registre de la Société des Amis des Noirs, p.235).

${ }^{498}$ Cf. Lettres du comte de Mirabeau à ses commettans, Lettre XIV, 26-27 de junho, pp.318-319.

499 "[...] il était démontré aujourd'hui que les résultats des prétendues balances de commerce étaient entièrement fautifs et insignifiants, que les colonies, fussent-elles d'une utilité aussi incontestable que l'ont nié et que le nient les meilleurs esprits, les têtes les plus fortes qui se soient occupées de ces matières, il était impossible de concevoir pourquoi elle réclameraient d'autres principes pour la proportion de leurs représentants, que ceux qui ont servi à la fixation de cette proportion dans toutes les provinces du royaume" (Ibidem, pp.321).

${ }^{500}$ A oposição de Brissot ao despotismo ministerial era manifesta. O líder antiescravista chegou até mesmo a atacar o marechal de Castries, ministro da Marinha favorável a reformas em prol dos negros e homens de cor das colônias, como um inimigo da Revolução (cf. BRISSOT DE WARVILLE, JacquesPierre. Affaire de Tabago. Paris: de l'imprimerie du Patriote français, s.d., p.2).
} 
diametralmente opostos que orientavam a metrópole e suas colônias, as suas relações internas não podiam ser governadas pelo mesmo sistema, de modo que a admissão dos deputados coloniais nos Estados Gerais seria "impolítica". Os colonos tinham o direito de manifestar o seu consentimento em relação às leis e impostos a que se submetiam, mas deveriam exercê-lo fora de uma assembleia geral da França. Deveriam ter "[...] em seu seio, uma Assembleia geral das Colônias, semelhante à nossa Assembleia Nacional, e Assembleias particulares, semelhantes às nossas Assembleias Provinciais". ${ }^{501}$ Com isso, a única relação que as colônias teriam com a França seria comercial, devendo esta ser regida de forma concertada para evitar um sistema de opressão. Nos Estados Gerais, as colônias teriam apenas agentes com poderes limitados, que representariam somente os interesses externos das colônias. ${ }^{502}$

Mas, enquanto esse sistema ideal não fosse instituído, Brissot admitia que se abrisse temporariamente aos deputados das colônias o "santuário" dos Estados Gerais, onde encontrariam asilo contra os abusos e o despotismo. Contestava a validade dos poderes dos deputados de São Domingos, eleitos apenas por homens brancos e sem convocação oficial, o que autorizava os Estados Gerais a ordenarem uma nova eleição. Quanto ao número de representantes, dada a proporção de um deputado para 40 mil habitantes adotada na França, São Domingos teria direito a apenas um deputado. ${ }^{503}$

Brissot parecia não perceber que a autonomia que defendia entusiasticamente tenderia a aumentar ainda mais o poder dos colonos sobre a população negra e de cor, que já era considerável. Ainda não compreendia que a luta antiescravista, nos moldes dos Amigos dos Negros, isto é, sem uma base escrava, tinha de passar necessariamente pelo caminho inverso: uma sujeição maior das colônias à metrópole e ao seu estatuto constitucional. Sob a Legislativa, Brissot seria levado a rever as suas posições. ${ }^{504}$

Em 3 de julho de 1789, com a retomada da discussão sobre a representação de São Domingos, o campo antiescravista, representado por Mirabeau, e o campo colonial, liderado por Gouy d'Arcy, voltaram a se enfrentar na Assembleia Nacional. O primeiro voltou a defender uma representação colonial proporcional apenas à população branca que havia participado das eleições. Outros, como Bouche e o Marquês de Montesquieu,

501 "[...] dans leur sein une Assemblée générale des Colonies, semblable à notre Assemblée Nationale, et des Assemblées particulières, semblables à nos Assemblées Provinciales" (BRISSOT DE WARVILLE, Jacques-Pierre. Réflexions sur l'admission, aux états généraux, des députés de Saint-Domingue, pp.7-9).

${ }^{502}$ Ibidem, pp.9-11.

${ }^{503}$ Ibidem, pp.17-18.

${ }^{504}$ No Patriote Français de 16 de março de 1792, ele afirmaria ter defendido o direito de legislar das assembleias coloniais apenas como forma de impedir a admissão dos deputados de São Domingos nos Estados Gerais. 
propuseram a redução da representação a quatro deputados. No campo contrário, Mounier e Malouet defenderam a admissão dos doze que já tinham sido provisoriamente admitidos. Gouy d'Arcy, por sua vez, reconheceu que os "mestiços" tinham sido excluídos das eleições, mas argumentou que, na sua condição de "alforriados", a lei não admitia a sua participação, o que era duplamente falso. Além disso, sustentou que a população não era o único critério válido e que as riquezas e os números do comércio de São Domingos autorizavam uma representação maior. No fim, admitiu reduzir o número de deputados de vinte para dezoito. ${ }^{505}$

Em contrapartida, o deputado Dominique Joseph Garat, do Labourd (país basco), sustentou que medir a extensão da representação com base na extensão das propriedades e das riquezas era submeter a Nação "à humilhante aristocracia dos ricos". ${ }^{506}$ Os homens de cor haviam sido excluídos das eleições por serem considerados inimigos dos brancos da ilha e, em nenhum caso, podia um homem representar o seu inimigo: "os escravos precisariam de representantes contra seus tiranos, e são os seus tiranos que pretendem ser seus representantes!". ${ }^{507}$ Garat propunha um total de quatro representantes para a ilha. Admitia que as colônias tivessem um voto adicional, caso seus deputados manifestassem a sua adesão aos princípios fundadores da Assembleia Nacional:

Que os deputados de São Domingos declarem hoje que vão entrar numa assembleia inteiramente fundada no direito natural, que eles veem a escravidão dos negros como um crime das nações, que nenhum interesse político pode justificar; que eles declarem que não se oporão jamais à busca que fará a assembleia nacional dos meios de fazer cessar o quanto antes esse crime; que eles declarem, por fim, que todas as vezes que esse objeto for tratado, eles não terão voz deliberativa na assembleia nacional. ${ }^{508}$

No dia seguinte, 4 de julho, Le Pelletier de Saint-Fargeau propôs uma solução intermediária: tendo em vista a divisão de São Domingos em três províncias, que fossem admitidos dois deputados para cada uma dela, isto é, seis deputados para a colônia. Os demais teriam apenas voz consultiva. Demagogicamente, Arthur Dillon, representante dos colonos da Martinica, relembrou a presença dos deputados coloniais

\footnotetext{
${ }^{505}$ Cf. AP, v.8, pp.186-188.

${ }^{506}$ Cf. Lettres du comte de Mirabeau à ses commettans, Lettre XVI, 3-4 juillet 1789, p.377.

507 "Les esclaves auraient besoin de représentants contre leurs tyrans, et ce sont leurs tyrans qui prétendent être leurs représentants!" (Ibidem, p.382)

508 "Que les députés de Saint-Domingue déclarent aujourd'hui, qu'ils vont entrer dans une assemblée toute fondée sur le droit naturel, qu'ils regardent l'esclavage des noirs comme un crime des nations, qu'aucun intérêt politique ne peut justifier; qu'ils déclarent qu'ils ne s'opposeront jamais à la recherche que fera l'assemblée nationale des moyens de faire cesser au plutôt ce crime; qu'ils déclarent enfin qur toutes les fois qu'on traitera cet objet, ils n'auront pas de voix délibérative dans l'assemblée nationale" (Ibidem, p.385).
} 
no juramento do jogo da péla, sustentando que os doze que haviam participado do juramento deveriam ter voz deliberativa. A questão foi submetida a votação: dentre os 756 votantes, houve um voto pela admissão de um deputado; nove votos pela admissão de quatro; 223 votos favoráveis à admissão de doze e 523 votos favoráveis à proposta de Le Pelletier de seis representantes para São Domingos. ${ }^{509}$ Os deputados admitidos foram: Larchevesque-Thibaud e Viau de Thébaudières para a província do Norte; Cocherel e Gouy d'Arcy para o Oeste; e Perrigny e Gérard para o Sul. ${ }^{510}$ Os demais deputados teriam, a exemplo de todos os suplentes, apenas um lugar marcado na sala, sem voz deliberativa ou consultiva. Contudo, no dia seguinte à votação, a deputação de São Domingos decidiu permanecer unida: os seis deputados admitidos agiriam de forma concertada com os seus colegas excluídos, para todos os assuntos referentes à colônia, decidindo com base numa votação interna da deputação.

A admissão da representação colonial gerou fortes preocupações em diferentes círculos. Os antiescravistas, é claro, previram dificuldades na sua campanha pela erradicação do tráfico, mas também os negociantes das cidades marítimas temiam pelos seus interesses e já preparavam deputações extraordinárias para fazer frente à ameaça. ${ }^{511}$ Os proprietários coloniais residentes na França também viam com maus olhos essa deputação, cuja presença na Assembleia significava a submissão dos assuntos internos das colônias à deliberação dos representantes da metrópole.

Em 7 de julho, os Amigos dos Negros decidiram enviar agradecimentos especiais a todos os não-membros da Sociedade que haviam tomado a defesa dos negros perante a Assembleia Nacional. ${ }^{512}$ Entre 7 de julho e 21 de agosto, em razão da efervescência revolucionária que tomaria conta do país, não houve sessão na Sociedade dos Amigos dos Negros.

\footnotetext{
${ }^{509}$ Cf. AP, v.8, pp.189-190.

${ }^{510}$ Cf. GAUTHIER, Florence. L'aristocratie de l'épiderme, p.24. Entre 1789 e 1791, outras colônias também conseguiriam os seus representantes: em 22 de setembro de 1789, a Guadalupe obteria dois representantes; em 4 de outubro do mesmo ano, a Martinica obteria dois e Marie-Galante, um deputado; em 12 de fevereiro de 1791, a Île-de-France conseguiria dois representantes na Assembleia (cf. MARTIN, Gaston. Histoire de l'esclavage dans les colonies françaises, p.187).

${ }^{511}$ Em carta a Mosneron de 29 de agosto, a Câmara de comércio de Nantes afirmou que os colonos tinham o direito de assumir um lugar na Assembleia, mas deviam, no que se referia à sua relação com a metrópole, se conformar ao "regime que lhes foi prescrito", isto é, o exclusivo (cf. ADLA C 608, fl.69/70).

${ }^{512}$ Cf. Registre de la Société des Amis des Noirs, pp.237-238.
} 


\section{I.2.3) Formação do bloco antagonista}

Nas suas memórias, Brissot diria a respeito da Sociedade dos Amigos dos Negros: "Ela fez um bem suficiente à liberdade, e me fez um mal suficiente, ou, ao menos, deu-me inimigos suficientes, para que eu tenha o direito de abordá-la". ${ }^{513} \mathrm{De}$ fato, por mais moderado que fosse o seu programa, ao questionar o sistema escravista instaurado nas colônias, a Sociedade confrontava importantes interesses financeiros, com profundas ramificações em diferentes setores da economia francesa.

Durante os primeiros anos da Revolução, a Sociedade dos Amigos dos Negros esteve no centro de todos os debates sobre as colônias. Os antiescravistas eram muito mais numerosos que os membros da Sociedade, mas esta tinha se tornado o símbolo da luta antiescravista na França. Mesmo alguns abolicionistas não pertencentes à Sociedade seriam chamados de amis des Noirs. ${ }^{514}$ A Sociedade havia se tornado, com isso, o principal objeto de ódio dos meios ligados à exploração colonial. Para os colonos, a própria existência da entidade punha em risco o frágil equilíbrio da sociedade colonial. A moderação de seu programa era um aspecto secundário e seria praticamente ignorada pelo campo escravocrata. ${ }^{515}$ Ela seria, ao longo de sua existência e mesmo depois, alvo de acusações diversas, sendo responsabilizada por praticamente todas as desgraças ocorridas nas colônias.

Dada a agitação popular em todo o país, a afirmação de direitos fundamentais do homem e a abolição de privilégios, o clima geral na França, era, pelo menos na aparência, favorável a uma erradicação das práticas sociais contrárias à liberdade, o que deixou os meios ligados ao comércio colonial em estado de pânico. As intervenções favoráveis aos negros, na Assembleia Constituinte, apareciam como um prenúncio de futuras transformações. Ainda não era possível medir os efeitos da Revolução nas

\footnotetext{
513 "Elle a fait assez de bien à la liberté, elle m'a fait assez de mal à moi-même, ou du moins assez d'ennemis, pour que j'aie le droit de m'y arrêter" (BRISSOT DE WARVILLE, Jacques-Pierre. Mémoires, v.2, p.71).

${ }^{514} \mathrm{O}$ próprio Robespierre foi citado, num panfleto direcionado contra a Sociedade, Découverte d'une conspiration contre les intérêts de la France, como um associado dos Amigos dos Negros.

${ }^{515}$ Em instruções dadas aos representantes da Île-de-France, em 27 de outubro de 1790, os deputados da assembleia colonial da ilha mostravam claramente desconhecer as bases do programa dos Amigos dos Negros: "Prestando homenagem à sensibilidade e aos motivos da sociedade dos Amigos dos Negros, somos obrigados a nos opor, com todo o nosso poder, às suas vistas, mais humanas que políticas, sobre a emancipação geral e súbita dos escravos" (grifo nosso) (citado em WANQUET, Claude. La France et la première abolition de l'esclavage 1794-1802: le cas des colonies orientales - ̂lle de France (Maurice) et la Réunion. Paris: Éditions Karthela, 1998, P.24).
} 
questões coloniais, mas os colonos tinham a consciência de que o movimento revolucionário inscrevia-se numa lógica potencialmente perigosa para a ordem colonial.

Desde a sua fundação, a Sociedade dos Amigos dos Negros foi objeto de constantes críticas e ameaças ${ }^{516}$ por parte dos meios ligados à ordem colonial, que a viam, ao mesmo tempo, como um perigoso instrumento de desorganização das colônias e como um perigo para a própria economia da metrópole. Muitos no campo escravocrata acreditavam realmente que os Amigos dos Negros eram agentes a serviço da Inglaterra. ${ }^{517}$

Em 9 de junho de 1789, Duval de Sanadon publicou um violento ataque contra a campanha dos Amigos dos Negros: Réclamations et observations des colons, sur l'idée de l'abolition de la traite et de l'affranchissement des nègres. Descrevendo os "defensores dos Negros" como os "perseguidores dos Brancos", Duval apresentou a escravidão como inerente à constituição das colônias e a causa abolicionista como um instrumento de sua destruição. Se ele reconhecia que, do ponto de vista puramente moral, a escravidão era condenável, entendia que nem todas as suas consequências eram viciosas e que, assim sendo, os obstáculos políticos à destruição de uma instituição aceita pela ordem civil eram importantes demais para serem ignorados. ${ }^{518}$ Para Duval, se a Inglaterra parecia ter se inscrito na via da abolição do tráfico, era porque tinha pouco a perder: "todas as Colônias ocidentais da Inglaterra atingiram o seu último grau de cultura, e tendem para o seu declínio; elas estão, ademais, suficientemente providas de Negros". ${ }^{519}$ Assim, sustentava que a proibição do tráfico seria muito menos danosa à Inglaterra do que à França, cujas colônias estavam em plena expansão. A França não devia, portanto, seguir o caminho indicado por um povo que podia estar querendo levála à ruína. ${ }^{520}$

Outras publicações mais violentas seguiriam. Um panfleto intitulado Découverte d'une conspiration contre les intérêts de la France, de dezembro de 1789, apresentou a

\footnotetext{
${ }^{516} \mathrm{Em} 1^{\circ}$ de setembro de 1789, por exemplo, em assembleia geral dos Amigos dos Negros, Clavière relatou as ameaças de morte que tinha recebido por parte dos colonos (cf. Registre de la Société des Amis des Noirs, p.243).

${ }^{517}$ No verão de 1790, os colonos do Clube Massiac enviaram um agente, o conde de Guitton, a Londres para investigar a natureza dos vínculos da Sociedade dos Amigos dos Negros com a Inglaterra. Guitton rejeitaria, ao término de suas investigações, a tese de um maquiavelismo dos antiescravistas britânicos, relatando que o que Pitt queria não era a abolição do tráfico, mas apenas uma lei humanitária sobre as condições da travessia (cf. THIBAU, Jacques. Le temps de Saint-Domingue, pp.228-229).

${ }^{518}$ Cf. DUVAL DE SANADON, David. Réclamations et observations des colons, sur l'idée de l'abolition de la traite et de l'affranchissement des nègres. S.1.: s.n., 1789, pp.6-11.

519 "Toutes les Colonies occidentales de l'Angleterre sont parvenues à leur dernier degré de culture, et tendent vers leur déclin; elles sont d'ailleurs plus que suffisamment pourvues de Nègres" (Ibidem, p.32).

${ }^{520}$ Ibidem, p.36.
} 
Sociedade como "uma seita que a Inglaterra concebeu para a destruição da França [...]". ${ }^{521}$ O panfleto, que incluía um quadro de membros dos Amigos dos Negros, acusava-os de enviar "assassinos" às colônias para incitar os escravos a matarem os seus senhores. ${ }^{522}$ Circulava, de fato, um rumor segundo o qual os Amigos dos Negros franceses e ingleses haviam enviado, por meio de um agente de Le Havre, 12 mil fuzis a São Domingos, para serem distribuídos entre os negros da colônia, o que era absolutamente falso. ${ }^{523}$ Uma guarda de soldados chegou a ser enviada para fazer uma busca nos locais da Sociedade. ${ }^{524}$

As acusações feitas pelo campo colonial naquela época antecipavam a interpretação, consagrada por Eric Williams e Cyril James, segundo a qual o apoio dado pelo ministro Pitt à campanha contra o tráfico na Inglaterra tinha por objetivo minar a prosperidade de São Domingos, que tinha dado à França o controle do mercado açucareiro europeu. Pitt teria percebido que o apogeu das ilhas açucareiras britânicas já tinha passado e que o tráfico de escravos favorecia os seus concorrentes franceses. Queria uma abolição internacional do tráfico ou, ao menos, uma abolição nacional, tendo em vista que as colônias francesas dependiam muito dos traficantes de escravos britânicos. ${ }^{525} \mathrm{O}$ patrocínio da propaganda antiescravista por Pitt teria tido, assim, fortes motivos econômicos. ${ }^{526}$ Antiescravistas como Clarkson e Wilberforce, por mais sinceros que fossem, teriam sido o veículo dessa estratégia política, o que explicaria a filiação entre a sociedade antiescravista de Londres e os Amigos dos Negros. A tese de que os Amigos dos Negros eram peças de uma grande conspiração para arruinar o

\footnotetext{
${ }^{521}$ Découverte d'une conspiration contre les intérêts de la France. S.1.: s.n., [1789], p.9.

${ }^{522}$ Ibidem, p.10. O panfleto em questão motivou uma resposta, intitulada Il est encore des aristocrates, em defesa da Sociedade, embora não publicada por esta. Outro panfleto anônimo, publicado por um "antigo Capitão de Infantaria" em 1790, também tomaria a defesa dos Amigos dos Negros contra as acusações do partido colonial. Isso mostra que havia antiescravistas fora dos limites dos Amigos dos Negros (cf. IL est encore des Aristocrates, ou Réponse à l'infâme auteur d'un écrit intitulé: Découverte d'une conspiration contre les intérêts de la France. S.l. [Paris]: s.n., s.d. [1789]; L'Homme redevenu homme, ou les Africains à l'Assemblée Nationale. Par un ancien capitaine d'infanterie. S.l.: 1790, p.9).

${ }^{523}$ Clavière denunciou e desmentiu esse rumor, por meio de uma carta a Brissot, publicada no Patriote Français (cf. Patriote Français, v.1, número XIX, 18 de agosto de 1789, pp.4-5).

${ }^{524} \mathrm{Cf}$. CLARKSON, Thomas. History of the Rise, Progress and Accomplishment of the Abolition of the Slave Trade, pp.386-387.

${ }^{525}$ Cf. WILLIAMS, Eric. Capitalismo e escravidão. Rio de Janeiro: Americana, 1975, pp.162-163; JAMES, C.L.R.. Os jacobinos negros, pp.61-64.

${ }^{526}$ Segundo Williams, Pitt afastou-se posteriormente da causa abolicionista quando, em razão da insurreição escrava em São Domingos, a possibilidade de tomar a colônia tornou-se real. Ele não abandonou publicamente a campanha antiescravista, mas seu apoio a ela tornou-se meramente protocolar. Paralelamente, dava estímulos ao tráfico de escravos, que mais do que duplicou durante o seu governo (cf. WILLIAMS, Eric. Capitalismo e escravidão, pp.164-165).
} 
império colonial francês foi colocada no centro da campanha de difamação promovida pelo campo colonial.

Longe de formar um bloco único e homogêneo, a oposição aos Amigos dos Negros era multifacetada. No centro desse "partido colonial", estavam os deputados de São Domingos, liderados por Gouy d'Arcy, descrito por Brissot como o pior inimigo dos Amigos dos Negros. ${ }^{527}$ Esse grupo tinha por objetivo agir dentro da Assembleia Nacional para obter uma autonomia constitucional para a colônia. Os seus objetivos estavam claramente enunciados em Apperçu sur la Constitution de Saint-Domingue, de Cocherel, um dos deputados da ilha: obter para São Domingos uma constituição própria, adequada às particularidades de uma sociedade habitada por povos de diferentes cores e origens, convivendo sob um clima tórrido. Para Cocherel, São Domingos não podia ser assimilada a uma província francesa; era uma província mista uma "Província Franco-Americana" -, sujeita apenas a uma parte das bases constitucionais da Nação francesa. ${ }^{528}$ Isso significava que os princípios de liberdade e igualdade que fundavam a Constituição francesa não podiam ser aplicados às colônias.

Contudo, o grupo formado por esses representantes não contava com a adesão total dos meios ligados ao status quo colonial. Nem todos os proprietários coloniais viam com bons olhos a admissão dos eleitos de São Domingos nos Estados Gerais. Concordavam quanto ao objetivo, mas não quanto ao método. Enquanto o grupo comandado por Gouy d'Arcy atuava no sentido de obter uma representação nos Estados Gerais, outros colonos, como Moreau de Saint-Méry, Barré de Saint-Venant e Belin de Villeneuve $^{529}$, moviam seus esforços num sentido diverso: pediam a criação de uma assembleia colonial, como a que existia na Martinica. Viam com desconfiança a admissão dos deputados coloniais na Assembleia, pois entendiam que ela expressava a inclusão das colônias na ordem constitucional francesa. Temiam também que a existência de uma representação das colônias colocasse em debate público as realidades coloniais. Assim, por meio de uma petição à Constituinte, de 29 de junho de 1789, um grupo formado por colonos de São Domingos tinha protestado contra a admissão dos

\footnotetext{
${ }^{527}$ Cf. BRISSOT DE WARVILLE, Jacques-Pierre. Mémoires, v.2, p.107.

${ }^{528}$ Cf. COCHEREL, Nicolas-Robert. Apperçu sur la Constitution de Saint-Domingue. S.l.: s.d., p.4.

${ }^{529}$ Belin de Villeneuve era um personagem de renome na sociedade colonial de São Domingos. Embora fosse inequivocamente um escravocrata, ele trabalhava em projetos para modernizar a colônia e torná-la mais desenvolvida. Um de seus projetos consistia em desenvolver uma modificação da moenda que permitiria diminuir a dependência da mão de obra servil na fabricação do açúcar. Quando chegaram a São Domingos as notícias da iminência da convocação dos Estados Gerais, Belin viajou, ao lado de Moreau de Saint-Méry e Barré de Saint-Venant, para Paris, onde pretendia organizar a defesa da colônia (cf. THIBAU, Jacques. Le temps de Saint-Domingue, pp.18-19 e 54).
} 
deputados coloniais. Alguns dos signatários dessa petição integrariam uma associação de proprietários absenteístas, surgida em 20 de agosto de 1789, sob o nome de Sociedade correspondente dos colonos franceses. ${ }^{530}$ Com sede na residência do marquês de Massiac, na proximidade do Ministério da Marinha, a Sociedade ficaria mais conhecida como Clube Massiac e tornar-se-ia o centro da resistência organizada dos colonos residentes na metrópole. Se os principais líderes da entidade, como Belin de Villeneuve, Barré de Saint-Venant, o marquês de Gallifet e Duval de Sanadon, eram colonos recém-chegados das colônias ${ }^{531}$, alguns de seus membros mal conheciam as ilhas, embora tivessem importantes propriedades nas partes mais ricas de São Domingos. ${ }^{532} \mathrm{O}$ seu objetivo fundamental era impedir que São Domingos e as colônias em geral fossem assimiladas à metrópole. Para eles, isso significava obter uma assembleia geral e uma constituição próprias à ilha.

Em 29 de agosto de 1789, o clube enviou ao rei uma petição assinada por 150 de seus membros, pedindo a criação de uma assembleia em cada província de São Domingos e uma assembleia central para elaborar um plano de administração da ilha. Em 26 de setembro, o ministro da Marinha informou o Clube Massiac que seu pedido tinha sido aceito pelo rei e que a assembleia colonial seria composta por 72 membros, escolhidos pelos proprietários de terras equivalentes a 100 mil libras e de vinte escravos recenseados. Mas essa decisão não dependia apenas da Coroa.

O Clube preferia agir nos bastidores, em silêncio, de modo a evitar um debate público sobre os temas coloniais. Com isso, evitava estimular confrontos abertos com os Amigos dos Negros. Esse silêncio era, na verdade, mais aparente do que real, na medida em que o Clube recorria a uma pluralidade de jornais ${ }^{533}$ para veicular as suas ideias, ainda que não assumisse um vínculo oficial com esses órgãos. Em dezembro de 1789, o Clube patrocinaria uma violenta campanha contra a Sociedade, distribuindo nos portos e

\footnotetext{
${ }^{530}$ Ibidem, p.191.

531 Cf. DEBIEN, Gabriel. Les colons de Saint-Domingue et la Révolution: Essai sur le Club Massiac. Paris: Librairie Armand Colin, 1953, pp.83-84.

${ }^{532}$ Dos 361 aderentes do Clube, 108 eram nobres (cf. BARLIER, Jean-Pierre. La Société des Amis des Noirs, p.106).

${ }^{533}$ É o caso da Gazette de Paris, dos Actes des Apôtres, do Journal de Monsieur Suleau, do Journal des Colonies, entre outros (cf. DEBIEN, Gabriel. Les colons de Saint-Domingue et la Révolution, pp.131139).
} 
câmaras de comércio panfletos contra os antiescravistas. ${ }^{534}$ Além disso, secretamente, o Clube tomava medidas para neutralizar quaisquer ameaças à paz nas colônias. ${ }^{535}$

O Clube não representava propriamente o conjunto dos interesses de São Domingos, mas ele assumiu, desde o início, a missão de coordenar a resistência dos meios ligados às colônias contra a ofensiva antiescravista. Assim, se os deputados das cidades marítimas ${ }^{536}$, eleitos por armadores e negociantes dos portos, opunham-se aos deputados coloniais quanto ao exclusivo, eles se uniam a estes quando o assunto era a preservação do sistema escravista e o combate aos Amigos dos Negros. As menções ao tráfico e aos negros na Assembleia durante a primavera-verão de 1789 haviam deixado a Câmara de comércio de Nantes preocupada quanto à possibilidade de uma medida capaz de arruinar o comércio francês. ${ }^{537}$ Isso levaria as diferentes praças do comércio francês a articular uma oposição aos Amigos dos Negros. ${ }^{538}$ O Clube Massiac tinha se atribuído a função de promover um entendimento entre todas as camadas de proprietários coloniais e os meios ligados ao comércio. Isso implicava evitar quaisquer conflitos de natureza econômica decorrentes do pacto colonial, conflitos estes que tendiam a dividir a oposição aos Amigos dos Negros, jogando plantadores contra negociantes.

Assim, o Clube Massiac procurava manter relações próximas com as principais cidades portuárias, como Nantes, Saint-Malo, Bordeaux e La Rochelle, onde os negociantes criariam comitês e sociedades de correspondência com o Clube. ${ }^{539}$ Para este, esses comitês eram importantes na medida em que podiam trazer informações frescas das colônias e, sobretudo, permitiam articular a aliança com o partido do comércio. O Clube era o elemento-chave da negociação desse compromisso entre os interesses de São Domingos e os da metrópole. Foi o Clube que orientou Barnave, um dos redatores do juramento do jogo da péla e um dos homens mais populares do país, a

\footnotetext{
${ }^{534}$ É o caso da Lettre d'un créole de Saint-Domingue à la Société établie à Paris sous le nom d'Amis des Noirs, de Belin de Villeneuve, um dos principais líderes do Clube Massiac.

${ }^{535}$ Em 27 de agosto de 1789, por exemplo, o Clube Massiac enviou uma circular aos principais portos do país (Dunkerque, Calais, Le Havre, Rouen, Lorient, Nantes, Saint-Malo, Rochefort, La Rochelle, Bayonne, Bordeaux e Marselha), propondo uma união para impedir a partida de homens de cor para as colônias, temendo que pudessem difundir ideais revolucionários entre os mulatos livres e os escravos (cf. DEBIEN, Gabriel. Les colons de Saint-Domingue et la Révolution, p.97).

${ }_{536}^{536}$ Dentre as principais figuras desse grupo, estavam Blin, Begouën e os irmãos Mosneron.

${ }^{537}$ Cf. Carta a Mosneron, 22 de agosto de 1789, ADLA C 608, fl.68.

${ }^{538}$ Cf. Carta à Câmara de Comércio de Bordeaux, 16 de janeiro de 1790, ADLA C 608, fl.93.

${ }^{539}$ Uma sociedade correspondente, por exemplo, foi criada em Bordeaux, em $1^{\circ}$ de setembro de 1789. Saint-Malo, em 24 de setembro, e La Rochelle, em 22 de outubro de 1789, seguiram o mesmo caminho (cf. LIÉBART, Déborah. Un groupe de pression contre-révolutionnaire: le clube Massiac sous la constituante. Annales historiques de la Révolution française, Paris, n.354, 2008, pp.34-35).
} 
se tornar o porta-voz do "partido colonial" e a mover seus esforços pela promoção desse pacto. $^{540}$

Para manter as aparências, o Clube evitava colocar-se no campo reacionário e não negava a necessidade de melhorar a condição da população negra das colônias francesas. Como diz Gabriel Debien, grande estudioso do Clube Massiac, os seus membros não se apresentavam como revolucionários, nem como contrarrevolucionários, mas como "tradicionalistas reformadores". ${ }^{541}$ Nas suas memórias, Brissot chamaria o Clube de uma "reunião de tartufos políticos". 542

Mas talvez o maior obstáculo para os Amigos dos Negros estivesse menos na oposição frontal conduzida pelos deputados coloniais e pelo Clube Massiac do que na recusa da maioria dos deputados da Nação, muitos deles ignorantes no assunto, em assumir uma posição firme a respeito da questão dos negros. ${ }^{543}$ Tendo em vista a utilidade das colônias ao comércio metropolitano, muitos na Assembleia preferiam evitar a questão, cobri-la com um véu, reservando-a para tempos distantes. Contudo, a proclamação dos direitos naturais do homem impunha necessariamente questionamentos relativos ao mundo colonial.

\footnotetext{
${ }^{540}$ Cf. THIBAU, Jacques. Le temps de Saint-Domingue, pp.192-193.

${ }^{541}$ Cf. DEBIEN, Gabriel. Les colons de Saint-Domingue et la Révolution, p.94.

${ }^{542}$ Cf. BRISSOT DE WARVILLE, Jacques-Pierre. Mémoires, v.2, p.88.

543 O Journal des Amis de la Constitution, de Choderlos de Laclos, expressava bem o pensamento da maioria dos representantes na Assembleia, pregando o silêncio sobre a questão colonial. Em 5 de abril de 1791, em meio à discussão sobre os direitos dos homens de cor, Laclos afirmaria que, se, por um lado, defender os plantadores e a distinção entre brancos e negros nas colônias era contradizer a Declaração dos direitos e cobrir a Assembleia de vergonha, por outro, pedir a aplicação da Constituição francesa nas colônias era decretar implicitamente a abolição da escravidão, estimulando, com isso, as colônias a se separarem da metrópole e os portos franceses a se insurgirem contra a Assembleia. Nos dois casos, a consequência seria a mesma: a anarquia. A argumentação de Laclos foi duramente criticada por Brissot (cf. Journal des Amis de la Constitution, 5 de abril de 1791. In LACLOS, Choderlos de. Oeuvres Complètes. Paris: Gallimard, 1979, pp.644-645).
} 


\section{I.2.4) A Declaração dos Direitos do Homem e do Cidadão}

Em 4 de agosto de 1789, dia da abolição dos privilégios na Assembleia, La Rochefoucauld interveio, em meio à aclamação parlamentar em torno do princípio da igualdade de todos perante a lei, para mencionar a questão dos negros. Sua moção, entretanto, não gerou respostas. A relação entre a defesa dos direitos do Homem e a condenação da escravidão foi, sob a Revolução, menos evidente do que se poderia pensar. Teoricamente, para um defensor dos direitos inalienáveis do Homem, a escravidão só podia ser incompatível com tais direitos, tornando a sua existência injustificável sob a nova ordem em construção. Contudo, historicamente, é possível observar, como diz David Brion Davis, a "capacidade da escravidão de gerar dualismos no modo de pensar ou de se acomodar aos já existentes". ${ }^{544}$

Em seu projeto de declaração dos direitos do homem, apresentado em 20 e 21 de julho de 1789, o abade Sieyès havia disposto, no art. V, que "todo homem é o único proprietário de sua pessoa. Ele pode dispor de seus serviços, seu tempo, mas não pode vender a si mesmo. Essa primeira propriedade é inalienável". ${ }^{545}$ Ora, as colônias eram povoadas por centenas de milhares de negros que não eram proprietários de si mesmos. Embora o texto de Sieyès não tenha sido conservado, ficava claro que a discussão em torno da própria ideia de direitos do Homem, ou seja, direitos inerentes à humanidade, entendida como a soma de todos os homens, gerava contradições com uma instituição que se baseava justamente na distinção entre categorias de homens e na propriedade de uns sobre outros.

Os artigos da Declaração dos direitos do Homem foram votados entre 20 e 26 de agosto de 1789. O primeiro deles dispunha que "todos os homens nascem e permanecem livres e iguais em direitos". Mas, se o art. $2^{\circ}$ estabelecia a liberdade como um direito natural e imprescritível do homem, ele a colocava ao lado da propriedade. ${ }^{546}$ Ora, os escravos eram, ao mesmo tempo, homens e propriedade. Aplicada a um território dominado por senhores de escravos, a Declaração dos direitos gerava

\footnotetext{
${ }_{544}$ Cf. DAVIS, David Brion. O Problema da Escravidão na Cultura Ocidental, p.141.

545 "Tout homme est seul propriétaire de sa personne. Il peut engager ses services, son temps, mais il ne peut pas se vendre lui-même. Cette première propriété est inaliénable" (SIEYÈS. Préliminaire de la Constitution Française. Reconnaissance et exposition raisonnée des Droits de l'Homme et du Citoyen. S.1.: s.n., 1789, p.42).

${ }^{546}$ Cf. Les déclarations des droits de l'homme - Du débat 1789-1793 au Préambule de 1946. Paris: Flammarion, 1989, p.12.
} 
profundas antinomias. $\mathrm{O}$ debate em torno da escravidão passava a ser um debate sobre a propriedade: a propriedade sobre si mesmo e a propriedade sobre outrem.

Apesar disso, a Declaração dos direitos foi lida, tanto por antiescravistas quanto por colonos, como um ato que continha em si o germe da abolição. Ao proclamar que todos os homens nasciam e permaneciam livres e iguais em direitos, ela fazia do Homem um sujeito e condenava, no plano dos princípios, a escravidão, entendida esta como a negação da personalidade jurídica de certos indivíduos. A Declaração não mencionava os negros, mas não abria nenhuma exceção à sua universalidade. Os Amigos dos Negros se valeriam constantemente de referências a ela para apresentar a escravidão como uma instituição já proscrita do direito.

Em artigo publicado no Courrier de Provence (número XXX, 20-21 de agosto de 1789), Mirabeau anunciou a libertação próxima dos escravos pela simples aplicação às colônias do artigo $1^{\circ}$ da Declaração dos direitos do Homem. Referiu-se, aliás, ao fato de que os deputados das colônias haviam aprovado o texto da declaração:

Nenhum deles reclamou contra um princípio do qual a libertação de seus escravos é uma consequência imediata; nenhum deles propôs como emenda declarar que apenas os homens brancos nascem e permanecem livres; nenhum deles propôs que se inserisse a seguinte cláusula, os homens negros nascem e permanecem escravos; a distinção de cor destrói a igualdade dos direitos. (itálico no original) ${ }^{547}$

O campo colonial também não tardou a se manifestar sobre a questão. Em meio à discussão parlamentar sobre o texto da Declaração, Malouet evocou, em $1^{\circ}$ de agosto, os perigos de uma carta geral dos direitos do Homem: "[...] creio, Senhores, que é necessário, num grande império, que os homens por ventura colocados numa condição dependente vejam antes os justos limites do que a extensão da liberdade natural". ${ }^{548}$ Malouet não precisava sequer se referir explicitamente aos escravos das colônias. Ele, que havia defendido a promoção de reformas no regime escravista, entendia que aos negros era preciso dar apenas um tratamento mais humano e não o reconhecimento de seus direitos inalienáveis.

\footnotetext{
547 "Aucun d'eux n'a réclamé contre un principe dont l'affranchissement de leurs esclaves est une conséquence immédiate; aucun d'eux n'a proposé comme un amendement de déclarer que les hommes blancs seuls naissent et demeurent libres; aucun d'eux n'a proposé qu'on insérât cette clause pour les Africains, les hommes noirs naissent et demeurent esclaves; la distinction de couleur détruit l'égalité des droits [...]" (Citado em DORIGNY, Marcel, GAINOT, Bernard. La Société des Amis de Noirs, pp.242243 , nota 443).

548 "[...] je crois, Messieurs, qu'il est nécessaire, dans un grand empire, que les hommes placés par le sort dans une condition dépendante voient plutôt les justes limites que l'extension de la liberté naturelle" (AP, v.8, p.323).
} 
A Declaração dos direitos tornou-se rapidamente o "terror dos colonos". ${ }^{549}$ Os deputados de São Domingos, inquietos com a discussão sobre os direitos do homem, escreveram, em 12 de agosto de 1789, uma carta aos seus eleitores na colônia, para alertá-los sobre o que estava ocorrendo na França e sobre as eventuais repercussões na colônia. A carta dizia que, na metrópole, "ESTÁ-SE INEBRIADO DE LIBERDADE" e recomendava que fossem presas todas as pessoas suspeitas e confiscados todos os escritos que contivessem a palavra "liberdade". ${ }^{550}$ A carta relatava ainda a formação da Sociedade dos Amigos dos Negros, uma "sociedade de entusiastas", que escrevia abertamente contra as colônias e aguardava o momento para atacar a escravidão. ${ }^{551}$ Secretamente, os deputados das colônias se colocavam no campo da contrarrevolução. Essa correspondência alarmista, que chegou a São Domingos em outubro, detonaria uma onda de conflitos raciais na colônia. ${ }^{552}$

Apesar da exaltação dos direitos naturais do homem e da comoção gerada nos meios coloniais, o fato é que, nos meses que seguiram a Declaração dos direitos, nenhuma real conclusão foi tirada a respeito da situação atual dos negros nas colônias. O campo antiescravista apresentava, naquele fim de 1789, apenas projetos de abolição gradual: Daniel Lescallier (Réflexions sur le sort des Noirs dans nos colonies) e o abade Sibire (L'Aristocratie Négrière) expuseram os seus planos aos deputados da Assembleia, enquanto Benjamin Frossard apresentou o seu tratado, La cause des esclaves nègres, ao comitê de agricultura e comércio, em 9 de novembro de 1789. A Sociedade dos Amigos dos Negros fazia questão de esclarecer que não pregava a liberdade imediata dos escravos, tida como potencialmente desastrosa tanto para as colônias quanto para os escravos. A Declaração não havia alterado o seu programa, que continuava voltado primordialmente para a proibição do tráfico.

\footnotetext{
${ }^{549}$ Cf. GAUTHIER, Florence. L'aristocratie de l'épiderme, p.25. No final de 1791, no Cap, um homem de cor, Dodo Laplaine, seria preso, açoitado e marcado por ter lido aos escravos a Declaração dos direitos do Homem e do Cidadão (cf. DAHOMAY, Jacky. L'esclavage et le droit: les légitimations d'une insurrection. In: M. DORIGNY (org.). Les abolitions de l'esclavage cit, p.41).

550 "ON EST IVRE DE LIBERTE" (Copie de la lettre écrite par Messieurs les députés de SaintDomingue, à leurs constituans au Cap, Versailles, le 12 août 1789. In: CORRESPONDANCE secrette des Colons députés à l'Assemblée Constituante, servant à faire connaître l'esprit des colons en général, sur la Révolution. Paris: Imprimerie d'Anjubault, s.d., p.9-11).

551 Ibidem, pp.9-10.

${ }^{552}$ Um juiz, Ferrand de Baudière, seria massacrado em 19 de novembro, por ter dito aos homens de cor de Petit-Goave, em São Domingos, que eles podiam aspirar a participar das eleições e por ter redigido um memorial para sustentar a sua causa. Outros atentados semelhantes ocorreriam naquele momento. Vários homens de cor seriam fuzilados e suas casas, devastadas (cf. GAUTHIER, Florence. L'aristocratie de l'épiderme, pp.173-175).
} 


\section{I.2.5) A campanha contra o tráfico}

\section{I.2.5.1) O tráfico negreiro: um comércio ruinoso para a Nação}

Os colonos de São Domingos gastavam cerca de 45 milhões de libras tornesas por ano na compra de escravos. Apesar disso, dados os riscos inerentes ao tráfico, o funcionamento desse comércio dependia, em parte, do fato de que ele era subvencionado pelo Estado, com isenções fiscais e, sobretudo, com a concessão de "prêmios" aos mercadores. A estratégia era bem sucedida: na década que precedeu a Revolução, São Domingos recebeu de 25 a 30 mil escravos por ano, elevando a sua população cativa para mais de 500 mil em $1788 .{ }^{553}$ Embora esse comércio fosse legalmente restrito aos armadores-negociantes franceses, na prática, os negreiros britânicos, seus concorrentes, também forneciam escravos às colônias francesas. Em muitos casos, esses negociantes estrangeiros, atraídos por um sistema que inexistia em seu país, chegavam a receber os prêmios previstos para os negreiros franceses. ${ }^{554}$

A concessão dos prêmios era a prova, para os Amigos dos Negros, de que o tráfico era em si mesmo não apenas a mais imoral das empresas, mas também um comércio pouco lucrativo para os traficantes e extremamente oneroso para o Estado. Assim, entendiam que a supressão das subvenções seria suficiente para pôr fim ao tráfico, pois tornaria os riscos a ele inerentes absolutamente insuportáveis.

Já os colonos procuravam fazer da manutenção da escravidão e, portanto, do tráfico uma condição necessária à prosperidade nacional. Resgatavam o argumento segundo o qual a destruição desse sistema seria nociva até mesmo aos próprios negros, mais felizes nas colônias do que em seu país de origem, de onde teriam sido salvos da pena de morte ou de uma escravidão mais dura. ${ }^{555}$ Submetidos a senhores mais

\footnotetext{
553 Segundo os números oficiais do intendente Barbé de Marbois, havia, em São Domingos, naquele ano, 509.642 escravos (cf. THIBAU, Jacques. Le temps de Saint-Domingue, p.72).

${ }^{554}$ Alguns negociantes franceses, incapazes de fazer o comércio de escravos, entravam em acordo com traficantes ingleses, que recebiam, além do valor da venda, uma parte dos prêmios previstos para a importação de escravos nas colônias francesas.

${ }^{555}$ Lanthenas, um Amigo dos Negros, rebateu esse argumento, numa resposta a De l'Afrique et des Africains, de Lamiral, obra que procurava justificar o tráfico negreiro por meio de notas explicativas às queixas dos habitantes do Senegal à Assembleia Nacional. Usando as informações passadas por Lamiral, Lanthenas procurou estabelecer uma oposição entre a escravidão na África, onde as diferenças entre o escravo e o senhor eram mínimas, e a escravidão nas ilhas do açúcar, onde o escravo era separado de seu senhor, tal como se fosse um animal (cf. LANTHENAS, François-Xavier. M. Lamiral réfuté par luimême, pp.6-7).
} 
humanos e inteligentes, os negros sofriam, portanto, uma influência positiva, que tendia a aumentar o seu grau de civilização. ${ }^{556}$

Inicialmente, a campanha pela abolição do tráfico se sustentou, para os Amigos dos Negros, em duas esperanças: a da viabilidade de uma decisão comum francobritânica, atestada pelo forte movimento de opinião que cercava o debate na câmara dos Comuns na Grã-Bretanha, e a de um apoio do Ministério francês aos seus esforços. Ambas foram frustradas. ${ }^{557}$ Como vimos, Necker limitou-se a propor, no seu discurso de abertura dos Estados Gerais (5 de maio de 1789), uma redução de $50 \%$ das subvenções dadas ao tráfico negreiro. Em sua correspondência com Necker, a Sociedade não foi capaz de obter do ministro uma posição mais avançada. Além disso, na Grã-Bretanha, a rejeição pelo Parlamento da proposta de abolição do tráfico, em 1788 e 1789, havia enfraquecido o projeto de um esforço conjunto contra esse comércio.

Desde o início da Revolução, os apelos dos Amigos dos Negros tinham estimulado o envio de numerosas petições contra o comércio de escravos à Assembleia. ${ }^{558}$ Mas, a partir do outono de 1789 , a situação política na França tornou-se cada vez mais delicada para os Amigos dos Negros. A chegada de notícias de levantes de escravos na Martinica e em São Domingos gerava preocupações quanto aos efeitos da campanha antiescravista nas colônias. ${ }^{559}$ Os ataques do campo colonial se intensificaram, o que levou alguns dos membros menos convictos a deixarem a Sociedade. Uma carta dos deputados de São Domingos, de 11 de janeiro de 1790, expressou pouca preocupação quanto à possibilidade de uma abolição da escravidão e mesmo do tráfico pela Constituinte, e revelou que a publicação do panfleto L'État des Nègres pelo marquês de Rouvray havia desferido um golpe violento nos Amigos dos

\footnotetext{
${ }^{556}$ Cf. OUDIN-BASTIDE, Caroline. Discours colonial et discours abolitionniste: entre passions et intérêts. In: O. PÉTRÉ-GRENOUILLEAU (org.). Abolir l'esclavage: un réformisme à l'épreuve (France, Portugal, Suisse, XVIII-XIXe siècles). Rennes: Presses Universitaires de Rennes, 2008, p.253.

${ }^{557}$ Cf. BÉNOT, Yves. La Révolution et la fin des colonies, p.89.

${ }^{558}$ É o caso do panfleto anônimo Traite des Nègres. A Messieurs les Députés à l'Assemblée Nationale (Paris: Baudouin, s.d.).

${ }^{559} \mathrm{Em}$ carta de $1^{\circ}$ de dezembro, o armador de La Rochelle Jean Baptiste Nairac escreveria sobre a insurreição na Martinica: "[...] a nova que nos foi transmitida espalhou o terror entre os colonos e os negociantes; ela não teve sequências, mas vós sentis o quanto essa primeira fagulha pode tornar-se funesta" ("[...] la nouvelle qui nous en est rendue, a répandu la terreur parmi les colons et parmi les négociants; elle n'a point eu de suites, mais vous avés (sic) surement senti combien cette première étincelle pouvoit devenir funeste", DEVEAU, Jean-Michel. Le Commerce rochelais face à la Révolution: Correspondance de Jean-Baptiste Nairac (1789-1790). La Rochelle: Editions La Rumeur des Ages, 1989, p.156).
} 
Negros. O texto os acusava de serem uma "seita" a serviço da Inglaterra que teria por objetivo a perda das colônias e a ruína do comércio francês e da manufatura dependente desse comércio. O grande projeto por trás da Sociedade dos Amigos dos Negros, o seu grande "mistério", seria "a derrubada de todos os Impérios". ${ }^{56}$ Devido ao impacto do panfleto, muitos amigos dos negros teriam abandonado a sociedade, ao se verem publicamente "denunciados à execração". ${ }^{561} \mathrm{~A}$ partida desses membros explica as dificuldades financeiras pelas quais passava a Sociedade no final de 1789 e que levaram-na, por exemplo, a trocar os locais das sessões. ${ }^{562}$

As acusações dos colonos forçaram os Amigos dos Negros a adotar uma postura defensiva, ressaltando a moderação de seu programa. Em carta de 25 de novembro de 1789, publicada no Patriote Français de $1^{\circ}$ de dezembro e no Journal de Paris de 14 de dezembro, a Sociedade respondia aos caluniadores. No intuito de esclarecer o público sobre as suas reais intenções, ela reiterava a sua rejeição da abolição imediata, afirmando pedir apenas a proscrição do comércio de escravos e uma melhoria da condição dos escravos:

[...] declaramos formalmente que nunca tivemos outra intenção senão a de procurar no estado dos negros as melhorias que a justiça e a humanidade reclamam, e que, longe de afetarem a cultura das Colônias, podem apenas favorecê-la e fazê-las prosperar. ${ }^{563}$

Mas, para os colonos e os negociantes dos portos, tráfico, escravidão e comércio colonial eram questões indissociáveis. A carta da Sociedade motivou uma resposta de Mosneron de l'Aunay, representante do comércio de Nantes e membro do clube dos Jacobinos, publicada no Journal de Paris de 28 de dezembro. Embora acreditasse na pureza das intenções dos Amigos dos Negros, Mosneron os acusava de não compreenderem a realidade complexa que girava em torno do tráfico e do comércio com as colônias e de atuarem ingenuamente em favor dos interesses da Inglaterra. Afirmava que esta podia renunciar às suas colônias açucareiras, em razão do alto grau

\footnotetext{
${ }^{560} \mathrm{Cf}$. De l'état des Nègres relativement à la prospérité des Colonies françaises et de leur Métropole; Discours aux représentans de la Nation. S.1.: s.n., 1789, pp.11 e 20.

${ }^{561} \mathrm{Cf}$. CORRESPONDANCE secrette des Colons députés à l'Assemblée Constituante, p.29.

${ }^{562} \mathrm{O}$ saldo da caixa da Sociedade corria, naquele momento, sérios riscos de esgotar-se. De acordo com o Registro, em 8 de dezembro de 1789, eram devidas mais de 1.600 libras em subscrições (cf. Registre de la Société des Amis des Noirs, p.251).

563 "[...] nous déclarons formellement que nous n'avons jamais eu d'autre intention que de procurer dans l'état des noirs des améliorations que la justice et l'humanité réclament, et qui, loin de nuire à la culture des Colonies, ne peuvent que la favoriser et les faire prospérer" (Journal de Paris. Paris: de l'Imprimerie de Quillau, s.d., número 348,14 décembre 1789, p.1632; Le Patriote Français, v.1, número CXV, $1^{\circ}$ de dezembro de 1789, p.4).
} 
de desenvolvimento da economia metropolitana, ao passo que a França, ainda pouco industrializada, dependia ainda demais do comércio colonial. ${ }^{564}$ Restava claro que, por trás do debate sobre a escravidão, era o próprio modelo econômico do país que estava em questão.

Na assembleia geral dos Amigos dos Negros de 3 de fevereiro de 1790, Brissot manifestou-se sobre a necessidade de reagir à campanha de difamação. Propunha que os Amigos o fizessem por meio do envio imediato à Assembleia Constituinte de uma petição relativa ao tráfico de escravos. Dois dias depois, a Sociedade publicou uma Adresse à l'Assemblée Nationale, pour l'abolition de la Traite des Noirs. Impressa em mil exemplares, ela seria distribuída entre os representantes da Nação francesa. Embora a petição invocasse o princípio de que todos os homens eram livres e iguais em direitos, ela insistia em estabelecer os limites da campanha dos Amigos dos Negros, ao afirmar: "Não pedimos que restituais aos Negros Franceses esses direitos políticos, os únicos, entretanto, que atestam e mantêm a dignidade do homem; sequer pedimos a sua liberdade". ${ }^{565}$ Procurava-se, com isso, desmentir as manifestações dos colonos e das cidades do comércio contra a Sociedade. A primeira petição dos Amigos dos Negros à Assembleia Nacional tinha essencialmente um caráter defensivo.

Os Amigos dos Negros limitaram-se, em acordo com seu programa básico, a pedir o fim do tráfico, deixando a abolição da escravidão - uma "operação fatal" tanto para as colônias quanto para os negros - para outros tempos. ${ }^{566}$ Procuravam, acima de tudo, convencer os colonos do seu interesse na erradicação de um comércio ruinoso e moribundo: forçados a cuidar melhor de seu plantel, veriam a sua mão de obra reproduzir-se internamente, dispensando-os de contrair enormes dívidas junto aos mercadores de escravos. A abolição seria vantajosa também para as manufaturas

\footnotetext{
${ }^{564}$ Cf. Journal de Paris, número 362, 28 décembre 1789, pp.1701-1703.

565 "Nous ne demandons point que vous restituiez aux Noirs François ces droits politiques, qui seuls cependant, attestent et maintiennent la dignité de l'homme; nous ne demandons pas même leur liberté" (ADRESSE à l'Assemblée Nationale, pour l'abolition de la Traite des Noirs. Par la Société des Amis des Noirs de Paris. Février 1790. Paris: Imprimerie de Potier de Lille, 1790, p.2).

566 Ibidem, pp.3-4. Naquele momento, vozes externas à Sociedade manifestavam-se a respeito da escravidão propriamente dita. Era o caso do Chevalier de Laborie, tenente-coronel de infantaria, envolvido, desde o final da década de 1770, numa campanha pessoal contra a escravidão colonial. Em 1790, ele publicou um projeto, em que argumentou pela improdutividade do trabalho escravo e a necessidade de não apenas devolver a liberdade ao negro, mas de dar-lhe estímulos para trabalhar, seja instituindo um sistema de meação, seja dando ao trabalhador negro uma parte dos lucros. Contudo, assim como os Amigos dos Negros, Laborie defendia uma emancipação apenas gradual e condicional dos escravos das colônias francesas (cf. LABORIE. Propositions soumises à l'examen du Comité de Marine de l'Assemblée Nationale. Paris: Cellot, 1790, pp.7-10).
} 
francesas, pois os capitais antes destinados à compra de escravos seriam então revertidos para o consumo de bens manufaturados da metrópole. ${ }^{567}$

Por fim, a petição procurava rebater as acusações segundo as quais os Amigos dos Negros procuravam provocar a perda das colônias francesas, incitando os escravos à revolta. Afirmava, ao contrário, que a única coisa que podia levá-los à insurreição era "a indiferença da Assembleia Nacional quanto à sua situação". ${ }^{568}$ A abolição do tráfico ou, ao menos, a sua imediata preparação eram os únicos meios de prevenir as revoltas. No fim, a petição sequer pedia a supressão imediata do tráfico, mas apenas que a Assembleia tomasse em consideração esse pedido de abolição e que ela declarasse os seus princípios sobre essa questão. ${ }^{569}$

Essa linha de argumentação moderada e voltada para os interesses coloniais não foi capaz de sensibilizar a oposição. A resposta foi imediata: em 12 de fevereiro de 1790, Jean-Claude Magol pronunciou, na assembleia geral do distrito de Filles-SaintThomas, onde residia Brissot, um discurso a favor da manutenção do tráfico e da escravidão. Afirmou que o pedido pelos Amigos dos Negros de abolir o tráfico tinha por objetivo favorecer a Inglaterra, cujas colônias estavam suficientemente providas de escravos e cuja balança comercial não era tão dependente das suas posses nas Antilhas, em razão do comércio bastante auspicioso que mantinha com a Índia. Magol propunha que seu discurso fosse comunicado aos 59 outros distritos e que estes se unissem para enviar à Assembleia Nacional uma deputação geral dos distritos com o objetivo de pedir a rejeição de quaisquer petições e discussões sobre a abolição da escravidão e do tráfico, autorizando apenas as propostas relativas ao regime administrativo das ilhas e à suavização da condição dos negros. ${ }^{570}$

O comércio francês reagia aos esforços dos Amigos dos Negros com uma avalanche de cartas e memoriais ao comitê de agricultura e comércio da Assembleia Nacional, em favor da manutenção do tráfico. Segundo Florence Gauthier, cartas a favor da manutenção do tráfico chegavam de toda parte: Lille, Le Rozoy, Reims, SaintLumier, Troyes, Le Havre, Yvetot, Rouen, Isigny, Lisieux, Vitré, Lyon, La Côte Saint-

\footnotetext{
${ }^{567} \mathrm{Cf}$. ADRESSE à l'Assemblée Nationale, pour l'abolition de la Traite des Noirs, pp.11-13.

568 Ibidem, p. 19.

${ }^{569}$ Ibidem, p. 21.

${ }^{570} \mathrm{Cf}$. MAGOL. Discours sur la question relative à la liberté des nègres, prononcé en l'assemblée générale du district des Filles-Saint-Thomas, le février (1790). Paris: imprim. de Monsieur, 1790, pp.3-8.
} 
André, Bordeaux, Monségur, Auvillar, Carcassonne, Marselha. ${ }^{571}$ A resistência aos projetos dos Amigos dos Negros estava armada.

\section{I.2.5.2) O discurso de Mirabeau}

Em toda a campanha dos Amigos dos Negros, os limites de sua argumentação foram superados apenas uma vez, com a apresentação do discurso de Mirabeau no clube dos Jacobinos. Mirabeau tinha crescido numa família onde as discussões sobre temas coloniais eram frequentes. O seu tio, Jean-Antoine de Mirabeau, oficial da Marinha, tinha sido governador da Guadalupe entre 1753 e 1755. Durante o seu exercício, ele havia procurado melhorar a condição dos negros nas plantations e impor $\mathrm{o}$ cumprimento da lei aos plantadores. Em cartas ao seu irmão, pai de Mirabeau, ele descrevia os abusos e injustiças da escravidão dos negros, mas também criticava a escravidão por oferecer um trabalho medíocre e por constituir um freio à valorização das terras. ${ }^{572}$ Mirabeau-pai tinha abordado, como vimos anteriormente, a questão em sua obra máxima, L'Ami des Hommes. O envolvimento direto de Mirabeau na campanha contra o tráfico era, portanto, natural e constituía um grande trunfo para o campo antiescravista. Ele era, naquele momento, a voz da França revolucionária.

O clube dos Jacobinos atraía um número tão grande de membros que, muitas vezes, a matéria era discutida e decidida nas suas sessões antes de ser levada para a Assembleia. ${ }^{573}$ Embora fosse a casa dos mais convictos revolucionários da França, o clube dos Jacobinos também contava com a presença de homens de São Domingos, como Moreau de Saint-Méry, Barré de Saint-Venant, Curt, Jean-Baptiste Gérard e Bodkin Fitz-Gérald. Mas, sobretudo, havia no clube uma forte presença das cidades marítimas, que conduziam a defesa do tráfico em nome dos interesses comerciais da Nação. Essa burguesia, que estava na vanguarda da Revolução no verão de 1789, estava determinada a manter o tráfico e a escravidão. Em 24 de fevereiro de 1790, um dia após ter comparecido à Assembleia Nacional, uma delegação de Bordeaux veio ao clube dos Jacobinos para expressar a sua apreensão quanto à situação de São Domingos e sustentar a necessidade da manutenção do tráfico. Na ocasião, o representante de

${ }^{571}$ Cf. GAUTHIER, Florence. L'aristocratie de l'épiderme, p.65.

572 Cf. LUTTRELL, Barbara. Mirabeau. Hertfordshire: Harvester Wheatsheaf, 1990, pp.16-17; GAUTHIER, Florence. À l'origine de la théorie physiocratique du capitalisme, la plantation esclavagiste. Actuel Marx, n.32, 2002, p.69. Disponível em: http://www.cairn.info/revue-actuel-marx-2002-2-page51.htm. Acesso em: 08 de fev de 2012.

${ }^{573}$ Cf. YOUNG, Arthur. Travels, during the years 1787, 1788, and 1789, p.268. 
Nantes, Mosneron de l'Aunay, manifestou-se a favor de um decreto da Assembleia que assegurasse a continuidade do tráfico de escravos. Mosneron expressou a consciência de que a Declaração dos direitos era um obstáculo e pediu que a sua validade se limitasse ao território metropolitano. ${ }^{574}$ Essa discussão sobre o tráfico abria espaço para uma intervenção dos Amigos dos Negros.

Mirabeau faria, em 26 de fevereiro de 1790, nos Jacobinos, a sua grande intervenção sobre o tráfico. Esse discurso tinha sido longamente preparado com o auxílio de seus colaboradores. Deve-se destacar a estreita cooperação entre Mirabeau e Thomas Clarkson ${ }^{575}$, o líder abolicionista britânico, que, aconselhado por Wilberforce, havia se transferido para Paris, em agosto de 1789, para participar dos trabalhos dos Amigos dos Negros. ${ }^{576}$ Clarkson tinha consciência de que a conjuntura revolucionária havia, de certa forma, invertido as coisas: havia agora uma forte esperança de obter da Assembleia Constituinte um decreto contra o tráfico, o que poderia estimular o Parlamento britânico a seguir o mesmo caminho. ${ }^{577}$ Entre 13 de novembro e o final de dezembro de 1789, ele enviou a Mirabeau, por intermédio de Étienne Dumont, uma grande quantidade de cartas contendo informações variadas a respeito do tráfico, com vistas à preparação de uma grande intervenção parlamentar sobre a questão. ${ }^{578}$

Clarkson insistia que a estratégia correta para o abolicionismo deveria limitar-se a obter uma abolição do tráfico:

Minha opinião, assim como a de todos que consideraram atentamente o assunto, é que deve-se pedir apenas a abolição do tráfico. É a fonte de todos os males, e se for destruído, a escravidão das ilhas cairá em seguida, e cairá vantajosamente para os plantadores e para os escravos, sem que seja tocada. Esse raciocínio nos obriga a afastar qualquer ideia de emancipação. ${ }^{579}$

\footnotetext{
${ }^{574}$ Cf. THIBAU, Jacques. Le temps de Saint-Domingue, p.166.

${ }^{575}$ Mirabeau e Clarkson mantiveram, no período, uma intensa correspondência. Mais de duas dezenas de cartas de Clarkson encontram-se reunidas na biblioteca do Museu Paul-Arbaud, em Aix-en-Provence. Essa correspondência foi extensamente estudada por Françoise Thésée (cf. THÉSÉE, Françoise. Autour de la Société des Amis des Noirs. Présence Africaine. Revue Culturelle du Monde Noir, n.125, pp.23-52, 1983).

${ }^{576}$ Durante a sua estadia, Clarkson chegou a se envolver numa polêmica com Mosneron de l'Aunay, que havia publicado, no Journal de Paris, um relato de testemunhos apresentados perante a Câmara dos Comuns em Londres, no intuito de justificar o tráfico. Clarkson desmentiu, em carta ao mesmo jornal, os argumentos apresentados pelas testemunhas, que tinham sido orientadas por mercadores de escravos ingleses (cf. CLARKSON, Thomas. Lettre aux auteurs du Journal de Paris. S.1. [Paris]: Imp. V-ve Hérissant, s.d. [1790], pp.1-4).

577 Cf. CLARKSON, Thomas. History of the Rise, Progress and Accomplishment of the Abolition of the Slave Trade, pp.382-383.

${ }^{578}$ Cf. DORIGNY, Marcel. Mirabeau et la Société des Amis de Noirs, pp.158-159.

579 "Mon opinion, comme celle de tous ceux qui ont attentivement considéré le sujet, est qu'on ne doit demander que l'abolition de la traite. C'est la souche de tous les maux, et si l'on y applique la hache, l'esclavage des îles tombera dans la suite, et tombera avantageusement pour les planteurs et pour les
} 
Esse ponto-de-vista estava aquém até mesmo do programa dos Amigos dos Negros que, se não pedia a abolição imediata da escravidão, previa, ao menos, planos para a sua erradicação progressiva. Ora, a abolição do tráfico não era concebida por Clarkson como o primeiro passo de um programa abolicionista mais amplo, mas como a medida decisiva que corroeria naturalmente o sistema escravista. A história mostraria que essa ideia era equivocada. Tudo indica que Mirabeau tinha uma visão mais ampla da questão, mas, influenciado por Clarkson, ele limitou a sua ação parlamentar à luta contra o tráfico.

No seu discurso aos Jacobinos, Mirabeau afirmou já não ser mais necessário provar o direito dos negros à liberdade, tendo em vista que a Assembleia da Nação francesa havia declarado que todos os homens nasciam e permaneciam iguais e livres. Manifestava a certeza de que, apesar da resistência dos escravocratas, a Revolução e a Declaração dos direitos iriam inevitavelmente espalhar-se pelo mundo, como se a semente da liberdade já tivesse sido plantada. Assim como os demais povos do planeta, os escravos das colônias iriam necessariamente reagir aos novos tempos e deveriam, portanto, ser preparados para a sua libertação futura. ${ }^{580}$

No que se refere especificamente ao tráfico, Mirabeau procurou sintetizar o conteúdo da crítica a esse modo de reposição da mão de obra. Não evitou a denúncia moral do comércio de escravos, mas enfatizou um de seus mais danosos efeitos para a economia colonial: a ausência de reprodução da escravaria. Apontou que, entre 1680 e 1775, 800 mil negros haviam sido introduzidos em São Domingos, ao passo que, em 1775, restavam 290 mil, dos quais apenas 140 mil eram crioulos. ${ }^{581} \mathrm{Se}$, para os colonos, a incapacidade da população escrava de se reproduzir era o principal argumento utilizado para afirmar a necessidade do tráfico, Mirabeau denunciava justamente o círculo vicioso que fazia com que o recurso ao tráfico permitisse aos colonos elevarem o grau de exploração da mão de obra a tal ponto que esta não se reproduzia naturalmente. $\mathrm{O}$ argumento de que era do interesse do senhor cuidar de seu escravo era, assim, um argumento hipócrita, visto que o trabalho a que este era submetido era tão intenso que, em poucos anos, ele já gerava um produto equivalente ou superior ao valor de sua

esclaves sans qu'on le touche... Ce raisonnement nous oblige à écarter toute idée d'émancipation" (CLARKSON, Thomas apud DORIGNY, Marcel. Mirabeau et la Société des Amis de Noirs, pp.160161).

580 Cf. MIRABEAU, Honoré-Gabriel Riqueti. Mémoires biographiques, littéraires et politiques. Paris: Delaunay Librairie, 1835, v.7, pp.122-123.

${ }^{581}$ Ibidem, pp.153-154. 
compra. A superexploração do escravo era uma decorrência do sistema. O problema era que, em razão das dificuldades crescentes em promover a reposição da mão de obra por meio do tráfico, os preços dos escravos subiam incessantemente, de modo que os custos de produção aumentavam numa proporção maior do que os produtos, cujos preços não podiam ultrapassar os limites ditados pelo consumo. Uma abolição do tráfico forçaria os senhores a favorecer a reprodução local de seus escravos. Para Mirabeau, isso traria uma economia anual de 20 milhões para os plantadores, soma que poderia ser aplicada no solo e no aumento da produtividade. ${ }^{582}$

Até esse ponto, o discurso de Mirabeau reproduzia, em linhas gerais, as ideias defendidas pela maioria dos textos dos Amigos dos Negros. Mas ele ultrapassou os limites do programa da Sociedade ao abordar a questão do tráfico numa perspectiva mais ampla dos interesses da metrópole. Ao contestar a rentabilidade do comércio de escravos, ele não se limitou ao plano do interesse individual e contornou, assim, os debates pouco frutíferos que usualmente se davam com plantadores e traficantes. Ele avaliou o caráter lucrativo ou não do tráfico a partir de uma visão de conjunto da economia nacional. $^{583}$

Assim, Mirabeau sustentou que o tráfico apenas encarecia os produtos coloniais, sobrecarregando o consumidor francês e diminuindo o seu consumo. Pior, nesse processo, o tráfico absorvia poucas produções nacionais e muitas produções estrangeiras. Mas, e aí estava a novidade, para Mirabeau, mesmo que o tráfico fizesse a França exportar os seus próprios produtos, a vantagem não seria grande. Contrariando uma das linhas de força do mercantilismo, negava que exportação significasse riqueza, entendendo que um povo que exporta as suas produções, em vez de consumi-las, não faz um comércio vantajoso e está sempre mais perto da pobreza do que da opulência. Da mesma forma, se havia reexportação de produções coloniais, era porque não havia consumo, o que traduzia a inexistência de um mercado interno significativo. Seguindo a linha de fisiocratas como Lemercier de la Rivière ${ }^{584}$, mas também de Arthur Young ${ }^{585}$, ele desmistificava os benefícios de uma balança comercial favorável. Reservas de ouro

\footnotetext{
${ }^{582}$ Ibidem, pp.158-165.

${ }^{583}$ Cf. BÉNOT, Yves. La Révolution et la fin des colonies, p.98.

${ }^{584}$ Cf. LEMERCIER DE LA RIVIÈRE, Pierre Paul. L'ordre naturel et essentiel des sociétés politiques. Paris: Fayard, 2001, pp.392-393.

${ }^{585}$ Cf. YOUNG, Arthur. Travels, during the years 1787, 1788, and 1789, pp.180, 431-433, 493-495.
} 
e prata não significavam prosperidade. Para ele, "[...] quanto mais uma nação consome internamente, maior é a sua riqueza e mais o seu comércio é fecundo". 586

Mirabeau citava, como exemplo, a Inglaterra, que consumia quase todo o açúcar que suas colônias produziam, reexportando apenas 10\% do que recebia. Embora tivesse uma população muito maior - 25 milhões contra 10 milhões -, a França consumia apenas 500 ou 600 mil quintais ${ }^{587}$ dos 1,6-1,8 milhões que recebia das colônias, isto é, pouco mais de 30\%. Isso significava que, para consumir o seu açúcar, a França precisava de mercados estrangeiros. Ora, para o conde, sem consumo fácil e acessível a todos os cidadãos, não podia haver verdadeira riqueza. Pior, o comércio com as colônias obrigava a França a exportar bens indispensáveis ao povo francês. No quadro geral da economia francesa, o comércio colonial era, portanto, uma calamidade. ${ }^{588}$ Contrário ao pacto colonial, Mirabeau condenava todo o sistema de monopólio que encarecia os produtos vendidos às colônias, contra os interesses dos colonos e da própria metrópole.

Mirabeau questionava também os números do comércio da França com as colônias e, mais do que isso, entendia que as vantagens da balança comercial eram ilusórias. Os comerciantes afirmavam que a exportação de 90 milhões em produtos para as colônias permitia alimentar de cinco a seis milhões de franceses. Para Mirabeau, isso era confundir circulação e produção: se era verdade que uma estimulava a outra, era a produção que permitia alimentar esses trabalhadores. ${ }^{589}$ Ora, o tráfico era movido principalmente por produções estrangeiras, de modo que ele não aumentava a riqueza nacional. No fundo, mais do que apenas criticar a escravidão colonial, o discurso de Mirabeau sugeria um novo modelo para a economia francesa, uma via alternativa de desenvolvimento voltada para uma ampliação do mercado interno, a partir do incremento das produções agrícola e manufatureira. Se não chegava a propor o abandono das colônias, Mirabeau dava a entender que a dependência da França em relação ao comércio colonial era um indício das deficiências internas que entravavam o desenvolvimento do país. O protesto de cunho moral estava presente no seu discurso, mas a sua postura antiescravista aparecia primordialmente como a base para um questionamento do modelo econômico vigente, de caráter mercantilista. Acreditava que

\footnotetext{
586 "[...] plus une nation consomme chez elle, plus sa richesse est grande et son commerce fécond" (MIRABEAU, Honoré-Gabriel Riqueti. Mémoires biographiques, littéraires et politiques, v.7, pp.180181).

${ }_{587}^{587}$ França antiga, o quintal, unidade de medida de peso, equivalia a 48,951 quilogramas.

588 Cf. MIRABEAU, Honoré-Gabriel Riqueti. Mémoires biographiques, littéraires et politiques, v.7, pp.182-184.

${ }^{589}$ Ibidem, pp.187-189.
} 
o fim do tráfico e o desaparecimento progressivo da escravidão imporiam à economia francesa uma nova orientação.

Mirabeau concluía o seu discurso pedindo a abolição imediata do tráfico, como forma de preparar uma emancipação gradual dos negros, "sem abalo, sem catástrofe". 590 Propunha que o rei transmitisse à Coroa inglesa o desejo da Nação francesa de unir-se à legislatura britânica para operar de maneira pacífica e durável a abolição do tráfico negreiro. Propunha também que a Assembleia Nacional nomeasse um comitê encarregado de examinar os meios de preparar a liberdade dos negros. ${ }^{591}$

O discurso de Mirabeau permaneceu um tanto excepcional dentro do antiescravismo francês. $\mathrm{O}$ banqueiro Clavière chegaria a retomar algumas de suas ideias na longa Adresse à l'Assemblée Nationale ${ }^{592}$, publicada na primeira metade de 1791. Contudo, os Amigos dos Negros recusaram-se, no geral, a questionar o sistema colonial como um todo, ou inserir a sua campanha no quadro de uma crítica à via econômica na qual o país estava inserido. Na sua maioria, eles queriam a continuação do comércio colonial, pregando apenas a conversão da produção a um sistema de trabalho livre e a criação de mercados internos nas colônias para os produtos franceses. Em 22 de março, Mirabeau faria nova leitura de seu discurso, na Sociedade dos Amigos dos Negros, que, após aclamação geral, prometeu publicá-lo. ${ }^{593}$ É, entrentato, interessante notar que essa publicação não ocorreu.

O partido colonial moveria esforços para impedir que Mirabeau apresentasse o seu discurso na Assembleia Constituinte. O seu envolvimento na campanha contra o tráfico gerava fortes preocupações, mas, naquele momento, a resistência mostrava-se suficientemente organizada. Em Nantes, Bordeaux e La Rochelle já se falava, por volta de novembro e dezembro de 1789, na iminência de uma moção de Mirabeau na Assembleia. Desde então, a oposição a qualquer medida contra o tráfico já vinha sendo preparada. ${ }^{594}$ Homens influentes, como o jacobino Le Chapelier, correspondiam-se com a Câmara de comércio de Nantes, trazendo avaliações sobre o clima na Assembleia. ${ }^{595}$ Antes de fixar uma data para apresentar seu discurso, Mirabeau chegou a consultar

\footnotetext{
${ }^{590}$ Ibidem, p. 204.

${ }^{591}$ Ibidem, pp.208-209.

${ }^{592}$ Clavière faria as mesmas críticas relativas ao comércio colonial, defendendo que "o mais rico, o mais vantajoso de todos os comércios é aquele que os filhos da pátria fazem entre si" (cf. CLAVIÈRE, Etienne. Adresse de la Société des Amis des Noirs, à l'Assemblée Nationale, p.92).

${ }_{593}$ Cf. Registre de la Société des Amis des Noirs, pp.281-282.

${ }^{594}$ Cf. ADLA C 608, fls.8/85/86/92; C 626, pasta 2, fls.16/50.

${ }^{595}$ Cf. Carta de Le Chapelier, 30 de novembro de 1789, ADLA C 626, pasta 2, fl.120.
} 
alguns membros da Assembleia para saber qual era a sua opinião sobre o tema do tráfico e tinha ficado bastante decepcionado: praticamente todos os entrevistados já tinham sido abordados previamente pelo partido colonial e, embora não dessem muito crédito às suas intrigas, hesitavam em dar o seu acordo à abolição naquele momento, seja porque temiam que ela pudesse afetar a Revolução como um todo, seja porque temiam que ela favorecesse a Inglaterra. Mirabeau tinha chegado à conclusão de que apenas 300 dentre os cerca de 1.200 deputados apoiariam a sua moção. Outros 500 alegaram que dariam o seu apoio, mas apenas se a Inglaterra desse provas inequívocas de sua intenção de abolir o tráfico. ${ }^{596}$ Em suas cartas de 2 e 3 de março à Câmara de Comércio de La Rochelle, Jean-Baptiste Nairac, armador e principal deputado extraordinário do comércio, fez uma avaliação do discurso lido nos Jacobinos: reconhecia a eloquência de Mirabeau, mas acreditava que a sua manifestação não seria capaz de provocar mais do que "vãos aplausos" e que a tendência favorável, dentro da Assembleia Nacional, à manutenção do tráfico não seria revertida. ${ }^{597}$ Nairac tinha razão.

\section{I.2.5.3) O debate de março de 1790}

Em março de 1790, o campo antiescravista aparecia politicamente enfraquecido. A Sociedade dos Amigos dos Negros havia perdido alguns de seus membros, como os irmãos Lameth, o duque de Aiguilhon e Lucas de Blaire. Colonos e representantes das cidades marítimas entravam em peso no clube dos Jacobinos, onde exerciam uma forte influência até mesmo sobre alguns patriotas avançados, como Cloots, o "orador do gênero humano", levando-os a se manifestarem contra os Amigos dos Negros. Além disso, a Assembleia Nacional contava agora com uma forte presença de representantes das cidades marítimas, que se apresentavam como deputados extraordinários do comércio. Esse grupo, que servia à articulação política da burguesia mercantil, reforçava o campo dos antiabolicionistas. A formação desse sólido bloco de oposição permitiria, por exemplo, abafar o discurso de Mirabeau, durante o debate de março, muito embora o seu silêncio também possa ter sido motivado por outras considerações. ${ }^{598}$ Nesse

\footnotetext{
${ }^{596}$ Cf. CLARKSON, Thomas. History of the Rise, Progress and Accomplishment of the Abolition of the Slave Trade, pp.400-401 e 403.

${ }^{597}$ Cf. DEVEAU, Jean-Michel. Le Commerce rochelais face à la Révolution, pp.198-200.

${ }^{598}$ Após o seu grande discurso no clube dos Jacobinos, Mirabeau parecia ter definido novas prioridades. Naquele momento, ele mantinha negociações secretas com o rei com vistas à aceitação real da Revolução. Essas negociações impunham uma certa discrição na sua conduta política. A sua pouca insistência em se fazer ouvir, durante o debate de março sobre as colônias, poderia ser reveladora de um deslize estratégico
} 
contexto pouco favorável à causa dos negros, tinha início o primeiro grande debate sobre as colônias na Assembleia.

A discussão teve como ponto de partida a proposta de formação de um comitê específico para examinar a questão colonial. A ideia já tinha sido apresentada no final do ano anterior. Em 27 de novembro de 1789, Curt, deputado da Guadalupe, havia apresentado uma moção, em nome das colônias reunidas, propondo a formação de um comitê de vinte membros, metade de colonos e metade de negociantes, para cuidar dos assuntos relativos às colônias. ${ }^{599}$ Entendia que, dada a especificidade das colônias, a definição de seu regime e de suas relações com a metrópole exigia conhecimentos que apenas os colonos e os negociantes possuíam dentro da Assembleia.

A proposta de um comitê colonial havia recebido apoio de muitas personalidades ligadas às colônias, como Malouet e Gouy d'Arcy. Moreau de Saint-de Méry também manifestou-se favoravelmente à moção de Curt, na sessão da Assembleia Nacional de $1^{\circ}$ de dezembro de $1789 .{ }^{600}$ Mas, mesmo dentro do campo colonial, houve quem se opusesse a ela. Blin, deputado de Nantes e membro do Clube Massiac, acreditava que as colônias tinham o direito de organizar o seu regime doméstico e compor sua própria constituição. Assim, se a Assembleia Nacional, composta por representantes do povo da metrópole, fizesse a constituição para as colônias, seria uma "usurpação". As colônias não podiam, a seu ver, ser equiparadas às demais províncias francesas; elas eram, na verdade, algo como "potências aliadas, partes federativas da Nação". ${ }^{601}$ Nesse sentido, ele se opunha à presença dos deputados das colônias na Assembleia e, da mesma forma, à formação de um comitê colonial, que julgava inútil e sem objeto. ${ }^{602}$ Essas divisões no campo colonial bloquearam, por um tempo, as iniciativas.

Em março de 1790, entretanto, as resistências foram vencidas. No dia 2, Goupilleau, do Comitê dos relatórios, fez a leitura de peças que revelavam o estado de fermentação das colônias. Na Martinica e em São Domingos, assembleias tinham sido constituídas pelos habitantes, sem convocação ou autorização real. Alexandre de

de sua parte. Mirabeau faleceria em 2 de abril de 1791, mas, àquela altura, sua participação no movimento antiescravista já tinha sido reduzida ao mínimo.

${ }^{599}$ Cf. CURT. Motion de M. de Curt, député de la Guadeloupe, au nom des Colonies réunies. Paris: Chez Baudouin, 1789, p.7.

${ }^{600}$ Cf. MOREAU DE SAINT-MÉRY, Médéric Louis Élie. Opinion sur la motion de M. de Curt, Député de la Guadeloupe, pour l'établissement d'un Comité chargé particulièrement de l'examen de tous les objets Coloniaux. Paris: de l'Imprimerie Nationale, s.d., pp.19-20.

${ }^{601}$ Cf. BLIN. Opinion de M. Blin, sur la proposition, faite par MM. les députés des colonies réunies, d'établir un Comité colonial, etc. 1er décembre 1789. Paris: Baudouin, s.d., pp.2-4.

${ }^{602}$ Ibidem, pp.8-10. 
Lameth propôs a formação de um comitê capaz de conciliar os interesses do comércio, das colônias e da França como um todo. Entendia que esse Comitê pouparia muito trabalho à Assembleia, então ocupada com a questão dos direitos feudais. ${ }^{603}$ Blin e o abade Maury procuraram lançar uma discussão a respeito do tráfico de escravos, exigindo que a Assembleia se manifestasse sobre esse tema, do qual dependiam a segurança e a tranquilidade das colônias ${ }^{604}$, mas a Assembleia entendeu por bem reunir todas as questões relativas às colônias nas mãos de um comitê específico.

Em 4 de março, foi feita a eleição dos membros do comitê. A composição não era equilibrada e não dava conta da diversidade de opiniões sobre a matéria. Ao contrário, era um comitê majoritariamente constituído por pessoas com interesses diretos nas colônias e no comércio colonial: Begouën, um armador de Le Havre; Nompère de Champigny, oficial da marinha; Thouret, antigo advogado no parlamento de Rouen, importante praça comercial; Gérard, um grande proprietário de São Domingos; Le Chapelier, do clube Bretão e dos Jacobinos e que tinha ligações com os portos franceses; Garesché, um negociante de La Rochelle; Pellerin de la Buxière, magistrado em Touraine; o Conde de Reynaud, ex-governador de São Domingos e proprietário nas colônias; Alquier, oficial do Almirantado de La Rochelle; Payen de Boisneauf, proprietário no vale do Loire, mas também nas colônias; Alexandre de Lameth, cuja família tinha propriedades em São Domingos; e Barnave, o porta-voz do partido colonial, escolhido como presidente e relator do comitê. Cazalès e o abade Maury foram nomeados suplentes. ${ }^{605}$ Mirabeau, cujas opiniões eram certamente tidas como radicais demais, foi deixado de fora.

Muitos colonos do Clube Massiac viram a criação do comitê das colônias como algo perigoso, na medida em que simbolizava o reconhecimento da competência da Assembleia Nacional sobre os assuntos relativos às colônias. Mas, mesmo dentro do Clube, não havia unanimidade: o comitê diretor viu na criação desse comitê um possível instrumento de controle sobre essas questões, uma forma de enquadrá-las dentro da perspectiva colonial. ${ }^{606}$

A formação de um comitê das colônias e o anúncio de um relatório sobre a questão colonial indicavam a iminência de um debate sobre o tráfico. Entre os dias 4 e 5

\footnotetext{
${ }^{603}$ Cf. AP, v.12, p.4.

${ }^{604}$ Cf. AP, v.12, p.6.

605 Cf. AP, v.12, p.19; THIBAU, Jacques. Le temps de Saint-Domingue, pp.171-172; GARRETT, Mitchell Bennett. The French Colonial Question, 1789-1791. Ann Arbor, MI: George Wahr, 1918, p.47.

${ }^{606}$ Cf. DEBIEN, Gabriel. Les colons de Saint-Domingue et la Révolution, p.188.
} 
de março, o comitê colonial trabalhou na redação de um projeto sobre as colônias. No dia 6, uma deputação extraordinária de Le Havre compareceu à Assembleia Constituinte para defender o tráfico e a escravidão como os únicos meios viáveis de valorização das colônias e indicar os efeitos nocivos, para o comércio colonial, da mera ameaça de abolição. Nesse mesmo sentido, foi lida uma petição proveniente de Marselha, alertando para a necessidade de dissipar os temores da abolição. À noite, Begouën, do Comitê das colônias, escreveu aos negociantes do Havre, para tranquilizá-los, assegurando-os que o decreto que estava sendo preparado iria conservar o tráfico. ${ }^{607}$

No dia 8 de março, Barnave apresentou, em nome do comitê colonial, o primeiro texto legal produzido pela Assembleia Constituinte sobre a questão colonial. O relatório partia da afirmação do interesse da França e do comércio em conservar as colônias. Tendo isso em vista, o Comitê sustentava a necessidade de "[...] convidar as colônias a apresentar os seus votos sobre a sua constituição, e as suas vistas concertadas com o comércio no que se refere à suas relações com a metrópole". ${ }^{608}$ Era o que o Clube Massiac sempre quis: uma Constituição própria para as colônias. O relatório especificava que, se as colônias eram parte integrante do império francês, a Assembleia Nacional "[...] jamais pretendeu compreendê-las na constituição que ela decretou para o reino, e sujeitá-las a leis que poderiam ser incompatíveis com as suas conveniências locais e particulares". ${ }^{609}$ A mensagem era clara: em razão das particularidades da vida colonial (isto é, a escravidão), as colônias não podiam ser inseridas na mesma ordem constitucional que a metrópole. Era uma resposta colonial à Declaração dos direitos de 1789: os direitos naturais e imprescritíveis do homem não podiam ser invocados nas colônias.

O decreto proposto pelo comitê autorizava as colônias a manifestarem-se sobre a sua constituição, legislação e administração, de acordo com as suas conveniências, sob a única condição de conformarem-se aos princípios que uniam as colônias à metrópole e que garantiam os seus interesses respectivos (art. I). Ou seja, a constituição e as leis

\footnotetext{
${ }^{607}$ Afirmou que o tráfico "[...] está tão ligado à nossa existência financeira, política e comercial que ele não pode ser alterado sem a mais assustadora ruptura, sem causar a dissolução e a morte do corpo político" ("[...] est tellement lié à notre existence financière, politique et commerciale qu'il ne peut plus être changé sans le plus effoyable déchirement, sans causer la dissolution et la mort du corps politique", BEGOUËN apud THIBAU, Jacques. Le temps de Saint-Domingue, p.174).

608 "[...] inviter les colonies à présenter leurs voeux sur leur constitution, et leurs vues concertées avec le commerce pour ce qui concerne leurs rapports avec la métropole" (Moniteur Universel. Reimpressão. Paris: Au Bureau Central, 1841, v.3, p.552).

609 "[...] elle n'a cependant jamais entendu les comprendre dans la constitution qu'elle a décrétée pour le royaume, et les assujétir à des lois qui pourraient être incompatibles avec leurs convenances locales et particulières" (Ibidem, p.553).
} 
coloniais não podiam alterar as bases do pacto colonial. Sobre o regime do exclusivo, as colônias podiam somente enunciar o seu desejo sobre as eventuais modificações a serem feitas, para que a Assembleia Nacional pudesse, após ouvir os representantes do comércio, tomar uma decisão (art. VI). O relatório do Comitê procurava estabelecer um compromisso entre os interesses dos colonos e os do comércio. Como diz Thibau, os termos eram claros: "aos metropolitanos, o comércio, aos colonos, os escravos". 610

O decreto ainda reconhecia as assembleias coloniais já constituídas e determinava a formação imediata de assembleias semelhantes onde elas ainda não existiam (art. II). Previa a elaboração de uma instrução para esse efeito (art. III). Os planos preparados pelas Colônias para a sua Constituição ficariam sujeitos ao exame da Assembleia Nacional e à sanção do rei (art. IV). ${ }^{611}$

Mas o artigo mais importante do relatório dispunha que:

[...] a Assembleia Nacional declara que ela entendeu em nada inovar nenhum dos ramos do comércio, direto ou indireto, da França com as suas colônias; coloca os colonos e suas propriedades sob a salvaguarda especial da nação; declara criminoso perante a nação todo aquele que trabalhar para incitar levantes contra eles. ${ }^{612}$

Não inovar os ramos do comércio significava fundamentalmente manter o tráfico de escravos, tal como ele era praticado. Colocar os colonos e suas propriedades sob a salvaguarda na Nação era garantir a posse de escravos. Declarar criminoso aquele que procurasse incitar à revolta contra os colonos era tentar silenciar os Amigos dos Negros e todos aqueles que pretendessem provocar um debate sobre o tráfico e a escravidão dos negros. Sem sequer mencionar as palavras "tráfico" e "escravidão", o decreto tinha um sentido claro: assegurar os proprietários coloniais e os mercadores de escravos nos seus maiores interesses. Na sua primeira abordagem da questão colonial, a Assembleia Constituinte traía completamente os princípios e direitos por ela proclamados menos de um ano antes.

A leitura do relatório gerou muitos aplausos na Assembleia. Vários representantes se ergueram para expressar a sua aprovação, outros pediram a votação imediata. Alguns poucos tentaram manifestar a sua oposição. Mirabeau subiu à tribuna

\footnotetext{
610 "Aux métropolitains, le commerce; aux colonos, les esclaves" (THIBAU, Jacques. Le temps de SaintDomingue, p.180).

${ }^{611}$ Cf. Moniteur Universel, v.3, p.553.

612 "l'Assemblée nationale déclare qu'elle n'a entendu rien innover dans aucune des branches du commerce, soit direct, soit indirect de la France avec ses colonies; met les colons et leurs propriétés sous la sauvegarde spéciale de la nation; déclare criminel envers la nation quiconque travaillerait à exciter des soulèvements contre eux" (Ibidem, pp.553-554).
} 
para apresentar o seu discurso sobre o tráfico, mas foi silenciado pelos gritos e vaias dos representantes da Nação. ${ }^{613}$ Pétion de Villeneuve, da Sociedade dos Amigos dos Negros, fez outra tentativa, mas também foi impedido de falar. Por quase unanimidade, a Assembleia aprovou o decreto do Comitê. ${ }^{614}$ Apenas um punhado de deputados votou contra: Mirabeau, La Rochefoucauld, Sieyès, Pétion, Castellane e Montmorency. ${ }^{615} \mathrm{O}$ partido colonial havia obtido uma grande vitória; os Amigos dos Negros, a sua primeira grande derrota.

Os adeptos do tráfico reagiram com grande entusiasmo à nova lei. No mesmo dia, o deputado e armador Jean-Baptiste Nairac escreveu à Câmara de Comércio de La Rochelle, descrevendo os termos do decreto: "Sem chamar as coisas pelo seu verdadeiro nome, ele conserva o tráfico, a escravidão, o regime proibitivo". ${ }^{616}$ Em carta aos seus representantes Guinebaud e Mosneron, a Câmara de comércio de Nantes manifestou a sua profunda alegria com a medida e pregou o envio imediato da nova lei às colônias, para acalmar os ânimos mais exaltados que rumavam para o separacionismo. ${ }^{617}$ Além disso, com base no decreto, o partido colonial viu-se legitimado a iniciar uma perseguição a algumas figuras-chave da Sociedade dos Amigos dos Negros. Ainda no dia 8 de março, uma queixa contra Brissot foi debatida no distrito Filles-Saint-Thomas. Dez dias depois, ele seria demitido de sua função de representante do distrito na Comuna de Paris. ${ }^{618}$

O golpe havia sido duro para os Amigos dos Negros. O Patriote Français de 10 de março condenou Barnave por ter sacrificado os princípios que havia sempre defendido e protestou contra o artigo que buscava silenciar os defensores dos negros. ${ }^{619}$ Em carta a Bernardin de Saint-Pierre, de 13 de março, Brissot lamentava a sua incapacidade de fazer avançar a causa dos negros na Assembleia: "eu não sirvo para

\footnotetext{
${ }^{613}$ Brissot especularia, em agosto, a respeito dos motivos que haviam levado a Assembleia a silenciar Mirabeau: "Quem sabe os adeptos do tráfico e os próprios autores do relatório não ficaram tão assustados com o sucesso prodigioso de seu discurso nos Jacobinos, que eles empregaram todos os meios para evitar a sua apresentação na Assembleia Nacional, e para abafar a discussão?" (Patriote Français, v.3, número 372, 15 de agosto de 1790, p.3).

${ }^{614}$ Cf. Moniteur Universel, v.3, p.554.

${ }^{615}$ Cf. THIBAU, Jacques. Le temps de Saint-Domingue, p.178.

616 "Sans nommer les choses par leur vrai nom il concerve (sic) la traite, l'esclavage, le régime prohibitif" (DEVEAU, Jean-Michel. Le Commerce rochelais face à la Révolution, p.203).

${ }^{617}$ Cf. Carta a MM. Guinebaud e Mosneron, 11 de março de 1790, ADLA C 608.

${ }^{618}$ Cf. GAUTHIER, Florence. L'aristocratie de l'épiderme, p.146.

${ }^{619}$ Cf. Patriote Français, v.2, número 214, 10 de março de 1790, pp.3-4.
} 
nada, meu respeitável solitário, nem mesmo para esses pobres negros que, apesar de todos os meus esforços, foram tão cruelmente abandonados aos seus carrascos". ${ }^{620}$

$\mathrm{Na}$ assembleia geral dos Amigos dos Negros, de 15 de março de 1790, Brissot propôs diversas medidas relativas ao decreto de 8 de março, no intuito de declarar publicamente que a Sociedade não se deixaria intimidar e continuaria os seus trabalhos. Sieyès propôs que uma nova adresse fosse feita à Assembleia Nacional. ${ }^{621}$ Redigida por De Bourges, a Seconde Adresse à l'Assemblée Nationale, par la Société des Amis des Noirs, de 9 de abril de 1790, tinha por objetivo denunciar o abuso que se pretendia cometer por meio do decreto de 8 de março. Admitindo a sua derrota em relação à questão do tráfico, a Sociedade optou por não contestar o artigo sobre a conservação do comércio indireto com as colônias, na esperança de que circunstâncias mais favoráveis permitissem abordar a questão no futuro. A queixa dos Amigos dos Negros referia-se a outro item: o que declarava criminoso perante a nação todo aquele que procurasse incitar levantes contra os colonos. A carta apontava que alguns homens haviam insinuado que a intenção da Assembleia era pôr fim aos trabalhos da Sociedade, como se escrever em favor dos negros implicasse necessariamente incitá-los à revolta. Mal havia sido publicado o decreto, os Amigos dos Negros já eram vítimas de perseguições. $^{622}$ A Sociedade relembrava que a Declaração dos direitos havia consagrado o direito à liberdade de imprensa, abrindo exceção apenas para os "abusos", nos casos determinados pela lei. Defender os negros constituía um abuso? A campanha antiescravista parecia ter sido reduzida a uma mera luta pela liberdade de expressão. ${ }^{623}$

Embora acuada, a Sociedade dos Amigos dos Negros decidiu publicar uma lista de obras sobre o tráfico e a escravidão ${ }^{624}$, assim como o discurso que Pétion pretendia fazer no dia 8 de março. ${ }^{625}$ No texto, Pétion limitava-se a pedir que a Assembleia

\footnotetext{
620 "Je ne suis bon à rien, mon respectable solitaire, pas même à ces malheureux noirs qui, malgré tous mes efforts, ont été si cruellement abandonnés à leurs bourreaux" (BRISSOT DE WARVILLE, JeanPierre. Correspondance et papiers, p.249).

${ }^{621}$ Cf. Registre de la Société des Amis des Noirs, p. 279.

${ }^{622}$ Cf. SECONDE ADRESSE à l'Assemblée Nationale, par la Société des Amis des Noirs, établie à Paris. Paris: Imprimerie du Patriote François, s.d. [1790], pp.5-6.

${ }^{623}$ A medida de censura, contida no decreto de 8 de março, deve ter surtido efeito, pois os números do Patriote Français subsequentes à lei não incluíram praticamente nada sobre os temas da escravidão e do tráfico.

${ }^{624}$ Cf. LISTE des ouvrages sur la traite et l'esclavage. Paris: Imprimerie du Patriote François, s.d. [1790]. ${ }^{625}$ O Discours sur la traite des Noirs de Pétion trazia, em anexo, as Observations sur l'abolition de la traite des Noirs, de Carra, outro amigo dos Negros. Carra pregava a formação, em cada departamento das colônias, de um diretório nacional, composto por doze comissários protetores dos negros. Esses comissários fiscalizariam os trabalhos e o tratamento impostos aos escravos e os diretórios trabalhariam para preparar a abolição do tráfico nas ilhas (cf. Observations sur l'abolition de la traite des Noirs. In: PÉTION, Jérôme. Discours sur la traite des Noirs. Paris: Desenne, avril 1790, pp.79-80).
} 
examinasse a questão do tráfico. Não pregava, portanto, a sua interdição imediata, acreditando que a "sábia lentidão" daria ao comércio o tempo de preparar a mudança e buscar novas orientações mais seguras. ${ }^{626}$

Em 4 de junho de 1790, a Sociedade voltaria a manifestar-se publicamente, por meio da Adresse aux amis de l'humanité, para declarar que a entidade não abandonaria a sua causa e que um novo plano de trabalho seria adotado, com vistas à abolição do tráfico e a suavização da escravidão dos negros. A Sociedade anunciava ainda a sua intenção de promover uma série de publicações, dentre as quais a do discurso de Mirabeau sobre o tráfico, o que não foi feito. Pedia, para isso, novas contribuições financeiras. ${ }^{627}$

Embora tentassem manter as aparências, os Amigos dos Negros tinham desistido de tentar provocar a supressão do tráfico pela Constituinte. Depositavam as suas esperanças na próxima legislatura. Enquanto isso, a causa antiescravista parecia ter sido reduzida a pó. O tráfico tinha obtido a proteção legal da Assembleia. A discussão sobre a abolição, mesmo gradual, da escravidão tinha permanecido marginal durante todo o debate de março. Apenas um plano, apresentado em 26 de março de 1790, por Viefville des Essarts, deputado que não era da Sociedade, abordou o tema. ${ }^{628}$ Mas, no fim, ele mesmo reconhecia que o momento não era favorável a medidas dessa natureza e que seria mais prudente adiar a questão para tempos mais calmos.

Quanto aos Amigos dos Negros, suas manifestações sobre o tráfico perdiam força. Em 6 agosto de 1790, publicaram Réflexions sur le Code Noir, em que voltavam a apresentar a abolição do tráfico como a única forma realmente eficaz de pôr fim à barbárie. Mas, naquele momento, aceitando que considerações políticas pudessem impedir que o tráfico fosse abolido, os Amigos dos Negros já se contentavam em pedir apenas uma atenuação da condição dos escravos, por meio de novos regulamentos mais humanos, que substituíssem as disposições do Code Noir. ${ }^{629}$ Diante de resistências

\footnotetext{
${ }^{626}$ Cf. PÉTION, Jérôme. Discours sur la traite des Noirs, pp.61-64.

${ }^{627}$ Cf. ADRESSE aux Amis de l'humanité, par la Société des Amis des Noirs, sur le plan de ses travaux. Lue au Comité, le 4 juin 1790, et imprimée par son ordre. Paris: Imprimerie du Patriote François, s.d. [1790], pp.1-4.

${ }^{628}$ Viefville propunha a alforria sucessiva de todos os escravos das colônias francesas num prazo de dezesseis anos contados da publicação da lei, à razão de um dezesseis-avos por ano. $\mathrm{O}$ deputado propunha ainda a divisão e distribuição de todas as terras incultas e abandonadas aos novos livres, com vistas à formação de um campesinato negro nas colônias (cf. VIEFVILLE DES ESSARTS, Jean-Louis de. Discours et projet de loi pour l'affranchissement des nègres, pp.19 e 22-23).

${ }^{629}$ Cf. REFLEXIONS sur le Code Noir, et Dénonciation d'un crime affreux, commis à Saint-Domingue; adressés à l'Assemblée Nationale par la Société des Amis des Noirs. Paris: Imprimerie du Patriote Français, 1790, pp.8-9.
} 
políticas insuperáveis, a corrente antiescravista se refugiava no campo do mero reformismo. Também fora do quadro da Sociedade, manifestações parlamentares contra o tráfico se tornariam raras sob a Constituinte: apenas uma petição apresentada por Pépin, em abril 1791, merece destaque. ${ }^{630}$ Perdida, por enquanto, a luta contra o tráfico, os Amigos passariam a investir seus esforços em outra causa que já vinha ocupando a sua atenção desde o ano anterior: a dos chamados homens de cor livres.

${ }^{630}$ Cf. PÉPIN. Adresse d'un patriote François à l'Assemblée Nationale sur la Traite des Noirs. Avril 1791. S.1. [Paris]: Imprimerie de Valleyre, s.d. [1791]. 


\section{I.3) O combate pelos homens de cor livres}

\section{I.3.1) O movimento antiescravista na luta contra o preconceito}

O fracasso de março de 1790 havia praticamente esgotado as esperanças dos Amigos dos Negros de verem o tráfico de escravos abolido pela Constituinte. Mesmo um programa moderado como o da Sociedade parecia inviável num momento em que as colônias estavam, sob vários aspectos, vinculadas à Revolução. Com isso, a Sociedade viu-se obrigada a reduzir ainda mais as suas ambições, direcionando os seus esforços para uma segunda frente de combate, que já vinha sendo explorada paralelamente à campanha contra o tráfico: as reivindicações das pessoas de cor livres das colônias. O seu envolvimento nessa luta suscitava sérias interrogações, dada a presença, entre a população de cor livre, de um grande número de "escravistas declarados pelo interesse direto de proprietários e por uma política de reaproximação com os Brancos". 631 O combate pelos direitos dos homens de cor tinha, assim, para homens que se diziam antiescravistas, um aspecto um tanto paradoxal.

Objetivamente, era uma luta que buscava afastar a "cor da pele" como critério definidor do status do indivíduo nas colônias e promover a igualdade jurídica entre todos os homens livres, quaisquer que fossem as suas origens. O objetivo era derrubar o preconceito de cor, eliminando todas as suas expressões normativas. Na medida em que o preconceito era utilizado, nas colônias, como uma espécie de mecanismo ideológico de preservação da ordem escravista, os Amigos dos Negros se interessaram pela questão. Além disso, como veremos adiante, eles acreditavam que os homens de cor livres, os "mulatos" das colônias, tinham um papel importante a desempenhar na supressão gradual da escravidão colonial. Brissot defendia, por exemplo, a ideia de que os homens de cor livres, na sua condição de indígenas, eram instrumentos potenciais de regeneração das colônias e podiam atuar como intermediários entre os brancos e os escravos negros. Mais do que isso, alguns Amigos dos Negros atribuíam um papel ativo aos homens de cor num novo tipo de relação a ser estabelecida entre a metrópole e suas colônias. Entendiam que a valorização econômica das colônias deveria ser empreendida por sua população indígena, mais afeita ao solo. ${ }^{632}$ A derrubada do preconceito de cor

\footnotetext{
${ }^{631}$ Cf. SAINTOYANT, J.. La colonisation française pendant la Révolution, v.1, pp.310-311.

${ }^{632}$ Cf. PIQUET, Jean-Daniel. L'émancipation des Noirs dans la Révolution française, pp.201-204.
} 
aparecia então como uma condição essencial da supressão gradual da escravidão. ${ }^{633}$ Além disso, os Amigos dos Negros acreditavam que a eventual presença de homens de cor como deputados na Assembleia criaria condições favoráveis para a aprovação de uma moção contra o tráfico. ${ }^{634}$ Contudo, no debate sobre os homens de cor livres, os antiescravistas se veriam compelidos a manter-se no mesmo campo argumentativo de seus oponentes: toda a discussão giraria em torno do papel a ser desempenhado pelos mulatos na prevenção da revolta escrava.

\section{I.3.1.1) Julien Raimond e a Sociedade dos Cidadãos de Cor}

Os negros e mestiços livres das colônias formavam uma categoria à parte no mundo colonial do final do século XVIII. Muitos deles eram descendentes dos primeiros engagés $^{635}$ e aventureiros franceses, que, no intuito de deixar uma progenitura, haviam reconhecido e emancipado os filhos tidos com suas escravas, numa época onde quase não havia mulheres brancas nas colônias. Outros eram simplesmente antigos escravos ou filhos de escravos que haviam sido alforriados. O Code Noir incorporava a tradição romana da alforria como forma de diminuição das pressões do sistema escravista. Ele também consagrava o princípio da igualdade dos homens livres, reconhecendo, no seu art.59, aos homens de cor, negros ou mestiços, nascidos livres ou em cativeiro, os mesmos direitos que aos brancos. ${ }^{636} \mathrm{O}$ código, produto de uma época de escassez de mulheres brancas nas colônias, traduzia a necessidade de ampliar a população "francesa" desses territórios por meio de casamentos inter-raciais. ${ }^{637}$ Numa época em que ainda não havia direitos políticos, a cor, em princípio, não definia juridicamente os indivíduos.

Por muito tempo, a origem escrava não foi considerada de forma rígida para a categorização racial da população livre das colônias francesas. A exemplo do que acontecia no Brasil, o status social do indivíduo se baseava mais na riqueza do que na cor e famílias ricas de origem mestiça tendiam a se integrar à elite colonial. Essa

\footnotetext{
${ }^{633}$ Mirabeau tinha uma visão diferente dessa questão: para ele, o preconceito era uma decorrência da escravidão e desapareceria com o fim desta.

${ }^{634}$ Cf. CLARKSON, Thomas. History of the Rise, Progress and Accomplishment of the Abolition of the Slave Trade, pp.392-393.

${ }^{635}$ Trabalhadores recrutados durante o Antigo Regime para povoar as colônias francesas da América e submetidos a um regime de trabalho remunerado, mas semelhante à servidão. Correspondiam aos indentured servants das colônias britânicas.

${ }^{636}$ Cf. Code Noir (1685). Disponível em: http://www.axl.cefan.ulaval.ca/amsudant/guyanefr1685.htm.

${ }^{637}$ Cf. HALL, Gwendolyn Midlo. Social Control in Slave Plantation Societies, p.139.
} 
tendência era particularmente forte no Sul de São Domingos, onde brancos e mestiços se uniam em relações econômicas, sociais e familiares. Muitos mestiços eram vistos simplesmente como brancos, razão pela qual o censo de 1703 listava apenas 500 pessoas de cor livres em São Domingos. ${ }^{638}$

A importância dos livres de cor nas diferentes sociedades coloniais variava de um lugar para outro. Em São Domingos, eles ocupavam um lugar proeminente. A população mestiça livre havia crescido consideravelmente ao longo do tempo, especialmente após a Guerra dos Sete anos, passando de 5.500, em 1764, a 27.548 às vésperas da Revolução. Isso representava $89,4 \%$ da população branca da colônia. ${ }^{639}$ Esse crescimento demográfico estava relacionado, em parte, à ascensão econômica de um importante segmento da população mestiça.

Como diz Geggus, os homens de cor formavam mais uma categoria legal do que uma classe. ${ }^{640}$ As expressões gens de couleur, affranchis, mulâtres e sang-mêlés, comumente empregadas à época, mas também pela historiografia mais moderna, tendem a amalgamar uma variedade de situações e comportamentos. Os livres de cor eram, na sua maioria, artesãos, pequenos comerciantes e pequenos proprietários. Havia, entretanto, uma boa parcela de ricos plantadores e senhores de escravos, sobretudo no Sul e no Oeste da ilha. Esses proprietários de cor participaram do crescimento econômico de São Domingos após a Guerra dos Sete anos e se enriqueceram profundamente. Nos anos 1780, eles estavam envolvidos em 44\% das transações de terra no Sul da ilha e 57\% das vendas de escravos. Em 1789, eles possuíam cerca de um terço das plantações e um quarto dos cativos de São Domingos. ${ }^{641}$ Em princípio, não havia motivos para que houvesse, entre esses livres de cor e os plantadores brancos, uma oposição de classe: ambos exerciam a mesma atividade produtiva e beneficiavamse do mesmo sistema baseado na mão de obra escrava. A relação que se dava entre eles era mais de concorrência do que de oposição. ${ }^{642} \mathrm{~A}$ força dos livres de cor residia no fato

\footnotetext{
${ }^{638}$ Cf. GARRIGUS, John D. Before Haiti, pp.11, 44, 49-53.

${ }^{639}$ Cf. GHACHEM, Malick W. The Old Regime and the Haitian Revolution, p.77. Segundo número de Barbé Marbois, na Martinica, em 1987, eram 4.166 livres de cor, 11.008 brancos e 81.978 escravos; na Guadalupe, 1.877 livres de cor, 12.039 brancos e 82.978 escravos; em Caiena, 1.762 livres de cor, 1.346 brancos e 10.430 escravos. Bénot adverte que esses números, apresentados por Barbé de Marbois, embora oficiais, são pouco confiáveis (cf. BÉNOT, Yves. La Révolution française et la fin des colonies, p.60).

${ }^{640}$ Cf. GEGGUS, David Patrick. Haitian Revolutionary Studies, p.6.

${ }^{641}$ Cf. GARRIGUS, John D. Before Haiti, p.177; BÉNOT, Yves. La Révolution française et la fin des colonies, p.61.

${ }^{642}$ Nas demais colônias, a ascensão social dos livres de cor não havia ocorrido com a mesma intensidade. $\mathrm{Na}$ Martinica e na Guadalupe, os mulatos cumpriam, na sua maioria, funções de artesãos ou feitores,
} 
de que, ao contrário de boa parte dos plantadores brancos, que estavam apenas de passagem pela colônia, eles eram nascidos na ilha e não tinham uma segunda pátria. Não se viam como colonos, mas como verdadeiros filhos de São Domingos. No intuito de iniciar sua fortuna, muitos brancos que chegavam à ilha buscavam casar-se com mulheres de cor, em razão de suas posses e conhecimentos da sociedade colonial. ${ }^{643}$

Ao longo do século XVIII, entretanto, conforme a economia colonial crescia, o estigma da origem servil passou a se manifestar por meio de uma série de ordenações locais ou ministeriais, que multiplicaram as interdições e restrições aos homens de cor livres em São Domingos. As razões para isso eram múltiplas. A concorrência entre ricos plantadores brancos e mulatos pode ter tido sua influência, mas não deve ser vista como um fator essencial. O fato é que o aumento desproporcional da população escrava em relação à população branca gerava preocupações na Administração quanto à manutenção da ordem. Havia, por exemplo, questionamentos relativos ao impacto de alforrias excessivas na sociedade colonial, problema já abordado por Montesquieu no Espírito das Leis. A alforria era vista ora como uma forma de aliviar as pressões do sistema escravista, ora como um fator de subversão das hierarquias a ele inerentes. Temia-se, assim, o aumento excessivo de uma classe de indivíduos juridicamente livres, mas ainda ligados, por suas origens, ao mundo dos escravos. Desde as primeiras décadas do século XVIII, restrições foram impostas à alforria, tradicionalmente submetida ao império do senhor. ${ }^{644}$ De fato, o número de manumissões caiu drasticamente no último quartel do século XVIII, chegando a 739 em 1785 e 259 em 1789. As restrições à alforria se inseriam no quadro de uma política mais ampla, que procurava rebaixar os homens de cor livres à condição de cidadãos de segunda classe. ${ }^{645}$

Autoridades metropolitanas e coloniais decidiram consolidar a supremacia branca, degradando a posição social dos livres de cor com base na ideia de que a escravidão deixava uma marca indelével nos negros e seus descendentes. Uma forma comum de atacá-los era associá-los ao vício das relações extra-conjugais, isto é, vê-los

associando-se, assim, às atividades dos brancos (cf. BÉNOT, Yves. La Révolution française et la fin des colonies, pp.61-62).

${ }^{643}$ Cf. GARRIGUS, John D. Before Haiti, pp.47-48.

${ }^{644}$ A partir de 1711, as alforrias passaram a requerer autorização escrita dos administradores coloniais e, entre o final dos anos 1730 e início dos 1740, elas foram submetidas ao pagamento de um imposto de 800 libras. Esse imposto chegou a ser reduzido temporariamente a 300 libras pelo Governador d'Estaing, que queria aumentar a população dos livres de cor, para fazer deles a espinha dorsal da colônia. Suas reformas não sobreviveram ao seu mandato, encerrado prematuramente em 1766. Em 1775, o valor foi aumentado para mil libras para homens e 2 mil libras para mulheres de menos de 40 anos (Ibidem, pp.122-123)

${ }^{645}$ Cf. GHACHEM, Malick W. The Old Regime and the Haitian Revolution, p.79-8; 118-119. 
necessariamente como produto da luxúria e da licença. Uma ordenação de 1726 declarou que negros livres, seus filhos e descendentes não poderiam no futuro receber ou herdar bens de brancos, sob pena de confisco. Em 7 de outubro de 1733, por ordem do governador, não apenas os mestiços, mas também os brancos que tivessem desposado mulheres de cor foram excluídos dos cargos de judicatura e da oficialidade da milícia. Em 1758, o Conselho do Cap proibiu os homens de cor de portarem espadas e sabres, com exceção dos militares ou aqueles que estivessem em serviço. Ainda em 1758, uma proclamação do Conselho do Cap passou a exigir que negros e mulatos forros registrassem sua liberdade no prazo de três meses da sua alforria, sob o risco de não serem considerados livres. Em 24 de setembro de 1761, o mesmo Conselho decidiu que todos os atos cartoriais deveriam mencionar a origem das pessoas: livre, se de origem europeia; alforriado, se de origem africana. Em 17 de abril do ano seguinte, diante da carência de subsistências em São Domingos, um juiz de polícia do Cap proibiu aos padeiros que vendessem pão aos livres de cor e, aos negociantes das ilhas, que lhes vendessem farinhas; em 29 de maio, foi proibido aos homens de cor comprar armas e munições. A partir de 1763, esses homens já não podiam mais viajar para a França, a não ser com uma persmissão especial. ${ }^{646}$

Após a Guerra dos Sete anos, a legislação segregacionista se ampliou, em razão do incremento da população escrava, assim como da ascensão econômica dos livres de cor. Nessa época, entretanto, outro fator veio alimentar a tendência ao segregacionismo na Administração. Como aponta John Garrigus, havia um certo ceticismo quanto à lealdade dos colonos brancos em relação à metrópole e acreditava-se que a segregação permitiria solidificar a população branca das colônias em torno de uma identidade francesa que seria negada aos livres de cor. Sentia-se a necessidade de criar uma "linha de cor" rígida em São Domingos, de modo a estabelecer um forte vínculo cultural e político entre os brancos da colônia e a metrópole e, com isso, afastar as ameaças de separação, muito vívidas após um conflito em que a França havia praticamente abandonado as suas colônias caribenhas. Muitos quadrarões ricos, antes vistos como "brancos" pela sociedade crioula, eram agora reclassificados como "alforriados", o que também ajuda a explicar o aumento da população de cor livre ao longo do século XVIII. Essa onda discriminatória foi reforçada pela chegada em massa, na década de 1760, de

\footnotetext{
${ }^{646}$ Cf. GAUTHIER, Florence. L'aristocratie de l'épiderme, pp.55-56; GHACHEM, Malick W. The Old Regime and the Haitian Revolution, p.91; HALL, Gwendolyn Midlo. Social Control in Slave Plantation Societies, pp.142-143.
} 
novos imigrantes brancos a São Domingos. Eram, no geral, jovens que queriam fazer fortuna como plantadores de café, produto que exigia menores investimentos (cada plantação de café reunia, em média, 33 escravos, contra 100 para as de açúcar). Contudo, desprovidos de capital suficiente e de oportunidades, eles acabavam muitas vezes reclusos nos portos da ilha. Suas frustrações, que contrastavam com a ascensão econômica de proprietários de cor, ajudaram a reforçar o segregacionismo. Eram esses elementos os mais ferrenhos adversários dos homens de cor livres: queriam fazer do preconceito um instrumento de degradação social de uma população mais abastada, mais talentosa e que tendia a se tornar mais numerosa. A agressividade desses petitsblancs se manifestaria intensamente durante a Revolução. ${ }^{647}$

A partir do final da Guerra, as proibições aos mulatos se multiplicaram. Em 30 de abril de 1764, por exemplo, determinou-se a proibição do exercício da medicina e da cirurgia aos não brancos. Já uma ordenação de 1767, do ministro das relações exteriores Choiseul, proibiu aos mulatos o acesso a qualquer função pública. Mesmo nas suas próprias milícias, os homens de cor não podiam mais, a partir de 1769, tornar-se oficiais. Em 1773, as pessoas de cor foram proibidas de portar nomes de família brancas, devendo, a partir de então, usar apenas nomes "africanos". Também ficavam proibidas de sentar-se à mesa de brancos. Casamentos mistos foram proscritos. Uma ordenação de 9 de fevereiro de 1779 vedou-lhes o luxo vestuário, assim como o uso das mesmas roupas utilizadas pela população branca das colônias, para evitar qualquer aproximação. A origem servil permitia relegar os homens de cor - ou sang-mêlés, como passaram a ser chamados - à categoria de "alforriados", mesmo quando nascidos livres. Como diz James, um único "privilégio" lhes era permitido: o de emprestar dinheiro ao homem branco. ${ }^{648}$

É verdade que essas proibições nem sempre eram rigorosamente aplicadas e, no final do Antigo Regime, grande parte delas tinha caído em desuso. Sua aplicação na década de 1780 era laxista e não impediu a ascensão econômica de muitos proprietários e plantadores de cor. Aliás, imigrantes brancos continuaram a buscar o casamento com mulheres mestiças nos anos $1780 .{ }^{649}$ Contudo, a mera existência dessas leis dava força ao preconceito, que tornava-se, aos olhos dos colonos, uma poderosa arma ideológica de

\footnotetext{
${ }^{647}$ Cf. GARRIGUS, John D. Before Haiti, pp.5-8, 86, 118, 143-144, 173-174, 197.

${ }^{648}$ Cf. JAMES, C.L.R. Os jacobinos negros, p.52; GAUTHIER, Florence. L'aristocratie de l'épiderme, pp.55-56

${ }^{649}$ Cf. GHACHEM, Malick W. The Old Regime and the Haitian Revolution, p.240; GARRIGUS, John D. Before Haiti, pp.170-172, 178; BÉNOT, Yves. La Révolution française et la fin des colonies, p.59.
} 
manutenção da ordem escravista num momento em que a população escrava assumia proporções inéditas. Como escreveu Hilliard d'Auberteuil em 1777:

Em todos os povos que tiveram escravos, os filhos ou netos dos alforriados eram considerados ingênuos; mas, em São Domingos, o interesse e a segurança exigem que esmaguemos a raça dos Negros com tamanho desprezo que qualquer de seus descendentes, até a sexta geração, esteja coberto de uma mancha indelével. ${ }^{650}$

Na mesma linha, J.-Félix Carteau, antigo plantador de São Domingos, escreveria em 1802:

Na medida em que o regime colonial, isto é, a força que continha os escravos na ordem e na submissão, dependia, assim, muito mais desse útil preconceito do que dos meios coercitivos, desferir o menor golpe nessa ideia, enfraquecer neles essa espécie de servidão moral, apagando a linha de demarcação entre as duas cores originais e distintas, teria sido quebrar os únicos vínculos que, mesmo após a liberdade dada a todo escravo, conservando-os ainda um degrau enorme abaixo dos Brancos, mantinham íntegra essa salutar opinião, e consequentemente garantiam a subordinação, o trabalho e a tranquilidade pública. [...] A inalterável supremacia da espécie branca era, portanto, uma força fictícia, simples, cômoda, isenta de gastos e esforços, que, agindo incessantemente sobre o espírito dos escravos, os continha pacientemente em seu estado: é por meio desse prestígio, invariável e permanente, que cerca de 600 mil Negros, continuamente armados de instrumentos ofensivos, ferramentas de arte ou de cultura, tinham, até então, obedecido sem murmúrio a um punhado de senhores. ${ }^{651}$ (itálicos no original)

O crescimento da produção açucareira do Caribe francês, e a consequente entrada massiva de escravos nas colônias, impunham, na visão dos colonos brancos, a necessidade de criar uma barreira ideológica, sem a qual a extrema desproporção entre escravos e livres tornaria a conservação da ordem impossível. Assim, muitos na

\footnotetext{
650 "Chez tous les peuples qui ont eu des esclaves, les fils ou petit-fils des affranchis, étaient réputés ingénus; mais à Saint-Domingue, l'intérêt et la sûreté veulent que nous accablions la race des Noirs d'un si grand mépris, que quiconque en descend, jusqu'à la sixième génération, soit couvert d'une tache inéfaçable" (Cf. HILLIARD D'AUBERTEUIL, Michel René. Considérations sur l'état présent de la colonie française de Saint-Domingue. Paris: Chez Grangé, 1776-77, v.2, p.73).

651 "Le régime Colonial, ou la force qui contenait les esclaves dans l'ordre et dans la soumission, dépendant ainsi bien plus de cet utile préjugé, que des moyens coercitifs, donner la moindre atteinte à cette idée, affaiblir en eux cette sorte de servitude morale, en effaçant la ligne de démarcation entre les deux couleurs originelles et distinctes, ç'eut été briser imprudemment les seuls liens, qui, même après la liberté donnée à tout esclave, les tenant encore d'un cran enorme au-dessous des Blancs, conservaient en entier cette salutaire opinion, et conséquemment assuraient la subordination, le travail et la tranquillité publique. [...] L'inaltérable suprématie de l'espèce blanche était donc une force fictive, simple, aisée, exempte de dépense et d'efforts, qui, sans cesse agissait sur l'esprit des esclaves, les contenait patiemment dans leur état: c'est au moyen de ce prestige, invariable et permanente, que près de 600 mille Noirs, armés continuellement d'instruments offensifs, soit outils d'art ou de culture, avaient jusqu'alors obéi sans murmure à une poignée de maîtres" (CARTEAU, J.-Félix. Soirées bermudiennes, ou Entretien sur les évènemens qui ont opéré la ruine de la partie française de l'isle de Saint-Domingue. Bordeaux: chez Pellier-Lawalle, 1802, pp.60-61).
} 
sociedade colonial viam o mero sinal de reconhecimento da virtude dos homens de cor como algo perigoso. Em 1789, Moreau de Saint-Méry chegou a ser taxado de abolicionista por ter projetado dar uma medalha de virtude ao negro livre Jean Jasmin, responsável pela construção de um hospício na colônia. ${ }^{652}$ A segregação - isto é a separação jurídica estrita entre brancos e negros - tornava-se um elemento-chave daquela sociedade, marcada pela constituição de uma nova aristocracia, a da epiderme.

O mais leve traço de ancestralidade negra já era suficiente para acender o estigma da origem cativa. Brancos casados com mulheres de cor e pais de filhos mestiços sofriam com a rejeição da sociedade colonial. O preconceito tendia a ser particularmente forte entre os chamados petits blancs, os brancos mais pobres da colônia: artesãos dos portos, marinheiros, pequenos exploradores endividados, homens desprovidos de terra, miseráveis, esses homens não suportavam testemunhar a ascensão social dos livres de cor e procuravam fazer da cor da pele um sinal distintivo que lhes garantisse um certo status social, unindo-os ideologicamente aos grandes plantadores.

O barão de Wimpffen, oficial alemão adepto das novas ideias, escreveu, pouco tempo após chegar a São Domingos: "[...] é aqui a cor da pele que, em todas as nuances entre o branco e o negro, faz às vezes das distinções de status, de mérito, de nascimento, de honras, e mesmo de fortuna". Segundo ele, o respeito pela cor branca era "a lei suprema, o paládio ao qual estava vinculado o destino das colônias". ${ }^{653}$

Essa situação paradoxal, em que se mesclavam preconceito e ascensão econômica, alimentava a consciência política da população de cor. Os homens de cor reagiam à discriminação utilizando todos os recursos legais disponíveis. Eram, assim, bastante meticulosos em registrar todos os seus atos com documentos notariais para proteger seu status e seus interesses. Também recorriam constantemente ao Judiciário para fazer valer suas pretensões. ${ }^{654}$ Nos anos 1780, eles começaram a organizar-se politicamente como grupo de pressão.

Essa consciência política não os levou a uma contestação do sistema escravista. Ao contrário, grande parte dos homens de cor beneficiava-se dele na condição de proprietários de plantações e de escravos. Além disso, eles cumpriam uma função indispensável para a manutenção da ordem. Sua habilidade, seu maior conhecimento do

\footnotetext{
${ }^{652}$ Cf. GARRIGUS, John D. Before Haiti, p.221.

653 "[...] c'est ici la couleur de la peau qui, dans toutes les nuances du blanc au noir, tient lieu des distinctions du rang, du mérite, de la naissance, des honneurs, et même de la fortune"; "la loi suprême, le palladium auquel tient la destinée des colonies" (WIMPFFEN, Alexandre-Stanislas de. Haïti au XVIIIe siècle, p.76-77).

${ }^{654}$ Cf. GHACHEM, Malick W. The Old Regime and the Haitian Revolution, pp.92-96.
} 
terreno e seus contatos com o mundo dos escravos faziam dos mulatos os mais indicados para a defesa da sociedade escravista. Eles eram obrigados a servir nas milícias para negros e homens de cor livres, destinadas à defesa da colônia contra invasões externas. Além disso, muitos deles, sobretudo a sua parcela mais pobre, compunham a maréchaussée (marechalato), força destacada para a busca e captura de escravos fugitivos ou perigosos. ${ }^{655}$ Comandado por oficiais brancos, o serviço na maréchaussée era particularmente duro e brutal, exigindo muitas vezes a aplicação de penas corporais e capitais nos fugitivos. Com o tempo, as milícias foram praticamente incorporadas à maréchaussée e, portanto, à função de polícia da escravaria. A partir de 1775, o serviço armado tornou-se um meio de aquisição da liberdade para negros ou pessoas de cor em "estado duvidoso", sem pagamento de imposto: negros ou mulatos livres de fato, desprovidos de documentos, serviam por dez anos em troca da liberdade legal. Para a Administração, era uma forma de canalizar a concessão de alforrias no sentido da defesa da ordem. ${ }^{656}$

O serviço armado dos homens de cor era essencial para a conservação da sociedade escravista. Ao mesmo tempo, ele praticamente livrava a população branca das responsabilidades cívicas de defesa da colônia, o que permitia reforçar a sua fidelidade à pátria francesa. Se para alguns homens de cor, o serviço armado era uma via para garantir o seu status de livres, para os elementos mais abastados dessa população, ele era humilhante. ${ }^{657} \mathrm{O}$ que é certo, entretanto, é que a sua importância na repressão dos atos de resistência escrava lhes dava um trunfo, permitindo apresentar a luta pelos seus direitos como um combate pela manutenção da ordem escravista.

A política real relativa aos homens de cor não era consistente, variando muito de um ministério para outro. Se, num momento, podia prevalecer o entendimento de que a estabilidade da sociedade colonial exigia fazer dos homens de cor livres uma classe intermediária de habitantes, entre brancos e escravos, num outro, prevalecia a consciência de que era essa população que mantinha intacta a ordem escravista. Se alguns sustentavam a necessidade de degradar os homens de cor para solidificar os vínculos dos colonos brancos com a metrópole, outros acreditavam na necessidade de garantir a lealdade da população mestiça, principal barreira contra a revolta escrava.

\footnotetext{
${ }^{655}$ Cf. JAMES, C.L.R. Os jacobinos negros, p.49; FICK, Carolyn. The making of Haiti, pp.20-21.

${ }^{656}$ Cf. GHACHEM, Malick W. The Old Regime and the Haitian Revolution, pp.111-115, 121-122.

${ }^{657}$ Cf. GARRIGUS, John D. Before Haiti, pp.109-113, 197, 204-206, 213-214.
} 
Assim, nos últimos anos de Antigo Regime, um diálogo foi estabelecido entre alguns representantes dos homens de cor de São Domingos e o poder real. Difundia-se no Ministério da Marinha a ideia de que as leis discriminatórias enfraqueciam aquela que era a mais forte barreira contra a rebelião escrava e que era preciso estimular o patriotismo dos livres de cor. ${ }^{658}$ Uma participação dos mulatos na guerra da América lhes tinha valido a simpatia dos meios oficiais. Em 1779, uma unidade de pessoas de cor, os Chasseurs Volontaires, tinha sido enviada para a Geórgia, para lutar ao lado das forças revolucionárias americanas sitiadas pelos britânicos em Savannah. ${ }^{659}$ Durante o seu mandato no ministério da Marinha, o marechal de Castries tinha empreendido alguns esforços em favor dos homens de cor, reconhecendo a sua importância para a manutenção da ordem nas colônias. ${ }^{660}$

Como, na colônia, as reformas tentadas pelo ministério encontravam uma forte oposição, a população de cor livre sabia que as iniciativas em seu favor teriam de vir da metrópole. Isso levou representantes dessa população de cor livre, muitos deles proprietários de escravos, a se apresentarem em Paris para reivindicar a igualdade de direitos com os brancos das ilhas. O principal nome desse "lobby" dos cidadãos de cor da colônia era Julien Raimond.

Nascido em 1744, Raimond era um quadrarão, filho legítimo de um colono francês e de uma mulata, e herdeiro de uma importante fortuna no Sul de São Domingos. Quando jovem, tinha sido enviado a Bordeaux e Toulouse para estudos, ao lado de seus irmãos. Retornou a São Domingos nos anos 1760, quando os progressos do preconceito começavam a se fazer sentir. Isso não o impediu de tornar-se um rico plantador, dono de uma centena de escravos. À medida que os primeiros movimentos de resistência começavam a ser organizados, Julien Raimond assumiu o papel de principal representante dos homens de cor do Sul. Embora se apresentasse como um porta-voz da

\footnotetext{
${ }^{658}$ Cf. GHACHEM, Malick W. The Old Regime and the Haitian Revolution, p.120; GARRIGUS, John D. Before Haiti, pp.215-216.

${ }^{659}$ Os Chasseurs Volontaires d'Amérique eram uma unidade temporária composta por homens de cor, criada durante a Guerra dos Sete anos, para reforçar a defesa de São Domingos. Em 1779, essa companhia foi reformada e enviada para Savannah. A participação dos mulatos na Guerra de independência americana lhes tinha valido experiência militar e uma nova consciência política sobre a sua importância. De fato, vários dos principais líderes mulatos do período revolucionário tinham integrado o destacamento enviado à Geórgia: André Rigaud, Jean-Baptiste Chavannes, J.B. Villate, Louis-Jacques Bauvais (cf. GARRIGUS, John D. Before Haiti, p.116, 207-208; GEGGUS, David Patrick. Haitian Revolutionary Studies, p.8; GHACHEM, Malick W. The Old Regime and the Haitian Revolution, p.115). ${ }^{660} \mathrm{Em} \mathrm{1784}$, Castries foi responsável, por exemplo, pela supressão do serviço do piquete em São Domingos, que havia sido imposto aos negros e mulatos livres por decisão ministerial de 14 de março de 1741. O serviço seria, entretanto, restabelecido pelo governador Du Chilleau em 1788 (cf. GAUTHIER, Florence. L'aristocratie de l'épiderme, pp.368-369).
} 
população de cor de São Domingos, Raimond militava, acima de tudo, pelos interesses de quadrarões abastados como ele. Numa petição bastante reveladora, enviada ao rei, ele chegaria a argumentar que pessoas ricas, bem nascidas e educadas, de pele clara, sem parentes na escravidão, deveriam ser consideradas "novos brancos". Assim, ele não expressava necessariamente pontos de vista ou situações outras que os das famílias de cor abastadas do Sul. ${ }^{661}$ Já em 1783, numa tentativa de obter reconhecimento junto à realeza, Raimond organizou uma coleta de 9.410 libras entre os homens de cor da paróquia de Aquin para contribuir para a doação de um navio que a colônia oferecia ao rei. ${ }^{662} \mathrm{~A}$ oferta foi rejeitada pelos colonos segregacionistas, mas essa primeira ação comum foi o ponto de partida para a constituição de um movimento de pressão pelos direitos dos homens de cor livres. Em 1784, após ter conseguido uma autorização ministerial, Raimond se transferiu para a metrópole, onde se dedicou a esclarecer o aparecimento e os efeitos do preconceito de cor. ${ }^{663}$

No mesmo ano, Julien Raimond foi apresentado por Bellecombe, administrador colonial, ao ministro Castries, a quem submeteu uma série de memoriais sobre a situação das pessoas de cor livres. Interessado pela questão, Castries se comprometeu a remeter os memoriais às autoridades de São Domingos. ${ }^{664}$ Naquele momento, outros textos favoráveis aos homens de cor livres chegavam da Guiana. ${ }^{665}$ Em 11 de março de 1786, Castries enviou uma petição de Raimond a La Luzerne, governador de São Domingos que o sucederia no ministério no ano seguinte. Embora tivesse demonstrado interesse pela causa dos livres de cor e garantido a Raimond que cuidaria do assunto, La Luzerne não empreendeu grandes esforços para fazer avançar a questão e, às vésperas da Revolução, nenhuma decisão havia sido tomada a esse respeito. A saída de Castries do ministério, em 1787, privou Raimond de um importante interlocutor e, se a década de 1780 havia testemunhado algumas tentativas modestas de reforma por parte da Monarquia para atenuar o preconceito, a resistência dos segregacionistas tinha sido eficaz. A convocação dos Estados Gerais havia, entretanto, renovado as esperanças das

\footnotetext{
${ }^{661}$ Cf. GEGGUS, David Patrick. Haitian Revolutionary Studies, p.162. GARRIGUS, John D. Before Haiti, pp.220, 227-228.

${ }^{662}$ Cf. RAIMOND, Julien. Observations adressées à l'Assemblée nationale, par un député des colons amériquains. S.1.: s.n., 1789, pp.6-7.

${ }^{663}$ Cf. GAUTHIER, Florence. L'aristocratie de l'épiderme, pp.15-16.

664 Cf. RAIMOND, Julien. Réclamations adressées à l'Assemblée nationale par les personnes de couleur... de Saint-Domingue. S.1.: 1790, pp.5-6.

${ }^{665}$ Dois administradores da Guiana, Fitz-Maurice e Lescallier, sugeriam que, na quarta ou quinta geração, os homens de cor livres fossem assimilados aos brancos (cf. DEBIEN, Gabriel. Les colons de SaintDomingue et la Révolution, pp.38-39).
} 
pessoas de cor. Personagem importante e trágico da história colonial da Revolução, Vincent Ogé, outro quadrarão livre e de pele clara, comerciante de São Domingos ${ }^{666}$, decidiu transferir-se, no final de 1788, para a França, com o objetivo de reforçar o movimento em favor dos homens de cor livres.

Com a convocação dos Estados Gerais, a população de cor de São Domingos moveu, a exemplo dos Brancos, esforços para ter seus representantes admitidos na Assembleia. Pediram ao marquês Du Chilleau, governador de São Domingos, permissão para se reunirem em conformidade com o edito de convocação, mas seu pedido permaneceu sem resposta. Em 15 de março de 1789, os livres do Sul de São Domingos endereçaram, agora ao Ministro da Marinha, um pedido de representação nos Estados Gerais, ao que lhes foi respondido, em agosto, que qualquer decisão a esse respeito era da competência da Assembleia Constituinte. ${ }^{667}$ Entre os meses de julho e setembro de 1789, homens de cor vindos da colônia se reuniram a outros residentes em Paris para reclamar a admissão de uma deputação de cor na Assembleia Nacional. Panfletos expondo a situação de opressão em que viviam os mestiços das colônias começavam a aparecer em Paris. ${ }^{668}$ Em 29 de agosto, após obterem permissão de La Fayette e Bailly, dezenas desses livres de cor (dentre os quais havia alguns poucos negros livres) formariam, na casa de um advogado branco, Étienne-Louis Hector de Joly ${ }^{669}$, uma Sociedade de cidadãos de cor. Cerca de $70 \%$ de seus membros eram provenientes de São Domingos, muitos deles recém-chegados, mas também havia uma boa quantidade de mulatos que haviam se estabelecido na França nas décadas anteriores. Embora não seja fácil estabelecer a ocupação de todos os membros da Sociedade, o fato é que a liderança logo seria assumida por proprietários nas colônias. Era, acima de tudo, o ponto de vista dessa parcela da população de cor de São Domingos que seria representado por esse grupo. ${ }^{670}$

\footnotetext{
${ }^{666}$ Cf. THIBAU, Jacques. Le temps de Saint-Domingue, p.85.

${ }^{667}$ Cf. GAUTHIER, Florence. L'aristocratie de l'épiderme, p.27.

${ }^{668}$ É o caso do Précis des gémissements des sang-mêlés dans les Colonies Françaises (Paris: Baudouin, 1789), texto escrito por um "J.M.C. Americano, mestiço", mas, segundo Grégoire, de autoria de um mulato chamado Boirond Barbaud-Royer (cf. GRÉGOIRE, De la littérature des nègres, p.188).

${ }^{669}$ Advogado nos conselhos do rei e adepto das novas ideias, Étienne de Joly (1756-1837) seria, a partir de julho de 1792, o último ministro da Justiça de Luís XVI.

${ }^{670}$ Cf. Dictionnaire des gens de couleur dans la France moderne. Paris et son bassin. Érick Noël (org.). Genebra: Librairie Droz, 2011, pp. pp.83, 99-103, 107-110, 117, 153, 154-156, 172, 174, 181-182, 191, 196, 201-205, 246-247, 252-254, 268-279.
} 
Em 26 de agosto, antes de entrar para a Sociedade dos cidadãos de cor, Raimond tinha sido recebido no Clube Massiac, onde lhe tinha sido dito que o estado das pessoas de cor era uma questão interna das colônias, a ser decidida pelas assembleias coloniais. No dia seguinte, o Clube Massiac enviou uma carta circular às cidades marítimas, alertando que os Amigos dos Negros preparavam-se para enviar emissários de cor às ilhas, no intuito de insurgir os escravos. Apontou, assim, a necessidade de impedir a partida de qualquer negro ou mulato para São Domingos. As autoridades de Saint-Malo, Le Havre e Nantes responderam afirmativamente, ao passo que as de Bordeaux e La Rochelle afirmaram a necessidade de uma aliança entre brancos e homens de cor livres. ${ }^{671}$ Não havia unanimidade, dentro do campo colonial, a respeito da questão.

Em 7 de setembro, seria a vez de Ogé ser recebido no Clube Massiac, onde apresentou um projeto de reformas visando à conservação das propriedades nas colônias. Querendo mostrar-se alinhado com as preocupações dos colonos do Clube, atacou o despotismo ministerial e defendeu a liberdade no comércio. Sustentou a necessidade de dar a igualdade imediata a todos os cidadãos livres, mas, talvez de forma imprudente, tocou também no tema da escravidão, defendendo a atribuição da liberdade a todos os homens, de forma escalonada e sob certas condições. Pregava, no fundo, uma união dos proprietários de todas as cores para presidir esse processo gradual de emancipação dos escravos, única forma de evitar uma revolta generalizada nas colônias. ${ }^{672}$ Em 9 de setembro, De Joly, acompanhado por dois comissários, também se apresentou perante os colonos do Clube, para defender uma representação dos homens de cor livres na Assembleia. O Clube reiterou, por meio de uma carta de Billard, que essa questão era um assunto interno da colônia e só podia ser decidida por uma assembleia colonial regularmente convocada.

Em 12 de setembro, a sociedade dos livres de cor assumiu o nome de Société des Citoyens de Couleur, colons américains. Ao longo do mês de setembro, esses colonos americanos se dedicaram à redação de seu próprio caderno de queixas. ${ }^{673}$ Este tinha por base o princípio da divisão dos habitantes das colônias em duas classes: homens livres e escravos. Os livres compreendiam, é claro, os brancos e todos os homens de cor, negros ou mestiços. Retomava-se, assim, a regra do Code Noir segundo a qual todos os

\footnotetext{
${ }^{671}$ Cf. Carta a Mosneron, 5 de setembro de 1789, ADLA C 608 fl.71; THIBAU, Jacques. Le temps de Saint-Domingue, p.230.

${ }^{672}$ Cf. OGÉ JEUNE, Vincent. Motion faite à l'Assemblée des Colons Habitans de S. Domingue, à l'Hôtel de Massiac, Place des Victoires. S.1. [Paris]: s.n., s.d. [1789], pp.1-6.

${ }^{673}$ Cf. THIBAU, Jacques. Le temps de Saint-Domingue, p.221.
} 
alforriados e seus descendentes gozavam dos mesmos direitos e prerrogativas dos demais colonos (cf. artigos I e II). O caderno exigia a abolição de todas as distinções entre homens livres, o que implicava abrir aos livres de cor todas as funções do governo civil, da judicatura e do serviço militar, ficando abolida a formação de companhias distintas para não brancos. Ficaria também abolida a prática de indicar, em atos notariais e certificados de batismo e casamento, a cor da pessoa. Pedia-se ainda a revogação da proibição de casamentos entre brancos e pessoas de cor (art.XXI). O tema da escravidão aparecia por meio de uma política de emancipações em favor de mulheres grávidas e de filhos mestiços, assim como uma simplificação dos processos de alforria, inclusive com a abolição do imposto sobre os mesmos (artigos XXVII-XVIII). A ideia era garantir a liberdade de todos os mulatos e pessoas de cor que não as negras, de modo que não houvesse mais nenhum mestiço na escravidão (art.XX). O art.XXI dispunha ainda que todos os negros que pisassem em solo metropolitano, mesmo que acompanhados de seus senhores, seriam e permaneceriam livres. Por outro lado, o art. XXIX reforçava a proibição, já presente no Code Noir, das vias de fato por parte de escravos contra cidadãos de qualquer cor. No geral, o caderno expressava, acima de tudo, o projeto de uma consolidação da classe dos senhores de escravos, de todas as cores, que se uniriam nas Assembleias coloniais para determinar o regime interno da colônia. ${ }^{674}$

Naquele momento, algumas vozes na metrópole se erguiam em favor das pessoas de cor. O abade Cournand, com quem Raimond havia entrado em contato, denunciou aos deputados da Assembleia a existência de uma "conspiração geral dos Brancos" contra esses homens livres e industriosos, com o objetivo de rebaixá-los à condição de escravos. A obsessão existente nas colônias em torno da origem das pessoas havia se tornado um instrumento de exclusão de cidadãos inocentes. $\mathrm{O}$ preconceito havia gerado um novo tipo de aristocracia: "os brancos, com esse fantasma de sangue misto, fundaram, sob o trópico, uma aristocracia tão perigosa, e bem menos especiosa que a da Europa: na Europa, é a nobreza do nome; na América, é a da pele" (em itálico no original). ${ }^{675}$

\footnotetext{
${ }^{674}$ Cf. Cahier, contenant les Plaintes, Doléances et Réclamations des Citoyens-libres et Propriétaires de Couleur, des Isles et Colonies Françoises S.1.: s.n., s.d [1789], pp.1-15.

675 "les blancs, avec ce fantôme de sang mêlé, ont fondé, sous le tropique, une aristocratie aussi dangereuse, et bien moins spécieuse que celle d'Europe: en Europe, c'est la noblesse du nom; en Amérique, c'est celle de la peau" (COURNAND, Antoine de. Requête présentée à Nosseigneurs de l'Assemblée Nationale, en faveur des gens de couleur de l'île de Saint-Domingue. Paris: s.n., s.d. [1790], p.5).
} 
O apelo de Cournand, entretanto, estava essencialmente voltado para os direitos de plantadores como Raimond. O abade sustentava que os homens de cor, muitos deles ricos proprietários nas colônias, deveriam ter seus direitos de cidadania reconhecidos, para que pudessem eleger seus representantes na Assembleia Nacional. Pedia fundamentalmente que, eliminadas as distinções baseadas na cor da pele, as pessoas de cor proprietárias pudessem ter acesso a todos os empregos civis e militares, assim como gozar das mesmas prerrogativas dos Brancos, mas isso apenas a partir da segunda geração de legitimidade. Pregava também o reconhecimento da liberdade a todas as crianças mestiças, dada a sua participação no "sangue europeu". ${ }^{676}$ Não se tratava, portanto, de favorecer a totalidade da população não-branca livre, mas de aliar aos proprietários brancos a parcela dessa população mais vinculada à conservação da ordem colonial. Na base da sua intervenção estava a ideia de que não se tratava apenas de uma questão de justiça, mas também de segurança. Alertava que os brancos seriam, no final das contas, as vítimas de seu próprio sistema de ódio e preconceito.

Em outubro, Raimond encontrou a Sociedade dos cidadãos de cor e passou a assistir às reuniões. Ao lado de Ogé, ele foi escolhido pela Sociedade para representar os cidadãos de cor perante a Constituinte. Raimond enviou então uma petição ao deputado Fréteau, presidente da Assembleia, no intuito de obter permissão para apresentar-se perante a mesma. Retomando a ideia da existência de uma aristocracia da cor nas colônias, Raimond citava o direito constitucional de resistência à opressão, nunca exercido pelos cidadãos de cor, para atestar a sua aversão à violência e seu o amor à ordem e à pátria. ${ }^{677}$ Procurava, com isso, mostrar a disposição dos livres de cor a se aliarem à ordem estabelecida, reivindicando, de forma apenas pacífica, a igualdade de direitos entre todos os homens livres. Ao mesmo tempo, sugeria sutilmente, pela simples menção ao direito de resistência à opressão, que uma revolta desses cidadãos de cor seria justa e, portanto, não impossível. Pedia um decreto que suprimisse toda distinção entre os cidadãos livres e determinasse a formação em São Domingos de assembleias das pessoas de cor livres, para proceder à eleição de seus representantes na Assembleia Nacional. ${ }^{678}$ Fréteau prometeu a Raimond que a sua reclamação seria

\footnotetext{
${ }^{676}$ Ibidem, pp.8 e 10-11.

${ }^{677}$ Cf. RAIMOND, Julien. Réclamations adressées à l'Assemblée nationale, pp.2-3.

${ }^{678}$ Ibidem, pp.6-7.
} 
discutida assim que a Assembleia se transferisse para Paris, o que aconteceria na segunda metade de outubro. ${ }^{679}$

\section{I.3.1.2) Os Amigos dos Negros na luta pela igualdade da epiderme}

A campanha pelos homens de cor livres concentrou grande parte dos esforços dos Amigos dos Negros até setembro de 1791, deixando para o segundo plano as reivindicações referentes ao tráfico e à escravidão. O envolvimento da Sociedade nessa campanha alimentou uma oposição dos representantes das diferentes colônias, que assumiram o ponto-de-vista "antimulato" dos colonos de São Domingos. No fundo, a realidade era mais complexa e mesmo entre os representantes de São Domingos não havia unanimidade total quanto a essa questão. Gérard, no post-scriptum da famosa carta dos deputados da colônia de 12 de agosto de 1789, defendeu uma aliança dos colonos brancos com as pessoas de cor, que ele apresentava como "o verdadeiro baluarte da segurança da colônia". ${ }^{600}$ Mas a presença dos Amigos dos Negros na luta dos cidadãos de cor explicitava, aos olhos do partido colonial, um vínculo dessa luta com as reclamações contra a escravidão e o tráfico.

A questão dos homens de cor não fazia parte das preocupações iniciais da Sociedade dos Amigos dos Negros. Foi quando do debate sobre a admissão da deputação de São Domingos que alguns de seus membros começaram a abordar o assunto. Mirabeau foi um dos primeiros a manifestar-se sobre o caráter absurdo da pretensão dos deputados dos colonos brancos que queriam representar os cidadãos de cor excluídos das eleições. Desde o início da Revolução, os homens de cor haviam conquistado alguns defensores importantes. Em Voeux d'un solitaire, por exemplo, Bernardin de Saint-Pierre havia defendido a presença de representantes dos homens de cor na Assembleia Nacional:

[...] se é justo admitir os seus deputados brancos na assembleia nacional, não é menos justo convocar os seus deputados negros, na classe dos negros livres; pois, estando empregados na cultura e na defesa de nossas colônias, eles não estão menos interessados do que os demais cidadãos em deliberar sobre os interesses de sua metrópole. ${ }^{681}$

\footnotetext{
${ }^{679}$ Cf. GAUTHIER, Florence. L'aristocratie de l'épiderme, p.35.

${ }^{680}$ CORRESPONDANCE secrette des Colons, pp.14-15.

681 "...] s'il est juste d'admettre leurs députés blancs dans l'assemblée nationale, il ne l'est pas moins d'y appeler leurs députés noirs, dans la classe des noirs libres; puisque étant employés à la culture et à la défense de nos colonies, ils ne sont pas moins intéressés que les autres citoyens à délibérer sur les intérêts de leur métropole" (BERNARDIN DE SAINT-PIERRE, Jacques Henri. Voeux d'un solitaire, p.122).
} 
O autor via essa medida também como uma forma de preparar a supressão da escravidão nas colônias. Nesse mesmo sentido, os Amigos dos Negros se interessaram pela questão. Um grupo dos cidadãos de cor chegou a encontrar-se com Clarkson na casa de La Fayette. Na ocasião, afirmaram, em busca de apoio, que a sua luta pelo fim do preconceito era também uma luta contra o tráfico, fonte de todas as distinções nas colônias, e prometeram que, caso conseguissem um lugar na Assembleia, apresentariam uma moção pelo fim do comércio de escravos. ${ }^{62} \mathrm{Na}$ mesma época, em 9 de outubro de 1789, Brissot defendeu, no Patriote Français (número LXV), a admissão dos deputados de cor na Assembleia Nacional, citando o referido trecho da obra de Bernardin de SaintPierre. ${ }^{683} \mathrm{~A}$ abordagem que consistia em vincular a causa dos cidadãos de cor a um plano de abolição da escravidão era imprudente e os Amigos dos Negros ver-se-iam posteriormente obrigados a separar as duas questões, ou até mesmo colocá-las em oposição.

Em 22 de outubro de 1789, o advogado De Joly apresentou-se na Assembleia Constituinte, à frente de uma delegação dos cidadãos de cor, dentre os quais estavam Raimond e Ogé, para apresentar a reivindicação de um direito de representação. ${ }^{684} \mathrm{O}$ discurso de De Joly, que reiterava, em linhas gerais, o conteúdo das Réclamations adressées à l'Assemblée Nationale de Raimond, teve uma acolhida favorável e a deputação de cor recebeu as honras da sessão. Ela ofereceu ainda à Nação, em nome dos cidadãos de cor de São Domingos, uma contribuição patriótica de seis milhões de libras, valor equivalente a um quarto de suas receitas, além de sujeitar 1/50 de seus bens à hipoteca da dívida nacional. ${ }^{655}$ Fréteau, presidente da Assembleia, ressaltou que "nenhuma parte da nação reclamará em vão os seus direitos junto à Assembleia de seus representantes". ${ }^{68}$ A questão foi remetida ao comitê de verificação, encarregado de examinar os poderes dos deputados.

Essa acolhida simpática podia significar um sucesso próximo, mas discussões paralelas na Assembleia sugeriam algo diferente: no mesmo dia, a Assembleia decidia, sob os protestos de Robespierre e Pétion, dividir os cidadãos da França em ativos e

\footnotetext{
${ }^{682}$ Cf. CLARKSON, Thomas. History of the Rise, Progress and Accomplishment of the Abolition of the Slave Trade, pp.387-389.

${ }_{683}$ Cf. Patriote Français, v.1, número LXV, 9 de outubro de 1789, p.4.

${ }^{684}$ Cf. AP, v.9, pp.476-478.

${ }^{685}$ Cf. Les Révolutions de Paris, dédiées à la Nation. Publiées par L. Prudhomme. Paris: de l'Imprimerie des Révolutions de Paris, v.2, número 16, 24-31 de outubro de 1789, p.17.

686 "Aucune partie de la nation ne réclamera vainement ses droits auprès de l'Assemblée de ses représentants" (AP, v.9, p.478).
} 
passivos. Essa infração ao princípio da igualdade fornecia um argumento concreto aos adversários da reivindicação dos homens de cor, na medida em que a lei passava a estabelecer condições ao exercício dos direitos de cidadania. A desigualdade na metrópole seria usada para justificar a desigualdade nas colônias. $\mathrm{O}$ paradoxo é que os homens de cor das colônias cumpriam, em muitos casos, as condições para a obtenção da cidadania ativa, mas o que interessava ao campo colonial era o princípio da separação da população em categorias de cidadãos.

Inicialmente, a imprensa revolucionária não deu à questão dos cidadãos de cor o espaço devido. O jornal Les Révolutions de Paris, bastante popular entre as massas da capital, reconheceu que a única diferença entre os cidadãos brancos e os de cor estava na cor da pele e nas distinções humilhantes de que estes eram vítimas e que faziam deles "estrangeiros em sua própria pátria" (itálico no original). Mas, por outro lado, o jornal acreditava que a admissão de uma representação de colonos de cor teria por efeito acelerar demais a emancipação dos escravos negros, uma operação necessária, mas que deveria ser preparada cuidadosamente. Ademais, o jornal entendia que os deputados franceses não eram capazes de fazer leis apropriadas às colônias, por desconhecimento das particularidades locais, e que seria preferível que os deputados americanos fizessem as suas próprias leis. Propunha que as colônias formassem estados separados, com sua própria assembleia nacional, ligados à metrópole apenas por um pacto federativo. ${ }^{67}$

O campo colonial procurava afastar qualquer discussão relativa aos livres de cor, argumentando que essa era uma questão de competência interna das colônias, sendo, portanto, da competência de suas assembleias. Essa foi a linha de argumentação adotada por Cocherel em seu panfleto Opinion sur l'admission des Nègres et mulâtres libres aux assemblées provinciales. Para o deputado, cabia às colônias apresentar um plano para a constituição de novas assembleias provinciais, que passariam então a admitir as pessoas de cor. O fundamental era que as colônias fizessem a sua própria constituição, compatível com as conveniências locais. ${ }^{688}$

Os deputados dos cidadãos de cor persistiam na sua tentativa de obter uma decisão favorável da Assembleia. Em 23 de novembro de 1789, enviaram nova carta ao comitê de verificação da Assembleia. ${ }^{689}$ No dia seguinte, Raimond, Ogé, Dufournet de Naucel, Fleury, Honoré de Saint-Albert, acompanhados por De Joly, foram

${ }^{687}$ Cf. Les Révolutions de Paris, v.2, número 16, 24-31 de outubro de 1789, pp.17-18.

${ }^{688}$ Cf. COCHEREL, Nicolas-Robert. Opinion de M. de Cocherel,... sur l'admission des nègres et mulâtres libres aux assemblées provinciales. Paris: impr. de Clousier, s. d., pp.1-4.

${ }^{689}$ Cf. AP, v.10, pp.329-333. 
calorosamente recebidos na assembleia geral dos Amigos dos Negros. A partir de então, Raimond e, com menor frequência, Ogé participariam das sessões da Sociedade. De Joly aproveitou a ocasião para enfatizar as conexões das reclamações das pessoas de cor com a missão humanitária dos Amigos dos Negros. Brissot propôs que a Sociedade apoiasse os esforços dos deputados de cor na defesa de seus direitos e que os auxiliasse na busca de uma representação na Assembleia Nacional. A moção foi adotada, e Clarkson e o marquês de La Feuillade foram escolhidos para apresentar De Joly aos Amigos dos Negros que eram deputados na Assembleia. ${ }^{690}$

Para embaralhar as cartas, circulava em Paris um panfleto intitulado Réclamations des nègres libres, colons américains, publicado no final de novembro. $\mathrm{O}$ texto, supostamente escrito por uma delegação de negros livres, falava da superioridade dos negros, que tinham "sangue puro", sobre os homens de cor, que eram mestiços e, por isso, formavam uma "espécie abastardada". Reagindo à ingratidão dos cidadãos de cor que não os haviam incluído em sua petição, esses negros livres propunham uma hierarquização da sociedade colonial baseada na pureza de sangue. Colocavam-se sob a tutela dos representantes da Nação e, sobretudo, dos deputados de São Domingos, "seus patrões e seus protetores naturais". Ofereciam ainda uma doação patriótica de 12 milhões de libras, duas vezes maior do que a dos cidadãos de cor. ${ }^{691}$ Não assinado, o texto pode ter sido uma farsa patrocinada pelo partido colonial, que procuraria, com isso, evidenciar o fato de que Raimond e Ogé representavam apenas uma parcela da população não-branca das colônias. Os cidadãos de cor responderam a essa reclamação, denunciando-a como uma manobra de divisão e destacando que o seu caderno de queixas defendia os direitos dos negros livres tanto quanto os dos mestiços.

O campo colonial procurava maliciosamente se apropriar dos argumentos dos livres de cor para defender o seu exato contrário. Assim, em 28 de novembro, Cocherel distribuiu na Assembleia um panfleto, no qual relembrava que a questão da representação colonial já havia sido decidida e que, ao se apresentarem como uma classe distinta, os homens de cor contrariavam a Declaração dos direitos. Citava, como contraponto, a sabedoria dos "Negros livres", que haviam depositado a sua confiança nos deputados coloniais. ${ }^{692}$

\footnotetext{
${ }^{690}$ Cf. Registre de la Société des Amis des Noirs, pp.245-247.

${ }^{691}$ Cf. AP, v.10, p.329.

${ }^{692}$ Cf. COCHEREL, Nicolas-Robert. Observations de M. de Cocherel, ... à l'Assemblée Nationale, sur la demande des mulâtres. Paris: imprim. de Clousier, s.d., pp.4-6 e 11.
} 
O debate sobre as pessoas de cor livres intensificou-se ainda mais a partir da discussão da moção de Curt, apresentada em 27 de novembro, a respeito da criação de um comitê das colônias. Como vimos anteriormente, Curt, deputado da Guadalupe, propôs a formação de um comitê de vinte membros, constituído exclusivamente de colonos brancos e negociantes dos portos. $\mathrm{O}$ debate se estendeu até os primeiros dias de dezembro. Em resposta à moção de Curt, a Sociedade dos cidadãos de cor publicou, em 2 de dezembro, uma nova petição, para demonstrar que a liberdade das pessoas de cor era apenas ilusória e que um comitê formado, ainda que apenas em parte, por colonos brancos tenderia a perpetuar o sistema de opressão. Os cidadãos de cor pediam, portanto, que, antes de tomar qualquer decisão sobre o comitê das colônias, a Assembleia, por meio de seu comitê de verificação, se pronunciasse a respeito da admissão dos seus deputados. ${ }^{693}$

Em 3 de dezembro, o abade Grégoire, membro do comitê de verificação da Assembleia, interveio para reclamar uma decisão a respeito da admissão dos deputados de cor, antes de qualquer deliberação sobre a formação de um comitê das colônias. ${ }^{694} \mathrm{~A}$ sua intervenção gerou fortes protestos do campo colonial, que procurou encobrir-lhe a voz com gritos e vaias. Pétion procurou retomar a defesa dos homens de cor, mas também foi interrompido. Charles de Lameth, que ainda pertencia aos Amigos dos Negros, também interveio favoravelmente à admissão dos deputados de cor e reiterou a necessidade de tomar medidas para preparar a liberdade dos negros nas colônias. No fim, prevaleceu na Assembleia a opinião do abade Maury, que declarou que um comitê colonial mal preparado poderia ser perigoso e que o momento não era propício a uma decisão sobre o tema. ${ }^{695}$ Quanto ao pedido dos cidadãos de cor, o comitê de verificação decidiu admitir dois dos cinco deputados de cor propostos por Grégoire. Mas cabia à Assembleia aprovar ou não a recomendação do comitê, e nenhuma decisão foi tomada.

A assembleia geral dos Amigos dos Negros, de 4 de dezembro, contou, pela primeira vez, com a presença do abade Grégoire e de Pétion de Villeneuve. Brissot fez um relato das intervenções de Grégoire, Pétion e Charles de Lameth na Assembleia, em

${ }^{693}$ Cf. À l'Assemblée nationale. Supplique et pétition des citoyens de couleur des îles et colonies françaises sur la motion faite le 27 nov. 1789 par M. de Curt,... au nom des colonies réunies, tendante à faire nommer un comité des colonies... Du 2 déc. 1789. S.1.: s.n., s.d., pp.19-20.

${ }_{694}$ Cf. AP, v.10, p.362.

${ }^{695}$ Cf. Patriote Français, v.1, número CXIX, 5 de dezembro de 1789, pp.2-3; AP, v.10, pp.363-364 
favor dos cidadãos de cor, e propôs uma moção de agradecimento aos três deputados. Foi decidido que Grégoire seria incluído entre os membros honorários da Sociedade. ${ }^{696}$

\section{I.3.1.3) O memorial de Grégoire e a resposta do campo colonial}

Grégoire, que já havia assumido a defesa dos direitos dos judeus na metrópole, abraçava agora a causa das pessoas de cor das colônias. O abade manifestava uma oposição de princípio ao preconceito e à discriminação, oposição esta que tinha por base o universalismo cristão e o objetivo maior de reunir todos os povos sob a Igreja. Como explica Sepinwall, não se tratava, portanto, de defender a pluralidade de raças e culturas, mas, ao contrário, de permitir que povos oprimidos pudessem, uma vez finda a sua opressão, abandonar a sua particularidade cultural e até racial. Grégoire defenderia até mesmo a miscigenação como forma de integração. Assim como para os judeus, queria trazer os negros para a civilização europeia e a cristandade. ${ }^{697}$ A semelhança entre as duas causas permitiu a Raimond obter o seu apoio. ${ }^{698}$

Para difundir suas posições favoráveis à admissão dos deputados de cor na Assembleia, o abade publicou, em 10 de dezembro de 1789, o Mémoire en faveur des gens de couleur ou sang-mêlés de Saint-Domingue. Por meio da descrição detalhada do quadro das vexações e proibições impostas às pessoas de cor nas colônias, Grégoire procurou descrever o que era uma sociedade organizada e estruturada com base no preconceito. $^{699} \mathrm{O}$ abade reproduzia o ponto de vista de Raimond, destacando a qualidade e o valor dos homens de cor, plantadores dedicados que faziam florescer as plantações e aumentavam as riquezas coloniais, e que cumpriam, além disso, um papel fundamental para a segurança das ilhas: "Ninguém é mais ágil para subir os morros, e capturar os negros fugitivos; eles são um forte apoio contra a insurreição dos Escravos". ${ }^{700}$ Nesse sentido, Grégoire esforçava-se em traçar um quadro dócil da população de cor livre: industriosa, patriota, passiva e absolutamente vinculada à ordem

\footnotetext{
${ }^{696}$ Cf. Registre de la Société des Amis des Noirs, pp.249-250. Grégoire tornar-se-ia membro oficial a partir da sessão de 11 de dezembro de 1789.

${ }^{697}$ Cf. SEPINWALL, Alyssa Goldstein. Eliminating Race, Eliminating Difference. Blacks, Jews and the Abbé Grégoire. In: S. PEABODY, T. STOVALL (orgs). The Color of Liberty. Histories of Race in France. Durham, Londres: Duke University Press, 2003, pp.29 e 33-37.

${ }^{698}$ Cf. GARRIGUS, John D. Before Haiti, p.239.

${ }^{699}$ Cf. GRÉGOIRE, Henri. Mémoire en faveur des gens de couleur ou sang-mêlés de St.-Domingue, \& des autres Isles françaises de l'Amérique, adressé à l'Assemblée Nationale. Paris: Belin, 1789, pp.5-9.

700 "Personne n'est plus agile pour gravir les mornes, et ramener les Nègres marrons; ils sont un sûr appui contre l'insurrection des Esclaves" (Ibidem, p.17).
} 
escravista. Respondendo à reclamação dos "negros livres", Grégoire apontava até mesmo os benefícios da miscigenação, evidenciados na constituição robusta das pessoas de cor: "[...] o cruzamento das raças melhora a espécie". ${ }^{701}$

Assim, se o argumento primordial dos colonos consistia em afirmar que a equiparação das pessoas de cor aos brancos levaria inevitavelmente à perda das colônias, Grégoire, que manifestava dúvidas quanto à real utilidade destas para a França, respondia que, ao contrário, era a segregação dos homens de cor que as colocava em risco. Eles mantinham a segurança das colônias contra as ameaças de revoltas escravas, mas, cansados de insultos e humilhações, eles poderiam um dia unirse aos escravos para romper os laços com a metrópole. Nesse caso, o seu triunfo seria certeiro. Num tom profético próximo de Raynal, Grégoire afirmava:

Sim, o grito da liberdade ecoa nos dois Mundos, basta apenas um Otelo, um Padrejan $^{702}$, para despertar na alma dos Negros o sentimento de seus direitos inalienáveis. Vendo então que os mestiços não podem protegê-los contra os seus déspotas, eles talvez voltarão seus ferros contra todos eles, uma explosão súbita derrubará as suas correntes; e quem dentre nós, supondo-se em seu lugar, ousará condená-los $?^{703}$

Tal como na Histoire des deux Indes, esse tom de ameaça não apagava as intenções conciliadoras do autor: reconhecer os direitos dos homens de cor permitiria "cimentar a união entre eles e os Brancos" e manter de forma mais eficaz os escravos dentro da ordem. ${ }^{704}$

Grégoire afirmava ver tais considerações como secundárias, não admitindo que conveniências políticas pudessem afastar a justiça e o rigor na aplicação das leis. Reconhecer os direitos dos cidadãos de cor era, acima de tudo, um "ato de justiça", que traria, subsidiariamente, a vantagem de cimentar a classe dos proprietários coloniais e manter os escravos na ordem, enquanto a sua emancipação fosse preparada. ${ }^{705}$ No entanto, o papel dos homens de cor na contenção e repressão de movimentos de resistência escravos afirmava-se justamente como o leitmotiv de toda a campanha em favor de seus direitos.

\footnotetext{
${ }^{701}$ Ibidem, p.25.

${ }^{702}$ Negro espanhol que, em 1679, matou seu senhor e iniciou uma rebelião negra em São Domingos.

703 "Oui, le cri de la liberté retentit dans les deux Mondes, il ne faut qu'un Othello, un Padrejan, pour réveiller dans l'âme des Nègres le sentiment de leurs inaliénables droits. Voyant alors que les sang-mêlés ne peuvent les protéger contre leurs despotes, ils tourneront peut-être leurs fers contre tous, une explosion soudaine fera soudain tomber leurs chaînes; et qui de nous osera les condamner, s'il se suppose à leur place?" (GRÉGOIRE, Henri. Mémoire en faveur des gens de couleur, p.36).

${ }_{704}$ Ibidem, pp.31-32.

${ }^{705}$ Ibidem, p.38.
} 
Essa linha de argumentação gerava, no campo antiescravista, algumas inconsistências. Por um lado, Grégoire, a exemplo de outros amigos dos Negros, afirmava que recusar a igualdade aos mulatos era privar a colônia da melhor garantia contra a revolta dos escravos; por outro, via nessa mesma igualdade o primeiro passo rumo à extinção gradual da escravidão. Como diz Bénot, os mulatos apareciam sucessivamente como "[...] os melhores defensores do sistema contra uma revolta que todo mundo teme, e a vanguarda desse movimento de libertação". ${ }^{706}$ Os antiescravistas queriam convencer os colonos de seu interesse no reconhecimento dos direitos de cidadania dos "mulatos", mas manifestavam, por vezes, a sua crença de que os homens de cor livres, na posse de seus plenos direitos, poderiam servir como intermediários numa transição gradual da escravidão para a liberdade. No final, é a primeira linha de argumentação que acabaria prevalecendo.

O memorial de Grégoire gerou, por parte dos colonos, dois tipos de resposta. Cocherel atacou o abade num rodapé das Observations sur la demande des mulâtres. A sua argumentação traduzia bem a estratégia do campo colonial de dissimular a realidade colonial, negando a existência do preconceito de cor e apresentando os deputados dos colonos brancos como os representantes de toda a população livre das colônias. Mas nem todos adotavam essa estratégia. Em 16 de dezembro de 1789, foi publicada uma resposta anônima, assinada apenas com as iniciais P.V.C.P.D.D.L.M., e intitulada Observations d'un habitant des colonies sur le "Mémoire en faveur des gens de couleur..." adressé à l'Assemblée nationale par M. Grégoire. Questionando as informações apontadas por Grégoire a respeito das proibições impostas à população de cor das colônias, o anônimo afirmava que apenas a exclusão dos cargos e empregos públicos era de fato observada, mas ela encontrava sua razão na manutenção de uma determinada ordem social. Entendia, primeiramente, que:

Não é possível que seres que ontem estavam na escravidão, estejam hoje nos primeiros escalões da sociedade, encarregados de empregos que supõem a educação, os costumes e a confiança geral. ${ }^{707}$

\footnotetext{
706 "[...] les meilleurs défenseurs du systême contre une révolte que tout le monde redoute, et l'avant-garde de ce mouvement de libération" (BÉNOT, Yves. La question coloniale en 1789 ou l'année des déceptions et des contradictions. In: Les Lumières, l'esclavage, la colonisation. Paris: La Découverte, 2005, p.207)

707 "Il n'est pas possible que des êtres, qui étaient hier dans l'esclavage, soient aujourd'hui dans les premiers rangs de la société, chargés d'emplois, qui supposent l'éducation, les moeurs et la confiance générale" (OBSERVATIONS d'un habitant des colonies sur le "Mémoire en faveur des gens de couleur..." adressé à l'Assemblée nationale par M. Grégoire. S.l.: s.n., s.d., p.19).
} 
Assim, havia o problema do despreparo dos "alforriados" para cargos de responsabilidade, mas, para o anônimo, a principal razão da discriminação era outra. Para ele, a alforria possuía uma utilidade social específica, que era a de criar um estado intermediário entre a escravidão e a liberdade. Para que o escravo fosse mantido na ordem, era preciso persuadi-lo da superioridade do senhor branco e fazê-lo crer que apenas o branco podia alcançar a liberdade plena. Ou seja, era preciso que o escravo negro aceitasse a sua condição como uma decorrência de sua própria natureza inferior. Essa convicção desapareceria no minuto em que aquele que era o seu companheiro se tornasse, por meio da alforria, o igual de seu senhor. A ascensão social de negros ou mestiços abalaria o conformismo no seio da escravaria. Como dizia o anônimo: "Se o intervalo entre a servidão e o título de cidadão desaparece, vós destruís a força que mantém uma constituição talvez infeliz, mas necessária". ${ }^{708}$

O texto rompia com a estratégia habitual do partido colonial: não se tratava, portanto, de negar a existência do preconceito, mas, ao contrário, de exaltá-lo como um importante instrumento ideológico de controle social. O preconceito era "a força secreta de toda a máquina colonial". ${ }^{709}$ Com o tempo, ele podia ser atenuado, com a admissão restrita de alguns poucos eleitos na classe dos brancos, mas nunca eliminado. Chamar pejorativamente os homens de cor livres, na sua maioria nascidos livres, de "alforriados" fazia parte desse esforço de discriminação. A classe dominante branca precisava de uma proteção contra a massa dos escravos que mantinha sob o seu jugo. Essa proteção era de ordem ideológica e implicava a manutenção de três estados jurídicos diferentes nas colônias: livres, escravos e libertos. A cor negra da pele aparecia, mesmo quando imperceptível aos olhos, como uma mácula indelével que acompanhava o indivíduo de origem servil por toda a sua vida. Para o autor, a eficácia do preconceito como mecanismo ideológico de controle estava evidente no desprezo manifestado por determinadas categorias de mestiços em relação a outras: do mulato pelo negro, do quadrarão pelo mulato e assim por diante.

Não era, para o anônimo, uma questão de justiça. Afirmava não ter ódio algum pela raça negra. ${ }^{710}$ Era uma questão de necessidade, tendo em vista os particularismos

\footnotetext{
708 "Si l'intervalle entre la servitude et le titre de citoyen n'est plus rien, vous détruisez le ressort qui maintient une constitution malheureuse peut-être, mais nécessaire" (Ibidem, p.21).

${ }^{709}$ Ibidem, p.22.

${ }^{710}$ Essa abordagem supostamente racional do problema parecia excluir a defesa da ideia da servidão natural do negro: para o anônimo, o preconceito era um mal necessário. Mais tarde, conforme a campanha dos Amigos dos Negros se fortaleceria, os colonos passariam a buscar novas linhas de argumentação. As
} 
da realidade colonial. O anônimo sustentava que a Declaração dos direitos não havia sido feita para as colônias e que, consciente disso, a Constituinte não interviria na formação de sua constituição. ${ }^{711}$ Apenas as colônias estariam em condições de decidir a respeito do estado das pessoas de cor.

O texto motivou uma resposta violenta por parte de Cournand. Para o abade, se o anônimo não negava o preconceito de cor, ele procurava esconder o seu caráter opressivo, reduzindo-o a um simples instrumento de controle ideológico. Mais do que isso, Cournand sugeria que o anônimo talvez fosse um mestiço:

Perdoa a liberdade de meu estilo; a revolução me mimou um pouco; aprendi a chamar de tu ao me encontrar algumas vezes com os mulatos; eu te falo a língua do país; tu me compreenderás, sem dúvida, pois pareces ter conservado tão bem os seus costumes. ${ }^{712}$

Segundo Florence Gauthier, o anônimo era Moreau de Saint-Méry, um dos principais porta-vozes coloniais em Paris. Embora haja controvérsias a esse respeito, a autora acredita que ele era, na verdade, um mestiço "branqueado", que defendia o preconceito, admitindo apenas uma atenuação suficiente deste para admitir a integração à classe dominante de alguns poucos privilegiados, "neobrancos", como ele próprio. ${ }^{713}$

$\mathrm{Na}$ mesma época, Raimond reiterava, num panfleto dirigido à Assembleia Nacional, que era preciso que houvesse, na sociedade colonial, apenas duas classes, a dos livres e a dos escravos, com o objetivo de "[...] conter mais eficazmente estes últimos, até que a Nação tenha tomado as medidas seguras para conduzi-los ao estado de liberdade [...]". ${ }^{714}$ A ideia era, portanto, solidificar a população livre das colônias numa classe única, capaz de manter a escravaria dentro da ordem, enquanto uma supressão gradual e suave da escravidão era preparada. Sua argumentação estava perfeitamente alinhada com a dos Amigos dos Negros, que, àquela altura, tinham-se

Idées sommaires sur quelques règlements à faire à l'assemblée coloniale, de Beauvois, por exemplo, traria teorias aberrantes sobre uma hierarquia racial, na qual os negros se situariam em algum lugar entre os brancos e os símios (cf. BÉNOT, Yves. La Révolution française et la fin des colonies, p.83).

${ }^{711}$ Cf. OBSERVATIONS d'un habitant des colonies, pp.49-50.

712 "Pardonne à la liberté de mon style; la révolution m'a un peu gâté; j'ai appris à tutoyer en me trouvant quelquefois avec des mulâtres; je te parle la langue du pays; tu m'entendras sans doute, puisque tu parais en avoir si bien conservé les moeurs" (COURNAND, Antoine de. Réponse aux Observations d'un habitant des colonies, sur le Mémoire en faveur des gens de couleur, ou sang-mêlés, de Saint-Domingue, \& des autres Isles françaises de l'Amérique, par M. Grégoire, Curé d'Emberménil, Député de Lorraine. Paris: s.d. [1789], p.16).

${ }^{713}$ Cf. GAUTHIER, Florence. L'aristocratie de l'épiderme, pp.101-103.

714 "...] contenir plus efficacement ces derniers, jusqu'à ce que la Nation aît pris les moyens sûrs pour les ramener à l'état de liberté [...]" (RAIMOND, Julien. Observations adressées à l'Assemblée nationale, pp.14-15). 
associado plenamente à causa dos cidadãos de cor. ${ }^{715}$ É interessante observar que os dois lados opostos nesse debate se colocavam no mesmo campo argumentativo: defender ou negar os direitos dos homens de cor livres era, em qualquer caso, um imperativo de manutenção da ordem. Para os Amigos dos Negros, essa perspectiva preservacionista os colocava num beco sem saída.

Apesar da decisão parcialmente favorável do comitê de verificação, a Assembleia Constituinte ainda não havia se pronunciado sobre a admissão dos deputados de cor. Sem recusá-la explicitamente, ela apenas evitou a questão, impedindo que fosse discutida abertamente. As pressões eram fortes: colonos e negociantes dos portos faziam frente única quando tratava-se de manter o status quo colonial. Estabelecia-se a base de um compromisso: os colonos não mencionavam a questão do monopólio e os negociantes os apoiavam no debate sobre os homens de cor livres. ${ }^{716}$

Os cidadãos de cor decidiram então envolver o movimento popular, levando a sua reclamação à Comuna de Paris. Em $1^{\circ}$ de fevereiro de 1790, De Joly conduziu uma delegação de homens de cor e negros livres ao Hôtel de Ville. Apesar do entusiasmo popular com que foram recebidos e da presença de Brissot na sessão, a questão foi adiada, primeiramente para o dia 6 e, depois, para o dia 11 de fevereiro. Nesse dia, diante de um grande público, De Joly apresentou uma petição ${ }^{717}$, em nome de todos os cidadãos de cor, negros e mestiços, homenageando a Revolução e a Declaração dos direitos. Muito aplaudido, De Joly reclamou o direito à representação, apontando que várias categorias excluídas durante o Antigo Regime estavam começando a recuperar seus direitos, caso, por exemplo, dos judeus. Brissot também discursou, mas cometeu a imprudência de associar a queixa dos homens de cor à questão do tráfico e atacou os plantadores brancos. Apesar dos esforços de Brissot e De Joly, e do apoio manifestado por De Bourges, Bosquillon, o abade Bertholio, Garran de Coulon e Danton ${ }^{718}$, a oposição, mesmo dentro da Comuna, era forte naquele momento. ${ }^{719}$

\footnotetext{
${ }^{715}$ Como aponta Jean-Daniel Piquet, é preciso notar, entretanto, que houve Amigos dos Negros contrários à reclamação dos cidadãos de cor. Era o caso de Clermont-Tonnerre que se engajou contra a causa dos homens de cor em maio de 1791. Da mesma forma, Daniel Lescallier, membro da Sociedade e autor de obras abolicionistas, apresentava o mulato como uma raça viciosa (cf. PIQUET, Jean-Daniel. L'émancipation des Noirs dans la Révolution française, p.73)

${ }_{716}^{716}$ Cf. BÉNOT, Yves. La Révolution française et la fin des colonies, pp.70-71.

717 Essa petição havia sido previamente apresentada à Sociedade dos Amigos dos Negros, em 29 de janeiro de 1790 (cf. Registre de la Société des Amis des Noirs, p.267).

${ }_{718}$ Ibidem, p.275.

${ }^{719}$ Um indício da forte oposição à causa dos mulatos é a atitude do jornal Les Révolutions de Paris, então um dos principais órgãos da imprensa democrática e que tornar-se-ia posteriormente um veículo para as posições abolicionistas mais avançadas. Naquele momento, entretanto, o jornal posicionou-se contra os
} 
Dois membros da Comuna - De Marchais e Maissemy - responderam à petição usando argumentos típicos do Clube Massiac. De Marchais procurou justificar o tráfico e a escravidão como males necessários à prosperidade da colônia, instituições cuja abolição beneficiaria apenas a Inglaterra, principal concorrente da França no comércio colonial. Poiterin de Maissemy, membro do Clube Massiac, atacou diretamente os Amigos dos Negros, acusando-os de serem "incendiários" e agentes ingleses. Esclareceu ainda que a questão dos livres de cor não era da competência da Comuna e não devia ser discutida no Hôtel de Ville. No fim, a Comuna recusou-se a apoiar o pedido da delegação de cor, levando-a a abandonar o local. ${ }^{720}$ Naquela fase da Revolução, antes da radicalização do movimento popular, o partido colonial conseguia prevalecer nas mais diferentes esferas.

esforços de Brissot e dos Amigos dos Negros pelos homens de cor: "o Brissot não cessará de remexer, de apresentar moções, de intrigar até que ele veja cinco ou seis filhos do Congo sentados numa Assembleia nacional da França" ("le Brissot ne cessera pas de remuer, de motionner, d'intriguailler, qu'il n'ait vu cinq ou six enfants du Congo assis dans une Assemblée nationale de France"; Les Révolutions de Paris, número 32, 13-20 de fevereiro de 1790, p.23).

${ }^{720}$ Cf. THIBAU, Jacques. Le temps de Saint-Domingue, p.224; DEBIEN, Gabriel. Les colons de SaintDomingue et la Révolution, pp.181-183. 


\section{I.3.2) Março e outubro de 1790: reviravoltas no debate colonial}

\section{I.3.2.1) As Instruções de 28 de março: uma vitória aparente}

Como vimos anteriormente, em março de 1790, ocorreu o primeiro grande debate parlamentar sobre as colônias. O decreto de 8 de março reconheceu a legitimidade das assembleias coloniais já constituídas e determinou a formação de novas assembleias onde elas ainda não existiam. Foi determinado que o decreto seria completado por instruções para a constituição das novas assembleias, o que abria, para os cidadãos de cor, novas possibilidades de ação política.

De fato, Raimond e os cidadãos de cor intervieram junto ao comitê das colônias para pedir que as instruções especificassem, no que se referia à cidadania ativa, que ela fosse reconhecida para todas as pessoas de cor que preenchessem as condições exigidas pela lei. ${ }^{721}$ No final de janeiro, havia chegado a notícia de que um magistrado de São Domingos, Ferrand de Baudière, havia sido massacrado por brancos por ter participado da redação de uma petição dos homens de cor da colônia. ${ }^{722}$ A notícia do incidente havia provocado certa comoção nos portos franceses, sobretudo em Bordeaux, onde tradicionalmente havia alguma simpatia pela causa dos livres de cor. ${ }^{723}$

No dia 23 de março, Barnave apresentou o relatório do comitê colonial sobre as instruções, mas a discussão se estendeu pelos dias seguintes. No dia 28, deu-se a discussão relativa ao mais importante dispositivo das Instruções. O art. $4^{\circ}$ dispunha que:

Imediatamente após a proclamação e afixação do decreto e da instrução em cada paróquia, todas as pessoas com vinte-e-cinco anos completos, proprietárias de imóveis, ou, na ausência de tal propriedade, domiciliadas na paróquia há mais de dois anos, e pagando uma contribuição, reunir-se-ão para formar a assembleia paroquial. ${ }^{724}$ (grifo nosso)

\footnotetext{
${ }^{721}$ Cf. GAUTHIER, Florence. L'aristocratie de l'épiderme, p.184.

722 A notícia do massacre de Baudière foi lida nos Amigos dos Negros, em 29 de janeiro de 1790 (cf. Registre de la Société des Amis des Noirs, p.268).

${ }^{723}$ Debien explica que Bordeaux era o porto dos produtos provenientes das pequenas Antilhas e contava com grande presença de proprietários da Martinica, muito mais favoráveis a um entendimento com os homens de cor livres. Havia também uma presença importante de mulatos na cidade, o que pode explicar a atitude dos negociantes (cf. DEBIEN, Gabriel. Les colons de Saint-Domingue et la Révolution, pp.105106).

724 "Immédiatement après la proclamation et l'affiche du décret et de l'instruction dans chaque paroisse, toutes les personnes âgées de vingt-cinq ans accomplis, propriétaires d'immeubles, ou, à défaut d'une telle propriété, domiciliées dans la paroisse depuis deux ans, et payant une contribution, se réuniront pour former l'assemblée paroissiale" (Moniteur, v.3, número 88, 29 de março de 1790, p.726).
} 
Assim, ao dispor sobre a cidadania ativa para a formação das assembleias, o projeto do comitê não estabeleceu nenhuma exceção ou exclusão baseada na cor da pele ou na origem étnica dos indivíduos. A expressão todas as pessoas incluía, pelo menos em tese, os homens de cor livres. Mas, ao não explicitar a inclusão dos cidadãos de cor, a lei permitia também algumas distorções. O desafio para os deputados das colônias era contornar qualquer debate em torno do art. $4^{\circ}$.

Ciente dos perigos inerentes a uma redação tão pouco esclarecedora, Grégoire consultou o comitê, pedindo que as instruções mencionassem especificamente as pessoas de cor, ao que lhe foi respondido que isso era desnecessário, na medida em que o texto legal não estabelecia nenhuma exclusão. Aceitando a versão do comitê, Grégoire afirmou então, perante toda a Assembleia:

Eu temia que o artigo IV deixasse alguma dúvida sobre um objeto importante; mas, senhores, os deputados das colônias me anunciam que eles entendem não privar as pessoas de cor da elegibilidade, e eu renuncio à palavra, sob a condição que eles renunciem à aristocracia da cor. ${ }^{725}$

A intervenção de Grégoire gerou protestos no campo colonial. Cocherel negou que os deputados coloniais tivessem feito tal observação. Charles de Lameth, que mostrava já ter passado para o bloco antagonista ${ }^{726}$, considerou a intervenção de Grégoire "indiscreta" e pediu que a discussão fosse fechada. ${ }^{727}$ No fim, nada mais foi dito a respeito das pessoas de cor, mas a fórmula genérica todas as pessoas permaneceu intacta. Ao aprovar o projeto do comitê, a Assembleia, de certa forma, lavava as mãos em relação aos homens de cor livres.

As reações à lei foram variadas. Muitos deram-se por satisfeitos, entendendo a questão resolvida; outros mostravam-se mais cautelosos. Brissot, no Patriote Français de 29 de março, afirmou a necessidade, por parte da Assembleia, de nomear especificamente as pessoas de cor na lei: "Se ela entendeu compreendê-los, era preciso dizê-lo claramente, pois a denominação de proprietários não elimina o equívoco". ${ }^{728}$ Brissot acreditava que as divergências de interpretação poderiam ter efeitos perversos

\footnotetext{
725 "Je craignais que l'article IV ne laissât quelque louche sur un objet important; mais, messieurs, les députés des colonies m'annoncent qu'ils entendent ne pas priver les gens de couleur de l'éligibilité, et je renonce à la parole, à condition qu'ils renonceront à l'aristocratie de la couleur" (Idem, v.3, número 89, 30 de março de 1790, p.732).

${ }^{726}$ No Patriote Français do dia seguinte, Brissot diria sobre Lameth: "Ele foi ontem o amigo da igualdade; ele é hoje apenas um plantador" (cf. Patriote Français, v.2, número 233, 29 de março de 1790, p.3).

${ }_{727}$ Cf. Moniteur, v.3, número 89, 30 de março de 1790, p.733.

728 "Si elle a entendu les comprendre, il falloit le dire nettement, puisque la dénomination de propriétaires ne lève pas l'équivoque" (Patriote Français, v.2, número 233, 29 de março de 1790, p.2).
} 
nas ilhas, onde os mais fortes certamente imporiam a sua vontade, mas a sua conclusão era globalmente otimista: dado o sentido conferido pela Assembleia ao artigo, não havia dúvida de que os homens de cor (proprietários e contribuintes) eram cidadãos ativos e, portanto, eleitores e elegíveis.

Em carta publicada no Patriote Français de 31 de março, De Joly mostrou-se ainda mais confiante na vitória dos cidadãos de cor, elogiando a redação adotada pelo Comitê. $^{729}$ Pouco tempo depois, De Joly deixaria de representar a Sociedade dos Cidadãos de cor, talvez por considerar ter feito seu trabalho, talvez por ter sido ameaçado. ${ }^{730}$ Da mesma forma, os homens de cor em geral interpretaram o decreto de março de 1790 como favorável às suas pretensões. Entendiam que não havia motivos para privá-los do direito de voto, caso preenchessem os requisitos para a cidadania ativa. Eles estavam enganados. ${ }^{731}$ Mais lúcidos, Raimond e Ogé não estavam tão convencidos.

Em 10 de abril, Raimond enviou aos seus irmãos as suas próprias instruções relativas aos decretos de março de 1790. Queria acreditar na correta aplicação da lei nas colônias, mas consciente da obscuridade do texto legal, indicava o caminho a ser seguido caso os colonos brancos colocassem obstáculos à aplicação do artigo 4 das instruções de 28 de março. Raimond pregava aos cidadãos de cor que não se rebelassem e que suportassem, com a paciência habitual, os atos de opressão dos brancos, a menos que estes quisessem entregar a colônia a uma potência estrangeira. Nesse caso, os livres de cor deveriam "sacrificar suas vidas e suas fortunas" para impedi-los. Raimond determinava ainda que os cidadãos de cor tinham de prestar juramento de não perturbar a tranquilidade pública, de manter a polícia interna dos escravos, de submeter-se à constituição e às leis da Assembleia Nacional, de continuar a sofrer todas as vexações pessoais até a chegada dos decretos da Assembleia, e de sacrificar suas vidas e fortunas para conservar a colônia à Nação e ao rei. Para Raimond, era preciso, acima de tudo,

\footnotetext{
${ }^{729}$ Idem, v.2, número 235, 31 de março de 1790, p.5.

${ }^{730}$ Cf. GAUTHIER, Florence. L'aristocratie de l'épiderme, pp.149-150.

${ }^{731}$ No mesmo momento em que a Assembleia Nacional votava essas instruções, São Domingos ampliava a sua política segregacionista. Em 15 de abril, antes da chegada dos decretos de março, a Assembleia geral de São Domingos foi constituída em Saint-Marc, mas os livres de cor não foram chamados a participar. Em julho, quando essa Assembleia teve de ser confirmada, foram organizadas novas eleições, mas novamente os livres de cor não votaram. Além disso, um decreto de 9 de maio ampliou as vexações e proibições aos homens de cor livres, proibindo-os de portar armas e de deixar as suas respectivas paróquias sem autorização do comitê paroquial. Estava claro que as assembleias coloniais tinham interpretado o decreto de 8 de março em favor apenas dos colonos brancos (cf. GAUTHIER, Florence. L'aristocratie de l'épiderme, p.192; DEBIEN, Gabriel. Les colons de Saint-Domingue et la Révolution, p.196).
} 
que os homens de cor se mostrassem incondicionalmente fiéis à metrópole e à ordem estabelecida. O juramento continha até mesmo uma súplica para que a Assembleia considerasse o fato de que os escravos eram sua "propriedade adquirida sob a salvaguarda das leis". ${ }^{732}$

Mais realista e menos conciliador, Vincent Ogé sabia que a questão teria de ser concretamente decidida em São Domingos, à força se preciso. ${ }^{733} \mathrm{Com}$ o acordo dos Amigos dos Negros, Ogé deixou Paris em 19 de maio de 1790, para reivindicar os direitos dos homens de cor em São Domingos. O desfecho de sua missão seria trágico.

\section{I.3.2.2) 12 de out. de 1790: consagração da competência colonial}

Desde o início do período revolucionário, a vida colonial, sobretudo em São Domingos, havia sido marcada por fortes conflitos entre as autoridades metropolitanas e as assembleias coloniais. A chegada das notícias da Revolução na metrópole havia estimulado as aspirações independentistas dos colonos, que identificavam naquele momento de convulsão política e de exaltação da liberdade contra o despotismo uma oportunidade de reivindicar a sua própria autonomia.

Em São Domingos, esse processo tinha desencadeado uma disputa entre as assembleias formadas na colônia: de um lado, a Assembleia da província do Norte, constituída majoritariamente por negociantes ${ }^{734}$ e fiel à metrópole, isto é, ao sistema do exclusivo; de outro, a Assembleia Geral da colônia, instituída em Saint-Marc, principal reduto dos colonos autonomistas. $\mathrm{O}$ decreto de 8 de março tinha convidado as colônias a se expressarem a respeito de sua própria constituição, mas quando ele chegou a São Domingos, a assembleia de Saint-Marc já tinha ido mais longe. No final de julho de 1790, chegou à França uma carta da assembleia colonial, de 7 de junho, apresentando decretos coloniais, datados de 28 de maio e $1^{\text {o }}$ de junho, que traziam as Bases Constitucionais da colônia, declarando-a soberana em matéria de legislação interna. $\mathrm{O}$

\footnotetext{
${ }^{732}$ Cf. Instructions envoyées aux Citoyens de Couleur de la Colonie de Saint-Domingue. In: RAIMOND, Julien. Correspondance de Julien Raimond, avec ses frères, de Saint-Domingue, et les pièces qui lui ont été adressées par eux. Paris: de l'imprim. du Cercle Social, 1793, p.12.

${ }^{733}$ Nas suas memórias, Brissot relatou que Ogé lhe havia dito, antes de partir, que, se os brancos se obstinassem a não reconhecer os mulatos como homens livres, eles os forçaria com armas em mãos (cf. BRISSOT DE WARVILLE, Jacques-Pierre. Mémoires, v.2, p.97).

${ }^{734}$ Como explica Stein, os grandes mercadores de São Domingos estavam, em geral, vinculados às casas de comércio francesas e agiam primeiramente como representantes dos interesses do comércio metropolitano, mesmo que não pudessem mostrar-se alheios aos interesses da colônia (STEIN, Robert Louis. The French Sugar Business in the Eighteenth Century, pp.82-83).
} 
texto reservava a definição do regime interno de São Domingos à Assembleia Geral da colônia, privando a Constituinte até mesmo da sanção das leis. Apenas o rei podia sancioná-las e torná-las executórias. Essa constituição apontava para uma independência de fato de São Domingos, que se organizava como um "estado paralelo à França". ${ }^{735}$ As implicações práticas dessa política já se manifestaram em julho, quando os portos da colônia foram abertos à importação irrestrita de certos alimentos. ${ }^{736}$

As aspirações de independência da Assembleia Geral de São Domingos dividiram a colônia em dois campos: de um lado, os pompons blancs, representados pela Administração, apoiada pela Assembleia provincial do Norte; de outro, os pompons rouges, isto é, os "patriotas" que apoiavam a Assembleia de Saint-Marc. ${ }^{737}$ Os pompons blancs recusavam-se a prestar juramento de fidelidade à Assembleia de Saint-Marc. Em 17 de julho, esta ordenou a supressão do corpo dos voluntários de Porto Príncipe e determinou a cassação da Assembleia provincial do Norte, condenando todos os resistentes à perda dos direitos de cidadania por dez anos. Os cidadãos do Cap-Français aproximaram-se então do governador Peynier, que tomou a decisão, em 29 de julho, de dissolver a Assembleia Geral de Saint-Marc e reafirmar a autoridade metropolitana. Após intensos combates, a Assembleia Geral dissolvida deixou a colônia na noite de 8-9 de agosto de 1790: 85 deputados embarcam para Paris, a bordo do Léopard, para protestar perante a Constituinte. Na França, a chegada dos 85 léopardins, em 14 de setembro, anunciava a iminência de um novo debate sobre as colônias. Num outro navio, chegavam representantes das cidades de Porto-Príncipe e La Croix-des-Bouquets (Oeste da ilha).

A conduta dos colonos autonomistas começava a inspirar opiniões mais radicais sobre a questão colonial. O jornal patriótico Les Révolutions de Paris incluiu, no número 63, de 18-25 de setembro de 1790, um longo artigo sobre as colônias, de autoria daquele que seria um dos personagens-chave da Revolução de São Domingos, LégerFélicité Sonthonax. O texto falava sobre o impacto da Revolução nas colônias, onde "todo mundo pensou na liberdade; mas cada um quis ser livre à sua maneira, e exclusivamente". ${ }^{738}$ As atitudes das assembleias das colônias indicavam o seu ânimo de romper os laços com a metrópole, o que permitia situar a conduta dos colonos no campo da resistência contrarrevolucionária. Sonthonax elogiava os patriotas do Norte de São

\footnotetext{
${ }^{735}$ Cf. DEBIEN, Gabriel. Les colons de Saint-Domingue et la Révolution, p.217.

${ }^{736}$ Cf. FICK, Carolyn. The making of Haiti, p.81.

${ }^{737}$ Ibidem, pp.81-82.

${ }^{738}$ Les Révolutions de Paris, v.5, número 63, 18-25 de setembro de 1790, p.519.
} 
Domingos, que haviam permanecido fiéis à França, mas afirmava que ainda não estavam no nível dos princípios da Revolução, pois recusavam os direitos de cidadania às pessoas de cor e queriam perpetuar a escravidão e o tráfico de escravos. ${ }^{739}$ Para o autor, os princípios da liberdade universal propagar-se-iam inevitavelmente entre as nações, de modo que o fim da escravidão era inexorável. Sonthonax ia além e profetizava a entrada dos deputados negros das colônias - que aconteceria de fato em fevereiro de 1794:

Sim! Ousamos prever com confiança que chegará o tempo, e o dia não está longe, em que se verá um Africano, de cabeça crespa, sem outra recomendação que o seu bom senso e suas virtudes, vir participar da legislação no seio de nossas assembleias nacionais. ${ }^{740}$

De seu lado, os recém-chegados de São Domingos procuravam conquistar aliados em Paris. Em 29 de setembro, os Léopardins foram recebidos no Clube Massiac, ao passo que, no dia seguinte, os deputados de Porto-Príncipe e La Croix des Bouquets foram ouvidos na Assembleia Nacional, onde manifestaram o seu apoio ao governador Peynier e explicaram o conflito com a assembleia de Saint-Marc. O debate sobre as colônias tinha sido reaberto e, agora, o compromisso entre negociantes e colonos estava fragilizado. Para o comitê das colônias, era preciso restabelecer os termos dessa aliança.

Em 11 e 12 de outubro de 1790, teve início a discussão parlamentar relativa aos abusos cometidos pela Assembleia Geral de São Domingos. Barnave apresentou à Constituinte um relatório sobre a conduta das assembleias coloniais em São Domingos. Para o deputado, a Assembleia Geral de Saint-Marc havia atribuído a si mesma os poderes legislativo e executivo, rompendo, desta forma, quase todos os seus laços com a metrópole. Havia aberto os seus portos aos estrangeiros, violando os termos do sistema exclusivo de comércio entre a metrópole e suas colônias. A única solução era, assim, a anulação de seus decretos, por "abuso de poder", assim como a supressão da própria Assembleia. $^{741}$ Barnave recomendava ainda que a Constituinte expressasse o seu reconhecimento a todos aqueles que haviam defendido os interesses da Nação francesa. O projeto decretava a nulidade das leis e atos da Assembleia de Saint-Marc e declaravaa desprovida de seus poderes, mas, sobretudo, dava satisfação à Assembleia do Norte ao declarar, como artigo constitucional, "[...] que nenhuma lei sobre o estado das pessoas

\footnotetext{
${ }^{739}$ Ibidem, p.523.

740 "Oui! nous osons le prédire avec confiance, un temps viendra, et le jour n'est pas loin, où l'on verra un Africain, à tête crêpue, sans autre recommandation que son bon sens et ses vertus, venir participer à la législation dans le sein de nos assemblées nationales" (Ibidem, p.524).

${ }^{741}$ Cf. Moniteur, v.6, número 286, 13 de outubro de 1790, pp.105-106.
} 
será decretada para as colônias a não ser com o pedido formal e preciso de suas assembleias coloniais" (grifo nosso). ${ }^{742}$

Assim, numa lei destinada em princípio a dissolver a Assembleia Geral de São Domingos, Barnave havia introduzido um novo dispositivo constitucional, que proibia a Constituinte de deliberar a respeito do "estado das pessoas", a menos que a iniciativa fosse tomada pelas assembleias coloniais. Isso era colocar a sorte de todos os elementos não-brancos das colônias - livres e escravos - nas mãos de assembleias compostas por seus inimigos. De um lado, a lei condenava as aspirações independentistas dos colonos; de outro, ela garantia a manutenção da escravidão e da segregação. $O$ fundamental para Barnave era manter o monopólio do comércio colonial, que pertencia à burguesia dos portos. Na medida em que os colonos eram hostis a esse monopólio, era preciso fazer concessões, deixando para as colônias a iniciativa legislativa sobre o estado das pessoas. ${ }^{743}$ Aderindo implicitamente à ordem escravista, a Constituinte estabelecia um compromisso entre os interesses da Nação e os das colônias.

Não houve debate na Assembleia Nacional. Percebendo o sentido da manobra do comitê das colônias, Mirabeau, Pétion e Grégoire tentaram manifestar-se, mas a Assembleia decidiu que a palavra não seria dada a ninguém. Passou-se diretamente à votação e o decreto foi aprovado com ampla maioria. ${ }^{744}$ A sorte dos homens de cor tinha sido abandonada aos colonos brancos. Ao receber o decreto de 12 de outubro, a assembleia do Norte mandaria erigir um busto de Barnave, "salvador da colônia", na sala de reunião.

\section{I.3.2.3) Reações do campo antiescravista}

No Patriote Français de 13 de outubro ( $\left.\mathrm{n}^{\mathrm{o}} 431\right)$, Brissot protestou contra o decreto, descrevendo-o como um "abandono covarde de todos os princípios de humanidade, de liberdade, de justiça e de política" (itálico no original). ${ }^{745}$ Concordava com a dissolução da Assembleia de Saint-Marc, mas não com os agradecimentos à

\footnotetext{
742 "[...] qu'aucunes lois sur l'état des personnes ne seront décrétées pour les colonies que sur la demande formelle et précise de leurs assemblées coloniales" (Ibidem, p.107).

${ }^{743}$ Cf. BÉNOT, Yves. La Révolution française et la fin des colonies, p.74.

${ }^{744}$ Cf. Moniteur, v.6, número 286, 13 de outubro de 1790, p.107.

${ }^{745}$ Cf. Patriote Français, v.3, número 431, 13 de outubro de 1790, p.2.
} 
assembleia provincial do Norte, cujas intenções eram basicamente as mesmas: impedir a Nação francesa de pronunciar-se sobre o regime interno das colônias. ${ }^{746}$

Outras manifestações apontavam para o risco de revoltas, caso a Assembleia não adotasse medidas compatíveis com os princípios da Constituição. Nas Révolutions de Paris de 9-16 de outubro ( $\left.{ }^{\circ} 66\right)$, Sonthonax atacou a decisão da Constituinte, baseada em noções imperfeitas sobre as colônias. Denunciou as pretensões de independência da Assembleia Geral de São Domingos, mas mostrou-se cético quanto ao alegado patriotismo da assembleia do Norte, interessada apenas na manutenção do regime proibitivo de comércio. Sonthonax observou ainda que, em meio aos conflitos entre os brancos da colônia, nenhuma voz havia se erguido para pedir uma melhoria da condição dos escravos africanos:

Ao contrário, os movimentos da colônia têm a sua origem no temor de ver a emancipação dos negros tornar-se a sequência dos decretos da assembleia nacional. Os colonos são tão inimigos dos escravos, que eles perpetuam a sua ruína e seu desprezo até sobre aqueles que escaparam de seu infame domínio. As pessoas de cor e os negros livres foram excluídos de todos os cargos, e até mesmo do direito de cidadania. ${ }^{747}$

O decreto de Barnave, que colocava o estado das pessoas de cor e dos escravos nas mãos dos colonos brancos, era, portanto, uma "blasfêmia política e moral". Adepto da abolição progressiva da escravidão, Sonthonax alertava que a política adotada pela Assembleia Nacional dava aos negros apenas uma solução, a revolta:

Eis então os negros abandonados ao furor, à discrição dos habitantes das colônias! Eis as suas correntes eternamente presas, e jamais as esperanças da filosofia serão realizadas! jamais os negros serão livres! Que dizemos? eles o serão a despeito de seus tiranos, a despeito da própria assembleia nacional; mas a sua liberdade custará sangue, e seus bárbaros opressores serão cruelmente punidos por terem rejeitado o grito da natureza e da humanidade. A declaração dos direitos já os torna livres de direito, e a natureza das coisas completará o resto. ${ }^{78}$

\footnotetext{
${ }^{746}$ Idem, v.3, número 436, 18 de outubro de 1790, pp.3-4.

747 "Au contraire, les mouvements de la colonie ont leur origine dans la crainte de voir l'affranchissement des nègres devenir la suite des décrets de l'assemblée nationale. Les colons sont tellement les ennemis des esclaves, qu'ils perpétuent leur ruine et leur mépris jusque sur ceux qui ont échappé à leur infâme domination. Les gens de couleur et les nègres libres sont exclus de toutes les places, et même du droit de cité" (Les Révolutions de Paris, v.6, número 66, 9-16 de outubro de 1790, p.12).

748 "Voilà donc les nègres abandonnés à la fureur, à la discrétion des habitants des colonies! Voilà leurs fers éternellement rivés, et jamais les espérances de la philosophie ne seront réalisées! jamais les nègres ne seront libres! Que disons-nous? ils le seront malgré leurs tyrans, malgré l'assemblée nationale ellemême; mais leur liberté coûtera du sang, et leurs barbares oppresseurs seront cruellement punis d'avoir repoussé le cri de la nature et de l'humanité. Déjà la déclaration des droits les rend libres de droit, et la nature des choses achèvera le reste" (Ibidem, p.13).
} 
A intenção de Sonthonax não era de incitar os escravos à insurreição, mas demonstrar a necessidade de uma participação ativa da Assembleia Nacional na legislação colonial, que permitisse a supressão gradual da servidão. Para isso, as colônias precisavam de uma verdadeira representação colonial, que levasse em conta a totalidade de seus cidadãos. Recomendava o envio de comissários para garantir a execução dos decretos da Assembleia nas colônias, entendendo que, sem essas precauções, os deputados coloniais expressariam não o voto das colônias, mas o voto de alguns indivíduos preocupados apenas em tiranizar outros homens e arruinar o comércio francês. ${ }^{749}$

Ainda em outubro, Grégoire publicou uma "Carta aos filantropos", onde afirmava que 12 de outubro de 1790 havia sido uma data funesta para a liberdade, em que a nação havia se rendido ao preconceito e à cupidez:

Decide-se (coisa inaudita em todas as nações!) que não alterar-se-á em nada o estado das pessoas nas nossas ilhas, a não ser a pedido dos colonos; isto é, que os abusos serão extirpados apenas pela vontade daqueles que vivem deles, que solicitam o seu prolongamento. ${ }^{750}$

Além de atentar contra os direitos do Homem, anteriores à própria Constituição, o decreto de 12 de outubro era, na opinião de Grégoire, "impolítico", na medida em que os cidadãos de cor eram "[...] o mais firme apoio da colônia contra a insurreição dos Negros e a fuga de escravos". ${ }^{751}$ Se cabia às colônias emitirem a sua vontade quanto ao estado das pessoas, a população de cor livre participaria desse voto? Grégoire sabia que, para os colonos, isso estava fora de cogitação. Ora, se os homens de cor não eram reconhecidos como cidadãos, capazes de expressar a sua vontade sobre os assuntos de sua terra, então eles eram um povo oprimido e tinham o direito de resistir à opressão. ${ }^{752}$

Para Grégoire, a Revolução havia evidenciado as contradições existentes no mundo e iria inevitavelmente espalhar-se por todo o planeta: "O vulcão da liberdade aceso na França causará em breve uma explosão geral, e mudará o destino da espécie

\footnotetext{
${ }^{749}$ Ibidem, pp.17-18.

750 "On décide, (chose inouie chez toutes les nations!) qu'il ne sera rien changé à l'état des personnes dans nos îles, que sur la demande des colons; c'est-à-dire, que l'on n'extirpera les abus que sur le voeu de ceux qui en vivent, qui en sollicitent la prolongation!" (GRÉGOIRE, Henri. Lettre aux philanthropes, sur les malheurs, les droits et les réclamations des gens de couleur de Saint-Domingue, et des autres îles françoises de l'Amérique. Paris: Belin... et au Bureau du Patriote François, outubro 1790, p.1).

${ }^{751}$ Ibidem, p.4.

${ }^{752}$ Cf. GRÉGOIRE, Henri. Lettre aux philanthropes, pp.9 e 11.
} 
humana nos dois hemisférios". ${ }^{753}$ Os homens de cor, que viam elevar-se o "estandarte da revolução" e ouviam o "grito da liberdade", não poderiam, portanto, suportar por muito tempo esse estado de coisas que violentava a natureza. Grégoire aventava, aliás, a possibilidade de fazerem "causa comum com os Negros". ${ }^{754}$ Fazer dos "mulatos" cidadãos a parte inteira não era, portanto, apenas uma forma de garantir o respeito aos princípios de justiça e humanidade, mas era também uma condição para a manutenção da paz e da tranquilidade nas colônias.

Em novembro de 1790, Brissot retomou mais uma vez a questão, numa longa carta aberta a Barnave, na qual fez um balanço da atuação do presidente do comitê das colônias, que ele via como um joguete nas mãos dos plantadores das ilhas. Sustentava que o decreto de 12 de outubro era não apenas injusto, mas politicamente fatal, entendendo que vincular os homens de cor à França, por meio do reconhecimento de seus direitos de cidadãos, era condição necessária à conservação e ao florescimento das colônias. Via nos homens de cor, que formavam a verdadeira população indígena das ilhas, os únicos capazes de promover melhorias na agricultura colonial e acreditava que, um dia, eles haveriam de ser os únicos habitantes das colônias. Estavam habilitados a serem os "principais regeneradores dos negros escravos", agindo como intermediários de paz entre estes e os brancos e podendo servir de barreira em caso de uma insurreição. ${ }^{755}$ Os Amigos dos Negros faziam dos homens de cor livres o seu instrumento principal de regeneração do sistema colonial, mas, naquele momento, entretanto, nenhum desses argumentos se mostrava suficiente para contrabalançar a força do compromisso estabelecido entre colonos e metropolitanos: a fidelidade à pátria - e, portanto, ao pacto colonial - em troca da autonomia quanto ao regime interno.

\footnotetext{
753 "Le volcan de la liberté allumé en France, amènera bientôt une explosion générale, et changera le sort de l'espèce humaine dans les deux hémisphères" (Ibidem, p.12).

${ }^{754}$ Ibidem, pp.13-14.

${ }^{755}$ Cf. BRISSOT DE WARVILLE, Jacques-Pierre. Lettre à M. Barnave. Paris: Desenne/Bailly, 1790, pp.16-21 e 43-45.
} 


\section{I.3.3) O martírio de Ogé e as novas investidas dos cidadãos de cor}

A derrota de outubro de 1790 havia desferido um golpe duro nos cidadãos de cor. O seu combate seria, entretanto, rapidamente relançado com as notícias que chegavam das colônias. Os problemas coloniais não estavam naquele momento restritos a São Domingos. A convulsão política e social também se manifestava em outras ilhas, como a Martinica, onde os grandes comerciantes de Saint-Pierre haviam entrado em conflito com os homens de cor. ${ }^{756}$ Em 29 de novembro de 1790, a Constituinte aprovou um decreto, apresentado por Barnave, que suspendia a assembleia colonial da Martinica e determinava o envio de seis mil homens de tropa e quatro comissários para restabelecer a ordem nas ilhas de Barlavento. O Clube Massiac viu nessa lei uma frustração das promessas de 12 de outubro, no que se referia à autonomia colonial para os assuntos internos. ${ }^{757}$ Mas os Amigos dos Negros também se manifestaram contra a lei. Em dezembro, Brissot voltou a atacar Barnave, que parecia não compreender a natureza dos conflitos existentes nas colônias. Para o líder antiescravista, a causa dos tumultos na Martinica era uma causa comum a todas as ilhas: o ódio e a rivalidade dos brancos pobres para com os mulatos. ${ }^{758}$ Esses brancos, desprovidos de propriedades, eram os piores inimigos da população de cor livre, com quem concorriam no âmbito profissional. Como os mulatos trabalhavam melhor, gastavam menos e eram sempre preferidos pelos grandes plantadores, esses petits-blancs eram os mais ardentes defensores do preconceito, única forma de alçar-se socialmente acima dos homens de cor. $^{759}$ A obscuridade dos decretos da Assembleia Nacional havia desencadeado uma série de atrocidades contra os mulatos. Para Brissot, era, mais do que nunca, necessário que ela se pronunciasse claramente sobre o assunto.

\footnotetext{
756 A Martinica vivia um conflito entre, de um lado, os comerciantes de Saint-Pierre e, de outro, o governador e a Assembleia colonial. A crise se agravou quando, durante a festa de louva-Deus em SaintPierre, os brancos locais recusaram à milícia dos homens de cor o direito de participar da procissão. Seguiram-se tumultos que foram duramente reprimidos pelos brancos da cidade. Cerca de trinta homens de cor foram enforcados. A ordem foi então restabelecida pelo Governador, apoiado pela milícia de cor (cf. BANGOU, Henri. La Guadeloupe, 1492-1848, ou l'histoire de la colonisation de l'île liée à l'esclavage noir, de ses débuts à sa disparition. Paris: L'Harmattan, 1987, pp.131-132).

757 A preocupação dos colonos aumentou ainda mais quando foi determinado que, entre os quatro comissários designados, estariam Daniel Lescallier, membro dos Amigos dos Negros, e Lemercier de la Rivière, antigo intendente da Martinica e fisiocrata. O Clube protestou junto ao Ministro da Marinha e conseguiu impedir a partida dos dois comissários. Os dois outros comissários designados eram Lacoste, membro do Clube Massiac, e Magnytot, que seria prefeito colonial de São Domingos em 1802 (cf. DEBIEN, Gabriel. Les colons de Saint-Domingue et la Révolution, pp.258-259).

758 Cf. BRISSOT DE WARVILLE, Jacques-Pierre. Réflexions sur le nouveau décret rendu pour la Martinique et les colonies le 29 novembre 1790, pour servir de suite à la lettre à M. Barnave. Paris: de l'impr. du Patriote françois, 1790, p.2.

${ }^{759}$ Ibidem, p.3.
} 
A questão dos mulatos ganhou novo impulso com as notícias que chegavam de São Domingos, a respeito do movimento conduzido por Ogé. Após uma viagem atribulada ${ }^{760}$, Ogé havia chegado a São Domingos em 21 de outubro de $1790 .{ }^{761}$ Teve de desembarcar clandestinamente, pois a entrada de homens de cor vindos da Europa tinha sido proibida na colônia. Ao lado de Chavannes, que havia participado da guerra de independância norte-americana, Ogé organizou um agrupamento de algumas centenas de homens de cor livres com o objetivo de pedir às autoridades a aplicação das instruções de 28 de março. As autoridades rejeitaram o pedido e emitiram ordens de prisão para os líderes dos mulatos, com tropas para reprimir o movimento. Após alguns dias de intenso combate, Ogé e seus companheiros fugiram para a parte espanhola da ilha, onde foram presos em 29 de dezembro de $1790 .{ }^{762}$

A tragédia repercutia na imprensa. Na edição de 25 de dezembro de $1790-1^{\circ}$ de janeiro de 1791 ( $\mathrm{n}^{\circ} 77$ ), antes mesmo das notícias da prisão dos rebeldes, o jornal Révolutions de Paris relatava a aventura de Ogé, apresentando-o como uma espécie de novo messias, cuja missão era dar aos seus irmãos de cor e negros livres os seus direitos de cidadania. O jornal já dava como certa a morte de Ogé, mas previa também que o mártir seria vingado por "novos libertadores", que reunir-se-iam "[...] para arrancar as pessoas de cor da opressão sob a qual gemem, para destruir essa aristocracia de brancos [...]". ${ }^{763}$ Parafraseando Raynal-Pechméja, profetizava, em relação a Ogé, que "[...] um novo Espártaco renascerá da tua cinza". ${ }^{764}$ Os homens de cor eram apresentados como os verdadeiros revolucionários das ilhas.

Em 5 de janeiro de 1791, o Patriote Français também manifestou-se sobre a insurreição dos mulatos em São Domingos. Relembrou os esforços de Ogé em esclarecer, movido por uma "lealdade magnânima", o comitê das colônias a respeito das consequências fatais da recusa do reconhecimento dos direitos dos homens de cor. Suas ações em São Domingos eram, portanto, uma justa reação à política de Barnave e da Assembleia Nacional. O estado de guerra civil instaurado na ilha nada mais era do que a

\footnotetext{
${ }^{760}$ Por influência do Clube Massiac, a partida de Ogé tinha sido recusada no Havre. Com isso, ele teve de ir para Londres, onde remeteu cartas da Sociedade dos Amigos dos Negros a Clarkson. Este entregou-lhe então uma carta de recomendação aos seus amigos em Charleston, nos Estados Unidos, onde Ogé teria ido procurar armas. De lá, teria finalmente conseguido embarcar para o Caribe (cf. BARLIER, JeanPierre. La Société des Amis des Noirs, p.134).

${ }^{761}$ Cf. JAMES, C.L.R. Os jacobinos negros, p.80.

762 Cf. THIBAU, Jacques. Le temps de Saint-Domingue, pp.204-207. Ogé e seus companheiros foram extraditados, em janeiro de 1791, para o Cap, onde foram executados no mês seguinte.

${ }_{763}$ Cf. Les Révolutions de Paris, v.6, número 77, 25 de dezembro de $1790-1^{\circ}$ de janeiro de 1791, p.641.

${ }^{764}$ Ibidem, p.644.
} 
confirmação de tudo o que os Amigos dos Negros haviam dito a respeito dos perigos inerentes a uma legislação marcada pela obscuridade. Para Brissot, apenas o reconhecimento imediato dos direitos dos "mulatos" permitiria salvar as colônias. ${ }^{765}$

Ao receber a notícia da prisão de Ogé na parte espanhola de São Domingos, Brissot afirmou, na edição de 15 de janeiro, que "o crime atribuído ao Sr. Ogé é um ato de virtude, um dever, um santo dever", assimilando a sua revolta à tomada da Bastilha. ${ }^{766}$ A insurreição dos mulatos, enquanto exercício do direito - ou dever - de resistência à opressão, era o braço colonial da Revolução da metrópole.

As notícias vindas das colônias haviam gerado alguma simpatia pela causa dos negros e homens de cor em outros círculos. Manifestações de apoio aos Amigos dos Negros chegavam das Sociedades dos Amigos da Constituição (Jacobinos) de Nantes e de Lorient. $^{767}$ Além disso, os Amigos dos Negros abandonavam a sua postura conciliadora. Brissot atacava diretamente a deputação de São Domingos, na pessoa de seu principal líder, Gouy d'Arcy, que lhe havia escrito uma carta, manifestando hipocritamente "sentimentos de estima e confraternidade". ${ }^{768}$ No Patriote Français de 6 de janeiro, Brissot respondeu a Gouy, reafirmando o seu desprezo pela deputação de São Domingos, que havia

[...] constantemente violado a verdade, a humanidade, a liberdade, a constituição, perseguindo os homens de cor, enganando a assembleia nacional, as colônias, os negociantes e a França inteira, amotinando cidades inteiras contra uma sociedade de homens respeitáveis, fazendo continuar o infame tráfico, desonrando o nome Francês... ${ }^{769}$

A resposta de Brissot levou Gouy a atacar o líder antiescravista com acusações de todo tipo. Em 10 de fevereiro, Brissot retrucou com nova carta aberta. ${ }^{770}$ Gouy d'Arcy havia sustentado o argumento, bastante comum entre os colonos, de que a condição dos negros nas colônias era melhor do que a dos camponeses na França. Com

\footnotetext{
${ }^{765}$ Cf. Patriote Français, v.4, número 515, 5 de janeiro de 1791, pp.18-19.

${ }^{766}$ Idem, v.4, número 525, 15 de janeiro de 1791, p.58.

${ }^{767}$ Cf. BRISSOT DE WARVILLE, Jacques-Pierre. Réplique à la première et dernière lettre de LouisMarthe Gouy, Défenseur de la Traite des Noirs et de l'Esclavage. Paris: Belin, et au Bureau du Patriote François, 10 février 1791, anexos, pp.52-54.

${ }^{768}$ Cf. Patriote Français, v.4, número 516, 6 de janeiro de 1791, p.22.

769 "[...] constamment violé la vérité, l'humanité, la liberté, la constitution, en persécutant les hommes de couleur, en trompant l'assemblée nationale, les colonies, les négocians et la France entière, en ameutant des villes entières contre une société d'hommes respectables, en faisant continuer l'infâme traite, en flétrissant le nom François..." (Ibidem, p.22).

${ }^{770} \mathrm{O}$ texto era um verdadeiro ato de acusação contra o deputado de São Domingos, retraçando a sua conduta desde antes da Revolução, quando havia se envolvido no escândalo do desvio de 20 milhões do tesouro público, no seio da Companhia das águas de Paris (cf. BRISSOT DE WARVILLE, JacquesPierre. Réplique à la première et dernière lettre de Louis-Marthe Gouy, p.5).
} 
ironia, Brissot respondia que, se isso era verdade, por que então o deputado colonial não havia proposto a implantação de um "tráfico de brancos"? Para o líder dos Amigos dos Negros, "o princípio da caça aos negros conduz à caça aos brancos; o princípio da servidão de uns conduz à servidão dos outros [...]". ${ }^{771}$

Sob a cobertura dos Amigos dos Negros, os homens de cor reunidos em Paris também voltavam a atacar. Àquela altura, Raimond era uma figura conhecida em Paris. Tinha se mudado para perto da Orangerie, no coração da cidade. Além disso, Brissot e Raimond tinham entrado para o clube dos Jacobinos, onde procuravam articular apoio à causa dos mulatos. ${ }^{772}$ Em 26 de janeiro de 1791, Raimond publicou Observations sur l'origine et les progrès du préjugé des colons blancs contre les hommes de couleur, panfleto em que manifestava a sua percepção a respeito do surgimento do preconceito de cor. Este teria se desenvolvido efetivamente a partir da chegada de um importante número de mulheres brancas às colônias, num momento em que a produção colonial estava em franca expansão. Essas mulheres, de moral suspeita e poucas posses, eram geralmente preteridas pelos plantadores brancos, que preferiam viver com as mulheres de cor, descendentes dos primeiros colonos, que lhes traziam geralmente como dote certa quantidade de terras e escravos. Essa preferência teria estimulado a inveja das mulheres europeias; e essa inveja logo transformou-se em ódio. ${ }^{773}$ Jovens de cor eram enviados à metrópole para serem educados e os seus talentos, associados à sua fortuna, ampliavam ainda mais a inveja dos brancos menos afortunados das colônias, os petitsblancs. Estes atacavam a origem das pessoas de cor, pois não tinham mais nada para atacar. Aos poucos, esse ódio deu lugar a humilhações públicas, que, por sua vez, foram acompanhadas de leis opressivas, que procuravam neutralizar os talentos e a indústria das pessoas de cor. ${ }^{774}$

Raimond ressaltava que a população de cor, na sua grande maioria, tinha nascido livre, não havendo, em seu seio, sequer duzentos indivíduos nascidos na escravidão. Assim, os homens de cor não eram libertos que deviam a sua liberdade aos brancos. Eram indivíduos que, três décadas atrás, gozavam dos mesmos direitos que os

\footnotetext{
771 "le principe de la chasse donnée aux noirs mène à la chasse de blancs; le principe de la servitude des uns mène à la servitude des autres [...]" (Ibidem, p.19).

${ }^{772}$ Cf. GARRIGUS, John D. Before Haiti, p. 257.

${ }^{773}$ Cf. RAIMOND, Julien. Observations sur l'origine et les progrès du préjugé des colons blancs contre les hommes de couleur, sur les inconvéniens de le perpétuer, la nécessité, la facilité de le détruire, sur le projet de comité national, etc. Paris: chez Belin, 1791, pp.4-5.

${ }^{774}$ Ibidem, pp.6-8.
} 
brancos. ${ }^{775} \mathrm{Na}$ verdade, Raimond continuava a expressar o ponto de vista particular dos homens de cor do Sul, onde famílias de plantadores de cor estavam estabelecidas há muito tempo. Suas observações não davam conta da situação dos milhares de negros e mulatos alforriados por seus proprietários ou pelo serviço armado na maréchaussée, nem das mulheres negras e mulatas alforriadas por casamento com seus senhores. Raimond expressava a visão de um plantador abastado, ameaçado pela inveja dos petitsblancs e humilhado por uma legislação que o rebaixava à condição de recém-alforriado.

No início de março de 1791, o campo colonial contra-atacava, procurando atribuir os tumultos nas colônias à campanha incendiária dos Amigos dos Negros. Num panfleto dedicado aos "amigos do repouso e da felicidade da França", Moreau de SaintMéry atribuiu o caos nas colônias a:

[...] uma massa de escritos onde pregou-se, aconselhou-se e desejou-se a revolta dos escravos; vomitou-se as mais horríveis imprecações contra os habitantes das colônias, contra os comerciantes, e buscou-se todos os meios de propagar uma doutrina que incita milhares de homens a massacrarem uns aos outros, que tende a despovoar ilhas inteiras, e que só pode ter por termo a ruína dos impérios. ${ }^{776}$

Apresentando Ogé como um agente dos Amigos dos Negros enviado para operar a destruição da colônia, Moreau sustentava que a França e o seu império estariam em perigo enquanto não fossem silenciadas as declamações produzidas por um "delírio pretensamente filosófico". ${ }^{777}$

Além disso, Moreau sustentava que os homens de cor só eram livres por uma concessão dos brancos, não havendo, para ele, qualquer distinção entre os alforriados e seus descendentes. As condições impostas no ato de emancipação se estendiam à descendência dos beneficiados, de modo que os homens de cor só eram livres sob certas condições. Argumentava que a situação não era tão diferente da que existia na metrópole, onde nem todos eram cidadãos ativos, muito embora a Declaração dos direitos tivesse consagrado a igualdade de todos em direitos. Citava o caso dos judeus, que encontravam tantas dificuldades em ver seus direitos reconhecidos, muito embora a

\footnotetext{
${ }^{775}$ Ibidem, pp.13-14.

776 "[...] une foule d'écrits où l'on a prêché, conseillé et désiré la révolte des esclaves; où l'on a vomi les plus horribles imprécations contre les habitants des colonies, contre les commerçants, et cherché tous les moyens de propager une doctrine qui incite des milliers d'hommes à s'entr'égorger, qui tend à dépeupler des isles entières, et qui ne doit avoir pour terme que la ruine des empires" (MOREAU DE SAINTMÉRY, Médéric Louis Élie. Considérations présentées aux vrais amis du repos et du bonheur de la France, à l'occasion des nouveaux mouvemens de quelques soi-disant Amis des noirs. S.l: s.n, [1791], p.6).

${ }_{777}$ Ibidem, pp. 15 e 28.
} 
sua pele fosse branca como a dos demais cidadãos. ${ }^{778}$ De forma astuta, Moreau se valia das contradições da legislação revolucionária para justificar a opressão.

Para o autor, se a Assembleia decidisse a respeito das pessoas de cor, as colônias estariam perdidas, pois os escravos sentir-se-iam estimulados a pretender o mesmo sucesso:

se nossos escravos podem desconfiar que existe uma potência à qual cabe estatuir sobre a sua condição, independentemente da vontade de seus senhores; se, sobretudo, eles adquirirem a prova de que os mulatos recorreram com sucesso a essa potência; se eles forem convencidos de que não estão mais, quanto a nós, numa dependência absoluta; se eles virem, enfim, que sem a nossa participação, os mulatos se tornaram ou devem tornar-se nossos iguais, não há mais esperança para a França de conservar as suas colônias. ${ }^{779}$

Assim, Moreau sustentava que, ao apoiar a causa dos homens de cor, os Amigos dos Negros pretendiam realmente provocar o fim da escravidão nas colônias e, com isso, o fim das próprias colônias. Concluía com uma ameaça de independência das colônias, caso fosse permitido aos antiescravistas continuar a fazer o seu "jogo cruel". ${ }^{780}$

Em 3 de março de 1791, após a notícia da prisão de Ogé, a Sociedade dos cidadãos de cor foi recebida por Louis de Noailles, presidente da Assembleia Nacional. Ela apresentou-lhe uma petição, na qual relembrava que, até então, os livres de cor não haviam sido excluídos dos direitos políticos por nenhum decreto nacional. Pedia que a Assembleia, fundada em princípios de igualdade, protegesse os livres de cor da ação das assembleias coloniais, por meio do envio de comissários civis especialmente habilitados. Noailles propôs a data de 5 de março para que a Sociedade dos cidadãos de cor fosse ouvida na Assembleia. Em 4 de março, Arthur Dillon, deputado da Martinica, respondeu com violência a essa proposta, alertando para os efeitos nefastos que a admissão das pessoas de cor na Assembleia produziria nas colônias. Relembrou ainda que, por meio do decreto de 12 de outubro de 1790, a Assembleia havia decretado não

\footnotetext{
${ }^{778}$ Ibidem, pp.37-39.

779 "si nos esclaves peuvent soupçonner qu'il est une puissance à laquelle il appartienne de statuer sur leur sort, indépendamment de la volonté de leurs maîtres; si surtout ils acquièrent la preuve que les mulâtres ont recouru utilement à cette puissance; s'ils sont convaincus qu'ils ne sont plus à notre égard dans une dépendance absolue; s'ils voient enfin que sans notre participation, les mulâtres sont devenus ou doivent devenir nos égaux, il n'est plus d'espoir pour la France de conserver ses colonies" (Ibidem, p.48).

${ }^{780}$ Cf. MOREAU DE SAINT-MÉRY, Médéric Louis Élie. Considérations présentées aux vrais amis du repos, p.70. O texto de Moreau motivaria uma resposta de Julien Raimond, publicada apenas em 12 de maio, durante o debate sobre os homens de cor. O líder dos cidadãos de cor procurou desmentir as calúnias lançadas contra os Amigos dos Negros, acusando, ao contrário, os deputados coloniais de terem gerado, por meio de suas cartas incendiárias, as instabilidades nas ilhas (cf. RAIMOND, Julien. Réponse aux considérations de M. Moreau, dit de Saint-Méry, député à l'Assemblée nationale, sur les colonies. Paris: de l'imprim. du Patriote Français, 1791, pp.4 e ss.).
} 
tocar no assunto, a não ser a pedido expresso das colônias. ${ }^{781}$ Dillon aproveitou para lançar novos ataques contra os Amigos dos Negros, acusando-os formalmente de terem provocado os tumultos nas colônias e de terem se vendido a potências estrangeiras. ${ }^{782}$ Pétion, Mirabeau, Buzot e Le Chapelier tentaram intervir para que a decisão de Noailles fosse respeitada, mas, após algum tumulto, foi decidido que a sessão seria encerrada. Com isso, a audiência dos cidadãos de cor acabou sendo anulada.

Em resposta às calúnias de Arthur Dillon, os Amigos dos Negros pediram na Assembleia, no dia 5 de março, que fossem tomadas medidas contra o deputado, ou então que fosse suspensa a sua imunidade parlamentar para que pudessem persegui-lo judicialmente. ${ }^{783} \mathrm{O}$ seu pedido não foi atendido. No dia seguinte, 6 de março, Dillon esteve ausente, mas uma carta sua foi lida por Moreau de Saint-Méry, esclarecendo que nunca tinha sido sua intenção responsabilizar todos os Amigos dos Negros pelos incidentes nas colônias e que tinha pela maioria de seus membros todo o respeito e estima. Em carta aberta, de 10 de março, os Amigos dos Negros rejeitaram tais explicações, pois, embora tivesse apresentado certas nuances, Dillon continuava acusando os Amigos dos Negros de provocarem, por meio de seus escritos, todos os malogros das colônias, e, continuava acusando alguns de seus membros de serem vendidos. ${ }^{784}$ Os Amigos dos Negros desafiavam Dillon a especificar os nomes dos textos e dos homens a que tinha se referido. ${ }^{785}$

Em 18 de março de 1791, a Sociedade dos Cidadãos de Cor decidiu publicar sua petição à Assembleia Nacional. O texto, que seria incluído no Patriote Français de 25 de março, pedia que comissários civis fossem instruídos a promover a efetiva execução do decreto de 28 de março de 1790 , e ressaltava que o seu pedido nada tinha a ver com a causa dos escravos, apontando, ao contrário, a importância dos homens de cor, os futuros "regeneradores das ilhas", para a manutenção da ordem colonial. ${ }^{786}$

Entre o final de março e o início de abril, a Sociedade dos Amigos dos Negros publicou o seu texto mais longo, endereçado à Assembleia, às cidades comerciais, manufaturas, colônias e clubes dos Jacobinos. Preparado desde 1789 e redigido por Clavière, ele compilava todas as posições da Sociedade a respeito do tráfico, da

\footnotetext{
${ }^{781}$ Cf. AP, v.23, p.665.

${ }^{782}$ Cf. Patriote Français, v.4, número 575, 6 de março de 1791, p.240.

${ }^{783}$ Cf. PLAINTE de la Société des Amis des Noirs, contre M. Dillon, à l'Assemblée Nationale. S.1. [Paris]: s.n., s.d. [1791], p.2.

${ }^{784}$ Cf. LA SOCIÉTÉ des Amis des Noirs à Arthur Dillon, Député de la Martinique à l'Assemblée Nationale. S.1. [Paris]: Imprimerie du Patriote François, s.d. [1791], pp.7-8.

${ }_{785}^{78}$ Ibidem, p.8.

${ }^{786}$ Cf. Patriote Français, v.4, número 594, 25 de março de 1791, pp.319-320.
} 
escravidão, dos homens de cor e da questão colonial em geral. Respondendo a Moreau de Saint-Méry, Clavière recusava a comparação do preconceito de cor nas colônias com o sistema censitário na metrópole: "Na França, a faculdade de eleger resulta de uma desigualdade pecuniária que cada um pode pretender superar. Nas colônias, essa desigualdade, resultante da cor da pele, seria insuperável". ${ }^{787}$

Essa troca infindável de acusações indicava a iminência de um novo debate sobre as colônias. Desta vez, a Sociedade dos Amigos dos Negros decidiu preparar melhor a opinião e enviou 400 exemplares da sua Adresse aos Jacobinos de Paris. ${ }^{788}$ Por sua vez, o Comité de correspondência do clube dos Jacobinos transmitiu o texto às filiais provinciais do clube. Pela primeira vez, os Amigos dos Negros construíam uma base de apoio às suas pretensões.

As notícias da prisão de Ogé haviam feito dele um símbolo da luta contra o preconceito, e foram usadas para envolver determinadas esferas de opinião no debate colonial. Mais do que bons sentimentos em relação ao destino de Ogé, o que a história do personagem suscitava eram preocupações quanto à capacidade dos homens de cor de se estruturarem num movimento de revolta organizado. A perspectiva de uma aliança com os escravos diante da negação de seus direitos de cidadania começava a pesar sobre a integridade do império colonial. $\mathrm{Na}$ metrópole, muitos começavam a ver o reconhecimento desses direitos como um sacrifício pequeno. Assim, a campanha dos Amigos dos Negros junto aos Jacobinos, isto é, a elite do que se chamava outrora o Terceiro Estado (negociantes, advogados, oficiais, rentistas), gerou resultados. As diferentes filiais da Sociedade dos Amigos da Constituição emitiram cartas e petições em apoio à reclamação dos homens de cor livres. A Sociedade de Angers manifestou-se em primeiro, por meio de uma petição à Assembleia Nacional, de 8 de março de 1791. Prestando homenagem à coragem de Ogé e seus companheiros, perguntava:

Mas que perigo, que inconveniente poderia haver em conceder esses direitos incontestáveis aos homens de cor livres que, pelos seus sentimentos e pela sua educação, não diferem em nada dos brancos dos quais descendem, e que, possuindo a maior parte das terras de nossas colônias, são os maiores interessados na prosperidade pública. ${ }^{789}$

\footnotetext{
787 "En France, la faculté d'élire tient à une inégalité pécuniaire que chacun peut espérer de franchir. Dans les colonies, cette inégalité, tenant à la couleur de la peau, serait insurmontable" (CLAVIÈRE, Étienne. Adresse de la Société des Amis des Noirs, p.156).

${ }^{788}$ Cf. BRISSOT, Jacques-Pierre. Correspondance et papiers, p.265.

789 "Mais quel danger, quel inconvénient même y aurait-il à accorder ces droits incontestables aux hommes de couleur libres qui, par leurs sentiments et par leur éducation, ne diffèrent point des blancs
} 
No dia seguinte, os Jacobinos de Angers enviaram uma circular, redigida por Milscent, a todas as sociedades patrióticas do reino. Entre março e abril, as Sociedades dos Amigos da Constituição de, pelo menos, quinze cidades responderam favoravelmente à circular: Verneuil (18 de março), Fougères (19 de março), Le Mans (20 de março), Pontarlier (20 de março), Niort (20 de março), Bordeaux (22 de março), Libourne (23 de março), Coutances (23 de março), Riom (24 de março), Vannes (26 de março), Lisieux (29 de março), Saint-Tropez (30 de março), Montauban (30 de março), Saint-Étienne (3 de abril) e Bourg-em-Bresse (17 de abril). ${ }^{790}$ Já os Jacobinos de Cantal, em Aurillac, enviaram uma petição em favor dos homens de cor diretamente à Assembleia Nacional. Além disso, os Amigos dos Negros receberam cartas de apoio do Círculo Social (3 de abril), da Sociedade popular dos Amigos da Constituição das Trinta e uma seções de Lyon (20 de abril) e do clube popular do cantão de Condrieux, no departamento de Rhône-et-Loire (27 de abril). ${ }^{791}$ Os negociantes de Bordeaux enviaram uma carta às câmaras de comércio e negociantes das colônias criticando os Amigos dos Negros, mas fazendo uma defesa da causa dos homens de $\operatorname{cor}^{792}$, que, pela primeira vez, tornava-se o objeto de uma verdadeira mobilização. Esse apoio de grandes cidades portuárias à questão dos mulatos era frágil, mas produziria efeitos concretos no debate parlamentar de maio. Naquele momento, o reconhecimento dos direitos dos livres de cor parecia uma pequena concessão pela salvação das colônias.

No final de abril, instruções aos comissários civis, elaboradas pelo comitê das colônias, foram submetidas à apreciação dos comitês da Marinha, da Constituição e do Comércio. Embora fossem apresentadas apenas como instruções, a intenção de Barnave era fazer delas um instrumento para dar às colônias a sua própria constituição. ${ }^{793}$ Aliás, em 25 de abril, os 85 léopardins pediram, por meio de uma petição à Constituinte, que as instruções recebessem o nome de "Constituição colonial provisória". Mas, àquela altura, um novo debate sobre as colônias estava para ser aberto.

dont ils tirent leur origine, et qui possédant la plus grande partie des terres de nos colonies, sont le plus intéressés à la prospérité publique" (LETTRES des diverses Sociétés des Amis de la Constitution, qui réclament les droits de Citoyen actif en faveur des hommes de couleur des Colonies. S.1. [Paris]: Imprimerie du Patriote François, s.d. [1791], p.18).

${ }^{790}$ Ibidem, pp.1-19.

${ }^{791}$ Cf. CLAVIÈRE, Étienne.. Adresse de la Société des Amis des Noirs, pp.233-236.

792 Ibidem, p. 291.

${ }^{793}$ Cf. DEBIEN, Gabriel. Les colons de Saint-Domingue et la Révolution, p.269. 


\section{I.3.4) O debate de maio de 1791: uma vitória momentânea}

\section{I.3.4.1) Constitucionalização da escravidão, igualdade da epiderme}

Em $1^{\circ}$ de maio de 1791, o Patriote Français relatava, com grande indignação, o suplício de Ogé:

Ogé não vive mais, ele expirou sobre a roda com seus desafortunados companheiros; ele expiou não crimes, mas a infelicidade de ter sucumbido na reclamação dos direitos do homem, desses direitos que os decretos lhes restituíam, e que o injusto despotismo dos brancos lhes recusava... ${ }^{794}$

Ogé e seus companheiros haviam sido executados em 9 de fevereiro de 1791 . Sua execução foi um verdadeiro espetáculo de horror: tiveram seus braços, pernas, coxas e rins rompidos no cadafalso, antes de serem colocados em rodas, com a face voltada para o céu, onde permaneceram até que a vida lhes escapasse. ${ }^{795}$ As manifestações de revolta a respeito do martírio de Ogé e seus comandados tinham preparado o terreno para um novo debate sobre as colônias, em maio de 1791. A questão dos homens de cor livres não podia mais ser contornada.

No dia 7 de maio, Delâtre apresentou um relatório sobre as colônias, em nome dos Comitês reunidos das colônias, da Marinha, da Constituição e da Agricultura e Comércio. O relatório tinha dois objetivos essenciais: em primeiro lugar, transformar o preâmbulo do decreto de 12 de outubro em artigo constitucional; em seguida, propor a formação de um comitê de representantes de todas as colônias, a ser reunido na ilha de Saint-Martin, para discutir a questão das pessoas de cor livres. Esse Comitê geral das colônias reuniria doze delegados de São Domingos, seis da Martinica, seis da Guadalupe, dois de Sainte-Lucie, dois de Tobago e dois da Guiana. Esses representantes reunir-se-iam por quarenta dias, a partir de $1^{\circ}$ de dezembro de 1791 , para cuidar exclusivamente da questão dos homens de cor livres. No Patriote Français, Brissot qualificou o decreto proposto de "absurdo, ridículo e atroz", vendo nele apenas uma estratégia do campo colonial para ganhar tempo. ${ }^{796}$

\footnotetext{
794 "Ogé n'est plus, il a expiré sur roue avec ses compagnons infortunés; il a expié, non des forfaits, mais le malheur d'avoir succombé dans la réclamation des droits de l'homme, de ces droits que les décrets leur restituaient, et que l'injuste despotisme des blancs leur refusait...." (Patriote Français, v.4, número 631, $1^{\circ}$ de maio de 1791, p.472).

${ }^{795}$ Cf. THIBAU, Jacques. Le temps de Saint-Domingue, p. 246.

${ }^{796}$ Cf. Patriote Français, v.4, número 638, 8 de maio de 1791, p.502.
} 
O campo colonial procurou evitar o debate na Assembleia, mas, desta vez, ele ocorreu. Enquanto Moreau de Saint-Méry e Malouet pediam o voto imediato, Grégoire interveio para denunciar o caráter inconstitucional da lei de 12 de outubro e pedir o adiamento da votação. Pétion tomou a palavra para demolir o projeto de um congresso de colonos: "O que é esse congresso que vos é proposto? Imaginem se, na origem da revolução, vos tivesse sido oferecido submeter a aprovação dos direitos das comunas a um congresso dos padres e dos nobres, o que serieis hoje?". ${ }^{797}$ No fim, a votação acabou sendo adiada, marcando uma primeira derrota do preconceito. Enquanto isso, na Inglaterra, a abolição do tráfico era, mais uma vez, rejeitada pela Câmara dos Comuns.

Em 11 de maio, o projeto de Delâtre voltou a ser debatido na Assembleia Nacional. Os Amigos dos Negros aproveitaram a ocasião para distribuir na Assembleia um suplemento à sua petição em favor dos cidadãos de cor. ${ }^{798}$ Grégoire tomou a palavra para anunciar o apoio manifestado por várias cidades, como Bordeaux ${ }^{799}$, Lorient e Angers, à causa dos homens de cor. Muito aplaudido, o abade pediu a não deliberação sobre o projeto dos comitês reunidos e propôs que se declarasse que as pessoas de cor gozariam dos direitos de cidadãos ativos, assim como os demais franceses. ${ }^{800}$

No campo contrário, a estratégia de Barnave era evitar a discussão sobre o fundo da questão - os direitos de cidadania dos homens de cor - e reduzir o debate a uma simples questão de competência legislativa sobre o estado das pessoas nas colônias. Ou seja, não se negava abertamente os direitos dos livres de cor; apenas afirmava-se que seu reconhecimento era da competência das assembleias coloniais. De forma hipócrita, Barnave sustentava a pertinência da realização do congresso na ilha de Saint-Martin, longe da influência dos brancos não-proprietários, maiores inimigos das pessoas de cor, o que permitiria "[...] afastar a influência desse preconceito, e garantir a liberdade das opiniões em favor dos homens livres de cor". ${ }^{801}$ Em resposta a essa linha de

\footnotetext{
797 "Qu'est-ce que le congrès qu'on vous propose? Imaginez qu'à l'origine de la révolution, on vous eût offert de faire décider les droits des communes par un congrès des prêtres et des nobles, que seriez-vous aujourd'hui?" (Ibidem, p.502).

${ }^{798}$ Cf. Supplément nécessaire à l'adresse de la Société des Amis des Noirs en faveur des hommes de couleur. Distribué le 11 Mai 1791, à l'Assemblée nationale. In: CLAVIÈRE, Étienne. Adresse de la Société des Amis des Noirs, pp.179-208.

${ }^{799}$ Uma carta de Gensonné, membro do tribunal de cassação, eleito pelo departamento da Gironda, atestava que a opinião de Bordeaux sobre a questão dos direitos das pessoas de cor era a de que privá-las dos direitos imprescritíveis que lhes garantia a sua condição de cidadãs era uma derrogação inaceitável da declaração dos direitos. Acreditava ainda que a iniciativa reclamada pelos colonos lhes parecia contrária também ao interesse da metrópole (cf. BAUX; GENSONNÉ. Lettres importantes relatives à la question des citoyens de couleur. S.1.: Imprimerie du Patriote François, s.d., pp.2-3).

${ }^{800}$ Moniteur, v.8, número 132, 12 de maio de 1791, pp.366-367.

${ }^{801}$ Idem, v.8, número 133, 13 de maio de 1791, p.376.
} 
argumentação, alguns, como Tracy e Dupont de Nemours, procuraram restringir a competência sobre o estado das pessoas unicamente ao estado dos escravos, no intuito de sugerir um compromisso: a preservação da escravidão contra os direitos dos homens de cor. ${ }^{802}$

Alguns colonos, entretanto, abordaram diretamente o fundo do problema. Assim, Malouet argumentou pela incompatibilidade da Declaração dos direitos com as colônias, tendo em vista a composição de sua população e os seus usos e costumes:

Não se trata de examinar se a instituição da escravidão pode ser sustentada em direito e em princípio: nenhum homem não desprovido de sensatez e moralidade professa essa doutrina; trata-se de saber se é possível, sem um acúmulo de crimes e infortúnios que vos assustariam, alterar tal estado de coisas nas vossas colônias. ${ }^{803}$

O que Malouet pedia era a definição de princípios constitutivos para as colônias, que garantissem o seu modo de existência e a sua conservação e, nesse sentido, entendia que cabia a elas decidir a respeito das pessoas de cor livres. Ou seja, para ele, não havia separação entre a questão dos homens de cor e a dos escravos.

Em resposta, amigos dos Negros, como Pétion, relembravam que os homens de cor faziam parte da classe dos proprietários coloniais e cumpriam função essencial para a manutenção da ordem escravista. Para Pétion, a frustração das aspirações dessa classe poderia ter consequências desastrosas para as colônias. ${ }^{804}$ Por sua vez, o Marquês de La Fayette apresentou o seguinte silogismo:

A Assembleia nacional convoca os colonos para deliberar sobre os seus interesses. Não é evidente que os homens livres, proprietários, cultivadores, contribuintes de uma colônia, são colonos? Ora, aqueles de que se trata são contribuintes, cultivadores, proprietários livres; seriam eles também homens? Penso que sim [...]. ${ }^{80 .}$

No fundo, ambos os campos advogavam em favor da manutenção da ordem colonial, divergindo apenas quanto ao papel que a segregação exerceria na manutenção

\footnotetext{
802 "Puisqu'il n'y a plus de noblesse, il ne faut laisser que deux états de personnes: la liberté et l'esclavage" (Ibidem, pp.370-371).

803 "Il ne s'agit pas d'examiner si l'institution de l'esclavage peut être soutenue en droit et en principe: aucun homme non dépourvu de sens et de moralité ne professe cette doctrine; il s'agit de savoir s'il est possible, sans une accumulation de crimes et de malheurs dont vous seriez effrayés, de changer un tel état de choses dans vos colonies" (Ibidem, p.373).

${ }^{804}$ Ibidem, p.375.

${ }^{805}$ "L'Assemblée nationale convoque les colons pour délibérer sur leurs intérêts. N'est-il pas évident que les hommes libres, propriétaires, cultivateurs, contribuables, d'une colonie, sont des colons? Or, ceux dont il est question sont contribuables, cultivateurs, propriétaires, libres; sont-ils aussi des hommes? Moi, je le pense [...]" (Ibidem, p.374).
} 
ou na destruição da mesma. Ao término da sessão, a Assembleia parecia dividida. No mesmo dia, o debate se estendeu ao clube dos Jacobinos, onde confrontaram-se Brissot e Barnave. ${ }^{806}$ Contudo, ao comentar o debate no Patriote Français, Brissot, de forma pouco prudente, voltou a estabelecer o vínculo entre a causa dos mulatos e a abolição gradual da escravidão:

É sob a salvaguarda desses crioulos, cuja inteligência acompanhará a fidelidade, e que deve-se temer aviltar, que os colonos brancos verão acalmar-se todas as suas inquietações; que o comércio ganhará o maior impulso, e que amadurecerão e executar-se-ão com sabedoria os projetos que a humanidade e o interesse reclamam em favor dos escravos, cujo recrutamento pelo tráfico, dirige-se necessariamente ao seu fim. ${ }^{807}$

No dia 12, a discussão retomou com a leitura de uma carta de Julien Raimond sobre a exata extensão da população de cor livre de São Domingos, que ele estimava em 30 mil pessoas, número igual ou superior ao de brancos. Os Amigos dos Negros e alguns simpatizantes multiplicaram as intervenções em favor dos mulatos: Lanjuinais, Tracy, Grégoire, Dupont de Nemours e Sieyès manifestaram-se contra o projeto dos comitês. ${ }^{808}$ Para eles, a questão dos direitos dos homens de cor tinha sido resolvida com as instruções de 28 de março de 1790, mas a obscuridade daquela lei continuava a gerar conflitos.

Para colonos como Moreau de Saint-Méry, se a Assembleia se pronunciasse sobre o estado dos homens de cor, ela estaria antecipando, nesse ponto, a constituição das colônias, cuja elaboração competia às assembleias coloniais. Para ele, a cidadania ativa era uma "convenção puramente social", fora, portanto, do âmbito do direito natural: assim como a metrópole tinha seus cidadãos inativos, as colônias tinham os seus "alforriados", que tinham recebido dos brancos a liberdade, sob certas condições. ${ }^{809}$

A sessão foi marcada pela entrada em cena de Robespierre, que até então havia se mantido silencioso a respeito das questões coloniais. ${ }^{810}$ Para ele, o que estava em debate não era o reconhecimento dos direitos dos livres de cor, mas a sua conservação, tendo em vista que a legislação pré-revolucionária já lhes garantia a igualdade dos

${ }^{806}$ Cf. AULARD, F.A. La Société des Jacobins - Recueil de documents pour l'histoire du club des Jacobins de Paris. Paris: Léopold Cerf/Noblet/Quantin, 1889-1897, v.2, p.412.

${ }^{807}$ Cf. Patriote Français, v.4, número 642, 12 maio de 1791, p.519.

${ }^{808}$ Cf. Moniteur, v.8, número 134, 14 de maio de 1791, pp.380 e 384-385.

${ }^{809}$ Ibidem, p.383.

${ }^{810}$ Jean-Daniel Piquet afirma que a causa dos negros esteve na origem das relações entre Robespierre e Brissot, que seriam mantidas até os debates sobre a declaração da guerra. Em maio de 1791, Brissot teria ido até Robespierre, no quadro do clube dos Jacobinos, para obter apoio à causa dos mulatos. Embora Robespierre nunca tenha integrado os Amigos dos Negros, naquele momento, eles fizeram causa comum (cf. PIQUET, Jean-Daniel. L'émancipation des Noirs dans la Révolution française, p.85). 
direitos civis, os únicos de que todos os cidadãos gozavam até então. Ora, a Revolução havia devolvido os direitos políticos a todos os cidadãos, determinando que todo homem que pagasse a contribuição de três jornadas de trabalho era cidadão ativo, independentemente da sua cor. A lei de 12 de outubro não havia alterado em nada esse estado de coisas: ao submeter o estado das pessoas à iniciativa das colônias, isto é, dos cidadãos das colônias, ela só podia incluir as pessoas de cor nessa iniciativa. ${ }^{811}$

Robespierre entendia que o verdadeiro motivo da recusa dos colonos em reconhecer os direitos dos livres de cor era o temor de que tal operação diminuiria "o respeito dos escravos pelos seus senhores". Para o jacobino, essa objeção era absurda, na medida em que esse reconhecimento reforçaria o poder dos senhores, solidificando a classe dos proprietários de escravos. Inversamente, privá-los de seus direitos seria incitá-los a se aproximar dos escravos: "Se houvesse alguma insurreição a temer por parte dos escravos, é evidente que [os homens de cor] não teriam então o mesmo interesse em reprimi-la, pois a sua causa seria quase comum...". ${ }^{812}$ Quanto ao congresso em Saint-Martin, isso era submeter a sorte dos homens de cor aos seus adversários:

É como se tivesse sido realizado, quando tratou-se na França de saber se o terceiro estado teria uma representação dupla, um congresso composto de metade de clero, metade de nobres, para dar ao governo a sua opinião sobre os direitos das comunas. ${ }^{813}$

A argumentação de Robespierre era, portanto, dúplice: por um lado, invocava os direitos do Homem, recusando uma discriminação baseada na cor; por outro, reforçava a ideia de que o reconhecimento dos direitos dos homens de cor fortaleceria a posição dos senhores de escravos, fazendo deles um bloco único. A defesa dos princípios era o ponto de partida necessário, porém insuficiente para convencer o partido colonial, na medida em que era a própria extensão dos princípios às colônias que estava em discussão. No final, a luta era travada no mesmo campo adotado pelo partido contrário: o da manutenção da ordem.

Apesar dos esforços dos Amigos dos Negros e de Robespierre, 378 deputados contra 276 decidiram que cabia deliberar sobre o projeto dos comitês. Isso apontava para uma possível derrota da ala esquerda, mas a votação já demonstrava progressos evidentes, o que não deixou de inquietar o partido colonial.

\footnotetext{
${ }^{811}$ Cf. Moniteur, v.8, número 134, 14 de maio de 1791, pp.381-382.

${ }^{812}$ Ibidem, p.382.

813 "C'est comme si, lorsqu'il s'est agi en France de savoir si le tiers état aurait une double représentation, on eût fait un congrès composé de moitié de clergé, moitié de nobles, pour donner au gouvernement son avis sur les droits des communes" (Ibidem, p.382).
} 
Após a sessão de 12 de maio, os colonos, liderados por Gouy d'Arcy, fariam publicar uma lista dos 276 deputados que haviam votado contra o projeto dos comitês. O documento portava o seguinte título: Liste des députés qui ont voté pour l'Angleterre contre la France dans la question de savoir si l'Assemblée nationale sacrifierait ses colonies, oui ou non, 12 mai 1791. Na manipulação ideológica da questão colonial, os adversários da igualdade se apresentavam como "patriotas" em oposição aos serviçais da Inglaterra. ${ }^{814}$ A conexão inglesa dos Amigos dos Negros era, mais uma vez, usada como argumento contra os partidários dos homens de cor livres.

Na sessão parlamentar de 13 de maio, diante das fraturas existentes no seio da Assembleia, Barère tomou a iniciativa de propor uma redação alternativa para 0 art. $1^{\circ}$ do decreto:

A Assembleia nacional, considerando que os homens de cor livres, proprietários e contribuintes, devem gozar de todos os direitos de cidadãos ativos, decreta, como artigo constitucional, que a iniciativa pertencerá às assembleias coloniais da mesma maneira que foi fixada pelo decreto de 8 de março, sem qualquer prejuízo da soberania nacional. (grifo nosso $)^{815}$

Dupont de Nemours pediu a aprovação do projeto de Barère e, rebatendo insinuações de independência feitas pelos deputados colonos, lançou a famosa frase: "Se, entretanto, essa cisão devesse ocorrer, se fosse preciso sacrificar o interesse ou a justiça, seria melhor sacrificar as colônias do que um princípio". 816

A verdade é que nem todos os colonos eram contrários aos direitos dos homens de cor. A oposição era liderada, essencialmente, pelos representantes de São Domingos. Por outro lado, Monneron, deputado das colônias orientais ${ }^{817}$ e defensor convicto da escravidão colonial, interveio em favor dos homens de cor nascidos livres, sustentando que a competência para uma questão tão complexa quanto o estado civil das pessoas de cor só podia caber à Assembleia Nacional. O projeto dos comitês, argumentou, consistia em "causar a morte civil de uma classe numerosa de cidadãos", submetendo a sua sorte a um tribunal de 29 juízes em Saint-Martin, que eram, na verdade, partes interessadas na

\footnotetext{
${ }^{814} \mathrm{Cf}$. LISTE des députés qui ont voté pour l'Angleterre contre la France dans la question de savoir : Si l'Assemblée nationale sacrifierait ses colonies, oui ou non. Le 12 mai 1791. S.1: s.n., s.d., p.8.

815 "L'Assemblée nationale, considérant que les hommes de couleur libres, propriétaires et contribuables, doivent jouir de tous les droits de citoyens actifs, décrète, comme article constitutionnel, que l'initiative appartiendra aux assemblées coloniales de la même manière qu'elle a été fixée par le décret du 8 mars, sans entendre rien préjuger sur la souveraineté nationale" (Moniteur, v.8, número 134, 14 de maio de 1791, p.387).

816 "Si toutefois cette scission devait avoir lieu, s'il fallait sacrifier l'intérêt ou la justice, il vaudrait mieux sacrifier les colonies qu'un principe" (Idem, v.8, número 135, 15 de maio de 1791, p.391).

${ }^{817}$ Vale observar que, na ilha Bourbon, grande parte dos proprietários era mestiça.
} 
questão. Afirmou que, um dia, os homens de cor seriam suficientemente numerosos para expulsarem os europeus e que era, portanto, necessário prevenir esse desastre. ${ }^{818}$

Novas redações do decreto foram propostas à Assembleia. No lugar do artigo sobre o congresso em Saint-Martin, Roederer, do clube dos Jacobinos, sugeriu um novo dispositivo, que inovava ao introduzir um elemento distintivo: "Os homens de cor, nascidos de pai e mãe livres, e reunindo as condições necessárias para obter a qualidade de cidadão ativo, gozarão de todos os direitos vinculados a essa qualidade" (grifo nosso). ${ }^{819}$ Essa proposta consistia em estabelecer uma divisão na classe dos livres de cor, excluindo os alforriados e filhos de alforriados dos direitos de cidadania. No final, ela acabaria se impondo.

Quanto ao art. $1^{\circ}$ do projeto dos comitês, Lucas pediu que à expressão estado das pessoas fossem acrescentadas as palavras não livres, mas Moreau argumentou que era necessário evitar novos equívocos e propôs substituir a expressão pessoas não livres pela palavra escravos, esclarecendo ainda que isso não significava o abandono da iniciativa sobre os homens de cor. Propôs uma redação nos seguintes termos:

A Assembleia nacional decreta que nenhuma lei sobre o estado dos escravos nas colônias da América poderá ser feita a não ser sob o pedido espontâneo das assembleias coloniais. (grifo nosso) (20 $^{820}$

Isso provocou uma intervenção enfurecida de Robespierre, que compreendeu a armadilha dos colonos: "No momento em que, em um de vossos decretos, pronunciardes a palavra escravo, tereis pronunciado vossa própria desonra [...]". ${ }^{821}$ Retomando a fórmula de Dupont de Nemours ${ }^{822}$, Robespierre proclamou:

\footnotetext{
${ }^{818}$ Cf. Moniteur, v.8, número 135, 15 de maio de 1791, pp.394-395.

819 "Les hommes de couleur, nés de père et mère libres, et réunissant les conditions nécessaires pour obtenir la qualité de citoyen actif, jouiront de tous les droits attachés à cette qualité" (Ibidem, p.395).

820 "L'Assemblée nationale décrète qu'aucune loi sur l'état des esclaves dans les colonies d'Amérique ne pourra être faite que sur la demande spontanée des assemblées coloniales" (Idem, v.8, número 134, 14 de maio de 1791, p.388).

821 "Dès le moment où dans un de vos décrets vous aurez prononcé le mot esclave, vous aurez prononcé et votre propre déshonneur, et... " (Idem, v.8, número 135, 15 de maio de 1791, p.395).

${ }^{822}$ A célebre fórmula Périssent les colonies! inspirava-se dos artigos de Jaucourt para a Enciclopédia. Ela havia se tornado bastante popular, aparecendo, sob diversas formas, nos primeiros anos da Revolução. Algumas semanas antes do debate de maio, ela tinha sido usada por Servant, presidente do clube popular de Condrieux. A formulação definitiva viria num artigo de Camille Desmoulins sobre o debate de maio, publicado nas Révolutions de France et de Brabant: "pereçam as colônias antes que os princípios!" (Révolutions de France et de Brabant, par Camille Desmoulins. Reimpressão. Frankfurt am Main: Keip Verlag, 1789, v.6, número 77, 16 de maio de 1791, pp.571-572). Marx retomaria a célebre fórmula num artigo para o New York Daily Tribune, de 2 de julho de 1858, em que atacou a política de Napoleão III contra os esforços do governo britânico pelo fim do tráfico: "Pereçam as colônias, mas que vivam os princípios!" (MARX, Karl apud GAUTHIER, Florence. Périssent les colonies plutôt qu'un principe! De Jaucourt à Marx en passant par Robespierre et Desmoulins. In: Périssent les colonies plutôt
} 
O interesse supremo da nação e das colônias é que vós permaneceis livres, e que não derrubais, com vossas próprias mãos, as bases da liberdade. Pereçam as colônias! [...] se isso tiver de custar a vossa felicidade, vossa glória, vossa liberdade! Repito: pereçam as colônias se os colonos quiserem, por meio de ameaças, nos forçar a decretar o que convém mais aos seus interesses! Declaro, em nome da Assembleia... em nome daqueles membros dessa Assembleia que não querem derrubar a constituição; declaro em nome da nação inteira, que quer ser livre, que não sacrificaremos aos deputados das colônias que não defenderam seus eleitores [...]; declaro, digo, que nós não lhes sacrificaremos nem a nação, nem as colônias, nem a humanidade com um todo! $!^{823}$

Alguns historiadores, como Jean-Daniel Piquet, quiseram ver na intervenção de Robespierre uma "profissão de fé anticolonialista" ${ }^{824}$, interpretação que se coaduna muito mal com outras atitudes posteriores do líder jacobino. ${ }^{825} \mathrm{O}$ que ele pretendia era, antes, evitar a consagração legal da escravidão, determinando a proscrição da palavra escravidão do vocabulário revolucionário, de modo a impedir a sua perpetuação nas colônias ou mesmo a sua reinstituição na metrópole. Foi uma intervenção contra a sujeição das colônias e da Nação aos interesses privados dos senhores de escravos.

As suas palavras surtiram algum efeito. Acuado, Moreau retirou a palavra escravo. Entretanto, a Assembleia decidiu adotar a emenda que acrescentava as palavras não livres e há de se perguntar se havia, na cabeça dos deputados da Assembleia, alguma diferença fundamental entre escravos e pessoas não livres. É provável que não houvesse, o que explicaria a pequena resistência do campo colonial à nova redação. $\mathrm{O}$ art. $1^{\mathrm{o}}$ foi adotado nos seguintes termos:

qu'un principe! Contribution à l'histoire de l'abolition de l'esclavage. Paris: Société des études robespierristes, 2002, pp.102-103).

823 "L'intérêt suprême de la nation et des colonies est que vous demeuriez libres, et que vous ne renversiez pas de vos propres mains les bases de la liberté. Périssent les colonies! [...] s'il doit vous en coûter votre bonheur, votre gloire, votre liberté! Je le répète: périssent les colonies si les colons veulent, par les menaces, nous forcer à décréter ce qui convient le plus à leurs intérêts! Je déclare, au nom de l'Assemblée..., au nom de ceux des membres de cette Assemblée qui ne veulent pas renverser la constitution; je déclare au nom de la nation entière, qui veut être libre, que nous ne sacrifierons pas aux députés des colonies qui n'ont pas défendu leurs commettants [...]; je déclare, dis-je, que nous ne leur sacrifierons ni la nation, ni les colonies, ni l'humanité entière!" (Moniteur, v.8, número 135, 15 de maio de 1791, p.395).

${ }^{824}$ Cf. PIQUET, Jean-Daniel. L'émancipation des Noirs dans la Révolution française, p.205.

${ }^{825}$ Essa questão é bastante debatida na historiografia. Hardy aponta que Robespierre tinha aspirações expansionistas que eram distintas dos interesses dos colonos, mas que permitiam qualificá-lo como um colonialista. Essa interpretação é contestada por Florence Gauthier, para quem Hardy apenas projeta em Robespierre o seu próprio colonialismo. O jacobino teria sido, acima de tudo, um defensor do direito dos povos de disporem de si mesmos (cf. HARDY, G.. Robespierre et la question noire. Annales Historiques de la Révolution Française, Paris, n. 12, 1920 (reimpressão: 1965), p.361; GAUTHIER, Florence. In: Périssent les colonies plutôt qu'un principe!, p.101). 
A Assembleia nacional decreta, como artigo constitucional, que nenhuma lei sobre o estado das pessoas não livres poderá ser feita pelo corpo legislativo, para as colônias, a não ser sob o pedido formal e espontâneo das assembleias coloniais. (grifo nosso) ${ }^{826}$

Quanto ao congresso em Saint-Martin, por enquanto, nenhuma decisão tinha sido tomada. Para os homens de cor, era uma vitória parcial, pois estavam fora da iniciativa das colônias. A sessão foi encerrada, com protestos da direita.

Ainda no dia 13, à noite, Robespierre, no clube dos Jacobinos, retomou os seus argumentos sobre a questão colonial e passou a palavra a Julien Raimond. O líder dos livres de cor foi muito aplaudido, o que mostrava que o clima tinha mudado. Charles de Lameth tentou pedir a palavra, mas, sob vaias, não conseguiu se fazer ouvir. Se havia divisões entre os Jacobinos, estes pareciam, na sua maioria, apoiar os cidadãos de cor. ${ }^{827}$

A imprensa patriótica também manifestou-se sobre a questão. As Révolutions de Paris atacaram o projeto dos comitês, vendo nele apenas um instrumento de conservação do "muro odioso de separação" existente entre os brancos e as pessoas de cor, fonte de "divisões intestinas" que não tardariam a produzir "a revolta dos escravos e o massacre dos tiranos". Para o jornal, havia um único meio de restabelecer a paz nas colônias e vinculá-las definitivamente à metrópole: "sendo justos com todas as espécies de colonos". 828

A discussão parlamentar de 14 de maio foi aberta, sob protestos dos deputados coloniais, com a apresentação por Julien Raimond de uma petição da delegação dos cidadãos de cor. A acolhida favorável nos Jacobinos na noite anterior certamente permitiu organizar essa intervenção. $\mathrm{O}$ discurso de Raimond consistiu essencialmente numa compilação de informações sobre os homens de cor de São Domingos, sua população, suas posses, sua utilidade para a segurança interna das colônias. Fez questão de ressaltar que, na sua condição de proprietários, os homens de cor tinham todo o interesse em manter os negros subordinados, de modo que o reconhecimento de seus direitos sedimentaria a classe dos colonos. ${ }^{829}$

Embora a intervenção de Raimond tenha sido aplaudida por uma parte dos deputados, a Assembleia mantinha-se dividida. Grégoire e Monneron aproveitaram o clima relativamente favorável para propor o reconhecimento dos direitos ativos das pessoas de cor livres, ao passo que Moreau de Saint-Méry reiterou as ameaças de cisão,

\footnotetext{
${ }^{826}$ Cf. Moniteur, v.8, número 136, 16 de maio de 1791, p.397.

${ }^{827}$ Cf. AULARD, F.A. La Société des Jacobins, v.2, pp.413-415.

${ }^{828}$ Cf. Les Révolutions de Paris, v.8, número 96, 7-14 de maio de 1791, pp.234-237.

${ }^{829}$ Cf. Moniteur, v.8, número 136, 16 de maio de 1791, pp.399-400.
} 
alertando que, se a Assembleia privasse as assembleias coloniais da iniciativa sobre um ponto tão essencial da constituição colonial, ela perderia a confiança dos colonos. ${ }^{830}$ Diante do impasse, nenhuma decisão foi tomada. A profunda divisão no seio da representação nacional começava a sugerir a necessidade de uma solução intermediária.

Em 15 de maio, foi feita a leitura de nova carta dos cidadãos de cor, com uma pronunciada mudança de tom. Admitindo a possibilidade de derrota, limitavam-se a pedir uma autorização para emigrar:

Se nossas observações ouvidas na tribuna não puderem determinar a Assembleia a rejeitar o decreto que lhe é proposto; se os colonos brancos conseguirem tornar-se, sem nossa participação, os nossos legisladores; se não nos restar nenhuma esperança de liberdade, pedimos que possamos deixar esse solo banhado do sangue de nossos irmãos [...]. Se a Assembleia decidir adotar uma lei que faça depender o nosso destino de vinte e nove brancos, nossos inimigos convictos, pedimos por emenda que os homens de cor tenham a faculdade de emigrar com a sua fortuna, sem que possam ser inquietados. ${ }^{831}$

O teor dramático da carta comoveu parte da Assembleia e rendeu-lhe fortes aplausos. Certamente, muitos deputados vislumbraram as dificuldades que viveriam as colônias, caso fossem privadas de parte de seus plantadores, sobretudo quando essa "classe intermediária" era a principal responsável pela polícia da colônia. Sentia-se a necessidade de resolver a questão. Rewbell, deputado de Colmar, propôs uma solução de compromisso, que dividia a classe das pessoas de cor em dois grupos: por um lado, a Assembleia decretaria não deliberar sobre o estado das pessoas de cor não nascidas de pais de mães livres, sem o voto prévio, livre e espontâneo das colônias; por outro, a Assembleia garantiria os direitos políticos às pessoas de cor nascidas de pais e mães livres, assegurando a sua admissão nas assembleias paroquiais e coloniais futuras. ${ }^{832}$

Juridicamente, a proposta era insustentável, pois não havia nada que justificasse uma distinção inexistente até mesmo no Code Noir. Mas ela se apresentava como uma solução mediadora e, por isso, tendia a impor-se mais facilmente. Os libertos continuariam privados dos direitos de cidadania, mas a população mestiça mais

\footnotetext{
${ }^{830}$ Ibidem, pp.400-401.

831 "Si nos observations entendues à la barre ne peuvent déterminer l'Assemblée à rejeter le décret qui lui est proposé; si les colons blancs parviennent à devenir, sans notre participation, nos législateurs; s'il ne nous reste aucun espoir de liberté, nous demandons à pouvoir quitter ce sol arrosé du sang de nos frères. (On entend quelques murmures et des applaudissements.) Si l'Assemblée se décide à porter une loi qui fasse dépendre notre sort de vingt-neuf blancs, nos ennemis décidés, nous demandons par amendement que les hommes de couleur aient la faculté d'émigrer avec leur fortune, sans qu'ils puissent être inquiétés" (Ibidem, p.402).

${ }^{832}$ Ibidem, p.402
} 
integrada à sociedade colonial seria equiparada à população branca. Mesmo contestando a coerência da proposta com os princípios da Nação, deputados como Rey e Régnaud de Saint-Jean d'Angély deram o seu apoio, vendo nela uma solução conciliadora capaz de pôr fim a uma discussão que já tinha se alongado terrivelmente. ${ }^{833}$ Muitos na Assembleia pediram a votação imediata.

Barnave fez ainda uma última tentativa de bloquear a medida proposta por Rewbell, ocasionando nova intervenção de Robespierre: "[Barnave] pretende que, na medida em que já consagrou por um decreto a escravidão, nós não devemos impor tantas dificuldades quanto ao resto". Mas o fato é que Robespierre tampouco defendia a emenda de Rewbell. Para ele, nada justificava a divisão dos homens de cor livres em categorias diferentes: "Quanto a mim, sinto que estou aqui para defender os direitos dos homens; não posso consentir com nenhuma emenda, e peço que o princípio seja adotado na sua integralidade". 834

Robespierre foi muito aplaudido, mas, diante da voracidade do partido colonial, a esquerda da Assembleia entendeu ser mais prudente aceitar a solução conciliatória de Rewbell. No final das contas, a emenda foi aprovada, mesmo sem os votos de Robespierre, Grégoire e Pétion, avessos à ideia de estabelecer uma distinção entre os homens de cor livres. Após votação, o artigo foi decretado nos seguintes termos:

A Assembleia nacional decreta que ela não deliberará jamais sobre o estado das pessoas de cor que não são nascidas de pais e mães livres, sem o voto prévio, livre e espontâneo das colônias; que as assembleias coloniais atualmente existentes subsistirão; mas que as pessoas de cor, nascidas de pais e mães livres, serão admitidas em todas as assembleias paroquiais e coloniais futuras, se reunirem as qualidades requeridas. ${ }^{835}$

Era uma forma de estabelecer uma gradação na atribuição dos direitos: os alforriados e homens livres cujos pai e/ou mãe ainda estivessem em estado de escravidão ficariam privados dos direitos, mas seus filhos não. A lei não deixava, entretanto, de marcar um avanço: a cor, enquanto critério de definição da cidadania, tinha sido derrubada. Era uma vitória, ainda que parcial, para os Amigos dos Negros.

\footnotetext{
${ }^{833}$ Ibidem, pp.402-403.

834 "Il prétend qu'ayant déjà par un décret consacré l'esclavage, nous ne devons pas, ou, pour mieux dire, vous ne devez pas faire tant de difficulté sur le reste. [...] Quant à moi, je sens que je suis ici pour défendre les droits des hommes; je ne puis consentir à aucun amendement, et je demande que le principe soit adopté dans son entier" (Ibidem, p.404).

835 "L'Assemblée nationale décrète qu'elle ne délibérera jamais sur l'état des gens de couleur qui ne sont pas nés de pères et mères libres, sans le voeu préalable, libre et spontané des colonies; que les assemblées coloniales actuellement existantes subisteront; mais que les gens de couleur, nés de pères et mères libres, seront admis dans toutes les assemblées paroissiales et coloniales futures, s'ils ont d'ailleurs les qualités requises" (Ibidem, p.404).
} 
A historiografia consagrou a tese de que, na prática, a lei beneficiava apenas cerca de 400 homens de cor em São Domingos. ${ }^{836}$ Jean-Daniel Piquet explica, entretanto, que essa tese, inaugurada por Saintoyant, está fundada numa carta do governador de São Domingos, De Blanchelande, de julho de 1791, que falava em apenas 400 beneficiários. Para Piquet, Saintoyant deve ter confundido a emenda Rewbell com uma subemenda proposta por Maury, que pedia prova da legitimidade do nascimento aos beneficiários de modo a excluir os filhos bastardos ${ }^{837}$, o que, na prática, teria privado a quase totalidade dos mulatos de seu direito de voto. De fato, não é possível que houvesse apenas algumas poucas centenas de homens de cor de pai e mãe livres. Se fosse o caso, uma medida favorecendo um número tão reduzido de pessoas não teria gerado tanta indignação no campo colonial. Quando De Blanchelande falou em apenas 400 beneficiários, tratava-se apenas de uma forma de minimizar uma medida que ele não tinha nenhuma intenção de pôr em execução. ${ }^{838}$ Julien Raimond afirmava que $90 \%$ dos homens de cor tinham nascido livres, de pais livres e casamentos legítimos. Esse número era um claro exagero, que traduzia a tentativa de Raimond de estender ao conjunto da população de cor de São Domingos as características das famílias mais antigas do Sul e do Oeste. Contudo, como aponta Garrigus, o rápido aumento da população de cor livre nessas regiões, a partir dos anos 1760, muito por conta da reclassificação, permite afastar o número ínfimo de 400 indivíduos. ${ }^{839}$

\section{I.3.4.2) Repercussões do decreto de 15 de maio}

Os debates e o decreto de maio de 1791 repercutiram fortemente em diferentes esferas. O seu primeiro efeito foi o de promover uma ruptura do clube dos Jacobinos com os colonos. Já na noite de 15 de maio, foi lida nos Jacobinos uma adresse de Jennesson que propunha o envio de uma carta às sociedades filiadas para informá-las de que o clube desaprovava a posição assumida por vários de seus membros. $\mathrm{O}$ artigo $4^{\circ}$ do regulamento da sociedade permitia a exclusão dos membros que tomassem posições

\footnotetext{
${ }^{836}$ Thibau, Blackburn e Fick, por exemplo, adotaram essa tese (cf. THIBAU, Jacques. Le temps de SaintDomingue, p.258; BLACKBURN, Robin. A Queda do Escravismo Colonial, p.205; FICK, Carolyn. The French Revolution in Saint-Domingue cit, p.59).

${ }^{837}$ Maury alegava que muitas pessoas de cor deviam a sua existência à "mais vergonhosa prostituição" e não podiam ser assimiladas aos filhos legítimos. Mas a sua proposta foi rejeitada (cf. Moniteur, v.8, número 136, 16 de maio de 1791, p.404).

${ }^{838}$ Cf. PIQUET, Jean-Daniel. L'émancipation des Noirs dans la Révolution française, pp.91-94.

${ }^{839}$ Cf. GARRIGUS, John D. Before Haiti, p.259.
} 
contrárias à Constituição e aos direitos do homem. ${ }^{840}$ Uma cisão se insinuava dentro do Clube.

A situação se agravou quando, em protesto contra o decreto de 15 de maio, os deputados coloniais se recusaram a retornar à Assembleia. Isso levou, em 12 de junho, os Jacobinos a excluirem do Clube os deputados que haviam assumido essa postura rebelde. Os deputados atingidos por essa medida foram: Barnave, Gouy d'Arcy, Curt, Moreau de Saint-Méry, Alexandre de Lameth, Gérard, Bodkin de Fitz-Gérald, Reynaud de Villeverd, Levasseur de Villeblanche, Vaussenay, Alquier e Pellerin de Nantes. ${ }^{841}$ Foi decidido que ficariam excluídos até que, por meio de seu retorno à Assembleia, provassem sua fidelidade às leis da Nação e à Constituição. Após o episódio de Varennes, a cisão dos colonos com os Jacobinos seria consolidada. Os deputados das colônias retornariam à Assembleia, mas não ao Clube: uma nova sociedade seria formada nos Feuillants. ${ }^{842}$ Fortalecida, a ala mais avançada dos Jacobinos, proporia uma refundação da Sociedade.

Se, no campo colonial, a lei de maio gerou revolta, nos meios patrióticos, as reações foram variadas. Alguns celebraram a medida como uma vitória dos direitos do homem; outros viram na distinção estabelecida entre os livres de cor uma verdadeira traição. Brissot, no Patriote Français de 16 de maio ( $\left.{ }^{\circ} 646\right)$, comemorou a conquista dos homens de cor e destacou a existência de uma corrente de opinião popular em favor de sua causa: "Esse decreto produziu a mais viva satisfação na assembleia e fora dela; pois o povo tinha por ele um forte interesse". ${ }^{843}$ Aludindo às distinções estabelecidas entre os homens de cor, Brissot admitia que o decreto ainda estava longe do ideal, mas via nele um inegável avanço:

Esse decreto não satisfaz certamente a expectativa dos patriotas rígidos, ele viola até mesmo o princípio, assim como o precedente; mas ele é um encaminhamento para o retorno aos princípios; ele prova que a assembleia ainda os defende, e que o lado esquerdo vai se aliar, se solidificar fortemente, para terminar a constituição de uma maneira digna dele. ${ }^{844}$

\footnotetext{
${ }^{840}$ Cf. AULARD, F.A. La Société des Jacobins, v.2, pp.440-441; GAUTHIER, Florence. L'aristocratie de l'épiderme, pp.323-324.

${ }^{841}$ Cf. GAUTHIER, Florence. L'aristocratie de l'épiderme, p.325.

${ }^{842}$ Cf. PIQUET, Jean-Daniel. L'émancipation des Noirs dans la Révolution française, pp.90-91.

843 "Ce décret a produit la satisfaction la plus vive dans l'assemblée et au-dehors; car le peuple y prenait un vif intérêt" (Patriote Français, v.4, número 646, 16 de maio de 1791, pp.537-538).

844 "Ce décret ne remplit pas certainement l'attente des patriotes rigides, il viole même le principe, ainsi que le précédent; mais il est un acheminement vers le retour aux principes; mais il prouve que l'assemblée
} 
Nesse mesmo sentido, Garat, no Journal de Paris de 16 de maio, anunciou o decreto de 15 de maio como uma "via de conciliação própria a pacificar as querelas, a conciliar todos os partidos num decreto que seria como um tratado de paz". 845

Por outro lado, no número 77 das Révolutions de France et de Brabant, de 16 de maio, Camille Desmoulins mostrou-se pouco interessado pela questão. Abordou o debate de maio de forma um tanto irônica, estranhando que as clivagens políticas da Assembleia estivessem misturadas nessa discussão: Dupont de Nemours, Régnaud de Saint-Jean d'Angély e La Fayette combatendo ao lado de Grégoire, Robespierre e Pétion. Evocando a distinção entre cidadãos ativos e passivos na metrópole, Desmoulins denunciava a "[...] hipocrisia risível desses homens, que reduziram à condição das pessoas de cor milhões de seus concidadãos, de se dedicarem às pessoas de cor da América, e de embarcarem para as colônias a liberdade que afastaram de seu meio". 846 Essa contradição também tinha sido apontada pelos colonos, o que mostrava que, nas questões coloniais, esquerda e direita tendiam a se misturar.

Marat também se pronunciou sobre o decreto, no no 462 do Ami du Peuple (18 de maio). Elogiou a resistência patriótica conduzida por Bouche, Grégoire, Pétion e Robespierre, com a notável participação de Raimond. Mas, quanto ao decreto de 15 de maio, ele o qualificou de "ultrajante para a humanidade", acreditando que em vez de conciliar os dois partidos, ele tendia a descontentar ambos. Os deputados coloniais já tinham deixado a Assembleia; logo, os homens de cor e negros nascidos de pais não livres não tardariam a se armar para reclamar os seus direitos. ${ }^{847}$

O jornal Révolutions de Paris de 14-21 de maio ( $\mathrm{n}^{\circ}$ 97) lamentou que os alforriados tivessem sido excluídos, mas apresentou o decreto de 15 de maio como o compromisso possível diante da obstinação dos colonos brancos em recusar os direitos dos livres de cor e de sua influência sobre a Assembleia: "[...] a influência do mau

\footnotetext{
y tient encore, et que le côté gauche va se rallier, se serrer fortement, pour finir la constitution d'une manière digne de lui" (Ibidem, p.538).

845 "voie de conciliation propre à pacifier les querelles, à concilier tous les partis dans un décret qui serait comme un traité de paix" (Journal de Paris, número 136, 16 de maio de 1791, p.548).

846 "[...] hypocrisie risible, à ces hommes qui ont réduit à la condition des gens de couleur des millions de leurs concitoyens, de se passionner pour les gens de couler d'Amérique, et d'embarquer pour les colonies la liberté qu'ils chassent du milieu d'eux" (Révolutions de France et de Brabant, v.6, número 77, p.569).

${ }_{847}$ Cf. L'Ami du Peuple, número 462, 18 de maio. In: MARAT, Jean-Paul. Oeuvres politiques. Bruxelas: Pôle Nord, 1993, v.6, pp.2890-2891.
} 
princípio foi tal que foi preciso, por assim dizer, transigir com o vício para fazer triunfar a boa causa. Sacrificou-se a sorte dos alforriados para garantir a de seus filhos [...]". 848

O abade Grégoire publicou, em 8 de junho, uma Lettre aux citoyens de couleur et nègres libres de Saint-Domingue, com a intenção dar certas recomendações à população de cor livre da colônia. Manifestando um otimismo exacerbado e uma visão estreita da realidade colonial, apresentou o 15 de maio como "o dia em que reconquistastes vossos direitos". ${ }^{849}$ Para o abade, agora que a questão dos mulatos tinha sido resolvida, era preciso começar a pensar na escravidão, cuja abolição, mesmo a longo prazo, parecia-lhe inevitável. Cabia agora aos homens de cor iniciar esse processo, tratando com mais humanidade os seus escravos. ${ }^{850}$ Grégoire sabia que o preço dos direitos dos homens de cor tinha sido a manutenção da escravidão.

Julien Raimond e a delegação dos cidadãos de cor também enviaram uma carta aos seus irmãos nas ilhas. O texto, publicado no Patriote Français de 5 de julho, comemorava o decreto de 15 de maio como um triunfo da justiça e da humanidade sobre a tirania. Era, acima de tudo, o triunfo de quadrarões abastados como ele e seus companheiros do Sul. Para ele também, a questão estava resolvida. Avisava que, ao terem seus direitos reconhecidos, os homens de cor haviam contraído importantes obrigações perante a Nação. A primeira delas era a de "[...] contribuir por todos os meios ao restabelecimento da ordem e da paz nas colônias". ${ }^{851}$ Isto é, Raimond pregava a aliança com os brancos na manutenção do sistema colonial. Os homens de cor tinham, portanto, de confirmar a sua qualidade de instrumentos de regeneração das colônias. No que se refere aos homens de cor não nascidos de pai e mãe livres, limitou-se a recomendar:

Que vossa elevação acima da classe intermediária que acaba de ser criada não vos dê nenhum sentimento de orgulho. Buscai, ao contrário, suavizar nela o sentimento dessa inferioridade, por todos os cuidados que merece o infortúnio. ${ }^{852}$

\footnotetext{
848 "[...] l'influence du mauvais principe a été telle qu'il a fallu, pour ainsi dire, transiger avec le vice pour faire triompher la bonne cause. On a sacrifié le sort des affranchis pour assurer celui de leurs enfants [...]" (Les Révolutions de Paris, v.8, número 97, 14-21 de maio de 1791, p.293).

${ }^{849}$ Cf. GREGOIRE, Henri. Lettre aux citoyens de couleur, et nègres libres de Saint-Domingue, et des autres Isles Françoises de l'Amérique. S.l. [Paris]: Imprimerie du Patriote François, s.d. [1791], p.6.

${ }^{850}$ Ibidem, pp.12-13.

${ }^{851}$ Cf. LETTRE des Comissaires des Citoyens de couleur en France, à leurs frères et commettans dans les Isles Françoises. S.l. [Paris]: s.d. [1791], p.2.

${ }_{852}$ "Que votre élévation au-dessus de la classe intermédiaire qui vient d'être créée, ne vous donne aucun sentiment d'orgueil. Cherchez, au contraire, à adoucir en elle le sentiment amer de cette infériorité, par tous les égards que mérite l'infortune" (Ibidem, p.7).
} 
A Sociedade dos Amigos dos Negros manifestou-se oficialmente sobre o decreto na introdução à segunda edição da Adresse à l'Assemblée Nationale..., publicada em $1^{\circ}$ de julho, comemorando o decreto como uma vitória do movimento popular:

Enquanto, lá dentro, as exposições eloquentes, e de uma dialética sólida, esclareciam a assembleia, lá fora, o povo se instruía, e assumia abertamente a defesa dos homens de cor. Os artesãos não podiam entender como era possível recusar aos seus irmãos os direitos de cidadãos ativos; como era possível recriar uma aristocracia fundada na cor da pele, após ter suprimido a do nascimento. ${ }^{853}$

Por outro lado, a Sociedade alertava para os limites da nova lei, acreditando que, ao privar os alforriados dos direitos políticos, ela havia criado uma classe intermediária, gerando uma nova contradição jurídica:

A contradição é aqui tão chocante, que nada pode justificá-la; pois, de um lado, é em virtude do princípio da igualdade que se restitui aos homens de cor, nascidos de pai e mãe livres, os direitos de cidadão ativo; e, de outro, priva-se desses mesmos direitos os alforriados, tão livres quanto eles, e que são, consequentemente, seus iguais. ${ }^{854}$

A Sociedade lamentava ainda a constitucionalização da escravidão, por meio do artigo que impedia a Assembleia Nacional de pronunciar-se a respeito das pessoas não livres. Mas reconhecia que tais compromissos, na perspectiva da Assembleia, talvez fossem necessários naquele momento de instabilidade, em que era necessário conciliar todos os interesses e evitar medidas abruptas. Embora não concordassem inteiramente com o seu teor, os Amigos dos Negros pregavam a submissão ao decreto, acreditando tratar-se de uma vitória significativa demais para ser desprezada. ${ }^{855}$

Nas cidades marítimas, houve protestos contra o decreto ${ }^{856}$, mas este também recebeu a aprovação de alguns dos portos franceses. Manifestações de apoio chegaram

\footnotetext{
853 "Tandis que les plaidoyers éloquens, et d'une dialectique serrée, éclairaient l'assemblée au-dedans, le peuple s'instruisait au-dehors, et prenait ouvertement la défense des hommes de couleur. Les artisans ne pouvaient pas concevoir comment on pouvait refuser à leurs frères les droits de citoyens actifs; comment on pouvait recréer une aristocratie fondée sur la couleur de la peau, après avoir supprimé celle de la naissance" (CLAVIÈRE, Étienne. Adresse de la Société des Amis des Noirs, p.VIIII).

854 "La contradiction est ici tellement choquante, que rien ne peut la justifier; car, d'un côté, c'est en vertu du principe de l'égalité qu'on restitue aux hommes de couleur, nés de père et mère libres, les droits de citoyen actif; et, d'un autre, on prive de ces mêmes droits des affranchis aussi libres qu'eux, et qui, par conséquent, sont leurs égaux" (Ibidem, p.XII).

${ }^{855}$ Ibidem, pp.XIV-XV.

${ }^{856}$ Debien fala de cartas provenientes de Nantes, Le Havre, Rouen, Honfleur, Rennes e Bordeaux, mas relata que nenhuma delas foi lida na Assembleia, onde, naquele momento, o clima ainda era pouco favorável aos colonos (cf. DEBIEN, Gabriel. Les colons de Saint-Domingue et la Révolution, pp.318319).
} 
de Brest, Le Havre, Nantes, Marselha e, sobretudo, Bordeaux. O diretório do departamento da Gironda enviou uma carta à Assembleia Nacional, em 21 de maio, felicitando-a pelo decreto. A campanha dos Amigos dos Negros tinha dado frutos: na medida em que seu principal argumento em favor dos direitos dos livres de cor era a preservação da ordem colonial, eles podiam estabelecer um diálogo com o comércio marítimo francês, que, de fato, reproduzia essa linha de raciocínio na sua correspondência. O diretório da Gironda comunicou ainda que alguns colonos e representantes planejavam incitar tumultos para prejudicar a execução do decreto, razão pela qual estava provisoriamente suspensa a partida de navios de comércio, que poderiam levar cartas incendiárias e interpretações falsas do decreto. Pedia à Assembleia que tomasse medidas para a pronta execução do mesmo e oferecia o socorro dos guardas nacionais da Gironda para esse efeito. ${ }^{857}$

Dez dias depois, a municipalidade de Bordeaux enviou às assembleias, municipalidades e comitês das colônias francesas uma carta louvando o decreto de 15 de maio e criticando a atitude dos deputados coloniais. Afirmou que, ao excluir os alforriados, a lei havia criado a classe intermediária de que os colonos tanto precisavam para manter os escravos na ordem:

Queríeis uma classe intermediária: ela existia antes apenas por uma usurpação e uma violação da lei; ela existirá doravante em virtude da lei; nenhum alforriado poderá entrar nas vossas assembleias eletivas, nem, consequentemente, aspirar às vossas magistraturas; eis, portanto, a barreira instalada. ${ }^{858}$

Nas colônias, contudo, manifestações de apoio ao decreto foram mais raras. Em alguns lugares, como na Martinica, onde os conflitos entre bancos e mulatos eram menores, a lei foi recebida com certa satisfação. Mas, em São Domingos, onde a notícia da lei de maio de 1791 chegou em julho, as autoridades, apoiadas nos petits-blancs, se opuseram ferrenhamente à medida. ${ }^{859}$ Simbolicamente, Grégoire foi enforcado em

\footnotetext{
${ }^{857} \mathrm{Cf}$. Copie de la lettre écrite à l'assemblée nationale, par le directoire du département de la Gironde, le 21 mai 1791. In: CLAVIÈRE, Étienne. Adresse de la Société des Amis des Noirs, pp.291-292.

858 "Vous vouliez une classe intermédiaire: elle n'existait autrefois que par usurpation et par une violation de la loi, elle existera maintenant en vertu de la loi: aucun affranchi ne pourra entrer dans vos assemblées électives, ni par conséquent aspirer à vos magistratures; voilà donc la barrière posée" (Adresse de Messieurs les Maire et Officiers municipaux de la ville de Bordeaux, à Messieurs composant les Assemblées coloniales, les Municipalités et les Comités dans les Colonies françoises. Du 31 mai 1791. In: CLAVIÈRE, Étienne. Adresse de la Société des Amis des Noirs, p.299).

${ }^{859}$ Em relação aos plantadores brancos residentes, a sua atitude é mais difícil de caracterizar. Houve, por exemplo, manifestações de apoio ao decreto, como a carta de Degournay, publicada no Patriote Français de 31 de maio de 1791, que declarava que grande parte dos plantadores brancos dos bairros de SaintLouis, Cavaillon e Les Cayes, não se opunham aos direitos de cidadania dos homens de cor livres (cf.
} 
efígie, enquanto colonos cantavam, em crioulo, "não, os mulatos jamais serão brancos... apenas nós somos senhores". No Sul e no Oeste, pessoas de cor fugiam das cidades e planícies, onde, entre outras humilhações, eram obrigadas a assinar petições contra o decreto de maio. ${ }^{860}$ Em carta de 3 de julho, o governador De Blanchelande comunicou à metrópole que a aplicação da lei não era viável, tendo em vista os seus efeitos na ordem social da colônia: "Essa perfeita assimilação aos cidadãos atuais da colônia de pessoas que têm ainda irmãos e pais escravos, pode eliminar a subordinação". ${ }^{861} \mathrm{O}$ partido colonial não iria aceitar essa derrota tão facilmente.

Patriote Français, v.4, número 661, 31 de maio de 1791, p.603). Outras cartas desse tipo seriam publicadas pelo jornal, durante o debate de setembro de 1791 (cf. Patriote Français, v.5, número 773, 22 de setembro de 1791, p.356).

${ }^{860}$ Cf. GARRIGUS, John D. Before Haiti, p.259.

861 "Cette assimilation parfaite aux citoyens actuels de la colonie de gens qui ont encore des frères et des parents esclaves, peut anéantir la subordination" (BLANCHELANDE apud THIBAU, Jacques. Le temps de Saint-Domingue, p.277). 


\section{I.3.5) Maio-setembro de 1791: o retrocesso}

\section{I.3.5.1) A ofensiva colonial contra o decreto de 15 de maio}

O mês de setembro de 1791 seria marcado por um grave retrocesso na questão dos homens de cor, com a revogação do decreto de 15 de maio. Mas, meses antes, logo após a aprovação da referida lei, já era possível sentir os sinais de um recuo. Nas sessões de 17, 21 e 29 de maio, a Assembleia dedicou-se a elaborar uma instrução que acompanharia o decreto, para esclarecer o seu sentido e os limites de sua aplicação. Essa instrução, de autoria de Dupont de Nemours, reiterava que as colônias teriam a iniciativa legislativa sobre o estado das pessoas não livres, assim como dos "alforriados e mesmo as pessoas livres, nascidas de um pai ou de uma mãe que não o seriam". ${ }^{862}$ Isso já estava implicado na lei de 13-15 de maio, mas, ao explicitar de tal forma essa determinação, a instrução impedia novos avanços que viessem a contemplar os direitos dos alforriados e mesmo aqueles nascidos livres que tivessem apenas um dos pais escravo. A intenção da instrução era deixar claro aos colonos que o decreto tinha criado a classe intermediária por eles solicitada.

As instruções ainda deixavam claro, na exposição de motivos, que a tomada de posição contra o preconceito não alterava em nada o problema da escravidão, e que as exigências locais das colônias podiam "admitir algumas exceções aos princípios". O que justificava essas exceções era o fato de que os não-livres eram

[...] indivíduos de uma nação estrangeira, que, pela sua profunda ignorância, os infortúnios de sua expatriação, a consideração de seu próprio interesse, a imperiosa lei da necessidade, podem esperar apenas do tempo, do progresso do espírito público e das Luzes, uma mudança de condição que, no estado atual das coisas, seria contrária ao bem geral e poderia ser-lhes igualmente funesta. ${ }^{863}$

Paralelamente, o partido colonial preparava uma ofensiva contra o decreto de 15 de maio. No dia 31 de maio, foi lida na Assembleia Nacional uma carta do abade Raynal na qual renunciava aos seus escritos mais revolucionários do passado e esclarecia que nunca havia pretendido fazer das concepções rigorosas da filosofia a

\footnotetext{
${ }^{862}$ Cf. AP, v.26, p.605.

863 "[...] des individus d'une nation étrangère, qui, par leur profonde ignorance, les malheurs de leur expatriation, la considération de leur propre intérêt, l'impérieuse loi de la necessite, ne peuvent espérer que du temps, du progrès de l'esprit public et des Lumières, un changement de condition qui, dans l'état actuel des choses, serait contraire au bien général et pourrait leur devenir également funeste" (Ibidem, p.604).
} 
medida para atos de legislação: "Fizestes uma declaração dos direitos e essa declaração é perfeita se a despojardes das abstrações metafísicas, que tendem apenas a difundir no império francês germes de desorganização e de desordem". ${ }^{864}$ A carta foi, provavelmente, estimulada por Malouet, uma das figuras-chave do campo conservador em matéria colonial. ${ }^{865}$ Debien aponta que, em troca, Raynal pode ter recebido 24 mil libras para compensar dívidas contraídas em razão de batalhas judiciais. ${ }^{866}$ De qualquer forma, a carta caiu como uma bomba no campo antiescravista. As Révolutions de Paris denunciaram-na como uma tentativa da aristocracia de tomar para si o autor da Histoire des deux Indes, aproveitando-se de sua idade avançada. ${ }^{867}$ Nas suas memórias, Brissot procuraria minimizar o impacto da "queda de Raynal": "A carta de Raynal à Assembleia foi um ato perdido para o partido que a tinha ditado; ela serviu apenas para desonrar o seu autor". ${ }^{868}$ Mas a realidade era mais sombria. Em junho de 1791, os 85 léopardins foram perdoados pela Assembleia Nacional, permitindo que retornassem a São Domingos, para serem reeleitos. ${ }^{869}$

Para fazer aplicar o decreto, o poder executivo nomeou, em agosto de 1791, três novos comissários civis: Philippe Rose-Roume de Saint-Laurent, Saint-Léger e Mirbeck. Tratava-se de uma escolha reveladora de certas reticências em relação ao decreto de 15 de maio. Roume tinha escrito, em maio de 1791, uma brochura hostil aos "filantropos", Sur la question des gens de couleur. Nesse texto, ele dizia, de forma nuançada, que não se podia abalar a dominação branca nas colônias, sob pena de perdêlas, e pregava o silêncio sobre a questão. Afirmava que não era possível abolir a escravidão e, na medida em que esta devia ser mantida, era preciso que houvesse uma

\footnotetext{
864 "Vous avez fait une déclaration des droits et cette déclaration est parfaite si vous la dégagez des abstractions métaphysiques, qui ne tendent qu'à répandre dans l'empire françois des germes de désorganisation et de désordre" (Lettre de M. l'abbé Raynal à l'assemblée nationale. In: Patriote Français, v.4, número 664, 3 de junho, p.616).

${ }^{865}$ Nas suas memórias, Malouet pintou o retrato de um Raynal avesso à efervescência revolucionária da época, uma imagem que contrastava com seus escritos: "Esse homem tão ardente, tão exagerado nos seus escritos, tremia com os exageros que se anunciavam já na opinião pública". Malouet revelou ainda ter mantido desde então uma correspondência ininterrupta com Raynal, estimulando-o a manifestar à Assembleia a sua inquietação quanto aos excessos da Revolução: "Ele transmitia tamanha indignação que acreditei dever tirar partido dela. Encorajei-o a vir a Paris ou a escrever de Marselha uma carta de reprovações à Assembleia. Eu lhe dizia [...] que se alguém podia conter essa revolução em justos limites, era aquele que tinha antecipado a sua explosão, que talvez a tivesse preparado, e cujo nome encontrava-se sempre na boca dos patriotas ao lado do nome de Jean-Jacques. $\mathrm{O}$ abade Raynal me respondeu que ele $\mathrm{o}$ faria, que ousaria tudo o que eu quisesse [...]" (MALOUET, Mémoires, v.1, p.216 e v.2, pp.126-127).

${ }^{866}$ Cf. DEBIEN, Gabriel. Les colons de Saint-Domingue et la Révolution, pp.295-296.

${ }^{867}$ Cf. Les Révolutions de Paris, v.8, número 99, 28 de maio - 4 de junho de 1791, pp.367-368.

868 "La lettre de Raynal à l'Assemblée constituante fut un acte perdu pour le parti qui l'avait dictée; ele ne servit qu'à déshonorer son auteur" (BRISSOT DE WARVILLE, Jacques-Pierre. Mémoires, v.2, p.85.

${ }^{869}$ Cf. FICK, Carolyn. The making of Haiti, p.85.
} 
classe intermediária entre os brancos e os escravos, uma classe formada pelas pessoas de cor livres, argumento comum entre os colonos. Anos mais tarde, Roume diria ter sido escolhido por ser um adversário do preconceito, mas o fato é que, em maio 1791, ele estava alinhado com o campo colonial. Saint-Léger era um crioulo, embora nada indicasse que tivesse alguma hostilidade particular para com o decreto. Por outro lado, Mirbeck tinha ligações com o Clube Massiac. ${ }^{870}$ Este, aliás, agia nos bastidores, junto ao ministro da Marinha e ao rei, para adiar a partida dos comissários e, com isso, ganhar algum tempo. ${ }^{871}$

Por outro lado, o comitê das colônias tinha sofrido mudanças, em 23 de agosto de 1791, com a entrada de três novos integrantes que haviam se manifestado anteriormente em favor dos homens de cor nos debates parlamentares: La Rochefoucauld, Destutt de Tracy e Monneron. Além deles, outros três integrantes novos: Brossaret (advogado), Perisse du Luc (impressor de Lyon), Castellanet (tabelião de Marselha). ${ }^{872}$ Mas a carta do governador De Blanchelande e a chegada de notícias de revoltas em São Domingos contra o decreto levariam o comitê colonial a suspender o envio dos comissários às colônias. Um dia depois, em 29 de agosto, Tracy, Castellanet, La Rochefoucauld e Perisse du Luc pediram demissão. La Rochefoucauld explicou o motivo:

Senhores, quando a Assembleia nos deu a honra de nos integrar, o objetivo era cuidar dos meios de fazer executar vosso decreto de 15 de maio. Nas 3 sessões a que assisti, cuidou-se, ao contrário, expressamente e apesar de nossos esforços, dos meios de revogar esse decreto. Não creio que essa revogação seja necessária e, sobretudo, não creio que estejais suficientemente esclarecidos por uma única carta do Sr. De Blanchelande, a qual poderia não ter sido escrita com a maior liberdade; parece-me que essa única peça não basta para propor à Assembleia a revogação de um decreto que, da minha parte, vejo como muito justo. Entendi, assim, a minha presença no comitê colonial inútil. ${ }^{873}$

A pressão pela supressão do decreto de 15 de maio era forte: cartas e petições chegavam de São Domingos e de alguns portos franceses alertando para os perigos que

\footnotetext{
${ }^{870}$ Cf. PIQUET, Jean-Daniel. L'émancipation des Noirs dans la Révolution française, pp.101-103.

${ }^{871}$ Cf. DEBIEN, Gabriel. Les colons de Saint-Domingue et la Révolution, pp.313-314.

${ }^{872}$ Cf. THIBAU, Jacques. Le temps de Saint-Domingue, p.289.

873 "Messieurs, lorsque l'Assemblée nous a fait l'honneur de nous adjoindre au comité colonial, il s'agissait d'aviser aux moyens de faire exécuter votre décret du 15 mai. Dans les trois séances auxquelles j'ai assisté, on ne s'est au contraire expressément, et malgré nous, occupé que des moyens de révoquer ce décret. Je ne crois pas cette révocation nécessaire et je ne crois pas surtout que vous soyez suffisamment éclairés par une seule lettre de M. de Blanchelande, laquelle pourrait bien n'avoir pas été écrite avec la plus grande liberté; il me parraît que cette seule pièce ne suffit pas pour proposer à l'Assemblée, la révocation d'un décret que je regarde pour ma part comme très juste. J'ai donc trouvé ma présence au comité colonial inutile" (AP, v.30, pp.55-56).
} 
resultariam dessa medida, caso fosse aplicada. Em 31 de agosto, chegou nova carta de Blanchelande, que se dizia incapaz de aplicar o decreto de 15 de maio, que sequer havia sido oficialmente recebido na colônia. Essa pressão alimentava um movimento subterrâneo pela derrubada do decreto.

Em 5 de setembro, dois deputados extraordinários da cidade de Brest vieram denunciar, perante a Assembleia, tentativas de revogação do decreto de 15 de maio. Apontaram a existência de mais de 80 peças manuscritas, depositadas no comitê colonial, que atestavam que as dissenções nas colônias estavam sendo fomentadas pelas próprias pessoas encarregadas de pôr em execução a lei. Acusavam o comitê de negligenciar essas peças, no intuito de atribuir ao decreto sobre os mulatos os males que afligiam as colônias. ${ }^{874}$

Diante das acusações, enquanto alguns deputados pediam a execução do decreto, Alexandre de Lameth procurou enfatizar o estado de calamidade nas colônias, argumentando pela impossibilidade dessa execução. Robespierre interveio para defender os peticionários e acusar os que procuravam promover a revogação da lei Barnave e Lameth - de serem "traidores da pátria". ${ }^{875}$ Em meio à aclamação da extrema esquerda da Assembleia, Robespierre pediu a execução imediata da lei sobre as pessoas de cor. Barnave respondeu às acusações, alegando que o decreto, além de ser inexequível, teria por inevitável resultado o extermínio da classe menos numerosa das colônias (os brancos) pela mais numerosa (os negros). ${ }^{876}$

Dois dias depois, apoiado na leitura de cartas de Le Havre, Rouen e Rennes contra o decreto de 15 de maio, Barnave voltou a se pronunciar na Assembleia sobre a necessidade

[...] de dar, com uma mão, aos colonos, de maneira imutável, de maneira a fazer cessar toda esperança assim como toda inquietude, todo o necessário para a sua segurança interna, e de reter imutavelmente, com a outra mão, todo o necessário ao interesse comercial da metrópole. ${ }^{877}$

Queria, com isso, afirmar que a conservação do decreto de 15 de maio - isto é, a ingerência metropolitana nos assuntos internos das colônias - punha em risco o pacto

\footnotetext{
${ }^{874}$ Ibidem, p. 235 .

${ }^{875}$ Ibidem, pp.236-237.

${ }^{876}$ Ibidem, p.239.

877 "[...] donner d'une manière immuable, d'une manière qui fasse cesser toute espérance comme toute inquiétude, de donner, dis-je, d'une main aux colonos ce qui est nécessaire pour leur sûreté intérieure, et de retenir immuablement de l'autre main ce qui est nécessaire à l'intérêt comercial de la métropole" (Ibidem, p.285).
} 
colonial e, portanto, os interesses do comércio. A Assembleia decretou, com base nessa opinião, a necessidade de um novo relatório do comitê colonial.

Em 12 de setembro, por decisão dos comitês reunidos de constituição, da marinha, da agricultura e comércio e das colônias, foi distribuída na Assembleia uma compilação de petições, cartas e outras peças relativas ao decreto de 15 de maio. $\mathrm{O}$ objetivo era fornecer um quadro de insatisfação quase generalizada a respeito da lei. É claro que o quadro apresentado era bastante distorcido, opondo apenas oito cartas favoráveis à lei a dezenas de condenações formais. ${ }^{878}$ No mesmo dia, Brissot, sentindo a iminência de uma reviravolta na política colonial da Assembleia, apresentou, nos Jacobinos, um discurso em favor do decreto de 15 de maio, no qual assinalou que, ao contrário do que afirmava o comitê colonial, a maioria das cidades do comércio tinha sido favorável ao decreto e que mesmo a maioria dos plantadores residentes de São Domingos tinha a consciência de que a tranquilidade interna da colônia dependia da erradicação do preconceito. Se havia tumultos nas colônias, o que era questionável, isso se devia à má fé das autoridades encarregadas da execução do decreto, que faziam de tudo para retardá-la e procuravam alarmar a população com interpretações distorcidas da lei. ${ }^{879}$ Somente a pronta execução do decreto poderia restabelecer a ordem.

\section{I.3.5.2) O debate de setembro de 1791}

Em 23 de setembro de 1791, em relatório apresentado à Assembleia, Barnave discorreu sobre os efeitos da chegada do decreto de 15 de maio a São Domingos, indicando que a oposição a ele tinha sido capaz de promover a união dos dois partidos que dividiam a ilha: o que era favorável e o que era contrário aos decretos da Nação. Essa situação, já bastante calamitosa, tendia a agravar-se, pois as colônias estavam convencidas de que o regime interno já não lhes pertencia mais:

elas acreditam perceber nesse ato não apenas os perigos indiretos que resultam dos direitos de cidadãos ativos concedidos aos homens de cor, mas o perigo próximo de uma conduta do corpo legislativo, que, já tendo faltado

\footnotetext{
${ }^{878}$ Ibidem, pp.592-600.

${ }^{879}$ Cf. BRISSOT DE WARVILLE, Jacques-Pierre. Discours sur la nécessité de maintenir le décret rendu le 15 mai en faveur des hommes de couleur libres, prononcé le 12 septembre 1791, à la séance de la Société des Amis de la Constitution... Imprimé par ordre de la Société. S.1. [Paris]: s.n., s.d. [1791], pp.910 .
} 
com as suas promessas, pode chegar ao ponto de atacar direta e imediatamente o regime colonial pela emancipação dos escravos. ${ }^{880}$

Preocupado em manter o pacto colonial, Barnave sabia que era preciso dar garantias às colônias quanto à autonomia de seu regime interno. Nesse sentido, propôs que fossem decretados dois princípios fundamentais: 1) que as leis do regime externo das colônias fossem da competência do corpo legislativo, sujeitas à sanção do rei, e que as colônias tivessem apenas a esse respeito o direito de fazer petições, as quais, em nenhum caso, poderiam ser convertidas em regulamentos provisórios nas colônias; 2) que as leis sobre o estado das pessoas fossem feitas pelas assembleias coloniais, executadas provisoriamente após sanção do governador e levadas diretamente ao rei para serem definitivamente sancionadas. ${ }^{881}$ Ou seja, por um lado, garantia-se a manutenção do exclusivo; por outro, a manutenção da escravidão e da segregação. Barnave era, mais do que nunca, o homem do compromisso entre os interesses das colônias e do comércio.

Em vez de manifestar-se a respeito da inexecução da lei de 15 de maio, Barnave abordou o fundo da questão e retomou a tese de Moreau de Saint-Méry que justificava o preconceito como um "meio moral" de controle da massa dos escravos:

Em São Domingos, cerca de quatrocentos e cinquenta mil escravos são contidos por cerca de trinta mil brancos, e os escravos não podem ser considerados desarmados; pois homens que trabalham na cultura das terras, que têm constantemente instrumentos em suas mãos, sempre carregam armas; é, portanto, fisicamente impossível que o pequeno número dos brancos possa conter uma população tão considerável de escravos, se o meio moral não vier compensar a fraqueza dos meios físicos. Esse meio moral está na opinião que põe uma distância imensa entre o homem negro e o homem de cor, entre o homem de cor e o homem branco, na opinião que separa absolutamente a raça dos ingênuos dos descendentes dos escravos, qualquer que seja a distância que os separe. ${ }^{882}$

\footnotetext{
880 "elles croient apercevoir dans cet acte non-seulement les dangers indirects qui résultent des droits de citoyens actifs accordés aux hommes de couleur, mais le danger prochain d'une démarche du corps législatif, qui, ayant déjà manqué à ses promesses, peut aller jusqu'à attaquer directement et immédiatement le régime colonial par l'affranchissement des esclaves" (Moniteur, v.9, número 268, 25 de setembro de 1791, p.758).

${ }^{881}$ Ibidem, pp.758-759.

882 "A Saint-Domingue près de quatre cent cinquante mille esclaves sont contenus par environ trente mille blancs, et les esclaves ne peuvent pas être considérés comme désarmés; car des hommes qui travaillent à la culture des terres, qui ont sans cesse des instruments dans leurs mains, ont toujours des armes; il est donc physiquement impossible que le petit nombre des blancs puisse contenir une population aussi considérable d'esclaves si le moyen moral ne venait à l'appui de la faiblesse des moyens physiques. Ce moyen moral est dans l'opinion, qui met une distance immense entre l'homme noir et l'homme de couleur, entre l'homme de couleur et l'homme blanc, dans l'opinion qui sépare absolument la race des ingénus des descendants des esclaves, à quelque distance qu'ils soient" (Ibidem, p.759).
} 
Barnave reiterava, portanto, o argumento da necessidade de uma classe intermediária, que simbolizasse a existência de uma distância intransponível entre o branco e o negro. Reconhecia que o sistema era absurdo, opressivo e bárbaro, mas entendia que os preconceitos eram as "únicas salvaguardas" das colônias, pois se o negro acreditasse que podia ser o igual do branco, ele não poderia mais ser controlado. Era um sistema que se impunha pela experiência e, como sempre no discurso contrarrevolucionário, era esta que determinava as expectativas para o futuro.

O decreto proposto por Barnave, em nome do comitê colonial, consistia, basicamente, numa revogação da lei de 15 de maio. $\mathrm{O}$ art. III dispunha que:

As leis referentes ao estado das pessoas não livres, e o estado político dos homens de cor e negros livres, assim com os regulamentos dessas mesmas leis, serão feitas pelas assembleias coloniais, executar-se-ão provisoriamente com a aprovação dos governadores das colônias, e serão levadas à sanção do rei, sem que nenhum decreto anterior possa fazer obstáculo ao pleno exercício do direito conferido pelo presente artigo às assembleias coloniais. (grifo nosso) ${ }^{883}$

No dia seguinte, o projeto de Barnave foi atacado pelos adeptos da lei de 15 de maio - Rewbell, Dupont de Nemours, Pétion -, mas sem sucesso. ${ }^{884}$ Robespierre fez aquela que seria a sua última grande intervenção parlamentar nas questões coloniais. Negou que o estabelecimento de uma distância intransponível entre os brancos e os homens de cor fosse um meio eficaz de conter os escravos: para ele, era a distância entre a escravidão e a liberdade que os mantinha em subordinação. Negou ainda que a notícia da Declaração dos direitos pudesse ter provocado insurreições escravas nas ilhas, entendendo que, em razão do estado de embrutecimento em que se encontravam, os escravos sequer eram capazes de tirar as consequências dos direitos declarados. ${ }^{885}$ Essa visão estereotipada do escravo, bastante comum mesmo na esquerda revolucionária, revelar-se-ia bastante equivocada nos meses seguintes.

Para o jacobino, a questão dos homens de cor livres ultrapassava os limites do debate colonial. Era uma questão que repercutia no debate sobre a cidadania ativa em geral. Para ele, não podia haver felicidade, prosperidade ou moralidade sem liberdade e

\footnotetext{
883 "III. Les lois concernant l'état des personnes non libres, et l'état politique des hommes de couleur et nègres libres, ainsi que les règlements relatifs à l'exécution de ces mêmes lois, seront faites par les assemblées coloniales, s'exécuteront provisoirement avec l'approbation des gouverneurs des colonies, et seront portées directement à la sanction du roi, sans qu'aucun décret antérieur puisse porter obstacle au plein exercice du droit conféré par le présent article aux assemblées coloniales" (Moniteur, v.9, número 267, 24 de setembro de 1791, p.756).

${ }^{884}$ Idem, v.9, número 268,25 de setembro de 1791, pp.766-767.

${ }^{885}$ Ibidem, pp.768.
} 
esta implicava o exercício da cidadania. Entendia que um homem privado de seus direitos de cidadão ativo

é um homem que não pode influir nem diretamente, nem indiretamente, nos interesses mais tocantes, mais sagrados da sociedade da qual faz parte; é um homem que é governado por magistrados, de cuja escolha não pode participar de maneira alguma; por leis, por regulamentos, por atos de administração que pesam constantemente sobre ele, sem que tenha exercido o direito que pertence a todo cidadão de influir, de sua parte, nas convenções sociais, no que toca ao seu interesse particular. É um homem aviltado, cujo destino está abandonado aos caprichos, às paixões, aos interesses de uma casta superior. ${ }^{886}$

Contudo, na medida em que nem mesmo na metrópole essa ideia conseguia se impôr, era difícil convencer a Assembleia, bastante temerosa quanto ao futuro das colônias, de que os princípios deveriam prevalecer sobre os interesses do comércio. $\mathrm{O}$ estado de caos nas colônias, aliado à ameaça de independência dos colonos, havia fragilizado o argumento de que cabia à metrópole impor às colônias o respeito aos direitos dos descendentes de escravos. No final, o projeto do comitê foi aprovado por 389 votos contra $276 .{ }^{887}$ A lei de 15 de maio tinha sido revogada e o destino dos homens de cor livres estava agora nas mãos das assembleias coloniais. ${ }^{888}$

\section{I.3.5.3) Reações à lei de 24 de setembro}

O primeiro efeito do decreto de 24 de setembro foi o de reforçar as exclusões do clube dos Jacobinos. Já no dia 25 de setembro, em sessão do clube, após moção de Regnier, foi decidido que Barnave, Duport, os irmãos Lameth e Prefelne eram "indignos" de entrar na Sociedade, que era reservada aos verdadeiros amigos da Constituição e da humanidade. Polverel foi mais longe e pediu a exclusão de todos os que tinham votado a favor da revogação do decreto de 15 de maio. ${ }^{889} \mathrm{Na}$ verdade, os lamethistas já tinham sido expulsos em julho de 1791, mas essa nova decisão declarava

\footnotetext{
886 "C'est un homme qui ne peut influer ni directement, ni indirectement, sur les intérêts les plus touchants, les plus sacrés de la société dont il fait partie; c'est un homme qui est gouverné par des magistrats au choix desquels il ne peut concourir en aucune manière; par des lois, par des règlements, par des actes d'administration pesant sans cesse sur lui, sans avoir usé du droit qui appartient à tout citoyen d'influer pour sa part dans les conventions sociales, en ce qui concerne son intérêt particulier. C'est un homme avili, dont la destinée est abandonnée aux caprices, aux passions, aux intérêts d'une caste supérieure" (Ibidem, p.770).

${ }^{887}$ Ibidem, p.771.

${ }^{888}$ Suprimido em São Domingos, o decreto de 15 de maio seria, entretanto, mantido nas Ilhas de Barlavento.

${ }^{889}$ Cf. AULARD, F.A. La Société des Jacobins, v.3, pp.148-150.
} 
a sua indignidade. Quando da cisão de julho, a fundação do clube dos Feuillants havia determinado a saída de vários jacobinos que temiam uma radicalização da Revolução e suas repercussões na ordem estabelecida. Uma das decorrências daquela ruptura tinha sido o conflito entre Feuillants e Jacobinos sobre a questão colonial. Isso já havia levado alguns deputados, antes favoráveis aos homens de cor a mudarem de campo, como Rabaut Saint-Étienne e La Rochefoucauld-Liancourt, ou a se calarem, caso de Sieyès e La Fayette, que tinham sido Amigos dos Negros, mas estavam agora à frente dos Feuillants. ${ }^{890}$ Inversamente, os Amigos dos Negros tinham levado a sua causa para o clube dos Jacobinos. O decreto de 24 de setembro tinha marcado a vitória dos Feuillants.

O bloco comércio-colônias estava exultante. No mesmo dia do decreto, Begouën escreveu uma carta comemorando uma "grande vitória sobre a Sociedade dos amigos dos negros". ${ }^{891}$ A revogação da lei de 15 de maio foi também objeto de correspondência entre Barnave e Maria-Antonieta, que felicitou-o pelo decreto de 24 de setembro. ${ }^{892}$

No campo contrário, o sentimento era de revolta. Brissot, no Patriote Français de 25 de setembro $\left(\mathrm{n}^{\circ} 776\right)$, anunciou a vitória da "intriga" sobre o decreto de 15 de maio. Argumentou ainda que a Assembleia não tinha mais competência para adotar decretos constitucionais, já que, em razão do fim dos trabalhos de elaboração da Constituição, ela era agora apenas uma assembleia legislativa. Mesmo que ainda fosse constituinte, ela não poderia derrubar um decreto constitucional, revogável apenas após o pedido sucessivo de três legislaturas. Para Brissot, a Assembleia desprezava a autoridade das leis por ela aprovadas. ${ }^{893}$ No número seguinte, o líder dos Amigos dos Negros acusou o decreto de 24 de setembro de ser o "ato de independência das colônias, e o sinal dos mais horríveis massacres". ${ }^{894}$ Lamentou ainda as traições de La Fayette e Sieyès:

\footnotetext{
${ }^{890}$ Brissot traçaria, nas suas memórias, um retrato globalmente favorável de La Fayette, reconhecendo que suas faltas não apagavam as suas contribuições para a liberdade: "La Fayette é culpado também perante a liberdade, mas o que ele tinha feito por ela não deve ser esquecido: quando o tempo tiver resfriado os eventos, talvez perdoaremos mais facilmente as faltas que o desviaram e que ele expia, e levaremos em conta apenas as suas mercês" ("La Fayette est coupable aussi envers la liberté, mais ce qu'il avait fait pour elle ne doit pas s'oublier: quando le temps aura refroidi les évènements, peut-être lui pardonnera-t-on plus facilement les fautes qui l'ont perdu et qu'il expie, qu'on ne lui tiendra compte de ses bienfaits"; BRISSOT DE WARVILLE, Jacques-Pierre. Mémoires, v.2, p.76).

891 BEGOUËN apud THIBAU, Jacques. Le temps de Saint-Domingue, pp.306-307.

892 Cf. MARIE-ANTOINETTE. Correspondance. Tome III: Correspondance secrète avec Barnave, juillet 1791 - janvier 1792. Clermont-Ferrand: Paleo, 2005, p.82.

${ }^{893}$ Cf. Patriote Français, v.5, número 776, 25 de setembro de 1791, p.365.

${ }^{894}$ Idem, v.5, número 777, 26 de setembro de 1791, p.369.
} 
O Sr. LAFAYETTE, que tinha se pronunciado tão energicamente em favor do decreto de 15 de maio, traiu, pela sua ausência, a causa da humanidade. É, sem dúvida, a esse preço que ele entrou na coalizão. O Sr. SIEYÈS teve a fraqueza (para não dizer outra coisa) de retirar-se no momento da chamada nominal. ${ }^{895}$

No Ami du Peuple de 29 de setembro ( $\left.{ }^{\circ} 561\right)$, Marat acusou o ministério de preparar esse golpe por meses, adiando a execução do decreto de 15 de maio. Agora que este tinha sido revogado, medidas já eram tomadas para a partida dos comissários com o novo decreto da Assembleia. Mas Marat alertava que a expedição não teria o sucesso almejado pelos "inimigos da pátria" e anunciava a iminência de uma aliança dos homens de cor com os escravos, a qual levaria inevitavelmente à independência das colônias:

Não é certo que os soldados dos regimentos embarcados se voltem contra o povo, que se tornem instrumentos vis de furor nas mãos de seus chefes, sempre vendidos à corte. $\mathrm{E}$, além disso, os homens de cor não são covardes como os Parisienses. Eles tremerão de raiva ao saberem da revogação do decreto de 15 de maio, eles entrarão em fúria à vista dos preparativos do governo para sujeitá-los. Nos seus santos rompantes de indignação, eles pegarão em armas, eles as colocarão nas mãos dos negros; e alguns dias bastarão para ver todos os colonos brancos serem massacrados, com os adeptos do despotismo. Ora, esse massacre horrendo, obra da venalidade de nossos legistas, será infalivelmente seguido da perda de nossas colônias. ${ }^{896}$

Nas Révolutions de Paris, Chaumette, que tinha iniciado a sua colaboração com o jornal em dezembro de 1790, atacou a competência da Assembleia para revogar, no mesmo exercício legislativo, um de seus decretos. Para ele, o decreto de 24 de setembro era nulo. Assim como Marat, previa a união das pessoas de cor e dos escravos numa grande vingança contra os colonos brancos:

Livres e formando uma classe particular entre os brancos e os escravos, é necessário ou que os brancos as coloquem no seu nível, ou que as pessoas de cor elevem até elas os negros escravos: não seria nada surpreendente se, após terem desarmado os brancos, elas os condenassem por sua vez à servidão. $\mathrm{O}$

\footnotetext{
895 "M. LAFAYETTE, qui s'était si énergiquement prononcé en faveur du décret du 15 mai, a trahi, par son absence, la cause de l'humanité. C'est sans doute à ce prix qu'il est entré dans la coalition. M. SIEYES a eu la faiblesse (pour ne rien dire de plus) de se retirer au moment de l'appel nominal" (Ibidem, p.370). 896 "Il n'est pas sûr que les soldats des régiments embarqués se tournent contre le peuple, qu'ils deviennent de vils instruments de fureur dans la main de leurs chefs, toujours vendus à la cour. Et puis les hommes de couleur ne sont pas des lâches comme les Parisiens. Ils frémiront de rage à l'ouïe de la révocation du décret du 15 mai, ils entreront en fureur à la vue des préparatifs du gouvernement pour les asservir. Dans leurs saints transports d'indignation, ils prendront les armes, ils les mettront à la main des nègres; et quelques jours suffiront pour voir massacrer tous les colons blancs, avec les suppôts du despotisme. Or, ce massacre affreux, ouvrage de la vénalité de nos légistes, sera infailliblement suivi de la perte de nos colonies" (L'Ami du Peuple, número 561, 29 de setembro de 1791, v.6, p.3439).
} 
desejo da vingança é natural a todos os homens; mas ele o é ainda mais àqueles que quiseram ser generosos. ${ }^{897}$

\section{I.3.5.4) Duas ordens constitucionais distintas}

A revogação da lei de 15 de maio foi acompanhada da aprovação de medidas, que podem ser interpretadas como leis de compromisso, ou acordos de circunstância entre jacobinos e feuillants: a lei de 27 de setembro, que concedeu os direitos de cidadania aos judeus do Leste do país; e a lei de 28 de setembro, que declarou que todo homem que entrasse no território francês seria livre e admissível a todos os direitos consagrados pela Constituição. A lei reconhecia, desta forma, os direitos políticos dos negros e homens de cor residentes na metrópole e que preenchiam as condições para a cidadania ativa.

A lei sobre os judeus foi apresentada por Duport, que encontrou, com isso, uma "compensação moral" para a sua traição em relação aos mulatos. Já a lei de 28 de setembro foi uma proposta do jacobino Dubois-Crancé, apoiada pelo feuillant Lanjuinais. ${ }^{898}$ As contradições geradas pela votação dessas leis e a manutenção do status quo nas colônias seriam exploradas tanto pela esquerda quanto pela direita.

No campo colonial, Gouy d'Arcy apontou a incoerência de Rewbell, autor da emenda de 15 de maio e que tinha se oposto à moção de Duport sobre os judeus. ${ }^{899}$ Curiosamente, Grégoire, que tinha sido um dos grandes defensores dos judeus em 1789, havia silenciado a respeito da moção de Duport, como se a questão dos negros tivesse se tornado mais importante para ele naquele momento. No Patriote Français de 29 de setembro, Brissot protestou contra as contradições da legislação. Embora aplaudisse a lei que reconhecia os direitos dos homens de cor e negros da metrópole, perguntava: "E

\footnotetext{
897 "Libres et formant une classe particulière entre les blancs et les esclaves, il est nécessaire ou que les blancs les mettent à leur niveau, ou que les gens de couleur libres élèvent jusqu'à eux les négres esclaves: il n'y aurait rien d'étonnant qu'après avoir une fois désarmé les blancs, ils les condamnassent à leur tour à la servitude. Le désir de la vengeance est naturel à tous les hommes; mais il l'est bien davantage à ceux qui ont voulu être généreux" (Les Révolutions de Paris, v.9, número 116, 24 de setembro - $1^{\circ}$ de outubro de 1791, p.583).

${ }^{898}$ Cf. PIQUET, Jean-Daniel. L'émancipation des Noirs dans la Révolution française, pp.117 e 119.

${ }^{899}$ Rewbell sustentava que os judeus da Alsácia, sua região, viviam de acordo com suas leis particulares, fortemente impregnadas de religião. A sua recusa em renunciar a tais leis e submeter-se às leis francesas os impedia, na sua opinião, de serem reconhecidos como cidadãos ativos (cf. AP, v.30, p.284).
} 
por que não nas colônias? - Ó, é bem diferente. - Por quê? - É que os brancos da França não comprarão por seis mil louis um discurso contra as pessoas de cor". 900

Como aponta Piquet, embora essa lei pudesse ser vista como mero compromisso, ela viabilizaria uma popularização da campanha antiescravista em 1793-94. Ela permitiria, sobretudo, que os negros e homens de cor residentes na França pudessem agir pela emancipação de seus irmãos nas colônias. ${ }^{901}$

O fato é que essas novas leis inseriam-se inteiramente na nova ordem constitucional, marcada pela consagração dos direitos do homem na metrópole, mas também pela exclusão das colônias de seu âmbito. A Constituição, proclamada em setembro de 1791, dispunha, no Título VII, art. $8^{\circ}$, que: "As colônias e as posses francesas na Ásia, África e América, embora façam parte do Império francês, não estão compreendidas na presente Constituição". ${ }^{902}$ Mais do que nunca, o que valia para a metrópole não valia para as colônias. Enquanto, no território francês, prevalecia o princípio da liberdade e o fim das discriminações, nas colônias, consolidava-se um sistema baseado na segregação e na desigualdade jurídica dos indivíduos. Para manter viva a ordem escravista colonial, erigia-se uma ordem constitucional distinta.

Em 28 de setembro, determinou-se a ida dos comissários a São Domingos, para levar o decreto do dia 24. A partir do dia seguinte, a Constituinte deixaria de se reunir, deixando para a Legislativa uma herança terrível em matéria colonial. Como disse Grégoire, em discurso aos Jacobinos em 26 de setembro, a obra colonial da Constituinte tinha sido marcada pela vitória dos "mercadores de carne humana".903

Houve, após aquele verão de 1791, uma clara perda de influência da Sociedade dos Amigos dos Negros. Muitos membros a haviam abandonado, e, naquele momento, o clube dos Jacobinos parecia ter se tornado um espaço mais adequado para a articulação da causa antiescravista com a representação nacional. Com as exclusões que seguiram os decretos de maio e setembro, o clube parecia ter se livrado dos elementos mais ligados à ordem colonial e as condições tinham sido criadas para fazer avançar a

\footnotetext{
900 "Et pourquoi pas dans les colonies? - Oh! c'est bien différent. - Pourquoi? - C'est que les blancs de France n'acheteront pas six mille louis un discours contre les gens de couleur" (Patriote Français, v.5, número 780, 29 de setembro 1791, p.382).

${ }^{901}$ Cf. PIQUET, Jean-Daniel. L'émancipation des Noirs dans la Révolution française, p.118.

902 "les colonies et possessions françaises dans l'Asie, l'Afrique et l'Amérique, quoiqu'elles fassent partie de l'Empire français, ne sont pas comprises dans la présente Constitution" (Constitution Française, décrétée par l'Assemblée Nationale Constituante, aux années 1789, 1790 et 1791; Acceptée par le Roi le 14 septembre 1791. Paris: de l'Imprimerie de Didot Jeune, 1791, p.108).

903 Cf. GRÉGOIRE, Henri. Adresse aux députés de la seconde législature. In: Oeuvres de l'abbé Grégoire. Nendeln (Liechtenstein): KTO; Paris: EDHIS, 1977, v.4, pp.129-132.
} 
questão dos homens de cor dentro da organização. Ou seja, a estrutura dos Amigos dos Negros, sociedade de elite, de acesso restrito, já não se prestava mais aos propósitos da sua causa. Esta precisava ser transferida para um espaço mais democrático e mais apto a difundir eficazmente as suas ideias em diferentes esferas de opinião.

O fato é que os Amigos dos Negros tinham, até então, fracassado na sua tentativa de conduzir a luta antiescravista pela via indireta e gradual. Essa incapacidade de fazer avançar um programa tão moderado indicava que o antiescravismo francês operava dentro de limites que o tornavam sem ação diante dos interesses dominantes na França revolucionária. Os Amigos dos Negros contestavam a escravidão e o tráfico, mas, com a exceção de Mirabeau, não questionavam o sistema do qual essas duas instituições eram, naquele momento, indissociáveis.

Homens de letras e profissionais liberais, como Brissot, mas também todos os membros pertencentes à aristocracia liberal, eles viam a erradicação da escravidão como parte de um processo de generalização de certos ideais de cidadania. Essa postura não implicava para esses indivíduos questionar a posse das colônias. Ao contrário, manifestavam o entendimento de que a França, enquanto país de características imperiais, precisava de territórios ultramarinos que não apenas lhe permitissem desenvolver seu comércio, mas também lhe garantisse, de um ponto de vista geopolítico, uma posição condizente com sua condição de potência. Nesse sentido, a defesa de princípios de justiça e humanidade não implicava para esses homens fomentar revoluções abolicionistas nas colônias, revoluções essas que poderiam levar à sua independência. Na medida em que os Amigos dos Negros mantinham-se favoráveis à manutenção do sistema colonial, o seu programa tinha necessariamente de caracterizarse pela moderação, a tal ponto que, em última instância, ele acabava sendo reduzido a um conjunto de medidas voltadas para o melhor funcionamento desse sistema. Colonos e antiescravistas desenvolviam seus argumentos dentro do mesmo universo ideológico e a linha que separava o antiescravismo dos Amigos dos Negros da crítica meramente preservacionista da escravidão mostrou-se, por vezes, um tanto tênue.

Por outro lado, o aspecto econômico do discurso dos Amigos dos Negros contra o tráfico traduzia a revolta com o bloqueio de recursos financeiros em atividades que viam como parasitárias ou prejudiciais à economia francesa. Havia o entendimento que o comércio de produtos coloniais, articulado em torno do tráfico negreiro, movimentava uma enorme massa de capitais sem verdadeiros efeitos econômicos nacionais, sendo 
favoráveis apenas aos seus detentores. A burguesia mercantil ligada ao comércio colonial era vista como uma classe que se beneficiava de um modelo de exploração desintegrado do resto da economia francesa. Mas, mesmo sob esse aspecto, a crítica dos Amigos dos Negros não implicava questionar a importância das colônias. Tratava-se apenas de repensar o sistema colonial, para que este deixasse de ser um fator de imobilismo econômico. Nesse sentido, as novas orientações sugeridas à colonização francesa apontavam para um modelo colonial que integraria desenvolvimento interno e comércio, por meio da criação de mercados de consumo em outros territórios. Embora contestassem alguns dos alicerces da política mercantilista, os Amigos dos Negros não deixavam de reproduzir, em seu discurso, algumas de suas preocupações centrais.

Assim, apesar das acusações e calúnias de que foram objeto por parte dos colonos, os Amigos dos Negros se apresentavam, acima de tudo, como um movimento voltado para o bom funcionamento do sistema colonial. Nesse sentido, caíram em sua própria armadilha, pois não se concebia naquela época que esse sistema pudesse operar sem o tráfico e a escravidão. A Revolução tinha sido feita com a participação massiva da burguesia dos portos franceses, que estava amplamente representada na Assembleia Nacional. Numa época em que o país ainda carecia de um forte setor manufatureiro e comercial ligado ao mercado interno, essa burguesia marítima afirmava-se como uma classe particularmente influente. Fortalecida pelo compromisso estabelecido com os deputados coloniais, ela neutralizava todas as tentativas de alteração de um sistema do qual tirava o seu poder econômico e político.

Incapaz de fazer avançar a causa da abolição do tráfico nesse contexto, a Sociedade dos Amigos dos Negros encontrou-se reduzida, ao término da Constituinte, a um movimento pelos direitos dos livres de cor, conduzido sob o argumento de que esses plantadores e proprietários de escravos cumpriam um papel primordial na manutenção da ordem colonial. Para um movimento antiescravista, era um programa um tanto magro. Contudo, uma notícia vinda de São Domingos estava prestes a explodir e alterar profundamente a percepção que se tinha do problema colonial. 


\section{Parte II}

A Revolução na via abolicionista (outubro de 1791 - julho de 1794) 


\section{II.1) A insurreicão escrava no debate colonial (outubro de 1791 - abril de 1792)}

\section{II.1.1) A Legislativa e a ascensão política dos Brissotinos}

A eleição dos deputados para a Assembleia Legislativa ocorreu entre os dias 29 de agosto e 5 de setembro de 1791. Elas se deram em meio a uma forte agitação popular que começava a ganhar contornos republicanos. Os meses anteriores tinham sido marcados por fatos que haviam abalado a estabilidade da monarquia constitucional. A fuga do rei Luís XVI e a sua prisão em Varennes, em 20-21 de junho de 1791, haviam projetado sobre a monarquia a imagem da contrarrevolução, abrindo a via para a formulação de um projeto republicano na França. Menos de um mês depois, a fuzilaria do Campo de Marte ${ }^{904}$, de 17 de julho, um dia após a cisão dos Jacobinos, havia sacramentado a ruptura das massas parisienses com a instituição monárquica. As tensões internas tinham sido fortemente agravadas pela declaração de Pillnitz, de 27 de agosto, pela qual Leopoldo II, soberano austríaco, e Frederico-Guilherme II, rei da Prússia, fizeram da situação de Luís XVI um objeto de interesse comum de todos os soberanos da Europa e convidaram as potências europeias a se unirem para enfrentar as ameaças que pairavam sobre a Monarquia francesa. Era o sinal de uma futura coalizão europeia contra a França revolucionária.

O recém-criado clube dos Feuillants, que teria muitos de seus membros escolhidos nas eleições, tinha por objetivo consolidar a obra da Constituinte, entendendo que a Revolução já tinha sido completada. Contudo, um decreto de 16 de maio de 1791 tinha estabelecido que nenhum dos membros da Constituinte podia ser reeleito para a próxima legislatura. Ou seja, a Assembleia Legislativa contaria com um quadro totalmente novo de representantes e isso, mesmo num sistema de sufrágio censitário, abria a possibilidade para mudanças de rumo.

Entre 29 de agosto e 5 de setembro, 745 representantes foram escolhidos. Embora minoritária (136 membros), a nova esquerda da Assembleia era composta essencialmente por jacobinos, e, dentre eles, grande parte dos futuros girondinos. Os

\footnotetext{
${ }^{904}$ Após a fuga do rei e sua prisão em Varennes, a desconfiança do povo francês em relação à Monarquia tinha atingido o seu ápice. A Constituinte, numa tentativa de salvar o projeto constitucionalista, votou, em 15-16 de julho de 1791, decretos que asseguravam o rei no trono. Isso motivou os Cordeliers a comporem uma petição em favor do não reconhecimento de Luís XVI como rei da França e a organizar um abaixoassinado no Campo de Marte no dia 17 de julho. O confronto entre os milhares de signatários e a Guarda Nacional, à frente da qual estavam La Fayette e Bailly, resultou em cinquenta civis mortos e centenas de feridos.
} 
Amigos dos Negros da Constituinte deram lugar a outros nomes do movimento, como Garran de Coulon, Emmanuel Pastoret, Louis-Gustave Doulcet, Lacépède e, sobretudo, aqueles que compunham a cúpula da Sociedade: Brissot, Condorcet e Clavière. Além dos Amigos dos Negros, a Legislativa contava com outras figuras que seriam importantes na história do antiescravismo revolucionário, como Mathieu Blanc-Gilli, Armand-Guy Kersaint e Joseph Eschassériaux. Mas, acima de tudo, a nova força política dos brissotinos resultaria da formação, na esfera parlamentar, do "partido" dos Girondinos. Consagrado pela historiografia, o termo Girondinos, na verdade, amalgama diferentes grupos que, no seio da Assembleia e da Convenção, se uniram em torno de causas comuns, como a guerra na Europa e a defesa da propriedade privada. A forte presença de deputados da região de Bordeaux (departamento da Gironda) no seio dessa associação explica a origem da expressão. O fato é que, ao se unirem a esse grupo, Brissot e seus aliados viram-se politicamente articulados com o comércio marítimo francês. Dentre os Girondinos, vários eram provenientes de famílias de negociantes de Bordeaux, caso de Jean-François Ducos, Jean-Baptiste Boyer-Bonfrède, Jean-Pierre Sers e Bernard Journu-Auber. Outros, como Pierre-Victurnien Vergniaud, Armand Gensonné e Elie Guadet, vinham dos meios jurídicos da cidade e estavam, portanto, vinculados aos interesses primordiais daquele que era o principal porto do comércio colonial.

Ao chegarem a Paris, esses deputados da Gironda buscaram aproximar-se de Brissot, cujas opiniões sobre as colônias eram muito conhecidas. Eles se reuniriam semanalmente na casa de Vergniaud para discutir, durante o jantar, os temas em debate na Assembleia e determinar previamente as posições a serem assumidas pelo grupo. Brissot, então presidente dos Jacobinos, se tornou rapidamente a figura dominante. ${ }^{905} \mathrm{~A}$ composição desse grupo daria enorme força política aos brissotinos e, no que se refere à causa dos homens de cor, permitiria formar um bloco contra os colonos. Por outro lado, associar o comércio francês à causa dos Amigos dos Negros não deixava de impor limites ainda mais estreitos à campanha antiescravista.

Ainda assim, o fato é que girondinos como Guadet, Ducos, Vergniaud e Gensonné reforçariam o campo brissotino nos debates coloniais, frente a um campo colonial que já não encontrava na Legislativa o mesmo número de aliados e simpatizantes que tinha na Constituinte. Havia, entre os novos deputados, alguns

\footnotetext{
${ }^{905}$ Cf. LINTILHAC, Eugène. Vergniaud. Le drame des Girondins. Paris: Librairie Hachette, 1920, pp.6869 e $74-75$.
} 
negociantes dos portos, como Lafond-Ladébat, cujo pai era membro do Clube Massiac, e Tarbé, que tinham alguma experiência com assuntos coloniais, além de homens como Claude Basire, deputado da Côte d'Or, que defenderiam a sua causa. Mas os plantadores e proprietários coloniais estavam em pequeno número: Brulley, Coustard, Giroust, PuyMontbrun, Théodore de Lameth e Viénot-Vaublanc, além de alguns parentes de colonos, como Antoine-Louis Levasseur e Antoine-Joseph-Marie Despinassi. É desse grupo reduzido que sairia o comitê das colônias da Legislativa. ${ }^{906}$

A Sociedade dos Amigos dos Negros passava, portanto, a ter os seus principais porta-vozes na Assembleia, o que lhe permitiria transferir mais facilmente as suas discussões para a esfera parlamentar. Brissot, em particular, se destacaria como uma forte liderança política no seio da Legislativa, onde defenderia uma nova política de progresso para levar a França à guerra na Europa e reafirmar a autoridade metropolitana nas colônias. ${ }^{907}$ Da mesma forma, a eleição de Pétion como prefeito de Paris, em 14 de novembro de 1791, podia gerar um clima mais favorável a uma campanha antiescravista mais aberta na capital francesa. Por outro lado, a entrada desses homens nas esferas do poder faria com que dessem prioridade a outras questões, o que iria, aos poucos, dissolver os Amigos dos Negros enquanto organização política. Mas, no início da Legislativa, a questão colonial seria rapidamente colocada na ordem do dia, por conta de um evento que fugia aos planos dos Amigos dos Negros: a insurreição dos escravos em São Domingos.

\footnotetext{
906 Cf. AP, v.34, pp.25-49 e 412; DEBIEN, Gabriel. Les colons de Saint-Domingue et la Révolution, pp.339-341. O comitê colonial seria composto por Despinassi, Levasseur, Brulley, Vergniaud, JournuAubert, Queslin, Courtin l'âné, Barbotte, Nogaret fils, Lécurel, Gossuin e Tarbé. A lista completa dos membros trazia ainda, como suplentes: Ducos fils, Merlet, Marie Davigneau, Guérin, Barris fils, Grégoire aîné, Daverhoult.

${ }^{907}$ Cf. BLACKBURN, Robin. A Queda do Escravismo Colonial, p.213.
} 


\section{II.1.2) Insurreição geral em São Domingos}

\section{II.1.2.1) A Revolução nas colônias}

Conquistada pelos espanhóis, que lhe deram originalmente o nome de Hispaniola, a ilha de São Domingos havia sido, pela sua posição privilegiada, constantemente cobiçada por outras nações europeias. O Tratado de Ryswick, de 1697, ao pôr fim à Guerra dos Nove Anos, havia dado à França o direito legal sobre toda a parte ocidental da ilha. Ao longo do século XVIII, esta foi gradualmente se transformando na principal colônia açucareira do mundo e no maior mercado individual para o tráfico negreiro europeu. De acordo com os dados apontados pelo barão de Wimpffen, o número de plantações de açúcar da colônia cresceu praticamente ao ritmo de uma centena por decênio: em 1713, eram 138; em 1730, 339; em 1789, 793. Jacques Thibau indica um número ainda maior para o ano de 1788: 959 plantações. Entre 1709 e 1789, a produção de açúcar bruto cresceu a uma taxa de 3,5\% ao ano, o que significa que foi multiplicada por 16 durante o período. Já a produção de açúcar branco verificou uma taxa de crescimento ainda maior: $6 \%$ ao ano, para o período 1720-88. Se, em 1715, São Domingos havia exportado sete mil toneladas em mercadorias para a metrópole, em 1787, esse número já subia para 87 mil toneladas. E esses números sequer compreendiam o autoconsumo e o contrabando, que era bastante intenso. Na década de 1780, o açúcar de São Domingos já abastecia mais da metade dos mercados continentais europeus. A colônia não se limitava, entretanto, apenas à produção açucareira. São Domingos havia se tornado, sobretudo após a Guerra dos Sete Anos, uma das principais produtoras de café do mundo: entre os anos 1768-69 e 1788-89, as suas exportações cafeeiras foram multiplicadas por sete. Às vésperas da Revolução, o café era, aliás, o produto em mais rápida expansão na ilha: o número de plantações tinha passado de 2.810 em 1788 para 3.117 em 1789, isto é, um aumento de quase $11 \%$ em apenas um ano. Com o boom do café, a região Sul, tradicionalmente a mais atrasada da colônia, foi a que conheceu o mais rápido crescimento nas décadas de 1770-80. Além disso, a colônia também contava com importantes produções de anil e algodão. ${ }^{908}$ São

\footnotetext{
908 Cf. CROUZET, François. La guerre économique franco-anglaise aux XVIIIe siècle. Paris: Fayard, 2008, pp. 105-107; BERBEL, Márcia, MARQUESE, Rafael, PARRON, Tâmis. Escravidão e Política, pp.67-68; WIMPFFEN, Alexandre-Stanislas de. Haïti au XVIIIe siècle, p.209; THIBAU, Jacques. Le temps de Saint-Domingue, p.87.
} 
Domingos era, antes dos eventos que abalariam completamente a metrópole e suas posses ultramarinas, a colônia mais produtiva do mundo.

Esse aumento de produtividade gerava efeitos importantes na composição da população. A posição ocupada por São Domingos no comércio internacional de insumos coloniais havia, ao longo do século XVIII, ampliado a demanda de mão de obra nas plantations da colônia. A cana-de-açúcar, em particular, era um produto cujo cultivo, extração e processamento exigiam uma forte concentração de mão de obra. Os imperativos de produtividade determinavam a entrada contínua e massiva de indivíduos que eram arrancados de seus lares e de suas famílias na África para serem submetidos à condição de instrumentos de produção. Entre o final do século XVII e o final do século XVIII, cerca de 800 mil negros foram importados em São Domingos e isso a um ritmo cada vez mais intenso. Nos anos que precederam a Revolução, a entrada anual média de escravos em São Domingos se situava entre 25 e 30 mil escravos. Mesmo o Sul, tradicionalmente pouco abastecido em mão de obra, conheceu um forte aumento da importação de escravos, muito por conta dos incentivos dados pelo Estado francês para atender às exigências do crescimento do café na região. ${ }^{909} \mathrm{O}$ resultado concreto desse processo era uma considerável desproporção da população escrava em relação à população livre, já bastante desfalcada pelo absenteísmo crescente dos proprietários coloniais. Segundo o recenseamento oficial de 1789, havia na colônia 30.831 brancos, 24.843 pessoas de cor e 434.429 escravos. Mas esses números oficiais subestimavam a população de cor e a população escrava: segundo o intendente Barbé de Marbois, o número de escravos para o ano de 1788 já era de 509.642, e é quase certo que os números reais fossem ainda maiores. ${ }^{910}$

Não apenas tinha crescido o número de escravos, mas também a proporção dos elementos nascidos na África em relação à totalidade da população escrava: segundo Moreau de Saint-Méry, eles constituíam cerca de dois terços da escravaria, número talvez excessivo, mas que permite medir a importância da população africana nas colônias. Eram, na sua grande maioria, homens entre 17 e 35 anos. Em São Domingos, a escravaria, submetida a uma exploração cada vez mais intensa, pouco se reproduzia:

\footnotetext{
${ }^{909}$ Desde 1786, a Coroa dava aos armadores um prêmio de 200 libras por escravo levado ao Sul de São Domingos. Foi ainda permitido que eles fossem levados diretamente da África para os portos da região. As importações anuais no Sul subiram de 1.258 para 4.792 cativos (cf. GARRIGUS, John D. Before Haiti, pp.173-174).

${ }^{910}$ Cf. WIMPFFEN, Alexandre-Stanislas de. Haïti au XVIIIe siècle, pp.202-203, nota c, e 296; THIBAU, Jacques. Le temps de Saint-Domingue, pp.70-72.
} 
em 1787, por exemplo, foram 6.111 mortes para apenas 3.566 nascimentos. ${ }^{911}$ Nessas condições, a economia escravista não se sustentava sem o tráfico. Para os administradores coloniais, isso era problemático, pois acreditavam que esses boçais, nascidos em liberdade, em outro continente, tendiam a ser mais combativos do que os crioulos. Estes, nascidos nas colônias e dentro da escravidão, tinham o conhecimento da língua local, estavam acostumados a plantar sua comida e a vender o excedente no mercado. Valiam-se de suas relações pessoais e familiares, por mais precárias que fossem, para obter uma situação melhor dentro do sistema e, assim, tendiam menos a se lançar em atos desesperados de revolta. ${ }^{912}$ Esses indivíduos eram, entretanto, minoritários. No momento em que a colônia atingia o auge de sua produção, a sua segurança e estabilidade encontravam-se sensivelmente fragilizadas. Os imperativos da produção determinavam um grau de exploração ainda mais acentuado da mão de obra, resultando em condições extremamente degradantes para a escravaria: aumento da carga de trabalho, redução do tempo livre, alimentação insuficiente, castigos corporais, etc. Durante os 3-5 primeiros anos nas plantations, os escravos morriam a uma taxa de $50 \%{ }^{913}$ Trabalhavam até morrer e eram simplesmente substituídos. A massa de escravos de São Domingos, entretanto, não aceitava passivamente a sua condição. Paradoxalmente, o crescimento econômico da colônia convertia-se num fator possível de sua própria destruição. O contexto seria dado pelos eventos ocorridos na metrópole e as suas repercussões no espaço colonial.

Em 1802, Félix Carteau, plantador de São Domingos exilado na metrópole, explicou aquelas que entendia serem as causas da insurreição dos escravos em São Domingos que explodiu em agosto de 1791. Para Carteau, uma das razões fundamentais teria sido a difusão dos ideais revolucionários entre a escravaria. Acreditava que os Amigos dos Negros, que ele qualificava de "monstros" invejosos das riquezas coloniais, tinham sido particularmente responsáveis pela disseminação entre os negros da colônia

\footnotetext{
911 Cf. THIBAU, Jacques. Le temps de Saint-Domingue, p.62; BARTHÉLEMY, Gérard. Le rôle des bossales dans l'émergence d'une culture de marronnage en Haïti. Cahiers d'études africaines, v.37, n.148, 1997, p.839. Disponível em: http://www.persee.fr/web/revues/home/prescript/article/cea 00080055 1997 num $37 \quad 148 \quad 1835$. Acesso em: 14 de out de 2013.

912 Cf. GEGGUS, David Patrick. Haitian Revolutionary Studies, p.7. Como explica Barthélemy, os escravos chamados boçais passavam, com o tempo, por um processo de crioulização parcial, espelhandose nos crioulos como um modelo de sobrevivência dentro do sistema. Por outro lado, podemos acreditar que a chegada constante de novas levas de escravos e o esgotamento rápido dessa mão de obra impediam que esse processo de crioulização (ou ladinização) da população africana se completasse (cf. BARTHÉLEMY, Gérard. Le rôle des bossales dans l'émergence d'une culture de marronnage en Haïti, pp.843-844).

${ }^{913}$ Cf. GHACHEM, Malick W. The Old Regime and the Haitian Revolution, p.35-36.
} 
de obras - como as do abade Raynal - e gravuras que denunciavam os maus tratos a que estavam submetidos. Se a grande maioria dos escravos era analfabeta, bastava, dizia o autor, que um deles soubesse ler para que as ideias se disseminassem. Nesse sentido, Carteau denunciava ainda o papel nefasto de oficiais da Marinha "negrófilos", que vendiam secretamente essas obras e gravuras, e de marinheiros vindos da metrópole, que difundiam os ideais da Revolução entre os negros, com quem trabalhavam nos portos da colônia: "Que efervescente escola de insurreição!". ${ }^{914}$

Embora as explicações de Carteau, plantador reacionário, fossem permeadas de teorias conspiratórias pouco verossímeis, elas não deixavam de traduzir a preocupação bastante concreta dos colonos com a frágil estabilidade da sociedade escravista. Para eles, a manutenção da ordem dependia inteiramente da crença da massa de escravos na autoridade de seus senhores sobre o seu destino. Qualquer influência externa na gestão dos escravos era, portanto, vista como perigosa e potencialmente subversiva. Naquele final de século XVIII, em que ideias reformistas a respeito da necessidade de intervenção pública na gestão da mão de obra se disseminavam na Administração, os colonos mostravam-se particularmente resolutos em defender a primazia da autoridade doméstica.

Amplamente estudado por autores como Jacques Thibau e Malick Ghachem, o caso da plantação Lejeune é bastante exemplar dos conflitos que se davam então entre os colonos de São Domingos e a Administração. O caso também é indicativo das expectativas que os escravos formavam à luz das informações que recebiam e que lhes permitiam testar os limites do sistema. No início da década de 1770, casos semelhantes já haviam revelado os riscos que os escravos se dispunham a correr quando os limites do suportável tinham sido ultrapassados. Assim, em 1770, os escravos da plantação Cassarouy tinham fugido, em razão do excesso de trabalho e da falta de alimentação. Presos pela milícia, eles tiveram as suas mãos queimadas e foram devolvidos ao seu proprietário. Alguns empreenderam nova fuga e queixaram-se junto ao promotor. No ano seguinte, um grupo de dez escravos fugitivos também veio colocar-se nas mãos da Justiça, para denunciar as atrocidades cometidas pelo senhor Dessources, que tinha torturado escravos sob acusação de envenenamento e agressão a um feitor. Dessources queimou pernas e pés de três escravos, antes de enterrá-los vivos. Também queimou uma escrava grávida, antes de colocá-la numa solitária, onde acabaria falecendo. Em

914 "Quelle bouillante école d'insurrection!" (CARTEAU, J.-Félix. Soirées bermudiennes, pp.75-77). 
ambos os casos, a decisão da Justiça foi a mesma: a devolução dos escravos ao proprietário. Ficava claro que nenhum juiz ou promotor podia facilmente interferir na disciplina que os senhores impunham aos escravos. O princípio da soberania doméstica prevalecia sobre as disposições do Code Noir, que não era observado. A enorme maioria dos casos de mutilação e tortura não chegava aos tribunais. ${ }^{915}$

As ordenações de 1784-85, que reforçavam e completavam as disposições protetivas do Code Noir, podem ter produzido algum efeito sobre as expectativas da população escrava de São Domingos, que se valeria das disposições que proibiam a tortura para acusar seus senhores. Em março de 1788, 14 negros da região de Plaisance tinham fugido e acusado, perante um jovem magistrado - Couët de Montarand -, o senhor Lejeune de ter cometido brutalidades em duas escravas, Zabette e Marie Rose, queimando as suas pernas e coxas. Não era a primeira vez que esse plantador de café havia cometido esse tipo de ilegalidade. Investigado pelo jovem juiz, Lejeune justificou seus atos com a alegação de que as duas escravas teriam envenenado uma terceira - o que provou-se ser falso - e ele as teria torturado precisamente para arrancar uma confissão. Mas, acima de tudo, o plantador protestou contra essa intervenção da Justiça em seu domínio e perguntou às autoridades o que aconteceria se, após testemunharem a intervenção de uma autoridade externa em seu favor, os negros deixassem de obedecêlo. Para ele, a mera entrada de um juiz na sua propriedade já semeava um germe de revolta, pois não era a lei que impedia o escravo de apunhalar o seu senhor, mas a percepção do poder absoluto que este exercia sobre a sua pessoa. Ou seja, na sua defesa, Lejeune sequer negava o crime. Dias depois, as duas escravas faleceram em agonia, em razão das graves queimaduras, e Couët de Montarand, apoiado pelo governador Vincent e pelo intendente Barbé de Marbois, ordenou a prisão de Lejeune, que fugiu.

Os eventos deixaram os colonos extremamente preocupados com a publicidade que o caso poderia alcançar. Reconheciam que as atrocidades cometidas por Lejeune não eram desejáveis, mas entendiam que, se os escravos pudessem formular queixas em juízo contra seus senhores, eles já não os veriam como autoridade máxima e tenderiam, portanto, a resistir às suas exigências. Para o intendente e o governador, ao contrário, era perigoso impedir que escravos formulassem suas queixas e obtivessem satisfação na Justiça, pois, levados ao desespero, não teriam outra saída a não ser recorrer a atos de violência privada. Para os administradores, era importante que Lejeune fosse pública e

${ }^{915}$ Cf. GHACHEM, Malick W. The Old Regime and the Haitian Revolution, pp.132-139. 
exemplarmente punido. As duas posições tinham no seu âmago a mesma preocupação: o temor da rebelião escrava. Colonos escreveram ao governador para pedir o encerramento do processo, sob o argumento de que, nas plantações vizinhas, já era possível perceber murmúrios entre a escravaria, sinais de uma possível revolta. A pressão teve resultado: os juízes do Conselho superior, órgão judiciário máximo da ilha, mantiveram a decisão da primeira instância e consideraram que as atas elaboradas por Couët de Montarand, assim como todas as medidas que as seguiram, eram nulas por vício de forma e extinguiram o processo sem julgamento de mérito. Embora o intendente e o governador integrassem o Conselho, este era formado, essencialmente, por alguns oficiais civis e militares e por seis juízes provenientes da classe dos plantadores mais ricos da colônia. Essa vinculação da classe dominante com o aparelho judiciário era suficiente para bloquear ameaças aos seus interesses. A única obrigação imposta a Lejeune foi a de apresentar perante o tribunal, sempre que lhe fosse pedido, os escravos que haviam deposto contra ele, como forma de evitar represálias mais terríveis. A decisão foi festejada enfaticamente na cidade. ${ }^{916}$

O caso Lejeune era revelador da incapacidade do governo colonial de intervir eficazmente na relação escravo-senhor. Era revelador também dos temores da sociedade escravocrata: o temor da revolta, o temor dos envenamentos, o temor das interferências públicas na esfera privada e suas consequências para a manutenção da ordem colonial. Ao contrário do que procuraram disseminar visões estereotipadas da escravidão colonial, o mundo dos escravos não se encontrava separado da sociedade por uma muralha. Os escravos tinham conhecimento do que se passava ao redor deles e mesmo na França, de modo que as notícias dos eventos que abalavam a metrópole chegavam, ainda que distorcidas, aos ouvidos dos escravos. ${ }^{917}$ A maior parte da população cativa

\footnotetext{
${ }^{916}$ Cf. THIBAU, Jacques. Le temps de Saint-Domingue, pp.17-80; GHACHEM, Malick W. The Old Regime and the Haitian Revolution, pp.42, 167-210.

${ }^{917}$ Nesse sentido, é interessante observar que os líderes da insurreição foram, em geral, nègres à talent, isto é, escravos ou ex-escravos que estavam em contato mais próximo com a sociedade dos proprietários brancos. Toussaint Louverture foi cocheiro, o que lhe permitiu manter com os senhores uma relação mais próxima. Christophe era cozinheiro, tendo até mesmo adquirido a Auberge de la Couronne de sua antiga patroa (cf. BÉNOT, Yves. La Révolution française et la fin des colonies, p.141). É preciso também destacar o possível papel de membros do clero de São Domingos na difusão de certos ideais de igualdade que podem ter alimentado as aspirações da escravaria. Havia precedentes. Os jesuítas tinham sido expulsos da colônia em 1763, um ano antes da extinção da ordem, por conta da cumplicidade de alguns de seus membros com escravos marrons. Durante a revolução, pelo menos três padres seriam executados na colônia por terem seguido os insurretos. Um deles foi Philémon, padre de Limbé, onde a revolta teve início, que foi descrito, no relatório de Garran de Coulon, de 1795, como um instigador da revolta. Outros padres sofreriam acusações semelhantes. Alguns, como o padre Bienvenu, de Marmelade, atuariam como intermediários entre os colonos e os revoltosos (cf. HURBON, Laënnec. Église et esclavage au XVIIIe
} 
trabalhava no campo, mas havia também, no seio da escravaria, muitos artesãos, domésticos, commandeurs, condutores de animais, isto é, pessoas com maior mobilidade e relativa autonomia dentro da sua condição servil. Escravos domésticos, que tinham relações mais próximas e pessoais com seus senhores, transmitiam as palavras que ouviam aos demais escravos. Estes as interpretavam à sua forma e tiravam delas conclusões que se conformavam às suas aspirações. Em carta de julho de 1790, quando a ilha já se encontrava imersa na agitação revolucionária, o barão de Wimpffen descreveu a facilidade com que as notícias se espalhavam entre a escravaria:

Vejo com pesar, Senhor, que o espírito de vertigem já fez tantos progressos entre os habitantes que, mesmo à mesa, rodeados de mulatos e negros, eles se permitem discussões da mais alta imprudência sobre a liberdade. Logo, os escravos das plantações vizinhas, em comércio com os da cidade, levarão consigo e comentarão à sua maneira as palavras que terão ouvido. 'Se esses Brancos são livres apenas desde hoje, eles dirão, o que, portanto, eram eles ontem? escravos como nós?' E deus me livre de ser testemunha das consequências desse raciocínio! discutir os direitos do homem perante tais homens, não seria isso ensinar-lhes que o poder reside na força e a força no número? $?^{918}$

O mundo dos escravos era permeado por redes de contatos bastante amplas, de modo que as notícias vindas do exterior se propagavam com grande rapidez. Escravos se encontravam constantemente em festas, rituais religiosos e mercados públicos. Nas últimas décadas antes da Revolução, o crescimento dos espaços urbanos era outro fator que estimulava a troca de ideias e informações. O centro do Cap-Français era um espaço público, frequentado por todas as classes de indivíduos: plantadores brancos, petitsblancs, homens de cor e escravos. O mercado de domingo trazia cerca de 15 mil negros à praça Clugny, onde a feira dos negros era realizada. Com isso, escravos das diferentes plantations estabeleciam uma rede informal de comunicação. ${ }^{919} \mathrm{Na}$ área rural, havia, ainda, os chamados ateliers vacants (as task gangs das colônias inglesas), turmas de escravos que eram arrendadas por tempo limitado a plantadores que precisavam de um

siècle à Saint-Domingue. In: M. DORIGNY (org.). Les abolitions de l'esclavage, pp.95-97; FICK, Carolyn. The making of Haiti, p.65).

918 "Je vois avec peine, Monsieur, que l'esprit de vertige a déjà fait de tels progrès parmi les habitants, qu'à table même, entourés de mulâtres et de Nègres, ils se permettent sur la liberté, des discussions de la plus haute imprudence. Bientôt les esclaves des Habitations voisines, en commerce avec ceux de la ville, rapporteront chez eux et commenteront à leur manière les propos qu'ils auront entendu. 'Si ces Blancs ne sont libres d'aujourd'hui, diront-ils, qu'étaient-ils donc hier.? des esclaves comme nous?' Et dieu me preserve d'être témoin des conséquences de ce raisonnement! discuter les droits de l'homme devant de pareils hommes, est-ce autre chose que leur apprendre que le pouvoir reside dans la force et la force dans le nombre?" (WIMPFFEN, Alexandre-Stanislas de. Haïti au XVIIIe siècle, pp.254).

${ }^{919}$ Cf. GHACHEM, Malick W. The Old Regime and the Haitian Revolution, pp.268-270. 
acréscimo de mão de obra. ${ }^{920} \mathrm{O}$ deslocamento desses plantéis itinerantes criava novos laços entre os escravos das diferentes plantations e permitia a difusão de notícias e rumores.

Antes mesmo da Revolução, os eventos ocorridos na metrópole geravam repercussões frequentes entre os escravos das colônias. Agitações em torno de rumores vindos da França eram comuns. Quando chegavam às colônias, as notícias vinham geralmente distorcidas por relatos incompletos e pouco objetivos, levando a interpretações muitas vezes equivocadas por parte das diferentes camadas sociais das sociedades coloniais. Assim, a escolha de Turgot como controlador das Finanças na França havia gerado um clima de otimismo entre a escravaria, em razão de uma suposta conversa com Luís XVI, na qual ele teria dito que seria, um dia, necessário pôr fim à escravidão. Propagou-se, então, nas ilhas, o rumor, absolutamente infundado, de uma iminente emancipação geral. Se a abolição, como se sabe, não ocorreu, uma fagulha tinha sido acesa. ${ }^{921}$ As ordenações de 1784-85 também podem ter sido lidas como um sinal das boas intenções da Monarquia francesa para com os escravos, intenções estas que se chocavam com a resistência promovida pela elite local, como havia mostrado o caso Lejeune. Da mesma forma, o surgimento de uma sociedade antiescravista na França não podia ser interpretado como mais um indício de uma emancipação próxima? A notícia da existência da Sociedade dos Amigos dos Negros certamente chegou aos ouvidos da escravaria. Em março e abril de 1788, chegavam a São Domingos números do Mercure de France, nos quais Mallet du Pan fazia menção ao surgimento de uma sociedade em Paris para a defesa dos negros:

Que os negros saibam que eles contam, entre os Brancos, com tantos defensores quanto existem homens virtuosos. Possam eles ser instruídos de que todos os depositários da autoridade pública na Europa, todos os homens se sensibilizaram com seu infortúnio! Que eles saibam, enfim, que um sentimento novo de benevolência e piedade anima todos os homens. ${ }^{922}$

\footnotetext{
${ }^{920}$ Cf. WIMPFFEN, Alexandre-Stanislas de. Haïti au XVIIIe siècle, p.244.

${ }^{921}$ Cf. THIBAU, Jacques. Le temps de Saint-Domingue, p. 25.

922 "Que les nègres apprennent que parmi les Blancs ils ont aujourd'hui autant de défenseurs qu'il existe d'hommes vertueux. Puissent-ils être instruits que tous les dépositaires de l'autorité publique en Europe, que tous les hommes se sont émus de leur infortune! Qu'ils sachent enfin qu'un sentiment nouveau de bienveillance et de pitié anime tous les hommes" (citado em THIBAU, Jacques. Le temps de SaintDomingue, p.53).
} 
Segundo Moreau de Saint-Méry, a notícia do surgimento da Sociedade gerou grande comoção na colônia. ${ }^{923} \mathrm{O}$ programa dos Amigos dos Negros excluía a emancipação imediata dos negros escravizados, mas essas "nuances" provavelmente se perdiam no meio do caminho. Para os escravos, os Amigos dos Negros eram apenas mais um dado que alterava o seu horizonte de expectativas. Em março de 1789, Wimpffen já manifestava a preocupação dos colonos com a propaganda antiescravista, afirmando que a única forma de conter centenas de milhares de escravos estava na "força da opinião". Para ele, os Amigos dos Negros não podiam desprezar os interesses estabelecidos: "Em uma palavra, que eles sejam os amigos dos Negros sem ser os inimigos dos Brancos". ${ }^{924}$ Durante a Revolução, quaisquer agitações no seio da escravaria seriam sistematicamente atribuídas à ação de "emissários secretos" de Brissot e seus aliados. ${ }^{925}$

A conjuntura revolucionária que tomou conta da colônia a partir da chegada das notícias da convulsão política da primavera-verão de 1789 teve um papel crucial na formação da revolta geral dos escravos negros. Os eventos ocorridos na metrópole repercutiam das mais variadas formas nas colônias, de modo que os diferentes grupos que compunham a sociedade de São Domingos viam naquele momento de transformação uma oportunidade para levar adiante os seus projetos e aspirações. Nas colônias, a Revolução apresentava-se como um momento aberto, em que a ruptura com instituições tidas como injustas ou ilegítimas se fazia possível. Com isso, as contradições próprias ao sistema colonial davam lugar a conflitos abertos.

Para os colonos brancos, a Revolução apresentava-se como uma via de libertação das amarras do exclusivo e de seu instrumento político, o "despotismo ministerial", representado na ilha pelo governador e, sobretudo, pelo intendente. Num período de alta da produção colonial, o sistema de monopólio, que num outro contexto podia ser visto como uma proteção, tornava-se insuportável. Os colonos acreditavam que um regime economicamente aberto lhes garantiria melhores preços na compra e maiores lucros na venda. A Guerra dos Sete Anos, durante a qual a França havia se mostrado incapaz de defender e abastecer suas colônias, havia sido traumatizante. Da mesma forma, durante a guerra de independência americana, o sistema exclusivo havia

\footnotetext{
${ }^{923}$ Cf. MOREAU DE SAINT-MÉRY, Médéric Louis Élie. Considérations présentées aux vrais amis du repos, p.4.

924 "En un mot, qu'ils soient les amis des Noirs sans être les ennemis des Blancs" (WIMPFFEN, Alexandre-Stanislas de. Haïti au XVIIIe siècle, p.83).

${ }^{925}$ Ibidem, p.253.
} 
sido temporariamente suspenso. Na década de 1780, os colonos pressionavam mais do que nunca por uma maior liberdade e entravam em choque com a burocracia. Uma lei de 30 de agosto de 1784 deu ao exclusivo uma forma mitigada, ao permitir a abertura de alguns portos da ilha ao comércio estrangeiro, mas os colonos queriam uma liberdade total. Essa medida tampouco agradou aos negociantes franceses, pois, embora soubessem que a França era incapaz de abastecer as suas colônias em produtos e escravos, temiam que o sistema do monopólio fosse progressiva e totalmente erradicado. ${ }^{926}$ Além disso, sabiam que o recurso ao contrabando era particularmente intenso nas colônias francesas. ${ }^{927} \mathrm{O}$ contrabando, sobretudo com as colônias britânicas, era a forma encontrada pelos plantadores de compensar os limites impostos pelo pacto colonial. ${ }^{928}$ Havia, portanto, um forte conflito de interesses entre colonos e negociantes, o qual era profundamente agravado pelas enormes dívidas contraídas pelos colonos junto ao comércio francês. Com o recurso incessante ao tráfico como forma de reposição da mão de obra, os colonos aumentavam continuamente as suas dívidas, que, em 1789, já se situavam entre 300 e 500 milhões. ${ }^{929}$ Wimpffen descreveu essa situação com as seguintes palavras:

[...] a maioria dos colonos, em vez de empregar o preço de suas primeiras colheitas para quitar dívidas ruinosas, as destina a comprar um número ainda maior de negros, isto é, a contrair novas dívidas, sem ter calculado previamente se os lucros que lhes faz esperar o produto de uma cultura mais extensa compensará a diferença, sempre muito considerável, entre o crédito e o saldo. ${ }^{930}$

926 Cf. MARTIN, Gaston. Histoire de l'esclavage dans les colonies françaises, pp.145-147 e 175; THIBAU, Jacques. Le temps de Saint-Domingue, p.179; BERBEL, Márcia, MARQUESE, Rafael, PARRON, Tâmis. Escravidão e Política, pp.63-64; DEVEAU, Jean-Michel. Le Commerce rochelais face à la Révolution, pp.86-88.

${ }^{927}$ A interlope em São Domingos no ano de 1788 atingiu, segundo dados oficiais, 800 mil libras. Mas os dados do comércio francês apontam um valor muito maior: 13 milhões de libras (cf. WIMPFFEN, Alexandre-Stanislas de. Haïti au XVIIIe siècle, p.297).

${ }^{928}$ No caso da Guadalupe, o contrabando era uma questão de sobrevivência. Em média, 40\% de sua produção eram negociados com contrabandistas. Em razão de sua posição marginal em relação a São Domingos e a Martinica, a ilha era sempre preterida por armadores e negociantes franceses e ficava subabastecida. No século XVIII, São Domingos recebeu 74,3\% e a Martinica 10,9\% dos escravos levados para as colônias francesas. À Guadalupe, restaram entre 1 e $2 \%$ dos escravos. Um dos resultados desse processo é que a ilha tinha uma das maiores proporções de escravos crioulos em relação aos africanos (cf. DUBOIS, Laurent. A Colony of Citizens, p.51; STEIN, Robert Louis. The French Sugar Business in the Eighteenth Century, p.76).

${ }_{929}$ Cf. JAMES, C.L.R. Os jacobinos negros, p.60.

930 "[...] la plupart des colons, au lieu d'employer le prix de leurs premières recoltes à acquitter des dettes ruineuses, les destinent à acheter un plus grand nombre de Nègres, c'est-à-dire, à contracter de nouvelles dettes, sans avoir calcule d'avance si les bénéfices que leur fait espérer le produit d'une culture plus étendue, compensera la différence, toujours três considérable, entre le crédit et le comptant" (WIMPFFEN, Alexandre-Stanislas de. Haïti au XVIIIe siècle, p.246). 
Assim, os negociantes franceses viam a pressão dos colonos por maior liberdade também como uma forma de escapar ao pagamento de seus débitos. Um espírito de independência se difundia nas ilhas, alimentado pela experiência norte-americana. Uma de suas expressões foi a criação dos Conselhos superiores, instâncias judiciárias máximas das colônias, que davam proteção aos proprietários coloniais e seus bens contra as pretensões dos comerciantes da metrópole, seus credores. ${ }^{931}$ Textos contra o exclusivo se tornaram comuns na década de 1780. Em Du commerce des Colonies, ses principes et ses lois (1785), por exemplo, um autor anônimo afirmava claramente que o sistema proibitivo era tão maléfico que a única solução era infringi-lo e apontava a independência dos Estados Unidos como o sinal de que era necessário flexibilizá-lo. ${ }^{932}$ Em 1789, o governador de São Domingos, pressionado pelos colonos, entrou em choque com o intendente Barbé de Marbois ao determinar a abertura de três portos do Sul da colônia (Jacmel, Jéremie e Les Cayes) à entrada de escravos, animais e alimentos trazidos por navios estrangeiros. A decisão foi cassada pelo Conselho do rei, mas, naquele momento, a autoridade metropolitana já era bastante contestada. ${ }^{933}$

Como vimos anteriormente, com a chegada da Revolução em São Domingos, a sociedade colonial viu-se dividida. Os plantadores crioulos, especialmente os mais endividados, identificaram naquele o momento uma oportunidade de levar adiante os seus projetos de independência. Eles se tornaram os "revolucionários" e "patriotas" das colônias, sendo chamados de pompons rouges. Mas a sua "revolução" nada tinha a ver com os direitos dos homens, e sim com a luta por uma maior autonomia na gestão de seus interesses, o que incluía a exploração da escravaria. Confrontavam-se aos pompons blancs, os "contrarrevolucionários", adeptos da submissão à metrópole, o que compreendia a burocracia real, mas também negociantes e os petits blancs, que se associaram, por um tempo, à Administração, no intuito de obter uma maior participação na gestão da ilha. Quando os brancos pobres decidiram se aliar à "revolução", a burocracia chegou a se aproximar dos mulatos. Essa divisão interna da sociedade colonial assumiu a forma de um confronto aberto, quando a Assembleia de Saint-Marc, sede dos colonos independentistas, atribuiu-se poderes constituintes, rejeitando qualquer controle do parlamento francês. Diante dessa situação, a Assembleia da Província do Norte, composta essencialmente por advogados e comerciantes do Cap-Français, se fez

\footnotetext{
${ }_{931}$ Cf. THIBAU, Jacques. Le temps de Saint-Domingue, pp.78-79.

${ }^{932} \mathrm{Cf}$. Du commerce des Colonies, ses principes et ses lois, pp.7 e 14.

${ }^{933}$ Cf. DEVEAU, Jean-Michel. Le Commerce rochelais face à la Révolution, pp.89.
} 
defensora dos interesses comerciais e financeiros da metrópole. O conflito, é bom lembrar, levou a Constituinte a dissolver a Assembleia de Saint-Marc. ${ }^{934}$

Vimos também que, além dessa luta entre brancos, São Domingos tinha se tornado ainda o palco de um violento confronto entre brancos e pessoas de cor. Se os plantadores endividados viram na Revolução a possibilidade de se livrarem dos limites impostos pelo pacto colonial, os homens de cor livres da ilha vislumbraram nela uma oportunidade de reivindicar os seus direitos de cidadania e o fim das leis discriminatórias. O seu combate e a resistência imposta pela elite branca quase mergulharam a colônia na guerra civil. Todos em São Domingos percebiam a Revolução como um momento de ruptura e, nesse sentido, procuraram organizar-se no intuito de obter uma situação melhor para si. Tomando emprestado uma expressão de Emília Viotti da Costa, pode-se dizer que a Revolução alterou a "percepção do possível"935 dos diferentes agentes históricos. Os mais de 500 mil escravos que habitavam a colônia não estavam alheios aos acontecimentos.

As notícias da Revolução não demoraram a chegar aos ouvidos dos escravos, que assistiam seus senhores discutirem o tema abertamente na sua presença. Soldados vindos da metrópole transmitiam, nos portos das colônias, as notícias e os ideais da nova França, que tinha declarado os homens livres e iguais. Em $1^{\circ}$ de outubro de 1789 , em São Domingos, o plantador de cor Francis Raimond escreveu ao seu irmão Julien, então em Paris, para traçar um quadro da agitação que tinha tomado conta da ilha desde o início da Revolução na metrópole: "[...] o mais terrível são os Negros que, ao ouvirem que o cocar é pela liberdade e a igualdade, quiseram se insurgir". ${ }^{936}$ Antes do final de 1789, levantes na Martinica já tinham suscitado temores quanto aos efeitos da efervescência revolucionária sobre a escravaria. Em agosto de 1789, por exemplo, os escravos de Saint-Pierre já acreditavam que o rei da França, encorajado pelos antiescravistas, tinha abolido a escravidão. ${ }^{937} \mathrm{E}$ esses primeiros movimentos tinham

\footnotetext{
${ }^{934}$ Cf. JAMES, C.L.R. Os jacobinos negros, pp.71-75; MARTIN, Gaston. Histoire de l'esclavage dans les colonies françaises, p.199.

${ }^{935}$ Cf. COSTA, Emília Viotti da. História, Metáfora e Memória: a Revolta de Escravos de 1823 em Demerara. Arquivo: Boletim Histórico e Informativo, São Paulo, v.9, n.1, jan./jun. 1988, p.19.

936 "[...] le plus terrible sont les Noirs qui, entendant que la cocarde est pour la liberté et l'égalité ont voulu se soulever" (RAIMOND apud GARRAN-COULON, Jean-Philippe. Rapport sur les troubles de SaintDomingue. Paris: Imprimerie nationale, 1796-1799, v.2, p.195)

${ }^{937}$ Em agosto de 1789, os escravos em revolta enviaram cartas ao comandante de Saint-Pierre e ao governador da Martinica, exigindo a liberdade: "Todos os escravos se unem num só grito para reclamar uma liberdade que eles mereceram justamente após um século de sofrimentos e de servidão ignominiosa. Não se trata mais de uma nação cegada pela ignorância que tremia diante dos mais leves castigos. Esses sofrimentos a esclareceram e a determinaram a derramar até a última gota de sangue antes de continuar a
} 
ocorrido antes mesmo que a notícia do 14 de julho pudesse ter chegado à Martinica. Teria sido o efeito da efervescência gerada pelos Estados Gerais, ou talvez até mesmo da campanha antiescravista? David Geggus fala em rumores de uma tendência abolicionista e de reformas promovidas pela monarquia. ${ }^{938} \mathrm{O}$ fato é que, com a agitação revolucionária na metrópole, os negros podiam conceber a liberdade não como o resultado de uma fuga ou de uma alforria, ou seja, uma liberdade à margem ou dentro da própria sociedade escravista, mas como o resultado de um sistema legal de abolição capaz de promover uma emancipação geral da população escrava. As condições tinham sido criadas para uma mudança da própria sociedade em que viviam.

O mesmo fenômeno se reproduzia em outras colônias. Em abril de 1790, ocorreu uma tentativa de insurreição na Guadalupe e, em 4-6 de dezembro de 1790, um pequeno levante teve início em Approuague, na Guiana. ${ }^{939}$ Em maio de 1791, novas tentativas foram reprimidas na Martinica e em Sainte-Anne, na Guadalupe. Neste último caso, escravos tinham sido recrutados por um homem de cor que afirmava que o governador tinha recebido da Assembleia Nacional um decreto declarando livres todos os escravos, mas que se recusava a proclamar a liberdade até que pudesse vender suas propriedades. São Domingos, a maior colônia escravista francesa, não ficaria fora desse processo, registrando alguns movimentos no Sul desde outubro de $1789 .^{940}$

Rebeliões escravas não eram propriamente uma novidade na principal colônia francesa, mas tampouco havia precedentes para o que ocorreu em agosto de 1791. Antes do período revolucionário, o exemplo mais próximo de um movimento de revolta talvez tenha sido a campanha instigada por Makandal (ou Macandal) nos anos 1750. Velho feiticeiro mandingo, Makandal havia dado ordens aos seus discípulos de envenenar animais, escravos inimigos e, sobretudo, os senhores contra os quais havia algum

suportar o jugo vergonhoso da escravidão, um jugo horroroso condenado pelas leis, pela humanidade, pela natureza como um todo, pela Divindade, por nosso bom rei Luís XVI..." ("Tous les esclaves ne font qu'un cri pour réclamer une liberté qu'ils ont justement gagnée par un siècle de souffrances et de servitude ignominieuse. Ce n'est plus une nation aveuglée par l'ignorance qui tremblait à l'aspect des plus légers châtiments. Ces souffrances l'ont éclairée et l'ont déterminée à verser jusqu'à la dernière goutte de sang plutôt que de supporter davantage le joug honteux de l'esclavage, un joug affreux blâmé par les lois, par l'humanité, par la nature entière, par la Divinité, par notre bon roi Louis XVI...") (citado em MARIUSHATCHI, Fabien. La Révolution caribéenne comme ultime rempart du droit naturel. In: GAUTHIER, Florence (org.). Périssent les colonies plutôt qu'un principe!, p.68). As notícias desse levante chegaram à metrópole no final de novembro de 1789.

${ }^{938}$ Cf. GEGGUS, David. Haitian revolutionary studies, p.66 e 170.

${ }^{939}$ Embora curta, essa revolta inspirou o decreto de 5 de abril de 1791 , que concedeu cidadania francesa aos índios da Guiana. Bénot explica que a lei tinha por objetivo opor os índios aos negros, fazendo daqueles uma base de sustentação da população livre da colônia (cf. BÉNOT, Yves. La Guyane sous la Révolution française, pp.54-55).

${ }^{940}$ Cf. BÉNOT, Yves. La chaîne des insurrections d'esclaves dans les Caraïbes, de 1789 à 1791. In: M. DORIGNY (org.). Les abolitions de l'esclavage, p.179; DUBOIS, Laurent. A Colony of Citizens, p.107. 
ressentimento. O movimento assumiu proporções inéditas, detonando um clima de paranoia entre os plantadores da ilha. Durante seis anos, os brancos ignoraram a existência do líder marron, mas, em 1757, os planos de Makandal foram frustrados após ter sido denunciado por um escravo submetido à tortura. Ele foi preso e executado em janeiro de 1758, mas esse episódio pesaria para sempre sobre a sociedade de São Domingos. ${ }^{941}$ Para Carolyn Fick, a revolta de Makandal mesclava formas tradicionais de resistência escrava (marronnage, envenenamentos, práticas religiosas), não numa perspectiva restauracionista, mas como veículo para um plano de destruição da ordem escravista. ${ }^{942}$ Geggus, por outro lado, aponta que muitas das teses elaboradas a respeito do episódio Makandal basearam-se em evidências pouco seguras. Não houve, na sua opinião, motivações revolucionárias ou conspiração em larga escala. ${ }^{943}$ Tampouco houve, na década antes da Revolução francesa, grandes rebeliões escravas na colônia. O movimento que teve em agosto de 1791 era algo sem precedentes.

Nesse sentido, foram determinantes os conflitos internos das classes possuidoras de São Domingos. A agitação que tomou conta da colônia, com os embates entre os colonos independentistas e a burocracia, entre os plantadores da assembleia geral de Saint-Marc e os comerciantes do Norte, entre brancos e mulatos, geraram repercussões imediatas entre os escravos. Essa conjuntura de crise foi identificada pela massa de cativos como o contexto propício a um movimento mais amplo e organizado. A história da escravidão colonial está repleta de exemplos que atestam a capacidade dos escravos de aproveitarem os momentos de crise interna das sociedades escravistas para iniciar movimentos de revolta. ${ }^{944}$ Ao mesmo tempo, as notícias dos debates parlamentares na metrópole, como, por exemplo, os relativos aos direitos das pessoas de cor podiam ser interpretados pelos escravos como o sinal de uma emancipação próxima. Tratava-se, no mínimo, de um indício de que havia uma autoridade superior à dos plantadores e que essa autoridade se mostrava inclinada a ajudar os negros. Os escravos interpretavam tudo à sua forma e isso os motivava a mobilizarem-se contra os seus opressores. Revoltas escravas estavam longe de ser uma novidade, mas o que havia de novo era o quadro de crise generalizada em que São Domingos se encontrava. É esse quadro,

${ }^{941}$ Cf. THIBAU, Jacques. Le temps de Saint-Domingue, p.36; DUBOIS, Laurent. Avengers of the New World. Cambridge, Massachussetts: The Belknap Press of Harvard University Press, 2005, pp.51-52.

${ }^{942}$ Cf. FICK, Carolyn. The making of Haiti, p.61.

${ }^{943}$ Cf. GEGGUS, David Patrick. Haitian Revolutionary Studies, p.75.

${ }^{944}$ No Brasil, foi o caso do levante dos Malês, na Bahia, em 1835. O Estado vivia então um período de crise política e econômica, marcado, de um lado, por revoltas das classes livres pobres e, de outro, pelo movimento dos dissidentes liberais. A divisão entre os homens livres agiu como um fator de estímulo ao levante (cf. REIS, João José. Rebelião escrava no Brasil. São Paulo: Companhia das Letras, 2003, p.545). 
formado no contexto da Revolução, que explica a dimensão que a insurreição escrava ganharia.

Inicialmente, os atos de rebelião em São Domingos se limitaram a alguns movimentos restritos a poucas fazendas, reprimidos violentamente pelas forças da ordem. O fracasso dessas revoltas devia-se, em grande parte, ao funcionamento do sistema tradicional da maréchaussée e das milícias de cor. Mas, em agosto de 1791, a coisa havia mudado de figura. Um fator decisivo para que a resistência escrava assumisse, em meados daquele ano, a forma de uma insurreição generalizada foi a repressão aos homens de cor livres. A resistência dos colonos brancos ao reconhecimento dos direitos de cidadania dos homens de cor livres havia gerado profundas fraturas entre os proprietários de São Domingos, desestruturado o aparelho repressivo que mantinha o sistema escravista em funcionamento. A revolução escrava explodiria justamente na região onde a presença mulata era menos importante. Se a resistência escrava era uma constante no mundo colonial, as condições objetivas existentes naquele momento ampliavam o campo de possibilidades dos negros de São Domingos.

\section{II.1.2.2) São Domingos em chamas}

A revolta de agosto de 1791 foi preparada durante semanas. Aos domingos, representantes de escravos das grandes plantações se reuniam para elaborar planos de insurreição. Na noite de 14 de agosto, em Morne Rouge, plantação de Lenormand de Mézy, o plano final foi traçado. Cerca de duzentos escravos negros, delegados dos plantéis da região da planície do Norte, se reuniram em volta do sacerdote (ou papaloi) Boukman, cocheiro na plantação Clément, para estabelecer as bases da organização do levante. Os homens presentes eram escravos que gozavam de relativa liberdade de movimento e exerciam certa autoridade em seus ateliers, sendo muitos deles commandeurs, o que indica que a hierarquia interna dos plantéis se reproduziu na insurreição. Foi lido o depoimento de um mulato (ou quadrarão) segundo o qual o rei tinha dado três dias livres por semana a todos os escravos e abolido o castigo com o açoite. Foi dito que senhores e autoridades se recusavam a executar o decreto e que forças reais estavam a caminho para impor a sua aplicação. A notícia era falsa, mas era indicativa das aspirações dos escravos naquele momento. Embora alguns quisessem 
esperar a chegada das tropas reais, a maioria decidiu que a guerra com os brancos tinha de ser instigada. ${ }^{945}$

A reivindicação dos três dias não era uma novidade. Em janeiro de 1791, em Port-Salut, perto de Les Cayes, no Sul, duzentos escravos tinham se armado para reclamar os três dias livres, supostamente concedidos pelo rei. A conspiração foi reprimida, mas o rumor persistiu. Em junho e julho, movimentos semelhantes ao de Port-Salut tinham sido organizados no Oeste. Em Morne Rouge, o tema dos três dias voltava a ser invocado pelos rebeldes. ${ }^{946}$ Assim, não se falava ainda em liberdade, mas apenas na ampliação do espaço de autonomia que os escravos já encontravam dentro do sistema.

A reunião foi seguida de uma cerimônia vodu na floresta de Bois-Caïman. ${ }^{947}$ Trata-se de um notável exemplo de manifestação cultural transformada, no quadro da experiência colonial, em instrumento de resistência e combate à escravidão, muito embora Geggus entenda que o papel do vodu na formação da consciência revolucionária dos escravos de São Domingos foi exagerado pela historiografia. Para o autor, o vodu oferecia soluções que eram mais mágicas do que políticas às dores da vida terrena. ${ }^{948}$ Pode-se, entretanto, atribuir à prática religiosa um caráter, no mínimo, instrumental no quadro da formação do movimento insurreicional. As cerimônias religiosas, assim como as festas e danças, tinham se tornado o espaço para a circulação de notícias e para a organização de atos de rebelião. ${ }^{949}$

Embora a data do início da revolta tivesse sido fixada provavelmente para o dia 24 de agosto $^{950}$, alguns escravos não se contiveram. No dia 16 , uma primeira tentativa de ataque ocorreu na paróquia de Limbé, com o incêndio da plantação Chabaud, mas foi rapidamente contida. Um dos rebeldes presos revelou, sob interrogatório, os planos de

\footnotetext{
${ }^{945}$ Cf. DUBOIS, Laurent. Avengers of the New World, pp.97-98; FICK, Carolyn. The making of Haiti, pp.91-92.

${ }_{946}$ Cf. Idem. The French Revolution in Saint-Domingue, p.63.

${ }^{947}$ Baseados na pioneira Histoire de la Révolution de Saint-Domingue (1814) de Antoine Dalmas, os relatos da revolta geralmente indicam que a cerimônia se deu logo após o encontro do dia 14 de agosto. Dubois e Geggus, entretanto, acreditam que a cerimônia ocorreu provavelmente uma semana depois, no dia 21. Já Aimé Césaire afirma que a cerimônia ocorreu em 22 de agosto, logo antes da ofensiva geral (cf. DALMAS, Antoine. Histoire de la Révolution de Saint-Domingue. Paris: Mame Frères, 1814, v.1, pp.117; DUBOIS, Laurent. Avengers of the New World, p.100; GEGGUS, David Patrick. Haitian Revolutionary Studies, p.86; CÉSAIRE, Aimé. Toussaint Louverture: la Révolution française et le problème colonial. Paris: Présence Africaine, 1981, p.200).

${ }_{948}$ Cf. GEGGUS, David Patrick. Haitian Revolutionary Studies, pp.76-79.

${ }^{949}$ Cf. DUBOIS, Laurent. Avengers of the New World, pp.97-98.

${ }^{950}$ Essa é a tese de David Geggus, para quem a revolta explodiu prematuramente. Carolyn Fick, entretanto, acredita que a revolta ocorreu na data planejada pelos insurretos, 22 de agosto. (GEGGUS, David Patrick. Haitian Revolutionary Studies, p.87; FICK, Carolyn. The making of Haiti, p.96).
} 
uma insurreição generalizada, o que obrigou os líderes negros a anteciparem as ações. Assim, na noite de 22-23 de agosto, sob a liderança de Boukman, explodiu a grande insurreição dos escravos de São Domingos. ${ }^{951} \mathrm{O}$ bando de algumas centenas de negros se espalhou pelas propriedades da paróquia de Acul, insurgindo os escravos, queimando as plantações e massacrando os senhores. Campos militares eram estabelecidos em cada uma das plantações tomadas. Na manhã do dia 23, o número de escravos envolvidos já subia a dois mil. Alguns brancos tentavam resistir, muitas vezes ajudados por seus próprios escravos, mas muitos outros fugiam antes mesmo de esboçarem uma resistência. Em numerosas plantações, os escravos rapidamente passavam para o lado dos insurretos. No Cap-Français, o governador Blanchelande já tinha sido avisado de um plano de ataque contra a cidade no dia 22 de agosto. Quando os rumores foram confirmados, ele ordenou a concentração das tropas na cidade, o que permitiu preservar o Cap, mas não as plantações da região. O movimento rebelde crescia exponencialmente. Não é um acaso se a revolta explodiu no Norte da ilha, região coberta de fazendas muito próximas umas às outras, onde os escravos de fazendas vizinhas tinham relações mais estreitas e onde as notícias se espalhavam mais rapidamente. Em 27 de agosto, o número de insurretos já era estimado em 10 mil. A revolta assumia a feição de um movimento generalizado. ${ }^{952}$

A insurreição se dispersava, com diferentes bandos atacando em lugares diferentes ao mesmo tempo. Massacres ocorriam por toda a planície do Norte. Plantações de açúcar encontravam-se devastadas. As tropas brancas executavam praticamente todos os negros que encontravam para reprimir o movimento, mas este continuava a crescer. Tratava-se de uma insurreição em larga escala, que rompia com a tradição de pequenas revoltas locais. A rapidez com que a revolta assumia a forma de um movimento amplo e organizado surpreendia os plantadores, que estavam convencidos da existência de uma influência externa. Laurent Dubois sustenta que muitos negros faziam uso de uma experiência militar adquirida nas guerras africanas, de modo que as táticas típicas daqueles conflitos eram reproduzidas em São Domingos: ataques em pequenos grupos, com avanços e recuos sucessivos. ${ }^{953}$ Em oito dias, os escravos tinham devastado sete paróquias e 184 plantações de açúcar no Norte. Em

\footnotetext{
${ }^{951}$ Cf. THIBAU, Jacques. Le temps de Saint-Domingue, pp.271-273; DUBOIS, Laurent. Avengers of the New World, pp.98-99.

${ }^{952}$ Cf. DUBOIS, Laurent. Avengers of the New World, pp.94-97; JAMES, C.L.R. Os jacobinos negros, p.68; FICK, Carolyn. The making of Haiti, pp.96-97 e 102.

${ }^{953}$ Cf. DUBOIS, Laurent. A Colony of Citizens, p.110.
} 
menos de um mês, a contagem subiria para 200 plantações de açúcar e mais de 1.200 de café. Em setembro, todas as plantações numa área de 50 milhas do Cap estariam dizimadas. ${ }^{954}$ Alguns plantadores decidiram pedir ajuda aos britânicos, propondo uma ocupação da ilha, mas estes não se decidiram a enviar tropas. A solução mais viável para a repressão da revolta era garantir o apoio dos homens de cor livres. Sua experiência nas milícias e na perseguição aos marrons fazia deles a solução ideal para combater os insurretos. ${ }^{955}$

$\mathrm{Na}$ verdade, desde o final de agosto, muitos homens de cor do Cap já tinham se apresentado espontaneamente como voluntários para enfrentar a revolta dos escravos. Muitos brancos, no Oeste e no Sul da colônia, acreditavam que reconhecer os direitos desses plantadores de cor era um pequeno sacrifício se comparado à perspectiva de um sucesso da insurreição escrava, mas, no Norte, as assembleias rejeitavam a intervenção desses veteranos das milícias, preferindo adiar qualquer discussão sobre os direitos dos livres de cor para depois que a revolta tivesse sido contida. ${ }^{956}$

Na Província Oeste da colônia, já no início de agosto, os homens de cor livres tinham organizado um conselho político em Mirebalais, com Pinchinat como presidente. Seu objetivo era reclamar a aplicação do decreto de 15 de maio de 1791 , sabotado pela administração colonial, sob a pressão dos brancos segregacionistas. Em 7 de agosto, esse conselho tinha eleito 40 delegados para apresentar as suas queixas à Assembleia Nacional, assim como às autoridades e assembleias locais, jurando jamais se separar até que a vitória fosse alcançada. Em 21 de agosto, os homens de cor do Oeste se constituíram em força armada, sob o comando de Beauvais e Rigaud. O conselho enviou ao governador de São Domingos, Blanchelande, uma carta com suas reivindicações. O governador retrucou, em 22 de agosto, no mesmo momento em que explodia a revolta dos escravos no Norte, que a assembleia dos homens de cor era ilícita, ordenando a sua dissolução imediata, assim como a submissão pacífica dos mulatos a todas as leis a eles referentes. Isso levou os livres de cor, enfurecidos, a pegarem em armas contra as forças da ordem. Cerca de trezentos escravos de Cul-deSac, os chamados "Suíços", foram incorporados às forças mulatas, contra a promessa de liberdade. O conflito com os homens de cor livres abria uma brecha na frente escravista.

\footnotetext{
${ }^{954}$ Cf. FICK, Carolyn. The making of Haiti, p. 105.

${ }^{955}$ Cf. DUBOIS, Laurent. Avengers of the New World, pp.117-118.

${ }^{956}$ Ibidem, pp.118-119.
} 
A simultaneidade das revoltas constituía-se num fator decisivo para o sucesso dos negros de São Domingos. ${ }^{957}$

\section{II.1.2.3) A rebelião escrava na via revolucionária}

Assim como em qualquer colônia escravista, atos de rebelião escrava eram uma ameaça constante em São Domingos. Ao contrário do que sugerem os relatos que apresentam o escravo como uma figura passiva diante de seu opressor ${ }^{958}$, a resistência do negro à escravidão era contínua e multifacetada, assumindo a forma de fugas, sabotagens, roubos, suicídios ${ }^{959}$, abortos, infanticídios, envenenamentos e, por vezes, rebeliões locais. As fugas de escravos (marronnage) eram particularmente comuns e tinham sido bastante frequentes durante a Guerra dos Sete Anos. ${ }^{960}$

Os atos de revolta surgiam comumente como uma reação dos escravos a um endurecimento do regime de trabalho e das condições de vida. A redução do tempo livre para cultivar as suas pequenas hortas, os castigos corporais, a separação de famílias, a restrição ao lazer... Todos esses atos feriam a concepção que os escravos tinham de seus "direitos". Embora o Code Noir definisse o escravo como coisa móvel, o que excluía, portanto, a possibilidade para o escravo de ter direitos, a legislação e os costumes geravam fortes contradições na ordem escravista. O próprio Code Noir, assim como outras leis posteriores, regulamentava os castigos e estabelecia padrões mínimos para a alimentação, moradia e cuidados médicos. A prática também havia dado aos escravos a possibilidade de praticar, por conta própria e no seu tempo livre, uma agricultura de subsistência, num pedaço de terra cedido pelo senhor. Essa pequena produção podia render-lhe um excedente que podia ser trocado ou vendido nos mercados, rendendo-lhe um pecúlio, isto é, uma propriedade. Ou seja, a coisificação do escravo nunca se dava de forma completa e, em certas ocasiões, a sua humanidade era reconhecida. ${ }^{961}$ Mesmo

\footnotetext{
${ }^{957}$ Cf. BÉNOT, Yves. La Révolution française et la fin des colonies, p.68; DUBOIS, Laurent. Avengers of the New World, p.119; CÉSAIRE, Aimé. Toussaint Louverture, pp.142-143; FICK, Carolyn. The making of Haiti, pp.119-120.

958 Temos consciência de que o conformismo e a passividade também podiam ser estratégias de sobrevivência dentro da sociedade escravista. Muitos escravos recorriam a elas para buscar uma situação mais confortável para si (cf. FICK, Carolyn. The making of Haiti, p.10).

${ }_{959}$ Os escravos, sobretudo os vindos da África, tinham o hábito de comer terra quando decidiam morrer. Mais recentemente, etnólogos interpretaram esse ato como um símbolo do desejo de retornar à terra. De qualquer forma, o significado permanece o mesmo: a recusa de viver na escravidão (cf. THIBAU, Jacques. Le temps de Saint-Domingue, p.44).

${ }_{960}$ Cf. MARTIN, Gaston. Histoire de l'esclavage dans les colonies françaises, p.164.

${ }^{961}$ Cf. SAES, Décio. A formação do Estado burguês no Brasil, pp.106-107.
} 
que esses "direitos" atribuídos aos escravos tivessem sido, em última instância, instituídos no interesse do senhor, o fato é que eles estabeleciam, na ótica do escravo, uma espécie de contrato tácito. Como diz Emília Viotti da Costa, a escravidão era, para ele, uma espécie de "sistema de obrigações recíprocas"962, cujo descumprimento gerava repercussões imediatas. Nesse sentido, os atos de resistência escrava frequentemente adquiriam o sentido de pressão por modificações nas condições de vida nas plantations, como a ampliação do tempo livre para o escravo, a melhoria da alimentação e a redução dos castigos corporais. Eram modificações que tendiam a promover uma alteração do sistema escravista, sem, entretanto, derrubá-lo.

Quanto às revoltas armadas, elas eram mais frequentes a bordo dos navios negreiros, onde as possibilidades de resistência eram escassas. Numa sociedade escravista, entretanto, a revolta armada não era o meio mais eficaz de obter uma melhoria das próprias condições de vida. As rebeliões no espaço colonial tendiam a ser restritas e rapidamente reprimidas. ${ }^{963}$ Havia sérios obstáculos a um tipo de resistência mais organizada: a heterogeneidade da origem dos escravos, sobretudo em São Domingos, onde numa plantation de duzentos escravos, podia haver mais de vinte grupos linguísticos diferentes ${ }^{964}$; a distância entre as propriedades; a polícia exercida pelas milícias dos homens de cor; a carência de meios materiais, etc.

Atos de revolta tendiam preferencialmente a assumir a forma da fuga, isto é, do abandono da sociedade escravista. Escravos crioulos e ladinos aproveitavam-se da sua maior mobilidade para fugir e procurar reintegrar-se em outros pontos da colônia, às vezes como negros livres. ${ }^{965}$ Os boçais, por outro lado, tendiam a recorrer ao marronnage coletivo. Com base na sua identidade cultural, esses marrons formavam, à margem da sociedade colonial, comunidades quilombolas que reproduziam, até certo ponto, formas comunitárias existentes na África. Usando a terminologia de Genovese, as revoltas assumiam, muitas vezes, um caráter isolacionista, ou seja, de fuga, de abandono da sociedade escravista ${ }^{966}$, mas não se deve ser taxativo. Os marrons não rompiam completamente os laços com a sociedade colonial.

Carolyn Fick entende que a insurreição de agosto de 1791 foi uma extensão da prática do marronnage, que teria desempenhado um papel crucial na elaboração e na

\footnotetext{
${ }^{962}$ Cf. COSTA, Emília Viotti da. Coroas de glória, lágrimas de sangue, pp.99-100.

${ }^{963}$ Cf. FICK, Carolyn. The making of Haiti, pp.48-51.

${ }^{964}$ Cf. GEGGUS, David Patrick. Haitian Revolutionary Studies, p.7.

${ }^{965}$ Cf. FICK, Carolyn. The making of Haiti, pp.53-54.

${ }^{966}$ Eugene Genovese emprega os termos isolacionismo e restauracionismo para descrever esses processos (cf. GENOVESE, Eugene. Da rebelião à revolução, p.14).
} 
execução do plano de ataque. Geggus discorda, destacando que a reunião em Morne Rouge, em 14 de agosto, não foi um encontro de fugitivos, mas de escravos que gozavam de maior mobilidade dentro do sistema. Dentre os líderes da insurreição, apenas Jean-François era, de fato, um marron. ${ }^{967}$

O fato é que o marronnage tradicionalmente representava para os escravos uma alternativa à revolta armada. Embora ele fosse percebido como uma séria ameaça à ordem escravista, ele significava a possibilidade de fuga e de reconstrução de uma nova vida, dentro ou à margem da sociedade colonial. Para João Pedro Marques, a formação de comunidades marrons (quilombos) criava até mesmo uma válvula de escape para o sistema, permitindo que escravos mais insubmissos se dirigissem para a periferia da sociedade colonial. ${ }^{968} \mathrm{O}$ movimento que se formou na colônia a partir de agosto de 1791 assumia um caráter diverso. Tratava-se de um amplo movimento de massa, com um plano de ataque e alvos militares precisos. O objetivo não era mais simplesmente a fuga ou a recriação, em paralelo, de modos de vida tradicionais, mas a transformação do sistema que os oprimia. A conjuntura revolucionária, na metrópole e na colônia, havia criado as condições para que a revolta escrava assumisse um caráter verdadeiramente abolicionista.

Deve-se ressaltar, entretanto, que a conversão da revolta em movimento abolicionista revolucionário e, posteriormente, em movimento independentista, deu-se por etapas. De início, quando perguntados sobre o motivo de sua revolta, alguns negros afirmaram que seu objetivo era punir a colônia por ter derrubado o rei, por não ter fé, lei ou religião e por ter queimado em Porto-Príncipe a suposta ordem real que concedia aos negros três dias da semana para si próprios, assim como a abolição do açoite como forma de punição. Durante os primeiros meses da revolta, os escravos repetiram comumente o pedido dos "três dias", objeto da reunião em Morne Rouge, o que significa que, naquele estágio inicial, não se falava ainda em abolir a escravidão, mas apenas em ampliar uma brecha já existente dentro do sistema escravista. ${ }^{969}$ Curiosamente, aos gritos de "viva o rei!", os negros revoltosos lutavam pela realeza, que viam como uma possível via de ampliação de sua autonomia.

\footnotetext{
${ }^{967}$ Cf. FICK, Carolyn. The making of Haiti, pp.8-10; GEGGUS, David Patrick. Haitian Revolutionary Studies, pp.40-41.

${ }^{968}$ Cf. MARQUES, João Pedro. Slave Revolts and the Abolition of Slavery, pp.13-14.

${ }^{969}$ Cf. THIBAU, Jacques. Le temps de Saint-Domingue, pp.280-281; DUBOIS, Laurent. A Colony of Citizens, p.109.
} 
Houve quem interpretasse o "monarquismo" dos insurretos como uma herança da experiência que os negros traziam da África. É possível que isso tenha exercido alguma influência, mas o fator mais decisivo para essa tomada de posição era, como diz Ghachem, a tradição da Monarquia de se interpor, por meio de leis como o Code Noir, entre os escravos e a autoridade doméstica do senhor. ${ }^{970}$ A lei real aparecia, aos olhos dos escravos, como um instrumento de limitação da autoridade dos plantadores e isso pode ter induzido os insurretos a identificar na Monarquia um ponto de apoio adequado aos seus propósitos.

Contudo, o discurso dos insurretos não se manteve linear ao longo da revolução, incorporando, de acordo com o momento e a conveniência, diferentes linhas de argumentação. No seu diálogo com as autoridades, mostrariam-se capazes de manipular desde o discurso precaucionário do Antigo Regime até o discurso patriótico da Revolução francesa, passando por referências aos direitos naturais e imprescritíveis do homem. Ao longo da insurreição, a abolição da escravidão seria incorporada e consolidada como objetivo primordial.

Tradicionalmente, procurou-se atribuir a conversão da insurreição em movimento abolicionista revolucionário ao papel exercido pelas lideranças negras mais qualificadas. O que ficou claro, ao longo de toda a revolução, entretanto, era o descompasso entre a atuação dos líderes negros e as aspirações das massas. Com a morte de Boukman, a liderança foi assumida por Jean-François, Biassou e Jeannot Bullet. Durante um cessar-fogo, Jean-François pediria à Assembleia colonial, em troca do retorno dos escravos às plantações, a anistia geral para os insurretos, a liberdade para cinquenta lideranças e algumas centenas de oficiais, reservando à massa da população cativa apenas uma melhoria das suas condições de vida. Essas lideranças não falavam em nome da totalidade dos escravos, mas em nome das unidades que dirigiam, dentro das quais tampouco havia unidade de opiniões e ambições. ${ }^{971}$ Seria necessário aguardar até julho de 1792 para que a insurreição escrava assumisse, por meio de uma carta de seus líderes, as feições de um ataque contra a escravidão. ${ }^{972}$ Ainda assim, sabe-se que, a partir de 1793, as lideranças negras chegariam a vender escravos aos seus então aliados

\footnotetext{
${ }^{970}$ Cf. GHACHEM, Malick W. The Old Regime and the Haitian Revolution, pp.275-276.

${ }^{971}$ Cf. FICK, Carolyn. The making of Haiti, pp.114-115. GHACHEM, Malick W. The Old Regime and the Haitian Revolution, p.258.

972 Cf. carta de Biassou, Jean-François e Belair, à assembleia geral, aos comissários nacionais e aos cidadãos da parte francesa de São Domingos, publicada em Le Créole Patriote, número 282, 9 de fevereiro de 1793, pp.1147-1148.
} 
espanhóis. ${ }^{973}$ Esses homens lutavam, acima de tudo, por sua própria liberdade e por alguma forma de poder.

Quanto a Toussaint Louverture, tampouco ele foi, de início, o líder abolicionista que a história consagrou. Toussaint era filho de um rei africano que, em razão de uma guerra, tinha sido vendido como escravo. Sua origem nobre the tinha valido uma condição privilegiada entre os escravos da plantação Bréda: recebeu educação religiosa, aprendeu a ler e adquiriu conhecimentos em ervas. Serviu como cocheiro, posição bastante cobiçada entre os escravos. Alforriado aos 30 anos por Bayon de Libertat, o antigo escravo vivia confortavelmente com sua família, tirando lucro do arrendamento de uma pequena fazenda de café e do cultivo de outra maior, que tinha tomado em arrendamento. ${ }^{974}$ Em novembro de 1791, aos 48 anos, Toussaint Bréda entraria na revolta. Não se sabe exatamente qual a sua participação no planejamento da insurreição ou qual a razão da sua relutância em passar efetivamente para o campo dos rebeldes. Sua adesão nos esclarece sobre a presença na insurreição de negros livres, homens que haviam sido alforriados, mas não haviam perdido contato com o mundo dos escravos, do qual ainda faziam parte amigos e familiares. Sabe-se que Toussaint não tardou a assumir um papel preponderante entre os insurretos. Sua experiência pregressa como escravo e atual como plantador e senhor de escravos lhe davam um conhecimento profundo das engrenagens daquela sociedade particular e lhe permitiam dialogar com os diferentes campos com grande desenvoltura. Toussaint se destacaria rapidamente, ao organizar uma tropa de dois mil negros disciplinados e militarmente organizados. Suas atitudes, ao longo da Revolução, nem sempre seriam fáceis de elucidar, como veremos adiante.

A transição de uma revolta generalizada por uma melhoria das condições de vida dos escravos a um movimento pela liberdade geral deve ser compreendida no quadro das relações entre os eventos das colônias e a Revolução na metrópole. Não se deve reiterar o ponto de vista daqueles, como Jacques Thibau, que veem a insurreição dos escravos apenas como uma página da Revolução na metrópole e entendem que ela "[...] explica-se, no fundo, apenas pelo face a face da Revolução francesa e da escravidão". ${ }^{975}$ Num outro extremo, Louis Sala-Molins entende que, se a colônia tinha conhecimento

\footnotetext{
${ }^{973}$ Cf. MARQUES, João Pedro. Slave Revolts and the Abolition of Slavery, p.22.

${ }^{974}$ Cf. THIBAU, Jacques. Le temps de Saint-Domingue, pp.25-26 e 38-39.

975 Ibidem, p.330.
} 
do que se passava em Paris, o laço ideológico entre as duas revoluções resulta, essencialmente, de uma construção da literatura. ${ }^{976}$ Para ele,

os negros não podiam saber o que liberdade podia significar, nem direitos individuais, e ainda menos igualdade ou independência. Os conceitos não nascem nas pessoas por geração espontânea. É preciso que as condições existam. As condições não existiam no Haiti, mas apenas nos burgueses franceses e na nobreza esclarecida da grande Nação. ${ }^{977}$

Assim, para o autor, os negros teriam se apropriado, graças à literatura vinda da metrópole, de uma linguagem e de um sistema de valores que não tinham produzido, e nem poderiam produzir.

De fato, os negros lutavam pelos seus próprios interesses e teriam se aliado à Monarquia - inclusive a estrangeira, como fizeram em determinado momento ${ }^{978}-$ se acreditassem que ela romperia as suas correntes. As suas motivações concretas nada tinham a ver com a Revolução na metrópole. Como vimos, inicialmente, a revolta sequer visava à abolição da escravidão, mas apenas a uma ampliação do tempo livre dos escravos. Contudo, a inexistência de um elo ideológico subjetivo não significa que, do ponto de vista histórico objetivo, a insurreição escrava de São Domingos possa ser dissociada da Revolução francesa. Esta não apenas forneceu o contexto para uma insurreição generalizada, mas permitiu aos escravos que ampliassem os seus horizontes, concebendo a própria liberdade como o resultado de uma transformação revolucionária do sistema. A Revolução na metrópole e a sua transposição à colônia, detonando lutas intestinas na sociedade de São Domingos, foi o palco da tranformação progressiva da insurreição escrava de uma luta dentro do sistema para uma luta contra o sistema. Por outro lado, se o impacto da Revolução francesa na insurreição é inegável, a recíproca é verdadeira: como veremos, a insurreição dos escravos foi o fator determinante para que a política colonial da Revolução superasse os seus limites iniciais. As duas revoluções

\footnotetext{
${ }^{976}$ A lenda de que as Luzes fizeram Toussaint, com o mito de que ele teria lido Raynal e se reconhecido no Espártaco negro, seria o grande exemplo dessa construção literária que procura teorizar a revolta dos negros, como se não tivesse havido uma Revolução haitiana, mas apenas "um episódio dominicano da Revolução francesa" (cf. SALA-MOLINS, Louis. Les misères des Lumières. Paris: Robert Laffont, 1992, pp.159-160).

977 "Les Noirs ne pouvaient pas savoir ce que liberté pouvait bien vouloir dire, ni droits individuels, ni, moins encore, égalité ou indépendance. Les concepts ne naissent pas chez les gens par génération spontanée. Il y faut des conditions. Les conditions n'étaient pas à Haïti, mais uniquement chez les bourgeois français et chez la noblesse éclairée de la grande Nation" (Ibidem, p.159).

${ }^{978}$ Antes dos decretos abolicionistas de 1793 e 1794, os insurretos não sabiam em quem se apoiar. Assim, quando os espanhóis ofereceram uma aliança contra o governo francês, os negros aceitaram. Até que a França se inscrevesse definitivamente na via da abolição, os revoltosos lutariam em nome da realeza contra a República.
} 
avançaram paralelamente, até encontrarem um ponto de convergência. Esse processo, entretanto, não se deu de forma imediata. A chegada das notícias da revolta de agosto de 1791 geraram as reações mais variadas, como veremos a seguir. 


\section{II.1.3) A Assembleia Nacional diante da insurreição negra}

\section{II.1.3.1) O ceticismo perante o "impensável"}

A chegada da notícia da insurreição à metrópole promoveria uma divisão progressiva na frente antiescravista. De um lado, os gradualistas veriam no levante dos negros de São Domingos a prova da necessidade de promover as reformas que sempre tinham defendido, como, por exemplo, o reconhecimento dos direitos dos homens de cor livres. De outro, correntes mais radicais, longe de conceberem a insurreição como um mal, procurariam reconhecer a justiça da luta dos escravos, fazendo dela a extensão da Revolução nas colônias, como veremos no próximo capítulo.

Os Amigos dos Negros, antiescravistas moderados, confrontaram-se com uma situação para a qual não estavam preparados. Muito embora os prognósticos de grandes revoltas escravas fossem constantes na sua argumentação, eles apontavam menos para uma realidade concreta do que para uma sombra, uma ameaça distante que pesava sobre uma sociedade que era preciso transformar gradualmente. Assim, a reação inicial de Brissot e dos Amigos dos Negros foi de ceticismo.

Michel Trouillot entende que, para os antiescravistas da época, a ideia de uma revolução escrava era impensável, na medida em que não havia um quadro de referência conceitual que permitisse interpretá-la. Para o autor, mesmo as "profecias" ou utopias de Mercier e Raynal eram, nas suas conclusões, bastante ambíguas. Assim, a possibilidade de uma rebelião escrava vitoriosa era situada apenas num futuro longínquo, como "[...] um espectro do que poderia ocorrer se o sistema permanecer inalterado". ${ }^{979}$ Contudo, com a chegada das notícias da revolta, o "impensável" tinha se tornado fato e, assim mesmo, a reação inicial dos Amigos dos Negros foi de descrença. Para eles, não era concebível que os escravos negros, no seu estado de embrutecimento completo, no baixíssimo grau de humanidade em que se situavam, fossem capazes de se insurgir contra a ordem colonial escravista. Para Trouillot, "a Revolução Haitiana entrou, assim, na história com a característica peculiar de ser impensável no momento mesmo em que ela ocorria". ${ }^{980}$

\footnotetext{
979 "[...] a spectre of what might happen if the system remains unchanged" (TROUILLOT, Michel-Rolph. Silencing the Past, p.86).

980 "The Haitian Revolution thus entered history with the peculiar characteristic of being unthinkable even as it happened" (Ibidem, p.73).
} 
A notícia da insurreição chegou à metrópole em 22 de outubro de 1791. O navio Triton, que tinha partido de Léogane em 29-30 de agosto, chegou em Le Havre com o relato de que os escravos negros de São Domingos estavam em insurreição na parte Norte da ilha. Segundo os relatos, as planícies do Cap, Lime e Borgue teriam sido incendiadas. Com a repressão promovida pelas autoridades, muitos negros teriam morrido. No Patriote Français de 23 de outubro (n $\left.{ }^{\circ} 804\right)$, Brissot previa que muitos procurariam apresentar os eventos como um resultado do decreto de 15 de maio. Para o amigo dos Negros, a revolta era, na verdade, um resultado da recusa do governo francês em enviar um corpo de guardas nacionais ao lado dos comissários civis para manter a ordem. Ressaltou, entretanto que, antes de tirar quaisquer conclusões, seria preciso conhecer melhor os fatos, pois essas notícias, que tinham sido escritas por colonos e tinham passado pelas mãos de negociantes, eram suspeitas. ${ }^{981}$

O Patriote Français de 27 de outubro de $1791\left(\mathrm{n}^{\circ} 808\right)$ voltou a comentar as notícias vindas do Caribe, para esclarecer que tinham sido trazidas de São Domingos por um navio pertencente a Bégouën, colono e deputado na Assembleia. Diante da afetação com a qual os colonos difundiam essa notícia em Paris, o jornal chegava à conclusão de que só podia tratar-se de uma "manobra colonial", uma intriga elaborada para fazer revogar o decreto de 15 de maio e que era agora negada, pois o decreto já tinha sido revogado. ${ }^{982}$

No mesmo dia, as notícias foram formalmente apresentadas à Assembleia. Viénot-Vaublanc apresentou uma carta de François de Neufchâteau, deputado do departamento de Vosges, sobre os problemas em São Domingos. Neufchâteau afirmava ter recebido notícias frescas de Bordeaux a respeito do levante dos negros em São Domingos. Entendia que o momento não era de apurar responsabilidades e discutir as razões da revolta, mas de "salvar São Domingos e a França". A crise da colônia era, para ele, uma "crise nacional". São Domingos não possuía forças para resistir aos ataques, de modo que cabia ao comitê colonial da Assembleia propor medidas de urgência. Neufchâteau encaminhava aos membros da Assembleia Legislativa cópia de uma carta, datada de 25 de agosto, da comissão da assembleia geral de São Domingos aos oficiais municipais de Cayes. A carta falava num complô generalizado, em que bandos de negros incendiavam as propriedades e assassinavam os brancos da ilha. De

\footnotetext{
${ }^{981}$ Cf. Patriote Français, v.5, número 804, 23 de outubro de 1791, p.475.

982 Idem, v.5, número 808, 27 de outubro de 1791, pp.490-491.
} 
acordo com um relato, uma centena de negros tinha sido morta durante um ataque e o resto estava em fuga. ${ }^{983}$

Na sessão da noite, os comitês das colônias e da marinha reunidos apresentaram o primeiro de muitos relatórios sobre a questão. Com base em informações transmitidas pelo ministério, o relatório apresentava um quadro das forças militares presentes em São Domingos: um batalhão de Artois, um da Normadia, o regimento do Cap e uma brigada de artilharia, totalizando apenas 1.500 homens. As guardas nacionais de colonos formavam um corpo considerável, mas estavam dispersas pela colônia, sendo o seu reagrupamento inviável. Além das deficiências militares, havia problemas de ordem política e social. $\mathrm{O}$ decreto de 24 de setembro tinha sido enviado, mas ainda não era possível saber que efeitos produziria na colônia. Embora as cartas recebidas parecessem atestar a veracidade da insurreição, os comitês reunidos entendiam que os fatos "[...] podiam, entretanto, não ser tão graves quanto pareciam à primeira vista". O silêncio do governador Blanchelande parecia confirmar essa esperança. Por outro lado, por prudência, os comitês propunham que preparativos fossem feitos para o envio de socorros à colônia e que o ministro ficasse encarregado de tomar as medidas necessárias a este fim. ${ }^{984}$

Um membro não identificado aplaudiu as medidas propostas pelo comitê, procurando assegurar a Assembleia de que os relatos sobre a insurreição eram necessariamente exagerados: "Conheço as localidades em São Domingos; conheço o gênio e os meios dos negros. Assim, estou quase convencido de que, no momento em que vos falo, tudo se encontra, senão pacificado, pelo menos de volta à ordem". ${ }^{985}$ Lançou ainda suspeitas sobre os homens de cor livres que, pressentindo o decreto de 24 de setembro, poderiam ter sido os chefes dessa revolta, única forma de atacar o "odioso preconceito" de que eram vítimas. Se, de fato, os homens de cor tinham feito causa comum com os negros, então o envio de socorros se fazia urgente para salvar a colônia. Pedia o envio de 6 mil homens a São Domingos, caso informações confirmassem essa possibilidade. $^{986}$

Outro membro atacou as medidas propostas como inúteis e injustas e aproveitou para tocar no problema da escravidão. Embora não tenha falado explicitamente na

\footnotetext{
${ }^{983}$ Cf. AP, v.34, pp.437-438.

${ }^{984}$ Ibidem, p.455.

985 "Je connais les localités à Saint-Domingue; je connais le génie et les moyens des noirs. Ainsi, je suis presque assuré qu'au moment où j'ai l'honneur de vous parler, tout est, sinon pacifié, du moins rentré dans l'ordre" (Ibidem, p.455).

${ }^{986}$ Ibidem, pp.455-456.
} 
abolição, sua defesa da aplicação dos Direitos do Homem nas colônias sugeria que a única forma de conter a insurreição era pôr fim ao estado de opressão existente nas sociedades coloniais:

Nós declaramos nos Direitos do Homem que a insurreição contra a escravidão e contra a servidão é o mais santo dos deveres. Consequentemente, não devemos nunca condenar homens a elas. É preciso ser consequente para com o habitante do novo mundo, assim como para com o habitante do antigo; é preciso que os direitos sejam iguais nos dois continentes. Assim, peço que, em vez de tomar medidas de rigor, empreguemos as medidas de suavidade, de moderação, de sabedoria e de justiça. ${ }^{987}$

Muito aplaudido nas tribunas, o seu discurso foi seguido de uma intervenção de Brissot, mas este não se pronunciou sobre o tema da escravidão. Sem se opor às medidas propostas pelo comitê, o líder dos Amigos dos Negros pediu cautela à Assembleia. Entendia que, nesse caso, os fatos eram "mais do que duvidosos", tendo em vista a fonte pela qual tinham sido transmitidos. Para Brissot, as causas das sedições nas colônias estavam nas leis que tinham humilhado as pessoas de cor. Estas eram "o mais firme baluarte da colônia", as únicas pessoas capazes de manter os negros na ordem e conter os inimigos externos. Ao privar essas pessoas de seus direitos, esses "baluartes" tinham sido desarmados. Não era coincidência o fato de a revolta ter ocorrido na planície do Cap-Français, onde o despotismo dos brancos era mais forte. Desarmados e obrigados a deixar o Cap para fugir das perseguições, os homens de cor haviam deixado a ordem social à mercê de ameaças internas e externas. Isso explicava o fato de os negros terem conseguido se revoltar contra os seus opressores. Assim, a "causa provável das insurreições nas colônias" estava "[...] no fato de que os negros não temem mais os mulatos". No fim, diante da necessidade de examinar a questão com maior profundidade, Brissot propunha adiar qualquer decisão sobre o problema. ${ }^{988}$

Em resposta às palavras de Brissot, Tarbé relembrou que, quando o decreto de 24 de setembro tinha sido votado, a insurreição em São Domingos já estava em curso, de modo que esse decreto não podia estar na origem dos eventos. As pessoas de cor não podiam estar ofendidas, pois, ao contrário, o decreto de 15 de maio ainda lhes atribuía

\footnotetext{
987 "Nous avons déclaré dans les Droits de l'Homme que l'insurrection contre l'esclavage et contre la servitude est le plus saint des devoirs. Par conséquent nous ne devons point y condamner des hommes. Il faut être conséquent pour l'habitant du nouveau monde, comme pour l'habitant de l'ancien; il faut que les droits soient égaux dans les deux continents. Ainsi je demande, qu'au lieu de prendre des mesures de rigueur, nous employions les mesures de douceur, de modération, de sagesse et de justice" (Ibidem, p.456).

${ }_{988}$ Ibidem, pp.456-457.
} 
os direitos de cidadania que reclamavam. Brissot retrucou que o mau-humor dos mulatos não se devia à revogação do decreto de 15 de maio, mas às perseguições sangrentas de que foram vítimas após a chegada do mesmo à colônia. Desarmados e expostos ao furor dos petits blancs e dos homens de justiça do Cap, muitos mulatos se viram forçados a deixar a localidade, chegando, em alguns casos, a buscar refúgio na parte espanhola da ilha. Como aqueles que os continham na ordem encontravam-se desarmados, os negros teriam se aproveitado da situação para se revoltar. Sem querer prolongar a discussão com Brissot, Tarbé, assim como a maioria dos deputados, decidiu dar o seu apoio à moção de adiamento e não houve deliberação sobre o projeto dos comitês. Os deputados da Assembleia preferiam aguardar a chegada de relatos oficiais sobre o que acontecia em São Domingos. ${ }^{989}$

Brissot continuava a pôr em dúvida a veracidade dos relatos. Em 28 de outubro, comentou no seu jornal ter recebido outras cartas, também datadas de 25 de agosto, que traçavam um quadro de tranquilidade nas colônias. ${ }^{990}$ No campo antagonista, entretanto, as notícias da revolta haviam injetado vida nova no Clube Massiac, que se tornava uma espécie de centro de informações. Em 29 de outubro, o Clube obteve a confirmação da revolta, por meio de cartas vindas de Londres. ${ }^{991}$ No mesmo dia, na Assembleia, foi feita a leitura de uma carta vinda de São Domingos, de 26 de setembro, trazida por um navio inglês. A carta trazia detalhes perturbadores:

Cinquenta mil escravos armados se vingavam, por meio de terríveis devastações, dos rigores de sua servidão. Eles tinham massacrado mais de trezentos brancos, devastado e incendiado mais de duzentas habitações. Encontram-se agora refugiados nas planícies do Cap, com peças de canhões. O que há de mais assustador é que, para enfrentá-los, dispõe-se de apenas mil e quinhentos homens de tropas de linha. ${ }^{992}$

Diante da gravidade do relato, exclamações desesperadas na Assembleia foram seguidas de propostas de medidas de urgência: um membro propôs o envio de uma deputação junto ao rei para pedir-lhe o envio de forças a São Domingos. Outro sugeriu enviar três navios de linha, três fragatas, além de tropas. Uns acusaram a doutrina de Grégoire e dos antiescravistas de ser responsável pelos eventos; outros jogaram a culpa

\footnotetext{
${ }^{989}$ Ibidem, pp.457-458.

${ }^{990}$ Cf. Patriote Français, v.5, número 809, 28 de outubro de 1791, p.493.

${ }_{991}$ Cf. DEBIEN, Gabriel. Les colons de Saint-Domingue et la Révolution, pp.337-338.

992 "Cinquante mil esclaves armés se vengeaient par d'affreux ravages des rigueurs de leur servitude. Ils avaient massacré plus de trois cents blancs, ravagé et incendié plus de deux cents habitations. Ils sont maintenant retranchés dans les plaines du Cap avec des pièces de canons. Ce qu'il y a de plus effrayant, c'est qu'on n'a à leur proposer que quize cents hommes de troupes de ligne" (citado em Patriote Français, v.5, número 811, 30 de outubro de 1791, p.501).
} 
nas crueldades cometidas pelos senhores contra seus escravos. Ainda cético, Brissot afirmava que não era necessário alarmar-se tão rapidamente, visto que as notícias, bastante inverossímeis em si, tinham sido transmitidas por um navio inglês, sem qualquer confirmação oficial do governador, da administração ou da assembleia da colônia. Conseguiu convencer a Assembleia a remeter as cartas aos comitês da marinha e das colônias para que um novo relatório fosse realizado. ${ }^{993}$

No dia 30 de outubro, entretanto, foi feita a leitura de uma carta de Bertrand, ministro da marinha, com novidades do Cap. Ele retransmitia notícias vindas da Inglaterra, que eram "[...] tão assustadoras que não permitem sequer o consolo de duvidar do destino terrível dessa bela e rica colônia". Bertrand informava a Assembleia de que o rei havia, sem hesitar, dado ordens para que 2.300 homens de tropa embarcassem imediatamente para São Domingos, até que expedições mais importantes fossem preparadas. ${ }^{994}$ Para os comitês das colônias e da marinha, o conjunto de cartas recebidas até então não deixavam mais dúvidas quanto à existência da insurreição. Os relatos eram provavelmente exagerados - o número de negros reunidos, assim como o número de plantações devastadas, não eram, na sua opinião, verossímeis - mas a ausência de uma confirmação oficial não era suficiente para pôr em dúvida a veracidade da calamidade que ameaçava o futuro da "mais importante das posses francesas". Era necessário, assim, tomar medidas imediatas para prevenir um desastre maior. ${ }^{995}$

Brissot tomou então a palavra para fazer um longo discurso sobre a questão. Pela primeira vez, manifestou a sua preocupação com o futuro da colônia. Contudo, diante da inverossimilhança dos relatos e do silêncio das autoridades coloniais, continuava a questionar a veracidade dos detalhes, como o número dos negros em revolta. A confirmação da notícia tinha vindo de Le Havre, trazida pelo navio inglês Daphné, que tinha chegado ao Cap em 25 de setembro. Brissot achava estranho que, desde fins de agosto, nenhum navio francês, além do Triton e da Ferme (que tinha trazido notícias de Les Cayes), houvesse trazido uma confirmação dos eventos e que apenas os ingleses difundiam notícias por toda a Europa. Suspeitava que as cartas trazidas pelos ingleses fossem fraudulentas. A razão de sua suspeita residia na própria incapacidade dos negros de organizar um levante dessa magnitude: "como os negros, ignorando a tática e a arte das fortificações, adivinharam repentinamente o segredo para traçar um campo bem

\footnotetext{
${ }^{993}$ Ibidem, p.501.

${ }^{994}$ Cf. AP, v.34, p.522.

${ }^{995}$ Ibidem, p.522
} 
fortificado?". Para ele, sem uma liderança qualificada, sem disciplina e sem suprimentos, a reunião de 50 mil Negros, embrutecidos pelo estado de servidão, era improvável. Assim, se não afirmava categoricamente que os fatos alegados eram falsos, Brissot acreditava que eram exagerados, podendo até mesmo ser a obra de "especuladores" que procuravam encarecer os produtos coloniais. O deputado ressaltava ainda que os eventos ocorriam no momento em que as emigrações se multiplicavam e em que alguns deputados pareciam desejar subtrair as ilhas à supremacia legislativa. Para ele, tudo podia fazer parte de um grande plano. ${ }^{996}$

Brissot aproveitou, entretanto, a comoção em torno das colônias para relançar a sua campanha em favor dos homens de cor livres. Se havia revoltas parciais de escravos na colônia, elas se deviam, dizia, ao desarmamento dos mulatos, encarregados da manutenção da ordem nos plantéis: "[...] eu vos pergunto, desarmar os homens de cor não era acorrentar ou matar o cão fiel que vigia a porta do curral? Não era preparar a revolta dos negros?". ${ }^{997}$ Ressaltava que a revolta tinha explodido justamente na região do Cap, parte da colônia em que os homens de cor tinham sido mais humilhados e perseguidos. Se os negros estavam tranquilos na Martinica era porque, lá, os homens de cor estavam armados. Assim, a solução para os problemas em São Domingos era simplesmente rearmar os homens de cor e não enviar soldados europeus, não acostumados com o clima, a geografia e a vegetação da ilha. Brissot pedia que a Assembleia autorizasse os comissários civis a fazerem com que os homens de cor gozassem do direito de escreverem livremente as suas cartas, de se corresponderem com a França, de se reunirem, de enviarem petições, de viajarem à Europa. Em uma palavra, queria que os comissários empregassem "[...] todos os meios possíveis para vincular [os homens de cor] aos brancos e à prosperidade das Colônias". ${ }^{998}$ O que Brissot queria era atacar a lei de 24 de setembro e preparar o caminho para uma volta ao decreto de 15 de maio. De uma revolta de escravos, o líder dos Amigos dos Negros só tirava conclusões relativas à população de cor livre. Para um gradualista como ele, a revolta escrava não constituía uma via abolicionista legítima. Ao propor o armamento dos homens de cor livres e proprietários contra os negros rebeldes, Brissot apresentava-se, de certa forma, como um defensor da ordem colonial escravista.

\footnotetext{
${ }^{996}$ Cf. BRISSOT DE WARVILLE, Jacques-Pierre. Discours sur un projet de décret relatif à la révolte des noirs. Paris: Imprimerie Nationale, 1791, pp.2-12.

997 "[...] je vous demande, désarmer les hommes de couleur, n'était-ce pas enchâner ou tuer le dogue fidèle qui veille à la porte de la bergerie? n'était-ce pas préparer la révolte des noirs?" (Ibidem, p.14).

${ }^{998}$ Ibidem, pp.14-17.
} 
Ainda assim, as palavras de Brissot não agradaram aos colonos e tampouco convenceram o resto da Assembleia. Representante de Bordeaux, Guadet afirmou que, se as notícias podiam ter sido exageradas, era necessário tomar, ao menos, medidas de precaução para evitar a perda da colônia e a ruína do comércio francês. Propunha que fossem enviados à colônia não tropas de linha, mas batalhões de guardas nacionais, verdadeiros patriotas capazes de atuar como mediadores. Citou especificamente a milícia patriótica de Bordeaux, que já tinha se disposto a ir para as colônias executar as leis da Assembleia. ${ }^{999}$ Já Leremboure, cuja família era de São Domingos, apontou a imprudência da proposta de Brissot, dada a possibilidade de os homens de cor lutarem ao lado dos negros. Pediu o envio de forças aos três portos principais da ilha - Cayes, Cap e Porto-Príncipe - de modo a formar um regimento completo em cada uma dessas cidades. No fim, a Assembleia, estimando que o rei já havia tomado medidas em resposta aos eventos de São Domingos, decidiu fechar a discussão e deixar a questão a cargo do Executivo. ${ }^{1000}$

Em 3 de novembro, novas informações chegavam à Assembleia, enviadas por armadores de Le Havre. Elas procuravam apresentar os Amigos dos Negros como os instigadores da insurreição negra:

Elas se realizaram, as predições dos pretensos amigos dos negros, esses detestáveis inimigos dos brancos, esses traidores inimigos da prosperidade de seu país!... Os negros são dirigidos, nós os sabemos, pelos pérfidos emissários dos traidores.

No Patriote Français do dia seguinte, Brissot atacou a carta como uma manobra dos especuladores para encarecer os produtos coloniais e desacreditar os amigos da humanidade. ${ }^{1001}$

Em 8 de novembro, entretanto, as dúvidas a respeito dos eventos em curso na colônia foram dissipadas. Na Assembleia, foi feita a leitura da primeira carta oficial do governador de São Domingos, Blanchelande, sobre a revolta dos negros. Transmitida pelo ministro da Marinha, que a tinha recebido de navios ingleses, a carta confirmava as desastrosas notícias divulgadas anteriormente. Datada de 2 de setembro, ela relatava os eventos de 22-23 de agosto, a extensão contínua do levante, o confronto entre as forças da ordem e os insurretos e o estado de caos em que a colônia se encontrava então.

\footnotetext{
${ }^{999}$ Cf. AP, v.34, p.528.

${ }^{1000}$ Ibidem, pp.529-531.

1001 "Elles sont accomplies, les prédictions des soi-disants amis des noirs, de ces détestables ennemis des blancs, de ces traîtres ennemis de la prospérité de leur pays!... Les nègres sont dirigés, nous le savons, par les perfides émissaires des trâitres" (Patriote Français, v.5, número 816, 4 de novembro de 1791, p.521).
} 
Blanchelande relatava ter pedido ajuda ao governo de Santo Domingo (parte espanhola da ilha) e à Jamaica, para suprir a absoluta carência de armas na colônia. Pedia à metrópole que enviasse mais 15 mil fuzis, 6 mil pares de pistolas, 6 mil homens de tropas, 3 navios de linha, duas fragatas e corvetas e 6 mil selas para a cavalaria. Manifestava a confiança de que, aliadas aos voluntários de cor, as tropas de linha e patrióticas conseguiriam conter os rebeldes. ${ }^{1002}$

Blanchelande anexava à carta um projeto de proclamação aos negros que ele próprio havia elaborado, na esperança de conter o ímpeto dos revoltosos. Ordenava, em nome do rei, o fim da rebelião e o retorno dos negros ao trabalho nas suas respectivas plantações, prometendo anistia a todos os que obedecessem. Em caso de desobediência, Blanchelande ameaçava os rebeldes de extermínio. Julgando a proclamação "impolítica", a assembleia geral de São Domingos a tinha rejeitado. ${ }^{1003}$ Blanchelande queria acreditar que a revolta não tinha sido "[...] combinada por brancos filantropos que, muito se suspeita, teriam sido enviados da França para ocasionar essa abominável e desumana revolução". ${ }^{1004}$ A frase caía como uma bomba sobre os Amigos dos Negros, particularmente visados pelo partido colonial.

O ministro da marinha anunciava que o rei já havia dado ordens para acelerar o envio de socorros a São Domingos: de Brest, dois navios de linha partiriam em breve com parte das tropas e suprimentos. O resto partiria mais tarde, de outros portos franceses (Lorient, Le Havre, Nantes, La Rochelle, Rochefort). Pedia, assim, a aprovação da Assembleia para as medidas, submetendo à sua apreciação uma previsão de gastos, estimados em três milhões. ${ }^{1005}$ A Assembleia encarregou os comitês da marinha e das colônias da elaboração de um relatório com base nas novas informações.

A insurreição negra em São Domingos tinha sido oficialmente confirmada. O que, nos termos de Michel Trouillot, era antes "impensável" tornava-se o fato principal do debate colonial. Para Brissot e os Amigos dos Negros, a estratégia da negação não era mais viável. Restava-lhes agora apenas reconhecer a gravidade da situação e argumentar pela urgência de uma aliança dos colonos brancos com os homens de cor livres da colônia.

\footnotetext{
${ }^{1002}$ Cf. AP, v.34, pp.696-698.

1003 Ibidem, p.698.

1004 "...] combinée par des blancs philanthropes que l'on soupçonne beaucoup avoir été envoyés de France pour occasionner cette abominable et inhumaine révolution" (Ibidem, p.697).

1005 Ibidem, p.696.
} 


\section{II.1.3.2) Os Amigos dos Negros contra a parede}

$\mathrm{Na}$ metrópole, a confirmação da insurreição escrava detonou uma onda de acusações recíprocas entre os campos escravista e antiescravista. Todos se atacavam mutuamente, com base nas teorias conspiratórias mais fantasiosas. O partido colonial atribuía inteiramente a insurreição à ação dos Amigos dos Negros. Para ele, era inconcebível que os escravos organizassem por si sós um movimento generalizado de revolta: a explicação tinha de ser externa. Num panfleto, Cocherel atribuiu o problema a três causas principais: o despotismo ministerial, o rigor das leis proibitivas e, sobretudo, "os alarmes difundidos, de todas as partes, nas Colônias, pelos escritos incendiários dos Amigos dos Negros [...]". ${ }^{1006}$ Para o colono, era essa "seita" que estava na origem de todas as outras causas que determinaram a insurreição nas colônias. Pedia que a Assembleia Nacional decretasse "[...] a dissolução dessa Sociedade, como destrutiva dos princípios do Comércio e da segurança das Colônias". ${ }^{1007}$

Algumas praças do comércio assumiram o mesmo discurso. Em 10 de novembro, as autoridades municipais de Nantes denunciaram ao rei as causas da revolta:

A parte Norte já está destruída, os negros armados de punhais afiados por uma seita pretensamente filantropa mataram seus senhores, incendiaram as suas propriedades [...]. Monstros, que a França ainda mantém em seu seio, meditaram e fizeram executar, a sangue-frio, terriveis atentados; seus escritos levaram o ferro e o fogo a um país cujas riquezas teriam bastado para devolver ao império o seu ANTIGO ESPLENDOR. Pedimos, Majestade, anátema e vingança sobre suas cabeças. O terço da nação reduzido à mendicidade pela execução de seu complô infernal não os deixará IMPUNES. ${ }^{1008}$ (itálico no original)

Da mesma forma, em 5 de dezembro, um "Apelo aos Franceses", de autoria do Clube Massiac, seria afixado nos muros de Paris, apresentando um quadro avassalador

\footnotetext{
1006 COCHEREL, Nicolas-Robert. Observations sur le Mémoire du ministre de la Marine, renvoyé au Comité des douze (au sujet des troubles de Saint-Domingue). S.1.: 1791, pp.1-2.

${ }^{1007}$ Ibidem, p.8.

1008 "Déjà la partie du Nord est détruite, les nègres armés de poignards aiguisés par une secte prétendue philanthrope ont égorgé leurs maîtres, ont incendié leurs propriétés [...]. Des monstres, que la France recèle encore dans son sein, ont médité et fait exécuter de sang-froid des affreux attentats; leurs écrits ont porté le fer et le feu dans un pays dont les richesses auraient suffi pour rendre à l'empire son ANCIENNE SPLENDEUR. Nous appelons, Sire, anathème et vengeance sur leurs têtes. Le tiers de la nation réduit à la mendicité par l'exécution de leur infernal complot ne les laissera pas IMPUNIS" (reproduzido no Patriote Français, v.5, número 834, 22 de novembro de 1791, p.596)
} 
das plantações destruídas em São Domingos como o resultado da campanha dos Amigos dos Negros. ${ }^{1009}$

Essas acusações eram fortemente alimentadas pela correspondência vinda das colônias. Desde o início da Revolução, os colonos tinham testemunhado a chegada de soldados e marinheiros vindos da metrópole, que traziam notícias sobre os esforços dos antiescravistas. Os colonos desconheciam as sutilezas da argumentação dos Amigos dos Negros: estes eram os seus inimigos e todos aqueles que transmitissem aos negros a sua existência eram fatalmente identificados como seus agentes. O marquês de Rouvray, colono de São Domingos, escreveu à sua filha, refugiada nos Estados Unidos, uma série de cartas a respeito dos eventos que abalavam a colônia. Em carta do dia 6 de dezembro, ele disse:

Os Amigos dos Negros foram, sem dúvida, a primeira causa de nossos malogros, minha querida filha. Parece-me evidente que eles nos enviaram muitos de seus emissários, dos quais dois foram enforcados por terem pregado seus dogmas entre nossos escravos. ${ }^{1010}$

Entre o final de novembro e o início de dezembro, a ofensiva contra os Amigos dos Negros na imprensa francesa se intensificaria. Panfletos contra Brissot apareceriam com abundância. Um deles, L'Anti-Brissot, par un Petit-Blanc de Saint-Domingue, de autoria de Baillio, um cidadão do Cap-Français, denunciava a disseminação da filantropia dos Amigos dos Negros sob a máscara de um dogma patriótico, de tal modo que "[...] não se pode mais ser jacobino, e por assim dizer patriota, sem ser amigo dos negros". Sugeria a existência de uma coalizão dos aristocratas e dos filantropos para promover a destruição de São Domingos. ${ }^{1011}$

Até mesmo antiescravistas moderados culpavam os Amigos dos Negros pelo caos nas colônias. A escritora Olympe de Gouges, por exemplo, conseguiria finalmente publicar a sua peça L'esclavage des nègres ou l'heureux naufrage em março de 1792. Mas, no prefácio, ela acusaria Brissot de ter estimulado a insurreição negra nas colônias, pregando ideias de liberdade e igualdade desmedidamente. ${ }^{1012}$ Essa campanha de difamação, entretanto, era contrabalançada pela influência crescente dos brissotinos na

\footnotetext{
${ }^{1009}$ Cf. DEBIEN, Gabriel. Les colons de Saint-Domingue et la Révolution, pp.353-354.

1010 "Les Amis des Noirs ont sans doute été la cause première de nos malheurs, ma chère enfant. Il m'est évident qu'ils nous ont envoyé beaucoup de leurs émissaires et on en a pendu deux qui ont eté convaincus d'avoir prêché leurs dogmes parmi nos esclaves..." (Une correspondance familiale au temps des troubles de Saint-Domingue. Paris: Société de l'histoire des colonies françaises/Librairie Larose, 1959, p.40).

${ }_{1011}$ Cf. BAILLIO. L'Anti-Brissot, par un Petit-Blanc de Saint-Domingue. Paris: Girardin, s.d., pp.1-2.

1012 Cf. GOUGES, Olympe de. L'esclavage des Noirs, pp.7-9.
} 
Legislativa. Na sessão de 9 de novembro, Brissot afirmou: "Declaro estar pronto para levar minha cabeça ao cadafalso, se alguém puder provar que eu escrevi uma só linha nas colônias, e que eu tenha nelas alguma correspondência ou qualquer relação". ${ }^{1013}$ Ressaltou que, embora defendesse a suavização da condição dos negros, ele jamais admitiria uma insurreição negra nas colônias:

eu seria indigno da liberdade se eu tivesse podido suspirar ao ouvido de um negro que se revoltasse contra o seu senhor. É odioso que aqueles que conhecem a minha moral, que conhecem a dos senhores Pétion, Robespierre, Grégoire, Clavière, Condorcet, sejam os autores de semelhantes calúnias. ${ }^{1014}$

Para os Amigos dos Negros, a insurreição escrava não era uma via legítima para a supressão da escravidão, que eles apenas concebiam de acordo com a lógica gradualista de seu programa. Logo, as notícias da revolta não os autorizavam a propor um debate sobre uma abolição, ainda que gradual, da escravidão. $\mathrm{O}$ debate que se daria entre Amigos dos Negros e colonos na Assembleia giraria apenas em torno dos meios a serem adotados para restabelecer a ordem nas colônias.

1013 "Je déclare que je suis prêt à porter ma tête sur l'échafaud, si l'on peut me prouver que j'ai écrit une seule ligne dans les colonies, et que j'y aie aucun correspondance, ni relation quelconque" (Ibidem, p.722).

1014 "je serais indigne de la liberté, si j'avais pu souffler à l'oreille d'un noir de se révolter contre son maître. Il est odieux que ceux qui connaissent ma morale, qui connaissent celle de MM. Pétion, Robespierre, Grégoire, Clavière, Condorcet, soient les auteurs de pareilles calomnies" (AP, v.34, p.723). 


\section{II.1.4) A igualdade da epiderme}

\section{II.1.4.1) Os cidadãos de cor e a preservação da ordem colonial}

No outono de 1791, os efeitos dos eventos em São Domingos já se faziam sentir na metrópole. O encarecimento dos produtos coloniais (açúcar, café, rum) contribuía para o agravamento dos tumultos ligados às subsistências. ${ }^{1015}$ Ao longo do século XVIII, o sucesso da produção antilhana havia reduzido os preços desses produtos na metrópole, tornando-os mais acessíveis à população em geral. Embora fossem pouco conhecidos nos campos, o café e açúcar tinham se tornado objetos de consumo relativamente comuns nas grandes cidades. No inverno de 1791-92, ocorreu uma série de manifestações populares contra a penúria e os altos preços do açúcar. ${ }^{1016}$

Uma carta do diretório do distrito de Bordeaux declarava que, embora as notícias vindas de São Domingos fossem provavelmente exageradas, os seus efeitos no comércio francês eram bastante reais. Verdadeiras ou falsas, as notícias haviam, desde a sua chegada, praticamente interrompido os armamentos do porto de Bordeaux. O diretório recomendava, portanto, que medidas fossem tomadas com urgência para neutralizar os efeitos colaterais da revolta. ${ }^{1017}$ Nesse contexto, a Assembleia Legislativa examinava as respostas a serem dadas à crise colonial.

No debate parlamentar, duas modalidades de resposta seriam propostas para a crise nas colônias. De um lado, havia aqueles, como Brissot, que sustentavam a necessidade de uma solução interna às colônias, isto é, a aliança dos brancos com os homens de cor livres, a partir do reconhecimento de seus direitos de cidadania. Outros, em especial os colonos, militavam por uma solução externa, limitada ao envio pela metrópole de socorros em tropas e mantimentos. Essa segunda solução visava a evitar que a Legislativa inovasse a legislação colonial tal como ela tinha sido definida pela Constituinte. Em 9 de novembro, Forfait apresentou, em nome dos comitês da marinha e das colônias reunidos, um relatório sobre as despesas extraordinárias relativas aos socorros a serem enviados a São Domingos. O poder executivo estimava o montante dos fundos necessários à operação não mais em três milhões, mas em 10.370.912 de

1015 Cf. MATHIEZ, Albert. La Révolution Française. v.1. Paris: Librairie Armand Colin, 1978, pp.229230. Brissot alertava, entretanto, que, se os eventos de São Domingos tinham contribuído para a alta do açúcar, esta se devia principalmente à queda do câmbio e à ação dos especuladores (cf. Patriote Français, v.6, número 988, 26 de janeiro de 1792, p.103).

${ }^{1016}$ Cf. THIBAU, Jacques. Le temps de Saint-Domingue, p.327.

1017 AP, v.34, pp.720-721. 
libras tornesas. ${ }^{1018}$ Dada a urgência da situação em São Domingos, os comitês recomendavam que a Assembleia aprovasse a soma pedida pelo ministério. ${ }^{1019}$

O envio de socorros tão importantes gerava sérios questionamentos no seio da Assembleia. Alguns, como Merlet, ainda não estavam convencidos da veracidade ou da extensão dos tumultos que agitavam as colônias e pediam maiores investigações. Outros, como Merlin, argumentavam que seria injusto tirar do pobre trabalhador, que não consumia café ou açúcar, o preço dos socorros a serem enviados às colônias, cujas "pretensas vantagens" só interessavam aos ricos e ao comércio. ${ }^{1020}$ Também entre os colonos, havia o temor de que as tropas enviadas pudessem, após dissipar a insurreição dos escravos, subjugar os "patriotas", isto é, os colonos independentistas. ${ }^{1021}$ Apesar dessas divisões, em 14 de novembro, a Assembleia decidiu aprovar o valor de 10 milhões para os socorros a serem levados a São Domingos. ${ }^{1022}$ O restabelecimento da ordem em São Domingos já se apresentava, entretanto, como uma empresa extremamente custosa e a Assembleia não tardaria a admitir a possibilidade de uma outra linha de ação.

Enquanto a Assembleia ainda discutia a veracidade dos relatos sobre a insurreição, em São Domingos, os eventos já geravam repercussões na própria estrutura da sociedade colonial. Incapazes de lidar com duas revoltas simultâneas - a dos negros e a dos livres de cor - os brancos da ilha se viram obrigados a rever suas posições e medidas locais já indicavam uma superação da política promovida pela Constituinte. A necessidade de pôr fim aos conflitos entre os brancos e os homens de cor livres do Oeste haviam levado à realização de uma série de concordatas, em 7 de setembro, 11 de setembro e 19 de outubro de $1791 .^{1023}$ A intenção era garantir aos cidadãos de cor os

\footnotetext{
${ }^{1018}$ Essa soma compreendia: 3.640.740 libras para as despesas anuais relativas às colônias; 891.100 para o transporte das tropas e a compra de móveis; 800.000 para as munições de guerra e víveres; 3 milhões em fundos para substituir as despesas de percepção dos direitos nacionais; 2.039.072 para a manutenção de dois navios com 74 canhões, duas fragatas e cinco outras embarcações durante um ano, totalizando 10.370.912 libras (cf. AP, v.34, p.720).

${ }^{1019}$ Ibidem, pp.719-720.

${ }^{1020}$ AP, v.35, p.63.

1021 AP, v.34, p.721.

${ }^{1022}$ Foi decidido que um terço desse valor seria entregue imediatamente e o restante de forma parcelada, ao longo de doze meses (AP, v.35, p.64).

${ }^{1023}$ Após a concordata de 11 de setembro, os cidadãos de cor de Porto-Príncipe haviam pedido armas, munições e canhões à municipalidade, mas o seu pedido tinha sido continuamente negado. A assembleia colonial da cidade enviou, ao contrário, comissários ao Cap para obter do general uma proclamação contrária a quase todos os artigos da concordata, ordenando a dissolução do exército dos homens de cor. Em 11 de outubro, uma decisão da paróquia de Porto-Príncipe anulou a concordata em todos os seus efeitos. Isso levou à necessidade de um tratado de paz, em 19 de outubro (cf. CONCORDAT, ou Traité de
} 
seus direitos de cidadania em troca de sua união às forças da ordem na colônia. Isso havia permitido obter inicialmente uma conciliação entre brancos e homens de cor, mas, mal haviam sido assinadas, as concordatas já eram subvertidas pelos "patriotas" de Les Cayes, Porto Príncipe e Cap Français, que convenceram o governador Blanchelande a não ratificá-las. Para piorar, o decreto de 24 de setembro de 1791, que dava às assembleias coloniais a competência legislativa para determinar o estado das pessoas de cor, chegava à colônia, lançando novas dúvidas sobre o futuro dessa união. Desprotegidos pela legislação, os homens de cor decidiram entrar em guerra. Hostilidades entre brancos e mulatos explodiriam em Porto Príncipe. ${ }^{1024}$

$\mathrm{Na}$ metrópole, novas cartas de São Domingos sinalizavam à Assembleia a urgência de uma decisão sobre a colônia. Uma carta da assembleia geral da colônia, lida em 16 de novembro, anunciava que, ainda à espera de socorros da metrópole, os colonos tinham pedido ajuda às ilhas vizinhas, o que só podia significar a Jamaica, uma colônia britânica. ${ }^{1025}$ Por outro lado, uma carta do governador Blanchelande, lida dois dias depois, anunciava uma revolta das pessoas de cor, que exigiam a execução do decreto de 15 de maio. Afirmava que esse decreto, aliado às palavras incendiárias do abade Grégoire, poderia levar à perda da colônia. ${ }^{1026}$ Ciente do perigo que uma intervenção britânica e revoltas simultâneas de escravos e mulatos apresentavam para a conservação da colônia, a Assembleia ouviu então os termos da concordata de 11 de setembro, feita entre os comissários da guarda nacional dos cidadãos brancos de PortoPríncipe e os cidadãos de cor. Tinha sido acordado que:

1) Os cidadãos brancos fariam causa comum com os de cor na execução literal e estrita das leis votadas pela Assembleia Nacional e sancionadas pelo rei. Mais especificamente, os cidadãos brancos prometiam jamais opor-se direta ou indiretamente à execução do decreto de 15 de maio;

2) As assembleias primárias e coloniais seriam convocadas nos termos do art. 4 das instruções de 28 de março de 1790, o que significava que os cidadãos de cor poderiam finalmente votar e nomear seus deputados;

paix entre les Citoyens Blancs et les Citoyens de Couleur des quatorze paroisses de la Province de l'Ouest de la partie française de Saint-Domingue. Paris: Imprimerie du Patriote François, s.d. [1791], pp.3-4).

${ }^{1024}$ Cf. CÉSAIRE, Aimé. Toussaint Louverture, pp.143-144; FICK, Carolyn. The making of Haiti, pp.122-127.

${ }_{1025}$ Cf. AP, v.35, p.87.

${ }^{1026}$ Ibidem, p. 131 . 
3) Os cidadãos de cor que haviam lutado em nome de interesses legítimos não seriam responsabilizados pelos seus atos de rebelião, e os prisioneiros dos dois campos seriam imediatamente libertados;

4) Todas as proscrições dos cidadãos de cor cessariam e seriam imediatamente revogadas. Da mesma forma, o segredo de correspondência e a liberdade de imprensa seriam restabelecidos;

5) A guarda-nacional de Porto-Príncipe se comprometia a contribuir para o abastecimento do exército das pessoas de cor enquanto durasse a sua atividade contra os inimigos comuns do bem público, isto é, os ecravos em rebelião;

6) Os cidadãos de cor de Porto-Príncipe declaravam que, apesar da sinceridade manifestada pelos cidadãos brancos, nada os impediria de unirem-se aos seus irmãos de outras partes da ilha que encontrassem obstáculos ao reconhecimento de seus direitos.

Diante da aceitação pelos cidadãos brancos dos termos da concordata, os cidadãos de cor se reuniriam a eles para restabelecer a ordem e tranquilidade na colônia. ${ }^{1027}$ A leitura da concordata gerou fortes aplausos na Assembleia, que reconhecia nela uma possível solução para o caos na colônia. Tarbé fez a leitura de uma carta de São Domingos, transmitida pela municipalidade de Bordeaux, que manifestava a esperança de que, após a concordata, as pessoas de cor, mais preparadas para a repressão da revolta, se uniriam às tropas brancas, mas isso ainda não havia se concretizado. ${ }^{1028}$ Àquela altura, os cidadãos de cor eram a melhor, senão a única, aposta viável para salvar a colônia.

Os Jacobinos estavam bastante envolvidos na campanha pelos cidadãos de cor. Em 20 de novembro, a Assembleia recebeu uma carta dos Jacobinos de Bordeaux que acusavam a assembleia colonial de ser responsável pela insurreição e até mesmo de tê-la provocado para apelar então às potências estrangeiras e entregar-lhes a colônia. Acreditavam, portanto, que o envio de tropas seria perigoso se estas ficassem submetidas à assembleia colonial, opressora dos cidadãos de cor:

Trememos por essa classe preciosa de cidadãos, cuja generosidade confunde tanto a injustiça de seus opressores, por essa brava gente cujo civismo é o verdadeiro baluarte da colônia, e que, após tê-la salvado, prestou o

${ }^{1027}$ Ibidem, pp.132-134.
${ }^{1028}$ Ibidem, pp.134-135. 
juramento de conservá-la à pátria-mãe, ao preço de sua fortuna e de seu sangue. ${ }^{1029}$

Era significativo que Bordeaux, principal praça do comércio colonial, se manifestasse de forma tão contundente a respeito do tema. Isso sinalizava que as atitudes das assembleias coloniais desde o início da Revolução haviam gerado desconfiança entre os homens de comércio marítimo francês quanto à fidelidade dos colonos à metrópole. É certo que a posição dos jacobinos da cidade não representava a da totalidade de seus negociantes, mas era um indício de que muitos deles talvez entendessem que estimular o patriotismo dos homens de cor livres fosse uma solução mais segura para a conservação das colônias.

Diante dessa tendência, uma deputação da assembleia geral de São Domingos compareceu à Assembleia Nacional, em 30 de novembro de 1791, para garantir a fidelidade da colônia à metrópole e solicitar socorros urgentes. Seu orador, J.-B. Millet, fez um relato detalhado da insurreição, acentuando os seus aspectos mais sangrentos. ${ }^{1030}$ Não se limitou a dar números, nomeando especificamente algumas das vítimas da fúria dos insurretos. Ao mesmo tempo, procurou contrapor a "coragem" dos resistentes brancos à "barbárie" dos chefes negros, que massacravam os escravos que permaneciam fiéis aos seus senhores. Segundo Millet, o objetivo dos revoltosos era não apenas devastar as plantações de São Domingos, mas aniquilar totalmente a raça branca. ${ }^{1031}$

Millet procurava apresentar a revolta como um ato não motivado, na medida em que os negros encontravam-se sob um "governo paternal", numa "condição suportável e suave", muito superior àquela em que se encontravam na África. Se a revolta tinha ocorrido, era por força de elementos externos: acusou a Sociedade dos Amigos dos Negros de preparar "[...] de longe os tormentos e as convulsões a que estamos sujeitos" e semear "[...] o espírito de insubordinação entre nossos escravos e a inquietação entre nós". ${ }^{1032}$ Com suas mentiras e manipulações, os Amigos dos Negros teriam semeado a discórdia entre o comércio francês e as colônias, ora apoiando os colonos contra os comerciantes e o sistema exclusivo, ora armando os comerciantes contra os colonos, a

\footnotetext{
1029 "Nous tremblons pour cette classe précieuse de citoyens, dont la générosité confond si hautement l'injustice de leurs oppresseurs, pour ces braves gens dont le civisme est le vrai boulevard de la colonie, et qui, après l'avoir sauvée, ont fait le serment de la conserver à la mère-patrie, au prix de leur fortune et de leur sang" (Ibidem, p.259).

${ }^{1030}$ Millet afirmou, por exemplo, que: "Eles [os negros] tinham por estandarte o cadáver de uma criança empalada na ponta de uma lança" ("Ils avaient pour bannière le cadavre d'un enfant empalé au bout d'une pique" (Ibidem, p.461).

${ }^{1031}$ Ibidem, pp.460-463

${ }^{1032}$ Ibidem, p.464.
} 
quem atribuíam projetos de independência. Pior do que isso, os Amigos dos Negros enviavam a Declaração dos direitos às colônias, anunciando, em seus escritos, que nela já estava pronunciada a liberdade dos negros. Seduzidos por "homens profundamente perversos", os negros teriam esquecido a "doçura" com que eram tratados para envolverem-se numa campanha de destruição desenfreada. ${ }^{1033}$ Concluía que:

Está hoje demonstrado que a influência dos amigos dos negros é destrutiva das colônias [...]. Não pode haver um homem de boa fé que duvide que seus trabalhos, suas declamações, seus escritos, seus infames emissários sejam a causa ativa e constante que, há 2 anos, prepara a nossa ruína e que acaba enfim de realizá-la. ${ }^{1034}$

No dia seguinte ( $1^{\circ}$ de dezembro), num longo e inflamado discurso de três horas, Brissot contra-atacou. No intuito de aliar o comércio às suas pretensões, procurou atribuir a causa do caos aos projetos de independência movidos por uma parte dos brancos da colônia:

Não é apenas uma revolta de negros que tereis de punir, é uma revolta de brancos. A revolta desses negros foi apenas um meio, um instrumento na mão desses brancos que queriam, ao libertar-se da dependência francesa, libertar-se das leis que humilhavam a sua vaidade, e dessas dívidas que afetavam o seu gosto pela dissipação. ${ }^{1035}$

Brissot procurava, entretanto, separar, de um lado, os grandes proprietários, favoráveis aos homens de cor e fiéis à França, e, de outro, os colonos endividados e os petits blancs, inimigos das leis francesas e adeptos da supremacia da raça branca na colônia. Contrapunha, assim, as classes úteis (os grandes plantadores brancos e de cor) às classes perniciosas aos interesses da metrópole. Se afirmava que "a causa dos homens de cor era a causa dos patriotas, do antigo terceiro estado, enfim, do povo há tanto tempo oprimido", o seu esforço estava em mostrar que ela era também a causa dos grandes proprietários coloniais e do comércio francês. ${ }^{1036}$

Brissot atribuía a insurreição dos escravos à ação dos "colonos dissipadores" e dos petits blancs, que haviam visto na Revolução a oportunidade de estabelecerem a sua

\footnotetext{
${ }^{1033}$ Ibidem, p.465.

1034 "Il est aujourd'hui démontré que l'influence des amis des noirs est destructive des colonies [...]. Il ne peut pas exister un homme de bonne foi qui doute que leurs travaux, leurs déclamations, leurs écrits, leurs infames émissaires soient la cause active et constante qui, depuis 2 ans, prepare notre ruine et qui vient enfin de la réaliser" (Ibidem, p.467).

1035 "Ce n'est pas une révolte de noirs que vous avez seulement à punir, c'est une révolte de blancs. La révolte de ces noirs n'a été qu'un moyen, qu'un instrument dans la main de ces blancs, qui voulaient, en s'affranchissant de la dépendance française, s'affranchir des lois qui humiliaient leur vanité, et de ces dettes qui gênaient leur goût pour la dissipation" (Ibidem, p.475).

${ }^{1036}$ Ibidem, pp.475-476.
} 
primazia na colônia e romper os vínculos com a metrópole. ${ }^{1037}$ Ao ameaçarem continuamente a metrópole de uma cisão caso não obtivessem autonomia sobre o seus assuntos internos, esses colonos haviam conseguido convencer até mesmo os seus principais inimigos, os comerciantes franceses. Ora, o seu objetivo era justamente transferir o poder legislativo para as assembleias coloniais e, com isso, romper qualquer vínculo comercial com a França. O decreto de 15 de maio de 1791 teria sido o sinal para esses colonos de que era o momento de provocar a separação. Deputados teriam ido à Jamaica pedir auxílio militar contra o decreto, mas os ingleses lhes teriam respondido que só enviariam tropas no caso de uma revolta de escravos. ${ }^{1038}$ Foi portanto, preciso provocar uma.

Assim, dizia Brissot, não era surpreendente que a revolta tivesse explodido na região do Cap, onde o partido que queria o domínio inglês era mais forte. O levante de alguns plantéis de negros na noite de 22-23 de agosto poderia ter sido rapidamente reprimido, se a resposta usual a esse tipo de problema - isto é, a ação da milícia de cor tivesse sido adotada. Mas a intenção, afirmava o líder antiescravista, era justamente permitir que a revolta alcançasse proporções tais que justificassem o apelo às nações estrangeiras. Na teoria conspiratória de Brissot, tal negligência era parte da realização de um plano longamente elaborado de rompimento com a França. ${ }^{1039}$ Se a causa mais geral das revoltas era a própria Revolução e os efeitos que ela produziu nas ilhas, a causa mais fecunda estava no "[...] sistema de independência sustentado pelos colonos brancos desde o início da Revolução". ${ }^{1040}$

Para Brissot, se a escravidão era uma fonte perpétua de revoltas era porque os atos de violência dos negros, embora terríveis, eram apenas o fruto dos crimes cometidos pelos brancos. Havia uma única barreira capaz de neutralizar esse perigo: "[...] todo país que tem a infelicidade de possuir numerosos rebanhos de escravos deve ter numerosos e fiéis guardiões para impedir essas revoltas; e esses homens de cor são, pela natureza das coisas, os únicos defensores contra os revoltosos". ${ }^{1041}$ Ao desarmá-los, os colonos haviam dado o sinal da insurreição. Bastante aplaudido, Brissot reiterava o argumento de que o único remédio possível à situação residia nos homens de cor livres.

\footnotetext{
${ }^{1037}$ Ibidem, pp.476-478.

1038 Ibidem, pp.480-484.

${ }^{1039}$ Ibidem, pp.485-487.

${ }^{1040}$ Ibidem, p.489.

1041 "...] tout pays qui a le malheur de posséder de nombreux troupeaux d'esclaves, doit avoir de nombreux et fidèles gardiens pour y empêcher ces révoltes; et les hommes de couleur sont, par la nature des choses, les seuls défenseurs contre les révoltés" (Ibidem, p.488).
} 
Os girondinos Ducos, Vergniaud e Guadet manifestaram-se no mesmo sentido e pregaram a manutenção provisória da execução da concordata entre os homens de cor e os brancos. ${ }^{1042}$

É interessante observar que, no debate sobre a insurreição escrava, tanto num campo quanto no outro, os negros apareciam apenas como joguetes nas mãos de uma força externa. Eram peças de uma conspiração cujo objetivo final era a perda das colônias. Apareciam, assim, ora como parte do projeto dos Amigos dos Negros de provocar a destruição das colônias, ora como executores do plano dos colonos endividados de romper os vínculos com a metrópole. A insurreição escrava não tinha verdadeiro significado em si.

Dois dias depois, em 3 de dezembro, foi apresentada na Assembleia uma petição dos deputados da assembleia colonial de São Domingos, manifestando a sua consternação com as propostas de ratificação da concordata, em detrimento da aplicação da lei de 24 de setembro de 1791. Sustentaram que violar as disposições da lei seria dar um novo impulso aos motivos que provocaram as calamidades em São Domingos, pois os laços de obediência capazes de manter os negros na ordem seriam irremediavelmente rompidos. ${ }^{1043}$ Os deputados concebiam um compromisso temporário com os mulatos em razão das circunstâncias, mas não queriam que a Assembleia Nacional transformasse as disposições da concordata em lei nacional.

Brissot tomou a palavra para apresentar um projeto de lei que trazia medidas rigorosas, destinadas a neutralizar a ação dos colonos independentistas, garantir os livres de cor nos seus direitos e satisfazer os interesses do comércio francês. Retomando a sua tese de uma conspiração para separar a colônia da metrópole e livrá-la a uma potência estrangeira, pedia decretos de acusação contra a assembleia geral de São Domingos e contra o governador Blanchelande. Para favorecer uma aliança com os homens de cor, pedia a formação de uma nova assembleia colonial, em conformidade com o decreto de 28 de março de 1790, isto é, sem distinção de cores. A aplicação da medida ficaria a cargo de novos comissários civis patriotas, que seriam enviados ao lado de três mil guardas nacionais. Apontava ainda a necessidade de um projeto de decreto para autorizar os plantadores a hipotecar os seus bens móveis e imóveis nas colônias e autorizar os credores - isto é, os negociantes e armadores franceses - a obter, pelas vias legais, as posses dos plantadores de São Domingos para satisfazer os créditos

\footnotetext{
${ }^{1042}$ Ibidem, p.490.

${ }^{1043}$ Ibidem, pp.535-536.
} 
concedidos. ${ }^{1044}$ Brissot propunha, em linhas gerais, o fim da hegemonia dos colonos independentistas e a instauração de uma nova ordem fortemente apoiada nos proprietários de cor. A inclusão de um dispositivo relativo ao ressarcimento das dívidas dos colonos tinha o sentido claro de associar o comércio francês a essa operação. ${ }^{1045}$

Nos dias 6 e 7 de dezembro, a Assembleia voltou a discutir o envio de tropas. Homens simpáticos aos colonos, como Castel e Dumas ${ }^{1046}$, defendiam o seu envio imediato, procurando sustentar as boas intenções das assembleias coloniais e do governador Blanchelande para com as pessoas de cor. ${ }^{1047}$ No campo contrário, não havia consenso. O jacobino Blanchon entendia que, dada a "perversidade dos colonos brancos", enviar-lhes tropas sem tomar as devidas precauções seria dar carta branca aos crimes que poderiam cometer contra os homens de cor. Inversamente, o girondino Ducos sustentou a necessidade de uma missão militar, temendo que os colonos independentistas tirassem proveito do abandono da colônia pela metrópole para aliaremse aos inimigos da Nação. Outros sugeriam que uma solução militar exigiria instruções específicas. Brival, que tinha posses em São Domingos, mas era contrário à escravidão, respondeu que o envio de tropas poderia gerar grandes abusos, tendo em vista que os oficiais das tropas de linhas eram "[...] por princípios e por hábito, os agentes e os cúmplices do despotismo". Para ele, os negros eram os "novos heróis da Bastilha" e entendia que, caso as tropas fossem enviadas, elas deveriam ser usadas apenas para garantir a segurança das pessoas e não para manter a escravidão ou privar as pessoas de cor livres de sua qualidade de cidadãos ativos. Na mesma linha, Merlet argumentou que os chefes - não os soldados - das tropas de linha estavam a serviço da contrarrevolução e propôs enviar, em seu lugar, guardas nacionais, sob o comando de chefes patriotas. ${ }^{1048}$ Da mesma forma, embora não descartassem a possibilidade de abusos, Guadet e Vergniaud entendiam que as necessidades de São Domingos eram reais demais para serem ignoradas, mas ressaltaram que as tropas não deveriam partir sem instruções claras da Assembleia. ${ }^{1049}$ Convencida da necessidade de uma solução militar para São Domingos, a Assembleia decidiu pelo envio das tropas.

\footnotetext{
1044 Ibidem, pp.537-542.

1045 Ibidem, p.544-546.

${ }^{1046}$ Castel era um deputado sem grande expressão e, aparentemente, sem interesses diretos na questão colonial. Dumas, entretanto, tinha atuado como chefe de estado-maior do exército de São Domingos em 1783 (cf. Dictionnaire des législateurs, v.1, pp.126-127 e 259-261).

1047 AP, v.35, pp.603-604 e 609.

1048 Ibidem, pp.604-608.

${ }^{1049}$ Ibidem, pp.607-610.
} 
Quanto às instruções a serem dadas às tropas, Brissot e Gensonné, cuja família tinha raízes nas colônias, apresentaram projetos pelos quais as forças nacionais seriam empregadas apenas para conter a insurreição dos negros e manter a união estabelecida entre os homens de cor livres e os colonos brancos. O projeto de Brissot especificava não prejulgar nada a respeito do fundo da questão - os direitos dos homens de cor - e, nesse sentido, não abrogava o decreto de 24 de setembro. ${ }^{1050}$ Era uma medida estranha, pois, embora garantisse às pessoas de cor que as tropas não seriam usadas para privá-las de seus direitos, ela certificava aos colonos brancos que a competência legislativa da assembleia colonial sobre os assuntos internos não seria afetada. Ciente disso, Garran de Coulon manifestou o seu apoio ao projeto, mas, vendo o decreto de 24 de setembro como perigoso e contrário à Declaração dos direitos, acrescentou a necessidade de ratificar expressamente as concordatas entre os brancos e os homens de cor. ${ }^{1051}$

No fim, após vivas discussões, a Assembleia adotou o decreto proposto por Brissot, com uma emenda introduzida por Gensonné:

A Assembleia nacional, considerando que a união dos brancos e dos homens de cor livres contribuiu principalmente para parar a revolta dos negros de São Domingos; que essa união gerou diferentes acordos entre os brancos e os homens de cor, e a diversas decisões tomadas quanto aos homens de cor, nos últimos 20 e 25 de setembro ${ }^{1052}$, pela assembleia colonial sediada no Cap, Decreta que o rei será convidado a dar ordens, para que as forças nacionais destinadas a São Domingos só possam ser empregadas para reprimir a revolta dos negros, sem que possam agir direta ou indiretamente para proteger ou favorecer os atentados que poderiam ser levados ao estado dos homens de cor livres, tal como foi fixado em São Domingos, na época do último 25 de setembro. ${ }^{1053}$

O decreto sancionava, em larga medida, a política de conciliação esboçada entre colonos e homens de cor em certas partes da colônia, mas sem revogar a lei de 24 de setembro de 1791. Assim mesmo, não deixava de ser uma derrota importante para o

\footnotetext{
${ }^{1050}$ Ibidem, pp.612-614 e 628.

1051 Ibidem, p.629.

1052 Em 20 de setembro, a assembleia geral de São Domingos tinha decretado que não se oporia à execução da lei de 15 de maio, quando esta fosse oficialmente enviada, e que se comprometia a melhorar a condição das pessoas de cor, mesmo aquelas não nascidas de pai e mãe livres (Ibidem, p.709-710).

1053 "L'Assemblée nationale, considérant que l'union entre les blancs et les hommes de couleur libres a contribué principalement à arrêter la révolte des nègres de Saint-Domingue; que cette union a donné lieu à différents accords entre les blancs et les hommes de couleur, et à divers arrêtés pris à l'égard des hommes de couleur, les 20 et 25 septembre derniers, par l'assemblée coloniale séant au Cap. Décrète que le roi sera invité à donner des ordres, afin que les forces nationales destinées pour Saint-Domingue, ne puissent être employées que pour réprimer la révolte des noirs, sans qu'elles puissent agir directement ou indirectement pour proteger ou favoriser les atteintes qui pourraient être portées à l'état des hommes de couleur libres, tel qu'il a été fixé à Saint-Domingue, à l'époque du 25 septembre dernier" (Ibidem, p.645).
} 
campo colonial, que ainda tentou contra-atacar nos dias seguintes. ${ }^{1054}$ Naquele momento, entretanto, as questões relativas à guerra que se anunciava no continente europeu começavam a tornar-se prioritárias na esfera parlamentar. No que tocava aos assuntos coloniais, isso significava que a inclinação da Assembleia em enviar armas, soldados e fundos para as colônias seria reduzida. Isso estimularia os representantes da Nação a priorizar, para os problemas coloniais, uma solução interna e, para muitos, os homens de cor livres eram essa solução.

Ora, em São Domingos, a situação ainda não tinha sido resolvida, pois parte da população branca ainda recusava-se a executar as concordatas. O Patriote Français, nos números de 13 e 16 de dezembro, noticiou que essa recusa havia levado os cidadãos de cor a assumirem o controle das cidades de Léogane e Porto-Príncipe, à espera do cumprimento dos termos do acordo. ${ }^{1055}$ Para tentar acalmar os ânimos, Tarbé trouxe à Assembleia, em 25 de dezembro, uma carta do prefeito de Porto-Príncipe aos negociantes de Nantes, que indicava que, no final de outubro, a situação em São Domingos tinha supostamente sido acalmada. Os rebeldes negros não tinham sido dissipados, mas encontravam-se reduzidos a uma posição pouco ameaçadora. No Oeste, várias paróquias tinham finalmente dado a sua adesão à concordata de 11 de setembro, levando à celebração de um tratado de paz entre os brancos e os homens de cor em 19 de outubro. Os cidadãos de cor da província do Oeste tinham seus direitos reconhecidos e aliavam-se, desta forma, aos colonos brancos na luta contra os negros rebeldes. Ao apresentar os termos dessa nova concordata, em 23 de outubro, o prefeito de PortoPríncipe havia proclamado: "Cidadãos de cor, meus amigos, perdeis aqui essa denominação; não há mais distinção, não há mais diferença. Teremos, no futuro, todos juntos, apenas uma mesma qualificação: a de cidadão". ${ }^{1056}$ Um juramento solene de lutar pela tranquilidade e pela segurança pública havia selado a união entre os brancos e os homens de cor do Oeste. Na sua carta, o prefeito de Porto-Príncipe reconhecia que a união com as pessoas de cor era, naquele momento, rigorosamente necessária para salvar a colônia, e que se a França quisesse, um dia, restabelecer o regime da desigualdade, ela teria de enviar forças suficientes para fazer executar as suas leis. ${ }^{1057}$ No mesmo sentido, em 29 de setembro, foi lida, na Assembleia, uma carta do

\footnotetext{
${ }^{1054}$ Ibidem, pp.672-673 e 705.

${ }^{1055}$ Cf. Patriote Français, v.5, números 855 e 858, 13 e 16 de dezembro de 1791, pp.683 e 696.

1056 "Citoyens de couleur, mes amis, vous perdez ici cette dénomination; il n'existe plus de distinction, plus de différence. Nous n'aurons à l'avenir, tous ensemble, qu'une même qualification: celle de citoyen" (AP, v.36, p.400).

${ }^{1057}$ Ibidem, p.418.
} 
governador Blanchelande, de 22 de outubro de 1791, em que também reconhecia que, àquela altura, não era possível conceber a salvação da colônia sem a união com as pessoas de cor. ${ }^{1058} \mathrm{O}$ partido colonial se esforçava em mostrar que as medidas locais eram suficientes para selar a aliança entre brancos e mulatos. Naquele momento, entretanto, Porto-Príncipe estava dividida em dois partidos, os que queriam a execução das concordatas e os petits-blancs, que se opunham a ela. ${ }^{1059}$ Era preciso que a Assembleia Nacional decidisse definitivamente essa questão.

\section{II.1.4.2) A lei de 24 de março - 4 de abril de 1792: maior e derradeira vitória dos Amigos dos Negros}

No início de 1792, as notícias que chegavam de São Domingos indicavam que, apesar das concordatas, a situação ainda era instável. A revolta dos escravos não tinha sido dissipada e muitos homens de cor teriam abandonado o campo da ordem após perceberem que os brancos não tinham real intenção de executar o tratado de paz. ${ }^{1060} \mathrm{O}$ Patriote Français de 9 de janeiro indicava que, no final de outubro, por conta da recusa da assembleia colonial de confirmar a concordata de Porto-Príncipe, 800 mulatos tinham se juntado aos escravos rebeldes em Maribarou. O jornal alertava: "Se a Assembleia não vier em socorro da concordata, essa colônia estará perdida". ${ }^{1061}$ A chegada do decreto de 24 de setembro de 1791 tinha reacendido o incêndio em São Domingos, pois alguns brancos pretendiam se valer dele para romper com a concordata. Uma carta de $1^{\circ}$ de dezembro indicava que Porto-Príncipe era consumida pelas chamas e que muitos homens de cor tinham sido mortos. ${ }^{1062}$

$\mathrm{Na}$ Assembleia, essas notícias fortaleciam a opinião favorável aos homens de cor como solução aos problemas de São Domingos. Apesar disso, o partido colonial mantinha-se firme na sua vontade de impedir uma nova lei sobre o tema e de restringir a solução para o caos na colônia ao envio de socorros. Assim, em 11 de janeiro de 1792, sob protestos da ala esquerda da Assembleia,Tarbé sustentou a impossibilidade de ratificação da concordata, entendendo que tratava-se de uma medida local e que torná-la obrigatória para toda a colônia seria fazer uma lei sobre o estado das pessoas, violando

\footnotetext{
1058 Ibidem, pp.612-613.

${ }^{1059}$ Cf. Patriote Français, v.5, número 869, 27 de dezembro de 1791, p.740.

${ }^{1060}$ Idem, v.6, número 881,8 de janeiro de 1792 , p. 31 .

${ }^{1061}$ Idem, v.6, número 882, 9 de janeiro de 1792, pp.35-36).

${ }^{1062}$ Idem, v.6, número 889, 16 de janeiro de 1792, p.62.
} 
as disposições do decreto constitucional de 24 de setembro do ano anterior. Para os colonos, uma aliança tática de brancos e homens de cor era admissível para fazer frente à revolta escrava, mas não queriam vê-la cristalizada sob a forma de uma lei que garantisse a igualdade de direitos. ${ }^{1063}$

No início de fevereiro, novas cartas de São Domingos indicavam que a guerra civil ainda estava bastante viva na colônia. Na sua luta pela execução da concordata, os homens de cor estavam em conflito aberto com os petits blancs no Oeste e no Sul, enquanto, no Norte, os insurretos negros ainda não tinham sido derrotados. ${ }^{1064}$ No dia 10 de fevereiro, o deputado Journu-Aubert, negociante de Bordeaux, apresentou novo relatório, em nome dos comitês do comércio e das colônias, para pedir o envio de 3 milhões de libras para as subsistências e materiais necessários à restauração das manufaturas. Brissot retrucou que enviar socorros a São Domingos antes de ratificar as concordatas e revogar o decreto fatal de 24 de setembro do ano anterior era "[...] enviar ouro para continuar uma guerra ímpia e fratricida". ${ }^{1065}$ Muito influente naquele momento, Brissot era aplaudido enfaticamente pela ala esquerda da Assembleia. Inversamente, naquele momento, ocorria uma desintegração do Clube Massiac, com a saída de muitos membros importantes, como Lafond de Ladébat e Belin de Villeneuve. Muitos colonos pediam para partir para as colônias ou então usavam a situação nas colônias como pretexto para emigrar. ${ }^{1066} \mathrm{O}$ campo colonial aparecia, naquele início de 1792, enfraquecido.

Em 29 de fevereiro, em novo relatório à Assembleia, Tarbé, do comitê das colônias, chegou a apresentar os homens de cor livres como instrumentos da contrarrevolução. ${ }^{1067}$ Em resposta, Guadet leu uma opinião de Garran de Coulon sobre as causas da insurreição dos negros. Afirmava que o efeito contagioso da Revolução havia despertado as aspirações de liberdade nos povos oprimidos, e eram aqueles que tentavam conter o seu ímpeto - isto é, os colonos - que agiam como contrarrevolucionários. Para enfrentar os problemas das colônias, a nação francesa tinha de estender definitivamente às suas colônias os Direitos do homem, o que significava reconhecer definitivamente aos homens de cor livres os seus direitos de cidadania. ${ }^{1068}$

Garran de Coulon não rejeitava a legitimidade das aspirações de independência

\footnotetext{
1063 Cf. AP, v.37, pp.226-227.

${ }^{1064}$ Cf. Patriote Français, v.6, número 916, 12 de fevereiro de 1792, p.172.

1065 Cf. AP, v.38, p.358.

${ }^{1066}$ Cf. DEBIEN, Gabriel. Les colons de Saint-Domingue et la Révolution, p.366

${ }^{1067}$ Cf. Patriote Français, v.6, número 934, 2 de março de 1792, p.247.

1068 AP, v.39, pp.210-212.
} 
dos povos, mas, para o deputado, a independência das colônias não podia servir de instrumento de opressão, para sujeitar os homens de cor livres e eternizar a escravidão. O caos reinante nas colônias indicava que elas ainda precisavam da "tutela materna" da metrópole e não podiam ter uma legislatura à parte. ${ }^{1069}$ Propunha concretamente a formação de uma nova assembleia colonial, em cada colônia, para emitir sua vontade a respeito da sua organização interna, para que a Assembleia Nacional decidisse definitivamente sobre esses objetos. Em conformidade com o decreto de 28 de março de 1790, toda pessoa livre, proprietária, ou domiciliada há mais de dois anos, e contribuinte, gozaria do direito de sufrágio. Para Garran, uma das questões sobre as quais as assembleias coloniais deveriam emitir o seu voto era o melhoramento da condição dos negros não livres e os meios de abolir progressivamente a escravidão. ${ }^{1070}$ A Assembleia decidiu pela impressão do discurso, mas não houve debate.

A evolução da situação política na França permitiria, entretanto, superar os obstáculos. Na primeira metade de março de 1792, os Feuillants, que controlavam o ministério, foram derrubados, dando lugar a um novo governo, encabeçado por Roland e Clavière e alinhado com o programa brissotino. Naquele momento, o grupo de Brissot, que começava a planejar a guerra na Europa, conquistava, aos poucos, a maioria dos deputados na Assembleia. Cientes do agravamento da situação em São Domingos, portos do comércio com as colônias, como Bordeaux e Nantes, manifestavam o seu apoio à política em favor dos homens de cor livres. Na segunda metade de março, o debate sobre as colônias foi reaberto.

Em 21 de março, Brissot voltou a manifestar-se na Assembleia sobre a guerra civil em São Domingos. Não falava agora apenas em sancionar as concordatas feitas na colônia, mas em revogar a lei de 24 de setembro de 1791. Dizia ainda que era preciso ir além do decreto de 15 de maio e superar as distinções entre os homens de cor nascidos de pais livres e os demais. ${ }^{1071}$ No dia seguinte (22 de março), a proposta de Brissot ganhou forma num novo projeto de lei apresentado pelo girondino Gensonné. Este dispunha que:

1) Proceder-se-ia, nas ilhas, à reeleição das assembleias coloniais e das municipalidades, nas formas previstas pelos decretos de 8 e 28 de março de 1790 , isto é, sem restrições relativas à origem dos sujeitos $\left(\operatorname{art} .1^{\circ}\right)$.

\footnotetext{
1069 Ibidem, pp.214-215.

${ }^{1070}$ Ibidem, pp.219-220.

${ }^{1071}$ Cf. Moniteur, v.11, número 82, 22 de março de 1792, p.689-692; número 83, 23 de março de 1792, p.695.
} 
2) As pessoas de cor, mulatos e negros livres, gozariam, assim como os colonos brancos, da igualdade de direitos políticos, sendo admitidos a votar em todas as assembleias primárias e eleitorais e sendo elegíveis para todos os cargos, quando reunissem as condições prescritas pela instrução de 28 de março $\left(\operatorname{art} .2^{\circ}\right)$.

3) Três comissários civis seriam enviados a São Domingos e quatro para Martinica, Guadalupe, Sainte-Lucie e Tabago. Eles seriam autorizados a pronunciar a suspensão das assembleias coloniais existentes e tomar medidas para acelerar a convocação das assembleias primárias e eleitorais, além de manter a ordem e a paz e velar pela regularidade das eleições. Ficariam ainda encarregados de recolher informações sobre os autores dos tumultos em São Domingos, determinando a sua eventual prisão e seu envio à França para julgamento. $\left(\operatorname{artigos} 3^{\circ}\right.$ a $\left.8^{\circ}\right)$.

4) O rei seria convidado a substituir os agentes do executivo nas colônias por homens avessos ao preconceito $\left(\operatorname{art} .9^{\circ}\right)$.

5) Imediatamente após a sua formação, as assembleias coloniais emitiriam o seu voto particular sobre a constituição, a legislação e a administração que lhes conviesse, sob a condição de conformarem-se aos princípios gerais que ligavam as colônias à metrópole, isto é, o pacto colonial. As colônias poderiam enviar representantes à metrópole para levarem o seu voto ao corpo legislativo (art.10-11).

6) Os decretos anteriores sobre as colônias seriam executados, salvo no que contrariassem as disposições do atual decreto (art.12). ${ }^{1072}$

O projeto não suprimia totalmente o sistema da Constituinte, na medida em que as colônias conservariam as suas assembleias e o direito a uma constituição própria. Reafirmava também a impossibilidade para as colônias de promover mudanças no sistema do exclusivo. A única inovação era a afirmação expressa dos direitos de cidadania reconhecidos a todos os homens de cor livres. Ao contrário do decreto de 15 de maio do ano anterior, o projeto não estabelecia distinções entre as pessoas de cor: tanto aquelas nascidas de pais livres quanto as que haviam sido alforriadas gozariam dos mesmos direitos reconhecidos aos brancos. Gensonné foi muito aplaudido.

Nas sessões seguintes, alguns deputados tentaram impedir a aprovação da lei, sempre argumentando que tratava-se de uma questão da competência das assembleias

${ }^{1072}$ Cf. Moniteur, v.11, número 84, 24 de março de 1792, pp.703-707. 
coloniais. Aubert-Dubayet ${ }^{1073}$, por exemplo, sustentou que seria impolítico revogar o decreto de 24 de setembro e que era preciso deixar aos colonos brancos o "mérito" de uma aliança com os homens de cor. ${ }^{1074}$ Da mesma forma, no dia 24 de março, o colono Viénot-Vaublanc lembrou que o próprio Brissot, em 1789, havia dito que as colônias estavam longe demais da metrópole para terem o mesmo regime interno. ${ }^{1075}$ Os argumentos de Brissot de 1789 eram, portanto, os mesmos que fundamentavam o decreto de 24 de setembro, que não privava os homens de cor de seus direitos, mas apenas dava às assembleias coloniais a iniciativa legislativa sobre a matéria. Contudo, as resistências do campo colonial já estavam enfraquecidas. O próprio Viénot-Vaublanc não se opôs ao projeto de Gensonné, pedindo apenas que ele ficasse restrito a São Domingos e que não fosse aplicado caso medidas locais já tivessem sido tomadas para garantir os direitos dos livres de cor. ${ }^{1076}$

A Assembleia já estava convencida de que a salvação das colônias passava pelo reconhecimento da cidadania plena dos homens de cor livres. Após discussão a respeito de alguns dispositivos, o projeto de Gensonné foi aprovado na sua integralidade. ${ }^{1077} \mathrm{O}$ decreto de 24 de março de 1792, ao conceder a igualdade plena de direitos a todas as pessoas de cor livres das colônias, foi a maior e talvez única vitória dos Amigos dos Negros.

Em 26 de março de 1792, Ducos procurou ampliar o alcance da lei votada dois dias antes e apresentou uma emenda que declarava livres e iguais todos os mulatos ao nascerem, independentemente do estado de sua mãe. Ou seja, era uma revogação do princípio partus sequitur ventrem, adotado pelo Code Noir. Além disso, Ducos propôs a supressão do imposto sobre a alforria. Queria, portanto, fazer da lei sobre os homens de cor livres o princípio de um plano de abolição gradual da escravidão. ${ }^{1078}$ Sua proposta, entretanto, foi rejeitada, o que mostra que as duas coisas estavam bem separadas na cabeça dos membros da Assembleia. No dia seguinte, Journu-Aubert e Tarbé

\footnotetext{
${ }^{1073}$ Militar de carreira que tinha, em 1786, publicado anonimamente um panfleto antissemita, Le cri du citoyen contre les juifs de Metz, par un capitaine d'infanterie (cf. Dictionnaire des législateurs, v.1, p.17). ${ }_{1074}$ Cf. Moniteur, v.11, número 84, 24 de março de 1792, p.711.

${ }^{1075}$ O Patriote Français traria uma resposta a essa acusação. Segundo o jornal, se Brissot havia defendido a existência de uma assembleia colonial em 1789, era para impedir a admissão dos deputados coloniais na Assembleia Nacional. Como eles foram admitidos, Brissot passou a sustentar que as colônias não deveriam ter um sistema colonial independente. Assim, não haveria contradição. $O$ fato, entretanto, é que Brissot tinha mudado de opinião, ao perceber que a realização da igualdade nas colônias só podia vir da metrópole (cf. Patriote Français, v.6, número 959, 26 de março de 1792, p.343).

${ }^{1076}$ Cf. Moniteur, v.11, número 85, 25 de março de 1792, pp.717-719.

1077 Idem, v.11, número 86, 26 de março de 1792, p.724.

${ }^{1078}$ Cf. AP, v.60, p.487.
} 
apresentaram, em nome dos comitês colonial e de comércio, artigos adicionais ao decreto de 24 de março. Um dos artigos previa que um projeto de lei deveria ser apresentado para garantir aos credores (isto é, os mercadores metropolitanos) uma hipoteca sobre os bens de seus devedores nas colônias. ${ }^{1079}$

Frustrando as últimas esperanças dos colonos, o rei ratificou o decreto, que seria finalmente promulgado em 4 de abril de 1792. O primeiro grande efeito da insurreição escrava era o de ter derrubado as barreiras raciais entre a população livre da colônia. Entretanto, a lei era, acima de tudo, uma resposta a uma emergência militar. O próprio título da lei expressava isso: Loi relative aux colonies, et aux moyens d'y apaiser les troubles (lei relativa às colônias, e aos meios de nelas apaziguar os tumultos). O decreto era a tradução concreta do argumento, sempre defendido por Raimond e Brissot, de que os homens de cor eram a melhor barreira contra a revolta escrava.

Os homens de cor residentes em Paris não deixaram de se manifestar. Em 30 de março, uma delegação presidida por Julien Raimond veio prestar homenagem à Assembleia Nacional pelo decreto do dia 24. Raimond jurou doar até a sua última gota de sangue pela defesa da Constituição e se ofereceu para ir a São Domingos, para guiar os seus irmãos à paz e ajudar os brancos a reconstruir a colônia. ${ }^{1080}$

Os Amigos dos Negros destacaram em seus jornais a grande vitória da igualdade da epiderme. No Patriote Français do dia 25 de março, Brissot mostrou-se exultante: "[...] o 24 de março será conhecido para sempre nos anais do patriotismo, da filosofia [...]". ${ }^{1081}$ Na Chronique de Paris do mesmo dia, Condorcet aproveitou o debate sobre a autonomia legislativa das colônias para afirmar que, se a independência podia eventualmente ser concebida sob um governo despótico, agora que a França era uma nação livre e poderosa, uma mesma constituição deveria unir a metrópole e suas colônias. Condorcet manifestava a esperança de que, uma vez resolvida a questão dos homens de cor, os interesses dos escravos não seriam esquecidos. ${ }^{1082}$

Apesar das palavras de Condorcet, o decreto sobre os mulatos pode ser visto como o derradeiro ato dos Amigos dos Negros, a sua única verdadeira conquista. O grupo brissotino já estava, àquela altura, mais voltado para a guerra de "libertação" na Europa e mais preocupado em prevenir uma radicalização da Revolução na

\footnotetext{
1079 Ibidem, pp.534-537.

${ }^{1080}$ Cf. Patriote Français, v.6, número 964, 31 de março de 1792, p.364.

1081 "[...] le 24 mars sera à jamais célèbre dans les annales du patriotisme, de la philosophie [...]" (Idem, v.6, número 958, 25 de março de 1792, p.339).

1082 Cf. Chronique de Paris, v.5, número 85, 25 de março de 1792, p.337.
} 
metrópole. ${ }^{1083}$ A grande realização dos Amigos dos Negros era uma lei destinada a reprimir uma revolta escrava, solidificar a classe dos plantadores de todas as cores e salvaguardar os vínculos entre a metrópole e suas colônias. Durante o longo debate sobre as colônias que se estendeu desde o final de 1791 até março de 1792, muito pouco foi dito a respeito da emancipação dos escravos.

\section{II.1.4.3) Uma nova comissão civil}

A atuação dos comissários do povo constitui uma das maiores peculiaridades da administração pública sob a Revolução francesa. No caso dos comissários enviados às colônias, embora fossem nomeados pelo rei, eles recebiam seus poderes da Assembleia Nacional. Esses poderes eram bastante amplos, permitindo-lhes recorrer à força para suspender as assembleias eleitorais nas colônias; determinar novas eleições; conduzir investigações com vistas a prender os culpados e enviá-los à metrópole; estabelecer autoridades judiciais; e requerer contingentes de tropas para impor a execução de sua política. ${ }^{1084}$ Para restaurar a autoridade metropolitana em São Domingos, a Legislativa havia determinado o envio de nova comissão civil.

A escolha dos comissários, feita em junho, traduzia, desta vez, a prevalência dos brissotinos nas esferas do poder. Munidos da lei de 24 de março de 1792, eles tinham por missão primordial reorganizar as colônias com base no princípio da igualdade entre os cidadãos livres. Os comissários nomeados foram: Jean-Antoine Ailhaud, Étienne Polverel e Léger-Félicité Sonthonax. Se Ailhaud não se destacava por nenhuma inclinação ideológica específica, Polverel e, sobretudo, Sonthonax já tinham manifestado anteriormente posturas mais radicais. ${ }^{1085}$

Por ocasião da expulsão dos lamethistas dos Jacobinos, foi Polverel, um membro convicto do Clube, que tinha pedido, em 25 de setembro, a exclusão de todos aqueles que tinham votado a favor da revogação do decreto de 15 de maio de 1791, favorável aos homens de cor. Polverel apresentava-se, assim, como uma escolha adequada para fazer valer a igualdade dos homens livres nas colônias.

\footnotetext{
${ }^{1083}$ Cf. DAVIS, David Brion. The Problem of Slavery in the Age of Revolution 1770-1823. Ithaca, N.Y.: Cornell University Press, 1975pp.146-147.

${ }^{1084}$ Cf. SCHMITT, Carl. La Dictadura. Madrid: Alianza, 1985, pp.199 e 202.

1085 Chaumette, um antiescravista ainda mais avançado, chegou a ser considerado como secretário da Comissão civil, mas não assumiu a função, por razões que não se conhece bem. Em 1795, Polverel apresentaria duas cartas de Chaumette sobre o assunto, revelando que foi este que se propôs como secretário da Comissão, mas não foi aceito (cf. PIQUET, Jean-Daniel. L'émancipation des Noirs dans la Révolution française, pp.186-187).
} 
Quanto a Sonthonax, a sua nomeação como comissário em 1792 é comumente explicada pelas suas relações com Brissot. De fato, a sua escolha - assim como a de Polverel - teria sido o resultado direto da intervenção do líder dos Amigos dos Negros junto ao Ministro da Marinha. Marcel Dorigny aponta, entretanto, que a filiação entre Sonthonax e o líder girondino foi, em muitos momentos, bastante tênue e difícil de evidenciar. Dorigny levanta a hipótese de que Sonthonax teria frequentado a Sociedade dos Amigos dos Negros, o que explicaria o seu interesse pelas colônias e o seu antiescravismo moderado. Certas declarações de Sonthonax retomariam algumas das principais linhas de argumentação da Sociedade, como, por exemplo, a sua recusa de uma abolição abrupta da escravidão. ${ }^{1086}$ Uma carta de Sonthonax a Brissot, de 4 janeiro de 1793, traz indícios de uma conexão entre o comissário e os Amigos dos Negros. Ele iniciava a carta com as palavras: "Quando vós e vossos amigos me confiastes a missão de São Domingos [...]". ${ }^{1087} \mathrm{Na}$ mesma carta, Sonthonax manifestava uma filiação ideológica ao ressaltar o patriotismo dos livres de cor e rejeitar a ideia de uma abolição abrupta da escravidão: "[...] a minha oposição aos decretos da Convenção só pode ser entendida no caso de uma emancipação súbita, que determinaria, sem nenhuma dúvida, a morte de todos os Brancos". ${ }^{1088}$ Da mesma forma, o lugar que ele atribuiria à pedagogia na sua política relativa aos novos livres, quando da sua segunda missão em São Domingos, poderia ser interpretado como uma aplicação da doutrina dos Amigos dos Negros, que afirmavam que a liberdade supunha homens esclarecidos e formados nas virtudes cívicas e sociais. ${ }^{1089}$

Dito isso, é pouco provável que Sonthonax tenha pertencido à primeira Sociedade dos Amigos dos Negros. Seu nome não consta de nenhuma das listas de membros e o registro das sessões não o cita. O engajamento de Sonthonax no debate colonial não se deu no quadro da Sociedade dos Amigos dos Negros, mas por meio de seus artigos para o jornal Les Révolutions de Paris, nos quais, entre setembro de 1790 e julho de 1791, ele havia manifestado posições bastante contundentes sobre a questão colonial. Nesses artigos, Sonthonax havia expressado inclinações radicais, que superavam, de certa forma, o tom moderado do discurso dos Amigos dos Negros. Foi o

\footnotetext{
${ }^{1086}$ Cf. DORIGNY, Marcel. Sonthonax et Brissot: le cheminement d'une filiation politique assumée. In: Léger Félicité Sonthonax., pp.29 e 31.

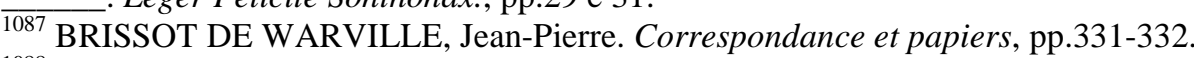

1088 "[...] mon opposition aux décrets de la Convention ne peut s'entendre que d'un affranchissement subit, qui à coup sûr ferait égorger tous les blancs" (BRISSOT DE WARVILLE, Jean-Pierre. Correspondance et papiers, pp.334).

${ }^{1089}$ Cf. DORIGNY, Marcel. Sonthonax et Brissot, p.32.
} 
caso no número de 18-25 de setembro de 1790, no qual ele havia profetizado a entrada de deputados negros na Assembleia Nacional. ${ }^{1090}$

A relação de Sonthonax com Brissot pode ter surgido no seio do clube dos Jacobinos, ao qual, no final de dezembro de 1791, ambos pertenciam. Sonthonax tinha sido rapidamente promovido ao Comitê de correspondência do clube, ao lado de Lanthenas, Roland - dois amigos próximos de Brissot - e Polverel, seu futuro colega na Comissão civil. Esse comitê foi, entre o inverno e a primavera de 1792, o pivô da propaganda dos brissotinos. Sonthonax, em particular, foi bastante ativo na campanha em favor da guerra, uma das principais causas brissotinas, o que lhe valeria sérios problemas sob o Terror. ${ }^{1091}$ Sonthonax não era um mero agente de Brissot, mas os seus vínculos com o chefe girondino seriam amplamente explorados pelos seus inimigos e serviriam de pretexto para a sua acusação. ${ }^{1092}$

Os comissários partiram para São Domingos em 30 de junho. Os seus poderes tinham sido ampliados por um decreto do dia 15 do mesmo mês. Estavam acompanhados de seis mil soldados: quatro mil guardas nacionais e dois mil soldados de linha. Sua chegada a São Domingos, em 18 de setembro de 1792, daria início a uma política de força, apoiada nos homens de cor livres. Em carta de 30 de maio, Julien Raimond já tinha escrito aos seus compatriotas para ressaltar a pureza de princípios dos comissários e pedir que os ajudassem a cumprir a sua missão. ${ }^{1093}$

As primeiras medidas adotadas em São Domingos pelos comissários civis confirmavam que o seu objetivo era aplicar o princípio do decreto de 24 de março de 1792 e restabelecer a ordem na colônia, mas a execução da nova legislação não se daria de forma ordinária. É verdade que, quando o decreto chegou a São Domingos, a situação das pessoas de cor já tinha sido resolvida, com uma nova concordata, de 14 de abril, que havia selado a união dos brancos com os mulatos. ${ }^{1094}$ Para consolidar essa

\footnotetext{
${ }^{1090}$ Cf. Les Révolutions de Paris, v.5, número 63, 18-25 de setembro de 1790, p.524.

${ }^{1091}$ Cf. DORIGNY, Marcel. Sonthonax et Brissot, p.35.

${ }^{1092}$ Há especulações sobre instruções secretas que teriam sido dadas por Brissot a Sonthonax, prevendo a abolição como etapa posterior à aplicação da lei de 4 de abril. Não há provas claras da existência dessas instruções. O próprio Sonthonax negou que tivessem existido. Uma carta, entretanto, foi entregue por Brissot a Sonthonax antes de sua partida para a ilha. O seu teor permite sugerir que a emancipação dos escravos era o objetivo final da lei de igualdade entre livres de cor e brancos. Mas as modalidades de tal operação não são especificadas e nenhuma insurreição é legitimada. A carta não pode, portanto, ser vista como uma permissão tácita dada a Sonthonax para proclamar a abolição, mas ela sugere que os dois homens tinham, de fato, discutido os próximos passos a serem dados, uma vez aplicada a lei sobre a igualdade dos homens de cor livres (Ibidem, p.37).

${ }^{1093}$ Cf. RAIMOND, Julien. Correspondance de Julien Raimond, avec ses frères, de Saint-Domingue, p.72.

${ }^{1094}$ Cf. Patriote Français, v.6, número 1023, 29 de maio de 1792, pp.599-600.
} 
aliança, postos de comando numa força militar mista seriam entregues a mulatos como Rigaud, Beauvais, Pinchinat, Vilatte e Chanlatte. Em vez de promover a formação de novas assembleias, os comissários ordenariam a criação de uma comissão intermediária com poder executivo, composta de doze membros: seis brancos e seis homens de cor, dentre os quais um negro livre. ${ }^{1095} \mathrm{Na}$ parte Norte, Sonthonax instituiria um imposto de um quarto sobre as receitas, para desagrado dos proprietários. ${ }^{1096}$ Ao mesmo tempo, os comissários procuravam acalmar os colonos brancos, assegurando-lhes, por meio de uma série de proclamações nos meses de outubro e dezembro de 1792, que a escravidão era necessária e seria conservada, e que a autonomia legislativa das assembleias coloniais em relação ao estado dos escravos seria respeitada enquanto eles estivessem na ilha. ${ }^{1097}$

Na Guadalupe, a aplicação da lei de 24 de março foi mais problemática, pois o capitão Lacrosse, enviado pela Assembleia Nacional na condição de governador da Guadalupe e da Martinica, teve de confrontar os realistas da assembleia colonial, que haviam tomado conta da ilha. Apoiando-se nos patriotas da colônia e nas pessoas de cor, as tropas republicanas enfrentaram as forças realistas entre o final de 1792 e o início de 1793. A vitória dos patriotas permitiu o desembarque de Lacrosse em Point-àPitre, dando início a uma série de medidas republicanas: o estabelecimento de administrações populares, a reorganização das municipalidades, a eleição de uma assembleia geral extraordinária para substituir a assembleia colonial, o sequestro dos bens do clero e dos emigrados, e uma propaganda republicana voltada para a integração dos negros livres às assembleias, clubes e mesas dos brancos. ${ }^{1098}$

O impulso republicano se difundia nas colônias assim como na metrópole, onde a monarquia foi derrubada em 10 de agosto de 1792. Nesse contexto, ocorria uma dissolução de todos os agrupamentos associados à realeza e vistos, portanto, como contrarrevolucionários. Foi o caso do Clube Massiac, que, após o 10 de agosto, se apagou definitivamente. ${ }^{1099}$ Todos os jornais associados à sua campanha também desapareceram. Algumas figuras importantes como Malouet, Cormier e Moreau de Saint-Méry se viram obrigadas a se esconder na França ou a fugir para a Inglaterra. No

\footnotetext{
${ }^{1095}$ Idem, v.7, número 1228, 21 de dezembro de 1792, p.710..

1096 Cf. PAGE, Pierre-François, BRULLEY, Augustin-Jean. Notes fournies au Comité de Salut Public. S.l.: s.n., s.d., pp.28-29.

${ }^{1097}$ Ibidem, p.22.

${ }^{1098}$ Cf. BANGOU, Henri. La Guadeloupe, pp.133-134.

${ }^{1099}$ Cf. PIQUET, Jean-Daniel. L'émancipation des Noirs dans la Révolution française, p.219.
} 
verão de 1792, os Amigos dos Negros saíam, pela primeira e última vez, vitoriosos na luta contra o partido dos colonos. 


\section{II.1.5) Fim do antiescravismo sob a Revolução?}

\section{II.1.5.1) O apagamento dos Amigos dos Negros}

É curioso observar que a vitória de março de 1792 se deu num momento em que os Amigos dos Negros praticamente encerravam as suas atividades. Não se conhece exatamente a data do desaparecimento da primeira formação da Sociedade. O registro das suas sessões vai até 11 de junho de 1790, mas sabe-se que a sessão dessa data não foi a última. Sua extinção se deu lenta e progressivamente: entre o outono de 1791 e a primavera de 1792 , os traços de sua atividade se tornaram cada vez mais raros. ${ }^{1100}$ Os fatores para esse apagamento são diversos.

Em primeiro lugar, a entrada de Brissot e Condorcet na Assembleia, a eleição de Pétion como prefeito de Paris e a constituição de um ministério alinhado com o programa brissotino haviam transferido, em larga medida, a discussão de gabinete dos Amigos dos Negros para as esferas do poder, o que dava aos seus principais membros a possibilidade de agir mais diretamente junto aos representantes da Nação e aos membros do Executivo. ${ }^{1101}$ Nesse sentido, a integração da campanha dos Amigos dos Negros ao clube dos Jacobinos foi muito importante. Os fracassos iniciais de 1790 e 1791 levaram Brissot e seus aliados a compreender que o modelo da Sociedade dos Amigos dos Negros era inadequado para a preparação de intervenções parlamentares. Os Jacobinos compunham um espaço de discussão mais aberto e mais influente junto a diferentes esferas de opinião. ${ }^{1102}$ Antes de romper com o Clube, Brissot e seus aliados se valeram desse espaço para garantir apoio na esfera legislativa. Desde os últimos meses de 1791, Brissot estava no centro da arena política, como presidente dos Jacobinos e principal animador do grupo dos Girondinos. Isso lhe deu capital político suficiente para encaminhar o debate que levou à lei de 24 de março de 1792.

Deve-se, por outro lado, também ter em mente que a associação de Brissot aos Girondinos impunha limites ao avanço da campanha antiescravista. O combate pelos homens de cor chegou a bom termo na medida em que tinha sido possível conduzi-lo

\footnotetext{
${ }^{1100}$ Com o fim da Sociedade dos Amigos dos Negros, os papéis e registros da entidade ficaram com o seu fundador, Brissot. Posteriormente, em 1829, eles seriam comprados por François de Montrol, um dos principais agitadores da Sociedade Francesa pela Abolição da Escravidão, fundada em 1834.

${ }^{1101}$ Um dado interessante e pouco lembrado é que, em 1791, a Assembleia Nacional havia proscrito o direito de petição coletiva, de modo que os ataques ao tráfico e à escravidão pela via de um movimento institucionalizado ficavam prejudicados. A Sociedade só podia manifestar-se junto à Assembleia por meio de seus representantes eleitos.

${ }^{1102}$ Cf. PIQUET, Jean-Daniel. L'émancipation des Noirs dans la Révolution française, p.162.
} 
com base em argumentos capazes de convencer o comércio marítimo francês: a necessidade de aliar os homens de cor à defesa da ordem colonial contra a insurreição escrava e a necessidade de combater os projetos de autonomia dos colonos devedores. A lei de 24 de março teve, essencialmente, o sentido de unir antiescravistas e negociantes em torno da defesa do pacto colonial. Continuar avançando no programa antiescravista, entretanto, era mais problemático. A supressão do tráfico e a preparação da abolição gradual da escravidão, naquele contexto de insurreição nas colônias, eram causas muito mais difíceis de disseminar e, provavelmente, Brissot e seus aliados consideraram que a operação não era oportuna, ou mesmo viável.

Além disso, deve-se atentar para o fato de que os brissotinos estavam, desde o final de 1791, cada vez mais voltados para a campanha em favor da guerra. Com a declaração de guerra à Áustria-Prússia, em 20 de abril de 1792, o conflito com as potências europeias passou a ser o centro das atenções. Em 11 de julho de 1792, a Assembleia havia declarado a pátria em perigo! Na concepção dos Amigos dos Negros, a guerra com as potências deixava a causa abolicionista, uma causa internacional por natureza, em suspenso. Nesse sentido, também na Inglaterra, a declaração de guerra à França em 1793 promoveria uma ruptura dentro da corrente abolicionista, enfraquecida por conta da mobilização contrarrevolucionária. Assim, o voto do decreto de 24 de março de 1792 e talvez a nomeação dos comissários civis enviados a São Domingos podem ser vistos como as últimas expressões de atividade política por parte da Sociedade dos Amigos dos Negros. Após junho de 1792, o Patriote Français dedicaria pouco ou nenhum espaço às questões coloniais. A ironia é que os brissotinos não haviam se dado conta de que a guerra que tanto queriam seria um fator primordial para a abolição de fevereiro de 1794.

\section{II.1.5.2) A guerra entre Girondinos e Montanheses: a tese de um deslize da esquerda}

A campanha em favor da guerra determinou a ruptura progressiva do grupo de Brissot com os jacobinos alinhados com a Montanha. Esse processo culminou, no final de 1792, com a saída dos Girondinos do clube dos Jacobinos. O fato é que, para além das discussões sobre a guerra, havia um forte conflito ideológico entre as duas tendências. Ligados à burguesia dos negócios, os Girondinos eram adeptos das doutrinas econômicas liberais e contrários a qualquer tipo de intervencionismo estatal. 
Legalistas, eles se afirmaram como os defensores mais fervorosos do direito de propriedade, o que os colocava em oposição ao movimento popular, cujas reivindicações questionavam, senão a propriedade em si, pelo menos o seu uso irrestrito. A concepção social dos Girondinos era a de uma sociedade que uniria harmonicamente, de um lado, grandes proprietários e investidores e, de outro, uma massa de assalariados. Nesse sentido, eles entravam necessariamente em choque com os jacobinos da Montanha, cujo ideal de uma sociedade de pequenos proprietários e produtores independentes apontava para uma política de intervenção na vida econômica e limitação da propriedade privada. Ao igualitarismo puramente jurídico da Gironda, opunha-se o relativo igualitarismo socioeconômico da Montanha, que se aproximava mais das aspirações das massas parisienses. A radicalização do processo político, durante a Revolução, tornou a ruptura inevitável. ${ }^{1103}$

Esse rompimento foi marcado por uma onda de acusações recíprocas, nas quais as políticas respectivas de cada grupo foram sucessivamente questionadas perante a opinião pública. Nesse quadro, o ódio aos brissotinos fez com que os jacobinos embaralhassem as cartas: todas as ideias defendidas por Brissot tinham de ser condenadas e a causa dos negros estava muito associada ao seu nome. Com isso, Brissot viu o seu envolvimento na luta antiescravista ser usado como instrumento de acusação, o que alimentaria a tese, muito difundida na historiografia, de um deslize ideológico da esquerda revolucionária nas questões coloniais.

De fato, a partir do mês de dezembro de 1791, Brissot passou a ser o alvo de contínuos ataques dos meios patrióticos. No Ami du Peuple de 10 de dezembro, por exemplo, Marat criticou o líder dos Amigos dos Negros por sua hesitação em reconhecer, no seu discurso de 7 de dezembro, a concordata entre os brancos e os homens de cor do Oeste de São Domingos:

Assim, Senhor Brissot, quando um número considerável de vossos colegas vos solicita que desprezeis vossos deveres, que vendais os direitos de vossos concidadãos e que traiais a pátria, acreditais ser vosso dever deferir as suas solicitações. ${ }^{1104}$

1103 Cf. DORIGNY, Marcel. Les Girondins et Jean-Jacques Rousseau. Annales historiques de la Révolution française, Paris, n. 234: Jean-Jacques Rousseau. Pour le deuxième centenaire de sa naissance, 1978 pp.572-582. Disponível em: http://www.persee.fr/web/revues/home/prescript/article/ahrf_00034436_1978 num 234_1 1029. Acesso em: 16 de abril de 2012. SOBOUL, Albert. Histoire de la Révoltution Française, v.2, pp.319-324.

1104 "Ainsi, Monsieur Brissot, lorsqu'un nombre considérable de vos collègues vous solliciteront de fouler aux pieds vos devoirs, de vendre les droits de vos concitoyens et de trahir la patrie, vous croirez devoir déférer à leurs sollicitations" (L'Ami du Peuple, número 622, 10 de dezembro de 1791, v.6, p.3779). 
No que se refere especificamente aos Jacobinos, a tese do deslize tem por base um panfleto de Camille Desmoulins contra Brissot, publicado em 1792: Jean-Pierre Brissot démasqué. ${ }^{1105}$ A querela entre Desmoulins e Brissot não era nova. Já em maio de 1791, os dois tinham se envolvido num debate, por meio da imprensa: Desmoulins tinha atacado Brissot por suas acusações contra Barnave e Lameth, então dois membros importantes do clube dos Jacobinos; o líder dos Amigos dos Negros havia justificado as suas críticas com base na conduta dos deputados na discussão sobre os homens de cor. ${ }^{1106}$ Em fevereiro de 1792, o debate em torno da guerra levou o grupo robespierrista a uma ofensiva contra Brissot e seus aliados. Com isso, os esforços antiescravistas de Brissot foram usados como elemento de acusação, de modo a apresentar a campanha dos Amigos dos Negros como um detonador da revolta escrava nas colônias. Em seu panfleto, Desmoulins afirmava:

Eu sei que parte teve o poder executivo e a Espanha, e a contrarrevolução nos incêndios, nos massacres e nas devastações de São Domingos; mas não foi Brissot quem primeiro incendiou essas belas terras? Sim, Brissot, isso vos é impossível negar; pois nós vos havíamos alertado para esses males antes que eles ocorressem; nós vos havíamos perguntado se não tremíeis diante da terrível responsabilidade da qual vos encarregava vossa precipitação. Nós vos havíamos mostrado as chamas de Porto-Príncipe e do Cap, e não podeis alegar causa de ignorância. Sim, se tantas habitações encontram-se reduzidas às cinzas, se mulheres foram estripadas, se uma criança, levada na ponta de uma lança, serviu de estandarte aos negros, se os próprios negros morreram aos milhares, és tu, miserável, que foste a primeira causa de tantos males! $!^{1107}$

Demagogicamente, Desmoulins argumentava que Rousseau, para quem a liberdade teria sido demasiadamente cara se tivesse custado o sangue de um só homem,

\footnotetext{
${ }^{1105}$ Note-se o equívoco do título do planfleto: o nome do líder girondino era Jacques-Pierre e não JeanPierre.

${ }^{1106}$ Cf. Patriote Français, v.4, números 656, 657 e 659, 26, 27 e 29 de maio de 1791, pp.583, 586 e 595 596.

1107 "Je sais quelle part a eu le pouvoir exécutif et l'Espagne, et la contre-révolution aux incendies, aux massacres et aux dévastations de Saint-Domingue; mais n'est-ce pas Brissot qui a le premier incendié ces belles contrées? Oui, Brissot, il vous est impossible de le nier; car nous vous avions prédit ces maux avant qu'ils arrivassent; nous vous avions demandé si vous ne trembliez pas de l'affreuse responsabilité dont vous chargeait votre précipitation. Nous vous avions montré les flammes du Port-au-Prince et du Cap, et vous ne pouvez prétexter cause d'ignorance. Oui, si tant d'habitations sont réduites en cendres, si on a éventré les femmes, si un enfant, porté au bout d'une pique, a servi d'étendard aux noirs, si les noirs euxmêmes ont péri par milliers, c'est toi, misérable, qui as été la première cause de tant de maux!" (DESMOULINS, Camille. Jean-Pierre Brissot démasqué. In: BUCHEZ, Philippe-Joseph-Benjamin, ROUX-LAVERGNE, Pierre-Célestin. Histoire parlementaire de la Révolution française. Paris: Paulin, 1834-1838, v.13, p.205).
} 
teria adiado a questão dos negros para outros tempos, evitando assim esses resultados funestos. $^{1108}$

Para Yves Bénot, "esse texto é o sinal inquietante de um deslize da esquerda revolucionária sobre a questão colonial", motivado por uma oposição sistemática a todos as questões defendidas por Brissot. ${ }^{1109}$ Que palavras tenham sido proferidas contra os esforços de Brissot e os Amigos dos Negros em favor dos negros, é inegável, mas deve-se ter cautela ao medir a extensão ou até mesmo a existência desse "deslize".

Outro elemento sobre o qual se sustenta essa tese é a ligação dos Jacobinos com os colonos Pierre-François Page ${ }^{1110}$ e Augustin-Jean Brulley, dois pretensos representantes enviados por uma assembleia colonial que deixaria de existir em outubro de 1792. A Assembleia Nacional jamais questionou a sua representatividade e os seus comitês consultaram-nos sucessivamente como parte legítima da legislatura. Realistas convictos, Page e Brulley chegaram a Paris em julho de 1792. O curso dos eventos políticos motivou uma conversão pragmática ao republicanismo e uma aproximação estratégica dos meios jacobinos. A "atividade 'jacobina'" dos dois coloniais consistiu essencialmente em campanhas contra o seu inimigo número um, Brissot. ${ }^{111}$ Page assinou, por exemplo, Réflexions sur les colonies, um ataque direto aos "aristocratas da Gironda", liderados por Brissot, que queriam submeter as colônias ao despotismo. ${ }^{112}$ Os dois foram admitidos no clube em 25 de fevereiro de 1793, mas, segundo o seu próprio relato, eles teriam deixado de assistir as sessões dois meses depois, o que enfraquece a tese de que estariam por trás da ofensiva jacobina contra os Girondinos. ${ }^{113}$

A partir de abril de 1793, as tensões entre a Gironda e a Montanha, já bastante fortes desde o debate sobre a guerra, se agravaram. Os brissotinos, na sua tentativa de conter o processo de radicalização da Revolução, haviam atiçado a ira do movimento popular. Incitadas pelos robespierristas, as jornadas populares de 31 de maio - 2 de junho de 1793 levaram à prisão dos ministros Clavière e Lebrun-Tondu e de 29 deputados girondinos, dentre os quais Guadet, Gensonné, Lanjuinais, Vergniaud,

\footnotetext{
1108 Ibidem, pp.205-206.

${ }^{1109}$ Cf. BÉNOT, Yves. La Révolution française et la fin des colonies, p.153.

${ }^{1110}$ Page era um colono de Jérémie, em São Domingos, que tinha vindo a Paris em julho de 1792, com o objetivo de obter a sanção real para um decreto da assembleia colonial que proclamava a escravidão eterna. Posteriormente, tornou-se republicano e anti-brissotino, o que explica a sua evolução nos meios jacobinos (Ibidem, p.144).

${ }_{1111}$ Ibidem, pp.163-164.

1112 Cf. PAGE, Pierre-François. Réflexions sur les colonies. Paris: Imprimerie Potier de Lille, s.d.

${ }^{1113}$ Cf. PIQUET, Jean-Daniel. L'émancipation des Noirs dans la Révolution française, p.358.
} 
Pétion, Buzot e Brissot. O movimento antiescravista, na sua versão encarnada pelos Amigos dos Negros, tinha sofrido um golpe fatal.

Essa depuração detonou ainda uma verdadeira perseguição ao partido girondino, levando à prisão de mais de setenta outros deputados nas semanas seguintes. Assim, em razão de suas ligações com Brissot, os comissários civis enviados a São Domingos também foram incluídos entre os alvos da ofensiva antibrissotina. Em 8 de julho de 1793, ao apresentar à Assembleia o seu relatório sobre os girondinos presos em 2 de junho, Saint-Just apresentou Sonthonax e Polverel como parte do projeto de dominação brissotino: "A conjuração se estendia por toda a Europa. Ela agitava as colônias por meio de Santhonax e Polverelle (sic) que reinaram verdadeiramente em São Domingos". ${ }^{1114}$ Em 16 de julho, Bréard acusou os comissários de empregar as forças nacionais para operar a contrarrevolução e pediu que a sua acusação fosse decretada. Por razões claramente políticas, Billaud-Varenne apoiou a moção: "Esses comissários são as criaturas dos Brissot, dos Clavière, etc. Apoio o decreto de acusação". ${ }^{1115}$ Assim, em razão de suas conexões brissotinas, a Assembleia decretou a acusação de Polverel e Sonthonax. Victor Hugues foi oficialmente encarregado, em agosto de 1793, de executar o decreto de prisão dos comissários, embora a operação tenha sido abortada. Em 3 de setembro de 1793, o jacobino Jeanbon Saint-André usou o mesmo argumento, isto é, o vínculo brissotino, para pedir a aplicação do decreto de acusação contra os comissários. Acusou-os de federalismo, e apresentou os colonos brancos como vítimas dos negros e da tirania dos comissários. ${ }^{1116}$

Page e Brulley também exerceram a sua influência para obter a prisão de outros desafetos, como Leborgne, secretário dos comissários civis Polverel e Sonthonax, e o homem de cor Julien Raimond, ambos acusados de "brissotismo". Raimond seria preso em 27 de setembro de 1793. Na prisão, escreveu uma carta prestando homenagem a todos os que tinham defendido a causa dos homens de cor livres, dando destaque especial a Robespierre, no intuito de mostrar que a sua causa era compartilhada pela Gironda e pela Montanha. No fim, diante da ausência de provas contra ele e talvez por

\footnotetext{
1114 "La conjuration s'étendait dans toute l'Europe. Elle agitait les colonies par le moyen de Santhonax et Polverelle qui régnèrent véritablement à Saint-Domingue" (AP, v.68, p.434).

1115 "Ces commissaires sont les créatures et les agentes des Brissot, des Clavière, etc. J'appuie le décret d'accusation" (AP, v.69, p.39).

${ }^{1116}$ Cf. PIQUET, Jean-Daniel. L'émancipation des Noirs dans la Révolution française, pp.279-280.
} 
influência de Robespierre, Raimond e Leborgne não foram convocados perante o Tribunal Revolucionário. ${ }^{1117}$

Alguns montanheses chegaram a fazer algumas investidas em favor dos colonos, mesmo que sem grande sucesso. No início de outubro de 1793, por exemplo, dois relatórios referentes às colônias foram apresentados à Convenção: o de Martel e o de Amar, dois deputados ligados a Page e Brulley. No dia 2, Martel apresentou, em nome do comitê da marinha, um relatório sobre os colonos deportados, isto é, os que haviam fugido da guerra civil em São Domingos. Procurou inocentá-los como vítimas da política ditatorial dos comissários civis, que haviam provocado as divisões na colônia e incitado os negros a massacrar os brancos. Seu relatório foi, contudo, rejeitado. ${ }^{1118}$ No dia seguinte, Amar, do Comitê de segurança geral, apresentou um ato de acusação contra os girondinos enquanto autores de uma conspiração contra a unidade e a indivisibilidade da República. Brissot e seus aliados eram denunciados como agentes de uma facção inglesa cujo objetivo era desmembrar a França, o que implicava o seu império colonial. Assim, "sob o véu da filantropia", os Girondinos teriam operado, por meio dos comissários civis, seus cúmplices, os tumultos que levariam à perda das colônias. $^{1119}$

No interrogatório de Brissot, de 15 de outubro de 1793, a questão colonial foi invocada com a intenção de atribuir ao líder antiescravista os malogros das colônias. Perguntado se ele era responsável pelos problemas ocorridos em São Domingos, em razão das ideias que difundiu, Brissot respondeu negativamente, assim como negou ter conhecimento dos supostos abusos cometidos pelos comissários civis na colônia. Apenas admitiu ter recomendado aos ministros os nomes de Sonthonax, Polverel e Genet, que ele tinha por patriotas, para os cargos de comissários. ${ }^{1120}$ Brissot morreria guilhotinado em 31 de outubro de 1793, na praça da Concorde. Alguns dias antes de sua morte, escreveu que seu grande arrependimento era que a Revolução não tinha abolido a escravidão. $^{1121}$

Qual foi a posição assumida por Robespierre em meio aos acontecimentos? A sua oposição ferrenha ao partido brissotino e a utilização da questão colonial na

\footnotetext{
${ }^{1117}$ Ibidem, pp.293-294; PIOLLET, Sophie et alii. Milscent créole historien de la Révolution de SaintDomingue 1790-1794. In: GAUTHIER, Florence (org.). Périssent les colonies plutôt qu'un principe!, p.39.$$
{ }_{1118} \text { Cf. AP, v.75, pp.461-470. }
$$$$
1119 \text { Ibidem, pp.522-537. }
$$$$
{ }^{1120} \text { Cf. BRISSOT DE WARVILLE, Jean-Pierre. Correspondance et papiers, pp.380-381. }
$$$$
{ }^{1121} \text { Cf. THIBAU, Jacques. Le temps de Saint-Domingue, p.67. }
$$ 
ofensiva contra Brissot contribuiu para difundir a tese de um Robespierre avesso à luta antiescravista. Esse argumento resiste mal ao exame dos debates de maio e setembro de 1791, onde o jacobino fez causa comum com os Amigos dos Negros pela defesa dos homens de cor livres e contra a constitucionalização da escravidão. Alguns sustentam que a força das circunstâncias teria levado o líder montanhês a se afastar do combate dos Amigos dos Negros e até mesmo a condenar a sua causa como nociva aos interesses da Nação. ${ }^{1122}$ A maior evidência dessa guinada estaria no seu relatório de 17 de novembro de 1793, sobre a situação política da República, no qual traçou um quadro das repercussões da Revolução no mundo. Robespierre referia-se, de forma crítica, ao engajamento antiescravista dos brissotinos:

É assim que a mesma facção que na França queria reduzir todos os pobres à condição de hilotas, e submeter o povo à aristocracia dos ricos, queria, num instante, libertar e armar todos os negros para destruir nossas colônias. ${ }^{1123}$

A frase de Robespierre procurava ressaltar, como havia feito Desmoulins em maio de 1791, o caráter contraditório daqueles que defendiam os negros nas colônias, mas que relegavam os pobres da metrópole à condição de cidadãos de segunda classe. Ao mesmo tempo, a frase de Robespierre continha em si um equívoco: ela não condenava propriamente o antiescravismo da Gironda, mas a sua defesa de uma abolição imediata da escravidão, algo que os Amigos dos Negros haviam sempre rejeitado. Robespierre sabia disso. O fato é que as lutas políticas pela defesa da Revolução, que opuseram a esquerda às outras facções, embaralharam as cartas no que se referia aos assuntos coloniais, criando uma situação politicamente ambígua que os colonos souberam, por um momento, explorar.

Não se deve acreditar, portanto, numa guinada pró-escravista de Robespierre, que, mesmo em meio à ofensiva contra a Gironda, teve o cuidado de ressaltar o mérito de Brissot no seu combate pelos homens de cor. Quando o jacobino se opôs, em 1792

\footnotetext{
${ }^{1122}$ Cf. BIONDI, Jean-Pierre, ZUCARELLI, François. 16 pluviôse an II - Les colonies de la Révolution. Paris: Editions Denoel, 1988, p.189.

${ }_{1123}$ "C'est ainsi que la même faction qui en France voulait réduire tous les pauvres à la condition d'ilotes, et soumettre le peuple à l'aristocratie des riches, voulait en un instant affranchir et armer tous les nègres pour détruire nos colonies" (ROBESPIERRE, Maximilien. Oeuvres. Paris: Phénix éditions, 2000, v.10, pp.173-174). Alguns autores como Florence Gauthier e Jean-Daniel Piquet esforçaram-se em encontrar autores secundários por trás dessa famosa frase: Gauthier afirma em que seu verdadeiro autor teria sido César Duny, ao passo que, para Piquet, a frase poderia ser atribuída à influência de LarchevesqueThibaud. A discussão é estéril, pois, na medida em que Robespierre assinou o texto, supõe-se que ele concordasse com as opiniões nele manifestadas. No máximo, esses esforços conseguem sugerir aquilo que é certo: que os chefes Montanheses se viam, muitas vezes, obrigados a articular com diferentes grupos de pressão e estabelecer compromissos.
} 
ao belicismo dos Girondinos, ele empreendeu, no Défenseur de la Constitution de 31 de maio de 1792, pouco mais de um mês após a declaração de guerra, um balanço bastante negativo da ação dos Girondinos na Assembleia Legislativa. Contrariando o panfleto de Desmoulins, entretanto, ele apontou um elemento positivo: o combate zeloso dos Brissotinos pela igualdade entre brancos e livres de cor, que resultou na lei de 24 de março:

Eu lhes concedo graça, em nome da Humanidade, por terem defendido os direitos dos homens de cor livres de nossas colônias. Longe de imitar a injustiça daqueles que procuraram erros até nessa ação louvável em si mesma, eu me teria por culpado de ingratidão, se eu recusasse essa homenagem àqueles que fizeram triunfar a causa da humanidade que eu havia pleiteado por várias vezes na mesma tribuna. Pouco me importam os motivos quando os fatos são úteis ao bem geral. ${ }^{1124}$

Também vale lembrar que, no seu projeto de Declaração dos direitos, apresentado em 24 de abril de 1793, Robespierre, submetia o direito de propriedade à ética, e citava formas de exercício da propriedade que eram incompatíveis com o direito natural. Nesse sentido, ele mencionava o traficante de escravos, "esse mercador de carne humana", que tratava os homens empilhados a bordo de seu navio como propriedades invioláveis. ${ }^{1125}$

Mais tarde, Robespierre encorajaria o próprio Camille Desmoulins a atacar Cloots, no Le Vieux Cordelier de 20 frimário do ano II (10 de dezembro de 1793), apontando o seu passado de defensor da supremacia branca nas colônias:

Embora ele tenha entranhas de pai para todos os homens, Cloots as parece ter menos para os negros; pois, no passado, ele combatia por Barnave contra Brissot, no caso das colônias; o que demonstra uma flexibilidade de princípios e uma predileção pelos brancos pouco dignas do embaixador do gênero humano. ${ }^{1126}$

É certo que a causa abolicionista estava longe de ser uma prioridade para os líderes montanheses, mas deve-se evitar um exame superficial das fontes que deduza da

\footnotetext{
1124 "Je leur rend grâce, au nom de l'Humanité, d'avoir défendu les droits des hommes libres de couleur de nos colonies. Loin d'imiter l'injustice de ceux qui leur ont cherché des torts jusque dans cette action louable en elle-même, je me croirais coupable d'ingratitude, si je refusais cet hommage à ceux qui ont fait triompher la cause que j'avais plusieurs fois plaidée dans la même tribune. Peu m'importent les motifs quand les faits sont utiles au bien général" (citado em PIQUET, Jean-Daniel. L'émancipation des Noirs dans la Révolution française, p.155);

${ }^{1125}$ Cf. ROBESPIERRE, Maximilien de. Oeuvres, v.9, p.460.

1126 "Quoiqu'il ait des entrailles de père pour tous les hommes, Cloots semble en avoir moins pour les nègres; car, dans le temps, ils combattait pour Barnave contre Brissot, dans l'affaire des colonies; ce qui montre une flexibilité de principes et une prédilection pour les blancs peu dignes de l'ambassadeur du genre humain" (Le vieux Cordelier, número II, 20 frimário do ano II, pp.21-22).
} 
guerra entre as facções uma oposição sistemática da Montanha à causa dos negros. Prevaleceu na historiografia a ideia de que, com a morte de Brissot e o fim dos Amigos dos Negros, o antiescravismo sob a Revolução teria ficado "adormecido", como diz Bénot $^{1127}$, até ressurgir de forma abrupta com a lei de abolição de 16 pluvioso do ano II (4 de fevereiro de 1794). Essa posição é, como veremos em seguida, equivocada.

${ }^{1127}$ Cf. BÉNOT, Yves. La Révolution française et la fin des colonies, p.95. 


\section{II.2) Insurreicão escrava e impulso republicano: a superacão do gradualismo}

\section{II.2.1) A ascensão do abolicionismo radical}

Recentemente, historiadores como Jean-Daniel Piquet e Florence Gauthier dedicaram-se a mostrar a existência de uma forte opinião abolicionista durante o ano II, contrariando a tese de que, com o apagamento da primeira formação dos Amigos dos Negros, o antiescravismo na França revolucionária teria sido dissolvido. Essa visão permite afastar a interpretação segundo a qual a lei abolição de 4 de fevereiro de 1794 teria sido uma mera lei de circunstância. Piquet talvez tenha ido um pouco longe demais ao interpretar certas atitudes dos líderes jacobinos como manifestações de um abolicionismo militante. Como veremos adiante, as atitudes dos robespierristas foram demasiadamente ambíguas para que se possa adotar interpretações tão taxativas. A questão essencial talvez seja menos conhecer com exatidão as opiniões pessoais dos chefes do governo revolucionário do que compreender as condições objetivas que informaram as decisões políticas, condições estas que modificaram o campo de possibilidades dos agentes históricos. Nesse sentido, é necessário, acima de tudo, compreender que a República jacobina foi $\mathrm{o}$ espaço privilegiado para $\mathrm{o}$ desenvolvimento de uma corrente abolicionista alternativa ao modelo gradualista e parlamentar dos Amigos dos Negros. O elemento detonador dessa nova vertente antiescravista foi, é claro, a grande insurreição dos escravos em São Domingos.

Como vimos anteriormente, após o ceticismo inicial, as reações às notícias da revolta se dividiram entre, de um lado, acusações contra os Amigos dos Negros e, de outro, a reiteração de projetos em favor dos homens de cor livres. Brissot e seus aliados venceram a disputa, jogando a carta da unificação das diferentes camadas de proprietários coloniais pelo restabelecimento da ordem. O resultado foi a lei de 24 de março de 1792.

Naquele momento, os brissotinos, mais preocupados com a guerra na Europa do que com a luta antiescravista, praticamente abandonaram a questão dos escravos. Com isso, a campanha antiescravista se deslocou progressivamente para fora do círculo brissotino, o que lhe permitiu tomar outros rumos. Se as discussões parlamentares acerca da insurreição escrava tenderam, inicialmente, a se concentrar no exame dos meios de neutralização e repressão do levante, uma corrente alternativa começou a 
ganhar forma, vendo na luta dos escravos pela liberdade uma extensão da revolução do povo da metrópole.

\section{II.2.1.1) Alguns planos de abolição gradual}

É interessante observar que das notícias da insurreição negra em São Domingos os Amigos Negros não tiraram nenhuma conclusão quanto à necessidade de pôr fim à escravidão colonial. Sua única reação foi a de ressaltar a necessidade de reconhecer os direitos dos livres de cor, e isso tão somente como uma forma de restabelecer a ordem na sociedade escravista. Para os gradualistas, a revolta escrava apresentava-se como uma via ilegítima de libertação: ela tinha de ser contida antes que um processo de emancipação gradual pudesse ter início.

Contudo, de forma isolada, alguns projetos de emancipação gradual da escravidão, bastante próximos do programa dos Amigos dos Negros, apareceram nos meses seguintes à chegada das notícias da insurreição. Assim, em dezembro de 1791, um plano de abolição progressiva foi depositado por Matthieu Blanc-Gilli, deputado de Bouches-du-Rhône e negociante de Marselha. O deputado acusava a Assembleia de ter reduzido o seu exame da convulsão em São Domingos à disputa entre brancos e homens de cor, esquecendo a terceira classe que habitava a colônia, a dos escravos. ${ }^{1128}$ Para ele, se a condição dos escravos não fosse imediatamente melhorada, os recursos e os soldados enviados seriam inúteis. Blanc-Gilli não pregava a abolição da escravidão, mas uma melhoria das condições de existência dos cativos que lhes permitisse alcançar, a longo prazo, a liberdade. Suas propostas retomavam ideias-chave do gradualismo daquele final do século: a proibição dos castigos corporais por parte dos senhores (artigos I a V); medidas protetivas para escravos idosos ou enfermos (art.VI); a possibilidade para os escravos de comprarem sua alforria, sem qualquer imposto (art.VII); "libertação" dos filhos de escravos no nascimento, podendo, entretanto, os senhores exigirem deles serviços proporcionais até os doze anos, mediante alimentação, e até os 17 anos, mediante remuneração (art.VIII); libertação, no prazo de quatro anos, dos negros que já tinham servido como escravos por mais de quatro anos; emancipação dos novos escravos, após um prazo de oito anos (art.X). Seu projeto ainda concedia

\footnotetext{
${ }^{1128}$ Cf. BLANC-GILLI, Matthieu. Observations importantes sur les troubles de Saint-Domingue. Paris:
} Imprim. nationale, s.d.p.3. 
anistia a todos os revoltosos que retornassem às suas plantações no prazo de cinco dias, a contar da publicação da lei, excetuados aqueles culpados de assassinato (art.XIII). ${ }^{1129}$

O plano de Blanc-Gilli não foi sequer discutido na Assembleia, apesar da presença de Brissot, seus aliados girondinos e outros Amigos dos Negros. Alguns planos semelhantes foram publicados nos primeiros meses de 1792. Armand-Guy Kersaint, antigo senhor de escravos, publicou, em duas partes, o seu tratado Moyens proposés à l'Assemblée Nationale, pour rétablir la paix et l'ordre dans les colonies, que ele conseguiu apresentar na Assembleia. Ao contrário dos autores de muitos textos antiescravistas do início da Revolução, Kersaint, que não era dos Amigos dos Negros, não se preocupava mais em demonstrar o interesse econômico dos colonos na erradicação progressiva da escravidão; era agora uma questão de sobrevivência. Nesse sentido, as tentativas dos colonos de se aliarem a potências estrangeiras eram fúteis:

[os colonos] se enganam num ponto, digo, na esperança de escapar a esse perigo mudando de mestre; é mudando de princípios que eles salvarão sua vida e sua fortuna, e não pelos meios combinados da perseguição e do terror. ${ }^{1130}$

Kersaint já concebia, portanto, a possibilidade da vitória da insurreição e a necessidade de negociar com os vencedores. Para ele, só havia duas hipóteses:

A França pode conservar São Domingos cultivada por mãos livres; ela a perderá sem recursos se quiser perpetuar a servidão: no primeiro caso, ela terá produtos e consumidores; no segundo, ela consumirá, em troca de nada, muitos homens e muito dinheiro. ${ }^{1131}$

Para neutralizar a insurreição e evitar a guerra, era preciso extinguir progressivamente a escravidão. No seu sistema de emancipação graduada, pregava a liberdade imediata para os escravos artesãos contra o pagamento de uma contribuição para indenizar o seus respectivos senhores. Quanto aos demais, estabelecia uma diferença entre escravos nascidos na colônia e os nascidos na África. Os crioulos

\footnotetext{
${ }^{1129}$ Ibidem, pp.8-11.

1130 "[... ils se trompent en un point, je veux dire dans l'espoir d'échapper à ce danger en changeant de maître; c'est en changeant de principes qu'ils sauveront leur vie et leur forune, et non par les moyens combinés de la persécution et de la terreur" (KERSAINT, Armand-Guy. Suite des moyens proposés à l'Assemblée Nationale, pour rétablir la paix et l'ordre dans les Colonies. Paris: Imprimerie du Cercle Social, 1792, p.2).

1131 "La France peut conserver St. Domingue cultivé par des mains libres, elle le perd sans ressources en voulant y perpétuer la servitude: dans le premier cas, elle aura des produtis et des consommateurs; dans le second, elle consummera pour ne rien avoir, beaucoup d'hommes et beaucoup d'argent" (Ibidem, p.28).
} 
gozariam de uma liberdade condicional, devendo trabalhar por 10 a $20 \operatorname{anos}^{1132}$ antes de gozar da liberdade plena. Durante esse tempo, eles teriam o direito de comprar a própria alforria. Quanto aos boçais, incapazes de viverem autonomamente, eles seriam considerados como "crianças menores da pátria sob a tutela da lei", sendo protegidos até a sua emancipação, que poderia ser obtida após o exame de uma magistratura criada para este fim. Enquanto isso, os seus antigos senhores atuariam como "depositários". ${ }^{1133}$

Kersaint pregava ainda a concessão de incentivos ao trabalho e à reprodução da população negra. ${ }^{1134}$ Curiosamente, não pedia o fim do tráfico, mas apenas uma alteração de seu objeto: não seria mais um comércio de escravos, mas de cultivadores, que seriam educados para um dia tornarem-se homens livres, ideia que seria adotada por Toussaint na sua Constituição de São Domingos. ${ }^{1135}$ Kersaint propunha, aliás, estabelecer um novo sistema educacional, sem distinções de cor, em que as crianças negras seriam educadas ao lado de jovens brancos, destruindo o preconceito na sua origem. ${ }^{1136}$

$\mathrm{Na}$ mesma linha de Kersaint, Antoine-Jean Bonnemain publicou, em $1^{\mathrm{o}}$ de março de 1792, Régéneration des colonies, projeto escrito dois anos antes, na época em que tinha entrado para os Amigos dos Negros. Mas agora seu projeto era apresentado como um remédio à crise colonial. O sistema de emancipação gradual de Bonnemain era típico dos Amigos dos Negros, na sua vontade manifesta de conciliar o interesse dos plantadores com os dos escravos. Estabelecia a concessão dos direitos de cidadania aos livres de cor e a abolição do tráfico como medidas preparatórias à abolição gradual da escravidão. ${ }^{1137}$ No seu plano, todo escravo que tivesse exercido um trabalho útil por 18 anos - considerando que o trabalho útil tinha início aos 18 anos de idade - seria livre dentro de dois anos. Da mesma forma, todas as crianças nascidas durante a escravidão de sua mãe seriam declaradas livres aos 36 anos de idade. Bonnemain previa ainda um

\footnotetext{
${ }^{1132}$ Para os pais de família, estimava o prazo adequado em 10 anos para os maiores de 30 anos e em 15 anos para os menores de 30 anos. Para os solteiros, o prazo seria de 20 anos.

${ }_{1133}$ Cf. KERSAINT, Armand-Guy. Suite des moyens proposés à l'Assemblée Nationale, pp.39-41.

${ }^{1134}$ Propunha, por exemplo, que todo negro vindo da África, casado há mais de 10 anos, com uma horta em bom estado e seis crianças, teria direito a três dias livres por semana. Após 20 anos de casamento e com quatro filhos subsistentes, ele e sua esposa seriam considerados libertos; seus filhos o seriam aos 25 anos e seus netos seriam livres sem condições. Em contrapartida, um dever de cultivar as terras e valorizar as propriedades de seus antigos senhores seria imposto aos negros como uma "dívida para com a pátria".

${ }_{1135}$ Cf. KERSAINT, Armand-Guy. Suite des moyens proposés à l'Assemblée Nationale, pp.41-45.

1136 Ibidem, p.33.

${ }^{1137}$ Cf. BONNEMAIN, Antoine-Jean-Thomas. Régénération des colonies, p.63.
} 
sistema de recompensas, com diminuição da escravidão em razão de boa conduta e até mesmo libertação de escravas que gerassem um certo número de filhos. ${ }^{1138}$

Julien Raimond, líder do movimento dos cidadãos de cor, também se manifestou num sentido semelhante. Entendia que, agora que os direitos dos homens de cor livres tinham sido satisfeitos, era o momento de se ocupar da massa dos escravos negros, de modo a vinculá-los à Revolução. Sabia que não seria possível derrotar os insurretos e restabelecer a ordem escravista tal como ela existia antes. Ao mesmo tempo, como plantador e senhor de escravos, Raimond rejeitava a abolição imediata.

Em Réflexions sur les véritables causes des troubles et des desastres de nos colonies (publicado no início de 1793), Raimond mostrava-se fiel ao princípio gradualista, e lançava aos escravos em revolta a seguinte pergunta: "Acharíeis justo que a nação recompense com a liberdade todos os crimes e devastações que cometestes?". ${ }^{1139}$ Para ele, o caos nas colônias favorecia as intenções da Inglaterra, cujas posses na América não lhe forneciam muitas produções. A melhor forma de frustrar os planos dos ingleses era emitir leis justas e vantajosas para todos os que compunham a população das colônias, para que todos os indivíduos, livres ou escravos, estivessem interessados na sua defesa. Isso significava "[...] reaproximar os escravos do estado de liberdade, de modo que possam atingi-lo sem abalos e unicamente pelos meios que a lei lhes oferecerá". ${ }^{1140}$ Os escravos tinham de ser convencidos de que a sua condição não seria melhor sob outro governo. Dentro da ideia de que indivíduos mantidos no estado de servidão tinham de ser educados para a liberdade, Raimond propunha que uma proclamação fosse feita aos escravos, para que retornassem ao trabalho, na espera das leis que fossem regenerá-los. ${ }^{1141}$ Acreditava que aquele que não tinha propriedade não podia respeitar a propriedade alheia. Assim, a primeira medida a ser tomada era a de garantir aos escravos os meios legais de adquirir e conservar uma propriedade. E a primeira propriedade a ser adquirida era a da sua própria pessoa. A lei tinha de fixar a soma exata a ser paga por cada escravo em troca de sua liberdade e, mais do que isso, tinha de colocar os cativos em condições de obter essa soma, assim como de comprar

\footnotetext{
${ }^{1138}$ Ibidem, pp.77-80.

1139 "Trouveriez-vous juste vous-mêmes que la nation recompensât par la liberté tous les crimes et les dévastations que vous avez commis?" (RAIMOND, Julien. Réflexions sur les véritables causes des troubles et des désastres de nos colonies. Paris: Imprimerie des Patriotes, 1793, pp.23-24).

1140 "[...] rapprocher les esclaves de l'état de liberté, en sorte qu'ils puissent y arriver sans secousses et par les seuls moyens que la loi leur offrira" (Ibidem, pp.11-13).

${ }^{1141}$ Ibidem, pp.19-20.
} 
porções de liberdade até completar o valor total. ${ }^{1142}$ Para reunir tais valores, os escravos teriam três horas por dia para trabalhar em benefício próprio. Raimond propunha, assim, apenas uma ampliação da economia própria do escravo.

Esses textos reiteravam, com algumas variações, os planos de abolição gradual publicados no final da década de 1780. A diferença é que, agora, eles eram apresentados como um meio de restabelecer a ordem nas colônias e fazer frente à ameaça britânica. Contudo, naquele momento, eles surtiram pouco efeito. A situação exigia medidas emergenciais e não planos de execução sucessiva. Nenhum desses projetos foi discutido na Assembleia, e isso num momento em que a influência de Brissot era particularmente forte. Para a parcela moderada dos deputados, a questão colonial estava resolvida com o reconhecimento dos direitos dos cidadãos de cor. Nos meios patrióticos mais avançados, entretanto, o problema colonial começava a ser encarado sob um novo prisma.

\section{II.2.1.2) A insurreição negra na imprensa patriótica: os primeiros sinais de uma evolução}

Antes de outubro de 1791, a perspectiva de uma insurreição geral dos escravos nas colônias era vista, tanto pelos escravistas como pelos seus adversários, como um mal a ser impedido de todas as formas. O debate se dava essencialmente em torno dos meios pelos quais era possível prevenir a perda das colônias: para uns, era preciso decretar a autonomia das colônias em relação ao regime constitucional instaurado na metrópole, para que as instituições que permitiam manter a ordem colonial fossem preservadas; para outros, o único meio de salvar as colônias era fazer com que passassem lenta e progressivamente para um regime compatível com os princípios da Nação francesa. A insurreição dos negros de São Domingos apareceu como um divisor de águas. Aquilo que todos apresentavam como uma ameaça longínqua tinha se tornado uma realidade e se, para muitos, a questão era examinar que remédios deveriam ser aplicados àquela situação, para os espíritos mais avançados, a insurreição já inaugurava uma nova era na história do império colonial francês. Os sinais dessa evolução já

\footnotetext{
${ }^{1142}$ Raimond sugeria o valor de 3 mil libras para os escravos masculinos, de 14 a 40 anos, e de 2,6 mil libras para as escravas de 12 a 26 anos. Cada ano a mais importaria uma redução de 100 libras. Escravos que tivessem algum talento especial custariam um preço maior (4 mil libras), para compensar os gastos com sua formação. Uma soma de 250 libras (no caso dos homens) ou 200 libras ( no caso das mulheres) permitiria a obtenção de meio-dia de liberdade por semana (Ibidem, p.24).
} 
estavam presentes no relato que alguns órgãos da chamada "imprensa patriótica" fizeram da revolta.

Assim, ao comentar as reações na metrópole às notícias da insurreição, a Chronique de Paris, de $1^{\circ}$ de novembro de 1791 ( $\left.{ }^{\circ} 305\right)$, apresentou a troca de acusações entre os plantadores e os Amigos dos Negros como algo infrutífero. A razão da desordem das colônias não estava nos decretos da Assembleia, como alegavam os dois campos, mas pura e simplesmente nas injustiças cometidas contra os negros. Se a insurreição era algo a ser temido, o artigo afirmava: "[...] nossa dor é semelhante à dos nossos tiranos, quando viram cair as torres de nossas bastilhas". ${ }^{1143}$

$\mathrm{O}$ autor entendia que a questão não era o impacto dos escritos dos publicistas ou dos projetos dos legisladores franceses, que os negros não tinham lido e nem eram capazes de compreender. A razão estava nas sucessivas crueldades sofridas pelos negros nas mãos de seus opressores: as "guerras suscitadas pela avareza sanguinária dos brancos", a perda de seu lar, a separação de sua família, os horrores da travessia... Para o escravo, "[...] nada pode suprimir a lembrança do dia em que foi vendido a um senhor bárbaro; a dos males que ele sofre desde então; dos males que ainda o aguardam!". ${ }^{144}$ Com isso, o jornal restituía à insurreição negra a sua autonomia, desvinculando-a de teorias conspiratórias mirabolantes. Os insurretos não lutavam para concretizar um plano de destruição ou de independência das colônias; lutavam por si próprios.

De acordo com o autor, os negros em revolta apenas estavam cumprindo o mais santo dos deveres: o de insurreição. Se muitos brancos podiam morrer, isso não era nada comparado aos milhões de negros mortos na escravidão: "a cor da pele é diferente, é verdade, mas a cor do sangue não é a mesma?". Se apoiava o envio de tropas, o jornal não queria que estas se tornassem um instrumento de opressão. Uma vitória da insurreição não era apresentada como algo ruim. Livres, os antigos escravos poderiam trabalhar como camponeses, contra um salário. Nesse processo, os colonos ganhariam menos dinheiro, mas o comércio colonial seria mantido. ${ }^{1145}$

Posições radicais também foram manifestadas por Chaumette no jornal Les Révolutions de Paris, bastante popular entre a sans-culotterie. Chaumette, que desempenhou um papel central na formação dessa nova corrente antiescravista,

\footnotetext{
1143 "[...] notre douleur est semblable à celle de nos tyrans, quando ils ont vu tomber les tours de nos bastilles" (Chronique de Paris, v.4, número 305, $1^{\circ}$ de novembro de 1791, p.1228).

1144 "[...] rien ne peut anéantir le souvenir du jour où il a été vendu à un maître barbare; de celui des maux qu'il endure depuis; de celui des maux qui l'attendent encore!" (Ibidem, p.1228).

1145 "la couleur de la peau est diferente, il est vrai, mais la couleur du sang n'est-elle pas la même?" (Ibidem, pp.1228-1229).
} 
conhecia bem as questões coloniais, devido a uma experiência passada como marinheiro ${ }^{1146}$, que o tinha levado a participar da guerra de independência norteamericana e a conhecer São Domingos de perto. ${ }^{1147}$

Sua reação inicial à notícia do levante escravo foi a de atribuí-lo à não-execução do decreto de 15 de maio de 1791, favorável aos livres de cor. Nesse sentido, apresentou a insurreição dos negros como uma espécie de vingança contra o martírio de Ogé: "o teu suplício atroz não terá sido em vão para os seus irmãos! Ei-los que se inscrevem também na lista dos povos que, custe o que custar, querem firmemente ser livres". ${ }^{1148}$ Assim, a revogação do decreto de 15 de maio teria servido para provocar a insurreição e precipitar a independência de 500 mil negros. Em relação à possibilidade de perder as colônias, Chaumette parafraseava a famosa frase eternizada por Robespierre, mas agora com um outro sentido:

pois sim! Pereçam! sim, pereçam trinta mil brancos empanturrados de ouro, de vícios e de preconceitos, antes que nossos trinta mil mulatos, dos quais nossa constituição fará cidadãos estimáveis; antes que quinhentos mil negros igualmente dispostos a se tornarem homens, a despeito da cor. ${ }^{1149}$

Chaumette via na vingança dos negros e dos mulatos o sinal de uma revolução semelhante à que tinha ocorrido na metrópole. Para ele, as mesmas causas tinham de provocar os mesmos resultados. A insurreição dos negros era a extensão da Revolução francesa nas colônias: "O que nós fizemos no continente, os insulares de cor se propõem hoje a tentar, e eles devem conseguir. Eles têm para si o clima, o número, as forças e motivos ainda maiores do que os nossos". ${ }^{1150}$ Chaumette pregava o envio de comissários e tropas às colônias, mas não para reprimir os insurretos, mas para protegê-los da artilharia dos colonos brancos. Pediriam apenas aos negros que poupassem a vida dos brancos e preservassem as plantações, para que pudessem então cultivá-las por sua

\footnotetext{
${ }^{1146}$ Chaumette atuou como marinheiro por 13 anos, entre 1776 e 1782.

1147 Cf. BÉNOT, Yves. La Révolution française et la fin des colonies, p.126.

1148 "ton supplice atroce n'aura point été perdu pour tes frères! les voilà aussi que s'inscrivent, à leur tour, sur la liste des peuples qui, à tel prix que ce soit, veulent fermement être libres" (Les Révolutions de Paris, v.10, número 121, 29 de outubro - 5 de novembro de 1791, p.215).

1149 "eh bien! périssent! oui, périssent trente mille blancs gorgés d'or, de vices et de préjugés, plutôt que nos trente mille mulâtres, dont notre constitution va faire tout autant de citoyens estimables; plutôt que cinq cent mille nègres tout disposés à devenir des hommes, à la couleur près" (Ibidem, p.215).

1150 "Ce que nous avons fait sur le continent, les insulaires de couleur se proposent aujourd'hui de le tenter, et ils doivent réussir. Ils ont pour eux le climat, le nombre, les forces, et plus de motifs encore que nous" (Ibidem, p.217).
} 
conta, dirigidos pelos homens de cor. ${ }^{1151}$ Não propunha a independência das colônias, mas um novo pacto entre a metrópole e os negros e mulatos das colônias.

No número seguinte das Révolutions de Paris (5-12 de novembro de 1791), Chaumette continuou a traçar os paralelos entre as duas revoluções. Dedicou-se a denunciar a solicitude com que o rei e a rainha tinham recebido os colonos do Clube Massiac: "é justo que o rei, que carrega no seu coração os aristocratas dos dois mundos, gema com os colonos sobre as perdas que sofreram, e não dê maior atenção aos negros fuzilados no Cap do que aos patriotas assassinados no altar da pátria". ${ }^{1152} \mathrm{Na}$ medida em que os colonos e a realeza apareciam unidos como parte de um complô contrarrevolucionário, as revoluções da metrópole e a das colônias apareciam como duas faces de uma mesma moeda.

O jornal rompia categoricamente com os planos de abolição graduais típicos da Sociedade dos Amigos dos Negros. O número de 26 de novembro - 3 de dezembro de 1791 comentava, nesse sentido, a campanha da Sociedade, procurando defendê-la das calúnias dos colonos, mas criticando, ao mesmo tempo, os limites de seu programa:

Os amigos dos negros são os amigos da humanidade, são filósofos, filantropos a quem a humanidade e a filantropia têm uma crítica a fazer, a de não terem sido suficientemente humanos e filantropos. Que sejam lidos todos os escritos dessa sociedade de sábios, e nós desafiamos a provar que ela tenha publicado uma só linha em favor da liberdade atual dos negros. A sociedade dos amigos dos negros soube sacrificar os suaves impulsos de seu coração aos preconceitos de seu país; ela se impôs o mais profundo silêncio sobre a condição desses pobres Africanos, da escravidão dos quais se têm falado a sangue-frio. A sociedade dos amigos dos negros sustentou apenas uma opinião, a da liberdade política dos homens de cor livres [...]. ${ }^{1153}$

No número de 7-14 de abril de 1792, as Révolutions de Paris acentuaram as críticas aos Amigos dos Negros, lamentando que, após a vitória de 24 de março de 1792, relativa aos direitos dos mulatos, eles ainda não tivessem se manifestado sobre o

\footnotetext{
${ }^{1151}$ Ibidem, pp.220-221.

1152 "il est juste que le roi, qui porte dans son coeur les aristocrates des deux mondes, gémisse avec les colons sur les pertes qu'ils ont essuyées, et ne prenne pas plus garde aux noirs fusillés au Cap, qu'aux patriotes égorgés sur l'autel de la patrie" (Les Révolutions de Paris, v.10, número 122, 5-12 de novembro de 1791, p.243).

1153 "Les amis des noirs sont les amis de l'humanité, sont des philosophes, des philantropes à qui l'humanité et la philantropie ont même un reproche à faire, celui de n'avoir été ni assez humains ni assez philantropes. Qu'on lise tous les écrits de cette société de sages, et nous défions de prouver qu'elle ait publié une seule ligne en faveur de la liberté actuelle des nègres. La société des amis des noirs a su sacrifier les tendres élans de son coeur aux préjugés de son pays; elle s'est imposé le plus profond silence sur le sort de ces malheureux Africains, de l'esclavage desquels on vient nous parler de sang froid. La société des amis de noirs n'a soutenu qu'une opinion, celle de la liberté politique des hommes libres de couleur [...]" (Idem, v.10, número 125, 26 de novembro - 3 de dezembro de 1791, pp.386-387)
} 
tráfico e a escravidão. Chaumette atacava duramente o princípio gradualista, que se baseava na ideia de que os negros tinham de ser educados para tornarem-se dignos da liberdade:

Os preconceitos do comércio, o hábito do despotismo, a calúnia dos colonos brancos, fizeram com que até mesmo bons espíritos pensassem que os negros não estavam maduros para a liberdade, que era preciso prepará-los e conduzi-los a ela por degraus; mas a insurreição das colônias, a emancipação de fato dos negros lhes ensinaram mais em 6 meses do que um catecismo constitucional e metafísico teria feito em seis anos. ${ }^{1154}$

Chaumette não era propriamente favorável a uma independência das colônias, até porque entendia que cabia à França proteger os patriotas (de cor) da fúria sanguinária dos colonos contrarrevolucionários. Entendia, contudo, a necessidade de reformular os laços entre a metrópole e as colônias, unindo-as por uma espécie de pacto federativo. Posições ainda mais radicais seriam defendidas por Marat, no Ami $d u$ Peuple.

Marat tinha defendido anteriormente ideias muito semelhantes às dos Amigos dos Negros em relação à escravidão. Em maio de 1791, ao comentar a lei do dia 15 sobre os homens de cor, ele havia proposto um plano de emancipação gradual, bastante próximo dos princípios defendidos por Brissot e seus aliados:

O seu primeiro cuidado devia ser de passar aos colonos brancos e mestiços as melhores obras contra a escravidão e suavizar a crueldade da condição dos infelizes a ela condenados. Deveriam então ter tido o cuidado de instruílos, de ordenar todo ano a alforria de um certo número de escravos e fazer com que esse ato de justiça fosse usado para recompensar aqueles que mais teriam se aplicado para merecê-lo. Enfim, se tivessem julgado conveniente conceder alguma indenização aos proprietários desses infelizes que servem de bestas de carga no novo mundo, eles a teriam encontrado, seja na isenção de certos impostos por um tempo determinado, seja em certas somas pagas para cada alforriado $[\ldots]{ }^{1155}$

\footnotetext{
1154 "Les préjugés du commerce, l'habitude du despotisme, la calomnie des colons blancs, avaient fait penser, même à de bons esprits, que les nègres n'étaient pas mûrs pour la liberté, qu'il fallait les préparer et les y conduire insensiblement par degrés; mais l'insurrection des colonies, l'émancipation de fait des nègres, leur en ont plus appris depuis 6 mois qu'un catéchisme constitutionnel et métaphysique n'aurait fait pendant six ans" (Idem, v.12, número 144, 7-14 de abril de 1792, pp.57-58).

1155 "Leur premier soin devait donc être de faire passer aux colons blancs et métis les ouvrages les mieux faits contre l'esclavage et d'adoucir la cruauté du sort des malheureux qui y sont condamnés. Ils auraient dû ensuite prendre soin de les instruire, d'ordonner chaque année l'affranchissement d'un certain nombre d'esclaves et de faire servir cet acte de justice à récompenser ceux qui se seraient le plus appliqués à le mériter. Enfin, s'ils avaient jugé convenable d'accorder quelque indemnité aux propriétaires de ces infortunés qui servent de bêtes de somme dans le nouveau monde, ils l'auraient trouvée, soit dans l'exemption de certains impôts pour un temps déterminé, soit dans certaines sommes payées pour chaque affranchi [...]" (L'Ami du Peuple, v.5, número 462, 18 de maio, pp.2891-2892).
} 
Contudo, a partir da chegada das notícias do levante, suas posições sofreram uma sensível evolução. Inicialmente, ele procurou, assim como Brissot, apresentar a insurreição como o resultado da obra da Assembleia Constituinte, que tinha falhado em reconhecer os direitos dos homens de cor livres. Assim, na edição de 2 de novembro de 1791 do Ami du Peuple, afirmou:

Eis a obra da facção dos pais conscritos constituintes, e, sobretudo, da prostituição de Barnave, que, de concerto com o ministro da Marinha, retardaram o envio das forças que deveriam garantir a execução do decreto de 25 de maio [sic], e deram todo o tempo aos colonos brancos de exercerem impunemente a sua tirania sobre os homens de cor e os negros, de reduzi-los ao desespero e de forçá-los a pegar em armas para a sua própria salvação. ${ }^{1156}$

Marat sustentava então que o plano do gabinete ministerial era incitar, por meio de agentes secretos, os povos à insurreição, forçando a Assembleia a autorizar continuamente o uso da força pública para restabelecer a ordem. O objetivo seria acostumar o exército e os guardas nacionais a seguirem as ordens do Executivo. Mas Marat alertava que essa política não funcionaria contra os homens de cor e os negros das colônias e estas seriam rapidamente reduzidas a "um deserto coberto de ruínas e amontoados de cinzas". ${ }^{1157}$ Esperava apenas que os oprimidos exercessem a sua vingança unicamente contra os colonos culpados e que "[...] as propriedades dos Lameth, dos Saint-Méry, dos Motier e de todos os celerados que se opuseram ao decreto de 15 de maio tenham sido as primeiras das que foram reduzidas a cinzas". ${ }^{1158} \mathrm{Na}$ sua conclusão, Marat depositava as suas esperanças nos excessos da tirania, que forçaria finalmente os povos a se armarem contra os seus opressores.

Em números posteriores, Marat assumiria uma postura ainda mais radical. No Ami du Peuple de 12 de dezembro, a sua opinião sobre a questão colonial aparecia reformulada. Agora, não se tratava mais de apurar as responsabilidades em relação ao caos em São Domingos, mas de questionar a legitimidade do estatuto colonial, em nome do direito dos povos à autodeterminação. Marat defendia o "direito que têm nossas colônias de abalar o jugo tirânico da metrópole". Os habitantes das colônias constituíam

\footnotetext{
1156 "Voilà l'ouvrage de la faction des pères conscrits constituants, et surtout de la prostitution de Barnave, lesquels, de concert avec le ministre de la Marine, ont retardé le départ des forces qui devaient assurer l'exécution du décret du 25 mai, et ont donné tout le temps aux colons blancs d'exercer impunément leur tyrannie sur les hommes de couleur et les noirs, de les réduire au désespoir et de les pousser à prendre les armes pour leur propre salut" (Idem, v.6, número 588, 2 de novembro de 1791, p.3592).

${ }^{1157}$ Ibidem, p.3592.

1158 "[...] les habitations des Lameth, des Saint-Méry, des Motier et de tous les scélérats qui se sont opposés au décret du 15 mai et qui ont provoqué la révocation, soient à la tête de celles qui ont été réduites en cendres" (Ibidem, p.3594).
} 
um povo absolutamente separado dos habitantes da França, sobre o qual esta não podia ter nenhum direito, seguindo a ideia de que "o fundamento de todo governo livre é que nenhum povo está submetido de direito a outro povo, que ele não deve ter leis outras que as que ele deu a si mesmo [...]". ${ }^{1159}$

Assim, a supremacia da metrópole sobre as colônias se devia apenas ao direito do mais forte, marca do despotismo. Mas essa defesa que Marat fazia da independência das colônias não era uma defesa das políticas conduzidas pelos colonos brancos desde o início da Revolução. O autor fazia, assim, uma importante ressalva:

Do fato que nossas colônias têm o pleno direito de se emanciparem da metrópole, não concluais que penso dar ganho de causa aos colonos brancos. Sim, sem dúvida, eles são inexcusáveis aos meus olhos por terem querido se erigir em senhores despóticos dos mulatos e em senhores tirânicos dos negros. Se as leis da natureza são anteriores às das sociedades, e se os direitos do homem são imprescritíveis, aquele que os colonos brancos têm em relação à nação francesa, os mulatos e os negros têm em relação aos colonos brancos. Para abalar o jugo cruel e vergonhoso sob o qual eles gemem, eles estão autorizados a empregar todos os meios possíveis, até mesmo a morte, se tiverem de ser reduzidos a massacrar até o último de seus opressores. ${ }^{1160}$

Não era apenas uma justificação da insurreição negra. Era a condenação da própria existência do pacto colonial e uma defesa da independência das colônias nas mãos dos negros e dos homens de cor. Nas palavras de Marat, a insurreição dos escravos em São Domingos era parte de um processo maior de emancipação dos povos do jugo do despotismo. Nesse ponto, essa posição, livre de contradições, permaneceu excepcional mesmo no quadro do abolicionismo radical, no seio do qual a abolição tendia a ser defendida como um meio de conservação das colônias.

De qualquer forma, todas essas manifestações, inseridas em veículos de imprensa amplamente difundidos entre as massas populares, permitiam criar um vínculo ideológico entre as duas revoluções. Para o povo da metrópole, a luta dos negros pela liberdade começava a evocar a sua própria experiência revolucionária.

\footnotetext{
1159 "Le fondement de tout gouvernement libre est que nul peuple n'est soumis de droit à un autre peuple, qu'il ne doit avoir d'autre lois que celles qu'il s'est données à lui-même [...]" (L'Ami du Peuple, v.6, número 624, 12 de dezembro de 1791, pp.3787-3788).

1160 "De ce que nos colonies sont en plein droit de s'affranchir de la métropole, n'allez pas conclure que je songe à donner gain de cause aux colons blancs. Oui, sans doute, ils sont inexcusables à mes yeux d'avoir voulu s'ériger en maîtres despotiques des mulâtres et en maîtres tyranniques des noirs. Si les lois de la nature sont antérieures à celles des sociétés et si les droits de l'homme sont imprescriptibles, celui qu'ont les colons blancs à l'égard de la nation française, les mulâtres et les noirs l'ont à l'égard des colons blancs. Pour secouer le joug cruel et honteux sous lequel ils gémissent, ils sont autorisés à employer tous les moyens possibles, la mort même, dussent-ils être réduits á massacrer jusqu'au dernier de leurs oppresseurs" (Ibidem, p.3788).
} 


\section{II.2.1.3) A popularização da causa antiescravista}

Como aponta Jean-Daniel Piquet, esse processo de radicalização das ideias foi acompanhado de um esforço de difusão da causa antiescravista em esferas onde, até então, ela tinha pouca penetração. Nesse sentido, havia, por parte dos abolicionistas mais avançados, uma vontade de finalmente envolver as massas camponesas no debate colonial. Um exemplo dessa tendência pode ser identificado na publicação do Almanach du Père Gérard, no início de 1792. Essa obra pedagógica, composta por Jean-Marie Collot d'Herbois, tinha sido escolhida por um júri jacobino para difundir entre a população, sobretudo a dos campos, os valores da Constituição. E, ao fazê-lo, contribuiria para informar a população camponesa sobre a situação nas colônias.

O abade Grégoire tinha o projeto de difundir, por meio da publicação de panfletos didáticos, as ideias patrióticas nos campos franceses. Assim, a seu pedido, em 19 de setembro de 1791, o clube dos Jacobinos organizou um concurso de almanaques, para o qual seis jurados foram escolhidos: Condorcet, Clavière, Lanthenas, Polverel e Dussaulx, além do próprio Grégoire. Os três primeiros eram, ao lado de Grégoire, membros ativos dos Amigos dos Negros e Polverel, que seria um dos escolhidos de Brissot para a comissão civil de São Domingos, já tinha manifestado a sua postura antiescravista ao pedir, em 25 de setembro de 1791, que todos os que tivessem votado a favor da lei de 24 de setembro fossem excluídos dos Jacobinos. Dos 42 almanaques apresentados, o escolhido foi o de Collot d'Herbois. ${ }^{1161}$

Embora o objetivo fosse louvar os valores da Constituição, o texto expressava as dificuldades dos Jacobinos em defender uma Constituição que continha contradições com os valores universais inscritos na Declaração dos direitos. Era uma Constituição feuillante, o que implicava, para os Jacobinos, alguns desacordos. O personagem escolhido por Collot d'Herbois era o deputado Michel Gérard, um dos nomes da Liste des députés qui ont voté pour l'Angleterre contre la France de maio de 1791. Na obra, por meio de uma conversa de Gérard com um camponês, Collot inseria uma denúncia da escravidão dos negros. Se Gérard se apresentava como um advogado da Constituição de 1791, ele não deixava de atacar a manutenção do despotismo nas ilhas, o que incluía a escravidão.

${ }^{1161}$ Cf. PIQUET, Jean-Daniel. L'émancipation des Noirs dans la Révolution française, p.162-164. 
Assim, em determinada passagem, Gérard, ao explicar ao camponês o que era a Nação, afirmava: "[...] a nação não é apenas composta de cidadãos ativos; ela o é por todos os Franceses, quaisquer que sejam a sua religião, o seu estado e a sua cor". O camponês perguntava então: "Os negros também pertencem, portanto, à nação?". Gérard respondia afirmativamente, explicando que, na França, só existiam homens livres e que não havia cores para as virtudes. Ao que o camponês retrucava: "Dizem que não é a mesma coisa nas ilhas da América". Gérard respondia:

Sim, alguns homens de espírito disseram, na assembleia nacional, que a política queria que houvesse escravos na América; esses falastrões são verdadeiros demônios, com a sua política. Quanto a mim, sou apenas um homem simples; não pude compreendê-los; assim mesmo, puderam manter os escravos de ultramar. Felizmente, o decreto não proíbe de amar os bons negros, e sempre que eu os encontrar, eu os amarei. De resto, é da minha opinião que os oradores que defendiam tão firmemente o despotismo dos brancos foram furiosamente obscurecidos na opinião pública. ${ }^{1162}$

O Almanach foi um enorme sucesso editorial, com oito edições em poucos meses. Em resposta à popularidade da obra de Collot d'Herbois, os meios aristocráticos de Coblentz compuseram e publicaram o Almanach de l'abbé Maury. O texto reconhecia que os negros eram franceses e tinham o direito à liberdade, mas afirmava que, na medida em que não tinham a educação, os usos e costumes dos brancos, a liberdade seria para eles um verdadeiro "flagelo". Assim, o texto submetia o gozo da liberdade a uma preparação que tornasse os negros "capazes de fazer um bom uso dela". ${ }^{1163}$ Isso era significativo, pois tratava-se de uma retomada do princípio da emancipação gradual, antes rejeitado pelo campo colonial. Mas, agora, o gradualismo era usado para fins dilatórios, o que traduzia a evolução do antiescravismo e o fortalecimento da ideia de uma abolição imediata da escravidão.

O mesmo esforço de popularização da questão negra entre o campesinato foi empreendido pela Feuille Villageoise. Tratava-se de um periódico semanal, fundado por

\footnotetext{
1162 "[...] la nation n'est pas seulement composée des citoyens actifs; elle l'est de tous les Français, quel que soit leur religion, leur état et leur couleur"; "Les nègres sont donc aussi de la nation"; "On dit que ça n'est pas de même aux îles d'Amérique?"; "Oui, quelques hommes d'esprit ont dit, à l'assemblée nationale, que la politique voulait qu'il y ait des esclaves en Amérique; ces beaux parleurs là sont de vrais démons, avec leur politique. Moi, je ne suis qu'un homme simple; je n'ai pu les comprendre; tant y a que les esclaves outre-mer leur sont restés. Heureusement le décret ne défend pas d'aimer les bons nègres, et partout où j'en trouverai, je les aimerai. Au reste, m'est avis que les orateurs qui plaidaient si fort pour le despotisme des blancs se sont furieusement noirci dans l'opinion publique" (COLLOT-D'HERBOIS, Jean-Marie. Almanach du Père Gérard, pour l'année 1792. Paris: de l'Imprimerie du Patriote François, 1792, pp.27-28).

${ }^{1163}$ Cf. Almanach de l'abbé Maury, ou Réfutation de l'almanach du Père Gérard, couronné par la Société des Amis de la monarchie. Coblenz: chez tous les libraires royalistes, s.d., pp.151-152.
} 
Joseph-Antoine Cerutti, em setembro de 1790, em Paris, com o objetivo de informar o povo dos campos franceses a respeito dos fatos políticos e das leis votadas na capital, assim como esclarecer o mundo rural a respeito de seus direitos e deveres patrióticos. Enviado aos vilarejos da França inteira, o periódico passou a incluir em suas edições artigos sobre os problemas coloniais, no intuito de difundir os valores antiescravistas entre os camponeses. No número 41, de 5 de julho de 1792, a Feuille Villageoise trouxe um longo texto intitulado Sur l'esclavage des Noirs ${ }^{1164}$, destinado a apresentar um panorama da escravidão colonial sob a forma de uma ficção que relatava as peripécias de Aza, um escravo fugitivo. O drama do personagem permitia dar aos leitores um quadro detalhado dos horrores do tráfico e da escravidão: da captura na África às crueldades sem limites dos colonos brancos, passando pelas condições subumanas da travessia, o relato de Aza cobria todos os aspectos do problema.

Em passagem com toques shakespearianos, Aza recebia a visita do fantasma do pai, que lhe pedia vingança contra os brancos. Decidido a reencontrar a liberdade perdida, Aza optava por fugir e juntar-se aos marrons. Três anos depois, recebia a notícia de que os negros da ilha em que se encontrava estavam em revolta. O motivo era a recusa dos brancos em executar a lei pela qual uma "nação generosa" tinha reconhecido os direitos civis dos filhos dos negros livres, uma referência ao decreto de 15 de maio de 1791. Os brancos teriam redobrado as crueldades contra os escravos, levando-os à revolta contra o estado de opressão. Aza e os marrons decidiam juntar-se aos insurretos, não para participar da carnificina, mas para mostrar-lhes as "virtudes que nem os tiranos, nem os escravos conhecem". Capturado em combate, o herói se via preso numa embarcação espanhola. Estirado ao chão após uma tentativa de tomar o navio, Aza era libertado por um jovem oficial francês que, comovido pela sua coragem, ainda lhe entregava as suas pistolas, uma imagem que simbolizava a união dos patriotas franceses e dos insurretos negros. Não apenas a insurreição era justificada, mas pregavase ainda uma aliança dos povos livres contra a tirania. $\mathrm{O}$ texto se encerrava com a seguinte pergunta: "não deve a insurreição ser sempre o fruto da tirania, e o sangue inocente ser vingado?". 1165

Opiniões abolicionistas dessa ordem também apareciam em panfletos e memoriais mais longos. Autor da lei de 28 de setembro de 1791, que tinha decretado a

\footnotetext{
${ }^{1164}$ Não se sabe quem é o autor do texto, mas sabe-se que Lanthenas, um amigo dos Negros, colaborava com o jornal.

${ }^{1165}$ Cf. La Feuille Villageoise, $2^{\circ}$ ano, $4^{\mathrm{a}}$ parte, número 41, 5 de julho de 1792, pp.342-352.
} 
abolição da escravidão e a igualdade dos negros e pessoas de cor no território francês, o jacobino Dubois-Crancé publicou, no início de 1792, Le véritable portrait de nos législateurs. O panfleto, que procurava fazer um balanço da obra da Constituinte por meio de um quadro biográfico de seus membros, abordava os temas coloniais. O autor atacou violentamente os proprietários coloniais absenteístas, associando-os, a exemplo de Chaumette, à aristocracia contrarrevolucionária:

Desde o início da revolução, existe uma cabala astuciosamente urdida por conspiradores profundos, e que vinculam aos seus interesses a causa do rei, a dos aristocratas e, no geral, de todos os descontentes.

Essa cabala é a dos proprietários plantadores residentes na França, infectados pelo duplo veneno de sua pretensa nobreza na Europa e do horrível direito de servidão que exercem sobre os seus semelhantes na América. ${ }^{1166}$

O objetivo desses indivíduos - os colonos do clube Massiac - era tornar as colônias independentes para perpetuar o regime de opressão nelas existente. DuboisCrancé tampouco poupava os plantadores domiciliados nas próprias colônias, que, para livrarem-se das imensas dívidas contraídas junto ao comércio francês, queriam tornar-se independentes sob a proteção da Inglaterra. ${ }^{1167}$

Para o autor, a causa da insurreição negra não estava na propaganda dos Amigos dos Negros, mas na crueldade dos senhores, que haviam levado os seus escravos ao desespero. Dubois-Crancé lançava um virulento ataque contra os colonos, defendendo a insurreição: "Morram, carrascos de vossos irmãos! o céu e a terra o exigem; mais ferozes que os abutres, é justo que, enfim, vós lhes servis de pasto! Não esperem de nós nem piedade, nem socorros, não sois de nossa espécie!". ${ }^{1168}$

Em novembro de 1792, outro jacobino, o deputado Joseph Lequinio publicou Les préjugés détruits, dedicando o capítulo XVI exclusivamente à questão dos escravos. $\mathrm{O}$ autor manifestou uma postura antiescravista que também rompia com a moderação dos Amigos dos Negros. Com efeito, Lequinio mostrava-se bastante reticente quanto aos métodos de abolição gradual:

\footnotetext{
1166 "Depuis le commencement de la révolution il existe une cabale astucieusement ourdie par des conspirateurs profonds, et qui lient à leurs intérêts la cause du roi, celle des aristocrates, et généralement de tous les mécontents. Cette cabale est celle des propriétaires planteurs demeurant en France, infectés du double venin de leur prétendue noblesse en Europe, et du droit affreux de servitude qu'ils exercent sur leurs semblables en Amérique" (DUBOIS-CRANCÉ, Edmond-Louis-Alexis. Le véritable portrait de nos législateurs. Paris: s.n., 1792, p.95).

${ }^{1167}$ Ibidem, pp.96-97.

1168 "Mourez, bourreaux de vos frères! le ciel et la terre le demandent; plus féroces que les vautours, il est juste enfin que vous leur serviez de pâture! N'attendez de nous ni pitié, ni secours, vous n'êtes pas de notre espèce!" (Ibidem, p.99).
} 
Que se prepare para a liberdade, por meios suaves, e de longa mão, essa multidão de homens desafortunados que a novidade de sua condição poderia talvez levar a excessos, se passassem subitamente para esse estado feliz tão diferente do seu, é uma precaução contra a qual não me elevarei, muito embora ela ainda pareça resultar demais da pusilanimidade e da má-fé. ${ }^{1169}$

Ou seja, com o advento da insurreição negra, o autor entendia que uma proposta de abolição apenas gradual da escravidão, em princípio não condenável, podia assumir o caráter de estratégia dilatória. Lequinio legitimava plenamente a insurreição dos negros de São Domingos, com base no direito de resistência à opressão:

o escravo que rompe suas correntes, onde quer que seja, resiste à opressão; ele retoma seus direitos usurpados e só pode ser acusado por um pérfido. Se a resistência à sua libertação for tanta que, para livrar-se, ele seja obrigado a massacrar o seu tirano, ele ainda estará exercendo o seu direito. ${ }^{170}$

Fazendo uma emotiva exaltação da unidade da espécie humana ${ }^{1171}$, Lequinio não se limitava a justificar a revolta dos escravos das colônias; ele conclamava para uma insurreição de todos os escravos da terra contra os seus opressores. Isso incluía os povos submetidos a uma "servidão menos exata", isto é, os povos submetidos ao despotismo absoluto dos chefes que os governavam. ${ }^{1172}$ A luta dos escravos de São Domingos aparecia como parte desse grande processo de luta contra a opressão.

Esse movimento editorial em favor da popularização da causa dos negros logo foi acompanhado de algumas propostas concretas. Assim, no início de 1792, na esteira das primeiras reações sobre a insurreição em São Domingos, uma petição anônima em favor da abolição foi publicada. $\mathrm{O}$ autor ${ }^{1173}$ entendia que era importante que a opinião pública, e não apenas as partes diretamente interessadas, se envolvesse nesse debate.

1169 "Que l'on prépare à la liberté, par des moyens doux, et de longue main, cette multitude d'hommes infortunés que la nouveauté de leur sort pourrait porter à des excès, peut-être, s'ils passaient subitement à cet état heureux si différent du leur; c'est une précaution contre laquelle je ne m'élèverai pas, quoiqu'elle me paraisse tenir encore trop et de la pusillanimité même et de la mauvaise foi" (LEQUINIO, Joseph. Les préjugés détruits. Paris: Imprimerie Nationale, 1792, p.152).

1170 "l'esclave qui rompt sa chaîne, en quelque lieu que ce soit, resiste à l'oppression; il reprend ses droits ravis et ne peut être inculpé que par un fourbe. Si la résistance à sa libération se trouve telle, que pour se délivrer il soit contraint de massacrer son tyran, il use encore de son droit" (Ibidem, p.153).

${ }^{1171}$ O autor afirmava: "Sou homem, e a terra é a minha pátria; não conheço a espécie humana pelo tamanho ou pela cor, e o sangue de um europeu não é mais precioso para mim do que o sangue de um asiático; o sangue de um branco não me é mais precioso que o de um vermelho ou que o de um mulato ou de um negro; o homem escravo ainda é o meu irmão" ("Je suis homme, et la terre est ma patrie; je ne connais l'espèce humaine ni à la taille, ni à la couleur, et le sang d'un européen n'est pas plus précieux pour moi que le sang d'un asiatique; le sang d'un blanc ne m'est pas plus précieux que le sang d'un rouge ou que celui d'un mulâtre ou d'un noir; l'homme esclave est toujours mon frère"; Ibidem, p.154).

1172 Ibidem, p.155 e 157.

1173 Para Piquet, o autor talvez seja Blanc-Gilli (cf. PIQUET, Jean-Daniel. L'émancipation des Noirs dans la Révolution française, p.213). É uma possibilidade, pois o texto da Petição fazia referência a uma petição anterior, de dezembro de 1791. Blanc-Gilli havia, de fato, apresentado um projeto antiescravista naquela época. 
Para ele, à luz da legislação francesa, não havia mais como tolerar a existência da escravidão, mesmo fora da metrópole: "[...] Franceses, não percais de vista que a questão não pode ser a de saber se os Negros são livres ou escravos; se a Declaração dos Direitos do Homem subsiste, eles são livres de direito, ou vós não sois". ${ }^{1174}$ Vendo na Declaração dos direitos o "ato de sua emancipação", o anônimo pedia que os negros fossem declarados livres pela Assembleia.

É preciso observar, entretanto, que a petição não pregava propriamente o fim do tráfico de escravos, mas a sua conversão em "tráfico de Negros a título de simples alistamento", uma espécie de alistamento voluntário. O engajamento do Negro comportaria três fases: uma como aprendiz, durante a qual não receberia salário; uma como companheiro, durante a qual o seu salário seria regulado para o reembolso do Estado ou do particular que custeou o tráfico; e uma como veterano, durante a qual o seu salário seria guardado até atingir uma soma necessária para que fosse transportado de volta ao seu país e pudesse viver entre os seus com certo conforto; se decidisse permanecer na colônia, o valor de seu transporte lhe seria entregue em plena propriedade. $^{1175}$

Além disso, embora defendesse o fim da escravidão, o anônimo rejeitava a ideia de atribuir aos negros a qualidade de cidadãos franceses, acreditando que isso seria transformar colônias francesas em "Colônias Negras". Ao se tornarem livres, os negros não ficariam isentos da obrigação de trabalhar para pagar a "dívida" que teriam contraído para com a Nação. ${ }^{1176}$ Ou seja, embora falasse em romper com o regime da escravidão, o autor não pretendia, com isso, atacar o sistema colonial como um todo. A abolição era pensada nos termos da continuidade da grande produção que alimentava o comércio colonial francês. Nesse sentido, o plano prenunciava, em certa medida, os sistemas de trabalho compulsórios que seriam instituídos após a abolição de fevereiro de 1794, como veremos na terceira parte desta tese.

\section{II.2.1.4) Milscent: o modelo de uma evolução}

\footnotetext{
1174 "[...] Français, ne perdez pas de vue qu'il ne peut être question de sçavoir (sic) si les Noirs sont libres ou esclaves; la Déclaration des Droits de l'Homme subsistant, ils sont libres de droit, ou vous ne l'êtes pas" (cf. PÉTITION ampliative en faveur des Blancs et des Noirs. S.1. [Paris]: s.n., s.d. [1791], p.2).

1175 Ibidem, pp.10-11.

${ }^{1176}$ Ibidem, pp.5-6.
} 
Milscent é um personagem que merece ser estudado à parte, na medida em que traduziu melhor do que ninguém a evolução da consciência antiescravista ao longo da Revolução. Alinhado, inicialmente, com os modelos gradualistas pregados pelos Amigos dos Negros, ele evoluiu, a partir do advento da insurreição dos negros de São Domingos, para um abolicionismo em sentido estrito.

Claude Michel Louis Milscent de Mussé, ou simplesmente Milscent, nascido em São Domingos por volta de 1740, tinha sido capitão da maréchaussée, unidade encarregada de reprimir movimentos de escravos marrons na colônia. Após um período de treze anos na Nova-Inglaterra, retornou à ilha, tornando-se eleitor e membro da assembleia provincial do Cap-Français, assim como comandante das milícias patrióticas do bairro da Grande Rivière. Vítima de calúnias após ter defendido publicamente a Declaração dos direitos do homem, ele foi forçado a deixar São Domingos em 2 de junho de 1790, para instalar-se em Angers, ao lado de sua esposa mulata, Marie Anne Bonne Courtois. ${ }^{1177}$

Na metrópole, ele se envolveu ativamente nos debates relativos às colônias. Sob a Constituinte, no quadro da discussão sobre os homens de cor livres, Milscent se pronunciou sobre o tema na redação do Creuset, jornal que fundou em julho de $1791 \mathrm{e}$ que funcionou até 21 de setembro do mesmo ano. Chegou a enviar, sob o pseudônimo de Michel Mina, "mulato livre de São Domingos", uma longa petição à Assembleia, para denunciar o estado de opressão em que viviam os livres de cor em São Domingos. Milscent alertou para os perigos da segregação de uma classe da qual dependia a segurança da colônia. ${ }^{1178}$ Como antigo capitão da maréchaussée, ele sabia disso melhor do que ninguém. Durante a campanha que precedeu o debate de maio de 1791, ele teria desempenhado um papel importante na busca do apoio dos jacobinos das províncias à causa das pessoas de cor livres. ${ }^{1179}$

A notícia da insurreição dos escravos em São Domingos levou Milscent a publicar, em 31 de outubro de 1791, Sur les troubles de Saint-Domingue, um ensaio sobre as origens e as razões desses eventos que apenas os homens de cor livres teriam sido capazes de prevenir e apenas eles podiam fazer cessar. Milscent valia-se da sua experiência na repressão do marronnage para apontar a importância dos mulatos na

1177 Cf. PIOLLET, Sophie et alii. Milscent créole historien de la Révolution de Saint-Domingue, p.23. Dictionnaire des gens de couleur, p.279-280.

${ }^{1178}$ Cf. [MILSCENT, Claude]. Adresse à l'Assemblée Nationale par les hommes de couleur libres de Saint-Domingue. S.1.: s.n., 1791, p.11.

${ }^{1179}$ Cf. GEGGUS, David Patrick. Haitian Revolutionary Studies, p.166. 
manutenção da ordem colonial. Dava exemplos concretos, extraídos de seu passado como comandante de milícia, da capacidade dos homens de cor de enfrentar bandos de escravos rebeldes. Ao mesmo tempo, argumentava que, nas colônias, as notícias de pequenas rebeliões costumavam ser distorcidas e exageradas, de modo que, a exemplo de Brissot, mantinha-se cético quanto à extensão da insurreição que tinha explodido em agosto de 1791. Não acreditava na possibilidade de um agrupamento de 50 mil negros. Para ele, podia ser apenas mais um caso de marronnage, usado como pretexto pelos colonos para fazer revogar o decreto de 15 de maio. Acreditava ainda que os escravos teriam aproveitado as injustiças cometidas contra os homens de cor, os únicos capazes de persegui-los nas montanhas de São Domingos, para iniciar a rebelião. ${ }^{180}$

Se a sua reação inicial à revolta foi apenas pregar o reconhecimento dos direitos de cidadania dos mulatos, como meio de restabelecimento da ordem, Milscent logo procurou associar a defesa dos homens de cor a um plano de reforma do sistema escravista. Em Du Régime Colonial, concluído em 18 de dezembro de 1791 e publicado no início do ano seguinte, ele afirmou que, para restaurar a ordem nas colônias, não bastava fazer justiça para com os homens de cor livres, armando-os contra os escravos; era preciso também suavizar a condição destes. Os escravos que eram bem tratados pelos seus senhores não tinham participado da revolta, de modo que melhorar a condição dos escravos nas colônias permitiria neutralizar o perigo de novos levantes. ${ }^{1181}$ O texto incluía, em anexo, propostas para melhorar o estado dos negros, como a redução dos castigos corporais, a concessão de maior liberdade para o lazer e o favorecimento do casamento entre a escravaria. Para o autor, a melhor forma de vincular o escravo ao interesse de seu senhor era dar-lhe uma propriedade, isto é, a possibilidade de trabalhar em seu próprio benefício nas horas vagas, e vender o produto de sua labuta, para, um dia, poder comprar a própria liberdade. O senhor seria beneficiado por esse sistema, pois o seu escravo teria uma motivação concreta para trabalhar e aumentar a sua produtividade. Milscent acreditava que, em média, os escravos teriam cerca de 60 ou 70 anos quando tivessem reunido o valor necessário à sua alforria. ${ }^{1182} \mathrm{Ou}$ seja, naquele momento, Milscent, como muitos outros, limitava-se a propor a ampliação da economia

\footnotetext{
${ }^{1180}$ Cf. MILSCENT, Claude. Sur les troubles de Saint-Domingue. Paris: Imprimerie du Patriote François, 1791, pp.4-13.

${ }^{1181}$ Idem. Du régime colonial, pp.23-24.

${ }^{1182}$ Ibidem, pp.29-31.
} 
própria do escravo. Não reconhecia qualquer legitimidade à revolta dos escravos. Aos poucos, entretanto, ele passou a manifestar posições muito mais radicais. ${ }^{1183}$

Entre 21 de setembro de 1792 e 21 de fevereiro de 1793, Milscent abordou as questões coloniais em seu novo jornal, o Créole Patriote. ${ }^{1184}$ Se nos primeiros números, o jornalista mantinha a sua posição em favor de uma abolição apenas gradual, no final de 1792, os seus artigos já manifestavam uma sensível evolução. De 23 de dezembro daquele ano até 21 de fevereiro de 1793, o Créole Patriote serviu de órgão oficial da Sociedade dos Amigos da Liberdade e da Igualdade (novo nome dos Jacobinos), tornando-se um dos periódicos mais apreciados pela sans-culotterie. ${ }^{1185}$ Justamente nessa época, Milscent começou a dar sinais de uma evolução. No número de 26 de dezembro, pronunciou-se sobre as causas dos problemas nas colônias:

Nós quisemos não apenas gozar entre nós e exclusivamente das vantagens dessa revolução, mas ainda publicá-las abertamente, diante de nossos escravos que suportavam tão impacientemente o jugo da servidão. Em todos os lugares e a todo momento, tínhamos na boca as palavras: liberdade, igualdade ou a morte, e queríamos que os nossos negros fossem insensíveis a elas! ${ }^{1186}$

Milscent acreditava que uma volta dos escravos à servidão tal como ela existia no antigo regime já não era mais possível. Sustentava a urgência de um plano de emancipação. Embora ainda rejeitasse uma abolição abrupta, entendia que os escravos deveriam ter representantes nas assembleias primárias, para dar a sua opinião sobre a questão. Acreditava que isso permitiria estabelecer as bases de um pacto entre os livres e os escravos, que sentiriam que a sua existência estaria "[...] imediatamente submetida à dependência absoluta da pátria mãe". ${ }^{1187}$

Em 8 de fevereiro de 1793, Milscent sustentou a impossibilidade de uma ação militar em São Domingos contra os negros em revolta, cujo exército não cessava de crescer. Pregou o uso de "forças morais" para restabelecer a ordem, como o

\footnotetext{
${ }^{1183}$ Apesar de sua moderação na época, Milscent já era execrado pelos colonos de São Domingos, que o viam como traidor. As sucessivas acusações feitas contra ele levaram-no a publicar Justification de M. Milscent, Créole, à l'Assemblée Coloniale de S. Domingue.

${ }^{1184}$ Inicialmente denominado Revue du Patriote, o jornal ganharia o nome de Créole Patriote em 27 de junho de 1792.

${ }^{1185}$ Cf. PIQUET, Jean-Daniel. L'émancipation des Noirs dans la Révolution française,p.235-236.

1186 "Nous avons voulu, non seulement jouir entre nous et exclusivement, des avantages de cette révolution, mais encore les publier au grand jour, devant nos esclaves qui supportaient déjà si impatiemment le joug de la servitude. Partout et sans cesse, nous avions à la bouche les mots: liberté, égalité ou la mort, et nous voulions que nos nègres y fussent insensibles!" (Le Créole Patriote, número 192, 26 de dezembro de 1792, p.772).

${ }^{1187}$ Ibidem, p.772.
} 
oferecimento de uma remuneração aos negros em troca de seu trabalho. ${ }^{1188}$ No número seguinte, Milscent teve a ousadia de publicar uma carta, de julho de 1792, dos chefes da revolta negra à assembleia geral, aos comissários nacionais e aos cidadãos da parte francesa de São Domingos. A carta, assinada por Biassou, Jean-François e Belair, falava de: "[...] uma feliz revolução que ocorreu na Pátria Mãe e que nos indicou o caminho que nossa coragem e nossos trabalhos saberão nos fazer percorrer para chegar ao templo da Liberdade, como esses bravos Franceses que são nossos modelos [...]" (itálico no original). Pediam, em nome da Declaração dos direitos do homem, a liberdade geral de todos os homens mantidos na escravidão. ${ }^{1189}$

Essa carta provavelmente marcou o momento em que a insurreição escrava incorporou a abolição da escravidão como objetivo primordial. A sua publicação também sugeria uma mudança de postura de Milscent, em favor da abolição. No número de 11 de fevereiro, Milscent louvou a justiça e a moderação das demandas dos negros. ${ }^{1190}$ Em 13 de fevereiro, voltou a sustentar que o trabalho dos negros das colônias deveria ser assalariado: "[...] abolida a escravidão de fato, restará à convenção apenas a honra de abolir o seu título [...]". ${ }^{1191}$ Para Milscent, a abolição da escravidão aparecia, cada vez mais, como a única forma de conservar as colônias. Diante da impossibilidade de conter a insurreição e a ameaça britânica, a salvaguarda do império dependia da associação das massas negras à Nação francesa.

Por razões financeiras, após o 21 de fevereiro de 1793, Milscent foi obrigado a abandonar o Créole Patriote, mas conseguiu um espaço no Bulletin des Amis de la Vérité, jornal do abade Fauchet, um convencional girondino ${ }^{1192}$, onde escreveu uma dúzia de artigos sobre as colônias, numa coluna chamada, justamente, Le Créole Patriote. Apesar de escrever para um jornal girondino, Milscent manteve a mesma linha de argumentação, com um questionamento do princípio da abolição gradual da escravidão. No número 55, de 23 de fevereiro de 1793, manifestou-se a respeito da

\footnotetext{
${ }^{1188}$ Idem, número 280, 8 de fevereiro de 1793, p.1140.

1189 "[...] une heureuse révolution qui a eu lieu dans la Mère Patrie et qui nous a frayé le chemin que notre courage et nos travaux sauront nous faire gravir pour arriver au temple de la Liberté comme ces braves Français qui sont nos modèles [...]" (Idem, número 282, 9 de fevereiro de 1793, pp.1147-1148).

${ }^{1190}$ Idem, número 285, 11 de fevereiro de 1793, p.1159.

${ }^{1191}$ Idem, número 289, 13 de fevereiro de 1793, p.1175.

${ }^{1192}$ Milscent tinha se tornado um dos principais alvos do partido colonial, que o via como um traidor. Por influência de Page e Brulley, que ele tinha atacado em seus artigos, Milscent seria excluído dos Jacobinos, em dezembro de 1793. O pretexto para a sua exclusão foi o fato de ter trabalhado no jornal girondino Bulletin des Amis de la Vérité.
} 
impossibilidade da coexistência da França livre com uma constituição escravista para as colônias:

poderão os nossos irmãos de armas, que abalaram o despotismo, manter-se, assim, entre dois princípios tão opostos, defender duas constituições tão contrárias, e lutar incessantemente, com uma das mãos, contra a escravidão, e com a outra, em sua defesa? ? $^{193}$

Para Milscent, era preciso que os princípios da Nação fossem propagados por todo o império, abafando, assim, "os gritos de alguns homens cegamente cúpidos", que não mediam esforços "para conservar uma imensidão de braços à sua tirânica disposição e à sua criminosa indolência". ${ }^{1194}$ No número de 2 de março, Milscent dedicou-se a provar que o retorno à escravidão era agora impossível, rejeitando até mesmo o gradualismo que, um dia, havia defendido:

É preciso, dizem algumas pessoas, e eu mesmo acreditei nisso, enquanto ainda havia tempo para isso, é preciso conduzi-los insensivelmente à liberdade por uma transição suave e insensível; isso porque, acrescenta-se, libertá-los abruptamente seria expor as colônias a uma suspensão súbita de trabalhos e de receitas, e talvez a uma violenta comoção, sem falar dos mendigos que desolarão as colônias. [...] Esse raciocínio é enganoso; veremos que as alegações sobre as quais se sustenta não têm mais fundamento. Deve-se, antes, examinar se é possível impedir que os escravos recuperem a sua liberdade; em seguida, tratar-se-á de saber se suas tentativas, mesmo quando infrutíferas, não acarretarão resultados desastrosos, e se os custos da guerra perpétua que, nesse caso, ter-se-á de conduzir contra eles, não excederão todos os sacrifícios momentâneos que fariam os plantadores se consentissem que fossem livres desde já. ${ }^{195}$

Em números ulteriores, Milscent admitiu a possibilidade de uma ruína momentânea das plantações, após a emancipação geral, mas acreditava que ela seria compensada pela eliminação dos gastos com a compra dos escravos. ${ }^{1196}$ Para atenuar os efeitos da emancipação sobre as plantações, entendia que a Convenção tinha de garantir

\footnotetext{
1193 "nos frères d'armes, qui ont bouleversé le despotisme, pourront-ils se tenir ainsi entre deux principes si opposés, défendre deux constitutions si contraires, et lutter sans cesse d'une main contre l'esclavage, et de l'autre pour le conserver?" (Bulletin des Amis de la Vérité, número 55, 23 de fevereiro de 1793, p.3).

${ }^{1194}$ Ibidem, p.3.

1195 "Il faut, disent d'autres personnes, et moi-même je l'avait pensé, lorsqu'il ne pouvait être temps encore, il faut les amener insensiblement à la liberté par une transition douce et insensible; parce que, ajoute-t-on, les affranchir brusquement, c'est exposer les colonies à une suspension subite de travaux et de revenus, et peut-être à une violente commotion, sans parler des mendiants qui désoleront les colonies [...] $\mathrm{Ce}$ raisonnement n'est que spécieux; l'on verra que les allégations dont il est étayé n'ont pas plus de fondement. Il faut d'abord examiner s'il est possible d'empêcher que les esclaves recouvrent leur liberté: ensuite il s'agira de savoir si leurs tentatives, lors même qu'elles seraient infructueuses, n'entraîneront pas des suites désastreuses, et si les frais de la guerre perpétuelle qu'il faudra en ce cas se résoudre à leur faire, n'excéderont pas tous les sacrifices momentanés que feraient les planteurs en consentant qu'ils fussent libres dès ce moment" (Idem, número 62, 2 de março de 1793, p.3).

${ }^{1196}$ Idem, número 68, 8 de março de 1793, p.2.
} 
aos proprietários o trabalho durante um prazo determinado, sugerindo, assim, um sistema de trabalho compulsório, mas remunerado. ${ }^{1197}$ Acreditava que os negros, ao se tornarem livres, sentiriam a necessidade de continuar trabalhando, de modo que as plantações não ficariam privadas de mão de obra. ${ }^{198} \mathrm{Em}$ suma, ao contrário de Brissot $^{1199}$, Milscent, um antigo adepto do gradualismo, tinha se rendido, em função da insurreição dos negros de São Domingos, à ideia de uma abolição geral e imediata da escravidão. Tratava-se de uma adesão, até certo ponto, ideológica, mas motivada por uma apreciação bastante realista da situação colonial: não era mais possível reconduzir os negros ao estado de servidão.

\section{II.2.1.5) Os homens de cor na luta abolicionista}

Essa evolução das mentalidades também repercutiu na formação de uma corrente dos cidadãos de cor favorável à abolição. Como vimos anteriormente, o movimento conduzido por Julien Raimond combateu pelos direitos de cidadania dos homens de cor livres, apresentando-os como proprietários zelosos e a melhor barreira contra a revolta escrava nas colônias. No máximo, fazia esporadicamente uma defesa da supressão gradual da escravidão, seguindo a linha defendida pelos Amigos dos Negros. Em janeiro de 1793, Raimond ainda rejeitava categoricamente uma abolição geral e imediata da escravidão, pregando apenas a sua supressão gradual. Paralelamente, entretanto, alguns homens de cor e negros livres residentes na metrópole passaram a reforçar a corrente abolicionista radical. A legislação revolucionária tinha reconhecido a sua plena cidadania e o seu direito de petição, o que lhes dava maiores possibilidades de ação política. Eles não retomariam o discurso de conciliação com a classe dos colonos brancos das ilhas, isto é, o argumento de que os homens de cor, reconhecidos como cidadãos, reforçariam a classe dos colonos, promovendo um controle mais eficiente sobre a escravaria. Procurariam, ao contrário, apresentar o colono branco como um inimigo comum de escravos rebeldes e negros livres.

Em 7 de setembro de 1792, Julien Raimond, à frente de uma deputação numerosa de homens de cor, tinha sido recebido na Assembleia Nacional para pedir a formação de uma legião de soldados de cor para defender a Revolução. A proposta tinha

\footnotetext{
${ }^{1197}$ Idem, número 73, 13 de março de 1793, p.3.

1198 Idem, número 77, 17 de março de 1793, p.3.

1199 No início de 1793, Brissot continuava a defender o princípio da abolição apenas gradual da escravidão (cf. Patriote Français, v.8, número 1263, 26 de janeiro de 1793, p.104).
} 
sido aceita, dando origem à Légion des Américains. ${ }^{1200}$ A Legião, entretanto, não era composta por ricos mulatos ou quadrarões do Sul de São Domingos. Era formada, sobretudo, por negros e mulatos livres ou recém-libertos. Provavelmente, muitos deles estavam entre os beneficiados pela ação do Parlamento de Paris e do Amirauté de France na segunda metade do século XVIII, que haviam emancipado um grande número de escravos com base no princípio da liberdade. Os membros da Legião eram, na sua maioria, provenientes das colônias da América, mas muitos deles tinham nascido na África. Traziam, portanto, uma outra perspectiva da escravidão, que nada tinha a ver com a visão de um proprietário abastado como Julien Raimond: eram homens recémsaídos da condição servil, com vínculos muitos mais próximos com o mundo dos escravos. $^{1201}$

Plantandores de cor estavam longe de ser os aliados naturais dos escravos. Em São Domingos, embora algumas alianças de conveniência tivessem sido estabelecidas, os homens de cor do Sul e do Oeste mantiveram-se, desde o início da Revolução, firmemente favoráveis à manutenção da escravidão. Muitos, aliás, correriam para os braços dos ingleses após a decisão dos comissários Sonthonax e Polverel de abolir localmente a escravidão. Por outro lado, sabe-se que a insurreição dos escravos contou, desde o início, com a cumplicidade de negros e mulatos alforriados, dos quais Toussaint Louverture é o exemplo mais notável. Para esses homens, a ordem escravista não era necessariamente vista como fonte de riqueza pessoal; ela podia ser um sistema de opressão que era necessário erradicar para que homens que outrora viveram sob o jugo da escravidão pudessem finalmente gozar plenamente da condição de cidadãos.

Em 17 de maio de 1793, a Legião dos Americanos publicou uma Adresse à la Convention Nationale, à tous les Clubs et Sociétés Patriotiques, pour les Nègres détenus en esclavage dans les Colonies Françaises de l'Amérique, sous le régime de la République, reclamando um decreto de abolição da escravidão. Escrita na primeira pessoa do plural, em nome dos escravos, a petição pedia a liberdade para todos os negros e a sua conversão em trabalhadores assalariados. Se a petição denunciava a contradição entre a proclamação dos Direitos do homem e a manutenção da escravidão nas colônias, ela também apresentava a emancipação geral como necessária à segurança

\footnotetext{
${ }^{1200} \mathrm{Na}$ primavera de 1793, esses soldados receberam a ordem de voltar para as colônias. Recusaram-se a obedecer, por temerem voltar para a escravidão. Em 15 de maio de 1793, a Convenção revogou essa ordem (cf. GAUTHIER, Florence. Le rôle de la députation de Saint-Domingue dans l'abolition de l'esclavage. In: M. DORIGNY (org.). Les abolitions de l'esclavage, p.200).

${ }^{1201}$ Cf. Dictionnaire des gens de couleur, pp.34-36, 193, 203-204, 282-292.
} 
e à prosperidade do império. Ressaltava que a mudança seria benéfica aos plantadores, pois, além da satisfação de terem terras cultivadas apenas por mãos livres, eles se beneficiariam de um trabalho mais produtivo. Além disso, os negros, antes uma ameaça à nação e às propriedades, se tornariam os seus maiores defensores: "eles logo se tornariam os mais ardentes e maiores defensores da pátria, de seus libertadores, de suas copropriedades e de seus bens pessoais [...]". ${ }^{1202}$ Não havia, no texto, qualquer menção a gradações ou condições para o reconhecimento da liberdade. Tratava-se de uma abolição pura e simples da escravidão.

Se a insurreição escrava permanecia uma força autônoma no processo abolicionista, a formação, na metrópole, de um movimento de opinião ideologicamente vinculado aos rebeldes negros permitia que as consequências práticas da insurreição, em termos de uma legislação abolicionista, começassem a ser formuladas. Mais do que uma opinião antiescravista, havia agora uma opinião abolicionista em sentido estrito. Mesmo sem assumir uma forma institucionalizada, a existência dessa nova corrente expressava a evolução das mentalidades e, mais do que isso, a evolução das condições objetivas que informavam as opiniões sobre as colônias. Os escravos eram a força motora do movimento; os abolicionistas da metrópole assumiam uma função dirigente, valendo-se da existência da revolta escrava para reclamar uma erradicação do direito escravista nas colônias. ${ }^{1203}$

É verdade, entretanto, que o vínculo entre as duas instâncias manteve-se indireto: não havia contato entre os abolicionistas metropolitanos e os líderes da insurreição, nem favorecimento material das suas ações. Ainda não havia, naquele momento, dentro das colônias, uma verdadeira corrente abolicionista que pudesse estabelecer esse vínculo, na medida em que inexistia, na classe proprietária, uma fração que não fosse escravista ou uma classe média oposta à ideologia escravista. Os brancos pobres (petits blancs) estavam entre os grandes defensores da escravidão e do preconceito de cor. Até mesmo as autoridades administrativas e judiciárias estavam associadas ao sistema escravista, muitas vezes por vínculos pessoais. Os insurretos operavam de forma absolutamente independente.

${ }^{1202}$ Cf. ADRESSE à la Convention Nationale, à tous les Clubs et Sociétés Patriotiques, pour les Nègres détenus en esclavage dans les Colonies Françaises de l'Amérique, sous le régime de la République. Paris: Imprimerie Galletti, s.d. [1793], pp.6-7.

${ }^{1203}$ Para o conceito de força dirigente do processo abolicionista, ver SAES, Décio. A Formação do Estado burguês no Brasil (1888-1891). 2a edição. São Paulo: Paz e Terra, 1990, p.51 e 284. 
Entretanto, pela via indireta, a revolta escrava acabava se articulando com o movimento na metrópole pela liberdade e a igualdade dos indivíduos. Ao reconhecer a legitimidade do movimento insurrecional nas colônias, essa corrente ganhava o impulso necessário para formular o projeto de uma abolição imediata da escravidão. A luta autônoma dos escravos na colônia e a militância abolicionista radical na metrópole apresentavam-se como duas forças simultâneas capazes de operar a erradicação da ordem escravista no império francês. Mas, para isso, era preciso que o encontro dessas duas forças se desse num quadro político específico que lhes permitisse superar as resistências tradicionais à alteração do status quo colonial. 


\section{II.2.2) A República radical}

\section{II.2.2.1) A petição de 4 de junho de 1793}

As jornadas de 31 de maio-2 junho de 1793 marcaram o início de uma nova fase na Revolução francesa, em que o domínio da Montanha na Convenção e a instauração de uma ditadura jacobina de salvação pública apoiada na sans-culotterie permitiram vencer as resistências quanto à promoção de um relativo igualitarismo social. Durante o ano II da República, as relações da Comuna de Paris e as suas 48 seções com o governo revolucionário e a Convenção foram bastante próximas, embora tensas. Organizado em torno de uma vasta rede de sociedades populares ou secionárias, o movimento popular, apoiado nas camadas inferiores do que costumava ser o Terceiro Estado da capital (artesãos, pequenos lojistas, operários, indigentes), assumiu o caráter de um poder paralelo e autônomo, dotado de uma força armada própria e capaz de exercer pressão direta sobre as esferas de poder. Os sans-culottes seguiam os seus próprios objetivos, às vezes em aliança com a burguesia, às vezes em oposição a ela. $O$ governo revolucionário precisava do movimento popular para combater os moderados e sustentar a guerra, e a sans-culotterie se valeu disso para procurar impor a economia dirigida. Entre junho de 1793 e os primeiros meses de 1794, foi essa aliança que permitiu a consolidação do governo revolucionário e instituição da ditadura de salvação pública. Consciente do papel capital das sociedades populares na luta contra o moderantismo e o federalismo, a Convenção, agora dominada pelos Montanheses, conferiu-lhes, em 25 de julho de 1793, a sua proteção. Elas se tornavam a base de apoio do governo republicano. $^{1204}$

Nesse contexto, a Revolução avançou numa via mais radical. Além da derrubada final dos direitos senhoriais (17 de julho de 1793), o ano II foi marcado por sucessivas medidas de direção da economia, fixação dos preços, repressão aos especuladores e distribuição da propriedade. $\mathrm{O}$ fim da distinção constitucional entre cidadãos ativos e passivos $^{1205}$, o Terror e a ameaça constante de novas jornadas populares passavam a ser

\footnotetext{
${ }^{1204}$ Cf. SOBOUL, Albert. Les Sans-culottes parisiens en l'an II. Mouvement populaire et gouvernement révolutionnaire (1793-1794). Paris: Éditions du Seuil, 1968, pp.14, 21, 185-186.

${ }^{1205}$ Vale observar que, após a declaração da "pátria em perigo", a Assembleia Nacional já havia determinado, em 3 de agosto de 1792, a outorga da cidadania ativa a todos aqueles que participassem da guerra contra os inimigos da França. A supressão formal da distinção entre cidadãos ativos e passivos e a proclamação do sufrágio universal masculino, entretanto, só se deram com a Constituição de 1793, muito embora esta não tenha sido de fato aplicada (cf. HIPPLER, Thomas. Service militaire et citoyenneté sous
} 
fatores que pesavam constantemente sobre os representantes da nação, e criavam um contexto privilegiado para a derrubada de instituições que contrariavam o espírito republicano. O temor de serem identificados como contrarrevolucionários inibia os deputados da Convenção, que já não tinham a mesma liberdade de ação. Após os massacres de setembro de 1792 e as jornadas de 31 de maio - 2 de junho de 1793, a tradicional participação popular nas sessões da Assembleia ganhava ares particularmente ameaçadores.

Para o sans-culotte, tudo aquilo que afrontasse o seu sentido de igualdade era enquadrado dentro de uma certa concepção de aristocracia. Este é um termo sob o qual procurava reunir todos os seus adversários, apontando para a existência de diversas aristocracias além da nobreza: a aristocracia financeira, a ministerial, a clerical, a mercantil, a burguesa e, por que não, a colonial. O aristocrata era aquele que procurava frear o curso da Revolução em nome de seus próprios interesses, ferindo o espírito de igualdade e fraternidade que deveria reinar entre os cidadãos. A luta contra os Girondinos, por exemplo, tinha, em grande medida, o caráter de luta contra a burguesia do comércio - a aristocracia mercantil - , defensora da liberdade de acumulação, de produção e de troca. Os Montanheses partilhavam dessa hostilidade e procuraram estimular, num primeiro momento, a exaltação punitiva da sans-culotterie. ${ }^{1206}$

Os sans-culottes defendiam uma concepção de soberania popular e governo direto que eventualmente os colocaria em oposição ao governo revolucionário. ${ }^{1207} \mathrm{Um}$ dos aspectos fundamentais dessa concepção residia no exercício popular da justiça, o que envolvia o controle e a censura sobre os eleitos, dos quais as massas exigiam fidelidade ao mandato. As jornadas de 31 de maio -2 de junho tinham justamente o sentido de revogação do mandato de deputados que haviam traído a Nação por meio da defesa dos interesses da grande burguesia mercantil. A violência popular aparecia,

la Révolution française. In: R. MONNIER. Citoyen et citoyenneté sous la Révolution française. Paris: Société des études robespierristes, 2006, p.278).

${ }^{1206}$ Ibidem, pp.22-33.

${ }^{1207}$ Essa tendência já se manifestaria a partir de setembro de 1793. A Convenção e o Comitê de Salvação Pública moveriam esforços para fortalecer o poder central e subordinar o movimento secionário. Os comitês revolucionários das seções seriam colocados sob controle dos comitês da Convenção. Com o decreto de 4 de dezembro de 1793, a Convenção procuraria centralizar o poder, subordinando a Comuna de Paris ao Comitê de Salvação Pública. Assim, o procurador da Comuna, Chaumette, tornar-se-ia agora não mais um escolhido das massas da capital, mas um "agente nacional". Além disso, as relações entre as comunas de outras cidades do país seriam proibidas, de modo a impedir a federalização do movimento popular (cf. GUÉRIN, Daniel. Bourgeois et bras nus, 1793-1795. Paris: Gallimard, 1973, pp.192-193; OLIVEIRA, Josemar Machado de Oliveira. $O$ Père Duchesne no interior da Revolução democrática: Jacques-René Hébert e as ideias aristocráticas do movimento secionário sans-culotte durante o ano I e o ano II (1792-94). 1998. Dissertação (Mestrado em História Social) - Faculdade de Filosofia, Letras e Ciências Humanas, Universidade de São Paulo, São Paulo, 1998, pp.43-45). 
assim, como uma arma poderosa a ser usada contra a aristocracia, em defesa da Revolução. ${ }^{1208}$ Esse aspecto estava presente também nas prisões efetuadas pelas seções parisienses ao longo do ano II. A atuação do movimento popular teria, como veremos, repercussões na questão das colônias.

Nessa conjuntura, defender interesses financeiros - tais como os do comércio colonial - em detrimento dos princípios revolucionários era uma tarefa arriscada, quando a Convenção se via, dia após dia, tomada por uma multidão de sans-culottes empenhados no cumprimento do seu dever de vigilância revolucionária. Se a queda dos Amigos dos Negros tinha privado o antiescravismo de um movimento organizado, a conjuntura marcada pela insurreição negra nas colônias e a república radical na metrópole permitia ao antiescravismo, livre das amarras do gradualismo, superar as estratégias de compromisso com as classes possuidoras.

Os sinais dessa evolução não demoraram a se manifestar. Logo no dia 3 de junho, no clube dos Jacobinos, foi celebrada a reunião de patriotas brancos e negros no seio da Sociedade. Uma cidadã de cor de 114 anos foi recebida na tribuna. Sob aplausos, Chabot, um dos membros mais exaltados do clube, exclamou: "Os Jacobinos devem jurar que eles tornarão livres os homens de cor, e eu o juro em meu próprio nome!". ${ }^{1209}$

No dia seguinte, 4 de junho de 1793, uma delegação de "Americanos livres", composta, essencialmente, de negros e pessoas de cor, apresentou-se à Convenção, acompanhada de um grupo de sans-culottes da Comuna de Paris, conduzidos por Chaumette. ${ }^{1210}$ Pode-se imaginar o efeito que a entrada conjunta de negros e sansculottes produziu sobre os deputados, dois dias após as jornadas populares que haviam derrubado os Girondinos. A delegação ofereceu à assembleia uma bandeira tricolor, com um branco, um mulato e um negro representados em pé, armados com uma lança sobre a qual pairava um barrete da liberdade. A bandeira, que seria retomada por Toussaint Louverture quando da sua aliança à República, em maio de 1794, expressava a união das duas revoluções: a do povo da metrópole e a dos escravos das colônias. A comitiva depositou uma petição, em nome dos negros detidos na escravidão nas colônias francesas da América. Não se tem o texto da petição, mas Piquet e Gauthier

${ }^{1208}$ Cf. SOBOUL, Albert. Les Sans-culottes parisiens en l'an II., pp.106, 111-117, 155; OLIVEIRA, Josemar Machado de Oliveira. $O$ Père Duchesne no interior da Revolução democrática, pp.37-38.

1209 "Les Jacobins doivent jurer qu'ils rendront libres les hommes de couleurs, et je le jure en mon nom particulier!" (AULARD, F.A. La Société des Jacobins, v.5, p.228).

${ }_{1210}$ A respeito da presença da delegação da Comuna de Paris, conduzida por Chaumette, cf. Journal de la Montagne, número 92, 25 pluvioso do ano II, p.732. 
acreditam - e concordamos com eles - tratar-se provavelmente da Adresse à la Convention nationale que a Légion des Américains tinha apresentado, em 17 de maio, pela abolição da escravidão. ${ }^{1211} \mathrm{O}$ Presidente da Convenção aceitou a bandeira e concedeu aos peticionários a honra de desfilar perante a assembleia. Atravessaram a sala ao som de uma música militar, com o estandarte tricolor à sua frente, trazendo a inscrição: "Nossa união fará a nossa força". Entre os peticionários, encontrava-se a mesma mulher de cor de 114 anos, que caminhava apoiada nos braços de dois outros peticionários. O orador declarou que ela se chamava Jeanne Odo e que tinha nascido em Porto-Príncipe. A Convenção, em homenagem à centenária, levantou-se em bloco e seu Presidente deu-lhe o beijo fraternal. ${ }^{1212}$

$\mathrm{O}$ abade Grégoire tomou a palavra para denunciar a existência de uma última aristocracia que tinha de ser derrubada: "a da pele". Manifestando uma profunda radicalização de princípios, afirmou que era o momento de suprimi-la definitivamente:

Eu espero que a Convenção nacional aplicará os princípios de igualdade aos nossos irmãos das colônias, que diferem de nós apenas pela cor; espero que essa petição depositada no vosso gabinete, cuja leitura seria longa demais a essa hora, não permanecerá enterrada, como muitas outras, num comitê, e que, imediatamente, um relatório vos seja feito sobre o qual pronunciareis a liberdade dos negros. ${ }^{1213}$

A Convenção remeteu a petição aos comitês das colônias e de legislação para que um relatório fosse imediatamente preparado. Naquele momento, a maior parte dos membros do comitê colonial, do qual faziam parte Grégoire e Marat, encontrava-se em missão, de modo que não foi possível deliberar a respeito. ${ }^{1214}$

De acordo com o mulato martinicano Julien Labuissonnière, portador e primeiro signatário da petição, estavam, entre os signatários, vários montanheses, como Robespierre e Jeanbon Saint-André. ${ }^{1215}$ É verdade, entretanto, que, naquele momento, era comum usar o nome de Robespierre para legitimar um projeto ou pretensão. Em 5 de junho de 1793, Labuissonnière pregou um cartaz relativo à recepção da petição do dia anterior na Convenção. O cartaz trazia os seguintes dizeres:

1211 Cf. PIQUET, Jean-Daniel. L'émancipation des Noirs dans la Révolution française, p.258-259; GAUTHIER, Florence. Le rôle de la députation de Saint-Domingue dans l'abolition de l'esclavage, p.201. ${ }^{1212}$ Cf. AP, v.66, pp.56-57.

1213 "J'espère bien que la Convention nationale appliquera les principes d'égalité à nos frères des colonies, qui ne diffèrent de nous que par la couleur; j'espère que cette pétition déposée sur votre bureau, dont la lecture serait trop longue à cette heure, ne restara pas enfouie, comme tant d'autres, dans un comité, et qu'incessamment on vous fera un rapport sur lequel vous prononcerez la liberté des noirs" (Ibidem, p.57). ${ }_{1214}$ Cf. WANQUET, Claude. La France et la première abolition de l'esclavage, p. 31.

1215 Cf. PIQUET, Jean-Daniel. L'émancipation des Noirs dans la Révolution française, p.253. 
O humano, o virtuoso GRÉGOIRE, os SAINT-ANDRÉ, os ROBESPIERRE e o resto desses justos clamaram do topo da montanha; suas vozes se faziam ouvir com as trovoadas da verdade [...] Parisienses, verdadeiros sansculottes... Republicanos incorruptíveis... vós que fostes sempre as colunas da França, vinde plantar conosco a árvore da liberdade junto aos vossos irmãos da zona tórrida. ${ }^{1216}$

O episódio gerou fortes preocupações entre os colonos, que sentiam que a associação da causa abolicionista a um movimento de base popular poderia pressionar a Convenção a tomar uma medida que representaria a sua ruína. Cossigny e Broutin, representantes oficiosos da Île-de-France, manifestaram a sua inquietação quanto à iminência da abolição numa carta aos membros da assembleia da ilha, de 19 de julho de 1793: "Não devemos vos esconder que pareceu-nos que a maioria da Convenção tinha uma opinião conforme aos princípios enunciados na petição". ${ }^{1217}$

Nos dias seguintes, Chaumette patrocinou, na Comuna de Paris, manifestações de solidariedade para com os negros, marcando o envolvimento crescente do movimento popular na causa da abolição. Em 8 de junho de 1793, a deputação dos cidadãos de cor foi recebida pelo Conselho geral da Comuna de Paris, que organizou uma manifestação no Campo de Marte e recebeu a bandeira da igualdade da epiderme. Milscent participou desses eventos, apresentando-se ao Conselho geral da Comuna, em 8 de junho, como "o defensor oficioso dos homens de cor que sofrem uma terrível escravidão". ${ }^{1218}$ É interessante observar que, àquela altura, a expressão "homens de cor" começava a ser usada como sinônimo de "negros", o que não acontecia no início da Revolução. Em 11 de junho, a Comuna de Paris ofereceu à deputação de cor um estandarte, com, de um lado, um branco, um negro e um mulato e a inscrição "Homens de cor, vós sereis livres" e, de outro, a liberdade e a igualdade sustentando um globo com as palavras "Liberdade e igualdade universais". No dia seguinte, a Comuna de Paris promoveu uma espécie de batismo da liberdade: Chaumette apresentou uma

\footnotetext{
1216 "L'humain, le vertueux GRÉGOIRE, les SAINT-ANDRÉ, les ROBESPIERRE et le reste de ces justes ont tonné du sommet de la montagne; leurs voix se faisaient entendre avec les tonnerres de la vérité [...] Parisiens, vrais sans-culottes... Républicains incorruptibles... vous qui fûtes toujours les colonnes de la France, venez planter avec nous l'arbre de la liberté chez vos frères de la zone torride" (citado em PIQUET, Jean-Daniel. L'émancipation des Noirs dans la Révolution française, pp.259-260).

1217 "Nous ne devons pas vous dissimuler qu'il nous a paru que la majorité de la Convention avait une opinion conforme aux principes énoncés dans la pétition" (citado em WANQUET, Claude. La France et la première abolition de l'esclavage, p.33).

${ }^{1218}$ Cf. PIQUET, Jean-Daniel. L'émancipation des Noirs dans la Révolution française, p.260.
} 
criança de cor e pediu a sua coadoção, por ele e pela Comuna de Paris. O presidente do conselho geral declarou a criança livre e renovou a promessa de abolição. ${ }^{1219}$

Essas eram manifestações apenas simbólicas, mas elas se davam em esferas marcadas por uma participação popular ativa. Naquele momento, o envolvimento das massas parisienses numa campanha em favor da liberdade dos negros era um fator capaz de diluir as resistências a medidas que alterassem o sistema colonial tal como ele existia antes da Revolução. Os efeitos concretos desse novo ambiente não tardariam a se manifestar.

\section{II.2.2.2) A abolição das subvenções ao tráfico}

Os sinais de uma abolição vindoura começavam a aparecer na legislação. A nova Declaração dos direitos do Homem, votada em 24 de junho de 1793, inspirada quase que integralmente no projeto de Condorcet, atacava diretamente a escravidão. Além de proclamar os homens iguais por natureza e perante a lei $\left(\operatorname{art} .3^{\circ}\right)$, ela proibia expressamente a escravidão no seu art.18:

Todo homem pode oferecer seus serviços, seu tempo; mas ele não pode vender a si mesmo ou ser vendido: a sua pessoa não é uma propriedade alienável. A lei não admite nenhuma domesticidade; pode existir apenas um compromisso de cuidados e de reconhecimento entre o homem que trabalha e aquele que o emprega. ${ }^{1220}$

Tratava-se de uma proibição constitucional da escravidão, mas, na medida em que era apenas a proclamação de um princípio, a questão era saber se essa proibição valia para as colônias ou apenas para a metrópole. O sistema da Constituição de 1791 havia colocado as colônias fora de sua zona de aplicação. Todavia, o impulso da nova onda antiescravista começou a gerar resultados já naquele verão de 1793, quando a Convenção tomou a primeira grande medida legislativa contra o tráfico de escravos.

Após a lei sobre os mulatos, de 24 de março - 4 de abril de 1792, a campanha pela abolição do tráfico tinha sido retomada de forma discreta. Na primavera de 1792, a Grã-Bretanha tinha debatido a questão na Câmara dos Comuns, que, por ampla maioria,

1219 Cf. GAUTHIER, Florence. Le rôle de la députation de Saint-Domingue dans l'abolition de l'esclavage, pp.202-203.

1220 "Tout homme peut engager ses services, son temps; mais il ne peut se vendre, ni être vendu: sa personne n'est pas aliénable. La loi ne reconnaît point de domesticité; il ne peut exister qu'un engagement de soins et de reconnaissance, entre l'homme qui travaille et celui qui l'emploie" (Déclaration des Droits de l'Homme (24 juin 1793). Bordeaux: Publications de la Tribune de la Gironde, 1870, p.6). 
tinha decidido que o tráfico seria abolido, mas apenas gradualmente, solução que não agradou aos antiescravistas britânicos. ${ }^{1221} \mathrm{Na}$ França, em 10 de abril, Condorcet tinha submetido, por meio de seu amigo Pastoret, uma moção de abolição do tráfico. Embora não tivesse sido rejeitada, a moção não tinha sido discutida e acabou enterrada nos comitês competentes. Mais tarde, sob a Convenção, Benjamin Frossard tinha apresentado, em 12 de dezembro de 1792, uma nova petição pela supressão do tráfico, publicada, no início do ano seguinte, sob o nome Observations sur l'abolition de la traite des Nègres. Alinhado com os Amigos dos Negros, Frossard tinha procurado separar a supressão do tráfico da questão da escravidão, que entendia ser possível erradicar apenas gradualmente. ${ }^{1222}$ Novamente, não tinha havido discussão. Foi apenas após a queda dos Girondinos e o fim da hegemonia dos negociantes dos portos franceses que a questão foi definitivamente discutida.

Em 27 de julho de 1793, mesmo dia da entrada de Robespierre no Comitê de Salvação Pública, foi lida uma carta de Garat, ministro do interior, que solicitava à Convenção uma decisão relativa ao pagamento dos encorajamentos e gratificações concedidos ao tráfico negreiro, entendendo que esses prêmios não podiam continuar a ser pagos como no passado. ${ }^{1223} \mathrm{O}$ abade Grégoire, um antigo amigo dos Negros, agora aliado à Montanha, tomou a palavra para louvar as observações do ministro e pedir o fim das subvenções ao tráfico:

Até quando, cidadãos, permitireis esse comércio infame? Até quando concedereis encorajamentos para um tráfico que desonra a espécie humana? Mostrai-vos dignos do que sempre fostes, que não seja mais permitido a nenhum Francês ir buscar homens, que são nossos semelhantes apesar da cor diferente, em sua terra natal, para transportá-los para um solo estrangeiro, onde são empregados como bestas de carga. Peço que decreteis imediatamente que não será mais concedido prêmio aos navios negreiros. ${ }^{1224}$

A proposta era relativa ao pagamento de gratificações ao comércio de escravos, mas Grégoire a apresentava como uma medida direcionada para a supressão efetiva do

\footnotetext{
${ }^{1221}$ Cf. Patriote Français, v.6, número 974, 10 de abril de 1792, pp.405-406.

1222 Cf. FROSSARD, Benjamin-Sigismond. Observations sur l'abolition de la traite des Nègres. Présentées à la Convention Nationale. S.1. [Paris]: Imprimerie de Gueffier, 1793, pp.26-27.

${ }^{1223}$ Segundo Patrick Villiers, os prêmios foram pagos normalmente até 1789. Em 1790, 105 navios receberam a gratificação. No ano seguinte, foram apenas 31 e, em 1792, somente 28 (cf. VILLIERS, Patrick. The slave and colonial trade in France just before the Revolution, p.232).

1224 "Jusques à quand, citoyens, permettrez-vous ce commerce infame? Jusques à quand accorderez-vous des encouragements pour un trafic qui déshonore l'espèce humaine? Montrez-vous dignes de ce que vous avez toujours été, qu'il ne soit plus permis à aucun Français d'aller chercher des hommes, qui sont nos semblables quoique d'une couleur différente, sur leur terre natale, pour les transporter sur un sol étranger, où on les emploie comme des bêtes de somme. Je demande que vous décrétiez à l'instant qu'il ne sera plus accordé de prime aux vaisseaux négriers" (AP, v.69, p.580).
} 
tráfico de escravos. A Convenção aprovou a moção. Um membro chegou a propor que uma decisão definitiva fosse tomada a respeito da abolição do tráfico. A Convenção não deliberou a respeito, acreditando que tal decisão só deveria ser tomada após a apresentação de um relatório completo sobre a questão colonial. ${ }^{1225}$ De qualquer forma, sem as subvenções estatais, o comércio de escravos dificilmente subsistiria na França, pois os riscos tornavam-se demasiadamente elevados para os mercadores. Era, no fundo, uma abolição indireta do tráfico negreiro, ainda que a medida não fosse capaz de neutralizar a ação dos contrabandistas estrangeiros.

No dia 19 de setembro de 1793, a Convenção foi ainda mais longe, aprovando um decreto que tornava retroativo o não pagamento dos prêmios, encorajamentos e gratificações ao tráfico. Ou seja, mesmo as transações realizadas antes da supressão das subvenções não davam mais direito ao pagamento dos prêmios. ${ }^{1226}$ Era um golpe duro nos armadores dos portos franceses. O que tornou, entretanto, essa abolição indireta do tráfico particularmente eficaz foram os eventos que, naquele momento, se produziam em São Domingos.

${ }^{1225}$ Ibidem, p.580.

${ }^{1226}$ Cf. AP, v.74, p.408. 


\section{II.2.3) A conquista da liberdade em São Domingos}

O envio de novos comissários civis a São Domingos tinha gerado, na metrópole, a esperança de que a situação na colônia seria finalmente estabilizada. Entretanto, a política dos comissários favorável aos homens de cor livres estava na origem de uma nova onda de conflitos com os brancos da ilha. No final de 1792, a guerra civil tinha explodido em São Domingos. Uma grande parte dos cidadãos e das tropas viu com maus olhos a política dos comissários civis, que davam preferência aos homens de cor na nomeação dos oficiais. No dia 2 de dezembro, confrontos entre homens de cor e tropas brancas do regimento do Cap tinham ocorrido na cidade. ${ }^{1227}$ Sonthonax, muito apreciado pelos mestiços da ilha ${ }^{1228}$, havia conseguido restabelecer parcialmente a ordem, mas a instabilidade na colônia tinha levado os comissários a fazerem uma proclamação, ressaltando que havia na colônia apenas duas classes de homens: a dos livres, sem distinção de cor, e a dos escravos. Para acalmar os plantadores da ilha, proclamaram ainda que a escravidão era necessária à cultura e à prosperidade das colônias e que cabia apenas aos colonos decidir sobre o estado dos escravos. ${ }^{1229}$

Nos primeiros meses de 1793, esse quadro de instabilidade não estava restrito a São Domingos. Na Guadalupe, em 20 de abril de 1793, uma insurreição de centenas de escravos da área próxima a Trois-Rivières resultou na morte de 22 brancos e na devastação de diversas plantações. ${ }^{1230}$ Num contexto de guerra com a Grã-Bretanha, o controle sobre a massa escrava tornava-se indispensável e, ao mesmo tempo, inviável com táticas meramente repressivas. Nesse contexto, o governador da Guadalupe, Collot, tinha se dado conta de que era preciso aliar os escravos à ordem para conter a ameaça realista e estrangeira: tinha criado, assim, um batalhão de 300 chasseurs noirs para defender a colônia de um ataque, prometendo a liberdade aos escravos alistados. Um mulato livre tinha sido colocado no comando. A medida não foi capaz de impedir que os britânicos atacassem a Guadalupe no final de março de 1794, com o apoio dos realistas da ilha, mas ela prenunciava a política que seria adotada em São Domingos. ${ }^{1231}$

\footnotetext{
${ }^{1227}$ Cf. Patriote Français, v.8, número 1257, 20 de janeiro de 1793, p.80.

${ }^{1228}$ Elogios a Sonthonax eram constantes em cartas dos cidadãos de cor de São Domingos. Louis Boiron, membro da comissão intermediária do Cap, apresentou o comissário civil como "o salvador de São Domingos" (Idem, v.8, número 1293, 25 de fevereiro de 1793, p.233).

${ }^{1229}$ Idem, v.8, número 1263, 26 de janeiro de 1793, pp.103-104.

${ }^{1230}$ Cf. DUBOIS, Laurent. A Colony of Citizens, p.23.

${ }^{1231}$ Ibidem, pp.149-152.
} 
De fato, nessa época, por conta do agravamento da situação militar na Europa, a ideia de incorporar as massas negras das colônias ao exército republicano ganhava força. Se, para os brissotinos, a guerra havia deixado a questão dos negros em segundo plano, outros entenderam que a guerra dava a ela uma maior urgência. O conflito com as potências europeias foi o contexto para uma radicalização geral do processo revolucionário, gerando repercussões nos mais diferentes campos, inclusive nas questões coloniais. As Antilhas se tornariam uma das frentes de combate de uma guerra mais abrangente, alterando a percepção que se tinha na França das massas negras em revolta.

O início de 1793, em particular, marcou uma nova etapa no conflito contra as nações europeias. Em $1^{\circ}$ de fevereiro, a Convenção declarou guerra à Grã-Bretanha e às Províncias Unidas, que se juntavam à Áustria e à Prússia numa grande coalizão contra a França revolucionária e reicida. Estados ligados à Grã-Bretanha por tratados, como a Espanha e Portugal, viram-se envolvidos nessa mesma ofensiva. Os britânicos, desprovidos de um grande exército, mas dotados de uma poderosa marinha, pretendiam atingir a França por meio de um bloqueio marítimo e de uma ofensiva contra as colônias. O ministro Pitt ambicionava usar a guerra para arruinar a potência colonial francesa, atacando diretamente as suas colônias. Era a oportunidade de tomar uma das colônias mais ricas do mundo ou, pelo menos, de destruí-la e tirá-la da concorrência. Na frente colonial dessa guerra, aquele que conquistasse o apoio dos insurretos negros teria a chave da vitória.

Diante do agravamento da situação militar, algumas opiniões começavam a apontar a necessidade de uma nova política colonial. Em 13 de fevereiro, o Créole Patriote publicou uma carta do deputado Charles Villette, antigo combatente da guerra dos Sete anos, que fazia um apelo à abolição, usando a guerra como motivação. Ao comentar a possibilidade de as potências estrangeiras tomarem as colônias, Villette propunha transformar os insurretos em soldados da pátria:

E as colônias! deem a vossos negros a liberdade, vos cobrireis a terra de combatentes que saberão morrer para defendê-la; isso vos custará um só decreto, e essa bela eclusa política engoliria nossos inimigos. ${ }^{1232}$ (itálico no original)

\footnotetext{
1232 "'Et les colonies! donnez à vos nègres la liberté, vous couvrez la terre de combattans qui sauront mourir pour la défendre; il ne nous en coûtera qu'un seul décret, et cette belle écluse politique engloutirait nos ennemis'" (Le Créole Patriote, número 289, 13 de fevereiro de 1793, p.1174).
} 
O apelo de Villette não foi isolado. Em 18 de fevereiro, Gaspard Monge, ministro da Marinha, escreveu aos comissários civis em São Domingos, sugerindo-lhes que se apoiassem nos negros contra os espanhóis. A sua recomendação chegou tarde demais, pois os espanhóis já tinham tomado a iniciativa de buscar uma aliança com os rebeldes, mas essa atitude era um prenúncio do que estava por vir. Em 5 de março de 1793, Camboulas propôs e obteve, na Convenção, um decreto que declarava as colônias em estado de guerra e aumentava os poderes dos comissários civis. A lei permitia aos comissários promover todas as modificações que julgassem necessárias "nos regulamentos de polícia e de disciplina dos plantéis". ${ }^{1233}$ Essa formulação vaga podia sugerir uma nova competência para intervir na organização das plantações e no regime de trabalho dos escravos. Duas semanas depois, por pressão dos colonos, a Assembleia decidiu suspender o envio do decreto, mas foi tarde demais. Os comissários em São Domingos receberiam o decreto com seus novos poderes, cuja ampliação seria decisiva na sua conduta posterior.

Enquanto essas ideias eram discutidas na metrópole, a principal colônia francesa mergulhava na guerra civil. Em janeiro, novas insurreições escravas explodiam em São Domingos. Os líderes escravos do Norte, Jean-François e Biassou, formalizavam a sua aliança com a Espanha, em troca de armas, terras e uma promessa de liberdade para os soldados negros e suas famílias. Em junho, Toussaint Louverture seguiria o seu exemplo. Os brancos da ilha também voltavam-se para os estrangeiros. A facção "patriota" começou a negociar com os britânicos, que se preparavam para invadir a colônia. Isso obrigou os comissários a organizar uma marcha armada em Porto Príncipe, no mês de abril. A cidade se rendeu, mas havia também problemas no Norte, com os realistas. Assim, no início de junho de 1793, os comissários civis entraram em choque com o recém-chegado governador François Galbaud du Fort. Nas colônias, após a proclamação da República na França (em 21 de setembro de 1792), muitos monarquistas se colocaram em oposição aos agentes da metrópole. Adepto da realeza, Galbaud declarou-se favorável ao domínio branco e contrário à autoridade dos comissários e à sua política de favorecimento dos homens de cor livres. Sonthonax e Polverel tiveram de ir para o Cap, onde destituíram Galbaud de suas funções e colocaram-no num navio. Ajudado por simpatizantes, Galbaud resolveu desembarcar novamente em 20 de junho. Apoiado por colonos brancos, ele tomou o arsenal da

${ }^{1233}$ Cf. Moniteur, v.15, número 66, 7 de março de 1793, pp.628-670. 
cidade e promoveu uma tentativa de golpe contra o governo, em 20-21 de junho de 1793, levando os comissários a fugir para a plantação Bréda. O Cap-Français tornou-se um campo de batalha. Temendo uma derrota, Sonthonax deu ordens para que os escravos e prisioneiros do Cap fossem armados, prometendo o perdão e a liberdade para todos os que atendessem ao chamado. Cerca de 10 mil escravos negros da cidade vieram socorrer os comissários e derrotaram as tropas de Galbaud. ${ }^{1234}$

A deportação de Galbaud e a fuga dos brancos contrarrevolucionários permitiram a Sonthonax e Polverel conduzir uma política inteiramente favorável aos negros. Em 21 de junho, os comissários ordenaram a emancipação de todos os escravos que haviam combatido pela República, assim como o fim de todas as ofensivas contra os insurretos negros, permitindo apenas o combate em legítima defesa. Fazia-se, contudo, necessário conquistar o apoio dos principais líderes da insurreição - JeanFrançois, Biassou e Toussaint Louverture -, que mantinham-se no campo espanhol. ${ }^{1235}$

Em 29 de agosto de 1793, quatro dias após uma votação que contou com a participação de 15 mil indivíduos de todas as cores, Sonthonax proclamou, no intuito de "restabelecer a ordem e a tranquilidade pública", a abolição pura e simples da escravidão para toda a parte Norte de São Domingos. Na sua proclamação, Sonthonax procurou justificar a mudança de postura: ele, que era provavelmente um antiescravista moderado, via-se agora obrigado a adotar uma medida que havia antes rejeitado. Relembrou que o objetivo de sua missão na colônia era fazer executar a lei de 24 de março - 4 de abril de 1792 e preparar gradualmente, sem abalos, a emancipação geral dos escravos. Ao chegarem a São Domingos, os comissários tinham encontrado a população branca dividida por motivos de interesse, unida apenas pela vontade de perpetuar a servidão dos negros e proscrever qualquer sistema de liberdade. Sonthonax afirmou que, para "acalmar os espíritos", os comissários tinham declarado acreditar que a escravidão era necessária ao cultivo. Naquela época, disse o comissário, teria sido altamente imprudente romper os laços que mantinham os escravos presos aos seus senhores. Acreditava, entretanto, que a situação tinha mudado: os "negreiros e

\footnotetext{
${ }^{1234}$ Cf. FICK, Carolyn. The making of Haiti, pp.157-159. Na verdade, como explica Bénot, a presteza com que os negros vieram socorrer os comissários explica-se por negociações que estes tinham mantido com os líderes negros durante o mês de junho (cf. BÉNOT, Yves. La Révolution française et la fin des colonies, p.178).

${ }^{1235}$ Não é fácil avaliar com precisão a dimensão do exército negro aliado à Espanha. Os espanhóis falavam num total de 14 mil soldados negros, mas, segundo David Geggus, trata-se provavelmente de um exagero (cf. GEGGUS, David Patrick. Haitian Revolutionary Studies, p.179).
} 
antropófagos" tinham deixado a colônia, e os brancos remanescentes eram "amigos da lei e dos princípios franceses". ${ }^{1236}$

Embora Robert Stein atribua a proclamação de Sonthonax a um suposto abolicionismo radical do comissário, o fato é que a medida se explica essencialmente pelo contexto de guerra civil existente na colônia. Com as principais lideranças aliadas aos espanhóis, a perspectiva de uma invasão britânica e a necessidade de combater tanto os brancos realistas quanto os "patriotas", o recurso às massas negras apresentava-se como a única solução viável para restabelecer a autoridade metropolitana em São Domingos. Sabe-se que Sonthonax era um antiescravista e talvez tenha aproveitado o contexto para tomar uma medida pela qual já tinha uma inclinação de princípio, mas as suas tomadas de posição anteriores sugeriam um homem adepto das teses gradualistas pregadas pelos Amigos dos Negros. De qualquer forma, quaisquer que fossem as suas inclinações abolicionistas, é fundamentalmente a necessidade de conquistar o apoio das massas negras, num quadro de guerra, que explica a sua decisão de abolir a escravidão.

Assim, Sonthonax queria fazer da liberdade o princípio de uma dívida dos negros para com a República:

Não esqueçais jamais, cidadãos, que deveis a eles [os brancos amigos das leis francesas] as armas que vos deram a conquista da liberdade; não esqueçais jamais que é pela República francesa que combatestes; que, de todos os brancos do universo, os únicos que são vossos amigos são os Franceses da Europa. ${ }^{1237}$

Era preciso deixar claro que a liberdade era possível apenas sob o domínio francês: "O espanhol liberta os seus próprios escravos? Sem dúvida, não; ao contrário, ele promete a si mesmo vos acorrentar assim que vossos serviços lhe forem inúteis". ${ }^{1238}$

Ao mesmo tempo, Sonthonax anunciava aos novos livres que a liberdade de que gozariam não seria um "estado de preguiça e ócio". O comissário associava a proclamação da liberdade à definição de um novo regime de trabalho. Os negros teriam de retomar o trabalho nas suas antigas plantações, agora de forma remunerada. Assim, a proclamação determinava, no seu art. II, que:

\footnotetext{
1236 Cf. SONTHONAX, Léger-Félicité. Au nom de la République, Proclamation [de] Léger-Félicité Sonthonax, commissaire civil de la République, délégué aux îles française de l'Amérique. Le Cap: s.n., 1794, pp.1-2.

1237 "N'oubliez jamais, citoyens, que vous tenez d'eux les armes qui vous ont conquis votre liberté; n'oubliez jamais que c'est pour la République française que vous avez combattu; que, de tous les blancs de l'univers, les seuls qui soient vos amis sont les Français d'Europe" (Ibidem, p.2).

1238 "L'espagnol affranchit-il ses esclaves? non, sans doute; il se promet bien, au contraire, de vous charger de fers sitôt que vos services lui seront inutiles" (Ibidem, p.3).
} 
todos os negros e mestiços atualmente na escravidão serão declarados livres para gozar de todos os direitos vinculados à qualidade de cidadão Francês; eles estarão, entretanto, sujeitos a um regime cujas disposições estão contidas nos artigos seguintes. ${ }^{1239}$

Havia algo de contraditório nisso, pois, se a proclamação apresentava-se como reconhecimento da cidadania francesa aos negros, ela já abria exceções que contrariavam a própria definiçãa constitucional dessa cidadania. Isso significava, essencialmente, que os negros atualmente vinculados às plantações de seus antigos senhores deveriam nelas permanecer, para serem empregados na cultura da terra (art. IX). A proclamação previa um contrato de um ano, durante o qual os antigos escravos cultivadores não poderiam mudar de plantação, a não ser com uma permissão de juízes de paz, em casos determinados (saúde, incompatibilidade de caráter reconhecida...) (art. XI e XXXII). As punições corporais estavam proscritas: a pena mais dura para faltas disciplinares seria a perda de parte ou da totalidade do salário, e teria de ser pronunciada pelo juiz de paz (art. XXVII). No que tocava à remuneração dos trabalhadores, as receitas de cada plantation seriam divididas em três porções iguais, deduzidos os impostos: dois terços caberiam ao plantador, por ser o proprietário da terra e o responsável pelos custos de produção, e um terço seria dividido entre os cultivadores (art. XII). A parte que caberia aos cultivadores seria dividida da seguinte forma: três partes para os condutores; duas partes para os subcondutores; duas partes para os empregados na fabricação do açúcar e do anil; uma parte para cada um dos demais cultivadores de 15 anos ou mais; 2/3 de parte para as mulheres de 15 anos ou mais; meia-parte para as crianças de 10 a 15 anos; uma parte inteira para as mulheres com um ou mais filhos menores de 10 anos (arts. XIV-XVIII e XX). Outras disposições determinavam que os cultivadores teriam duas horas por dia para cultivar pequenos lotes de terra, que seriam repartidos igualmente entre cada família (arts. XIX e XXIX). ${ }^{1240}$

\footnotetext{
1239 "Tous les nègres et sang-mêlés, actuellement dans l'esclavage sont déclarés libres pour jouir de tous les droits attachés à la qualité de citoyen Français; ils seront cependant assujettis à un régime dont les dispositions sont contenues dans les articles suivants" (SONTHONAX, Léger-Félicité. Au nom de la République, p.4).

${ }^{1240}$ Ibidem, pp.5-7. Em recente estudo, Gauthier abordou a preparação das modalidades práticas da abolição da escravidão em São Domingos, sobretudo no que se refere aos meios de existência dos novos livres. Uma carta do cidadão Richebourg, do Cap, a Sonthonax, de 26 de agosto de 1793, três dias antes da proclamação, apontava dois caminhos: 1) estabelecer uma comunidade de bens entre os cidadãos; 2) estabelecer um arranjo entre o proprietário e os cultivadores, com uma repartição dos frutos de sua associação. A ideia de um salário fixo era rejeitada, pois Richebourg acreditava que apenas o sistema de ganhos proporcionais daria ao cultivador a motivação de trabalhar mais e melhor (cf. GAUTHIER,
} 
Tratava-se, portanto, de um sistema de trabalho assalariado, porém compulsório, que exigia, complementarmente, um forte regime disciplinar que reprimisse a "mendicidade". Assim, as pessoas empregadas no cultivo ou no serviço doméstico ficavam proibidas de deixar, sob qualquer pretexto, a comuna em que residiam sem uma permissão da municipalidade. A lei previa até que os homens e mulheres que, 15 dias após a promulgação da lei, estivessem desprovidos de propriedades ou que não estivessem empregados em nenhuma plantação ou serviço doméstico seriam presos, caso fossem encontrados errando pela colônia. Os indivíduos permaneceriam detidos por um mês, na primeira infração, e três meses, na segunda, sendo condenados a trabalhos públicos durante um ano, se fossem presos uma terceira vez (arts. XXXIIIXXXVI). ${ }^{1241}$ Ficava claro que a proclamação da liberdade nas colônias não se daria nos mesmos termos ditados pela Revolução na metrópole. O direito à liberdade vinha acompanhado de um dever de trabalhar. Assim como na escravidão, era essencialmente no tempo reservado ao cultivo de suas hortas que os negros exerceriam de fato uma forma de liberdade.

O decreto foi publicado em idioma crioulo, para que não deixasse de ser lido pelas massas. Polverel estenderia a medida às demais províncias da colônia. Em 27 de agosto, dois dias antes da abolição de Sonthonax, ele havia feito uma proclamação na qual sinalizava para um outro sistema de emancipação. Prometia aos escravos de plantações abandonadas, assim como aos insurretos e aos que tinham lutado pela República, porções de terra como pagamento pelos seus serviços. ${ }^{1242}$ Isso apontava para a formação de um pequeno campesinato negro em São Domingos, algo que teria contemplado as aspirações das massas de antigos escravos. Contudo, essa promessa não foi mantida nas proclamações posteriores. Em 21 de setembro, Polverel proclamou a liberdade geral para a parte Oeste de São Domingos e, em 31 de outubro, ele estendeu a medida ao Sul da ilha. A partir dessa nova proclamação, Polverel instituiria um regime de trabalho semelhante ao de Sonthonax, em que um terço dos resultados da produção seria atribuído ao conjunto dos trabalhadores, sendo o resto repartido entre o

Florence. En guise de conclusion: ouverture à de nouvelles recherches. Richebourg: comment abolir l'esclavage à Saint-Domingue? 1793. In: Périssent les colonies plutôt qu'un principe!, pp.105107).

1241 Ibidem, pp.7-8;

1242 Cf. BÉNOT, Yves. La Révolution française et la fin des colonies, p.179; DUBOIS, Laurent. A Colony of Citizens, p.205. 
proprietário e o Estado. Mas o seu sistema trazia inovações importantes, como a participação dos trabalhadores nas decisões relativas à organização da produção. ${ }^{1243}$

Sonthonax organizou então eleições no Norte da ilha. Em 23 de setembro, no momento em que os britânicos chegavam à parte sul de São Domingos, seis representantes e três suplentes forem eleitos, seguindo o princípio da igualdade dos homens de todas as cores: três negros, três brancos e três mulatos. Uma parte dessa "deputação da igualdade da epiderme" embarcaria para a França, via Filadélfia, sendo que apenas três representantes chegariam a Paris.

A proclamação de Sonthonax não teve o efeito imediato esperado. Havia ainda um forte ceticismo, entre os líderes negros, quanto à sinceridade e à legitimidade da medida. Os escravos que tinham sido libertados por Sonthonax mantiveram-se fiéis a ele, mas líderes como Jean-François e Biassou continuavam ao lado dos espanhóis, que talvez considerassem como uma via mais segura para a sua liberdade pessoal. Toussaint Louverture mantinha-se reticente. Desconfiava dos espanhóis, mas talvez julgasse a medida de Sonthonax e Polverel insuficiente: era uma medida local, tomada por agentes da metrópole, mas sem que esta a tivesse autorizado ou confirmado. Os comissários haviam, na sua chegada à ilha, afirmado o seu compromisso com a manutenção da ordem escravista e agora prometiam a liberdade. Em junho, Toussaint tinha até mesmo escrito a Laveaux, comandante das forças do Norte, para oferecer uma aliança em troca da anistia e da emancipação geral. A recusa da proposta faria com que Toussaint ainda permanecesse com os espanhóis por quase um ano. ${ }^{1244}$

Os britânicos chegaram à ilha em 19 de setembro de 1793, com o apoio dos colonos $^{1245}$, que percebiam que a conservação da ordem escravista já não era mais possível no quadro da República francesa. Cerca de três quartos dos brancos da colônia tinham passado para o lado dos invasores e, dentre os mulatos, se muitos permaneciam fiéis aos comissários, outros, furiosos com a emancipação dos escravos, preferiam colocar-se em mãos estrangeiras. Isso dava à questão novos contornos. ${ }^{1246}$ Era preciso

\footnotetext{
${ }^{1243}$ Cf. GAUTHIER, Florence. En guise de conclusion, pp.110-111.

1244 Cf. FICK, Carolyn. The making of Haiti, p.160.

1245 As negociações dos colonos de São Domingos com o governo britânico vinham acontecendo desde 1792. Londres tinha se tornado um reduto da contrarrevolução, que, àquela altura, tinha incorporado os colonos escravistas de São Domingos. O governo britânico teria, aliás, o cuidado de colocar, à frente das tropas enviadas a São Domingos, oficiais franceses, proprietários nas colônias (Cf. GAUTHIER, Florence. La première abolition de l'esclavage ou l'ouverture du procès du colonialisme. In: Périssent les colonies plutôt qu'un principe!, p.14).

${ }^{1246}$ Cf. FICK, Carolyn. The making of Haiti, p.161.
} 
uma medida da metrópole que consolidasse a aliança dos comissários com os insurretos e permitisse a reconquista de São Domingos. 


\section{II.3) A abolição (lei de 16 pluvioso do ano II - 4 de fevereiro de 1794)}

A explosão da insurreição dos escravos em São Domingos, a guerra contra a grande coalizão europeia, a formação de uma corrente abolicionista radical, a ascensão na metrópole de um governo revolucionário apoiado no movimento popular, a proclamação da liberdade geral na principal colônia francesa... A evolução das revoluções da metrópole e das colônias havia criado as condições objetivas para que um golpe fatal fosse desferido na escravidão. Não se tratava, é claro, apenas de uma tomada de consciência ideológica, mas da própria compreensão de que, naquele momento, não era mais possível voltar atrás. A Revolução havia fornecido o quadro para que as contradições existentes nas sociedades escravistas se convertessem em confrontos abertos entre as diferentes camadas que as compunham. Para a França, apenas duas possibilidades se apresentavam àquela altura: ou ela estendia a sua revolução às suas posses coloniais, ou ela as perderia para sempre.

\section{II.3.1) A deputação da igualdade e a supressão da escravidão colonial}

No final de setembro de 1793, a notícia da abolição em São Domingos tinha chegado à metrópole, sem gerar de imediato fortes repercussões, favoráveis ou desfavoráveis, na esfera parlamentar. Tanto na Convenção quanto no Comitê de Salvação Pública, a ênfase dada aos problemas relativos à guerra e às subsistências deixava as questões coloniais em segundo plano. Mesmo entre os adversários da escravidão, a notícias da emancipação não estimulou grandes manifestações. É preciso também lembrar que, àquela altura, preparava-se o julgamento de Brissot e os Girondinos, que teve início em 3 brumário (24 de outubro de 1793). Hesitava-se, assim, em fazer o elogio de uma medida tomada por Sonthonax e Polverel, identificados como agentes brissotinos em São Domingos. Durante o processso, a política supostamente tirânica que os comissários teriam conduzido nas colônias foi denunciada como parte de um plano de Brissot para destruir as colônias. Chaumette atuou como testemunha no julgamento e denunciou os atos despóticos dos comissários civis, alegando que eles defendiam princípios contrários aos dele, enquanto abolicionista declarado. ${ }^{1247}$ Nada era dito a respeito da liberdade dos escravos proclamada no mês de agosto.

${ }^{1247}$ Cf. Procès de J.P. Brissot et complices, ex-duputés à la Convention Nationale. Paris: Clement, imprimeur, ano II, pp.56, 71-72 e 249. 
A situação mudou de figura no início de 1794, muito por conta de uma campanha militar massiva da Grã-Bretanha - o Great Push - destinada a ampliar a presença inglesa no Caribe. Se o objetivo primordial era São Domingos, essa campanha permitiu a ocupação da Martinica, da Guadalupe e de Sainte-Lucie. ${ }^{1248}$ Em São Domingos, as forças britânicas já ocupavam alguns pontos importantes da ilha. ${ }^{1249} \mathrm{O}$ espaço caribenho transformava-se numa importante frente de batalha na guerra entre as nações europeias. Nesse contexto, a dimensão internacional que os Amigos dos Negros haviam atribuído à luta antiescravista desaparecia por completo. Na Grã-Bretanha, a campanha pela abolição do tráfico, após ter atingido o seu auge em 1792, tinha caído num período de quase inação. A declaração de guerra à França, somada ao início da fase jacobina da Revolução, havia dividido os abolicionistas britânicos. Muitos deles aderiram à mobilização contrarrevolucionária e se aliaram ao status quo contra os republicanos. Enquanto isso, a escravidão nas colônias britânicas conhecia um momento de plena expansão, alimentada pela perspectiva de uma conquista das Índias Ocidentais francesas. ${ }^{1250}$ Nesse contexto, a postura antiescravista na França adquiria as feições de um combate nacional pelo controle dos territórios coloniais.

Na metrópole, a ocasião para um debate parlamentar sobre a escravidão foi dada pela chegada de três dos novos deputados de São Domingos. Jean-Baptiste Mills (um mestiço), Louis Pierre Dufay (um oficial branco de São Domingos) e Jean-Baptiste Belley (um negro, alforriado antes de 1789) tinham percorrido um caminho tortuoso até a sua chegada à Convenção: foram quatro meses de viagem, ao longo dos quais tinham sofrido seguidas ameaças e agressões, especialmente na Filadélfia, onde, durante uma curta estadia, escaparam de serem assassinados por emigrados franceses. ${ }^{1251}$ Sua chegada à metrópole gerou todo tipo de reação, o que indicava a existência, dentro da República radical, de um debate, ainda que subterrâneo, sobre as questões coloniais.

\footnotetext{
${ }^{1248}$ Cf. DUBOIS, Laurent. A Colony of Citizens, p.230.

${ }^{1249}$ Geggus entende que a historiografia tendeu a superdimensionar a presença britânica na colônia. Assim, C.L.R. James sustentou a tese de que os britânicos ocupavam toda a província Oeste e a maior parte da província Sul da colônia. Geggus adverte que, na verdade, toda a área em volta de Porto Príncipe estava em mãos republicanas. Em abril de 1794, a forças britânicas não somavam mais do que 900 homens (cf. GEGGUS, David Patrick. Haitian Revolutionary Studies, pp.130-131).

${ }^{1250}$ Cf. BLACKBURN, Robin. A queda do escravismo colonial, pp.163-167; DRESCHER, Seymour. Capitalism and antislavery: Bristish mobilization in Comparative Perspective. New York, Oxford: Oxford University Press, 1987, pp.80-89 e 98.

${ }^{1251}$ Cf. carta de Dufay e Mills de 12 pluvioso do ano II (31 de janeiro de 1794), reproduzida em, GAUTHIER, Florence. Inédits de Dufay, Santerre et Léonard Leblois, au sujet de l'arrivée de la députation de Saint-Domingue à Paris. Janvier-février 1794. Annales historiques de la Révolution française, Paris, n. 293-294, 1993, p.515.
} 
Antes de chegarem a Paris, os três deputados passaram pela cidade de Lorient. Em missão no litoral atlântico, o deputado Marc-Antoine Jullien - conhecido como Jullien de Paris - escreveu a seu amigo Robespierre, em 26 nivoso do ano II (15 de janeiro 1794), para avisar da partida dos deputados de São Domingos rumo à Convenção. Indicava que, por ordem de Prieur, eles seriam acompanhados pelo cidadão Barbier, um patriota de Lorient. ${ }^{1252}$ Por outro lado, Victor Hugues, que também estava na cidade naquele momento, manifestou, em carta a Page e Brulley, a sua vontade de obter a prisão dos três deputados, atitude surpreendente por parte daquele que aplicaria a abolição na Guadalupe.

Os deputados da colônia chegaram à capital em 4 pluvioso (23 de janeiro de 1794). No dia seguinte, eles foram denunciados na Convenção por Léonard Leblois, crioulo que tinha retornado de São Domingos. Talvez mal informado, Legendre apoiou a sua moção. No mesmo dia, entretanto, os deputados foram recebidos pelo Comitê de Salvação Pública, a quem competia julgar a validade de seus poderes. Em 6 pluvioso (25 de janeiro), por pressão de Page e Brulley, foi emitida por Jean-Pierre-André Amar, do Comitê de Segurança Geral, uma ordem de prisão dos três deputados. Ela só seria executada na noite do 9-10 pluvioso (28-29 de janeiro de 1794), mas os deputados ficariam presos por apenas quatro dias. ${ }^{1253}$ Detentos em Saint-Lazare, em péssimas condições, os deputados Mills e Dufay escreveram à Convenção para denunciar as manobras dos colonos. ${ }^{1254}$ Não se sabe exatamente que efeito essa correspondência provocou, mas sabe-se que, ao tomar conhecimento da prisão dos deputados, o Comitê de Salvação Pública determinou a sua soltura imediata. Segundo Yves Bénot, no dia 2 de fevereiro, Barère teria comunicado a Page e Brulley a insatisfação do Comitê de Salvação Pública com a prisão dos deputados. De acordo com os registros de Page e Brulley, Barère lhes teria declarado

que é notório que os Brancos são os aristocratas nessa colônia e que os homens de cor e os negros são os patriotas. Barère trata os proprietários de príncipes-colonos, diz que é natural que o povo se tenha revoltado contra eles.

\footnotetext{
${ }^{1252}$ Cf. Papiers inédits trouvés chez Robespierre, Saint-Just, Payan, etc... Paris: Baudouin frères, 1828, v.3, p.55.

${ }^{1253}$ Segundo Piquet, Belley não teria sido preso, pois Page e Brulley, que tiveram papel determinante na ordem de prisão, desconheciam o nome do deputado negro (cf. PIQUET, Jean-Daniel. L'émancipation des Noirs dans la Révolution française, pp.326-327).

${ }^{1254}$ Cf. carta de Dufay e Mills de 12 pluvioso do ano II (31 de janeiro de 1794), reproduzida em GAUTHIER, Florence. Inédits de Dufay, Santerre et Léonard Leblois, pp.515-516.
} 
No mesmo dia, mais tarde, Lindet teria confirmado as palavras de Barère e anunciado que os deputados seriam libertados, para indignação dos dois colonos. ${ }^{1255}$

Agora em liberdade, os deputados da nova São Domingos podiam finalmente apresentar-se perante a Convenção Nacional. Em 25 de setembro de 1790, Sonthonax tinha previsto, num artigo do jornal Les Révolutions de Paris que, um dia, um "Africano com a cabeça crespa" participaria da legislação no seio da assembleia dos representantes do povo francês. A sua predição se realizou em 15 de pluvioso do ano II (3 de fevereiro de 1794), com a entrada dos três deputados coloniais, dentre os quais Mills, um mulato, e Belley, um negro. Os três foram fraternalmente acolhidos na Convenção.

A discussão sobre as colônias foi aberta com a intervenção de Monnel, um representante do comitê dos decretos, que afirmou que os poderes dos deputados enviados por São Domingos tinham sido verificados e estavam em ordem. Propôs a sua admissão imediata na Convenção Nacional. Camboulas interveio para ressaltar o caráter histórico dessa admissão:

Desde 1789, um grande processo estava em suspenso; a aristocracia nobiliária e a aristocracia sacerdotal tinham sido derrubadas, mas a aristocracia cutânea ainda dominava; esta acabou de dar o seu último suspiro: a igualdade está consagrada; um negro, um amarelo, um branco vão sentar-se entre vós em nome dos cidadãos livres de São Domingos. ${ }^{1256}$ (grifo nosso)

As suas palavras geraram fortes aplausos da assembleia. Os deputados receberam o beijo fraternal do presidente da Convenção. ${ }^{1257}$ Danton ainda tomou a palavra para denunciar as manobras dos colonos para impedir a chegada dos deputados de São Domingos à assembleia e atacou a ordem de prisão emitida pelo Comitê de Segurança Geral:

Não é apenas à igualdade das cores que devemos prestar homenagem: devemos vingar a representação nacional, ultrajada na pessoa dos três

\footnotetext{
1255 "qu'il est bien connu que les Blancs sont les aristocrates dans cette colonie et que les hommes de couleur et les nègres sont les patriotes. Barrère traite les propriétaires de princes-colons, il dit qu'il est naturel que le peuple se soit révolté contre eux" (citado em BÉNOT, Yves. Comment la Convention a-telle voté l'abolition de l'esclavage? Annales Historiques de la Révolution Française, Paris, n. 293-294, 1993, pp.352-353).

1256 "Depuis 1789 un grand procès restait en suspens; l'aristocratie nobiliaire et l'aristocratie sacerdotale étaient anéanties, mais l'aristocratie cutanée dominait encore; celle-ci vient de pousser le dernier soupir: l'égalité est consacrée; un noir, un jaune, un blanc vont siéger parmi vous au nom des citoyens libres de Saint-Domingue" (Moniteur, v.19, número 137, 5 de fevereiro de 1794, p.385).

${ }^{1257}$ Ibidem, p.388.
} 
deputados munidos dos poderes do povo de São Domingos, que acabam de ser admitidos. ${ }^{1258}$

Montant apoiou a moção de Danton, atribuindo a opressão da qual os deputados eram objeto à "espelunca aristocrática que existia em 1790, sob o despotismo monárquico, sob o nome de residência-Massiac". ${ }^{1259}$ No mesmo dia, Leblois, que era, no fundo, um crioulo bastante progressista (o que tinha lhe valido, em 1792, uma expulsão de São Domingos pela assembleia colonial, em razão de sua defesa dos mulatos), se retratou, em carta ao Comitê de Segurança Geral, pela sua denúncia do dia 24 de janeiro e reconheceu ter sido enganado por grupos de pressão (isto é, Page e Brulley), sem ter visto que Dufay, Mills e Belley eram representantes do povo de São Domingos. ${ }^{1260}$

Curiosamente, ainda na sessão de 15 pluvioso, o ministro da Marinha apresentou uma carta sobre as diligências que tinha tomado para garantir a execução do decreto contra Sonthonax e Polverel. A sua carta foi remetida, sem ser lida, ao Comitê de Salvação Pública. ${ }^{1261}$ Isso mostra que, para a Convenção, a questão dos negros e a prisão dos comissários eram duas questões bem distintas. Devido à pequena presença de deputados, a apresentação da petição dos três deputados coloniais foi adiada para o dia seguinte. ${ }^{1262}$ Ao tomarem conhecimento da recepção dos deputados na assembleia, Page e Brulley redigiram protestos ao Comitê de Salvação Pública e à Convenção. À noite, encontraram-se com Amar no Comitê de Segurança Geral para avisá-lo da existência de cartas perigosas contra eles. $^{1263}$

\footnotetext{
1258 "Ce n'est pas seulement à l'égalité des couleurs que nous devons rendre hommage: il nous faut venger la représentation nationale outragée dans la personne des trois députés munis des pouvoirs du peuple de Saint-Domingue, qui viennent d'être admis" (Journal de Perlet, número 500, 4 de fevereiro de 1794, p.26).

${ }^{1259}$ Ibidem, p.26

${ }^{1260}$ Isso não impediu que Leblois fosse perseguido pela sua atitude inicial. Em 13 pluvioso $\left(1^{\circ} \mathrm{de}\right.$ fevereiro), Santerre tinha escrito ao Comitê de Salvação Pública, denunciando duas intervenções de Léonard Leblois contra os deputados de São Domingos, que ele chamava de "três sans-culottes". O Comitê de Salvação Pública receberia a carta dois dias depois e a transmitiria ao Comitê de Segurança Geral em 19 ventoso (9 de março) (cf. carta de Santerre de 13 pluvioso do ano II $\left(1^{\circ}\right.$ de fevereiro de 1794), reproduzida em GAUTHIER, Florence. Inédits de Dufay, Santerre et Léonard Leblois, pp.516517).

${ }^{1261}$ Cf. Journal de Perlet, número 500, 4 de fevereiro de 1794, p.26.

${ }^{1262}$ Cf. Moniteur, v.19, número 137, 5 de fevereiro de 1794, p.388. Alguns historiadores procuraram difundir a tese de que, no dia da abolição, havia um pequeno número de deputados. Ora, o fato que a discussão sobre as colônias tenha sido adiada do dia 3 para o dia 4 de fevereiro, em razão do pequeno número de presentes, permite deduzir que, no dia 4 , o número de deputados na Convenção estava dentro da normalidade.

${ }^{1263}$ Para Yves Bénot, poderiam ser cartas do verão de 1792, nas quais os dois colonos se declaravam realistas (cf. BÉNOT, Yves. Comment la Convention a-t-elle voté l'abolition de l'esclavage?, pp.353).
} 
No dia seguinte, 16 de pluvioso do ano II (4 de fevereiro de 1794), Dufay finalmente apresentou, em nome dos três deputados, um relatório extenso sobre a situação de São Domingos. Em seu discurso, a ênfase foi dada a considerações políticas e não morais, fazendo da guerra, e não dos princípios, o fator-chave para a definição de uma nova política colonial. Assim, os negros de São Domingos foram apresentados como a principal arma contra as intrigas da Inglaterra e da Espanha, que tinham incitado a colônia à guerra civil, e dos contrarrevolucionários comandados por Galbaud, que queriam livrar-se dos comissários, amigos dos homens de cor: "[...] os negros armados para a causa da França frustraram, com sua coragem, esses pérfidos projetos, e pediram, como preço de seus serviços, a liberdade, que lhes foi concedida". ${ }^{1264}$ Continuamente interrompido por aplausos, o orador pedia à Assembleia que confirmasse essa promessa. Perguntava: "Não era uma política sábia e esclarecida a de criar novos cidadãos para a República, para opô-los aos nossos inimigos?". ${ }^{265}$ Contrapondo-os aos colonos, vistos como agentes da Inglaterra, Dufay apresentava os negros como os verdadeiros patriotas de São Domingos e a única via para a conservação da colônia contra uma invasão estrangeira. Os negros teriam jurado, em reconhecimento à França, defender a ilha até a morte contra os seus inimigos. Como representantes eleitos pelo povo livre da colônia, Dufay e seus colegas tinham vindo apresentar "[...] a homenagem de sua união ao povo francês e de sua devoção à república una e indivisível". ${ }^{1266}$

A guerra, entretanto, não era o único aspecto envolvido na questão da emancipação. Dufay queria deixar claro que a abolição da escravidão não significava o fim da produção colonial. Ressaltava, assim, que a proclamação de Sonthonax de 29 de agosto de 1793, ao declarar os negros livres, não deixava de submetê-los a uma disciplina rígida: eles estavam "fixados na gleba" e submetidos a um trabalho diário, contra um salário determinado. Dufay afirmava que os negros trabalhariam agora para reembolsar a sua liberdade, de modo que os proprietários não perderiam nada, pois o que antes era produzido por 600 mil escravos seria agora produzido por 600 mil homens livres. Livre dos altos custos da escravidão, a colônia viveria uma nova era de prosperidade. ${ }^{1267}$ Em suma, na sua defesa da liberdade, Dufay não apelava para a

\footnotetext{
1264 "[...] les nègres armés pour la cause de la France ont déjoué par leur courage ces perfides projets, et ont demandé, pour prix de leurs services, la liberté, qui leur a été accordée" (Moniteur, v.19, número 137, 5 de fevereiro de 1794, p.387).

1265 "N'était-il pas d'une politique sage et éclairée de créer de noveaux citoyens à la république pour les opposer à nos ennemis?" (Idem, v.19, número 138, 6 de fevereiro de 1794, p.391).

${ }^{1266}$ Ibidem, p.394.

${ }^{1267}$ Ibidem, p.391.
} 
fidelidade aos princípios republicanos, mas para considerações pragmáticas relativas à conservação das colônias e à manutenção da produção.

Após o discurso de Dufay, entretanto, o montanhês Levasseur ${ }^{1268}$, da Sarthe, invocou os princípios para propôr a abolição da escravidão no conjunto dos territórios pertencentes à França:

Eu peço que a Convenção, cedendo não a um movimento de entusiasmos, mas aos princípios da justiça, fiel à Declaração dos Direitos do Homem, decrete, desde esse momento, que a escravidão está abolida em todo o território da República. São Domingos faz parte desse território, e, entretanto, nós temos escravos em São Domingos. Peço, portanto, que todos os homens sejam livres, sem distinção de cor. ${ }^{1269}$

Como disse Claire Blondet, naquele momento, a Convenção cometia a ousadia de reconhecer legalmente a vitória de uma insurreição de escravos ${ }^{1270}$, mas ao referir-se a "todo o território da República", Levasseur pretendia não apenas confirmar a abolição em São Domingos, mas estender a liberdade a todas as colônias francesas. O "dantonista" Jean François de Lacroix, deputado da Eure-et-Loire, ressaltou que era o momento de reparar um grave erro cometido para com os negros das colônias, esquecidos na obra da constituinte:

Inutilmente nós decretamos que nenhum direito feudal seria percebido na república francesa. Acabastes de ouvir um de nossos colegas dizer que ainda há escravos nas nossas colônias. É tempo de elevar-nos à altura dos princípios da liberdade e da igualdade. [...] Proclamemos a liberdade dos homens de cor. Ao cometer esse ato de justiça, dais um grande exemplo aos homens de cor escravos nas colônias inglesas e espanholas. Os homens de cor quiseram, assim como nós, romper as suas correntes; nós quisemos romper as nossas, não quisemos submeter-nos ao jugo de nenhum mestre; concedamo-lhes a mesma benção. ${ }^{1271}$

\footnotetext{
${ }^{1268}$ René Levasseur era sobrinho de um rico plantador de São Domingos, com quem se indispunha por conta de suas ideias sobre a liberdade. Ao morrer, seu tio lhe legou apenas 15 mil libras de sua imensa fortuna (cf. KUSCINSKI, A. Dictionnaire des conventionnels. Brueil-en-Vexin: Éditions du Vexin Français, 1973, pp.406-408).

1269 "Je demande que la Convention, ne cédant pas à un mouvement d'enthousiasme, mais aux principes de la justice, fidèle à la Déclaration des Droits de l'Homme, décrète dès ce moment que l'esclavage est aboli sur tout le territoire de la république. Saint-Domingue fait partie de ce territoire, et cependant nous avons des esclaves à Saint-Domingue. Je demande donc que tous les hommes soient libres, sans distinction de couleur" (Moniteur, v.19, número 137, 5 de fevereiro de 1794, p.387).

${ }^{1270}$ Cf. BLONDET, Claire. Quand les "terroristes" font le procès du colonialisme esclavagiste les thermidoriens organisent son oubli. In: GAUTHIER, Florence (org.). Périssent les colonies plutôt qu'un principe!, p.43.

1271 "Inutilement avons-nous décrété que nul droit féodal ne serait perçu dans la république française. Vous venez d'entendre un de nos collègues dire qu'il y a encore des esclaves dans nos colonies. Il est temps de nous élever à la hauteur des principes de la liberté et de l'égalité. [...] Proclamons la liberté des hommes de couleur. En faisant cet acte de justice, vous donnez un grand exemple aux hommes de couleur esclaves dans les colonies anglaises et espagnoles. Les hommes de couleur ont, comme nous, voulu briser
} 
Alguns membros, sem se oporem à proposta, pediram que a discussão fosse adiada e remetida aos comitês. ${ }^{1272}$ Lacroix pediu então ao presidente que a Convenção não se desonrasse com uma discussão mais longa. De acordo com o relato do Moniteur, a assembleia inteira ergueu-se "por aclamação". O presidente pronunciou a abolição da escravidão, "em meio a aplausos e gritos mil vezes repetidos de viva a república! viva a Convenção! viva a Montanha!". Os dois deputados de cor receberam o beijo fraternal do presidente e dos demais deputados. ${ }^{1273}$ Cambon chamou a atenção para uma cidadã de cor - Marie Dupré - que assistia regularmente às sessões da Convenção e que, emocionada com a liberdade concedida aos seus irmãos, desmaiou. $\mathrm{O}$ deputado pediu que seu nome fosse inscrito nas atas da audiência. ${ }^{1274}$ Um outro deputado pediu que a notícia da abolição fosse imediatamente enviada às colônias francesas.

Danton tomou então a palavra para ressaltar que, naquele dia, a Revolução assumia finalmente a sua vocação universalista:

Representantes do povo francês, até agora, não só tínhamos decretado a liberdade como egoístas e para nós mesmos. Mas, hoje, nós proclamamos à face do universo, e as gerações futuras encontrarão a sua glória nesse decreto, nós proclamamos a liberdade universal. ${ }^{1275}$

Contudo, Danton alertava que, após terem concedido a liberdade, era preciso que os representantes da França atuassem como "moderadores". Manifestando a sua preocupação com a aplicação da abolição e a transição do regime escravista para um regime de liberdade, pedia que o decreto de abolição fosse remetido aos comitês de Salvação Pública e das colônias para que compusessem um relatório sobre "[...] os meios de tornar esse decreto útil à humanidade, sem nenhum perigo para ela" (grifo

leurs fers; nous avons voulu brisé les nôtres, nous n'avons voulu nous soumettre au joug d'aucun maître; accordons-leur le même bienfait" (Moniteur, v.19, número 137, 5 de fevereiro de 1794, pp.387-388).

${ }^{1272}$ Cf. Journal de Perlet, número 501, 17 pluvioso do ano II (5 de fevereiro de 1794), p.37.

${ }^{1273}$ Cf. Moniteur, v.19, número 137, 5 de fevereiro de 1794, p. 388.

${ }^{1274}$ Para Claude Wanquet, a explicação para o desmaio de Marie Dupré poderia ser outra: segundo o inspetor de polícia Béraud, Marie Dupré era proprietária de escravos e teria caído em desespero diante da perda de seu patrimônio. Essa explicação nos parece incorreta. Havia duas mulheres de cor que poderiam corresponder à personagem em questão: 1) Marie Anne Dupré, nascida em Paris, declarada em 1778 como vendedora de canções; 2) Marie-Louise Dupré, nascida na Martinica e que tinha chegado a Bordeaux em 1759; declarada, em 1778, como funcionária de um prateador em Bourg-l'Abbé. Nenhuma das duas corresponde à descrição de uma senhora de escravos (cf. WANQUET, Claude. La France et la première abolition de l'esclavage, pp.160-161; Dictionnaire des gens de couleur, p.211-212).

1275 "Représentants du peuple français, jusqu'ici nous n'avons décrété la liberté qu'en égoïstes et pour nous seuls. Mais aujourd'hui nous proclamons à la face de l'univers, et les générations futures trouveront leur gloire dans ce décret, nous proclamons la liberté universelle" (Moniteur, v.19, número 137, 5 de fevereiro de 1794, p.388). 
nosso). ${ }^{1276}$ A formulação era extremamente vaga, mas a preocupação com a utilidade da abolição remetia a antigos questionamentos relativos ao processo de adaptação da massa dos antigos escravos, e da economia colonial como um todo, a um novo regime. Mesmo num contexto excepcional, essa preocupação, que era a base do gradualismo, mantinhase viva, na medida em que o ânimo de manter o estatuto colonial também mantinha-se intacto.

Por fim, Danton abordou a questão essencial da guerra contra a Inglaterra e do papel das colônias nesse conflito:

Nós trabalhamos para as gerações futuras, lancemos a liberdade nas colônias; é agora que o Inglês está morto. (Aplausos) [...] Em vão, Pitt e seus cúmplices tentarão, por considerações políticas, afastar o gozo dessa benção, eles serão arrastados para o vazio; a França irá retomar o patamar e a influência que lhe garantem a sua energia, o seu solo e a sua população. ${ }^{1277}$

A intervenção de Danton explicitava a dimensão militar da abolição. O exército negro aparecia como a única força capaz de derrotar os ingleses em São Domingos e vencer para a França a batalha colonial da guerra contra as potências, não apenas em São Domingos, mas também nas pequenas Antilhas, então cobiçadas pelos ingleses: Tobago (sitiada desde 15 de abril de 1793); Martinica (a partir de 24 de março de 1794); Sainte-Lucie (a partir de 4 de abril de de 1794); Guadalupe (a partir de 20 de abril de 1794); e Marie-Galante (a partir de 21 de abril de1794). As palavras de Danton também podiam expressar a ideia de que a abolição poderia repercutir nas colônias inglesas, detonando uma onda de movimentos pela liberdade.

Bourdon de l'Oise retomou a questão da acusação contra os comissários civis em São Domingos, entendendo que à luz do decreto que acabava de ser aprovado, um novo exame da conduta de Sonthonax e Polverel se fazia necessário: "é preciso saber se o que fizeram não foi comandado pelas circunstâncias em que se encontraram, e para a salvação da colônia". Isto é, o decreto de abolição sancionava, em larga medida, as medidas tomadas pelos comissários na colônia e podia ser interpretado como a sua absolvição indireta. A questão foi remetida ao Comitê de Salvação Pública, mas o fato é

\footnotetext{
${ }^{1276}$ Ibidem, p.388.

1277 "Nous travaillons pour les générations futures, lançons la liberté dans les colonies; c'est aujourd'hui que l'Anglais est mort. (On l'applaudit) [...] En vain Pitt et ses complices voudront par des considérations politiques écarter la jouissance de ce bienfait, ils vont être entraînés dans le néant; la France va reprendre le rang et l'influence que lui assurent son énergie, son sol et sa population" (Ibidem, p.388).
} 
que os comissários eram culpados de "brissotismo", e a sua postura abolicionista era, para o grupo no poder, quase secundária. ${ }^{1278}$

Sem dar maiores detalhes, o Moniteur menciona que, ainda na sessão de 16 pluvioso, "alguns debates" ocorreram quando da discussão da redação do decreto de abolição. ${ }^{1279}$ Isso permite afastar a imagem, muito difundida, de uma unanimidade absoluta na Convenção quanto à abolição. Mas que essa magra e fracassada tentativa de oposição tenha sido completamente silenciada é certamente mais significativo do que teria sido um eventual consenso. Que houvesse pessoas opostas à abolição dentro da Convenção é bastante natural. Lá estavam, por exemplo, deputados de colônias escravistas, como Crassous de Médeuil da Martinica, Lion da Guadalupe e Gouly da Île-de-France. Mas o fato de que essa oposição não tenha tido força suficiente para sequer se fazer ouvir dá a medida do declínio da influência dos colonos e do comércio marítimo naquela fase da Revolução. Era praticamente impossível, naquele contexto específico, sob o olhar vigilante da sans-culotterie, contestar, em nome de interesses financeiros, a aplicação dos princípios. Lacroix propôs a redação final ao decreto:

A Convenção nacional declara abolida a escravidão dos negros em todas as colônias; em consequência, ela decreta que todos os homens, sem distinção de cor, domiciliados nas colônias, são cidadãos franceses e gozarão de todos os direitos garantidos pela constituição.

Remete ao comitê de salvação pública para que este lhe faça imediatamente um relatório sobre as medidas a tomar para a execução do presente decreto. ${ }^{1280}$ (grifo nosso)

Ou seja, ao contrário do que afirmam alguns historiadores, o decreto não se limitava a ratificar a liberdade geral já proclamada por Sonthonax: ele estendia aos novos livres de todas as colônias francesas os direitos de cidadania dos quais gozava o povo da metrópole. Num momento em que a distinção entre cidadãos ativos e passivos tinha sido suprimida, isso significava que os antigos escravos eram agora

\footnotetext{
${ }^{1278}$ Após a abolição, os deputados de São Domingos reagiriam à informação de que um antigo condutor de Negros chamado Secondez estava prestes a partir para pôr em execução o decreto de acusação contra os comissários civis em São Domingos. Embora não contestassem a medida, os deputados questionavam a sua propriedade e suspeitavam que a escolha do mandatário talvez fosse uma manobra dos colonos para incitar os negros a desconfiarem da França e se jogarem nos braços da Inglaterra (cf. WANQUET, Claude. La France et la première abolition de l'esclavage, pp.166-167).

${ }^{1279}$ Cf. Moniteur, v.19, número 137, 5 de fevereiro de 1794, p. 388.

${ }_{1280}$ "La Convention nationale déclare aboli l'esclavage des nègres dans toutes les colonies; en conséquence, elle décrète que tous les hommes, sans distinction de couleur, domiciliés dans les colonies, sont citoyens français, et jouiront de tous les droits assurés par la constitution. Renvoie au comité de salut public pour lui faire incessamment un rapport sur les mesures à prendre pour l'exécution du présent décret" (Ibidem, p.388).
} 
eleitores e tinham sido incorporados à ordem republicana francesa. Em celebração da grande vitória, a sessão parlamentar foi encerrada mais cedo.

O decreto de 16 pluvioso do ano II - ao contrário da abolição final de 1848 recusava qualquer tipo de indenização aos proprietários de escravos. A mera menção a uma indenização teria contrariado inteiramente o espírito da Convenção montanhesa. Impulsionada pela ação constante do movimento popular, a política revolucionária do ano II foi inteiramente marcada por medidas que traduziam concepções sobre a propriedade privada que rompiam com a ortodoxia liberal, ao impor à propriedade um limite, uma medida ditada pela ética. Essa concepção justificava, por exemplo, limitações ao direito do produtor de subsistências sobre a sua produção e medidas de redistribuição da propriedade fundiária. A lei sobre o máximo geral dos bens de primeira necessidade (29 de setembro de 1793), as leis sobre a igualdade dos herdeiros na sucessão (26 de outubro de 1793 e 6 de janeiro de 1794) e as leis relativas ao fracionamento dos bens nacionais (3 de junho de 1793) e dos bens comunais em pequenas parcelas (10 de junho de 1793) eram medidas que se inscreviam numa mesma lógica de evitar um exercício abusivo do direito de propriedade que promovesse a extrema riqueza de uns e extrema pobreza de outros. A propriedade só era sagrada conquanto fosse legítima; a propriedade sobre o escravo não o era e não podia gozar de nenhuma proteção. ${ }^{1281}$

Na mesma hora em que a Convenção abolia a escravidão, Page e Brulley eram recebidos pelo Comitê de Salvação Pública. Sete de seus membros estavam presentes (Saint-Just, Billaud-Varenne e Prieur de la Marne estavam em missão, Couthon estava doente). Ocupado com questões relativas aos armamentos e às subsistências ${ }^{1282}$, o Comitê se dispôs a receber seus memoriais e analisá-los, mas não lhes concedeu uma confrontação com os deputados de São Domingos. Quando deixavam as dependências do Comitê, Page e Brulley foram informados da tão temida abolição. ${ }^{1283}$

Ainda em 16 pluvioso, à noite, os três deputados de São Domingos foram acolhidos com exaltação no Clube dos Jacobinos por um grande número de membros.

\footnotetext{
${ }^{1281}$ Nesse sentido, a Jean-Daniel Piquet compete certa razão quando afirma que é estanho que certos historiadores façam o processo de intenções do pessoal revolucionário, que aboliu a escravidão, sem contrapartida financeira para os colonos, e, ao mesmo tempo, louvem a coragem de Victor Schoelcher, que a aboliria, em 1848, apenas com indenização para os colonos (cf. PIQUET, Jean-Daniel. L'émancipation des Noirs dans la Révolution française, p.346).

${ }^{1282}$ Cf. Recueil des actes du Comité de salut public. Paris: Imprimerie nationale,1889-1910, v.10, pp.670680.

${ }^{1283}$ Cf. BÉNOT, Yves. Comment la Convention a-t-elle voté l'abolition de l'esclavage?, p.355.
} 
Cada um dos três deputados pronunciou um discurso, antes de presentear a Sociedade com a bandeira tricolor, na qual estavam representados um branco, um negro e um mulato. $^{1284}$

No dia seguinte, na Convenção, houve uma tentativa de recuo, quando foi discutida a redação do decreto de abolição. O Journal de Perlet fala de "algumas reclamações sobre a redação do decreto que determina que a escravidão está abolida em todas as colônias francesas". ${ }^{1285}$ Embora sem contestar a medida em si, alguns deputados pediram que o decreto não mencionasse a palavra escravidão. Lacroix, apoiado por Dufay, refutou essa possibilidade, argumentando que a República não podia esconder o fato de que a escravidão tinha existido nas colônias e que cabia a ela reconhecer o erro e destruir a escravidão. Grégoire, traumatizado por experiências passadas, insistiu para que a lei não admitisse equívocos e que a palavra "escravidão" fosse incluída. ${ }^{1286}$ Após nova redação proposta por Chalier, Levasseur afirmou: "Não mintamos à posteridade, não mintamos a nós mesmos: é fato que, apesar da declaração dos direitos, a escravidão existia nas nossas colônias: declaremos francamente que ela está abolida". ${ }^{1287}$ Após "alguns debates", a redação final do decreto foi remetida ao Comitê de Salvação Pública, também encarregado de formular as medidas de sua execução. ${ }^{1288}$ No final, a ata do dia anterior acabou sendo mantida, assim como o decreto de abolição, nos termos aprovados em 16 pluvioso. ${ }^{1289}$ Essa tentativa velada de contra-ataque, que atestava a existência de uma enfraquecida oposição colonial à abolição, tinha sido derrotada.

Ainda na sessão de 17 pluvioso, o jusnaturalista Coupé de l'Oise, alegando que não bastava devolver a liberdade aos negros, chegou a propor uma medida radical: a distribuição das terras incultas das ilhas e a venda dos bens dos colonos emigrados aos novos cidadãos das colônias francesas. ${ }^{1290}$ Essa proposta, que não foi adotada, contrariava a percepção que se tinha então da necessidade de manter a economia das

\footnotetext{
${ }^{1284}$ Cf. Journal de la Montagne, número 85, 18 pluvioso do ano II, p.677.

${ }^{1285}$ Cf. Journal de Perlet, número 502, 18 pluvioso do ano II (6 de fevereiro de 1794), p.41.

${ }^{1286}$ Cf. AP, v.84, p.326.

1287 "Ne mentons point à la postérité, ne nous mentons point à nous mêmes: il est de fait que, malgré la déclaration des droits, l'esclavage existait dans nos colonies: déclarons franchement qu'il est aboli" (Journal de Perlet, número 502, 18 pluvioso do ano II (6 de fevereiro de 1794), p.42).

${ }^{1288}$ O pedido de remissão da lei ao Comitê de Salvação Pública não deve ser interpretado como uma tentativa de enterrar a lei. Era bastante usual que uma medida de aplicação tão complexa fosse submetida à análise dos comitês para que instruções fossem emitidas para a sua regulamentação.

${ }^{1289} \mathrm{O}$ decreto de abolição seria finalmente apresentado, na sua versão definitiva, em 23 germinal do ano II (12 de abril de 1794).

${ }^{1290}$ Cf. AP, v.84, p.327.
} 
grandes plantações, adaptando-as ao trabalho livre. A ideia de Coupé de formar uma classe de pequenos proprietários negros - ideia próxima das aspirações das massas negras - permaneceu excepcional no quadro dos debates coloniais, o que explica, em parte, muitos dos problemas que a aplicação da abolição enfrentaria nos anos seguintes.

Pela primeira vez, entretanto, uma grande potência colonial, para a qual o sistema escravista revestia-se de uma importância fundamental, proscrevia a escravidão de suas colônias. ${ }^{1291}$ A Revolução tinha levado cinco anos para aplicar à escravidão os princípios da Declaração dos direitos. A abolição não era uma consequência da corrente antiescravista desenvolvida a partir da metade do século XVIII. Ela representava a superação da lógica gradualista e parlamentar dos Amigos dos Negros, herdeiros dessa corrente, mesmo que essa lógica voltasse a se manifestar no momento da aplicação da lei, como veremos adiante. A abolição era o resultado da ascensão de um ideal abolicionista radical impulsionado pela revolta dos escravos em São Domingos e favorecido por fatores conjunturais importantes, tais como a guerra externa e a evolução da Revolução na França para um republicanismo de base popular. A insurreição escrava nas colônias, a postura contrarrevolucionária dos colonos e a ameaça estrangeira forneceram o impulso necessário para que se passasse do plano das ideias para o plano da ação política concreta.

Apresentada muitas vezes como "lei de circunstância" por alguns historiadores $^{1292}$, o decreto de 16 pluvioso do ano II deve, na verdade, ser atribuído à ação das forças abolicionistas em movimento - os escravos das colônias e os republicanos da metrópole - que, sob a influência dos fatores objetivos que informavam a sua ação, formularam as suas pretensões e identificaram nas circunstâncias o momento de levá-las adiante. Assim como ocorreu com outras importantes leis do período revolucionário, tais como as leis agrárias e de regulamentação da economia, a transformação da política colonial da Revolução foi impulsionada pela constituição de movimentos sociais. Foram os abolicionistas - negros e brancos - que fizeram a abolição, muito embora a tenham feito em circunstâncias muito específicas.

\footnotetext{
${ }^{1291}$ Antes da lei de 16 pluvioso, alguns estados do Norte dos Estados Unidos tinham decretado a abolição e a Dinamarca tinha suprimido o tráfico, mas esses não eram estados de economia escravista, de modo que a sua economia não dependia fundamentalmente do trabalho escravo (cf. DORIGNY, Marcel. Les abolitions de l'esclavage, p.8).

1292 É o caso, por exemplo, de Seymour Drescher, para quem "em 1794, a França revolucionária incorporou brevemente a libertação dos escravos num programa geral de guerra revolucionária" (cf. DRESCHER, Seymour. British Way, French Way: Opinion Building and Revolution in the Second French Emancipation. In: From Slavery to Freedom, pp.193).
} 


\section{II.3.2) As reações à lei: sinais de uma adesão popular}

Para compreender o voto de 16 pluvioso, não basta observar isoladamente a postura dos deputados que compunham a Convenção nacional. A assembleia dos representantes do povo não se encontrava separada da sociedade francesa por uma muralha. Ela estava, ao contrário, sob a vigilância contínua de um movimento popular que, naquele momento, exercia pressão considerável sobre as esferas de poder. O 14 de julho de 1789, o Grande Medo, o 10 de agosto de 1792, os massacres de setembro, as jornadas populares de 31 de maio - 2 de junho de 1793, todos esses eventos pesavam sobre as decisões dos deputados, que já não podiam mais advogar o interesse das classes possuidoras sem correr o risco de verem-se taxados de contrarrevolucionários e aristocratas. Comumente omitido das transcrições dos debates parlamentares, o povo francês esteve presente como testemunha e árbitro das decisões de seus representantes. O envolvimento popular no processo abolicionista pode ser atestado por uma série de manifestações de apoio à lei de abolição: por meio de artigos de jornal, de cartas à Convenção, de canções, obras literárias ou manifestações públicas, os patriotas não deixaram de manifestar a sua adesão à liberdade geral dos homens. Avessos a todas as instituições que ferissem o seu sentido de igualdade, os sans-culottes podiam reconhecer na luta dos negros contra a escravidão o seu próprio combate contra todas as formas de opressão e de privilégio. Ao comemorar o decreto de 16 pluvioso, a imprensa republicana procurou enfatizar esse aspecto.

Assim, ao relatar a sessão que culminou na supressão da escravidão, o Journal de Paris, de 5 de fevereiro, falou numa "vitória conquistada sobre os preconceitos e sobre os ingleses, inimigos da igualdade". ${ }^{1293}$ Figura extremamente influente no movimento popular, Jacques-René Hébert, que, até então, havia se mostrado pouco atento às questões coloniais, abordou enfaticamente o tema, no número 347 do Père Duchesne (1 ${ }^{\circ}$ ventoso do ano II/19 de fevereiro de 1794), no qual atacou o argumento de que as colônias, sem escravos, não poderiam existir:

como! nossas ilhas seriam estéreis se fossem cultivadas por homens livres. Sim, diabo, elas o seriam, mas para quem? para os mercadores, os açambarcadores, os ricos egoístas, para esses aventureiros, esses vagabundos, o refugo da Europa, para esses tigres brancos que engordam com o sangue dos negros; mas, diabo, esses negros tornados livres serão menos industriosos? [...] Não, diabo, o negro tornado livre e proprietário será

${ }^{1293}$ Cf. Journal de Paris, número 401, 5 de fevereiro de 1794 (17 pluvioso do ano II), p.1623. 
mais industrioso, mais ativo. Não será mais para um senhor bárbaro que ele regará a terra com seu suor e suas lágrimas. Seus filhos lhe pertencerão e o farão prezar a vida, e em troca do açúcar e dos outros produtos que ele terá cultivado, nós lhe daremos nossos tecidos e as produções de nosso solo. Então, faremos com ele tratados de aliança e de comércio. ${ }^{1294}$

Hébert via, portanto, além da abolição: o antigo escravo aparecia como um pequeno cultivador independente e um consumidor de produtos franceses.

O procurador da Comuna de Paris, Chaumette, comentou, nas Révolutions de Paris de 18-25 pluvioso, a questão num longo artigo, chamado Les Nègres enfin libres. Louvou a lei, mas apresentando-a como uma conquista tardia da Revolução francesa:

Essa lei faltava à nossa revolução. Não se devia ter esperado a preferência de dois representantes escolhidos na casta de nossos irmãos os Negros, para reabilitar estes em todos os seus direitos primitivos, naturais e civis. Mas ainda é melhor que o bem seja feito tardiamente do que nunca. ${ }^{1295}$.

Na passagem mais forte do texto, Chaumette apresentava o decreto como uma conquista não da burguesia revolucionária da metrópole, mas dos sans-culottes das ilhas, os insurretos negros:

Esse reparo retumbante feito à natureza e aos princípios é, mais uma vez, a obra dos sans-culottes; pois seria em vão se nós o dissimulássemos: eles eram outrora na França, em relação aos nobres, os ricos e os padres, o que, nas nossas ilhas, os Negros eram para os brancos e para os jesuítas. ${ }^{1296}$

Estabelecia-se, assim, o vínculo entre as massas populares das colônias e da metrópole. O jornal também destacava a importância da medida para a guerra contra a Inglaterra, afirmando que a libertação geral dos negros nas colônias serviria de escudo para a República francesa. A declaração da liberdade de todos os homens de cor não era, assim, apenas uma homenagem aos princípios, mas também "[...] uma medida sábia

\footnotetext{
1294 "quoi! nos isles, seraient stériles si elles étaient cultivées par des hommes libres. Oui, foutre, elles le seraient, mais pour qui? pour les marchands, les accapareurs, les riches égoïstes, pour ces aventuriers, ces vagabonds, le rebut de l'Europe, pour ces tigres blancs qui s'engraissent du sang des noirs; mais, foutre, ces noirs devenus libres en seront-ils moins industrieux? [...] Non, foutre, le nègre devenu libre et propriétaire, deviendra plus industrieux, plus actif. Ce ne sera plus pour un maître, barbare qu'il arrosera la terre de ses sueurs et de ses larmes. Ses enfants lui appartiendront et lui feront chérir la vie, en échange du sucre et des autre denrées qu'il aura cultivées, nous troquerons avec lui nos étoffes et les productions de notre sol. Alors nous ferons avec lui des traités d'alliance et de commerce" (Je suis le véritable Père Duchesne, foutre!., número 347, pp.2-3).

1295 "Cette loi manquait à notre révolution. Il ne fallait pas attendre la préférence de deux représentants du peuple choisis dans la caste de nos frères les Nègres, pour réhabiliter ceux-ci dans tous leurs droits primitifs, naturels et civils. Mais encore vaut-il mieux que le bien ce fasse tard que jamais" (Les Révolutions de Paris, v.17, número 224, 18-25 pluvioso do ano II, p.506).

1296 "Cette réparation éclatante faite à la nature et aux principes, est encore l'ouvrage des sans-culottes; car on se le dissimulerait en vain: ils étaient jadis en France, à l'égard des nobles, des riches et des prêtres, ce que dans nos îles les Nègres étaient pour les blancs et pour les jésuites" (Ibidem, p.506).
} 
e muito política nas circunstâncias presentes, que frustrará os planos do gabinete de Saint-James". ${ }^{1297}$ Chaumette transmitia a imagem da Revolução como uma onda que ia engolindo tudo à sua volta, em todos os cantos do planeta:

sobre todo o resto do continente, assim como no novo mundo e nas índias, a revolução francesa, na próxima primavera, inoculará o globo inteiro, sem distinção de cores ou de formas. Todos os corpos de nações expelirão as pústulas aristocráticas que contêm em si. Em uma palavra, os sans-culottes da França serão os inoculadores do gênero humano. ${ }^{1298}$

Chaumette não se limitou a festejar a abolição por escrito. Em 18 pluvioso (6 de fevereiro), manifestou-se sobre a abolição na Comuna de Paris, apresentando-a não como uma obra dos homens, mas do "eterno". Propôs que a Comuna felicitasse a Convenção pelo decreto, que consolidava a confiança que os sans-culottes depositavam nela. Sob os aplausos da sans-culotterie parisiense, ele foi escolhido para apresentar uma homenagem à Convenção. ${ }^{1299}$ Em 21 pluvioso (9 de fevereiro), os três deputados de São Domingos apresentaram-se ao conselho da Comuna, onde juraram fidelidade à República indivisível. O Journal de la Montagne afirma que a sua presença provocou "transportes de alegria que poderiam fazer acreditar que a liberdade acabava de nascer". ${ }^{1300}$ Chaumette fez novo discurso, bastante emotivo, para exaltar as leis da Convenção. Propôs ainda que a festa em homenagem aos direitos do homem, prevista para o 30 pluvioso, no Templo da Razão (Notre-Dame), fosse também uma celebração da abolição da escravidão. ${ }^{1301}$

Com efeito, a adesão popular à abolição também pode ser atestada pelo número de festas organizadas em celebração da lei de 16 pluvioso. A principal delas foi, justamente, a de Paris, de 30 pluvioso (18 de fevereiro de 1794). Segundo os relatos, a catedral de Notre-Dame, convertida em Templo da Razão, foi tomada por uma massa entusiasmada que mal cabia nas suas dependências. Representando a Comuna de Paris, Chaumette fez um longo discurso em homenagem ao fim da escravidão: "o dia da justiça reluziu num canto do globo; o oráculo da verdade se fez ouvir no seio de uma

\footnotetext{
${ }^{1297}$ Ibidem, pp.507-508.

1298 "sur tout le reste du continent, comme dans le nouveau monde et dans les indes, la révolution française, au printemps prochain, innoculera tout le globe, sans distinction de couleurs ni de formes. Tous les corps de nations rejetteront les pustules aristocratiques qu'ils renferment. En un mot, les sans-culottes de France seront les inoculateurs du genre humain" (Ibidem, p.508).

${ }^{1299}$ Cf. Journal de la Montagne, número 87, 20 pluvioso do ano II, pp.692-693.

${ }^{1300}$ Idem, número 92, 25 pluvioso do ano II, p.732

${ }^{1301}$ Idem, número 93, 25 pluvioso do ano II, pp.732-733.
} 
assembleia de sábios, e A ESCRAVIDÃO ESTÁ SUPRIMIDA". ${ }^{1302}$ Remontando às origens da servidão, Chaumette procurou demonstrar o caráter destrutivo dessa instituição sobre as diferentes civilizações e destacou que os esforços feitos para mantêla tinham levado grandes povos à sua própria destruição. Assim, se a escravidão era "o maior dos males", a sua abolição era o "maior dos bens, tanto para os estados quanto para os particulares": preservava os Estados das agitações violentas que aceleravam a sua queda e preservava os homens do contágio de todos os vícios que nasciam com a escravidão. ${ }^{1303}$

É interessante, entretanto, observar que, assim como havia feito Danton em 16 pluvioso, Chaumette concluía a sua intervenção com um apelo à prudência na execução da lei:

temamos que muita pressa não acabe retardando ainda mais a felicidade de nossos irmãos de cor; esperemos com confiança o efeito das medidas sábias que deve tomar o governo para preparar olhos enfraquecidos às torrentes de luz que vão atingi-los; temamos que uma embriaguez súbita não tome com violência demasiada esses homens inteiramente novos para a liberdade, e não excite entre eles movimentos que poderiam ser funestos, para eles como para nós. Cabe ao piloto que ordena a manobra do navio dirigi-la e segui-la com seu olhar. ${ }^{1304}$

Chaumette, um abolicionista radical, manifestava, após a abolição, a velha preocupação com as dificuldades que envolviam a aplicação da medida: tratava-se do problema da inserção social dos novos livres, que traduzia, por sua vez, a preocupação com a manutenção e o funcionamento das colônias. No fundo, essas eram as mesmas preocupações que fundavam o princípio gradualista defendido pelos Amigos dos Negros e que agora reapareciam na esteira da abolição.

A festa contou com outros discursos, como o da mestiça Marie Thérèse Lucidor F. Corbin, filha de um antigo escravo estabelecido em Paris. ${ }^{1305}$ Ao comemorar o

\footnotetext{
1302 "le jour de la justice a lui sur un coin du globe; l'oracle de la vérité s'est fait entendre du sein d'une assemblée de sages, et l'ESCLAVAGE EST ANÉANTI" (CHAUMETTE, Anaxagoras. Discours prononcé au nom de la Commune de Paris, p.4).

${ }^{1303}$ Ibidem, pp.9-10.

1304 "craignons que trop d'empressement ne retarde encore le bonheur de nos frères de couleur; attendons avec confiance l'effet des mesures sages que doit prendre le gouvernement pour préparer des yeux affoiblis, aux torrents de lumière qui vont les frapper; craignons qu'une ivresse hâtive ne s'empare avec trop de violence de ces hommes tout neufs pour la liberté, et n'excite encore parmi eux des mouvements qui pourraient être funestes, et à eux, et à nous. C'est au pilote qui ordonne la manoeuvre du vaisseau à la diriger et la suivre de l'oeil" (Ibidem, pp.21-22.

${ }^{1305}$ Seu pai, André Lucidor, negro nativo de Azanda, na África, tinha sido escravo na Martinica e emancipado após sete anos de serviço no regimento da ilha. Em Paris, ele se casou, em 1745, com uma jovem branca, Thérèse-Charlotte Richard, com quem teve duas filhas, Louise e Marie-Thérèse (cf.
} 
decreto de abolição, Corbin prestou homenagem a Ogé, "assassinado pela aristocracia nas nossas Ilhas", e a Marat: "Foi tu, que, por meio de teus escritos, nos inspiraste o santo amor pela Liberdade, ao qual conservaremos sempre um eterno reconhecimento". ${ }^{1306}$ Corbin celebrou a reunião dos três povos representados na bandeira da igualdade da epiderme, livres da linha de demarcação traçada pela aristocracia.

No Père Duchesne, Hébert descreveu a festa abolicionista do Templo da Razão com entusiasmo:

Nunca, diabo, as abóbadas da antiga catedral ressoaram um tamanho Te Deum. Todos os bons Sans-Culottes, as sociedades populares, as autoridades constituídas envolviam o altar da razão. Uma deputação da convenção veio também lhe oferecer o incenso dos representantes do povo. Todos os olhares estavam fixos nos três montanheses americanos. ${ }^{1307}$

Hébert acreditou ver nos três deputados de São Domingos - Belley, Mills e Dufay - os "três reis magos" quando vieram visitar, em seu berço, o "Sans-Culotte Jesus". Mas, agora, não tinham sido conduzidos por uma estrela, mas pela "tocha da verdade". ${ }^{1308}$ Hébert anunciava que o exemplo de Paris estava sendo seguido no resto do país. Reproduzia o texto do juramento dos sans-culottes de Moulins, que juravam "[...] reconhecer como irmão todo homem justo e verdadeiro amigo da humanidade, qualquer que seja a sua cor, seu tamanho e seu país". ${ }^{1309}$

Muitas outras festas foram celebradas na França, em homenagem ao decreto de abolição, organizadas pelas municipalidades ou por sociedades populares. Diferentes historiadores apresentaram estudos valiosos a respeito dessas celebrações. Jean-Claude Halpern encontrou referências a 22 festas, das quais seis foram realizadas em 30 pluvioso (18 de fevereiro de 1794), onze durante o mês de ventoso e as demais num período posterior. Segundo Halpern, além da grande festa de Paris, foram registradas as

BARDIN, Pierre. Lucidor, ancien esclave, et sa fille Marie-Thérèse, à Paris. Disponível em: http://www.ghcaraibe.org/bul/ghc227/p5982.rtf. Acesso em: 17 de maio de 2012).

1306 "Ce fut toi, qui par tes écrits nous inspira le saint amour de la Liberté, dont nous te conserverons toujours une éternelle reconnaissance" (CORBIN, Lucidor F. Discours de la citoyenne Lucidor F. Corbin, Créole Républicaine, prononcée (sic) par elle-même au Temple de la Raison, l'an $2^{e}$ de la Liberté. Paris: chez Colubrier, graveur, s.d., pp.1-2).

1307 "Jamais, foutre, les voûtes de la ci-devant cathédrale ne retentirent d'un pareil Te Deum. Tous les bons Sans-Culottes, les sociétés populaires, les autorités constituées environnaient l'autel de la raison. Une députation de la convention vint aussi lui offrir l'encens des représentants du peuple. Tous les regards étaient fixés sur les trois montagnards américains" (Je suis le véritable Père Duchesne, foutre!., número 347, p.5).

${ }_{1308}$ Ibidem, p.5.

${ }^{1309}$ Ibidem, pp.6-7. 
seguintes celebrações: Auxerre (30 pluvioso), Bar-sur-Aube (data não conhecida), Bergues-sur-Colme (20 ventoso), Bernay (30 pluvioso), Bordeaux (30 pluvioso), Bourg-Régénéré (20 ventoso), Bourg-sur-Rhône (30 germinal), Bourgoin (10 ventoso), Évreux (data não conhecida), Faverges (data não conhecida), Fontenay-le-Peuple (30 ventoso), Le Havre-Marat (20 ventoso), Loubens (10 ventoso), Montereau (30 pluvioso), Orbec (10 germinal), Pont-Audemer (data não conhecida), Pontgibaud (10 germinal), Provins (30 pluvioso), Sète (data não conhecida), Troyes (10 ventoso), Vervins (data não conhecida). ${ }^{1310}$ Embora tenham ocorrido em pontos diferentes do território, as celebrações se concentraram, na sua maioria, na região próxima a Paris, na Alta Normandia, na Champanha e na Borgonha, assim como na região do RódanoAlpes.

Autores como Jean-Daniel Piquet e Lucie Maquerlot indicaram a ocorrência de outras festas de emancipação até então ignoradas, como as de Rouen, importante porto negreiro, e Châlons-sur-Marne. ${ }^{1311}$ Outra festa importante, indicada por Piquet, ocorreu em Lyon, rebatizada Commune-Affranchie, em 20 ventoso do ano II. Lá, a celebração contou com a presença dos representantes do povo Fouché, Laporte e Méaulle. Membro da sociedade dos sans-culottes de Bourg, Antoine Dorfeuille, fez um discurso, apresentando o decreto de abolição como "[...] digno da Montanha, que lutou por tanto tempo para arrancá-lo aos inimigos da natureza humana". ${ }^{1312}$ Dorfeuille celebrou ainda a derrota do partido dos colonos, "esses monstros coalizados com o trono e o altar; esses monstros que queriam, sob os nomes de federalismo e de política, republicanizar a escravidão e a realeza". ${ }^{1313}$ Assim, se a maioria das festas ocorreu em cidades próximas a Paris, pelo menos duas outras grandes cidades - Bordeaux e Lyon - organizaram comemorações importantes.

É certo que não se deve confundir o discurso oficial com um sinal de adesão popular espontânea. Mesmo nas cidades marítimas, a elite ligada ao comércio tinha, durante o ano II, sumido da política local, dando lugar a autoridades alinhadas com o governo jacobino. Em Bordeaux, maior porto do comércio colonial dos anos 1780, no dia 30 pluvioso, uma celebração foi organizada por iniciativa da sociedade popular

\footnotetext{
${ }^{1310}$ Cf. HALPERN, Jean-Claude. Les fêtes révolutionnaires et l'abolition de l'esclavage en l'an II, p.188.

1311 Cf. PIQUET, Jean-Daniel. L'émancipation des Noirs dans la Révolution française, p.400; MAQUERLOT, Lucie. Rouen et Le Havre face à la traite et à l'esclavage. In: M. DORIGNY (org.). Esclavage, résistances et abolitions. Paris: Éditions du CTHS, 1999, p.184.

${ }^{1312}$ Cf. DORFEUILLE, Antoine. Discours prononcé après la lecture du Décret sur les Hommes de couleur, dans la fête célébrée à Commune-Affranchie le 20 Ventôse. Commune Affranchie: Imprimerie Républicaine, s.d., p.1.

${ }^{1313}$ Ibidem, p.1.
} 
montanhesa. De caráter solene, a comemoração reuniu, no Clube Nacional, mais de duzentos homens de cor, que se dirigiram, cada um deles ao lado de um homem branco, em cortejo ao Templo da Razão da cidade. A Declaração dos direitos de 1793 foi lida em voz alta e seu artigo 18, que já continha em si o princípio da abolição, foi publicamente aclamado. Tallien, representante em missão fez um discurso para ressaltar o valor da liberdade e da Revolução contra os horrores da tirania e da escravidão. Os homens de cor aclamaram a Montanha e a Convenção e juraram combater pela liberdade. Após a cerimônia, todos se reuniram numa refeição frugal em homenagem à liberdade. $^{1314}$ Bastante formalizada e dotada de um caráter oficial, a festa foi essencialmente animada por militantes montanheses, provavelmente sem uma mobilização popular massiva.

Algumas das festas, entretanto, foram suficientemente espetaculares para indicar a existência de uma participação popular efetiva. Em Le Havre (rebatizada Le HavreMarat), outro importante porto negreiro, uma municipalidade jacobina e com forte apoio popular tinha sido instituída em setembro de $1793 .{ }^{1315} \mathrm{Na}$ cidade, a festa em homenagem à abolição foi organizada por iniciativa da sociedade popular, em colaboração com o conselho geral da comuna. Foi organizado um espetáculo em que cidadãos e cidadãs de cor eram vistos rompendo guirlandas de folhas que representavam as correntes da escravidão. Em seguida, um boneco do rei, simbolizando a ordem aristocrática, foi queimado. A associação das duas imagens tinha por objetivo vincular a abolição da escravidão à luta revolucionária contra a tirania. ${ }^{1316}$ Esse tipo de simbologia também esteve presente na festa de Pontgibaud, de 10 germinal. Nessa comemoração menos solene e de caráter popular ainda mais pronunciado, um asno foi introduzido no templo da Razão, portando os atributos da realeza, do fanatismo e da escravidão. ${ }^{1317}$

No departamento do Ain, a festa de Bourg-en-Bresse (rebatizada BourgRégénéré) chegou, segundo os relatos, a reunir entre 7 e 8 mil pessoas, número considerável para uma cidade de porte médio. Foi formado um cortejo, no qual um número importante de alegorias republicanas foi encenado. Assim, por exemplo, duas cidadãs, representando a Liberdade e a Virtude, andavam a cavalo acompanhadas de negros e brancos. Num carro, a bandeira tricolor era carregada por uma jovem cidadã representando a igualdade, também cercada por homens negros e brancos. Em outro

\footnotetext{
${ }^{1314}$ Cf. AP, v.85, pp.563-564.

1315 Cf. HALPERN, Jean-Claude. Les fêtes révolutionnaires et l'abolition de l'esclavage en l'an II, p.192.

${ }^{1316}$ Cf. MAQUERLOT, Lucie. Rouen et Le Havre face à la traite et à l'esclavage, p.185.

${ }^{1317}$ Cf. AP, v.93, p.227.
} 
carro, podiam ser vistas mulheres negras amamentando crianças brancas, e mulheres brancas amamentando crianças negras. ${ }^{1318}$

Várias festas mesclaram a comemoração da abolição com outros temas, como o aniversário da morte do rei ou a inauguração de monumentos. Assim, em Bernay, a abolição foi comemorada junto com a inauguração dos bustos de Brutus, Lepelletier e Marat. Os bustos foram levados num cortejo que incluiu um grupo de negros acorrentados. Diante da Árvore da Liberdade, onde os bustos foram depositados, a deusa da Liberdade anunciou aos homens de cor que os legisladores franceses tinham vingado a humanidade e, com um golpe, ela quebrou as suas correntes. ${ }^{1319}$ Também em Rouen, o programa de uma festa já prevista anteriormente foi modificado para incluir o tema da abolição. ${ }^{1320}$ Em Montereau, os jacobinos da cidade incluíram o tema da abolição numa cerimônia comemorativa dos "mártires da liberdade". No discurso pronunciado pelo cidadão Rouère, a abolição foi apresentada como a concretização máxima da Revolução:

Nossa feliz revolução, cidadãos, superior à da Grécia e à de Roma, deve consolidar-se sobre duas bases indestrutíveis: a liberdade e a igualdade. Podemos dizer que elas só foram realmente reconhecidas no dia memorável em que nossos mandatários deram às nações, por meio de seus decretos, o exemplo da emancipação. ${ }^{1321}$

Outras festas do período incluíram referências abolicionistas, caso da festa do Ser Supremo, realizada em várias partes do país. Em Brest, ela ocorreu em 20 prairial, com a presença do representante do povo Prieur de la Marne. De acordo com o relato do Journal de la Montagne, em determinado momento da cerimônia, um negro, antigo escravo, apresentou-se ao lado do representante:

Prieur o designa ao povo, e pergunta, após algumas reflexões repletas de sentimentos, se todos o reconhecem como seu irmão. Essa palavra mal é pronunciada e aclamações afirmativas ressoam de todas as partes, e o representante dá a esse digno Africano o abraço fraternal. ${ }^{1322}$

\footnotetext{
${ }^{1318}$ Cf. AP, v.87, pp.561-562.

${ }^{1319}$ Cf. AP, v.87, pp.361-363.

${ }^{1320}$ Cf. MAQUERLOT, Lucie. Rouen et Le Havre face à la traite et à l'esclavage, p.185.

1321 "Notre heureuse révolution, citoyens, supérieure à celle de la Grèce et de Rome, doit s'affermir sur deux bases indestructibles: la liberté et l'égalité. Nous pouvons dire qu'elles ne sont vraiment reconnues que du jour mémorable où nos mandataires ont donné aux nations, par leurs décrets, l'exemple de l'affranchissement" (ROUÈRE apud BERNET, Jacques. Provins et Montereau fêtent l'abolition de l'esclavage. Annales historiques de la Révolution française, Paris, n. 293-294, 1993. Disponível em: http://www.persee.fr/web/revues/home/prescript/article/ahrf_0003-4436_1993_num_293_1_1589.

Acesso em: 15 de abr. de 2013, p.513).

1322 "Prieur le désigne au peuple, demande après quelques réflexions pleines de sentiments, si on le reconnaît pour frère. Ce mot est à peine achevé que des acclamations affirmatives retentissent de toutes
} 
Além das festas revolucionárias, a adesão do movimento popular ao princípio abolicionista também pode ser atestada pelo grande número de cartas enviadas à Convenção, felicitando-a pela lei de 16 pluvioso. Jean-Claude Halpern indicou o envio de 356 cartas entre os meses de pluvioso e thermidor do ano II, mas o autor omitiu as manifestações das delegações. Florence Gauthier fala num número maior: 593 cartas à Convenção, entre 8 de fevereiro e 19 de julho de 1794. Jean-Daniel Piquet acredita, entretanto, que o número real possa ser ainda mais expressivo, alçando-se acima de $600 .^{1323}$

A maioria das cartas proveio de sociedades populares, base da organização política dos sans-culottes, na capital e nas províncias. Essas manifestações permitiam a incorporação da revolta dos escravos ao combate revolucionário conduzido na metrópole. Em diversas cartas, como, por exemplo, a da sociedade popular de Vervins, pequena cidade da Picardia, os negros foram apresentados como os sans culottes das colônias, retomando uma ideia disseminada pela imprensa popular desde as primeiras notícias do levante de São Domingos. ${ }^{1324}$ Já os sans-culottes da Sociedade da seção do Bonnet Rouge, em Paris, ressaltaram a anterioridade da luta dos marrons das colônias pela liberdade. ${ }^{1325}$ Por sua vez, a sociedade popular de Braine-sur-Vesle, no departamento da Aisne, comemorou a lei de abolição como o marco da união dos franceses da metrópole e das colônias na luta contra a opressão:

Vós conquistastes para nós novos irmãos ao dar a liberdade aos homens de cor; que os franceses dos dois mundos façam apenas uma família, que, por sua postura orgulhosa, surpreende os tiranos e denuncia os seus projetos liberticidas... ${ }^{1326}$

Vale observar que algumas cartas abordavam o aspecto econômico da questão, apresentando o trabalho livre como forma de relançar a economia colonial, enquanto outras abordavam o seu aspecto militar. Assim, por exemplo, Sherlock, capitão do $2^{\circ}$ batalhão do $92^{\circ}$ regimento de infantaria, pediu, em 20 pluvioso do ano II (8 de fevereiro), que seu batalhão fosse imediatamente preparado e enviado a São Domingos,

parts et le représentant donne à ce digne Africain l'accolade fraternelle" (Journal de la Montagne, número 74, 22 messidor do ano II, pp.600-601).

${ }^{1323}$ Cf. PIQUET, Jean-Daniel. L'émancipation des Noirs dans la Révolution française, p.352.

${ }^{1324}$ Cf. AP, v.85, p.557.

1325 Citado em HALPERN, Jean-Claude. L'universel et le lointain, pp.767-768.

1326 Vous nous avez conquis de nouveaux frères en donnat la liberté aux hommes de couleur; que les français des deux mondes ne fassent q'une seule famille, qui, par sa contenance fière, étonne les tyrans et dénonce leurs projets liberticides..." (Ibidem, p.768). 
para confraternizar com os cidadãos de cor, formá-los na arte da guerra e combater com eles pela causa da liberdade. ${ }^{1327}$ Essas adresses assumiam, no seu conjunto, o caráter de um movimento de pressão pela execução efetiva da lei de abolição.

Por fim, o entusiasmo em torno da abolição foi expresso em diferentes manifestações artísticas que seguiram o voto da abolição e que evidenciam a incorporação do tema da liberdade dos negros das colônias à cultura revolucionária e republicana. Canções em homenagem à liberdade dos negros apareceram na esteira da lei de pluvioso. Lucidor F. Corbin, a mulata que havia discursado na festa do Templo da Razão de 30 pluvioso, compôs o Hymne des citoyens de couleurs:

Dos ferros vergonhosos da escravidão

Eles libertaram o seu país

O despotismo na sua fúria

Os imolou em seus restos... (bis)

Mas ao sacrificar sua vida,

Calmos em meio aos tormentos

Eles sofreram nesses momentos

Apenas os males de sua pátria

Terrível verdade

Razão e liberdade

Vingados, vingados

Os direitos do homem e da igualdade. ${ }^{1328}$

Outra republicana, a cidadã Dubois, compôs L'Union Américaine produit [sic]

par la liberté française, que trazia o seguinte trecho:

Gozaremos de todos os nossos direitos

$O$ véu foi, enfim, rasgado

Pelos feitores bárbaros e frios

Não seremos mais maltratados (Bis.)

Prezaremos a Liberdade

A Igualdade. Fraternidade.

Não queremos mais a Escravidão

Para conhecer a Liberdade

Precisávamos (Bis) desse Decreto sábio. ${ }^{1329}$

\footnotetext{
${ }^{1327}$ Cf. AP, v.84, p.470.

1328 "Des fers honteux de l'esclavage Ils ont affranchi leur pays Le Despotisme dans sa rage Les immola sur ses débris... (bis) Mais en sacrifiant leur vie, Calmes au milieu des tourments Ils n'ont souffert en ces moments Que sur les maux de leur patrie Terrible vérité Raison et Liberté Vengés, vengés Les droits de l'homme et de l'égalité" (CORBIN, Lucidor F. Hymne des citoyens de couleurs, par la citoyenne Corbin, créole et républicaine. Paris: chez Colubrier, graveur, s.d., p.2).

1329 "Nous jouirons de tous nos droits Le voil est enfin déchiré Des conducteurs barbares et froids Nous ne serons plus maltraités (Bis.) Nous chérirons la Liberté L'Egalité. Fraternité. Nous ne voulons plus d'Esclavage Pour connaître la Liberté Il nous fallait (Bis) ce Décret sage" (DUBOIS. L'Union Américaine produit par la liberté française. Par la C-ne Dubois. S.1., s.d., p.2).
} 
Além das canções, nos anos que seguiram a abolição, um número expressivo de peças de teatro prestou homenagem à lei de abolição. Foi o caso de Sélico, ou les Nègres généreux (1796) de Guilbert de Pixerécourt, Le Blanc et le Noir (1796) de Pigault Lebrun, Adonis, ou le Bon Nègre (1798) de Béraud de la Rochelle e Rosny, e Elisca, ou l'Habitante de Madagascar (1799) de Favières. ${ }^{1330}$ As peças eram, na sua maioria, melodramas que procuravam ressaltar a nobreza da alma dos negros, de modo a legitimar a sua emancipação pela Nação francesa. Uma peça de Larivallière, Les Africains, ou le Triomphe de l'humanité (1795), por exemplo, apresentou o drama de Zamor, negro que se oferecia como escravo a um traficante para cobrir uma dívida de seu pai. Ao final da história, o capitão do navio negreiro, comovido pelos bons sentimentos dos negros, perdoava a dívida e decidia abandonar o tráfico, no mesmo momento em que chegava uma carta da metrópole anunciando o fim do tráfico e da escravidão. O capitão concluía a peça com as seguintes palavras: "Meus bons amigos, os homens não terão mais de nos temer, mas de nos imitar". ${ }^{1331}$

Esse amplo conjunto de manifestações políticas e culturais mesclava duas linhas de conduta. Em alguns casos, como a festa da abolição em Bordeaux ou o discurso feito por Rouère em Montereau, tratava-se essencialmente de celebrar a Convenção Nacional e o governo revolucionário. Procurava-se, com isso, sedimentar, por meio da comemoração da abolição enquanto faceta da luta contra a tirania, os laços entre o povo francês e as esferas de poder. Outras manifestações, de caráter mais abertamente popular, como a festa da pequena cidade de Pontgibaud ou a canção da cidadã Dubois, procuravam exaltar a solidariedade entre os revolucionários da metrópole e das colônias. Eram, assim, manifestações mais espontâneas de um movimento popular que reconhecia na luta dos negros das colônias uma contrapartida colonial do seu próprio combate contra todas as formas de opressão. No seu conjunto, todas essas manifestações atestavam o peso da participação popular na vida política do país.

\footnotetext{
${ }^{1330}$ Cf. SEEBER, Edward. Anti-slavery Opinion in France During the Second Half of the Eighteenth Century. New York: Lenox Hill, 1937, pp.183-185.

1331 "Mes bons amis, les hommes n'auront plus à nous craindre, mais à nous imiter" (LARIVALLIERE. Les Africains, ou le Triomphe de l'humanité, comédie en un acte et en prose, représentée sur les principaux théâtres de la République. Paris: Meurant, l'an III, p.48).
} 


\section{II.3.3) A guerra pela liberdade}

\section{II.3.3.1) A atitude dos robespierristas}

No que se refere à posição da cúpula do governo revolucionário diante da abolição, a historiografia da Revolução se viu envolvida em controvérsias que nos parecem pouco frutíferas. Buscou-se identificar nas opiniões particulares dos principais personagens do período a definição dos mocinhos e vilões da história da abolição de 1794, deslocando o exame das condições históricas que orientaram a política revolucionária para uma mera luta entre facções.

O antigo amigo dos Negros, Garran de Coulon, afirmaria, num relatório sobre as colônias, apresentado durante a reação thermidoriana, que os robespierristas - e Robespierre em particular - eram absolutamente contrários à abolição e que até mesmo a execução de Danton se deveu, em grande parte, ao seu apoio ao decreto de 16 pluvioso, o que não era verdade. ${ }^{1332}$ Isso ajudou a alimentar, na historiografia, o mito de um complô escravista contra Danton, tese explorada por Michelet. O decreto de 16 pluvioso se inseria, na opinião do historiador, no quadro de uma série de medidas de "ternura" pregadas pelos dantonistas e que teriam enfurecido os robespierristas. ${ }^{1333}$

O envolvimento não apenas de Danton e Lacroix, mas também de Chaumette no voto da abolição, todos eles adversários dos robespierristas, talvez tenha influenciado certas atitudes em relação à emancipação geral. Os três seriam condenados e executados, sob acusações infundadas, nos meses seguintes: Chaumette, em 24 de março (4 germinal), ao lado dos hebertistas, e Danton e Lacroix, em 5 de abril (16 germinal). Mas a tese de que os dantonistas formavam um bloco antiescravista contra 0 qual se opuseram os robespierristas é bastante falha. Em primeiro lugar, é preciso ressaltar que nem todos os dantonistas tiveram atitudes claras em relação à questão colonial. Como vimos anteriormente, Camille Desmoulins havia manifestado posições reacionárias sobre a questão colonial, atacando o movimento antiescravista num

${ }^{1332}$ Cf. GARRAN DE COULON, Jean-Philippe. Rapport sur les troubles de Saint-Domingue, v.4, p.567 e 581. O próprio Garran de Coulon afirmava que essa hipótese era sugerida pelos memoriais de Page e Brulley, que eram pouco confiáveis. Além disso, como aponta Piquet, o relatório de Saint-Just contra Danton, apresentado em 11 germinal do ano II, não continha nada nesse sentido (cf. PIQUET, JeanDaniel. L'émancipation des Noirs dans la Révolution française, p.392).

${ }^{1333}$ Dentre essas medidas, poder-se-ia citar a proposta de Desmoulins de formar um comitê de clemência, assim como a proposta de Cambon de elevar para 10 milhões a soma prevista para os socorros dos indigentes, contra os 500 mil propostos pelos robespierristas (cf. MICHELET. Histoire de la Révolution française. Paris: Gallimard, 1952, v.2, p.775). 
panfleto contra Brissot. Thuriot, outro dantonista, havia adotado uma postura ambígua no debate de 16 pluvioso, sugerindo uma redação diferente e absurda para o decreto, pela qual a Convenção declararia que a escravidão nunca havia existido. Portanto, fazer da questão da abolição um ponto central na ofensiva robespierrista contra Danton e seus aliados parece-nos uma grave distorção dos acontecimentos.

Além disso, é bom lembrar que, após o 9 thermidor, Robespierre foi alvo de muitas acusações, que devem ser encaradas com ceticismo. Assim, Dufay acusaria o líder jacobino de manter relações próximas com os principais articuladores do lobby colonial, chegando ao ponto de alegar que Robespierre tinha a intenção de fazer de Brulley o ministro da justiça, de Page o ministro da marinha, e de LarchevesqueThibault ministro plenipotenciário nos Estados-Unidos. ${ }^{1334}$ Nada indica que isso tenha ocorrido. Aliás, é bom destacar que Dufay tinha sido acusado por Page e Brulley, em notas ao Comitê de Salvação Pública, de ter dito que as plantations de São Domingos estavam repletas de hordas "ferozes, estúpidas, atrozes, antropófogas" e que os negros não tinham nenhuma ideia dos costumes, da língua, das leis dos brancos. Page e Brulley concluíam que, à luz do discurso de 16 pluvioso, Dufay só podia ser um "traidor sem pudor, que mente na medida de seu interesse". ${ }^{1335}$ Assim, as trocas de acusações devem sempre ser examinadas com o devido cuidado.

Por outro lado, é verdade que a postura de Robespierre diante da abolição não está livre de contradições e sugere sérias reticências de sua parte a respeito da oportunidade da medida. A tese de um Robespierre escravista aliado dos colonos resulta mais da campanha de difamação empreendida após o 9 thermidor do que de uma análise imparcial dos fatos, mas a sua atitude no debate colonial foi demasiadamente ambígua e, nesse sentido, decepcionante - para que se possa fazer dele um abolicionista radical ao mesmo título que Chaumette. O grande líder jacobino não se pronunciou claramente sobre uma medida que, à luz dos princípios por ele defendidos ao longo da Revolução, deveria ter contado com a sua total adesão. Ora, no dia 17 de pluvioso (5 de fevereiro), um dia após a abolição e na mesma sessão em que foi discutida a redação do decreto,

${ }^{1334}$ Cf. DUFAY, Louis-Pierre. Un représentant du peuple calomnié, à un représentant du peuple calomniateur. Paris: Imprimerie de Pain, s.d., p.10.

${ }^{1335}$ Cf. Cf. PAGE, Pierre-François, BRULLEY, Augustin-Jean. Notes fournies au Comité de Salut Public, pp.38-39. 
Robespierre fez um discurso sobre os princípios da moral revolucionária, no qual não fez nenhuma menção à escravidão colonial. ${ }^{1336}$

Nas suas Notas contra os Dantonistas, que Mathiez reproduziu em Études sur Robespierre, podemos ler as seguintes palavras de Robespierre a respeito da abolição:

Danton me disse um dia: 'É uma pena que não se possa propôr a cessão de nossas colônias aos Americanos; seria um meio de fazer aliança com eles'. Desde então, Danton e Lacroix fizeram passar um decreto cujo resultado mais provável era a perda das colônias. ${ }^{1337}$

A frase expressava, por um lado, a vontade do advogado de Arras de apresentar Danton como um inimigo da integridade da República francesa, e, por outro, o seu desacordo quanto ao princípio de uma abolição abrupta. Esse pessimismo quanto aos efeitos da lei traduzia, provavelmente, um desacordo quanto à oportunidade da medida, considerada imprudente, mais do que quanto ao seu mérito.

A historiografia ofereceu explicações variadas para a postura do jacobino. Cyril James sustentou, em Os Jacobinos Negros (1938), que, no fundo, Robespierre era um burguês que havia desservido a causa abolicionista por conta da sua luta contra os enraivecidos e hebertistas, gelando a relação do movimento popular com o governo revolucionário. Já o escritor haitiano Aimé Césaire explicou a atitude de Robespierre por "uma certa estreiteza de nacionalismo", aliada à sua "ordinária prudência". Acreditava que Robespierre, então em busca de uma coexistência pacífica com a Inglaterra, que vivia a ameaça de uma revolta escrava na Jamaica, poderia ter visto uma iniciativa revolucionária em matéria colonial como uma medida impolítica. ${ }^{1338}$ Em linha semelhante, Yves Bénot destacou que o "nacionalismo expansionista" de Robespierre implicava a manutenção do status quo colonial. No campo contrário, Florence Gauthier e Jean-Daniel Piquet veem em Robespierre o grande defensor do direito natural, de modo que as suas ambiguidades e eventuais contradições encontrariam a sua explicação no quadro das disputas políticas com os brissotinos e, mais tarde, com os dantonistas. Já para Claude Wanquet, há três explicações possíveis para o silêncio de Robespierre a

\footnotetext{
${ }^{1336}$ Um dado frequentemente negligenciado, quando se trata dos silêncios de Robespierre a respeito da lei de abolição, é que o líder jacobino adoeceu alguns dias após o decreto e, durante um mês, ele se ausentou das sessões do Comitê de Salvação Pública, da Convenção e dos Jacobinos (cf. PALMER, Robert. Twelve Who Ruled: The Year of the Terror in the French Revolution. Princeton: Princeton University Press, 1969, p.249). Ainda assim, isso não explica o seu silêncio na sessão de 5 de fevereiro de 1794.

1337 "Danton m'a dit un jour: 'Il est fâcheux que l'on ne puisse pas proposer de céder nos colonies aux Américains; ce serait un moyen de faire alliance avec eux. Danton et Lacroix ont depuis fait passer un décret dont le résultat le plus vraisemblable était la perte des colonies" (citado em MATHIEZ, Albert. Études sur Robespierre. Paris: Messidor/Éditions Sociales, 1988, p.136).

${ }^{1338}$ Cf. CÉSAIRE, Aimé. Toussaint Louverture, p.186.
} 
respeito da abolição: 1) a convicção, manifestada no debate de setembro de 1791, de que os negros, embrutecidos pela escravidão, não estavam em condições de receber imediatamente a liberdade; 2) a sua prudência costumeira; 3) um nacionalismo tão pronunciado que a ideia de perder as colônias lhe era insuportável. ${ }^{1339}$

Essas diferentes interpretações privilegiam um aspecto ou outro da vida política de Robespierre, sem, entretanto, dar conta da complexidade do personagem. Um dos primeiros a abordar, num artigo publicado em 1920, a postura do líder jacobino em relação aos negros das colônias, G. Hardy procurou identificar uma dualidade na postura antiescravista de Robespierre, mesmo que sua análise se revista de alguns sérios equívocos. Hardy rejeitou a tese de um relativo desinteresse do líder jacobino pelas questões coloniais, entendendo que "era-lhe impossível admitir a escravidão e o tráfico e sacrificar aos interesses de uma casta comercial a dignidade e o futuro de toda uma raça de homens e de toda uma categoria de franceses". ${ }^{1340}$ Assim, Robespierre teria sido, por princípio, um abolicionista. Não por acaso o seu nome era citado em muitos discursos antiescravistas do período pré-thermidor. ${ }^{1341}$ Além disso, a partir do momento em que a conservação das colônias ficou atrelada à liberdade dos negros, ele, político astuto que era, não menosprezou esse imperativo.

Contudo, para Hardy, existiam dois Robespierres:

um homem de doutrina, que não teme levar os princípios às suas últimas consequências, mas cujos planos só valem para o futuro, e um homem de governo, um político que conhece a força dos fatos, que não ignora a necessidade de se adaptar às circunstâncias. ${ }^{1342}$

Desta forma, haveria uma diferença profunda entre a doutrina e a política colonial de Robespierre e é nessa diferença que os seus adversários identificaram ou quiseram identificar tendências reacionárias, sem fazer a distinção entre a estratégia e a tática. Uma das principais preocupações de Robespierre teria sido a de adaptar a ação política às circunstâncias locais, à luz do interesse nacional. Se o objetivo final era o triunfo dos princípios de humanidade, a condição desse triunfo era a manutenção da

\footnotetext{
${ }^{1339}$ Cf. WANQUET, Claude. La France et la première abolition de l'esclavage, pp.171-172.

1340 "il lui était impossible d'admettre l'esclavage et la traite et de sacrifier aux intérêts d'une caste commerciale la dignité et l'avenir de toute une race d'hommes et de toute une catégorie de Français" (HARDY, G.. Robespierre et la question noire, pp.357-358).

${ }^{1341}$ Cf, por exemplo, o discurso de Dufay nos Jacobinos em 19 ventoso do ano II (3 de março de 1794), no Journal de la Montagne, número 120, 23 ventoso do ano II, p.953.

1342 "un homme de doctrine, qui ne craint pas de pousser les principes jusqu'à leurs extrêmes circonstances, mais dont les plans ne valent que pour l'avenir, et un homme de gouvernement, un politique qui connaît la puissance des faits, qui n'ignore pas la nécessité de s'adapter aux circonstances" (HARDY, G.. Robespierre et la question noire, pp.364-365).
} 
integridade e da força da Nação francesa, a única capaz de fazer prevalecer tais princípios. ${ }^{1343}$ Hardy acreditava, assim, que Robespierre rejeitava, em matéria colonial, os extremos. O autor se engana ao identificar os Amigos dos Negros como um desses extremos $^{1344}$, mas tem razão quando afirma que o jacobino queria uma política, ao mesmo tempo, inspirada em princípios maiores e condicionada pelas realidades concretas, isto é, uma política que afastasse o perigo da perda das colônias. Queria melhorar progressivamente a condição dos escravos, antes de devolver-lhes a liberdade. $^{1345}$

No fundo, a sua postura era vizinha da dos Amigos dos Negros, que, preocupados com a inserção social dos negros e com a manutenção das colônias pela França, temiam os efeitos de uma abolição abrupta. Robespierre e Brissot teriam permanecido unidos na questão colonial se não tivessem rompido por outros motivos. Em setembro de 1791, ele havia dito que não era possível esperar que homens embrutecidos pela escravidão e incapazes de compreender as leis da Nação francesa tivessem suas correntes rompidas de forma abrupta, acreditando que tal medida poderia levar à perda das colônias. Assim, era normal que não houvesse, de sua parte, nenhuma manifestação aberta de apoio a uma abolição que ele provavelmente julgava inoportuna. Por outro lado, tampouco houve por parte daquele que era o homem forte do governo revolucionário do ano II a adoção de medidas que visassem a bloquear a aplicação da lei. Ao contrário, o decreto de abolição foi seguido de medidas de repressão ao partido colonial presente na metrópole e de execução da lei de abolição nas colônias. Embora não estivesse no campo dos antiescravistas radicais, Robespierre, que tinha se oposto em 1791 à constitucionalização da escravidão, não pode ser associado à oposição escravista conduzida por Page e Brulley.

Além disso, é possível identificar, no campo robespierrista, algumas posturas contrárias à escravidão. Saint-Just, então em missão como representante do povo, não se manifestou na época da lei de pluvioso sobre o tema da abolição. Contudo, nos Fragments d'Institutions Républicaines, obra inacabada e publicada postumamente em

\footnotetext{
${ }^{1343}$ Ibidem, pp.367-368.

${ }^{1344} \mathrm{O}$ autor quer ver nos Amigos dos Negros representantes de um abolicionismo radical, em oposição ao abolicionismo moderado e racional de Robespierre. Hardy, aliás, acredita que Brissot e os seus aliados tinham, de fato, agentes em São Domingos para incitar os escravos à revolta. Sonthonax teria sido um desses agentes. Com a queda dos Girondinos, o "perigo abolicionista" continuaria na pele de Danton, que conseguiria fazer com que a escravidão fosse abolida em 4 de fevereiro de 1794. Sua atitude explicar-seia pelo seu caráter corruptível e pelo fato de que as colônias francesas eram cobiçadas por potências dotadas de fundos abundantes (Ibidem, pp.380-381).

${ }^{1345}$ Ibidem, pp.369 e 372.
} 
1800, Saint-Just oferecia indícios de sua opinião a respeito da escravidão. A obra era permeada de condenações a todas as formas de servidão, sugerindo uma adesão ao princípio da abolição. Em determinada passagem, Saint-Just se referia expressamente à questão dos negros das colônias e formulava a seguinte proposta:

O Estado ordenará a compra dos negros nas costas da África para serem transplantados nas colônias; eles serão livres no mesmo instante, ser-lhes-ão dados três arpents de terra e as ferramentas necessárias ao seu cultivo. ${ }^{1346}$

Tratava-se de uma proposta curiosa, na medida em que mantinha a importação de negros em funcionamento, mas Saint-Just não apenas especificava que eles seriam livres nas colônias, mas queria fazer deles pequenos proprietários autônomos, a exemplo do que pretendia com os camponeses franceses. Assim, se Saint-Just não era um abolicionista militante, tampouco pode ele ser apresentado como um opositor da abolição.

Embora não fosse um robespierrista, Collot d'Herbois - aliás um dos arquitetos do 9 thermidor - era membro do Comitê de Salvação Pública e, portanto, parte da cúpula do governo do ano II. Abolicionista declarado, tinha sido o autor do Almanach du Père Gérard e seria um dos signatários do decreto de prisão de Page e Brulley. Mais tarde, deportado na Guiana, ele seria acusado de tentar insurgir os negros, o que lhe renderia, pouco antes de sua morte, um encarceramento no forte de Sinnamari. ${ }^{1347}$

Mais importante do que conhecer a opinião pessoal desses homens, entretanto, é identificar, no contexto específico de sua atuação, os fatores que informavam os seus atos. É preciso destacar que o envolvimento popular na questão colonial, sobretudo no que se refere à sua oposição radical à aristocracia da pele, conduziu o governo revolucionário à adoção de medidas bastante rígidas em favor da abolição. Assim, outros membros do Comitê, como Prieur de la Marne, Jeanbon Saint-André, Couthon e Billaud-Varenne, também mostrariam a sua adesão à emancipação na política de repressão aos colonos, como veremos a seguir.

\section{II.3.3.2) A perseguição aos colonos}

\footnotetext{
1346 "L'État fera acheter les nègres sur les côtes d'Afrique pour être transplantés dans les colonies; ils seront libres à l'instant même, il leur sera donné trois arpents de terre et les outils nécessaires à leur culture" (SAINT-JUST, Antoine-Louis de. Institutions républicaines. In: Oeuvres complètes. Paris: Gallimard, 2004, pp.1108-1109).

${ }^{1347}$ Cf. WANQUET, Claude. La France et la première abolition de l'esclavage, pp.173-174.
} 
Em 20 pluvioso do ano II (8 de fevereiro de 1794), quatro dias após o decreto abolicionista, uma delegação de cidadãos e cidadãs de cor residentes em Paris veio à Convenção para felicitá-la por ter libertado os seus irmãos da América e tê-los compensado por dois séculos de perseguições. $\mathrm{O}$ orador alertou apenas que as colônias estariam perdidas para a República se os colonos que se encontravam na França pudessem a elas retornar sem que medidas fossem tomadas para a sua organização. Um deputado de cor - provavelmente, Belley - subiu, pela primeira vez, à tribuna para pedir um decreto de prisão contra esses colonos conspiradores. A proposta foi remetida ao Comitê de Salvação Pública, mas essa primeira intervenção já era um indício do que aguardava os colonos, que, àquela altura, procuravam amparar-se no Comitê de Segurança Geral. ${ }^{1348}$

Antes mesmo que a Convenção ou um de seus comitês tomassem qualquer medida oficial, o movimento popular já tinha dado início à perseguição aos colonos. Em 27 pluvioso do ano II (15 de fevereiro de 1794), Michel Derragis, autor de uma brochura escravista, e Gabriel Derosière tinham sido presos pelo movimento popular (seção de Bonne Nouvelle), por terem peticionado contra a deputação de São Domingos na sua chegada a Paris, e por terem se oposto ao decreto sobre a liberdade dos negros. ${ }^{1349}$ Ao receberem essa notícia, Page e Brulley escreveram ao Comitê de Segurança Geral para obter a liberdade de Derragis e Derosière, mas sem sucesso.

Então, seria a vez de Page e Brulley, principais articuladores do lobby escravista. Segundo os dois colonos, a decisão de sua prisão tinha sido originalmente tomada por uma seção popular, a das Tuileries, após denúncia de Dufay. Page e Brulley foram presos, em 14 ventoso (4 de março), por iniciativa do movimento popular, antes mesmo da intervenção oficial dos Comitês da Convenção. Em 15 ventoso (5 de março), o Comitê de Segurança Geral tinha decidido soltá-los, pedindo-lhes que retornassem à noite. Page e Brulley compareceram, mas, ocupado com a prisão dos hebertistas, o Comitê não os recebeu. À meia-noite, entretanto, em seu domicílio, os dois foram informados de sua prisão por comissários do Comitê. No dia 16 ventoso (6 de março), Larchevesque-Thibaud, antigo procurador da comuna do Cap-Français, protestou junto a Amar, do Comitê de Segurança Geral, ligado a Page e Brulley, mas este respondeu

\footnotetext{
${ }^{1348}$ Cf. AP, v.84, p.470; Journal de la Montagne, número 88, 21 pluvioso do ano II, p.703; BÉNOT, Yves. Comment la Convention a-t-elle voté l'abolition de l'esclavage?, p.358.

${ }^{1349}$ Cf. PIQUET, Jean-Daniel. L'émancipation des Noirs dans la Révolution française, p.423.
} 
que não havia sido possível resistir à pressão do Comitê de Salvação Pública. ${ }^{1350}$ Em 4 thermidor do ano II, Page e Brulley seriam transferidos para a prisão do Luxembourg, por ordem da polícia, dirigida por Robespierre: o motivo, segundo os dois colonos, era pôr fím à sua relativa liberdade de escrever e neutralizar, com isso, a rede de cumplicidades que eles mantinham até mesmo na prisão. ${ }^{1351}$

A prisão dos dois principais comissários dos colonos de São Domingos era indicativa de que uma política geral de repressão estava sendo traçada. O exercício da justiça popular pela sans-culotterie obrigava o governo revolucionário e a Convenção a tomar uma posição oficial a respeito do partido colonial. A ocasião veio no dia 19 ventoso do ano II (9 de março de 1794). Um membro da Convenção, Goupilleau, denunciou a tentativa da "aristocracia dos colonos-plantadores" de impedir a execução do decreto de abolição. Um ministro tinha nomeado o cidadão Josnet (ou Josne), chefe de brigada e patriota reconhecido, para comandar a operação em São Domingos. No momento em que se dispunha a partir, ele foi encarcerado em Nantes, sem que nenhum motivo fosse apresentado e sem que se soubesse de onde tinha vindo a ordem. Para o deputado, era tempo de pôr fim a todos esses atos vexatórios e descobrir quem eram aqueles que entravavam a marcha da Revolução. A Convenção decidiu que Josnet seria ouvido para que os culpados fossem denunciados. Na mesma sessão, Josnet compareceu para informar que o mandado de sua prisão provinha da administração de polícia da prefeitura de Paris. Embora desconhecesse os motivos de sua prisão, presumia que os colonos podiam estar por trás da operação, tendo em vista a natureza de sua missão e o fato de que ele havia sempre professado princípios contrários aos deles. O cidadão Froidure, um dos membros da administração de polícia, respondeu que a prisão tinha sido ordenada a partir de uma denúncia do comitê revolucionário de Nantes e endereçada à prefeitura de Paris. Outro deputado da Convenção, Moïse Bayle, exclamou que os dois membros do comitê revolucionário de Nantes que haviam assinado a denúncia - Chaux e Goullin (ou Golin) - eram colonos de São Domingos. Para muitos na assembleia, a prisão de Josnet era o resultado das "intrigas dos príncipes colonos do Clube de Massiac". Bayle, que era membro do Comitê de Segurança Geral, interveio para denunciar a existência de pressões dos colonos para retardar ou impedir a aplicação do decreto, enquanto o deputado Clauzel pediu a prisão de "todos os membros do clube

\footnotetext{
${ }^{1350}$ Cf. Débats entre les accusateurs et les accusés, dans l'affaire des colonies. Paris: De l'Imprimerie Nationale, an III [1795], v.2, pp.283-284.

${ }^{1351}$ Cf. PIQUET, Jean-Daniel. L'émancipation des Noirs dans la Révolution française, p.427.
} 
colonial do palacete Massiac". Duhem propôs que a medida atingisse "todos os colonos indistintamente que se encontram na França". Bourdon de l'Oise considerou a medida excessiva, apontando a existência de colonos patriotas. Naquele momento, chegava a notícia de que Page e Brulley tinham sido presos por ordem do Comitê de segurança geral, provocando aplausos entusiasmados na Convenção. ${ }^{1352}$ Após alguns debates, a Convenção decretou que:

Art. I. Todos os colonos que foram membros da assembleia de Saint-Marc e daquela conhecida desde então como assembleia colonial, os agentes dessas assembleias atualmente na França, e os membros dos clubes de Massiac e das colônias, serão presos.

II. Os lacres judiciais serão colocados sobre os documentos de todos os colonos residentes em Paris.

III. Os signatários das denúncias feitas ao comitê extraordinário de Nantes, contra o general Josnet, serão presos e conduzidos perante o comitê de segurança geral da Convenção. ${ }^{1353}$

O decreto de 19 ventoso deu início à perseguição sistemática do partido colonial escravista existente na metrópole, permitindo a prisão dos antigos membros do Clube Massiac e das assembleias coloniais, assim como o controle dos papéis dos colonos presentes em Paris. No mesmo dia (9 de março), Dufay, um dos deputados de São Domingos, fez, nos Jacobinos, um longo discurso para acusar os "príncipes colonos" presentes na metrópole de conspirarem contra a política colonial da Convenção. Um panfleto de Page e Brulley acusava Dufay de ser um nobre, o mulato Mills de ser um inglês e o negro Belley de ser um africano. ${ }^{1354}$ As três "acusações" eram falsas. ${ }^{1355}$ Segundo Dufay, os colonos, e em particular Page e Brulley, tinham, desde o início da Revolução, manipulado a credulidade dos franceses, com suas calúnias e artimanhas. Os colonos, "todos eles Ingleses de coração e de espírito", visavam a operar a contrarrevolução na França. Dufay dispunha-se, ao lado de seus colegas, a dar aos deputados, jacobinos e patriotas franceses todas as informações relativas às colônias. ${ }^{1356}$

\footnotetext{
1352 Cf. Journal de la Montagne, número 117, 20 ventoso, pp.931-932; AP, v.86, pp.241-242 e 256-258.

1353 "Art. I. Tous les colons qui ont été membres de l'assemblée de Saint-Marc et de celle connue depuis sous le nom d'assemblée coloniale, les agents de ces assemblées actuellement en France, et les membres des clubs de Massiac et des colonies, seront mis en état d'arrestation. II. Les scellés seront apposés sur les papiers de tous les colons résidants à Paris. III. Les signataires des dénonciations faites au comité révolutionnaires de Nantes, contre le général Josnet, seront mis en état d'arrestation et traduits devant le comité de sûreté générale de la Convention" (AP, v.86, p.258).

${ }^{1354}$ Cf. PAGE, Pierre-François, BRULLEY, Augustin-Jean. Notes fournies au Comité de Salut Public, p.65.

${ }^{1355}$ Dufay, nascido em Paris, não era de família nobre. Mills tinha nascido no Cap e Belley, no território francês do Senegal (cf. Journal de la Montagne, número 120, 23 ventoso do ano II, p.952).

${ }^{1356}$ Ibidem, pp.952-953.
} 
No Oeste do país, Prieur de la Marne e Jeanbon Saint-André, dois robespierristas do Comitê, foram encarregados de pôr em aplicação as medidas de vigilância e prisão dos colonos inimigos do decreto. Em Nantes, principal porto negreiro, Prieur obteve, em aplicação da lei de 19 ventoso do ano II, a neutralização de três colonos - César Duny, Clausson e Thomas Millet (um dos 85 léopardins) - que foram, posteriormente, enviados a Paris, em abril de 1794, para serem oficialmente presos. Em Brest, onde muitos colonos de São Domingos tinham desembarcado em junho ${ }^{1357}$, Prieur e Jeanbon Saint-André comandaram, durante o mês de prairial (junho de 1794), uma aplicação rigorosa da lei, com o objetivo de investigar a origem das deportações. Para isso, Prieur nomeou uma comissão colonial de oito membros ${ }^{1358}$ para identificar, entre os recémchegados, os contrarrevolucionários. ${ }^{1359}$ Entre junho e agosto de 1794, 341 pessoas se apresentaram diante da Comissão de Brest, sendo que 65 interrogatórios foram realizados especificamente sobre os eventos de junho de 1793, no Cap. ${ }^{1360}$ A Comissão determinaria a prisão de 78 pessoas vindas do comboio de São Domingos. Todos os dados foram transmitidos ao Tribunal Revolucionário de Brest, para julgamento. Em seu relatório final, a Comissão de Brest denunciaria o preconceito como a arma utilizada pelos colonos aristocratas para dominar a colônia e concluiria pela impossibilidade de um compromisso com os colonos escravistas, aliados das potências estrangeiras. ${ }^{1361}$

Em Paris, a Comuna também dedicou-se a uma aplicação bastante intensa das diretrizes de prisão dos colonos contrarrevolucionários. Além de Page e Brulley, que tinham sido detidos antes mesmo da votação da lei, vários colonos importantes foram presos, como Larchevesque-Thibaud ${ }^{1362}$, Nicolas Thérou (um crioulo deportado por Sonthonax e Polverel), Molart e Michel Schoenperg. ${ }^{1363}$ Da mesma forma, todos os

\footnotetext{
${ }^{1357}$ Um comboio tinha desembarcado em Brest em 13 de junho de 1794. Ele era composto de centenas de colonos que, após a abolição de 1793, tinham se refugiado nos Estados Unidos. Sua missão era tentar uma retomada do controle de São Domingos a partir da metrópole (cf. BLONDET, Claire. Quand les "terroristes" font le procès du colonialisme esclavagiste les thermidoriens organisent son oubli, p.47).

${ }^{1358}$ Faziam parte da comissão: Bayard, Catineau, Dubois, Dermoncourt, Lodin, Godard, Arnault Pretty e Gentou (Ibidem, pp.52-53).

${ }^{1359}$ Cf. PIQUET, Jean-Daniel. L'émancipation des Noirs dans la Révolution française, p.404.

${ }^{1360}$ Cf. BLONDET, Claire. Quand les "terroristes" font le procès du colonialisme esclavagiste les thermidoriens organisent son oubli, pp.55-56.

${ }^{1361}$ Ibidem, pp.58-60.

1362 Por razão de saúde, durante 15 dias (10-24 março de 1794), Larchevesque-Thibaud foi mantido em prisão domiciliar por um sans-culotte da seção da Halle au Bled. Na noite do 24-25 de março, em plena depuração dos Hebertistas, a polícia da Comuna de Paris transferiu o colono para a prisão do Luxembourg. Até o outono de 1794, nenhuma reclamação de sua parte gerou efeitos (cf. PIQUET, JeanDaniel. Robespierre et la liberté des noirs en l'an II d'après les archives des comités et les papiers de la comission Courtois. Annales Historiques de la Révolution Française, Paris, n. 323, jan-mar de 2001, p.9. Disponível em: http://ahrf.revues.org/1822. Acesso em: 5 de mar de 2010).

${ }^{1363}$ Cf. PIQUET, Jean-Daniel. L'émancipation des Noirs dans la Révolution française, p.395.
} 
membros do Clube Massiac, assim como os refugiados e deportados de São Domingos, foram alvo dessa onda repressiva.

Além disso, indivíduos suspeitos eram vigiados por ordem do Comitê de Salvação Pública. Janvier Littée, da Martinica, o primeiro deputado mestiço a entrar na Assembleia, em setembro de $1793^{1364}$, pertencia, apesar de suas origens, ao campo escravista. Em messidor do ano II (junho-julho de 1794), Robespierre, na presidência do Gabinete de polícia geral do Comitê de Salvação Pública, ordenou uma vigilância sobre esse deputado, tendo em vista as suas relações com Page e Brulley, que o viam como o seu protetor na Convenção. ${ }^{1365}$

Infelizmente, a perseguição aos colonos acabou gerando, para o campo abolicionista, uma importante baixa. Inimigo jurado de Page e Brulley, Milscent, crioulo antiescravista, acabaria tornando-se vítima das intrigas de seus desafetos. Com o decreto de 19 ventoso (9 de março), a Convenção tinha determinado a prisão dos colonos que tivessem pertencido a uma assembleia colonial ou a um clube de colonos. Por ter sido membro da assembleia colonial do Cap-Français, Milscent foi preso em 21 ventoso do ano II (11 de março de 1794), sendo libertado três dias depois, graças ao testemunho dos deputados de São Domingos. No dia de sua libertação, 14 de março, Milscent e dois outros crioulos de São Domingos, Claudin e Vautrin, prestaram depoimento segundo o qual tinham ouvido três outros colonos - Bardet-Fromenteau (crioulo deportado por Sonthonax), Serres e Galibert - tratarem o deputado Dufay de "celerado" e os membros da Convenção que votaram a lei de 16 pluvioso de "tremendas bestas". Porém, em 29 floreal (18 de maio de 1794), Milscent foi acusado de falso testemunho ${ }^{1366}$, pois Bardet-Fromenteau e Serres - Galibert tinha falecido - haviam negado os fatos em 26 de março, e Claudin e Vautrin, que tinham ligações com Page e Brulley, tinham retratado o seu testemunho. A atitude dos juízes do tribunal revolucionário foi bastante parcial: o acusador público Fouquier-Tinville não procurou

\footnotetext{
${ }^{1364} \mathrm{Na}$ Guadalupe e na Martinica, os realistas ainda estavam no poder quando a Assembleia Nacional convocou eleições, em meados de 1792. Isso levou um grupo de republicanos e patriotas, brancos e de cor a constituírem, na colônia britânica de Dominica, uma assembleia eleitoral racialmente integrada, que elegeu, pela primeira vez, um cidadão de cor como representante: Janvier Littée, da Martinica (cf. DUBOIS, Laurent. A Colony of Citizens, pp.120-121).

${ }^{1365}$ Cf. Débats entre les accusateurs et les accusés, v.2, pp.282-283. Piquet exagera ao ver nessa atitude o "testamento colonial" de Robespierre, que teria manifestado "[...] a convicção de que a manutenção da escravidão, e não a sua abolição imediata, conduziria à perda das colônias" (cf. PIQUET, Jean-Daniel. L'émancipation des Noirs dans la Révolution française, pp.415 e 420). A preocupação de Robespierre podia se dever, preponderantemente, a suspeitas de relações de Littée com os ingleses, como sugere uma carta de Guérin, agente encarregado de sua vigilância, a Robespierre (cf. Papiers inédits trouvés chez Robespierre, Saint-Just, Payan, etc..., v.1, pp.277-278).

${ }^{1366}$ A lei de 5 de janeiro de 1794 condenava à pena de morte toda pessoa culpada de falso testemunho.
} 
esclarecer a verdade sobre o que havia sido dito anteriormente e o juiz Coffinhal ampliou a acusação, afirmando que Milscent tinha defendido as opiniões de Brissot e tinha sido adepto de Danton e Fabre d'Églantine. ${ }^{1367}$ Desamparado, Milscent foi condenado e executado, em 7 prairial do ano II (26 de maio de 1794), por crime de falso testemunho. Visto como um traidor pelos colonos brancos de São Domingos, Milscent acabou sendo a única pessoa executada, sob a Revolução, por suas opiniões antiescravistas.

\section{II.3.3.3) As medidas de execução}

O vigor com que a abolição foi decretada e com que a oposição escravocrata foi reprimida na esteira do 16 pluvioso contrasta com as dificuldades que o governo revolucionário encontrou na execução da lei. Tratava-se não apenas de emancipar juridicamente populações inteiras de escravos, mas de suprimir a base fundamental sobre a qual se estruturava o império colonial francês e todo o comércio que este alimentava. O desafio que se apresentava à França revolucionária era o de reestruturar as suas colônias, sem justamente abalar o estatuto colonial.

De acordo com um relatório de Latour-Lamontagne, apresentado no dia 21 pluvioso (9 de fevereiro) nos Jacobinos, um membro propôs que a parte espanhola de São Domingos fosse deixada aos antigos escravos libertados pelo decreto de 16 pluvioso. Segundo o relatório, a proposta encontrou "aprovadores e contraditores". ${ }^{1368}$ Mas propostas dessa ordem permaneceram excepcionais naquele momento. Não se concebia a liberdade dos negros fora do domínio colonial francês. Mais do que isso, não se concebia a economia colonial fora do modelo da grande produção para exportação. Assim, abolir a escravidão era, na prática, uma tarefa complexa que o governo revolucionário empreendeu com grande dificuldade.

O Comitê de Salvação Pública se ocupou da questão na sessão de 23 germinal do ano II (12 de abril de 1794). Decidiu que o ministro da Marinha enviaria a São Domingos, às Ilhas de Barlavento, à Île-de-France e Caiena uma cópia da lei de abolição. O cidadão Chambon, que tinha sido encarregado de executar a ordem de

\footnotetext{
${ }^{1367}$ Cf. PIQUET, Jean-Daniel. L'émancipation des Noirs dans la Révolution française, p.431. Num texto do início de 1795, Dufay alegava que Coffinhal e Fouquier-Tinville eram convidados a jantar duas vezes por semana pelos líderes dos colonos, isto é, Page e Brulley (cf. DUFAY, Louis-Pierre. Un représentant du peuple calomnié, à un représentant du peuple calomniateur, p.10).

${ }^{1368}$ Cf. Paris pendant la Terreur - Rapports des agents secrets du Ministre de l'Intérieur. P. Caron (org.). Paris: Librairie de la Société de l'Histoire de France, 1949, v.4, p.7.
} 
prisão de Sonthonax e Polverel ${ }^{1369}$, levaria consigo o exemplar destinado a São Domingos, ficando encarregado de remetê-lo às autoridades constituídas, encarregadas por sua vez de promulgar a lei "sem demora". O exemplar destinado às Ilhas de Barlavento seria entregue aos comissários civis nomeados para tal e embarcações seriam enviadas à Île-de-France e Caiena com os exemplares destinados a essas colônias, para que os comissários civis locais os fizessem publicar imediatamente. ${ }^{1370} \mathrm{O}$ Comitê mostrava-se, assim, bastante firme quanto à sua intenção de abolir a escravidão nas colônias.

O decreto de abolição partiria, aliás, acompanhado de instruções que o Comitê de Salvação Pública já tinha aprovado em 3 pluvioso (22 de janeiro), para os comissários na Ilhas de Barlavento, visando à sua "organização provisória e revolucionária", o que mostra que, antes mesmo da abolição, o Comitê já estava empenhado em aplicar à administração das colônias novos princípios. ${ }^{1371}$

Para levar a abolição às Ilhas de Barlavento, foram nomeados Pierre Chrétien e Victor Hugues. As razões para a nomeação de Hugues como comissário permanecem um mistério. Ele tinha uma vasta experiência colonial, na condição de antigo comerciante de São Domingos ${ }^{1372}$, mas as suas ligações com os colonos, com Page e Brulley, e, sobretudo, o fato de ter denunciado Belley, Mills e Dufay na sua chegada à metrópole faziam dele uma escolha um tanto temerária para a execução de um decreto abolicionista. ${ }^{1373} \mathrm{O}$ fato, entretanto, é que Hugues partiu em condições bastante estritas, o que limitava a sua autonomia no comando da comissão. Tinha a obrigação de prestar mensalmente contas de sua missão ao Comitê de Salvação Pública. ${ }^{1374}$ Em abril, os comissários partiram para as ilhas, à frente de uma expedição de sete navios e 1.500

\footnotetext{
${ }^{1369}$ Cf. Recueil des actes du Comité de salut public, v.12, p.511. Segundo Piquet, Dufay, Mills e Belley tinham escrito ao Comitê para protestar contra a nomeação de Simondes, que era amigo de Page e Brulley e, portanto, um inimigo dos homens de cor. O Comitê decidiu, assim, substituí-lo por Chambon, um jacobino patriota (cf. PIQUET, Jean-Daniel. L'émancipation des Noirs dans la Révolution française, pp.385-386).

${ }^{1370}$ Cf. Recueil des actes du Comité de salut public, v.12, p.532.

1371 Idem, v.10, p.375.

${ }^{1372}$ Entre 1791 e 1792, a loja de Hugues em Porto Príncipe tinha sido queimada. O seu irmão foi, na ocasião, assassinado. Com isso, Hugues transferiu-se para Paris, onde chegou em outubro de 1792. Por meio de seus contatos junto aos Jacobinos, foi nomeado para o tribunal revolucionário de Rochefort (cf. DUBOIS, Laurent. A Colony of Citizens, p.189).

${ }^{1373}$ O capitão Maublanc denunciaria, em 27 de março de 1794, ao Comitê de Salvação Pública, as palavras contrarrevolucionárias e pró-escravistas de Victor Hugues. O documento seria, entretanto, registrado pelos destinatários apenas em 30 de abril de 1794. A essa data, a Comissão já tinha partido para as ilhas (cf. PIQUET, Jean-Daniel. L'émancipation des Noirs dans la Révolution française, p.391).

${ }^{1374}$ Ibidem, pp.390-391.
} 
soldados. ${ }^{1375}$ Chrétien faleceu em junho de 1794, um mês após a sua chegada às ilhas, o que fez com que Hugues assumisse sozinho a aplicação do decreto.

Um mês após a partida de Hugues, chegou a notícia, em Brest, de que a Martinica tinha sido ocupada pelos britânicos. Em 19 de fevereiro de 1794, em White Hall, os colonos brancos da Martinica e da Guadalupe haviam se colocado sob a jurisdição da Coroa britânica, que oferecia, em troca da submissão das colônias francesas, a garantia da manutenção da escravidão. Com isso, os britânicos já tinham ocupado a Martinica no final de março. Em $1^{\circ}$ de prairial (20 de maio de 1794), Prieur de la Marne comunicou o fato em carta ao Comitê de Salvação Pública e ordenou uma investigação por parte do tribunal revolucionário. ${ }^{1376}$ Encarregado da missão emancipadora, Victor Hugues não conseguiria retomar a ilha. A Martinica, assim como Tobago, permaneceu, entre 1794-1802, sob ocupação da Grã-Bretanha, que manteve a escravidão.

Na Guadalupe, entretanto, a chegada de Victor Hugues, em 4 de junho de 1794, à frente de uma pequena tropa de 1.150 homens, permitiu a reconquista da colônia. Confrontado à presença das tropas inglesas, Hugues se apoiou nos escravos que vinha libertar. Se estava longe de ser um abolicionista convicto, ele agia como um militar leal às leis da Convenção e às diretrizes do Comitê de Salvação Pública. Naquele momento, isso implicava tomar todas as medidas necessárias à aplicação da lei de 16 pluvioso. Assim que chegou, o comissário tratou de proclamar a abolição, obtendo com isso a adesão dos antigos escravos às forças republicanas.

A abolição era a arma principal do exército republicano para derrotar os britânicos: as forças francesas, inicialmente pouco numerosas, foram rapidamente ampliadas com a associação de muitos negros. Segundo números apontados por Laurent Dubois, em 1796, dos 4.600 soldados que compunham a guarnição da Guadalupe, cerca de $50 \%$ eram antigos escravos. ${ }^{1377}$ A transformação de cativos em soldados da República talvez tenha sido a primeira e mais sólida forma de aplicação da abolição. Naquela época, outra possibilidade de serviço militar se apresentava aos negros: os corsários republicanos, que atacavam navios britânicos e embarcações provenientes da Inglaterra ou a ela destinadas. De fato, logo após a sua chegada, Hugues começou a armar corsários para enfrentar as embarcações britânicas. No final de 1795, ele já

1375 Cf. GAUTHIER, Florence. Le rôle de la députation de Saint-Domingue dans l'abolition de l'esclavage, p.205.

${ }^{1376}$ Cf. PIQUET, Jean-Daniel. L'émancipation des Noirs dans la Révolution française, p.407.

${ }^{1377}$ Cf. DUBOIS, Laurent. A Colony of Citizens, p.227. 
contava com 25 navios operando em águas próximas à Guadalupe. Neles, vários antigos escravos foram incorporados. Até mesmo entre os capitães corsários, havia um número significativo de homens de ascendência africana: pelo menos 15 entre 1793-1801. ${ }^{1378}$

A incorporação militar de escravos não era uma novidade, mas, no passado, ela tinha sido feita, geralmente, para a defesa da ordem escravista. ${ }^{1379}$ A novidade agora era que os negros lutavam pela emancipação geral. Mais do que isso, as forças armadas republicanas, imbuídas de um espírito meritocrático, constituíam um espaço privilegiado de inserção e de ascensão social. O exército republicano do Caribe destacava-se pelas rápidas e contínuas promoções dadas a soldados de diferentes classes e cores. Nesse espaço marcado pela mobilidade social, o soldado negro era inequivocamente cidadão.

A incorporação dos negros da Guadalupe às forças francesas foi decisiva para a retomada da ilha. Entre setembro e dezembro de 1794, a ofensiva republicana obrigou os britânicos e seus aliados a recuarem e, finalmente, a capitularem. Em 11 de dezembro, a bandeira francesa foi hasteada por toda a colônia. ${ }^{1380}$

A chegada de Hugues à Guadalupe teve repercussões em outras ilhas. Já no início de 1795, uma revolta negra explodiu em Saint-Vincent, então em mãos britânicas. Da mesma forma, em março de 1795, uma insurreição de escravos e homens de cor teve início em Granada. Da Guadalupe, Victor Hugues emitiu uma declaração de guerra geral contra os ingleses e enviou agentes e soldados às duas ilhas. Para conter o avanço republicano, as forças britânicas chegaram a recorrer aos escravos, prometendo-lhes a liberdade. Isso permitiu evitar uma derrota completa. Assim mesmo, em meados de 1796, a maior parte de Granada estava sob controle francês. ${ }^{1381}$

Em Sainte-Lucie, continuamente disputada por ingleses e franceses, as forças republicanas chegaram a proclamar a abolição. O comissário Goyrand, enviado por Hugues em abril de 1795, procurou aplicar os princípios da administração postos em prática na Guadalupe. A abolição da escravidão seria feita duas vezes na colônia, que

\footnotetext{
1378 Ibidem, pp.241-244.

${ }^{1379}$ É, contudo, preciso lembrar que, muito tempo antes da abolição, alguns senhores integravam os seus escravos ao serviço militar colonial, também como forma de alforriá-los, sem pagamento de imposto.

${ }^{1380}$ Cf. BANGOU, Henri. La Guadeloupe, pp.135-138.

${ }^{1381}$ Cf. DUBOIS, Laurent. A Colony of Citizens, pp.230-233.
} 
chegou a viver sob o regime da liberdade por um ano. Ela seria, contudo, desfeita em maio de 1796 após a reconquista da ilha pela Grã-Bretanha. ${ }^{1382}$

Na Guiana, o comissário civil Nicolas Jeannet-Oudin, sobrinho de Danton, recebeu o decreto de abolição em 13 de junho de 1794 e o publicou no dia seguinte, proclamando a liberdade geral nos territórios de Caiena e da Guiana francesa. Já em setembro do mesmo ano, os novos livres tiveram a ocasião de exercer os seus direitos, quando Jeannet-Oudin promoveu as eleições das municipalidades da colônia pelo novo corpo de cidadãos. ${ }^{1383}$ A Guiana permanece um caso único entre as colônias francesas, na medida em que, exceção feita a uma tentativa de revolta do final de 1790 , o processo abolicionista não foi marcado por nenhuma grande insurreição escrava ou guerra de reconquista. Impulsionada pelos eventos ocorridos nas outras colônias e pela política emancipadora da República jacobina, a abolição deu-se de forma relativamente pacífica. $^{1384}$

No Senegal, onde a França possuía um estabelecimento, a lei de abolição seria promulgada, mas, de acordo com Pelletan, antigo diretor da Companhia do Senegal, a sua aplicação teria se limitado a uma suposta erradicação do tráfico, sem que os escravos do país fossem realmente emancipados. ${ }^{1385}$

Os esforços do governo revolucionário em executar o decreto de abolição permaneceram inicialmente restritos ao Atlântico. Em 2 floreal do ano II (21 de abril de 1794), graças à pressão dos deputados das colônias orientais, o Comitê de Salvação Pública decretou a suspensão, até segunda ordem, do envio do decreto de 16 pluvioso às Mascarenhas. ${ }^{1386}$ Nos dias 19 e 20 pluvioso (7-8 de fevereiro), logo após a abolição, Gouly, da Île-de-France, já tinha apresentado um relatório ao Comitê para protestar contra uma abolição feita de forma abrupta, sem regulamentar o modo pelo qual os negros deveriam fazer uso dessa liberdade. Defendendo uma abolição apenas por etapas, Gouly havia pedido a suspensão da execução do decreto enquanto perdurasse a ameaça de uma invasão inglesa, para, com isso, garantir a fidelidade das ilhas à

\footnotetext{
${ }^{1382}$ Cf. GAUTHIER, Florence. La convention thermidorienne et le problème colonial: sept. 1794 - sept. 1795. In: M. VOVELLE (org.). Le Tournant de l'an III. Paris: Comité des travaux historiques et scientifiques, 1997, p.110.

${ }^{1383}$ Cf. BÉNOT, Yves. La Guyane sous la Révolution française, p.71.

${ }^{1384}$ Ibidem, pp.10-11.

${ }^{1385}$ Cf. PELLETAN, Jean-Gabriel. Mémoire sur la colonie française du Sénégal. Paris: Ve Panckouke, 1801.

${ }^{1386}$ Cf. Recueil des actes du Comité de salut public, v.12, p.723.
} 
República. ${ }^{1387} \mathrm{O}$ fato é que não havia nas colônias orientais qualquer movimento contrarrevolucionário violento e elas tinham resistido com sucesso às investidas inglesas, o que lhes dava uma posição favorável diante do Comitê. ${ }^{1388}$ Contudo, uma tentativa de aplicação da abolição nas colônias orientais seria feita em 1796, sob o Diretório, como veremos mais adiante.

É em São Domingos que se esperava que a abolição gerasse maiores repercussões no que se refere à luta contra os avanços estrangeiros. Jean-François e Biassou decidiram manter-se ao lado dos espanhóis, decisão que os obrigaria posteriormente a deixar a ilha. ${ }^{1389}$ Quanto a Toussaint, não se sabe com exatidão quando ou por quais motivos exatos abandonou o campo espanhol, mas, em maio de 1794, ele já havia se juntado às forças republicanas. Os relatos contemporâneos, veiculados por Laveaux, Toussaint e outros personagens trouxeram versões inconsistentes que induziram muitos historiadores a equívocos. O general Laveaux, por exemplo, afirmou que Toussaint tinha combatido até então contra a França, acreditando que apenas um rei poderia dar a liberdade aos negros. Quando foi convencido de que a República lhe dava essa liberdade, veio para o campo francês combater os espanhóis. ${ }^{1390}$ Baseado nessa versão, Cyril James atribuiu a adesão de Toussaint à chegada da notícia do decreto de 16 pluvioso, o que é pouco provável, visto que o decreto só chegou oficialmente a São Domingos em 8 de junho e, segundo Geggus, a decisão de Toussaint já tinha sido tomada no dia 6 de maio, após correspondência com Laveaux. ${ }^{1391}$ Há também quem entenda que o líder negro era relativamente indiferente à causa da liberdade ${ }^{1392}$ e que o motivo de sua adesão teria sido o ressentimento contra os espanhóis ou então uma avaliação de que o equilíbrio de forças tinha mudado após a proclamação de Sonthonax de 29 de agosto de 1793.

\footnotetext{
${ }^{1387}$ Cf. GOULY, Benoît. Rapport sur le décret du 16 pluviose, relatif à la liberté des nègres dans les colonies, sur le mode d'exécution, suivi du projet de décret. In: Vues générales sur l'importance du commerce des Colonies. Paris: Imprimerie de Rubat, s.d., pp.56-61.

${ }^{1388} \mathrm{Cf}$. WANQUET, Claude. La France et la première abolition de l'esclavage, p.167.

${ }^{1389}$ Após um curto período em Santo Domingos, eles se dirigiram a Cuba, onde o seu desembarque foi recusado. O grupo de Biassou foi então para a Flórida, enquanto o de Jean-François, muito mais numeroso, dividiu-se entre a Espanha (líderes e oficiais) e Trinidad, Honduras, Panamá e outros lugares (cf. GEGGUS, David Patrick. Haitian Revolutionary Studies, pp.182-184).

${ }^{1390}$ Cf. LAVAUX, Étienne Maynaud Bizefranc de. Discours prononcé par C. Lavaux [sic], député de Saint-Domingue, le troisième jour complétmentaire, an V. Paris: De l'Imprimerie Nationale, ano VI [1797], pp.6-8

${ }^{1391}$ Cf. GEGGUS, David Patrick. Haitian Revolutionary Studies, p.121.

${ }^{1392}$ Toussaint não tinha se manifestado a favor da abolição nos primeiros anos da insurreição. Sua primeira manifestação abolicionista se deu por meio de uma carta de 25 de agosto de 1793, na qual parecia reagir à votação do mesmo dia, que levou à proclamação da abolição quatro dias depois (Ibidem, pp.126-127).
} 
É provável que todas essas hipóteses tenham um fundo de verdade. Se a lei de abolição ainda não tinha chegado oficialmente quando da virada de Toussaint, é possível que, à luz das medidas tomadas pelos comissários e das negociações com Laveaux, o líder negro já aguardasse uma lei vinda da metrópole. ${ }^{1393}$ É preciso dizer também que o tempo transcorrido entre a abolição (fevereiro) e a adesão de Toussaint (maio) era mais do que suficiente para que a notícia da lei atravessasse o Atlântico. Na Guadalupe, por exemplo, ela chegou em 5 de maio. Talvez a notícia já circulasse na colônia, embora não se tenha evidências disso. Dito isso, é provável também que o status de Toussaint no seio do campo espanhol tivesse se deteriorado com o tempo. Sabe-se, por exemplo, que Biassou tinha o hábito de tomar soldados de Toussaint e vendê-los como escravos aos espanhóis. A rivalidade com os demais chefes negros pode ter pesado na decisão de Toussaint. ${ }^{1394}$ Por fim, homem perspicaz que era, Toussaint certamente compreendeu que, após as proclamações de Sonthonax e Polverel, o equilíbrio de forças na colônia tinha mudado. Ele tinha se aliado aos espanhóis antes das proclamações, acreditando, como muitos outros, que a liberdade sob a Coroa espanhola era mais certeira. Após a abolição dos comissários, ficava claro que as massas negras não apoiariam a Espanha por muito tempo. ${ }^{1395}$ O que é certo é que, como diz Geggus, a adesão de Toussaint ao campo republicano adquiria, objetivamente, o sentido de adesão à causa da liberdade negra. ${ }^{1396}$ Era nos termos da liberdade geral proclamada por Sonthonax e confirmada pela Convenção que o comandante negro assumiria, a partir de então, a liderança das forças republicanas na colônia.

Quando Lavaux recebeu Toussaint Louverture no Cap, ele o saudou como o Espártaco negro anunciado por Raynal em 1774. Toussaint seria nomeado general de brigada. Os revolucionários negros finalmente aliavam-se à Revolução francesa e voltavam-se agora contra os invasores estrangeiros. Essa aliança seria fundamental para que a França retomasse o controle da colônia, que, naquele momento, estava em parte ocupada pelas forças inimigas. A segunda parte da deputação de São Domingos eleita em setembro de 1793 - Laforest, Boisson e Garnot - entraria na Convenção no início de julho de 1794. Agora, seis deputados da ilha, dentre os quais quatro negros, sentavam-se na Assembleia. ${ }^{1397}$

\footnotetext{
1393 Ibidem, p. 124.

${ }^{1394}$ Ibidem, pp.128-129.

1395 Ibidem, pp.133-134.

${ }^{1396}$ Ibidem, p. 124.

${ }^{1397}$ Cf. GAUTHIER, Florence. La convention thermidorienne et le problème colonial, p.111.
} 
Assim, em execução do decreto de 16 pluvioso do ano II, São Domingos, Guiana e Guadalupe viam-se agora livres da escravidão. O partido colonial na metrópole, com a exceção notável dos representantes das Mascarenhas, tinha sido, pelo menos naquele momento, neutralizado. A Revolução tinha finalmente convertido os princípios da Declaração dos direitos em leis abolicionistas e assumia uma vocação universalista. Confrontada a uma guerra contra as potências europeias, a França fazia da liberdade dos negros uma poderosa arma contra as pretensões britânicas no Caribe.

A evolução política da França revolucionária, entretanto, comprometeria gradualmente as conquistas abolicionistas de 1793-94. Nos dias 8-9 thermidor (26-27 de julho de 1794), os robespierristas seriam atacados na Convenção em razão do regime de Terror sob o qual tinham mantido a França durante o ano II. Na noite de 9-10 thermidor, Robespierre seria preso por ordem da assembleia, sendo executado ainda no dia 10 thermidor, ao lado de 21 de seus seguidores, dentre os quais Saint-Just e Couthon. Mesmo que os robespierristas não fossem os arquitetos da política abolicionista do ano II, a sua queda marcaria o início de um processo de reação política, com repercussões profundas em diversos campos, como, por exemplo, as leis agrárias e a regulamentação da economia. Embora essa reação não tenha levado imediatamente à revogação da lei de 16 pluvioso, veremos a seguir que ela deu início a um recuo gradual que culminaria, em 1802, no restabelecimento da escravidão colonial. 


\section{Parte III}

Do colonialismo assimilacionista ao restabelecimento da escravidão (1794-1802) 


\section{III.1) Emancipação dos negros e assimilação das colônias}

\section{III.1.1) A aplicação da abolição: o problema dos regimes de trabalho}

Proclamada a abolição da escravidão nas colônias francesas, o governo revolucionário e os administradores por ele designados tiveram imediatamente de enfrentar os problemas derivados da aplicação concreta do princípio da liberdade geral. Havia, de um lado, o problema da coesão social em sociedades que haviam sido inteiramente construídas em torno da escravidão; de outro, o problema da sobrevivência de economias ainda inseridas na lógica do pacto colonial. A experiência da aplicação do decreto de 16 pluvioso seria reveladora dos obstáculos encontrados pela Revolução ao estender-se aos espaços coloniais. Seria reveladora também das atitudes das massas negras diante da liberdade que lhes era atribuída. O processo faria reaparecer alguns dos limites do discurso antiescravista do final do século XVIII, incapaz de pensar a supressão da escravidão colonial fora dos limites ditados pelo estatuto colonial.

As expedições enviadas às colônias para a aplicação da abolição tiraram a sua força dos homens e mulheres que vinham libertar. Lutando pela própria liberdade, os novos cidadãos, incorporados às forças armadas republicanas, tornaram-se o elementochave da vitória sobre a resistência escravocrata. ${ }^{1398}$ Os senhores de escravos não podiam admitir o fim de uma instituição que era a fonte primordial não apenas de sua riqueza, mas também de seu poder político e prestígio social. A luta pela manutenção da escravidão era, para eles, uma luta pela civilização tal como a julgavam possível naquele espaço. A proclamação da liberdade geral os empurrou para os braços dos inimigos da França.

Diante da traição dos colonos brancos, Lavaux, em São Domingos, e Hugues, na Guadalupe, apoiados nas tropas dos "novos livres", aplicaram medidas típicas do Terror, como a nacionalização dos bens dos colonos emigrados, deportações em massa de contrarrevolucionários e execução de centenas de colonos, muitas vezes com base em testemunhos de antigos escravos. Assim, na Guadalupe, os franceses que haviam lutado ao lado dos britânicos foram considerados traidores e punidos de acordo: 140 deles foram guilhotinados, 363 foram fuzilados e muitos outros foram condenados aos

${ }^{1398}$ Cf. MARIUS-HATCHI, Fabien. La Révolution caribéenne comme ultime rempart du droit naturel, p.73. 
trabalhos forçados. ${ }^{1399}$ Hugues chegaria a instituir um tribunal revolucionário itinerante para percorrer as comunas, julgar os suspeitos e punir os culpados com a morte. ${ }^{1400}$

A política de aliança com as massas negras contra os colonos rebeldes mostrouse bem sucedida. Amparado por oficiais negros e mulatos, o general Lavaux mantinha, já na primavera de 1795, o controle sobre toda a parte Norte de São Domingos. Além disso, as tropas republicanas tinham iniciado a ofensiva contra as forças britânicas nas províncias Oeste e Sul da colônia. Na Guadalupe, Hugues tinha retomado o controle do território. Os britânicos haviam se rendido em 16 frimário do ano III (6 de dezembro de 1794), seis meses após a chegada das tropas republicanas. Para consolidar a aliança com os negros da ilha, Hugues assegurou a promoção de um certo número de oficiais de cor, como Magloire Pélage, que tinha se destacado na luta contra os invasores estrangeiros. Para sinalizar a mudança dos tempos, alguns nomes de comunas foram alterados: SaintRose tornou-se Tricolore; Saint-François tornou-se Égalité. ${ }^{1401}$

Mas, se a abolição havia permitido resolver a situação militar nas colônias, o futuro da economia colonial ainda suscitava muitas interrogações. Isso porque não se cogitava alterar o modelo da grande produção para exportação, base da economia colonial tal como ela havia sido praticada até então. Ora, esse modelo de exploração, que exigia uma mão de obra abundante, se chocava com as aspirações dos novos livres, que viam na abolição justamente a possibilidade de abandonar as grandes plantations para ocupar pequenos lotes de terra que cultivariam por si próprios. A reforma agrária, isto é, a passagem para uma economia de subsistência ou, no máximo, voltada para o mercado interno significava, aos olhos dos administradores franceses, o fim do comércio colonial e era inviável do ponto de vista das necessidades imediatas das colônias, sobretudo num contexto de guerra. Havia a necessidade de alimentar e armar as tropas republicanas. Concluíram que a aplicação da abolição não podia resultar na instituição pura e simples da liberdade de trabalho. Era preciso instituir um sistema híbrido que permitisse, por meio da manutenção dos antigos escravos nas plantações, o funcionamento da economia colonial e do comércio com a metrópole.

Em São Domingos, Sonthonax e Polverel já tinham anunciado, em suas proclamações abolicionistas, um regime de trabalho que unia a compulsoriedade do trabalho a um sistema de remuneração. Os negros seriam obrigados a continuar

\footnotetext{
${ }^{1399}$ Cf. DUBOIS, Laurent. A Colony of Citizens, p.201.

${ }^{1400}$ Cf. MARIUS-HATCHI, Fabien. La Révolution caribéenne comme ultime rempart du droit naturel, pp.72-73.

${ }^{1401}$ Cf. BANGOU, Henri. La Guadeloupe, pp.138-140.
} 
trabalhando nas grandes plantações, agora não mais como escravos, mas como trabalhadores remunerados. Um regulamento de cultivo, composto por Polverel e aprovado por Sonthonax em 7 de fevereiro de 1794, completado por um código rural de 28 de fevereiro, estabelecia um sistema em que os frutos eram repartidos entre o Estado (duas partes), o proprietário (uma parte) e os cultivadores (uma parte). Assim, os antigos escravos, obrigados a retornarem ao trabalho nas plantações, receberiam um quarto da produção anual. Havia a previsão de penas de prisão e trabalho forçado em obras públicas para aqueles que se recusassem a trabalhar. Milícias negras foram criadas para fazer o policiamento nas plantações. No regulamento de Polverel, os trabalhadores tinham de continuar trabalhando, mas podiam transferir-se para outras plantations. No intuito de atenuar as semelhanças do novo regime para com o anterior, também havia sido dado aos negros o direito de participar, por meio de representantes no conselho administrativo, da escolha dos condutores e gerentes das plantações. Também era dada aos trabalhadores a possibilidade de escolher trabalhar cinco ou seis dias por semana. 1402

Mais tarde, o sistema de Sonthonax e Polverel seria retomado e aprimorado por Toussaint Louverture. O líder negro manifestaria, de tal forma, a percepção de que a conservação do sistema da grande produção exportadora era fundamental para manter a inserção de São Domingos no mercado e, desta forma, atender às muitas necessidades da ilha, não apenas em alimentos e instrumentos de produção, mas também em armas e munições. A França não era capaz de fornecer todo o necessário e, para que a colônia pudesse pagar o seu principal fornecedor, os Estados Unidos, as suas plantações tinham de continuar funcionando. Para Toussaint, São Domingos era, naquele momento, uma sociedade vulnerável, onde a preservação da liberdade geral impunha restrições à liberdade individual. ${ }^{1403}$

Assim, preocupado em evitar o fracionamento das terras cultiváveis e a expansão da pequena agricultura de subsistência, Toussaint não ordenaria o confisco das propriedades e sua distribuição aos novos livres. Além disso, quando, depois da abolição, alguns plantadores decidiriam vender as terras menos utilizadas ou produtivas, Toussaint chegaria a proibir a aquisição de terras menores de 3,3 acres, para evitar o seu fracionamento nas mãos das massas rurais. Não queriam que estas deixassem as grandes

\footnotetext{
${ }^{1402}$ Cf. DUBOIS, Laurent. A Colony of Citizens, p.204; GARRIGUS, John D. Before Haiti, pp.270-271; FICK, Carolyn. The making of Haiti, p.173.

${ }^{1403}$ Cf. GARRIGUS, John D. Before Haiti, pp.274-275.
} 
plantações de café e açúcar para dedicar-se ao cultivo de pequenas explorações. Seu objetivo era o de restabelecer a produção açucareira em níveis próximos aos do período pré-revolucionário. Isso implicava fixar os trabalhadores nas grandes plantações e garantir os direitos de propriedade dos antigos senhores remanescentes, cujo know-how lhe parecia fundamental para a recuperação da economia colonial. A exemplo do que haviam feito Sonthonax e Polverel anteriormente, Toussaint estabeleceria um regime de trabalho no qual um quarto dos rendimentos das plantações caberia aos trabalhadores, um quarto aos proprietários e metade ao Tesouro. ${ }^{1404}$

Esse sistema seria oficialmente instituído por meio do decreto sobre o trabalho agrícola de outubro de 1800, que daria aos antigos escravos que estavam longe de suas antigas plantações oito dias para retornarem a elas. Uma força de polícia seria organizada para capturar os "vagabundos" que não obedecessem. Estes seriam julgados por um tribunal militar e punidos de acordo com a lei. As plantações seriam inspecionadas por oficiais e, embora o uso do chicote estivesse proibido, outras formas de castigo corporal seriam mantidas. ${ }^{1405} \mathrm{O}$ sistema seria consolidado com a Constituição de São Domingos, proclamada em 1801, como veremos mais tarde.

Toussaint teria dito a respeito de seu sistema de trabalho compulsório:

"Se obriguei meus semelhantes a trabalhar, foi para fazer-lhes provar o preço da verdadeira liberdade sem licença; era para impedir a corrupção dos costumes; era para a felicidade geral da ilha, para o interesse da República. E eu tinha sido bem-sucedido em minha tarefa, visto que não havia, em toda a colônia, um só homem ocioso e que o número dos mendigos tinha diminuído a tal ponto que, com exceção de alguns poucos nas cidades, não se via um só nos campos". ${ }^{1406}$

A liberdade individual submetia-se assim a um valor maior, identificado no interesse da República e este exigia a continuidade do cultivo em larga escala. Um regime de trabalho semelhante seria mantido no Sul, onde o mulato Rigaud tinha sido colocado no comando por Polverel, após a sua partida. ${ }^{1407}$ Esse sistema não agradava à

1404 Cf. JAMES, C.L.R.. Os jacobinos negros, p.217; FICK, Carolyn. The making of Haiti, p.207; GARRIGUS, John D. Before Haiti, pp.279-281.

${ }^{1405}$ Cf. DUBOIS, Laurent. A Colony of Citizens, p. 337.

1406 "Si j'ai fait travailler mes semblables, c'était pour leur faire goûter le prix de la véritable liberté sans licence; c'était pour empêcher la corruption des moeurs; c'était pour le bonheur général de l'île, pour l'intérêt de la République. Et j'avais effectivement réussi dans ma tâche, puisqu'on ne voyait pas dans toute la colonie un seul homme désoeuvré et que le nombre des mendiants était diminué au point qu'à part quelques-uns dans les villes, on n'en voyait pas un seul dans les campagnes" (LOUVERTURE, Toussaint. Mémoires du Général Toussaint Louverture, écrits par lui-même. Paris: Pagnerre, 1853, pp.59-60).

${ }^{1407}$ Após a independência do Haiti, Dessalines e Christophe também procurariam manter um sistema de trabalho compulsório, mas as pressões dos trabalhadores negros continuariam fortes. Sob a presidência de 
maioria da população negra, avessa à ideia de continuar trabalhando para os mesmos plantadores brancos, ou mesmo para uma nova elite negra e mulata, proveniente da alta oficialidade das forças republicanas. Essa situação acabava reproduzindo algumas das condições que os haviam levado a lutar pela liberdade. Isso não significa que nada havia mudado para eles, afinal não podiam mais ser vendidos e açoitados, tinham agora alguma voz nas assembleias para nomeação de agentes e condutores e tinham direito a alguma forma de remuneração. ${ }^{1408}$ Entretanto, esses homens e mulheres não admitiam que, dada a sua nova condição de homens livres, fosse exigido deles trabalho nos mesmos locais em que haviam sido submetidos à condição servil. Para eles, o fim da escravidão tinha de significar o abandono da grande produção exportadora. $\mathrm{O}$ acesso à terra e a autonomia no seu cultivo eram os principais elementos definidores da liberdade para os novos cidadãos de São Domingos. Sem isso, a liberdade tendia a ficar reduzida a uma abstração.

Muitos, aliás, aproveitavam uma eventual ausência do proprietário da plantação para aumentar seus pequenos lotes de terra e vender o excedente de produção no mercado. Mesmo quando o proprietário estava presente, era comum que os trabalhadores pedissem a redução da semana de trabalho para cinco dias, aumentando o tempo livre para o cultivo de suas hortas. Isso significava reduzir sua parte na receita para $1 / 6$ ou 3/11, mas muitos ainda preferiam privilegiar o cultivo nos pequenos lotes, manifestando, com isso, a percepção de que, apenas naquele espaço, eles gozavam verdadeiramente de uma forma de liberdade. Assim, os antigos escravos continuavam a resistir ao trabalho que lhes era imposto. Alguns fugiam, outros sabotavam o trabalho; uns cometiam roubos, outros se recusavam a trabalhar à noite. ${ }^{1409}$ As antigas formas de resistência conhecidas na escravidão se reproduziam, de alguma forma, no novo regime.

Para Carolyn Fick, o desejo dos antigos escravos de viverem como plantadores independentes estava, de alguma forma, relacionado às suas origens africanas. ${ }^{1410} \mathrm{E}$ possível, porém acreditamos que essas aspirações significavam, acima de tudo, uma

Pétion e Boyer, as massas negras conseguiriam o que sempre tinham desejado: uma reforma agrária que lhes desse o acesso à terra para uma produção agrícola de autossubsistência (cf. GORENDER, Jacob. $A$ escravidão reabilitada, p.131).

${ }^{1408}$ Cf. FICK, Carolyn. The making of Haiti, p.169.

${ }^{1409}$ Ibidem, pp.168-176.

${ }^{1410}$ Idem. The French Revolution in Saint-Domingue, pp.69-70. 
ampliação de algo que já conheciam dentro do sistema escravista, isto é, a economia própria que desenvolviam em suas pequenas hortas. ${ }^{1411}$

O sistema de trabalho compulsório instituído em São Domingos permitiu o enriquecimento pessoal de boa parte da alta oficialidade do exército negro. Assim como havia feito o mulato André Rigaud no Sul da ilha, Toussaint determinaria, a partir de 1796, que as plantações abandonadas do Norte fossem arrendadas a novos possuidores. Os beneficiários seriam, geralmente, oficiais negros e de cor. Dessalines e Christophe, por exemplo, extrairiam lucros enormes das terras sob seu controle. O primeiro chegaria a controlar cerca de trinta propriedades. $\mathrm{O}$ enriquecimento dos oficiais negros e mulatos permitiria a formação de uma nova elite negra, associada à economia de plantation. ${ }^{1412}$

Os resultados do sistema de trabalho imposto por Toussaint foram, no geral, positivos, determinando uma inegável recuperação econômica. Em 1801, a exportação de açúcar atingiu 13\% do que era em 1789, contra 1,2\% em 1795; a exportação de café subiu de 2,8\% (1795) para 57\% do que era em 1789; já a de algodão subiu para $35 \%$ do que era em 1789. Em 1802, se o café caiu para 45\% do nível de 1789, o açúcar subiu para $38 \%$ e o algodão para $58 \%{ }^{1413}$

Sistemas semelhantes de trabalho foram instituídos em outras colônias. Na Guiana, o comissário civil Nicolas Jeannet-Oudin promoveu negociações entre senhores e antigos escravos a respeito do novo regime de trabalho a ser adotado. As propostas giraram em torno de dois sistemas: o de repartição das receitas, com um terço destinado aos cultivadores, e o sistema salarial. ${ }^{1414}$ Os sucessores de Jeannet-Oudin na Guiana Cointet (1794-96) e Burnel (1798-99) - também se inscreveriam na mesma linha,

\footnotetext{
${ }^{1411}$ Jacob Gorender vê nesse aspecto um reflexo do caráter regressivo da ideologia antiescravista dos próprios escravos, que negavam a escravidão com a finalidade de regressar a um estado anterior em que eles, ou seus antepassados, tinham sido livres. Assim, a pressão dos antigos escravos se dava no sentido de suprimir a forma plantagem em prol de um modelo de pequena exploração camponesa. Por razões estruturais, a consciência antiescravista espontânea dos escravos não teria sido capaz de adquirir um conteúdo progressivo, voltado para um estado social novo resultante da transformação do sistema escravista e do aproveitamento das forças produtivas da plantagem exportadora como ponto de partida para o desenvolvimento econômico-social. Nesse sentido, as massas negras teriam sido incapazes de compreender aquilo que Toussaint havia compreendido: a necessidade de reconstruir o país a partir de uma transformação das estruturas nele estabelecidas. A explicação de Gorender parece-nos um tanto estereotipada, na medida em que vê a grande propriedade como a única via possível de desenvolvimento. Além disso, é provável que, aos olhos dos trabalhadores negros, as diferenças entre a escravidão e o novo sistema de trabalho fossem mínimas. É verdade, contudo, que as necessidades prementes da colônia não possibilitavam, naquele momento, a adoção de outra via econômica (cf. GORENDER, Jacob. A escravidão reabilitada. São Paulo: Ática, 1990, pp.122-123 e anexo A, p.221).

${ }^{1412}$ Cf. DUBOIS, Laurent. A Colony of Citizens, pp.206 e 337.

1413 Ibidem, p.338.

${ }^{1414}$ Cf. BÉNOT, Yves. La Guyane sous la Révolution française, p.71.
} 
tentando equilibrar o status de homens livres dos negros com um sistema de imposições que privavam-nos da mobilidade própria à liberdade civil. ${ }^{1415}$

Na Guadalupe, verificou-se a mesma situação. Diante da necessidade de garantir a autossuficiência alimentar da ilha, num contexto de guerra, a comissão encabeçada por Hugues instituiu, a partir de outubro de 1794, um sistema no qual o Estado se fazia proprietário das terras, mantendo de forma coercitiva os antigos escravos nas plantações, para garantir o cultivo. ${ }^{1416}$ Um severo regime disciplinar foi imposto aos trabalhadores, que não podiam afastar-se das propriedades desmunidos de um laisserpasser. Aquele que fosse encontrado sem esse documento ficava detido num local onde o plantador podia recuperá-lo, após pagar os custos de captura e detenção. O indivíduo que não pudesse comprovar seu domicílio ou estado era considerado "vagabundo", podendo ser julgado e até mesmo fuzilado. Em contrapartida, a exemplo do que ocorria em São Domingos, à massa dos trabalhadores de uma plantation era, em princípio, reservado um quarto do produto líquido, distribuído da seguinte forma: uma parte para o cultivador, operário ou empregado entre 15-50 anos; três partes para o primeiro chefe de atelier; duas partes para cada chefe refinador; uma meia-parte para as crianças entre 1015 anos; e uma parte para cada cidadão empregado no hospital. Além disso, os proprietários tinham de respeitar os horários de trabalho estabelecidos, cuidar dos idosos e enfermos e atribuir a cada trabalhador uma porção de terra para ser cultivada no seu tempo livre. ${ }^{1417}$

Laurent Dubois esclarece, entretanto, que esse sistema não foi de fato adotado e os trabalhadores não tiveram, na prática, direito à parte que lhes cabia na produção. Em troca, Hugues tinha prometido salários, mas, não podendo cumprir essa promessa, buscou outras formas de encorajamento, como a concessão de maior tempo livre. Hugues decidiu, assim, dar dois dias livres sobre os dez que compunham a semana republicana aos trabalhadores, para combater o êxodo de mão de obra: no fundo, isso era apenas ampliar a pequena margem de liberdade que os negros já conheciam sob a escravidão. Com isso, muitos negros não viram grande diferença em relação ao seu estado anterior e preferiram não retornar às plantações ou então abandoná-las. Hugues podia ter consciência da necessidade de instituir um sistema salarial e educar os novos

1415 Cf. FOUCK, Serge Mam Lam. La résistance au rétablissement de l'esclavage en Guyane française: traces et regards 1802-1822. In: Y. BÉNOT, M. DORIGNY (orgs). Rétablissement de l'esclavage dans les colonies françaises. Paris: Maisonneuve \& Larose, 2003, p. 254.

1416 Cf. MARIUS-HATCHI, Fabien. La Révolution caribéenne comme ultime rempart du droit naturel, pp.74-75.

${ }^{1417}$ Cf. BANGOU, Henri. La Guadeloupe, pp.150-151. 
livres, mas não dispunha de recursos materiais para isso. Em agosto de 1795, ele fez uma tentativa de instituir salários aos trabalhadores: prometeu aos que recolhessem café uma meia-gourde ${ }^{1418}$ por barril coletado. Fez a mesma promessa aos cultivadores de açúcar e de algodão, mas nenhuma medida foi adotada. Muitos trabalhadores continuaram a receber apenas comida, roupa e os dois dias livres para cultivar a sua horta. $^{1419}$

Hugues justificava as limitações à liberdade com base nas necessidades da República e nas responsabilidades dos novos cidadãos: a liberdade tinha um preço, isto é, tinha de ser merecida, o que contrariava a ideia de que todos nasciam livres. Os que não participavam da defesa da colônia tinham de continuar trabalhando nas plantações. Os crimes cometidos contra a propriedade eram considerados "crimes nacionais", julgados por um tribunal militar. Na verdade, como diz Laurent Dubois, essa política não deixava de resgatar as preocupações dos antiescravistas gradualistas, que temiam que a transição abrupta da escravidão para a liberdade promovesse a ruína das colônias. Assim, a liberdade tinha de ser concedida, mas de forma limitada. ${ }^{1420}$ No centro das políticas coloniais, persistia a preocupação com a preservação da ordem. A lei de abolição, produto de um contexto de republicanismo radical, não havia sido votada de acordo com os termos pregados pelos gradualistas, mas, no momento de sua aplicação, as mesmas preocupações retornaram. Os administradores franceses, preocupados em definir os termos de uma liberdade já conquistada pelos negros, tinham agora de adequar o sistema da emancipação ao objetivo de manutenção do estatuto colonial.

Na Guadalupe, de acordo com os números trazidos por Dubois, a produção caiu bastante entre 1790 e 1799 . Mais de $10 \%$ das plantations foram abandonadas por falta de cultivadores. Com isso, o número de grandes explorações diminuiu consideravelmente em prol do número de pequenas plantações. A superfície total explorada caiu de 51.279 hectares, em 1790, para 18.469 hectares, em 1799. O algodão foi o setor mais prejudicado, com queda de $75 \%$ da superfície plantada, contra $61 \%$ para o café e $68 \%$ para o açúcar. Contudo, os números também revelam que, apesar da abolição, muitos plantadores continuaram produzindo como antes e que uma recuperação econômica ainda era possível. ${ }^{1421}$

\footnotetext{
1418 A gourde era a moeda utilizada no Caribe.

${ }^{1419}$ Cf. DUBOIS, Laurent. A Colony of Citizens, pp.208-213.

${ }^{1420}$ Ibidem, pp.176-177.

${ }^{1421}$ Ibidem, p. 214.
} 
Pode-se dizer que a abolição permanecia, para muitos, palavra-morta e que o novo estado dos negros das colônias francesas diferia do anterior apenas no nome. Por outro lado, a perseverança com a qual as massas negras do Caribe se oporiam ao restabelecimento da escravidão indica que, por mais rigoroso que fosse o regime de trabalho compulsório, a abolição lhes tinha trazido algo de novo, modificando as suas aspirações. Por menores que fossem as inovações do novo regime de trabalho, os antigos escravos não admitiriam uma volta ao seu estado anterior. Não se deve, além disso, esquecer que, para os que compunham o exército republicano colonial, a abolição e o reconhecimento da cidadania eram realidades concretas que seria preciso defender com unhas e dentes.

Por outro lado, as dificuldades que os agentes do governo revolucionário encontraram na execução da lei de 16 pluvioso podem hoje ser vistas como o prenúncio do recuo que ocorreria na política colonial da Revolução. A contradição existente entre o objetivo de recuperar economicamente as colônias e as aspirações da massa dos antigos escravos alimentaria, na metrópole, uma tendência à reversão da liberdade, com base no argumento da incompatibilidade das colônias com o sistema de emancipação e da incapacidade dos negros de incorporarem noções de liberdade e cidadania. $\mathrm{O}$ debate em torno da impossibilidade da aplicação da abolição seria o ponto de partida para um retrocesso gradual da legislação colonial. Mas, se esse retrocesso foi impulsionado pelas dificuldades na aplicação da lei de 16 pluvioso do ano II, ele também foi o produto de um contexto político específico, marcado pelo fim do governo montanhês na metrópole. 


\section{III.1.2) A transição thermidoriana}

A queda da Convenção montanhesa em 9 thermidor do ano II (27 de julho de 1794) constitui um divisor de águas na história da Revolução. Ela marcou o fim de um projeto republicano radical que apontava para um relativo igualitarismo social. Marcou também o fim do dirigismo econômico e das medidas repressivas de salvação pública, elementos definidores de uma política contrária aos interesses da grande burguesia mercantil. O 9 thermidor também sinalizou o início de um processo de desarticulação do movimento popular. É verdade que, antes mesmo do golpe, as relações deste com o governo revolucionário encontravam-se já bastante degradadas, na medida em que as reivindicações de participação política mais direta da sans-culotterie colidiam com o projeto de fortalecimento da ditadura do aparelho de governo. Nesse embate, ambos os campos falharam em perceber o quanto um dependia do outro. A sans-culotterie, já um tanto esgotada pela luta constante desde o início da Revolução, não reconheceu a ameaça que a queda do governo revolucionário trazia para ela. Uma das linhas de força da política thermidoriana seria neutralizar a capacidade combativa do movimento popular. Dez dias após o golpe de 9 thermidor, os comitês do governo já decidiram colocar o comando da guarda nacional parisiense sob o controle da Convenção e dos Comitês de Salvação Pública e Segurança Geral. Ao longo do ano III, outras medidas viriam atenuar o caráter popular da guarda, até a sua neutralização completa em 16 vendemiário do ano IV (8 de outubro de 1795). ${ }^{1422}$

Se as repercussões dessa reviravolta na história da Revolução seriam evidentes no que se refere, por exemplo, à política de controle de preços e de repressão à especulação, com o fim do máximo dos preços já em 9 de dezembro de 1794, o seu efeito na questão colonial foi, a princípio, mais sutil. O processo que levou à revogação da abolição foi longo. Mas sinais de que as coisas tinham mudado logo se fariam notar, preparando o caminho para uma volta da política colonial pré-revolucionária.

Para os historiadores da tradição "jacobina", o 9 thermidor marcou, de fato, uma reviravolta na página colonial da Revolução. Assim, Florence Gauthier entende que a reação thermidoriana "[...] pôs fim, passo a passo, à política de aliança com a revolução da igualdade da epiderme". ${ }^{1423}$ Da mesma forma, Claire Blondet fala do 9 thermidor

\footnotetext{
${ }^{1422}$ Cf. SOBOUL, Albert. Les Sans-culottes parisiense en l'an II, p.180.

${ }^{1423}$ GAUTHIER, Florence. La première abolition de l'esclavage ou l'ouverture du procès du colonialisme, p. 16 .
} 
como o marco de uma política "reacionária em matéria colonial". ${ }^{1424}$ Já Marius-Hatchi fala num

assassinato do direito natural iniciado em 9 thermidor - 27 de julho de 1794 , data que marca o abandono da aliança revolucionária firmada entre os povos da França e do Caribe desde 15-16 pluvioso - 3-4 de fevereiro de 1794, quando da recepção da deputação de São Domingos na Convenção. ${ }^{1425}$

Essas afirmações dramáticas, embora não totalmente incorretas, devem ser nuançadas, tendo em vista que o fim do governo jacobino não significou, de imediato, uma ruptura com a política consagrada em fevereiro de 1794. Muitos thermidorianos eram antiescravistas e continuariam o seu combate na Convenção e sob o Diretório, o que permitiria manter por quase uma década as conquistas em matéria colonial. Mais importante do que isso era o fato de que a França ainda estava em guerra e as colônias na América ainda constituíam uma frente de combate importante no quadro do conflito com as potências europeias. A abolição não podia ser facilmente desfeita enquanto essa situação perdurasse.

Dito isso, é certo que um dos fatores que havia tornado a abolição possível - o regime radical de base popular do ano II - havia sido suprimido. O novo contexto político abria, de fato, novas possibilidades de ação para os que desejavam a restauração da escravidão nas ilhas e, munidos do argumento do "fracasso" da experiência da abolição, esses homens promoveriam gradualmente um retorno ao status quo colonial pré-revolucionário. Os sinais de um possível recuo não tardariam a se fazer sentir.

\section{III.1.2.1) O fim da repressão aos colonos}

A manifestação mais rápida de uma mudança de orientação em matéria colonial foi o fim da perseguição sistemática dos colonos, fato que deve ser inserido no contexto mais geral do fim da política repressiva instaurada pelo governo robespierrista. Em agosto de 1794, no quadro da soltura em massa de prisioneiros do Terror, vários colonos foram postos em liberdade pelo Comitê de Salvação Pública, como Thérou, Molar e Schoenperg, sem, contudo, que uma política mais geral fosse ainda delineada.

${ }^{1424}$ Cf. BLONDET, Claire. Quand les "terroristes" font le procès du colonialisme esclavagiste les thermidoriens organisent son oubli, p.61.

1425 "assassinat du droit naturel entamé le 9 thermidor - 27 juillet 1794, date qui marque l'abandon de l'alliance révolutionnaire passée entre les peuples de France et de la Caraïbe depuis les 15-16 pluviôse an II - 3-4 février 1794, lors de la réception de la députation de Saint-Domingue à la Convention" (cf. MARIUS-HATCHI, Fabien. La Révolution caribéenne comme ultime rempart du droit naturel, p.69). 
A presença de montanheses thermidorianos na Convenção, como Dubois-Crancé, Bréard, Thuriot e Cambon, impedia a suspensão pura e simples das leis de proscrição dos colonos, assim como do decreto de prisão de Sonthonax e Polverel. ${ }^{1426}$

Nos dias que seguiram o 9 thermidor, a repressão aos colonos aparentemente ainda seguia o seu curso, por conta da ação dos deputados de São Domingos. Em 17 thermidor (4 de agosto de 1794), por exemplo, Mills, Dufay e Belley conseguiram a prisão judiciária de Derragis, colono deportado por Sonthonax, e Legrand, este último secretário de Page e Brulley. No mesmo dia, chegou à Convenção uma carta de Polverel anunciando que, na sua chegada à metrópole, o Comitê de Salvação Pública havia executado o decreto de acusação votado contra eles. O decreto de prisão dos comissários civis de 16 de julho de 1793 não tinha sido revogado pela abolição de 94, mas, como a chegada dos comissários acontecia após a queda dos robespierristas, a situação havia mudado. Polverel pedia a sua transferência para Paris para que pudesse justificar as suas ações perante a Convenção e indicar os meios de restabelecer a ordem nas colônias. Bréard, um dos autores do decreto de acusação contra os comissários, afirmou que a Convenção podia ter sido enganada a respeito dos dois comissários e conseguiu, com o apoio de Dubois-Crancé, a suspensão da acusação e a libertação temporária de Polverel e Sonthonax. ${ }^{1427}$

Em 5 fructidor (22 de agosto de 1794), um dos colonos deportados por Sonthonax, Verneuil, leu na Convenção um discurso para atacar os comissários civis e pedir a libertação de Page e Brulley e de todos os colonos presos sob o Terror. Pedia ainda que os dois colonos fossem ouvidos contraditoriamente com Polverel e Sonthonax. O deputado Pierre Guyomar também interveio em favor dos dois colonos, pedindo ainda a libertação de Julien Raimond. Após aprovação inicial da proposta, Thuriot e Cambon denunciaram as ligações dos dois homens com os ingleses e conseguiram encaminhar a questão aos Comitês de Salvação Pública, de Segurança Geral e da Marinha e das colônias. ${ }^{1428}$ Nessa mesma sessão, entretanto, a Convenção

\footnotetext{
${ }^{1426}$ Cf. PIQUET, Jean-Daniel. L'émancipation des Noirs dans la Révolution française, pp.430 e 447-449. Isso permite talvez explicar o fato de que Larchevesque-Thibaud, um dos colonos presos pelo governo do ano II, tenha publicado, em 17 thermidor, uma carta na qual fazia uma surpreendente apologia do regime da liberdade, apresentando a abolição como um verdadeiro despertar: "Era preciso um abalo para mudar nossas ideias; era preciso que a escravidão dos negros fosse abolida, para que reconhecêssemos a sua inutilidade" ("Il fallait cette secousse pour changer nos idées; il fallait que l'esclavage des noirs fût aboli, pour que nous en reconnussions l'inutilité", LARCHEVESQUE-THIBAUD, Gabriel-Jean-Baptiste. Lettre d'un colon de Saint-Domingue à un de ses amis. Paris: Imprimerie Ch. Desbrière, s.d. [ano IV], p.4).

${ }^{1427}$ Cf. AP, v.94, pp.181-182.

1428 Cf. Recueil des actes du Comité de salut public, v.16, p.798, nota 1. PIQUET, Jean-Daniel. L'émancipation des Noirs dans la Révolution française, pp.444-445.
} 
decidiu autorizar, em nome da liberdade de expressão, a publicação do número 5 das Notes fournies au Comité de Salut Public, panfleto em que Page e Brulley atacavam pessoalmente a deputação de São Domingos ${ }^{1429}$, o que indicava um relaxamento da censura antes estabelecida pelo Comitê de Salvação Pública do ano II. Belley foi o único a verdadeiramente protestar contra a indulgência manifestada para com os colonos, opondo-se ao princípio da liberdade ilimitada de imprensa. ${ }^{1430}$ Poucos dias depois, em 9 fructidor (26 de agosto), Derragis, que tinha sido preso por ter levado esse panfleto ao gabinete de distribuição da Convenção, foi libertado, por ordem assinada por Carnot. Na mesma época, vários colonos, como Derosière, também seriam libertados, muitas vezes por uma alegada ausência de provas de sua pertinência às assembleias coloniais ou ao Clube Massiac. ${ }^{1431}$

Após o 9 thermidor, a Comissão de Brest, liderada por Prieur de la Marne, também suspenderia as suas atividades de perseguição aos colonos. Em 11 de agosto, um dia antes de receber o relatório de Prieur sobre os trabalhos da comissão de Brest, o Comitê de Salvação Pública determinou que Ragmey, juiz do tribunal de Brest, cessasse as suas atividades e tivesse seus papéis examinados. ${ }^{1432}$ Ragmey acabaria sendo preso e seu caso seria encaminhado, em 2 de setembro, aos comitês de Segurança Geral e de Legislação. ${ }^{1433}$ Em cumprimento das leis de 26 thermidor (13 de agosto) e 12 fructidor (29 de agosto), que determinavam o retorno dos representantes em missão do Comitê de Salvação Pública, Prieur, que por um tempo aguardou um substituto para Ragmey, retornou a Paris, pondo definitivamente fim à sua missão em Brest, cujo trabalho seria praticamente ignorado.

Alguns meses depois, as últimas resistências foram dissipadas. Em 17 brumário do ano III (7 de novembro de 1794), Dufay, alegando que a Convenção não podia confundir o erro e o crime, propôs que todos os colonos das ilhas francesas fossem colocados em liberdade, com exceção dos que compunham o clube Massiac. Bourdon de l'Oise apoiou a moção, que foi aprovada pela assembleia. ${ }^{1434}$ Era, na prática, o fim da repressão ao partido colonial escravista. ${ }^{1435}$

\footnotetext{
${ }^{1429}$ Cf. PAGE, Pierre-François, BRULLEY, Augustin-Jean. Notes fournies au Comité de Salut Public, pp.65-71.

${ }_{1430}$ Cf. AP, v.95, pp.375-377.

${ }^{1431}$ Cf. PIQUET, Jean-Daniel. L'émancipation des Noirs dans la Révolution française, pp.429-430 e $443-$ 444.

${ }^{1432}$ Cf. Recueil des actes du Comité de salut public, v.16, pp.20 e 57.

${ }^{1433}$ Ibidem, pp.466.

${ }^{1434}$ Cf. Moniteur, v.22, número 50, 20 brumário ano III (10 de novembro de 1794), p.456.

${ }^{1435}$ Cf. GAUTHIER, Florence. La convention thermidorienne et le problème colonial, p.112.
} 
Nesse novo contexto, muitos emigrados retornaram à França e até mesmo às colônias, o que não deixou de gerar problemas, pois muitas de suas propriedades tinham sido tomadas pelo Estado e estavam nas mãos de arrendatários. Isso levou muitos plantadores a reclamarem judicialmente o retorno de seus bens. Quando conseguiam, voltavam a controlar os seus antigos escravos, que observavam o retorno dos opressores de um passado recente com grande inquietação. ${ }^{1436} \mathrm{Na}$ metrópole, muitos colonos aproveitariam o clima de reação para tentar minar as conquistas abolicionistas do ano II.

\section{III.1.2.2) Uma nova ofensiva colonial}

A libertação dos colonos abriu o caminho para uma nova investida colonial que teve por alvos principais a deputação de São Domingos e os comissários civis Sonthonax e Polverel. Quando ainda estavam na prisão, Page e Brulley já haviam lançado uma vasta campanha contra a política colonial da Montanha. O objetivo final era impedir a aplicação do decreto de abolição e promover a libertação dos colonos aprisionados, mas, naquele momento, a estratégia adotada pelos dois colonos havia sido a de caluniar a deputação de São Domingos, questionando a legalidade do mandato de homens que simbolizavam a nova ordem colonial. Os esforços de Page e Brulley encontravam amparo num pequeno grupo de deputados coloniais: Gouly, Defrance, Creuzé-Pascal, Littée, Lassalle e Serres. ${ }^{1437}$

A partir de 19 de agosto, plantadores contrarrevolucionários intervieram na Convenção e na imprensa para sustentar a campanha dos dois colonos. O preconceito de cor aparecia frequentemente na sua argumentação: Belley, o deputado negro, era acusado de ser incapaz de redigir as suas próprias respostas. Outro tema recorrente na campanha era o de uma "Vendéia Negra": o objetivo era associar a revolução dos escravos à contrarrevolução e aos movimentos monarquistas.

Os comissários Sonthonax e Polverel tinham sido soltos no início de agosto. Contudo, a libertação quase simultânea dos colonos lançou uma nova ameaça sobre os dois agentes. Page e Brulley pediram a formação de uma comissão contraditória, formada, de um lado, por Polverel e Sonthonax, e, de outro, por sete dos colonos

\footnotetext{
${ }^{1436}$ Cf. DUBOIS, Laurent. A Colony of Citizens, p.280.

1437 Cf. GAUTHIER, Florence. Le rôle de la députation de Saint-Domingue dans l'abolition de l'esclavage, p.206.
} 
aprisionados, dentre os quais, eles próprios. ${ }^{1438}$ A pressão não foi em vão, pois a Convenção aceitou, em 9 vendemiário do ano III (30 de setembro de 1794), criar uma comissão de deputados para analisar a Revolução de São Domingos. ${ }^{1439}$ Os membros nomeados para a Comissão foram: Garran de Coulon (presidente), Guyomar, Fouché, Grégoire, Thibaudeau, Mazade e Castillon. Page e Brulley tentaram ainda obter, sem sucesso, a exclusão de Grégoire. ${ }^{1440}$ Por meio da lei de 4 pluvioso do ano III (23 de janeiro de 1795), foi decidido que a comissão das colônias ouviria os acusadores e os acusados na questão das colônias.

Assim, durante a primeira metade de 1795, ocorreu um longo debate ao longo do qual a comissão, presidida por Garran de Coulon, ouviu contraditoriamente os acusados - os comissários civis Polverel e Sonthonax - e os acusadores - um grupo de colonos que reunia Page, Brulley, Thomas Millet, Verneuil, Duny, Senac, Clausson, Fondeviolle, Daubonneau e Larchevesque-Thibaud. ${ }^{1441}$ Era bastante revelador que o procedimento colocasse contra a parede os comissários, que haviam proclamado a abolição, e permitisse que as acusações fossem formuladas por colonos escravistas, que haviam conspirado com os britânicos. Prudentes, os colonos tomaram o cuidado de não contestar diretamente a abolição e mesmo a proclamação de Sonthonax de 29 de agosto de 1793, muito embora elas fossem a razão de ser daquele confronto. Procuraram, ao contrário, situar a acusação num plano legalista, denunciando o suposto sistema de tirania instituído pelos comissários, a não execução por estes das leis da metrópole (isto é, a lei de 24 de março de 1792) e seu envolvimento numa conspiração estrangeira contra a República francesa. ${ }^{1442}$ Polverel e Sonthonax apareciam como os "devastadores da parte francesa de São Domingos". 1443

Nas suas conclusões, apresentadas em 3 brumário do ano IV (25 de outubro), a comissão das colônias absolveu os comissários. Por outro lado, os colonos não foram julgados pelos atos de traição cometidos ao longo da Revolução. Não eram eles e sim o campo abolicionista que estava sob julgamento. A absolvição dos comissários mostrava que os adeptos da abolição ainda eram capazes de fazer frente ao partido colonial, mas o episódio em si era indicativo da força política por este readquirida após o 9 thermidor. Livre das acusações que pesavam sobre ele desde 1793, Sonthonax seria colocado à

\footnotetext{
${ }^{1438}$ Idem. La convention thermidorienne et le problème colonial, pp.111-112.

${ }^{1439}$ Cf. Moniteur, v.22, número 12, 12 vendemiário ano III (3 de outubro de 1794), pp.125-126.

1440 Cf. PIQUET, Jean-Daniel. L'émancipation des Noirs dans la Révolution française, pp.445-446.

${ }^{1441} \mathrm{Cf}$. Débats entre les accusateurs et les accusés, dans l'affaire des colonies, v.1, pp.6-7.

1442 Ibidem, pp. 15 e $23-25$.

1443 Ibidem, p.3.
} 
frente da terceira comissão civil nomeada para São Domingos, que chegaria à ilha em maio de 1796.

\section{III.1.2.3) Os representantes das ilhas Mascarenhas}

Além da ofensiva conduzida pelos colonos das ilhas americanas, uma outra campanha paralela era movida pelos deputados das colônias do Oceano Índico. As Mascarenhas - Île-de-France (futura ilha Maurício) e Ilha da Reunião (antiga ilha Bourbon) - constituíam um caso à parte no espaço colonial francês. Desde o início da Revolução, seus representantes, embora fossem defensores fervorosos da escravidão, haviam, em diversas ocasiões, se destacado do grupo dos demais deputados coloniais, como, por exemplo, no debate a respeito dos homens de cor livres. A fidelidade manifestada pelas ilhas à metrópole e às suas leis, em meio à convulsão política que tinha agitado o mundo colonial desde o início da Revolução, dava-lhes uma posição diferenciada no seio da legislatura. Os deputados dessas ilhas valeram-se dessa posição para obter medidas excepcionais em termos de política colonial, preservando as Mascarenhas das transformações mais radicais promovidas pela República.

Após o fim da Convenção Montanhesa, os representantes das Mascarenhas assumiram a vanguarda da ofensiva colonial, sobretudo a partir de brumário do ano III (novembro de 1794), o que fez com que colidissem frequentemente com os deputados da nova São Domingos. Os dois eleitos da Île-de-France, Gouly e Serres, tinham até então se apresentado como jacobinos militantes. Tinham sido admitidos no clube em 16 de outubro de 1793 e, na Convenção do ano II, costumavam sentar-se nos bancos da Montanha, o que fez com que Gouly tivesse de se defender de acusações de "robespierrismo". Afirmou que, se o 9 thermidor não tivesse ocorrido, ele provavelmente teria sido guilhotinado, dadas as distâncias que tinha assumido em relação à política de Robespierre. A sua adesão aos thermidorianos foi total. ${ }^{1444}$

A missão primordial desses deputados era evitar a aplicação da abolição nas Mascarenhas. Nesse intuito, agiam como verdadeiros camaleões. Para manter as aparências, evitavam atacar diretamente a lei de 16 pluvioso e procuravam mostrar-se patriotas convictos, manifestando uma profunda anglofobia. Gouly tinha, por exemplo, movido esforços para libertar dois jacobinos antiescravistas: Léonard Leblois, antigo

${ }^{1444}$ Cf. WANQUET, Claude. La France et la première abolition de l'esclavage, pp.56-59. 
colono e autor de um panfleto abolicionista apresentado ao clube dos Jacobinos em 20 fructidor do ano II (6 de setembro de 1794) ${ }^{1445}$, e Leborgne. ${ }^{1446}$ Leblois tinha recebido ordens de retornar a São Domingos, mas tinha permanecido na metrópole, o que lhe tinha valido a acusação "[...] de intrigar e perpetuar os ódios e as divisões [...]". ${ }^{1447}$ A intervenção de Gouly em favor dos dois jacobinos explica o fato de Leborgne ter poupado Gouly em seus ataques à "facção inglesa", comandada por Page e Brulley, em panfletos como Enfin la vérité sur les colonies. ${ }^{1448}$ Gouly chegaria até mesmo a pedir para entrar na segunda formação da Sociedade dos Amigos dos Negros, sem sucesso.

Ao mesmo tempo, os deputados das Mascarenhas queriam convencer a Convenção dos perigos de uma aplicação impensada do decreto de abolição. Para isso, ressaltavam a importância não apenas econômica, mas também estratégica e militar das colônias orientais. Chegavam ao ponto de sustentar as supostas virtudes do regime escravista, que conferia proteção aos negros, recuperando a tese de que estes, imaturos para a liberdade, seriam as primeiras vítimas de uma abolição mal preparada ou mal controlada. Pregavam o envio de leis particulares para as colônias, adaptadas às condições locais e elaboradas com a participação dos colonos; medidas transitórias e autoritárias destinadas a acompanhar a emancipação dos escravos e que permitissem indenizar previamente os senhores pelas suas perdas. ${ }^{1449}$

Após a queda dos robespierristas, os deputados da Île-de-France multiplicaram os memoriais e relatórios aos comitês da Convenção. O mais importante deles foi Vues Générales sur l'importance du commerce des colonies, de 7 frimário (27 de novembro de 1794), de Gouly, uma verdadeira defesa da autonomia legislativa colonial, com base em argumentos que poderíamos hoje chamar de racistas. Construído em forma de diálogo, o texto contestava o princípio segundo o qual todos os homens nascem e permanecem livres e iguais em direitos. Para Gouly, os homens não eram naturalmente iguais: "A espécie homem apresenta diversas raças que diferem entre si, assim como

1445 Em Réflexions d'un observateur sur les malheurs que Saint-Domingue a éprouvés depuis la révolution (1794), Leblois denunciava os projetos federalistas dos colonos brancos que, coalizados com os ingleses, tinham feito de tudo para manter intacta a ordem escravista e segregacionista em São Domingos e alertava para a campanha de mentiras do partido colonial (cf. LEBLOIS, Léonard. Réflexions d'un observateur sur les malheurs que Saint-Domingue a éprouvés depuis la révolution, adressées aux Jacobins. S.1.: Iprimerie du citoyen Pain, [1794], pp.2-3).

${ }_{1446}$ Cf. PIQUET, Jean-Daniel. L'émancipation des Noirs dans la Révolution française, pp.451-453.

${ }^{1447}$ Cf. Recueil des actes du Comité de salut public, v.16, p.263.

1448 Cf. LEBORGNE, P.J.. Enfin la vérité sur les colonies, en réponse à Janvier Litté, homme de couluer, Député à la Convention. Paris: Imprimerie de Pain, an III [1794].

${ }^{1449}$ Cf. WANQUET, Claude. La France et la première abolition de l'esclavage, pp.53-54, 65-69 e 73115 . 
diferem todos os indivíduos que compõem cada raça" (grifo nosso). Acreditava, referindo-se aos negros, que a "[...] igualdade de direitos, estabelecida como princípio de uma associação de homens esclarecidos, não pode ser sentida pelos povos que apenas o temor anima, que cedem e obedecem apenas à força". Para Gouly, numa sociedade constituída por diferentes raças, a igualdade absoluta de direitos não era possível, sendo necessário distinguir os direitos específicos de cada raça, que tinham de ser "[...] relativos ao que cada uma delas põe na sociedade". Assim, dessa concepção racial de justiça distributiva ele concluía que "a igualdade só pode ser estabelecida constitucionalmente nas Colônias nas relações entre os indivíduos de cada raça, e apenas entre eles". ${ }^{1450}$

Para Gouly, os direitos do indivíduo na sociedade tinham de decorrer de suas faculdades físicas e mentais, as quais estavam associadas à raça à qual pertenciam. Nas colônias, a cor era o "sinal do valor intrínseco do homem", na medida em que o estado das pessoas se baseava no "sentimento íntimo de seu valor real, e numa convicção profunda da diferença de valor". Ou seja, os negros se sentiam inferiores aos brancos, não porque estes o diziam, mas porque não se sentiam capazes de fazer o que os brancos faziam e estavam persuadidos de que a sua raça era incapaz de progredir e atingir o estágio de excelência representado pelo branco. Gouly se valia desse argumento para provar que, antes de poder gozar dos mesmos direitos que o branco, o negro tinha de percorrer "vários períodos de conhecimento europeu". Assim, o negro era um homem privado de sentimento moral e necessitava de "tutores" que pudessem conduzi-lo a um estado que lhe permitisse gozar dos direitos comuns à espécie humana. Gouly pregava a necessidade de uma lei, isto é, uma constituição particular às colônias, feita pelos próprios colonos, que permitisse unir os extremos (brancos e negros), assim como os intermediários (os homens de cor), demarcando, ao mesmo tempo, o lugar que deveriam guardar na proporção de suas necessidades, de suas faculdades e relações recíprocas. ${ }^{1451}$

O panfleto de Gouly provocou respostas violentas por parte da deputação de São Domingos. Em 9 frimário (29 de novembro), Dufay se pronunciou na Convenção contra o texto, propondo o seu "repúdio solene": "Essas Vues générales [vistas gerais], ouso

\footnotetext{
1450 "L'espèce homme présente plusieurs races qui diffèrent entr'elles, et tous les individus de chaque race diffèrent entr'eux"; "[...] égalité de droits établie comme principe d'une association d'hommes éclairés, ne peut être sentie par les peuples que la crainte seule anime, qui ne cedent et n'obéissent qu'à la force"; "L'égalité ne peut être établie constitutionnellement dans les Colonies que dans les rapports des individus de chaque race, et entr'eux seulement" (GOULY, Benoît. Vues générales sur l'importance du commerce des Colonies, pp.27 e 45).

${ }^{1451}$ Ibidem, pp.34-36.
} 
dizê-lo, são antissociais, antirrepublicanas, antipolíticas, evidentemente contrárias à unidade, à indivisibilidade da República". Apoiado por Bourdon de l'Oise, Pelet e Lecarpentier, Dufay ressaltou a importância do decreto de 16 pluvioso, não apenas pelo seu caráter humanitário, mas para atuar como uma "alavanca revolucionária", capaz de neutralizar os avanços da Inglaterra e fazer da França a primeira potência marítima e comercial. Tentar reverter a política abolicionista seria, ao mesmo tempo, uma imoralidade e uma impossibilidade prática. ${ }^{1452}$

Dufay não se limitou a essa intervenção parlamentar e publicou anonimamente um violento e satírico ataque ao deputado colonial, Les Aventures du petit Gouly suivies de sa promenade, de sa confession et de sa mort arrivée le même jour, no qual narrava a futura prisão, julgamento e humilhação pública do deputado da Île-de-France. Ao fim do relato, antes de morrer, vítima de uma forte febre, Gouly confessava todos seus crimes, que eram, na verdade, os dos colonos em geral. ${ }^{1453} \mathrm{O}$ deputado negro Belley também se manifestou, por meio de um panfleto chamado Le bout d'oreille des colons, ou le systême de l'hôtel de Massiac, mis au jour par Gouly, no qual acusou Gouly de defender apenas os seus próprios interesses, como proprietário de escravos. Propôs um decreto pelo qual a lei de abolição seria enviada para todos os locais onde ainda não havia sido promulgada. ${ }^{1454}$

Na sua resposta a Belley, Réponse au Libelle distribué par l'Africain Belley, Gouly afirmou demagogicamente que, embora se opusesse ao decreto "contrarrevolucionário" de 16 pluvioso, ele tinha emancipado os escravos que mantinha nas suas propriedades na Île-de-France. Respondia também às acusações de que seria um robespierrista, alegando não ter mantido relações próximas com Robespierre ou qualquer um de seus aliados, e sugerindo que Belley e seus amigos não podiam dizer o mesmo. $^{1455}$

Gouly multiplicou então suas intervenções na Convenção, em 16, 24, 25 e 26 pluvioso ano III (4, 12, 13 e 14 de fevereiro de 1795), sempre para acusar os eleitos de

\footnotetext{
1452 "Ces Vues générales, j'ose le dire, sont antisociales, antirépublicaines, antipolitiques, evidemment contraires à l'unité, à l'indivisibilité de la République" (Extrait du Bulletin de la Convention nationale, du 10 Frimaire, deuxième année républicaine. In. GOULY, Benoît. Vues générales sur l'importance du commerce des Colonies, pp.68-70).

${ }^{1453}$ Cf. [DUFAY, Louis-Pierre]. Les aventures du petit Gouly, suivies de sa Promenade, de sa Confession et de sa mort arrivée le même jour. Paris: De l'Imprimerie des Sans-Culottes, s.d. [1795], pp.12-15.

${ }^{1454}$ Cf. BELLEY, Le bout d'oreille des colons. In GOULY, Benoît. Vues générales sur l'importance du commerce des Colonies, pp.62-67.

${ }^{1455}$ Cf. GOULY, Réponse au Libelle distribué par l'Africain Belley. In: Vues générales sur l'importance du commerce des Colonies, pp.74-77.
} 
São Domingos de serem responsáveis ou, no mínimo, cúmplices dos crimes ocorridos na colônia. Outros deputados retomaram essas acusações, como Creuzé-Pascal, proprietário em São Domingos. Em 10 de dezembro de 1794, ele apresentou, na Convenção, um panfleto, Conspiration contre la République, no qual apresentou os negros de São Domingos como os instrumentos passivos de uma grande conspiração contra a França, conduzida pelos comissários civis Sonthonax e Polverel. ${ }^{1456}$ Também Defrance, médico e deputado da Seine-et-Marne, envolveu-se na campanha de difamação contra os novos deputados de São Domingos, com o panfleto Defrance au citoyen Creuzé-Pascal son collègue.

Dufay respondeu às calúnias de Defrance com Un représentant du peuple calomnié à un représentant du peuple calomniateur, de fevereiro de 1795, no qual acusou os colonos rebeldes das assembleias coloniais - o "partido inglês" - de não serem cidadãos franceses: "O seu patriotismo é o ódio a toda autoridade superior à sua vontade particular, e sobretudo o ódio à França". ${ }^{1457}$ Além disso, no quadro da reação thermidoriana, Dufay se esforçava em associar o partido colonial ao governo do Terror, apresentando Robespierre como o seu "protetor". ${ }^{1458}$

No final de agosto de 1795, Dufay recebeu o apoio de um novo eleito de São Domingos, o cidadão de cor Étienne Bussières Laforest, autor de outro violento ataque ao deputado da Île-de-France. ${ }^{1459}$ Em meio a essa troca desenfreada de acusações, nenhum real projeto de revogação do decreto de abolição foi apresentado. A transição thermidoriana tinha criado as condições para uma volta dos colonos à arena política, mas não lhes havia ainda dado força suficiente para reverter a legislação dos anos anteriores. Procuravam criar entraves à sua execução, atacando os homens mais diretamente associados à abolição. Naquele momento, entretanto, esta estava para ser consolidada, por meio da consagração de um novo texto constitucional que redefiniria o status jurídico das colônias e de seus habitantes.

\footnotetext{
${ }^{1456}$ Cf. CREUZÉ PASCAL. Conspiration contre la République, prouvée par pièces officielles. S.1.: De l'Imprimerie de Becquart, s.d.

1457 "Leur patriotisme est la haine de toute autorité supérieure à leur volonté particulière, et surtout la haine de la Francce (sic)" (DUFAY, Louis-Pierre. Un représentant du peuple calomnié, à un représentant du peuple calomniateur, pp.7 e 9).

1458 Ibidem, pp.10-11.

${ }^{1459}$ Cf. LAFOREST, Étienne Bussières. Laforest, citoyen de couleur, député de Saint-Domingue, à son collègue Gouly, député de l'Isle de France. Paris: Imprimerie de l'Union, ano III [1795], pp.3-7.
} 


\section{III.1.3) A Constituição do ano III}

\section{III.1.3.1) Rumo a uma nova política colonial}

Enquanto Gouly e Dufay trocavam acusações, a Convenção ainda discutia a aplicação do decreto de abolição. Essa discussão se encaminhava para a formulação de uma nova doutrina em matéria colonial. Poderíamos dizer, para empregar uma expressão talvez anacrônica, que rumava-se, naquele momento, para uma espécie de colonialismo não-escravista. ${ }^{1460} \mathrm{Um}$ dos elementos definidores dessa nova política era o imperativo de recuperação do comércio colonial.

Em 4 pluvioso do ano III (23 de janeiro de 1795), Pelet apresentou, em nome do Comitê de Salvação Pública, um relatório sobre as colônias, no qual dedicou-se a ressaltar a importância, para a prosperidade da França, de seu comércio, cujo movimento geral representava, em 1789, um total de 971,5 milhões de libras, sendo as Antilhas responsáveis por um terço desse montante. Ora, no estado atual, o comércio encontrava-se paralisado e as colônias à mercê dos inimigos da França. Pelet atacava aqueles que defendiam a autonomia das colônias e o fim do exclusivo, afirmando que isso apenas as colocaria nas mãos dos inimigos da Nação. Defendia, ao contrário, o fortalecimento dos laços que uniam as colônias à metrópole.

Sobre o decreto de 16 pluvioso, Pelet entendia que teria sido "mais útil" se ele tivesse sido precedido das "luzes da instrução e da maturidade conveniente", capazes de prevenir as comoções e preservar os interesses políticos, mas entendia que não cabia contestar o decreto e que este devia agora ser executado. Para ele, os meios de defender as ilhas da ameaça estrangeira e de restabelecer a produção nas colônias residiam justamente nos milhões de braços libertados pelas leis da República. Era necessário aliálos à causa da República o quanto antes. Concluía pela necessidade de enviar representantes às colônias para dar início a esse processo de restauração da autoridade metropolitana. ${ }^{1461}$ Embora o relatório tenha sido aplaudido, a Convenção adiou a sua discussão para depois do confronto dos comissários com seus acusadores, mas a linha

${ }^{1460}$ Tzvetan Todorov valeu-se do conceito de colonialismo não escravista, ao analisar as ideias de Las Casas a respeito da presença espanhola nas Américas e do emprego da mão de obra indígena (cf. TODOROV, Tzvetan. A conquista da América: a questão do outro. São Paulo: Martins Fontes, 2003, pp.245-265).

${ }^{1461}$ Cf. Moniteur, v.23, número 128, 8 pluvioso do ano III (27 de janeiro de 1795), pp.298-301. 
mestra que orientaria a política colonial do Diretório tinha sido dada. Dois temas-chave eram associados à nova política pós-abolição: guerra e comércio.

Além disso, naquele momento, ganhava força a ideia de que a França, renovada e fortalecida pela Revolução, tinha de ampliar as suas posses territoriais. Em 11 pluvioso do ano III (30 de janeiro de 1795), Boissy d'Anglas, um dos líderes da ala moderada e um dos inspiradores da futura Constituição do ano III, fez um longo discurso na Convenção para justificar uma política expansionista e anexacionista na Europa, no momento em que a França ocupava a Bélgica, a Holanda e a Renânia. ${ }^{1462}$ Esse relatório apontava para uma política de potência conquistadora. ${ }^{1463}$

Em 16 pluvioso do ano III (4 de fevereiro de 1795), a Convenção recebeu uma deputação de negros e pessoas de cor para celebrar o primeiro aniversário da abolição. A deputação destacou que, nas partes das colônias dominadas pelos ingleses e pelos espanhóis, aliados aos colonos, os negros ainda sofriam o jugo da escravidão e pediu, assim, o envio de armas e munições. Aplaudida pela Assembleia, a moção recebeu o apoio de Crassous de Médeuil, um dos deputados da Martinica, ainda fiel à Montanha. Aproveitando o clima de exaltação patriótica, Pelet tentou submeter novamente à assembleia o seu projeto de envio de representantes às colônias. ${ }^{1464}$

Gouly interveio no debate para pregar uma política de expansão colonial rumo ao Mediterrâneo e à Índia, sob o argumento de que o domínio inglês na Ásia colocava a França numa posição de submissão. Mas a intenção do deputado era, sob a aparência de uma defesa de uma política de conquista, preservar as colônias orientais de uma aplicação da abolição. Assim, para Gouly, a chave para uma política de expansão na Ásia era conservar a Île-de-France e a Reunião, que serviriam de base para a conquista e que eram cobiçadas pelos ingleses por sua posição estratégica. Gouly não se opunha ao envio de representantes, mas sustentava que, aplicado nessas ilhas, o decreto de 16 pluvioso geraria dissenções internas que poderiam favorecer as vistas da Inglaterra. A mensagem era clara: uma tentativa de aplicação da abolição nas Mascarenhas conduziria os colonos para os braços da Inglaterra, que consolidaria, com isso, o seu domínio na Ásia. ${ }^{1465}$ No dia 24 pluvioso (12 de fevereiro de 1795), Dufay retrucou que

\footnotetext{
1462 Idem, v.23, número 133, 13 pluvioso do ano III ( $1^{\circ}$ de fevereiro de 1795), pp.340-343.

${ }^{1463}$ Cf. GAUTHIER, Florence. La convention thermidorienne et le problème colonial, pp.114-115.

${ }^{1464}$ Cf. Moniteur, v.23, número 139, 19 pluvioso do ano III (7 de fevereiro de 1795), pp.385-386.

1465 Ibidem, pp.386-388.
} 
o comércio da Índia nunca tinha sido muito vantajoso para a França e que a Île-deFrance era, no que se referia às suas produções territoriais, nula. ${ }^{1466}$

Nos dias 25 e 26 pluvioso (13 e 14 de fevereiro), a Convenção adotou, por ampla maioria, o princípio do envio de representantes às colônias. A discussão foi formada em torno dos poderes a serem dados aos representantes. Dufay pediu que fosse votado um decreto que impedisse os representantes de revogar as leis da Convenção, isto é, um decreto que protegesse a abolição. Após alguns debates, a Convenção aprovou, por 304 votos contra 178, uma lei que impedia os comissários enviados às colônias de se afastarem dos princípios segundo os quais as colônias integravam a república francesa una, indivisível e democrática e de alterarem o estado das pessoas fixado pela lei de 16 pluvioso. ${ }^{1467}$ Assim, a campanha escravista que procurava excluir as colônias orientais da égide da lei de 16 pluvioso parecia ter fracassado, pois o princípio da abolição havia sido mantido. Ao mesmo tempo, a conjuntura política na França dava sinais de que as condições que haviam favorecido a decisão da abolição já não eram as mesmas.

Em 3 ventoso do ano III (21 de fevereiro de 1795), ocorreu a eleição da primeira comissão prevista para as Índias orientais: Barras, Letourneur e Harmand foram os escolhidos. Preparativos foram feitos para a expedição, mas esta foi continuamente adiada, em razão dos problemas políticos internos: as insurreições jacobinas de germinal e prairial do ano III. Insatisfeitos com o fim do dirigismo econômico e a volta da liberdade do comércio, que haviam levado a uma alta dos preços dos bens de primeira necessidade, os sans-culottes invadiram a Convenção em 12 germinal do ano III $\left(1^{\circ}\right.$ de abril), para pedir a aplicação da Constituição de 1793. A rebelião foi duramente reprimida, mas uma nova tentativa ocorreu no mês seguinte. Em $1^{\circ}$ prairial (20 de maio), as seções jacobinas de Paris - Faubourgs Saint-Antoine e Saint-Marceau invadiram a Convenção, novamente para pedir a aplicação da Constituição. Alguns montanheses tentaram, na ocasião, restaurar o governo revolucionário, mas foram derrotados.

Esses episódios tiveram por efeito acelerar a desarticulação do movimento popular parisiense, que tinha sido, até então, um importante fator de pressão sobre os parlamentares. Em 10 de abril de 1795, a Convenção decretou o desarmamento dos homens conhecidos nas suas respectivas seções por terem participado dos "horrores" cometidos sob a "tirania" que precedeu o golpe de thermidor. Depois, em 29 de maio,

\footnotetext{
${ }^{1466}$ Idem, v.23, números 147-8, 27-28 pluvioso do ano III (15-16 de fevereiro de 1795), pp.455-460.

${ }^{1467}$ Idem, v.23, número 149, 29 pluvioso do ano III (17 de fevereiro de 1795), p.471.
} 
outro decreto praticamente eliminou os sans-culottes da guarda nacional - que já tinha sido subtraída à autoridade das seções desde agosto do ano anterior -, dispensando os artesãos, jornaleiros e operários menos abastados do serviço. Em 23 de agosto, a Convenção decretou que todos os clubes ou sociedades populares estavam dissolvidos. Por fim, em 9 de outubro, as assembleias das seções foram simplesmente proibidas. Era o golpe de misericórdia no movimento popular. ${ }^{1468}$

A repressão das jornadas populares de germinal e prairial do ano III teve consequências indiretas na questão das colônias. Ela permitiu operar, na esfera parlamentar, a eliminação dos elementos mais radicais, o que abriu a via para a supressão da constituição de 1793. Além disso, ela reforçou consideravelmente a posição dos deputados colonos, que estavam do lado dos vencedores. Homens como Gouly, Page e Brulley participaram ativamente da repressão, procurando com isso eliminar os seus adversários, mesmo quando estes não tinham nenhuma relação com os insurretos. Após a derrota das insurreições, a repressão antijacobina livrou Gouly de vários de seus oponentes em matéria colonial, como Duhem e Pautrizel. ${ }^{1469}$ Em 9 prairial (28 de maio de 1795), Gouly denunciou os membros dos Comitês de Salvação Pública e de Segurança Geral do ano II que ainda estavam em atividade na Convenção: Lindet, Voulland, Jeanbon Saint-André, Jagot, Lacoste, Lavicomterie, David, Carnot, Prieur, Barbau-Dubarran e Bernard de Saintes. ${ }^{1470}$ Com exceção de Carnot, todos foram presos. ${ }^{1471}$ Em 31 de maio, Gouly pediu e obteve a acusação de Levasseur de la Sarthe, que tinha desempenhado um papel de destaque na abolição. ${ }^{1472}$

Os deputados de São Domingos, que se mantiveram à margem das jornadas insurrecionais, não foram afetados pela repressão, mas a legalidade de seus poderes voltou a ser questionada. Em 28 prairial do ano III (16 de junho de 1795), uma denúncia contra eles foi assinada por um grupo de colonos de São Domingos, entre os quais estavam Page e Brulley. Após intervenções de Gouly e Dufay, a questão acabou sendo remetida aos comitês. ${ }^{1473}$ A tentativa dos colonos não obteve sucesso, mas ela evidenciava a situação política delicada em que estavam os eleitos de São Domingos diante dos deputados das Mascarenhas, situados no campo dos vencedores.

\footnotetext{
${ }^{1468}$ Cf. GUÉRIN, Daniel. Bourgeois et bras nus, pp.298-299.

1469 Pautrizel, um deputado antiescravista da Guadalupe, tinha sido confundido por Bourdon de l'Oise com um deputado de São Domingos. Foi, entretanto, denunciado em 25 de maio e preso assim mesmo.

${ }^{1470}$ Cf. Moniteur, v.24, número 253, 13 praririal do ano III ( $1^{\circ}$ de junho de 1795), pp.570-571.

${ }^{1471}$ Idem, v.24, número 254, 14 praririal do ano III (2 de junho de 1795), pp.570-576.

1472 Idem, v.24, número 256, 16 prairial do ano III (4 de junho de 1795), p.594.

${ }^{1473}$ Idem, v.25, número $271,1^{\circ}$ messidor do ano III (19 de junho de 1795), pp.4-5.
} 
As jornadas de germinal e prairial levaram a uma retomada do debate constitucional, com consequências importantes para as colônias. Antes mesmo da revolta, a Convenção já tinha encarregado uma comissão de examinar a Constituição de 1793 e preparar diversas leis orgânicas para completá-la. Após a insurreição, o antigo texto constitucional, aprovado pelos Montanheses, aparecia inteiramente desacreditado. Com isso, foi pedido a uma comissão de 11 membros a elaboração de uma Constituição inteiramente nova. Os deputados das colônias pressionaram para não serem deixados à margem de sua elaboração, sobretudo no que tocava à definição do status das colônias, que caminhava na direção de duas possibilidades: regime constitucional comum ou regime diferenciado. ${ }^{1474}$

\section{III.1.3.2) A nova constituição}

A elaboração da nova constituição foi um processo longo. O ponto de partida foi a apresentação de um relatório preliminar de Boissy d'Anglas, em 5 messidor (23 de junho de 1795). Nesse projeto, as colônias não tinham sido incluídas, sendo previsto para elas um relatório específico posterior. Um mês depois, em 5 thermidor do ano III (23 de julho de 1795), o debate sobre as colônias foi reaberto, com a apresentação por Defermon de um relatório sobre São Domingos, em nome do Comitê de Salvação Pública. Embora reconhecesse os entraves à aplicação da abolição, Defermon traçou um quadro relativamente moderado das calamidades que acometiam a colônia. Elogiou fortemente o governador general interino Lavaux, os oficiais de cor Rigaud, Beauvais e Vilatte, assim como o general negro Toussaint Louverture, vendo neles homens capazes de restabelecer a ordem e a paz na ilha.

Defermon contestou a ideia de que a abolição provocaria o inevitável desabamento da agricultura colonial. Embora reconhecesse que a abolição deveria ter sido precedida de medidas preparatórias, pedia que a nova Constituição garantisse o princípio proclamado em 16 pluvioso, vendo nele uma conquista irreversível da humanidade. A prosperidade futura das colônias tinha de ser pensada com base no trabalho livre e na incorporação constitucional dos territórios ultramarinos e de seus habitantes. Dizia que o "amor da liberdade" tornava o africano capaz de tudo. Mais do que isso, a abolição era vital para a manutenção da República nas Antilhas. Era preciso,

${ }^{1474}$ Cf. WANQUET, Claude. La France et la première abolition de l'esclavage, pp.233-234. 
assim, dar garantias aos negros quanto à sua liberdade e convencer os brancos proprietários de que era de seu interesse submeter-se às leis da república. ${ }^{1475}$ Apesar das objeções de Gouly, a Convenção adotou o decreto de Defermon, que atribuía distinções militares aos oficiais negros e suprimia toda assembleia colonial até que a Constituição dispusesse a respeito. O decreto valia, entretanto, apenas para São Domingos. ${ }^{1476}$

Em novo relatório, de 17 thermidor (4 de agosto de 1795), destinado a redefinir os vínculos da França com as colônias por meio de novos artigos constitucionais, Boissy d'Anglas, em nome da comissão dos onze, ressaltou a importância da conservação das colônias: "No estado atual das sociedades, uma nação é poderosa apenas quando é rica, e ela só pode ser rica quando é laboriosa e comerciante, pois sua riqueza só pode resultar do produto de seu trabalho, comprado pelos demais povos" (grifo nosso). ${ }^{1477}$

Nessa concepção de clara orientação mercantilista, as colônias ocupavam um espaço privilegiado na esfera do comércio e eram, portanto, fundamentais para a riqueza nacional. Boissy d'Anglas opunha-se, assim, à ideia de uma independência das colônias e da liberdade de comércio, que ele considerava lesiva para a França, incapaz de competir, pela capacidade de sua marinha e sua posição geográfica, com a Inglaterra e os Estados Unidos. Legitimava, ao contrário, um comércio de dominação que impunha a necessidade de reforçar os laços entre a metrópole e suas colônias, regidas pelas mesmas leis e o mesmo governo. Em vez de criar assembleias coloniais, Boissy propunha a divisão das colônias em departamentos, com a instituição, em cada um deles, de uma administração de cinco membros, investidos das mesmas funções, submetidos às mesmas leis e nomeados, pelo menos de início, pela metrópole. A criação de municipalidades em cada cantão e de tribunais judiciários nos diferentes departamentos completaria a organização das colônias. Quanto ao estado dos cidadãos e o exercício de seus direitos, eles seriam regulados pela própria Constituição, que não admitiria nenhuma exceção. O primeiro artigo do projeto de Boissy foi adotado nos seguintes termos: "Art. $I^{\mathbf{o}}$. As colônias francesas, em todas as partes do mundo, são parte

\footnotetext{
${ }^{1475}$ Cf. Moniteur, v.25, número 310, 10 thermidor do ano III (28 de julho de 1795), pp.316-319.

${ }^{1476}$ Idem, v.25, número 311, 11 thermidor do ano III (29 de julho de 1795), pp.322-323.

1477 "Dans l'état actuel des sociétés, une nation n'est puissante que lorsqu'elle est riche, et elle ne peut être riche que lorsqu'elle est laborieuse et commerçante, car sa richesse ne peut résulter que du produit de son travail, acheté par les autres peuples" (Idem, v.25, número 322, 22 thermidor do ano III (9 de agosto de 1795), p.415).
} 
integrante da república francesa, e estão submetidas às mesmas leis constitucionais". ${ }^{1478}$ Ele se tornaria, mais tarde, o artigo $6^{\circ}$ da Constituição.

Com esse relatório, Boissy d'Anglas consagrava a tese do assimilacionismo, isto é, a integração dos territórios coloniais à ordem jurídica francesa, com a equiparação de seus habitantes aos da metrópole. Não se tratava, portanto, mais de afirmar o direito universal dos povos a se autodeterminarem, mas de pregar uma política expansionista de potência. ${ }^{1479}$ Como diz Miranda Spieler, o objetivo de Boissy d'Anglas não era fazer justiça com os antigos escravos, mas combater a autonomia colonial nas Américas e fortalecer o controle da metrópole sobre o império. ${ }^{1480}$ Ao mesmo tempo, o princípio da assimilação também favorecia as intenções dos que acreditavam que cabia à França revolucionária promover a liberdade dos povos com base em seus princípios constitucionais.

As reações dos deputados das Mascarenhas ao relatório foram negativas. Criticaram severamente o princípio da assimilação, isto é, de uma gestão colonial imposta de fora pelo poder metropolitano. Em 25 thermidor (12 de agosto), Serres afirmou que a proposta era boa apenas para colônias em guerra, mas catastrófica e injusta para com as que tinham preservado a paz e o seu elo com a França, caso da îlede-France e da Reunião. ${ }^{1481} \mathrm{Na}$ mesma linha, Gouly insistia na necessidade de uma legislação específica para as colônias, sobretudo para as Mascarenhas, que tinham se mantido intactas e fiéis à França. ${ }^{1482}$

Para estabelecer um compromisso, a comissão dos onze e os deputados das ilhas reuniram-se então para discutir os artigos da Constituição relativos às colônias. Os resultados das conferências, apresentados à Convenção em 27 thermidor (14 de agosto de 1795), dividiam as colônias em departamentos, da seguinte forma: 1) São Domingos, que o corpo legislativo subdividiria em 4 a 6 departamentos; 2) Guadalupe, MarieGalande e Désirade; 3) Martinica; 4) Guiana e Caiena; 5) Sainte-Lucie e Tobago; 6) Îlede-France; 7) Ilha da Reunião, ilha Rodrigo, Echellons, parte da ilha de Madagascar,

\footnotetext{
1478 "Art. Ier. Les colonies françaises, dans toutes les parties du monde, font partie intégrante de la république française, et sont soumises aux mêmes lois constitutionnelles" (Idem, v.25, número 323, 23 thermidor do ano III (10 de agosto de 1795), pp.418-419).

${ }^{1479}$ Cf. GAUTHIER, Florence. La convention thermidorienne et le problème colonial, p.118; Idem. Le rôle de la députation de Saint-Domingue dans l'abolition de l'esclavage, p.210; WANQUET, Claude. $L a$ France et la première abolition de l'esclavage, pp.248-255.

${ }^{1480}$ Cf. SPIELER, Miranda Frances. The Legal Structure of Colonial Rule during the French Revolution. The William and Mary Quarterly, v.66, n.2, 2009, pp.365-408.

${ }^{1481}$ Cf. Moniteur, v.25, número 332, 2 fructidor do ano III (19 de agosto de 1795),p.496.

1482 Cf. WANQUET, Claude. La France et la première abolition de l'esclavage, pp.261-262.
} 
Pondichéry, Chandernagor, Mahé e outros estabelecimentos franceses nas Índias Orientais. A possibilidade de o corpo legislativo autorizar o Diretório a enviar agentes às colônias foi mantida, mas perdeu o seu caráter sistemático, o que agradou aos deputados coloniais. Além disso, foi feita exceção explícita à Île-de-France e à Reunião na disposição que previa a nomeação até a paz de funcionários públicos das colônias pelo Poder executivo (art.155). Assim, apesar de orientada pelo princípio da indivisibilidade da república, a Constituição reconhecia uma certa especificidade às Mascarenhas. ${ }^{1483}$

A despeito dessas pequenas concessões, o fato é que a Constituição de 5 fructidor do ano III (22 de agosto de 1795) incorporou o princípio da assimilação das colônias à metrópole, confirmando a sua integração à esfera político-jurídica da República. As colônias francesas eram partes integrantes da República una e indivisível, e estavam submetidas à mesma lei constitucional. $\mathrm{O}$ art.314 ainda especificava que o Corpo legislativo determinaria as contribuições das colônias e as relações comerciais destas com a metrópole.

No que se referia à escravidão, a abolição era confirmada pela extensão das disposições do art.15 a todos os territórios que compunham a República: "Todo homem pode vender seu tempo e seus serviços; mas não pode vender a si mesmo ou ser vendido; sua pessoa não é uma propriedade alienável". Ou seja, a exploração da força de trabalho só podia, em princípio, se dar pela forma contratual. Por outro lado, no seu título II, ao dispor sobre o estado político dos cidadãos, a nova Constituição reinstituía o sufrágio censitário, submetendo a cidadania ao pagamento de uma contribuição direta, fundiária ou pessoal (art. $8^{\circ}$ ). Nas colônias, isso teria por efeito excluir a grande maioria dos "novos livres" dos direitos de cidadania, o que contrariava o espírito da lei de 16 pluvioso. Como compensação, no seu art. $9^{\circ}$, a Constituição garantia, sem quaisquer condições de contribuição, a cidadania a todos os franceses que tivessem participado de uma ou mais campanhas para o estabelecimento da República, o que significava que os milhares de soldados negros que haviam lutado e continuavam lutando nas Américas pela França estavam habilitados a votar e escolher seus representantes para o parlamento francês. ${ }^{1484}$

1483 Cf. Moniteur, v.25, número 333, 3 fructidor ano III (20 de agosto de 1795), p.504; WANQUET, Claude. La France et la première abolition de l'esclavage, pp.263-264.

1484 "Article 15 - Tout homme peut engager son temps et ses services, mais il ne peut se vendre ni être vendu; sa personne n'est pas une propriété aliénable" (Constitution du 5 fructidor an III. Disponível em: 
A Constituição do ano III havia, desta forma, recepcionado o princípio da abolição da escravidão, por meio da assimilação jurídica das colônias aos departamentos que compunham o território francês. Rompia, assim, com o sistema da Constituição de 1791, que tinha estabelecido duas ordens constitucionais distintas, para as colônias e a metrópole. Mas o novo texto constitucional também rompia com o sistema da Constituição do ano II, que nunca foi de fato aplicada, ao substituir uma concepção de cidadania ligada à pessoa, por outra vinculada à riqueza. A abolição tinha sido mantida, mas a maioria dos novos livres, que tinham se tornado, em princípio, cidadãos ativos em 16 pluvioso, perdiam, assim como muitos franceses pobres, os seus direitos políticos.

\section{III.1.3.3) As tentativas de aplicação}

Em carta de 10 fructidor (27 de agosto de 1795) às assembleias coloniais das ilhas, os deputados das Mascarenhas, Besnard, Gouly e Serres, fizeram um exame da nova Constituição. Não contestaram propriamente a abolição, mas sustentaram a necessidade de uma regulamentação que antecedesse a sua execução: pregaram, assim, para os novos livres, um sistema de trabalho compulsório muito próximo daqueles instituídos na Guadalupe e em São Domingos, com a fixação dos antigos escravos nas plantations e a atribuição de um quinto das receitas como remuneração. O projeto tinha um aspecto inovador: a facilitação da partida dos antigos escravos para seu país de origem ou para Madagascar. Aconselhava-se aos brancos que desejassem partir que também o fizessem. O motivo era, de um lado, a manutenção da boa ordem e, de outro, a possibilidade de colonização de Madagascar a partir das Mascarenhas. A carta dizia que era preciso provar aos negros que eles deviam a sua liberdade e sua felicidade futura aos seus antigos senhores e, ao mesmo tempo, atenuar o clima de pânico que a abolição tinha gerado. ${ }^{1485}$

A Constituição foi oficialmente proclamada em $1^{\circ}$ vendemiário do ano IV (23 de setembro de 1795), após um referendo. Agora, era preciso aplicá-la por todo o império. A Constituição havia diluído o poder dos parlamentares, dividindo o corpo legislativo em dois Conselhos - o dos Quinhentos e o dos Anciões - acima dos quais havia sido instituído um órgão executivo, o Diretório. Em outubro de 1795, o Diretório indicou

http://www.conseil-constitutionnel.fr/conseil-constitutionnel/francais/la-constitution/les-constitutions-dela-france/constitution-du-5-fructidor-an-iii.5086.html. Acesso em: 10 de jan de 2012.

${ }^{1485}$ Cf. WANQUET, Claude. La France et la première abolition de l'esclavage, pp.266-267. 
como Ministro da Marinha e das colônias o contra-almirante Laurent Jean-François Truguet, antigo combatente da guerra de independência americana e adepto convicto do princípio da liberdade geral. ${ }^{1486}$

O art.156 da Constituição autorizava o Diretório a enviar, com o aval do Corpo legislativo, novos agentes às colônias francesas. O governo deu, de certa forma, a sua sanção oficial à política conduzida até então nas colônias, ao reenviar Sonthonax a São Domingos como agente do governo e confirmar Victor Hugues nas suas funções. Contudo, a missão que tinham de executar não era simples. Hugues se recusaria a aplicar a Constituição na Guadalupe, opondo-se ao princípio da assimilação das colônias à França. Acreditava que assimilar os negros aos cidadãos franceses teria efeitos perversos para a economia colonial, dada a "preguiça natural" dos africanos. ${ }^{1487}$ Ao sustentar que os negros ainda não estavam prontos para exercerem o seu papel de cidadãos, o agente manifestava a consciência de que o sistema de trabalho compulsório por ele instituído era incompatível com os princípios da constituição. A Constituição havia tornado ilegal a submissão de um homem ao trabalho e, ao fazê-lo, tornou-se inaplicável nas colônias. Hugues queria manter a produção colonial e, para isso, precisava de um regime autoritário, um regime de exceção e não um regime constitucional. Mas, como explica Laurent Dubois, Hugues também via a participação política dos brancos como perigosa, em razão de sua hostilidade à República. Para ele, os plantadores eram traidores, leais apenas à escravidão. O que Hugues defendia era um controle estrito sobre a população, branca e negra, das colônias. ${ }^{1488}$

Cinco agentes foram enviados a São Domingos: além de Sonthonax, foram escolhidos Roume (comissário civil em 1791), Giraud (plantador na colônia), Leblanc (ministro da França junto aos Estados Unidos) e Julien Raimond (porta-voz dos cidadãos de cor em Paris). Com a chegada da comissão e da nova Constituição, proclamada oficialmente em 19 thermidor do ano IV (6 de agosto de 1796), Toussaint foi promovido a general e, em setembro, novas eleições foram realizadas. Na verdade, as disposições da Constituição não foram respeitadas, pois o sufrágio universal foi mantido quando da reunião das assembleias primárias. Aconselhado por Toussaint a candidatar-se, Lavaux foi um dos eleitos, assim como Sonthonax, mas este decidiria

\footnotetext{
1486 Truguet tinha apoiado a criação, nas imediações de Paris, de um colégio para crianças negras e mestiças. Esse colégio receberia, aliás, os filhos de Toussaint Louverture, antes de ser fechado por ordem ministerial em 1802, sob o Consulado.

${ }^{1487}$ Cf. BANGOU, Henri. La Guadeloupe, pp.141-142.

${ }^{1488}$ Cf. DUBOIS, Laurent. A Colony of Citizens, pp.283-284.
} 
permanecer na colônia. Além deles, também foram escolhidos Thomany, Boisrond, Pétignaud e Brothier. Sonthonax nomeou Toussaint comandante em chefe do exército de São Domingos, no lugar de Lavaux. ${ }^{1489}$

Ocorre que Rigaud, homem de cor que mantinha o controle no Sul e operava com certa autonomia, organizou eleições paralelas. Ele tinha se aliado a vários setores da população de cor da ilha, setores que se viam como herdeiros legítimos do poder político de São Domingos. Com isso, dois grupos de deputados partiram para a França, para reclamar a sua admissão no corpo legislativo. ${ }^{1490}$

A aprovação da nova constituição levou o governo francês a finalmente empreender uma tentativa de aplicação da abolição nas colônias do Oceano Índico. Em 1796, uma missão foi enviada às Mascarenhas, para levar o decreto de 16 pluvioso. A decisão foi tomada pelo Conselho dos Quinhentos em 5 pluvioso do ano IV (25 de janeiro de 1796). René-Gaston Baco de la Chapelle e Étienne-Laurent-Pierre Burnel foram os homens encarregados de levar a lei de pluvioso à Île-de-France e à Reunião. Contudo, a expedição, que deixou a metrópole em março e chegou ao seu destino em 18 de junho de 1796, foi um retumbante fracasso. Os agentes chegaram a tomar medidas para a efetiva execução da lei, pedindo a formação de uma comissão na assembleia colonial para determinar o modo de aplicação da medida. Sua proposta consistia num processo escalonado em doze meses, ao longo dos quais os antigos escravos ficariam submetidos a um regime probatório de trabalho compulsório. Acreditavam que essa solução contaria com a adesão da classe dirigente local, mas o fato é que as negociações evoluíram para o confronto aberto entre as elites crioulas e os agentes do governo: inflexíveis, os colonos invadiram, em 21 de junho, o local de reunião, reconduziram os agentes ao porto e exigiram a sua partida imediata, no que foram prontamente obedecidos. $^{1491} \mathrm{O}$ motivo alegado para essa atitude teria sido o comportamento "terrorista" dos agentes: era comum na época associar os defensores da abolição ao robespierrismo. A assembleia das Mascarenhas procurou ainda justificar-se pela alegação de que ela mesma preparava uma abolição progressiva da escravidão, o que era

\footnotetext{
${ }^{1489}$ Cf. GUETATA, Jouda. Le refus d'application de la constitution de l'an III à Saint-Domingue 17951797. In: GAUTHIER, Florence (org.). Périssent les colonies plutôt qu'un principe!, pp.84-86; FICK, Carolyn. The making of Haiti, p.196.

${ }^{1490}$ Cf. DUBOIS, Laurent. A Colony of Citizens, p.295.

${ }^{1491}$ Cf. WANQUET, Claude. La tentative de Baco et Burnel d'application de l'abolition aux Mascareignes en 1796. Analyse d'un échec et de ses conséquences. In: M. DORIGNY (org.). Les abolitions de l'esclavage, pp.231-232.
} 
falso. ${ }^{1492}$ Àquela altura, propostas de emancipação gradual adquiriam o caráter de medidas protelatórias, que tinham por objetivo salvaguardar a propriedade escrava. Assim, posturas como a dos Amigos dos Negros, que podiam parecer avançadas no início da Revolução, assumiam, no novo contexto, um caráter conservador.

Baco e Burnel alegaram que, antes da sua expulsão, a missão estava perto do sucesso e que uma nova expedição certamente alcançaria o resultado almejado. Mas, naquele momento, já era possível perceber uma relativa falta de empenho por parte do Diretório na aplicação da abolição, forte indício de que a onda abolicionista radical do ano II tinha passado. Em colônias que haviam permanecido fiéis à metrópole e onde não havia ocorrido uma insurreição escrava, a lei de abolição perdia a sua urgência.

${ }^{1492}$ Wanquet explica que várias decisões adotadas pela assembleia da Reunião já apontavam a vontade das ilhas de recusarem a aplicação da abolição, por conta de uma suposta incapacidade dos negros de assumirem a liberdade concedida (Ibidem, p.234). 


\section{III.1.4) Os escravistas no seio da reação monarquista}

\section{III.1.4.1) Uma tendência reacionária em matéria colonial}

O regime do Diretório foi marcado, durante a sua existência, pela instabilidade. Continuamente ameaçado por forças situadas à sua esquerda como à sua direita, o governo diretorial carecia de poder político para alçar-se acima das facções e pôr fim à Revolução. A Constituição mal tinha sido proclamada, o regime já se via ameaçado por uma nova onda monarquista, que faria da questão colonial uma de suas frentes de combate.

Assim, os passos dados pelo Diretório no sentido de uma aplicação mais generalizada da abolição seriam neutralizados por conta da ascensão de uma corrente reacionária que começava a ganhar espaço naquele momento. Essa tendência, de caráter antirrepublicano, teve fortes repercussões em matéria colonial. Os anos de 1797 e 1798 foram marcados por um debate na metrópole acerca dos resultados da emancipação dos escravos. De um lado, os adeptos da abolição procuravam consolidá-la por meio da assimilação político-jurídica das colônias à metrópole. Argumentavam ser possível conservar as colônias e manter a produção em larga escala sem escravidão. De outro lado, os opositores da abolição dedicavam-se a traçar um quadro de caos nas colônias pós-emancipação, atribuindo à lei de abolição a destruição selvagem da economia colonial. Para eles, o recurso a regimes coercitivos de trabalho atestava a impossibilidade prática da abolição da escravidão colonial, em razão da preguiça natural dos negros. $^{1493}$

No intuito de afastar a aplicação imediata da abolição, alguns colonos começavam a pregar planos de passagem gradual à liberdade. Era o caso de Marie StElaire, representante dos plantadores de Caiena, na Guiana, que sustentava que, até que adquirissem as qualidades morais necessárias, os negros deveriam, a exemplo dos soldados, ser submetidos a um estado de servidão. A cidadania plena deveria ser reconhecida apenas aos que tivessem propriedades ou estabelecimentos comerciais. Sem falar em escravidão propriamente dita, afirmava que os demais negros deveriam retornar às plantações, onde assinariam contratos de seis anos, durante os quais poderiam receber salários de acordo com a produtividade e a disponibilidade de capital na região. ${ }^{1494}$

\footnotetext{
${ }^{1493}$ Cf. DUBOIS, Laurent. A Colony of Citizens, pp.277-278.

${ }^{1494}$ Ibidem, pp.291-293.
} 
Outros textos iam mais longe. Um texto anônimo de 1797 falava não apenas em restaurar a escravidão nas colônias, mas também em adotá-la na metrópole! O autor de De la nécessité d'adopter l'esclavage en France sustentava que uma escravidão moderada pelas leis não seria contrária aos Direitos do homem e poderia cumprir três funções:

1) Meio de prosperidade para as colônias. $\mathrm{Na}$ medida em que não era possível substituir, naquele momento, o trabalho dos escravos negros por outro, a prosperidade colonial dependia do restabelecimento, ainda que parcial e sob uma forma mais moderada, da escravidão. ${ }^{1495} \mathrm{O}$ anônimo propunha que, para fazer reviver a agricultura, fossem distribuídas aos negros as terras abandonadas, regulamentando o tipo de cultura que teriam de realizar nelas e exigindo dos beneficiários um imposto in natura, compatível com o tipo de exploração. Os negros e homens de cor que se recusassem a trabalhar nessas condições deveriam ser restituídos ao estado de servidão. Ou seja, o plano era neutralizar o potencial de revolta dos negros dividindo-os em duas classes: os que se tornariam pequenos proprietários e os que retornariam à escravidão. Segundo o autor, sua intenção não era perpetuar a escravidão, mas apenas garantir a prosperidade das colônias e até mesmo a felicidade dos negros. Nesse sentido, sugeria a alforria anual de $1 / 10$ ou $1 / 15$ dos negros. ${ }^{1496}$

2) Punição para criminosos. O anônimo propunha fazer da escravidão na metrópole a pena para determinados crimes. Com base em elaborada argumentação a respeito da natureza da pena, o autor apresentava a escravidão dos criminosos como a única forma de unir à segurança dos cidadãos a utilidade pública. A dureza do tratamento e a extensão do trabalho a que os criminosos seriam submetidos poderiam ser determinados com base no princípio da gradação das penas. ${ }^{1497}$

3) Recurso para os indigentes. Por fim, a escravidão aparecia também como um recurso para os indigentes. O autor mostrava-se cético em relação ao culto da liberdade promovido pela Filosofia. Para "o desafortunado que geme sob o peso de sua miséria e que obtém apenas à força de trabalhos um pão de dor", o

\footnotetext{
${ }^{1495}$ Cf. De la nécessité d'adopter l'esclavage en France. Paris: chez Baillio, 1797, pp.10-18.

${ }^{1496}$ Ibidem, pp.20-21.

${ }^{1497}$ Ibidem, pp.37-41.
} 
entusiasmo para com a liberdade inexistia. ${ }^{1498}$ Os direitos do homem nada significavam para o pobre desprovido de pão. Assim, para um indigente, seria preferível colocar-se sob o império de um senhor, que ficaria obrigado a protegê-lo, a alimentá-lo e a cuidar de sua saúde. ${ }^{1499}$ Seria, assim, uma forma de destuir a mendicidade, "obrigando a classe abastada a ocupar-se mais da condição daquela que não o é". 1500

Textos dessa natureza, cuja publicação seria impensável sob o Terror, podem ser vistos como o indício de que uma corrente abertamente escravista voltava a emergir, aproveitando-se de uma conjuntura mais favorável à condenação da abolição. ${ }^{1501}$ Os eventos que marcaram a cena política em 1797 confirmariam essa tendência.

\section{III.1.4.2) As eleições da primavera de 1797 e a ofensiva antirrepublicana}

A primavera de 1797 veria a consagração política de uma corrente antirrepublicana no seio da legislatura. Essa corrente tinha como centro nervoso o clube de Clichy $^{1502}$, sociedade formada em 1794 , na esteira da queda dos robespierristas e que tinha reunido, de início, deputados excluídos ou encarcerados durante o Terror. Aos poucos, entretanto, os elementos mais moderados tinham se afastado do clube, que tornou-se um reduto para os monarchiens e outros elementos reacionários. Eles procuravam se aproveitar do cansaço da burguesia de negócios em relação aos ultrajes da Revolução. Os principais líderes dessa direita clichyenne - o crioulo de São Domingos Viénot-Vaublanc, o antigo intendente Barbé-Marbois ${ }^{1503}$, Villaret de Joyeuse

\footnotetext{
1498 Ibidem, p.47.

${ }^{1499}$ Ibidem, pp.8-9.

${ }^{1500}$ Ibidem, p.54.

${ }^{1501}$ Nesse sentido, é interessante observar a publicação, em francês, de um texto de Azeredo Coutinho, em 1798, no qual o autor dedicava-se a defender a legitimidade do tráfico português e da escravidão negra. Embora o texto original não contivesse referências ao caso de São Domingos, o editor britânico decidiu adaptar a obra, sob o nome Analyse sur la justice du commerce de rachat des esclaves de la Côte d'Afrique, de modo a transformá-la numa denúncia das consequências da política antiescravista da Revolução francesa (cf. BERBEL, Márcia, MARQUESE, Rafael, PARRON, Tâmis. Escravidão e Política, p.104).

${ }^{1502} \mathrm{O}$ nome se devia ao fato de que os notáveis que dirigiam o grupo se reuniam em Clichy, na residência do antigo secretário de estado Bertin (cf. WANQUET, Claude. La France et la première abolition de l'esclavage, p.408).

${ }^{1503}$ Tinha sido o último intendente de São Domingos no Antigo Regime, sendo responsável pelos serviços financeiros e administrativos da colônia às vésperas da Revolução. Empreendeu obras de utilidade pública, restabeleceu o equilíbrio orçamentário e reformou o aparelho judiciário da ilha. Embora adepto do escravismo, ele moveu esforços para frear as crueldades cometidas contra os escravos. Deu, assim, ordens para que Lejeune, plantador acusado de queimar seus escravos, fosse preso e julgado de acordo com as leis (cf. THIBAU, Jacques. Le temps de Saint-Domingue, pp.40-42).
} 
e Bourdon de l'Oise - fariam do problema colonial uma das frentes de combate contra o Executivo: talvez vissem na ofensiva contra a aplicação da Constituição nas colônias uma forma de abalar o edifício constitucional como um todo e preparar, assim, a volta da Monarquia. Alguns representantes dos colonos, como Serres e Brulley, tinham se aproximado dos Clichyens, que incluiriam, na sua pauta, a restauração da ordem colonial pré-abolição. Curiosamente, Boissy d'Anglas, um dos formuladores da tese assimilacionista, também se associaria a essa direita monarquista.

Como parte dessa ofensiva, os Clichyens haviam se voltado contra o grupo dos novos eleitos de São Domingos, do qual faziam parte Sonthonax, Lavaux, Annecy, Mentor, Leborgne e Thomany, todos eles futuros membros da Sociedade dos Amigos dos Negros e das Colônias. Sua eleição era contestada como o resultado do despotismo militar instaurado na colônia por Sonthonax e tida como irregular, pois baseada em regulamentos anteriores à constituição do ano III. Os Clichyens procuravam apoiar os representantes das assembleias eleitorais do Sul, Pierre Pinchinat e Rey-Delmas, ligados aos oficiais mulatos de André Rigaud, que tinham entrado em dissidência com os agentes da metrópole. Com isso, apresentavam os homens de cor como os verdadeiros republicanos da colônia para desacreditar os comissários civis, que tinham apoiado os oficiais negros contra os mulatos do Sul, em 1796.

Os Clichyens obtiveram ganho de causa em 8 ventoso (26 de fevereiro de 1797), quando Dulcet de Pontécoulant, em nome de uma comissão especial, conseguiu do Conselho dos Quinhentos uma resolução que declarava nulas todas as nomeações feitas por uma "pretensa assembleia eleitoral" de São Domingos, em 21 fructidor do ano IV (7 de setembro de 1796), entendendo que elas tinham sido feitas em desacordo com a Constituição. ${ }^{1504}$ A resolução foi confirmada pelo Conselho dos Anciões em 11 germinal do ano V (31 de março de 1797). As eleições da primavera dariam à direita monarquista poder suficiente para levar a sua ofensiva adiante.

A Constituição do ano III havia previsto a renovação de um terço dos membros dos Conselhos. Novas eleições foram realizadas entre março e abril e, em 20 germinal do ano V (9 de abril de 1797), os resultados apontaram para uma vitória dos realistas sobre os republicanos: foram eleitos 105 monarquistas moderados, contra 28

${ }^{1504}$ Cf. Moniteur, v.28, número 161, 11 ventoso ( $1^{\circ}$ de março de 1797$)$, p.590. 
republicanos e 44 independentes. ${ }^{1505}$ O campo colonial havia sofrido as baixas de Serres, Gouly e Besnard, das Mascarenhas, deixando apenas Detcheverry como representante das colônias orientais, mas esse fato tinha sido compensado pela entrada massiva de simpatizantes de suas teses. No novo terço eleito, apareciam figuras emblemáticas do movimento realista: o antigo conde de Fleurieu, que tinha sido ministro de Luís XVI, o monarquista militante Jacques Imbert-Colomès e os generais Jean-Charles Pichegru e Amédée Willot. ${ }^{1506}$ A Sociedade de Clichy, sede da direita monarquista, tomava as rédeas da situação. Assim, quando os novos Conselhos se reuniram em $1^{\circ}$ prairial (20 de maio de 1797), a eleição de seus presidentes já tinha sido preparada em Clichy: Pichegru foi escolhido no Conselho dos quinhentos e BarbéMarbois no dos Anciões.

Os objetivos dessa nova maioria não eram claros: alguns pensavam num golpe que promovesse a restauração monárquica; outros queriam emendar a Constituição do ano III de modo a promover uma transição mais suave para uma monarquia constitucional que não apagasse as conquistas socioeconômicas da Revolução. De qualquer forma, esse partido entrou em choque com o Diretório, especialmente com o "triunvirato" formado por Barras, La Reveillière e Rewbell, defensores do projeto republicano. A luta entre a maioria dos Conselhos e o Diretório marcaria a vida política francesa até setembro de $1797 .^{1507}$

A questão colonial foi colocada no centro da ofensiva anticonstitucional da direita. A maioria clichyenne propunha-se a contestar o princípio da universalidade do direito constitucional, afirmado na Constituição do ano III. ${ }^{1508}$ Os Clichyens evitavam justificar diretamente a escravidão, mas denunciavam a barbárie irremediável dos negros. Se a abolição era, no geral, vista como irrevogável, homens como VillaretJoyeuse e Viénot-Vaublanc procuravam denunciar, com base na experiência atual, os efeitos de uma abolição abrupta e sem controle. ${ }^{1509}$ Ou seja, o gradualismo, antes defendido pelos Amigos dos Negros, agora era retomado pelos escravistas, que pressionavam, acima de tudo, por uma legislação de exceção nas colônias.

\footnotetext{
1505 Cf. Élection politique. Disponível em: http://www.electionpolitique.com/resultats.php?page=Pays.php\&cle1=FR\&cle2=2\&cle3=1797-04-01\&cle4=législative. Acesso em: 12 de jan de 2012.

${ }^{1506}$ Cf. WANQUET, Claude. La France et la première abolition de l'esclavage, pp.408-409.

${ }^{1507}$ Ibidem, pp.409-411.

${ }^{1508}$ Cf. GAINOT, Bernard. La députation de Saint-Domingue au corps législatif du Directoire. In: M. DORIGNY (org.). Léger Félicité Sonthonax. La première abolition de l'esclavage, p.96.

${ }^{1509}$ Cf. WANQUET, Claude. La France et la première abolition de l'esclavage, pp.418-421.
} 
Algumas vozes se opuseram a essa ofensiva. Embora detivessem a maioria nos Conselhos, os Clichyens não faziam a unanimidade em matéria colonial. Havia uma resistência republicana, encarnada pelo jornal Le Républicain des colonies, redigido por Bottu, defensor convicto da abolição e ligado a Truguet e Sonthonax. ${ }^{1510}$ O jornal, dedicado aos debates sobre a questão colonial, funcionava como porta-voz de um grupo de representantes do Conselho dos Quinhentos ainda fiéis à República e à abolição: Rallier, Quirot, Garran-Coulon e Eschassériaux. ${ }^{1511}$ Isso implicava, naquele momento, mover uma campanha tenaz contra os Clichyens. Nos números de 30 floreal e 5 prairial do ano V (19 e 24 de maio de 1797), por exemplo, o jornal denunciou o projeto de alguns agitadores, referindo-se a Viénot-Vaublanc e seus aliados, de afastar a aplicação da Constituição nas colônias e, com isso, tornar sem efeito a lei que aboliu a escravidão. O jornal defendia a ideia de que a Constituição era o único meio de conservar as colônias e restabelecer a economia colonial. ${ }^{1512}$

Com grandes dificuldades, os republicanos também procuravam mover a sua resistência dentro do corpo legislativo. Na sessão de 2 prairial (21 de maio de 1797), nos Quinhentos, o montanhês Joseph Eschassériaux exigiu que a legislatura assumisse a responsabilidade de restabelecer a ordem nas colônias, pois apenas as leis, e sobretudo a Constituição, seriam capazes de fazê-lo. Pedia ainda que a questão da divisão constitucional do território das colônias fosse discutida o quanto antes. ${ }^{1513}$ Contudo, apesar da resistência republicana, entre maio e setembro de 1797, o avanço das propostas dos Clichyens ameaçou as conquistas constitucionais em matéria colonial. Segundo Wanquet, muitos republicanos aceitavam fazer concessões no que se refere às colônias para não agravar as tensões políticas na metrópole. ${ }^{1514}$

Já no final de maio de 1797, os Clichyens partiram para a ofensiva na tribuna. Evitando atacar diretamente a política colonial do Diretório, eles preferiram voltar-se

\footnotetext{
${ }^{1510}$ No início do Diretório, Bottu tinha, por recomendação da Truguet, sido integrado à comissão civil enviada a São Domingos em 1796. Nessa condição, ele colaborou com os comissários Sonthonax e Leblanc, cujas ações ele defenderia, na sua volta a Paris, por meio do jornal Le Républicain des Colonies. Antes de deixar o cargo de ministro da Marinha, Truguet teria feito, em nome do ministério, 600 assinaturas do jornal (cf. GAINOT, Bernard. Bottu, «Le Républicain des Colonies» (1797). Annales historiques de la Révolution française, Paris, n. 293-294: Révolution aux colonies, 1993, pp.431-444. Disponível em: $\quad$ http://www.persee.fr/web/revues/home/prescript/article/ahrf 00034436_1993 num 293 1_1584. Acesso em: 16 de jan de 2012, pp.431 e 442.

${ }^{1511} \mathrm{Cf}$. WANQUET, Claude. La France et la première abolition de l'esclavage, p.431.

${ }^{1512}$ Cf. Le Républicain des colonies, número 11, 30 floreal do ano V (19 de maio de 1797), pp.1-5; número 12, 5 prairial do ano $\mathrm{V}$ (24 de maio de 1797), pp.1-5.

${ }^{1513}$ Cf. ESCHASSÉRIAUX, Joseph. Corps législatif. Conseil des Cinq-cents. Motion d'ordre relative aux colonies. Séance du 2 prairial an V. Paris: De l'Imprimerie Nationale, ano V [1797], pp.1-6.

${ }^{1514} \mathrm{Cf}$. WANQUET, Claude. La France et la première abolition de l'esclavage, p.436.
} 
contra os homens encarregados de sua execução. Sonthonax, o "Robespierre das Antilhas" segundo Villaret-Joyeuse, e o ministro da Marinha Laurent Truguet, símbolo da doutrina oficial do Diretório em matéria colonial, eram seus principais alvos. Em 10 prairial do ano V (29 de maio de 1797), Viénot-Vaublanc, relator de uma nova comissão das colônias dominada pelo partido colonial ${ }^{1515}$, fez, perante os Quinhentos, um feroz ataque contra os agentes em São Domingos. Vaublanc, que era de uma família de colonos de São Domingos, acusava o Diretório de insistir em fazer das colônias um retrato floreado que não correspondia à realidade. Atacou diretamente tanto Sonthonax, por suas atitudes ditatoriais, quanto o governo militar atual de São Domingos, atribuído a "negros ignorantes e grosseiros, incapazes de distinguir a licença mais desenfreada da austera liberdade que se curva perante as leis". ${ }^{1516}$

Vaublanc queria mostrar que o resultado dessa política só podia ser a destruição das colônias, em razão da incapacidade dos antigos escravos de serem livres. Assim, o estado de calamidade das colônias não se devia aos temores dos negros quanto à sua própria liberdade; ele se devia ao seu ímpeto de destruição e sua vontade de "massacrar os Franceses". Para evidenciar a falta de segurança para os brancos na colônia, citou uma decisão dos comissários que previa pena de três a nove meses de prisão para todo aquele que dissesse publicamente que a liberdade não tinha sido irrevogavelmente devolvida aos negros. Anunciou ainda a representação, no Cap, de uma peça em que eram retratados dois proprietários que tinham o projeto de massacrar todos os negros. Os personagens levavam nomes de colonos conhecidos, como Page, Brulley, Larchevesque-Thibaud e Verneuil. ${ }^{1517}$ Vaublanc alertava para a existência de um verdadeiro "sistema de desapropriação dos legítimos proprietários" da ilha, atingindo não apenas os brancos, mas também os homens de cor. Não condenou diretamente a liberdade dos negros, mas afirmou que estes deveriam ter sido conduzidos a ela de forma prudente, passando da escravidão à "dependência" e, então, desta para a liberdade. $^{1518}$

Vaublanc propôs que a lei que autorizava o Diretório a enviar agentes particulares à colônia fosse suspensa para São Domingos, determinando a cessação dos

${ }^{1515}$ Na nova comissão, estavam Doulcet de Pontécoulant, Charles Tarbé, Bourdon de l'Oise e VillaretJoyeuse (Ibidem, pp.412-413).

1516 "des nègres ignorants et grossiers, incapables de distinguer la licence la plus effrénée de l'austère liberté fléchissant sous les lois" (VIÉNOT-VAUBLANC. Corps législatif. Conseil des Cinq-Cents. Discours sur l'état de Saint-Domingue et sur la conduite des agens du Directoire, prononcé par ViénotVaublanc. Séance du 10 prairial an V. Paris: De l'Imprimerie Nationale, ano V [1797], pp.3-9).

1517 Ibidem, pp.13-20 e 35-36.

1518 Ibidem, pp.20-24. 
poderes desses agentes, que deveriam retornar à metrópole para prestar contas de sua conduta. $^{1519} \mathrm{O}$ que os colonos queriam era desvincular as colônias do regime republicano da metrópole. A proposta recebeu apoio de Tarbé, Villaret-Joyeuse, Bourdon e Doulcet de Pontécoulant.

O teor do discurso de Vaublanc enfureceu Toussaint Louverture, que acompanhava tudo de longe. Em resposta, o líder negro publicou uma refutação, onde esclarecia que, mesmo com a guerra, a ordem e boa parte da produção tinham sido restabelecidas na colônia. Se a colônia estava longe dos 200 milhões que exportava antigamente, as receitas para o ano poderiam chegar a 50 milhões, o que era expressivo dado que a Revolução havia provocado, por um tempo, o abandono total do cultivo. Embora reconhecesse que alguns negros haviam individualmente cometido excessos, a grande maioria das propriedades havia sido preservada. ${ }^{1520}$ Toussaint jurava fidelidade à República, afirmando que os generais negros e de cor "[...] preferirão sempre serem enterrados sob as ruínas de seu país a passar sob uma dominação outra que a da França, que os declarou livres [...]". ${ }^{1521}$ Ou seja, a liberdade e a fidelidade à metrópole eram absolutamente indissociáveis.

$\mathrm{Na}$ França, contudo, a ofensiva dos colonos continuava. Em 11 prairial (30 de maio), Delahaye e Tarbé pediram a volta dos agentes do governo em São Domingos. Delahaye pediu também a suspensão da execução da Constituição republicana nas colônias, ao menos para a organização das assembleias primárias e eleitorais. ${ }^{1522}$ Já Tarbé defendeu a anulação de todas as decisões, proclamações, julgamentos ou atos desses agentes que fossem contrários às leis. Propôs ainda o envio de novos agentes, mas sob condições mais estritas e com poderes mais delimitados. ${ }^{1523}$ No dia seguinte, vieram novos ataques: primeiro com Corbun, deputado da Gironda ${ }^{1524}$; em seguida com Villaret-Joyeuse. Este último acreditava que a proposta de Tarbé de enviar uma nova comissão, mesmo sob novas condições, era inadequada, pois a colônia não precisava de novos agentes, que, ignorantes das condições locais e seduzidos pelo poder, tenderiam a

\footnotetext{
${ }^{1519}$ Ibidem, p.48.

${ }^{1520}$ Cf. TOUSSAINT-LOUVERTURE. Réfutation de quelques assertions d'un Discours prononcé au Corps législatif le 10 Prairial an cinq, par Viénot-Vaublanc. S.1. (Le Cap), s.d. [ano VI], pp.11-16.

${ }^{1521}$ Ibidem, p.32.

${ }^{1522}$ Cf. DELAHAYE, J.C.G. Corps législatif. Conseil des Cinq-Cents. Discours de J.-C.-G. Delahaye sur l'affaire des Colonies. Séance du 11 prairial an V. Paris: De l'Imprimerie Nationale, ano V [1797], p.19.

${ }^{1523}$ Cf. TARBÉ, Charles. Corps législatif. Conseil des Cinq-Cents. Discours prononcé par Ch. Tarbé... sur l'état actuel de la colonie de Saint-Domingue. Séance du 11 prairial an V. Paris: De l'Imprimerie Nationale, ano V [1797], pp.15-18.

${ }^{1524}$ Cf. CORBUN, Jean Marie. Discours sur l'état actuel des colonies et leur amélioration. Paris: De l'Imprimerie Nationale, ano V [1797].
} 
incorrer nos mesmos crimes cometidos pelos anteriores. Comparando São Domingos à Vendéia, o deputado sustentava que apenas "pela força das armas e pela energia mesclada à doçura e à clemência", seria possível restabelecer a ordem. Concretamente, suas palavras apontavam para o estabelecimento de um regime militar na colônia, o único capaz de proteger os brancos e obrigar os negros a retornar ao trabalho. Isso permitiria, dizia, readaptá-los não à escravidão, que tinha sido destruída, mas à obediência e à subordinação. ${ }^{1525}$

Os ataques a Sonthonax continuaram em 15-16 prairial de 1797 (3-4 de junho), por meio de Tarbé, que, confrontado por alguns republicanos, pedia agora a revogação da lei de 5 pluvioso do ano IV (25 de janeiro de 1796), que permitia ao Diretório enviar agentes à colônia. ${ }^{1526}$ No debate, Joseph Eschassériaux, voltou a se manifestar a favor do "pronto estabelecimento da constituição", que teria por principal efeito eliminar qualquer "[...] dúvida no coração dos negros a respeito de sua liberdade", permitindo restabelecer o cultivo, vincular os negros à administração, aos trabalhos, ao estado, e dar-lhes o "gosto da civilização". ${ }^{1527}$ Garran de Coulon também tentou impedir o avanço da proposta de Tarbé, fazendo uma extensa justificação das ações dos comissários ${ }^{1528}$, mas ela foi adotada por imensa maioria nos Quinhentos, assim como nos Anciões (em 24 prairial - 12 de junho). Era, em princípio, uma grande vitória para os Clichyens, que viam no não-envio de agentes uma possibilidade de afastar a aplicação da Constituição nas colônias.

O Diretório, entretanto, observou que, justamente em razão da impossibilidade de pôr em vigor a Constituição nas colônias, era preciso que os agentes do governo as governassem. O impasse foi resolvido com um compromisso: em 3 messidor (21 de junho), os conselhos aceitaram que o Diretório enviasse, no máximo, três novos agentes a São Domingos, por um período de apenas 18 meses. ${ }^{1529}$ Dois dias depois, em 5 messidor (23 de junho), Gabriel Marie Joseph Hédouville foi designado como agente único para São Domingos, reunindo todos os poderes civis e militares. Hédouville era

\footnotetext{
1525 Cf. VILLARET-JOYEUSE. Discours sur l'importance des Colonies et les moyens de les pacifier. Paris: De l'Imprimerie Nationale, ano V [1797], pp.6-8.

${ }^{1526}$ Cf. Moniteur, v.28, número 261, 22 prairial (9 de junho), p.723.

${ }^{1527}$ Cf. ESCHASSÉRIAUX, Joseph. Corps législatif. Conseil des Cinq-Cents. Opinion d'Eschassériaux (â̂né) sur les moyens de rétablir les colonies. Séance du 16 prairial an V. Paris: Imprimerie Nationale, ano V [1797], pp.5 e 11-12.

${ }^{1528}$ Cf. GARRAN DE COULON, Jean Philippe. Corps législatif. Conseil des Cinq-Cents. Opinion de J.Ph. Garran, sur les dénonciations formées contre les agens du Directoire, à Saint-Domingue. Séance du 16 prairial an V. Paris: De l'Imprimerie Nationale, ano V [1797].

${ }^{1529}$ Cf. Moniteur, v.28, número 279, 9 messidor do ano V (27 de junho de 1797), p.732.
} 
um general de origem nobre, conhecido por ter sido o pacificador da Vendéia, uma escolha que agradava aos colonos. Em 12 messidor (30 de junho), a mesma medida foi adotada para a Guiana e as Ilhas do Barlavento (Martinica e Guadalupe). ${ }^{1530}$

No mês seguinte, os Clichyens continuaram a obter pequenas vitórias. Em 22 messidor (10 de julho), por exemplo, foi decidido que os colonos franceses deportados ou refugiados, que pudessem provar a sua não emigração, seriam reconduzidos às suas respectivas colônias aos custos da República. ${ }^{1531}$ Em seguida, os monarquistas direcionaram os seus ataques contra o ministro da Marinha, Truguet. Usaram como pretexto os problemas judiciais de Bottu, redator do Républicain des Colonies, que era subvencionado por Truguet. Bottu tinha sido processado por Brulley por tê-lo representado de forma burlesca numa peça montada no Cap alguns meses antes, $L a$ Liberté générale. Bottu afirmou ter sido apenas o conselheiro dramático e não o autor da peça, mas, assim mesmo, foi condenado pelo tribunal civil do departamento da Seine a pagar uma multa e uma indenização. Em 13 messidor ( $1^{\circ}$ de julho), Viénot-Vaublanc denunciou, perante os Quinhentos, a ajuda financeira de 1.800 libras que Truguet dava a Bottu, o suposto autor de uma peça que representava proprietários brancos como assassinos dos negros. ${ }^{1532}$ Truguet, que já tinha uma acusação de corrupção nas costas, acabou sendo sacrificado pelo Diretório por ocasião do remanejamento ministerial de 26-28 messidor (14-16 de julho). Foi substituído por Pléville-le-Pelley, experiente oficial da Marinha ${ }^{1533}$, aberto à ideia de uma restauração colonial. O gabinete das colônias do ministério, que estava nas mãos de Vatry, um inimigo dos deputados das Mascarenhas, foi confiado a Daniel Lescallier, que tinha sido membro dos Amigos dos Negros, mas que, após ter sido comissário civil nas ilhas do Oceano Índico entre 179297, passava progressivamente para o campo colonial. Ele redigiria, aliás, um relatório inocentando totalmente as assembleias das Mascarenhas pela expulsão dos agentes do Diretório Baco e Burnel em junho de 1796. Poucos dias após a partida de Truguet, o Républicain des Colonies deixaria de circular. ${ }^{1534}$ No verão de 1797 , um triunfo dos adeptos da restauração da ordem colonial começava a se desenhar.

Ciente da situação política na metrópole e determinado a preservar sua posição na colônia, Toussaint Louverture procurava diversificar os seus correspondentes,

\footnotetext{
${ }^{1530}$ Idem, v.28, número 289, 19 messidor do ano V (7 de julho de 1797), p.737.

${ }^{1531}$ Idem, v.28, número 299, 29 messidor do ano V (17 de julho de 1797), p.744.

1532 Idem, v.28, número 291, 21 messidor do ano V (9 de julho de 1797), p.738.

1533 Pléville Le Pelley tinha atuado, como oficial da Marinha, tanto na Guerra dos Sete Anos quanto na Guerra de independência norte-americana.

${ }^{1534}$ Bottu se tornaria secretário de Truguet em Madri, onde o ex-ministro tinha sido nomeado embaixador.
} 
evitando vincular-se definitivamente a um partido ou outro. Assim, informado da tendência reacionária que havia levado à vitória da direita clichyenne na primavera de 1797, o líder negro decidiu forçar Sonthonax a deixar São Domingos, em 7 fructidor do ano V (24 de agosto de 1797), no intuito de se demarcar daquele que era o homem mais visado pelos grupos no poder. Era uma forma de entregar aos colonos o seu principal inimigo, desviar a sua atenção e, com isso, canalizar a sua fúria vingativa. ${ }^{1535}$

Num relatório ao Diretório de 18 fructidor do ano V (4 de setembro de 1797), Toussaint denunciou, sob a forma de um diálogo, um suposto plano de Sonthonax de declarar a independência de São Domingos e massacrar todos os europeus ainda restantes na ilha, como única forma de preservar a liberdade geral. Para justificar a expulsão do "pérfido" Sonthonax, Toussaint apresentava-se como um homem de princípios, fiel à França e ao Diretório ${ }^{1536}$, mas, no fundo, atribuía ao comissário civil as suas próprias aspirações de independência. ${ }^{1537} \mathrm{O}$ general negro acreditava, com isso, atestar a sua vinculação à metrópole e proteger-se da ofensiva da direita monarquista. Mal sabia ele que, na mesma data em que havia enviado o relatório, a situação política na metrópole sofria uma nova reviravolta.

${ }^{1535}$ Cf. GAINOT, Bernard. La constitutionnalisation de la liberté générale sous le Directoire (1795-1802). In: M. DORIGNY (org.). Les abolitions de l'esclavage, pp.218-221; Idem. Métropole / Colonies. Projets constitutionnels et rapports e forces 1798-1802. In: Y. BÉNOT, M. DORIGNY (orgs). Rétablissement de l'esclavage dans les colonies françaises, p.17; WANQUET, Claude. La France et la première abolition de l'esclavage, pp.439-441.

1536 Toussaint alegava ter respondido ao projeto de independência de Sonthonax com as seguintes palavras: "Como quereis que eu, chefe negro, que recebi as graças da França, que tenho filhos que são educados pela República, eu que fui nomeado, pelo diretório, chefe de brigada e confirmado por ele no grau de general de divisão, possa trair o meu governo?" ("Comment voulez-vous que moi, chef noir, qui ai reçu les bienfaits de la France, qui y ai des enfans qui sont élevés par la République, moi qui ai été nommé, par la directoire, général de brigade, et confirmé par lui dans le grade de général de division, j'aille trahir mon gouvernement?", LOUVERTURE, Toussaint. Extrait du Rapport adressé au Directoire exécutif par le citoyen Toussaint-Louverture, général en chef des Forces de la République française à Saint-Domingue. Au Cap Français: chez P.Roux, s.d. [ano V], p.5)

${ }^{1537}$ Ibidem, pp.1-39. 


\section{III.1.5) $O$ golpe de 18 fructidor do ano V (4 de setembro de 1797)}

Na noite de 17 para 18 fructidor (3-4 de setembro), o triunvirato formado, no seio do Diretório, por La Revellière-Lépeaux, Barras e Rewbell, utilizando tropas reunidas em volta de Paris, ordenou a ocupação dos dois palácios legislativos e a prisão dos principais chefes do partido clichyen. O golpe tinha sido motivado por razões de política interna - o fortalecimento do poder executivo e a supressão da maioria monarquista da esfera legislativa - mas o fato também promoveria uma reviravolta na questão colonial. O envolvimento dos deputados coloniais na ofensiva antirrepublicana determinou, após o golpe de 18 fructidor, um novo desmantelamento do partido escravista.

Ao todo, 177 deputados foram cassados dos Conselhos. Entre eles, estavam Delahaye, Viénot-Vaublanc, Villaret-Joyeuse e Boissy d'Anglas. Em posse de provas de uma conspiração realista, o Diretório ordenou um grande número de prisões. Representantes das Mascarenhas, como Jean-Baptiste Detcheverry, deputado da Ilha da Reunião, conseguiram escapar às sanções, mas cerca de 65 conspiradores foram banidos para as Guianas, caso de Barbé-Marbois, Bourdon de l'Oise e Pichegru. Outros, como Viénot-Vaublanc, Delahaye, Villaret-Joyeuse e Boissy d'Anglas, fugiram ou então se refugiaram na clandestinidade. $\mathrm{O}$ fato é que os principais nomes do partido colonial tinham sido derrubados. ${ }^{1538} \mathrm{Com}$ isso, o golpe permitiu neutralizar a tendência reacionária que ameaçava derrubar a abolição. Adeptos da liberdade geral ocupariam posições-chave no seio do Corpo Legislativo, o que faria com que a posição dos Conselhos sobre as questões coloniais sofresse uma profunda mudança.

Uma das primeiras medidas adotadas pelos vencedores foi a eleição de uma comissão legislativa, presidida por Joseph Eschassériaux. Em 25 fructidor do ano V (11 de setembro de 1797), essa comissão apresentou um relatório sobre as deputações de São Domingos que revertia o curso dos eventos. Eschassériaux via na admissão dos eleitos de São Domingos a melhor forma de fortalecer os vínculos da metrópole com as colônias. No seu projeto, propunha que a lei que declarava nulas as eleições feitas no Cap-Français no ano IV (setembro de 1796) fosse revogada e que, consequentemente, fossem admitidos, no Conselho dos Anciões, os cidadãos Brothier e Lavaux e, no dos Quinhentos, os cidadãos Thomany, Sonthonax, Petitniaud e Boisrond jeune. Também as

1538 Cf. GAINOT, Bernard. Métropole / Colonies, pp.17-18; WANQUET, Claude. La France et la première abolition de l'esclavage, pp.451-452. 
eleições feitas no Cap em 20 germinal do ano 5 (abril de 1797) deveriam ser declaradas válidas, permitindo a entrada de Etienne Mentor e Jacques Tonnelier no Conselho dos Anciões e Leborgne e Vergniaud no dos Quinhentos. ${ }^{1539}$ A validação essas eleições foi aprovada em 28 fructidor (14 de setembro de 1797). ${ }^{1540}$ Com isso, quatro mulatos (Boisrond, Tonnelier, Thomany e Petitniaud) e dois negros (Mentor e Annecy) entravam para o corpo legislativo.

Após o golpe, os representantes de São Domingos se vincularam à corrente fructidoriana, explicitando, com isso, a sua oposição aos adeptos da restauração realista. Para marcar a sua posição, afirmaram publicamente que o 18 fructidor havia salvo a França e as colônias. Assim o fez Leborgne, em 27 vendemiário do ano VI (18 de outubro de 1797): "Se o 18 fructidor é, de fato, uma época memorável que salvou a França, seus aliados e os povos livres, esse dia fixou os destinos da América e o gozo pacífico da liberdade sem anarquia: que gratidão vos devem as colônias!"1541 Da mesma forma, o negro Mentor louvaria o golpe de fructidor, no Conselho dos Quinhentos, em 12 prairial do ano VI (31 de maio de 1798). ${ }^{1542}$

Étienne Lavaux tornou-se, naquele momento, o porta-voz da doutrina colonial oficial, que retomava o princípio proclamado em 1795, isto é, o da assimilação jurídica das colônias às demais partes integrantes da República. Lavaux anunciou essa doutrina na tribuna do Conselho dos Anciões, em 19 de setembro de 1797, dia da admissão dos deputados de São Domingos. Sustentou a tese de que o Corpo legislativo, agora livre da "facção liberticida" derrubada pelo golpe de 18 fructidor, devia, para garantir a posse das colônias, colocar em execução a Constituição em São Domingos e, com isso, dar uma nova força ao decreto de abolição. Era preciso, dados os imperativos militares atuais, apagar todas as incertezas quanto ao estado político dos cidadãos negros. Nesse sentido, perguntava aos membros do Conselho: "Que interesse teria o negro em defender a colônia, se não fosse para defender o seu direito de cidadão francês?". Propunha, para eliminar as ambiguidades relativas ao status dos antigos escravos, que se

\footnotetext{
${ }^{1539}$ Cf. ESCHASSÉRIAUX, Joseph. Corps législatif. Conseil des Cinq-Cents. Rapport fait au nom de la commission des colonies par Eschassériaux aîné sur les députations de Saint-Domingue. Séance du 25 fructidor an V. Paris: De l'Imprimerie Nationale, ano V [1797], pp.11-12.

${ }^{1540}$ Cf. Moniteur, v.28, número 365, 21 de setembro de 1797, p.823.

1541 "Certes, si le 18 fructidor est une époque mémorable qui a sauvé les France, ses alliés et les peuples libres, ce jour a fixé les destinés de l'Amérique, et la jouissance paisible de la liberté sans anarchie: que de reconnaissances ne vous doivent pas les colonies!" (LEBORGNE DE BOIGNE, Claude Pierre Joseph. Corps législatif. Conseil des Cinq-Cents. Compte rendu par Leborgne, sur la situation actuelle de la colonie de Saint-Domingue. Séance du 27 vendémiaire an VI. Paris: Imprimerie Nationale, ano VI, p.5).

${ }^{1542}$ Cf. MENTOR, Etienne-Victor. Conseil des Cinq-Cents. Discours prononcé dans la séance du 12 prairial an 6. Paris: Imprimerie Nationale, ano VI, pp.2-3.
} 
declarasse que o negro arrancado de seu país para ser transportado a São Domingos não era estrangeiro. O seu objetivo era garantir, por meio da cidadania, a adesão daqueles que constituíam dois terços da população negra de São Domingos: "Na paz, eles serão os cultivadores da colônia [...]. Na guerra, todos eles serão, de acordo com a necessidade, soldados e valentes, pois defenderão seus direitos e sua pátria [...]". ${ }^{1543}$ Note-se que, nesse sistema de liberdade, ao negro eram reservados apenas dois papeis sociais: cultivador e soldado.

Lavaux fez o elogio de Toussaint-Louverture, "um homem dotado de todos os talentos militares", sendo, ao mesmo tempo "modesto na vitória" e "intrépido na derrota". Contrariando a imagem bastante difundida de um "bebedor de sangue", apresentou Toussaint como "um republicano repleto de sentimentos de humanidade", mostrando-se sempre misericordioso e atencioso para com os seus prisioneiros. Ressaltava, em especial, o fato de Toussaint ter sido capaz de convencer os negros da necessidade do trabalho e do restabelecimento do cultivo. Estendia os elogios a outros oficiais negros, dentre os quais Christophe e Dessalines, que ele chamava de futuros "restauradores da colônia". ${ }^{1544}$ Naquele momento, Lavaux era a ponte entre o governo republicano na França e o exército negro do Caribe.

Nos meses seguintes, a obra legislativa seguiu as linhas gerais enunciadas por Lavaux. A estratégia de Toussaint de buscar interlocução com os Clichyens tinha se revelado um mau negócio após o golpe de fructidor, que reforçou a posição de Sonthonax na metrópole. O líder negro passou a temer as repercussões dessa reviravolta quanto à sua posição em São Domingos. Continuou a comunicar-se com seus interlocutores habituais, Grégoire e Lavaux, denunciando as reais intenções de Sonthonax. Nesse novo contexto, a Sociedade dos Amigos dos Negros voltaria a se reunir.

\footnotetext{
1543 "Quel intérêt le noir aurait-il à défendre la colonie, s'il n'avait pas à défendre son droit de citoyen français?"; "En paix, ils seront les cultivateurs de la colonie [...]. En guerre, ils seront tous, au besoin, soldats et vaillants, puisqu'ils défendront leurs droits et leur patrie [...]" (LAVAUX, Étienne Maynaud Bizefranc de. Discours prononcé par C. Lavaux [sic], pp.2-4).

${ }^{1544}$ Ibidem, pp.6-8.
} 


\section{III.2) A Sociedade dos Amigos dos Negros e das Colônias}

A consolidação da República, após o golpe de 18 fructidor, forneceu o contexto para a reconstituição de uma sociedade antiescravista organizada na França. Desde o desaparecimento da Sociedade dos Amigos dos Negros em 1792, o antiescravismo havia assumido uma forma difusa, sendo incorporado a outros espaços de luta, como a Comuna de Paris ou o movimento dos cidadãos de cor. A nova conjuntura, entretanto, estimulava o retorno do antiescravismo à sua forma mais institucionalizada. As coisas, entretanto, haviam mudado bastante desde 1792: na esteira da insurreição dos escravos da principal colônia francesa, a abolição geral da escravidão tinha sido proclamada pelo governo revolucionário, sem que os Amigos dos Negros, muitos deles vítimas do Terror, tivessem participação no processo. A volta da Sociedade suscitava, portanto, importantes interrogações quanto à direção a ser tomada por um movimento que tinha se notabilizado, desde a sua origem, pela moderação e a rejeição de medidas abruptas. Longe, entretanto, de atacar a legislação abolicionista, os Amigos dos Negros procurariam fazer dela o ponto de partida para a retomada de alguns projetos já avançados desde 1788.

\section{III.2.1) Continuidade e renovação do movimento antiescravista}

\section{III.2.1.1) A fundação}

A ideia de retomar as atividades da Sociedade dos Amigos dos Negros surgiu algum tempo antes de suas primeiras sessões oficiais. Em carta de 20 pluvioso do ano IV (9 de fevereiro de 1796), Lanthenas, um Amigo dos Negros, referiu-se a uma reunião da antiga Sociedade no domicílio de Benjamin Frossard. Anunciava que: "[...] o Diretório vê com prazer a reunião dos cidadãos que foram membros da Sociedade dos Amigos dos Negros, e que vão recomeçar". A carta indicava ainda que essa sociedade se reuniria provisoriamente na residência de Benjamin Frossard, na rua neuve SaintEustache, e que Lanthenas tinha ficado encarregado de prevenir as autoridades constituídas. $^{1545}$

\footnotetext{
${ }^{1545}$ Lettre du 20 pluviôse an IV (9 février 1796). In: DORIGNY, Marcel, GAINOT, Bernard. La Société des Amis de Noirs, p.369.
} 
Não se sabe exatamente que fim levou essa primeira tentativa de retomar os trabalhos dos Amigos dos Negros, mas é possível que, naquele momento, o ambiente não fosse favorável a uma iniciativa dessa natureza. Segundo Bernard Gainot, pouco tempo após a referida carta, o ministro de polícia, Cochon de Lapparent, restringiu drasticamente o direito de associação e lançou uma política de repressão aos clubes democráticos. ${ }^{1546}$ É possível que, somente após o golpe de 18 fructidor, a conjuntura tenha se tornado mais propícia ao retorno dos Amigos dos Negros.

Não se conhece com exatidão a data da retomada das atividades dos Amigos dos Negros. A primeira reunião devidamente registrada foi a de 10 frimário do ano VI (30 de novembro de 1797). Ora, uma das atividades indicadas no registro desse dia foi justamente a leitura da ata de uma sessão anterior, o que indica a realização de outras reuniões anteriores. ${ }^{1547}$

$\mathrm{Na}$ verdade, há indícios de que a Sociedade possa ter sido reiniciada vários meses antes. Em 9 de maio de 1797, uma Convenção que reuniu, na Filadélfia, os delegados das sociedades abolicionistas estadunidenses escreveu uma carta à Sociedade dos Amigos dos Negros de Paris. A carta já manifestava a satisfação em ver que a Sociedade parisiense tinha retomado os seus trabalhos. ${ }^{1548}$ Por outro lado, também é possível que essa retomada de trabalhos estivesse limitada ao plano das intenções e que nenhuma reunião oficial tivesse sido realizada. Foi no outono de 1797 , num contexto de multiplicação dos Círculos Constitucionais ${ }^{1549}$, que a Sociedade de fato passou para o plano da ação concreta.

A Sociedade exerceria abertamente as suas atividades entre 10 frimário do ano VI (30 de novembro de 1797) e 10 germinal do ano VII (30 de março de 1799). Contam-se 31 sessões registradas, mas sabe-se com certeza que ocorreram outras, em razão das menções nas atas de reuniões não constantes do registro. Assim, se o registro indica uma média de duas sessões por mês durante o curto período em que funcionou a

\footnotetext{
${ }^{1546}$ Essa política acabaria ocasionando a prisão de Babeuf e seus aliados.

${ }^{1547}$ Cf. Notes des séances de la Société des Amis des Noirs et des Colonies. In: DORIGNY, Marcel, GAINOT, Bernard. La Société des Amis de Noirs, p.329.

${ }^{1548}$ Cf. Lettre de la Convention pour l'abolition de l'esclavage aux États-Unis, réunie en Philadelphie, à la Société des Amis des Noirs à Paris. In: DORIGNY, Marcel, GAINOT, Bernard. La Société des Amis de Noirs, p.370.

${ }^{1549}$ O Círculo Constitucional era uma organização política que se multiplicou em vários pontos da França, transformando-se no local de reunião dos patriotas mais avançados, a tal ponto que muitos viram na sua formação o ressurgimento do clube dos Jacobinos (cf. THIERS, Adolphe. Histoire de la Révolution française. $8^{\mathrm{a}}$ edição. Bruxelas: Adolphe Wahlen, 1836, v.2, p.406).
} 
Sociedade, o ritmo das sessões foi provavelmente mais intenso. ${ }^{1550} \mathrm{O}$ mês de maior atividade foi o mês de abril de 1798, com cinco sessões registradas. Os registros de dez sessões encontram-se incompletos, sem indicar o nome ou o número de participantes, mas, para as demais, é possível indicar uma média de 11,7 presentes por sessão. O número de participantes numa mesma sessão nunca passou de 24 (sessão de 9 de maio de 1798) e em algumas ocasiões não passou de cinco ou seis, o que mostra que a nova formação dos Amigos dos Negros reunia um grupo ainda mais restrito do que a primeira encarnação da sociedade. ${ }^{1551} \mathrm{O}$ número pequeno de membros contribuintes deixaria, aliás, a Sociedade em situação financeiramente frágil. ${ }^{1552}$

Inicialmente, a Sociedade se reuniu no escritório de Lanthenas, que se encarregou de redigir os seus regulamentos. ${ }^{1553}$ Posteriormente, este seria atingido por uma grave doença, o que obrigaria a Sociedade a buscar um novo local de encontro. Mal informado sobre a natureza da Sociedade, o ministro Bruix autorizaria a utilização de locais do ministério para atividades da entidade, o que eventualmente renderia a esta sérios problemas. ${ }^{1554}$ Com isso, a nova Sociedade reunir-se-ia no escritório de Granet, chefe da divisão colonial do gabinete da Marinha e membro dos Amigos dos Negros desde 10 pluvioso do ano VII (29 de janeiro de 1799). ${ }^{1555}$

\section{III.2.1.2) Composição}

$\mathrm{Na}$ lista de presentes da primeira sessão registrada, estavam reunidos deputados coloniais (Lavaux, Tonnelier, Petitniaud, Leborgne, Thomany e Dupuch), um antigo membro do gabinete das colônias do Ministério (Bourdon de Vatry), um militar (Bayard), um antiescravista sueco (Wadström), e dois membros da primeira formação

${ }^{1550}$ O Regulamento da Sociedade previa a realização de uma sessão pública a cada seis meses (art.III). Sabe-se que pelo menos uma foi realizada, em 16 pluvioso do ano VII (4 de fevereiro de 1799) (cf. Règlement de la Société des Amis des Noirs et des colonies adopté dans sa séance tenue à Paris le 30 frimaire an VII. In: DORIGNY, Marcel, GAINOT, Bernard. La Société des Amis de Noirs, p.384)

${ }^{1551}$ Cf. Notes des séances de la Société des Amis des Noirs et des Colonies, pp.329-367.

${ }^{1552}$ Nas sessões de 20 e 30 prairial e 20 messidor do ano VI ( 8 e 18 de junho e 8 de julho de 1798), foi feito um balanço das receitas e despesas da Sociedade. Na de 20 prairial, para uma receita de 62,7 libras, havia gastos gerais de 36,7, que, somados a 64 libras em gastos de impressão, geravam um déficit de 38 . $\mathrm{Na}$ sessão de 30 prairial, a receita tinha subido para 94,5, mas os gastos também tinham subido para 100,11, gerando um déficit menor de 6,6 libras. Na sessão de 20 messidor, entretanto, a receita de 123,9 superou a despesa de 117,43, o que dava à entidade um pequeno superávit de 5,4 libras (Ibidem, pp.346347).

${ }^{1553}$ Ibidem, p.330.

${ }^{1554}$ A ata da sessão de 20 fructidor do ano VI (6 de setembro de 1798) menciona um encontro que Servan teve com o ministro da marinha e das colônias Bruix, que teria prometido levar em consideração todas as reclamações da Sociedade. Mas não se sabe exatamente o conteúdo da conversa (Ibidem, p.349).

1555 Ibidem, p.353 e 355. 
dos Amigos dos Negros (Servan e Grégoire). ${ }^{1556}$ Esse pequeno grupo já indicava as principais tendências que orientavam a composição da nova Sociedade.

Com base no registro e na documentação existente, pudemos levantar um total de 94 membros para a entidade (ver Apêndice B), sendo que, para 14 dos nomes, não foi possível obter informações biográficas. Em relação aos 80 nomes restantes, percebese que, comparada à primeira formação dos Amigos dos Negros, a nova Sociedade inscrevia-se numa orientação relativamente diferente. Havia, é claro, uma certa continuidade, atestada pela presença de onze remanescentes da primeira sociedade, isto é 13,75\% dos membros: Bancal des Issarts, Brack, Benjamin Frossard, Grégoire, Lamarre, Lanthenas, os irmãos Pierre e C.A. Lepage, Daniel Lescallier, Parraud e Servan de Gerbey.

Contudo, a enorme maioria dos Amigos dos Negros originais estava ausente. As razões para isso eram variadas: a saída, ao longo da Revolução, de muitos dos membros mais moderados, muitos dos quais emigraram após a queda da realeza; a derrubada do grupo brissotino em 1793, o que privou os Amigos dos Negros daquele que era o núcleo de sua primeira formação; e, finalmente, a quase ausência do pessoal ligado aos meios financeiros, fortemente representados na primeira formação. Alguns desses homens tinham sido executados quando da eliminação em massa dos fazendeiros-gerais em 1794. Dos financistas da primeira sociedade, reencontramos apenas Brack, Parraud e Dufossey de Bréban.

Em compensação, o movimento se beneficiava agora da presença de homens com maior experiência administrativa. Cerca de $24 \%$ de seus membros exercia ou tinha exercido alguma função na administração, sendo que alguns deles, como Bourdon de Vatry e Granet, atuavam no Ministério da Marinha e no gabinete das colônias. Além disso, a Sociedade contava com uma forte presença de membros do Corpo legislativo (conselhos dos Quinhentos e dos Anciões): cerca de 26\%. Deve-se ressaltar ainda que, dentre esses representantes, havia um total de 14 deputados das colônias, que reuniam, assim, 17,5\% do total de membros da Sociedade. Esses deputados constituíam o núcleo duro da nova formação, que, em razão da forte presença de parlamentares e administradores, assumia a natureza de comissão extra-legislativa para a discussão e formulação de projetos em matéria colonial. Sonthonax, o homem da abolição de 1793,

${ }^{1556}$ Ibidem, p.329. 
era a figura-chave desse grupo e trazia para si o apoio de deputados como Merlino e Deydier, que integrariam a oposição democrática ao segundo Diretório.

O grupo dos deputados das colônias era reforçado pela presença de sete antigos agentes da França nas colônias, como Étienne Burnel, Saint-Léger e Daniel Lescallier, assim como alguns habitantes das colônias, que atuavam às vezes como correspondentes. No total, $30 \%$ dos membros da Sociedade tinham uma experiência concreta e direta nos espaços coloniais. Essa era uma diferença importante em relação à primeira sociedade, cujos membros eram, na sua grande maioria, nobres, publicistas, advogados e financistas sem vínculos diretos com as colônias e que, portanto, olhavam para o problema da escravidão de fora. A nova Sociedade reunia, ao contrário, um grande número de pessoas com conhecimentos vastos sobre as realidades concretas das colônias, podendo, apesar da distância, abordar o problema colonial com um enfoque interno. Deve-se notar, aliás, que a entidade reunia, entre seus membros regulares, seis negros (Annecy, Belley, Boisson, Deville, Thomany e Larose) e quatro mulatos (Petitniaud, Boisrond, Mentor e Tonnelier). O negro Thomany foi, aliás, levado à presidência da Sociedade em frimário do ano VII (dezembro de 1798). ${ }^{1557}$

Por outro lado, essa tendência de reunir membros com uma experiência colonial não se estendia aos proprietários e comerciantes de escravos. O regulamento da Sociedade previa, no seu art.VIII, que "aquele que estiver direta ou indiretamente interessado no comércio de escravos não pode ser recebido como membro da Sociedade e sequer assistir às suas sessões". ${ }^{1558}$ Alguns colonos escravistas das ilhas orientais, como Gouly e Detcheverry, tentaram, assim mesmo, se infiltrar na Sociedade, mas seu pedido de admissão foi recusado. ${ }^{1559}$ Nesse ponto também, a nova Sociedade se distanciava da primeira: se aquela tinha, na sua formação, feito um convite aos proprietários coloniais e armadores para que contribuíssem com seus conhecimentos para a formação de projetos que aliassem os interesses da humanidade aos dos próprios colonos, a nova entidade parecia excluir a possibilidade de um compromisso. A experiência da Revolução havia evidenciado a impossibilidade prática de um diálogo. Além disso, colonos e antiescravistas assumiam agora posturas opostas no que se referia

\footnotetext{
1557 Ibidem, pp.352-353.

1558 "quiconque serait intéressé directement ou indirectement dans le commerce d'esclaves ne peut être reçu membre de la Société ni même assister à ses séances" (Règlement de la Société des Amis des Noirs et des colonies, p.384).

${ }^{1559}$ Cf. Notes des séances de la Société des Amis des Noirs et des Colonies, p.332.
} 
à abolição: enquanto aqueles queriam a restauração da escravidão, estes se esforçavam em repensar o sistema colonial num regime de liberdade geral.

Embora o conflito com as potências europeias tornasse difícil a comunicação com sociedades antiescravistas estrangeiras, a dimensão internacional que a primeira Sociedade mantinha como um de seus princípios reproduzia-se na nova formação por meio da presença de uma dúzia de membros estrangeiros ${ }^{1560}$, como o pedagogo John Walker e a escritora Helen Maria Williams, ambos ingleses. Os regulamentos da Sociedade previam a correspondência e a troca de informações com outras sociedade do mêsmo gênero. ${ }^{1561}$ Os Amigos dos Negros e das Colônias manteriam contatos com as sociedades americanas ${ }^{1562}$, mesmo que a tensão crescente entre a França e os Estados Unidos sob o Diretório inviabilizasse uma correspondência mais significativa. ${ }^{1563}$ Esforços para uma interlocução com outros países também seriam empreendidos. ${ }^{1564}$

$\mathrm{O}$ associado estrangeiro mais importante era o antiescravista sueco C. B. Wadström, que tinha fundado, em 1779, uma sociedade em Norköpping com o objetivo de formar colônias num modelo alternativo ao escravista. Uma experiência na costa africana havia inspirado algumas obras importantes sobre o tema, como An Essay on Colonization, publicada em Londres em 1795. Wadstrom sustentava, em seus escritos, que os projetos de formação de novas colônias sem escravidão dificilmente se concretizariam num quadro de conflito entre as potências europeias. Entendia, aliás, que esses projetos seriam fortemente favorecidos se a Inglaterra e a França não apenas cessassem as hostilidades, mas se unissem para concretizá-los. ${ }^{1565}$

\footnotetext{
1560 O Regulamento da Sociedade previa que os membros de outras sociedades antiescravistas estrangeiras seriam admitidos a deliberar, desde que os seus governos estivessem em paz com a República francesa (art.VI) (cf. Règlement de la Société des Amis des Noirs et des colonies, p.384).

${ }^{1561}$ Cf. WADSTROM, Carl Bernhard. Additions aux règlemens de la Société des Amis des Noirs et des Colonies. S.l. [Paris]: s.d. [ano II], p.6.

${ }^{1562}$ Ver, nesse sentido, a carta da Convenção das sociedades americanas pela abolição da escravidão, de 9 de maio de 1797, que já indicava que a dimensão internacionalista da antiga Sociedade dos Amigos dos Negros seria mantida pela nova. A Convenção remetia à sociedade parisiense as atas das Convenções de 1794, 1795, 1796 e 1797, na esperança de que "[...] nossos esforços combinados possam ser eminentemente instrumentais na realização desse grande trabalho de Filantropia" (Lettre de la Convention pour l'abolition de l'esclavage aux États-Unis, pp.370-371).

${ }^{1563}$ Cf. DORIGNY, Marcel, GAINOT, Bernard. La Société des Amis de Noirs, p.316.

${ }^{1564}$ Em 10 germinal do ano VII (30 de março de 1799), Lasteyrie anunciou à Sociedade que faria uma viagem à Alemanha e à Suécia. Propunha levar os regulamentos da Sociedade para esses países. Foi-lhe pedido que trouxesse informações que permitissem completar uma obra na qual Grégoire trabalhava, sobre a história do tráfico negreiro. A Sociedade esperava que Lasteyrie pudesse trazer detalhes sobre os esforços empreendidos em diferentes países da Europa em favor da liberdade dos negros (cf. Notes des séances de la Société des Amis des Noirs et des Colonies, p.363).

${ }_{1565}$ Cf. WADSTRÖM, Carl Bernhard. Précis sur l'établissement des colonies de Sierra Léona et de Boulama. Paris: Pougens, 1798, p.46.
} 
Wadström já era conhecido na França, onde havia publicado Voyage au pays de Dahomé, em 1794-95, obra na qual abordava em minúcias as várias formas de abastecimento do tráfico de escravos na costa africana. ${ }^{1566}$ Além disso, em frimário do ano IV (dezembro de 1795), Wadström tinha apresentado ao Corpo Legislativo e ao Diretório os resultados de sua viagem à África, onde suas pesquisas contribuíram para a criação de dois estabelecimentos na colônia de Serra Leoa e na ilha de Boulama, no intuito de abolir o tráfico e colocar os habitantes do continente africano "sob as doces leis de uma sábia cilização". Wadstrom atribuiu o fracasso da empresa ${ }^{1567}$ à influência do comércio, que tinha se tornado apenas uma atividade especulativa e não mais baseada nas necessidades naturais do homem e na dependência recíproca existente entre os povos. Acreditava que, um dia, a França e a Inglaterra se uniriam para combater os abusos do sistema comercial europeu e seu sistema de crédito artificial. Um dos aspectos dessa luta seria a abolição do tráfico, a erradicação progressiva da escravidão nas ilhas da América e a criação de estabelecimentos na África, sem escravidão e destinados a levar a civilização aos negros do continente. ${ }^{1568}$ Suas propostas se adequavam inteiramente aos princípios dos Amigos dos Negros. Um dos principais animadores da nova Sociedade, Wadström era próximo dos Ideólogos ${ }^{1569}$, alguns dos quais também fariam parte da entidade, caso de Charles Théremin, Antoine Labaume, Pierre Jean Georges Cabanis e o famoso economista Jean-Baptiste Say, que ainda não tinha escrito suas obras de economia política, mas que defendia suas posições sobre a questão colonial na revista La Décade Philosophique, Littéraire et Politique.

Deve-se notar também a presença de mulheres na Sociedade. Se na primeira formação, elas não cumpriram uma função efetiva, agora sua presença se revestia de um caráter político mais pronunciado, em razão da evolução do movimento pelos direitos das mulheres ao longo da Revolução. Se elas eram, na sua maioria, esposas de dirigentes da Sociedade, havia também personalidades mais influentes, como a escritora

\footnotetext{
${ }^{1566}$ Idem. Voyage au pays de Dahomé. Paris: Gay et Gide, Ano III, pp.175-207.

1567 Após o sucesso inicial, a colônia teria sucumbido à ação nefasta dos grupos ligados ao comércio de escravos, protegidos pelo ministério britânico. A França tinha enviado uma esquadra para destruir a colônia, mas Wadström atribuía a culpa pelo fato ao ministério britânico, que havia adotado como regra de conduta os princípios mais contrários à humanidade (Idem. Adresse au Corps Législatif et au Directoire Exécutif de la République Française. Paris: Imprimerie des Sciences et Arts, s.d., pp.4-5).

${ }^{1568}$ Ibidem, pp.1-9.

1569 A sociedade dos Ideólogos, fundada por Destutt de Tracy, reunia homens de letras, juristas, professores e cientistas que buscavam combater, por meio dos ideais da Filosofia e da Economia política do século XVIII, o despotismo e o obscurantismo. Entre os membros mais famosos dessa corrente intelectual estavam Condorcet, Sieyès, Cambacérès e a Madame de Staël.
} 
inglesa Helen Maria Williams, cujas relações com os Girondinos lhe tinham rendido uma estadia na prisão, sob o Terror. O artigo IX do regulamento especificava que:

$\mathrm{Na}$ medida em que as intenções filantrópicas da Sociedade incidem igualmente sobre os dois sexos entre os habitantes das colônias, as mulheres, tão aptas a contribuir para os progressos da civilização e para o alívio dos desafortunados, podem ser membros da Sociedade. ${ }^{1570}$

O procedimento para a admissão dos membros ainda era bastante formalizado $^{1571}$, de modo que a Sociedade não havia perdido o seu caráter fechado e elitista. $\mathrm{O}$ objetivo novamente não era fazer agitação política e envolver um movimento popular cuja participação no processo político, após as várias reviravoltas ocorridas na Revolução, era vista como particularmente perigosa. Os negros já tinham sido declarados livres; agora, para os Amigos dos Negros e das Colônias, a principal tarefa era redefinir a política colonial da Nação, de modo a preservar tanto a abolição quanto o estatuto colonial.

Comparada à sua primeira encarnação, a nova Sociedade parecia ter um perfil mais definido. A experiência anterior dos Amigos dos Negros e a evolução da página colonial da Revolução talvez permitisse à entidade determinar com maior precisão a sua linha política. Questões como a abolição do tráfico e da escravidão tinham sido, bem ou mal, resolvidas. A questão agora era como administrar a questão colonial pós-abolição.

\footnotetext{
1570 "Les intentions philanthropiques de la Société se portant également sur les deux sexes parmi les habitants des colonies, les femmes, si propres à contribuer aux progrès de la civilisation et au soulagement des malheureux, peuvent être membres de la Société" (Règlement de la Société des Amis des Noirs et des colonies, p.384).

${ }^{1571}$ Cada candidato a membro precisava do apoio e da assinatura de quatro membros da Sociedade, além daquele que o apresentou. $\mathrm{O}$ nome, as qualidades e o endereço do candidato ficavam afixados nos locais das sessões durante vinte dias, após os quais um relatório era feito sobre a moralidade e as opiniões do candidato. Após o relatório, procedia-se a um escrutínio: se reunisse dois terços dos votos, o candidato era proclamado membro da Sociedade. O arquivista ficava encarregado de comunicar a decisão da Sociedade ao candidato admitido, que tinha de responder em dez dias. De acordo com sua resposta, ele recebia um diploma e tinha seu nome inscrito na lista de membros (artigos X a XII) (Ibidem, pp.384-385)
} 


\section{III.2.2) O programa}

\section{III.2.2.1) Linhas gerais}

A nova Sociedade não conheceu o mesmo ritmo de publicações que a primeira formação dos Amigos dos Negros. Contudo, é possível, com base nos textos produzidos diretamente pela entidade e individualmente pelos seus membros, elencar os pontos fundamentais de seu programa. Podemos identificar, nesses documentos, a reiteração dos mesmos elementos.

Assim, na carta de 20 pluvioso do ano IV (9 de fevereiro de 1796), que indicava uma primeira tentativa de refundar os Amigos dos Negros, Lanthenas já abordava, ainda que de forma passageira, aquelas que seriam as preocupações essenciais da nova Sociedade. Falava em: "[...] buscar os meios de formar com segurança e sucesso, de estender e fazer florescer sob os Trópicos, colônias fundadas sobre o princípio da liberdade e da civilização dos povos...". Com isso, as atividades da sociedade estariam voltadas para todos os aspectos relacionados aos territórios coloniais: "culturas novas e comércio, história natural, química, medicina, legislação, observações de viajantes, meditações dos filósofos". ${ }^{1572} \mathrm{~A}$ iniciativa não havia se concretizado naquele momento, mas essas formulações já prenunciavam a natureza do programa da Sociedade.

Dois anos mais tarde, uma carta de convocação redigida por Wadström e datada de 25 de abril de 1798, voltava a traçar as diretrizes do movimento. O sueco afirmava que, agora que a "espinhosa questão" da emancipação dos negros estava mais ou menos resolvida, era o momento de refletir a respeito de outras questões relativas às colônias. Era preciso: 1) refletir sobre os meios de fazer com que o solo das colônias fosse fertilizado por homens livres, isto é, por homens que haviam trabalhado sob o "jugo vergonhoso da escravidão" e poderiam agora cultivar com prazer, pois seu interesse estaria associado à sua produtividade; 2) ocupar-se da formação de estabelecimentos para levar às colônias a educação, a ciência e as artes, na medida em que era "[...] um dever para nós colocar nossos irmãos das colônias no nível dos conhecimentos úteis que ilustram a pátria-mãe"; 3) destruir, no mundo inteiro, o tráfico de escravos; 4) "abrir as comunicações comerciais entre os povos, não para oprimi-los, mas para servi-los nas

1572 "[...] rechercher les moyens de former avec assurance et succès, d'étandre et de faire fleurir sous les Tropiques, des colonies fondées sur le principe de la liberté et de la civilisation des peuples..."; "cultures nouvelles et commerce, histoire naturelle, chimie, médecine, législation, observations des voyageurs, méditations des philosophes" (Lettre du 20 pluviôse an IV (9 février 1796), pp.369-370). 
suas necessidades recíprocas". ${ }^{1573}$ Em nota sobre a reunião realizada no dia seguinte, Wadström retomou as mesmas considerações. ${ }^{1574}$

As linhas gerais do programa da Sociedade dos Amigos dos Negros e das Colônias também foram enunciadas numa carta enviada à revista La Décade Philosophique e publicada na edição de 20 floreal do ano VI (9 de maio de 1798). A carta admitia que os rumos tomados pela questão colonial ao longo da Revolução haviam superado as expectativas dos Amigos dos Negros originais:

Trabalhar para destruir o tráfico e suavizar a condição dos Negros nas Colônias foi o objetivo único da associação que se formou, antes mesmo da revolução, sob o nome de Sociedade dos Amigos dos Negros. Eventos que não se podia prever, ou calcular, precipitaram a marcha da revolução, e os Negros tornaram-se inteiramente livres no momento em que se ousava apenas esperar ver o peso de suas correntes diminuído. ${ }^{1575}$

Contudo, no intuito de manifestar a continuidade com os trabalhos da primeira sociedade, a carta dizia que a tarefa dos Amigos dos Negros ainda não tinha terminado. $\mathrm{Na}$ medida em que os "africanos" estavam desprovidos de instrução e conhecimentos das artes úteis, eles ignoravam os benefícios que podiam extrair de seu solo e de seu clima, para si e para outrem. Havia, portanto, a necessidade de atribuir-lhes uma instrução moral e física suficiente para que aprendessem certos ofícios e, sobretudo, aprendessem a cultivar melhor o solo, inclusive com o uso de máquinas agrícolas. Assim, um dos objetivos das reuniões dos Amigos dos Negros era, agora, de reunir luzes referentes à melhoria da cultura de cana-de-açúcar por homens livres. ${ }^{1576}$

Os Regulamentos da Sociedade, adotados em 30 frimário do ano VII (23 de dezembro de 1798), também anunciavam, na sua introdução, uma pauta de trabalho:

[...] traçar planos por meio dos quais as colônias verão, em pouco tempo, seu solo fertilizado por homens livres; demonstrar como esses homens, antes curvados sob o jugo da escravidão, cultivarão a terra com mais coragem e

\footnotetext{
1573 "[...] un devoir pour nous de mettre nos frères des colonies au niveau des connaissances utiles, qui illustrent la mère-patrie"; "ouvrir les communications commerciales parmi les peuples, non pour les opprimer, mais pour les servir dans leurs besoins reciproques" (WADSTRÖM, Carl Bernhard. [Circulaire datée du 7 floréal an 6, 38 rue des Fossés-Germain-des-Prés, invitant à une réunion de la Société des amis des noirs, le 10 floréal.S.1.: s.n., 1798, pp.1-2).

${ }^{1574}$ Idem. Note sur la réunion de la Société des Amis des Noirs du 7 floréal an VI. S.1. [Paris]: s.d., p.2

1575 "Travailler à détruire la traite et à adoucir le sort des Noirs dans les Colonies, fut l'unique but de l'association qui se forma, même avant la révolution, sous le nom de Société des Amis des Noirs. Des événemens qu'on n'avait pu ni prévoir, ni calculer, précipitèrent la marche de la révolution, et les Noirs devinrent entièrement libres au moment où l'on osait à peine espérer de voir diminuer le poids de leur chaîne" (LETTRE de la Société des Amis des Noirs, aux Auteurs de la Décade Philosophique. S.l. [Paris]: s.n., s.d., p.1).

${ }^{1576}$ Ibidem, pp.1-2.
} 
sucesso, quando encontrarem nela o seu interesse e o de suas famílias; formar estabelecimentos próprios a difundir, nesses climas longínquos, a educação, as ciências e as artes; terminar de destruir, em todas as partes do globo, esse comércio monstruoso da espécie humana, comércio que é a vergonha dos Estados policiados, e que serviu apenas para introduzir todos os crimes da avareza mais vil, a mais revoltante e a mais impolítica; enfim, abrir todos os tipos de comunicações comerciais entre os povos, não para oprimi-los, mas para servi-los nas suas necessidades e aumentar os seus gozos. ${ }^{1577}$

$\mathrm{O}$ artigo $1^{\circ}$ do regulamento ainda especificava que a sociedade continuaria a se ocupar "[...] da abolição da escravidão, do aperfeiçoamento moral e físico dos habitantes, dos progressos da agricultura, da indústria e do comércio nas colônias, e da formação de colônias novas". ${ }^{1578}$ Nas adições aos regulamentos, Wadström falou na formulação de "planos para encorajar o trabalho, a agricultura, as plantações e o comércio", e um "plano de educação capaz de tornar os cidadãos laboriosos e úteis". ${ }^{1579}$

A organização interna dos trabalhos da Sociedade também era indicativa de seus objetivos primordiais. Na sessão de 30 de novembro de 1797, primeira sessão registrada, a sociedade decidiu dividir-se em três comissões especializadas: Instrução, Cultura e Colonização. ${ }^{1580}$ Mais tarde, como indica uma peça anexa a uma carta ao ministro Bruix, de 28 de dezembro de 1798, as atividades foram relocadas em quatro comissões:

1) A comissão das colônias existentes, voltada para tudo o que pudesse melhorar os estabelecimentos atuais nas colônias. O seu trabalho se dividia em quatro temas fundamentais: agricultura; comércio e artes; legislação; e instrução dos colonos. Quanto à agricultura, tratava-se de encontrar meios de aperfeiçoar as culturas antigas das colônias e determinar quais novas culturas seria vantajoso introduzir. No que se refere ao comércio, o objetivo era examinar as relações comerciais a serem estabelecidas entre as colônias existentes e a metrópole e

\footnotetext{
1577 "[...] tracer des plans d'après lesquels les colonies verront en peu de temps leur sol fertilisé par des hommes libres; démontrer comment ces hommes jadis courbés sous le joug de l'esclavage cultiveront la terre avec plus de courage et de succès, lorsqu'ils y trouveront leur intérêt et celui de leurs familles; former des établissements propres à répandre dans ces climats lointains, l'éducation, les sciences, et les arts; achever de détruire sur toutes les parties du globe ce commerce monstrueux de l'espèce humaine, commerce qui est la honte des États policés, et qui n'a servi qu'à y introduire tous les crimes de l'avarice la plus vile, la plus revoltante, et la plus impolitique; enfin, ouvrir toutes sortes de communications commerciales parmi les peuples, non pour les opprimer, mais pour les servir dans leurs besoins et augmenter leurs jouissances" (Règlement de la Société des Amis des Noirs et des colonies, p.383).

1578 "[...] de l'abolition de l'esclavage, du perfectionnement moral et physique des habitants des colonies, des progrès de l'agriculture, de l'industrie et du commerce dans les colonies, et de la formation des colonies nouvelles" (Ibidem, pp.383-384).

${ }^{1579}$ Cf. WADSTROM, Carl Bernhard. Additions aux règlemens, p.1.

${ }^{1580}$ Cf. Notes des séances de la Société des Amis des Noirs et des Colonies, p.330.
} 
buscar meios de ampliar o comércio e a indústria nas colônias. O florescimento da indústria e do comércio permitiria a disseminação das artes nas colônias regeneradas. Eram esses objetivos que deveriam orientar a legislação. Quanto à instrução dos colonos, o texto referia-se aos "colonos devolvidos à liberdade", isto é, os antigos escravos, cuja instrução era necessária para que pudessem exercer os seus direitos de cidadania de forma vantajosa, para si e para a pátria.

2) A comissão das colônias novas, destinada a examinar quatro questões: os locais mais vantajosos para a fundação de novas colônias; a necessidade ou não de estabelecer um sistema de legislação e de administração diferente para colônias novas, criadas de acordo com os princípios da filantropia e sob a égide da liberdade; tipos de comércio e de indústria a serem admitidos nas colônias para que os colonos e a metrópole encontrassem um interesse recíproco; encorajamentos e condições a serem estabelecidos para famílias republicanas, de qualquer país, que quisessem se apresentar para formar, sob a proteção do governo francês, novas colônias, em acordo com os projetos da Sociedade dos Amigos dos Negros e das Colônias.

3) A comissão da história do tráfico dos negros, encarregada de reunir, classificar todos os documentos relativos ao tema do tráfico, no intuito de redigir uma história desse comércio.

4) A comissão dos objetos a traduzir e a analisar, destinada a examinar todas as obras, francesas e estrangeiras, relativas aos objetos da Sociedade, e distribuir o resultado dessa análise às demais comissões. Cabia também aos membros dessa comissão indicar as obras que mereciam ser traduzidas e publicadas. ${ }^{1581}$

Todas essas formulações gerais reiteravam essencialmente os mesmos quatro pontos: 1) a consolidação da abolição da escravidão e a supressão do tráfico onde ele ainda era praticado; 2) a educação dos negros emancipados; 3) a conversão das colônias ao trabalho livre; e 4) a expansão colonial com vistas ao desenvolvimento de um novo tipo de comércio. Vejamos agora, mais concretamente, como esses quatro pontos foram desenvolvidos nos trabalhos da Sociedade.

\section{III.2.2.2) Emancipação dos negros}

\footnotetext{
${ }^{1581}$ Cf. Dossier du ministère de la marine, pièces annexées: Organisation des travaux de la Société des Amis des Noirs et des colonies. In: DORIGNY, Marcel, GAINOT, Bernard. La Société des Amis de Noirs, pp.378-380.
} 
Se havia uma continuidade entre a primeira e a segunda fase dos Amigos dos Negros, havia também uma certa descontinuidade, motivada por aquele que era o grande acontecimento da história colonial da Revolução francesa: a abolição de fevereiro de 1794. A escravidão tinha sido suprimida segundo modalidades rejeitadas pela primeira Sociedade. A abolição feita de forma abrupta e generalizada suscitava interrogações a respeito da atitude dos novos Amigos dos Negros diante da lei de 16 pluvioso. Deveria esta ser revogada como uma lei de circunstância cuja execução era inviável? Ou, ao contrário, deveria ela ser mantida e complementada com leis adicionais destinadas a garantir a sua execução? Foi esta segunda opção que orientou os trabalhos da Sociedade.

O preâmbulo do regulamento, adotado em 23 de dezembro de 1798, considerava a abolição como um fato consumado no império francês e em vias de sê-lo no resto do mundo. Não cabia, portanto, voltar a discutir a liberdade dos negros. Nesse sentido, a Sociedade dos Amigos dos Negros e das Colônias nunca contestou a legitimidade de uma lei que teria sido considerada catastrófica pelos membros da primeira formação. Manifestações de apoio ao decreto e comemorações de sua aprovação seriam, ao contrário, comuns no seio da Sociedade.

Assim, uma sessão pública extraordinária foi organizada no dia 16 pluvioso do ano VII (4 de fevereiro de 1799), aniversário do decreto abolicionista. O Círculo Constitucional, do qual Merlino fazia parte, cedeu provisoriamente o seu local para a realização da festa. ${ }^{1582}$ Durante a sessão, uma versão impressa do decreto de 16 pluvioso foi distribuída aos presentes. ${ }^{1583}$ Um relato da comemoração foi publicado na Chronique universelle ( $\mathrm{n}^{\circ} 2219,29$ pluvioso do ano VII - 17 de fevereiro de 1799). O teor da cerimônia reforçava duas convicções: a necessidade de manter a abolição e a importância de reconstruir as colônias. De acordo com o relato, assinado por Dugour, um Amigo dos Negros e das Colônias, um grande número de pessoas compareceu à sessão, dentre as quais um jovem negro de 14 anos, trazido à França pelo cidadão Michault, que se propunha a enviá-lo para o interior da África assim que o jovem fosse capaz de difundir entre seus companheiros "as artes úteis e os princípios da civilização".

\footnotetext{
${ }^{1582}$ Cf. Notes des séances de la Société des Amis des Noirs et des Colonies, p.356. Merlino atuou, aliás, como intermediário na locação do Círculo Constitucional da Rue du Bac, para a realização da cerimônia. ${ }^{1583}$ Cf. SOCIÉTÉ des Amis des Noirs et des Colonies. Décret de la Convention Nationale, du 16-ème jour de Pluviôse, an second de la République Française Une et Indivisible, qui abolit l'esclavage des Nègres dans les Colonies. S.1. [Paris]: s.n., s.d. [ano VII-1799].
} 
Sonthonax fez um discurso muito aplaudido a respeito dos horrores da escravidão e do tráfico. Referindo-se a todos os colonos avessos ao preconceito, argumentou pela necessidade de "cimentar entre o Negro e o Branco a mais sincera reconciliação". ${ }^{1584}$

A sessão teve continuidade com uma série de outras intervenções. Jean Baptiste Say fez a leitura de um poema sobre a liberdade de Helen Maria Williams. Bayard leu um discurso a respeito da admissão das mulheres nas sociedades filantrópicas. Já Grégoire leu trechos de uma obra, ainda em andamento, sobre as qualidades morais dos negros, enquanto Servan comunicou a primeira parte de um relatório sobre os motivos que, até então, tinham levado os Europeus a fundar colônias e sobre os que poderiam levá-los a fundar outras. ${ }^{1585}$ Por fim, o deputado de cor de São Domingos, Mentor, concluiu a sessão com uma apologia da abolição, destacando os seus efeitos sobre a população negra:

Não tememos mais transmitir a existência a uma posteridade que a escravidão não difamará, a uma posteridade que conhecerá apenas por tradição a tirania que pesou sobre o inocente e infeliz Africano. Não veremos mais nossas companheiras, esmagadas sob o peso do trabalho, olhar o hímen como um suplício, e sua fecundidade como um flagelo. Essa felicidade sois vós que a preparastes; essa felicidade é a obra da grande nação! ${ }^{1586}$

Após a sessão, foi realizado um "banquete fraternal", durante o qual versos abolicionistas foram entoados. De acordo com o relato, "uma alegria franca e cordial reinou durante toda a refeição; e cada um retirou-se com essa doce satisfação que vivencia o filantropo após ocupar-se da felicidade de seus semelhantes". ${ }^{1587}$ No mesmo dia, o deputado negro Thomany pronunciou uma moção de ordem no Conselho dos Quinhentos, no sentido de fazer do 16 pluvioso uma festa nacional nas colônias. ${ }^{1588}$

Além de louvar a abolição, os Amigos dos Negros procuravam dar a ela efeitos mais abrangentes. Assim, eles se envolveriam no debate acerca das dívidas resultantes da compra de negros. O Conselho dos Quinhentos tinha recebido uma série de petições

\footnotetext{
${ }^{1584}$ Cf. Compte rendu de la cérémonie commémorative du décret d'abolition, organisée le 16 pluviôse an VII (4 février 1799). In: DORIGNY, Marcel, GAINOT, Bernard. La Société des Amis de Noirs, p.393.

${ }^{1585}$ Ibidem, pp.393-394.

1586 "Nous ne craignons plus de transmettre l'existence à une postérité que l'esclavage ne flétrira point, à une postérité qui ne connaîtra que par tradition la tyrannie qui a pesé sur l'innocent et malheureux Africain. Nous ne verrons plus nos compagnes, accablées sous le poids du travail, regarder l'hymen comme un súplice, et leur fécondité comme un fléau. Ce bonheur, c'est vous qui l'avez préparé; ce bonheur, c'est l'ouvrage de la grande nation!" (Ibidem, p.394).

1587 "une gaieté franche et cordiale a régné pendant tout le repas; et chacun s'est retire avec cette douce satisfaction, qu'éprouve le philanthrope, quand il s'est occupé du bonheur de ses semblables" (Ibidem, p.394).

${ }^{1588}$ Cf. THOMANY, Pierre. Conseil des Cinq-Cents. Motion d'ordre sur l'anniversaire de la liberté des noirs dans les colonies françaises. Séance du 16 pluviôse an 7, pp.1-4.
} 
que reclamavam o pagamento das dívidas contraídas pelos colonos junto aos armadores antes de 16 pluvioso do ano II. Essas petições se baseavam no argumento de que a lei abolicionista não tinha efeito retroativo, de modo que todas as compras e vendas feitas anteriormente continuariam válidas. Uma comissão da qual faziam parte três Amigos dos Negros (Sonthonax, Thomany e Duplantier) examinou a questão e respondeu, em 15 de outubro de 1798, que a compra e venda de escravos não era uma transação comum e tinha um caráter acessório em relação a um instituto que a lei de 16 pluvioso tinha abolido. Proscrita a escravidão, todas as transações envolvendo escravos perdiam o seu efeito, mesmo quando anteriores à lei, e os créditos resultantes do tráfico tinham de ser igualmente abolidos. ${ }^{1589} \mathrm{Na}$ sessão de 20 frimário do ano VII (13 de dezembro de 1798) dos Amigos dos Negros, Leborgne louvou a decisão da comissão. ${ }^{1590}$

Longe, portanto, de contestar o decreto de abolição, a Sociedade manifestava a sua preocupação em consolidar a liberdade geral proclamada em 1794. Isso não significava negar a tese gradualista pela primeira Sociedade, mas compreender que, justamente por não ter sido precedida de uma fase preparatória, a abolição era frágil. Assim, a consolidação da liberdade geral passava necessariamente por uma política de estabilização que devia vir da metrópole. Proteger a abolição significava estender às colônias a ordem constitucional da República francesa. Lavaux, em particular, dedicouse à tarefa de compor uma lei que permitisse a inclusão das colônias no sistema da Constituição do ano III, como veremos adiante. Mas, se os Amigos dos Negros viam a abolição como frágil, era também porque entendiam que os negros, despreparados que estavam para a vida civil, tinham sido devolvidos à liberdade de forma súbita.

\section{III.2.2.3) Educação dos novos livres}

Na medida em que a emancipação dos negros havia ocorrido sem as etapas preparatórias necessárias à inserção social dos indivíduos escravizados nas colônias, era necessário, para consolidar a abolição, fornecer aos novos livres uma formação cívica e escolar que derrubasse qualquer pretexto para um retorno ao sistema anterior. Os Amigos dos Negros e das Colônias queriam, de modo geral, realizar a posteriori o trabalho de moralização dos negros que a primeira Sociedade via como condição primordial para a emancipação dos escravos. Continuava viva, portanto, a ideia de que

\footnotetext{
${ }^{1589}$ Cf. DORIGNY, Marcel, GAINOT, Bernard. La Société des Amis de Noirs, p.354, nota 72.
}

${ }^{1590}$ Cf. Notes des séances de la Société des Amis des Noirs et des Colonies, p.354. 
os escravos não estavam prontos para a liberdade e que era, portanto, necessário tomar medidas para evitar que abusassem de seu novo estado. Era preciso criar, em suma, as condições para o seu aperfeiçoamento físico e moral.

O tema da educação dos negros era uma das principais preocupações dos antiescravistas norte-americanos. Na carta aos Amigos dos Negros, de 9 de maio de 1797, a Convenção das sociedades abolicionistas dos Estados Unidos enfatizou a necessidade de promover a instrução dos negros, para transformá-los em cidadãos:

Convencida de que a boa educação é essencial para a boa cidadania, esta Convenção e as Sociedades dos diferentes Estados nela representadas, se comprometem a aumentar o número de escolas úteis para a Instrução dos Africanos e suas crianças. É inculcando nas suas mentes os benefícios do conhecimento e treinando-os em hábitos regulares e econômicos que eles são capacitados a fazer uma verdadeira avaliação da natureza da liberdade de respeitar os direitos dos outros homens tanto quanto os deles, isto é, eles são instruídos a serem industriosos e serem honestos. ${ }^{1591}$

Nos Estados Unidos, a criação de escolas para crianças negras tornou-se uma das tarefas mais importantes para os abolicionistas. Como não possuímos as atas completas das sessões, não se sabe ao certo se os Amigos dos Negros e das Colônias chegaram a formular um projeto mais concreto de educação. Sabe-se que, em 20 pluvioso do ano VI (8 de fevereiro de 1798), houve uma discussão a respeito dos meios de aperfeiçoar a agricultura e a instrução pública nas colônias. De acordo com o registro, foram, na ocasião, apresentados "[...] exemplos que provam a sensibilidade dos jovens Negros, e que demonstram que tudo o que foi feito pela mão dos homens podia ser realizado pelas mãos dos Negros". 1592

Contudo, a lei de 12 nivoso do ano VI (1 ${ }^{\circ}$ de janeiro de 1798), para a qual os Amigos dos Negros e, sobretudo, Lavaux contribuíram, abordaria o tema da instrução dos negros, como veremos adiante. Dupuch, um membro da Sociedade e um dos agentes designados para aplicar a lei nas colônias pronunciaria em 30 messidor do ano VI (18 de julho de 1798), pouco antes de sua partida, um longo discurso sobre diversos

\footnotetext{
1591 "Convinced that good education is essential to good citizenship, this Convention, and the Societies in the different States represented in it, endeavour to increase the number of useful schools for the Instruction of the Africans and their children. By instilling into their minds the benefits of knowledge, and by training them up in regular and oeconomical habits, they are enabled to form a true estimate of the nature of liberty to respect the rights of other men as well as their own, in short, they are instructed to be industrious and to be honest" (Lettre de la Convention pour l'abolition de l'esclavage aux États-Unis, p.370).

1592 "[...] des exemples qui prouvent la sensibilité des jeunes Négres, et qui démontrent que tout ce qui a été fait par la main des hommes pouvait être réalisé par les mains des Noirs" (cf. Notes des séances de la Société des Amis des Noirs et des Colonies, p.336).
} 
objetos relativos às colônias, em especial, a instrução pública, a agricultura e o comércio. Sobre a organização da instrução pública na Guadalupe, Dupuch indicaria que o cidadão Blanche, professor de letras nas escolas centrais, tinha se voluntariado para cooperar com essa tarefa. Blanche propunha-se a formar uma coleção completa de livros elementares para as escolas primárias e o ensino da moral republicana, assim como uma coleção de livros clássicos, modelos, gravuras, mapas, planos, instrumentos e máquinas. O próprio Dupuch informaria que levaria consigo materiais preciosos e livros antigos para serem depositados nas bibliotecas da Guadalupe, e convidava os Amigos dos Negros e das Colônias a designar as obras mais adequadas ao objetivo da instrução pública. $^{1593}$

Não se deve duvidar da sinceridade dos Amigos dos Negros quanto aos planos de instrução dos antigos escravos. Contudo, o fato é que, por trás desses planos, estava a ideia de que, por não estarem aptos a gozar plenamente de seu novo estado, a liberdade dos negros podia sofrer restrições. A inserção social dos antigos escravos, a sua conversão em "cidadãos", só era pensada dentro dos limites do trabalho nas grandes plantações de café e açúcar. Preparar os negros para a liberdade significava, acima de tudo, fazer deles bons operários agrícolas: disciplinados, capazes de assimilar novas técnicas e aptos a viver em sociedade de acordo com os valores, costumes e hábitos de consumo europeus. Até que atingissem esse estágio, os negros deveriam ser mantidos num estado de liberdade restrita. Era, no fundo, essa percepção que tinha inspirado os sistemas de trabalho compulsórios instituídos em São Domingos e na Guadalupe. Na medida em que os Amigos dos Negros não abandonavam a sua postura colonial, a emancipação dos negros exigia a fixação de estágios intermediários de semi-liberdade para os antigos escravos. Essa convicção permitia aos antiescravistas recuperarem o gradualismo que havia orientado o programa da primeira Sociedade.

\section{III.2.2.4) Trabalho livre nas colônias e inovações na cultura colonial}

Tema bastante discutido nas sessões da Sociedade foi o da transição da economia colonial escravista para uma economia baseada no trabalho livre. Essa era, afinal, uma das preocupações essenciais dos Amigos dos Negros. Dentro da ideia da incompatibilidade do trabalho servil com a evolução tecnológica do cultivo da terra, as

${ }^{1593}$ Cf. Discours prononcé à la Société des Amis des Noirs et des colonies à Paris (30 messidor an VI). In: DORIGNY, Marcel, GAINOT, Bernard. La Société des Amis de Noirs, pp.373-374. 
suas esperanças residiam na possibilidade de introduzir nas colônias, agora livres da escravidão, novas técnicas de produção que permitissem a valorização do solo.

Logo nas primeiras sessões da Sociedade, em 10, 20 e 30 nivoso do ano VI (30 de dezembro de 1797, 9 e 19 de janeiro de 1798), foi apresentado um memorial de Wadström sobre a cana de açúcar em Batavia (Mémoire sur la culture des Cannes à sucre). ${ }^{1594}$ Nesse que foi o texto mais discutido nas primeiras sessões da Sociedade, Wadström indicava que a cana de açúcar, assim como o rum, era cultivada nas Índias orientais (China, Cochinchina, Bengala, costa do Malabar e Batavia) com mão de obra livre e que a produção era de uma qualidade superior e menos custosa que a das ilhas do golfo do México e igualava o melhor açúcar produzido nas ilhas ocidentais.

Wadström dava detalhes da organização da produção na ilha de Batavia, onde a cultura de cana era a mais considerável. Em geral, o grande proprietário dividia as suas plantações em parcelas de 300 arpents (cerca de 150 hectares), construindo em cada uma delas edifícios sólidos. Alugava, então, cada uma dessas divisões a chineses que as ocupavam como fazendeiros (arrendatários) e as subarrendavam, em parcelas de 50 arpents (cerca de 25 hectares), a pessoas livres, sob a condição de que estas deveriam plantar a cana de açúcar contra o pagamento de um determinado valor por pecúlio (153,5 libras) de açúcar produzido. O principal fazendeiro contratava, para fazer a colheita, operários das aldeias vizinhas: uns ficavam encarregados do corte da cana e seu transporte para o moinho; outros de fazer ferver o suco dela proveniente; os demais cobriam esse suco com uma camada fina de argila para branquear o açúcar e enchiam as cestas para serem vendidas. Esses diferentes operários recebiam um determinado valor por pecúlio produzido e, com o fim da colheita, retornavam a seus lares durante sete meses. No terreno, permaneciam apenas os sub-fazendeiros ou os plantadores que preparavam o solo para a colheita seguinte. A destilação não era feita nas plantações de cana, mas por um destilador, que podia comprar o produto de cem plantações. Essa organização revelava-se mais lucrativa do que a feita nas colônias americanas, onde cada plantação tinha a sua própria destilaria. ${ }^{1595}$

O sueco destacava ainda a aplicação de métodos mais modernos de produção. Nas ilhas americanas, a enxada era o único instrumento utilizado para o cultivo da cana, exigindo do negro um uso intenso de suas forças. O resultado era sempre insatisfatório,

\footnotetext{
${ }^{1594}$ Cf. Notes des séances de la Société des Amis des Noirs et des Colonies, p.331-332.

${ }^{1595}$ Cf. La Décade philosophique, littéraire et politique, número 23, 20 floreal do ano VI (9 de maio de 1798), pp.263-265.
} 
em razão de: 1) a imperfeição das enxadas; 2) a desigualdade da força dos operários; 3) a maior ou menor boa vontade destes. Em Batavia, uma charrua leve, puxada por um único animal, era empregada com sucesso. Com esse método, duas pessoas faziam, num dia, o trabalho de dez negros com uma enxada. Wadström concluía que era preciso assim, nas ilhas ocidentais: 1) dar mais trabalho aos animais e menos aos homens; 2) empregar a maior parte dos terrenos em pastos ou prados artificiais; 3 ) executar todos os transportes ao moinho ou outros locais sobre charretes e não nas costas de homens; 4) não ter mais destilarias nas plantações, deixando essa etapa do processo para estabelecimentos especializados; 5) preferir a charrua à enxada; 6) refinar ou branquear nas colônias apenas a quantidade de açúcar necessária ao consumo dos Colonos, e enviar o excedente para as refinarias já estabelecidas na França; 7) fazer pequenos canais para o transporte e a irrigação; 8) adotar, para a irrigação dos campos da cana e dos pastos, a descoberta de Montgolfier e Argant ${ }^{1596}$, que permitiriam facilmente levar a água para locais mais distantes. ${ }^{1597}$

O texto propunha, portanto, a transição para um sistema de produção alternativo, com a introdução de animais e outras técnicas mais modernas que dispensariam o uso de uma mão de obra numerosa para o preparo da terra. A conversão de escravos em trabalhadores remunerados era apenas uma parte de um processo mais amplo de reestruturação da produção. Esse memorial seria publicado na Décade Philosophique, $\mathrm{n}^{\circ} 23$, de 20 floreal do ano VI (9 de maio de 1798). Foi também decidido que 2 mil cópias desse jornal seriam impressas, para serem distribuídas ao Corpo Legislativo e mesmo enviadas às colônias. ${ }^{1598}$

Discussões sobre técnicas de produção foram recorrentes nas sessões da Sociedade. Em 10 frimário do ano VI (30 de novembro de 1797), por exemplo, Lavaux fez novas observações sobre a implantação da charrua nas colônias, instrumento cuja utilização permitiria, segundo ele, substituir o trabalho de cinquenta negros. ${ }^{1599}$ Em 30 nivoso do ano VI (19 de janeiro de 1798), houve uma discussão sobre a possibilidade de transposição para as colônias ocidentais dos métodos de cultivo de cana de açúcar empregados na Índia. No mesmo dia, Servan discursou a respeito das vantagens que

\footnotetext{
${ }^{1596}$ Wadström referia-se aos experimentos conduzidos pelos irmãos Montgolfier, com o auxílio do físico e químico suíço Argant, que levaram à invenção de balões de ar quente que permitiram, em 1783, ao homem voar pela primeira vez.

${ }^{1597}$ Cf. La Décade philosophique, littéraire et politique, número 23, 20 floreal do ano VI (9 de maio de 1798), pp.265-268.

${ }^{1598}$ Cf. Notes des séances de la Société des Amis des Noirs et des Colonies, p.344.

${ }^{1599}$ Ibidem, p.330.
} 
traria a introdução de novas técnicas de irrigação nas colônias, fazendo nova referência aos balões de ar quente de Argant e Montgolfier. Na sessão de 10 pluvioso do ano VI (20 de janeiro de 1798), Wadström fez uma exposição a respeito do aperfeiçoamento do moinho de cilindro para esmagar a cana de açúcar. ${ }^{1600}$ Alguns meses depois, em 30 floreal do ano VI (19 de maio de 1798), foi a vez de Malenfant ler um memorial sobre a cultura de cana. ${ }^{1601}$

Em 30 messidor do ano VI (18 de julho de 1798), Dupuch, então de partida para a Guadalupe, abordou o tema da modernização da agricultura na ilha. Falou da introdução de máquinas e novas técnicas de produção que pudessem simplificar o trabalho na agricultura e nas manufaturas, reduzindo o custo de produção. Pediu que a Sociedade examinasse essa questão e propusesse meios de promover o progresso da agricultura colonial. Dupuch ainda sustentou que, dado o princípio da utilidade recíproca que orientava as relações comerciais entre a França e suas colônias, estas deveriam apenas fabricar açúcar bruto, deixando o seu processamento para a metrópole, o que favoreceria as manufaturas francesas. ${ }^{1602}$

Todas essas manifestações apontavam para o mesmo caminho: a modernização da produção agrícola, impossível no antigo sistema escravista. Nesse sentido, os Amigos dos Negros retomavam as lições de Adam Smith e dos Fisiocratas a respeito da produtividade do trabalho escravo. É preciso, entretanto, esclarecer que, para alguns antiescravistas, dado o futuro incerto das colônias americanas, as discussões sobre a modernização da produção colonial estavam voltadas menos para as colônias existentes do que para os estabelecimentos que a França ainda haveria de criar.

\section{III.2.2.5) Expansão colonial sobre novas bases}

Ao longo de sua existência, em momento algum, os Amigos dos Negros defenderam a ideia da independência das colônias como complementar à emancipação dos negros. Ao contrário, desde 1788, os seus planos tinham por objetivo a conservação dos territórios ultramarinos pela França e, mais do que isso, a expansão do império colonial francês, com base num modelo colonial alternativo ao da plantation escravista. Esse ponto, já importante na primeira Sociedade, tornou-se central na sua segunda

\footnotetext{
${ }^{1600}$ Ibidem, pp.333-334.

${ }^{1601}$ Ibidem, p.345.

${ }^{1602}$ Ibidem, pp.375-376.
} 
formação e assumiu, na maioria dos casos, a forma de projetos para a África. As palavras "e das colônias", acrescentadas ao nome da Sociedade original expressavam justamente a ideia de que o abolicionismo não implicava uma rejeição da empresa colonial; ao contrário, ele podia ser o ponto-de-partida para uma nova forma de colonização.

Com o fim da escravidão, a ampliação do império colonial tornava-se legítima do ponto de vista dos princípios. A França, potência republicana e libertadora, estava credenciada a levar a liberdade e a civilização para outras terras e outros povos. A lógica assimilacionista que havia orientado a Constituição de 1795 reproduzia-se integralmente no discurso da Sociedade dos Amigos dos Negros e das Colônias.

A ideia de fundar novas colônias, com base nos princípios da República, não era nova. Como vimos anteriormente, os primeiros Amigos dos Negros haviam formulado, ainda que de forma vaga, projetos nesse sentido. Mesmo fora da Sociedade, alguns simpatizantes haviam aderido a essa ideia. Bernardin de Saint-Pierre, por exemplo, tinha aventado, em Suite des voeux d'un solitaire, de janeiro de 1792, a possibilidade de estabelecer novas colônias sem escravidão, especialmente na Nova-Holanda (atual Austrália ocidental), como opção para trabalhadores franceses desprovidos de terras. ${ }^{1603}$

Mesmo após o fim da primeira Sociedade, alguns de seus principais membros continuavam a desenvolver a ideia de uma nova etapa para a colonização francesa. Condorcet, um dos principais agitadores da Sociedade original, havia concluído em outubro de 1793, pouco antes de sua morte, uma de suas obras máximas, Esquisse d'un tableau historique des progrès de l'esprit humain (publicada postumamente, em 1795). O autor formulava, em termos gerais, as bases de uma missão civilizadora das grandes nações europeias e, sobretudo, da França. Pretendia demonstrar que a natureza não havia fixado nenhum termo ao aperfeiçoamento das faculdades humanas e que os progressos das luzes e da virtude, do respeito pelos direitos naturais do homem e da felicidade tornar-se-iam inseparáveis quando as luzes tivessem atingido um número maior de nações e tivessem "[...] penetrado a massa inteira de um grande povo, cuja língua seria universalmente difundida, cujas relações comerciais cobririam toda a

${ }^{1603}$ Cf. BERNARDIN DE SAINT-PIERRE, Jacques Henri. Suite des voeux d'un solitaire. In: Oeuvres complètes. Paris: Méquignon-Marvis, 1818, v.11, pp.278-279. 
extensão do globo" (grifo nosso). ${ }^{1604} \mathrm{O}$ comércio aparecia como o veículo para a difusão da civilização entre os povos.

Mas, se Condorcet legitimava a expansão colonial francesa, ele a concebia apenas com base num modelo diverso daquele que havia levado ao caos nas ilhas. $\mathrm{O}$ autor afirmava que a história da colonização havia demonstrado que os monopólios, as traições e o desprezo sanguinário dos brancos por homens de outra cor ou crença, assim como o proselitismo extravagante e as intrigas dos padres, haviam destruído o sentimento de respeito que a superioridade das luzes europeias e as vantagens de seu comércio tinham conseguido inicialmente. Aproximava-se, entretanto, o momento em que os europeus se revelariam a esses povos, não mais como tiranos ou corruptores, mas como "instrumentos úteis, ou generosos libertadores". Acreditava, assim, que, estabelecida no continente africano, a cultura de açúcar destruiria o terrível comércio de escravos que o despovoava há mais de dois séculos. Estabelecimentos antes destinados ao tráfico se converteriam em "colônias de cidadãos que [difundiriam], na África e na Ásia, os princípios e o exemplo da liberdade, as luzes e a razão da Europa". ${ }^{1605}$ Esse novo tipo de comércio permitiria "civilizar" os continentes africano e asiático, de tal forma que, um dia, a terra abrigaria apenas homens livres, comandados pela razão. ${ }^{1606}$ Ou seja, Condorcet falava em civilizar os homens não apenas por meio do trabalho, mas também pelo consumo.

Cabia à Europa, situada no topo de uma hierarquia dos diferentes estágios de sociedade, civilizar pacificamente o restante do planeta. A expansão colonial permitiria não apenas gerar riquezas, mas obter e transmitir verdades sobre a humanidade. ${ }^{1607}$ Essa missão civilizatória tinha um instrumento privilegiado, o comércio, desde que purificado e conduzido de acordo com os princípios ditados pela razão e pela virtude.

Essa mesma ideia de redefinição e ampliação do império colonial sobre novas bases foi extensamente explorada por alguns dos principais líderes da segunda fase dos Amigos dos Negros, caso do sueco Wadström. Num momento em que as colônias americanas pareciam perdidas, a África apresentava-se como a melhor possibilidade para a formação de um novo império colonial, capaz de satisfazer a demanda por produtos coloniais, sem a necessidade de recorrer ao escravismo. Em Précis sur

\footnotetext{
${ }^{1604}$ Cf. CONDORCET, Jean-Antoine-Nicolas de Caritat. Esquisse d'un tableau historique des progrès de l'esprit humain. Paris: Edition, 1966, pp.77 e 83.

${ }^{1605}$ Ibidem, pp.256-257.

1606 Ibidem, pp.258-259.

${ }^{1607}$ Cf. PITTS, Jennifer. Naissance de la bonne conscience coloniale, pp.197-201.
} 
l'établissement des colonies de Sierra Léona et Boulama, Wadström, que havia conhecido de perto a costa africana, abordou os experimentos de colonização livre conduzidos pelos antiescravistas ingleses em Serra Leoa, assim como o experimento semelhante empreendido na ilha de Boulama, parte do arquipélago de Bissagos, próximo à atual Guiné-Bissau. Os dois estabelecimentos haviam sido pautados pelos mesmos objetivos: "1 $1^{\circ}$. a abolição do tráfico; $2^{\circ}$. a civilização dos negros na África; $3^{\circ}$. o estabelecimento de um comércio humano e social entre a Europa e a África, fundado mais sobre a troca de produtos úteis do que sobre especulações pecuniárias". ${ }^{1608} \mathrm{~A}$ guerra entre as potências europeias havia arruinado a empresa, mas Wadström acreditava, assim mesmo, que a experiência já tinha sido capaz de provocar mudanças na região, levando os reis locais a darem encorajamentos à agricultura, após perceberem que os progressos da produção agrícola, na medida em que multiplicavam a população e a circulação de produtos em seus reinos, valiam mais do que as especulações dos mercadores de escravos europeus. ${ }^{1609}$ Wadström acreditava que essas "colônias filantrópicas" poderiam se desenvolver por si próprias quando, por meio de encorajamentos à cultura, os seus habitantes estivessem em condições de tirar partido dos dons da natureza, tão rica e generosa nessa parte do mundo:

Então, e desta maneira, veremos abrir-se entre a Europa e o trópico uma comunicação aprovada pela justiça e a razão, igualmente salutar e vantajosa para essas duas partes do mundo, e consoladora para a humanidade, há tanto tempo ultrajada pelo horrível tráfico de escravos. Então, os povos civilizados e as nações não-civilizadas estenderão mutuamente uma mão caridosa às suas necessidades respectivas: qualquer outro objetivo das colônias deve ser visto como uma verdadeira loucura que lança as suas pátrias-mães em gastos e guerras ruinosas. ${ }^{1610}$

Seguindo a mesma lógica do projeto de Wadström, Montlinot distribuiu, na sessão de 30 floreal do ano VI (19 de maio de 1798), vinte exemplares de um projeto a respeito da ilha de Boulama. O projeto consistia em instalar na ilha uma colônia penitenciária, assim como outros estabelecimentos que seriam valorizados por

\footnotetext{
$1608 " 1^{\circ}$. l'abolition de la traite; $2^{\circ}$. la civilisation des nègres en Afrique; $3^{\circ}$. l'établissement d'un commerce humain et social entre l'Europe et l'Afrique, fondé plutôt sur l'échange de denrées utiles, que sur des spéculations pécuniaires" (WADSTRÖM, Carl Bernhard. Précis sur l'établissement des colonies de Sierra Léona et de Boulama, p.37).

${ }^{1609}$ Ibidem, pp. 14 e 36.

1610 "Alors et de cette manière on verra s'ouvrir enfin entre l'Europe et le tropique une communication avouée par la justice et la raison, également salutaire et avantageuse à ces deux parties du monde, et consolante pour l'humanité, depuis si longtemps outragée par l'horrible traite des esclaves. Alors les peuples civilisés et les nations non-civilisées se tendront mutuellement une main secourable pour leurs besoins respectifs: tout autre but des colonies doit être regardé comme une véritable folie qui jette leurs mères-patries dans des dépenses et des guerres ruineuses" (Ibidem, p.40).
} 
camponeses sem terra da metrópole. Monlinot estimava que as Antilhas já estavam perdidas e que era necessário transpor para a África as produções das colônias americanas, mas agora sem escravidão. ${ }^{1611}$

Na mesma sessão, outro membro da Sociedade, Geoffroy de Villeneuve leu um memorial a respeito de suas viagens na África, que seria publicado em 1814, sob o título L'Afrique, ou histoire, moeurs, usages et coutumes des Africains. Le Sénégal. Villeneuve acreditava que as colônias americanas estavam decadentes e que era necessário substituir esses estabelecimentos de grandes culturas por "meios que estejam de acordo com as ideias emitidas hoje". Ou seja, pregava novos rumos para a empresa colonial, baseado num modelo de colônia livre que o autor definia como:

[...] um local onde a maioria das plantas comerciais é indígena, onde pode-se reunir em pouco tempo os elementos dispersos de uma população imensa, levar para uma parte do mundo até aqui não civilizada, e com o tempo talvez até mesmo para o próprio coração da África, as luzes, a civilização e a agricultura, fazer nascer, para a felicidade dos povos e para a prosperidade do comércio da França, os gozos e as necessidades que trazem consigo o conhecimento das artes [...]. ${ }^{1612}$

Para Villeneuve, a África - e, mais especificamente, Cabo Verde - oferecia possibilidades imensas para esse novo tipo de colonização. $\mathrm{O}$ autor via nessa ilha um local de clima salubre e de solo particularmente fértil - uma "terra vegetal de um vermelho escuro, que, mesmo sob um céu ardente, sabe conservar um frescor salutar". ${ }^{1613}$ Acreditava que as plantações da África não deviam nada às de São Domingos, possuindo até mesmo maior força e vigor e, se não tinham se transformado em bens de comércio, era por carência de técnicas e instrumentos que apenas as nações civilizadas dominavam. ${ }^{1614}$ Villeneuve argumentava que as culturas de cana de açúcar e café podiam ser perfeitamente realizadas em Cabo Verde, onde o anil e o algodão já eram produzidos naturalmente. Dada a salubridade do clima, a qualidade de seu solo, a abundância dos recursos naturais, a facilidade das construções e a sua população, a ilha era o local ideal para substituir, de forma vantajosa e em acordo com os princípios da

\footnotetext{
${ }^{1611}$ Cf. Notes des séances de la Société des Amis des Noirs et des Colonies, pp.345-346 e nota 54.

1612 "[...] un lieu où la plupart des plantes commerciales sont (sic) indigènes, où l'on peut rassembler en peu de temps les éléments épars d'une population immense, porter dans une partie du monde non civilisée jusqu'ici, et par suíte de temps peut-être jusque dans le coeur même de l'Afrique, les lumières, la civilisation et l'agriculture, faire naître, pour le bonheur des peuples et pour la prospérité du commerce de la France, les jouissances et les besoins qui entrainent avec eux la connaissance des arts [...]" (GEOFFROY DE VILLENEUVE, René Claude. L'Afrique, ou histoire, moeurs, usages et coutumes des Africains. Le Sénégal. Paris: Neupveu, 1814, v.1, pp.110-111).

1613 Ibidem, pp.114-115.

1614 Ibidem, pp.116-117.
} 
filantropia, os estabelecimentos coloniais na América. A proteção e a civilização que a metrópole traria para a nova colônia, em troca de seus produtos, constituiria a base de um comércio salutar, que atrairia as populações limítrofes e se estenderia com o tempo ao interior da África. Esse novo comércio promoveria uma verdadeira "revolução moral" no continente. ${ }^{1615}$ A Sociedade decidiu que uma comissão, formada por Servan, Bourdon e Lescallier, ficaria encarregada da apresentação de um projeto para a criação de um estabelecimento em Cabo Verde, com base nas informações contidas no memorial de Villeneuve. ${ }^{1616}$ Ideias desse tipo seriam recorrentemente exploradas nas sessões da Sociedade. Em 30 pluvioso do ano VII (18 de fevereiro de 1799), por exemplo, Deniay apresentou um memorial sobre o estabelecimento francês no reino de Judah, na costa ocidental da África, para o qual propunha a transferência da cultura das Antilhas, como experiência colonial alternativa ao sistema de plantation. ${ }^{1617}$

Deve-se, por fim, notar que o economista e membro da Sociedade Jean-Baptiste Say também pregaria a necessidade de mudar os rumos do comércio francês no célebre Traité d'économie politique, cuja primeira versão seria publicada apenas em 1803 . Na obra, Say expressaria com precisão a aversão dos antiescravistas ao comércio colonial tal como ele era praticado. Embora, na primeira edição, ainda sustentasse o caráter lucrativo do trabalho escravo ${ }^{1618}$, contrariando o argumento, explorado por Smith, da falta de motivação do escravo para trabalhar, Say situava a sua condenação da escravidão no quadro mais geral de uma crítica ao sistema colonial como um todo, benéfico aos comerciantes da metrópole, em detrimento do restante da Nação, pois o consumidor ficava submetido a preços muito superiores aos que seriam oferecidos num sistema de livre comércio:

\footnotetext{
${ }^{1615}$ Ibidem, pp.125-129.

${ }^{1616}$ Cf. Notes des séances de la Société des Amis des Noirs et des Colonies, p.346.

${ }^{1617}$ Ibidem, p.361; DORIGNY, Marcel, GAINOT, Bernard. La Société des Amis de Noirs, p.361, nota 89.

1618 Cf. SAY, Jean-Baptiste. Traité d'économie politique, ou simples exposition de la manière dont se forment, se distribuent, et se consomment les richesses. Paris: Deterville, 1803, v.1, pp.216-224. Com o tempo, Say se mostraria cada vez menos convicto do caráter lucrativo do trabalho escravo: assim, na terceira edição do Tratado, de 1817, Say já reconhecia que a escravidão era perniciosa a todos os demais desenvolvimentos da indústria, pois desonrava o trabalho; em 1826, na $5^{\text {a }}$ e última edição, ele mudaria radicalmente de posição, afirmando que o sistema de plantation não lhe parecia mais rentável e que o trabalho servil não era mais produtivo. Passou a ressaltar a melhor qualidade do trabalho livre, mesmo que fosse mais caro. Pregaria uma mudança radical nas relações de trabalho, única forma de viabilizar a verdadeira indústria (cf. STEINER, Philippe. J.-B. Say et les colonies, ou comment se débarasser d'un héritage intempestif. Cahiers d'économie politique, Paris, n.27-28, pp.157-158, 1996; ROCHA, Antonio Penalves. As observações de Jean-Baptiste Say sobre a escravidão. Estudos Avançados, São Paulo, v.1, n.1, 1987, pp.197-199).
} 
Os governos não podem deixar de sentir, mais cedo ou mais tarde, que é uma bobagem, mesmo diante dos interesses atuais, enriquecer alguns particulares em detrimento de uma nação, da qual eles tiram, afinal, todas as suas receitas, e chamar isso de favorecer o comércio. ${ }^{1619}$

Mas o objetivo de Say era menos o de propor a independência das colônias do que propor uma reformulação dos laços que as uniam à metrópole. Imaginava, sobretudo, a definição de novos rumos para o comércio francês a partir de um projeto de colonização moderna voltado para a difusão da civilização europeia entre os povos mais atrasados. Nesse sentido, Say defendeu, ainda durante a existência dos Amigos dos Negros e das Colônias, um projeto de conquista do Egito, como primeiro passo de uma reformulação profunda do sistema comercial. A Décade Philosophique, littéraire et politique, revista da qual participavam Say e outros Amigos dos Negros (Labaume, Thérémin...), procurava difundir essas ideias. Nos números de 20 e 30 germinal do ano VI (10 e 20 de março de 1798), por exemplo, a revista trouxe um longo artigo, em duas partes, de Le Breton, favorável à conquista do Egito e da Síria na perspectiva de estabelecer novas relações comerciais. ${ }^{1620}$

Essas ideias não ficaram adstritas às discussões internas dos Amigos dos Negros. Vale observar que vários membros da Sociedade, como Stone, Wadström, HelenaMaria Williams, Say e Grégoire, tinham relações com Talleyrand, ministro das relações exteriores. ${ }^{1621}$ Ora, Talleyrand havia justamente defendido publicamente projetos de colonização para a África e o Oriente Médio. Em 15 messidor do ano V (4 de julho de 1797), ele tinha apresentado, em sessão pública do Instituto Nacional, um ensaio voltado para a definição de uma nova política colonial, publicado sob o nome Essai sur les avantages à retirer des colonies nouvelles dans les circonstances présentes. Na medida em que dava como certa e inevitável a separação futura das colônias americanas, Talleyrand acreditava que era possível apenas retardar o processo, tirando o maior proveito possível do tempo que restava. Ao mesmo tempo, frisava a necessidade de olhar para outras partes do mundo, no intuito de preparar o estabelecimento de novas colônias, cujos laços com a metrópole seriam "mais naturais, mais úteis e mais

\footnotetext{
${ }^{1619}$ "Les gouvernements ne peuvent manquer de sentir tôt ou tard, que c'est une sottise, même dans les intérêts actuels, d'enrichir quelques particuliers aux dépens d'une nation, de laquelle après tout ils tirent leurs revenus, et d'appeler cela favoriser le commerce" (SAY, Jean-Baptiste. Traité d'économie politique, pp.227-228).

${ }^{1620}$ Cf. La Décade philosophique, littéraire et politique, número 20, 20 germinal do ano VI (10 de março de 1798), pp.74-86; número 21, 30 germinal do ano VI (20 de março de 1798), pp.147-154.

${ }^{1621}$ Cf. DORIGNY, Marcel, GAINOT, Bernard. La Société des Amis de Noirs, p.313; WANQUET, Claude. La France et la première abolition de l'esclavage, pp.464-465.
} 
duráveis". Defendia a tese de que "o efeito necessário de uma constituição livre é o de tender incessantemente a tudo ordenar, dentro e fora dela, para o interesse da espécie humana". Entendia que as revoluções, sobretudo quando feitas em nome da liberdade, tendiam a provocar uma "inquietude geral nos espíritos, uma necessidade de movimento, uma disposição vaga nas empresas arriscadas, e uma ambição nas ideias, que tende sempre a mudar e a destruir". ${ }^{1622}$ Ora, na medida em que essa agitação não podia ser neutralizada, ela tinha de ser regulada, direcionada em proveito do bem público. Nos Estados Unidos, essa necessidade de agitação pôde se satisfazer num continente vasto e ainda inexplorado. Para a França, colônias novas poderiam oferecer um campo para essa expansão. Talleyrand acreditava que, após as convulsões da Revolução e da guerra, muitos homens industriosos na França ambicionariam um novo começo e poderiam encontrar nesses estabelecimentos coloniais um novo lar. ${ }^{1623}$

Visando apenas a despertar a atenção pública, Talleyrand dava poucos detalhes a respeito dos novos estabelecimentos coloniais, mas refletia a respeito dos vínculos que manteriam com a metrópole. Para ele, embora os governos estivessem acostumados a impor leis proibitivas às suas colônias, era o interesse recíproco que constituía o verdadeiro laço que os unia, sobretudo quando esse interesse era reforçado por uma origem comum. O ministro caracterizava esse modelo colonial da seguinte forma: "[...] nada de dominação, nada de monopólio; sempre a força que protege, nunca a que toma para si; justiça, benevolência; eis os verdadeiros cálculos para os estados como para o indivíduos; eis a fonte de uma prosperidade recíproca". ${ }^{1624}$

Talleyrand sugeria que a costa da África se apresentava como um espaço viável para a constituição desses novos estabelecimentos. Citou, nesse sentido, o memorial de Montlinot, um Amigo dos Negros e das Colônias, sobre um arquipélago de terras férteis ao longo da costa africana, assim como o projeto do duque de Choiseul que, em 1769, tinha concebido uma ocupação do Egito, no intuito de substituir as colônias americanas em caso de separação. Mencionou ainda os empreendimentos ingleses em Bengala, Serra Leoa e Boulama, projetos que se inscreviam no mesmo modelo de colonização

\footnotetext{
1622 "L'effet nécessaire d'une constitution libre est de tendre sans cesse à tout ordonner, en elle et hors d'elle, pour l'intérêt de l'espèce humaine"; "inquietude générale dans les esprits, un besoin de mouvement, une disposition vague aux entreprises hasardeuses, et une ambition dans les idées, qui tend sans cesse à changer et à détruire" (TALLEYRAND, Charles Maurice. Essai sur les avantages à retirer de colonies nouvelles dans les circonstances présentes. S.1.: Baudouin, s.d., pp.3-5).

${ }^{1623}$ Ibidem, pp.5-6 e 9-10.

1624 "[...] point de domination, point de monopole; toujours la force qui protège, jamais celle qui s'empare; justice, bienveillance; voilà les vrais calculs pour les états comme pour les individus; voilà la source d'une prospérité reciproque" (Ibidem, pp.12-13).
} 
livre, sem tráfico ou sistema exclusivo, onde a cultura dos produtos coloniais tinha de ser feita no local de nascimento dos cultivadores. ${ }^{1625}$ Wadström escreveu a Talleyrand em 17 frimário do ano VI para parabenizá-lo por sua conferência no Instituto. Essa carta foi publicada como introdução ao Précis sur l'établissement des colonies de Sierra Léona et Boulama, que o sueco endereçou ao ministro das relações exteriores, na esperança de contribuir para o projeto de estabelecer novas colônias. ${ }^{1626}$

Pode-se, eventualmente, especular que a grande campanha do Egito, decidida pelo Diretório em 5 de março de 1798 e conduzida pelo general Bonaparte, teria sido uma aplicação prática dessas concepções. A expedição se situava no quadro da disputa comercial com a Grã-Bretanha e um de seus objetivos era estabelecer um ponto estratégico para o comércio francês na rota para o Oriente.

De qualquer forma, todos esses projetos eram reveladores do verdadeiro sentido do combate dos Amigos dos Negros naquele contexto pós-abolição. Se, para a primeira formação, a prioridade era pensar uma transformação progressiva das colônias francesas com vistas à superação por etapas de um modelo de exploração que consideravam perigoso para a conservação desses territórios, o objetivo fundamental agora era a definição de um novo modelo para o funcionamento e a expansão do império colonial francês. O bom funcionamento do sistema colonial e a sua capacidade de influir positivamente na economia metropolitana continuavam a ser preocupações fundamentais para os Amigos dos Negros, mesmo que sua estratégia tivesse sido alterada pelo curso dos eventos.

\section{III.2.2.6) Projetos gradualistas}

Naquele contexto, os Amigos dos Negros e das Colônias, mais preocupados em redefinir os rumos da colonização francesa, praticamente esqueceram os antigos projetos gradualistas da sua primeira formação. Para o bem ou para o mal, a abolição geral e abrupta já era vista como um fato consumado. Isso não impediu alguns supostos antiescravistas de retomarem algumas das ideias defendidas nos primeiros anos da Revolução. Daniel Lescallier, membro das duas formações dos Amigos dos Negros, poderia em tese ser visto como uma exceção no seio dos antiescravistas, mas o fato é

\footnotetext{
${ }^{1625}$ Ibidem, pp.14-15.

${ }^{1626}$ Cf. WADSTRÖM, Carl Bernhard. Précis sur l'établissement des colonies de Sierra Léona et de Boulama, pp.v-viii.
} 
que, àquela altura, ele passava discretamente para o campo antagonista. Sua participação na segunda Sociedade foi, aliás, bastante apagada. Em 1798, ele publicou Notions sur la culture des terres basses dans la Guiane et sur la cessation de l'esclavage dans ces contrées, onde descreveu, sob a forma de uma correspondência mantida entre um colono francês e um holandês, as mudanças provocadas pela abolição na Guiana. ${ }^{1627}$ A quarta e última carta versava sobre os meios de promover a abolição sem afetar a prosperidade das Colônias. O texto não condenava propriamente a abolição, mas indicava que, na Guiana, a liberdade abrupta dada aos antigos escravos tinha levado ao abandono ou à ruína da quase totalidade das plantations do bairro de Aprouague. ${ }^{1628}$ Esse resultado impunha questionamentos a respeito da transição de colônias escravistas para a liberdade. Lescallier acreditava que, se os efeitos da abolição tinham sido desastrosos, esse resultado se devia não ao princípio, mas à forma. Condenava, assim, o "sistema Robespierre" que tinha lançado a liberdade nas colônias, não como um ato de justiça, mas "como um meio de guerra e de defesa contra os oponentes da revolução e os inimigos da república", instaurando a anarquia nas colônias francesas. $^{1629}$

Lescallier entendia que a experiência da abolição tinha resultado em "[...] desastres que podem oferecer uma lição útil às demais colônias". A "lição útil" era, para Lescallier, a retomada dos mesmos argumentos gradualistas que defendia em 1789. As demais colônias deveriam chegar à liberdade, mas "sem choque, sem perturbações de propriedades particulares, e, sobretudo, sem efusão de sangue". ${ }^{1630}$ Isto é, a emancipação tinha de ser feita no longo prazo e de forma graduada. Acreditava que os negros boçais, não acostumados com a língua e os costumes europeus, não podiam ser todos postos em liberdade, sem precauções e intervalos. ${ }^{1631}$

Suas propostas estavam reduzidas a uma abolição do tráfico e à adoção de medidas destinadas a favorecer o aumento de sua população escrava, o que significava

\footnotetext{
${ }^{1627}$ Embora tivesse se baseado numa correspondência existente, a redação das cartas era de Lescallier e eram as suas ideias que estavam sendo veiculadas.

${ }^{1628}$ Cf. LESCALLIER, Daniel. Notions sur la culture des Terres basses dans la Guiane, Et sur la cessation de l'Esclavage dans ces Contrées. Paris: Imprimerie de F. Buisson, ano VII [1798], pp.73-74.

${ }^{1629}$ Lescallier afirmava que, se o caos não tinha sido instaurado na Guiana, era porque a população dessa colônia era pequena e dispersa e, sobretudo, porque um administrador humano - provavelmente, ele próprio, que tinha atuado como comissário na Guiana - tinha preparado a via para essa mudança, reprimindo as barbáries e inconsequências dos senhores, destruindo o marronnage e a vagabundagem e acostumando os negros a tirar certo proveito de seu trabalho. Assim mesmo, as culturas sofreram com a abolição, sendo quase totalmente arruinadas (Ibidem, pp.99-100).

${ }^{1630}$ Ibidem, pp.79-80.

1631 Ibidem, pp.83-84.
} 
apenas uma mudança na forma de reposição da mão de obra. No que se refere à passagem gradual dos negros para a liberdade, sugeria um sistema de gratificações, com participação crescente nas receitas, para encorajar os negros ao trabalho e convertê-los em consumidores de manufaturados europeus. ${ }^{1632}$

As propostas de Lescallier eram uma mera retomada das ideias que o autor tinha defendido em 1789. Isso poderia ser interpretado como um sinal de coerência, mas, naquele contexto pós-abolicionista, essa postura já assumia as feições de um próescravismo disfarçado. $\mathrm{O}$ autor chegava a sugerir que caberia às assembleias coloniais emitir as leis e regulamentos que presidiriam esse processo de emancipação progressiva. ${ }^{1633}$ Suas propostas tinham uma finalidade política concreta: evitar que a abolição fosse concretizada nas colônias onde ela ainda não havia sido proclamada, sobretudo nas colônias orientais, onde havia atuado como comissário civil após 1792. Diante das dificuldades na aplicação da abolição nas colônias francesas, o abolicionismo gradualista tendia a rumar para um restauracionismo escravista.

Que as ideias de Lescallier tenham permanecido marginais na Sociedade dos Amigos dos Negros e das Colônias é significativo. A aversão a uma abolição abrupta, manifestada pelos membros da primeira formação, não havia degenerado numa posição anti-abolição por parte de seus sucessores. A liberdade dos Negros era, afinal, um ato de justiça. Essa postura traduzia também um certo realismo quanto à impossibilidade de uma volta atrás, sobretudo em São Domingos.

Por outro lado, se os Amigos dos Negros e das Colônias não questionavam a abolição de 1794, isso não significa que eles tivessem abandonado as preocupações fundamentais que haviam orientado os esforços da primeira formação da sociedade. Ao contrário, o programa da nova Sociedade tornava ainda mais explícita a natureza da organização. O seu objetivo era pensar em formas de manter produtivas as colônias após uma medida que julgavam precipitada. Os temas abordados por esse grupo de homens a educação dos antigos escravos com vistas à sua inserção na economia colonial, a modernização do cultivo, a ampliação do império colonial sobre novas bases - são reveladores de inquietações relativas ao futuro da produção colonial e do comércio por esta alimentado. No geral, o que estava em discussão era mais a ideia de colônia do que fundamentalmente a luta contra a escravidão.

1632 Ibidem, pp.87-88 e 92-96.
${ }^{1633}$ Ibidem, p.89. 


\section{III.2.3) A organização constitucional das colônias}

\section{III.2.3.1) A lei de 12 nivoso do ano VI ( $\left(^{\circ}\right.$ de janeiro de 1798)}

Os Amigos dos Negros e das Colônias sabiam que a conservação e ampliação do território da Repúbica passavam necessariamente pela redefinição jurídica das colônias e de seus habitantes. A Constituição do ano III tinha estabelecido o princípio da assimilação das colônias à metrópole, mas ela tinha de ser complementada por uma lei específica sobre a organização colonial que tornasse os princípios constitucionais aplicáveis nas ilhas, o que implicava, aliás, distorcê-los. Naquele momento, a situação nas colônias era bastante instável. Em São Domingos, Toussaint Louverture movia a sua administração na direção de uma crescente autonomia. Na Guadalupe, em março de 1797, uma revolta havia explodido contra o regime de Hugues, quando alguns homens de cor incitaram os cultivadores a assumirem o controle das plantações. ${ }^{1634} \mathrm{O}$ contexto exigia que se desse às populações das colônias garantias de que a abolição não seria desfeita, única forma de assegurar a lealdade dos soldados negros e a autoridade da metrópole sobre suas colônias. Era preciso, por outro lado, regulamentar a liberdade de um modo compatível com o interesse nacional.

Como deputado e membro da Sociedade, Lavaux movia seus esforços na preparação de uma nova lei sobre a organização constitucional das colônias, destinada a criar as bases jurídicas para a sua assimilação à metrópole. $\mathrm{O}$ golpe de 18 fructidor tinha criado as condições para a formulação desse novo dispositivo. O projeto, apresentado por Lavaux ao Conselho dos Anciões, seria aprovado em 12 nivoso do ano VI $\left(1^{\circ}\right.$ de janeiro de 1798), marcando a principal conquista da segunda formação dos Amigos dos Negros.

O escopo da lei era estender às colônias as normas da Constituição, assim como as leis relativas à ordem judiciária e à administração civil e militar. A lei estabelecia a continuidade territorial e jurídica entre a metrópole e seus territórios ultramarinos, visando à generalização do regime constitucional em detrimento de regimes de exceção. Desta forma, ela confirmava a autorização dada ao Diretório de enviar agentes às colônias - três para São Domingos, três para a Guadalupe e demais ilhas de Barlavento e um para Caiena - por um prazo de 18 meses, com a missão de fazer executar a

${ }^{1634}$ Cf. DUBOIS, Laurent. A Colony of Citizens, pp.308-313. 
legislação sobre a divisão do território e colocar em atividade todas as partes da Constituição (artigos I e VIII). Esses agentes estavam autorizados a fazer regulamentos de cultura baseados na Constituição, que seriam executados provisoriamente até a adoção de leis específicas pelo corpo legislativo. Esses regulamentos compreenderiam: as obrigações recíprocas dos proprietários e cultivadores, os meios de educar as crianças, os meios de subsistência dos idosos e dos enfermos, e os meios de favorecer a população encorajando os casamentos e recompensando a fecundidade da união legítima (art. IX).

Sobre o estado civil e os direitos dos cidadãos, a lei trazia disposições destinadas a regulamentar a situação de antigos escravos. Além de revogar, no art. XXXI, o Code noir de 1685 e todas as outras leis contrárias à Constituição e ao decreto de 16 pluvioso, a lei determinava que todo indivíduo negro, nascido na África ou em colônias estrangeiras, seria livre assim que pusesse os pés nas ilhas francesas, enquanto parte do território da República (art. XVIII). Ela parecia estender a todos os antigos escravos os direitos inscritos na Constituição francesa, mas estabelecia, no art. XV, uma importante ressalva para os negros africanos, que constituíam a maioria da população das colônias:

Os indivíduos negros ou de cor, arrancados de sua pátria e transportados nas colônias, não são considerados estrangeiros; eles gozam dos mesmos direitos que um indivíduo nascido no território francês, se estão vinculados à cultura, se servem nas forças armadas, se exercem uma profissão ou emprego. (grifo nosso) ${ }^{1635}$

Dufay protestaria, perante o Conselho dos Anciões, que esse dispositivo criava uma distinção entre os negros nascidos em território francês e os nascidos em território estrangeiro ("franceses por adoção"). Ele podia, desta forma, gerar "um tipo de aristocracia capaz de reacender novamente nas colônias, e perpetuar nelas, os tumultos e a guerra civil". ${ }^{1636} \mathrm{O}$ fato é que a lei expressava a preocupação de combater a "vagabundagem" entre os antigos escravos, o que significava, em larga medida, neutralizar a sua tendência a abandonar as grandes plantações para empreender uma pequena cultura de subsistência. A liberdade e a cidadania, nos termos da lei, estavam vinculadas às funções que os novos livres tinham de cumprir nas sociedades coloniais:

\footnotetext{
1635 "Les individus noirs ou de couleur, enlevés à leur patrie et transportés dans les colonies, ne sont point réputés étrangers; ils jouissent des mêmes droits qu'un individu né sur le territoire français, s'ils sont attachés à la culture, s'ils servente dans les armées, s'ils exercent une profession ou métier" (art.XV)

${ }^{1636}$ Cf. DUFAY, Louis-Pierre. Opinion sur le titre III de la résolution soumise au Conseil des Anciens, concernant l'organisation de la Constitution dans les Colonies. De l'état et des droits de citoyen pour les Noirs dans les Colonies. Paris: Baudouin, s.d. [1798], p.3.
} 
as de cultivadores nas plantations, soldados no exército e, para uma minoria, artesãos ou assalariados no comércio. Nesse mesmo sentido, a lei determinava, nos artigos seguintes, que todo indivíduo condenado por vagabundagem por um tribunal seria privado dos direitos concedidos pelo artigo anterior, até que retomassem o cultivo ou ofício, ou profissão. Seria considerado vagabundo todo aquele que não pudesse certificar um domicílio ou um estado conhecido. O sentido do dispositivo era claro: estabelecer as condições para a transição das colônias para um regime de liberdade sem operar a ruína da produção agroexportadora. Na prática, isso estabelecia gradações na concessão da liberdade, restringindo-a para aqueles que não eram nascidos em território francês.

Quanto aos direitos de cidadania, todos estavam, em princípio, habilitados a exercê-los, mas, apesar dos esforços de Lavaux em favor dos cultivadores, a lei acabou estabelecendo condições que tornavam o seu exercício inviável para grande parte dos novos livres. O art. XIX dispunha que todo cidadão que quisesse gozar do direito de votar nas assembleias primárias teria de pagar uma contribuição pessoal equivalente a três jornadas de trabalho agrícola e deveria apresentar a quitação desse pagamento dez dias antes da realização das eleições. Dufay também contestaria esse artigo, alegando que os negros eram os criadores das riquezas coloniais e estas eram a sua verdadeira propriedade, de modo que não era cabível exigir deles que pagassem para votar. ${ }^{1637} \mathrm{O}$ caráter censitário da lei contrariava o espírito da lei de 16 pluvioso do ano II, mas coadunava-se com a Constituição do ano III, que havia restabelecido a distinção entre cidadãos ativos e passivos. No fundo, esse conjunto de dispositivos tinha o mesmo sentido: reafirmar a abolição da escravidão, mas restringir de tal forma os direitos dos novos livres que não lhes restasse outra alternativa a não ser continuar trabalhando nas grandes plantações de açúcar e café. A lei reconhecia, em princípio, os antigos escravos como sujeitos de direito, dotados de vontade subjetiva, mas não os autorizava a manifestá-la no que se referia à venda de sua força de trabalho. É dentro desses limites muito estreitos que a liberdade dos negros era preservada.

Contudo, a lei dispensava, no seu art. XX, os soldados do exército republicano negro dessa contribuição, fazendo deles cidadãos a parte inteira. Bastava que apresentassem, com dez dias de antecedência, um certificado do conselho de administração que atestasse a sua participação em uma ou mais campanhas contra os

${ }^{1637}$ Ibidem, pp.8-10. 
inimigos da República. ${ }^{1638}$ Esses soldados foram talvez os únicos a terem realmente exercido a cidadania prometida pelas assembleias da metrópole.

O artigo LXXXV era dedicado a um tema caro aos Amigos dos Negros, a instrução pública, tida como necessária para educar os antigos escravos para a sua nova existência como cidadãos da República. O dispositivo encarregava os agentes do Diretório de organizar, o quanto antes, a instrução pública nas colônias, em acordo com as leis existentes. $\mathrm{O}$ artigo seguinte previa ainda que, em cada departamento das colônias, no dia $1^{\circ}$ germinal, dia da festa da juventude, fossem escolhidos, entre os alunos da escola central, seis jovens, sem distinção de cor, para serem transportados para a França e educados em escolas especiais. ${ }^{1639}$

A lei trazia ainda dispositivos sobre os bens nacionais (artigos XLVIII e XLIX), determinando que, após a paz, estes seriam dados em arrendamento e adjudicados publicamente ao autor da melhor oferta. O leilão tendia a excluir a massa dos negros emancipados. Assim, a possibilidade de uma reforma agrária, destinada a favorecer o desenvolvimento de um pequeno campesinato negro nas colônias, ficava excluída. ${ }^{1640}$

Em suma, a lei de 12 nivoso procurava cumprir os seguintes objetivos: 1) consolidar a abolição da escravidão nas colônias, de modo a neutralizar quaisquer movimentos de independência entre as massas negras; 2) reconhecer os direitos de cidadania dos soldados negros do exército republicano colonial, cuja lealdade à França era necessária para garantir a defesa dos territórios ultramarinos; 3) coagir os novos livres ao trabalho, o que significava, essencialmente, forçá-los a permanecer nas plantações e dar continuidade à produção para exportação; 4) preparar gradualmente a inserção social desses novos livres e seus descendentes, por meio da instrução pública. A lei procurava reafirmar a abolição, mas dentro de limites que permitiriam manter os negros num estado de submissão suficiente para garantir a conservação das colônias e o restabelecimento do comércio. As semelhanças com os projetos gradualistas da década de 1780 não são mera coincidência.

\section{III.2.3.2) Aplicação da lei}

\footnotetext{
${ }^{1638}$ Cf. Moniteur, v.29, número 110, 20 nivoso do ano VI (9 de janeiro de 1798), pp.119-121.

${ }^{1639}$ Idem, v.29, número 113, 23 nivoso do ano VI (12 de janeiro de 1798), p.130.

${ }^{1640}$ Idem, v.29, número 112, 22 nivoso do ano VI (11 de janeiro de 1798), p.123.
} 
Tanto nas Antilhas quanto nas Mascarenhas, a França tinha perdido o controle das situações locais, que viviam um estado de caos administrativo. Ela pretendia restabelecer a ordem e a sua autoridade com base na aplicação da lei de organização das colônias de 12 nivoso do ano VI. Cabia ao Executivo tomar as medidas para a sua pronta execução, mas o fato de o ministério da Marinha estar nas mãos de Bruix, um nostálgico da antiga ordem colonial, gerava inquietações no campo antiescravista. $\mathrm{Na}$ prática, a aplicação dessa lei foi desigual, enfrentando, em certos casos, a oposição dos poderes estabelecidos nas colônias.

Para a Guadalupe, o general Desfourneaux, um antigo chouan $^{1641}$, foi nomeado governador em substituição a Victor Hugues, que tinha se recusado a aplicar a Constituição do ano III. Desfourneaux seria acompanhado por Dupuch, deputado da colônia no corpo legislativo e membro dos Amigos dos Negros e das Colônias. Ambos partiram em thermidor do ano VI (julho de 1798), com a missão de executar a lei de 12 nivoso. Esse esforço de implantação da ordem constitucional encontrou a resistência local dos adeptos de Hugues, que tinha derrotado os britânicos e contava com grande prestígio junto aos republicanos da ilha. ${ }^{1642}$ Assim, a chegada dos agentes do Diretório foi interpretada como uma manobra dos realistas e dos plantadores contrarrevolucionários. Desfourneaux, por sua vez, atribuiu a hostilidade à presença de Hugues e decidiu enviá-lo para a metrópole.

Na prática, Desfourneaux pôs em execução apenas os aspectos mais opressivos da nova lei. Em linhas gerais, esta viabilizava os regulamentos de trabalho compulsório que Hugues havia adotado, ao determinar que aqueles que fossem encontrados sem domicílio seriam considerados culpados de vagabundagem e seriam privados da cidadania até o seu retorno às plantações ou ao comércio, uma disposição que podia ser considerada inconstitucional. Tendo isso em vista, Desfourneaux declarou, após ter publicado a Constituição na colônia, que, na medida em que as colônias francesas estavam imersas na guerra contra as potências europeias, a ilha permaneceria em estado de sítio, de modo que o texto constitucional seria aplicado apenas parcialmente. Em

${ }^{1641}$ Os chouans eram os rebeldes monarquistas que protagonizaram, entre 1791 e 1800, um grande número de movimentos de revolta antirrepublicanos. Sua ação se concentrou no Oeste da França, na Bretanha, na Normandia, no Maine e no Anjou.

${ }^{1642}$ Vale observar que também na metrópole, Hugues era tido em alta conta nos meios democráticos. O Journal des hommes libres, principal órgão da corrente democrata, propôs, em messidor do ano VII, o nome de Victor Hugues para substituir Bruix no cargo de Ministro da Marinha. O escolhido, entretanto, seria Bourdon-Vatry, talvez por intervenção de Lavaux (cf. DORIGNY, Marcel, GAINOT, Bernard. La Société des Amis de Noirs, p.320). 
outras palavras, era uma forma de continuar a impor um regime de trabalho forçado que, pela sua própria natureza, contrariava os princípios da Constituição francesa.

Em fevereiro de 1799, Desfourneaux publicou uma lei detalhada sobre o regime de trabalho. Na medida em que rejeitava a distribuição de terras aos novos livres, a remuneração dos cultivadores era, para ele, a melhor forma de garantir a continuação da produção. Assim, foi instituído um sistema semelhante ao que Sonthonax havia adotado em São Domingos, em 1793: os cultivadores dividiriam entre si um quarto da receita, após dedução dos gastos de manutenção e dos salários dos gerentes. Em plantações de café e algodão, onde a colheita era feita apenas uma vez ao ano, adiantamentos seriam feitos aos cultivadores e deduzidos após a colheita. Desfourneaux fixou também os salários dos domésticos. Ao contrário de Sonthonax, entretanto, ele deu o mesmo pagamento a homens e mulheres. A sua política foi posta em prática em várias plantations privadas de Basse Terre, o que lhe permitiu obter certa estabilidade. ${ }^{1643}$

Em abril, foram organizadas eleições legislativas na Guadalupe. Durante o seu exercício, Hugues tinha simplesmente recusado o voto aos antigos escravos, mas Desfourneaux aplicou efetivamente a lei do Diretório, com todas as suas limitações, submetendo o direito de voto ao pagamento de um taxa, o que, na prática, acabava excluindo a grande maioria. Assim mesmo, na medida em que os soldados estavam isentos dessa contribuição, muitos antigos escravos realmente exerceram o seu direito. As eleições contaram com a participação de 16.600 votantes, número muito superior aos 3.989 brancos adultos recenseados em 1796. No mínimo, vários milhares de antigos escravos votaram efetivamente. ${ }^{1644}$

Nas Mascarenhas, a situação interna tinha evoluído muito pouco. As assembleias coloniais, dominadas por plantadores brancos, mantinham o regime de quase-autonomia que tinha rejeitado a lei de 16 pluvioso do ano II. Uma aplicação da lei de departamentalização de 12 nivoso era politicamente improvável, sobretudo porque a frota das Mascarenhas era um elemento estratégico indispensável do dispositivo de defesa contra os britânicos, no Oceano Índico. Por razões conjunturais, o Ministro da Marinha Bruix não queria desestabilizar as sociedades escravistas das colônias orientais. ${ }^{1645}$ Em 5 brumário do ano VII (26 de outubro de 1798), o Diretório nomeou Louis Monneron como agente do governo nas Mascarenhas, com a missão de fazer

\footnotetext{
${ }^{1643}$ Cf. DUBOIS, Laurent. A Colony of Citizens, pp.334-336.

${ }^{1644}$ Ibidem, p.339.

${ }^{1645}$ Cf. DORIGNY, Marcel, GAINOT, Bernard. La Société des Amis de Noirs, p.321.
} 
aplicar a Constituição e a nova legislação. Isso significava, em tese, aplicar a abolição, mas as suas instruções prescreviam que a operação fosse feita com toda a lentidão e a prudência necessárias. Na prática, Monneron proporia medidas de transição entre o estado de servidão e o de liberdade, mas a sua missão fracassaria. ${ }^{1646}$

Em São Domingos, a tentativa de aplicação da lei seria fonte de novas tensões entre o Diretório e a administração de Toussaint Louverture. O agente escolhido para aplicar a nova lei foi, talvez por influência de colonos emigrados, o general Hédouville. Ele tinha recebido ordens de limitar os poderes de Toussaint, que, àquela altura, era o governante de fato da colônia. Assim, na sua chegada à ilha, Hédouville procurou aliarse ao rival de Toussaint, o mulato Rigaud, e substituiu tropas negras por brancas em pontos estratégicos da colônia. Quanto ao regime de trabalho nas plantações, o general impôs aos cultivadores a obrigação de assinar contratos de seis a nove anos e ordenou a prisão de todos os "vagabundos". A truculência com que Hédouville conduzia a sua missão gerou revolta entre a população negra. Para neutralizar qualquer movimento de rebelião, Hédouville mandou prender Moïse, sobrinho adotado de Toussaint e comandante popular entre os cultivadores. Moïse escapou e organizou uma resistência, o que levou Toussaint a ordenar ao seu general Dessalines que prendesse e expulsasse o agente francês da colônia. Hédouville deixou a colônia em 22 de outubro de 1798, menos de seis meses após a sua chegada. Roume foi colocado por Toussaint em seu lugar. O único resultado da missão de Hédouville foi agravar as tensões entre Toussaint e Rigaud. Para enfrentar seu rival, Toussaint se voltou para os Estados Unidos e a GrãBretanha, com vistas a obter armas e suprimentos. Isso gerava novos problemas, tendo em vista que as ações dos corsários franceses tinham interrompido as relações entre a França e os Estados Unidos. Assim mesmo, Toussaint escreveu ao presidente John Adams para pedir o restabelecimento do comércio com São Domingos, o que fez com que milhares de armas começassem a entrar na colônia. ${ }^{1647}$

No geral, apesar do relativo sucesso inicial de Defourneaux na Guadalupe, a situação interna das sociedades crioulas, somada às tensões políticas na metrópole, acabou frustrando essa tentativa de reconquista constitucional das colônias. O Corpo legislativo, no seio do qual estavam muitos Amigos dos Negros, pressionava pela instituição do regime constitucional nos territórios ultramarinos, mas o ministério

${ }^{1646}$ Cf. WANQUET, Claude. La France et la première abolition de l'esclavage, p.492.

${ }^{1647}$ Cf. DUBOIS, Laurent. A Colony of Citizens, p.305-306; GAUTHIER, La première abolition, p.16. 
comandado por Bruix parecia querer limitar-se a restabelecer a autoridade metropolitana, sem dar satisfação à massa dos antigos escravos.

\section{III.2.3.3) Os Amigos dos Negros e Toussaint Louverture}

A aprovação da lei de 12 nivoso tinha sido acompanhada de comemorações do aniversário do decreto de abolição, com intervenções dos Amigos dos Negros e das Colônias nos dois Conselhos. Os discursos apontaram para dois caminhos distintos no que se referia às relações com Toussaint Louverture. No Conselho dos Quinhentos, Sonthonax apresentou um relatório sobre sua missão nas colônias, para defender-se das acusações contra ele dirigidas e denunciar Toussaint como o instrumento de um complô comandado por padres e emigrados. ${ }^{1648}$ Nos Anciões, ao contrário, ao celebrar o aniversário da liberdade geral, Brothier fez o elogio do grande general negro. ${ }^{1649}$ Essa disparidade de atitudes entre os Amigos dos Negros era indicativa das dificuldades que marcavam o posicionamento dos antiescravistas diante da administração de Toussaint Louverture. A autonomia para a qual este se dirigia contrariava o assimilacionismo pregado pela Sociedade, mas, ao mesmo tempo, a aliança da República com o líder negro podia ser a única estratégia viável de conservação da colônia.

No seio da Sociedade e da deputação de São Domingos, Lavaux e Brothier eram os principais defensores de Toussaint. Lavaux, em particular, tentava agir como mediador entre o líder negro e os representantes da colônia. Contudo, a influência de Sonthonax entre os deputados era crescente e formou-se, em torno dele, um grupo hostil a Toussaint, no qual estavam Leborgne, Mentor, Vergniaud, Thomany, Annecy, Tonnelier, Belley e Boisson. Apesar dos esforços de Lavaux, Toussaint não podia confiar numa deputação sob a influência crescente do antigo comissário civil que ele tinha expulso da colônia. Aos poucos, Lavaux deixaria de frequentar as sessões dos Amigos dos Negros e das Colônias, privando Toussaint de seu principal interlocutor na metrópole, e deixando o campo livre para Sonthonax. ${ }^{1650}$

É bem verdade que, àquela altura, as relações entre Toussaint e Lavaux já estavam deterioradas. Este, que tinha apoiado o líder negro até então, mostrou-se chocado com a notícia, que chegou em 12 thermidor do ano VII (29 de julho de 1799),

\footnotetext{
${ }^{1648}$ Cf. Moniteur, v.29, números 138-9, 18-19 pluvioso do ano VI (6-7 de fevereiro de 1798), p.146.

${ }^{1649}$ Idem, v.29, número 140, 20 pluvioso do ano VI (8 de fevereiro de 1798), p.147.

${ }^{1650}$ Cf. DORIGNY, Marcel, GAINOT, Bernard. La Société des Amis de Noirs, p.319.
} 
de uma convenção concluída entre Toussaint e o general britânico Maitland, em presença do cônsul americano. O acordo abria todos os portos de São Domingos não apenas a navios americanos, mas também a embarcações americanas portando a bandeira parlamentar britânica. ${ }^{1651}$

Intensificavam-se as críticas à política de Toussaint, que, suspeitava-se, escondia um verdadeiro projeto de independência. Sonthonax o acusava de estar sob a influência de contrarrevolucionários, de plantadores brancos e da Grã-Bretanha. Membros negros dos Amigos dos Negros, como Mentor, Thomany e Belley, seguiam uma linha semelhante de pensamento. Um clima de desconfiança recíproca se instaurou entre as autoridades que controlavam São Domingos e os seus representantes na metrópole. ${ }^{1652}$

Sonthonax tinha anteriormente se oposto aos oficiais mulatos Rigaud e Vilatte $^{1653}$, que ele acusava de tentar oferecer São Domingos aos inimigos da França, mas, após o acordo assinado com Maitland, as coisas mudaram. Rigaud condenou o acordo como uma traição e proclamou a sua lealdade à República. Com isso, em dezembro de 1799, Sonthonax, assim como Mentor e Leborgne, manifestaram o seu apoio aos mulatos, acreditando que uma vitória de Toussaint mergulharia a colônia na barbárie. ${ }^{1654} \mathrm{O}$ jornal L'ennemi des oppresseurs de tous les temps, sucessor do Journal des hommes libres de tous les pays, publicava quase que diariamente notícias sobre os conflitos entre Toussaint e Rigaud, que rumavam para a guerra civil. Por influência de Sonthonax, o jornal proclamava que, caso esta ocorresse, era Rigaud quem representaria os interesses da República. ${ }^{1655}$ Dito isso, foi Toussaint Louverture quem comandou a expulsão das forças britânicas de São Domingos. Por um lado, a sua habilidade estratégica e sua influência sobre as massas faziam dele o único homem capaz de manter alguma estabilidade na colônia e protegê-la de ameaças externas. Por outro, a crescente autonomia com que governava a ilha lançava fortes suspeitas sobre a sua lealdade à metrópole. A situação se tornava insustentável.

\footnotetext{
${ }^{1651}$ Cf. WANQUET, Claude. La France et la première abolition de l'esclavage, p.509.

${ }^{1652}$ Cf. DORIGNY, Marcel, GAINOT, Bernard. La Société des Amis de Noirs, pp.319-320.

${ }^{1653}$ Vilatte tinha sido o protagonista de uma tentativa dos mulatos do Norte de São Domingos de derrubar Lavaux em 20 de março de 1796. A intervenção de Toussaint tinha permitido neutralizar e derrotar o levante (cf. FICK, Carolyn. The making of Haiti, p.191).

${ }^{1654}$ Cf. GAINOT, Bernard. La députation de Saint-Domingue au corps législatif du Directoire, p.109; Idem. 1799, un nouveau Jacobinisme? La démocratie représentative, une alternative à brumaire. Paris: Éditions du CTHS, 2001, p.475.

${ }^{1655}$ Idem. 1799, un nouveau Jacobinisme?, pp.476-477.
} 


\section{III.2.4) O fim da Sociedade}

A situação política da França sofreu ao longo de todo o período 1794-99, reviravoltas sucessivas. O Diretório equilibrava-se com enormes dificuldades em meio às facções e via-se obrigado a recorrer a medidas drásticas para restabelecer a sua autoridade. Se o golpe de 18 fructidor tinha reinserido o país numa linha abertamente republicana, abrindo, com isso, a via para a ascensão de uma corrente democrática mais avançada no seio do corpo legislativo, já na primeira metade de 1798, havia sinais claros de uma tendência mais conservadora no seio do governo. Ela se evidenciou com a aprovação da lei de 22 floreal do ano VI (11 de maio de 1798), que adquiriu o sentido de um golpe de estado, ao invalidar a eleição de 106 deputados jacobinos - e, portanto, indesejáveis aos olhos do Diretório - para o Conselho dos Quinhentos. ${ }^{1656}$

A primeira metade de 1799 , entretanto, foi marcada por um novo impulso republicano, que alguns historiadores chamaram de neojacobino. Essa corrente democrata estava fortemente representada na Sociedade dos Amigos dos Negros e das Colônias, por meio de Sonthonax, Lavaux, Mentor, Leborgne, Duplantier, Deydier e, sobretudo, Merlino, que procurava articular a resistência legislativa ao Diretório a uma oposição neojacobina extraparlamentar. ${ }^{1657}$ Vários desses homens participariam ativamente da Réunion des Amis de la Liberté et de l'Égalité, fundada em julho de 1799, também conhecida como Club du Manège, que muitos veriam como uma espécie de ressurgimento dos Jacobinos. ${ }^{1658}$

Os vínculos da Sociedade dos Amigos dos Negros com a oposição democrática lhe valeram sérios problemas com o Ministério, sobretudo no que se refere ao local das sessões. De início, a Sociedade costumava reunir-se no local administrativo do comissário do poder executivo junto à municipalidade do $2^{\circ}$ arrondissement, cargo ocupado por Lanthenas até a sua morte, em 13 nivoso do ano VII (2 de janeiro de 1799). O sucessor de Lanthenas, Thobie, não desejava mais ver as reuniões dos Amigos dos Negros nesse local e determinou o seu despejo. Foram, assim, tomadas medidas para obter um local oficial nos escritórios do ministério. Os esforços foram conduzidos por Grégoire e Lescallier, que não suscitavam desconfiança por não pertencerem à oposição ao governo. Isso explica o fato de o ministro Bruix, que era proprietário em São

\footnotetext{
${ }^{1656}$ Cf. WANQUET, Claude. La France et la première abolition de l'esclavage, pp.466-467.

${ }^{1657}$ Cf. DORIGNY, Marcel, GAINOT, Bernard. La Société des Amis de Noirs, p.322.

${ }^{1658}$ Cf. WANQUET, Claude. La France et la première abolition de l'esclavage, pp.501-502.
} 
Domingos, ter dado a sua autorização para que a entidade realizasse as suas reuniões no ministério, num local ligado ao gabinete do chefe das colônias, Marc-Antoine Granet, membro da Sociedade. Em carta de 8 nivoso do ano VII (28 de dezembro de 1798), a Sociedade agradeceu ao ministro Bruix a autorização dada à realização das sessões nos locais do ministério, assim como o acesso aos documentos disponíveis nesses locais. ${ }^{1659}$

Mas o almirante Bruix logo atentou para a influência crescente de Sonthonax no seio dos Amigos dos Negros e das Colônias. A presença de um dos principais líderes da oposição ao governo no espaço do ministério, adquiria o caráter de provocação. ${ }^{1660}$ Ao ler mais atentamente os estatutos da Sociedade, Bruix talvez tenha se dado conta do caráter político da entidade. Furioso em ver Sonthonax à frente da Sociedade, o ministro decidiu privá-la de seu local de reuniões no ministério da Marinha. Em carta ao Diretório executivo a respeito das atividades da Sociedade, Bruix alegou ter sido enganado a respeito das intenções da entidade, acreditando que a reunião de seus membros formava apenas um "instituto colonial", sem caráter político e cujo objetivo era apenas contribuir para o "aperfeiçoamento da cultura colonial, da educação, dos animais, do progresso das plantações, dos arroteamentos [...]". ${ }^{1661}$ Afirmou ao Diretório que, caso fosse confirmado que a sociedade possuía um regulamento, um presidente, um secretário e um registro próprios, ela não poderia mais exercer as suas atividades nos locais do ministério. ${ }^{1662}$ Em carta de $1^{\circ}$ pluvioso do ano VII (20 de janeiro de 1799) ao diretor Merlin de Douai, Bruix afirmou ter encontrado, na gaveta de uma pequena mesa instalada no local das reuniões da Sociedade, o regulamento e o registro das sessões. ${ }^{1663}$ Com isso, a Sociedade teve, mais uma vez, de mudar de endereço. Ela seria acolhida pelo Círculo Constitucional do $10^{\circ}$ arrondissement, o que reforçava as suas ligações com a oposição democrática. ${ }^{1664}$

A partir de então, as relações com o ministério se degradaram ainda mais. Em 21 ventoso do ano VII (11 de março de 1799), por exemplo, Mentor atacou publicamente o almirante Bruix. O motivo era a formação, em maio de 1798, de um

\footnotetext{
${ }^{1659}$ Cf. Lettre du bureau de la Société adressée au ministre. In: DORIGNY, Marcel, GAINOT, Bernard. La Société des Amis de Noirs, pp.377-378.

${ }^{1660}$ Cf. DORIGNY, Marcel, GAINOT, Bernard. La Société des Amis de Noirs, pp.323-324.

${ }^{1661}$ Lettre de Bruix, ministre de la marine et des colonies au Directoire exécutif, concernant les activités de la Société des Amis des Noirs. In: DORIGNY, Marcel, GAINOT, Bernard. La Société des Amis de Noirs, p.381.

1662 Ibidem, p.382.

${ }^{1663}$ Cf. Lettre du ministre de la marine et des colonies au citoyen directeur Merlin, 1er pluviose an VII. In: DORIGNY, Marcel, GAINOT, Bernard. La Société des Amis de Noirs, p.382.

${ }^{1664}$ Cf. DORIGNY, Marcel, GAINOT, Bernard. La Société des Amis de Noirs, pp.324-325.
} 
corpo de militares negros e de cor na ilha de Aix. Esses militares tinham sido deportados pelos britânicos em 1793 e, sem seguida, libertados. Uma decisão de 3 prairial do ano VI (22 de maio de 1798) havia determinado a sua separação dos militares brancos. ${ }^{1665}$ Eles encontravam-se retidos em Aix, impossibilitados de ir para o continente sem uma ordem do comandante da Marinha, o que era grave, visto que estavam mal providos em vestimentas e alimentos. O seu salário tinha sido reduzido pela metade. Humilhados, esses soldados escreveram a Mentor para expor o problema e pedir que fossem empregados no exército da República nas mesmas condições que seus companheiros brancos. ${ }^{1666}$ Mentor denunciou publicamente as "operações liberticidas" de Bruix, que havia tomado medidas segregacionistas e discriminatórias no quadro das forças armadas da República. O deputado questionou o republicanismo do ministro da Marinha, que via como parte do partido dos colonos. ${ }^{1667}$ Mentor conseguiu convencer os representantes da Nação a dissolver esse corpo de soldados.

Apesar do fortalecimento dessa corrente democrática no seio do Legislativo, a Sociedade dos Amigos dos Negros e das Colônias encontrava-se, naquele momento, em situação precária. Ela estava fragilizada politicamente por conta de seus problemas com o ministério. Além disso, à morte de Lanthenas, em janeiro, veio juntar-se, em abril de 1799, a de Wadström, outro de seus mais influentes membros. Grégoire também sofria de problemas de saúde, que podem ter justificado a sua discreta saída de cena. Na primavera de 1799, após 16 meses de existência, a Sociedade encerrou as suas atividades. As últimas notas de sessão disponíveis são de 10 germinal (30 de março de 1799). Sessões posteriores podem ter ocorrido, mas é improvável que a existência da entidade tenha se prolongado por um tempo substancial. Em $1^{\circ}$ fructidor do ano VII (19 de agosto de 1799), Bourdon-Vatry, membro dos Amigos dos Negros e novo ministro da Marinha, abriria um inquérito para investigar a expulsão, por Bruix, da Sociedade dos locais do ministério, numa tentativa mal-sucedida de reabilitar a Sociedade e talvez até mesmo ressuscitá-la. ${ }^{1668}$ Em 1822, Grégoire diria que, assim como a sua primeira

\footnotetext{
1665 Ibidem, p.322.

${ }^{1666}$ Cf. "Dernier mot d'Étienne Mentor, Représentant du Peuple, à Étienne Bruix, ministre de la marine et des colonies". In: DORIGNY, Marcel, GAINOT, Bernard. La Société des Amis de Noirs, p.387.

${ }^{1667}$ Ibidem, p.391.

${ }^{1668}$ Cf. DORIGNY, Marcel, GAINOT, Bernard. La Société des Amis de Noirs, pp.325-326.
} 
formação, a Sociedade dos Amigos dos Negros e das Colônias tinha, após uma existência efêmera, expirado por "inanição moral". 1669

Paralelamente, os conflitos entre a frente republicana e o Diretório se intensificavam. Nas eleições de germinal do ano VII (abril de 1799), o grupo dos neojacobinos, no seio do qual estavam Sonthonax, Lavaux e Leborgne, conseguiu 19,2\% dos assentos no Conselho dos Quinhentos e 16,5\% no dos Anciões, o que lhe deu forças para atacar diretamente os diretores. ${ }^{1670} \mathrm{Em} 1^{\circ}$ prairial (20 de maio), Rewbell deu seu lugar a Sieyès no seio do Diretório. Em 29-30 prairial do ano VII (17-18 de junho de 1799), os Conselhos, comandados pelos jacobinos, derrubaram outros três dos cinco Diretores - Treilhard, La Reveillière e Merlin de Douai -, para substituí-los por homens mais alinhados com suas posições: Gohier, Roger-Ducos e o general Moulin. Nesse período, costumeiramente chamado de Terceiro Diretório, todos os ministros, inclusive Talleyrand, foram substituídos. Após essa vitória dos Conselhos sobre o Diretório, parecia haver uma verdadeira vontade de regeneração por parte dos republicanos. No gabinete das colônias, François Omer Granet, um revolucionário avançado, assumiu o lugar que era de Daniel Lescallier. ${ }^{1671}$

Como nenhum dos lugares destinados às colônias foi preenchido nas eleições de germinal do ano VII ${ }^{1672}$, as colônias continuariam, até brumário do ano VII, a serem representadas unicamente por quatro antigos eleitos do Norte de São Domingos cujo mandato ainda não tinha expirado: Tonnelier e Annecy nos Anciões, Mentor e Leborgne nos Quinhentos. Lavaux e Vergniaud, reeleitos pela Saône-et-Loire e a Haute-Vienne, também podiam ser associados a esse grupo. Esses homens ainda continuavam a defender a causa abolicionista, mas as coisas estavam prestes a mudar.

No seio de um Diretório bastante desacreditado, Sieyès via o impulso neojacobino com inquietação e arquitetava um golpe que permitisse a derrubada da Constituição do ano III. Sob sua ordem, Fouché, ministro da polícia, determinou, em 26 thermidor (13 de agosto de 1799), o fechamento do Club du Manège, dando o sinal de uma reação governamental. Espalhavam-se rumores de uma conspiração "terrorista" contra o Diretório e, muito embora os Amigos dos Negros tivessem cessado as suas

${ }^{1669}$ Cf. prefácio de CLARKSON, Thomas. Histoire du commerce homicide appelé traite des Noirs, ou Cri des Africains contre les Européens, leurs oppresseurs. Paris: Les marchands de nouveautés, 1822, pp.7-8.

${ }^{1670}$ Cf. GAINOT, Bernard. 1799, un nouveau Jacobinisme?, p.500.

${ }^{1671}$ Cf. WANQUET, Claude. La France et la première abolition de l'esclavage, pp.500-501.

1672 A Île-de-France recusou-se a designar os dois representantes a que tinha direito. Na Guadalupe e em São Domingos, eleições foram realizadas, mas seus resultados foram anulados ou então os eleitos não tiveram tempo de chegar antes do golpe de 18 brumário. 
atividades, os seus vínculos com a frente republicana faziam com que fossem particularmente visados. Antiescravismo e neojacobinismo começavam a ser associados numa mesma reprovação. O engajamento de Sonthonax, Leborgne, Mentor e Lavaux no Club du Manège, fez com que muitos protagonistas dos assuntos coloniais fossem incluídos, em outubro de 1799, no Dictionnaire des jacobins vivants, uma espécie de lista de proscrição publicada anonimamente, provavelmente por L. Calinau, originário de Metz. ${ }^{1673}$ Na obra, homens como Lavaux e Sonthonax eram apresentados como "antropófagos missionários". ${ }^{1674}$ O grupo de Sonthonax, assim como toda a frente republicana, perdia as suas forças e, no que se referia às colônias, insinuava-se a tendência que levaria à restauração da ordem escravista em colônias afundadas em guerras civis e conflitos entre facções. Com o golpe de 18 brumário ( 9 de novembro), as condições foram criadas para esse retrocesso. ${ }^{1675}$

1673 Cf. Dictionnaire des jacobins vivans, dans lequel on verra les hauts faits de ces messieurs. Hamburgo: s.n., 1799, pp.88-91, 115-116 e 164-166.

${ }^{1674}$ Ibidem, p.74.

1675 Cf. DORIGNY, Marcel, GAINOT, Bernard. La Société des Amis de Noirs, pp.326-327. 


\section{III.3) O restabelecimento da escravidão (novembro de 1799 - maio de 1802)}

Em 18 e 19 brumário do ano VIII (9 e 10 de novembro de 1799), o general Napoleão Bonaparte, apoiado pelos diretores Sieyès e Roger Ducos, derrubou, sob o pretexto de uma ameaça jacobina, o Diretório e dissolveu os dois Conselhos. O projeto dos brumarianos era estabilizar politicamente o governo francês, concentrando o poder nas mãos de um homem forte, capaz de alçar-se acima das facções políticas e pôr fim à sucessão ininterrupta de reviravoltas políticas que haviam marcado o período revolucionário. O Diretório só havia conseguido se manter por meio de golpes alternados contra a direita (18 fructidor) e a esquerda (22 floreal). O regime corrupto e politicamente fraco do Diretório tinha perdido as suas bases de apoio, e não eram as aviltadas massas parienses que iriam defendê-lo. O sentido do golpe de brumário e da instauração de um novo regime político - o Consulado - foi estabilizar o país após dez anos de turbulência e reviravoltas sangrentas e solidificar as transformações operadas na sociedade e no Estado francês. O momento era de consolidação das conquistas da Revolução, isto é, das conquistas que favoreciam as classes possuidoras: isso incluía a grande burguesia dos negócios, mas também os novos proprietários das cidades e, sobretudo, dos campos, beneficiados pela políticas de reforma agrária (como a venda dos bens nacionais) e que desejavam o estabelecimento de um poder central forte, capaz de enfrentar as ameaças realista e jacobina e instituir uma ordem durável e protetora de suas posses. ${ }^{1676}$ A solução encontrada pela burguesia foi sacrificar as liberdades políticas para garantir a propriedade e as liberdades de comércio e indústria.

O Código Civil de 1804 reagruparia as leis relativas ao estatuto jurídico das pessoas, de seus bens e das relações entre os indivíduos privados. Seria a consolidação do direito de propriedade no seu sentido mais liberal, assim como da liberdade contratual. Bonaparte promoveria grandes reformas na educação, com a criação dos liceus e o resgate da Universidade; na economia, com a instituição de uma nova moeda (o franco germinal); e no Judiciário, com a criação de tribunais de apelação. O objetivo do regime seria o de criar as condições para a consolidação do capital comercial e o florescimento do capital industrial, garantindo o caráter ilimitado da propriedade e a

\footnotetext{
${ }^{1676}$ Cf. TARLÉ, Evguéni. Napoléon. Tradução de J. Champenois. Moscou: Éditions du Progrès, Librairie du Globe, 1990, pp.58-59; LEFEBVRE, Georges. Napoléon. Paris: Nouveau Monde éditions, 2005, pp.89-92.
} 
liberdade de contratar e, inversamente, privando os trabalhadores de qualquer possibilidade de luta coletiva contra seus exploradores. ${ }^{1677}$

Quando Bonaparte subiu ao poder, a situação econômica do país era problemática. O governo lutava para controlar a inflação. Os manufatureiros tinham dificuldade em escoar seus produtos e muitos rumavam para a ruína. Os produtores de tecidos de algodão eram uma exceção, pois ainda beneficiavam-se da política instituída pelo Diretório, que havia proibido a entrada dos produtos ingleses. ${ }^{1678}$ Contudo, em Lyon, os produtores de seda, tecido muito consumido pelas cortes europeias antes da Revolução, haviam sido arruinados pela guerra. O comércio marítimo agonizava, por conta dos eventos que haviam marcado a revolução nas Antilhas. Além disso, uma lei de 29 nivoso do ano VI (18 de janeiro de 1798), que autorizava o confisco de embarcações que carregassem mercadorias britânicas, mesmo que o proprietário fosse neutro, havia apavorado os armadores estrangeiros, que já não apareciam nos portos franceses. O comércio com as colônias havia sido reduzido a pó: a França recebia agora apenas 1,5 milhões de libras em produtos de suas colônias, contra os 236 milhões que tirava no final do Antigo Regime. Além disso, por conta da guerra, a França não conseguia mais exercer o seu papel de reexportadora de produtos coloniais, cujo mercado era agora dominado pela Grã-Bretanha. ${ }^{1679}$

O projeto econômico de Bonaparte consistia em fazer florescer o capital mercantil e industrial nacional. Isso implicava, aos olhos do Cônsul, a proteção dos mercados internos frente à concorrência estrangeira, assim como um ambicioso projeto expansionista, desenvolvido em várias frentes, com o objetivo de abrir novos mercados aos produtos franceses e esmagar a concorrência britânica. ${ }^{1680}$ Contudo, no momento em que Bonaparte assumia o poder, prevalecia na França a convicção de que era o comércio de insumos coloniais, e não a exportação de manufaturados para a Europa, a solução mais viável para o enriquecimento imediato do país. Na sociedade que aclamava a Bonaparte, estavam famílias que tinham feito fortuna com o comércio das

\footnotetext{
1677 Bonaparte incorporaria ao Código das leis civis a lei Le Chapelier de 1791, que criminalizava os movimentos de greve e de abandono do trabalho (Ibidem, pp.103 e 110).

${ }^{1678}$ Por meio da lei de 10 brumário do ano V (31 de outbro de 1796), o Diretório havia proibido a importação de mercadorias inglesas. Mais do que isso, ela havia designado uma série de mercadorias que seriam consideradas como inglesas, qualquer que fosse a sua verdadeira proveniência. A lei atingia até mesmo mercadorias inglesas já presentes no território francês, obrigando os seus possuidores ou depositários a comunicar as autoridades para o seu confisco (cf. JOUVENEL, Bertrand de. Napoléon et l'économie dirigée, pp.71-73).

1679 Ibidem, pp.91-92, 97-99, 134-135.

${ }^{1680}$ Cf. TARLÉ, Evguéni. Napoléon, pp.103 e 374.
} 
ilhas e que tinham sido arruinadas pelos eventos da revolução nas colônias. Para essas pessoas, a lembrança do sucesso da produção colonial era forte demais para que aceitassem uma nova orientação econômica para o país. ${ }^{1681}$ Os anseios dessa fração mercantil da burguesia francesa encontravam amparo em Bonaparte, que certamente via o restabelecimento do controle sobre as colônias francesas como parte de seu projeto de dominação. Para o entourage do Primeiro Cônsul, isso implicava restabelecer o "antigo regime colonial".

A política colonial conduzida por Bonaparte durante o Consulado permite evidenciar os avanços feitos durante a Revolução e, sobretudo, sob a República jacobina. Entre 1799 e 1802, o governo tratou de desfazer esses avanços, por meio de uma política que conduziria, passo a passo, ao restabelecimento da escravidão. A regressão não demorou a se fazer sentir na sociedade francesa, no seio da qual um movimento antiescravista praticamente desintegrado via-se completamente sobrepujado por uma propaganda escravista alinhada com o poder estabelecido.

\section{III.3.1) Um novo contexto}

\section{III.3.1.1) Bonaparte e seu círculo}

O golpe de 18-19 brumário colocava, em princípio, o poder executivo e a iniciativa legislativa nas mãos de três cônsules, Bonaparte, Sieyès e Ducos. Contudo, logo ficou claro que Bonaparte não iria dividir o poder com ninguém, para frustração de Sieyès. A nova Constituição, de dezembro de 1799, concentrou efetivamente o poder executivo nas mãos do Primeiro Cônsul, que também ficou com boa parte do poder legislativo, pois caberia a ele propor as leis do país. Bonaparte controlaria até mesmo a composição das assembleias, podendo afastar seus oponentes. Tratava-se de um poder pessoal com aparência republicana.

Durante o Consulado, Bonaparte instalaria um aparelho governamental forte e centralizado. Havia agora um Conselho de Estado, que reunia de 30 a 50 membros, nomeados pelo Primeiro Cônsul e encarregados de redigir as leis por ele propostas. O poder legislativo propriamente dito era difuso. Havia, em primeiro lugar, um Tribunado de 100 membros, que discutia os projetos e emitia a sua opinião, sem tomar decisão.

${ }^{1681}$ Cf. JOUVENEL, Bertrand de. Napoléon et l'économie dirigée, pp.125 e 129. 
Um Corpo legislativo de 300 membros se pronunciava então sobre esses projetos, mas apenas por sim ou não, sem discuti-los. Por fim, um Senado de 60 membros ficava encarregado de verificar a constitucionalidade das leis, podendo por vezes legislar por meio de senatus-consultos. Na prática, o poder pertencia a um homem apenas, Bonaparte. Ele nomeava os membros do Senado e este nomeava os membros do Tribunado e do Corpo Legislativo, a partir de uma lista de milhares de candidatos escolhidos pelos cidadãos, segundo uma modalidade de eleição extremamente complicada. Na prática, o Legislativo apenas executava a vontade do Cônsul. Era este ainda que nomeava para todos os cargos civis e militares. ${ }^{1682} \mathrm{O}$ povo, tão presente na vida política ao longo da Revolução, permaneceria distante dessas instâncias de poder, cujos atos se revestiam de um profundo segredo burocrático. A mudança de regime teria graves repercussões na política colonial francesa.

Quando Bonaparte chegou ao poder, a situação do império colonial era delicada. Os britânicos tinham conquistado a Martinica, Tobago, Sainte-Lucie e as ilhas Les Saintes. Tinham sido derrotados em São Domingos, mas Toussaint Louverture operava na ilha com grande liberdade. A Guadalupe, perdida momentaneamente para os britânicos, tinha sido reconquistada pelos soldados negros e brancos de Hugues. As Mascarenhas, a Guiana, e Saint-Louis do Senegal também permaneciam com a França. A França tinha conquistado, pelo tratado da Basiléia, de 1795, a parte espanhola de São Domingos. Além disso, ocupava a ilha de Malta desde 1798. Uma campanha no Egito, ainda curso, só se completaria em outubro de $1799 .{ }^{1683}$

Sob o Consulado, Bonaparte poria em execução um amplo projeto de conservação e ampliação do império francês. Suas ambições estavam mais voltadas para o Oriente, mas a América não seria deixada de lado. Embora o projeto imperial de Bonaparte tivesse outras prioridades, as colônias francesas não deixavam de chamar a sua atenção, por sua importância comercial e geopolítica. Na medida em que o Primeiro Cônsul tinha a intenção de preservar as colônias e restabelecer nelas a autoridade metropolitana, a abolição da escravidão, que havia alterado profundamente o sistema colonial, iria inevitavelmente ser repensada.

A posição pessoal de Bonaparte a respeito da escravidão negra não é simples de precisar, em razão do jogo duplo que o Cônsul exerceu na sua relação com os novos

\footnotetext{
${ }^{1682}$ Cf. WANQUET, Claude. La France et la première abolition de l'esclavage, p.521; TARLÉ, Evguéni. Napoléon, p.82-83.

${ }^{1683}$ Cf. BÉNOT, Yves. La démence coloniale sous Napoléon. Paris: La Découverte, 2006, pp.15-16.
} 
livres. Alguns documentos, entretanto, apontam para um Bonaparte claramente avesso à liberdade dos negros. Thibaudeau, um antigo deputado montanhês e antiescravista da Convenção e conselheiro de estado de Bonaparte, relatou a seguinte manifestação de Bonaparte, em conversa com Truguet, no verão de 1802:

Só é possível ver adeptos dos Ingleses nas colônias sob o pretexto de oprimilos. Pois bem, senhor Truguet, se vós tivestes vindo ao Egito pregar-nos a liberdade dos negros ou dos Árabes, nós vos teríamos enforcado no alto de um mastro. Os brancos foram entregues à ferocidade dos negros, e sequer querem que as vítimas estejam descontentes! Pois bem, tivesse eu estado na Martinica, eu teria ficado do lado dos Ingleses, pois é preciso, antes de tudo, salvar a própria vida. Estou do lado dos Brancos porque eu sou branco; não tenho outra razão, e essa é a boa. Como puderam conceder a liberdade a Africanos, a homens que não tinham nenhuma civilização, que sequer sabiam o que era uma colônia, o que era a França? $O$ fato é que simplesmente aqueles que quiseram a liberdade dos Negros querem a escravidão dos Brancos; ainda assim, credes que se a maioria da Convenção tivesse sabido o que fazia, e conhecido as colônias, ela teria dado a liberdade aos Negros? Não, sem dúvida; mas poucas pessoas eram capazes de prever os resultados, e um sentimento de humanidade é sempre mais poderoso do que a imaginação. Mas apegar-se, na situação atual, aos princípios! Não se trata de boa-fé! Trata-se de amor-próprio e hiprocrisia. ${ }^{164}$

Wanquet adverte que essa declaração deve ser vista com algum ceticismo, pois não é possível verificar a veracidade desse relato, escrito muitos anos depois, talvez no exílio. ${ }^{1685}$ É verdade, porém, que embora tivesse assumido posições antiescravistas no passado, Thibaudeau era um admirador de Bonaparte e manifestou apoio a ele até o final e teria, portanto, poucos motivos para forjar declarações que poderiam manchar a sua imagem. De qualquer forma, as opiniões pessoais de Bonaparte sobre os negros não devem ser vistas como o elemento determinante. Mesmo detestando os negros, ele poderia ter decidido manter a abolição, caso acreditasse que essa seria a única forma de manter as colônias. Deve-se lembrar, aliás, que ele aboliria o tráfico em 1815, por

\footnotetext{
1684 "On ne veut voir que des partisans des Anglais dans nos colonies, pour avoir le prétexte de les opprimer. Eh! bien, M. Truguet, si vous étiez venu en Égypte nous prêcher la liberté des noirs ou des Arabes, nous vous eussions pendu au haut d'un mât. On a livré les blancs à la férocité des noirs, et on ne veut pas même que les victimes soient mécontentes! Eh! bien, si j'eusse été à la Martinique, j'aurais été pour les Anglais, parce qu'avant tout il faut sauver sa vie. Je suis pour les Blancs parce que je suis blanc; je n'en ai pas d'autre raison, et celle-là est la bonne. Comment a-t-on pu accorder la liberté à des Africains, à des hommes qui n'avaient aucune civilisation, qui ne savaient seulement pas ce que c'était que colonie [sic], ce que c'était que la France? Il est tout simple que ceux qui ont voulu la liberté des Noirs veuillent l'esclavage des Blancs; mais encore croyez-vous que si la majorité de la Convention avait su ce qu'elle faisait, et connu les colonies, elle eût donné la liberté aux Noirs? Non, sans doute; mais peu de personnes étaient en état d'en prévoir les résultats, et un sentiment d'humanité est toujours puissant sur l'imagination. Mais à présent, tenir encore à ces principes! Il n'y a pas de bonne foi! Il n'y a que de l'amour-propre et de l'hypocrisie" (THIBAUDEAU, Antoine Clair. Mémoires sur le Consulat. 1799 à 1804. Par un ancien conseiller d'état. Paris: Ponthieu et Cie, 1827, pp.120-121).

${ }^{1685}$ Cf. WANQUET, Claude. La France et la première abolition de l'esclavage, pp.525-527.
} 
razões políticas. Se Bonaparte se lançou contra a abolição, isso se deve, em grande parte, às novas bases de apoio do governo.

Para reconciliar as forças que se degladiaram nos dez anos anteriores, Bonaparte colocou nas principais instâncias da administração pessoas do campo revolucionário e pessoas do campo contrarrevolucionário. No que tange ao problema das colônias, entretanto, o entourage de Bonaparte contava com uma prevalência de pessoas ligadas ao antigo sistema colonial. Dentre os brumarianos mais influentes, havia homens como Jean-Barthélémy Le Couteulx de Canteleu, antigo banqueiro de Rouen, deputado da cidade durante a Revolução e ligado à Câmara de comércio da Normandia. Sob o Consulado, ele seria nomeado membro do Senado e seria o fundador do Banco da França. Nos primeiros anos do Consulado, ele escreveria para defender que o futuro das exportações francesas estaria estreitamente vinculado ao sistema colonial que seria adotado com a paz. ${ }^{1686} \mathrm{Na}$ seção da marinha do Conselho de Estado, estava o vicealmirante Honoré Joseph Antoine Ganteaume, favorável ao restabelecimento da escravidão. Ele seria um dos principais interlocutores do Cônsul em assuntos coloniais. Logo em 6 nivoso do ano VIII (27 de dezembro de 1799), Bonaparte pediria a ele que apresentasse um projeto de regulamento provisório para São Domingos, Guadalupe e ilhas de France e da Reunião. ${ }^{1687}$ Ganteaume também participaria da expedição militar em São Domingos em 1802. O Ministério da Marinha seria confiado sucessivamente a dois adeptos da restauração escravista, Forfait e Decrès, auxiliados por Guillemin de Vaivres, antigo intendente geral das colônias e nomeado chefe do gabinete das colônias no Ministério da Marinha. Dentre todos os ministérios, o da Marinha recebia o segundo maior orçamento do Estado, atrás apenas do da Guerra, o que mostra a importância e o peso político desses homens. Além disso, François Barbé-Marbois, intendente de São Domingos em 1789, reapareceria como diretor e ministro do Tesouro. Ele tinha defendido reformas ao sistema escravista no final do Antigo Regime, com um controle mais estrito da administração sobre a relação senhor-escravo, mas era um defensor convicto da escravidão como única forma possível de exploração colonial. ${ }^{1688}$

\footnotetext{
${ }^{1686}$ Cf. JOUVENEL, Bertrand de. Napoléon et l'économie dirigée, pp.124-125.

1687 Cf. Correspondance de Napoléon $I^{e r}$, publiée par ordre de l'empereur Napoléon III. Paris: Henri Plon, J. Dumaine, 1861, v.6, pp.60-61.

${ }^{1688}$ Cf. GAINOT, Bernard. Métropole / Colonies, p.26; WANQUET, Claude. La France et la première abolition de l'esclavage, p.579; BRANDA, Pierre, LENTZ, Thierry. Napoléon, l'esclavage et les colonies. Paris: Fayard, 2006, pp.55-60.
} 
Além disso, aproveitando-se da anistia geral proclamada pelo Consulado ${ }^{1689}$, vários dos principais atores do lobby colonial retornavam à metrópole, onde assumiriam posições importantes. Pierre-Victor Malouet, proprietário em São Domingos e membro do Clube Massiac que tinha liderado as negociações, em 1793, por meio das quais os plantadores tinham oferecido a ilha aos britânicos, estava de volta à França após vários anos de refúgio na Inglaterra. Em 1803, ele seria nomeado comissário geral da Marinha, em Anvers. ${ }^{1690}$ Ele aproveitaria o novo contexto para republicar seus antigos relatórios e memoriais, em vários volumes, sob o nome Collection de mémoires sur les colonies et particulièrement sur Saint-Domingue. Da mesma forma, Moreau de Saint-Méry, que tinha retornado à França em 1798 após um exílio nos Estados Unidos, assumiria uma posição no Ministério da Marinha. Ele tinha publicado, em 1797-98, a Description topographique, physique, civile, politique et historique de la partie française de l'Ile Saint-Domingue, na qual lamentava a destruição de São Domingos operada com a abolição. A obra continha passagens absolutamente ultrajantes nas quais o autor se dedicava a examinar mais de cem misturas raciais possíveis para elencar os diferentes tipos encontrados na colônia. ${ }^{1691}$ Outras figuras eminentes do partido escravista retornaram do exílio, caso dos clichyens Viénot-Vaublanc, que seria eleito para o corpo legislativo, e Villaret-Joyeuse. ${ }^{1692}$ Em carta de 28 brumário do ano X (19 de novembro de 1801), Bonaparte teceria grandes elogios ao almirante Villaret-Joyeuse, então um dos encarregados de uma expedição militar que se preparava para as Antilhas. ${ }^{1693}$ Por fim, vale citar o fato de que Josefina, esposa do Cônsul, tinha profundos vínculos com o mundo dos colonos. Pertencia a uma família de ricos plantadores da Martinica, com propriedades importantes em São Domingos. Não há evidências de que ela tenha tido

\footnotetext{
${ }^{1689}$ Dos 145 mil emigrados, 141 mil receberam o direito de retornar à França, sob a vigilância da polícia. Apenas 3.373 ficaram excluídos da anistia. Mais tarde, em maio de 1802, Bonaparte determinou, por meio de um senatus consulto, que todo emigrado que prestasse sermão de fidelidade ao novo regime receberia o direito de retornar ao país (cf. TARLÉ, Evguéni. Napoléon, pp.94-95).

${ }^{1690}$ Cf. BÉNOT, Yves. La démence coloniale sous Napoléon, p.191.

${ }^{1691}$ Moreau sustentava que o branco e o negro eram constituídos de 128 partes, brancas para o primeiro e negras para o segundo. Um indivíduo se aproximaria mais de um ou do outro em razão do número de partes brancas ou negras que possuísse. Mas aquele que não tivesse as 128 partes brancas ou negras seria necessariamente uma "pessoa de cor" e aquele que não fosse nem branco e nem escravo seria um "liberto" (cf. MOREAU DE SAINT-MÉRY, Médéric Louis Élie. Description topographique, physique, civile, politique et historique de la partie française de l'isle Saint-Domingue. $2^{\mathrm{a}}$ edição: Paris: L.Guérin; T.Morgan, 1797-1798, v.1, pp.83-116).

${ }_{1692}$ Cf. GAINOT, Bernard. Métropole / Colonies, pp.25-26.

${ }^{1693}$ Cf. Correspondance de Napoléon I ${ }^{\text {er }}$, v.7, p.325.
} 
influência sobre as decisões do Cônsul, mas trata-se, no mínimo, de um vínculo concreto, mesmo que indireto, entre o Primeiro Cônsul e proprietários coloniais. ${ }^{1694}$

Por outro lado, também havia, no círculo de Bonaparte, defensores da abolição. Era o caso de seu amigo e conselheiro, o almirante Laurent Jean-François Truguet. Em 1799, Truguet, que tinha combatido ao lado de Bonaparte em 1793, escreveu cartas privadas ao Primeiro Cônsul para denunciar aqueles que atacavam a lei de emancipação, que ele via como uma conquista irreversível. Procurou convencer Bonaparte de que o verdadeiro povo das Antilhas eram os negros e de que era necessário apoiar Toussaint Louverture para manter São Domingos ligada à metrópole. ${ }^{1695}$ Truguet também se oporia à desastrosa expedição Leclerc.

É preciso ressaltar também que, mesmo no campo escravista, havia quem julgasse impossível uma volta à escravidão. Era o caso de Page, que, ao lado de Brulley, tinha sido um dos mais nefastos personagens da história colonial da Revolução. Mas, naquele momento, Page já considerava que a batalha estava perdida. No seu Traité d'économie politique et de commerce des colonies (1801), ele defendeu a ideia de que, abolida a escravidão em São Domingos, não era mais possível voltar atrás, pois o negro já não aceitaria mais a ideia de que a escravidão era inerente à sua natureza. Não era mais possível esperar de negros acostumados à insurreição a disciplina necessária ao cultivo do açúcar. ${ }^{1696}$ Mais do que isso, Page entendia que a liberdade já havia deitado raízes profundas na América, por conta da independência dos Estados Unidos e da emancipação dos negros em São Domingos, tornando inviável o estabelecimento na região de colônias agrícolas, que só poderiam ser cultivadas por negros. Para Page, a empresa colonial francesa deveria voltar-se para a criação de novos estabelecimentos na África, sobretudo no Senegal. ${ }^{1697}$

Ou seja, se a opinião de que era preciso restabelecer a escravidão nas colônias era dominante na administração consular, ela não era unânime. Essas vozes dissonantes, contudo, eram largamente minoritárias. De início, o único real obstáculo que o lobby colonial encontrou era o pragmatismo do Primeiro Cônsul, que, num contexto de guerra, ainda julgava imprudente tomar medidas capazes de provocar insurreições nas colônias. Logo nos dias que seguiram brumário, dois colonos, o ex-constituinte Monneron e o ex-

\footnotetext{
${ }^{1694}$ Cf. BRANDA, Pierre, LENTZ, Thierry. Napoléon, l'esclavage et les colonies, p.55.

${ }^{1695}$ Cf. DUBOIS, Laurent. A Colony of Citizens, pp.351-352; BRANDA, Pierre, LENTZ, Thierry. Napoléon, l'esclavage et les colonies, pp.52-54.

${ }^{1696}$ Cf. PAGE, Pierre-François. Traité d'économie politique et de commerce des colonies. Paris: Brochot, ano IX, v.1, pp.207-209.

${ }^{1697}$ Ibidem, pp.220-224 e 269.
} 
convencional Serres, chegaram a propor a Bonaparte o restabelecimento puro e simples da escravidão em todas as colônias. ${ }^{1698} \mathrm{O}$ Cônsul não tomou nenhuma medida naquele momento, mas a campanha pela revogação da abolição tinha começado.

\section{III.3.1.2) A propaganda escravista}

Como vimos anteriormente, o fim da República jacobina iniciou um processo de recuo político que culminaria no golpe de 18 brumário. Durante esse período, o movimento popular, que tinha sido responsável por uma forma de censura sobre quaisquer manifestações contrarrevolucionárias, foi neutralizado. Com isso, os libelos pró-escravistas, que haviam praticamente desaparecido durante o ano II, voltaram gradativamente à tona sob a Convenção thermidoriana e o Diretório. Da mesma forma, durante o Consulado e, sobretudo, no período próximo à lei de 1802, surgiu uma grande quantidade de obras escravistas que já sinalizavam a existência de uma conjutura favorável ao restabelecimento da escravidão.

Nem todas as manifestações pediam abertamente o retorno à escravidão. Algumas apenas contestavam a forma pela qual a abolição tinha sido feita e propunham planos de abolição gradual, que seriam aplicados nos territórios onde a liberdade geral não tinha sido proclamada, como as Mascarenhas. Autores como Le Boucher e Poullain desenvolveram o tema da emancipação como recompensa ao mérito e ao trabalho. Outros, como Bonnet, não se opunham à outorga da liberdade nas Mascarenhas, mas entendiam que ela deveria ser restrita e que os novos livres não deveriam gozar de qualquer direito político. ${ }^{1699}$

Por outro lado, muitos pediam claramente a revogação da abolição. Colonos como Barré de Saint-Venant e Deslozières dedicaram-se a pregar a volta da escravidão negra. Nessa nova campanha escravista, alguns argumentos velhos seriam retomados, mas agora a experiência da abolição também seria usada para justificar o restabelecimento da ordem escravista. Ela atestava, na opinião desses autores, a impossibilidade da liberdade geral dos negros nas colônias.

Uma das linhas de força propaganda escravista seria a de atacar os efeitos nefastos da Filosofia no espaço colonial. O jornal Mercure de France, em particular, se converteria num veículo para os ataques à Filosofia e todas as ideias dela derivadas. Da

\footnotetext{
${ }^{1698}$ Cf. BRANDA, Pierre, LENTZ, Thierry. Napoléon, l'esclavage et les colonies, p.55.

${ }^{1699}$ Cf. WANQUET, Claude. La France et la première abolition de l'esclavage, pp.561-562.
} 
mesma forma, obras como Les soirées bermudiennes (1801), de Carteau, denunciavam a "escola de insurreição" instaurada nas colônias com a chegada dos ideais revolucionários e da propaganda dos Amigos dos Negros, trazida pelos marinheiros e soldados vindos da metrópole. ${ }^{1700}$

Com Des colonies et de la traite des nègres (1800), C. Belu procurou fazer uma apologia da antiga ordem colonial. A obra era dedicada a "Bonaparte, primeiro cônsul da República", a quem o autor pedia que restabelecesse a ordem colonial. Apontava os efeitos desastrosos da Revolução nas colônias, cujo estado atual não podia em nada ser comparado ao "estado florescente que nossas Colônias obtinham outrora da subordinação geral dos Negros e das pessoas de cor, e da harmonia estabelecida entre todos os Brancos". ${ }^{1701}$ Para Belu, a questão era simples: "não existe qualquer colônia sem escravidão", de modo que "deve-se, portanto, ou renunciar às Colônias, ou consentir em restabelecer nelas a escravidão". ${ }^{1702}$

O autor desenvolvia uma ultrajante defesa da escravidão, impensável nos anos 1793-94. Apresentava-a como algo tão antigo quanto a espécie humana, inscrevendo-se, portanto, na natureza das coisas, sobretudo para o negro, que estava familiarizado com ela desde o seu nascimento. ${ }^{1703}$ Belu defendia ainda a tese de que os negros não eram tão infelizes nas colônias quanto a Filosofia alegava. Passava uma imagem suavizada da escravidão colonial, enfatizando a moderação do tratamento dado aos negros por seus senhores. Assim, se poucos negros atingiam uma idade avançada, a razão estava na libertinagem que os extenuava, nos licores fortes pelos quais tinham um gosto inato e as doenças para as quais não tinham resistência. ${ }^{1704}$ Belu defendia, desta forma, a restauração da escravidão e do tráfico negreiro, destacando o papel histórico deste na ampliação e no enriquecimento das relações comerciais da França, assim como no desenvolvimento das manufaturas francesas. ${ }^{1705}$

Em Des colonies modernes sous la zone torride, et particulièrement de celle de Saint-Domingue (1802), Jean Barré de Saint-Venant, um antigo militar, agrônomo e colono de São Domingos retomou, na sua defesa do restabelecimento da escravidão, argumentos bastante antigos. Sustentou, por exemplo, a tese de que, na zona tórrida, o

\footnotetext{
${ }^{1700}$ Cf. CARTEAU, J.-Félix. Soirées bermudiennes, pp.75-77.

1701 "état florrisant que nos Colonies obtenaient autrefois de la subordination générale des Nègres et des gens de couleur, et de l'harmonie établie entre tous les Blancs" (BELU, C.. Des colonies et de la traite des nègres. Paris: Debray, 1800, p.29).

1702 Ibidem, p.32.

1703 Ibidem, p.8.

1704 Ibidem, p. 12

1705 Ibidem, p.3.
} 
trabalho servil era "a base de todas as produções, de todas as prosperidades e de toda civilização" e que a imposição do trabalho servia aos povos civilizados para fazer com que os povos "bárbaros e selvagens" pudessem atingir a civilização. Assim, ao serem transpostos da África para as colônias, os negros, antes abandonados a todo tipo de barbárie e crime, tornavam-se fortes e vigorosos, atingindo uma situação superior à dos jornaleiros dos campos franceses. ${ }^{1706} \mathrm{O}$ autor sustentava a impossibilidade de implantar um sistema salarial nas colônias. Invocando a teoria dos climas, presente em Montesquieu, ele sustentava que, em países quentes, a natureza convidava o homem ao repouso, em razão da facilidade que este tinha em obter a sua subsistência. Assim, se, por um lado, "o homem, em todos os climas, tinha recebido o mesmo germe de inteligência que o tornava, em todos os lugares, perfectível", por outro, o Africano deveria ser governado por leis diferentes, que o submetessem ao trabalho, única forma de adquirir as capacidades intelectuais e morais próprias dos outros homens. ${ }^{1707}$ Barré de Saint-Venant procurava, com isso, justificar o fato de que as colônias tinham de ser regidas por leis especiais. Afirmava não ser um apologista da escravidão, mas do trabalho: nos países frios, o homem era escravo de suas necessidades e a natureza o obrigava a trabalhar, ao passo que, nos países quentes, o legislador tinha de preencher as funções da natureza, obrigando o negro a trabalhar. ${ }^{1708}$ É claro que "trabalhar", para um colono, significava exclusivamente trabalhar na grande produção para exportação e não numa pequena cultura de subsistência.

Para provar a impossibilidade de outro sistema de trabalho nas colônias, SaintVenant dedicou-se a contrapor o estado de prosperidade econômica de São Domingos antes da insurreição dos escravos à decadência vivida pela colônia sob o regime da liberdade. Para o autor, estava demonstrada a vantagem de "um governo paternal e regulado pela coação" sobre "aquele colocado em seu lugar, por meio da liberdade" (itálico no original). ${ }^{1709} \mathrm{O}$ autor entedia que ainda era tempo de recuperar a colônia, com a introdução de técnicas mais modernas de produção - como a charrua, por exemplo -, com o restabelecimento da autoridade dos brancos e, sobretudo, com a "submissão dos

1706 Cf. BARRÉ DE SAINT-VENANT, Jean. Des colonies modernes sous la zone torride, et particulièrement de celle de Saint-Domingue. Paris: chez Brochot père et compagnie, 1802, pp.viii-ix e 34-35).

1707 "l'homme, dans tous les climats, a reçu le même germe d'intelligence qui le rend partout également perfectible" (Ibidem, pp.5-6).

${ }_{1708}$ Ibidem, p.24.

${ }^{1709}$ Ibidem, pp.51-52. 
negros". ${ }^{1710}$ A prosperidade do comércio colonial francês não residia em projetos de ampliação do império, mas na recuperação daquela que era a sua colônia mais preciosa.

Outra obra do período, Les égarements du nigrophilisme (publicada em março de 1802), de Louis-Narcisse Baudry Deslozières, um dos fundadores do Círculo dos Filadelfos, unia o ataque ao antiescravismo aos velhos argumentos de defesa da escravidão. O autor acusava os "negrófilos", ignorantes das realidades coloniais, de serem verdadeiros "carrascos". ${ }^{1711}$ Assim como Barré de Saint-Venant, o autor sustentava que os negros, arrancados de uma escravidão cruel na África e, mais frequentemente, da morte, eram submetidos a um justo trabalho nas colônias, onde retribuíam aos seus libertadores o preço de sua "salvação". ${ }^{1712} \mathrm{O}$ autor afirmava, portanto, o interesse dos próprios negros em servir os colonos, de modo que a abolição geral do tráfico teria sido para eles desastrosa. ${ }^{1713}$ Da mesma forma, dada a "preguiça natural" do negro, a liberdade geral só podia gerar efeitos catastróficos para a economia colonial, pois o seu resultado imediato era necessariamente a cessação de todo trabalho. ${ }^{1714}$ Deslozières procurava amparar sua argumentação em cálculos que apontavam a impossibilidade econômica da substituição do trabalho escravo pelo assalariado. ${ }^{1715}$ Concluía que era "incontestável a necessidade de restabelecer a escravidão das Colônias". ${ }^{1716}$

Os colonos das Mascarenhas também deram sua contribuição. No Essai sur l'agriculture et le commerce des îles de France et de la Réunion (1803), Frédéric Descroizilles, negociante e plantador que tinha sido, na condição de membro da assembleia colonial da Île-de-France, um dos organizadores do motim contra Baco e Burnel em 1796, sustentou a necessidade de aumentar o número de negros nas duas ilhas, única forma de promover progressos sensíveis na agricultura. O autor, cujo discurso evidenciava a mudança de ambiente trazida pelo regime consular, comemorava o fato de que a onda abolicionista, provocada pela Revolução, tinha passado:

\footnotetext{
${ }^{1710}$ Ibidem, p.xii.

${ }^{1711}$ Cf. DESLOZIÈRES, Louis Narcisse Baudry. Les égaremens du nigrophilisme. Paris: Migneret, 1802, p.97.

${ }^{1712}$ Nesse sentido, é interessante observar que a obra continha constantes referências a Robespierre, apresentado como o arauto de uma falsa liberdade geral. $\mathrm{O}$ autor queria com isso sustentar que, perto da escravidão a que Robespierre tinha submetido a França, a escravidão dos negros nas colônias era "a menor de todas" (Ibidem, p.88).

${ }^{1713}$ Ibidem, pp.28-30 e 40-41.

${ }^{1714}$ Ibidem, pp.45-46.

${ }^{1715}$ Ibidem, pp.50-51.

${ }^{1716}$ Ibidem, p. 125.
} 
Felizmente, não nos encontramos mais no tempo em que um preconceito anticolonial e antinacional teria feito com que fosse vista como crime a mera menção a uma ordem de coisas que as pessoas pareciam gostar de representar sob as cores mais falsas e as mais odiosas. Todos os homens esclarecidos sobre os verdadeiros interesses do Estado estão hoje convencidos de que a existência das colônias, tão intimamente vinculada à prosperidade do comércio e da marinha nacional, depende da manutenção da servidão, único meio de constranger ao trabalho uma espécie de homens indolentes por natureza, e sobre os quais as afeições sociais e as instituições religiosas não têm nenhum efeito. ${ }^{1717}$

Descroizilles também retomava o argumento antigo de que o tráfico era favorável aos africanos, que apenas trocavam uma escravidão mais cruel, no seu país de origem, por outra mais branda, nas colônias. Pedia, sob esse argumento, até mesmo a volta das subvenções estatais ao tráfico de escravos. ${ }^{1718}$

Em Moyens d'amélioration et de restauration proposés au gouvernement (1803), Joseph François Charpentier-Cossigny de Palma, engenheiro e explorador que tinha posses na Île-de-France e cujo primo tinha sido governador geral das Mascarenhas, apresentou propostas referentes à agricultura, ao comércio, à administração das colônias. Defendeu a velha tese de que, no que se refere aos negros, não era possível emancipá-los abruptamente e exigir deles que se comportassem como os povos civilizados. Atacou diretamente o decreto de 16 pluvioso, que teria enfraquecido a França, prejudicando o seu comércio, a sua manufatura e a sua marinha, e favorecido a Inglaterra. Para Cossigny, esse decreto continha apenas a afirmação de um princípio, louvável em si, mas cuja aplicação só podia provocar a destruição das colônias. ${ }^{1719}$

Paralelamente a essas defesas abertas da escravidão, havia um movimento de vilanização de Toussaint Louverture, personagem que simbolizava a revolução dos escravos. Apareciam biografias distorcidas do chefe negro, que procuravam destacar os aspectos mais bárbaros de sua administração e, com isso, apontar os efeitos perversos do sistema de emancipação. É o caso de La vie de Toussaint Louverture, chef des noirs

\footnotetext{
1717 "Heureusement nous ne sommes plus au temps où un préjugé anti-colonial et anti-national, aurait fait regarder comme crime irrémissible la seule mention d'un ordre de choses qu'on avait paru se plaire à représenter sous les couleurs les plus fausses et les plus odieuses. Tous les hommes éclairés sur les vrais intérêts de l'État, sont aujourd'hui convaincus que l'existence des Colonies, si intimement liée avec la prospérité du commerce et de la marine nationale, dépend du maintien de la servitude, seul moyen de contraindre au travail une espèce d'hommes indolens par nature, et sur lesquels les affections sociales et les institutions religieuses n'ont aucune prise" (DESCROIZILLES, Frédéric. Essai sur l'agriculture et le commerce des îles de France et de la Réunion, suivi d'un Notice historique sur l'île de France pendant la Réunion. Rouen: Imprimerie des Arts, 1803, p.37).

${ }_{1718}^{1718}$ Ibidem, pp.38-41.

1719 Cf. CHARPENTIER-COSSIGNY, Joseph-François. Moyens d'amélioration et de restauration proposés au gouvernement et aux habitans des colonies; ou Mélanges politiques, économiques, agricoles et commerciaux, etc., relatifs aux colonies. Paris: Batilliot, 1803, v.1, pp.275-303.
} 
insurgés de Saint-Domingue (1802), de Dubroca, uma denúncia das "atrocidades" cometidas por Toussaint contra a França sob a bandeira da Espanha, da sua "perfídia ao abandonar os interesses dessa potência", dos "seus numerosos atentados contra os agentes da república francesas", dos "atos de sua independência" e dos "primeiros horrores que acompanharam sua resistência ao governo francês". ${ }^{1720}$ Toussaint era apresentado como um tirano, profundamente hipócrita e desleal, "um Africano coberto de sangue e de crimes". ${ }^{1721}$ Dubroca atacava menos a abolição do que as aspirações de independência de Toussaint. Pretendia mostrar que os negros de São Domingos

[...] não podem ter consentido com uma constituição que os separa de seus benfeitores, que os arranca de sua pátria das quais são os filhos, e que os coloca à mercê de um tirano feroz cujos furores eles tantas vezes suportaram. ${ }^{1722}$

Também em 1802, Cousin d'Avallon publicou Histoire de Toussaint-Louverture, chef des noirs insurgés de Saint-Domingue. A obra também procurava difundir a imagem de um Toussaint fanático, rebelde e manipulador, contrariando a imagem de um líder avesso aos excessos e crueldades: "Seu caráter é uma mistura horrível de fanatismo e de inclinações atrozes; ele passa friamente do altar à carnificina, e da prece às sombrias combinações da perfídia". ${ }^{1723}$

Em L'incendie du Cap, ou le Règne de Toussaint Louverture, René Périn fez um relato romanceado das atrocidades cometidas por Toussaint Louverture e seu general Christophe à frente de "uma horda feroz de Africanos, que uma piedade mal compreendida arrancou do freio da escravidão". ${ }^{1724} \mathrm{O}$ obra traçava um retrato pouco elogioso de Toussaint:

Essa reunião inaudita de perfídia, ingratidão, tolice, amor próprio e baixeza, um Toussaint-Louverture que esqueceu as bondades com as quais a França ousou agraciá-lo, que aumentou suas riquezas com os espólios de suas vítimas, que traiu, perseguiu aqueles que haviam abrigado a sua infância, esse hipócrita ignorante, que, em seu orgulho louco, em meio a uma orgia,

\footnotetext{
${ }^{1720}$ Cf. DUBROCA. La vie de Toussaint Louverture, chef des noirs insurgés de Saint-Domingue. Paris: Dubroca/Bonneville, 1802, página não numerada.

${ }^{1721}$ Ibidem, p.2.

1722 "[...] ne peuvent avoir consenti à une constitution qui les separe de leurs bienfaiteurs, qui les arrache à une patrie dont ils sont les enfants, et qui les met à la merci d'un tyran farouche dont ils ont tant de fois éprouvé les fureurs" (Ibidem, p.45).

1723 "Son caractère est un mélange affreux de fanatisme et de penchants atroces; il passe froidement de l'autel au carnage, et de la prière aux sombres combinaisons de la perfidie" (COUSIN D'AVALLON. Histoire de Toussaint-Louverture, chef des noirs insurgés de Saint-Domingue. Paris: chez Pillot, 1802, pp.14-15).

${ }_{1724}$ PÉRIN, René. L'incendie du Cap, ou le Règne de Toussaint Louverture. Paris: Marchand, 1802, p.xi.
} 
ousava dizer que Raynal o havia designado, vem enfim tirar a máscara política com a qual se cobria, e içar o estandarte da revolta. ${ }^{1725}$

A obra procurava passar a imagem de um Toussaint manipulador e ambicioso, capaz das mais profundas traições e atos de crueldade para atingir seus objetivos pessoais, e de um Christophe vingativo, enlouquecido por uma liberdade abruptamente concedida. Périn via Robespierre como o "horrível modelo" de Toussaint, a quem ele teria concedido a sua proteção. ${ }^{1726}$ Mas, mais do que um ataque pessoal aos líderes do exército negro de São Domingos, o texto era um ataque à abolição, que havia transformado "a palavra sagrada da liberdade" num "grito de furor" e dado início ao "reino dos carrascos", liderados por Toussaint. ${ }^{1727}$

Obras literárias também passaram a retratar os negros como bárbaros ferozes, que massacravam os brancos e violentavam suas mulheres. $\mathrm{O}$ abade Delille, considerado o grande poeta da época, denunciou a violência dos insurretos negros em seu longo poema La pitié (1803). O poeta abordou a insurreição negra em São Domingos no terceiro canto, que trazia outra referência a Robespierre:

Ó campos de São Domingos! ó cenas execráveis!

Ah! fugi, salvai-vos, famílias deploráveis;

Os tigres estão lançados; do sol africano

Todos os fogos fervem ao mesmo tempo em seu seio.

Para vós a sua arte cruel refina os sofrimentos;

O próprio Robespierre invejaria as suas vinganças. ${ }^{1728}$

O poeta reconhecia que os abusos da escravidão tinham provocado essa fúria, mas parecia sugerir o restabelecimento da escravidão sob uma forma moderada:

Evitai que um excesso de rigor, de indulgência

Encoraje a audácia, ou arme a vingança,

E que, enfim, esse solo, encharcado de seus suores

Não seja mais pintado de sangue e banhado de suas lágrimas. ${ }^{1729}$

1725 "Cet assemblage inoui de scélératesse, d'ingratitude, de sottise, d'amour propre et de bassesse, un Toussaint-Louverture, qui a oublié les bontés dont la France a daigné le combler, qui a grossi ses richesses des dépouilles de ses victimes, qui a trahi, persécuté ceux qui avaient abrité son enfance, cet hypocrite ignorant, qui, dans son fol orgueil, au milieu d'une orgie, osait dire que Raynal l'avait désigné, vient enfin de jetter le masque politique dont il se couvrait, et d'arborer l'étendart de la révolte" (Ibidem, pp.xii-xiii).

${ }^{1726}$ Ibidem, pp.133-134 e 136

1727 Ibidem, pp.42-43.

1728 "O champs de Saint-Domingue! ô scènes exécrables! Ah! fuyez, sauvez-vous, familles déplorables; Les tigres sont lancés; du soleil africain. Tous les feux à-la-fois bouillonnent dans leur sein. Pour vous leur art cruel raffine les souffrances; Robespierre lui-même envîrait leurs vengeances" (DELILLE, Jacques. La Pitié. Paris: Giguet et Michaud, 1803, p.29).

1729 "Évitez qu'un excès de rigueur, d'indulgence n"encourage l'audace, ou n'arme la vengeance, et que ce sol enfin, trempé de leurs sueurs, ne soit plus peint de sang et baigné de leurs pleurs" (Ibidem, p.30). 
Peças de teatro e romances, como Les fiancés de Saint-Domingue de Kleist, seguiam a mesma linha. Esse movimento literário se estenderia até os anos posteriores à perda de São Domingos e a criação do estado negro do Haiti. ${ }^{1730}$

No campo científico, esse recrudescimento da opinião escravista encontrava amparo no aparecimento de teses racistas. Era o caso da Histoire naturelle du genre humain (1801), do naturalista e antropólogo Julien-Joseph Virey. A partir da ideia de que o homem encontrava-se submetido às inúmeras variantes que compunham o seu ambiente, Virey sustentava que as diferentes feições e características que o homem assumia não permitiam a identificação de uma espécie única. Contrapondo-se à ideia de um Homem, representante da unidade do gênero humano, Virey defendia a existência de uma variedade de espécies e raças de homens. ${ }^{1731}$ Havia, assim, para o autor, duas espécies distintas, que se subdividiam em diferentes raças. Uma primeira espécie se caracterizaria pela pele branca, amarela ou bronzeada (mas nunca negra), cabelos lisos ou longos. De inteligência mais desenvolvida, essa primeira espécie se situaria num estágio de civilização mais avançado, com o uso de leis escritas, uma capacidade de trabalho e uma habilidade superiores, assim como "coragem e amor pela verdadeira glória". A essa espécie pertenceriam as raças branca, amarela, acobreada e morenaescura. A outra espécie, que reuniria as raças negra e enegrecida, caracterizava-se pela cor da pele marrom ou negra, cabelos crespos ou curtos, lábios grossos. Dotada de uma capacidade de compreensão limitada, menor coragem, indústria, uma inclinação para os prazeres sensoriais, essa espécie atingiria apenas um estágio de civilização imperfeito. $^{1732}$

É curioso observar que Virey desaprovava a escravidão e o tráfico e até legitimava a abolição, mesmo tendo sido feita sem a devida prudência. ${ }^{1733}$ Contudo, ao afirmar a falta de capacidades intelectuais do negro, contrapondo-o ao modelo superior representado pelo europeu, ele fornecia argumentos pretensamente científicos aos

\footnotetext{
${ }^{1730}$ Vale citar a Histoire des Mesdemoiselles de Saint-Janvier, les deux seules blanches sauvées du massacre de Saint-Domingue (1812), de Mlle de Palaiseau, que narrava a história de duas jovens irmãs brancas que haviam conseguido salvar-se dos massacres que seguiram o fracasso da expedição Leclerc em São Domingos. A autora procurava contrapor a inocência das jovens à crueldade e à barbárie dos combatentes negros, comandados por Dessalines. A obra obteve grande sucesso comercial, esgotando duas edições em três meses (cf. PALAISEAU, Mlle de. Histoire des Mesdemoiselles de Saint-Janvier, les deux seules blanches sauvées du massacre de Saint-Domingue. $3^{\mathrm{a}}$ edição. Paris: J.-J. Blaise, 1812).

${ }^{1731}$ Cf. VIREY, Julien-Joseph. Histoire naturelle du genre humain. Paris: Crochard, 1824, v.1, pp.397398 e 400.

${ }_{1732}$ Ibidem, pp.437-438.

${ }^{1733}$ Idem, v.2, p.105.
} 
defensores da servidão natural do negro. Suas ideias contribuíam para a construção da imagem do negro como selvagem e inapto para a civilização.

Essa profusão de publicações políticas, científicas e literárias, num momento em que o controle governamental sobre as atividades editoriais era estrito, era o sinal de um alinhamento do aparelho de Estado francês com o princípio do restabelecimento da antiga ordem colonial. Inversamente, as manifestações contrárias ao restauracionismo se fizeram bastante raras durante o período.

\section{III.3.1.3) O antiescravismo sob o Consulado}

É difícil avaliar a existência e a extensão de uma opinião contrária à escravidão num momento em que a imprensa era muito controlada. A repressão de opiniões consideradas revolucionárias era uma das prioridades do regime consular. Era praticamente proibido escrever sobre a Revolução e seus personagens. Imperava a lei do silêncio sobre temas capazes de despertar o "jacobinismo secreto" dos homens de letras. ${ }^{1734}$ Com uma decisão de 27 nivoso do ano VIII (17 de janeiro de 1800), por exemplo, Bonaparte ordenou o fechamento de 60 dos 73 jornais ainda existentes no país. Os 13 remanescentes ${ }^{1735}$ foram colocados sob a vigilância do ministro da Polícia, mas nove deles não sobreviveriam por muito tempo. A liberdade de imprensa, uma das primeiras conquistas da Revolução, tinha sido suprimida. ${ }^{1736}$

O movimento editorial permite, assim, avaliar a postura oficial do governo diante de certas questões. Se os escravistas não encontravam problemas para se expressarem, o mesmo não pode ser dito da oposição abolicionista, silenciada pelo novo regime. Havia certamente opiniões desaprovadoras da política colonial de Bonaparte, mas elas permaneceram, na sua maioria, ocultas. Assim, a Mme de Staël protestaria contra a prisão de Toussaint Louverture em Dix années d'exil, que ela escreveria no exílio a partir de 1811 e que só seria publicado em 1821, três anos após a morte da autora: "Era um homem muito criminoso; mas Bonaparte havia assinado condições com ele, e, desprezando tais condições, Toussaint foi levado para uma prisão na França, onde

\footnotetext{
${ }^{1734}$ Cf. TARLÉ, Evguéni. Napoléon, p.107.

${ }^{1735}$ Os jornais que foram autorizados pelo regime consular foram: Moniteur universel, Journal des débats et des décrets, Journal de Paris, Le Bien-informé, Le Publiciste, L'Ami des lois, La Clef du cabinet, Le Citoyen français, Gazette de France, Journal des hommes libres, Journal du soir par les frères Chaigneau, Journal des défenseurs de la patrie, Décade philosophique (cf. Collection générale des lois, décrets, arrêtés, sénatus-consultes, avis du conseil d'état et réglemens d'administration, publiés depuis 1789 jusqu'au $1^{\text {er }}$ avril 1814. Paris: De l'Imprimerie Royale, 1818, v.7, p.625).

${ }^{1736}$ Cf. TARLÉ, Evguéni. Napoléon, p.75.
} 
faleceu da maneira mais miserável". ${ }^{1737}$ Afirmações desse tipo não teriam passado pelo crivo da censura. Mesmo assim, elas não constituíam propriamente uma tomada de posição antiescravista, dirigindo-se essencialmente contra o caráter tirânico do governo consular.

Houve, no período, poucas manifestações contundentes. Grégoire continuava, de maneira solitária, o seu combate. Em 1800, ele leu no Instituto Nacional uma Notice sur Las Casas (que só seria publicada em 1802), uma espécie de refutação da tese de que Las Casas teria favorecido o tráfico negreiro para defender os índios. Grégoire aproveitou para sustentar que todo católico tinha de se opor à escravidão. Após a paz de Amiens, ele tentaria restabelecer contato com a Sociedade inglesa pela abolição do tráfico, retomando sua correspondência com Thomas Clarkson. ${ }^{1738}$ Também mantinha contato com as sociedades antiescravistas americanas, como atesta uma carta sua, de 2 de março de 1802, aos membros do Comitê de correspondência da Sociedade pela abolição da escravidão da Pensilvânia. Nela, Grégoire acusou o recebimento das atas das convenções anuais das sociedades abolicionistas americanas, de 1794 a 1801, que seriam bastante úteis para uma obra que estava completando sobre a liberdade dos negros. Destacando a frivolidade do público francês, Grégoire ressaltou que "o tempo favorável para a circulação dessa obra e, é claro, para a sua impressão ainda não chegou". Aproveitou para informar os americanos de que os Amigos dos Negros tinham sido dissolvidos e que eram poucos os que mantinham vivo o combate contra a escravidão. Sustentando que era a religião que dava aos homens a coragem de fazer o bem, Grégoire lamentava o fato de que "[...] na França, o número daqueles que são animados pelo espírito da cristandade é inconsiderável", mas assegurava aos norteamericanos que ele continuaria o seu combate pelos negros. ${ }^{1739}$

Além de Grégoire, alguns poucos se manifestavam abertamente contra a escravidão negra. Antigo administrador e diretor geral da Companhia do Senegal (companhia que detinha a exclusividade do comércio no Senegal, privilégio abolido pela Assembleia Nacional em 1791), Jean-Gabriel Pelletan publicou, em 1801, Mémoire sur la colonie du Sénégal. Sua experiência lhe tinha garantido um conhecimento profundo da costa ocidental africana e das possibilidades que existiam para o comércio

1737 "C'était un homme três criminel; mais toutefois Bonaparte signa des conditions avec lui, et au mépris de ces conditions, Toussaint fut amené dans une prison de France, où il a péri de la manière la plus misérable" (STAËL, Mme de. Dix années d'exil. Paris: La Renaissance du livre, 1909, p.37).

${ }^{1738}$ Cf. BÉNOT, Yves. La démence coloniale sous Napoléon, p. 257.

${ }^{1739}$ Lettre de Grégoire du 2 mars 1802. In: DORIGNY, Marcel, GAINOT, Bernard. La Société des Amis des Noirs, pp.395-396. 
francês. Endereçado ao Primeiro Cônsul, o texto reproduzia parte de um memorial redigido seis anos antes, na prisão, sob o regime do Terror. Seguindo a linha dos projetos coloniais defendidos pelos Amigos dos Negros, Pelletan queria mostrar o que podiam se tornar os estabelecimentos franceses da parte ocidental da África, sob um regime de liberdade.

Propunha instaurar um novo sistema colonial, no qual os habitantes do Senegal poderiam, após o fim do tráfico, voltar-se para "objetos mais úteis para o comércio e mais consolantes para a humanidade". A importação de manufaturados europeus tecidos, armas, aguardentes e outros produtos - na colônia criaria necessidades que, para serem satisfeitas, levariam os seus habitantes a obterem novos produtos para serem trocados. Assim, a abolição promoveria "[...] o duplo bem de enriquecer a República e de fornecer aos pobres negros gozos pacíficos e a felicidade doméstica [...]". ${ }^{1740}$

Pelletan acreditava ainda que todas as produções da América poderiam ser transplantadas para o Senegal, onde seriam cultivadas por "homens livres". Ainda assim, o autor tomava o cuidado de esclarecer que, no contexto africano, a expressão "homens livres" não podia ser levada ao pé da letra, pois a escravidão na África era tão leve que poderia ser considerado livre todo africano que trabalhasse no seu solo sem temer o risco de ser arrancado dele para ser vendido! Com uma mão de obra obtida a baixo custo, a produção se tornaria mais vantajosa e barata do que nas Américas. ${ }^{1741}$

O autor louvava o decreto de abolição, ressaltando a "glória da Nação francesa", que tinha vencido "pela sua coragem e sua constância, a luta culpada de todos os interesses particulares". ${ }^{1742}$ Mas alertava para o perigo da publicação da lei de abolição no Senegal, que teria por efeito não apenas acabar com o tráfico, mas também privar os habitantes de seus "cativos de cabana", escravos que viviam sob um suave "regime patriarcal". Privados desses cativos, os habitantes perderiam os seus capitais e os recursos de seu comércio. ${ }^{1743}$ Assim, Pelletan pedia uma modificação da lei de abolição que converteria o estado atual dos "cativos de cabana" numa "contratação a termo" de alguns anos, durante os quais seriam remunerados e após os quais seriam livres de direito. Além de evitar que os proprietários fossem privados de seus recursos abruptamente, isso permitiria aos escravos se acostumarem "gradualmente à liberdade e

\footnotetext{
${ }^{1740}$ Cf. PELLETAN, Jean-Gabriel. Mémoire sur la colonie française du Sénégal, pp.21-22, 45-47 e 8485.

${ }^{1741}$ Ibidem, pp.71, 82 (nota 20) e 82-83.

1742 Ibidem, p.69.

${ }^{1743}$ Ibidem, pp.98-102.
} 
à propriedade". ${ }^{1744}$ Ou seja, propunha trocar a abolição nos moldes aprovados em 16 pluvioso por uma emancipação gradual, o que era bastante magro.

Havia poucas obras mais ousadas. Pode-se citar uma: Les Trois Ages des colonies (1801-02), do abade de Pradt. Não se tratava propriamente de uma defesa da lei de 16 pluvioso, mas seu autor sustentava que o advento da Revolução havia determinado, inexoravelmente, o fim da escravidão e, mais do que isso, a independência das colônias:

[A revolução] convoca igualmente o negro e o branco, o senhor e o escravo; ela vê neles apenas o homem; ela destrói todas as sábias barreiras que os separavam, ela destrói ao mesmo tempo os laços das colônias com as metrópoles, ela as liberta da Europa, assim como emancipa o escravo de seu senhor. A independência ou o fim da escravidão são a mesma coisa; ela é até algo mais, pois é o próprio fim das colônias. ${ }^{1745}$

Para Pradt, não havia volta atrás e cabia à metrópole preparar a separação organizada das colônias, para evitar maiores desastres, tanto para as colônias quanto para a metrópole.

Alguns poucos jornais ainda veiculavam textos hostis à escravidão, mas não constiuíam propriamente uma militância. O periódico Bibliothèque Britannique, publicado por três genoveses - Marc-Auguste Pictet, seu irmão Charles e FrédéricGuillaume Maurice - publicava textos antiescravistas britânicos. ${ }^{1746}$ A Décade Philosophique, littéraire et politique - que depois assumiria o nome de La Revue Philosophique - mantinha-se até certo ponto fiel às ideias antiescravistas. A revista era dirigida por seis associados: Ginguené, Le Breton, Amaury Duval, Jean-Baptiste Say, Toscam e Auger. Eram antiescravistas, mas eram também brumarianos e alguns deles chegaram a ocupar postos importantes no novo regime, como Le Breton, que era funcionário do Ministério do Interior. Ginguené e Say entraram para o Tribunado, mas o primeiro foi eliminado pela depuração de março de 1802 e o segundo foi reduzido à impotência, permanecendo nas suas funções até $1804 .{ }^{1747}$

\footnotetext{
${ }^{1744}$ Ibidem, pp.104-105.

1745 "[La révolution] appelle également aux places le nègre et le blanc, le maître et l'esclave; elle ne voit en eux que l'homme; elle brise toutes les sages barrières qui les séparaient, elle brise par là-même les liens des colonies avec les metrópoles, elle les affranchit de l'Europe, comme elle affranchit l'esclave de son maître. L'indépendance ou la fin de l'esclavage sont la même chose; elle est même quelque chose de plus, car elle est la fin même des colonies" (PRADT, Dominique Georges Frédéric de. Les trois âges des colonies: ou de leur étát passé, présent et à venir. Paris: Giguet et Cie., 1801-02, v.3, p.317).

${ }^{1746}$ Cf. DAVID, Thomas. L'internationale abolitionniste, p.121.

${ }^{1747}$ Cf. BÉNOT, Yves. La démence coloniale sous Napoléon, p.234.
} 
Antes de brumário, o periódico defendia posições mais firmes, publicando, aliás, textos dos Amigos dos Negros e das Colônias. Sob Bonaparte, entretanto, teve de assumir um estilo mais discreto, alternando posições mais avançadas com outras mais prudentes. Opiniões antiescravistas aparecem de forma mais ligeira, como aponta Yves Bénot, em resenhas de obras. Assim, o número de 20 de abril de 1801 trouxe, por exemplo, comentários a um livro escravista de Bryan Edwards e ao poema La Pitié, de Delille. O número de 19 de julho de 1801 trouxe uma resenha de Voyage à la côte occidentale d'Afrique, de Grandpré, enquanto a edição de 29 de julho de 1801 contou com uma resenha de Voyage dans la partie méridionale de l'Afrique de John Barrow. ${ }^{1748}$ No final de 1801, a Décade publicou uma resenha de Les Trois Ages des colonies do abade de Pradt. Por vezes, entretanto, a revista abordava obras escravistas sem tecer quaisquer comentários. A Décade funcionou de 1794 a 1807, ano em que Napoleão a fundiu com o Mercure de France.

Também merecem algum destaque os Annales de la Religion, periódico da Sociedade Livre de Filosofia Cristã da Igreja constitucional, criada em 1795 por Grégoire, então um bispo constitucional. A Sociedade tinha por objetivo retomar o estudo da religião após a grande onda de descristianização das fases anteriores da Revolução. Por meio do periódico, ela sustentou a ideia de que a religão permitiria regenerar os vínculos da França com suas colônias.

Em 1800, o periódico trouxe um texto, datado de 27 de julho, assinado por Desbois, Grégoire e Wandelaincourt (bisco de Langres), sobre a sagração de Guillaume Mauviel como "bispo da antiga parte francesa da ilha São Domingos". O texto, intitulado Institution Canonique, dava instruções gerais ao bispo Mauviel para a sua missão de formar padres na colônia francesa. $\mathrm{O}$ texto pregava que o bispo agisse sempre em acordo com o princípio da igualdade:

Antes que a pátria tenha se determinado a contar os homens de todas as cores entre os seus filhos, o evangelho [...] nos tinha ensinado que, qualquer que seja a cor, o país ou a opinião que os distinguem, todos os homens são irmãos. Vós anunciareis, portanto, corajosamente essas verdades eternas; e, para acelerar o fim das infelizes divisões que, há tempo demais, fazem derramar o sangue, e cuja continuidade poderia levar à ruína completa das colônias, vós relembrareis constantemente aos seus habitantes que todos eles são filhos do mesmo pai, cidadãos da mesma pátria; que eles foram

${ }^{1748}$ Ibidem, pp.239-240. 
resgatados do mesmo sangue, que eles têm direitos iguais à mesma herança. ${ }^{1749}$

$\mathrm{O}$ artigo recomendava ao bispo que buscasse entre os jovens negros os futuros padres de São Domingos, vendo nesse ato "o mais poderoso meio que a religião possa vos oferecer para estirpar até os últimos restos de um preconceito bárbaro que divide ainda hoje homens cujos verdadeiros interesses são de se reunir e de se amar". ${ }^{1750}$ Os autores acreditavam que esse seria também um meio poderoso de reforçar os laços que uniam a colônia à metrópole. O bispo teria de recomendar aos fiéis, "como um dever de consciência, a submissão às leis da república" e exigir dos novos padres e bispos "a promessa de fidelidade à constituição francesa". ${ }^{1751}$

Em novembro de 1800, os Annales chegaram a tecer grandes elogios a Toussaint Louverture, apresentando-o como "amigo da religião" e louvando a sua vitória sobre o mulato Rigaud, no Sul de São Domingos. Um trecho da proclamação de Toussaint aos cidadãos da província foi publicado no periódico. ${ }^{1752}$ Aos poucos, entretanto, a revista abandonaria a sua postura mais ousada. Como explica Yves Bénot, depois da chegada da expedição Leclerc, Mauviel se voltaria contra Toussaint e a revista seguiria a mesma evolução. ${ }^{1753}$ Em 1803, ela deixaria de ser publicada, assumindo, sob o Império, o nome de Annales de la géographie.

Esses exemplos dão a medida do encolhimento da corrente abolicionista sob o Consulado. O que se verifica, no geral, é um claro descompasso entre a propaganda escravista, bastante incisiva e explícita, e os resquícios de uma opinião abolicionista que se manifestava de maneira bastante tímida ou hesitante. Se certamente eram muitos os adeptos do princípio da abolição, o fato é que eles se mantinham globalmente em silêncio. Num momento em que as relações entre a metrópole e as colônias pós-abolição estavam bastante degradadas, o movimento antiescravista tinha sido praticamente reduzido a pó.

\footnotetext{
1749 "Avant que la patrie se fût déterminée à compter les hommes de toutes les couleurs au nombre de ses enfants, l'évangile [...] nous avait appris que, quelle que soit la couleur, le pays ou l'opinion qui les distinguent, tous les hommes sont frères. Vous annoncerez donc courageusement ces éternelles vérités; et pour accélérer la fin des malheureuses divisions qui, depuis trop longtemps, font couler le sang, et dont la continuité pourrait entraîner la ruine entière des colonies, vous rappelerez sans cesse à leurs habitants qu'ils sont tous les enfants du même père, les citoyens de la même patrie; qu'ils ont été rachetés du même sang, qu'ils ont des droits égaux au même héritage" (Annales de la Religion, v.11, p.427).

1750 "le plus puissant moyen que la religion puisse vous offrir pour extirper jusqu'aux derniers restes d'un préjugé barbare qui divise encore aujourd'hui des hommes dont les véritables intérêts sont de se reunir et de s'aimer" (Ibidem, pp.428-429).

${ }^{1751}$ Ibidem, p.429).

1752 Idem, v.12, pp.242-243.

${ }^{1753}$ Cf. BÉNOT, Yves. La démence coloniale sous Napoléon, pp.229-231.
} 


\section{III.3.2) Uma nova política colonial}

\section{III.3.2.1) Relações tensas com as colônias}

Se, quando da ascensão de Bonaparte ao poder, a situação nas colônias já era bastante delicada, a mudança de regime tornou as relações com a metrópole ainda mais tensas. Na Guadalupe, as notícias da queda do Diretório detonaram movimentos de revolta nas principais cidades. Visto como um traidor pelos insurretos, o agente francês Desfourneaux foi preso e enviado à metrópole. $\mathrm{Na}$ verdade, dois meses antes, a sua substituição já vinha sendo planejada na França, onde Desfourneaux era tido como incapaz de lidar com a situação da ilha. Os nomeados para substituí-lo na Guadalupe, em 14 de agosto de 1799, foram: Nicolas-Georges Jeannet-Oudin, sobrinho de Danton e ex-governador da Guiana, onde tinha proclamado a abolição; Étienne Lavaux, antigo governador de São Domingos de 1793 a 1797; e René-Gaston Baco, o mesmo da missão nas Mascarenhas em 1796. Mesmo com o golpe de 18 brumário, os agentes partiram para a Guadalupe. Segundo Bangou, eles teriam se apressado em partir para as colônias assim que souberam do 18 brumário, temendo que seu mandato fosse revogado antes de poder exercê-lo. ${ }^{1754}$ Quando chegaram, Desfourneaux já tinha sido mandado embora pelos generais Paris e Pélardy, fiéis a Hugues, que tinham formado um conselho provisório. Os novos agentes procurariam manter uma administração centralizada e suprimir a oposição na colônia. Assim, em maio de 1800, vários homens negros ou mestiços foram acusados de conspirar contra as autoridades. Ao mesmo tempo, a situação era delicada, na medida em que, não podendo confiar na lealdade dos colonos brancos, os agentes dependiam das tropas negras. Lavaux procuraria se aproximar dos negros da Guadalupe, atitude considerada perigosa por Jeannet-Oudin e Baco, que o viam como um "negrófilo". Decidiram, assim, enviá-lo a Basse-Terre, para então prendê-lo e encaminhá-lo à França. ${ }^{1755}$ Os dois agentes remanescentes se dedicariam a conduzir uma política prudente, com o objetivo de reconquistar a confiança dos colonos, sem provocar uma insurreição dos negros.

Naquela época, entretanto, eram fortes as pressões vindas da Guadalupe quanto à necessidade de uma intervenção militar na ilha. Denúncias contra Jeannet-Oudin e

${ }^{1754}$ Cf. BANGOU, Henri. La Guadeloupe, p.147.

${ }^{1755}$ Cf. DUBOIS, Laurent. A Colony of Citizens, pp.345-347. 
Baco, acusados de serem opositores do novo regime na França, levaram Bonaparte a chamá-los de volta à metrópole. Uma decisão de 19 de abril de 1801 alterou o regime da colônia, prescrevendo que a Guadalupe e suas dependências fossem regidas por três magistrados: um Capitão-geral, responsável pela administração das forças armadas, das fortificações e do comércio; um Prefeito, responsável pelas finanças, salários, educação e agricultura, o que incluía o controle sobre os negros; e um Comissário de Justiça, responsável pela administração dos tribunais. ${ }^{1756}$ Com isso, um novo grupo de administradores chegaria à Guadalupe: Coster (comissário de justiça), Daniel Lescallier (prefeito colonial) e o almirante Lacrosse (capitão-geral).

Lacrosse tinha um passado republicano de peso: tinha derrotado os realistas na Martinica e na Guadalupe em 1793, tinha mandado aplicar a lei de 24 de março de 1792 nas duas colônias e criado o clube dos Jacobinos, ao lado de Leborgne, em Saint-Pierre e em Fort-de-France na Martinica. Mas agora ele retornava à Guadalupe para conduzir uma política contrária à que tinha defendido em 1792. Ele se chocaria com a resistência dos generais de cor Magloire Pélage e Louis Delgrès, dois combatentes das Antilhas. Chegou à ilha em maio de 1801, sendo bem recebido pelas massas por conta de seu passado republicano, mas logo daria sinais de que as coisas haviam mudado. Ordenou a prisão, sob falsas alegações de conspiração, de republicanos e homens de cor e convidou todos os emigrados a retornarem à colônia. Também tomou medidas para forçar os "vagabundos" a voltarem às plantações e determinou que administradores fiscalizassem o pagamento aos cultivadores. Os menores atos de resistência eram punidos com grande severidade. Como aponta Dubois, os temores da volta à escravidão eram fortes na ilha, fato atestado pela renovação frequente de alforrias que haviam sido feitas antes da Revolução: esses atos individuais de "reemancipação" proliferaram na época, sobretudo após a chegada de Lacrosse, como forma de assegurar uma liberdade que parecia cada vez mais ameaçada. ${ }^{1757}$

Em 5 de agosto de 1801, o general Antoine de Béthencourt, que comandava as forças armadas francesas na ilha, morreu de febre. Isso teve consequências graves, pois Béthencourt era visto como um contrapeso à política dura conduzida por Lacrosse. Ora, este decidiu colocar-se no comando do exército, em vez de promover o oficial de cor Magloire Pélage. A medida gerou grande insatisfação entre os soldados negros; alguns se revoltaram e foram presos ou, em alguns casos, até mesmo executados por ordem de

${ }^{1756}$ Cf. BANGOU, Henri. La Guadeloupe, pp.147-148.

${ }^{1757}$ Cf. DUBOIS, Laurent. A Colony of Citizens, pp.374-375. 
Lacrosse. Este mandou prender Pélage em outubro de 1801. Pélage resistiu e tropas negras se mobilizaram, sendo rapidamente reforçadas por cultivadores, dando forma a uma nova insurreição. ${ }^{1758}$ Pélage tentaria obter junto a Lacrosse uma anistia geral, mas sem sucesso. Diante da recusa do capitão-geral, um grupo de soldados de cor atacou e prendeu Lacrosse, que foi expulso da ilha. Delgrès que, até então, tinha se mantido fiel a Lacrosse, resolveu se juntar à rebelião. Pélage formou um governo provisório composto de brancos e mulatos, mas manteve o regime autoritário de trabalho e restaurou a ordem. Com isso, um regime autônomo tinha sido formado na colônia. Lacrosse foi para Dominica, onde encontrou Coster e Lescallier, que ainda não tinham chegado à Guadalupe. Enviou ao ministro francês das colônias, Denis Decrès, uma lista detalhada dos homens de cor e brancos que alegava terem participado da insurreição contra ele. Chegou até mesmo a colocar Desfourneaux na lista e afirmou que os rebeldes da Guadalupe queriam reinar sobre a ilha como os negros em São Domingos. ${ }^{1759}$

Na principal colônia francesa, Toussaint Louverture agia de forma independente. Desde a expulsão de Sonthonax, ele tinha assumido praticamente sozinho o comando de São Domingos, exceção feita à parte sul da ilha, onde o mulato Rigaud mantinha uma administração autônoma. Em 1798, embora não tivesse autoridade para tal, Toussaint tinha celebrado acordos comerciais com a Grã-Bretanha e os Estados Unidos, e isso num momento em que a França e os Estados Unidos tinham suspendido as trocas comerciais e estavam à beira de um conflito. Apesar disso, o Diretório, por meio do comissário Roume tinha aprovado o tratado. ${ }^{1760}$ Mais tarde, Toussaint derrotaria Rigaud na "guerra do Sul", estendendo o seu controle sobre o restante da colônia.

Talvez seja um pouco estereotipado afirmar, como fez Genovese, que o projeto de Toussaint fosse o de uma "europeização" de São Domingos ${ }^{1761}$, mas o grande líder negro certamente acreditava que a sobrevivência da São Domingos livre implicava uma modernização institucional largamente inspirada na metrópole: Toussaint dividiu a ilha em seis departamentos; criou um sistema judiciário complexo, com várias instâncias; reformou o sistema tributário, reduzindo impostos sobre a propriedade imobiliária e sobre a importação (sobretudo a de artigos de primeira necessidade); organizou uma polícia marítima para frear o contrabando; construiu escolas; e até incentivou a prática

\footnotetext{
${ }^{1758}$ Cf. BANGOU, Henri. La Guadeloupe, p.148; DUBOIS, Laurent. A Colony of Citizens, pp.353-360.

${ }^{1759}$ Cf. DUBOIS, Laurent. A Colony of Citizens, pp.360-365.

${ }^{1760}$ Cf. Moniteur, v.29, número 26, 26 vendemiário do ano VIII (18 de outubro de 1799), p.854.

${ }^{1761}$ Cf. GENOVESE, Eugene. Da rebelião à revolução, p.94.
} 
da religião. ${ }^{1762} \mathrm{O}$ seu governo buscava um certo equilíbrio entre as diferentes classes da colônia: queria preservar a abolição, mas buscava aliar a classe dos proprietários brancos, cujos conhecimentos e contatos ele entendia necessários para a recuperação econômica da ilha. ${ }^{1763}$ Mas os bons resultados dessa política de conciliação não apagavam o fato de que, aos olhos da metrópole, a semi-independência de São Domingos colocava em cheque o pacto colonial.

Quanto às colônias orientais, elas conseguiam manter-se à margem das transformações operadas no mundo colonial. As assembleias de colonos haviam resistido eficazmente às investidas dos agentes da metrópole e contavam com a leniência do governo francês, que não via grandes motivos para forçar uma legislação abolicionista em espaços livres de movimentos rebeldes, tanto por parte dos brancos quanto por parte dos negros. Charpentier-Cossigny de Palma, que publicaria, como vimos acima, em 1803, um libelo contra o decreto de abolição, foi enviado às Mascarenhas, em outubro de 1800, para fazer uma última tentativa de aplicação da abolição, mas logo mostrou-se conformado com as sucessivas recusas das autoridades locais. Nenhuma solução militar foi preparada pelo governo metropolitano para essa situação. ${ }^{1764} \mathrm{O}$ Consulado parecia perfeitamente confortável com a ideia de que a escravidão seria preservada nas Mascarenhas.

\section{III.3.2.2) A Constituição do ano VIII}

Diante da situação nas colônias, o Consulado definiria uma nova política colonial, cujas bases seriam dadas pelo novo texto constitucional. Como diz Josep Fradera, a "noção de excepcionalidade" tradicionalmente dominou as políticas coloniais das potências europeias. Diante da impossibilidade de estender aos territórios coloniais os quadros políticos existentes na metrópole, governos metropolitanos apelavam para "regimes especiais" ou "legislações particulares". Essa tendência manifestou-se com bastante clareza no início da Revolução francesa: consciente das consequências de uma aplicação dos princípios da nova ordem jurídica ao espaço colonial, a Constituinte,

\footnotetext{
1762 Cf. JAMES, C.L.R.. Os jacobinos negros, pp.225-226.

${ }^{1763}$ Ibidem, p.228.

${ }^{1764}$ Cf. GAINOT, Bernard. Métropole / Colonies, p.25; WANQUET, Claude. La France et la première abolition de l'esclavage, p.606.
} 
pressionada por colonos e negociantes dos portos, seguiu o princípio da exclusão das colônias do quadro legislativo metropolitano. ${ }^{1765}$

A partir do movimento dos homens de cor pelos seus direitos de cidadania e, sobretudo, com a insurreição dos escravos, a Revolução caminhou para a inclusão das colônias na ordem jurídica francesa, processo cuja expressão máxima foi a abolição de 16 pluvioso. A Constituição do ano III e a lei de departamentalização de 12 nivoso (1º de janeiro de 1798) consagraram o princípio da assimilação das colônias à metrópole, rompendo com a tradição da excepcionalidade. A ascensão de Napoleão, entretanto, marcou um retorno a esse sistema.

Ao derrubar o princípio da assimilação, a nova Constituição, de 22 frimário do ano VIII (13 de dezembro de 1799), cumpria a primeira etapa para o restabelecimento da escravidão. $\mathrm{O}$ art. $1^{\circ}$ afirmava que a República francesa era "una e indivisível", mas referia-se apenas ao seu "território europeu", o que sugeria a exclusão das posses ultramarinas. Já o art. 91 esclarecia que "o regime das colônias francesas é determinado por leis especiais". ${ }^{1766}$ Era uma volta ao sistema da Constituição de 1791, que excluía os territórios coloniais de seu âmbito de aplicação. A nova Constituição promovia uma mudança profunda no estatuto das colônias e das pessoas que nela viviam, pois na medida em que as colônias não se encontravam mais assimiladas à França, os seus habitantes não teriam mais necessariamente os mesmos direitos que os da metrópole e não poderiam mais eleger representantes para o parlamento francês. Seu status seria agora definido por leis especiais. Esse sistema abria finalmente a possibilidade de uma revogação da abolição, não mais amparada na rigidez dos princípios constitucionais.

Apesar disso, inicialmente, Bonaparte não se colocou em oposição aberta a Toussaint Louverture. Sabendo tratar-se do homem mais poderoso de São Domingos, ele o confirmou na sua posição de comandante-em-chefe e governador da colônia. Além disso, sua primeira decisão em matéria colonial foi a de prometer a manutenção do decreto de 16 de pluvioso do ano II. Em 4 nivoso do ano VIII (25 de dezembro de 1799), ele dirigiu uma carta aos cidadãos da colônia, os "bravos negros" de São Domingos, para informar-lhes das disposições da nova Constituição e, ao mesmo tempo, assegurar-lhes que a sua liberdade seria mantida. Notificava-os, entretanto, que,

\footnotetext{
1765 Cf. FRADERA, Josep M. L'esclavage et la logique constitutionnelle des empires. Annales. Histoire, Sciences Sociales, 63 (3), 2008, pp.533, 541-543.

1766 "Article 91. Le régime des colonies françaises est déterminé par des lois spéciales" (Constitution du 22 frimaire an VIII. Disponível em: http://www.conseil-constitutionnel.fr/conseilconstitutionnel/francais/la-constitution/les-constitutions-de-la-france/constitution-du-22-frimaire-anviii.5087.html. Acesso em: 12 de jun de 2012).
} 
de acordo com a nova Constituição outorgada ao povo francês, as colônias não poderiam mais ser representadas no Parlamento francês, e seriam governadas por leis especiais:

Cidadãos, uma constituição que não pode se sustentar contra violações múltiplas foi substituída por um novo pacto destinado a consolidar a liberdade.

O artigo 91 dispõe que as colônias francesas serão regidas por leis especiais. Essa disposição deriva da natureza das coisas e da diferença dos climas.

Os habitantes das colônias situadas na América, na Ásia, na África, não podem ser governados pela mesma lei.

A diferença dos hábitos, dos costumes, dos interesses, a diversidade do solo, das culturas, das produções, exigem modificações diversas.

Um dos primeiros atos da nova legislatura será a redação das leis destinadas a vos reger. Longe de serem para vós um motivo de alarme, vós reconhecereis nelas a sabedoria e a profundidade das vias que animam os legisladores da França.

Os Cônsules da República, ao vos anunciar o novo pacto social, vos declaram que os princípios sagrados da liberdade e da igualdade dos negros jamais sofrerão entre vós qualquer atentado ou modificação.

Se há, na colônia de São Domingos, homens mal intencionados, se há quem conserve relações com as potências inimigas, bravos negros, lembrai-vos que apenas o povo francês reconhece a vossa liberdade e a igualdade de vossos direitos. ${ }^{1767}$ (grifo nosso)

Na mesma data, Bonaparte decidiu que o homem de cor Julien Raimond partiria, ao lado do coronel e engenheiro Vincent, amigo de Toussaint, e do general Michel, para levar a declaração a São Domingos. O Cônsul especificou que as palavras "bravos negros, lembrai-vos que apenas o povo francês reconhece a vossa liberdade e igualdade de vossos direitos" deveriam ser inscritas em letras douradas em todas as bandeiras dos batalhões da guarda nacional da colônia de São Domingos. ${ }^{1768}$ Assim, Bonaparte fazia um jogo duplo: ao mesmo tempo em que estabelecia as bases para uma política contrária ao decreto de 16 pluvioso do ano II, ele procurava dar às populações

\footnotetext{
1767 "Citoyens, une constitution qui n'a pu se soutenir contre des violations multipliées est remplacée par un nouveau pacte destiné à affermir la liberté. L'article 91 porte que les colonies françaises seront régies par des lois spéciales. Cette disposition dérive de la nature des choses et de la différence des climats. Les habitants des colonies françaises situées en Amérique, en Asie, en Afrique, ne peuvent être gouvernés par la même loi. La différence des moeurs, des habitudes, des intérêts, la diversité du sol, des cultures, des productions, exigent des modifications diverses. Un des premiers actes de la nouvelle législature sera la rédaction des lois destinées à vous régir. Loin qu'elles soient pour vous un sujet d'alarme, vous y reconnaîtrez la sagesse et la profondeur des vues qui animent les législateurs français. Les Consuls de la République, en vous annonçant le nouveau pacte social, vous déclarent que les principes sacrés de la liberté et de l'égalité des noirs n'épouveront jamais parmi vous d'atteinte ni de modification. S'il est, dans la colonie de Saint-Domingue, des hommes malintentionnés, s'il en est qui conservent des relations avec les puissances ennemies, braves noirs, souvenez-vous que le peuple français seul reconnaît votre liberté et l'égalité de vos droits" (Correspondance de Napoléon I ${ }^{\text {er }}$, v.6, pp.53-54).

${ }^{1768}$ Ibidem, pp.54-55.
} 
emancipadas a garantia de que seu status de cidadãos livres não seria ameaçado. Queria passar uma imagem de continuidade, quando tudo apontava para uma ruptura.

Naquele final de 1799, o ministro da Marinha, Forfait, já conduzia consultas para saber se deveria haver uma intervenção militar em São Domingos. Mesmo entre os adeptos da abolição, eram muitos os que defendiam uma intervenção armada contra Toussaint, caso dos deputados ou antigos deputados da colônia - Dufay, Thomany e Belley -, que reconheciam a ameaça de independência da ilha. Por outro lado, entre os que pregavam uma intervenção militar, eram poucos os que já defendiam abertamente o restabelecimento da escravidão. Muitos pregavam uma aliança com os mulatos do Sul.

Havia também quem se opusesse à expedição. O deputado Louis Antoine Esprit Rallier, favorável a Toussaint, opunha-se a uma missão militar, acreditando que, em razão do clima e das doenças locais, ela estaria fadada ao fracasso. Pensava ainda que a desconfiança que a chegada de forças metropolitanas despertaria nos negros seria a perdição da missão francesa, pois os habitantes obedeciam fundamentalmente a Toussaint e não aceitariam outra autoridade. Sonthonax, embora contrário a Toussaint, também desaconselhava o envio de uma expedição, a menos que ela reunisse $30 \mathrm{mil}$ soldados, o que julgava impossível. Mesmo alguns colonos, como Paul Alliot Vaunef sustentavam a impossibilidade da reconquista militar. Page, antigo articulador do partido escravista, opunha-se agora a qualquer atentado à liberdade geral. Embora acreditasse que a independência das colônias americanas chegaria mais cedo ou mais tarde, propunha que se nomeasse Toussaint governador-geral, na esperança de que ele se mantivesse fiel à França. ${ }^{1769}$

Essa foi, aliás, a atitude inicial de Bonaparte que, ocupado com a sua campanha europeia e com os seus planos de conquista da Índia, preferia manter uma aparente boa vontade para com o governo de Toussaint. Ao mesmo tempo em que começava a preparar uma missão militar em São Domingos, o Cônsul procurava dar garantias de que a metrópole não reverteria o status quo na colônia. Em 14 brumário do ano IX (5 de novembro de 1800), mesmo dia em que dava ordens ao ministro Forfait para uma expedição secreta a São Domingos, Bonaparte encaminhou uma carta a Toussaint na qual anunciava uma nova organização para a ilha que convenceria o líder negro da "estima particular" do Cônsul para com ele e seus "bravos negros". ${ }^{1770}$ Mais tarde, em carta de 13 ventoso do ano IX (4 de março de 1801) a Toussaint, Bonaparte manifestou

${ }^{1769}$ Cf. BÉNOT, Yves. La démence coloniale sous Napoléon, pp.50-53.

${ }^{1770}$ Cf. Correspondance de Napoléon I ${ }^{\text {er }}$, v.6, n.5162-5164, pp.629-630. 
a sua esperança de que, no futuro, uma divisão do exército de São Domingos pudesse contribuir para ampliar as posses da República. Bonaparte comunicou ainda a nomeação de Toussaint como "capitão general da parte francesa de São Domingos", título que trazia em si uma "marca de confiança" da metrópole. ${ }^{1771}$ Numa instrução enviada no mesmo dia ao prefeito colonial, Bonaparte recomendava que se conquistasse a confiança de Toussaint, que era, naquele momento, "o primeiro agente da República em São Domingos". ${ }^{1772}$ Tratava-se de uma aliança de conveniência.

Contra as diretrizes de Bonaparte, entretanto, o líder negro tinha dado ordens ao seu sobrinho Moïse para marchar, ao lado de 10 mil soldados, sobre a parte espanhola de São Domingos, unificando a ilha em janeiro de 1801. Toussaint era agora a única autoridade na ilha. ${ }^{1773}$ Apenas após o fato consumado, pediu a aprovação do Cônsul. Bonaparte havia alertado Toussaint em 4 de novembro do ano anterior para que não entrasse em posse da parte espanhola da ilha antes da paz geral. ${ }^{1774}$ Indignado, ordenou secretamente, em março de 1801, que Toussaint fosse suprimido dos quadros do exército francês.

\section{III.3.2.3) A Constituição de São Domingos}

As relações entre São Domingos e o Consulado ficariam ainda mais tensas em meados de 1801. Em resposta à nova política de separação jurídica entre a metrópole e as colônias, Toussaint decidiu, após estabilizar a colônia, dar a São Domingos uma Constituição própria. Convocou uma comissão de seis homens, um de cada província, mesclando três brancos e três mulatos - dentre os quais, Julien Raimond - no intuito de elaborar o texto constitucional. Essa comissão era meramente decorativa, pois era Toussaint quem realmente dava as cartas.

Anunciada em 4 de fevereiro, redigida a partir de maio e aprovada por Toussaint em julho, a Constituição foi proclamada em 17 de agosto de 1801 . O seu art. $1^{\circ}$ dispunha que São Domingos e as ilhas adjacentes formavam o território de uma só colônia, sendo

\footnotetext{
${ }^{1771}$ Idem, v.7, n.5439, pp.61-62. Segundo Bénot, Toussaint jamais tomou conhecimento dessa nomeação, ocorrida em 6 de fevereiro de 1801, nem da decisão inversa, de março de 1801, que o eliminou dos quadros do exército (cf. BÉNOT, Yves. La démence coloniale sous Napoléon, p.24).

${ }_{1772}$ Cf. Correspondance de Napoléon I ${ }^{e r}$, v.7, n.5440, p.62.

${ }^{1773}$ Cf. FICK, Carolyn. The making of Haiti, pp.205-206.

${ }^{1774}$ Cf. Correspondance de Napoléon I ${ }^{e r}$, v.6, n.5160, pp.627-628.
} 
"parte do Império francês", mas "submetida a leis particulares". ${ }^{1775}$ Era exatamente o que dizia a constituição brumariana do ano VIII, mas a disposição era uma afronta, na medida em que estava implicado que a colônia faria as suas próprias "leis particulares". Para Bonaparte, era óbvio que cabia à França - isto é, a ele - legislar sobre as colônias.

$\mathrm{O}$ art. $3^{\circ}$ do título II confirmava de forma definitiva a abolição da escravidão: "Não pode haver escravos sobre este território; a servidão está nele abolida para sempre. Todos os homens nele nascem, vivem e morrem livres e franceses". Note-se a presença da palavra franceses, indicativa de que as aspirações de autonomia de Toussaint não implicavam uma ruptura completa com a metrópole. Os dois artigos seguintes proscreviam para sempre a discriminação de cor:

Art. 4. Todo homem, qualquer que seja a sua cor, é admissível em todos os empregos. Art.5. Não há outra distinção senão a das virtudes e dos talentos, e outra superioridade senão a que a lei dá no exercício de uma função pública. A lei é a mesma para todos, seja quando ela pune, seja quando ela protege. ${ }^{1776}$

O texto claramente tomava emprestado fórmulas consagradas pela Revolução francesa e se inscrevia na mesma lógica burguesa da igualdade jurídica entre os cidadãos. Por outro lado, a Constituição tinha peculiaridades. No seu art. $6^{\circ}$, por exemplo, ela tornava a religião católica a única a ser publicamente professada.

Acima de tudo, a Constituição continha dispositivos destinados a garantir a continuação da produção colonial e, nesse sentido, buscava preservar, pelo menos em parte, os interesses dos proprietários coloniais. O art.13 declarava:

A propriedade é sagrada e inviolável. Toda pessoa, por ela mesma ou por seus representantes, tem a livre disposição e a administração do que lhe é reconhecido pertencer. Aquele que atentar contra o exercício desse direito se torna criminoso perante a sociedade, e responsável perante a pessoa perturbada na sua propriedade. ${ }^{1777}$

\footnotetext{
${ }^{1775}$ Cf. CONSTITUTION de la Colonie Française de Saint-Domingue. Du 17 août 1801 (29 thermidor an 9). Paris: Imprimerie du Dépôt des Lois, s.d. [1801], p.1.

${ }^{1776}$ Art.3: "Il ne peut exister d'esclave sur ce territoire; la servitude y est à jamais abolie. Tous les hommes y naissent, vivent et meurent libres et français". Art. 4: "Tout homme, quelque soit sa couleur, y est admissible à tous les emplois". Art 5: "Il n'y existe d'autre distinction que celle des vertus et des talents, et d'autre superiorité que celle que la loi donne dans l'exercice d'une fonction publique. La loi y est la même pour tous, soit qu'elle punisse, soit qu'elle protège" (Ibidem, p.1).

1777 "La propriété est sacrée et inviolable. Toute personne, soit par elle-même, soit par ses représentans, a la libre disposition et l'administration de ce qui est reconnu lui appartenir. Quiconque porte atteinte à l'exercice de ce droit, se rend criminel envers la société, et responsable envers la personne troublée dans sa propriété" (Ibidem, p.2).
} 
O dispositivo retomava as garantias à propriedade privada consagradas pelas Assembleias da metrópole, mas tinha um segundo significado: dar aos proprietários absenteístas a certeza de que suas terras não seriam tomadas pelas massas negras e transformadas em pequenas plantações de subsistência. $\mathrm{O}$ art.73 o afirmava claramente:

Os proprietários ausentes por qualquer motivo conservam todos os seus direitos sobre os bens a eles pertencentes, e situados na colônia. Bastar-lhesá, para obter o levantamento do sequestro feito sobre os mesmos, apresentar seus títulos de propriedade, e, na ausência destes, os atos supletivos dos quais a lei determinará a fórmula. ${ }^{1778}$

A Constituição garantia ainda, no art.60, aos proprietários absenteístas e seus descendentes o direito à sucessão. ${ }^{1779}$ A política de Toussaint era de conciliação. Sabia que não podia confiar nos colonos brancos, mas precisava de sua experiência e de seus contatos para manter vivo o comércio de exportação de açúcar e café. Ficavam excluídos dessa proteção apenas os proprietários que estivessem inscritos na lista geral dos emigrados da França, cujos bens seriam administrados pelo Estado.

O Título VI era dedicado especialmente ao cultivo e ao comércio, e consolidava o sistema de trabalho compulsório já instituído por Sonthonax, Polverel e o próprio Toussaint Louverture. $\mathrm{O}$ art.14 dispunha que "a colônia, sendo essencialmente agrícola, não pode sofrer a menor interrupção nos trabalhos de suas culturas". Os artigos 15 e 16 descreviam a plantação como uma manufatura estruturada como uma "família", sendo o proprietário, ou seu representante, o "pai". Especificavam que "cada cultivador e operário é membro da família e porcionário nas receitas". O art.16 ainda esclarecia que "toda mudança de domicílio por parte dos cultivadores acarreta a ruína das culturas" e justificava com isso a adoção de regulamentos de polícia destinados a manter a mão de obra fixa nas plantações. A liberdade de movimento dos trabalhadores agrícolas era, assim, restrita. $\mathrm{O}$ art.17 abordava a necessidade da introdução contínua de cultivadores, indispensável para o restabelecimento e a ampliação da produção em São Domingos e encarregava o governador de tomar medidas para favorecer o aumento de mão de obra, o que sugeria autorizar o tráfico, ainda que os homens introduzidos na colônia fossem

\footnotetext{
1778 "Les propriétaires absents pour quelque cause que ce soit, conservent tous leurs droits sur les biens à eux appartenants, et situés dans la colonie. Il leur suffira, pour obtenir la main-levée du séquestre qui y aurait été posé, de représenter leurs titres de propriété, et à défaut de titres, des actes supplétifs dont la loi déterminera la formule". O art.58 dispunha apenas que o produto dos arrendamentos de bens sequestrados de proprietários ausentes e não representados integrariam provisoriamente parte da receita pública da colônia, para gastos de administração (Ibidem, pp.9 e 11).

${ }^{1779}$ Ibidem, p.10.
} 
declarados livres assim que tocassem o seu território. ${ }^{1780} \mathrm{O}$ sentido maior do novo regime era garantir a manutenção da produção para exportação, com base numa concepção restrita de liberdade. Essas normas já estavam, de alguma forma, em aplicação na ilha, mas, agora, elas adquiriam um caráter constitucional, o que era particularmente grave.

Como assinala Barthélemy, ao falar em "cultivadores", a Constituição de Toussaint referia-se à grande maioria de boçais que dariam sequência ao trabalho nas plantações. Caberia ao seu exército crioulo manter esses africanos no trabalho, o que não deixava de explicitar as tensões existentes entre duas culturas diferentes - a crioula e a africana - no seio da nova sociedade livre que se estava construindo. ${ }^{1781}$

No que se refere ao regime político da colônia, a Constituição concentrava os poderes nas mãos de Toussaint Louverture, nomeado Governador "pelo resto de sua gloriosa vida", tendo ainda o direito de escolher seu sucessor (artigos 28-29). A administração era confiada ao Governador, que corresponder-se-ia diretamente com o governo francês para tudo o que fosse relativo aos interesses da colônia (art.27). Caberia ao Governador propor as leis e submetê-las à aprovação ou rejeição da Assembleia central de São Domingos, eleita por administradores que ele próprio nomearia (art.19). ${ }^{1782} \mathrm{O}$ Governador tinha ainda o poder de promulgar as leis; nomear para todos os empregos civis e militares; comandar as forças armadas; determinar a divisão do território; velar pela sua segurança interna e externa; exercer a polícia geral das plantações e manufaturas; impor aos proprietários, fazendeiros e representantes a observância de suas obrigações para com os cultivadores e operários e vice-versa; propor leis e eventuais mudanças à Constituição; dirigir as finanças da colônia; exercer a censura sobre todos os escritos impressos na ilha e impedir a entrada de outros que fossem potencialmente subversivos; ordenar a prisão imediata de pessoas presumidas autoras ou cúmplices de conspiração contra a tranquilidade da colônia. Sua remuneração era fixada em 300 mil francos (artigos 34-41). ${ }^{1783}$ Embora previsse um sistema parlamentar, a Constituição estabelecia, na verdade, o poder pessoal de Toussaint Louverture.

\footnotetext{
${ }^{1780}$ Ibidem, p.3.

${ }^{1781}$ Cf. BARTHÉLEMY, Gérard. Le rôle des bossales dans l'émergence d'une culture de marronnage en Haïti, pp.846 e 858-859.

${ }_{1782}$ Cf. CONSTITUTION de la Colonie Française de Saint-Domingue, pp.3-5.

${ }^{1783}$ Ibidem, pp.6-7.
} 
A Constituição dispunha finalmente que caberia a Toussaint enviá-la à sanção do governo francês, mas que, dada a carência absoluta de leis na ilha e a necessidade urgente de sair da situação de perigo em que esta se encontrava, o governador a colocaria em execução em toda a extensão do território de São Domingos. ${ }^{1784}$ Embora a Constituição reafirmasse a lealdade à metrópole, ela tinha sido feita e colocada em vigor sem qualquer participação da França. Nenhuma função administrativa era atribuída aos franceses. Aos olhos do Consulado, isso era, na prática, uma independência.

Toussaint procurou se justificar. Argumentou que, após a tomada de Santo Domingo, vendo que o governo francês não lhe enviava leis sobre a colônia e sentindo a urgência de restabelecer a ordem, ele convidou todas as comunas a enviar seus deputados para formar uma Assembleia central e preparar uma Constituição adequada às particularidades locais. Toussaint enfatizava ter consciência de que a sua Constituição deveria ser submetida à sanção do governo francês, único a ter o direito de adotá-la ou rejeitá-la. Informou que, assim que as bases da Constituição e as leis orgânicas foram estabelecidas, ele as enviou ao governo francês, para obter a sanção. ${ }^{1785}$

O coronel Vincent foi encarregado de levar a Constituição a Bonaparte, mas ela entrou em vigor imediatamente. Tão logo aquele tinha partido, Toussaint ordenou a publicação do texto constitucional. Vincent censurá-lo-ia por tê-lo feito sem a sanção da metrópole. Uma carta redigida por Pascal, secretário de Toussaint, seria enviada à metrópole para negar qualquer projeto de independência. Toussaint sabia que, cercada por potências escravistas, São Domingos não podia entrar em conflito com a França, em tese, a única potência colonizadora não escravista da época. ${ }^{1786}$ Vincent chegou à França em outubro de 1801 com a Constituição de São Domingos. Embora criticasse a atitude de Toussaint, Vincent alertou o Cônsul, numa entrevista do início de novembro, para os perigos de uma expedição militar. ${ }^{1787}$

Muitos já viam a tomada da parte espanhola de São Domingos e a Constituição de 1801 como a concretização do projeto autonomista de Toussaint Louverture. A situação local, entretanto, era muito mais tensa para o grande líder do que essas medidas sugeriam. A legitimidade de sua política era questionada por boa parte da população, em razão do regime de trabalho compulsório por ele adotado na colônia. Esse sistema

\footnotetext{
${ }^{1784}$ Ibidem, p.12.

1785 Cf. LOUVERTURE, Toussaint. Mémoires, pp.86-87.

${ }^{1786}$ Cf. BÉNOT, Yves. La démence coloniale sous Napoléon, pp.28-29.

${ }^{1787}$ Vincent forneceria informações para a expedição militar, mas se recusaria a participar dela. Acabaria sendo enviado para a ilha de Elba pelo $1^{\circ}$ cônsul (Ibidem, pp.64-66).
} 
não agradava aos trabalhadores negros de São Domingos, para os quais a liberdade significava, acima de tudo, a possibilidade de deixar as grandes plantações de açúcar, anil e café e cultivar um pequeno lote de terra para si. Assim, aquela que era a base de sustentação do regime de Toussaint estava em desacordo com o seu projeto político e econômico. Furiosos com as normas da Constituição de Louverture, os trabalhadores se revoltaram em outubro de 1801. Toussaint acusou seu sobrinho Moïse pela rebelião. Embora tenha negado a acusação, Moïse era, de fato, contrário ao regime disciplinar instituído na colônia. Tinha pedido ao seu tio um parcelamento de terras e sua venda à baixa oficialidade e a soldados do exército negro de São Domingos, em detrimento dos altos oficiais. ${ }^{1788} \mathrm{O}$ seu programa, que implicava a eliminação dos plantadores brancos, estava, portanto, mais próximo das aspirações das massas negras. A resposta de Toussaint foi feroz e Moïse e outros foram executados em novembro de 1801. Com isso, novos regulamentos, ainda mais rígidos, para a agricultura foram anunciados. ${ }^{1789}$ Quando Leclerc chegaria com suas tropas em fevereiro de 1802, o regime de Toussaint já estaria fragilizado pela alienação da sua base de apoio.

Enfurecido pelas atitudes de Toussaint, Bonaparte já havia excluído Toussaint dos quadros do exército francês, mas ainda tinha de manter em segredo a sua real opinião sobre o líder negro enquanto persistisse a guerra contra os britânicos. Uma ruptura aberta com Toussaint ainda não era viável. Mas, naqueles últimos meses de 1801, a situação logo seria alterada com o fim do conflito na Europa.

\section{III.3.3) A revogação da abolição}

\section{III.3.3.1) A paz com a Inglaterra}

Com as negociações de paz entre a França e o Reino Unido, a ordem instaurada nas Antilhas com a lei de abolição de 1794 ver-se-ia ameaçada. Após o fim do governo do ano II, a manutenção de um "projeto republicano" na região havia se sustentado na necessidade estratégica de um exército forte. $O$ relaxamento da situação militar permitia, em tese, a superação da aliança de conveniência com as massas de antigos escravos. O tratado de Mortefontaine, de 30 de setembro de 1800, já havia posto fim à quase-guerra com os Estados Unidos e, antes do final do mesmo ano, tratados de paz

\footnotetext{
${ }^{1788}$ Cf. FICK, Carolyn. The making of Haiti, pp.208-209.

${ }^{1789}$ Cf. DUBOIS, Laurent. A Colony of Citizens, pp.382-383.
} 
com a Espanha também foram concluídos. Em 9 de fevereiro de 1801, por meio do tratado de Lunéville, a França pôs fim à guerra com a Áustria. Na Grã-Bretanha, George III substituía Pitt por Henry Addington no ministério, que abriria negociações com a diplomacia francesa. No outono de 1801, o primeiro-ministro Addington e o ministro francês das relações exteriores, Talleyrand-Périgord, iniciaram negociações que levariam a um tratado de paz entre as duas nações. As preliminares do tratado foram assinadas em outubro de 1801. Elas previam a restituição à França de todas as colônias que a Grã-Bretanha tinha tomado: Martinica, Sainte-Lucie, Tobago, Gorée e cinco cidades da Índia. Em troca, a França oferecia Trinidad e o Ceilão, sem, aliás, consultar a Holanda e a Espanha. As bases dessas preliminares seriam confirmadas com o Tratado de Amiens, de 26 de março de 1802.

A paz havia deixado os fabricantes de algodão, que haviam se beneficiado da política protecionista da Revolução, em estado de alarme. A lembrança dos resultados desastrosos do tratado de 1786 ainda era bastante viva e havia, de fato, no círculo de Bonaparte, quem fosse favorável ao restabelecimento de um acordo de comércio com a Grã-Bretanha, caso do ministro do Interior, Chaptal. Manufatureiros pressionavam agora pela manutenção da proibição pura e simples da entrada dos produtos britânicos no território nacional. ${ }^{1790}$ Inversamente, os meios ligados ao comércio marítimo observavam as negociações com esperanças renovadas. Com a paz, esperava-se que o comércio com as colônias pudesse ser restabelecido. Eram poucos os que ambicionavam dirigir os esforços comerciais da França num sentido continental. À medida que a paz foi se desenhando no horizonte, o Consulado voltou-se cada vez mais para a questão colonial. Em carta de 4 fructidor do ano X (22 de agosto de 1801), Bonaparte já havia pedido ao ministro da Marinha, Forfait, que traçasse um quadro geral das colônias francesas na América, na África e nas Índias, com a indicação da importância de cada uma delas para o comércio da França. ${ }^{1791}$

Em meio às negociações com a Grã-Bretanha, Talleyrand e Bonaparte conversaram sobre o que aconteceria se eles se aliassem a Toussaint Louverture em vez de atacá-lo. Em carta a Talleyrand de 22 brumário do ano X (13 de novembro de 1801), Bonaparte pediu ao ministro que comunicasse ao gabinete britânico, com quem negociava a partida de uma expedição para São Domingos, que se a França tivesse de adiar a expedição para outro ano, o Consulado seria obrigado a reconhecer o governo de

\footnotetext{
${ }^{1790}$ Cf. JOUVENEL, Bertrand de. Napoléon et l'économie dirigée, pp.138-141, 146-147.

${ }^{1791}$ Cf. Correspondance de Napoléon $I^{\text {er }}$, v.7, n.5698, p.230.
} 
Toussaint, renunciar a São Domingos e constituir na colônia cidadãos negros franceses. Afirmou que isso "[...] seria muito vantajoso para a República sob o ponto de vista da potência militar". Bonaparte alertava que, reconquistada pelos brancos, São Domingos precisaria do apoio constante da metrópole, ao passo que "[...] a liberdade dos negros, reconhecida em São Domingos e legitimada pelo Governo, seria, em todos os tempos, um ponto de apoio para a República no novo mundo". ${ }^{1792}$ Esse aparente reconhecimento das vantagens estratégicas da abolição nas colônias era uma forma de ameaçar os britânicos, evocando a possibilidade de um avanço sobre as suas colônias na América, e, assim, obter deles permissão para uma expedição militar em São Domingos.

Se acreditarmos nas palavras de Cambacérès - Segundo Cônsul desde janeiro de 1800 - Bonaparte não era propriamente contrário à abolição enquanto princípio. O seu objetivo primordial era restabelecer a autoridade metropolitana em São Domingos. Em suas memórias, Cambacérès escreveu que o Primeiro Cônsul sabia que a liberdade dos negros era o preço de sua submissão à metrópole, mas entendia que essa liberdade tinha de ser concedida gradualmente e que, até então, o sistema colonial tinha de ser mantido tal como ele existia antes da Revolução. As palavras de Cambacérès, entretanto, são as de um homem que procurou justificar decisões que se revelaram posteriormente catastróficas, devendo assim ser lidas com certo ceticismo. ${ }^{1793}$

Quaisquer que fossem as suas reais opiniões, Bonaparte continuava a querer manter as aparências. Em 15 vendemiário do ano X (7 de outubro de 1801), menos de uma semana após a assinatura das preliminares de paz em Londres, Bonaparte já escrevia, numa carta ao ministro da Marinha e das colônias, Decrès:

É necessário que uma fragata deixe os nossos portos em 25 vendemiário para levar à Guadalupe a notícia da paz, e a ordem ao general Lacrosse de informar, em nome do governo, aos habitantes da Martinica e de SainteLucie que eles nada devem temer quanto à liberdade dos negros, que serão mantidos no seu estado atual.

Por outro lado, na mesma carta, Bonaparte especificava ainda que outra ordem deveria partir na mesma época para a Île-de-France, onde a abolição não tinha sido feita: "Vós informareis o general Magallon da intenção do governo de manter os negros

1792 "[...] mais serait três avantageux à la République sous le point de vue de la puissance militaire"; "[...] la liberté des noirs, reconnue à Saint-Domingue et légitimée par le Gouvernement, serait dans tous les temps un point d'appui pour la République dans le nouveau monde" (Correspondance de Napoléon I ${ }^{\text {, }}$, v.7, n.5863, p.320).

${ }^{1793}$ Cf. CAMBACÉRÈS, Jean-Jacques Régis de. Mémoires inédits. S.1.: Librairie Académique Perrin, 1999, v.1, pp.586-587. 
na posição em que se encontram, e fazer tudo aquilo que poderá consolidar um estabelecimento que é o fundamento de nossa potência na Índia". ${ }^{1794}$ Anunciava ainda sua intenção de enviar secretamente o almirante Villaret-Joyeuse, um notório escravista, a São Domingos, com uma grande frota de navios (doze franceses e seis espanhóis) e seis ou sete mil homens de tropa, para fazer respeitar na colônia "os direitos da metrópole". Ordenava que, logo após a partida de Villaret, armamentos fossem preparados em Brest para o envio de socorros, em munições de guerra e homens, a São Domingos. ${ }^{1795}$ Assim, aos negros Bonaparte dava garantias de que a liberdade seria preservada; aos brancos, indicava precisamente o contrário.

Uma expedição militar sempre esteve nos planos de Bonaparte, mas a conjuntura não havia, até então, permitido passar para a ação concreta. A Constituição de São Domingos tinha lhe dado uma justificativa suficiente para uma intervenção contra $\mathrm{O}$ governo de Toussaint. Com a paz, nada mais podia detê-lo. Apesar disso, alguns tentaram dissuadir o Primeiro Cônsul. Além do coronel Vincent, outros personagens tentaram alertar para o perigo dessa expedição, como o ex-comissário Roume e o senador Volney, um antigo amigo dos Negros, que achava melhor abandonar essas posses longínquas, onerosas e impossíveis de conservar. Acreditava que a França, como potência continental, tinha de se limitar à sua esfera de atividade, sem sair do Mediterrâneo. ${ }^{1796}$ Apesar das advertências a respeito da força do exército negro de São Domingos, Bonaparte preferiu ouvir conselheiros escravistas, como Barbé-Marbois e Moreau de Saint-Méry. Assim, ele ordenou a formação de uma grande expedição militar, com 20 mil soldados sob o comando de seu cunhado, o general Leclerc, que tinha comandado as tropas que dispersaram o Conselho dos Quinhentos em 18-19 brumário. Uma expedição naval já tinha sido concebida pelos cônsules em 4 de maio de 1801, sob o comando de Villaret-Joyeuse, para retomar o Suriname e Trinidad, antes de rumar para São Domingos, mas sua partida tinha sido suspensa. Agora, uma nova

\footnotetext{
1794 "Il est nécessaire qu'une frégate parte le 25 vendémiaire de nos ports pour porter à la Guadeloupe la nouvelle de la paix, et l'ordre au général Lacrosse de faire connaître aux habitans de la Martinique et de Sainte-Lucie, au nom du gouvernement, qu'ils n'ont rien à craindre pour la liberté des nègres, qui seront maintenus dans leur état actuel"; "Vous ferez connaître au général Magallon l'intention où est le gouvernement de maintenir les nègres dans la position où ils se trouvent, et de faire tout ce qui pourra solider un établissement qui est le fondement de notre puissance dans l'Inde" (Correspondance de Napoléon I Ir , v.7, n.5786, p.277).

1795 Ibidem, pp.278-279.

${ }^{1796}$ Cf. BÉNOT, Yves. La démence coloniale sous Napoléon, p.68.
} 
expedição era formada. Em 23 de outubro de 1801, Leclerc foi nomeado chefe do exército expedicionário. ${ }^{1797}$

Bonaparte tinha dado a Leclerc, em 9 brumário do ano X (31 de outubro de 1801), instruções especiais. No que se refere à política interna, isto é, relativa aos negros, Bonaparte dizia: "Nunca a nação francesa colocará correntes em homens que ela reconheceu livres. Assim, todos os negros viverão em São Domingos tal como eles estão hoje na Guadalupe". Mas, na medida em que a escravidão seria restabelecida na Guadalupe, isso não queria dizer nada. Mais concretamente, Bonaparte ordenava o desarmamento dos negros: primeiramente, dos rebeldes; depois, dos demais. Recomendava conquistar a confiança de Toussaint e dos demais líderes negros, confirmando-os inicialmente em seus postos, para depois, sem fazer alarde, enviá-los para a França. Todos os brancos que haviam servido sob Toussaint teriam de ser enviados para a Guiana. Os negros dotados de alguma patente, mesmo que tivessem se comportado bem, teriam de ser enviados a Brest. Após serem desarmadas, as massas de antigos escravos seriam finalmente reintroduzidas no cultivo. Se ainda falava em manter "livres" os trabalhadores da parte francesa de São Domingos, Bonaparte já ordenava a reescravização dos da parte espanhola. Planejava ainda devolver aos colonos que estavam na França e que não tinham emigrado as suas propriedades, com a anulação de todas as doações de terras feitas pelo governo de Toussaint. Previa que, mais tarde, os regulamentos de comércio anteriores à Revolução seriam restabelecidos e que o comércio deixaria de ser acessível aos americanos. ${ }^{1798}$ Sem falar ainda no restabelecimento da escravidão, Bonaparte claramente dava instruções para a recomposição do antigo regime colonial.

O Cônsul mantinha, contudo, o seu duplo discurso. Em 27 brumário do ano X (18 de novembro de 1801), enviou a Toussaint uma carta na qual mostrou-se mais uma vez conciliador. Manifestou-lhe a sua "estima", reconhecendo "os grandes serviços" que tinha prestado ao povo francês. Sobre a Constituição de São Domingos, afirmava que ela continha "muitas coisas boas", assim como outras que eram "contrárias à dignidade e à soberania do povo francês, do qual São Domingos forma apenas uma porção". Desculpava, entretanto, os aspectos mais problemáticos da Constituição como um

1797 Cf. JAMES, C.L.R. Os jacobinos negros, pp.251-252; DUBOIS, Laurent. A Colony of Citizens, p.344; BÉNOT, Yves. La démence coloniale sous Napoléon, pp.26-27.

1798 "Jamais la nation française ne donnera des fers à des hommes qu'elle a reconnu libres. Ainsi donc tous les noirs vivront à Saint-Domingue comme ils sont aujourd'hui à la Guadeloupe" (Lettres du général Leclerc, commandant en chef de l'armée de Saint-Domingue en 1802. Paris: Société de l'histoire des colonies françaises, Librairie Ernest Leroux, 1937, pp.269-274). 
resultado das circunstâncias difíceis que envolveram a colônia nos tempos recentes. Agora que a paz tinha alterado as circunstâncias, esperava de Toussaint o reconhecimento da soberania da nação francesa. Informava o líder negro do envio do general Leclerc como "primeiro magistrado da colônia", acompanhado de "forças convenientes para fazer respeitar a soberania do povo francês". ${ }^{1799} \mathrm{Em}$ tom mais ameaçador, alertava que qualquer ato contrário aos interesses da França e à obediência que Toussaint e todos os cidadãos de São Domingos deviam ao delegado da metrópole seria visto como um "crime contra a soberania nacional", podendo fazer de São Domingos o "o teatro de uma guerra infeliz onde pais e filhos massacrariam uns aos outros". ${ }^{1800}$

Leclerc partiu em 14 de dezembro de $1801 .^{1801}$ A chegada da expedição a São Domingos não tardaria a desencadear a guerra civil, muito embora as ordens de Leclerc fossem de acalmar os ânimos e dissipar os temores entre a população negra. O general tinha sido incumbido de afixar nos muros da colônia uma proclamação consular, de 17 brumário (8 de novembro de 1801), que garantia que as forças francesas não vinham para privar os negros da liberdade e pregava união em torno do enviado da República: "Habitantes de São Domingos, qualquer que seja a vossa origem e a vossa cor, vós sois todos Franceses, vós sois todos livres e todos iguais perante Deus e perante a República". ${ }^{1802}$

Meses após a partida de Leclerc, chegava à França a notícia da revolta de Pélage na Guadalupe. O ministro Decrès declarou que a revolta era resultado da emancipação e que esta tinha de ser revertida. Em 7 de janeiro de 1802, Bonarparte ordenou uma missão à Guadalupe, com o general Richepanse à frente de 3.454 homens. A expedição deixou a França no início de abril e chegou à ilha em 6 de maio. Assim como Leclerc, Richepanse tinha sido instruído a assegurar aos negros que a abolição seria mantida, como forma de desmobilizar os antigos escravos associados aos rebeldes. ${ }^{1803}$

Pélage e seu Conselho fizeram de tudo para mostrarem-se fiéis à metrópole, reprimindo, aliás, os movimentos de antigos escravos que, nos primeiros meses de

\footnotetext{
1799 Cf. Correspondance de Napoléon I $I^{e r}$, v.7, n.5867, p.322.

${ }^{1800}$ Ibidem, p.323.

${ }^{1801}$ Cf. SANDEAU, Jacques. La Révolution à Saint-Domingue et le désastre du corps expéditionnaire français, 1789-1803. Revue de l'Institut Napoléon, Paris, n.191, 2005, p.23.

1802 "Habitants de Saint-Domingue, quelles que soient votre origine et votre couleur, vous êtes tous Français, vous êtes tous libres et tous égaux devant Dieu et devant la République" (Correspondance de Napoléon $I^{\text {er }}$, v.7, n.5859, p.315).

${ }^{1803}$ Cf. DUBOIS, Laurent. A Colony of Citizens, pp.368-369 e 389; BÉNOT, Yves. La démence coloniale sous Napoléon, p.69.
} 
1802, decidiram abandonar as plantações, após receberem notícias da missão Leclerc e da preparação de uma missão para a Guadalupe. O Conselho provisório chegou a emitir uma proclamação, em 5 de abril de 1802, denunciando os "adeptos secretos de Toussaint Louverture", considerados maus cidadãos. ${ }^{1804}$

Richepanse foi inicialmente bem recebido por Pélage, que queria dar provas de lealdade à metrópole. Mas, apesar disso, o agente francês determinou o desarmamento das tropas negras. Com isso, uma parte do exército de cor, liderada por Louis Delgrès, se insurgiu, com o apoio de antigos escravos. Para tentar neutralizar a resistência, Richepanse emitiu uma declaração prometendo que a liberdade geral não seria revogada, mas essa iniciativa não gerou efeitos. O conflito assumiu as proporções de uma guerra generalizada. Depois de semanas de intenso combate, os rebeldes seriam derrotados pelos franceses, com um trágico desfecho em Matouba, onde mais de 500 insurretos preferiram tirar a própria vida, com explosivos, a se entregarem. ${ }^{1805}$

\section{III.3.3.2) A lei de 30 floreal do ano $X$ ( 20 de maio de 1802)}

Até então, a política colonial consular tinha sido conduzida apenas com medidas secretas e falsas promessas. Com a paz assinada em Amiens em 25 de março de 1802, entretanto, a França tornaria pública a sua intenção de restabelecer a escravidão nas colônias, tendo como ponto de partida os territórios que lhe tinham sido devolvidos pela Grã-Bretanha. Bonaparte, agora declarado Cônsul vitalício, queria restabelecer a ordem nas colônias francesas, assim como a sua prosperidade econômica, mas, além disso, também pretendia usar as Antilhas e, sobretudo, São Domingos como plataforma para uma política ativa no continente americano. ${ }^{1806} \mathrm{O}$ decreto de 30 floreal do ano X (20 de maio de 1802) marcaria o início do processo de revogação da lei de abolição.

Esse processo restauracionista não se deu de forma unitária. Decrès, ministro da Marinha desde outubro de 1801, sugeriu a hipótese de instituir um regime colonial dualista, isto é, com uma diferença entre as colônias onde a liberdade tinha sido proclamada e deveria ser mantida e colônias onde ela não tinha sido proclamada e onde seria um erro tentar fazê-lo. No seu Exposé de la situation de la République,

\footnotetext{
${ }^{1804}$ Cf. DUBOIS, Laurent. A Colony of Citizens, pp.379-382; BÉNOT, Yves. La démence coloniale sous Napoléon, p.70

${ }^{1805}$ Cf. DUBOIS, Laurent. A Colony of Citizens, pp.318-320 e 395-400.

${ }^{1806}$ Cf. CHAMPION, Jean Marcel. 30 Floréal an X: le rétablissement de l'esclavage par Bonaparte. In: M. DORIGNY (org.). Les abolitions de l'esclavage, p.266.
} 
pronunciado perante o Corpo Legislativo em $1^{\circ}$ frimário do ano VIII (22 de novembro de 1801), Bonaparte parecia ter se rendido a essa tese:

Em São Domingos e na Guadalupe, não há mais escravos; lá, tudo é livre e tudo permanecerá livre. A sabedoria e o tempo restabelecerão nelas a ordem e restabelecerão a cultura e os trabalhos. Na Martinica, serão princípios diferentes: a Martinica conservou a escravidão e a escravidão será conservada. Ela custou demais à humanidade, para que se tente, nessa parte do mundo, uma nova revolução.

O cônsul assegurava também às Mascarenhas, que tinham permanecido fiéis à metrópole, que elas não tinham mais a temer "[...] que a metrópole, ao dar a liberdade aos negros, conduza à escravidão dos brancos". ${ }^{1807}$

Em $1^{\circ}$ floreal do ano X (21 de abril 1802), Decrès pediu ao Primeiro Cônsul uma lei que dissipasse o temor dos colonos e impedisse a aplicação das leis de 16 pluvioso do ano II e 12 nivoso do ano VI nas colônias recuperadas por meio do tratado de Amiens. ${ }^{1808}$ Contudo, nesse mesmo relatório, Decrès afirmava:

Entendo que seria mais desejável que a lei que eu proponho fosse mais generalizada; mas, por meio de um sistema controlado, seu resultado poderá se estender sem comoção e sem resistência em todas as nossas colônias num curto espaço de tempo; e, diante do fato consumado, será mais fácil do que hoje consagrar o seu princípio. ${ }^{1809}$ (grifo nosso)

Ou seja, o restabelecimento da escravidão em São Domingos, Guadalupe e Guiana era, de fato, previsto nas esferas do poder. Ele apenas teria de se dar de forma dissimulada, por meio de medidas parciais e não através de uma lei geral.

Isso fica ainda mais claro quando analisamos as notas enviadas por Bonaparte ao Segundo Cônsul Cambacérès, em 7 floreal do ano X (27 de abril de 1802), para servir de base para a redação de cinco projetos de lei a serem aprovados por senatus-consulto. Havia um projeto para a Île-de-France; um para Tobago, Martinica e Sainte-Lucie; um para a Guadalupe; um para São Domingos; e um quinto, para proibir a chegada de

\footnotetext{
1807 "A Saint-Domingue et à la Guadeloupe il n'est plus d'esclaves; tout y est libre, tout y restera libre. La sagesse et le temps y ramèneront l'ordre et y rétabliront la culture et les travaux. A la Martinique, ce seront des principes différents: la Martinique a conservé l'esclavage, et l'esclavage y sera conservé. Il en a trop coûté à l'humanité pour tenter encore, dans cette partie du monde, une révolution nouvelle"; "[...] que la métropole, en donnant la liberté des noirs, ne constitue l'esclavage des blancs" (Correspondance de Napoléon $I^{\text {er }}$, v.7, n.5874, p.331).

${ }^{1808}$ Cf. WANQUET, Claude. La France et la première abolition de l'esclavage, p.639.

1809 "Je conçois qu'il serait désirable que la loi que je propose fût plus généralisée; mais, moyennant un système suivi, son résultat pourra s'étendre sans commotion et sans résistance dans toutes nos colonies dans un court espace de temps; et, le fait établi, il sera plus facile alors qu'aujourd'hui d'en consacrer le principe" (citado em BÉNOT, Yves. La démence coloniale sous Napoléon, p.91).
} 
negros no continente da República. ${ }^{1810}$ A primeira nota de Bonaparte falava em dividir as colônias em duas classes: 1) aquelas em que as leis sobre a emancipação dos negros tinham sido publicadas e mais ou menos bem executadas"; 2) aquelas onde a antiga ordem tinha sido conservada. Para as primeiras, Bonaparte estipulava que seria feita uma lista com os nomes dos indivíduos negros que gozavam da liberdade antes da lei de abolição de 16 pluvioso do ano II e os nomes dos indivíduos negros que concorreram para defender o território da República contra os seus inimigos ou que serviram o Estado de alguma outra maneira. Todos os indivíduos constantes dessa lista seriam considerados livres. Contudo, aqueles dentre eles que não fossem proprietários e que não tivessem ofício ou emprego que lhes garantisse a subsistência seriam submetidos a "[...] regulamentos de polícia que os atribuirão aos proprietários para secundá-los nos trabalhos da agricultura, que determinarão o seu salário, e estatuirão a respeito de todas as disposições destinadas a prevenir a vagabundagem e a insubordinação". Os que se recusassem a cumprir essa determinação seriam eliminados dessa lista, podendo até mesmo ser deportados para ilhas onde a lei de abolição não tinha sido publicada. Quanto aos indivíduos que não constassem da lista mencionada, Bonaparte determinava que seriam submetidos "[...] às leis e regulamentos que, em 1789, compunham o código negro das colônias". Isto é, seriam reescravizados. Além disso, o Cônsul restabelecia o tráfico ao determinar que "será permitido importar negros [...] em conformidade com as leis e regulamentos sobre o tráfico que estavam em vigor em 1789". Para as colônias em que a abolição não tinha sido proclamada, as leis às quais os negros estavam submetidos em 1789 continuariam a vigorar e a importação de mão de obra continuaria a ser praticada, de acordo com as leis e regulamentos antigos. ${ }^{1811}$

Numa segunda nota, Bonaparte especificava que, na Martinica, em Sainte-Lucie, Tobago e Île-de-France, os negros continuariam a viver sob o regime existente em 1789, sendo que as leis que tivessem sido votadas pelos diferentes corpos legislativos, sob as diferentes constituições, seriam declaradas nulas e não aplicáveis às colônias. O tráfico de escravos e todas as leis a ele relativas existentes em 1789 seriam reinstituídos, até

\footnotetext{
${ }^{1810}$ Cf. Correspondance de Napoléon $I^{e r}$, v.7, n.6053, pp.444-445.

1811 "[...] des règlements de police qui les assigneront aux propriétaires pour les seconder dans les travaux de l'agriculture, qui détermineront leur salaire, et qui statueront sur toutes les dispositions pour prevenir le vagabondage et l'insubordination"; "il sera permis d'importer des noirs [...] en se conformant aux lois et règlements sur la traite qui étaient en vigueur en 1789" (Correspondance de Napoléon I ${ }^{e r}$, v.7, n.6054, pp.445-446).
} 
que o Governo francês pudesse se entender com o governo inglês e os outros governos para, de comum acordo, suprimi-lo. ${ }^{1812}$

Por fim, numa terceira nota, o Primeiro Cônsul determinava claramente que "todos os negros provenientes do tráfico, que chegarão às colônias da Martinica e de São Domingos, serão tratados como eles o são nas outras colônias europeias, e da mesma maneira que eles o eram em 1789 nas mesmas colônias". Isto é, seriam escravos. Ficariam protegidos apenas "os negros que defenderam as colônias contra os inimigos da República, e que prestaram serviços ao Estado". Apenas estes, os soldados do exército negro das colônias, seriam considerados definitivamente livres. Para um militar como Bonaparte, apenas eles eram dignos de consideração. ${ }^{1813}$

Para compor a lei sobre as colônias, Cambacérès reuniu um certo número de conselheiros de Estado, dentre os quais figuras conservadoras, como o almirante Bruix, crioulo de São Domingos, e André-Julien Dupuy, antigo administrador na Île-deFrance. O Senado observou que o sistema que se queria instituir era inconstitucional, na medida em que estabelecia dois regimes diferentes para as colônias francesas. Com isso, caminhou-se falsamente para um regime único, que mantinha a escravidão onde ela não tinha sido abolida e silenciava sobre as demais colônias, embora dando ao governo a competência para legislar sobre o seu regime interno. ${ }^{1814}$ Esse seria o sistema da lei de 30 floreal do ano $X$.

Antes de aprovar qualquer medida, era preciso depurar o Tribunado de homens como Benjamin Constant, Ginguené e Garat, que opunham-se ao regime ditatorial do Consulado e tentavam bloquear projetos importantes para Bonaparte, como o Código Civil. Em 18 de janeiro, vinte tribunos hostis ao Primeiro Cônsul foram excluídos da legislatura. Além disso, Grégoire, a figura mais ligada ao abolicionismo na época, foi nomeado para o Senado, o que significava que não teria mais direito à palavra sobre o fundo da questão. ${ }^{1815}$

O projeto de lei foi apresentado ao Tribunado em 27 floreal (17 de maio) por Adet, que afirmou que a escravidão, embora deplorável, era inevitável nas colônias. Na sessão do Corpo Legislativo, de 29 floreal (19 de maio), o projeto foi apresentado por

\footnotetext{
1812 Idem, n.6055, p.446.

1813 "tous les noirs provenant de la traite, qui arriveront aux colonies de la Martinique et de SaintDomingue, seront traités comme ils le sont dans les autres colonies européennes, et de la même manière qu'ils l'étaient en 1789 dans les mêmes colonies"; "les noirs qui ont défendu nos colonies contre les ennemis de la République, et qui ont rendu des services à l'État" (Idem, n.6056, p.447).

1814 Cf. CHAMPION, Jean Marcel. 30 Floréal an X, pp.268-269.

${ }^{1815}$ Cf. BÉNOT, Yves. La démence coloniale sous Napoléon, p.91.
} 
Regnault de Saint-Jean d'Angély. O orador afirmou que, com o Tratado de Amiens, a França tinha recuperado as suas colônias e cabia agora adotar uma legislação que desse à República os meios de conservá-las. Nesse sentido, relembrou que todas as potências coloniais recorriam à mão de obra escrava: "O interesse das Nações continentais criou, sancionou esse meio único de cultura, ao qual nenhuma delas pode renunciar sem perder suas vantagens na balança da Europa, sem descer do nível em que ela se encontra". ${ }^{1816}$

Regnault sugeriu que a Inglaterra havia habilmente estimulado, por meio de Wilberforce e Pitt, a ideia da abolição do tráfico, inspirando alguns "espíritos ardentes" na França a defender essa causa perante a Assembleia Constituinte. Contudo, esta teria percebido que destruir o regime das colônias significava destruir as colônias e, consequentemente, arruinar o comércio. $\mathrm{O}$ orador apontava a necessidade de restabelecer ou manter o regime das colônias, mas não apenas por razões políticas ou comerciais, mas também por razões de "humanidade", pois esta não podia consistir em expor a espécie humana a males terríveis para apiedar-se da condição de alguns homens. Regnault prestava uma homenagem aos bons sentimentos qui animavam a Sociedade dos Amigos dos Negros, que nunca desejou provocar os desastres dos quais a sua existência e seus escritos teriam sido a fonte ou pretexto. Para ele, a nova lei era um retrocesso necessário, após o fim de uma revolução que havia, por entusiasmo, levado a Nação a tomar caminhos desmedidos. O fim da Revolução coindicia com o fim do antiescravismo. A nova lei permitiria àquela que era "[...] a mais poderosa nação agrícola tornar-se poderosa também pelo seu comércio e sua indústria". ${ }^{1817}$ A lei seria, finalmente, apresentada ao Senado e aprovada em 30 floreal do ano X (20 de maio de 1802).

A lei continha quatro artigos. O primeiro deles dispunha que: "Nas colônias restituídas à França em execução do tratado de Amiens, de 6 germinal do ano X, a escravidão será mantida em conformidade com as leis e regulamentos anteriores a 1789". O artigo seguinte acrescentava que a mesma disposição valia para "as outras colônias francesas além do Cabo da Boa-Esperança". ${ }^{1818}$ Assim, estavam

\footnotetext{
1816 "L'intérêt des Nations continentales a créé, sanctionné ce moyen unique de culture, auquel aucune d'elles ne peut renoncer sans perdre de ses avantages dans la balance de l'Europe, sans descendre du rang auquel elle se trouve placée" (REGNAULT DE SAINT-JEAN-D'ANGÉLY. Discours sur le Projet de Loi relatif aux Colonies. Paris: De l'Imprimerie Nationale, ano X [1802], p.3).

1817 Ibidem, pp.4-8).

1818 "Art.Ier. Dans les colonies restituées à la France en exécution du traité d'Amiens, du 6 germinal an X, l'esclavage sera maintenu conformément aux lois et réglements antérieurs à 1789" (Loi relative à la traite des Noirs et au régime des Colonies. Du 30 floréal, l'an X de la République une et indivisible. Paris: De l'Imprimerie de la République, ano X, p.1).
} 
definitivamente livres da ameaça da abolição a Martinica, Tobago, Sainte-Lucie e as ilhas do Oceano Índico. O Art III restabelecia o comércio de escravos: "O tráfico de negros e sua importação nas mencionadas colônias ocorrerão em conformidade com as leis e regulamentos existentes antes da referida época de 1789". ${ }^{1819} \mathrm{Na}$ verdade, o tráfico não tinha sido oficialmente abolido. Com a abolição, ele tinha sido privado de seu objeto, mas continuava a operar numa escala reduzida. ${ }^{1820}$ Agora, entretanto, ele voltava a operar tal como no Antigo Regime, o que dava aos mercadores de escravos a esperança de voltarem a receber subvenções estatais.

O quarto e derradeiro artigo da lei retomava a disposição do art.91 da Constituição do ano VIII, que previa que o regime colonial seria determinado por leis especiais: "Não obstante todas as leis anteriores, o regime das colônias está submetido, durante dez anos, aos regulamentos que serão feitos pelo Governo". ${ }^{1821}$ Assim, se a lei não fazia menção a São Domingos, Guadalupe e Guiana, onde a abolição tinha sido, de fato, aplicada, ela abria ao governo a possibilidade de intervir diretamente na configuração do regime das colônias, o que, na cabeça de Bonaparte, lhe permitiria restabelecer progressivamente a escravidão.

É interessante também notar que o texto da lei continha duas referências ao ano de 1789. Bonaparte sabia que a abolição tinha sido decretada apenas em 4 de fevereiro de 1794, mas ele manifestava a compreensão de que a Declaração dos direitos do Homem e do Cidadão de 26 de agosto de 1789 continha em si a base constitucional da abolição. A Declaração simbolizava a própria Revolução, da qual a abolição era um dos efeitos mais radicais.

A reação das assembleias, depuradas de qualquer oposição, foi relativamente dócil, mas, ainda assim, não houve unanimidade. No Tribunado, o projeto foi aprovado por 54 votos contra 27, o que significa que exatamente um terço dos deputados o rejeitou. No Corpo Legislativo, a aprovação se deu por 211 votos contra 63. No quadro de um regime autoritário, esses números eram expressivos e mostravam que, para

\footnotetext{
1819 "III. La traite des noirs et leur importation dans lesdites colonies, auront lieu, conformément aux lois et réglements existants avant ladite époque de 1789" (Ibidem, p.1).

${ }_{1820}$ Bénot explica que escravos eram comprados de negreiros ingleses ou portugueses e revendidos aos negreiros americanos, que abasteciam Saint-Louis do Senegal, onde a abolição tinha sido desprezada (cf. BÉNOT, Yves. La démence coloniale sous Napoléon, p.17).

1821 "Nonobstant toutes lois antérieures, le régime des colonies est soumis, pendant dix ans, aux réglements qui seront faits par le Gouvernement" (Loi relative à la traite des Noirs et au régime des Colonies, pp.1-2).
} 
muitos, a abolição ainda era uma conquista importante, ainda que por razões puramente táticas. Nas ruas, não houve qualquer manifestação de apoio à lei. ${ }^{1822}$

A partir de então, leis segregacionistas seriam votadas na metrópole. Em notas a Cambacérès, de 7 floreal (27 de abril de 1802), Bonaparte já tinha pedido um senatusconsulto para coibir a chegada de negros ao continente. Ora, em 9 prairial ano X (29 de maio de 1802), uma decisão fixou o domicílio de oficiais, suboficiais e soldados de cor em reforma ou aposentados longe de Paris. Outra medida, de 6 messidor ( 25 de junho), proibiu aos negros, mulatos e outras pessoas de cor de entrarem, sem autorização dos tribunais coloniais e do Ministro das colônias, no território continental da República. Em 1803, uma nova lei declararia ilegais os casamentos mistos no Império francês. Essas medidas representavam, essencialmente, uma retomada da Police des Noirs, legislação de 1777 instituída, sem grandes resultados práticos, pela Monarquia do Antigo Regime. Essa nova política apontava para um esforço de supressão gradual da população negra e de cor no território metropolitano. ${ }^{1823}$

Se, na aparência, a liberdade tinha sido preservada em São Domingos e na Guadalupe, a realidade era muito mais sombria. Embora não o afirmasse abertamente, Bonaparte pretendia que Leclerc e Richepanse restaurassem, em algum momento, a escravidão nas duas ilhas. A correspondência de Leclerc traz palavras reveladoras. Em carta ao almirante Decrès, de 24 de julho de $1802^{1824}$, Leclerc recomendava:

Não pensais em restabelecer a escravidão aqui antes de algum tempo. Creio poder fazer tudo para que meu sucessor tenha apenas de executar a ordem do governo, mas após as inúmeras proclamações que fiz para garantir aos Negros a sua liberdade, não quero entrar em contradição comigo mesmo, mas garantis ao Primeiro cônsul que meu sucessor encontrará tudo preparado. ${ }^{1825}$

Pouco tempo depois, ao receber a notícia da lei de 30 floreal, Leclerc afirmou, numa carta de 18 thermidor (6 de agosto de 1802) a Bonaparte:

\footnotetext{
${ }^{1822}$ Cf. WANQUET, Claude. La France et la première abolition de l'esclavage, p.646.

${ }^{1823}$ Cf. DUBOIS, Laurent. A Colony of Citizens, pp.370-371; WANQUET, Claude. La France et la première abolition de l'esclavage, pp.646-647.

${ }^{1824}$ Paul Roussier, que organizou a correspondência de Leclerc datou a carta de 25 de agosto, mas, segundo Jean-Marcel Champion, que estudou o registro da correspondência do general, a data verdadeira é 24 de julho (cf. CHAMPION, Jean Marcel. 30 Floréal an X, p.269, nota 11).

1825 "Ne pensez pas rétablir l'esclavage ici avant quelque temps. Je crois pouvoir tout faire pour que mon successeur n'ait plus que l'arrêté du gouvernement à faire exécuter, mais après les proclamations sans nombre que j'ai faites ici pour assurer aux Noirs leur liberté, je ne veux pas être en contradiction avec moi-même, mais assurez le Premier consul que mon successeur trouvera tout disposé" (Lettres du général Leclerc cit, p.219)
} 
Eu vos havia pregado, Cidadão Cônsul, que nada fizesseis que pudesse fazêlos temer pela sua liberdade até o momento em que eu estivesse em condições, e eu caminhava a passos largos rumo a esse momento. De repente, chegou aqui a lei que autoriza o tráfico nas colônias, com cartas do comércio de Nantes e do Havre que perguntam se é possível introduzir negros aqui; mais do que tudo isso, o general Richepanse acaba de tomar uma medida para restabelecer a escravidão na Guadalupe. ${ }^{1826}$

A frase indica que Leclerc não queria a restauração antes que a situação fosse estabilizada e que as forças negras tivessem sido neutralizadas, mas ela deixa claro também que o restabelecimento da escravidão estava, de fato, previsto. Assim, embora a lei de 30 floreal do ano $\mathrm{X}$ fosse apenas uma revogação parcial da lei de 16 pluvioso, ela simbolizava a negação de toda a obra colonial da Convenção do ano II e era o ponto de partida para o restabelecimento da antiga ordem colonial. Ela marcava definitivamente o fracasso final do antiescravismo revolucionário.

\section{III.3.3.3) Resultado final}

Todas as promessas do governo francês às populações negras das colônias foram contrariadas. Na Guadalupe, embora a abolição tivesse sido proclamada em 1794, a derrota dos rebeldes em Matouba deu início a um processo de restabelecimento da escravidão. Richepanse ordenaria execuções e deportações em massa para eliminar os resquícios da rebelião ${ }^{1827}$ : mais de 10 mil homens e mulheres - isto é, cerca de $10 \%$ da população negra e mestiça - seriam executados ou deportados para os Estados Unidos ou Cartagena. Mais de mil soldados também seriam deportados. A Guadalupe não se enquadrava nos limites da lei de 20 de maio de 1802, de modo que era preciso uma medida específica para a colônia.

Em Paris, em 16 de julho de 1802 o Consulado emitiu um arrêté consulaire pedindo a restauração da escravidão na Guadalupe e em São Domingos. A decisão chegou à Guadalupe em setembro de 1802. A essa época, Richepanse já tinha falecido

\footnotetext{
1826 "Je vous avais prié, Citoyen Consul, de ne rien faire qui pût les faire craindre pour leur liberté jusqu'au moment où je serais en mesure, et je marchais à grand pas vers le moment. Soudaint est arrivée ici la loi qui autorise la traite dans les colonies avec des lettres du commerce de Nantes et du Hâvre qui demandent si on peut placer ici des noirs; plus que tout celà le général Richepanse vient de prendre un arrêté pour rétablir l'esclavage à la Guadeloupe" (Ibidem, p.202).

${ }^{1827} \mathrm{Na}$ verdade, a situação ainda manteve-se instável por um bom tempo. Mesmo após Matouba, alguns insurretos ainda continuaram o combate no interior de Basse-Terre, aliados aos marrons, mas em condições difíceis. Uma última insurreição explodiria, em outubro de 1802, em Sainte-Anne, na GrandeTerre, sendo duramente reprimida, com mais de cem execuções. Os últimos rebeldes só concordariam em deixar a ilha em 1804, após a independência do Haiti (cf. BÉNOT, Yves. La démence coloniale sous Napoléon, p.73).
} 
de febre em 3 de setembro, de modo que foi Lacrosse quem recebeu a ordem. Contudo, antes de falecer, Richepanse já tinha tomado a dianteira: em 17 de julho - praticamente no mesmo momento em que o Consulado havia emitido a sua ordem -, ele havia feito uma proclamação que praticamente já restabelecia a escravidão na Guadalupe, com a supressão de qualquer forma de remuneração aos trabalhadores negros e a exclusão dos homens de cor da classe dos cidadãos. Para Bénot, foi um caso de "telepatia entre escravistas". ${ }^{1828}$

Sem mencionar as coisas pelo seu nome, Richepanse afirmava, na exposição de motivos da proclamação, que "[...] por efeito da revolução e de uma guerra extraordinária, foi introduzido nos nomes e nas coisas desse país abusos subversivos da segurança e da prosperidade de uma colônia". ${ }^{1829}$ Os abusos eram, é claro, a abolição e a igualdade jurídica dos homens de cor. A conclusão era que

[...] a justiça nacional e a humanidade comandam o retorno dos verdadeiros princípios sobre os quais repousam a segurança e os sucessos dos estabelecimentos formados pelos Franceses nessa colônia, ao mesmo tempo em que o Governo proscreverá com ardor os abusos e os excessos que se tinham manifestado antigamente e que poderiam aparecer novamente. ${ }^{1830}$

A proclamação reinstituía claramente a escravidão, ainda que com a promessa vaga de impor limites aos seus excessos. Ela restabelecia ainda a segregação, ao prever que o título de cidadão francês seria reservado, no território da colônia e suas dependências, aos brancos, de modo que "nenhum outro indivíduo [poderia] tomar esse título ou exercer as funções ou empregos a ele vinculados...". ${ }^{1831}$

A reconversão dos trabalhadores negros em escravos se deu por meio de medidas pontuais. O sistema de dois dias livres sobre dez foi substituído pelo antigo, de um dia por semana. O salário dos cultivadores, que era de um quarto das receitas, foi substituído simplesmente pela alimentação, as roupas e os cuidados em caso de doença, como na época da escravidão. Os senhores não demorariam a recuperar o direito de usar

1828 Ibidem, pp.74-75. LACOUR, Auguste. Histoire de la Guadeloupe. Basse-Terre (Guadalupe): Imprimerie du Gouvernement, 1837-1858, v.3, p.354; RÉGENT, Frédéric. Le rétablissement de l'esclavage et du préjugé de couleur en Guadeloupe, pp.289-290. Disponível em: http://ihrf.univparis1.fr/IMG/pdf/retablissementesclavage.pdf. Acesso em: 12 de jul de 2012.

1829 "[...] par l'effet de la révolution et d'une guerre extraordinaire, il s'est introduit dans les noms et les choses de ce pays des abus subversifs de la sûreté et de la prospérité d'une colonie" (Reproduzido em LACOUR, Auguste. Histoire de la Guadeloupe, v.3, p.354).

1830 "...] la justice nationale et l'humanité commandent autant que la politique le retour des vrais principes sur lesquels reposent la sécurité et les succès des établissements formés par les Français en cette colonie, en même temps que le Gouvernement proscrira avec ardeur les abus et les excès qui s'étaient manifestés anciennement et qui pourraient se remontrer encore" (Ibidem, p.355).

${ }^{1831}$ Ibidem, p.355. 
o açoite. Os homens de cor e negros desprovidos de títulos que garantissem a sua liberdade tinham de retornar às plantations às quais estavam vinculados antes da guerra, no prazo de 24 horas para as cidades e cinco dias para os campos. Em caso de recusa, seriam perseguidos como rebeldes e, em caso de resistência, capturados vivos ou mortos. ${ }^{1832}$ Foi um caso raro de reescravização de um grande contingente populacional, um processo que levaria vários anos para ser completado.

Daniel Lescallier, que tinha sido um Amigo dos Negros e estava na Guadalupe na condição de prefeito colonial, procurou assegurar a liberdade aos homens de cor e negros nascidos livres ou alforriados antes de 1794. Mas, dentre estes, aqueles que tinham sido alforriados após 1789 tinham agora de pagar uma taxa de 1.200 francos para adquirir um título - a "patente de liberdade" - que atestava a sua liberdade. Lescallier dedicou-se então a transformar cidadãos livres em escravos. Emitiu uma lei determinando que todos os cidadãos da ilha apresentassem a oficiais locais os negros ou pessoas de cor que residiam com eles, mas que não lhes pertenciam. Os oficiais avaliariam esses negros, para fixar um preço. Se o cidadão pagasse o valor, o negro passaria a lhe pertencer de direito. ${ }^{1833}$ Seres humanos voltavam a ser propriedade de outros.

Na Guiana, a escravidão foi restabelecida por Victor Hugues em 1802. Em execução de uma decisão consular de 16 frimário do ano XI (7 de dezembro de 1802), foi feito um recenseamento de todos os negros e pessoas de cor existentes na colônia em 14 de junho de 1794, data da proclamação da abolição na Guiana. Foi imposto o status de escravo a todos os que não tinham sido libertados antes dessa data. O restabelecimento foi completado por um regulamento geral, de 5 floreal do ano XI (25 de abril de 1803), que dispunha sobre alimentação, roupa, trabalho, alforria e polícia dos escravos. $^{1834}$

Embora a correspondência de Hugues com o ministro da Marinha indique não ter havido resistência ao restabelecimento da escravidão na Guiana, Serge Fouck entende que ela aconteceu. Não houve uma subversão total, dentro do modelo haitiano, mas sim uma retomada de formas mais tradicionais de recusa da escravidão, isto é, o

${ }^{1832}$ Cf. DUBOIS, Laurent. A Colony of Citizens, pp.404-407; BÉNOT, Yves. La démence coloniale sous Napoléon, p.74; LACOUR, Auguste. Histoire de la Guadeloupe, v.3, p.355-356.

${ }^{1833}$ Cf. DUBOIS, Laurent. A Colony of Citizens, pp.411-414.

1834 Cf. FOUCK, Serge Mam Lam. La résistance au rétablissement de l'esclavage en Guyane française, pp.255-256. 
marronnage, a fuga e a formação de acampamentos à margem das plantations. ${ }^{1835}$ Esse movimento de resistência, embora relativamente magro, estendeu-se por vários anos. ${ }^{1836}$ A maioria dos negros, entretanto, retornou para as plantações, fazendo da restauração da escravidão na Guiana um processo relativamente pacífico.

Quanto à principal colônia francesa, sabe-se que a tentativa de nela reintroduzir a escravidão teve consequências catastróficas para a metrópole. Além de enfrentar condições climáticas desfavoráveis, o general Leclerc havia encontrado resistências desde o seu desembarque, em fevereiro de 1802. Bandos armados, comandados por lideranças africanas, como Sans-Souci, conduziam uma oposição obstinada às pretensões francesas. Contudo, por volta de maio, Leclerc havia conquistado a rendição dos principais líderes crioulos: Christophe, Dessalines e, sobretudo, Toussaint Louverture. Para isso, tinha prometido que a liberdade e a igualdade dos negros não seriam afetadas. Toussaint aceitou retirar-se na sua propriedade em Ennery e a colônia conheceu uma calmaria temporária. Temendo, entretanto, que a rendição de Toussaint fosse ilusória ou apenas temporária, Leclerc armou uma armadilha para o líder negro: convocou-o para uma conferência militar, mas na sua chegada ao local de encontro, em 10 de junho, Toussaint e sua família foram presos e levados para Brest, na França. ${ }^{1837}$ A prisão causou alguma comoção, mas não desencadeou grandes movimentos de revolta entre a população, avessa aos regulamentos de trabalho impostos por Toussaint na ilha. Leclerc continuava a afirmar que a abolição não seria revogada, mas notícias do que estava ocorrendo na Guadalupe esclareciam os negros de São Domingos a respeito das reais intenções da missão francesa. ${ }^{1838}$ Os relatos da rebelião na Guadalupe e de sua terrível repressão caíram como uma bomba em São Domingos. Os negros, sobretudo no Norte, perceberam logo que o objetivo da missão militar era restabelecer a ordem escravocrata e que, sem a independência, não seria possível preservar a sua liberdade. Em julho, a insurreição retomou em grande estilo. Convencidos de que a escravidão

\footnotetext{
1835 Ibidem, pp.259-260.

${ }^{1836}$ Simon Frossard, um dos chefes da resistência e principal alvo da repressão conduzida por Hugues, só seria morto em 1808 (Ibidem, p.264).

${ }^{1837}$ Cf. SANDEAU, Jacques. La Révolution à Saint-Domingue, pp.28-30; BARTHÉLEMY, Gérard. Le rôle des bossales dans l'émergence d'une culture de marronnage en Haïti, pp.847-848.

${ }^{1838}$ Havia uma crença quase generalizada de que Richepanse já tinha restabelecido a escravidão. Não era exatamente verdade, mas até mesmo Leclerc pensava isso. Numa carta de 15 vendemiário do ano XI (7 de outubro de 1802), ele disse ao Primeiro Cônsul que "o restabelecimento prematuro da escravidão na Guadalupe" tinha contribuído para fragilizar a sua situação na colônia (cf. Lettres du général Leclerc, p.256).
} 
seria restabelecida, os negros de São Domingos conduziram uma resistência feroz às tropas de Leclerc.

A resistência não era unificada, mas composta de centenas de pequenos movimentos, em diferentes esferas: os negros urbanos e das plantations, os militares, os marrons. ${ }^{1839}$ A resistência negra, contudo, não era o único problema das forças armadas francesas. Desde o final de abril de 1802, as primeiras manifestações de uma epidemia de febre amarela atingiram as forças francesas. Em maio de 1802, Leclerc já perdia cerca de 50 soldados por dia. No final de junho, já eram mais de dois mil mortos em razão da doença. ${ }^{1840}$

Compreendendo a intenção de Leclerc de prender todos os generais negros, Christophe e Dessalines passaram para o lado dos revolucionários. Leclerc foi levado pela febre amarela em 2 de novembro de 1802. Com sua morte, seu substituto, Rochambeau, conduziu uma ofensiva ainda mais violenta, cometendo atrocidades que incluíam desde afogamentos em massa à compra de 1.500 cães cubanos para caçar marrons. Ele promoveria o massacre de cerca de 20 mil negros e mulatos. ${ }^{1841}$ Mas, àquela altura, a colônia já estava perdida: neutralizadas pelas massas negras da ilha e dizimadas pela febre amarela, que matou, no verão de 1803 , de 100 a 120 solados por dia $^{1842}$, as forças francesas eram incapazes de assumir o controle da ilha.

Em maio de 1803, a Paz de Amiens foi rompida. Mas era tarde demais para reincorporar as massas negras de São Domingos numa luta contra a Grã-Bretanha. A retomada da guerra selou o destino da missão francesa em São Domingos. A marinha britânica tomou o controle do mar e São Domingos ficou cercada, encurralando o exército francês. Após conferência entre Rochambeau e Dessalines, a capitulação da expedição francesa ocorreu em 19 de novembro de 1803. Rochambeau também capitularia perante os britânicos em 30 de novembro de 1803, permanecendo como prisioneiro da Coroa até 1811. Entre 1789 e 1803, cerca de 60 mil homens foram enviados a São Domingos. Apenas sete mil aproximadamente sobreviveram, o que significa uma mortalidade de $88 \%{ }^{1843}$

Preso e enviado à metrópole, Toussaint Louverture nunca foi julgado. Encarcerado na prisão de Fort-de-Joux, nas montanhas do Jura, ele foi encontrado morto

\footnotetext{
${ }^{1839}$ Cf. FICK, Carolyn. The making of Haiti, pp.226-227.

${ }^{1840} \mathrm{Cf}$. SANDEAU, Jacques. La Révolution à Saint-Domingue, p.31.

${ }^{1841}$ Cf. BÉNOT, Yves. La démence coloniale sous Napoléon, p.83.

1842 Cf. SANDEAU, Jacques. La Révolution à Saint-Domingue, p.36.

1843 Ibidem, p.9.
} 
em sua cela, em 7 de abril de 1803, vítima de maus tratos. Em São Domingos, os líderes negros preparavam a Declaração de Independência. Em setembro, Dessalines já escrevia ao presidente americano Thomas Jefferson, para anunciar a independência iminente e lançar as bases da retomada das relações comerciais com os Estados Unidos. Em 29 de novembro de 1803, uma proclamação preliminar de independência foi divulgada por Dessalines, Christophe e Clairveaux. Em 31 de dezembro, a Declaração definitiva foi lida numa reunião com todos os oficiais. Em $1^{\circ}$ de janeiro de 1804 , proclamou-se a fundação de um novo Estado, batizado Haiti, nome indígena original da ilha e que significava "ilha montanhosa". ${ }^{1844}$ Dessalines foi nomeado governador-geral vitalício, mas, em 8 de outubro de 1804, ele foi coroado, sob o nome de Jacques I, imperador do Haiti. Inicialmente, foi proclamado que os franceses que permaneciam no novo estado nada tinham a temer, mas, sob a ditadura pessoal de Dessalines, ocorreria um massacre da população branca remanescente. ${ }^{1845}$ Os laços com a metrópole seriam completamente rompidos. Muitos países - e até mesmo os Estados Unidos - se recusariam a reconhecer diplomaticamente a nova nação negra. Com o tempo, a pressão das massas faria com que o Haiti, sobretudo sob o governo de Pétion e Boyer, abandonasse a grande produção de açúcar em prol da pequena produção de víveres, levando a uma profunda estagnação econômica. ${ }^{1846}$

Esse foi o turbulento desfecho da página colonial da Revolução. A política abolicionista lançada pelo governo jacobino em 1794 tinha sido desfeita e o preço tinha sido a perda da principal colônia francesa. A partir daí, pouco se falou, sob a ditadura de Bonaparte, da liberdade dos negros. Na primavera de 1803, num encontro no Instituto, na presença de Grégoire, o Primeiro Cônsul já dizia que os Amigos dos Negros deviam esconder o rosto diante das notícias que chegavam de São Domingos. ${ }^{1847}$ Grégoire seria um dos únicos a se manifestar, de forma bastante solitária, sobre a questão, com a publicação, em 1808, de De la littérature des nègres. ${ }^{1848}$ Na suas memórias, entretanto, ele afirmaria que o decreto de 16 pluvioso tinha sido uma "catástrofe em política", na

\footnotetext{
1844 Cf. JAMES, C.L.R.. Os jacobinos negros, p.335; SANDEAU, Jacques. La Révolution à SaintDomingue, p.40.

1845 Cf. SANDEAU, Jacques. La Révolution à Saint-Domingue, p.41.

${ }^{1846}$ Cf. FONER, Eric. Nada além da liberdade. Rio de Janeiro: Paz e Terra, 1988, pp.29-32; BÉNOT, Yves. La Révolution française et la fin des colonies, pp.309-310.

${ }^{1847}$ Cf. JAMES, C.L.R.. Os jacobinos negros, p. 328.

${ }^{1848}$ Cf. BÉNOT, Yves. La démence coloniale sous Napoléon, p.264.
} 
medida em que havia rompido com sábia estratégia de abolir gradualmente a escravidão. $^{1849}$

No Memorial de Santa-Helena (publicado em 1823), redigido por Emmanuel de Las Cases a partir das entrevistas cotidianas empreendidas com Napoleão durante seu exílio, consta que o Imperador teria supostamente manifestado arrependimento em relação à intervenção militar em São Domingos. Em 12 de junho de 1816, ele teria dito:

Tenho de me censurar por uma tentativa feita sobre essa colônia na época do Consulado. Foi um grande erro ter querido submetê-la pela força; eu devia ter me contentado em governá-la por intermédio de Toussaint. A paz ainda não tinha sido suficientemente estabelecida com a Inglaterra. As riquezas territoriais que eu teria adquirido ao submetê-la teriam enriquecido apenas nossos inimigos. ${ }^{1850}$

Las Cases ainda escreveu o seguinte comentário:

O Imperador se culpava particularmente por esse erro, dizia, pois ele o tinha antevisto e ele contrariava a sua inclinação. Tinha apenas cedido à opinião do Conselho de Estado e de seus ministros, levados pelas gritarias dos colonos, que formavam em Paris um grande partido e que, além disso, acrescentava, eram quase todos realistas e vendidos à facção inglesa. ${ }^{1851}$

Ao final, o Imperador reconhecia que:

O sistema colonial que nós vimos está acabado para nós, ele o está para todo o continente da Europa; temos de renunciar a ele e nos voltar doravante para a livre navegação dos mares e a inteira liberdade de uma troca universal. ${ }^{1852}$

Não se pode tomar o texto de Las Cases ao pé da letra, pois é clara a intenção do autor de construir a imagem de um Napoleão mais liberal. Mas, ao associar as decisões do então Cônsul à pressão do partido colonial, Las Cases passava a imagem, bastante realista, de um regime comprometido com os interesses do capital mercantil.

${ }^{1849}$ Cf. PIQUET, Jean-Daniel. L'émancipation des Noirs dans la Révolution française, p.333.

1850 "J'ai à me reprocher une tentative sur cette colonie lors du Consulat. C'était une grande faute que d'avoir voulu la soumettre par la force; je devais me contenter de la gouverner par l'intermédiaire de Toussaint. La paix n'était pas encore assez établie avec l'Angleterre. Les richesses territoriales que j'eusse acquises en la soumettant n'auraient enrichi que nos ennemis" (LAS CASES, Emmanuel de. Mémorial de Sainte-Hélène. Paris: Éditions du Seuil, 1968, v.1, p.806).

1851 "L'Empereur avait d'autant plus à se reprocher cette faute, disait-il, qu'il l'avait vue et qu'elle était contre son inclination. Il n'avait fait que ceder à l'opinion du Conseil d'État et à celle de ses ministres, entraînés par les criailleries des colons, qui formaient à Paris un gros parti et qui de plus, ajoutait-il, étaient presque tous royalistes et vendus à la faction anglaise" (Ibidem, p.806).

1852 "Le système colonial que nous avons vu est fini pour nous, il l'est pour tout le continent de l'Europe; nous devons y renoncer et nous rabattre désormais sur la libre navigation des mers et l'entière liberté d'un échange universel" (Ibidem, p.807-808). 
Entre o verão de 1794 e 1802, a obra abolicionista do ano II deu gradualmente lugar ao retorno da política colonial escravista do Antigo Regime e da Constituinte. A resistência promovida pelos últimos adeptos da liberdade e, sobretudo, pelas centenas de milhares de homens e mulheres negras que viviam nas colônias francesas, havia sido insuficiente para impedir que a lógica que havia orientado a política colonial da Revolução na sua fase inicial voltasse a se impor ao final. A recomposição do movimento de pressão conduzido por colonos e negociantes dos portos, associada à lembrança dos números do comércio colonial pré-1789, alimentaram a percepção de que, na competição econômica com a Grã-Bretanha, a força da França residia, primeiramente, nas suas posses coloniais. E restaurar a prosperidade colonial significava essencialmente restaurar a escravidão, tal como ela era praticada antes que discussões a respeito da liberdade e igualdade natural dos homens viessem perturbar a ordem estabelecida. Que essa política tenha resultado na perda da principal colônia francesa é certamente a justa moral imposta aos adeptos da escravidão negra, cuja maior vitória, a restauração da escravidão pelo Consulado, foi ironicamente a maior derrota. 
Conclusão 
O término da Revolução francesa, isto é, o processo de consolidação da obra revolucionária sob o Consulado, marcou também a derrota derradeira da corrente antiescravista do final do século XVIII. O sangrento desfecho da história colonial da Revolução é revelador dos limites que esta foi incapaz de ultrapassar, a despeito da vocação universalista que lhe era ideologicamente atribuída pelos burgueses que compunham a Assembleia Nacional. Assim, a conturbada história que procuramos reconstituir neste trabalho é portadora de ensinamentos relativos à natureza do grande processo de transformação pelo qual passou a França naquele momento. Procuramos, a partir da reconstrução do debate sobre a escravidão, tal como ele foi conduzido pelos Amigos dos Negros, refletir sobre a incapacidade da Revolução de resolver, de forma coerente com seus princípios, a questão da liberdade das centenas de milhares de homens e mulheres oprimidos nas colônias. Estruturamos o nosso trabalho com base na percepção de que às três grandes fases da Revolução francesa corresponderam também três momentos distintos para o antiescravismo.

Procuramos mostrar, na primeira parte deste trabalho, as enormes dificuldades que a Sociedade dos Amigos dos Negros, organização antiescravista de caráter moderado, enfrentou ao confrontar-se com o poderio econômico dos meios ligados ao comércio colonial, que a acusaram de querer fomentar movimentos de revolta entre os escravos e operar, com isso, a destruição das colônias. Vimos, entretanto, que, composta por nobres, homens de letras e financistas, a Sociedade defendia um programa gradualista, voltado fundamentalmente para a abolição do tráfico, e concebia o desaparecimento da escravidão apenas como o resultado final de um longo processo de reconversão do sistema colonial. Se a sua campanha era movida por um sentimento humanitário contra o caráter bárbaro da escravidão e do tráfico tais como eram praticados nas colônias, havia, na base do projeto dos Amigos dos Negros, uma preocupação fundamental com uma gestão colonial racional. Herdeiros das Luzes, eles retomavam as críticas dos Filósofos relativas aos efeitos desastrosos de uma escravidão sem controle, num momento em que, em razão do sucesso do comércio de insumos coloniais, a população escrava aumentava a um ritmo vertiginoso nos territórios ultramarinos.

Assim, a sua denúncia das crueldades cometidas contra a escravaria era contrabalançada por preocupações com a capacidade das economias coloniais de 
absorver o impacto de uma transformação do sistema de trabalho nelas empregado. Nesse mesmo sentido, havia também questionamentos quanto à capacidade das sociedades ultramarinas de acomodar uma população de antigos escravos que, em razão das condições subumanas a que eram submetidos, não estariam intelectualmente preparados para exercer a liberdade. A emancipação dos escravos era pensada dentro dos limites ditados pela continuidade da produção agroexportadora. A Sociedade acreditava que a supressão do comércio de escravos obrigaria os plantadores a promoverem melhoramentos no tratamento da mão de obra, de modo a favorecer a sua reprodução vegetativa. Tratados com suavidade e motivados pela possibilidade de aquisição de sua liberdade, esses negros forneceriam um trabalho mais produtivo e de melhor qualidade, compensando as eventuais perdas geradas pela interdição do tráfico, e não se revoltariam mais. Esse processo de adaptação permitiria, ao mesmo tempo, "educar" os negros para a liberdade, preparando-os para a sua inserção produtiva, como homens livres, no mesmo quadro do cultivo de açúcar e café. No final, todos os envolvidos (colonos, negros, comerciantes, administração) se beneficiariam com esse processo de conversão lenta e gradual das colônias para um regime de liberdade.

Os Amigos dos Negros estavam, portanto, longe de querer a destruição das colônias. Queriam, ao contrário, repensar a questão do trabalho nelas empregados em termos compatíveis com os direitos naturais do homem, mas também com uma determinada concepção da ordem colonial. Pensavam também na possibilidade de fazer das colônias um fator de dinamismo para a economia da metrópole, ao converter os povos colonizados em consumidores de produtos franceses. Essa perspectiva alimentava os seus projetos de ampliação do império. O programa da Sociedade dos Amigos dos Negros tinha, no seu âmago, uma concepção mais moderna da empresa colonial.

O contexto da Revolução francesa fornecia, em tese, aos Amigos dos Negros, a possibilidade de inserir a sua causa no conjunto das transformações operadas no país, na medida em que princípios de liberdade e igualdade dos homens eram definidos como a base da nova ordem jurídica. A extensão desses princípios aos territórios ultramarinos, entretanto, era um problema diverso. Confrontados ao bloco formado por colonos e negociantes dos portos franceses, os homens da Sociedade dos Amigos dos Negros viram-se incapazes de fazer avançar uma causa que atentava contra os interesses de setores fortemente representados nas esferas de poder. A abolição do tráfico, principal objetivo da Sociedade, nunca chegou a ser, de fato, discutida na Assembleia. 
Os Amigos dos Negros se pretendiam uma superação da crítica meramente preservacionista do sistema escravista, na medida em que estabeleciam como objetivo final a supressão da escravidão nas colônias. Contudo, o seu programa partia da mesma ideia de conservação desses territórios e do comércio de seus produtos. Se eles questionavam a necessidade do uso da mão de obra escrava nas colônias, não questionavam a importância destas para a economia francesa. E, na medida em que não havia como convencer colonos e mercadores de que a preservação das colônias passava pela supressão de seus principais alicerces (a escravidão e o tráfico), a batalha estava perdida de antemão. Os Amigos dos Negros atacavam a escravidão, mas não a base que a tornava possível. Dentre os líderes da Sociedade, apenas Mirabeau foi, de fato, capaz de inserir a causa antiescravista no quadro de uma crítica da via mercantilista dentro da qual a economia francesa operava e contestar, assim, a importância das colônias. No geral, entretanto, os Amigos dos Negros propunham essencialmente uma transformação suficiente do sistema colonial para torná-lo mais humano, mais estável e mais benéfico ao conjunto da Nação. Queriam associar o comércio de produções coloniais ao desenvolvimento econômico interno, e, nesse sentido, tendiam a entrar em conflito com os armadores e negociantes dos portos. Mas a sua ênfase na importância do comércio externo - e, dentro deste, do comércio com as colônias - fazia com que, de certa forma, partilhassem um mesmo quadro de pensamento.

Além disso, na medida em que não definiam com precisão quando e como se daria o fim da escravidão, a verdadeira mudança proposta pelos Amigos dos Negros era somente o fim do tráfico, o que, na prática, poderia resultar apenas numa alteração do modo de reposição da mão de obra escrava, passando do recurso ao tráfico à reprodução endógena da população cativa. Ao admitirem-se derrotados na questão do tráfico, só lhes restou lutar pelos direitos dos homens de cor livres e eles o fizeram com base no argumento de que estes - plantadores, senhores de escravos e contribuintes de ascendência europeia - constituíam a melhor barreira contra a revolta escrava e, portanto, contra a dissolução da ordem escravista. Essa postura contraditória expressava bem os limites do programa dos Amigos dos Negros e a sua incapacidade de fazer avançar a sua causa no quadro de uma revolução que tinha no comércio de produtos coloniais uma de suas bases econômicas. Se o seu discurso podia ser visto como antiescravista, o mesmo não pode ser dito da sua atividade política. Sua grande e única conquista - a lei de 24 de março de 1792 - foi uma medida de contenção da insurreição escrava e isso num momento em que os brissotinos dominavam a Assembleia. Não é, 
assim, tão estranho constatar que, após a abolição de 1794, os antigos planos dos Amigos dos Negros foram retomados pelo partido escravocrata, que reconheceram, afinal, nos argumentos gradualistas, preocupações próximas às suas.

Apenas numa conjuntura muito específica, as resistências do bloco escravocrata e as limitações dos Amigos dos Negros foram superadas. Como vimos na segunda parte deste trabalho, a abolição de 16 pluvioso do ano II (4 de fevereiro de 1794) foi o resultado de uma conjunção extraordinária de fatores. Transposta para as colônias, a Revolução exacerbou as contradições inerentes àquelas sociedades construídas em torno da escravidão e do pacto colonial. Cada um dos grupos que as compunham reconheceu naquele momento uma oportunidade de concretizar as suas aspirações. As centenas de milhares de escravos que faziam prosperar São Domingos não se mantiveram alheias a esse processo e identificaram nos conflitos entre as classes proprietárias da colônia o contexto ideal para um levante em larga escala. Ao se insurgirem em agosto de 1791, os escravos tornaram-se o verdadeiro motor do processo abolicionista, ainda que, de início, a emancipação geral não estivesse necessariamente nos planos dos insurretos. A chegada das notícias da revolta à metrópole inspirou a formação de uma opinião propriamente abolicionista, não mais confinada aos limites do discurso gradualista dos Amigos dos Negros, que, a essa altura, mostravam-se incapazes de tirar quaisquer conclusões a respeito da liberdade dos escravos. Na imprensa patriótica, proliferaram manifestações que reconheciam nos insurretos os verdadeiros revolucionários das colônias e pregavam a emancipação geral como o ato fundador de uma aliança histórica entre os sans-culottes dos dois mundos. Tais manifestações sinalizavam a entrada em cena do movimento popular, cada vez mais atuante na defesa de seus ideais igualitários e na repressão de atividades contrarrevolucionárias. Essa pressão popular fez com que, no quadro da emergência, em junho de 1793, de um governo revolucionário radical, a influência política da grande burguesia mercantil e da representação colonial fosse neutralizada. Por fim, a guerra contra as nações europeias e sua extensão ao espaço colonial, sobretudo com os avanços britânicos no Caribe, fomentou o projeto de uma aliança entre a República francesa e as massas negras como uma necessidade militar de combate ao invasor estrangeiro e de conservação dos territórios ultramarinos. Em São Domingos, os comissários civis da República já haviam antecipado essa política ao proclamarem localmente a abolição como forma de restabelecer o controle sobre a colônia, após uma tentativa de golpe. 
Todos esses fatores (a insurreição escrava, a formação de uma corrente abolicionista, a atuação do movimento popular parisiense, o quadro político na metrópole, a guerra) foram essenciais para que, na esteira das proclamações locais de Sonthonax e Polverel em São Domingos, a Convenção se decidisse a emancipar os escravos das colônias francesas e, mais do que isso, fazer deles, em tese, cidadãos franceses. A abolição geral e incondicional da escravidão nas colônias francesas, proclamada em 16 pluvioso do ano II (4 de fevereiro de 1794), deu-se, portanto, num quadro político muito preciso, onde a intervenção das massas - das colônias e da metrópole - alterou o programa da burguesia metropolitana e neutralizou a resistência promovida pelos grupos ligados ao tráfico. ${ }^{1853}$ Nessas circunstâncias excepcionais, a política colonial da Revolução superou, ainda que por um instante, a sua lógica inicial: não apenas os negros das colônias foram declarados livres, mas foram-lhes reconhecidos os direitos ligados à cidadania francesa.

Vimos, entretanto, que, mal havia sido proclamada a liberdade geral dos negros das colônias, manifestaram-se, mesmo entre os defensores da medida, preocupações relativas à aplicação do princípio da abolição. Embora a lei rompesse com as antigas formas de exploração colonial, não se tratava absolutamente de promover a independência das colônias. Ao contrário, a decisão da abolição visava a sua conservação e, quando tratou-se de definir os termos de sua execução, esta foi concebida nos limites ditados pela continuidade da produção de açúcar, café e demais commodities para exportação. Na prática, essas preocupações conduziram a uma aplicação mitigada do princípio da liberdade nas colônias, onde a escravidão deu lugar a regimes de trabalho mistos, que mesclaram formas de remuneração dos antigos escravos à compulsoriedade do trabalho nas plantações. Essa contradição entre a liberdade legalmente reconhecida aos negros e o caráter compulsório do trabalho que lhes era atribuído expressa bem a incapacidade dos homens da metrópole de conciliar a emancipação efetiva da população escrava com a sua própria ideia de colônia. Na prática, apenas os negros que compunham o exército republicano do Caribe exerceram, de fato, a cidadania prometida pela lei de 16 de pluvioso. Para os demais, a liberdade tal como a concebiam - liberdade para cultivar a sua própria terra e determinar os meios de sua existência - permaneceu letra morta. No fundo, apesar do caráter radical da abolição proclamada pela Convenção, a preocupação fundamental com a manutenção das

1853 Cf. AMIN, Samir. Autour de l'abolilition de l'esclavage par la Première République. In: M. DORIGNY (org.). Les abolitions de l'esclavage, pp.400-401. 
colônias e de seu comércio manteve-se viva. Suprimidas as condições objetivas que haviam tornado possível a abolição, a vigência da lei ficou comprometida.

Na terceira parte da tese, mostramos que a supressão da abolição não se deu de forma abrupta, mas por etapas, a partir da queda do governo jacobino do ano II. O 9 thermidor do ano II (27 de julho de 1794) foi o marco inicial de um amplo processo de reação política, em que os aspectos mais radicais da Revolução - o Terror, a proclamação do sufrágio universal, a direção da economia, o favorecimento da pequena propriedade - foram progressivamente suprimidos para que, sob o Consulado, o país entrasse numa fase de consolidação da obra revolucionária num sentido estritamente burguês: a consagração da propriedade privada, a liberdade de indústria e de comércio. Em matéria colonial, os primeiros efeitos desse processo, ainda no verão de 1794, foram o fim da repressão ao partido dos colonos e o ressurgimento da campanha escravista, tanto na esfera parlamentar quanto na imprensa.

Esse recuo político não se deu de forma fluida e harmônica. Mesmo após a queda do governo revolucionário do ano II, a ameaça de uma nova jornada popular ainda não havia sido dissipada. Medidas contrárias às aspirações da sans-culotterie, como o fim da regulamentação do comércio, por exemplo, estimulavam novas ondas de fúria popular. Assim, uma etapa importante para a revogação da abolição foi a neutralização do movimento popular, consolidada após as jornadas de germinal e prairial do ano III (abril-maio de 1795), com a supressão pelo Diretório das seções parisienses, órgãos políticos da sans-culotterie. A política de repressão do movimento sans-culotte teve por efeito livrar o governo e os parlamentares da pressão e da vigilância do povo parisiense sobre as suas decisões políticas, o que viabilizava a defesa de interesses econômicos privados em detrimento dos ideais igualitários defendidos pelas massas metropolitanas.

Ainda assim, os adeptos da manutenção da lei de abolição promoveram, durante todo o período diretorial, uma resistência obstinada ao partido colonial. É verdade que, para esses homens tratava-se, acima de tudo, de refletir a respeito do funcionamento das colônias num regime de liberdade. No quadro da nova Sociedade dos Amigos dos Negros e das Colônias, eles defenderam projetos destinados a promover a incorporação produtiva dos antigos escravos e a ampliar o império colonial sobre novas bases. Entre os adeptos da restauração escravista e os membros da Sociedade, o debate voltava a darse essencialmente em torno do funcionamento do sistema colonial. A lei de 12 nivoso do ano VI ( $1^{\circ}$ de janeiro de 1798), principal vitória da segunda formação dos Amigos 
dos Negros, tinha por objetivo consolidar a abolição, mas submetendo os antigos escravos a um sistema rígido, no qual lhes eram atribuídas, fundamentalmente, apenas duas possibilidades: a continuidade do trabalho nas grandes plantações ou o serviço nas forças armadas. Apresentado nesses termos, o debate sobre a questão negra tendeu para o fortalecimento da posição dos adeptos da restauração escravista, que se valiam das dificuldades de aplicação do decreto de abolição e da resistência oposta pelos antigos escravos à "liberdade" que lhes era atribuída.

A ascensão do regime consular, destinado a estabilizar politicamente o país, criou o contexto político para a revogação da abolição. Com o poder concentrado nas mãos de Bonaparte e livre da oposição "neojacobina", o governo francês podia agora conduzir uma política conforme aos interesses da burguesia mercantil, que sonhava em restabelecer o comércio colonial tal como ele existia antes da Revolução. A força da campanha favorável à escravidão, num momento em que a opinião antiescravista via-se praticamente silenciada, era o sinal da iminência de uma política restauracionista em matéria colonial. Se, inicialmente, Bonaparte relutou, por motivos táticos, em explicitar as suas intenções, a paz - ainda que temporária - com a Grã-Bretanha e seus aliados deu a oportunidade para que a abolição fosse desfeita e expedições militares fossem enviadas às colônias da América. Caía por terra o argumento da necessidade de uma aliança estratégica entre as forças armadas metropolitanas e os soldados negros do Caribe na frente colonial da guerra contra as nações da Europa. Esse argumento tinha permitido manter intacta a abolição durante oito anos, estimulando até mesmo homens avessos à liberdade dos negros a defender a sua preservação enquanto perdurasse o conflito. Agora, esses homens já não viam mais motivos para tal compromisso.

Os efeitos desastrosos desse recuo para as intenções colonialistas da França se deveram ao fato de que os atores políticos da época subestimaram a força da resistência negra à restauração da escravidão, especialmente em São Domingos. A manutenção ou o restabelecimento da escravidão foram possíveis em colônias menores, onde a resistência escrava não havia atingido a dimensão de um movimento insurrecional ou onde a população negra não era tão numerosa. Em São Domingos, entretanto, uma população de meio milhão de indivíduos emancipados não podia aceitar passivamente um regresso ao seu estado anterior. Mesmo que a experiência concreta da abolição não lhes tivesse atribuído um verdadeiro estado de liberdade, eles haviam sido juridicamente reconhecidos como cidadãos livres e não mais como propriedade de outrem e, com isso, suas expectativas para o futuro já haviam sido modificadas. Todos os fatores que 
haviam determinado a abolição tinham sido desfeitos, exceto um, a resistência das massas negras. Numa colônia com as peculiaridades de São Domingos, uma vez desencadeado o processo de emancipação dos escravos, não havia volta atrás.

Havia, no círculo de Bonaparte quem alertasse para os riscos de atentar contra a liberdade dos negros, mas o Primeiro Cônsul, desejoso de restabelecer a autoridade metropolitana em São Domingos, preferiu ceder à pressão dos adeptos da restauração da escravidão. Estes viram no Consulado, regime livre da influência de correntes radicais, o contexto ideal para reconstruir a sua hegemonia. Se Bonaparte tinha projetos de desenvolver a indústria francesa e abrir novos mercados para os seus manufaturados, a lembrança dos enormes ganhos propiciados pelos produtos das colônias até o advento da Revolução era forte demais para que se aceitasse virar a página do comércio colonial. Para a grande maioria da elite brumariana, não era possível conceber a economia francesa sem o comércio exterior, assim como não era possível conceber este sem as colônias, ou estas sem a escravidão. O significado imediato do recuo da Revolução na sua política abolicionista foi a prevalência política da fração da burguesia francesa ligada ao tráfico e à importação e reexportação dos produtos coloniais. Associada à Revolução desde o início, essa burguesia mercantil havia procurado, com sucesso, defender o seu interesse como sendo o interesse da França como um todo. Ela prevaleceu, assim, diante de um movimento antiescravista incapaz de convencer a Nação de que o interesse nacional exigia transformações num sistema que havia sido tão eficaz durante o século XVIII.

O longo e tortuoso processo de redefinição das bases jurídico-políticas da França - a revolução em sentido estrito - criou as condições para o desenvolvimento capitalista ulterior do país, a partir da segunda metade do século XIX. Mas essa transformação institucional não implicou uma erradicação imediata das bases sobre as quais se sustentava economicamente o país. Se a Revolução havia efetivamente posto fim ao regime feudal de exploração da terra, o fato é que, no que se referia ao comércio, as teses mercantilistas que haviam predominado durante o Antigo Regime - isto é, a ideia do comércio exterior como grande criador de riqueza - continuavam vivas ao término da Revolução e permaneceriam vivas durante algum tempo, mesmo que não necessariamente sob a forma de uma política imposta pelo Estado. Os grupos cujos interesses estavam vinculados a esse modelo - os negociantes dos portos franceses, os colonos - haviam neutralizado as tentativas feitas contra o seu poderio econômico. A 
Revolução não alterou o fato de que a França era uma potência colonial e, consequentemente, os grupos diretamente ligados ao comércio mantiveram o seu domínio econômico e político. Naquele momento histórico de concretização da hegemonia burguesa, a fração ligada ao comércio de produtos coloniais, unida aos colonos na defesa do tráfico e da escravidão, assumiu uma posição preponderante. Numa França ainda pouco industrializada, ainda não havia forças capazes de contrabalançar a sua influência e direcionar a administração do país para um modelo econômico alternativo.

Assim, a ascensão do capital mercantil ligado ao tráfico, num país ainda incapaz de superar a sua condição de potência colonial, é, em última instância, a chave para compreender a derrota do antiescravismo do final do século XVIII. O Estado liberal e moderno criado pela Revolução acomodou-se, em detrimento dos princípios por ele proclamados, à realidade do tráfico e da escravidão negra nas colônias por conta da reiteração da postura colonialista da França durante e após a Revolução. Incapazes de atacar a própria ideia de colônia, mesmo os homens da Sociedade dos Amigos dos Negros viram-se presos a contradições que os levaram a falsear, em larga medida, o seu combate contra a escravidão. O grande paradoxo da história colonial da Revolução está no fato de que esta também criou as condições para que os escravos de São Domingos conquistassem a sua liberdade e, num segundo momento, a independência, privando a França de sua principal colônia e o comércio francês de sua principal fonte de riqueza. Foram esses homens e mulheres, amparados momentaneamente pelas massas da metrópole, que constituíram o verdadeiro movimento abolicionista do período revolucionário, resistindo ao sistema de opressão que lhes era imposto e conquistando a sua liberdade. 
É interessante observar que, mesmo com a perda de São Domingos, a história posterior do antiescravismo francês reiterou, em grande parte, as mesmas tendências. Entre 1802, data que simboliza a derrota do antiescravismo do final do século XVIII, e 1848, ano da abolição final da escravidão pela França, as mudanças foram menos significativas do que se poderia imaginar. É bem verdade que, em 29 de março de 1815 , Napoleão, ao retornar da ilha de Elba, decretou a abolição do tráfico, como parte de sua tentativa de fazer uma reforma liberal das instituições do Império. A nova investida de Napoleão teve vida curta, mas a monarquia restabelecida, pressionada pela GrãBretanha ${ }^{1854}$, confirmaria formalmente a proibição do tráfico de escravos. ${ }^{1855}$ Contudo, entre a proclamação do fim do tráfico e seu desaparecimento real foram necessários, pelo menos, dezessete anos, durante os quais o comércio de escravos operou numa semi-clandestinidade, dada a ausência de verdadeiros instrumentos repressivos e a negligência da administração francesa em fiscalizar os armadores, cuja influência política ainda era substancial. ${ }^{1856}$

Sob a Restauração, o restabelecimento da economia colonial, arrasada após a independência de São Domingos-Haiti, continuou a ser visto como parte importante da recuperação econômica da França, obrigada então a importar produtos coloniais de Londres, da Índia, do Brasil e de Cuba. Nesse contexto, um novo lobby colonial reclamava, além da restauração do tráfico, uma política protecionista, como forma de lutar contra a baixa dos preços das commodities coloniais francesas. ${ }^{1857}$ No campo oposto, economistas e intelectuais, como Jean-Baptiste Say, escreviam contra o sistema colonial baseado no exclusivo e na escravidão. Eles expressavam a opinião de um novo grupo de negociantes e manufatureiros que consideravam que o sistema colonial, na sua

\footnotetext{
${ }^{1854}$ Em 25 de março de 1807, com o Abolition Act, o tráfico havia sido abolido no Império britânico, desencadeando uma forte pressão inglesa sobre outros países pela supressão universal do comércio de escravos.

${ }^{1855}$ Cf. MARTIN, Gaston. Histoire de l'esclavage dans les colonies françaises, p.252.

${ }^{1856}$ Para o período 1814-1831, Serge Daget identificou 612 navios franceses na Costa Africana, suspeitos de praticarem o tráfico de escravos. Mais da metade (309) dos navios eram provenientes de Nantes, tradicional porto negreiro (cf. DAGET, Serge. L'abolition de la traite des Noirs en France de 1814 à 1831. Cahiers d'études africaines, v.11, n.41, 1971, p.54-55. Disponível em: http://www.persee.fr/web/revues/home/prescript/article/cea 0008-0055_1971_num_11_41_2811. Acesso em: 25 de jun de 2012).

${ }^{1857}$ Essa pressão gerou resultados concretos, como a lei de 27 de julho de 1822, que aumentou as taxas sobre os açúcares estrangeiros de 10 para 25 francos para cada $50 \mathrm{~kg}$ (cf. DÉMIER, Francis. Esclavage, économie coloniale et choix de développement français durant la première industrialisation (1802-1840). In: M. DORIGNY (org.). Les abolitions de l'esclavage, pp.278-279).
} 
forma atual, era um entrave para a expansão e a modernização da economia. ${ }^{1858}$ Desses meios liberais, surgiu uma nova corrente antiescravista, no quadro da Société de la morale chrétienne, que criou, em 1822, um comitê para a abolição do tráfico. Era um movimento moderado, voltado para a efetivação da supressão do tráfico, com poucos ataques diretos à escravidão. Paralelamente, o propósito de emancipar escravos começou a ser usado como pretexto para as pretensões da França na África. A conquista de Argel, onde havia apenas uma centena de escravos, se inscreveu nessa tendência. ${ }^{1859}$ Apesar disso, o sistema colonial sobreviveu à crise dos preços da década de 1820 e aos ataques do movimento liberal. As medidas protecionistas conseguiram elevar os preços na metrópole e, na virada dos anos 1830, os lucros das plantações das Antilhas já tinham subido para a faixa de 9-10\%. ${ }^{1860}$ No momento em que a França avançava na sua primeira industrialização, o sistema colonial e a escravidão apareciam integrados à base da economia nacional.

Com a Revolução liberal de 1830, houve alguns sinais de evolução. Com a lei de 4 de março de 1831, o governo francês se decidiu a reprimir e penalizar duramente os infratores da proibição do tráfico. ${ }^{1861}$ Em 30 de novembro de 1831, a França assinou com a Grã-Bretanha as primeiras convenções sobre o direito de visita, instrumento mais efetivo de repressão ao tráfico. Em 1833, mesmo ano em que a abolição da escravidão foi decretada na Grã-Bretanha, ocorreu a fundação da Société française pour l'abolition de l'esclavage, reunindo desde protestantes orleanistas, como François Guizot, até republicanos maçons, como Victor Schoelcher. Quanto ao seu programa, a Sociedade retomava as linhas gerais dos Amigos dos Negros ${ }^{1862}$ : abolição efetiva do tráfico, humanização da escravidão e um plano de emancipação progressiva dos escravos,

${ }^{1858}$ Cf. DÉMIER, Francis. Esclavage, économie coloniale et choix de développement français, pp.279280.

${ }^{1859}$ Cf. ARZALIER, Francis. Les mutations de l'idéologie coloniale en France avant 1848: de l'esclavagisme à l'abolitionnisme. In: M. DORIGNY (org.). Les abolitions de l'esclavage, pp.299-303; DÉMIER, Francis. Esclavage, économie coloniale et choix de développement français, pp.280-281.

${ }^{1860}$ Cf. DÉMIER, Francis. Esclavage, économie coloniale et choix de développement français, pp.281282.

${ }^{1861}$ A lei previa pena de dois a cinco anos para os negreiros flagrados no porto de partida. Para que fossem punidos, bastava que se presumissem os fins da empresa com base no armamento do navio. Previa-se também uma pena de 10 a 20 anos de trabalhos forçados para os principais responsáveis pelo tráfico, além de uma pena de reclusão para a equipagem do negreiro flagrado em alto mar. Os funcionários implicados no tráfico ficariam sujeitos às penas previstas no Código Penal e os compradores e vendedores de escravos, sujeitos à Cour d'assises (tribunal criminal), na França e nas colônias (cf. DAGET, Serge. L'abolition de la traite des Noirs en France, pp.55-56).

${ }^{1862}$ Vale relembrar que os papeis e registros da Sociedade dos Amigos dos Negros tinham sido adquiridos por François de Montrol, um dos fundadores da nova Sociedade antiescravista. 
empurrando a liberdade geral para uma data distante. ${ }^{1863}$ Schoelcher se destacava no seio do movimento, por sua denúncia da "impotência da emancipação progressiva" e sua defesa da abolição imediata. Embora ele se referisse de forma elogiosa aos Amigos dos Negros, Schoelcher via o reformismo da burguesia francesa como uma tentativa de prolongar o mal e adiar a abolição. ${ }^{1864}$

Entre 1830 e 1848, o abolicionismo se conciliou com todo tipo de linha ideológica $^{1865}$, e viu-se, muitas vezes, amparado em interesses econômicos bastante específicos, especialmente no quadro da querela entre os "dois açúcares" dos anos 1840. A burguesia rural da Picardia, por exemplo, distante das correntes progressistas em outros campos, era uma das principais defensoras do açúcar de beterraba produzido na região, contra o açúcar colonial. Assim, produtores e negociantes regionais denunciavam os horrores da escravidão, ao mesmo tempo em que defendiam as virtudes do produto local. ${ }^{1866}$ Apesar disso, os abolicionistas continuavam se chocando com um poderoso partido escravista, que reunia representantes dos colonos - organizados em torno do Conselho dos delegados das colônias - e porta-vozes dos negociantes dos portos franceses, que se valiam da experiência traumática do Haiti para rejeitar uma abolição capaz de arruinar o que restava do comércio colonial francês. O direito de visita passou a ser usado pelos colonos para acusar o governo francês de atuar em favor dos interesses britânicos, o que levou Guizot, então chefe oficioso do governo, a praticamente suspender o exercício desse direito em 1841-42. Guizot tentou compensar essa medida fazendo votar, em 1845-46, reformas que traziam melhorias à condição dos escravos. $^{1867}$

Nas colônias, movimentos de revolta escrava eram constantes e o levante dos escravos da Martinica de 1848 pode ser visto como um uma espécie de sinal de que a

${ }^{1863}$ Um texto de Dufau, De l'abolition graduelle de l'esclavage dans les colonies européennes et notamment dans les colonies françaises; considérée à la fois dans l'intérêt des esclaves, des maîtres, des colonies et des métropoles (1829), trazia as linhas gerais da argumentação desse novo movimento. Previa um sistema de emancipação gradual em que o liberto ficaria preso ao serviço do senhor durante dez anos após a sua "libertação". Apenas ao término desse longo período, ele adquiriria os direitos de um trabalhador livre (cf. MARTIN, Gaston. Histoire de l'esclavage dans les colonies françaises, p.259).

${ }^{1864}$ Cf. SCHOELCHER, Victor. Esclavage et colonisation. Paris: Presses Universitaires de France, 1948, p.108).

${ }^{1865}$ Entre os abolicionistas, era possível encontrar representantes da esquerda republicana (Ledru Rollin, Béranger), centristas (Lamartine), liberais (Tocqueville) e orleanistas moderados (La Fayette, Broglie, Molé, Barrot).

${ }^{1866}$ Cf. ARZALIER, Francis. Les mutations de l'idéologie coloniale en France avant 1848, pp.304-305.

1867 Assim, a lei de 18 de julho de 1845 pretendia encorajar as alforrias ao atribuir ao escravo liberto um pequeno pecúlio que lhe permitia aceder à propriedade. Além disso, o Estado alforriou coletivamente os negros de seus domínios na Martinica, na Guadalupe, na Guiana e Bourbon. Essas disposições tiveram, entretanto, uma aplicação modesta (cf. VIGIER, Philippe. La recomposition du mouvement abolitionniste sous la monarchie de juillet. In: M. DORIGNY (org.). Les abolitions de l'esclavage, pp.289-291). 
questão da escravidão tinha de ser enfrentada. Foi, entretanto, necessário uma nova revolução na França, a republicana de 1848, para que as resistências fossem superadas. O impulso revolucionário levou à adoção pelo governo provisório de medidas como a adoção do sufrágio universal (masculino), o reconhecimento do direito ao trabalho dos operários, a redução da jornada de trabalho, o restabelecimento das liberdades de imprensa e de reunião pública e uma repartição mais justa dos impostos. ${ }^{1868}$ A abolição da escravidão se inscreveu nessa mesma tendência. Schoelcher viu na revolução a ocasião de convencer o ministro da Marinha, François Arago, da necessidade de abordar a questão antes que novos incidentes semelhantes aos de São Domingos ocorressem nas colônias. Assim, mais uma vez, a lógica preservacionista da ordem colonial se reproduzia mesmo entre os abolicionistas radicais. ${ }^{1869}$

Assim como em 16 pluvioso do ano II, foi a conjuntura revolucionária que permitiu vencer os obstáculos. O princípio da abolição foi adotado em 3 de março de 1848 pelo governo provisório e uma comissão presidida por Schoelcher foi formada para preparar a lei correspondente (adotada em 27 de abril de 1848), sem que nenhum colono tenha sido convidado a integrá-la. Delegados dos colonos pressionaram os trabalhos da Comissão, tentando impor as suas condições para a emancipação geral. Para seu desespero, a Comissão se decidiu pela abolição imediata da escravidão, superando a abolição britânica, feita progressivamente entre 1833 e 1838, embora seguindo o modelo britânico de indenização dos colonos. Assim como havia acontecido após a lei de 1794, uma das preocupações fundamentais da Comissão foi encontrar meios de garantir a continuação do cultivo, isto é, definir os termos da transição do escravismo para um sistema de trabalho assalariado. Em decretos anexos, a Comissão recomendou uma nova legislação de trabalho, com um sistema de recompensas para os melhores cultivadores. Outra recomendação foi o recurso à mão de obra europeia em caso de penúria de braços. A lei não gerou nenhuma crise durável da economia açucareira, apenas uma diminuição momentânea da produção. Mas a continuidade desta passou pela instituição, já em maio de 1848, de um regulamento de trabalho coercitivo, que atentava contra a liberdade individual dos novos livres. A mão de obra continuou a

\footnotetext{
${ }^{1868}$ Cf. ANCEAU, Éric. La France de 1848 à 1870. Entre ordre et mouvement. Paris: Librairie Générale Française, 2002, pp.28-30.

1869 Schoelcher tinha um projeto de modernização da economia colonial, com uma industrialização da produção açucareira. Queria transformar os escravos em trabalhadores livres, civilizados e consumidores de produtos franceses (cf. SCHMIDT, Nelly. L'élaboration des décrets de 1848. Application immédiate et conséquences à long terme. In: M. DORIGNY (org.). Les abolitions de l'esclavage, pp.351-352).
} 
ser introduzida em condições muito próximas às do tráfico. ${ }^{1870}$ As mesmas preocupações da época da Revolução continuavam vivas.

Logo nos seus primeiros meses, a nova República daria uma guinada conservadora, antes mesmo do golpe de Luís Bonaparte. O decreto de abolição foi uma medida de impulso, tomada pelo governo provisório em meio à euforia republicana. Os tempos de revolução, marcados por mobilizações sociais importantes, promoveram mudanças institucionais profundas, mas estas não implicaram a erradicação imediata das práticas e dos modos de pensar que moviam a sociedade pré-revolucionária.

Se, desta vez, não houve volta atrás no processo abolicionista, isso se deve a uma pluralidade de motivos, tais como a pressão britânica e a evolução das críticas relativas ao ônus do sistema colonial após a perda de São Domingos-Haiti. É verdade também que, a partir da segunda metade do século XIX, a França avançou num processo de industrialização e modernização do país, com a criação de um amplo sistema bancário e uma rede de transportes capaz de interligar os diferentes pontos do país. Nesse quadro, é possível pensar que a influência econômica e política da burguesia mercantil tenha sido progressivamente diminuída.

Deve-se ressaltar, entretanto, que mesmo esse processo de desenvolvimento industrial não levaria a França a abandonar a sua postura colonialista. Ao contrário, a partir das últimas décadas do século, a empresa colonial entraria numa nova fase de expansão, com base num novo modelo de colonização, sem escravidão, no qual as colônias constituiriam uma nova saída para os produtos metropolitanos, tornando-se, no final da década de 1920, o principal mercado consumidor de artigos franceses. ${ }^{1871}$ Esse modelo colonial não deixava de evocar os projetos colonizadores dos Amigos dos Negros. Em nenhum momento, mesmo após três revoluções - 1789, 1830 e 1848 -, deixou a França de pensar nas suas colônias.

\footnotetext{
${ }^{1870}$ Cf. SCHMIDT, Nelly. L'élaboration des décrets de 1848, pp.345-350.

${ }^{1871} \mathrm{Em}$ menos de trinta anos, a superfície dos territórios controlados passaria de $900 \mathrm{mil} \mathrm{km}^{2}$ para cerca de 12 milhões e sua população, de 3 para 50 milhões de habitantes. Em 1952, a zona franco chegaria a absorver $42,2 \%$ das exportações metropolitanas, constituindo um mercado privilegiado para os produtos franceses (cf. MARSEILLE, Jacques. Empire colonial et capitalisme français. Histoire d'un divorce. Paris: Albin Michel, 1984, p.35 e 40-41).
} 


\section{BIBLIOGRAFIA}

Observação: os títulos marcados com asterisco (*) pertencem à coleção La Révolution française et l'abolition de l'esclavage. (12 volumes. Paris: EDHIS, 1968; BN 944.04/306 REVO a1-a12). Colocamos ao lado do asterisco o volume e o número da peça correspondente a cada documento.

\section{FONTES}

\section{Fontes manuscritas}

Archives Départementales de Loire Atlantique (ADLA)

Fonds de la Chambre de Commerce de Nantes:

Séries C 599, C 600, C 604, C 605, C 607, C 608, C 624. C 626.

\section{Fontes impressas}

\section{1) Coleções e compilações de documentos}

Archives parlementaires de 1787 à 1860: recueil complet des débats législatifs et politiques des Chambres françaises. Première série, 1787 à 1799. Paris: Dupont, CNRS, 1867-1990. (BN 944.040 2 ARCH)

AULARD, F.A. La Société des Jacobins - Recueil de documents pour l'histoire du club des Jacobins de Paris. Paris: Léopold Cerf/Noblet/Quantin, 1889-1897. 6 v. (BN 944.040 2 AULA s1-s6)

BAUX, J.-L., GENSONNÉ, Armand. Lettres importantes relatives à la question des citoyens de couleur. S.1. [Paris]: Imprimerie du Patriote François, s.d. [1791]. (*, IV: 13)

BRISSOT DE WARVILLE, Jean-Pierre. Correspondance et papiers. Paris: Picard et fils, 1912. Disponível em: http://gallica.bnf.fr/ark:/12148/bpt6k1060966.

Collection générale des lois, décrets, arrêtés, sénatus-consultes, avis du conseil d'état et réglemens d'administration, publiés depuis 1789 jusqu'au $1^{\text {er }}$ avril 1814. v.7. Paris: De 
l'Imprimerie $\quad$ Royale, $1818 . \quad$ Disponível em: http://books.google.com/books?id=Um1OAAAAYAAJ.

Correspondance de Napoléon $I^{e r}$, publiée par ordre de l'empereur Napoléon III. Paris: Henri Plon, J. Dumaine, 1861. v.6-7. Disponível em: http://books.google.com/books?id=ogw_AAAAcAAJ; http://books.google.com/books?id=bbBAAAAcAAJ.

CORRESPONDANCE secrette des Colons députés à l'Assemblée Constituante, servant à faire connaître l'esprit des colons en général, sur la Révolution. Paris: Imprimerie d'Anjubault, s.d.. (*, VIII: 10)

DEVEAU, Jean-Michel. Le Commerce rochelais face à la Révolution: Correspondance de Jean-Baptiste Nairac (1789-1790). La Rochelle: Editions La Rumeur des Ages, 1989. (BN 944.640 3 DEVE c)

GRÉGOIRE, Henri. Oeuvres de l'abbé Grégoire. Nendeln (Liechtenstein): KTO; Paris: EDHIS, 1977. v.4. (BN 8-LA32-1272)

LACLOS, Choderlos de. Oeuvres Complètes. Paris: Gallimard, 1979. (BFF 843 L145oc)

Les déclarations des droits de l'homme - Du débat 1789-1793 au Préambule de 1946. Paris: Flammarion, 1989. (BFF 323.4 D295)

LETTRES de la Société des Amis des Noirs, à M. Necker, avec la Réponse de ce Ministre. S.1. [Paris]: s.d. [1789]. (*, VII: 2)

LETTRES des diverses Sociétés des Amis de la Constitution, qui réclament les droits de Citoyen actif en faveur des hommes de couleur des Colonies. S.1. [Paris]: Imprimerie du Patriote François, s.d. [1791]. (IV, 10)

Lettres du général Leclerc, commandant en chef de l'armée de Saint-Domingue en 1802. Paris: Société de l'histoire des colonies françaises, Librairie Ernest Leroux, 1937. (BN 980.929403 LECL I)

MARIE-ANTOINETTE. Correspondance. Clermont-Ferrand: Paleo, 2005. v.3: Correspondance secrète avec Barnave, juillet 1791 - janvier 1792 (BN 2007-58223)

MIRABEAU, Honoré-Gabriel Riqueti. Mémoires biographiques, littéraires et politiques. Paris: Delaunay Librairie, 1835. v. 7. (BN 8-LA33-84(7))

Papiers inédits trouvés chez Robespierre, Saint-Just, Payan, etc... précédés du Rapport fait au nom de la Commission chargée de l'examen des papiers de Robespierre, etc. Paris: Baudouin frères, 1828. 3 v. Disponível em: http://gallica.bnf.fr/ark:/12148/bpt6k46894m.r=.langPT.

Paris pendant la Terreur - Rapports des agents secrets du Ministre de l'Intérieur. P. Caron (org.). Paris: Librairie de la Société de l'Histoire de France, 1949. (BN 944.002 SHF 167.4) 
RAIMOND, Julien. Correspondance de Julien Raimond, avec ses frères, de SaintDomingue, et les pièces qui lui ont été adressées par eux. Paris: de l'imprim. du Cercle Social, 1793. Disponível em: http://gallica.bnf.fr/ark:/12148/bpt6k5460985t.

Recueil des actes du Comité de salut public avec la correspondance officielle des représentants en mission et le registre du Conseil exécutif provisoire. Paris: Imprimerie nationale, 1889-1910. 28 v. (BN 944.002 DOCS 198.1-28)

ROBESPIERRE, Maximilien. Oeuvres. Paris: Phénix éditions, 2000. 11 v. (BN 944.040 2 ROBE o1-o11)

TURGOT, Anne-Robert-Jacques. Oeuvres et documents le concernant. Paris: Felix Alcan, 1913-1923. v.2. Disponível em: http://gallica.bnf.fr/ark:/12148/bpt6k112908s.

Une correspondance familiale au temps des troubles de Saint-Domingue. Paris: Société de l'histoire des colonies françaises/Librairie Larose, 1959.

WIMPFFEN, Alexandre-Stanislas, baron de. Haïti au XVIIIe siècle: richesse et esclavage dans une colonie française. Paris: Karthala, 1993. (BFF 326.7294 W757h)

\section{2) Periódicos}

- Analyse des papiers anglois. Paris: s.n., 1787-1788. (BN 8-ND-4)

- Annales de la Religion, ou Mémoires pour servir à l'Histoire du dix-huitième siècle; par une Société d'Amis de la Religion et de la Patrie. Paris: Imprimerie-Librairie Chrétienne, ano VIII. v.11-12. Disponível em: http://books.google.com/books?id=v_SQgcmQ0EMC; http://books.google.com/books?id=MlU2SxvelIMC.

- Bulletin des Amis de la Vérité. Paris: de l'Imprimerie du Cercle Social, 1792-1793. (BN FOL-LC2-763)

- Chronique de Paris. Paris: s.n., 1790-1793. Alguns volumes disponíveis em: http://gallica.bnf.fr/Search?adva $=1 \& a d v=1 \&$ tri=title_sort\&t_relation=\%22Notice $+\mathrm{d} \% 2$ 7ensemble+\%3A+http $\% 3 \mathrm{~A} \% 2 \mathrm{~F} \% 2 \mathrm{Fcatalogue}$. bnf.fr\%2Fark $\% 3 \mathrm{~A} \% 2 \mathrm{~F} 12148 \% 2 \mathrm{Fcb} 375$ 72041q $\% 22 \& \mathrm{q}=$ chronique + de + paris \&lang $=$ pt.

- Le Créole Patriote, bulletin de Milscent-créole. Paris: de l'Imprimerie de MilscentCréole, 1792-1793. Microfilme. (BN MFILM RES M-2-813)

- La Décade philosophique, littéraire et politique. Paris: Au Bureau de la Décade, 17941807. Alguns volumes disponíveis em: http://gallica.bnf.fr/ark:/12148/cb327543836/date.r=\%22la+d\%C3\%A9cade+philosophi que+litt\%C3\%A9raire\%22.langPT.

- La Feuille Villageoise, adressée, chaque semaine, à tous les villages de la France, pour les instruire des lois, des évènements, des découvertes qui intéressent tout citoyen. 
Paris: Desenne, 1790-95. Volumes disponíveis em: http://gallica.bnf.fr/Search?adva=1\&adv=1\&tri=title_sort\&t_relation=\%22Notice+d\%2 7ensemble+\%3A+http\%3A\%2F\%2Fcatalogue.bnf.fr\%2Fark\%3A\%2F12148\%2Fcb375 720333\%22\&q=\%22feuille+villageoise $\% 22 \&$ lang=pt.

- Journal de la Montagne (1793-1794), redigido por J.-Ch. Laveaux. Paris: de l'impr. patriotique et républicaine, Les archives de la Révolution française, Pergamon press, cop. 1990. Alguns volumes disponíveis em: http://gallica.bnf.fr/Search?adva=1\&adv=1\&tri=title_sort\&t_relation=\%22Notice+d\%2 7ensemble+\%3A+http $\% 3 \mathrm{~A} \% 2 \mathrm{~F} \% 2 \mathrm{Fcatal}$ ogue.bnf.fr\%2Fark\%3A\%2F12148\%2Fcb375 $72046 \mathrm{f} \% 22 \& \mathrm{q}=\% 22 \mathrm{journal}+\mathrm{de}+\mathrm{la}+$ montagne $\% 22 \&$ lang $=\mathrm{pt}$.

- Suite du Journal de Perlet. Convention Nationale, Corps administratifs et nouvelles politiques et littéraire de l'Europe. Paris: s.n.., s.d. (BN 8-LC2-203)

- Journal de Paris. Paris: de l'Imprimerie de Quillau, s.d. Microfilme. (BN MICR D-80)

- L'Ami du Peuple. In: MARAT, Jean-Paul. Oeuvres politiques. Bruxelas: Pôle Nord, 1993. v.5-6. (BN 944.04 MARA o5-o6)

- Gazette Nationale ou Le Moniteur Universel. Reimpressão. Paris: Au Bureau Central, 1841. (BN $054 \mathrm{MONI})$

- Le Patriote Français. Journal libre, impartial et national. Par une Société de Citoyens, \& dirigée par J.P. Brissot de Warville. Reimpressão. Frankfurt am Main: Keip Verlag, 1989. (BN 944.040 2 PATR)

- Je suis le véritable Père Duchesne, foutre!. Paris: s.n, s.d. Alguns volumes disponíveis em:

http://gallica.bnf.fr/ark:/12148/cb32795546m/date.r=\%22je+suis+le+v\%C3\%A9ritable $+\mathrm{p} \% \mathrm{C} 3 \%$ A8re+duchesne\%22.langPT.

- Le vieux Cordelier de Camille Desmoulins, seule édition complète. précédée d'un Essai sur la vie et les écrits de l'auteur. Paris: Ébrard, 1834. Disponível em: http://gallica.bnf.fr/ark:/12148/bpt6k393802.

- Lettres du comte de Mirabeau à ses commettans, pendant la tenue de la première Législature. Paris: Chez Lavillette, 1791. Disponível em: http://books.google.com/books?id=Mb47AAAAMAAJ.

- Mercure de France. Reimpressão. Genebra: Slatkine Reprints, 1974. (BN HIST MERC)

- Le Républicain des colonies. Paris: De l'Imprimerie du Bureau central d'abonnement à tous les Journaux, 1797. (BN 8-LC12-85)

- Révolutions de France et de Brabant, par Camille Desmoulins. Reimpressão. Frankfurt am Main: Keip Verlag, 1989. (BN 944.040 2 REVO)

- Les Révolutions de Paris, dédiées à la Nation. Publiées par L. Prudhomme. Paris: de l'Imprimerie des Révolutions de Paris, 1789-1794. (BN 8-LC2-171) 


\section{3) Documentos impressos}

\section{1) Adresses, petições, discursos e relatórios}

À l'Assemblée nationale. Supplique et pétition des citoyens de couleur des îles et colonies françaises sur la motion faite le 27 nov. 1789 par M. de Curt,... au nom des colonies réunies, tendante à faire nommer un comité des colonies... Du 2 déc. 1789. S.1.: s.n., s.d. (BN 8-LK9-67)

ADRESSE à l'Assemblée Nationale, pour l'abolition de la Traite des Noirs. Par la Société des Amis des Noirs de Paris. Février 1790. Paris: Imprimerie de Potier de Lille, 1790. (*, VII: 7)

ADRESSE à la Convention Nationale, à tous les Clubs et Sociétés Patriotiques, pour les Nègres détenus en esclavage dans les Colonies Françaises de l'Amérique, sous le régime de la République. Paris: Imprimerie Galletti, s.d. [1793]. (*, V: 3)

ADRESSE aux Amis de l'humanité, par la Société des Amis des Noirs, sur le plan de ses travaux. Lue au Comité, le 4 juin 1790, et imprimée par son ordre. Paris: Imprimerie du Patriote François, s.d. [1790]. (*, VIII: 3)

BLANC-GILLI, Matthieu. Observations importantes sur les troubles de SaintDomingue. Inutilité absolue des moyens qu'on prend pour les apaiser, si l'on n'améliore pas en même temps le sort des nègres esclaves. Paris: Imprim. nationale, s.d.. (BN 8LE33-3(E,40))

BLIN. Opinion de M. Blin, sur la proposition, faite par MM. les députés des colonies réunies, d'établir un Comité colonial, etc. ler décembre 1789. Paris: Baudouin, s.d.. (BN 8-LE29-346)

BRISSOT DE WARVILLE, Jacques-Pierre. Discours sur la nécessité de maintenir le décret rendu le 15 mai en faveur des hommes de couleur libres, prononcé le 12 septembre 1791, à la séance de la Société des Amis de la Constitution... Imprimé par ordre de la Société. S.1. [Paris]: s.n., s.d. [1791]. (*, VIII: 8).

BRISSOT DE WARVILLE, Jacques-Pierre. Discours sur un projet de décret relatif à la révolte des noirs, prononcé à l'Assemblée Nationale le 30 octobre 1791. Paris: Imprimerie Nationale, 1791. (*, VIII: 9)

CHAUMETTE, Anaxagoras. Discours prononcé au nom de la Commune de Paris, le Décadi 30 pluviôse, l'an II de la République Française, une et indivisible, à la fête célébrée à Paris, en réjouissance de l'abolition de l'esclavage. Paris: Imprimerie Nationale, s.d. [ano II]. (*, V: 5)

[CLAVIÈRE, Étienne]. Adresse de la Société des Amis des Noirs, à l'Assemblée nationale, à toutes les villes de commerce, à toutes les manufactures, aux colonies, à 
toutes les sociétés des amis de la Constitution. Paris: de l'impr. du patriote françois, 1791. (*, IX: peça única)

COCHEREL, Nicolas-Robert. Observations de M. de Cocherel, ... à l'Assemblée Nationale, sur la demande des mulâtres. Paris: imprim. de Clousier, s.d. (BN-LE29343)

CORBIN, Lucidor F. Discours de la citoyenne Lucidor F. Corbin, Créole Républicaine, prononcée (sic) par elle-même au Temple de la Raison, l'an $2^{e}$ de la Liberté. Paris: chez Colubrier, graveur, s.d. (*, XI: 10)

CORBUN, Jean Marie. Discours sur l'état actuel des colonies et leur amélioration. Paris: De l'Imprimerie Nationale, ano V [1797]. (BN LE43-1015)

COURNAND, Antoine de. Requête présentée à Nosseigneurs de l'Assemblée Nationale, en faveur des gens de couleur de l'île de Saint-Domingue. Paris: s.n., s.d. [1790]. (*, IV: 3)

CURT. Motion de M. de Curt, député de la Guadeloupe, au nom des Colonies réunies. Paris: Chez Baudouin, 1789. (BN 8-LE29-341)

Débats entre les accusateurs et les accusés, dans l'affaire des colonies. Paris: Imprimerie nationale, ano III [1795]. 9 v. (BN 8-LE38-1662(1)-(9))

DELAHAYE, J.C.G. Corps législatif. Conseil des Cinq-Cents. Discours de J.-C.-G. Delahaye sur l'affaire des Colonies. Séance du 11 prairial an V. Paris: De l'Imprimerie Nationale, ano V [1797]. (BN LE43-1012)

DISCOURS sur la nécéssité d'établir à Paris une Société pour concourir, avec celle de Londres, à l'abolition de la traite \& de l'esclavage des Nègres. Prononcé le 19 février 1788, dans une Société de quelques amis, rassemblés à Paris, à la prière du Comité de Londres. [Paris]: s.n., s.d. [1788]. (*, VI: 1)

DORFEUILLE, Antoine. Discours prononcé après la lecture du Décret sur les Hommes de couleur, dans la fête célébrée à Commune-Affranchie le 20 Ventôse, en présence des Représentans du Peuple Fouché, Laporte, Méaulle. Commune Affranchie: Imprimerie Républicaine, s.d. [ano II]. (*, V: 4)

ESCHASSÉRIAUX, Joseph. Corps législatif. Conseil des Cinq-cents. Motion d'ordre relative aux colonies. Séance du 2 prairial an V. Paris: De l'Imprimerie Nationale, ano $\mathrm{V}$ [1797]. (BN 8-LE43-998)

ESCHASSÉRIAUX, Joseph. Corps législatif. Conseil des Cinq-Cents. Opinion d'Eschassériaux (aîné) sur les moyens de rétablir les colonies. Séance du 16 prairial an $V$. Paris: Imprimerie Nationale, an V [1797]. (BN 8-LE43-1026)

ESCHASSÉRIAUX, Joseph. Corps législatif. Conseil des Cinq-Cents. Rapport fait au nom de la commission des colonies par Eschassériaux aîné sur les députations de SaintDomingue. Séance du 25 fructidor an V. Paris: De l'Imprimerie Nationale, ano V [1797]. (BN 8-LE43-1368) 
FROSSARD, Benjamin-Sigismond. Observations sur l'abolition de la traite des Nègres. Présentées à la Convention Nationale. S.l. [Paris]: Imprimerie de Gueffier, 1793. (*, VIII: 11)

GARRAN DE COULON, Jean Philippe. Corps législatif. Conseil des Cinq-Cents. Opinion de J.-Ph. Garran, sur les dénonciations formées contre les agens du Directoire, à Saint-Domingue. Séance du 16 prairial an V. Paris: De l'Imprimerie Nationale, ano V [1797]. (BN LE43-1027)

GARRAN DE COULON, Jean-Philippe. Rapport sur les troubles de Saint-Domingue, fait au nom de la Commission des colonies, des Comités de salut public, de législation et de marine, réunis. Paris: Imprimerie nationale, 1796-1799. 4 v. Volumes disponíveis em:

http://gallica.bnf.fr/Search?adva=1\&adv=1\&tri=title_sort\&t_relation=\%22Notice+d\%2 7ensemble+\%3A+http $\% 3 \mathrm{~A} \% 2 \mathrm{~F} \% 2 \mathrm{Fcatalogue}$.bnf.fr\%2Fark\%3A\%2F12148\%2Fcb372 $285681 \% 22 \&$ lang $=$ pt.

GOULY, Benoît. Rapport sur le décret du 16 pluviose, relatif à la liberté des nègres dans les colonies, sur le mode d'exécution, suivi du projet de décret. In: Vues générales sur l'importance du commerce des Colonies. Paris: Imprimerie de Rubat, s.d. (BN 4LE38-1075)

KERSAINT, Armand-Guy. Moyens proposés à l'Assemblée Nationale, pour rétablir la paix et l'ordre dans les Colonies. Paris: Imprimerie du Cercle Social, 1792. (*, V: 2)

KERSAINT, Armand-Guy. Suite des moyens proposés à l'Assemblée Nationale, pour rétablir la paix et l'ordre dans les Colonies. Paris: Imprimerie du Cercle Social, 1792. $(*, \mathrm{~V}: 2)$

LABORIE. Propositions soumises à l'examen du Comité de Marine de l'Assemblée Nationale. Paris: Cellot, 1790. (*, IV: 6)

LAVAUX, Étienne Maynaud Bizefranc de. Discours prononcé par C. Lavaux, député de Saint-Domingue, le troisième jour complétmentaire, an V. Paris: De l'Imprimerie Nationale, ano VI [1797]. (BN 8-LE45-588)

LEBORGNE DE BOIGNE, Claude Pierre Joseph. Corps législatif. Conseil des CinqCents. Compte rendu par Leborgne, sur la situation actuelle de la colonie de SaintDomingue. Séance du 27 vendémiaire an VI. Paris: Imprimerie Nationale, ano VI. (BN 8-LE43-1470)

LOUVERTURE, Toussaint. Extrait du Rapport adressé au Directoire exécutif par le citoyen Toussaint-Louverture, général en chef des Forces de la République française à Saint-Domingue. Au Cap Français: chez P.Roux, s.d. [ano V]. (*, XI: 12)

MAGOL. Discours sur la question relative à la liberté des nègres, prononcé en l'assemblée générale du district des Filles-Saint-Thomas, le février (1790). Paris: imprim. de Monsieur, 1790. (BN 8-LB40-273(A))

MENTOR, Etienne-Victor. Conseil des Cinq-Cents. Discours prononcé dans la séance du 12 prairial an 6. Paris: Imprimerie Nationale, ano VI [1798]. (*, XI: 15) 
MENTOR, Etienne-Victor. Conseil des Cinq-Cents. Discours sur le projet de résolution tendant à faire annuler les dettes contractées pour achat de Noirs. Séance du 24 Vendémiaire an 7. Paris: Imprimerie Nationale, brumaire an 7. (*, XI: 16)

[MILSCENT, Claude]. Adresse à l'Assemblée Nationale par les hommes de couleur libres de Saint-Domingue. S.1.: s.n., 1791. Disponível em: http://gallica.bnf.fr/ark:/12148/bpt6k5785748p.

MILSCENT, Claude. Justification de M. Milscent, Créole, à l'Assemblée Coloniale de S. Domingue. S.l.: s.n., s.d. Disponível em: http://gallica.bnf.fr/ark:/12148/bpt6k5626502d.

MOREAU DE SAINT-MÉRY, Médéric Louis Élie. Opinion sur la motion de M. de Curt, Député de la Guadeloupe, pour l'établissement d'un Comité chargé particulièrement de l'examen de tous les objets Coloniaux. Paris: de l'Imprimerie Nationale, s.d. (BN 8-LE29-347)

OGÉ JEUNE, Vincent. Motion faite à l'Assemblée des Colons Habitans de S. Domingue, à l'Hôtel de Massiac, Place des Victoires. S.l. [Paris]: s.d. [1789]. (*, XI: 2)

PAGE, Pierre-François, BRULLEY, Augustin-Jean. Notes fournies au Comité de Salut Public. S.l.: s.n., s.d. Disponível em: http://gallica.bnf.fr/ark:/12148/bpt6k5772381q.

PÉPIN. Adresse d'un patriote françois à l'Assemblée Nationale sur la Traite des Noirs. Avril 1791. S.1. [Paris]: Imprimerie de Valleyre, s.d. [1791]. (*, IV: 11)

PÉTION, Jérôme. Discours sur la traite des Noirs. Paris: Desenne, avril 1790. (*, VIII: 1)

PÉTITION [ampliative en faveur des Blancs et des Noirs, et Projets d'un Traité important pour les Colonies et pour l'Etat]. S.l. [Paris]: s.n, s.d. [1791]. (*, IV: 12)

PLAINTE de la Société des Amis des Noirs, contre M. Dillon, à l'Assemblée Nationale. S.1. [Paris]: s.n, s.d. [1791]. (*, VIII: 6)

Procès de J.P. Brissot et complices, ex-duputés à la Convention Nationale. Paris: Clement, imprimeur, ano II. Disponível em: http://books.google.com/books?id=cxd2f5QGXIIC.

RAIMOND, Julien. Réclamations adressées à l'Assemblée nationale par les personnes de couleur... de Saint-Domingue. S.1.: 1790. Disponível em: http://gallica.bnf.fr/ark:/12148/bpt6k5785235b.

RAIMOND, Julien. Observations adressées à l'Assemblée nationale, par un député des colons amériquains. S.l.: s.n., $1789 . \quad$ Disponível em: http://gallica.bnf.fr/ark:/12148/bpt6k54615279.

RAIMOND, Julien. Rapport de Julien Raimond, commissaire délégué par le Gouvernement français aux Isles-sous-le-vent, au Ministre de la Marine. Cap Français: P. Roux, 1797. Disponível em: http://gallica.bnf.fr/ark:/12148/bpt6k5461557f. 
REGNAULT DE SAINT-JEAN-D'ANGÉLY. Discours sur le Projet de Loi relatif aux Colonies. Paris: De l'Imprimerie Nationale, ano X [1802].

SECONDE ADRESSE à l'Assemblée Nationale, par la Société des Amis des Noirs, établie à Paris. Paris: Imprimerie du Patriote François, s.d. [1790]. (*, VII: 8)

SIBIRE, Abbé Sébastien-André. L'Aristocratie négrière, ou Réfléxions philosophiques et historiques sur l'esclavage et l'affranchissement des Noirs, dédiées à l'Assemblée Nationale; par M. l'abbé Sibire, ancien ami des Africains, et leur premier missionnaire dans le Royaume de Loango. Paris: Lesclapart et Desray, 1789. (*, II: 1)

TARBÉ, Charles. Corps législatif. Conseil des Cinq-Cents. Discours prononcé par Ch. Tarbé... sur l'état actuel de la colonie de Saint-Domingue. Séance du 11 prairial an V. Paris: De l'Imprimerie Nationale, ano V [1797]. (BN 8-LE43-1013)

THOMANY, Pierre. Conseil des Cinq-Cents. Motion d'ordre sur l'anniversaire de la liberté des noirs dans les colonies françaises. Séance du 16 pluviôse an 7. Paris: Imprimerie Nationale, pluviôse an 7. (*, XI: 17)

TRAITE des Nègres. A Messieurs les Députés à l'Assemblée Nationale. Paris: Baudouin, s.d.. (*, IV: 2)

VIEFVILLE DES ESSARTS, Jean-Louis de. Discours et projet de loi pour l'affranchissement des nègres, ou l'adoucissement de leur régime, et Réponse aux objections des Colons. Paris: Imprimerie Nationale, s.d. [1790]. (*, VII: 6)

VIÉNOT-VAUBLANC, Vincent-Marie. Corps législatif. Conseil des Cinq-Cents. Discours sur l'état de Saint-Domingue et sur la conduite des agens du Directoire, prononcé par Viénot-Vaublanc. Séance du 10 prairial an V. Paris: De l'Imprimerie Nationale, ano V [1797]. (BN 8-LE43-1008)

VILLARET-JOYEUSE. Discours sur l'importance des Colonies et les moyens de les pacifier. Paris: De l'Imprimerie Nationale, ano V [1797]. (BN 8-LE43-1016)

WADSTROM, Charles-Bernard. Adresse au Corps Législatif et au Directoire Exécutif de la République Française. Paris: Imprimerie des Sciences et Arts, s.d. (*, VIII: 14)

\section{2) Panfletos}

Almanach de l'abbé Maury, ou Réfutation de l'almanach du Père Gérard, couronné par la Société des Amis de la monarchie. Coblenz: chez tous les libraires royalistes, s.d. Disponível em: http://gallica.bnf.fr/ark:/12148/bpt6k48782t.

BAILLIO. L'Anti-Brissot, par un Petit-Blanc de Saint-Domingue. Paris: Chez Girardin, s.d. Disponível em: http://gallica.bnf.fr/ark:/12148/bpt6k5786691n.

BELIN DE VILLENEUVE. Lettre d'un créole de Saint Domingue à la Société établie à Paris sous le nom d'Amis des Noirs. Paris: 1789. (BN 8-LK9-729) 
BELLEY, Jean-Baptiste. Le bout d'oreille des colons, ou le systême de l'hôtel de Massiac, mis au jour par Gouly. In: GOULY, Benoît. Vues générales sur l'importance du commerce des Colonies. Paris: Imprimerie de Rubat, s.d. (BN 4-LE38-1075)

BRISSOT DE WARVILLE, Jacques-Pierre. Affaire de Tabago: réponse de J. P. Brissot aux lettres insérées dans le journal de Paris, par MM. Dillon, député à l'Assemblée nationale, et Henrion (de Flozelles), avocat aux conseils, sur les réclamations des planteurs de Tabago. Paris: de l'imprimerie du patriote français, s.d. Disponível em: http://gallica.bnf.fr/ark:/12148/bpt6k44869x.

BRISSOT DE WARVILLE, Jacques-Pierre. Plan de conduite pour les députés du peuple aux Etats-généraux de 1789. S.1.: s.n., 1789. Disponível em: http://gallica.bnf.fr/ark:/12148/bpt6k478778.

BRISSOT DE WARVILLE, Jacques-Pierre. Réflexions sur l'admission, aux états généraux, des députés de Saint-Domingue. S.l.: s.n., s.d.. Disponível em: http://gallica.bnf.fr/ark:/12148/bpt6k417092.

BRISSOT DE WARVILLE, Jacques-Pierre. Lettre à M. Barnave, sur les rapports concernant les colonies, les décrets qui les ont suivis, leurs conséquences fatales... Paris: Desenne/Bailly, 1790. (microficha) (BN MFICHE LB39-4375(A))

BRISSOT DE WARVILLE, Jacques-Pierre. Réflexions sur le nouveau décret rendu pour la Martinique et les colonies le 29 novembre 1790, pour servir de suite à la lettre à M. Barnave. Paris: de l'impr. du Patriote françois, 1790. Disponível em: http://gallica.bnf.fr/ark:/12148/bpt6k44830w.

BRISSOT DE WARVILLE, Jacques-Pierre. Réplique à la première et dernière lettre de Louis-Marthe Gouy, Défenseur de la Traite des Noirs et de l'Esclavage. Paris: Belin, et au Bureau du Patriote François, 10 février 1791. (*, VIII: 5)

CLARKSON, Thomas. Lettre aux auteurs du Journal de Paris. S.l. [Paris]: Imp. V-ve Hérissant, s.d. [1790]. (*, VII: 5)

COCHEREL, Nicolas-Robert. Observations... sur le Mémoire du ministre de la Marine, renvoyé au Comité des douze (au sujet des troubles de Saint-Domingue). S.1.: s.n., 1791. Disponível em: http://gallica.bnf.fr/ark:/12148/bpt6k5786221m.

COCHEREL, Nicolas-Robert. Apperçu sur la Constitution de Saint-Domingue. S.l: s.n., s.d. Disponível em: http://gallica.bnf.fr/ark:/12148/bpt6k5786305v.

COCHEREL, Nicolas-Robert. Opinion de M. de Cocherel,... sur l'admission des nègres et mulâtres libres aux assemblées provinciales. Paris: impr. de Clousier, s. d. (BN 8LE29-342)

COLLOT-D'HERBOIS, Jean-Marie. Almanach du Père Gérard, pour l'année 1792. Paris: de l'Imprimerie du Patriote François, 1792. Disponível em: http://gallica.bnf.fr/ark:/12148/bpt6k48793g.

CONDORCET, Jean-Antoine-Nicolas de Caritat. Au Corps Electoral, contre l'esclavage des Noirs. In: Oeuvres Complètes. Brunswick, Paris: Heinrichs, 1804. (*, VI: 7) 
CONDORCET, Jean-Antoine-Nicolas de Caritat. Sur l'admission des députés des planteurs de Saint-Domingue dans l'Assemblée Nationale. In: Oeuvres Complètes. Brunswick, Paris: Heinrichs, 1804. (*, VI: 8)

COURNAND, Antoine de. Réponse aux Observations d'un habitant des colonies, sur le Mémoire en faveur des gens de couleur, ou sang-mêlés, de Saint-Domingue, \& des autres Isles françaises de l'Amérique, par M. Grégoire, Curé d'Emberménil, Député de Lorraine. Paris: s.n., s.d. [1789]. (*, I: 7)

CREUZÉ PASCAL. Conspiration contre la République, prouvée par pièces officielles. S.l.: De l'Imprimerie de Becquart, s.d. (BN LK12-475)

De l'état des Nègres relativement à la prospérité des Colonies françaises et de leur Métropole; Discours aux représentans de la Nation. S.l.: s.n., 1789. Disponível em: http://gallica.bnf.fr/ark:/12148/bpt6k57904291.

De la nécessité d'adopter l'esclavage en France. Paris: chez Baillio, 1797. Disponível em: http://gallica.bnf.fr/ark:/12148/bpt6k44817p.

Découverte d'une conspiration contre les intérêts de la France. S.1.: s.n., [1789]. Disponível em: http://gallica.bnf.fr/ark:/12148/bpt6k57904528.

DESCRIPTION d'un navire négrier. S.1. [Paris]: s.n., s.d. [1789]. (*, VI: 5)

DESLOZIÈRES, Louis Narcisse Baudry. Les égaremens du nigrophilisme. Paris: Migneret, 1802. Disponível em: http://gallica.bnf.fr/ark:/12148/bpt6k5790469j.

DESMOULINS, Camille. Jean-Pierre Brissot démasqué. In: BUCHEZ, PhilippeJoseph-Benjamin, ROUX-LAVERGNE, Pierre-Célestin. Histoire parlementaire de la Révolution française, ou Journal des assemblées nationales depuis 1789 jusqu'en 1815 : contenant la narration des événements... précédée d'une introduction sur l'histoire de France jusqu'à la convocation des États-Généraux. Paris: Paulin, 1834-1838. v.13. Disponível em: http://gallica.bnf.fr/ark:/12148/bpt6k28879s.

Dictionnaire des jacobins vivans, dans lequel on verra les hauts faits de ces messieurs. Hamburgo: s.n., 1799. (BN LB42-752)

DUBOIS-CRANCÉ, Edmond-Louis-Alexis. Le véritable portrait de nos législateurs, ou Galerie de Tableaux exposés à la vue du public depuis le 5 mai 1789, jusqu'au premier octobre 1791. Paris: s.n., 1792. (BN Z CORRE-10(9,224))

DUFAY, Louis-Pierre. Un représentant du peuple calomnié, à un représentant $d u$ peuple calomniateur. S.l.: Imprimerie de Pain, s.d. Disponível em: http://gallica.bnf.fr/ark:/12148/bpt6k5803934r.

[DUFAY, Louis-Pierre]. Les aventures du petit Gouly, suivies de sa Promenade, de sa Confession et de sa mort arrivée le même jour. Paris: De l'Imprimerie des SansCulottes, s.d. [1795]. (BN 8-LN27-8973)

DUFAY, Louis-Pierre. Opinion sur le titre III de la résolution soumise au Conseil des Anciens, concernant l'organisation de la Constitution dans les Colonies. De l'état et des 
droits de citoyen pour les Noirs dans les Colonies. Paris: Baudouin, s.d. [1798]. (*, XI: 13)

DUVAL DE SANADON, David. Réclamations et observations des colons, sur l'idée de l'abolition de la traite et de l'affranchissement des nègres. S.1.: s.n., 1789. Disponível em: http://gallica.bnf.fr/ark:/12148/bpt6k48101b.

GOUGES, Olympe de. Réponse au champion américain, ou colon très-aisé à connoître. S.l. [Paris]: s.n., s.d. [1790]. (*, IV: 8)

GOUY D'ARCY, Louis-Marthe de. Précis sur la position actuelle de la députation de Saint-Domingue aux États Généraux, le 20 juin 1789. S.1: s.n., s.d. (microficha) (BN MFICHE LB39-1850)

GOULY, Benoît. Vues générales sur l'importance du commerce des Colonies, sur l'origine et le caractere du peuple qui les cultive, ainsi que sur les moyens de faire la constitution qui leur convient, avec quelques observations sur les sources des désatres de celles du Nouveau-Monde depuis la Révoltuion. Paris: Imprimerie de Rubat, s.d. (BN 4-LE38-1075)

GOULY, Benoît. Réponse au Libelle distribué par l'Africain Belley. In: Vues générales sur l'importance du commerce des Colonies. Paris: Imprimerie de Rubat, s.d. (BN 4LE38-1075)

GREGOIRE, Henri. Lettre aux citoyens de couleur, et nègres libres de Saint-Domingue, et des autres Isles Françoises de l'Amérique. S.l. [Paris]: Imprimerie du Patriote François, s.d. [1791]. (*, IV: 14)

GRÉGOIRE, Henri. Lettre aux philanthropes, sur les malheurs, les droits et les réclamations des gens de couleur de Saint-Domingue, et des autres îles françoises de l'Amérique. Paris: Belin... et au Bureau du Patriote François, outubro 1790. (*, IV: 9)

IL est encore des Aristocrates, ou Réponse à l'infâme auteur d'un écrit intitulé: Découverte d'une conspiration contre les intérêts de la France. S.1. [Paris]: s.n, s.d. [1789]. (*, IV: 5)

L'HOMME redevenu homme, ou les Africains à l'Assemblée Nationale. Par un ancien capitaine d'infanterie. S.1.: 1790. (*, IV: 4)

LAFOREST, Étienne Bussières. Laforest, citoyen de couleur, député de SaintDomingue, à son collègue Gouly, député de l'Isle de France. Paris: Imprimerie de l'Union, ano III [1795]. (BN 8-LN27-1105)

LANTHENAS, François-Xavier. M. Lamiral réfuté par lui-même, ou Réponse aux Opinions de cet auteur, sur l'abolition de la Traite des Noirs, suivie de quelques idées sur les établissemens libres que la France ne doit point différer de faire au Sénégal. Par un Ami des Blancs \& des Noirs. S.1. [Paris]: Imp. Potier de Lille, 1790. (*, VII: 4)

LEBLOIS, Léonard. Réflexions d'un observateur sur les malheurs que Saint-Domingue a éprouvés depuis la révolution, adressées aux Jacobins. S.1.: Iprimerie du citoyen Pain, [1794]. Disponível em: http://gallica.bnf.fr/ark:/12148/bpt6k54607802. 
LEBORGNE DE BOIGNE, Claude Pierre Joseph. Enfin la vérité sur les colonies, en réponse à Janvier Litté, homme de couluer, Député à la Convention. Paris: Imprimerie de Pain, an III [1794]. (BN 8-LK9-219)

LEQUINIO, Joseph. Les préjugés détruits. Paris: Imprimerie Nationale, 1792. (BN R25453)

LARCHEVESQUE-THIBAUD, Gabriel-Jean-Baptiste. Lettre d'un colon de SaintDomingue à un de ses amis. Paris: Imprimerie Ch. Desbrière, s.d. [ano IV]. Disponível em: http://gallica.bnf.fr/ark:/12148/bpt6k5805617t.

LETTRE à MM. les Députés des Trois Ordres, pour les engager à faire nommer par les Etats-Généraux, à l'exemple des Anglois, une Commission chargée d'examiner la cause des Noirs. S.1. [Paris]: s.n, s.d. [1789]. (*, VII: 1)

LETTRE de la Société des Amis des Noirs, aux Auteurs de la Décade Philosophique. S.1. [Paris]: s.n, s.d.. (*, VIII: 14)

LETTRE des Comissaires des Citoyens de couleur en France, à leurs frères et commettans dans les Isles Françoises. S.1. [Paris]: s.n., s.d. [1791]. (*, XI: 3)

LA SOCIÉTÉ des Amis des Noirs à Arthur Dillon, Député de la Martinique à l'Assemblée Nationale. S.1. [Paris]: Imprimerie du Patriote François, s.d. [1791]. (*, VIII: 7)

LISTE des députés qui ont voté pour l'Angleterre contre la France dans la question de savoir : Si l'Assemblée nationale sacrifierait ses colonies, oui ou non. Le 12 mai 1791. S.l: s.n., s.d. gallica (http://gallica.bnf.fr/ark:/12148/bpt6k133942n)

LISTE des ouvrages sur la traite et l'esclavage. Paris: Imprimerie du Patriote François, s.d. [1790]. (*, VIII: 2)

LOUVERTURE, Toussaint. Réfutation de quelques assertions d'un Discours prononcé au Corps législatif le 10 Prairial an cinq, par Viénot-Vaublanc. S.l. (Le Cap), s.d. [ano $\mathrm{VI}] .(*, \mathrm{XI}: 14)$

MALOUET, Pierre-Victor. Examen de cette question: quel sera pour les colonies de l'Amérique le résultat de la Révolution française, de la guerre qui en est la suite et de la paix qui doit la terminer ?... Paris: Pougin, 1796. Disponível em: http://gallica.bnf.fr/ark:/12148/bpt6k5772178j.

MANDAR, Théophile. Observations sur l'esclavage et le commerce des Nègres. Pour répondre aux questions insérées dans le Journal de Paris... S.l. [Paris]: Imp. Grand, s.d. [1790]. (*, IV: 7)

MILSCENT, Claude. Sur les troubles de Saint-Domingue. Paris: Imprimerie du Patriote François, 1791. Disponível em: http://gallica.bnf.fr/ark:/12148/bpt6k5462001n.

MOREAU DE SAINT-MÉRY, Médéric Louis Élie. Considérations présentées aux vrais amis du repos et du bonheur de la France, à l'occasion des nouveaux mouvemens de quelques soi-disant Amis des noirs. S.1: s.n, s.d. [1791]. (BN 8-LK9-82) 
OBSERVATIONS d'un habitant des colonies sur le "Mémoire en faveur des gens de couleur..." adressé à l'Assemblée nationale par M. Grégoire. S.1.: s.n., s.d. (BN 8-LK971)

PAGE, Pierre-François. Réflexions sur les colonies. Paris: Imprimerie Potier de Lille, s.d [1792]. (*, XI: 5)

PASTORET, Emmanuel. Discours en vers sur l'union qui doit régner entre la Magistratur, la Philosophie \& les Lettres. Paris: Chez Jombert jeune, 1783. Disponível em: ftp://ftp.bnf.fr/622/N6227276_PDF_1_-1DM.pdf

PRÉCIS des gémissemens des sang-mêlés dans les Colonies Françaises. Par J.M.C. Américain, Sang-mêlé. Paris: Baudouin, 1789.(*, XI: 1)

RAIMOND, Julien. Observations sur l'origine et les progrès du préjugé des colons blancs contre les hommes de couleur, sur les inconvéniens de le perpétuer, la nécessité, la facilité de le détruire, sur le projet de comité national, etc. Paris: chez Belin, 1791. Disponível em: http://gallica.bnf.fr/ark:/12148/bpt6k44844k.

RAIMOND, Julien. Réponse aux considérations de M. Moreau, dit de Saint-Méry, député à l'Assemblée nationale, sur les colonies. Paris: de l'imprim. du Patriote Français, 1791. Disponível em: http://gallica.bnf.fr/ark:/12148/bpt6k448468.

RAIMOND, Julien. Preuves complettes et matérielles du projet des colons pour mener les colonies à l'indépendance, tirées de leurs propres écrits : ouvrage présenté à la Commission des colonies par J. Raimond, et dans lequel on reconnoîtra la cause et l'origine des malheurs de Saint-Domingue. Paris: de l'imprim. de l'Union, 1794-1795. Disponível em: http://gallica.bnf.fr/ark:/12148/bpt6k448348.

RAIMOND, Julien. Réflexions sur les véritables causes des troubles et des désastres de nos colonies, notamment sur ceux de Saint-Domingue, avec les moyens à employer pour préserver cette colonie d'une ruine totale; adressées à la Convention Nationale... Paris: Imprimerie des Patriotes, $1793 . \quad$ Disponível em: http://gallica.bnf.fr/ark:/12148/bpt6k54615242.

RÉFLEXIONS sur l'abolition de la Traite \& la liberté des Noirs. Orléans: L.P. Couret, s.d. [1789]. (*, IV: 1)

REFLEXIONS sur le Code Noir, et Dénonciation d'un crime affreux, commis à SaintDomingue; adressés à l'Assemblée Nationale par la Société des Amis des Noirs. Paris: Imprimerie du Patriote Français, août 1790. (*, VIII: 4)

RÉPONSE à l'écrit de M. Malouet sur l'esclavage des nègres. Dans lequel est exprimé le voeu formé par les colons d'avoir des Représentans aux Etats-Généraux. Par un Membre de la Société des Amis des Noirs. S. 1. [Paris]: s.n., 1789. (*, VI: 6)

WADSTROM, Charles-Bernard. Note sur la réunion de la Société des Amis des Noirs du 7 floréal an VI. S.l. [Paris]: s.n., s.d. (*, VIII: 15)

\section{3) Memoriais e tratados científicos e filosóficos}


ARISTÓTELES. A Política. Tradução Roberto Leal Ferreira. $2^{\mathrm{a}}$ edição. São Paulo, Martins Fontes, 1998. (BFF 185.1 A717po 2.ed)

BARÈRE, Bertrand. Montesquieu peint d'après ses ouvrages. S.1.: s.n., 1796. Disponível em: http://gallica.bnf.fr/ark:/12148/bpt6k5625879p.

BARNAVE, Antoine. Introduction à la Révolution française. In: Oeuvres. Paris: J. Chapelle et Guiller, 1843. v.1. Disponível em: http://gallica.bnf.fr/ark:/12148/bpt6k61664b/

BARRÉ DE SAINT-VENANT, Jean. Des colonies modernes sous la zone torride, et particulièrement de celle de Saint-Domingue. Paris: chez Brochot père et compagnie, 1802. Disponível em: http://books.google.com/books?id=uhU5AQAAIAAJ.

BAUDEAU, Nicolas. Idées d'un citoyen sur la puissance du roi et le commerce de la Nation dans l'Orient. Amsterdam: s.n., 1763. (BN F-25509)

BELU, C.. Des colonies et de la traite des nègres. Paris: Debray, 1800. Disponível em: http://gallica.bnf.fr/ark:/12148/bpt6k84490g.

BERNARDIN DE SAINT-PIERRE, Jacques Henri. Voeux d'un solitaire. In: Oeuvres complètes. Paris: Méquignon-Marvis, 1818. v.11. Disponível em: http://gallica.bnf.fr/ark:/12148/bpt6k202517g.r=bernardin+saintpierre+voeux $+\mathrm{d} \% 27 \mathrm{un}+$ solitaire.langPT.

BERNARDIN DE SAINT-PIERRE, Jacques Henri. Suite des voeux d'un solitaire. In: Oeuvres complètes. Paris: Méquignon-Marvis, 1818. v.11. Disponível em: http://gallica.bnf.fr/ark:/12148/bpt6k202517g.r=bernardin+saint-

pierre+voeux $+\mathrm{d} \% 27 \mathrm{un}+$ solitaire.langPT.

BODIN, Jean. Les Six livres de la République. Paris: Librairie Générale Française, 1993. (BFF 321 B667s)

BONNEMAIN, Antoine-Jean-Thomas. Régénération des colonies, ou moyens de restituer graduellement aux hommes leur état politique, et d'assurer la prospérité des Nations; et moyens pour établir promptement l'ordre dans les colonies Françaises. Paris: Imprimerie du Cercle Social, $1^{\circ}$ mars 1792. (*, V: 1)

BRISSOT DE WARVILLE, Jacques-Pierre. Examen critique des voyages dans l'Amérique septentrionale, de M. le marquis de Chatellux, ou Lettre à M. le marquis de Chatellux, dans laquelle on réfute principalement ses opinions sur les Quakers, sur les nègres, sur le peuple, et sur l'homme. Londres : [s.n.], 1786. Disponível em: http://gallica.bnf.fr/ark:/12148/bpt6k41708q.

BRISSOT DE WARVILLE, Jacques-Pierre, CLAVIÈRE, Étienne. De la France et des États-Unis, ou de l'importance de la Révolution de l'Amérique pour le bonheur de la France. (reprodução da edição: Londres: s.n, 1787). Paris: Éditions du CTHS, 1996. (BN 16-Z-27754 (22)) 
BRISSOT DE WARVILLE, Jacques-Pierre. Mémoire sur les Noirs de l'Amérique Septentrionale, lu à l'Assemblée de la Société des Amis des Noirs, le 9 février 1789. Paris: au Bureau du Patriote François, 20 décembre 1789. (*, VII: 3)

CANTILLON, Richard. Essai sur la nature du commerce en général. Londres: Fletcher Gyles, 1755. Disponível em: http://books.google.com/books?id=6007AAAAcAAJ.

CARTEAU, J.-Félix. Soirées bermudiennes, ou Entretien sur les évènemens qui ont opéré la ruine de la partie française de l'isle de Saint-Domingue. Bordeaux: chez Pellier-Lawalle, 1802. Disponível em: http://gallica.bnf.fr/ark:/12148/bpt6k44880f.

CHARPENTIER-COSSIGNY, Joseph-François. Moyens d'amélioration et de restauration proposés au gouvernement et aux habitans des colonies; ou Mélanges politiques, économiques, agricoles et commerciaux, etc., relatifs aux colonies. Paris: Batilliot, 1803. (BN 8-LK9-242)

CLARKSON, Thomas. Essai sur les désavantages politiques de la traite des nègres. Paris: A. Égron, 1814. (BN 8-LK9-41(A))

CLARKSON, Thomas. Histoire du commerce homicide appelé traite des Noirs, ou Cri des Africains contre les Européens, leurs oppresseurs. Paris: Les marchands de nouveautés, 1822. Disponível em: http://gallica.bnf.fr/ark:/12148/bpt6k115719q.

CLARKSON, Thomas. History of the Rise, Progress and Accomplishment of the Abolition of the Slave Trade by the British Parliament. Londres: John W. Parker, 1839. Disponível em: http://gallica.bnf.fr/ark:/12148/bpt6k618804.

CONDORCET, Jean-Antoine-Nicolas de Caritat. Esquisse d'un tableau historique des progrès de l'esprit humain. Paris: Edition, 1966. (BFF 194.09 C277e)

CONDORCET, Jean-Antoine-Nicolas de Caritat. Réflexions sur l'esclavage des nègres. Par M. Schwartz, Pasteur du Saint Evangile à Bienne, Membre de la Société économique de B.***. Nouvelle édition revue \& corrigée. Neufchâtel et Paris: Froullé, 1788. (*, VI: 2)

CRÈVECOEUR, Michel-Guillaume Jean. Lettres d'un cultivateur américain, écrites à W.S., écuyer, depuis l'année 1770 jusqu'à 1781. Paris: chez Cuchet, 1784. Disponível em: http://gallica.bnf.fr/ark:/12148/bpt6k73714r.

CUGOANO, Ottobah. Réflexions sur la traite et l'esclavage des nègres, traduites de l'Anglais d'Ottobah Cugoano, afriquain, esclave à la Grenade et libre en Anglaterre [par Antoine Diannyère]. Londres, Paris: Royer, 1788. (*, X: peça única)

DAZILLE, Jean-Barthélémy. Observations sur les maladies des nègres, leurs causes, leurs traitements et les moyens de les prévenir. Paris: Didot le jeune, 1776. Disponível em: http://gallica.bnf.fr/ark:/12148/bpt6k823169.

DESCROIZILLES, Frédéric. Essai sur l'agriculture et le commerce des îles de France et de la Réunion, suivi d'un Notice historique sur l'île de France pendant la Réunion. Rouen: Imprimerie des Arts, $1803 . \quad$ Disponível em: http://gallica.bnf.fr/ark:/12148/bpt6k44859m. 
DU commerce des Colonies, ses principes et ses lois. La Paix est de temps de régler \& d'agrandir le commerce. S.1.: 1785. (*, I: 3)

DUVAL DE SANADON, David. Discours sur l'esclavage des nègres et sur l'idée de leur affranchissement dans les colonies. Amsterdam: Hardouin et Gattey, 1786. (BN RES 8-LK9-32)

Encyclopédie ou Dictionnaire raisonné des sciences, des arts et des métiers, par une société de gens de lettres. Paris: Briasson, David, Le Breton, Durand, 1751-1765. v.5 e 16. Disponível em: http://gallica.bnf.fr/ark:/12148/bpt6k50537q; http://gallica.bnf.fr/ark:/12148/bpt6k50548c.

FORBONNAIS, François Véron Duverger de. Éléments du commerce. Leyde: Briasson, 1754. v.2. Disponível em: http://gallica.bnf.fr/ark:/12148/bpt6k110381g.

FROSSARD, Benjamin Sigismond. La cause des esclaves nègres et des habitans de la Guinée, portée au tribunal de la justice, de la religion, de la politique. Genebra: Slatkine Reprints, 1978. (BFF 326 F938c v.1-2)

GEOFFROY DE VILLENEUVE, René Claude. L'Afrique, ou histoire, moeurs, usages et coutumes des Africains. Le Sénégal. Paris: Neupveu, 1814. v.1. Disponível em: http://books.google.com/books?id=18ENAAAAQAAJ.

GRÉGOIRE, Henri. Mémoire en faveur des gens de couleur ou sang-mêlés de St.Domingue, \& des autres Isles françaises de l'Amérique, adressé à l'Assemblée Nationale. Paris: Belin, 1789. (*, I: 6)

GRÉGOIRE, Henri. De la littérature des nègres, ou Recherches sur leurs facultés intellectuelles, sur leurs qualités morales et leur littérature. Paris: chez Maradan, libraire, 1808. Disponível em: http://gallica.bnf.fr/ark:/12148/bpt6k844925.

HENRION DE PANSEY, Pierre-Paul-Nicolas, baron de. Mémoire pour un nègre qui réclame sa liberté. Paris: Hérissant, 1770 (*, I: 1)

HILLIARD D'AUBERTEUIL, Michel René. Considérations sur l'état présent de la colonie française de Saint-Domingue. Paris: Chez Grangé, 1776-77. 2 v. (BN 8- LK12$217(1)-(2))$

KEITH, George. An Exhortation \& Cation to Friends Concerning Buying or Keeping of Negroes. Disponível em: http://www.qhpress.org/quakerpages/qwhp/gk-as1693.htm. Acesso em: 17 de jan de 2011.

L'ESCLAVAGE des Nègres aboli, ou Moyens d'améliorer leur sort. Paris: Froullé, 1789. $(*, \mathrm{I}: 4)$

Le Commerce de l'Amérique par Marseille, ou explication des Lettres-Patentes du Roi, portant Règlement sur le commerce qui se fait de Marseille aux Iles Françaises de l'Amérique, données au mois de février 1719. Avignon: s.n., 1764. 2 v. (BN F12275F12276)

LABAT, Jean-Baptiste. Nouveau voyage aux Iles d'Amérique. Paris: G. Cavelier (et P.F. Giffard), 1722. v.3. Disponível em: http://gallica.bnf.fr/ark:/12148/bpt6k74103p. 
LECOINTE-MARSILLAC. Le More-Lack, ou Essai sur les moyens les plus doux \& les plus équitables d'abolir la traite \& l'esclavage des Nègres d'Afrique, en conservant aux Colonies tous les avantages d'une population agricole. Londres et Paris: Prault, 1789. (*, III: 1$)$

LEMERCIER DE LA RIVIÈRE, Pierre Paul. L'ordre naturel et essentiel des sociétés politiques. Paris: Fayard, 2001. (BN 194.33 LEME o)

LESCALLIER, Daniel. Réflexions sur le sort des Noirs dans nos colonies. Paris: s.n., 1789. (*, I: 5)

LESCALLIER, Daniel. Notions sur la culture des Terres basses dans la Guiane, Et sur la cessation de l'Esclavage dans ces Contrées. Paris: de l'Imprimerie de F. Buisson, ano VII (1798). Disponível em: http://gallica.bnf.fr/ark:/12148/bpt6k5785787s.

LOCKE, John. Dois tratados sobre o Governo. 2a edição. São Paulo: Martins Fontes, 2005. (BFF 192.2 L814tP 2.ed)

MALOUET, Pierre-Victor. Mémoire sur l'esclavage des nègres. Neufchâtel: 1788. (BN 8-LK9-34)

MELON, Jean-François. Essai politique sur le commerce. S.d.: s.n., 1761. Disponível em: http://books.google.com/books?id=QL4QyIvKKtYC.

MILSCENT, Claude-Louis-Michel. Du régime colonial. Paris: Imprimerie du Cercle Social, 1792. Disponível em: http://gallica.bnf.fr/ark:/12148/bpt6k57904276.

MIRABEAU, Victor Riqueti de. L'Ami des Hommes, ou Traité de la population. Troisième partie. Avignon: s.n., 1758. Disponível em: http://books.google.com/books?id=ZHAGAAAAQAAJ.

MOREAU DE SAINT-MÉRY, Médéric Louis Élie. Description topographique, physique, civile, politique et historique de la partie française de l'isle Saint-Domingue. $2^{\mathrm{a}}$ edição: Paris: L.Guérin; T.Morgan, 1797-1798. v.1. Disponível em: http://gallica.bnf.fr/ark:/12148/bpt6k5784239p.

MONTESQUIEU, Charles de Secondat. De l'esprit des lois. Paris: Éditions Garnier Frères, 1956. 2 v. (BFF 840 M789d v.1 1956/840 M789d v.2 1956)

NECKER, Jacques. De l'administration des finances de la France. In: Oeuvres Complètes. Paris: s.n., 1820-1821. v.4. Disponível em: http://gallica.bnf.fr/ark:/12148/bpt6k5750509h.

PAGE, Pierre-François. Traité d'économie politique et de commerce des colonies. Paris: Brochot, an IX. 2 v. (BN 8-LK9-239(1)-(2))

PELLETAN, Jean-Gabriel. Mémoire sur la colonie française du Sénégal. Paris: Ve Panckoucke, 1801. Disponível em: http://gallica.bnf.fr/ark:/12148/bpt6k84491t.

PETIT, Émilien. Traité sur le gouvernement des esclaves. Paris: Knapen, 1777. Disponível em: http://gallica.bnf.fr/ark:/12148/bpt6k84481h. 
PRADT, Dominique Georges Frédéric de. Les trois âges des colonies: ou de leur étát passé, présent et à venir. Paris: Giguet et Cie., 1801-02. (BN 8-LK9-240(1)-(2))

RAYNAL, Guillaume-Thomas. Histoire philosophique et politique des établissements et du commerce européen dans les deux Indes. Amsterdam : [s.n.], 1770. v.4. Disponível em: http://gallica.bnf.fr/ark:/12148/bpt6k109690m.

RAYNAL, Guillaume-Thomas. Histoire philosophique et politique des établissements et du commerce européen dans les deux Indes. Haia: Gosse fils, 1774. v.4. Disponível em: http://gallica.bnf.fr/ark:/12148/bpt6k61170976.

RAYNAL, Guillaume-Thomas. Histoire philosophique et politique des établissements et du commerce européen dans les deux Indes. Genebra: J.-L. Pellet, 1780. v.3. Disponível em: http://gallica.bnf.fr/ark:/12148/bpt6k106608q.

RAYNAL, Guillaume-Thomas. Essai sur l'administration de Saint-Domingue. S.1: s.n., 1785. Disponível em: http://gallica.bnf.fr/ark:/12148/bpt6k55512544.

ROUSSEAU, Jean-Jacques. Discours sur l'origine et les fondements de l'inégalité. Paris: Bookking International, 1996.

ROUSSEAU, Jean-Jacques. Du contrat social. Paris: Bookking International, 1996.

SACY, Claude-Louis-Michel de. L'Esclavage des Américains et des Nègres. Paris: Demonville, 1775. (*, I: 2)

SAINT-JUST, Antoine-Louis de. Institutions républicaines. In: Oeuvres complètes. Paris: Gallimard, 2004. (BN 944.040 2 SAIN o)

SAVARY DES BRÛLONS, Jacques. Un Négoce où des hommes sont les marchands d'autres hommes. In: L'abolition de l'esclavage. Un combat pour les droits de l'homme. GEORGEL, Chantal (org.). Paris: Éditions Complexe, 1998. (BFF 326 A154)

SAY, Jean-Baptiste. Traité d'économie politique, ou simple exposition de la manière dont se forment, se distribuent, et se consomment les richesses. Paris: Deterville, 1803. v.1. Disponível em: http://books.google.com/books?id=Y8LB9O042PkC.

SMITH, Adam. A Riqueza das Nações. São Paulo: Martins Fontes, 2003. 2 v. (BFEA 330 S642r v.1-v.2)

TALLEYRAND, Charles Maurice. Essai sur les avantages à retirer de colonies nouvelles dans les circonstances présentes. S.l.: Baudouin, s.d. Disponível em: http://gallica.bnf.fr/ark:/12148/bpt6k62587z.

TURGOT, Anne-Robert-Jacques. Réflexions sur la formation et la distribution des richesses. In: Oeuvres. Osnabrük: O. Zeller, 1966 (reimpressão da edição: Paris: Guillaumin, 1844). v.1. Disponível em: http://visualiseur.bnf.fr/ark:/12148/bpt6k5728q.

VIREY, Julien-Joseph. Histoire naturelle du genre humain. Paris: Crochard, 1824. 3 v. Disponível

em:

http://www2.biusante.parisdescartes.fr/livanc/?cote $=34003 \times 01 \&$ do=chapitre. 
VOLTAIRE. Essai sur les moeurs e l'esprit des nations. Paris: chez Treuttel et Würtz, 1835. v.3. (BN G-30089)

WADSTRÖM, Carl Bernhard. Précis sur l'établissement des colonies de Sierra Léona et de Boulama. Paris: Pougens, 1798. Disponível em: http://gallica.bnf.fr/ark:/12148/bpt6k104400h.

WADSTRÖM, Carl Bernhard. Voyage au pays de Dahomé, état situé à l'intérieur de la Guinée, avec l'histoire de ce royaume, suivie d'Observations sur la traite des nègres. Paris: Gay et Gide, Ano III (1794-1795). Disponível em: http://gallica.bnf.fr/ark:/12148/bpt6k737916.

YOUNG, Arthur. Travels, during the years 1787, 1788, and 1789. Undertaken more particularly with a view of ascertaining the cultivation, wealth, resources, and national prosperity of the Kingdom of France. London: J. Rackham for W. Richardson, 1792. Disponível em: http://books.google.com/books?id=110JAAAAQAAJ.

\section{4) Leis, atas, regulamentos, cadernos de queixas}

Arrêt du Conseil d'état du Roi, qui, à compter du 10 Novembre prochain, convertit en Gratifications \& Primes l'exemption du demi-droit accordée aux Denrées coloniales provenant de la Traite des Noirs. Paris: De l'Imprimerie royale, 1784. Disponível em: http://gallica.bnf.fr/ark:/12148/btv1b8620150b

Arrêt du Conseil d'état du Roi, qui permet aux Bâtimens étrangers arrivans directement des côtes d'Afrique, aux cargaisons de cent quatre-vingts Noirs, au moins, d'aborder dans le port principal de chacune des îles de la Martinique, la Guadeloupe, SainteLucie \& Tabago, jusqu'au Ier Août 1786... Paris: De l'Imprimerie royale, 1783. Disponível em: http://gallica.bnf.fr/ark:/12148/btv1b86198419

Cahier, contenant les Plaintes, Doléances et Réclamations des Citoyens-libres et Propriétaires de Couleur, des Isles et Colonies Françoises S.1.: s.n., s.d [1789]. Disponível em: http://archive.org/details/cahiercontenantl00joly.

Cahiers de doléances de la colonie de Saint-Domingue pour les états généraux de 1789. Paris: Ernest Leroux, 1933. (BFF 848 C134)

Code Noir, ou recueil d'édits, déclarations et arrêts concernant les esclaves nègres de l'Amérique (1685). Disponível em: http://www.axl.cefan.ulaval.ca/amsudant/guyanefr1685.htm

CONCORDAT, ou Traité de paix entre les Citoyens Blancs et les Citoyens de Couleur des quatorze paroisses de la Province de l'Ouest de la partie française de SaintDomingue. Paris: Imprimerie du Patriote François, s.d. [1791]. (*, XI: 4)

CONSTITUTION de la Colonie Française de Saint-Domingue. Du 17 août 1801 (29 thermidor an 9). Paris: Imprimerie du Dépôt des Lois, s.d. [1801]. (*, XI: 18) 
Constitution $d u \quad 5$ fructidor an III. Disponível em: http://www.conseilconstitutionnel.fr/conseil-constitutionnel/francais/la-constitution/les-constitutions-de-lafrance/constitution-du-5-fructidor-an-iii.5086.html. Acesso em: 10 de jan de 2012

Constitution Française, décrétée par l'Assemblée Nationale Constituante, aux années 1789, 1790 et 1791; Acceptée par le Roi le 14 septembre 1791. Paris: de 1'Imprimerie de Didot Jeune, 1791. Disponível em: http://books.google.com/books?id=tPdBAAAAcAAJ\&pg=PA3.

Constitution $d u 22$ frimaire an VIII. Disponível em: http://www.conseilconstitutionnel.fr/conseil-constitutionnel/francais/la-constitution/les-constitutions-de-lafrance/constitution-du-22-frimaire-an-viii.5087.html. Acesso em: 12 de jun de 2012.

Déclaration des Droits de l'Homme (24 juin 1793). Bordeaux: Publications de la Tribune de la Gironde, 1870 . Disponível em: http://gallica.bnf.fr/ark:/12148/bpt6k54391109.

Loi relative à la traite des Noirs et au régime des Colonies. Du 30 floréal, l'an X de la République une et indivisible. Paris: De l'Imprimerie de la République, ano X. Disponível em: http://commons.wikimedia.org/wiki/File:Loi_sur_la_traite_des_noirs_et_le_r\%C3\%A9 gime_des_colonies, 30_flor\%C3\%A9al_an_X_1802.jpg?uselang=fr. Acesso em: 19 de jun de 2012.

Notes des séances de la Société des Amis des Noirs et des Colonies. In: DORIGNY, Marcel, GAINOT, Bernard. La Société des Amis de Noirs 1788-1799: Contribution à l'histoire de l'abolition de l'esclavage. Paris: UNESCO, 1988. (BFF 326.0944 D697s)

REGISTRE de la Société des Amis des Noirs. In: DORIGNY, Marcel, GAINOT, Bernard. La Société des Amis de Noirs 1788-1799: Contribution à l'histoire de l'abolition de l'esclavage. Paris: UNESCO, 1988. (BFF 326.0944 D697s)

RÈGLEMENS de la Société des Amis de Noirs. S.1. [Paris]: s.n, s.d. [1789]. (*, VI: 3)

SIEYÈS. Préliminaire de la Constitution Française. Reconnaissance et exposition raisonnée des Droits de l'Homme et du Citoyen. S.l.: s.n., 1789. Disponível em: http://gallica.bnf.fr/ark:/12148/bpt6k41690g.

SOCIÉTÉ des Amis des Noirs et des Colonies. Décret de la Convention Nationale, du 16-ème jour de Pluviôse, an second de la République Française Une et Indivisible, qui abolit l'esclavage des Nègres dans les Colonies. S.1. [Paris]: s.n., s.d. [ano VII-1799]. (*, VIII: 16)

SONTHONAX, Léger-Félicité. Au nom de la République, Proclamation [de] LégerFélicité Sonthonax, commissaire civil de la République, délégué aux îles française de l'Amérique. Le Cap: s.n., $1794 . \quad$ Disponível em: http://gallica.bnf.fr/ark:/12148/bpt6k448092.

TABLEAU des Membres de la Société des Amis des Noirs. Année 1789. S.1. [Paris]: s.n., s.d. [1789]. (*, VI: 4) 
WADSTRÖM, Carl Bernhard. Additions aux règlemens de la Société des Amis des Noirs et des Colonies. S.l. [Paris]: s.n., s.d. [ano II]. (*, VIII: 12)

WADSTRÖM, Carl Bernhard. [Circulaire datée du 7 floréal an 6, 38 rue des FossésGermain-des-Prés, invitant à une réunion de la Société des amis des noirs, le 10 floréal. S.l.: s.n., 1798 Disponível em: http://gallica.bnf.fr/ark:/12148/bpt6k57903859.

\section{5) Memórias, obras literárias, peças, poemas, canções}

BRISSOT DE WARVILLE, Jacques-Pierre. Mémoires. Paris: Picard et fils, s.d. 2 v. Disponível em: http://gallica.bnf.fr/ark:/12148/bpt6k467423; http://gallica.bnf.fr/ark:/12148/bpt6k563368.

CAMBACÉRÈS, Jean-Jacques Régis de. Mémoires inédits. S.l.: Librairie Académique Perrin, 1999. 2 v. (BN 944.050 92 CAMB m1-m2)

CORBIN, Lucidor F. Hymne des citoyens de couleurs, par la citoyenne Corbin, créole et républicaine. Paris: chez Colubrier, graveur, s.d. [1794]. (*, XI: 9)

COUSIN D'AVALLON. Histoire de Toussaint-Louverture, chef des noirs insurgés de Saint-Domingue. Paris: chez Pillot, 1802. Disponível em: http://archive.org/details/histoiredetoussa00cous.

DELILlE, Jacques. La Pitié. Paris: Giguet et Michaud, 1803. Disponível em: http://gallica.bnf.fr/ark:/12148/bpt6k54456740.

DUBOIS. L'Union Américaine produit par la liberté française. Par la C-ne Dubois. S.1. [Paris]: s.n., s.d. [1794]. (*, XI: 8)

DUBROCA. La vie de Toussaint Louverture, chef des noirs insurgés de SaintDomingue. Paris: Dubroca/Bonneville, 1802. Disponível em: http://gallica.bnf.fr/ark:/12148/bpt6k5788090s.

FRANKLIN, Benjamin. Observations concerning the increase of Mankind, Peopling of Countries, etc. Boston: S. Kneeland, 1755. Disponível em: http://archive.org/details/increasemankind00franrich.

GOUGES, Olympe de. L'esclavage des Noirs, ou l'heureux naufrage. Paris: Côtéfemmes éditions, 1989. (BFF 844 G691e)

LARIVALLIERE. Les Africains, ou le Triomphe de l'humanité, comédie en un acte et en prose, représentée sur les principaux théâtres de la République. Paris: Meurant, l'an III. $(*, V: 6)$

LAS CASES, Emmanuel de. Mémorial de Sainte-Hélène. Paris: Éditions du Seuil, 1968. $2 \mathrm{v}$. 
LOUVERTURE, Toussaint. Mémoires du Général Toussaint Louverture, écrits par luimême. Paris: $\quad 1853 . \quad$ Pagnerre, Disponível em: http://gallica.bnf.fr/ark:/12148/bpt6k5470300x.

MALOUET, Pierre-Victor. Mémoires. Paris: E. Plon, 1874. 2 v. (BFF 944 M222m 2.ed. v.1-v.2)

MERCIER, Louis-Sébastien. L'an deux mille quatre cent-quarante: rève s'il n'en fut jamais. Paris: 1786. v.1. Disponivel em: http://gallica.bnf.fr/ark:/12148/bpt6k844569.

PALAISEAU, Mlle de. Histoire des Mesdemoiselles de Saint-Janvier, les deux seules blanches sauvées du massacre de Saint-Domingue. $3^{\mathrm{a}}$ edição. Paris: J.-J. Blaise, 1812. Disponível em: http://gallica.bnf.fr/ark:/12148/bpt6k5852078w.

ROUSSEAU, Jean-Jacques. Julie, ou la Nouvelle Héloïse: Lettres de deux amants habitants d'une petite ville au pied des Alpes recueillies et publiées par J.-J. Rousseau. Paris: Librairie Générale Française, 2002. (BFF 194.4 R864j 2002)

SAINT-LAMBERT, Jean-François de. Ziméo. In: Contes. Paris: Librairie des Bibliophiles, 1883. Disponível em: http://gallica.bnf.fr/ark:/12148/bpt6k108843c.

STAËL, Mme de. Dix années d'exil. Paris: La Renaissance du livre, 1909. Disponível em: http://gallica.bnf.fr/ark:/12148/bpt6k5787795z.

THIBAUDEAU, Antoine Clair. Mémoires sur le Consulat. 1799 à 1804. Par un ancien conseiller d'état. Paris: Ponthieu et Cie, 1827. Disponível em: http://gallica.bnf.fr/ark:/12148/bpt6k1154896.

VOLTAIRE. Candide ou l'optimisme. Paris: Larousse, 2004.

\section{BIBLIOGRAFIA}

ABÉRON, Lucien René. Port-la-Liberté, An III. Approche démographique des nouveaux citoyens. In: M. DORIGNY (org.). Les abolitions de l'esclavage, de L.F. Sonthonax à V. Schoelcher 1793-1794-1848. Paris: Presses Universitaires de Vincennes / Éditions UNESCO, 1995, pp.241-252.

AMIN, Samir. Autour de l'abolilition de l'esclavage par la Première République. In: M. DORIGNY (org.). Les abolitions de l'esclavage, de L.F. Sonthonax à V. Schoelcher 1793-1794-1848. Paris: Presses Universitaires de Vincennes / Éditions UNESCO, 1995, pp.387-402.

ANCEAU, Éric. La France de 1848 à 1870. Entre ordre et mouvement. Paris: Librairie Générale Française, 2002.

ARZALIER, Francis. Les mutations de l'idéologie coloniale en France avant 1848: de l'esclavagisme à l'abolitionnisme. In: M. DORIGNY (org.). Les abolitions de 
l'esclavage, de L.F. Sonthonax à V. Schoelcher 1793-1794-1848. Paris: Presses Universitaires de Vincennes / Éditions UNESCO, 1995, pp.299-308.

Atlas de la Révolution française. E. Ducoudray, R. Monnier, D. Roche (orgs). Pairs: Éditions de l'École des Hautes Études, 2000. v.11.

AZIMI, Vida. Un modele administratif de l'Ancien Régime: les commis de la Ferme générale et de la Régie générale des aides. Paris: Éditions du Centre National de la Recherche Scientifique, 1987.

BANGOU, Henri. La Guadeloupe, 1492-1848, ou l'histoire de la colonisation de l'île liée à l'esclavage noir, de ses débuts à sa disparition. Paris: L'Harmattan, 1987.

BARDIN, Pierre. Lucidor, ancien esclave, et sa fille Marie-Thérèse, à Paris. Disponível em: http://www.ghcaraibe.org/bul/ghc227/p5982.rtf. Acesso em: 17 de maio de 2012.

BARLIER, Jean-Pierre. La Société des Amis des Noirs, 1788-1791: Aux origines de la première abolition de l'esclavage (4 février 1794). Paris: Éditions de l'Amandier, 2010.

BART, Jean. Esclavage et servage tardif. In: M. DORIGNY (org.). Les abolitions de l'esclavage, de L.F. Sonthonax à V. Schoelcher 1793-1794-1848. Paris: Presses Universitaires de Vincennes / Éditions UNESCO, 1995, pp.27-29.

BARTHÉLEMY, Gérard. Le rôle des bossales dans l'émergence d'une culture de marronnage en Haïti. Cahiers d'études africaines, v.37, n.148, 1997, pp.839-862. Disponível em: http://www.persee.fr/web/revues/home/prescript/article/cea_00080055_1997_num_37_148_1835. Acesso em: 14 de out de 2013.

BÉNOT, Yves. Comment la Convention a-t-elle voté l'abolition de l'esclavage? Annales Historiques de la Révolution Française, Paris, n. 293-294, pp.349-361, 1993.

BÉNOT, Yves. La Révolution française et la fin des colonies. Paris: La Découverte, 1987.

BÉNOT, Yves. Le procès de Sonthonax ou les débats entre les accusateurs et les accusés dans l'affaire des colonies (an III). In: M. DORIGNY (org). Léger Félicité Sonthonax. La première abolition de l'esclavage. La Révolution française et la Révolution de Saint-Domingue. Paris: Société des études robespierristes, 2006, p.95110.

BÉNOT, Yves. Diderot, de l'athéisme à l'anticolonialisme. Paris: Maspero, 1970 (ou Paris: La Découverte, 1981).

BÉNOT, Yves. La Guyane sous la Révolution française, ou l'impasse de la Révolution pacifique. Kourou (Guiana francesa): Ibis Rouge éditions, 1997.

BÉNOT, Yves. Diderot, Pechmeja, Raynal et l'anticolonialisme. In: __. Les Lumières, l'esclavage, la colonisation. Paris: La Découverte, 2005, pp.107-123.

BÉNOT, Yves. Diderot-Raynal: l'impossible divorce. In: Les Lumières, l'esclavage, la colonisation. Paris: La Découverte, 2005, pp.138-153. 
BÉNOT, Yves. La question coloniale en 1789 ou l'année des déceptions et des contradictions. In: Découverte, 2005, pp.199-209.

BÉNOT, Yves. La démence coloniale sous Napoléon. Paris: La Découverte, 2006.

BÉNOT, Yves. La chaîne des insurrections d'esclaves dans les Caraïbes, de 1789 à 1791. In: M. DORIGNY (org.). Les abolitions de l'esclavage, de L.F. Sonthonax à V. Schoelcher 1793-1794-1848. Paris: Presses Universitaires de Vincennes / Éditions UNESCO, 1995, pp.179-186.

BERBEL, Márcia, MARQUESE, Rafael, PARRON, Tâmis. Escravidão e Política: Brasil e Cuba, 1790-1850. São Paulo: Hucitec, Fapesp, 2010.

BERNET, Jacques. Provins et Montereau fêtent l'abolition de l'esclavage. Annales historiques de la Révolution française, Paris, n. 293-294, pp.511-513, 1993. Disponível em: $\quad$ http://www.persee.fr/web/revues/home/prescript/article/ahrf_00034436_1993 num_293 1 1589. Acesso em: 15 de abr. de 2013.

Biographie universelle (Michaud) ancienne et moderne. Paris: Madame C. Desplaces; Michaud, 1855.

BIONDI, Jean-Pierre, ZUCARELLI, François. 16 pluviôse an II - Les colonies de la Révolution. Paris: Editions Denoel, 1988.

BLACKBURN, Robin. A Queda do Escravismo Colonial. 1776-1848. Rio de Janeiro: Record, 2002.

BLANNING, T.C.W. Aristocratas versus Burgueses? A Revolução Francesa. (trad: Cid Knipell Moreira). São Paulo: Editora Ática, 1991.

BLONDET, Claire. Quand les "terroristes" font le procès du colonialisme esclavagiste les thermidoriens organisent son oubli. In: F. GAUTHIER (org.). Périssent les colonies plutôt qu'un principe! Contribution à l'histoire de l'abolition de l'esclavage. Paris: Société des études robespierristes, 2002, pp.43-65.

BOISSONNADE, Pierre. Saint-Domingue à la veille de la Révolution française et la question de la représentation coloniale aux États Généraux (janvier 1788 - 7 juillet 1789). Paris: Paul Geuthner, 1906.

BOSI, Alfredo. A Escravidão entre dois Liberalismos. Estudos Avançados, São Paulo, v.2, n.3, pp.4-39, set/dez de 1988.

BOTTIN, Michel. "Les services centraux des Finances en 1788", Communication au Colloque organisé par l'Université de Rouen et le Ministère du Budget, des Comptes publics et de la Fonction publique, La Direction générale des Finances publiques. Vers une administration nouvelle?, 2008. Disponível em: www.michel-bottin.com. Acesso em 16 de jan de 2012.

BOULLE, Pierre H.. Les déclarations parisiennes de non-blancs entre 1738 et 1790: permanence des catégories et interchangeabilité des statuts. Nuevo Mundo Mundos 
Nuevos, colocado em linha em 19 de dezembro de 2009. Disponível em: http://nuevomundo.revues.org/58021. Consultado em: $1^{\circ}$ de abr. de 2013.

BRANDA, Pierre, LENTZ, Thierry. Napoléon, l'esclavage et les colonies. Paris: Fayard, 2006.

BROWN, Christopher Leslie. Moral Capital: Foundations of British abolitionism. Chape Hill: The University of North Carolina Press, 2006.

CAHEN, Léon. Condorcet et la Société des amis des Noirs. La Révolution Française, Paris, v.50, pp.481-511, 1906.

CARDOSO, Ciro Flamarion Santana. Agricultura, escravidão e capitalismo. $2^{\mathrm{a}}$ edição. Petropolis: Vozes, 1982.

CARDOSO, Ciro Flamarion Santana. Sobre los modos de producción coloniales de América. In: C.S. ASSADOURIAN et alii (orgs). Modos de producción en América Latina. $2^{a}$ edição. Córdoba: Ediciones Pasado y Presente, 1974, pp.135-159.

CARDOSO, Ciro Flamarion Santana. El modo de producción esclavista colonial en América. In: C.S. ASSADOURIAN et alii (orgs). Modos de producción en América Latina. 2a edição. Córdoba: Ediciones Pasado y Presente, 1974, pp.193-230.

CÉSAIRE, Aimé. Toussaint Louverture: la Révolution française et le problème colonial. Paris: Présence Africaine, 1981.

CHAMPION, Jean Marcel. 30 Floréal an X: le rétablissement de l'esclavage par Bonaparte. In: M. DORIGNY (org.). Les abolitions de l'esclavage, de L.F. Sonthonax à V. Schoelcher 1793-1794-1848. Paris: Presses Universitaires de Vincennes / Éditions UNESCO, 1995, pp.265-271.

CLAEYS, Thierry. Un agent de Calonne, Gabriel Palteau de Veymérange. In: Y. DURAND, J.P. BARDET (orgs). État et société en France aux XVIIe et XVIIIe siècles. Paris: Presses Universitaires de Paris-Sorbonne, 2000, pp.135 e ss.

CLARKE, Simon. Capital, Fractions of Capital and the State: 'Neo-Marxist' Analysis of the South-African State, pp.63-64. Disponível em: https://files.warwick.ac.uk/simonclarke/files/pubs/Fractions.pdf Acesso em: 8 de maio de 2012.

CLOUGH, Shepard B., MOODIE, Carol Gayle. Historia Económica de Europa. Tradução de Eduardo Goligorsky. Buenos Aires: Editorial Paidos, 1968.

COHEN, William. Thomas Jefferson e o problema da escravidão. Estudos Avançados. São Paulo, v.1, n.1, pp.151-180, 1987.

COLL, Elisa Badosa. Hacienda real y sociedad en la Francia del siglo XVII. Pedralbes: revista d'història moderna, Barcelona, n.14, pp.107-159, 1994. Disponível em: http://www.raco.cat/index.php/Pedralbes/article/view/101379. Acesso em: 7 de mar de 2013. 
COMNINEL, George C.. Rethinking the French Revolution: Marxism and the Revisionist Challenge. Londres, New York: Verso, 1987 (2a impressão, 1990).

COSTA, Emília Viotti da. História, Metáfora e Memória: a Revolta de Escravos de 1823 em Demerara. Arquivo: Boletim Histórico e Informativo, São Paulo, v.9, n.1, pp.720, jan./jun. 1988 .

COSTA, Emília Viotti da. Coroas de glória, lágrimas de sangue: a rebelião dos escravos de Demerara em 1823. São Paulo: Companhia das Letras, 1998.

CROUZET, François. La guerre économique franco-anglaise au XVIIIe siècle. Paris: Fayard, 2008.

DAGET, Serge. A Model of the French Abolitionist Movement. In: BOLT, DRESCHER (orgs). Antislavery, Religion and Reforms. Folkestone: Dawson; Hamden: Archon, 1980, pp.64-79.

DAGET, Serge. L'abolition de la traite des Noirs en France de 1814 à 1831. Cahiers d'études africaines, v.11, n.41, pp.14-58, 1971. Disponível em: http://www.persee.fr/web/revues/home/prescript/article/cea_00080055_1971_num_11_41_2811. Acesso em: 25 de jun de 2012.

DAGET, Serge. Les mots esclave, nègre, Noir, et les jugements de valeur sur la traite négrière dans la littérature abolitionniste française de 1770 à 1845. Nuevo Mundo Mundos Nuevos, colocado em linha em 19 de dezembro de 2009. Disponível em: http://nuevomundo.revues.org/58128. Acesso em: 31 de março de 2013.

DAHOMAY, Jacky. L'esclavage et le droit: les légitimations d'une insurrection. In: M. DORIGNY (org.). Les abolitions de l'esclavage, de L.F. Sonthonax à V. Schoelcher 1793-1794-1848. Paris: Presses Universitaires de Vincennes / Éditions UNESCO, 1995, pp.33-47.

DALMAS, Antoine. Histoire de la révolution de Saint-Domingue. Paris: Mame Freres, 1814.

DARNTON, Robert. The Brissot dossier. French Historical Studies, v. 17, n. 1, pp.191205, 1991. Disponível em: http://dash.harvard.edu/handle/1/3403050. Acesso em: 7 de fev. de 2013.

DAUDIN, Guillaume. Commerce et prospérité. La France au XVIIIe siècle. Paris: Presses de l'Université Paris-Sorbonne, 2005.

DAVID, Thomas. L'internationale abolitionniste: les Suisses et l'abolitionisme français, 1760-1840. In: O. PÉTRÉ-GRENOUILLEAU (org.). Abolir l'esclavage: un réformisme à l'épreuve (France, Portugal, Suisse, XVIII-XIXe siècles). Rennes: Presses Universitaires de Rennes, 2008, pp.115-131.

DAVIS, David Brion. The Problem of Slavery in the Age of Revolution 1770-1823. Ithaca, N.Y.: Cornell University Press, 1975.

DAVIS, David Brion. O Problema da Escravidão na Cultura Ocidental. Rio de Janeiro: Civilização Brasileira, 2001. 
DEBIEN, Gabriel. Les colons de Saint-Domingue et la Révolution: Essai sur le Club Massiac. Paris: Librairie Armand Colin, 1953.

DÉMIER, Francis. Esclavage, économie coloniale et choix de développement français durant la première industrialisation (1802-1840). In: M. DORIGNY (org.). Les abolitions de l'esclavage, de L.F. Sonthonax à V. Schoelcher 1793-1794-1848. Paris: Presses Universitaires de Vincennes / Éditions UNESCO, 1995, pp.273-283.

Dictionnaire des gens de couleur dans la France moderne. Paris et son bassin. Érick Noël (org.). Genebra: Librairie Droz, 2011.

Dictionnaire des Législateurs 1791-1792. Edna Hindie Lemay (org.). Fernay-Voltaire: Centre international d'étude du XVIIIe siècle, 2007. 2 v.

DONOVAN, Arthur. Antoine Lavoisier. Science, Administration and Revolution. Cambridge: Cambridge University Press, 1993.

DORIGNY, Marcel. Les Girondins et Jean-Jacques Rousseau. Annales historiques de la Révolution française, Paris, n. 234: Jean-Jacques Rousseau. Pour le deuxième centenaire de sa naissance, pp.569-583, 1978. Disponível em: http://www.persee.fr/web/revues/home/prescript/article/ahrf_00034436_1978_num_234_1_1029. Acesso em: 16 de abril de 2012.

DORIGNY, Marcel, GAINOT, Bernard. La Société des Amis de Noirs 1788-1799: Contribution à l'histoire de l'abolition de l'esclavage. Paris: UNESCO, 1988.

DORIGNY, Marcel. Mirabeau et la Société des Amis de Noirs: quelles voies pour l'abolition de l'esclavage. In: Les abolitions de l'esclavage, de L.F. Sonthonax à V. Schoelcher 1793-1794-1848. Paris: Presses Universitaires de Vincennes / Éditions UNESCO, 1995, pp.153-164.

DORIGNY, Marcel. Sonthonax et Brissot: le cheminement d'une filiation politique assumée. In: Léger Félicité Sonthonax. La première abolition de l'esclavage. La Révolution française et la Révolution de Saint-Domingue. Paris: Société des études robespierristes, 2006, pp.29-40.

DORIGNY, Marcel. Les abolitions de l'esclavage (1793-1794-1848). Une célébration nécessaire. In: . Les abolitions de l'esclavage, de L.F. Sonthonax à V. Schoelcher 1793-1794-1848. Paris: Presses Universitaires de Vincennes / Éditions UNESCO, 1995, pp.7-17.

DRESCHER, Seymour. Two Variants of Anti-Slavery: Religious Organization and Social Mobilization in Britain and France, 1780-1870. In: From Slavery to Freedom: comparative studies on the rise and fall of Atlantic Slavers. New York: New York University Press, 1999.

DRESCHER, Seymour. British Way, French Way: Opinion Building and Revolution in the Second French Emancipation. In: From Slavery to Freedom: comparative studies on the rise and fall of Atlantic Slavers. New York: New York University Press, 1999. 
DRESCHER, Seymour. Capitalism and antislavery: British mobilization in comparative perspective. New York: Oxford University Press, 1987.

DUBOIS, Laurent. A Colony of Citizens: Revolution and Slave Emancipation in the French Caribbean 1787-1804. Chapel Hill: Univ. North Carolina Press, 2004.

DUBOIS, Laurent. Avengers of the New World - The Story of the Haitian Revolution. Cambridge, Massachussetts: The Belknap Press of Harvard University Press, 2005.

DUCHET, Michèle. Diderot et l'Histoire des Deux Indes ou l'écriture fragementaire. Paris: Éditions A.-G. Nizet, 1978.

DURAND, Yves. Négociants et financiers en France au XVIIIe siècle. In: La fiscalité et ses implications sociales en Italie et en France aux XVIIe et XVIIIe siècles (Florence 56 Décembre 1978). Colloque organisé par l'École Française de Rome en collaboration avec L'Archivio di Stato di Firenze et l'Institut Français de Florence. Roma: École Française de Rome, 1980, pp.99-110.

EHRARD, Jean. L'esclavage devant la conscience morale des Lumières françaises: indifférence, gêne, révolte. In: M. DORIGNY (org.). Les abolitions de l'esclavage, de L.F. Sonthonax à V. Schoelcher 1793-1794-1848. Paris: Presses Universitaires de Vincennes / Éditions UNESCO, 1995, pp.143-152.

EHRARD, Jean. Audace théorique, prudence pratique: Montesquieu et l'esclavage colonial. In: O. PÉTRÉ-GRENOUILLEAU (org.). Abolir l'esclavage: un réformisme à l'épreuve (France, Portugal, Suisse, XVIII-XIXe siècles). Rennes: Presses Universitaires de Rennes, 2008, pp.27-39.

EHRARD, Jean. Lumières et esclavage. L'esclavage colonial et l'opinion publique en France au XVIIIe siècle. Bruxelas: André Versaille Éditeur, 2008.

ELISABETH, Léo. Résistances des esclaves aux XVIIe et XVIIIe siècles dans les colonies françaises d'Amérique, principalement aux Iles du Vent. In: M. DORIGNY (org.). Les abolitions de l'esclavage, de L.F. Sonthonax à V. Schoelcher 1793-17941848. Paris: Presses Universitaires de Vincennes / Éditions UNESCO, 1995, pp.77-86.

ELLERY, Eloise. Brissot de Warville: A Study o the History of the French Revolution. New York: Burt Franklin, 1970.

ELYADA, Ouzi. La modification de l'hégémonie médiatique pendant la Révolution française: le livre face à la presse. In: M. BIARD et alii (orgs). La plume et le sabre. Paris: Publications de la Sorbonne, 2002, pp.75-87.

ÈVE, Prosper. Les formes de résistance à Bourbon de 1750 à 1789. In: M. DORIGNY (org.). Les abolitions de l'esclavage, de L.F. Sonthonax à V. Schoelcher 1793-17941848. Paris: Presses Universitaires de Vincennes / Éditions UNESCO, 1995, pp.49-71.

FICK, Carolyn. The making of Haiti: the Saint Domingue revolution from below. Knoxville: The University of Tennessee Press, 1990. 
FICK, Carolyn. The French Revolution in Saint-Domingue. A Triumph or a Failure. In: D.B. GASPAR et alii (orgs). A Turbulent Time: the French Revolution and the Greater Caribbean. Bloomington: Indiana University Press, 1997, pp.51-77.

FONER, Eric. Nada além da liberdade. Rio de Janeiro: Paz e Terra, 1988.

FOUCK, Serge Mam Lam. La résistance au rétablissement de l'esclavage en Guyane française: traces et regards 1802-1822. In: Y. BÉNOT, M. DORIGNY (orgs). Rétablissement de l'esclavage dans les colonies françaises: ruptures et continuités de la politique coloniale française (1800-1830) - Aux origines d'Haïti. Paris: Maisonneuve \& Larose, 2003, pp.252-268.

FRADERA, Josep M. L'esclavage et la logique constitutionnelle des empires. Annales. Histoire, Sciences Sociales, 63 (3), pp.533-560, 2008.

FROSTIN, Charles. Les révoltes blanches à Saint-Domingue aux XVIIe et XVIIIe siècles (Haïti avant 1789). Rennes: Presses Universitaires de Rennes, 2008.

GAINOT, Bernard. Bottu, «Le Républicain des Colonies» (1797). Annales historiques de la Révolution française, Paris, n. 293-294: Révolution aux colonies, pp.431-444, $1993 . \quad$ Disponível em: http://www.persee.fr/web/revues/home/prescript/article/ahrf_00034436_1993_num_293_1_1584. Acesso em: 16 de jan de 2012.

GAINOT, Bernard. La constitutionnalisation de la liberté générale sous le Directoire (1795-1802). In: M. DORIGNY (org.). Les abolitions de l'esclavage, de L.F. Sonthonax à V. Schoelcher 1793-1794-1848. Paris: Presses Universitaires de Vincennes / Éditions UNESCO, 1995, pp.213-229.

GAINOT, Bernard. 1799, un nouveau Jacobinisme? La démocratie représentative, une alternative à brumaire. Paris: Éditions du CTHS, 2001.

GAINOT, Bernard. Robert BLANC, Un pasteur du temps des Lumières, Benhamin Sigismond Frossard, 1754-1830, Paris, Honoré Champion. Annales historiques de la Révolution française, Paris, n. 327, jan-mar de 2002, colocado em linha em 19 de mar de 2008. Disponível em: http://ahrf.revues.org/1219. Acesso em: 19 de maio de 2011.

GAINOT, Bernard. Métropole / Colonies. Projets constitutionnels et rapports e forces 1798-1802. In: Y. BÉNOT, M. DORIGNY (orgs). Rétablissement de l'esclavage dans les colonies françaises 1802: ruptures et continuités de la politique coloniale française (1800-1830) - Aux origines d'Haïti. Paris: Maissonneuve \& Larose, 2003, pp.13-28.

GAINOT, Bernard. La députation de Saint-Domingue au corps législatif du Directoire. In: M. DORIGNY (org). Léger Félicité Sonthonax. La première abolition de l'esclavage. La Révolution française et la Révolution de Saint-Domingue. Paris: Société des études robespierristes, 2006, pp.95-110.

GARRETT, Mitchell Bennett. The French Colonial Question, 1789-1791. Ann Arbor, MI: George Wahr, 1918.

GARRIGUS, John D. Before Haiti: Race and Citizenship in French Saint-Domingue. New York: Palgrave MacMillan, 2006. 
GAUTHIER, Florence. Triomphe et mort du droit naturel 1789-1795-1802. Paris: PUF, 1992.

GAUTHIER, Florence. Inédits de Dufay, Santerre et Léonard Leblois, au sujet de l'arrivée de la députation de Saint-Domingue à Paris. Janvier-février 1794. Annales historiques de la Révolution française, Paris, n. 293-294, pp.514-518, 1993.

GAUTHIER, Florence. Le rôle de la députation de Saint-Domingue dans l'abolition de l'esclavage. In: M. DORIGNY (org.). Les abolitions de l'esclavage, de L.F. Sonthonax à V. Schoelcher 1793-1794-1848. Paris: Presses Universitaires de Vincennes / Éditions UNESCO, 1995, pp.199-211.

GAUTHIER, Florence. La convention thermidorienne et le problème colonial: sept. 1794 - sept. 1795. In: M. VOVELLE (org.). Le Tournant de l'an III. Paris: Comité des travaux historiques et scientifiques, 1997, pp.109-131.

GAUTHIER, Florence. La première abolition de l'esclavage ou l'ouverture du procès du colonialisme. In: Périssent les colonies plutôt qu'un principe! Contribution à l'histoire de l'abolition de l'esclavage. Paris: Société des études robespierristes, 2002, pp.11-18.

GAUTHIER, Florence. Périssent les colonies plutôt qu'un principe! De Jaucourt à Marx en passant par Robespierre et Desmoulins. In: Périssent les colonies plutôt qu'un principe! Contribution à l'histoire de l'abolition de l'esclavage. Paris: Société des études robespierristes, 2002, pp.91-103.

GAUTHIER, Florence. En guise de conclusion: ouverture à de nouvelles recherches. Richebourg: comment abolir l'esclavage à Saint-Domingue? 1793. In: Périssent les colonies plutôt qu'un principe! Contribution à l'histoire de l'abolition de l'esclavage. Paris: Société des études robespierristes, 2002, pp.105-112.

GAUTHIER, Florence. À l'origine de la théorie physiocratique du capitalisme, la plantation esclavagiste. L'expérience de Le Mercier de la Rivière, intendant de la Martinique. Actuel Marx, n.32, pp.51-72, 2002. Disponível em: http://www.cairn.info/revue-actuel-marx-2002-2-page-51.htm. Acesso em: $8 \mathrm{de}$ fev de 2012.

GAUTHIER, Florence. L'aristocratie de l'épiderme. Le combat de la société des citoyens de couleur 1789-1791. Paris: CNRS éditions, 2007.

GEGGUS, David Patrick. Haitian Revolutionary Studies: Blacks in the Diaspora. Bloomington, IN: Indiana University Press, 2002.

GENOVESE, Eugene. A Economia Política da Escravidão. Rio de Janeiro: Pallas, 1976.

GENOVESE, Eugene. Da rebelião à revolução: as revoltas de escravos negros nas Américas. São Paulo: Global, 1983.

GHACHEM, Malick W. The Old Regime and the Haitian Revolution. New York: Cambridge University Press, 2012. 
GISLER, Antoine. L'esclavage aux Antilles françaises (XVIIe-XIXe siècle): contribution au problème de l'esclavage. Paris: Karthala, 1981.

GORENDER, Jacob. O escravismo colonial. São Paulo: Ática, 1978.

GORENDER, Jacob. A escravidão reabilitada. São Paulo: Ática, 1990.

GRENIER, Jean-Yves. "Faut-il rétablir l'esclavage en France?" Droit naturel, économie politique et esclavage au XVIIIe siècle. Revue d'Histoire moderne et contemporaine, Paris, n.57-2, pp.7-49, 2010.

GRINBERG, Keila. Código Civil e Cidadania. Rio de Janeiro: Zahar Editores, 2001.

GUÉRIN, Daniel. Bourgeois et bras nus, 1793-1795. Paris: Gallimard, 1973.

GUETATA, Jouda. Le refus d'application de la constitution de l'an III à SaintDomingue 1795-1797. In: GAUTHIER, F. (org). Périssent les colonies plutôt qu'un principe! Contribution à l'histoire de l'abolition de l'esclavage. Paris: Société des études robespierristes, 2002, pp.81-90.

HABERMAS, Jürgen. L'espace public: Archéologie de la Publicité comme dimension constitutive de la société bourgeoise. Tradução de Marc B. de Launay. Paris: Payot, 1978.

HALL, Gwendolyn Midlo. Social Control in Slave Plantation Societies: a comparison of St. Domingue and Cuba. Baltimore, Londres: The John Hopkins Press, 1971.

HALPERN, Jean-Claude. L'universel et le lointain. Les mondes exotiques dans la culture populaire, à la fin du XVIIIème siècle. History of European Ideas, v.15, n. 4-6, 1992, pp.767-772, 1992.

HALPERN, Jean-Claude. Les fêtes révolutionnaires et l'abolition de l'esclavage en l'an II. In: M. DORIGNY (org.). Les abolitions de l'esclavage, de L.F. Sonthonax à V. Schoelcher 1793-1794-1848. Paris: Presses Universitaires de Vincennes / Éditions UNESCO, 1995, pp.187-198.

HARDY, G.. Robespierre et la question noire. Annales Historiques de la Révolution Française, Paris, t.12, pp.357-382, 1920 (reimpressão: 1965).

HAUDRÈRE, Philippe. La Compagnie française des Indes.au XVIIIe siècle. 2a edição. Paris: Les Indes Savantes, 2005. 2 v.

HECTOR, Michel. L'historiographie haïtienne après 1946 sur la Révolution de SaintDomingue. Annales historiques de la Révolution française, Paris, n.293-294, 1993, pp.545-553. Disponível em: http://www.persee.fr/web/revues/home/prescript/article/ahrf_00034436_1993_num_293_1_3395. Acesso em: 4 de jun de 2013.

HURBON, Laënnec. Église et esclavage au XVIIIe siècle à Saint-Domingue. In: M. DORIGNY (org.). Les abolitions de l'esclavage, de L.F. Sonthonax à V. Schoelcher 1793-1794-1848. Paris: Presses Universitaires de Vincennes / Éditions UNESCO, 1995, pp.86-100. 
HILL, Christopher. Reformation to Industrial Revolution, 1530-1780. Middlesex/New York: Penguin Books, 1969.

HIPPLER, Thomas. Service militaire et citoyenneté sous la Révolution française. In: R. MONNIER. Citoyen et citoyenneté sous la Révolution française. Actes du coloque international de Vizille des 25 et 25 septembre 2004. Paris: Société des études robespierristes, 2006, p. 278.

JAMES, C.L.R.. Os jacobinos negros: Toussaint L'Ouverture e a revolução de São Domingos. São Paulo: Boitempo editorial, 2000.

JAURÈS, Jean. Histoire socialiste de la Révolution Française. 2a edição. Paris: Éditions de la Librairie de l'Humanité, 1927.

JOUVENEL, Bertrand de. Napoléon et l'économie dirigée. Le blocus continental. Bruxelas, Paris: Les Éditions de la Toison d'Or, 1942.

KAUTSKY, Karl. La lutte des classes en France en 1789. Tradução de Édouard Berth. Paris: Librairie G. Jacques \& Cie, 1901.

KOSELLECK, Reinhart. Le futur passé. Contribution à la sémantique des temps historiques. Paris: Éditions de l'École des Hautes Études en Sciences Sociales. 1990 (reimpressão: 2000).

KUSCINSKI, A. Dictionnaire des conventionnels. Brueil-en-Vexin: Éditions du Vexin Français, 1973.

LACOUR, Auguste. Histoire de la Guadeloupe. Basse-Terre (Guadalupe): Imprimerie du Gouvernement, 1837-1858. v.3.

LAMARTINE, Alphonse de. L'histoire des Girondins. Paris: L'Hachette et cie., 1870. v.1.

LARRÈRE, Catherine. Économie politique et esclavage au XVIIIe siècle, une rencontre tardive et ambiguë. In: O. PÉTRÉ-GRENOUILLEAU (org.). Abolir l'esclavage: un réformisme à l'épreuve (France, Portugal, Suisse, XVIII-XIXe siècles). Rennes: Presses Universitaires de Rennes, 2008, pp.209-223.

LEFEBVRE, Georges. La Révolution Française. 5a edição. Paris: Presses Universitaires de France, 1963.

LEFEBVRE, Georges. La France sous le Directoire 1795-1799. Paris: Messidor/Editions Sociales, 1984.

LEFEBVRE, Georges. Napoléon. Paris: Nouveau Monde éditions, 2005.

Les colons de Saint-Domingue (1789). Disponível em: http://www.domingino.de/stdomin/colons_s.htm. Acesso em 25 de jan de 2012.

LIÉBART, Déborah. Un groupe de pression contre-révolutionnaire: le clube Massiac sous la constituante. Annales historiques de la Révolution française, Paris, n. 354, pp.29-50, 2008. 
LINTILHAC, Eugène. Vergniaud. Le drame des Girondins. Paris: Librairie Hachette, 1920.

LUTTRELL, Barbara. Mirabeau. Hertfordshire: Harvester Wheatsheaf, 1990.

MAINTENANT, Gérard. Les papiers de Brissot (fonds François de Montrol). In: A. SOBOUL (org.). Colloque Girondins et Montagnards, Paris: Sorbonne, 14 décembre 1974, sous la direction d'Albert Soboul. Paris: Société des études robespierristes, 1980, pp.325-342.

MANTOUX, Paul. La révolution industrielle au XVIIIe siècle. Essai sur les commencements de la grande industrie moderne en Angleterre. Paris: Éditions Génin, 1959.

MAQUERLOT, Lucie. Rouen et Le Havre face à la traite et à l'esclavage. In: M. DORIGNY (org.). Esclavage, résistances et abolitions. Paris: Éditions du CTHS, 1999, pp.165-186.

MARIENSTRAS, Elise. Les lumières et l'esclavage en Amérique du Nord au XVIIIè siècle. In: M. DORIGNY (org.). Les abolitions de l'esclavage, de L.F. Sonthonax à V. Schoelcher 1793-1794-1848. Paris: Presses Universitaires de Vincennes / Éditions UNESCO, 1995, pp.111-132.

MARIUS-HATCHI, Fabien. La Révolution caribéenne comme ultime rempart du droit naturel. Déchoukaj et coup d'arrêt thermidorien aux îles du vent 1794-1795. In: GAUTHIER, F. (org). Périssent les colonies plutôt qu'un principe! Contribution à l'histoire de l'abolition de l'esclavage. Paris: Société des études robespierristes, 2002, pp.67-79.

MARQUES, João Pedro. Slave Revolts and the Abolition of Slavery: An Overinterpretation. In: DRESCHER, Seymour, EMMER, Pieter C. (eds.). Who Abolished Slavery? Slave Revolts and Abolitionism: a debate with João Pedro Marques. Oxford, New York: Berghahn Books, 2010.

MARQUESE, Rafael de Bivar. Feitores do corpo, missionários da mente: senhores, letrados e o controle dos escravos nas Américas, 1660-1860. São Paulo: Companhia das Letras, 2004.

MARSEILLE, Jacques. Empire colonial et capitalisme français. Histoire d'un divorce. Paris: Albin Michel, 1984.

MARTIN, Gaston. Histoire de l'esclavage dans les colonies françaises. Paris: Presses Universitaires de France, 1948.

MARTIN, Gaston. Nantes au XVIIIe siècle. L'ère des négriers (1714-1774). Paris: Éditions Karthala, 1993.

MATHIEZ, Albert. La Révolution Française. Paris: Librairie Armand Colin, 1978.

MATHIEZ, Albert. Études sur Robespierre. Paris: Messidor/Éditions Sociales, 1988. 
McCLELLAN III, James E.. L'historiographie d'une académie coloniale: le Cercle des Philadelphes (1784-1793). Annales historiques de la Révolution française, Paris, n. 320, avril-juin 2000, colocado em linha em 21 de fev de 2006. Disponível em: http://ahrf.revues.org/148. Acesso em: 22 de mar de 2013.

MÉTELLUS, Jean, DORIGNY, Marcel. De l'esclavage aux abolitions XVIIIè - XXè siècles. Paris: Éditions Cercle d'Art, 1998.

MICHELET. Histoire de la Révolution française. Paris: Gallimard, 1952. 2 v.

MILLS, Herbert Elmer. The Early Years of the French Revolution in San Domingo. Poughkeepsie, NY: A.V. Haight, 1892. Disponível em: http://archive.org/details/earlyyearsoffren00millrich.

MORGAN, Edmund S.. Escravidão e liberdade: o paradoxo americano. Estudos Avançados, São Paulo, v.1, n.1, pp.121-150, 1987.

MOTYLEWSKI, Patricia. La Société française pour l'abolition de l'esclavage 18341850. Paris: L'Harmattan, 1998.

MOULIN, Mathilde. Les rentes sur l'Hôtel de Ville de Paris sous Louis XIV. Histoire, économie et société, 17 (4), pp.623-648, 1998. Disponível em: http://www.persee.fr/web/revues/home/prescript/article/hes_07525702_1998_num_17_4_2005. Acesso em: 10 de dez de 2011.

OLIVEIRA, Josemar Machado de Oliveira. $O$ Père Duchesne no interior da Revolução democrática: Jacques-René Hébert e as ideias aristocráticas do movimento secionário sans-culotte durante o ano I e o ano II (1792-94). 1998. Dissertação (Mestrado em História Social) - Faculdade de Filosofia, Letras e Ciências Humanas, Universidade de São Paulo, São Paulo, 1998.

OLIVEIRA, Josemar Machado de Oliveira. A teoria democrática robespierrista: do republicanismo clássico à democracia social. 2005. Tese (Doutorado em História Social) - Faculdade de Filosofia, Letras e Ciências Humanas, Universidade de São Paulo, São Paulo, 2005.

OUDIN-BASTIDE, Caroline. Discours colonial et discours abolitionniste: entre passions et intérêts. In: O. PÉTRÉ-GRENOUILLEAU (org.). Abolir l'esclavage: un réformisme à l'épreuve (France, Portugal, Suisse, XVIII-XIXe siècles). Rennes: Presses Universitaires de Rennes, 2008, pp.247-275.

PALMER, Robert. Twelve Who Ruled: The Year of the Terror in the French Revolution. Princeton: Princeton University Press, 1969.

PEABODY, Sue. "There Are No Slaves in France": The Political Culture of Race and Slavery in the Ancien Régime (versão digital). New York: Oxford University Press, 1996.

PÉRIN, René. L'incendie du Cap, ou le Règne de Toussaint Louverture. Paris: Marchand, 1802. 
PERROUD, Claude. La Société française des Amis des Noirs. La Révolution française. Paris, v.69, pp.122-147, 1916.

PÉTRÉ-GRENOUILLEAU, Olivier. Abolitionnisme et idée nationale: divorces et compromis, France, 1789-1831. In: __. Abolir l'esclavage: un réformisme à l'épreuve (France, Portugal, Suisse, XVIII-XIXe siècles). Rennes: Presses Universitaires de Rennes, 2008, pp.185-206.

PIQUET, Jean-Daniel. Robespierre et la liberté des noirs en l'an II d'après les archives des comités et les papiers de la comission Courtois. Annales Historiques de la Révolution Française, Paris, n. 323, jan-mar de 2001. Disponível em: http://ahrf.revues.org/1822. Acesso em: 5 de mar de 2010.

PIQUET, Jean-Daniel. L'émancipation des Noirs dans la Révolution française (17891795). Paris: Éditions Karthala, 2002.

PICQUET, Daniel. Le Créole Patriote: apôtre de l'insurrection de Saint-Domingue. Annales Historiques de la Révolution Française, Paris, n. 293-294, pp.519-521, 1993.

PIOLLET, Sophie, PIQUIONNE, Nathalie, ROUX, Delphine. Milscent créole historien de la Révolution de Saint-Domingue 1790-1794. In: GAUTHIER, F. (org). Périssent les colonies plutôt qu'un principe! Contribution à l'histoire de l'abolition de l'esclavage. Paris: Société des études robespierristes, 2002, pp.23-42.

PITTS, Jennifer. Naissance de la bonne conscience coloniale. Paris: Atelier, 2008.

POULANTZAS, Nicos. Pouvoir politique et classes sociales. Paris: François Maspero, 1971. $2 \mathrm{v}$.

POSTMA, Johannes. The Atlantic Slave Trade. Gainesville: University Press of Florida, 2003.

PRUDHOMME, Claude. L'expérience et la conviction contre la tradition: les Églises chrétiennes et la critique de l'esclavage 1780-1888. In: O. PÉTRÉ-GRENOUILLEAU (org.). Abolir l'esclavage: un réformisme à l'épreuve (France, Portugal, Suisse, XVIIIXIXe siècles). Rennes: Presses Universitaires de Rennes, 2008, pp.57-77.

QUENUM, Alphonse. Some Remarks on the Christian Churches and the Atlantic Slave Trade from the Fifteenth to the Nineteenth Century. Doudou Diène (org). In: D. DIÈNE (ed.). From Chains to Bonds: the Slave Trade Revisited. New York: Bergahn/Paris: Unesco Publishing, 2001, pp.267-272.

RÉGENT, Frédéric. Le rétablissement de l'esclavage et du préjugé de couleur en Guadeloupe. Disponível em: http://ihrf.univparis1.fr/IMG/pdf/retablissementesclavage.pdf. Acesso em: 12 de jul de 2012.

REIS, João José. Rebelião escrava no Brasil - A história do levante dos malês em 1835. São Paulo: Companhia das Letras, 2003.

RESCH, Robert Paul. Althusser and the Renewal of Marxist Social Theory. Berkeley, Los Angeles, Oxford: University of California Press, 1992. 
RESNIK, D.P.. The Société des Amis des Noirs and the abolition of Slavery. French Historical Studies, v.7, n.4, pp.558-569, 1972.

RIX, Robert William. Carl Bernhard Wadström (1746-1799). Disponível em: http://www.brycchancarey.com/abolition/wadstrom.htm. Acesso em: 26 de out de 2011.

ROCHA, Antonio Penalves. As observações de Jean-Baptiste Say sobre a escravidão. Estudos Avançados, São Paulo, v.1, n.1, pp.181-212, 1987.

SAES, Décio. A Formação do Estado burguês no Brasil (1888-1891). $2^{\mathrm{a}}$ edição. São Paulo: Paz e Terra, 1990.

SAES, Laurent Azevedo Marques de. A propriedade sob a República jacobina: o impacto da legislação revolucionária sobre a questão fundiária. Dissertação de mestrado. São Paulo: Universidade de São Paulo, 2008.

SAINTOYANT, J.. La colonisation française pendant la Révolution. Paris: La Renaissance du Livre, 1930.

SALA-MOLINS, Louis. Sous l'éclat des lumières, l'inexistence du droit des noirs à l'existence. In: L'héritage philosophique de la Déclaration des Droits de l'homme et du citoyen de 1789: Signification pour le Caraïbe. Paris: L'Harmattan, 2002, pp.84-107.

SALA-MOLINS, Louis. Les misères des Lumières. Sous la raison l'outrage. Paris: Robert Laffont, 1992.

SALA-MOLINS, Louis. Le Code Noir ou le calvaire de Canaan. Paris: Presses Universitaires de France, 2002.

SALA-MOLINS, Louis. L'Afrique aux Amériques: le Code Noir espagnol. Paris: Presses Universitaires de France, 1992.

SANDEAU, Jacques. La Révolution à Saint-Domingue et le désastre du corps expéditionnaire français, 1789-1803. Revue de l'Institut Napoléon, Paris, n.191, pp.7-44, 2005 .

SAUGERA, Éric. Bordeaux port négrier XVIIe - XIXe siècles. Paris: Karthala, 2002.

SCHMIDT, Nelly. L'élaboration des décrets de 1848. Application immédiate et conséquences à long terme. In: M. DORIGNY (org.). Les abolitions de l'esclavage, de L.F. Sonthonax à V. Schoelcher 1793-1794-1848. Paris: Presses Universitaires de Vincennes / Éditions UNESCO, 1995, pp.345-353.

SCHMITT, Carl. La Dictadura. Madrid: Alianza, 1985.

SCHOELCHER, Victor. Esclavage et colonisation. Paris: Presses Universitaires de France, 1948.

SÉE, Henri. L'évolution commerciale et industrielle de la France sous l'Ancien Régime. Reimpressão da edição de 1925. Genebra: Slatkine Reprints, 1980. 
SEEBER, Edward. Anti-slavery Opinion in France During the Second Half of the Eighteenth Century. New York: Lenox Hill, 1937.

SEPINWALL, Alyssa Goldstein. Eliminating Race, Eliminating Difference. Blacks, Jews and the Abbé Grégoire. In: S. PEABODY, T. STOVALL (orgs). The Color of Liberty. Histories of Race in France. Durham, Londres: Duke University Press, 2003, pp.28-40.

SILVA, Eduardo. Fugas, revoltas e quilombos. In: J.J. REIS, E. SILVA. Negociação e conflito. São Paulo: Companhia das Letras, 1989.

SOBOUL, Albert. Histoire de la Révolution française. Paris: Gallimard, 1962. 2 v.

SOBOUL, Albert. Les Sans-culottes parisiens en l'an II. Mouvement populaire et gouvernement révolutionnaire (1793-1794). Paris: Éditions du Seuil, 1968.

SOBOUL, Albert. Comprendre la révolution: problèmes politiques de la révolution française (1789-1797). Paris: François Maspéro, 1981.

SPIELER, Miranda Frances. The Legal Structure of Colonial Rule during the French Revolution. The William and Mary Quarterly, v.66, n.2, pp.365-408, 2009.

STEIN, Robert Louis. The French Sugar Business in the Eighteenth Century. Baton Rouge, Londres: Louisiana University Presss, 1988.

STEINER, Philippe. L'esclavage chez les économistes français (1750-1830). In: M. DORIGNY (org.). Les abolitions de l'esclavage, de L.F. Sonthonax à V. Schoelcher 1793-1794-1848. Paris: Presses Universitaires de Vincennes / Éditions UNESCO, 1995, pp.165-175.

STEINER, Philippe. J.-B. Say et les colonies, ou comment se débarasser d'un héritage intempestif. Cahiers d'économie politique, Paris, n.27-28, pp.153-173, 1996.

STEWARD, T. G. The Haitian Revolution, 1791-1804, or Side Lights on the French Revolution. New York: Thomas Y. Crowell Company, 1914. Disponível em: http://archive.org/details/haitianrevoluti00stewgoog.

STODDARD, T. Lothrop. The French Revolution in San Domingo. Boston, New York: Houghton Mifflin Company, 1914.

TARLÉ, Evguéni. Napoléon. Tradução de J. Champenois. Moscou: Éditions du Progrès, Librairie du Globe, 1990.

TARRADE, Jean. Les colonies et les principes de 1789: les assemblées révolutionnaires face au problème de l'esclavage. In: La Révolution française et les colonies. Paris: Société française d'histoire d'outre-mer, 1989, pp.9-34.

TARRADE, Jean. L'esclavage est-il réformable? Les projets des administrateurs coloniaux à la fin de l'Ancien Régime. In: M. DORIGNY (org.). Les abolitions de l'esclavage, de L.F. Sonthonax à V. Schoelcher 1793-1794-1848. Paris: Presses Universitaires de Vincennes / Éditions UNESCO, 1995, pp.133-141. 
THÉSÉE, Françoise. Autour de la Société des Amis des Noirs: Clarkson, Mirabeau et l'abolition de la traite (août 1789 - mars 1790). Présence Africaine. Revue Culturelle du Monde Noir, n.125, pp.3-82, 1983.

THIBAU, Jacques. Le temps de Saint-Domingue: l'esclavage et la Révolution française. Paris: J.-C. Lattès, 1989.

THIERS, Adolphe. Histoire de la Révolution française. $8^{\mathrm{a}}$ edição. Bruxelas: Adolphe Wahlen, 1836.

THOMPSON, E.P. A miséria da teoria, ou um planetário de erros: uma crítica ao pensamento de Althusser. Tradução de Waltensir Dutra. Rio de Janeiro: Zahar, 1981.

TODOROV, Tzvetan. A conquista da América: a questão do outro. São Paulo: Martins Fontes, 2003.

TROUILLOT, Michel-Rolph. Silencing the Past: Power and the Production of History. Boston, Mass: Beacon Press, 1995.

VIGIER, Philippe. La recomposition du mouvement abolitionniste sous la monarchie de juillet. In: M. DORIGNY (org.). Les abolitions de l'esclavage, de L.F. Sonthonax à V. Schoelcher 1793-1794-1848. Paris: Presses Universitaires de Vincennes / Éditions UNESCO, 1995, pp.285-291.

VILLIERS, Patrick. The slave and colonial trade in France just before the Revolution. In: B.L. SOLOW (org.). Slavery and the Rise of the Atlantic System. Cambridge: Cambridge University Press, 1991, pp.210-236.

VISSIÈRE, Isabelle, VISSIÈRE, Jean Louis. La traite des Noirs au siècle des Lumières. In: _. La traite des Noirs au siècle des Lumières (Témoignages de négriers). Paris: Éditions Mátailié, 1982.

WALVIN, James. L'abolition anglaise de l'esclavage des noirs, 1787-1838. In: M. DORIGNY (org.). Les abolitions de l'esclavage, de L.F. Sonthonax à V. Schoelcher 1793-1794-1848. Paris: Presses Universitaires de Vincennes / Éditions UNESCO, 1995, pp.103-110.

WANQUET, Claude. La place des questions coloniales dans la réaction de l'an III. In: M. VOVELLE (org.). Le Tournant de l'an III. Paris: Comité des travaux historiques et scientifiques, 1997, pp.171-184.

WANQUET, Claude. La France et la première abolition de l'esclavage 1794-1802: le cas des colonies orientales - Île de France (Maurice) et la Réunion. Paris: Éditions Karthela, 1998.

WANQUET, Claude. La tentative de Baco et Burnel d'application de l'abolition aux Mascareignes en 1796. Analyse d'un échec et de ses conséquences. In: M. DORIGNY (org.). Les abolitions de l'esclavage, de L.F. Sonthonax à V. Schoelcher 1793-17941848. Paris: Presses Universitaires de Vincennes / Éditions UNESCO, 1995, pp.231240. 
WEBER, Jacques. La traite négrière nantaise de 1763 à 1793. Ètude statistique. Revue des Mascareignes, n.2, 2000, pp.25-39. Disponível em: http://www.cresoi.fr/IMG/pdf/revue mascareigne_02-part3.pdf. Acesso em: 29 de jan de 2013.

WHATMORE, Richard, LIVESEY, James. Étienne Clavière, Jacques-Pierre Brissot et les fondations intellectuelles de la politique des girondins. Annales historiques de la Révolution française, Paris, n. 321, jul-set de 2000. Disponível em: http://ahrf.revues.org/175. Acesso em: 7 de fev. de 2013.

WHITE, Eugene N. L'efficacité de l'affermage de l'impôt: la Ferme Générale au XVIIIe siècle. In: L'administration des finances sous l'Ancien Régime. Colloque tenu à Bercy les 22 et 23 février 1996. Paris: Comité pour l'histoire économique et financière, 1997, pp.103-127.

WILLIAMS, Eric. Capitalismo e escravidão. Rio de Janeiro: Americana, 1975.

ZERON, Carlos Alberto de Moura Ribeiro. Linha de fé. A Companhia de Jesus e a Escravidão no Processo de Formação da Sociedade Colonial (Brasil, Séculos XVI e XVII). Tradução de Antonio de Padua Danesi. São Paulo: Edusp, 2011. 


\section{APÊNDICE A - Lista de membros da Sociedade dos Amigos dos Negros}

Obs: A duas listas de membros que apresentamos a seguir foram elaboradas com base em diversas fontes. Para a primeira Sociedade, um quadro oficial foi publicado em 1789, com apenas 94 membros. Outras listas e informações foram trazidas por Eloise Ellery (cf. Brissot de Warville: A Study o the History of the French Revolution. New York: Burt Franklin, 1970) e Claude Perroud (cf. La Société française des Amis des Noirs. La Révolution française, v.69, 1916). Foi, sobretudo, o recurso ao Registro das duas formações dos Amigos dos Negros, publicado por Marcel Dorigny e Bernard Gainot, que permitiu preencher algumas das muitas lacunas das listas disponíveis. Também devemos a Dorigny e Gainot grande parte das informações biográficas indicadas nas presentes listas ${ }^{1872}$, embora tenhamos recorrido, para preencher lacunas e corrigir eventuais equívocos, a diversas outras fontes, tais como a coleção Biographie universelle ancienne et moderne, o Dictionnaire des législateurs e o Dictionnaire des conventionnels, assim como a bibliografia sobre o tema. Para a identificação dos personagens, recorremos também, em alguns casos, a sites especializados em genealogia, como www.geneanet.org e www.geni.com.

O conjunto dessas fontes primárias e secundárias permite estabelecer um quadro mais completo de membros, embora seja muito difícil determinar a lista exata de todos os membros que integraram, em algum momento, a Sociedade. O Registro da entidade é bastante incompleto e nem sempre confiável. Além disso, alguns dos nomes citados na bibliografia não constam do registro, sendo-nos por vezes difícil determinar a veracidade da informação.

Procuramos indicar a data de apresentação ou admissão de cada membro, ou, em certos casos, a data de sua primeira aparição registrada na Sociedade. Para alguns nomes, entretanto, não foi possível estabelecer uma data.

1) Agasse de Crosne, Pierre Guillaume: antigo conselheiro da cidade de Paris, Agasse voltou, ainda em 1789, a trabalhar na administração da cidade, na qualidade de presidente do distrito Saint-Honoré. Apresentado por Gallois e admitido em 13 de janeiro de 1789.

${ }^{1872}$ Cf. DORIGNY, Marcel, GAINOT, Bernard. La Société des Amis des Noirs, pp.61-291, notas 1-607; e pp.329-367, notas 1-101. 
2) Aiguillon, Armand Désiré Vignerot du Plessis, duque de: assim como seu pai, era militar de carreira. Em 1789, foi eleito deputado da nobreza nos Estados Gerais. Como constituinte, ficou famoso por sua intervenção na noite de 4 de agosto de 1789. Era maçom.

3) Allais: Não pudemos identificar com precisão esse personagem. Havia, contudo, na época, um pintor e gravurista parisiense chamado Louis-Jean Allais, autor de numerosas estampas revolucionárias. Primeira aparição no registro em 4 de junho de 1790 .

4) Autroche, d': pode eventualmente tratar-se de Claude de Loynes d'Autroche, nobre, autor do tratado sobre agricultura Mémoire sur l'amélioration de la Sologne e de traduções das Odes de Horácio para o francês.

5) Avaux, Albert Paul de Mesme, conde de: nobre e oficial, apresentado por Valady e admitido em 15 de abril de 1788.

6) Bancal des Issarts, Jean Henri: amigo de Brissot e tabelião no Châtelet em Paris, foi membro da Convenção. Primeira aparição no registro em 7 de abril de 1789. Fez parte da segunda formação dos Amigos dos Negros.

7) Beaupoil Saint-Aulaire, Charles Joseph de Beaupoil, marquês de: era pagem do rei, chefe de esquadra e pair de France (título honorífico atribuído aos principais senhores do reino e que dava acesso ao conselho do rei). Emigrou em 1791. Primeira aparição no registro em 12 de agosto de 1788.

8) Baussans, marquesa de: uma das primeiras mulheres aderentes.

9) Beauvau, Charles Juste, príncipe de: militar de carreira, Beauvau alcançou a posição de marechal da França em 1783. Em 1789, foi nomeado secretário de Estado na guerra por alguns meses. Foi membro da Academia Francesa. Seu sobrinho, o chevalier de Boufflers, também foi membro dos Amigos dos Negros. Primeira aparição no registro em 7 de abril de 1789.

10) Bellier: trata-se provavelmente de Martin Adrien Bellier, que tinha sido governador da ilha Bourbon (Ilha da Reunião), em 1767.

11) Bérard: não dispomos de maiores informações, mas talvez seja Thomas-Simon Bérard, negociante armador e fundador da última Companhia das Índias. Ele se rendeu aos princípios da Revolução, tornando-se capitão de batalhão da Guarda Nacional. Acusado de proteger o rei em 1792, foi executado em 1794. Apresentado por Blaire e admitido em 15 de abril de 1788. 
12) Bergasse, Nicolas: amigo de Brissot, com quem tinha criado a Société galloaméricaine, e fundador da Sociedade da harmonia universal, Bergasse era um advogado e publicista conhecido, que se tornou depois membro da Assembleia Constituinte. Embora seu nome não conste da ata da primeira sessão, parece ter feito parte da Sociedade desde o início. Sabe-se, entretanto, que sua participação na Sociedade foi bastante curta.

13) Bergerot: diretor das Fermes. Apresentado por Carra e admitido em 22 de abril de 1788.

14) Bergon: era um dos Premiers Commis des Finances, encarregados da direção de serviços que regulavam os movimentos de fundos para os ministérios. Nesse quadro, Bergon estava encarregado justamente da régie des traites e do comércio das colônias. ${ }^{1873}$ Primeira aparição no registro em 3 de fevereiro de 1789.

15) Bidermann, Jacques: trata-se provavelmente de Jacques Bidermann, banqueiro, negociante em Bruxelas, amigo de Brissot e Clavière. Tinha, ao lado deste último, sido um dos dirigentes da revolução de 1782. Foi oficial municipal de Paris em 1792 e administrador das subsistências em 1793. Admitido em 22 de abril de 1789.

16) Blaire, Lucas de: nobre, conselheiro da Cour des Aides. Foi deputado suplente da nobreza nos Estados Gerais de 1789. Admitido em 18 de março de 1788, por indicação de Brack, ele permaneceu por pouco tempo na Sociedade. Segundo alguns autores, ele teria se juntado ao Clube Massiac mais tarde, o que sugere que podia tratar-se de um colono infiltrado, mas a sua atuação ativa na apresentação de novos membros à Sociedade enfraquece essa tese.

17) Blot, Pierre-Charles: jurista, amigo de Brissot, que o apresentou à Sociedade, Blot era Controlador da Marque d'or et d'Argent ${ }^{1874}$ em Lyon e secretário geral da Sociedade Filantrópica da cidade. Admitido em 8 de abril de 1788.

18) Bonnemain, Antoine Jean Thomas: advogado, eleito membro da Convenção, onde se sentou em meio à Gironda. Autor da obra antiescravista Régénération

\footnotetext{
${ }^{1873}$ Cf. BOTTIN, Michel. "Les services centraux des Finances en 1788", Communication au Colloque organisé par l'Université de Rouen et le Ministère du Budget, des Comptes publics et de la Fonction publique, La Direction générale des Finances publiques. Vers une administration nouvelle? (2008). Disponível em: www.michel-bottin.com. Acesso em: 16 de jan de 2012.

${ }^{1874}$ A Marque d'or et d'argent era um direito cobrado sobre o ouro e a prata colocada em circulação. $\mathrm{O}$ direito de perceber esse direito era, a exemplo de outros tributos, arrendado.
} 
des colonies (publicada em 1792). Primeira aparição no registro em 29 de janeiro de 1790 .

19) Boufflers, Stanislas Jean, marquês de: mais conhecido como Chevalier de Boufflers, era um poeta e tinha sido governador do Senegal (1785-87), por indicação do ministro Castries. Era um antiescravista declarado, embora, mais tarde, em 1808, ele tenha passado para o campo contrário. Primeira aparição no registro da Sociedade em 19 de agosto de 1788.

20) Boullongne: trata-se, muito provavelmente, de Jean-Baptiste Tavernier de Boullongne, fermier général e comissário do rei na nova Companhia das Índias. Foi condenado à morte e executado em 8 de maio de 1794. Outra possibilidade, mais remota, é a de que se trata de Joseph Boulogne, chevalier de Saint-Georges, compositor e músico mulato, nascido na Guadalupe e radicado na metrópole, onde ficou conhecido como o "Mozart negro". Primeira aparição no registro em 18 de abril de 1789 .

21) Bouteiller: indicado simplesmente como "colono" no registro, trata-se provavelmente de Guillaume Bouteiller, negociante de Nantes, cuja família tinha plantações nas ilhas. Foi apresentado por Blaire e admitido em $1^{\circ}$ de abril de 1788.

22) Bouthillier: autor dramático

23) Brack, C.: censor real e diretor geral das alfândegas internas (traites). Era amigo pessoal de Brissot. Foi um dos fundadores da Sociedade, estando presente na primeira sessão, de 19 de fevereiro de 1788. Fez parte da segunda formação dos Amigos dos Negros.

24) Brissot de Warville, Jacques-Pierre: Filho de um mestre confeiteiro (pâtissiertraîteur) rico de Chartres, tornou-se conhecido na França por suas numerosas publicações sobre temas diversos: relações internacionais, direito penal, direito de propriedade, etc. Anglófilo declarado, mas também entusiasta da Revolução americana, Brissot era um jornalista notoriamente crítico das instituições do Antigo Regime. Uma breve passagem pela Bastilha lhe trouxe fama, mas também uma reputação duvidosa. De acordo com os estudos de Robert Darnton, Brissot teria atuado como informante da polícia sob o Antigo Regime. ${ }^{1875}$ Ele foi um dos líderes da Legislativa e da Convenção, antes de cair com os Girondinos

1875 Cf. DARNTON, Robert. The Brissot dossier. French Historical Studies, v.17, n.1, 1991, pp.191-205. Disponível em: http://dash.harvard.edu/handle/1/3403050. Acesso em: 7 de fev. de 2013. 
após as jornadas de 31 de maio - 2 de junho de 1793. Foi um dos fundadores da Sociedade, presente na primeira sessão, de 19 de fevereiro de 1788.

25) Buest, barão de: Acreditamos tratar-se de um erro de grafia constante da lista reproduzida por E. Ellory. Trata-se provavelmente de um barão de Beust.

26) Cabrol: talvez seja Cabrol de Nîmes, negociante, representante de Paris na casa de comércio Cabrol, Lombard et cie. Apresentado por Brack e admitido em $1^{\circ}$ de abril de 1788 .

27) Carra, Jean-Louis: autor de várias obras científicas e, sobretudo, de Le système de la raison ou le prophète philosophe, obra polêmica pelo seu materialismo e seu ateísmo. Após uma experiência como funcionário da Biblioteca do rei, ele empreendeu, sob a Revolução, uma carreira de jornalista e, em seguida de deputado. Foi um dos fundadores da Sociedade, presente na primeira sessão, de 19 de fevereiro de 1788.

28) Cerisier, A. M.: jornalista conhecido por seus escritos sobre assuntos americanos. Sob a Revolução, fundou a Gazette Universelle, onde assumiu frequentemente a defesa dos Amigos dos Negros. Foi eleito deputado suplente do terceiro estado em 1789. Foi um dos fundadores, presente na primeira sessão, de 19 de fevereiro de 1788.

29) Champion: Embora não possamos confirmá-lo, acreditamos tratar-se de Clément Félix Champion de Villeneuve, antigo advogado no Parlamento de Paris e, a partir de 1787, advogado nos Conselhos do rei. Foi escolhido ministro do interior em 1792. Foi apresentado por Brack e admitido em 6 de maio de 1788.

30) Charost, Armand Joseph, duque de Béthune: nobre ilustre que participou das assembleias de notáveis de 1787-88, opondo-se ao Ministério. Em julho de 1788, foi um dos três signatários a pedir a Brienne a Convocação dos Estados Gerais, muito embora ele fosse politicamente moderado. Apresentado por La Fayette e admitido em $1^{\circ}$ de abril de 1788.

31) Charton de la Terrière: segundo a lista oficial, tratar-se-ia de um correspondente localizado na América. Talvez seja Joachim Charton de la Terrière, marechal de campo. Admitido em 29 de abril de 1788.

32) Châtelet, Marquês do: militar, herói da guerra da América, ao lado de La Fayette, e colaborador de Condorcet. Admitido em 27 de janeiro de 1788. 
33) Chauveau de Lagarde, Claude François: famoso advogado que defendeu Brissot perante o tribunal revolucionário. ${ }^{1876}$ Primeira aparição no registro em 29 de janeiro de 1790.

34) Clamon (ou Calmon): negociante. Membro estrangeiro apresentado em 17 de março de 1789.

35) Clarkson, Thomas: associado estrangeiro. Negociante e filantropo anglicano, Clarkson era um dos líderes da Sociedade antiescravista londrina. Seus escritos serviram de fonte de inspiração para a formulação do programa da Sociedade. Participou ativamente de várias sessões dos Amigos dos Negros durante a sua estadia em Paris. Primeira participação em 21 de agosto de 1789.

36) Clavière, Étienne: banqueiro genebrino que tinha sido um dos principais dirigentes da revolução de 1782. Exilado na Inglaterra e na Irlanda, após a intervenção militar francesa, acabou instalando-se definitivamente em Paris em 1784, onde se associou a Brissot, com quem formou a Société gallo-américaine. Também era bastante ligado a Mirabeau, tendo exercido influência sobre seus escritos. Esse mestre das finanças foi também o introdutor do seguro sobre a vida na França, tornando-se administrador da Compagnie royale d'Assurance sur la vie. Durante a Revolução, foi um dos teóricos do assignat e atuou por duas vezes como ministro das finanças da Gironda. Foi um dos fundadores da Sociedade, estando presente na primeira sessão, de 19 de fevereiro de 1788.

37) Clavière, Marthe-Louise Garnier: esposa de Étienne Clavière. Seu nome está na lista de membros publicada em 1789.

38) Clavière (le jeune), Jean-Jacques: negociante, irmão mais jovem de Étienne, de quem era sócio. Primeira aparição no registro em 2 de dezembro de 1788.

39) Colin: abade, padre de Saint-Eustache. Admitido em 31 de março de 1788.

40) Condorcet, Marie Jean Antoine Nicolas, marquês de: secretário perpétuo da Academia de Ciências, membro da Academia Francesa, foi apresentado por La Fayette. Era advogado de três causas: educação, direitos da mulher (instrução e participação ativa) e liberdade dos Negros. Foi um dos principais teóricos dos Amigos dos Negros e um de seus membros mais ativos. Admitido na Sociedade em 8 de abril de 1788, sob apresentação de La Fayette.

${ }^{1876}$ Cf. DORIGNY, Marcel, GAINOT, Bernard. La Société des Amis des Noirs, p.266, nota 518. 
41) Condorcet, Sophie de Crouchy, marquesa de: esposa de Condorcet e primeira mulher admitida oficialmente na Sociedade. Apresentada por seu próprio marido em 23 de junho de 1789.

42) Cosson: abade, apresentado por Brissot em 30 de abril de 1790.

43) Cottin, fils, Jean-Louis: Banqueiro e futuro deputado de Nantes na Constituinte. Esteve ligado à gestão da Companhia das Índias reformada em 1785. Curiosamente, tanto o seu filho quanto sua filha se associaram, por casamento, a famílias de armadores de Bordeaux. Foi apresentado por Blaire e admitido em 29 de abril de 1788.

44) Coulon, Claude Antoine: abade. Sob a Revolução, seria levado a exilar-se, por não se submeter aos decretos da Assembleia.

45) Coustard Saint-Lô, Guy, conde de: militar de carreira, marechal de campo do 15 de setembro de 1792. Apresentado por Blaire e admitido em 15 de abril de 1788.

46) Crèvecoeur, Michel Guillaume Jean de: escritor, amigo e associado de Brissot na fundação da Société gallo-américaine, em 1787.

47) Crillon, François Félix Dorothé Berton des Balbes, Conde de: o coronel Crillon foi deputado da nobreza de Beauvais nos Estados Gerais e um dos primeiros a se unir ao Terceiro Estado. Primeira aparição no registro em 3 de fevereiro de 1789.

48) Croharé: mestre em farmácia, ele seria membro da comuna provisória de 18 de setembro de 1789. Admitido em 20 de janeiro de 1789.

49) Croissy: indicado apenas como "de Croissy" no registro, trata-se provavelmente de Georges Gougenot de Croissy, administrador da Companhia das Índias. Não sabemos com certeza se é o mesmo "Gougenot", também citado no registro, ou se estamos diante do pai deste. Primeira aparição no registro em 9 de junho de 1789.

50) Cuchet, Gaspard Joseph: livreiro, um dos eleitores de Paris em 1789. Apresentado por Brissot e admitido em 15 de abril de 1788.

51) Daer, Basil Douglas, Lord: jovem aristocrata escocês, amigo de Dumont e Condorcet, ambos da Sociedade. Apresentado por Condorcet em 30 de junho de 1789.

52) Dampierre, Anne Elzéard du Val, conde de: militar, o tenente-coronel Dampierre passou à história por ter sido massacrado pelas massas quando veio 
cumprimentar o rei na volta de Varennes. Apresentado por Valady e admitido em 15 de abril de 1788.

53) Daudignac de Jolivet: funcionário (liquidateur) da Ferme générale. Apresentado por Bréban e admitido em 6 de maio de 1788.

54) De Bourges, Jean Claude Antoine: homem de letras, amigo e colaborador de Mirabeau, que o apresentou à Sociedade. Fez parte da Comuna de Paris, onde desempenhou um papel decisivo nos primeiros anos da Revolução. Foi admitido em 4 de março de 1788.

55) Delorme: como diz Dorigny, talvez seja Guillot Delorme (ou de Lorme), sócio da Câmara de Seguros de Paris e recebedor geral das finanças em Paris. ${ }^{1877}$ Primeira aparição no registro em 15 de março de 1790.

56) Desbrus, Bertrand: negociante de Puy-en-Velay, amigo e sócio de Lanthenas, prefeito de Puy em 1793. Primeira aparição no registro em 9 de junho de 1789.

57) Desfaucherets, Jean-Louis Brousse: advogado no Parlamento de Paris e escritor. Foi deputado suplente de Paris nos Estados Gerais. Apresentado por Montcloux e admitido em 8 de abril de 1788 .

58) Dière (ou Dieres): conselheiro na Cour des Aides. Admitido em 8 de abril de 1788.

59) Diétrick (ou Dietrich), Frédéric, barão de: banqueiro de Strasbourg, membro da Academia de Ciências, prefeito de Strasbourg em 1790. Foi apresentado por Condorcet e admitido em 22 de abril de 1788.

60) Doazan, fils: trata-se de Jean Doazan, fermier général como seu pai, Pierre Éloi Doazan.

61) Doujan: personagem não identificado.

62) Duchesnay, Alexandre Claude Bellier: censor real ${ }^{1878}$, e prefeito de Chartres no início da Revolução. Em seguida, foi deputado na Legislativa. Duchesnay foi um dos fundadores da Sociedade, estando presente na primeira sessão, de 19 de fevereiro de 1788.

63) Dufossey de Bréban: diretor da Régie générale. Foi um dos fundadores da Sociedade, estando presente na primeira sessão, de 19 de fevereiro de 1788. Esteve também na segunda fase da Sociedade.

1877 Cf. DORIGNY, Marcel, GAINOT, Bernard. La Société des Amis des Noirs, p.279, nota 568.

${ }^{1878}$ A censura real era um companhia de especialistas encarregados de analisar os manuscritos que lhes eram submetidos, de modo a autorizar ou não a sua publicação exclusiva sob forma impressa, com privilégio real. 
64) Dufournet de Naucel: deputado dos cidadãos de cor. É difícil determinar se ele deve ser considerado membro da Sociedade. A exemplo de Raimond, Ogé, Fleury, Honoré de Saint-Albert e mesmo o advogado Joly, foi recebido na sessão de 24 de novembro de 1789, mas, com exceção de Raimond e Ogé, não consta do registro que esses outros delegados de cor tenham realmente frequentado a Sociedade. De qualquer forma, achamos melhor inscrever seus nomes na presente lista. Apresentado por Brissot em 24 de novembro de 1789.

65) Dumont, Étienne: associado estrangeiro, de Dublin, tinha sido companheiro de exílio de Clavière e era um dos colaboradores dos escritos de Mirabeau. Foi o autor de Souvenirs sur Mirabeau. Primeira aparição no registro em 7 de abril de 1789.

66) Dupleix de Mezy: conselheiro no Parlamento. Primeira aparição no registro em 7 de abril de 1789 .

67) Duport, Adrien: membro da nobreza de Paris, advogado no Parlamento da cidade e futuro constituinte. Primeira aparição no registro em 2 de setembro de 1788.

68) Duvaucel, Louis-Philippe: fermier général. Foi um dos 28 guilhotinados em 8 de maio de 1794. Apresentado por Brack e admitido em 15 de abril de 1788.

69) Emmanuel de Salm, Príncipe: príncipe estrangeiro a serviço da França e marechal de campo. Primeira aparição no registro em 3 de fevereiro de 1789.

70) Épinay, Anne Gilbert Georges d': adjunto à Ferme générale, membro da comuna provisória de 18 de setembro de 1789, mencionado na lista dos Feuillants de 1791. Primeira menção no registro em 15 de abril de 1789.

71) Esmangard, fils: conselheiro no Parlamento de Paris. Apresentado por Dufossey de Bréban e admitido em 8 de abril de 1788.

72) Etang: talvez seja Pierre Joseph Georges Callières de l'Etang, advogado no Parlamento e adepto fervoroso da Revolução. Ele seria, aliás, o idealizador e primeiro comandante de um batalhão de idosos. Primeira aparição no registro em 9 de junho de 1789.

73) Fleury: proprietário mulato de São Domingos (ver Dufournet de Naucel). Retornou à colônia antes de Ogé, para preparar a revolta. Apresentado por Brissot em 24 de novembro de 1789.

74) Fortin: não há maiores referências sobre esse personagem, exceto o seu endereço (rue de Choiseul). Dorigny indica a existência de um procurador da cidade de 
Paris com esse nome. ${ }^{1879}$ Primeira aparição no registro em 3 de fevereiro de 1789.

75) Fronsac, Louis Antoine Sophie de Vignerot du Plessis, duque de: Também conhecido como duque de Richelieu, foi marechal de campo e, depois, tenentegeneral. Pai de Armand Emmanuel du Plessis, duque de Richelieu, futuro ministro da Restauração.

76) Frossard, Benjamin: embora não conste das listas de membros, esse pastor e ativista político foi o autor de petições antiescravistas, como Observations sur l'abolition de la traite des Nègres, na qual apresentou-se como um Amigo dos Negros. Esteve na segunda formação da Sociedade.

77) Gallois, Jean-Antoine: ligado a Condorcet e Dupont de Nemours, era advogado no Parlamento de Paris. Também foi membro do Tribunado. Apresentado por Brissot e admitido em 15 de abril de 1788.

78) Garlike, Benjamin: diplomata britânico, conhecido de Brissot, que o apresentou à Sociedade. Era funcionário do British foreign office, como assessor do Lorde Auckland. Admitido em 8 de abril de 1788.

79) Garran de Coulon, Jean-Philippe, conde: esse advogado do Parlamento de Paris, eleito deputado suplente do Terceiro estado nos Estados Gerais, foi um dos personagens mais importantes da história colonial da Revolução. Eleito para a Legislativa em 1791, ele, aos poucos, assumiu uma posição de primeiro plano nos debates sobre as questões coloniais. Foi o autor do famoso relatório sobre as colônias apresentado à Convenção thermidoriana. Primeira aparição no registro em 30 de abril de 1790.

80) Gatterie: personagem não identificado. Primeira aparição no registro em 26 de fevereiro de 1789.

81) Gay: médico. Apresentado por Valady e admitido em 15 de abril de 1788.

82) Gayral, Nicolas: indicado como Garail no registro, trata-se de um advogado no Parlamento. Apresentado por Brissot e admitido em 8 de abril de 1788.

83) Gougenot, Louis Georges: trata-se, provavelmente, do filho de Georges Gougenot de Croissy, também membro da Sociedade. Nobre como seu pai, ele tinha sido síndico da Companhia das Índias. Condenado à pena de morte em 1794. Primeira aparição no registro em 2 de dezembro de 1788.

${ }^{1879}$ Cf. DORIGNY, Marcel, GAINOT, Bernard. La Société des Amis des Noirs, p.195, nota 313. 
84) Gouvernet, Frédéric Séraphin de La Tour du Pin, conde de: foi ajudante de campo de La Fayette, segundo em comando da Guarda Nacional em julho de 1789. Primeira aparição no registro em 3 de fevereiro de 1789.

85) Gramagnac: doutor em Medicina, tradutor de uma obra de Clarkson. Primeira aparição no registro em 20 de abril de 1788.

86) Grégoire, Henri: Apesar de sua entrada tardia, o famoso abade foi um dos membros mais ativos da Sociedade, tanto pela sua produção literária quanto por suas intervenções na Assembleia. Foi também um dos antiescravistas de maior longevidade. Membro honorário desde 4 de dezembro de 1789 e efetivo a partir de 11 de dezembro do mesmo ano. Esteve na segunda formação da Sociedade.

87) Grouchy, Emmanuel, conde e, depois, marquês de: cunhado de Condorcet, foi general da República e marechal do Império e, segundo Napoleão, responsável pela derrota em Waterloo. Apresentado por Condorcet em 30 de junho de 1789.

88) Guiral: não identificado. Poderia eventualmente tratar-se de outra grafia equivocada para Gayral. Primeira aparição na Sociedade em 5 de agosto de 1788.

89) Guyot (ou Guillot): abade. Admitido em 3 de junho de 1788.

90) Havré, duque de: indicado por La Fayette, era maçom e grande personagem da nobreza francesa, que o elegeu como deputado para os Estados Gerais. Recusou a reunião das ordens e emigrou para a Holanda. Admitido em 15 de abril de 1788.

91) Henry: apresentado como advogado no Parlamento nas listas oficiais, trata-se, para Dorigny, de Jean-Louis Henry de Longuêve, advogado e membro da Sociedade filantrópica de Orléans, por meio da qual conheceu Brissot. Foi eleito deputado do terceiro estado nos Estados Gerais. Primeira aparição no registro em 13 de janeiro de 1789.

92) Hocquart de Tremilly: advogado geral da Cour des Aides e membro da família do fermier général Jean Hyacinthe Hocquart. Apresentado por Blaire em 27 de janeiro de 1789 .

93) Honoré de Saint-Albert: deputado dos cidadãos de cor de São Domingos (ver Dufournet de Naucel). Apresentado por Brissot em 24 de novembro de 1789.

94) Hugon de Basville, Nicolas Jean: jornalista, redator do Mercure National. Primeira aparição no registro em 9 de abril de 1790. 
95) Joly (ou Dejoly), Étienne-Louis Hector de: advogado que assumiu, por um tempo, a causa dos cidadãos de cor, apresentando a sua queixa perante os representantes da Nação e a Comuna de Paris (ver Dufournet de Naucel). Apresentado por Brissot em 24 de novembro de 1789.

96) Kornman: famoso banqueiro e fundador da Sociedade da harmonia universal. Sua casa se tornou um dos focos de preparação da Revolução. Seu nome, presente nas listas oficiais de membros, não consta do registro, mas há um Korn admitido em 15 de abril de 1788.

97) La Fayette, Marie Joseph Paul Yves Roch Gilbert Motier, Marquês de: Esse militar, herói da guerra de independência dos Estados-Unidos, interessou-se desde o início pela Sociedade, intervindo em seu favor junto ao ministro Brienne. Seu envolvimento com a causa antiescravista não era acidental. Ele esteve à frente de uma experiência realizada na Guiana (Caiena), com o objetivo de provar a superioridade concreta do trabalho livre sobre o escravo. La Fayette adquiriu, por meio de Daniel Lescallier, duas plantações nas proximidades de Caiena, nas quais os negros seriam, em princípio, tratados como trabalhadores livres. Ao que parece, entretanto, a ideia nunca foi de fato aplicada. ${ }^{1880} \mathrm{La}$ Fayette tinha se apresentado, em 12 de fevereiro de 1788, perante a Sociedade abolicionista de Londres para propor uma ação comum entre a França e a GrãBretanha contra o tráfico de escravos. Pelos seus contatos internacionais e sua posição de liderança no seio da nobreza liberal, sua presença na Sociedade era tida como crucial. Embora ausente das primeiras sessões, La Fayette afirmou, por meio de uma carta, ter se considerado membro da Sociedade desde a sua fundação, mas abandonou a causa após a ruptura dos Feuillants com os Jacobinos.

98) La Fayette, Adrienne de Noailles, marquesa de: esposa do Marquês. Seu nome consta da lista publicada em 1789.

99) La Feuillade, Pierre-Jacques-Alexandre d'Aubusson, marquês de: apresentado por Brissot, interessava-se ativamente pela questão dos Negros, escrevendo sobre o assunto no Mercure de France (cf. artigo Lettre sur l'esclavage des Nègres, 6 de dezembro de 1788). Primeira aparição no registro em 3 de março de 1789.

1880 Cf. THIBAU, Jacques. Le temps de Saint-Domingue, pp.65-66; DORIGNY, Marcel, GAINOT, Bernard. La Société des Amis des Noirs, p.66, nota 15. 
La Pouge: personagem não identificado. Primeira aparição no registro em 15 de março de 1790 .

101) La Rochefoucauld-d'Enville, Louis-Alexandre, duque de: nobre liberal, admirador dos Estados-Unidos, amigo e tradutor de Benjamin Franklin na França. Apresentado à Sociedade por La Fayette, ele introduziu, em 27 de junho de 1789, na condição de deputado da nobreza de Paris, a questão dos negros no debate parlamentar. Não deve ser confundido com seu primo, o também deputado La Rochefoucauld-Liancourt, que exerceu um engajamento antiescravista após a sua emigração, na Pensilvânia. Foi admitido na Sociedade em $1^{\circ}$ de abril de 1788 .

102. La Rochefoulauld, Alexandrine de Rohan-Cabot, duqueza de: esposa de La Rochefoucauld d'Enville. Seu nome está na lista publicada em 1789.

103. Le Page (ou Lepage), C.A.: um dos membros mais importantes da segunda fase dos Amigos dos Negros. Primeira aparição no registro em 19 de maio de 1789.

104. Le Page (ou Lepage), Pierre: irmão de C.A. Lepage. Também fez parte da Sociedade dos Amigos dos Negros e das Colônias. Primeira aparição no registro em 15 de março de 1790.

105. La Poype, Jean-François Cornu de: de família nobre, esse tenente-general participou da catastrófica expedição Leclerc de 1802, em São Domingos. Primeira aparição no registro em 23 de abril de 1790.

106. Le Roi de Petitval: era um régisseur général, isto é, um dos financistas da Régie générale, responsável pela cobrança de impostos. Admitido em 31 de março de 1788.

107. Le Roy: Esse nome consta da lista publicada em 1789. É difícil dizer se trata-se de Le Roi de Petitval ou Leroy de Camilly, ou então de um terceiro personagem, para o qual não temos outras referências.

108. Le Sage: personagem de identificação difícil. Poderia eventualmente tratar-se do futuro deputado girondino Denis Toussaint Lesage, advogado.

109. Lacépède, Bernard Germain, conde de: célebre naturalista. Sob o Império, ele aderiu ao campo escravocrata, chegando a defender teses de teor racista. Apresentado por Carra e admitido em 6 de maio de 1788.

110. Lageare: abade. Não encontramos referências sobre esse personagem, o que nos permite desconfiar de algum erro de grafia na documentação original. 
111. Lamarre, Chevalier de. trata-se provavelmente de Nicolas Philippe, chevalier de Lamarre, filho de Charles Léopold, barão de Lamarre, e casado com Victoire Benoist Lagarde, que era de uma família de negociantes com interesses na Martinica. Foi apresentado por Condorcet em 23 de junho de 1789. Foi membro da segunda formação da Sociedade.

112. Lameth, Charles Malo, conde de: Irmão de Théodore e Alexandre, oficial do exército, casado com a filha de um proprietário de São Domingos, foi deputado nos Estados Gerais e na Constituinte. Foi também um dos fundadores do Clube dos Jacobinos, antes de passar para o campo conservador em meados de 1791. Primeira aparição no registro em 3 de fevereiro de 1789.

113. Lameth, Alexandre, Chevalier de: Irmão de Charles e Théodore, foi coronel na guerra da América antes de ser deputado nos Estados Gerais e na Constituinte. Sua rápida adesão ao Terceiro Estado lhe garantiu um status privilegiado sob a Constituinte. Depois de desempenhar uma forte liderança nos Jacobinos, ele foi um dos fundadores do clube dos Feuillants. Apresentado por Condorcet em 27 de janeiro de 1789.

114. Lameth, Théodore, chevalier de: Irmão de Charles e Alexandre. Participou da guerra da América como oficial da Marinha e foi eleito deputado na Legislativa. Os Lameth eram uma família ligada aos meios coloniais, possuindo propriedades em São Domingos. Embora fossem da Sociedade, isso não os impediu de frequentar o Clube Massiac - do qual não eram membros centro do lobby colonial em Paris. Apresentado por Condorcet em 27 de janeiro de 1789.

115. Lamothe, Benoît de: subchefe de contabilidade da Régie générale. Primeira aparição no registro em 3 de fevereiro de 1789.

116. Lanthenas, François Xavier: apresentado por Brissot, era doutor em medicina. Foi admitido em 28 de abril de 1788. Foi membro e um dos principais agitadores dos Amigos dos Negros e das Colônias.

117. Laterrière: trata-se talvez de Pierre Sales de Laterrière, aventureiro, livrepensador e maçom, que havia atuado como inspetor e diretor das Forges SaintMaurice, no Québec (Canadá). Primeira aparição no registro em 7 de maio de 1790.

118. Laugeau: abade. Não encontramos outras referências sobre esse personagem. Primeira aparição em 18 de abril de 1789. 
119. Lavoisier, Antoine Laurent de: proveniente da uma família da nobreza recente de Blois, o famoso químico era também fermier général e membro da Academia de Ciências, onde havia contribuído para o estabelecimento de estatísticas sobre o comércio colonial. Foi apresentado por Montcloux, outro fermier général, e admitido em 22 de abril de 1788.

120. Léaumur, Chevalier de: conhecemos apenas o endereço deste personagem (rue Thérèse, $\mathrm{n}^{\circ} 1$ ).

121. Leroy de Camilly, Louis Anne Adrien: administrador da Caisse d'Escompte e payeur des rentes no Hotel de Ville. ${ }^{1881}$ Primeira aparição no registro em 21 de fevereiro de 1789.

122. Lescallier, Daniel: comissário em Granada e na Guiana, onde participou do experimento de trabalho livre empreendido nas propriedades de La Fayette. Escreveu sobre o assunto nas Réflexions sur le sort des noirs. Admitido na Sociedade em 30 de junho de 1789. Mais tarde, foi comissário nas Mascarenhas, o que o levou a mudar de posição. Assim mesmo, foi membro da segunda fase dos Amigos dos Negros.

123. Lhomme: Não identificado. Foi apresentado por La Poype, em 7 de maio de 1790, o que sugere alguém proveniente dos meios militares.

124. Louis, Joseph Dominique: abade, padre liberal e secretário particular de Talleyrand, então bispo de Autun. Emigrou após a fuga do rei, mas retornou no início do Consulado. Mais tarde, foi administrador das finanças sob Napoleão e ministro das finanças da Restauração. Primeira aparição no registro em 7 de julho de 1789 .

125. Lubersac, Jean-Baptiste Joseph de: bispo de Chartres, eleito para os Estados Gerais. Era um dos mais liberais dentre os prelados da Constituinte. Foi conduzido à Sociedade por Brissot, com quem rompeu em 1790. Admitido em 15 de abril de 1789.

1881 No Antigo Regime, o rei, buscando capitalizar uma determinada receita fiscal e receber imediatamente as receitas desse capital, recorria à constituição de uma renda junto ao Hôtel de Ville. Era um contrato pelo qual o Estado vendia à outra parte uma renda da qual se constituía devedora por um preço combinado. O payeur des rentes (pagador das rendas) era um oficial encarregado de pagar ao Hotel de Ville, órgão da municipalidade, as rendas constituídas em nome do rei e sobre as receitas do estado (cf. MOULIN, Mathilde. Les rentes sur l'Hôtel de Ville de Paris sous Louis XIV. Histoire, économie et société, 17(4), 1998, p.624. Disponível em:

http://www.persee.fr/web/revues/home/prescript/article/hes_0752-5702_1998_num_17_4_2005. Acesso em: 10 de dez de 2011. 
126. Malartic de Fonda, Abel Louis François (chevalier de Fonda): Malartic era um maître des requêtes, título conferido a quem tinha cumprido uma alta função judiciária ou administrativa. Participou de outras sociedades politicamente moderadas, como a Sociedade de 1789. Apresentado por Brack, ele foi admitido em 31 de março de 1788.

127. Mazzey: trata-se, na verdade, de Philippe Mazzei, correspondente do rei da Polônia, ligado a Condorcet, e membro do clube de 89.

128. Mercier, Louis Sébastien: o autor de L'An 2440, rêve s'il en fut jamais, Tableau de Paris e outras obras importantes, e depois membro da Convenção. Renegou a Sociedade mais tarde, por conta da insurreição dos escravos em São Domingos. Apresentado por Valady e admitido em 15 de abril de 1788.

129. Messent: não dispomos de maiores informações sobre este personagem. Poderia eventualmente tratar-se de uma grafia equivocada para Milscent, crioulo antiescravista ligado aos Girondinos, mas não há outras informações que confirmem a presença desse personagem na Sociedade. Apresentado por Condorcet em 23 de junho de 1789.

130. Meulan, Charles-Jacques-Louis de: amigo de Turgot e receveur général des Finances em Paris. ${ }^{1882}$ Primeira aparição na Sociedade em 3 de março de 1789. Faleceu pouco tempo depois, em 1790.

131. Mirabeau, Honoré-Gabriel-Riquetti, conde de: filho do famoso economista fisiocrata Victor Riquetti, marquês de Mirabeau, Honoré-Gabriel foi um personagem controverso. Escritor, jornalista, maçom e homem político, ele se destacou como um dos principais nomes da fase inicial da Revolução. Como deputado na Constituinte, preparou uma grande intervenção sobre o tráfico, mas nunca chegou a apresentá-la à Assembleia Nacional. Mirabeau foi um dos fundadores dos Amigos dos Negros e estava presente na primeira sessão, de 19 de fevereiro de 1788 .

132. Missy, Samuel Pierre Joseph David de: armador protestante e maçom de La Rochelle, especializado no comércio com as colônias orientais, sobretudo a Île-de-France, onde viveu por algum tempo. Sua curta presença na Sociedade gerou uma forte polêmica em La Rochelle. Contudo, de acordo com o

${ }^{1882}$ Responsável pelo recebimento das receitas do Tesouro público na cidade de Paris. 
negociante J.-B. Nairac, Missy nada fazia no seio da Sociedade. ${ }^{1883}$ Primeira aparição no registro em 16 de junho de 1789.

133. Mollien, Nicolas-François, conde: admirador de Adam Smith, esse financista tinha sido responsável pela renovação da concessão da Ferme Générale, em 1786. Depois, chegou ao posto de Premier Commis des Finances. Foi preso com o grupo dos fermiers généraux sob o Terror, mas escapou à execução. Foi ministro do Tesouro sob o Primeiro Império. ${ }^{1884}$ Primeira aparição no registro em 3 de fevereiro de 1789.

134. Monage: para Dorigny, talvez seja Ménage de Pressigny fils, fermier général, um dos executados em 8 de maio de 1794. Admitido em 8 de abril de 1788.

135. Mons, Jullien, marquês de: Oficial das Guardas francesas. Apresentado por Valady e admitido em 15 de abril de 1788.

136. Montcloux (fils), Gilbert Georges de: fermier général, apresentado à Sociedade por Brack e admitido em 18 de março de 1788. Foi um dos fermiers généraux executados em 8 de maio de 1794.

137. Montcloux de la Villeneuve: Pai do anterior, conselheiro na Cour des Aides. Apresentado por Brack e admitido em 18 de março de 1788.

138. Montesson, Charles, conde de: tenente de embarcações e general dos exércitos do rei em 1791-92. Foi apresentado por Raimond em 4 de junho de 1790.

139. Moreau: talvez seja Étienne Vincent Moreau, advogado no Parlamento de Tours. Apresentado por Brack e admitido em 8 de abril de 1788.

140. Munier de Montengis, Claude: médico, residente no Hotel dos Inválidos. Primeira aparição no registro em 4 de novembro de 1788.

141. Noailles de Tessé, Adrienne Catherine, Condessa: irmã do famoso duque de Noailles.

142. Noël: abade, professor, jornalista, e, mais tarde, diplomata e prefeito do Império, assim como inspetor geral da Universidade. Admitido em 23 de junho de 1789.

\footnotetext{
${ }^{1883}$ Cf. DEVEAU, Jean-Michel. Le Commerce rochelais face à la Révolution, p.165.

1884 Cf. Bibliographie universelle (Michaud) ancienne et moderne. Paris: Madame C. Desplaces; Michaud, 1855, v.28, pp.578-580.
} 
143. Nordaud: cirurgião. Apresentado por Valady e admitido em 15 de abril de 1788.

144. Nordenskjöld, Auguste: mineralogista sueco, amigo de Wadström, e autor do Plan for a free community upon the coast of Africa, a respeito da formação de uma colônia não escravista na costa africana. Apresentado por Roussel e admitido em 7 de maio de 1790.

145. Ogé, Vincent: homem de cor livre e proprietário em São Domingos. Ao lado de Raimond, liderou a causa dos cidadãos de cor na metrópole. Mas, consciente da necessidade de obter a concretização das suas aspirações na própria colônia, liderou uma revolta de mulatos, que, no final, levou à sua execução. O martírio de Ogé teve grande repercussão, tantos nos meios coloniais quanto na metrópole. Apresentado por Brissot em 24 de novembro de 1789.

146. Pampelune de Genouilly, Étienne Denis, marquês de: comandante dos estábulos da rainha. Foi apresentado por Brissot e admitido em 18 de março de 1788.

147. Parraud, J.P.: Empregado na Tesouraria. Era tradutor e discípulo do espiritualista sueco Emanuel Swedenborg, cujos escritos sobre os africanos tinham exercido forte influência sobre o desenvolvimento dos ideais antiescravistas. Também teria sido um dos tradutores do primeiro volume dos Direitos do Homem de Thomas Paine. Fez parte da Sociedade dos Amigos dos Negros e das Colônias. Apresentado por Lanthenas e admitido em 29 de janeiro de 1790.

148. Pastoret, Emmanuel Claude Joseph Pierre: Conselheiro na Cour des Aides, promovido no início de 1788 a mestre das requisições e futuro membro da Assembleia Nacional. Tornou-se, depois, um dos chefes dos Feuillants. Em 1783, publicou um longo poema em que exaltava a necessidade de introduzir na Magistratura os princípios da Filosofia. ${ }^{1885}$ Apresentado por Blaire e admitido em 29 de abril de 1788.

149. Pétion de Villeneuve, Jérôme: advogado em Chartres, antes de ser eleito deputado em 1789. Apesar da sua entrada tardia na Sociedade - sua primeira aparição como membro no registro é de 3 de janeiro de 1790 -, ele foi um de seus principais agitadores.

${ }^{1885}$ Cf. PASTORET, Emmanuel. Discours en vers sur l'union qui doit régner entre la Magistratur, la Philosophie \& les Lettres. Paris: Chez Jombert jeune, 1783. 
150. Pétry: diretor das Fermes. Sob Napoleão, tornou-se alto funcionário no ministério das relações exteriores. Sua primeira aparição na Sociedade data de 5 de agosto de 1789 .

151. Piatoli: abade italiano. Aparece no registro como associado estrangeiro.

152. Pigott, Robert: inglês, quacre, pitagoriciano, conhecido de Brissot. Admitido em 15 de abril de 1788, por indicação de Valady.

153. Pilles: antigo procurador na Chambre des Comptes, jurisdição soberana especializada nas questões financeiras. Apresentado por Bréban e admitido na Sociedade em 8 de abril de 1788.

154. Poivre, Marie François Robin de: viúva de Pierre Poivre, que tinha sido intendente nas ilhas de France e Bourbon na década de 1760. Futura esposa do fisiocrata Dupont de Nemours, ela foi uma das primeiras mulheres aderentes à Sociedade.

155. Pontécoulant, Louis Gustave Doulcet, conde de: militar e membro da Convenção, foi proscrito com os Girondinos. Primeira aparição no registro em 18 de abril de 1789.

156. Raimond, Julien: proprietário quadrarão de São Domingos e principal líder da causa dos cidadãos de cor durante a Revolução. Sua entrada na Sociedade foi determinante para que os Amigos dos Negros se envolvessem na questão dos livres de cor. Após a abolição, Raimond foi nomeado comissário em São Domingos. Apresentado por Brissot em 24 de novembro de 1789.

157. Ricey, visconde de: personagem não identificado. Primeira aparição no registro em 3 de fevereiro de 1789.

158. Rochechouart, Aimery Louis Roger, conde de: personagem conhecido nos meios filantrópicos de Paris, foi eleito deputado da nobreza de Paris nos Estados Gerais. Militar de carreira, tinha participado da Guerra dos Sete Anos. Quando de sua entrada na Sociedade, era marechal de campo. Foi um dos primeiros sete deputados da nobreza a se unir ao Terceiro Estado. Apresentado por Condorcet em 27 de janeiro de 1789.

159. Rohan-Chabot, Louis Antoine Auguste, duque de: era também príncipe e barão de Léon, conde de Maillé e de la Marche. Militar de carreira, tinha sido marechal de campo antes de atingir o grau de tenente-general. Foi deputado suplente da nobreza de Paris nos Estados Gerais. Posteriormente, fez parte da 
nobreza emigrada. Apresentado à Sociedade por Condorcet, em 27 de janeiro de 1789.

160. Roman, Jacques: negociante de Genebra, com sucursais em Paris e outras grandes cidades da Europa. Era um dos sócios de Bidermann e acionista da Compagnie d'assurances sur la vie de Clavière. Primeira aparição no registro em 13 de janeiro de 1789.

161. Roucher, Jean Antoine: poeta e economista, autor de uma tradução da Riqueza das Nações, publicada em 1790. Como explica Dorigny, em seu poema mais famoso, Les mois, Roucher dedicava uma nota extensa à defesa dos escravos negros. ${ }^{1886}$ Apresentado por Condorcet em 23 de junho de 1789.

162. Roussel: personagem obscuro, apresentado por Brissot, em 30 de abril de 1790, como "membro correspondente". Fazia parte da Sociedade dos amigos da paz.

163. Roveray, Jacques-Antoine du: um proscrito genebrino, que tinha dirigido, ao lado de Clavière, a revolução democrática de 1782. Era também amigo e colaborador de Mirabeau, participando da elaboração dos textos e discursos do famoso parlamentar. Estava na sessão de $1^{\circ}$ de abril de 1788 , mas só foi admitido formalmente em 8 de abril do mesmo ano, após apresentação de Brissot.

164. Saint-Alphonse, Alphonse de Vismes de: fermier général e maçom. Sua primeira aparição na Sociedade data de 5 de agosto de 1788.

165. Saint-Lambert, Jean-François, marquês de: militar, filósofo e poeta, autor do poema antiescravista Ziméo.

166. Sannois, Denis-François Papillon: fermier général. Primeira aparição no registro em 3 de fevereiro de 1789.

167. Savalette de Lange: maçom e administrador do Tesouro real. Era de uma família de financistas. Consta da lista publicada em 1789.

168. Segretier: personagem difícil de identificar. Havia, contudo, em 1789, um colono de São Domingos chamado Jacques-Claude-Florimond Segretier (ou Segrettier). ${ }^{1887}$

\footnotetext{
${ }^{1886}$ Cf. DORIGNY, Marcel. GAINOT, Bernard. La Société des Amis des Noirs, p.234, nota 419.
}

1887 Cf. Les colons de Saint-Domingue (1789). Disponível em: http://www.domingino.de/stdomin/colons_s.htm. Acesso em 25 de jan de 2012. 
169. Seinie, Condessa de la: conhecida de Brissot, com quem manteve relação epistolar. $^{1888}$

170. Servan de Gerbey, Joseph Marie: proveniente de uma família da pequena nobreza do Dauphiné, esse militar de carreira havia servido na Guiana. Depois, tornou-se capitão de regimento, general e, enfim, ministro da guerra sob o governo girondino. Fez parte da Sociedade dos Amigos dos Negros e das Colônias. Primeira aparição nor egistro em 23 de abril de 1790.

171. Servant, chevalier de: embora o registro publicado por Dorigny indique o nome "Servant", poderia tratar-se de Servan de Sugny, um conhecido de Brissot, ou ainda um dos membros da família franco-irlandesa Walsh-Serrant, no seio da qual havia armadores de Nantes e proprietários em São Domingos. Primeira aparição no registro em 15 de março de 1790.

172. Servat, Jean-Baptiste: advogado no Parlamento e deputado da cidade de Bordeaux. Era também um financista e detinha ações na Buanderie de Sèvres, uma famosa blanchisserie (lavanderia). ${ }^{1889}$ Admitido na Sociedade em 20 de janeiro de 1789.

173. Sibire: abade, autor de L'Aristocratie négrière, famosa obra antiescravista. Admitido em 16 de junho de 1789.

174. Sieyès, Emmanuel Joseph: abade, grande-vigário do bispo de Chartres, famoso autor de Qu'est-ce que le Tiers-état?. Um dos mais notórios personagens da Revolução e um dos arquitetos do golpe de 18 brumário. Primeira aparição no registro em 7 de abril de 1789.

175. Siodier: negociante de Genebra.

176. Short, William: secretário da embaixada dos Estados Unidos. Thomas Jefferson, ministro plenipotenciário dos Estados Unidos na França, não podia, por razões de conveniência, integrar a Sociedade, mas permitiu que seu secretário o fizesse. Apresentado por La Fayette e admitido em $1^{\circ}$ de abril de 1788.

177. Soufflot, le jeune: sobrinho do famoso arquiteto Soufflot, autor da igreja Sainte-Geneviève, hoje conhecida como Panteão. Isso explica o fato de seu

\footnotetext{
${ }^{1888}$ Cf. BRISSOT DE WARVILLE, Jacques-Pierre. Mémoires, pp.186 e seguintes.

${ }^{1889}$ Cf. CLAEYS, Thierry. Un agent de Calonne, Gabriel Palteau de Veymérange. In: Y. DURAND, J.P. BARDET (orgs). État et société en France aux XVIIe et XVIIIe siècles. Paris: Presses Universitaires de Paris-Sorbonne, 2000, p.148, nota 63.
} 
sobrinho ser Inspecteur des Bâtiments de Sainte-Geneviève. Primeira aparição no registro em 7 de outubro de 1788 .

178. Souligné, M. de: diretor das Fermes, em Lyon. Seu nome é mencionado no registro em 31 de março de 1789, na condição de associado reinícola.

179. Strand, Jacob: sueco, associado de Wadström, que participou de uma expedição, na costa da África ocidental, para fundar uma colônia livre. Apresentado por Roussel e admitido em 7 de maio de 1790.

180. Suilly: membro da nobreza de Orléans.

181. Thierry: antigo negociante. Apresentado por Valady e admitido em 15 de abril de 1788.

182. Trudaine de Montigny: conselheiro no Parlamento de Paris, neto de Daniel Trudaine e filho de Jean Charles Philibert Trudaine, dois antigos intendentes das finanças. Foi membro de diversas sociedades filantrópicas antes de aderir aos Amigos dos Negros, onde foi admitido em 31 de março de 1788, por indicação de Brack. Foi executado em 26 de julho de 1794, sob acusação de conspiração pela realeza. Primeira aparição no registro em 3 de fevereiro de 1789.

183. Trudaine de la Sablière: irmão do precedente e, assim como ele, conselheiro no Parlamento de Paris. Primeira aparição no registro em 3 de fevereiro de 1789.

184. Vaynes: trata-se, provavelmente, de Jean Devaines, um colaborador de Turgot e, mais tarde, de Necker no Controle geral das Finanças, como premier commis. Era recebedor geral das finanças. Primeira aparição no registro em 7 de março de 1789.

185. Valady, Xavier d'Yzarn de Freissinet, marquês de: oficial do exército, amigo próximo de Brissot, que conheceu por meio de contatos ingleses. Foi membro da Convenção, onde sentou-se ao lado dos Girondinos, partilhando do mesmo destino: foi executado em 6 de dezembro de 1793. Foi um dos fundadores da Sociedade e esteve presente na primeira sessão, de 19 de fevereiro de 1788.

186. Valence, Louis Antoine Auguste Cyrus Marie Adélaïde Timbrune, visconde de: general, apresentado por Condorcet em 27 de janeiro de 1789.

187. Vallou de Villeneuve: subchefe da Régie générale. Seu nome consta da lista publicada em 1789. 
188. Verdet (ou Verdé): talvez seja François-Auguste Verdet, advogado no Parlamento de Aix. Primeira aparição no registro em 9 de abril de 1790.

189. Volney, Constantin François Chasseboeuf: conhecido simplesmente como Volney, era um célebre filósofo, redator do Sentinelle du Peuple, um dos primeiros jornais publicados sem autorização da censura, em 1788. Admitido na Sociedade em 8 de abril de 1788. 


\section{APÊNDICE B - Lista de membros da Sociedade dos Amigos dos Negros e das} Colônias

1) Annecy, Jean Louis: antigo escravo, alforriado aos 40 anos em razão das campanhas na guerra de independência norte-americana. Eleito pela assembleia eleitoral do Cap, ele se sentou no Conselho dos Anciões no outono de 1797, ao lado de Laveaux. Após o 18 brumário, foi excluído da legislatura e retornou a São Domingos. Quando da chegada da expedição Leclerc, Annecy tomou o partido de Toussaint Louverture contra a França, o que lhe valeu uma deportação, em 1802, para a Córsega, sendo posteriormente transferido para a ilha de Elba, onde teria falecido em 1807.

2) Arrault: personagem não identificado

3) Bancal des Issarts, Jean Henri: membro da primeira Sociedade dos Amigos dos Negros, Bancal tinha sido membro da Convenção, antes de ser deputado no Conselho dos Quinhentos.

4) Baudrais, Jean-Baptiste: homem de letras, membro do clube dos Jacobinos, ocupou diversas funções públicas ao longo da Revolução. Foi membro da Comuna de Paris, encarregado da administração da polícia parisiense durante o Terror. Suspeito de ter assumido posições moderadas, foi encarcerado até thermidor do ano II. Em seguida, atuou como juiz de paz, antes de instalar-se na Guadalupe, no fim de 1797, como juiz civil, criminal e de apelação em matérias comerciais. Permaneceu na colônia até o final de 1800, razão pela qual não participou das sessões dos Amigos dos Negros e das Colônias. Limitou-se a atuar como correspondente internacional.

5) Bayard, Ferdinand Marie: capitão de artilharia e autor de numerosos relatos de viagem.

6) Belley, Jean-Baptiste: Antigo escravo, ele tinha sido alforriado em razão do serviço militar, para, depois, tornar-se proprietário no Cap. Um dos três deputados de São Domingos admitidos em 15 pluvioso do ano II, Belley foi também o primeiro negro a sentar-se na representação nacional. Sob o Diretório, foi membro do Conselho dos Quinhentos até 1797. Retornou a São Domingos para uma curta experiência militar, como chefe de divisão da gendarmerie. De volta a Paris no final de 1798, ele se associou à Sociedade dos Amigos dos 
Negros e das Colônias. Retornou novamente a São Domingos com a expedição Leclerc no início de 1802. Foi preso em 12 de abril de 1802 e deportado para a fortaleza de Belle-Île-en-Mer, onde faleceu em 6 de agosto de 1805. Admitido em 29 de janeiro de 1799.

7) Besson: atuou no ministério da Marinha desde 1781, entrando para a administração central desse mesmo ministério em 1792.

8) Biauzat, Jean-François Gaultier de: advogado, eleito para os Estados Gerais de 1789, aderiu aos Feuillants em julho de 1791. Moderado, foi encarcerado sob o Terror por um curto período, antes de ser reabilitado durante a reação thermidoriana. Contudo, sob o Diretório, ele participou de algumas das frentes de luta da corrente neojacobina. Assim, no momento em que entrava para a Sociedade, ele era uma personalidade estimada pela esquerda republicana. Era membro do Tribunal da cassação.

9) Billoud: sua admissão foi proposta por Deydier em 30 de março de 1799, mas não se sabe se foi admitido. Seu nome não consta da lista oficial.

10) Blachon: não identificado.

11) Boisrond, Louis François: homem de cor de São Domingos, proprietário, eleito deputado da colônia em fructidor do ano IV. Exerceu influência sobre Sonthonax na sua adesão a André Rigaud, em oposição a Toussaint Louverture.

12) Boisson, Jean-Louis: da Martinica.

13) Boisson, Joseph: negro nascido em São Domingos, era um próximo de Belley, Mentor e Thomany. Eleito deputado da colônia, sentou-se à Convenção em 4 de julho de 1794. Sob o Diretório, integrou o Conselho dos Quinhentos.

14) Boltz (ou Bolts), William: holandês radicado na Inglaterra desde os 15 anos de idade, exerceu cargo público no tribunal civil em Bengala nos anos 1760. A serviço da imperatriz da Áustria, foi encarregado, em 1778, da missão de fundar estabelecimento comerciais em nome da Companhia austríaca das Índias ocidentais. Talvez em razão dessa experiência, foi um dos principais colaboradores de Wadström na redação do Essay on colonization, concluído em 1795.

15) Bourdon de Vatry, Marc-Antoine: atuou nos gabinetes do ministério da marinha desde os 14 anos de idade, antes de participar, como secretário geral da esquadra do almirante de Grasse, da guerra de independência norte-americana. Sob a Revolução, atuou nas questões coloniais, como diretor da administração geral 
das colônias em 1792 e chefe do gabinete das colônias em 1795. Deixou a administração em 1797. Suas ligações com Sieyès lhe valeram o posto de ministro da marinha após as jornadas de 29 e 30 prairial do ano VII. Sob o Consulado, Bonaparte o substituiu por Forfait. Antes da Restauração, entretanto, ainda atuou como intendente das forças navais, em 1814.

16) Brack, C.: foi censor real e diretor geral das alfândegas internas. Amigo de Brissot, Brack foi um dos fundadores da primeira Sociedade dos Amigos dos Negros.

17) Brosselard, Emmanuel: advogado antes da Revolução, foi, em seguida, deputado suplente da Assembleia Legislativa. Sob o Diretório, foi comissário do poder executivo junto aos tribunais de Paris. Sob o Consulado, trabalhou no ministério da Justiça, antes de se tornar chefe do gabinete de legislação estrangeira. Também seguiu carreira de jornalista, como redator do Républicain français, que, depois do 18 fructidor, se tornou La Chronique universelle. Publicou, no seu jornal, o relato de uma sessão pública dos Amigos dos Negros e das Colônias, de 16 pluvioso do ano VII.

18) Burnel, Étienne Laurent Pierre: militar de carreira, foi o comissário que, ao lado de Baco, tentou, sem sucesso, executar o decreto de abolição nas Mascarenhas, sendo expulso pelas assembleias locais. Em 1798, partiu para a Guiana, com a missão de vigiar os deportados políticos de Caiena. Após o 18 brumário, recusou-se a servir o regime consular.

19) Cabanis, Pierre Jean Georges: cunhado de Condorcet, Cabanis era representante no Conselho dos Quinhentos e Comissário do Diretório no $2^{\circ}$ arrondissement de Paris. Membro eminente do movimento intelectual dos Ideólogos.

20) Calès, Jean Marie: médico da região de Toulouse, foi eleito deputado na Convenção pelo departamento da Haute-Garonne. Republicano conservador, ele manteve-se relativamente independente em relação às clivagens políticas no seio da assembleia. Esteve, entretanto, entre os thermidorianos e atuou no fechamento das sociedades populares durante sua missão na Côte d'Or, em setembro de 1794. Foi membro do Conselho dos Quinhentos e aprovou o golpe de 18 fructidor do ano V. Deixou o Conselho em maio de 1798 para retirar-se para a sua propriedade rural. Não participou das sessões dos Amigos dos Negros e das Colônias, atuando apenas como correspondente local. 
21) Cavaignac, Jean-Baptiste: advogado e deputado da Convenção, ele se opôs às jornadas de 31 de maio -2 de junho de 1793. Assim mesmo, aliou-se ao governo do ano II, cumprindo uma série de missões militares. Em outubro de 1794, tornou-se membro do Comitê de Segurança Geral. Em seguida, foi membro do Conselho dos Quinhentos até maio de 1797. Foi recebedor das alfândegas e, a partir de março de 1798, chefe de divisão na Loteria nacional, posição que ocupava quando de sua entrada na Sociedade. Exerceu outros cargos nos anos seguintes, inclusive o de cônsul em Mascate entre 1802 e 1804, o que lhe permitiu manter uma correspondência com a Île-de-France.

22) Deniay (ou Denyau): diretor de um estabelecimento francês no reino de Juda, na costa ocidental africana, tinha escrito e apresentado aos Amigos dos Negros e das Colônias um memorial sobre a colonização da África, Détails sur le pays de Juda, sur les cultures dont il est susceptible, ses objets d'échange, et la nécessité de conserver cet établissement, le seul que les Français aient dans cette partie de la côte; offre d'y retourner avec les moyens nécessaires pour venir au but que se proposerait le gouvernement. Propunha uma transferência da cultura das Antilhas para o litoral africano, que serviria de laboratório para uma experiência colonial alternativa ao sistema de plantation. Admitido em 10 pluvioso do ano VII.

23) Deville, Jean Baptiste: Proprietário negro de São Domingos, Deville tinha exercido a função de subinspetor das propriedades no cantão de Acul, no norte da ilha. Foi um dos eleitos pelo departamento do Norte de São Domingos no ano VI cuja eleição foi validada pelo Conselho dos Quinhentos em agosto de 1799 e ratificada pelo dos Anciões em outubro do mesmo ano. Admitido em 19 de janeiro de 1799.

24) Deydier, Étienne: deputado do Ain na Assembleia Legislativa e na Convenção, onde se aliou ao campo montanhês. Durante o ano II, atuou na reorganização e na fiscalização da indústria siderúrgica, essencial no quadro da economia de guerra. Foi membro do Conselho dos Anciões sob o Diretório.

25) Dubois: talvez Edmond Louis Alexis Dubois de Crancé, militar e deputado jacobino na Constituinte, na Convenção e no Conselho dos Quinhentos. Na sua atividade parlamentar, defendeu frequentemente posições antiescravistas avançadas. Em setembro de 1799, foi nomeado Ministro da Guerra. 
26) Dufay de la Tour, Louis Pierre: membro de uma família da pequena nobreza militar, Dufay tinha participado da guerra de independência norte-americana no regimento do Cap. Isso permitiu que se estabelecesse como plantador em São Domingos, antes de retornar à França em 1785. Inscreveu-se no clube dos Jacobinos em 1790, para, no ano seguinte, retornar a São Domingos. Assumiu a função de inspetor geral das fronteiras no exército que combateu as forças negras que então estavam aliadas aos Espanhóis. Eleito deputado da colônia em 1793, ele foi um dos três admitidos na Convenção em 15 pluvioso do ano II, antes de fazer, no dia seguinte, o famoso discurso que levou ao decreto de abolição. Sob o Diretório, passou para o Conselho dos Quinhentos. Na época de sua entrada na Sociedade, ele atuava como inspetor dos correios. Apresentado à Sociedade em 18 de fevereiro de 1799.

27) Dufossey de Bréban: antigo diretor da Régie générale e membro da primeira Sociedade dos Amigos dos Negros.

28) Dugour, Antoine Jeudy: professor de história e livreiro, tinha sido um adepto da monarquia antes de evoluir para um republicanismo moderado, para não dizer conservador. Mais tarde, em 1804, partiu para a Rússia, onde lecionou história em São Petersburgo e se naturalizou russo, sob o nome de Gouroff.

29) Dugour, Clarisse: inglesa, nascida Clarisse Oliver, era a esposa de Antoine Dugour.

30) Duplantier, Jacques Paul Fronton: advogado de Bordeaux e fundador da Société pour le développement des sciences naturelles, foi membro da Assembleia Legislativa e da Convenção, onde foi associado aos Girondinos. Abandonou seu cargo após as jornadas de 31 de maio - 2 de junho de 1793. Em germinal do ano VI, foi novamente eleito representante no Conselho dos Quinhentos pelo departamento da Gironda. Passou a defender as ideias da corrente neojacobina. Manifestou-se, em setembro de 1798, a respeito do problema das dívidas contraídas pela compra de negros. Após o 18 brumário, ele foi excluído da representação nacional. Admitido em 30 de dezembro de 1798.

31) Dupuch, Élie Louis: originário da Guadalupe, onde atuava como notário, foi eleito representante da colônia na Convenção e no Conselho dos Anciões. Montanhês, ele integrou a corrente neojacobina. Após deixar o Conselho, ele foi reeleito pela assembleia eleitoral sediada no Oratório, mas sua eleição foi, a 
exemplo de outros neojacobinos, anulada pela lei de 22 floreal do ano VI. Foi eleito presidente da Sociedade em 9 de maio de 1798.

32) Duval, Charles François Marie: deputado da Montanha na Assembleia e na Convenção, Charles Duval foi também o fundador do Journal des hommes libres de tous les pays. Sob o Diretório, integrou o Conselho dos Quinhentos. Cumpria a função de tesoureiro-pagador geral junto ao exército do interior. Membro da corrente neojacobina, teve o seu mandato revogado após o 18 brumário.

33) Engelvin, Jean Baptiste: engenheiro-diretor das minas de chumbo argentífero de Pontgibaud desde antes da Revolução, Engelvin assumiu funções administrativas no departamento do Puy-de-Dôme. Em abril de 1798, foi eleito deputado no Conselho dos Quinhentos, posição que ocupava quando de sua entrada nos Amigos dos Negros e das Colônias.

34) Fenis (ou Fénis): poucas informações sobre este personagem.

35) Férère: correspondente de Caiena.

36) Frossard, Benjamin Sigismond: pastor protestante, autor de escritos antiescravistas nos primeiros anos da Revolução, quando se considerava membro dos Amigos dos Negros. Na época da formação da segunda Sociedade, ele teria se instalado como negociante em Paris.

37) Giroud: seu nome não consta das listas ou do registro, mas segundo Dorigny e Gainot, esse engenheiro estabelecido em Santo Domingo (parte espanhola da ilha) exerceu importante atividade como correspondente internacional. ${ }^{1890}$

38) Gombaud (ou Gombault): não identificado

39) Granet, Marc-Antoine: advogado em Toulon antes da Revolução, ele assumiu posteriormente a chefia do gabinete das colônias do ministério da Marinha. Isso explica o fato de que a Sociedade se reuniu, por um tempo, nos locais administrativos dessa divisão. Como deputado da Legislativa, integrou o comitê da marinha em 1791. Sob o Terror, foi preso em razão de sua proximidade aos Girondinos. Sob o Diretório, foi chefe do gabinete das colônias e, depois, chefe do gabinete do contencioso. No inverno de 1799, o fato de ter cedido os locais do gabinete das colônias para as sessões da Sociedade lhe custou temporariamente o seu cargo. Admitido em 29 de janeiro de 1799.

${ }^{1890}$ Cf. DORIGNY, Marcel, GAINOT, Bernard. La Société des Amis des Noirs, p.364, nota 97. 
40) Grégoire, Henri Jean Baptiste: um dos membros mais ativos da primeira Sociedade dos Amigos dos Negros e um dos antiescravistas mais persistentes de todo o período. Após ter sido deputado na Constituinte e na Convenção, sob o Diretório, Grégoire tinha se tornado membro do Conselho dos Quinhentos. Sob o Consulado, fez parte do Corpo Legislativo, antes de aceitar um lugar no Senado, no final de 1801. Em 1808, publicou De la littérature des nègres, atestando, mesmo após o restabelecimento da escravidão, a continuidade de seu engajamento antiescravista.

41) La Tour d'Auvergne, Théophile-Malo Corret de: militar de carreira, tinha sido preso pelos britânicos em 1795. Após dois anos de cárcere, foi libertado em razão de uma troca, em 1797.

42) Labaume, Antoine Gilbert Griffet: colaborador dos jornais Mercure de France, La Décade philosophique e Magasin Encyclopédique. Tradutor de obras importantes, como O Senso Comum, de Thomas Paine, e de numerosos relatos de viagem.

43) Lamarre: o antigo Chevalier de Lamarre, foi membro da primeira Sociedade dos Amigos dos Negros.

44) Lambert, Ferdinand Amable: antigo padre constitucional, tinha se tornado inspetor das subsistências em 1794. Sob o Diretório, atuou no gabinete dos emigrados no ministério do interior. Sob Napoleão, foi comissário de polícia na sua cidade natal, Boulogne-sur-Mer. Foi reintegrado à Igreja sob a Restauração.

45) Lanthenas, François Xavier: membro da primeira formação dos Amigos dos Negros, Lanthenas tinha se tornado, desde então, comissário do Diretório no $2^{\circ}$ arrondissement de Paris. Foi deputado no Conselho dos Quinhentos.

46) Larose, Jean-Louis: negro livre, proprietário no Cap-Français.

47) Lasteyrie-Dussaillant, Charles Philibert: cunhado de La Fayette, era um homem de múltiplos talentos, atuando como agrônomo, industrial, filantropo e homem de letras. Segundo Gainot, sua preocupação maior era encontrar, a partir de um estudo comparado dos sistemas de economia rural, "a melhor relação custo de produção/dispêndio de trabalho humano". ${ }^{1891}$

48) Lavaux, Étienne Maynaud de: militar de carreira, fez parte da expedição que acompanhou os comissários civis a São Domingos, em setembro de 1792. Foi

${ }^{1891}$ Ibidem, p.341, nota 39. 
nomeado governador geral da colônia em razão de sua conduta. Estabeleceu relação de confiança com Toussaint Louverture. Eleito deputado de São Domingos em 1796, ele foi o arquiteto da lei de 12 nivoso do ano VI ( $1^{\circ}$ de janeiro de 1798) sobre as colônias.

49) Leborgne de Boigne, Claude Pierre Joseph: secretário da primeira comissão civil enviada a São Domingos em 1791 e comissário-ordenador da comissão de 1796, presidida por Sonthonax. Foi eleito deputado da colônia no Conselho dos Quinhentos.

50) Lecomte: chefe no ministério da Polícia.

51) Lepage (ou Le Page), C.A.: irmão de Pierre Lepage e membro da primeira formação dos Amigos dos Negros.

52) Lepage (ou Le Page), Pierre: irmão de C.A. Lepage e membro da primeira formação dos Amigos dos Negros. Diretor geral do canal de Essonne.

53) Lepage, Mme: esposa de C.A. ou Pierre Lepage.

54) Lescallier, Daniel: antiescravista nos primeiros anos da Revolução e membro da primeira Sociedade dos Amigos dos Negros, Lescallier foi nomeado comissário civil dos estabelecimentos franceses situados além do cabo da Boa Esperança em 1792, e passou vários anos na Île-de-France. Essa experiência provocou sérias mudanças no seu engajamento político. Em 1797, foi chamado a assumir o gabinete das colônias do ministério da marinha, onde justificou a atitude dos colonos rebeldes das Mascarenhas, que tinham recusado a abolição. Quando entrou para os Amigos dos Negros e das Colônias, a sua maior preocupação era relativa aos meios de valorizar a colônia da Guiana. Após o 18 brumário, assumiu as questões coloniais no Conselho de Estado. Foi, em seguida, nomeado prefeito colonial na Guadalupe, quando do restabelecimento da escravidão em 1802. Sua presença na Sociedade não está, portanto, livre de contradições.

55) Lombard-Lachaux, Pierre: antigo pastor, tinha sido prefeito de Orléans em agosto de 1792. Foi deputado na Convenção antes de assumir o cargo de chefe de divisão no ministério das finanças no final de 1795. Na época de sua entrada na Sociedade, exercia a função de régisseur de l'enregistrement. Foi membro da assembleia neojacobina do Oratório, em 1798. Sob o Consulado, reassumiu a sua função de pastor.

56) Maillard: admitido em 19 de janeiro de 1799. 
57) Malenfant, Charles Marie François: militar de carreira, foi enviado como coronel a São Domingos, sob o Diretório. Integrou o estado maior de Toussaint Louverture. Desaconselhou qualquer iniciativa militar na colônia para restaurar a antiga ordem colonial. A lista oficial de membros o menciona como correspondente em Caiena.

58) Maret: não identificado.

59) Martin: não identificado.

60) Masclet, Amé-Thérèse-Joseph: antigo funcionário da Monarquia nas Antilhas, Masclet tinha sido oficial das forças armadas durante a Revolução, antes de emigrar. Mais tarde, tornou-se Cônsul da França. Participou de sessões da Sociedade a convite de Wadström.

61) Mentor, Étienne Victor: homem de cor originário de Saint-Pierre da Martinica, tinha participado da comissão civil como militar. Ligado a Sonthonax, foi eleito pela assembleia do norte de São Domingos como deputado. Após o 18 brumário, retornou a São Domingos, onde participou da administração de Dessalines e, depois, de Pétion. Foi condenado à morte, em outubro de 1806, por um conselho de guerra do exército do sul da ilha, formado pelos adeptos de Pétion.

62) Merlino, Jean-François Marie: negociante na origem, Merlino se tornou um parlamentar de peso na Convenção, no Conselho dos Quinhentos e no dos Anciões. Ao lado de Sonthonax, era um dos principais agitadores da oposição democrática ao Diretório no seio do Corpo Legislativo.

63) Michau: não identificado.

64) Montlinod (ou Montlinot), Charles Antoine Leclerc: antigo eclesiástico e filantropo, ele tinha trabalhado no Comitê de Mendicidade da Assembleia Constituinte. Quando da sua entrada na Sociedade, ele trabalhava no ministério do interior, como chefe de divisão. Publicou, em 1797, o Essai sur la transportation comme récompense, et la déportation comme peine, obra que foi discutida na Sociedade.

65) Nicolas: não identificado.

66) Oliver: parente de Clarisse Oliver, esposa de Antoine Dugour

67) Pain: Bernard Gainot levanta a hipótese de tratar-se de Thomas Paine. ${ }^{1892}$ Não é impossível, tendo em vista que Paine era um opositor da escravidão e que ele

${ }^{1892}$ Ibidem, p.363, nota 93. 
tinha mantido relações próximas com alguns dos Amigos dos Negros originais, como Condorcet. Dito isso, não há elementos que atestem a sua presença na Sociedade. Sua admissão foi proposta em 30 de março de 1799, mas não se sabe se foi aceita. Não consta da lista oficial.

68) Parraud: empregado na Tesouraria. Foi membro da primeira Sociedade dos Amigos dos Negros.

69) Perrin: não identificado

70) Perroud: comissário-ordenador que atuou na parte norte de São Domingos, entre 1794 e 1796, ao lado do general Laveaux.

71) Petitniaud, François: deputado de cor eleito pela assembleia do oeste de São Domingos, dominada pelos adeptos do mulato Rigaud. Sua passagem pela Sociedade foi efêmera.

72) Pierre Antoine: não identificado

73) Rang, Jean Alexandre: originário de Utrecht, Rang era casado com a cunhada de Benjamin Frossard, na casa do qual o casal ficou hospedado em 1797-98.

74) Rat: não identificado.

75) Saavedra, Francisco de: tinha sido comissário do rei da Espanha nas Américas. Fazia parte dos Illustrados, adeptos das reformas liberais e da aliança francesa. Ministro das finanças quando da sua entrada na Sociedade, ele logo se tornou primeiro ministro de Carlos IV, mas por pouco tempo.

76) Sabonadière, Jean Scipion: pastor proveniente de Nîmes, Sabonadière tinha passado pelos Estados Unidos durante a guerra de independência. Após instalarse em Londres, teve de deixar a Inglaterra no início de 1793. Na França, ele manteve contato com os exilados anglo-saxões, como Stone e Helen Williams, dois outros membros da Sociedade. No ano III, atuou como chefe dos gabinetes de comércio e de abastecimento do Comitê de Salvação Pública.

77) Saint-Léger, Jean Georges Laurent de: nomeado comissário civil nas colônias em 1791, encontrava-se em São Domingos quando da explosão da insurreição negra. De volta à metrópole, tornou-se um homem de letras, contribuindo para a redação do jornal Le Publiciste, onde abriu espaço para os problemas coloniais.

78) Sauvigny, Étienne-Louis Billardon, abade de: era um próximo de Grégoire. Em 15 de agosto de 1797, participou do concílio nacional da Igreja Constitucional, que se envolveu, a pedido de Toussaint Louverture, num projeto de recomposição dos quadros da Igreja de São Domingos. 
79) Say, Jean-Baptiste: proveniente de uma família de comerciantes protestantes de Lyon, tinha trabalhado para uma companhia de seguros dirigida por Clavière, um dos líderes da primeira Sociedade, que lhe apresentou os escritos de Adam Smith. No início da Revolução, trabalhou como jornalista para o Courrier de Provence, um dos jornais de Mirabeau, outra figura-chave da primeira Sociedade. Foi um dos fundadores de La Décade Philosophique, no seio da qual atuou como um dos inspiradores da Sociedade dos Amigos dos Negros e das Colônias. Atuou também como tribuno no início do Consulado e, em 1803, publicou a primeira versão de sua obra máxima, o Traité d'économie politique, onde abordou o tema da escravidão.

80) Say, Mme: nascida Mlle Deloches, esposa de Jean-Baptiste Say. Admitida em 29 de janeiro de 1799.

81) Servan de Gerbey, Joseph: militar de carreira e ministro da guerra sob o governo girondino, Servan foi membro da primeira formação dos Amigos dos Negros.

82) Siauve: não identificado.

83) Sonthonax, Léger Félicité: antes de ter atuação decisiva como comissário civil em São Domingos, tinha sido advogado e jornalista. Atuou na redação do jornal Les Révolutions de Paris nos primeiros anos da Revolução, onde abordou as questões coloniais numa ótica antiescravista. Como comissário civil, pronunciou a primeira abolição da escravidão para a parte norte de São Domingos. Com sua prisão decretada pela Convenção montanhesa, Sonthonax teve a sorte de chegar à metrópole após o 9 thermidor, o que permitiu a sua reabilitação. Sob o Diretório, em 1796, foi nomeado novamente comissário civil em São Domingos. Chocando-se com Toussaint Louverture, ele retornou à metrópole na condição de deputado da colônia. Sua primeira participação na Sociedade dos Amigos dos Negros e das Colônias foi em 8 de fevereiro de 1798.

84) Stone, John Hurford: mercador de carvão inglês, ele era membro da ala republicana radical londrina. Seu envolvimento numa conspiração republicana lhe valeu uma pena de morte, o que o forçou a deixar a Inglaterra em 1792 e a refugiar-se na França, onde administrou diversas manufaturas. Exerceu a função de intermediário entre os revolucionários franceses e os círculos radicais britânicos. Tornou-se presidente da Sociedade dos Amigos dos direitos do homem, que reunia os radicais ingleses exilados em Paris. Stone se interessou então pelo projeto de estabelecimentos livres em Serra Leoa e Boulama. Em 
1794, durante uma viagem na Suíça, conheceu Helen Maria Williams. O casal trouxe para os Amigos dos Negros uma rede de contatos bastante valiosa.

85) Théremin, Charles: descendente de uma família de huguenotes refugiados em Berlim, seguiu, desde antes da Revolução, uma carreira diplomática que o levou a Paris. Sob a Revolução, optou pela nacionalidade francesa e seguiu carreira como homem de letras. Foi um importante colaborador da Décade Philosophique.

86) Thomany, Pierre: deputado de São Domingos, eleito em 11 de setembro de 1796, pela assembleia do norte da colônia. Era um negro livre e proprietário, emancipado antes da Revolução.

87) Tibell: correspondente na Itália.

88) Tonnelier, Jacques: homem de cor, coletor de impostos em Gonaïves, no noroeste de São Domingos. Foi eleito representante do norte da ilha em germinal do ano $\mathrm{V}$.

89) Villegégu: trata-se provavelmente do Villegégu que tinha sido chefe dos gabinetes civis da Marinha.

90) Villeneuve, René Claude Geoffroy de: médico. Autor de um extenso tratado sobre suas viagens na África, que foi publicado, em 1814, sob o nome L'Afrique; ou histoire, moeurs, usages et coutumes des Africains; le Sénégal, no qual defendia a criação de estabelecimentos livres na costa africana.

91) Wadström, Carl-Bernhard: mineralogista e industrial sueco, fundador de uma sociedade em Norköpping em 1779, voltada para o estabelecimento de uma colônia na África baseada no comércio de produtos agrícolas como alternativa à escravidão. Depois transferiu-se para a Inglaterra, onde estabeleceu contato com antiescravistas como Clarkson, Sharp e Wilberforce. ${ }^{1893}$ Na França, foi um dos principais agitadores dos Amigos dos Negros e das Colônias. Foi o autor de Précis sur l'établissement des colonies de Sierra-Leone et du Boulama, à la côte occidentale de l'Afrique, obra na qual propunha um projeto de colonização livre, tema que esteve no centro dos debates da Sociedade. Era um adepto da expedição francesa no Egito, da qual foi um dos inspiradores.

92) Wadström, Ulrique: esposa de Charles Wadström.

1893 Cf. RIX, Robert William. Carl Bernhard Wadström (1746-1799). Disponível em: http://www.brycchancarey.com/abolition/wadstrom.htm. Acesso em: 26 de out de 2011. 
93) Walker, John: célebre pedagogo inglês, fortemente influenciado pelos quacres. Esteve na França em 1797 e 1798, período em que frequentou a Sociedade, muito embora a lista oficial de membros o mencione como correspondente na Holanda.

94) Williams, Helen Maria: romancista e poetisa nascida em Londres, Williams fazia parte do círculo literário frequentado pelos não-conformistas e dissidentes. Em 1788, escreveu um poema em favor da abolição do tráfico negreiro. Transferiu-se para a França no início da Revolução. Por volta de 1792, passou a frequentar os meios girondinos. Sob o Terror, isso lhe valeu uma curta estadia na prisão. Suas ligações com Grégoire, Servan e Jean-Baptiste Say tornavam a sua entrada na Sociedade dos Amigos dos Negros e das Colônias bastante natural. 